\title{
Espacios de oportunidad, estrategias y agentes para afrontar la problemática de la vivienda en el Área Metropolitana de Bilbao
}

TESIS DOCTORAL

Ion Etxabe Gutiérrez

Arquitecto 



\title{
Espacios de oportunidad, estrategias y agentes para afrontar la problemática de la vivienda en el Área Metropolitana de Bilbao
}

\author{
Ion Etxabe Gutiérrez \\ Arquitecto \\ Directores: \\ José Fariña Tojo \\ Doctor Arquitecto y Catedrático de Urbanismo \\ Unai Fernández de Betoño Sáenz de Lacuesta \\ Doctor Arquitecto
}



A mi madre, por su permanente apoyo, fe e inspiración.

A Izaskun. 



\section{Agradecimientos}

En primer lugar, al Departamento de Urbanística y Ordenación del Territorio de la Universidad Politécnica de Madrid, y especialmente a José Fariña, Agustín Hernández Aja, Fernando Roch y Álvaro Sevilla, pues a través de sus clases en el Máster en Planeamiento Urbano y Territorial han hecho posible encauzar una serie de inquietudes personales y profesionales, abriéndome la puerta a marcos y perspectivas intuidas, pero apenas vislumbradas, tras los estudios de arquitectura. Por insistir en la perspectiva crítica, la interseccionalidad, la transversalidad y la función social que debe incorporar toda mirada a cualquier proceso urbano. A Agustín, de nuevo, por acogerme desde el primer momento como en casa.

Al Gobierno Vasco, por su programa de becas pre-doctorales gracias al cual reciben un vital impulso y pueden llevarse a cabo trabajos como este, difíciles de financiar bajo otras circunstancias y contextos.

A mis directores, José y Unai, por ser pacientes y permitirme desarrollar este trabajo con relativa autonomía, para bien y para mal, a la espera de esa versión mínimamente acabada que nunca llegaba. Y por supuesto, por estar siempre dispuestos a ayudar en el camino, y a hacer interesantes y valiosos aportes a la investigación.

También, a aquellas compañeras con quienes he compartido y comparto este camino académico en las aulas y pasillos de la ETSAM, en su cafetería, o en los mensajes de correo y telefónicos. Aún en la distancia, siempre han estado cerca de esta investigación.

A Cris y Eneko, de la librería Louise Michel de Bilbao, por generar un espacio de lectura crítica tan necesario, donde han sido obtenidos algunos de los textos utilizados; y más que eso, por facilitar un espacio de encuentro, debate y risas.

A Gustavo Romero, por reconectarme con la función social de la arquitectura; a él y a Guadalupe Valencia, por acogernos tan maravillosamente en su casa de México D.F.

A Maider Uriarte, Kepa Iturralde y Zigor Iturbe, por compartir penas doctorales, espacios de trabajo, viajes y cervezas.

A Edu, Leire, Iñaki, Ane, María, Ekain, Igor, Juan, Ane, Amaia, Jon, Eneko, Javi y Almudena, porque también habéis sido claves en todo el proceso.

A Jone y Jean Nichola, alegrías de última hora con las que compartir paseos en Hendaya y charlas de sobremesa, que han ayudado a arrojar luz sobre los caminos que vienen.

A mi familia, que con paciencia ha estado siempre a mi lado apoyándome, sin poner cara de preocupación a medida que los años pasaban. Gracias aita, Oihana y José Mari. A mis sobrinas por llevarme a otros terrenos. Muy en especial a mi madre y mis abuelos, por hacer todo esto posible, y a mi hermano Ander, por los muchos ratos entre olas y viento compartidos en la mar, que tanta energía, paz y sosiego me han dado, necesarias para llevar este proceso. A mis tías Mary Carmen, Mabel y Miki, por su calor, charlas y hospitalidad. A Juli.

Y por supuesto, a Izaskun, por compartir esta vida juntos y crecer juntos en el camino; por estar ahí para escuchar, ayudar a abrir la mirada a otras perspectivas, relativizar lo malo y celebrar lo bueno. 

La presente tesis doctoral ha sido desarrollada en el marco académico del Programa de Doctorado 03e6 'Sostenibilidad y Regeneración Urbana' del Departamento de Urbanística y Ordenación del Territorio de la Universidad Politécnica de Madrid, en la Escuela Técnica Superior de Arquitectura de Madrid.

Ha sido también desarrollada, durante los años 2014 y 2015, en el Departamento de Arquitectura de la Universidad del País Vasco/Euskal Herriko Unibertsitatea, en la Escuela Técnica Superior de Arquitectura de San Sebastián, siendo el autor Personal Investigador en Formación en ese periodo.

El trabajo ha sido parcialmente financiado por el Programa de Formación de Personal Investigador No Doctor del Departamento de Educación, Universidades e Investigación del Gobierno Vasco durante los años 2012 a 2015.
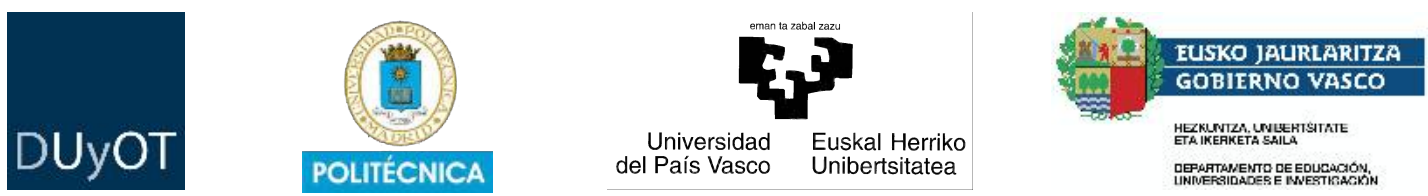

«No soy sabio, ya me gustaría, pero sí puedo presumir de ser muy curioso con todo lo que nos rodea, en eso no estoy nada especializado. Todo lo que he hecho ha sido por curiosidad, por tratar de entender las cosas y poder mejorarlas si es posible, que ya se ve que es complicado cuando todo eso no se convierte en proyectos colectivos».

Fernando Roch Peña 



\section{Resumen}

Pese a ser un derecho asumido y relativamente regulado, el acceso a una vivienda digna y adecuada se mantiene como una asignatura pendiente y estructural del capitalismo avanzado. En España, el sistema inmobiliario predominante y el marco de organización social hegemónico alimentan situaciones de exclusión y vulnerabilidad residencial, sin adaptarse a cambios socio-demográficos fundamentales. Las políticas públicas, agentes privados y parte de la sociedad civil van asimilando la necesidad de frenar la creación de nueva ciudad residencial para centrar los esfuerzos en la existente; sin embargo, esta se sigue abordando de manera rígida, desde una visión altamente mercantilizada y conservadora de la vivienda, dejando fuera importantes variables espaciales o sociológicas, y favoreciendo la reproducción de un parque que no fue diseñado para el contexto actual.

A través de la teoría urbana crítica es posible contextualizar todo ello en un marco internamente contradictorio, propio de la condición urbana, y en un sistema de gobernanza desigual. En ese escenario, tomando el Área Metropolitana de Bilbao como caso de estudio y a partir de una herramienta analítica de diseño propio, el trabajo permite demostrar dos cuestiones: frente a habituales discursos que tienden a simplificar estos y otros retos urbanos como una cuestión de bandos enfrentados y coherentes en sus posicionamientos, la complejidad de la problemática obliga a asumir el carácter transversal de unas contradicciones comunes a muchos de los diversos agentes y colectivos que, con desigual papel y poder, participan en este proceso de gobernanza urbana; desde esa misma teoría crítica, es posible plantear que fruto de dichas contradicciones, y debido a su carácter transversal, surgen diferentes alternativas dentro del propio sistema de organización social actual.

A partir del marco teórico anterior, se desarrolla un trabajo empírico centrado en algunas posibles alternativas surgidas de dos grandes contradicciones del capitalismo en las que pueden contextualizarse los fenómenos identificados en torno al acceso a la vivienda en esta región. Por un lado, en un mercado supuestamente autorregulado, hay un desfase entre las características de la oferta y las de la demanda. Este genera, a la vez que situaciones de exclusión, una serie de oportunidades de acceso desigualmente repartidas por la geografía de la misma. Por otro, hay un fuerte desequilibrio entre el valor de uso y el valor de cambio de la vivienda. Pero el predominio del segundo origina la aparición de diferentes agentes de gestión alternativos, a lo largo del proceso de acceso a la vivienda, con diversos niveles de responsabilidad social incorporada en su actividad.

Para que esas oportunidades puedan ser aprovechadas, se identifica una estrategia que señala como necesarias cuestiones como el desbordamiento de la estructura actual de la propiedad, la rotura del dogma de corresponder a una unidad de convivencia una vivienda actual como unidad indivisible, la transformación tipológica del parque residencial, o -frente a un sistema que favorece que cada unidad de convivencia aborde de manera individual el acceso a la vivienda- la acción colectiva por parte de la demanda. Aún contando con importantes retos y debilidades, los diversos agentes analizados pueden jugar un papel fundamental para llevar a cabo dicha estrategia, al concentrar la gestión de múltiples viviendas, contar con potencial para asesorar y acompañar, o capacidad de actuar a escalas mayores de planificación y ejecución. 


\begin{abstract}
Despite being an assumed and relatively regulated right, access to decent and adequate housing remains a pending and structural issue of advanced capitalism. In Spain, the predominant real estate system and the hegemonic framework of social organization feed situations of exclusion and residential vulnerability, without adapting to fundamental socio-demographic changes. Public policies, private agents and part of civil society are assimilating the need to stop the expansion of the residential city in order to focus efforts on the existing one; however, the latter is still being approached in a rigid manner, from a highly mercantilized and conservative view of housing, leaving out important spatial or sociological variables, and promoting the reproduction of a housing stock that was not designed for the current context.

Critical urban theory allows all of this to be contextualized both in an internally contradictory framework, typical of the urban condition, and in a system of unequal governance. Within this scenario, taking the Metropolitan Area of Bilbao as a case study and based on an analytical tool of its own design, the work allows to demonstrate two issues: as opposed to some usual discourses that tend to simplify these and other urban challenges as a matter of confronting sides that are coherent in their positions, the complexity of these problems forces to assume the transversal nature of certain contradictions that are common to many of the different agents and groups that, with uneven role and power, participate in this process of urban governance; from that same critical theory, it is possible to propose that as a result of those contradictions, and due to its transversal character, different alternatives arise within the current system of social organization itself.
\end{abstract}

Based on the previous theoretical framework, an empirical work is developed focusing on some possible alternatives arising from two major contradictions of capitalism in which the phenomena identified around access to housing in this region can be contextualized. On the one hand, in a supposedly self-regulated market, there is a gap between the characteristics of supply and those of demand. This generates, at the same time as situations of exclusion, a series of opportunities for access that are unequally distributed by the geography of the region. On the other hand, there is a strong imbalance between the use value and the exchange value of housing. But the predominance of the latter leads to the emergence of different and alternative management agents, throughout the process of access to housing, with different levels of social responsibility incorporated into their activity.

In order for these opportunities to be taken advantage of, a strategy has been identified that points to the need to address issues such as the overflow of the current property structure, the break with the dogma of corresponding to a cohabitation unit an actual dwelling as an indivisible unit, or -facing a system that favours each cohabitation unit to tackle individually the access to housing-collective action taken by the demand side. Despite their important challenges and weaknesses, these analysed agents can play a fundamental role in carrying out this strategy, by concentrating the management of multiple dwellings, having the potential to advise and accompany, or the capacity to act on larger scales of planning and execution. 
Índice

Índice General

Índice de Anexos $\quad$ VIII

Índice de Gráficas $\quad$ X

Índice de Tablas $\quad$ XIV

Índice de Mapas $\quad$ XVII

Índice de Imágenes $\quad$ XIX

Índice de Esquemas $\quad$ XXI

Índice de Figuras $\quad$ XXII

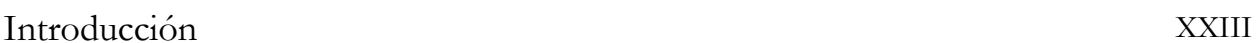

\section{Parte I}

Contexto, marco de análisis y planteamiento

\section{Objeto y contexto: \\ 1 la vivienda en el capitalismo avanzando}

1.1 LA DIMENSIÓN SOCIAL DE LA VIVIENDA EN UNA CRISIS URBANA GLOBAL 5

1.1.1 Presentación: la complejidad y los retos de abordar 'la vivienda' 5

1.1.2 Una ciudad residencial excluyente 11

$\begin{array}{ll}\text { 1.1.3 Carácter estructural de los retos urbanos } & 17\end{array}$

1.2 UN MARCO PARA LA COMPRENSIÓN Y LA BÚSQUEDA DE RESPUESTAS 32

1.2.1 La teoría urbana crítica como herramienta de investigación 33

1.2.2 La contradicción como característica de la condición urbana 37

1.2.3 Una gobernanza urbana desigual 41

1.2.4 La transversalidad de las contradicciones 49

1.3 PLANTEAMIENTO DE LA INVESTIGACIÓN 52

1.3.1 Necesidades, enfoque y objetivos

1.3.2 Estado de la cuestión

1.3.3 Hipótesis $\quad 65$

1.3.4 De la teoría urbana crítica al análisis empírico: aproximación metodológica 66 
Parte II

Material, métodos y resultados

\section{Contradicciones, efectos y respuestas 2 en procesos de gobernanza urbana}

2.1 UNA HERRAMIENTA DE ANÁLISIS

2.1.1 La generación de contradicciones 74

$\begin{array}{lll}\text { 2.1.2 } & \text { Reflexiones previas a su aplicación } & 80\end{array}$

2.2 EL ÁREA METROPOLITANA DE BILBAO COMO ÁMBITO

2.2.1 Justificación de la elección 84

$\begin{array}{lll}\text { 2.2.2 Justificación de la delimitación } & 94\end{array}$

2.3 SITUACIÓN PROBLEMÁTICA Y METAS 102

2.3.1 Necesidad de vivienda alta e incapacidad económica de demanda 105

2.3.2 Oferta inadecuada, pero no insuficiente 118

2.3.3 Ciudad existente con necesidad de intervención integradora 135

2.3.4 Respuestas en marcha: metas para enfrentar la situación 144

2.4 GENERACIÓN DE CONTENIDO 146

$\begin{array}{lll}\text { 2.4.1 Sociedad civil 'anónima' } & 147\end{array}$

2.4.2 Sociedad civil organizada y representada 155

$\begin{array}{lll}2.4 .3 & \text { Instituciones públicas } & 160\end{array}$

$\begin{array}{llr}2.4 .4 & \text { Academia } & 168\end{array}$

$\begin{array}{lll}2.5 & \text { DESARROLLO DE INSTRUMENTOS } & 172\end{array}$

2.5.1 Declaraciones, firmas, pactos y cartas 172

$\begin{array}{lll}\text { 2.5.2 Marco legislativo } & 176\end{array}$

$\begin{array}{llr}2.5 .3 & \text { Planificación } & 187\end{array}$

2.5.4 Otros 196

2.6 CONDICIONANTES Y OBSTÁCULOS 202

2.6.1 Poder económico por encima de la justicia social 204

2.6.2 Visión conservadora del espacio doméstico 217

2.6.3 Fuerte inercia urbanizadora heredada 232

2.7 ¿HAY ALTERNATIVAS? 255

2.7.1 Contextualizando las contradicciones en un marco estructural 256

2.7.2 Identificación de alternativas: una base para la investigación empírica 262 


\section{Alternativas espaciales: \\ 3 viviendas existentes infrautilizadas}

$3.1 \quad$ ACOTACIÓN DEL OBJETO DE ESTUDIO 283

3.1.1 El drama de un parque de viviendas infrautilizado 283

3.1.2 Metodología para explotar datos de la oferta de vivienda libre 285

3.2 TRABAJOS PREVIOS: INDICADORES DE BASE 303

3.2.1 Condiciones económicas para el acceso 303

3.2.2 Condiciones espaciales para el acceso 319

3.3 UN PARQUE POR ADAPTAR 330

3.3.1 Accesibilidad total 330

3.3.2 Análisis por áreas: homogeneización y polarización 341

3.3.3 Territorialización del potencial 358

$\begin{array}{lll}3.4 & \text { CONCLUSIONES PARCIALES } & 367\end{array}$

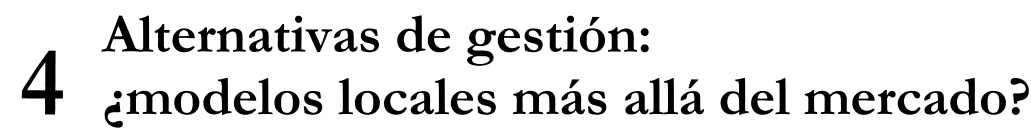

4.1 ACOTACIÓN DEL OBJETO DE ESTUDIO 381

4.1.1 Islas en un modelo inmobiliario hegemónico 381

4.1.2 Desarrollo de un mapa de agentes con capacidad de transformación 383

4.2 CARACTERÍSTICAS PRINCIPALES DE LAS INICIATIVAS 389

4.2.1 Sistema público de vivienda 389

4.2.2 Agentes privados 393

4.2.3 Programas de urgencia social 397

$\begin{array}{lll}4.2 .4 & \text { Otros caminos } & 400\end{array}$

4.3 SISTEMA PÚBLICO DE VIVIENDA 404

$\begin{array}{lll}4.3 .1 & \text { Visesa } & 404\end{array}$

$\begin{array}{lll}4.3 .2 & \text { Alokabide } & 412\end{array}$

$\begin{array}{lll}4.3 .3 & \text { Bizigune } & 418\end{array}$

$\begin{array}{lll}4.3 .3 & \text { ASAP } & 430\end{array}$ 
4.3.5 Reproducción de una estructura de unidades de convivencia atomizada 436

4.4 ALTERNATIVAS PRIVADAS EN BÚSQUEDA DE LO COLECTIVO 440

4.4.1 Sumae Coop. $\quad 440$

4.4.2 Urbania ZH Gestión 441

4.4.3 Marco para cooperativas de vivienda en Euskadi 444

4.4.4 Etxekoop 449

4.4.5 Egunsentia Aurora 451

4.4.6 Agrupación de unidades de convivencia como fundamento del proyecto 454

4.5 PROGRAMAS DE URGENCIA SOCIAL 457

4.5.1 Ayudas de Emergencia Social $\quad 457$

4.5.2 Prestación Complementaria de Vivienda 460

$\begin{array}{lll}\text { 4.5.3 Eguzkilore } & 461\end{array}$

4.5.4 Barriztu 463

4.5.6 Colaborar para incluir situaciones de vulnerabilidad 465

$\begin{array}{lll}\text { 4.6 OTROS CAMINOS Y ALTERNATIVAS } & 467\end{array}$

$\begin{array}{lll}\text { 4.6.1 Jóvenes Solidarios } & 467\end{array}$

$\begin{array}{lll}\text { 4.6.2 Etikalia } & 469\end{array}$

4.6.3 Renta Vitalicia y Alquiler Garantizado $\quad 472$

$\begin{array}{lll}4.7 & \text { SÍNTESIS DEL DAFO } & 475\end{array}$

$\begin{array}{lll}\text { 4.7.1 Debilidades } & 475\end{array}$

$\begin{array}{lll}\text { 4.7.2 Amenazas } & 481\end{array}$

$\begin{array}{lll}\text { 4.7.3 } & \text { Fortalezas } & 485\end{array}$

$\begin{array}{lll}\text { 4.7.4 Oportunidades } & 492\end{array}$

$\begin{array}{lll}4.8 & \text { CONCLUSIONES PARCIALES } & 494\end{array}$

Parte III

Discusión y conclusiones

\section{Agentes locales ante espacios de oportunidad y 5 agrupaciones}

5.1 VARIABLES Y CONDICIONANTES A TENER EN CUENTA 501

5.1.1 Estructura y escala de la propiedad 502

$\begin{array}{lll}\text { 5.1.2 Soporte elemental buscado } & 508\end{array}$ 
5.1.3 Tipología de vivienda ofertada 514

5.1.4 Modo de participación en el proceso 522

5.1.5 Utilización de estrategias colaborativas 532

5.1.6 Agrupación de personas como estrategia de empoderamiento 539

5.1.7 Síntesis de las variables 541

5.2 CAPACIDADES Y LIMITACIONES $\quad 544$

\section{De la contradicción a la alternativa:}

6 un cambio en marcha

6.1 CONFIRMACIÓN DE LA HIPÓTESIS 549

6.1.1 Un potencial de aprovechamiento sin explotar 549

6.1.2 La contradicción como generadora de alternativas 553

6.2 OPORTUNIDADES COMPLEMENTARIAS: DIVERSIFICACIÓN Y COHESIÓN 556

6.2.1 Diversificar la vivienda en respuesta a necesidades y usos cambiantes 556

6.2.2 Cohesionar la sociedad ocupando los espacios de acumulación 561

6.3 LA ACCIÓN COLECTIVA COMO HERRAMIENTA 565

6.4 NECESIDAD Y CONTRADICCIONES VIGENTES Y EN EVOLUCIÓN 574

6.5 ABRIR Y FLEXIBILIZAR LOS INSTRUMENTOS DE PLANIFICACIÓN 596

6.6 PERSPECTIVAS DE TRABAJO $\quad 601$

$\begin{array}{ll}\text { BIBLIOGRAFÍA } & 603\end{array}$ 
Índice de Anexos

\begin{tabular}{|c|c|c|}
\hline Anexo I & MAPAS DE LOS MUNICIPIOS Y LAS ÁREAS GEOGRÁFICAS & 623 \\
\hline \multirow[t]{25}{*}{ Anexo II } & RESUMEN DE DATOS DEL MERCADO INMOBILIARIO UTILIZADOS & 629 \\
\hline & Área Metropolitana de Bilbao & 630 \\
\hline & Abanto Zierbena - Zierbena & 632 \\
\hline & Alonsotegi - Arrigorriaga - Zaratamo & 634 \\
\hline & Barakaldo* & 636 \\
\hline & Barrika & 652 \\
\hline & Basauri* & 654 \\
\hline & Berango & 664 \\
\hline & Bilbao* $^{*}$ & 666 \\
\hline & Erandio - Astrabudua & 748 \\
\hline & Etxebarri & 750 \\
\hline & Galdakao & 752 \\
\hline & Getxo* & 754 \\
\hline & Leioa* & 780 \\
\hline & Loiu - Derio - Sondika & 790 \\
\hline & Muskiz & 792 \\
\hline & Ortuella & 794 \\
\hline & Portugalete* & 796 \\
\hline & Santurtzi* & 808 \\
\hline & Sestao* & 826 \\
\hline & Sopela & 836 \\
\hline & Trapagaran & 838 \\
\hline & Urduliz & 840 \\
\hline & Zamudio - Lezama - Larrabetzu & 842 \\
\hline & * Cuentan con áreas geográficas inframunicipales & \\
\hline \multirow[t]{6}{*}{ Anexo III } & MUESTRA DE VIVIENDAS PARA EL ESTUDIO TIPOLÓGICO & 845 \\
\hline & $30-45 \mathrm{~m}^{2}$ & 847 \\
\hline & $46-60 \mathrm{~m}^{2}$ & 848 \\
\hline & $61-75 \mathrm{~m}^{2}$ & 858 \\
\hline & $76-90 \mathrm{~m}^{2}$ & 881 \\
\hline & $91-105 \mathrm{~m}^{2}$ & 912 \\
\hline
\end{tabular}


$106-120 \mathrm{~m}^{2}$

$121-150 \mathrm{~m}^{2}$

944

$151-180 \mathrm{~m}^{2}$

957

$181-200 \mathrm{~m}^{2}$

969

201-250 m²

975

251-300 $\mathrm{m}^{2}$

985

$301-400 \mathrm{~m}^{2}$

990

$601-700 \mathrm{~m}^{2}$

993

$>1.500 \mathrm{~m}^{2}$

994 


\section{Índice de Gráficas}

Gráfica 2.1 Superficie de suelo del AMB respecto del total de Euskadi y Bizkaia.

Gráfica 2.2 Población del AMB respecto del total de Euskadi y Bizkaia.

Gráfica 2.3 Superficie de suelo del AMB respecto del total de Bizkaia, según su clasificación urbanística.

Gráfica 2.4 Superficie de suelo del AMB respecto del total de Euskadi, según su clasificación urbanística.

Gráfica 2.5 Superficie de suelo artificializado del AMB respecto del total de Euskadi y Bizkaia.

Gráfica 2.6 Superficie de suelo no artificializado del AMB respecto del total de Euskadi y Bizkaia.

Gráfica 2.7 Evolución de la necesidad de vivienda en Euskadi y Bizkaia (hogares).

Gráfica 2.8 Solicitudes de vivienda que constan en Etxebide (por cada 1.000 habitantes).

Gráfica 2.9 Unidades de convivencia perceptoras de Ayudas de Emergencia Social (por cada 1.000 habitantes).

Gráfica 2.10 Evolución de las personas atendidas por el Área de Atención Sin Hogar de Cáritas Bizkaia.

Gráfica 2.11 Evolución de la oferta de los precios de alquiler en Bilbao $\left(€ / \mathrm{m}^{2}\right)$.

Gráfica 2.12 Evolución de la renta de trabajo familiar media.

Gráfica 2.13 Evolución del desempleo en Euskadi (\%).

Gráfica 2.14 Porcentajes de régimen de tenencia de la vivienda por población total, Bilbao 1940-1960.

Gráfica 2.15 Número de transacciones inmobiliarias de vivienda libre en Bizkaia.

Gráfica 2.16 Evolución de la oferta de los precios de venta en Barakaldo, Basauri, Berango, Bilbao, Galdakao, Getxo, Leioa, Portugalete, Santurtzi, Sestao y Sopela $\left(€ / \mathrm{m}^{2}\right)$.

Gráfica 2.17 Evolución del número de renuncias a viviendas adjudicadas por Etxebide.

Gráfica 2.18 Población total en el Gran Bilbao, por lugar de nacimiento.

Gráfica 2.19 Evolución del tamaño de hogar en el Área Metropolitana de Bilbao (19912011).

Gráfica 2.20 Las tres principales preocupaciones de la sociedad vasca (suma de la multirrespuesta) entre 1999 y 2016.

Gráfica 2.21 Número de publicaciones académicas según palabra clave y periodo de publicación. 
Gráfica 2.22 Número de publicaciones académicas según palabra clave y periodo de

publicación.

Gráfica 2.23 Número de publicaciones académicas según palabra clave y periodo de publicación.

Gráfica 2.24 Evolución del parque, población y precio medio de oferta de la vivienda libre en España en el periodo 2001-2013 (base 100\% en 2001).

Gráfica 2.25 Evolución de la población en el Área Metropolitana de Bilbao.

Gráfica 2.26 Evolución de la población en el AMB. INE, Padrón Municipal.

Gráfica 3.1 Población de 18 años y más por estrato de renta personal anual en Bizkaia.

Gráfica 3.2 Variación del precio medio de venta $(€)$ por área de análisis respecto a la media del AMB.

Gráfica 3.3 Variación del precio medio de alquiler $(€)$ por área de análisis respecto a la media del AMB.

Gráfica 3.4 Precios unitarios de venta (€) de la muestra de viviendas ordenados de menor a mayor y precio medio, en el AMB.

Gráfica 3.5 Precios unitarios de alquiler $(€)$ de la muestra de viviendas ordenados de menor a mayor y precio medio, en el AMB.

Gráfica 3.6 Precios unitarios de venta $(€)$ de la muestra de viviendas ordenados de menor a mayor, por área de análisis (sin incluir áreas inframunicipales), y precio medio del AMB.

Gráfica 3.7 Precios unitarios de alquiler $(€)$ de la muestra de viviendas ordenados de menor a mayor, por área de análisis (sin incluir áreas inframunicipales), y precio medio del AMB.

Gráfica 3.8 Precios unitarios de venta $(€)$ de la muestra de viviendas ordenados de menor a mayor en las áreas geográficas de Barakaldo, y estructura de precios unitarios total del AMB.

Gráfica 3.9 Precios unitarios de venta $(€)$ de la muestra de viviendas ordenados de menor a mayor en las áreas geográficas de Getxo, y estructura de precios unitarios total del AMB.

Gráfica 3.10 Porcentaje de viviendas de la muestra de la oferta de venta analizada en las áreas geográficas y el $\mathrm{AMB}$, por grupos de precios $(€)$.

Gráfica 3.11 Porcentaje de viviendas de la muestra de la oferta de alquiler analizada en las áreas geográficas y el AMB, por grupos de precios (€).

Gráfica 3.12 Precios unitarios (€) de venta en el AMB, y accesibilidad económica según tamaño de agrupación bajo el PMT.

Gráfica 3.13 Precios unitarios (€) de alquiler en el AMB, y accesibilidad económica según tamaño de agrupación bajo el PMT

Gráfica 3.14 Accesibilidad económica a la oferta analizada por área geográfica y tamaño de la agrupación de personas necesario bajo el PMT.

Gráfica 3.15 Superficie de las viviendas analizadas, por franjas, en el AMB. 
Gráfica 3.16 Accesibilidad espacial a la oferta analizada por área geográfica y tamaño de la agrupación de personas necesario bajo la SMP.

Gráfica 3.17 Accesibilidad total a la muestra de viviendas en venta en el AMB, a partir del cruce de la accesibilidad económica y espacial en cada vivienda.

Gráfica 3.18 Accesibilidad total a la muestra de viviendas en alquiler en el AMB, a partir del cruce de la accesibilidad económica y espacial en cada vivienda.

Gráfica 3.19 Accesibilidad económica a la muestra de viviendas en venta en el AMB, según incremento de coste de transformación.

Gráfica 3.20 Accesibilidad total a la muestra de viviendas en venta en el AMB, según incremento de coste de transformación. Valores relativos por franja, conjunto de accesibles y muestra total.

Gráfica 3.21 Desglose en franjas de superficie de la accesibilidad total bruta a la muestra de viviendas en venta y alquiler en el AMB.

Gráfica 3.22 Porcentaje de viviendas de la muestra del AMB con accesibilidad total bruta y con una superficie por encima de la SMP.

Gráfica 3.23 Porcentaje de viviendas de la muestra del AMB con una superficie por encima de la SMP según accesibilidad total neta.

Gráfica 3.24 Accesibilidad económica a la muestra de viviendas en venta y alquiler del AMB de los municipios del Grupo 1.

Gráfica 3.25 Accesibilidad económica a la muestra de viviendas en venta y alquiler del AMB de los municipios del Grupo 2.

Gráfica 3.26 Accesibilidad económica a la muestra de viviendas en venta y alquiler del AMB de los municipios del Grupo 3.

Gráfica 3.27 Accesibilidad económica a la muestra de viviendas en venta y alquiler del AMB de los municipios del Grupo 4.

Gráfica 3.28 Accesibilidad económica a la muestra de viviendas en venta y alquiler por áreas inframunicipales de Barakaldo, Bilbao y Getxo.

Gráfica 3.29 Accesibilidad espacial a la muestra de viviendas en venta y alquiler del AMB de los municipios del Grupo 1.

Gráfica 3.30 Accesibilidad espacial a la muestra de viviendas en venta y alquiler del AMB de 346 los municipios del Grupo 2.

Gráfica 3.31 Accesibilidad espacial a la muestra de viviendas en venta y alquiler del AMB de los municipios del Grupo 3.

Gráfica 3.32 Accesibilidad espacial a la muestra de viviendas en venta y alquiler del AMB de los municipios del Grupo 4.

Gráfica 3.33 Accesibilidad espacial a la muestra de viviendas en venta y alquiler por áreas inframunicipales de Barakaldo y Getxo.

Gráfica 4.1 Número de viviendas libres movilizadas por el programa Bizigune entre 2003 y 2016.

Gráfica 6.1 Evolución de la renta media en Euskadi en el periodo 2009-2016.

Gráfica 6.2 Evolución de los ingresos mensuales netos per cápita en Euskadi en el periodo 2008-2016, por decilas de ingresos. 
Gráfica 6.3 Evolución de los precios de la oferta de vivienda usada en venta (municipios de

Barakaldo, Basauri, Berango, Bilbao, Galdakao, Getxo, Leioa, Ortuella,

Portugalete, Santurtzi, Sestao y Sopela) y alquiler (Bilbao) en el AMB en el periodo 2007-2018. 


\section{Índice de Tablas}

Tabla 1.1 Algunos hitos de las respuestas pública y privada ante la problemática de la vivienda en el AMB entre finales del siglo XIX y finales del siglo XX.

Tabla 1.2 Principales procesos dados en la evolución de la gobernanza urbana.

Tabla 1.3 Tres posibles grandes fases de gobernanza urbana en un proceso de transformación social.

Tabla 2.1 Síntesis de las dos aproximaciones analíticas a la gobernanza.

Tabla 2.2 Delimitaciones del área metropolitana de Bilbao en función del instrumento o fuente de consulta.

Tabla 2.3 Comparativa de diferentes delimitaciones del área metropolitana de Bilbao, y su peso respecto a Euskadi y Bizkaia.

Tabla 2.4 Municipios que conforman la delimitación del Área Metropolitana de Bilbao empleada en este trabajo.

Tabla 2.5 Indicadores del coste de emancipación de la población joven en Euskadi para los años 2007, 2011 y 2013.

Tabla 2.6 Estructura del hogar en el Área Metropolitana de Bilbao, por número de hogares.

Tabla 2.7 Empresas y personas empleadas en Bizkaia según no de empleados en 1971.

Tabla 2.8 Relación entre los principales conflictos de la situación problemática, las metas definidas como respuesta y los condicionantes y obstáculos detectados.

Tabla 2.9 Consideraciones cualitativas para corregir la planificación residencial del AMB.

Tabla 2.10 Año de aprobación del planeamiento vigente por municipio en el AMB, y número de modificaciones puntuales aprobadas desde entonces.

Tabla 2.11 Síntesis de la demostración parcial de la hipótesis general y construcción de la base para la demostración empírica y completa de la misma.

Tabla 3.1 Número de viviendas total existente en el AMB y número de viviendas utilizadas como universo de la muestra de venta para el análisis; sin desglosar en áreas inframunicipales en aquellos casos disponibles.

Tabla 3.2 Número de viviendas total existente en el AMB y número de viviendas utilizadas como universo de la muestra de alquiler para el análisis; sin desglosar en áreas inframunicipales en aquellos casos disponibles.

Tabla 3.3 Clasificación utilizada del número de personas o rentas medias de $1.400 €$ necesarias para un acceso económico digno a la vivienda.

Tabla 3.4 Superficie media por persona $\left(\mathrm{m}^{2}\right)$ según el tamaño de hogar en el AMB.

Tabla 3.5 Superficie media por persona $\left(\mathrm{m}^{2}\right)$ según la superficie útil media de la vivienda en el AMB.

Tabla 3.6 Superficie media por persona $\left(\mathrm{m}^{2}\right)$ según la estructura del hogar en el AMB. 
Tabla 3.7 Franjas de superficies en las que se han clasificado las viviendas o inmuebles de la muestra según los datos disponibles de su superficie.

Tabla 3.8 Número máximo de personas por vivienda definido según las franjas de superficie utilizadas y una superficie media por habitante de unos $30 \mathrm{~m}^{2}$.

Tabla 3.9 Situaciones de incompatibilidad entre accesibilidad espacial y económica según los criterios establecidos de PMT y SMP para la identificación de la Accesibilidad Total Bruta.

Tabla 3.10 Coeficientes estimativos de incremento del precio de oferta según el coste de la intervención de transformación de la vivienda.

Tabla 3.11 Situaciones de accesibilidad espacial por encima de la SMP con posibilidad de acoger a personas sin capacidad de pago.

Tabla 3.12 Posición del Gran Bilbao en las 30 provincias con el precio medio del $\mathrm{m}^{2} \mathrm{de}$ vivienda libre en venta más alto de España.

Tabla 3.13 Accesibilidad económica a la muestra de la oferta en el AMB según tamaño de agrupación bajo el PMT.

Tabla 3.14 Clasificación de las viviendas analizadas según franja de superficie y régimen de tenencia.

Tabla 3.15 Porcentaje de la muestra con valores positivos en los indicadores de flexibilidad actual utilizados en el análisis tipológico de las viviendas en oferta.

Tabla 3.16 Porcentaje de la muestra con valores positivos en los indicadores de adaptabilidad futura utilizados en el análisis tipológico de las viviendas en oferta.

Tabla 3.17 Accesibilidad total a la muestra de viviendas en oferta en el AMB, a partir del cruce de la accesibilidad económica y espacial en cada vivienda.

Tabla 3.18 Accesibilidad total neta a la muestra de viviendas en venta en el AMB, según incremento de coste de transformación.

Tabla 3.19 Accesibilidad total bruta a la muestra de viviendas en venta y alquiler en el AMB para viviendas con superficie por encima de la SMP correspondiente a su franja de accesibilidad total.

Tabla 3.20 Tamaño del hogar en el AMB.

Tabla 3.21 Viviendas de la muestra en venta y alquiler con accesibilidad total en el AMB, clasificadas por franja de superficie y tamaño máximo de la unidad de convivencia por encima de la SMP.

Tabla 3.22 Síntesis de la accesibilidad total estimada para las 98 áreas espaciales analizadas, clasificadas de más a menos favorable.

Tabla 4.1 Principales funciones relacionadas con el acceso a la vivienda de los casos seleccionados en el AMB.

Tabla 4.2 Renta media personal y alquileres máximos protegidos $(€)$ en el AMB para los programas ASAP y Bizigune.

Tabla 4.3 Tasa de ocupación en las viviendas movilizadas por el programa ASAP en el AMB.

Tabla 5.1 Análisis de la utilización de una estrategia de agrupación de unidades de convivencia como herramienta para el acceso digno a una vivienda por los diferentes agentes de gestión de vivienda analizados en el capítulo 4. 
Tabla 5.2 Síntesis del análisis de las variables de encaje de los agentes locales estudiados con los espacios de oportunidad.

Tabla 5.3 Síntesis de algunas de las principales características, de los agentes analizados, que pueden favorecer u obstaculizar una puesta en práctica de la estrategia de agrupación de unidades de convivencia y transformación de viviendas planteada para lograr un acceso espacial y económicamente digno.

Tabla 6.1 Comparativa de las posibles lecturas de las alternativas detectadas en la investigación según la manera de aproximarse a las mismas.

Tabla 6.2 Reparto del régimen de tenencia de la vivienda principal en Euskadi por grandes tipos en el periodo 1991-2017. 


\section{Índice de Mapas}

Mapas 2.1 y 2.2 Localización del Área Metropolitana de Bilbao en Europa, España, Euskadi y Bizkaia.

Mapa 2.3 El área metropolitana de Bilbao y su entorno inmediato.

Mapa 2.4 Cobertura de los usos del suelo en el Área Metropolitana de Bilbao.

Mapa 2.5 Clasificación urbanística de los usos del suelo en el Área Metropolitana de Bilbao.

Mapa 2.6 Municipios que conforman la delimitación del Área Metropolitana de Bilbao empleada en este trabajo.

Mapas 2.7 a 2.10 Alternativas de planificación en Bakio, según el Avance del PGOU.

Mapa 2.11 Porcentaje de voto del Partido Nacionalista Vasco en las elecciones municipales de 2015 en el AMB.

Mapa 2.12 Solicitudes de vivienda en Etxebide en 2015 en el AMB (por cada 1.000 habitantes).

Mapa 2.13 Evolución del padrón municipal de habitantes entre 1998 y 2017. Elaboración propia a partir del INE.

Mapas 3.1 y 3.2 Delimitaciones de los términos municipales del AMB, y de las 98 áreas utilizadas por el portal inmobiliario Idealista.

Mapa 3.3 Precio medio de la oferta en venta analizada.

Mapa 3.4 Precio medio de la oferta en alquiler analizada.

Mapas 3.5 y 3.6 Porcentaje de viviendas de la muestra por debajo del PMT, para la venta y el alquiler.

Mapa 3.7 Porcentaje de viviendas en venta por franja de superficie y área geográfica.

Mapa 3.8 Porcentaje de viviendas en alquiler por franja de superficie y área geográfica.

Mapas 3.9 a 3.12 Clasificación de las 98 áreas geográficas por grupo de accesibilidad económica y espacial, para la oferta en venta y alquiler.

Mapa 3.13 Accesibilidad económica a la oferta en venta de las áreas espaciales en la desembocadura de la ría del Ibaizabal.

Mapa 3.14 Accesibilidad espacial a la oferta en venta de las áreas espaciales en la desembocadura de la ría del Ibaizabal.

Mapa 3.15 Vista parcial de la accesibilidad económica a la oferta en venta de las áreas geográficas de los municipios de Etxebarri, Basauri y barrio de Bolueta en Bilbao, correspondiente a las imágenes 3.2 y 3.3 .

Mapa 3.16 Accesibilidad económica a la oferta en alquiler en los barrios de Las Arenas, Neguri y Romo, en Getxo. 
Mapa 3.17 Vista parcial de la accesibilidad económica a la oferta en venta de Bilbao.

Mapa 3.18 Vista parcial de la accesibilidad económica a la oferta en alquiler de Bilbao.

Mapa 3.19 Vista parcial de la accesibilidad espacial a la oferta en venta de Bilbao.

Mapa 3.20 Vista parcial de la accesibilidad espacial a la oferta en alquiler de Bilbao.

Mapa 3.21 Clasificación de las 98 áreas geográficas por grado de adecuación del cruce entre la accesibilidad económica y espacial según lo establecido en la Tabla 3.22, para la venta.

Mapa 3.22 Clasificación de las 98 áreas geográficas por grado de adecuación del cruce entre la accesibilidad económica y espacial según lo establecido en la Tabla 3.22, para el alquiler.

Mapa 3.23 Renta media familiar predominante por sección censal en el AMB.

Mapa 3.24 Tamaño medio del hogar predominante por sección censal en el AMB.

Mapa 3.25 Año de construcción de los edificios residenciales predominante por sección censal en el AMB.

Mapa 6.1 Clasificación de los municipios en función de la fecha en que se produce 578 el punto de inflexión y comienza una nueva fase de subida de precios de venta en el AMB. 


\section{Índice de Imágenes}

Imagen 2.1 Original y montaje sobre la casa Bianchetti de Luigi Snozzi hecho por Jean-Pierre Junker para el primer curso de Sociología en el ETH de Zurich en 1990.

Imagen 2.2 Vivienda en Coutras, Francia, de Lacaton\&Vassal.

Imagen 2.3 Edificio industrial en el barrio de Castaños, Bilbao.

Imagen 2.4 Edificio mostrado en la Imagen 2.3 en fase de transformación en apartamentos turísticos.

Imagen 2.5 Pintada (física o digital) sobre la fachada de una sede social del Partido Nacionalista Vasco en Getxo, Bizkaia.

Imagen 2.6 Barricada levantada en la estrada de Tosu, Getxo, como protesta y acto de protección ante la inminencia de las obras de ejecución del aparcamiento.

Imagen 2.7 Material publicitario de la promoción de un edificio de viviendas de nueva construcción en el municipio de Erandio.

Imágenes 2.8 y 2.9 Material publicitario de la promoción de un edificio de viviendas de nueva construcción en el municipio de Bilbao

Imágenes 2.10 a 2.15 Ejemplos de folletos publicitarios de oferta inmobiliaria residencial en Tokyo, Japón.

Imágenes 2.16 a 2.18 Zorrozaurre y Punta Zorroza, el paradigma de los espacios de oportunidad de Bilbao desde la óptica de la reproducción del urbanismo de las últimas décadas.

Imagen 3.1 Vista parcial de la desembocadura de la ría del Ibaizabal.

Imagen 3.2 Vista parcial de los municipios de Etxebarri, Basauri y barrio de Bolueta en Bilbao en 2001.

Imagen 3.3 Vista parcial de los municipios de Etxebarri, Basauri y barrio de Bolueta en Bilbao en 2017.

Imagen 3.4 Vista parcial de los barrios de Las Arenas, Neguri y Romo, en Getxo.

Imagen 3.5 Vista de la zona sureste del Ensanche y el barrio de San Francisco, en Bilbao.

Imagen 3.6 Evolución del barrio de Miribilla en Bilbao, desde su origen como punto de extracción de mineral en abandono (1991), pasando por su urbanización (2002) y su estado completado (2017).

Imagen 4.1 Esquemas conceptuales del Ecobarrio de Toledo en Santa María de Benquerencia.

Imagen 4.2 Esquema de la metodología de trabajo para el Estudio de Vivienda Vacía en Andoain, Gipuzkoa.

Imágenes 4.3 a 4.6 Visitas al solar, talleres de diseño, participación en la construcción, y 446 resultado final de una cooperativa de viviendas en Berlín. 
Imagen 4.7 Inmueble propiedad de Viviendas Municipales de Bilbao tapiado tras

Imágenes 5.1 y 5.2 Ejemplo de edificios de vivienda colectiva en el AMB (Sopela y Getxo, respectivamente) que encajan con la categoría de vivienda-caja y vivienda-estuche de Paricio y Sust.

Imágenes 5.3 a 5.5 Ejemplos de promociones de vivienda protegida recientes o en marcha en el AMB en Basauri, Bilbao y Leioa.

Imágenes 5.6 a 5.8 Ejemplos de promociones de vivienda libre recientes o en marcha en el AMB, en Erandio y Bilbao.

Imágenes 5.9 y 5.10 Ejemplos de promociones de vivienda protegida recientes o en marcha en el AMB en Barakaldo, Bilbao y Sondika.

Imágenes 5.11 a 5.14 Algunos de los tipos de vivienda planteados en el grupo Frauen-WerkStadten, Viena, vivienda tipo del edificio de viviendas en alquiler en Mataró, planta tipo de edifico de viviendas en Gavà, Barcelona, y una de las tipologías presente en un edificio de viviendas para jóvenes y mayores en Sevilla.

Imagen 5.15 Un integrante de un equipo técnico colabora con miembros de una asociación de inquilinos a planificar y diseñar el reacondicionamiento de sus viviendas.

Imágenes 6.1 a 6.4 Soporte espacial y cuatro ejemplos de apropiación diferentes en las viviendas sociales Nemausus de en Nimes, Francia.

Imagen 6.5 Vistas interiores de algunos apartamentos en el edificio Mitre, Barcelona.

Imágenes 6.6 a 6.9 Extracto de la serie fotográfica de Tom Hunter en las torres de Holly 560 Street, Londres.

Imagen 6.10 Vista exterior parcial del edificio de apartamentos en el 860-880 de 560 Lake Shore Drive, Chicago. 


\section{Índice de Esquemas}

Esquema 2.1 Esquema conceptual de la generación de contradicciones en procesos de gobernanza urbana.

Esquema 2.2 Ejes internos del esquema de generación de contradicciones en procesos de gobernanza urbana propuesto.

Esquema 2.3 Síntesis del desarrollo de la generación de contradicciones en procesos de gobernanza urbana planteada en el Esquema 2.1 a partir del contenido elaborado en el capítulo.

Esquema 2.4 Abstracción gráfica de la herramienta de análisis propuesta.

Esquema 2.6 Desarrollo de la hipótesis general a partir de las alternativas concretas identificadas completando el esquema de generación de contradicciones en procesos de gobernanza urbana.

Esquema 4.1 Adaptación de la matriz DAFO a la investigación.

Esquema 6.1 Esquema conceptual de las estrategias del megáfono y el embudo en procesos de 570 gobernanza. 


\section{Índice de Figuras}

Figuras 2.1 a 2-4 Situación en el Esquema 2.2 de un agente (dos variables o valor unificado), o de un mapa de agentes (dos variables o valor unificado). 


\section{Introducción}

Este trabajo busca abordar ciertos conflictos de un tema fundamental como es la vivienda, poniendo especial énfasis en los propios de los costes económicos de acceso, las carencias tipológicas respecto a unas necesidades habitacionales desde hace tiempo cambiantes, y la necesidad de gestionar un parque heredado obsoleto. La motivación de hacerlo no se debe a que sean cuestiones olvidadas, pues aparecen constantemente en el debate público y en las preocupaciones ciudadanas, y se vienen abordando desde hace tiempo desde diversas miradas especializadas. Pero a pesar de ello, una primera lectura diría que paradójicamente, no se logran soluciones firmes para atajarlos o reducirlos. En ese marco y con la intención de arrojar algo de luz, se ha pretendido desarrollar una investigación desde una posición post-disciplinar, moviéndose entre diversas especialidades y metodologías, abordando desde el análisis complejo un tema a menudo excesivamente simplificado. La investigación se sitúa entre determinadas referencias teóricas y críticas, el análisis exhaustivo de la realidad geográfica, y los resultados parcialmente abstractos -aunque enmarcados en un contexto específico-. Se entiende que es este un espacio y un momento académico orientado al análisis, el debate y la presentación de posibles vías alternativas, y no a propuestas concretas propias de un momento posterior de gestión y toma de decisiones colectivas.

\section{La vivienda en el capitalismo avanzado}

La permanente presencia de 'la vivienda' en múltiples esferas de la sociedad no resta complejidad, conflictividad ni retos por afrontar a una cuestión cuya dimensión social, aparentemente consensuada de manera colectiva como prioritaria, queda en demasiadas ocasiones en segundo plano. Sintéticamente puede afirmarse que la ciudad residencial de la ciudad capitalista ha sido y es excluyente, y que mientras su evolución ha ido de la mano de ciertas mejoras en dimensiones técnicas, constructivas o sanitarias, ha dependido a su vez del mantenimiento y desarrollo de conflictos en otras, como la social -con una alta exclusión económica y espacial- o la territorial -con una sobredimensionada ocupación y una alta fragmentación del territorio-. Los efectos de lo anterior han sido en general acertadamente diagnosticados por diversos agentes públicos y privados, pero las explicaciones de sus causas y las respuestas a dar suelen ser superficiales y enfrentadas. Esto hace que, al igual que ocurre con otros retos urbanos y más allá de ciertas variaciones coyunturales propias de su contexto histórico, la vivienda presente conflictos con una clara continuidad desde los mismos orígenes de la revolución industrial.

Para poder profundizar en esta contradicción en torno a la vivienda y con el fin de alcanzar y entender las causas que la generan, se toma la teoría urbana crítica como herramienta de investigación transformadora. Ella permite situar dicha contradicción en un marco internamente contradictorio más amplio como es el capitalismo, cuyo desarrollo desigual se apoya de manera fundamental en la dimensión geográfica de la producción, organización, transformación y adaptación socio-espacial. Así mismo, permite comprender el tipo de gobernanza que hace posible la reproducción de todos esos procesos simultáneos. Esta se formaliza en mecanismos y estrategias para coordinar la interdependencia existente y ha sufrido en las últimas décadas diversos procesos que conviven entre sí: inclusión de agentes, re-escalamiento geográfico y reestructuración de las relaciones de poder, conflictos entre la democratización y 
tendencias autocráticas y tecnocráticas, empoderamiento y exclusión, o el mantenimiento de jerarquías previas en un marco más complejo y cambiante. Ambas cuestiones -contradicción estructural de la urbanización y gobernanza desigual-, claves en esta investigación, se entienden como transversales a la diversidad de espacios, escalas, agentes, organizaciones o instituciones que participan y/o se ven afectadas en todo el proceso. Una transversalidad que presenta diversas responsabilidades y grados de poder, pero que funciona a casi todos los niveles si bien la percepción de estos es muy diferente.

Desde la motivación transformadora de la que parte este trabajo y a partir del marco anterior, la necesidad de realizar correcciones queda por lo tanto patente. La vía de abordar estas puede variar, desde el corto plazo pragmático al largo plazo utópico, pasando por el momento intermedio de 'lo posible'. Será en esta tercera opción en la que se ha pretendido enmarcar la investigación. Los objetivos marcados son comprender las causas de fondo de unos efectos ampliamente conocidos, y plantear alternativas de transformación y reforma rupturista dentro del marco actual para avanzar hacia un acceso a la vivienda económica y tipológicamente digno, haciéndolo posible en el entorno construido existente. Una primera hipótesis general señala que, ante retos urbanos estructurales como este, para que se puedan dar alternativas transformadoras que surgen de y por las contradicciones- será necesario abordar las causas de fondo que están detrás de los efectos más palpables que impiden dichos objetivos, asumiendo su transversalidad. Lo cual permitirá identificar y abordar de manera conjunta espacios de oportunidad en la ciudad existente que permitan adecuarla a las necesidades vigentes, y espacios de poder en las formas actuales de gobernanza urbana para gestionar y poner en carga los primeros mediante relaciones más horizontales y colectivas.

\section{Estudiando las contradicciones en procesos de gobernanza urbana}

El primer paso para la demostración de todo ello ha sido buscar la manera de, por un lado, identificar y comprender la generación de contradicciones en procesos de gobernanza urbana, y por otro, localizar y analizar alternativas surgidas de las mismas. El carácter transversal de las contradicciones y la gobernanza desigual ha llevado al diseño de una herramienta de análisis que permite situar de manera simultánea a los diferentes agentes en diferentes momentos y espacios de la gobernanza. Estos se han sintetizado en los siguientes: la identificación de una situación problemática, la generación de contenido y definición de metas para abordarla, el diseño de instrumentos para alcanzarlas, la ejecución y puesta en práctica de las herramientas, y unos condicionantes y obstáculos que causan y/o potencian la problemática, afectan a las respuestas, y frenan el desarrollo de las metas.

$\mathrm{Al}$ aplicar esta herramienta al estado de la dimensión social de la vivienda en el Área Metropolitana de Bilbao -cuya delimitación y justificación como caso a analizar es revisada-, ha sido posible tanto poner a prueba su validez como desgranar para el objeto y ámbito de estudio en cuestión cada uno de esos elementos del proceso de gobernanza definidos. La problemática puede sintetizarse en una necesidad de vivienda alta con una baja capacidad económica de demanda, una oferta inadecuada si bien no insuficiente, y una ciudad existente con necesidad de intervención integradora. Con mayor o menor consenso, las metas que la sociedad ha definido para afrontar la anterior son las del acceso económico, la adecuación tipológica, y el aprovechamiento del parque existente. Para la definición de dichos fines se da una generación de contenido por parte 
de la sociedad civil 'anónima' y la organizada, las instituciones públicas o la academia, entre otros. Ese marco es además desarrollado a través de muy diversos instrumentos, agentes, ámbitos y escalas: declaraciones, firmas, pactos, cartas, leyes y normativas, planes y programas, ayudas, impuestos,... Y sin embargo, se dan tres grandes condicionantes y obstáculos internos que se enfrentan de manera clara a las tres metas definidas: un interés económico en la vivienda que está por encima de su función social, una visión conservadora del espacio doméstico, y una fuerte inercia urbanizadora heredada. Todo ello permite contextualizar con precisión la problemática de esta región en dos grandes contradicciones estructurales del capitalismo:

- El enorme desfase entre las tipologías espaciales y precios de oferta del parque residencial público y privado por un lado, y las características de las unidades de convivencia con necesidad de vivienda y baja capacidad de demanda por otro, formaliza para esta cuestión la contradicción entre la oferta y la demanda, cuya supuesta autorregulación en el caso de la vivienda ha quedado ampliamente deslegitimada.

- La habitual convivencia conflictiva de una visión de la vivienda como derecho humano fundamental y como objeto de inversión y acumulación de capital, como objeto de mercantilización y como espacio fundamental de desarrollo vital, formaliza una contradicción entre el valor de uso y valor de cambio que suele estar en desequilibrio en favor del segundo.

Para ambas contradicciones, el análisis desarrollado hace posible identificar sendas potenciales alternativas:

- La primera de ellas tiene la posibilidad de equilibrar el desajuste entre la oferta y la demanda de vivienda, adaptando la primera a la segunda y no al revés, gracias principalmente a un margen de maniobra existente tras la evolución de las unidades de convivencia - cada vez más diversas y de menor tamaño- y el mantenimiento y la reproducción de una tipología obsoleta - diseñada para una familia cada vez menos frecuente de tamaño medio-.

- La segunda tiene la posibilidad de equilibrar la relación contradictoria entre valor de uso y valor de cambio, priorizando el primero sobre el segundo, gracias al surgimiento, como reacción y respuesta a ese desequilibrio, de ciertos agentes con algún papel en el proceso de acceso a una vivienda digna y adecuada que incorporan un verdadero interés por lograrlo.

Ambas formulaciones llevan a completar y concretar la hipótesis previa de la investigación, añadiendo además que hay una conexión entre ambas: muchos de esos agentes de gestión pueden tener el potencial, si no lo están haciendo ya, de aprovechar esos espacios de oportunidad del parque existente.

\section{Alternativas espaciales de un parque infrautilizado}

Para profundizar en ese potencial previsto de un parque residencial infrautilizado como el existente se ha buscado una metodología que recogiese e interpretase datos lo suficientemente válidos en torno a su precio, su superficie, su tipología, y su localización, para poder ser cruzados con los ya disponibles de tipos de unidades de convivencia y capacidad de pago. El objetivo, comprobar si permite una ocupación, una 
adecuación y una versatilidad mayor de las que el uso y características actuales suponen, respondiendo cuantitativa y cualitativamente a gran parte de la necesidad de vivienda existente en la región bajo unos precios máximos tolerables de gasto, a través de su transformación y adaptación. Razones metodológicas han llevado a acotar el objeto de estudio al parque libre en oferta -en venta y alquiler-, para lo cual se ha analizado el total de la oferta existente en mayo y junio de 2015 en el principal portal inmobiliario que actúa en la región -más de 19.000 viviendas, es decir, algo menos del 5\% del total-.

En primer lugar se analizan las condiciones económicas de acceso a la muestra. Para ello se ha definido un indicador de Precio Máximo Tolerable de gasto a destinar a la vivienda -siempre por debajo el $30 \%$ de la renta de referencia, algo menor a la renta media-, y se han analizado las estructuras de precios de la oferta de las diferentes áreas geográficas en las que se ha dividido el área metropolitana, cuyas características son muy diversas. A partir del cruce de lo anterior, se confirma una accesibilidad económica individual casi inexistente bajo criterios dignos. Como consecuencia, se estudian los niveles de accesibilidad económica a partir de la agrupación de varias rentas de referencia. Esta decisión está justificada por la naturaleza de la propia oportunidad detectada, arriba mencionada, y solo puede entenderse como parte de una estrategia más amplia como la de este trabajo que incorpore cuestiones tipológicas y de gestión y transformación de un parque obsoleto. Los resultados reflejan que ya al agrupar dos o tres rentas cerca de la mitad de la muestra queda bajo unas condiciones dignas de acceso económico, lo cual valida continuar con el siguiente paso. Este consta en analizar las condiciones espaciales de acceso a la muestra. En este caso se define otro indicador, la Superficie Mínima por Persona -en torno a $\operatorname{los} 30 \mathrm{~m}^{2}$ de superficie útil de vivienda- y se hace un estudio de las estructuras de franjas de superficie por cada área geográfica. Esto permite evaluar la accesibilidad espacial por agrupación de personas a la muestra -no planteando la convivencia entre ellas, si no como paso previo para una estrategia de transformación del parque-. Aunque predominan aquellas viviendas aptas para una ocupación aceptable de dos o tres personas, no son despreciables las que lo son para una o dos, o para cinco y más. Estos resultados se complementan con un estudio tipológico de aquellas viviendas de la muestra con información disponible. A partir de bibliografía especializada, se toman una serie de indicadores para analizar la flexibilidad actual y su adaptabilidad futura. Y aunque la primera no es muy alta, la segunda sí presenta un potencial interesante de cara a su posible transformación.

Los resultados de ese primer análisis del parque residencial llevan a una segunda fase: el cruce de ambas condiciones de acceso, económicas y espaciales, para ver si las viviendas de la muestra que son económicamente accesibles lo son también espacialmente, y viceversa -y para qué tamaño de agrupación de personas-. Esto se ha logrado a través del indicador de Accesibilidad Total Bruta, ajustado posteriormente incorporando la variable de personas sin capacidad de pago dentro de las unidades de convivencia y los costes de una posible intervención. Así, se observa que a partir de los criterios definidos en el trabajo entre un $52 \%$ y un $62 \%$ de la muestra analizada presenta condiciones de acceso económica y espacialmente dignos, incluidos los costes de transformación y adaptación de la misma a otras tipologías. El potencial de albergar en esa estrategia a personas sin capacidad de pago es también alto, gracias a que muchas viviendas cuentan con un margen de superficie por encima del mínimo respecto al número de rentas necesarias para costearlas. Comparados todos estos resultados con la estructura de unidades de convivencia existentes en la región, se constata que hay una carencia de oferta de viviendas para unidades pequeñas y un exceso de oferta para 
grandes, en un marco de precios altos. Lo cual reafirma la estrategia de agrupación de personas en paralelo a la transformación y adaptación del parque. Es decir, al potencial identificado se suma una importante necesidad. Esta parte de la investigación se cierra con un fundamental análisis de la territorialización de todo este potencial trasladando los resultados al espacio geográfico. En él se observan procesos simultáneos de homogeneización de las condiciones de acceso a la vivienda y polarización socioespacial -reflejo de la desigualdad urbana contemporánea-, lo que lleva a un reparto desequilibrado de las oportunidades detectadas, cuya viabilidad dependerá en gran medida de las características de su entorno urbano local.

\section{Alternativas de gestión 'más allá del mercado'}

Detectados esos espacios de oportunidad, queda por ver la manera en que llevarlos a su aprovechamiento y puesta en carga, para lo cual entra en juego su gestión. Pero antes, se ha de comprobar si, como la segunda parte de la hipótesis plantea, existen agentes alternativos trabajando por fortalecer el valor de uso de la vivienda desde posiciones distintas al mercado libre hegemónico, y cómo es su manera de funcionar. En este marco, se ha tomado una muestra de 16 agentes y/o programas públicos, privados y mixtos trabajando en la región que pueden considerarse, salvo excepciones, islas en un modelo inmobiliario muy homogéneo, orientado al lucro y muy poco dado a la transformación y flexibilización. A partir de material tanto propio de cada iniciativa como externo a las mismas, se ha realizado un extenso análisis de cada uno de los casos a través de la metodología DAFO -evaluando sus debilidades, amenazas, fortalezas y oportunidades para avanza hacia las metas previamente identificadas-. Los casos estudiados se han agrupado en cuatro grandes categorías: aquellos propios del sistema público de vivienda, alternativas privadas en búsqueda de lo colectivo, programas de urgencia social, y una última categoría que engloba otros caminos y alternativas que no encajan en las anteriores. Los principales resultados del análisis DAFO pueden resumirse de la siguiente manera:

\section{Debilidades:}

- Carencias en la gestión que frenan el desarrollo de intenciones favorables a las metas.

- Dificultades económicas que condicionan en gran medida muchas de las iniciativas.

- Con frecuencia se mantiene una vulnerabilidad residencial contra la cual se lucha.

- Falta de atención a las necesidades espaciales de las unidades de convivencia.

- Bajo nivel de participación de las unidades de convivencia en el proceso integral.

\section{Amenazas:}

- Una sociedad civil pasiva poco dada a la auto-organización en materia de vivienda.

- Instituciones incapaces de ver el potencial de la sociedad civil, ni de delegar en ella.

- Alta rigidez del marco normativo relativo al diseño habitacional.

- Ausencia de información detallada y actualizada en torno a las características del parque residencial existente y de la demanda con necesidad de vivienda. 
Fortalezas:

- Más allá del mayor o menor éxito en su puesta en práctica, hay una apuesta clara por la función social de la vivienda como objetivo y razón de ser.

- Interés y responsabilidad creciente por intervenir y trabajar sobre el parque existente.

- Aunque minoritarios, hay casos que identifican la necesidad de adecuar tipológicamente el parque actual y ofrecen servicios para ello.

- Control del coste económico final de acceso, tanto para hacerlo viable como para evitar situaciones de endeudamiento o sobrecarga excesiva de las rentas disponibles.

- Incorporación de estrategias y herramientas para avanzar hacia la convivencia y la cohesión social.

Oportunidades:

- Fortalecer las alianzas ya en marcha entre agentes, y desarrollar las potenciales.

- Encaje de buena parte de su actividad y objetivos en los intereses de las políticas públicas de vivienda.

- Cierta capacidad de influir en la definición y desarrollo de dichas políticas públicas.

\section{Encaje entre espacios de oportunidad y agentes de gestión}

Confirmados los espacios de oportunidad y los agentes de gestión, el siguiente paso ha sido evaluar su encaje. El fin ha sido estudiar la capacidad y los retos de los segundos para aprovechar y poner en carga los primeros. Es decir, evaluar las posibilidades de avanzar a través de las estrategias planteadas en el trabajo hacia el acceso económico, la adecuación tipológica, y el aprovechamiento del parque existente. Sobre la base de lo avanzado a lo largo de la investigación, ha sido posible seleccionar aquellas variables y condicionantes que se consideran como imprescindibles de cara a que lo anterior se dé exitosamente, si no se está dando ya:

Estructura y escala de la propiedad gestionada: es diversa -desde una única vivienda, a conjuntos de parcelas y edificios completos-, pero la acumulación de inmuebles bajo un mismo órgano gestor es deseable, y son de especial interés aquellos que operan sobre varias viviendas distribuidas por el parque debido a su capacidad potencial de intervenir en una parte del mismo de difícil gestión.

Unidad espacial básica tomada como soporte: existe una gran carencia de una lectura crítica de las características del parque existente y de un análisis profundo de la necesidad de vivienda, manteniendo el dogma ' 1 vivienda actual $=1$ unidad de convivencia', y siendo pocas las iniciativas que contemplan alterar ambos lados de esa ecuación a través de la transformación del parque y su número de viviendas totales, o que toman el edificio entero como soporte para una comunidad real.

Tipología de vivienda generada: la estrategia de agrupación de unidades de convivencia y transformación del parque choca con una alta reproducción de tipologías conservadoras y jerárquicas, en algunos casos con pequeñas alteraciones no sustanciales. Algunos casos minoritarios sí buscan un diseño adaptado y adecuado a las necesidades habitacionales. 
Papel jugado en el proceso: desde la promoción propia, la adquisición o gestión de inmuebles de terceros, el asesoramiento y acompañamiento externo, o la capacitación de rehabilitar los inmuebles, los servicios y herramientas disponibles ofrecen un alto potencial de aprovechar los espacios de oportunidad detectados, si bien todavía por aprovechar.

Utilización de estrategias colaborativas: existen algunos canales de comunicación entre agentes promotores y habitantes, pero son limitados y mantienen un proceso de acceso aislado, complejo y traumático. Hay casos excepcionales con amplios espacios y procesos de participación internos en desarrollo, y también se dan convenios y alianzas entre agentes para facilitar el logro de sus metas.

Agrupación de personas como estrategia de empoderamiento: en general no existe una incorporación similar a ningún caso, pues la mayoría de ellos -y los que más viviendas gestionan- reproducen el modelo actual de correspondencia entre viviendas existentes y unidades de convivencia, salvo algunos modelos cooperativos u otras experiencias muy minoritarias difíciles de ser extendidos a gran escala.

\section{Conclusiones}

A través de tres partes fundamentales de la investigación -capítulos 3, 4 y 5- la hipótesis de trabajo ha sido demostrada a dos niveles. Esto permite confirmar como válido el marco teórico utilizado en la investigación, así como la herramienta de análisis para la identificación y comprensión de contradicciones en procesos de gobernanza urbana. En un primer nivel, más concreto, se ha confirmado que:

- En el Área Metropolitana de Bilbao existe un alto potencial -latente- de acceso a la vivienda económica y espacialmente digno aprovechando para ello ciertos espacios de oportunidad de un parque considerablemente infrautilizado, a través de unas estrategias que incorporen simultáneamente la agrupación de unidades de convivencia y la transformación profunda de ese parque.

- Existe una serie de agentes muy diversos que participan en diferentes momentos del proceso de acceso a la vivienda desde un modelo de gestión y un posicionamiento diferentes al hegemónico, con interés y cierta capacidad para avanzar hacia un derecho a la vivienda actualmente no extendido a toda la población, y cuyo objeto de trabajo es en muchos casos el parque existente.

- El análisis multi-variable ha permitido determinar que hay una importante capacidad de que estos agentes puedan aprovechar y poner en carga los espacios de oportunidad identificados en el parque haciéndose cargo total o parcialmente de la gestión de las estrategias de acceso señaladas, si bien esta capacidad está lejos de ser desarrollada en toda su amplitud posible.

En un segundo nivel, propio de la teoría, los resultados del trabajo apoyan el estudio de las contradicciones propias del sistema de organización social capitalista como vía para profundizar más allá de sus efectos evidentes y buscar, comprender y poner en valor las soluciones y vías alternativas que el mismo genera fruto de sus conflictos internos. Así ha ocurrido en los dos grandes conflictos aquí analizados: 
- La oportunidad detectada de acceder bajo condiciones económicas y espaciales dignas transformando las viviendas no es gracias a la agrupación de unidades de convivencia y rentas; es el desfase de precios y tipologías existente entre la oferta y la demanda de vivienda el que posibilita y lleva a plantear, mediante la agrupación de unidades de convivencia y rentas, que se puedan adaptar, transformar y aumentar en número las viviendas existentes repartiendo los costes entre un mayor número de unidades de menor tamaño que aquellas para las que fueron diseñadas dichas viviendas.

- La existencia de agentes alternativos que participan en la gestión de la vivienda y hacen posible abordar y luchar contra los condicionantes y obstáculos identificados para acceder a la misma no surgen de manera azarosa; es la presión y la urgencia de la situación social debidas a la asfixia que el predominio del valor de cambio de la vivienda genera sobre su valor de uso las que motivan la aparición de agentes alternativos en lucha por reducir la situación problemática del acceso a un alojamiento digno.

La investigación ofrece así mismo otras conclusiones complementarias de gran interés, abriendo la puerta a posibles futuros trabajos que continúen y amplíen este:

La oportunidad de diversificar la vivienda en respuesta a unas necesidades y usos cambiantes: se ha visto que es posible, aunque no carece de retos, una diversificación más o menos radical tanto en términos de gestión como del propio espacio habitacional. Pero esta oportunidad se ha de aprovechar, dado el caso, para ir más allá de ofrecer 'nuevas' soluciones formales fijas y centrarse en facilitar un proceso flexible a lo largo del cual las unidades de convivencia deben jugar un papel de participación fundamental que tenga como resultado final permitir la apropiación y personalización del espacio doméstico a lo largo del tiempo.

La oportunidad de favorecer la cohesión social ocupando los espacios de acumulación: posible debido a las características de muchos de los agentes de gestión analizados -que incorporan la búsqueda de una mezcla social en su actividad- y la superposición de un doble reparto geográfico desigual: el de los espacios de oportunidad identificados para el acceso digno a la vivienda, y el de la polarización social de la región. Esto supone que áreas de rentas y precios altos e incluso muy altos en el mercado libre ofrezcan un alto potencial de transformación y acceso según los criterios del trabajo gracias a un mayor tamaño de su parque -en ocasiones formado por grandes viviendas con dificultad para despertar interés en el mercado-, mientras otras áreas de rentas bajas y precios bajos ofrecen mucho menos margen de adaptación, en parte debido a un parque de tamaño medio más pequeño.

La necesidad de tomar la acción colectiva como herramienta de transformación: otra de las cuestiones clave que atraviesa el trabajo, y que puede concluirse como fundamental. En este sentido, la estrategia de agrupación de unidades de convivencia como manera de acceder dignamente a la vivienda no ha de tomarse tanto como una propuesta instrumental definida con precisión, si no como un argumento para poner el foco en una oportunidad ante una situación de obsolescencia e ineficiencia -que podrá ser abordada también por otras vías y estrategias-. Los resultados del trabajo llevan a afirmar que existen pequeñas experiencias profundizando en un proceso de empoderamiento ciudadano y en el desarrollo de una gobernanza más inclusiva en torno 
a la vivienda. Pero son todavía minoritarias. Tanto unidades de convivencia como muchos de los agentes analizados actúan habitualmente de manera individualizada, siendo mucho el camino por avanzar hacia una red de agentes y ciudadanía que podría dar forma a una suerte de ecosistema en torno a la vivienda digna. La pérdida de algunas prácticas cotidianas para el funcionamiento colectivo en un contexto favorable a la individualización y la competitividad, o la desmovilización de una sociedad excesivamente pasiva por el estado del bienestar ante la reivindicación de derechos no cubiertos, conforman unos complicados retos para esta re-colectivización. Ante estos, el cambio de mentalidad hacia la responsabilidad social compartida que puede observarse en algunos casos deberá extenderse y atravesar experiencias públicas y privadas a través de una toma de decisiones informada, abierta y participada.

Peligro de apropiación y anticipación por parte del modelo hegemónico: algunas de las oportunidades señaladas en este trabajo podrían parcialmente ser aprovechadas de manera simplista y parcial por el modelo inmobiliario comúnmente extendido, al estar inmersas y surgir precisamente de sus contradicciones. Así se está, de hecho, haciendo ya en algunos lugares a través de la segregación de viviendas como doble maniobra de inversión y gentrificación. Lo cual no hace si no sumar una mayor urgencia e interés al desarrollo y aplicación de estrategias como las aquí planteadas.

Vigencia y evolución de la problemática: a pesar de que el material utilizado en la investigación es una suerte de fotografía del momento en que se desarrolló el trabajo de campo, tanto la necesidad como las contradicciones en las que se enmarcaron siguen vigentes, a pesar de sus evoluciones. Los cambios en la estructura demográfica, en los precios de oferta, o en las características espaciales del parque son lentos. Y los fundamentos del sistema de organización social capitalista necesitan de grandes fenómenos transformadores para ser alterados. Un breve repaso final -realizado unos años después del trabajo de campo- a la evolución de precios y rentas, a la diversificación constante de unidades de convivencia, a la parcialmente cambiante aunque mantenida exclusión residencial, a la constante presencia en muy diversos ámbitos de las dos contradicciones trabajadas, o a los pasos que se están dando hacia una posible burbuja del alquiler, lo confirman.

Sobre la planificación de los espacios, agentes y estrategias: muchos de los planteamientos desarrollados encajan en la evolución de la política pública de vivienda vasca, y algunas de las amenazas que rodean a los agentes analizados pueden ser abordadas desde las instituciones públicas. Lo cual sumado a las oportunidades y potenciales detectados, hacen deseable un aumento de la escala y ritmo de planificación y transformación de una estrategia que actualmente es minoritaria y generalmente aislada. Los resultados ofrecen material de interés para enriquecer tanto la actividad gestora de diversos agentes públicos y privados como la planificación y las políticas públicas de vivienda a diferentes escalas y ámbitos, a través de un análisis detallado y multi-variable -del que este trabajo puede servir de experimento piloto-.

\section{Estructura del trabajo}

El texto se estructura en seis capítulos agrupados en tres partes. La primera de ellas, con un solo capítulo, desarrolla tres cuestiones. Presenta y acota el objeto y contexto de estudio; define el marco teórico crítico desde el que abordar y comprender la problemática; y presenta los principales elementos de la investigación: enfoque y 
posicionamiento, objetivos, estado de la cuestión, una primera hipótesis general y una breve aproximación metodológica que se va desarrollando en cada capítulo debido a la diversidad de métodos utilizados.

La segunda parte concentra el principal material generado en la investigación para la demostración de la hipótesis, y se desarrolla en tres capítulos. El segundo tiene como objetivo aterrizar la hipótesis general al objeto y ámbito de estudio, para lo cual presenta la herramienta de análisis de diseño propio pensada para identificar tanto la generación de contradicciones en procesos de gobernanza urbana como posibles alternativas a las mismas. Esta es aplicada sobre la situación de la vivienda en el Área Metropolitana de Bilbao, sitúa los conflictos detectados en las dos contradicciones de la vivienda propias del capitalismo arriba señaladas, e identifica sendas alternativas relacionadas, completando y afinando así la hipótesis de partida. Las alternativas espaciales se desarrollan en el capítulo tercero, a través de un estudio del mercado inmobiliario regional y su cruce con las características de las unidades de convivencia existentes, pasando los resultados a una dimensión geográfica. Las alternativas de gestión se desarrollan en el capítulo cuarto, y repasan algunos de los principales agentes que podrían suplir la carencia de organización colectiva existente, y sin embargo necesaria, para aprovechar los espacios de oportunidad detectados en el capítulo previo.

En la tercera parte, centrada en la discusión y las conclusiones, el capítulo quinto analiza el potencial de aprovechamiento de las alternativas espaciales que los agentes pueden desarrollar a través de la selección y estudio de algunas de las principales cuestiones que lo pueden favorecer o dificultar. Finalmente, en el capítulo sexto se confirma la hipótesis de la investigación, y se apuntan conclusiones complementarias algunas de las cuales han sido avanzadas de manera parcial en los capítulos segundo, tercero y cuarto-.

Lo diverso del enfoque ha dado como resultado un trabajo extenso y cambiante, si bien se considera que con una serie de líneas claras y coherentes que lo atraviesan hasta lograr una estructura comprensible. No obstante, para facilitar su lectura -además de esta introducción a su contenido y su estructura- la redacción se apoya en una serie de tablas y esquemas puntuales. Estos tienen funciones diversas: aportar nueva información complementaria; sintetizar y resumir un apartado, un capítulo, o varios; reflejar y apoyar el contenido del texto; avanzar la estructura de apartados y/o capítulos que siguen; o enlazar información avanzada en diferentes partes del trabajo para aportar nuevas lecturas. En base a las anteriores, su disposición a lo largo del texto varía, apareciendo tanto al inicio o final de un capítulo, como presentación o cierre de un apartado, o en un punto intermedio del mismo. 
Parte I. Contexto, marco de análisis y planteamiento

\author{
Parte II. \\ Material, \\ métodos y \\ resultados
}

Parte III.

Discusión y

Conclusiones 



\section{CAPÍTULO 1}

\section{Objeto y contexto: la vivienda en el capitalismo avanzado}

«No estamos ante un problema. Estamos frente a una problemática. Los problemas tienen una solución parcelaria, pueden ser abordados "fácilmente" desde una disciplina particular. La problemática es diversa y compleja, precisa de un enfoque holístico, integrador, buscando que las acciones humanas en sectores concretos, lejos de generar efectos negativos en otros sectores, favorezcan la generación de procesos para la transformación social. Es decir, la intervención disciplinaria en un determinado sector debe estar impregnada de otras expresiones y experiencias disciplinarias, de tal forma que tenga la potencialidad y capacidad de ofrecer el apoyo en otros sectores y, a la vez, obtenerlo de las intervenciones en los mismos».

(Alguacil, 1995: 78) 



\title{
La dimensión social de la vivienda en una crisis urbana global
}

\author{
- 1.1.1 - \\ Presentación: la complejidad y los retos de \\ abordar 'la vivienda'
}

Existen diferentes motivaciones y perspectivas desde las que afrontar la investigación a través de una tesis doctoral. En este caso, y con la responsabilidad social de la profesión y la academia como horizonte, el acercamiento ha sido desde la identificación de una situación problemática a la que enfrentarse. A esta condición le siguen otras impuestas por el propio autor, como el ser un tema de interés personal, con relevancia y utilidad social; que sea un trabajo innovador y original, capaz de aportar avances y conocimiento; viable tanto en el tiempo como por los medios económicos y personales disponibles; y con un desarrollo riguroso y eficaz. Estos han sido los principios que han intentado guiar desde el inicio este trabajo.

Sin perder de vista que una investigación en el marco de un programa de doctorado universitario ha de ser -teniendo en cuenta la reciente evolución de los mismos, especialmente en cuanto a sus límites temporales- adecuadamente acotada a un tema y ámbito de estudio concretos para un desarrollo exitoso de la tesis doctoral que tiene como fin, se ha entendido como imprescindible una contextualización del proyecto investigador en un panorama más amplio, en ocasiones casi global. El objeto de estudio elegido hace inevitable este ejercicio, dado el papel multidimensional que juega la vivienda en el desarrollo no solo social y económico, si no también urbano, territorial y ambiental de las diversas sociedades humanas. Sin pretender hacer un repaso exhaustivo a los innumerables estudios que han abordado este tema, este primer capítulo sí busca resaltar, apoyándose en ocasiones en marcos más locales, algunas de las cuestiones clave sobre las que se construye en capítulos posteriores el cuerpo de la investigación, y a partir de las cuales se profundiza en el ámbito de estudio trabajado.

Esta primera aproximación al tema de fondo de la investigación señala como objeto de estudio principal a la vivienda. Una decisión 
ambiciosa, aunque no carente de justificación, pues existe -como se verá- una importante necesidad de abordarlo y de superar el vértigo que puede generar hacerlo de una manera más o menos profunda y desde perspectivas y planteamientos no habituales. En cualquier caso, no nace este trabajo con la utópica idea de afrontar la compleja problemática existente en torno a este concepto en su conjunto -algo inasumible no ya para el ámbito de acción de una tesis doctoral, si no incluso para grupos de trabajo más amplios y preparados-. Pero sí de arrojar algo de luz en algunos de los frentes abiertos en este «tema intemporal sobre el que quizás se hayan dicho muchas cosas, pero sin que se hayan conseguido soluciones» (Vinuesa, 2013: 2).

\section{Un tema... ¿conocido?}

Se trata de un tema que indudablemente pertenece, entre otros, al ámbito de lo cotidiano. Es parte fundamental en la vida de toda persona y, por lo tanto, no es desconocido por la sociedad -si no más bien todo lo contrario, al menos de una manera parcial-. Podría afirmarse que prácticamente cualquier persona en el planeta puede identificar sin problema una vivienda o un alojamiento dentro de su contexto económico, social y cultural, así como representar en su imaginario lo que para sí misma significa. Pero al mismo tiempo, no es un concepto fácil de comprender en toda su riqueza y complejidad si se desea abarcar todas las dimensiones que incorpora y afecciones que sufre. La vivienda alberga y recoge tal cantidad de variables, se ve influenciada por un abanico tan amplio de intereses y factores externos, que la dotan de una complejidad considerable y puede llegar a ser dificultoso definirla, comprenderla y gestionarla en su totalidad. Al fin y al cabo una vivienda puede ser, y de hecho lo viene siendo, varias cosas a la vez.

La vivienda viene definida por el diccionario de la Real Academia de la Lengua Española como aquel «lugar cerrado y cubierto construido para ser habitado por personas». La definición realizada por el Oxford Dictionary of English viene a ser prácticamente similar, haciendo referencia a un edificio para la habitación humana («a building for human habitation»). En ambos casos se hace referencia a un recinto espacial concreto, el edificio, como continente de la vivienda, dejando de lado otras muchas posibilidades y variaciones. En cualquier caso, no es aquí el objetivo adentrarse en consideraciones sobre los posibles espacios que pueden configurar una vivienda. Por otro lado, el campo de estudio de este trabajo sí está precisamente definido por edificios que conforman y aglutinan viviendas. Por lo que puede tomarse la descrita como una definición inicial válida del concepto. Muchas han sido las reflexiones en torno a lo que es y no es la vivienda; según la fuente que se consulte, la mayor o menor concreción en algunos de sus aspectos lleva a que existan variaciones y extensiones de esta definición. En cualquier caso, «cuando hablamos de vivienda tratamos de conjugar, en sus múltiples 
aspectos, la necesidad básica de todo ser humano de disponer de un alojamiento y la solución material que se le da» (Vinuesa, 2013: 8).

Como uno de los principales -si no el principal- espacio de desarrollo de la vida humana que es, también es lugar de desarrollo personal, reproducción social, trabajo, ocio, aprendizaje y educación; es aquel espacio donde se viven experiencias muy íntimas, tanto personales como familiares -hasta hace no tantos años era frecuente dar a luz en las casas, creando un fuerte nexo de unión, y en muchas ocasiones es lugar de fallecimiento-. Por supuesto, puede ser mucho más: desgraciadamente en algunos casos es el espacio principal donde se da la violencia de género, fuente de hacinamiento y reclusión, de negocios y actividades contrarias a la ley, de producción, almacenamiento y punto de distribución de mercancías y actividades económicas ilegales, y también es un uso altamente demandante de recursos naturales en forma de energía y materias primas, así como punto de generación de gran cantidad de residuos. La aproximación a lo que es la vivienda es por lo tanto muy abierta, y se podría «proseguir con una larguísima lista de distintos usos que se le pueden dar [...] son, en resumen, aparentemente infinitos y muy a menudo puramente idiosincrásicos» (Harvey, 2014: 32). Si bien para cada vez más personas se trata de una esfera vital que aglutina conflictos y formaliza desigualdades:

«Para una parte cada vez más grande de la población, la vivienda es una fuente de inseguridad con múltiples rostros: vivir bajo la amenaza de desahucio y con el miedo a tener que mudar a los hijos de escuela a medio curso; tener que aceptar empleos que en otras circunstancias no aceptaríamos; mantener relaciones íntimas con personas a las que ya no se ama o en entornos abusivos; tener que realizar desplazamientos muy largos a centros de trabajo lejanos; sufrir angustia con graves repercusiones para la salud [...]. La lista es larga» (Madden y Marcuse, 2018: 17)

Pero en lo que a este trabajo respecta, y además de todo lo anterior, la vivienda es -especialmente en un modelo inmobiliario como el español- una importante fuente de generación de plusvalía económica; uno de los objetos de inversión y ahorro más estables del mercado; una razón y símbolo de lucha social; una importante fuente de mano de obra; objetivo de políticas públicas diversas y documentos de planeamiento espacial; y un elemento fundamental de la configuración espacial de la ciudad y de la ocupación del territorio. Son estas algunas de las numerosas caras de un espacio doméstico que no hace si no reflejar la condición humana en toda su diversidad, riqueza y contradicción; «demasiados y contradictorios roles para un objeto que, en principio no debería tener otro que alojar satisfactoriamente a sus usuarios» (Roch, 2009: 194). Esta naturaleza compleja lo convierte en una verdadera problemática tal y como afirma Alguacil (1995), e implica una gran dificultad a la hora de 
abordar por separado cualquiera de sus esferas y problemas de manera aislada. Ya que una de las razones de la complejidad del concepto reside precisamente en las interferencias que las fuerzas, intereses, usos o necesidades operantes en las distintas dimensiones y realidades de la vivienda ejercen entre sí. De tal manera que se anulan, fortalecen o transforman mutuamente, y se establecen claros predominios de unas sobre otras, quedando estas últimas desplazadas o excluidas. Lo que por otra parte, hace difícil abordar todas ellas en su conjunto de cara a la gestión de la vivienda como concepto multidisciplinar; en la medida en que «no puede haber una manera única de abordar la vivienda, por lo tanto, tampoco puede haber una teoría unitaria para explicar algo denominado vivienda» (González et al., 2003: 176). Asumiendo y aceptando todas estas dificultades ${ }^{1}$, en esta investigación se ha trabajado principalmente una de sus dimensiones, la que se ha venido a denominar dimensión social de la vivienda -aunque de manera inevitable se abordarán otras, por las razones de interdependencia ya mencionadas-. La elección de esta se debe, principalmente y además de estar fuertemente motivada por inquietudes personales del autor, a la relevancia de la misma como eje fundamental vertebrador del propio concepto de vivienda, a su carácter de condición previa para que se den muchas de esas otras dimensiones, y a no contar hoy en día con un nivel de consecución mínimo extendido en la sociedad.

\section{La prioridad de su dimensión social}

La dimensión social de la vivienda que centra la mirada de este trabajo se entiende como la cualidad que tiene esta para garantizar el derecho humano fundamental y necesario de alojamiento ${ }^{2}$. Una dimensión que viene siendo -como se demostrará más tardedesatendida por múltiples esferas de la sociedad en el AMB. Y ello a pesar de que son a su vez muchos los agentes públicos, privados y de la sociedad civil que vienen trabajando y demandando un cambio y un giro en las políticas públicas y en la conciencia social para cambiar dicha situación. También esto otro quedará demostrado en el trabajo. La elección no ha sido por lo tanto discrecional, entendiendo que posiblemente sea esta una de las principales y más urgentes cuestiones a abordar en la vivienda. La dependencia de otras muchas esferas vitales del hecho de contar con un espacio seguro y digno donde habitar reafirman este supuesto. La falta de vivienda multiplica y magnifica otros conflictos y carencias (Madden y Marcuse, 2018: 87); bajo este paradigma se construyen programas de urgencia social como el Housing First. Y que puede, al menos de manera parcial, ser

\footnotetext{
1 Desde una perspectiva más general, Mumford ya reflexionaba sobre esto mismo, asumiendo que «ninguna mente humana comprende más que de forma fragmentaria las actividades complejas y especializadas de sus ciudadanos» (Mumford, 1970: 234).

2 Término también utilizado con el mismo propósito por otros autores (Madden y Marcuse, 2018).
} 
abordada desde los estudios urbanos complementados con la investigación en disciplinas como el urbanismo y arquitectura. En este sentido, actualmente se echa en falta cierto ejercicio de responsabilidad en algunos círculos de ambas disciplinas para poner en la agenda esta cuestión como urgente. Ya que si existe alguna mirada a dirigir hacia la vivienda cuya relevancia hace que pueda y deba priorizarse sobre el resto, esta es la dimensión social de la misma. En cualquier situación y ámbito de trabajo, no ha de olvidarse que ante todo y por encima de todo, la vivienda es un derecho humano básico y fundamental -fuertemente afectado por el derecho a la propiedad privada y sus interpretaciones, como se tratará más adelante-. Probablemente, el principal hito en este sentido fue su reconocimiento como tal el 10 de diciembre de 1948, en el artículo 25.1 de la Declaración Universal de Derechos Humanos:

«Toda persona tiene derecho a un nivel de vida adecuado que le asegure, así como a su familia, la salud y el bienestar, y en especial la alimentación, el vestido, la vivienda, la asistencia médica y los servicios sociales necesarios» (Naciones Unidas, 2015: 52).

Proclamación que se vio completada por el mismo órgano internacional años más tarde -aprobado en 1966, pero con entrada en vigor en 1976- en el artículo 11.1 del Pacto Internacional de Derechos Económicos, Sociales y Culturales:

«Los Estados Partes en el presente Pacto reconocen el derecho de toda persona a un nivel de vida adecuado para sí y su familia, incluso alimentación, vestido y vivienda adecuados, y a una mejora continua de las condiciones de existencia. Los Estados Partes tomarán medidas apropiadas para asegurar la efectividad de este derecho, reconociendo a este efecto la importancia esencial de la cooperación internacional fundada en el libre consentimiento» (Naciones Unidas, 1966).

El contenido de este pacto lo ha desarrollado el Comité de Derechos Económicos, Sociales y Culturales de Naciones Unidas en varias Observaciones Generales. La número 4, adoptada en la sexta sesión del comité en diciembre de 1991, reafirmaba la existencia de un importante desfase entre lo pactado y la situación real en muchas regiones del mundo. Ello a pesar de la predisposición aparente de la comunidad internacional para el desarrollo del derecho a la vivienda. Esta cuestión la concretaba con una interesante afirmación: aunque la principal carencia de este derecho se daba en algunos países en desarrollo con importantes limitaciones, también se identificaban «considerables problemas de falta de vivienda y de viviendas inadecuadas en algunas de las sociedades más desarrolladas económicamente» (Comité de Derechos Económicos, Sociales y Culturales de Naciones Unidas, 1991: 2). Efectivamente, el derecho a la vivienda no se reduce a disponer de un espacio físico, ese lugar cerrado y cubierto del que habla el diccionario. 
En este sentido, es de gran relevancia que en el Pacto se concretase el concepto de vivienda con el adjetivo de adecuada. Lo que significa, como recuerda el citado comité que reconocían la Comisión de Asentamientos Humanos y la Estrategia Mundial de Vivienda, «disponer de un lugar donde poderse aislar si se desea, espacio adecuado, seguridad adecuada, iluminación y ventilación adecuadas, una infraestructura básica adecuada y una situación adecuada en relación con el trabajo y los servicios básicos, todo ello a un costo razonable» (Comité de Derechos Económicos, Sociales y Culturales de Naciones Unidas, 1991: 2). Esta idea de adecuación está por supuesto condicionada por diversos factores de diferente naturaleza. Pero en la citada Observación General No 4 se estableció que, para cualquier contexto, existen una serie de aspectos básicos a tener en cuenta, como son la seguridad jurídica de la tenencia, la disponibilidad de servicios, materiales, facilidades e infraestructura, unos gastos relativos a la vivienda soportables, la habitabilidad, la asequibilidad, el lugar adecuado, y la adecuación cultural. El concepto quedo así considerablemente completo desde el punto de vista de la necesidad social del mismo.

A nivel continental, la Carta Social Europea aprobada por el Consejo de Europa en 1961, y revisada posteriormente en 1996, habla del derecho a la vivienda en varios de sus artículos. Así lo hace en el 16, relativo al derecho de la familia, en el que las partes se comprometen a fomentar la protección económica, jurídica y social de la misma mediante, entre otras cosas, la construcción de viviendas adaptadas a sus necesidades. Así mismo, el artículo 19 relativo al derecho de los trabajadores migrantes y sus familias compromete en su punto 4.c a las partes a garantizar a dichos trabajadores en situación legal dentro del territorio nacional, entre otras cuestiones, el alojamiento. Pero es su artículo 31 el que de manera especifica establece el derecho a la vivienda:

«Para garantizar el ejercicio efectivo del derecho a la vivienda, las Partes se comprometen a adoptar medidas destinadas a favorecer el acceso a la vivienda de un nivel suficiente, a prevenir y paliar la situación de carencia de hogar con vistas a eliminar progresivamente dicha situación y a hacer asequible el precio de las viviendas a las personas que no dispongan de recursos suficientes» (Consejo de Europa, 1996: 44-45).

España hizo propios estos tres documentos -en 1955 la Declaración Universal de Derechos Humanos con su entrada en Naciones Unidas, en 1971 con la firma del Pacto y en 1980 con la ratificación de la Carta respectivamente-, constituyéndose así en Estado Parte de dichos pactos y declaraciones. En 1978 aprobó su propia Constitución, la cual de igual manera establece el derecho a la vivienda en su artículo 47: 
«Todos los españoles tienen derecho a disfrutar de una vivienda digna y adecuada. Los poderes públicos promoverán las condiciones necesarias y establecerán las normas pertinentes para hacer efectivo este derecho, regulando la utilización del suelo de acuerdo con el interés general para impedir la especulación» (Constitución Española, 1978: 16).

En este caso, al adjetivo de adecuada se le suma la característica de digna. Algo que hace explícito y recoge lo que se venía ya indicando en los anteriores documentos. El Pacto Internacional de Derechos Económicos, Sociales y Culturales ya recordaba en su preámbulo la dignidad inherente a la persona humana. Afirmación a partir de la cual la Observación General N $N^{\circ}$ antes citada exigía que «el término "vivienda" se interprete en un sentido que tenga en cuenta otras diversas consideraciones, y principalmente que el derecho a la vivienda se debe garantizar a todos, sean cuales fueren sus ingresos o su acceso a recursos económicos» (Comité de Derechos Económicos, Sociales y Culturales de Naciones Unidas, 1991: 2).

Finalmente, a escala autonómica, el Estatuto de Autonomía para el País Vasco aprobado en 1979 recoge también el derecho a la vivienda de manera indirecta, pues establece en su artículo 9.1 que los «derechos y deberes fundamentales de los ciudadanos del País Vasco son los establecidos en la Constitución» (Ley Orgánica 3/1979, de 18 de diciembre, 1979:2). Lo cual se desarrolla en el siguiente punto estableciendo que los poderes públicos vascos, en el ámbito de su competencia, «velarán y garantizarán el adecuado ejercicio de los derechos y deberes fundamentales de los ciudadanos», así como que «impulsarán particularmente una política tendente a la mejora de las condiciones de vida y trabajo». Es importante aquí destacar que, por otro lado, este propio Estatuto recoge en el artículo que le sigue, el 10, las competencias exclusivas pertenecientes a la Comunidad Autonómica del País Vasco. Entre las que está la ordenación del territorio y del litoral, el urbanismo y la vivienda.

\section{$-1.1 .2-$}

\section{Una ciudad residencial excluyente}

A continuación se expone de manera breve la naturaleza estructuralmente excluyente de un modelo residencial propio de lo que puede denominarse capitalismo avanzado, en lo que se refiere a la recién vista dimensión social de la vivienda ${ }^{3}$. En contraposición, dicha

\footnotetext{
3 Acudiendo a alguno de los muchos estudiosos del capitalismo como sistema de organización social, se entiende aquí por capitalismo avanzado aquel nivel de desarrollo y evolución de este sistema en el cual la contrarrevolución neoliberal viene siendo afianzada desde finales de la década de 1970, y entre cuyas características está una generalizada
} 
exclusión es compatible con, si no alimentada por, otras dimensiones propias de la vivienda que ejercen una importante función en el desarrollo de la misma como uno de los elementos tractores fundamentales de la economía. Especialmente en el caso español. Todo ello será adecuadamente contextualizado en posteriores apartados y capítulos.

\section{Compatible con mejoras técnico-constructivas}

Si se atiende a aquellos aspectos pertenecientes a la vivienda abordables desde las disciplinas del urbanismo y la arquitectura, y a pesar de los grandes retos que todavía quedan por afrontar, el modelo urbanístico y edificatorio residencial español ha dado y está dando en las últimas décadas importantes pasos hacia la mejora de sus características constructivas y físicas. Las normativas de edificación aprobadas el siglo pasado fueron renovadas y mejoradas, entre otras, por la evolución de las ordenanzas municipales o, especialmente, por el Código Técnico de la Edificación aprobado en la primera década del siglo XXI. Con él, cuestiones como la habitabilidad, el abastecimiento de energía para climatización, el comportamiento térmico y acústico, la seguridad estructural, constructiva y de uso o la accesibilidad universal fueron dotadas de un amplio soporte técnico y legal -no carente de conflicto por la incompatibilidad interna entre algunos de sus documentos, y por hacer más compleja la fase del proyecto edificatorio-. Así mismo, han surgido nuevos instrumentos, técnicas y marcos normativos para abordar la eficiencia energética de los edificios de manera más o menos parcial -como la Certificación Energética de Edificios, o los sistemas Passiv House o Leadership in Energy and Environmental Design (LEED)-. Estas y otras cuestiones gozan de un amplio apoyo institucional y empresarial, pues satisfacen algunas importantes necesidades sociales relativas al confort, la habitabilidad o la accesibilidad, responden a los grandes retos propios de unos altos niveles de consumo de recursos materiales y energéticos demandados por el sector residencial, y forman parte del engranaje de lo que en España viene a llamarse el sector económico de la construcción o, informalmente, el ladrillo.

En cuanto al control y actuación sobre el parque existente, también se vienen realizando grandes esfuerzos por hacer un inventario del mismo -a través de las Inspecciones Técnicas o Informes de Evaluación de Edificios obligatorios-, así como por la cada vez más decidida y asumida apuesta por su renovación y rehabilitación -a través de la aprobación de planes especiales, desarrollo de herramientas legales, o convocatoria de ayudas y subvenciones-. El valor que todas estas iniciativas tienen de cara a mejorar la calidad de vida de las personas que habitan dicho parque

construcción de viviendas con fines especulativos como mercancía destinada al mercado (Harvey, 2014). 
intervenido es desde luego considerable. Sin embargo, puede llegar a ser difícil distinguir si detrás hay motivaciones sinceras de corte social, o si más bien -o además de- se ve como una vía para encauzar y reflotar todo un entramado de empresas y puestos de trabajo perdidos tras los años del boom inmobiliario y el consiguiente pinchazo de la burbuja, con un gran peso en la economía nacional. Ambas vías son compatibles y deseables, aunque como se verá más tarde (Burón, 2010; Eusko Langileen Alkartasuna, 2010), en ocasiones la primera se queda en una fase discursiva y los esfuerzos parecen centrarse en una visión de la vivienda como motor económico exclusivamente.

Por otro lado, un aspecto tan importante como el de los residuos generados en los procesos de construcción y demolición, de muy difícil gestión y con grandes obstáculos todavía por salvar, también ha sido abordado dotándolo de herramientas de diseño de planes de gestión, de control del desarrollo de estos, de sistemas de tratamiento, así como del fomento de la reutilización de materiales de construcción mediante la revalorización de los mismos. Todas estas cuestiones, aún siendo muchos los retos pendientes -incorporar en los sistemas y procesos constructivos los propios de la economía circular, el análisis del ciclo de vida, el comercio justo, garantizar unas condiciones de trabajo dignas,...- podrían englobarse dentro del avance y la mejora de una dimensión técnico-constructiva del sector de la construcción en general, y de la vivienda en particular, que se ha visto de facto compatible con la reproducción y continuación del modelo urbanístico y residencial hegemónico. Y en la que tendrían cabida también cuestiones como los avances en la optimización constructiva -prefabricación, sistemas de diseño y gestión tipo Building Information Modeling (BIM), automatización de procesos de obra,...-, o la paulatina incorporación de la información sobre el ciclo de vida de los materiales, entre otros.

\section{Apoyada en el mantenimiento de conflictos en otras}

Frente a las anteriores, pueden identificarse otras dimensiones de la vivienda en las que se han cosechado menos avances hasta el momento. Son ámbitos también abordables -entre otras disciplinasdesde el urbanismo y la arquitectura, aunque desde un perfil menos técnico y quizás más cercano a las ciencias sociales. Se trata de temas que afectan sin duda a la ciudad residencial y esta ha de incorporarlos en su proceso de diseño e intervención. Muchas de estas no están recibiendo toda la atención que por su relevancia en la mejora de la calidad de vida urbana parece que debieran, si bien sí se están dando avances parciales y hay muy diversos agentes trabajando en las mismas.

Por ejemplo, quedando todavía avances por hacer, son muchos los municipios que en los últimos años han incorporado a sus instrumentos de planificación urbana variables de género, así como promovido y/o desarrollado mapas de identificación de áreas 
vulnerables desde dicha perspectiva. Existen también estudios sobre parámetros dotacionales en la ciudad con el fin de proporcionar aquellos instrumentos necesarios para evaluar la calidad de los tejidos urbanos de las ciudades españolas y de las propuestas de intervención que se pueden realizar en ellas, entendiendo que las dotaciones son un elemento característico de la calidad urbana (Hernández Aja y Leiva, 2006). En cuanto a una visión más transversal, hace unos años se desarrolló el Libro Blanco de la Sostenibilidad en el Planeamiento Urbanístico Español (España, Ministerio de Vivienda, 2010). Igualmente, los Ministerios de Fomento y de Ciencia, Innovación y Universidades de España vienen trabajando durante los últimos años con el ámbito académico para desarrollar herramientas como el Atlas Urbanístico de Barrios Vulnerables a partir de los censos de población y vivienda (Hernández Aja et al., 2015), o para poner en marcha estrategias de diseño y evaluación de planes y programas de regeneración urbana integrada bajo un modelo que suma a la dimensión espacial la integralidad de las operaciones (Hernández Aja et al., 2016). Son estos ejemplos de gran interés de un enfoque de la ciudad (también de la residencial) como algo más que un mero soporte para el desarrollo del mercado, la economía y los flujos de capital, poniendo el énfasis en algunas de sus cruciales dimensiones: género, dotaciones, sostenibilidad, vulnerabilidad, integralidad. Pero muchas otras dimensiones están carentes de una mayor atención a la hora de producir y/o intervenir en la ciudad residencial, como la territorial, la ecosistémica, la doméstica, la antropológica o la convivencial por citar algunas.

En cuanto a los conflictos propios de la dimensión social de la vivienda, en este trabajo se defiende la idea de que se trata de una cuestión fuertemente unida a la naturaleza del modelo urbanístico actual, el cual viene dando continuidad a los procesos de crecimiento y/o sustitución de la ciudad residencial de una manera muy específica. Una reproducción que sigue ofertando, como se desarrollará más adelante, un producto económicamente inalcanzable para muchas personas y generando y/o fortaleciendo situaciones de precariedad, vulnerabilidad y exclusión residencial, entre otras cuestiones. Por lo tanto, el planteamiento inicial para aproximarse a una comprensión de la problemática seleccionada es que si bien la mejora en aspectos más técnicos como los mencionados antes se han demostrado con los años compatibles con el modelo hegemónico, existen otros conflictos indisociables al mismo:

«La vivienda es el uso que da sentido a nuestras ciudades. Sin embargo, desde la formación de la ciudad actual en el siglo XIX, los procesos de especulación inmobiliaria y la dificultad en el acceso a la vivienda son dos de los principales problemas a los que se enfrentan los gobiernos locales, lo que parece convertirlos en una característica del hecho urbano en sí» (Rodríguez Alonso, 2018). 
«La crisis de la vivienda es el resultado predecible y lógico de una característica básica del desarrollo espacial capitalista [...] no se produce como consecuencia de un fallo del sistema, sino porque el sistema funciona como debe» (Madden y Marcuse, 2018: 35).

Así, lo que se afirma aquí es que el modelo predominante no permite avances sustanciales en la materia, en la medida en que su supervivencia y desarrollo depende de y se sustenta principalmente en la reproducción en el tiempo de estos otros conflictos. Es decir, la alimentación y la desatención estructural de conflictos generados en otras dimensiones de la vivienda, como la social -en cuanto a la falta de acceso a la vivienda- o la territorial -en cuanto al desequilibrio entre la urbanización para un uso residencial y el resto de funciones del territorio- no son consecuencias evitables mediante ajustes parciales del modelo que han sido dejadas de lado u olvidadas, si no que son aspectos intrínsecos y estructurales del mismo. Las raíces de ello tienen arraigo en las geografías del capitalismo y su desarrollo geográfico desigual (Smith, 2010: 4). De tal manera que con mayor o menor intensidad, según el contexto socio-económico, tendrán una presencia constante mientras perdure el modelo actual. El argumento aquí planteado no es un planteamiento nuevo, pues en diferentes tiempos y contextos las contradicciones propias del modelo de vivienda contemporáneo han sido analizadas. A finales del siglo XIX Engels ya establecía las conexiones y dependencias del modelo de vivienda con el contexto socio-económico, afirmando que «mientras exista el modo de producción capitalista, será absurdo querer resolver aisladamente la cuestión de la vivienda o cualquier otra cuestión social que afecte la suerte del obrero» (Engels, 2006: 80). Más recientemente, el problema sigue vigente y viene siendo señalado igualmente como una cuestión de naturaleza política:

«Plantear el problema de la vivienda hoy en día significa revelar las conexiones que existen entre el poder de la sociedad y la experiencia residencial. Supone preguntar para quién y para qué son las viviendas, quién las controla, a quiénes empoderan, a quiénes oprimen. Implica cuestionar la función de la vivienda dentro del capitalismo neoliberal globalizado» (Madden y Marcuse, 2018: 31).

En cualquier caso, el argumento para defender esta dependencia planteada se sustenta en una corriente más general de pensamiento crítico, y en dos fundamentos específicos del propio modelo. Se comienza por señalar estos últimos, dejando para más tarde el desarrollo del marco teórico que sirve de referencia del trabajo. En primer lugar, se trata de un sistema inmobiliario y urbanístico basado en la dependencia de la obtención de plusvalías como manera de sostenimiento y única forma de generar oferta residencial, salvo excepciones aisladas. Lo que desplaza del centro la naturaleza de derecho y necesidad básica que tiene la vivienda. Un modelo con 
origen en la Ley del Suelo de 1956 que, a pesar de las evoluciones y cambios sufridos, sigue en el fondo vigente -en el caso de Euskadi, con la Ley 2/2006 de Suelo y Urbanismo- y que atribuyó las plusvalías de transformación de la actividad urbanizadora -en otros casos correspondientes a la persona o entidad que desarrolla la actividad en cuestión - «a una de las materias primas utilizadas en el proceso, el suelo objeto de transformación» (Tejerina, 2016: 27). Se buscaba así ofrecer -y proteger- la obtención de beneficios a través de la acción urbanizadora para atraer a la iniciativa privada, y garantizar de esta manera la necesaria creación de ciudad que desde las instituciones públicas no se podía financiar. Esto con el tiempo ha desencadenado una extendida cultura de búsqueda del máximo beneficio económico en sus diferentes fases, escalas y agentes intervinientes a través de la clasificación y calificación de suelo, operaciones urbanísticas, reparcelaciones, promociones residenciales, o la compraventa de viviendas (Naredo y Montiel, 2011).

En segundo lugar, el modelo depende a su vez de la existencia constante de una parte de la población con necesidad de vivienda, lo que sirve de justificación a aquellas posturas en favor de continuar con la construcción de más y más viviendas y, por consiguiente, la obtención de plusvalías; «todo el discurso inmobiliario va dirigido a legitimar la necesidad de que esta máquina privada siga produciendo viviendas y, para ello, la escasez crónica de alojamientos para los estratos no solventes proporciona una excusa inagotable» (Roch, 2003: 121). Esto hace que, mirando con cierta perspectiva, pueda afirmarse que desde ciertos sectores o posiciones la defensa del derecho de acceso universal a la vivienda no conlleva un cuestionamiento del modelo predominante, y en cambio sí sirve como promesa constante sobre la que el propio sistema se legitima (Madden y Marcuse, 2018: 207). La cuestión de fondo tras todo esto puede identificarse en la fuerte relación señalada por Harvey (2014: 219-240) entre el buscado crecimiento exponencial del capitalismo y la necesaria producción -en este caso lucrativa- de espacio para lograrlo. De tal manera que, como Roch (2003) plantea, el modelo se basa en tensar al máximo la capacidad de pago social produciendo una inevitable exclusión y una consecuente necesidad. Las lógicas del mercado inmobiliario tienden a estirar al máximo -o incluso más- de lo que permite este el precio de las viviendas. Lo cual supone que detrás de la demanda con capacidad de pago para alcanzar esos precios hay una buena parte de la población que se ve excluida, ya que ese estiramiento de precios conlleva un efecto muelle que hace subir los precios de las franjas de precios menores (Madden y Marcuse, 2018: 14; Roch, 2000, 2009). Así, muchos han sido y son los agentes, participantes directamente o no, a los que interesa en última instancia el rendimiento económico, directo o indirecto, de la ciudad residencial. Y que buscan y aplauden la construcción de nuevas viviendas y la subida de precios del producto final ajenos a un contexto social en crisis. Lo cual lleva inevitablemente a una exclusión de toda aquella persona que no tenga capacidad económica de 
demandarlo. De esta manera, el mercado inmobiliario se ha definido desde algunas posturas como estructuralmente incapaces de ser eficientes ni racionales, a pesar de su representación mediante modelos abstractos que sí lo pretenden ser (Madden y Marcuse, 2018: 69).

\section{- 1.1.3 -}

\section{Carácter estructural de los retos urbanos}

«Aunque las distintas formas de opresión residencial puedan parecer muy variadas, sus patrones no son aleatorios. Surgen porque el sistema de la vivienda está integrado en ciertas estructuras sociales que, a su vez, reflejan las líneas de antagonismo y poder de la sociedad de clases» (Madden y Marcuse, 2018: 119).

El carácter estructural recién defendido de los conflictos existentes en torno a la dimensión social de la vivienda que van a ser desgranados en esta primera parte del trabajo, no es algo exclusivo de esta cuestión. Como se argumentará posteriormente, este carácter es inherente a un sistema capitalista cuya supervivencia depende y a la vez genera una serie de contradicciones. Así, sin perder de vista el tema central del trabajo -la vivienda como derecho básico y su papel en la producción y reproducción del espacio social urbano- y tomando este como eje para estructurar la redacción, se tratan a continuación una serie de cuestiones que por las razones anteriores puede decirse que son comunes y extensibles a otros muchos retos urbanos. El contexto tomado para ello es el ya citado capitalismo avanzado. Los denominados retos urbanos se refieren a aquellas situaciones problemáticas complejas existentes en los procesos de territorialización de la sociedad urbana para avanzar hacia el desarrollo justo y equilibrado de la misma, entendida esta como la que surge de la industrialización, de la urbanización completa, y en definitiva hace que la problemática urbana se imponga a una escala global (Lefebvre, 1976). Obviando las fuerzas e intereses que pueden llegar a actuar deliberada y directamente en contra de la consecución de dichos retos -más adelante se incorporan al análisis-, estos presentan tres características compartidas: una relativa toma de conciencia y extendido consenso sobre su existencia, urgencia y veracidad; un choque de posturas a la hora de ofrecer explicaciones y respuestas para su resolución, abordada esta generalmente de manera superficial centrándose en sus efectos; y consecuentemente, una permanencia en el tiempo, con diversas intensidades y características cambiantes, de la problemática de fondo. 


\section{Toma de conciencia y consenso sobre los efectos}

La vivienda, un uso y una necesidad humana con una gran influencia en la conformación y el desarrollo tanto de la calidad de vida (Alguacil, 1998) como de los espacios sociales y los sistemas urbanos (González et al., 2003), ha sido y es un tema de permanente estudio, análisis, regulación e intervención desde muy diversas esferas. Ya sea desde el ámbito académico - por parte de diversas disciplinascomo el político, el técnico, el financiero o el empresarial, entre tantos otros, hay un amplio reconocimiento de la existencia de una crisis de la vivienda (Madden y Marcuse, 2018: 19). En un contexto español, y centrando la mirada en lo que se viene denominando aquí su dimensión social, se puede afirmar que entre muchos de esos diferentes acercamientos a la vivienda existe un relativo consenso sobre la existencia y nivel de desarrollo de múltiples problemas que la afectan y que conforman una compleja problemática. Entre todos ellos se destacan tres, con sus respectivas líneas de estudio. La inevitable selección ${ }^{4}$ de estos y no otros tiene tres motivaciones.

Primero, el hecho de que se aborda la cuestión desde un acercamiento a los estudios urbanos desde la arquitectura, y especialmente el urbanismo, como disciplinas clásicas, aunque con una visión no carente de cierta libertad disciplinaria (pero quedando así fuera otros acercamientos posibles propios del derecho, la antropología, la sociología, la economía, o la administración pública). Segundo, y como se busca demostrar a lo largo de todo el trabajo, se cree que se trata de tres cuestiones con una fuerte interrelación. Esta no es exclusiva, pues como se ha argumentado previamente, muchas de las dimensiones y afecciones en torno a la vivienda sufren de esa influencia mutua. Pero sí se ha tomado esta como condición necesaria a la hora de plantear la investigación. Tercero, y sin caer en un ejercicio de comparación, se cree que son tres de las cuestiones con mayor urgencia hoy en día en torno a la situación de la vivienda como derecho humano fundamental. Tanto en un contexto español en general, como en un contexto más regional propio de la Comunidad Autónoma de Euskadi en particular, y más específicamente en el contexto del Área Metropolitana de Bilbao (AMB), ámbito de estudio sobre el que se desarrolla el cuerpo de la investigación.

De esta manera, se adelantan aquí estas tres patas de la situación problemática seleccionada para ser desarrolladas con mayor profundidad en el capítulo segundo. Primero, la situación del acceso económico -o falta del mismo- se caracteriza por una vulnerabilidad y una exclusión residencial que afecta a una parte importante de la población. Principalmente, debido al desfase existente entre los precios y la capacidad de generar rentas; es decir, una baja capacidad de afrontar el gasto residencial (Inurrieta et al., 2013; Leal, 1995;

${ }^{4}$ Como se ha comentado más arriba, la idea de abordar la problemática en su totalidad, y más desde una tesis doctoral, parece un acto poco razonable. 
Naciones Unidas, 2008; Vinuesa, 2013). Segundo, la evolución de las unidades de convivencia a lo largo de las últimas décadas ha traspasado y desbordado conceptos habitualmente usadas en las políticas púbicas de vivienda como el tamaño, la estructura y, quizás más profundamente, la familia. Y ha incorporado múltiples y cambiantes variables en forma de otro tipo de necesidades, niveles e intensidades de convivencia, lazos de relación, dinámicas laborales, biografías vitales, o perfiles socio-culturales de personas migrantes (Amann, 2005; Guidotti y Arroyo, 2004; Inurrieta et al., 2013; Muxí, 2009). Tercero, en un contexto con una población en estancamiento demográfico y en el que se conocen y han asumido las consecuencias del modelo de ciudad expansivo y la necesidad de reducir la huella urbana, para hacer de los sistemas urbanos artefactos más eficientes en su funcionamiento, eficaces en sus objetivos, y equilibrados con el planeta, se cuenta con un soporte residencial heredado que presenta dos fenómenos que hacen que pueda catalogarse como de infrautilizado en lo que a su dimensión social se refiere. Tipológicamente, las viviendas existentes no han sido en general adaptadas ni transformadas para adecuarse a los cambios recién mencionados; incluso las nuevas viviendas siguen reproduciendo espacios domésticos obsoletos (Montaner et al., 2011; Monteys y Fuertes, 2002; Paricio y Sust, 2000). Por otro lado, una visión mercantilista de la vivienda como objeto de inversión ha ejercido una fuerte influencia sobre la planificación urbana española, y ha llevado a la coexistencia de múltiples desarrollos urbanos residenciales con diversos colectivos incapaces de acceder a ellos, alimentando tanto el número de viviendas usadas vacías como el de viviendas nuevas sin vender o alquilar (Naredo, 2015; Naredo y Montiel, 2011; Roch, 2000).

Sin entrar en existentes excepciones y contradicciones, un repaso al marco normativo y a los instrumentos de planificación de vivienda más recientes, así como a movimientos sociales o poderes políticos, entre otros actores -sobre todos ellos se hablará más tarde-, demuestra cómo en el diagnóstico general de la situación se da el relativo consenso al que se hacía mención. Tanto en la exposición de motivos de instrumentos legislativos, como en el desarrollo de estos, así como en las diferentes líneas de acción y objetivos de programas de gobierno y planes de vivienda, o en recientes movilizaciones de la sociedad civil, pueden localizarse lecturas similares a las recién expuestas. Y sin embargo, la problemática, con sus evoluciones y variaciones, perdura en el tiempo.

\section{Explicaciones y respuestas enfrentadas y superficiales}

Se plantea aquí que, detrás de esa permanencia en el tiempo de algunas importantes problemáticas urbanas actuales, hay dos grandes razones -sin descartar otras variables que afectan a este fenómeno-. Por un lado, una frecuente controversia, en función de la perspectiva desde los que se aborden, sobre tanto la manera de afrontar y dar 
solución a estos retos como sobre las explicaciones de sus orígenes. En general puede afirmarse que, en torno a la crisis de la vivienda:

«...no se comprenden bien cuáles son sus causas ni mucho menos qué medidas se pueden tomar al respecto. La opinión dominante en la actualidad es que el sistema de la vivienda está estropeado, que se trata de una crisis temporal que puede resolverse con medidas aisladas y específicas. En los debates en los medios de comunicación de masas se suele analizar la vivienda con un enfoque estrecho de miras. Se considera que la provisión de un parque de viviendas adecuado constituye un mero problema técnico y se buscan medios tecnocráticos para solucionarlo» (Madden y Marcuse, 2018: 29).

Pero como afirman los propios autores, la crisis abarca mucho más; se enmarca en un sistema superior complejo, desigual y contradictorio con afecciones políticas o ideológicas, entre otras: «plantea interrogantes sobre el poder, la desigualdad y la justicia en la sociedad capitalista» (Madden y Marcuse, 2018: 30). Por otro lado, la atención suele estar excesivamente centrada en los efectos últimos producidos por diversas causas de fondo, y no en estas. Estas dos razones aquí señaladas suelen ser habituales a la hora de abordar retos urbanos complejos; esto no supone que no existan ejemplos de estrategias más integrales y con mayor consenso, si bien se enfrentan a un marco lleno de obstáculos y condicionantes, y suelen quedar relegadas a un segundo plano y con una presencia minoritaria. Como ejemplo paradigmático en el caso del modelo inmobiliario residencial español, está la manera en que se intenta esclarecer y responder al problema de acceso a la vivienda. En general, y en el propio caso vasco, pueden identificarse dos grandes posturas:

«Sobre la base de un diagnóstico compartido -la carestía del suelo y de la vivienda, la lucha contra la especulación- las recetas propuestas por las posiciones más conservadoras partidarios del libre funcionamiento del mercado de suelo y vivienda - y las progresistas - defensores de la función pública urbanística, de la planificación territorial y urbanística y de la intervención pública en el mercado de suelo y de viviendasiguen siendo irreconciliables» (Maguregui, 2007: 304).

La primera, aquella que entiende la vivienda como una mercancía si bien con una función social-, y por consiguiente como un elemento que se comporta bajo las leyes económicas clásicas de la oferta y la demanda en el contexto de un mercado que supuestamente se autoregula. De esta manera, el argumento habitual de este tipo de posiciones ante la subida de precios se suele resumir en ofertar producir- más vivienda para aumentar la oferta, esperando que así se equilibre a la demanda y bajen los precios. Lo cual va unido a una necesaria expansión y ocupación de suelos por parte de la ciudad residencial. Propia de visiones cercanas a planteamientos liberales y neoliberales de la economía -y por lo tanto afianzando una visión 
mercantilista de la vivienda-, tuvo en España uno de sus hitos normativos en la Ley 6/1998 sobre régimen del suelo y valoraciones. Como se abordará más tarde, este instrumento amplió y alteró drásticamente el enfoque desde el que ordenar el suelo urbanizado bajo este tipo de planteamientos. Sin embargo, se trata de una estrategia propia de visiones simplistas y abstractas de la problemática, pues se construye sobre el supuesto de que, ante el aumento de la oferta, el resto de variables y factores se mantendrían igual; pero la realidad ha demostrado no comportarse así (Madden y Marcuse, 2018: 70).

La segunda postura, opuesta a la anterior, parte de una visión de la vivienda centrada en su función social como eje vertebrador de cualquier política, regulación e intervención. Respaldada -como se ha visto más arriba y se verá en apartados siguientes- por un amplio abanico de instrumentos y documentos de ámbito tanto internacional como regional, tiene entre uno de sus principales objetivos el ofertar vivienda asequible a aquellas personas con dificultades de acceder al mercado libre. Para ello despliega diversas herramientas, aunque estas pueden en general y de manera simplificada, resumirse en trasladar una parte importante del coste final habitual de una vivienda libre a las administraciones públicas en forma de gasto social. Aunque con costes de producción generalmente más reducidos, las políticas de vivienda pública aglutinan diferentes formatos de ayudas. Bien dirigidas a los agentes encargados de la construcción o alquiler para que el precio de salida final disminuya -o, en el caso de la promoción pública, de asumirla dentro de ese gasto social-, bien dirigidas a las unidades de convivencia adjudicatarias de una vivienda para que su gasto destinado a la vivienda disminuya. Estas estrategias tienen como gran condicionante el estar enmarcadas, con mayor o menor profundidad, en un marco predominante propio de la primera postura. Es decir, el de la construcción como importante sector económico y productivo. Así, la habitual segregación entre vivienda libre y vivienda protegida realizada tanto en políticas públicas, medios de comunicación e imaginario social como si fueran dos ámbitos estancos y no relacionados, se enfrenta a una realidad altamente interrelacionada que dificulta esa teórica disociación. En esta, políticas de movilización de vivienda vacía privada hacia el alquiler social pueden ayudar a mantener y reproducir un mercado excluyente, la necesidad de vivienda existente en colectivos de difícil acceso económico puede ayudar a justificar y defender la nueva clasificación de suelos urbanizables para desarrollos residenciales que no están dirigidos a estos, o la producción de tanto promociones privadas como públicas y sociales pueden estar en manos de los mismos agentes de la construcción, orientados al lucro. En consecuencia, ambas posiciones muestran, aunque de manera diferente, una aproximación centrada principalmente en los efectos causados por unos conflictos de fondo complejos -que no son abordados- sobre el mercado residencial: 
«La constitucionalidad y legalidad capitalistas están basadas al parecer en una mentira o como mucho en ficciones confusas, si es que cabe deducir algo de lo acontecido en los mercados financieros y de la vivienda durante los últimos años. Sin embargo, carecemos de una percepción común de cuál podría ser la naturaleza exacta de esa mentira. Como consecuencia, solemos reducir el problema de la acumulación por desposesión a la incapacidad para aplicar, poner en práctica y regular satisfactoriamente el comportamiento de los mercados» (Harvey, 2014: 71).

Un análisis similar de estas dos grandes aproximaciones posibles desde las que abordar la problemática ha sido planteado por Madden y Marcuse (2018: 104). Enfatizando que la segunda lo que hace en el fondo es dar por supuesto que el modelo en general funciona bien, ocultando fallos sistémicos disfrazándolos de problemas individuales y buscando integrar a los colectivos afectados en el mercado inmobiliario predominante. De esta manera, tanto desde planteamientos progresistas y sociales en búsqueda de la consecución del derecho a la vivienda, como desde visiones neoliberales que priorizan los intereses empresariales y financieros, los esfuerzos son habitualmente puestos en unas políticas de vivienda que no profundizan en el origen de la problemática -dejando este fuera de las agendas políticas mayoritarias, dando a entender que las necesidades fundamentales residenciales están solucionadas (Madden y Marcuse, 2018: 226)-. Incluso en ocasiones, contrariamente, la alimentan (Beltrán, 2009; Burón, 2015b; Vinuesa, 2013). Algo que, paradójicamente y al igual que en el caso estadounidense (Madden y Marcuse, 2018: 101), llama la atención dada la importancia ideológica que se da a aquellos valores relacionados con la familia y el hogar familiar desde ciertos sectores de la sociedad española y vasca -de especial relevancia para el ámbito de esta investigación en el segundo caso, siendo el Partido Nacionalista Vasco un gran defensor de estos valores y teniendo amplias cuotas de poder y presencia en múltiples organismos y agentes públicos, privados y civiles-. Aunque variable en el tiempo, esta continuidad en la acumulación de conflictos de diferente naturaleza en torno a la vivienda en España genera una diversa y compleja problemática que puede ser catalogada como de estructural y contradictoria. Por supuesto, los conflictos no afectan de igual manera al espectro social -ni a su totalidad-, estando parte de la población con el derecho a la vivienda adecuadamente resuelto; lo cual permite y a la vez oculta que la situación general se mueva permanentemente entre la consecución del citado derecho y la formalización de una ciudad residencial excluyente. Se acercará más a uno de los dos en función de múltiples variables coyunturales.

Esto exige abordar la cuestión considerando dos aspectos. El primero es hacerlo desde un enfoque, en la medida de lo posible, holístico e integrador (Alguacil, 1995: 78). Ya que, como ocurre con otros complejos retos urbanos y espaciales, no se trata del reflejo de 
un único -e internamente coherente- mecanismo causal, si no de la consecuencia de una agregación de diversas tendencias y fenómenos socio-espaciales (Brenner, 2004: 31). El segundo lleva a posicionarse en la crítica constructiva, y desde esta hacer un ejercicio de abstracción de la realidad analizada para relacionar los hechos y efectos más evidentes con los factores y las causas que los provocan, para superar un análisis descriptivo ya que «la tarea es comprender, reconocer los hechos por lo que son, por lo que "significan" para aquellos a quienes le son dados como hechos y tienen que vivir con ellos. En la teoría social, el reconocimiento de los hechos es crítica de los hechos» (Marcuse, 1985: 149). En definitiva, los efectos más claramente palpables de esta problemática se cree que están directamente relacionados con contradicciones embebidas en el corazón de las sociedades capitalistas, y por lo tanto requieren un análisis del modelo residencial dentro de contextos más generales (Madden y Marcuse, 2018: 105). Con esa intención, el objeto de estudio de este trabajo es situado en un marco más amplio que se desarrollará en el siguiente apartado 1.2, propio de un capitalismo internamente contradictorio que incorpora de una manera estructural diversos conflictos. Pero no sin antes hacer un breve repaso histórico para apoyar esta afirmación de que muchos de estos problemas, con mayor o menor intensidad, resisten con fuerte arraigo el paso de los años.

\section{Permanencia histórica de los conflictos}

«La idea de crisis implica que el hecho de que la vivienda sea inadecuada o que no sea asequible es algo anormal, una desviación temporal de una norma que funciona bien. Pero para la clase trabajadora y las comunidades pobres, la crisis de la vivienda es la norma» (Madden y Marcuse, 2018: 34).

Como se ha buscado reflejar parcialmente al abordar la situación de la dimensión social de la vivienda, la urbanización como proceso social histórico de territorialización de la sociedad urbana es un fenómeno desequilibrado y excluyente, a la vez que instrumento, medio y objeto de desarrollo del capitalismo desde sus orígenes hasta su versión actual más avanzada (Harvey, 1977; Lefebvre, 1976; Massey, 1995). Se puede afirmar así que existe una crisis urbana global como tal, en la medida en que se trata de un modelo de desarrollo socio-espacial con una alta densidad de conflictos internos y permanentes dentro de su acotada evolución y cambio. En lo relativo a la vivienda, la permanencia histórica de una situación de desigualdad y vulnerabilidad residencial afectando a los colectivos y grupos de población más débiles ha sido incluso identificada en tiempos anteriores a la revolución industrial y su consecuente superpoblación y aglomeración de mano de obra, extendiéndola a «todas las clases oprimidas de todos los tiempos» (Engels, 2006: 18). Con ánimo de ofrecer un pequeño reflejo local y temporalmente acotado de este 
marco histórico y global, se desarrolla a continuación un breve ejemplo de cómo la problemática del acceso a la vivienda en el AMB permanece a la vez que evoluciona desde los mismos orígenes de la ciudad industrial.

El recorrido se ha hecho a través de diversas iniciativas surgidas para la consecución de un acceso a la vivienda digna en episodios temporales anteriores al actual en el AMB. No es objeto de este trabajo -ni tampoco el diseño de la investigación así lo exige- hacer una recopilación detallada y amplia de estas. Sin embargo, sí se cree de interés rescatar algunos ejemplos. Un fin complementario de este ejercicio es mostrar que, a pesar de darse en diferentes contextos temporales, sociales, culturales, políticos o económicos, tanto ahora (se aborda en el capítulo 4) como en épocas pasadas, la carencia de vivienda asequible en un contexto institucional incapaz de responder mediante grandes políticas a la totalidad de necesidad habitacional generó la aparición de iniciativas -al margen, en algunos casos, del urbanismo predominante- de muy diversa naturaleza. Algo que, por supuesto, no se limitó al AMB, si no que se dio en múltiples ciudades y áreas urbanas (Madden y Marcuse, 2018: 46). Experiencias que, de una $\mathrm{u}$ otra manera, aportaron soluciones $\mathrm{o}$ avances hacia dicho derecho. Es decir, se plantea que los casos a analizar en este trabajo no son una anomalía de estos tiempos, fruto de la situación residencial actual -que ha vivido épocas más conflictivas y urgentes-, si no un ejemplo del tipo de iniciativas que existen hoy en día como respuesta a dicha problemática. No se busca aquí comparar las razones actuales y pasadas de todo ello. Pero sí parece confirmarse que el problema de la vivienda es más una constante temporal sin resolver, con variaciones y alteraciones en función del contexto socioeconómico, que un problema puntual que aflora cada cierto tiempo.

Las iniciativas aquí señaladas fueron generadas al margen de los procesos de desarrollo y gestión residencial convencionales, como respuesta a la incapacidad de los anteriores de responder a las complicadas necesidades que se repiten, o directamente no desaparecen. Para el desarrollo de este breve ejercicio se ha apostado por una tabla de síntesis (Tabla 1.1). En ella se ha indicado, a modo de ejemplo ilustrativo para el argumento aquí buscado y no como un mapa completo de la situación, el seguimiento de tres variables a lo largo de casi un siglo en el AMB. La primera es la definición general del contexto en el que se encontraba la situación problemática de la vivienda en cada época, a través de una serie de pinceladas que ponen de relieve las principales características de la misma. La segunda variable hace referencia a hitos y/o declaraciones institucionales clave en relación a la política de vivienda como respuesta al contexto anterior. Por último, la tercera hace lo propio con otras iniciativas no institucionales o alternativas -si bien en muchos casos hay interacción y relación entre ambas esferas-, señalando algunos casos paradigmáticos de desarrollo residencial fuera de las grandes políticas públicas de vivienda. 
Se ha trabajado a partir de la consulta de una serie de fuentes, entre muchas otras, que han analizado esta temática. Una de las más aclaratorias ha sido la rica recopilación de información realizada por Muñoz (2009). Aunque su enfoque se centra en la utilización y ocupación de la periferia como escenario habitual para el desarrollo de respuestas a la necesidad de vivienda, el artículo incorpora datos y referencias de gran interés para el objeto de este apartado. Este trabajo se ha visto complementado por otros, en general centrados en temas más específicos (Bilbao, 2016; Domingo, 2005; Etxezarreta y Etxezarreta, 2007; Gondra, 2004; López, 2016; Ruzafa, 1993).
Tabla 1.1. Algunos hitos de las respuestas pública y privada ante la problemática de la vivienda en el AMB entre finales del siglo XIX y finales del siglo XX. Elaboración propia a partir de bibliografía señalada.

\begin{tabular}{llll}
\multicolumn{1}{c|}{ Contexto } & \multicolumn{1}{c}{ Marco institucional } & \multicolumn{1}{c}{ Otras iniciativas } \\
\hline \multicolumn{1}{c}{ Primer periodo de industrialización (1850-1900) } \\
\hline - La fuerte y rápida migración & - 1876: Julio de Saracíbar, & - 1856: construcción de \\
hacia el AMB atraída por el & alcalde de Vitoria-Gasteiz y & viviendas para el personal \\
desarrollo industrial a lo & futuro alcalde de Bilbao & obrero de la fábrica Nuestra \\
largo de la ría generó una & señala «la importancia social & Señora del Carmen en \\
alta carencia de viviendas, & de que el Ayuntamiento, o & Barakaldo -una de las \\
ubicándose estas personas & quienes tuviesen medios & figuras clave de la futura \\
en zonas marginales yen & para ello, construyeran & Altos Hornos de Vizcaya \\
condiciones de habitabilidad & viviendas económicas & (AHV)-, como estrategia de \\
lamentables. & destinadas a la clase & cuidado de la mano de obra, \\
- Primeros debates sobre la & proletaria» (Muñoz, 2009: & pero también de fijación y \\
responsabilidad de la & 775). & control de su reproducción y \\
promoción, el tipo de & $-1885:$ Pedro de Alzola, & estabilidad social para \\
alojamiento y el régimen de & alcalde de Bilbao, apunta «la & asegurar la productividad. \\
tenencia. & descuidada necesidad de & - Compañías mineras \\
& construir en la capital & desarrollan un barrio \\
& "viviendas baratas y & residencial en el monte \\
& suficientemente holgadas & Arnábal entre el barrio de El \\
& para familias de escasos & Regato de Barakaldo, y La \\
& recursos"» (Muñoz, 2009: & Arboleda, en Trapagaran. \\
& 776). & Oferta exclusivamente \\
& & destinada a las personas \\
& & empleadas, no a luchar \\
& & contra la grave situación de \\
& & la vivienda.
\end{tabular}

Primeros años del siglo XX

- La «provisión de habitaciones en la mayoría de los casos quedó en manos del hacinamiento, la miseria o el chabolismo, así como de un incipiente negocio inmobiliario que se encargó de proporcionar viviendas en un oneroso alquiler en espacios marginales de la ciudad,
- Carencia de una política de vivienda aglutinadora.

- 1911: primera ley centrada de manera específica en la problemática residencial, la Ley de Casas Baratas. Aunque «su incidencia fue prácticamente nula en Bilbao» (Muñoz, 2009: 780).

- El Ayuntamiento de Bilbao decide -como otros
- Las primeras iniciativas de promoción de vivienda asequible en Bilbao se dan por parte de empresarios locales y «fueron iniciativas puntuales sin carácter de continuidad, que reflejaron de manera tímida las propuestas que se estaban llevando a cabo en el resto de Europa» (Muñoz, 2009: 
originando problemas de insalubridad y de falta de espacio» (Muñoz, 2009: 779).

- El realquiler de habitaciones era una práctica habitual, a la vez que «capataces y contramaestres de las fábricas, tolerados por los industriales dentro de la práctica de la coexplotación, instauraron un mercado subterráneo del alojamiento obrero» (Ruzafa, 1993: 293).

- El joven Ensanche, con suelo disponible, fue acaparado por la especulación y el negocio inmobiliario.

- El Casco Viejo y sus arrabales albergaban un alto número de infraviviendas.

- Baja incidencia de las primeras medidas legales en torno a la necesidad de vivienda. Las Casas Baratas, presentadas «como la panacea a la insuficiencia de residencias obreras [...] se convirtieron en el ideal de vivienda para la población trabajadora. Ideal al que, no obstante, el grueso de ese sector social no pudo acceder» (Domingo, 2005: 529). municipios en Españapromover directamente viviendas.

- 1918: crea la empresa pública Casas Baratas de Bilbao con financiación propia, estatal, y provincial, apostando por desarrollos de vivienda colectiva en alquiler.

\section{Década de 1920}

- Las nuevas actuaciones públicas proporcionan alojamiento a personal municipal, y las privadas a las familias vinculadas a las empresas. Se generalizan así las críticas en torno a los proyectos de casas baratas, ya que «las casas baratas tan sólo estuvieron al alcance de aquellos ciudadanos con un sueldo estable y algunos ahorros con los que poder hacer frente a la propiedad

\section{- 1921: Ricardo Bastida,} arquitecto municipal de Bilbao, señalaba la baja participación municipal en la construcción directa de viviendas, para lo que pedía mayor autonomía económica y mejor organización del régimen municipal.

- La legislación se limita a impulsar la iniciativa privada, «sin formular el problema de la vivienda como un
779) y optaban por un régimen de propiedad.

- Irala-Barri (1908-1918), promovida por Juan José Irala junto a su Compañía Bilbaína de Molinería y Panificación.

- Barrio de La Cruz (1910), levantado por la Sociedad de Construcciones Baratas, constituida por empresarios bilbaínos católicos.

- 1914: AHV participa en la sociedad Casas Baratas de Barakaldo y Sestao, entrando «en el negocio de la construcción para obreros en la margen izquierda del Nervión» (Ruzafa, 1993: 293). 
de su vivienda, que además era unifamiliar. Por lo que los empleados, los funcionarios y los trabajadores cualificados fueron los principales beneficiarios de estas leyes, así como las sociedades cooperativas que entendieron las leyes de casas baratas como un negocio inmobiliario» (Muñoz, 2009: 790).

- Por otro lado, se considera que fueron instrumentos para la reproducción entre cierta clase obrera y media de una serie de valores como propiedad, moral, individualismo, higiene y orden social.

- 1924: un estudio del ayuntamiento de Bilbao detecta la necesidad de 8.000 habitaciones.

- La problemática sigue sin solución, y se siguen dando situaciones de hacinamiento, insalubridad y chabolismo. problema de Estado» (Muñoz, 2009: 783).

- Número de viviendas construidas inferior a años precedentes, a lo que «contribuyó la inactividad del consistorio bilbaíno» (Muñoz, 2009: 788). viviendas.

\section{Década de 1930}

\footnotetext{
- Primeras reflexiones sobre otras ideas de alojamiento colectivo en línea con experiencias europeas; «el obrero español tiene derecho a vivir como viven los obreros alemanes, - 1932-1933: desarrollo de una promoción en Solokoetxe, Bilbao, bajo criterios de mayor densidad y apuesta por el alquiler, siguiendo nuevos preceptos franceses, americanos, etc. El Gobierno español ha dado muchos millones para ello, pero le han estafado» (Aizpúrua, 1930: 9). arquitectónicos. - «...los organismos locales no dispusieron de los medios económicos necesarios para poder llevar a cabo un programa de alojamiento masivo que siguiese el modelo marcado por Solokoetxe de vivienda mínima en altura» (Muñoz, 2009: 796).
}

\section{Década de 1940}

\begin{tabular}{lcc}
\hline - La escasez de alojamiento & -1939 : a nivel estatal, & - La iniciativa privada como \\
favorece una subida del & aprobación de la Ley de & principal agente promotor \\
precio del alquiler. & Viviendas Protegidas y el & de vivienda, apoyada por
\end{tabular}


- El subarriendo, el hacinamiento y el chabolismo continúan.

- 1943: el ayuntamiento de Bilbao estima una necesidad de 12.000 viviendas.

- El fomento de la propiedad contribuyó al fracaso de las iniciativas municipales y estatales.

- Exclusión de sectores con menos rentas de las promociones municipales. Las viviendas en propiedad de la Obra Sindical del Hogar requerían una estabilidad laboral y capacidad de ahorro para afrontar entrada e hipoteca; las viviendas municipales en alquiler tenían precios altos «destinados a los empleados municipales, así como a los trabajadores de las empresas locales que adquirieron acciones de la sociedad» (Muñoz, 2009: 801).

- 1949: el Colegio Oficial de Arquitectos Vasco-Navarro calcula una necesidad de 10.000 viviendas en Bilbao.
Instituto Nacional de Vivienda.

- Creación del Patronato Social de Viviendas y Obra Sindical del Hogar.

- El enfoque estatal en el desarrollo rural desatiende «las necesidades de los principales centros urbanos como Bilbao, donde el problema de la falta de viviendas era precisamente mucho más apremiante» (Muñoz, 2009: 797).

- 1941: el ayuntamiento de Bilbao crea la Sociedad Inmobiliaria Viviendas Municipales en Comandita.

- 1944: cambio en la política estatal, apuesta por construcción de viviendas sociales en principales ciudades.

- Desarrollo de grandes promociones en Bilbao, como Torre Madariaga (1941-1950) con 685 viviendas y San Ignacio de Loyola (primera fase entre 1945-1951) con 1.069. subvenciones y ayudas públicas, en un contexto de fomento de empleo $y$ actividad económica.

- Sociedades inmobiliarias como principales beneficiarias de estas iniciativas.

\section{Década de 1950}

\footnotetext{
- En los últimos años de la década, el fin de la política - 1955: puesta en marcha desde el Estado de los autárquica y la progresiva liberalización económica inician un desarrollo económico, especialmente intenso en el AMB; el enorme crecimiento poblacional consecuente «hizo que el hacinamiento, el subarriendo y especialmente el chabolismo fuese mucho más acentuado que en años anteriores» (Muñoz, 2009: 802).

- La oferta de vivienda existente era incapaz de responder a un incremento de necesidad residencial tan Planes de Urgencia Social para incentivar la propiedad entre las clases de rentas bajas y eliminar el chabolismo.
} 
significativo.

- Crecimiento informal del área metropolitana en lugares de orografía pronunciada, con mala o ninguna comunicación con el centro, sin dotaciones ni servicios, y en condiciones deficientes.

\section{Décadas de 1960 y 1970}

- Extrema gravedad de la situación de la vivienda.

- 1961: se estiman unas 4.987 chabolas en Bilbao alojando a 26.314 personas.

- 1964: 34.448 nuevos habitantes llegan a Bilbao.

- A principios de la década de 1960 se estimaban más de 15.000 familias viviendo en subarriendo y un déficit de más de 16.000 viviendas.

- 1968: a pesar de haber construido ese año 13.248 viviendas el déficit sigue aumentando; en 1971 está en 25.000 viviendas.

- Primeros años de la década de 1970: «el chabolismo tuvo un gran repunte como consecuencia de los nuevos movimientos migratorios y de la escasez de viviendas asequibles para las clases más bajas» (Bilbao, 2016: 102).
- 1961: alentados por diversos sectores sociales y religiosos, las instituciones bilbaínas «anunciaron la puesta en marcha de un plan para dar solución a lo que identificaron como un "problema social y moral de primer orden"» (López, 2016:319).

\section{- 1960: se inicia el desarrollo} de un caso paradigmático de los Planes de Urgencia Social, el barrio de Otxarkoaga, por parte del Ministerio de Vivienda.

- 1963: el ayuntamiento, al recibir el derecho de gestión de Otxarkoaga denuncia el mal estado de conservación de las viviendas -ya ocupadas-.

- Instituciones afirman que los principales problemas urbanísticos de Bilbao han quedado solucionados.

- Pero algunos agentes denuncian la «escasa capacidad que demostraron las autoridades al pretender resolver este problema» (Bilbao, 2016: 99).

- 1966: se inicia la urbanización del barrio de Txurdinaga y el Ensanche de Begoña en Bilbao con una previsión de 11.000 viviendas, y una importante participación de sociedades cooperativas.
- Grandes actuaciones en la periferia por parte de la iniciativa privada con ayudas públicas, logran erradicar el chabolismo en gran medida, pero a través de un urbanismo pésimo o inexistente.

- Importantes inversiones por parte de la iniciativa privada en adquirir suelo para la edificación de viviendas como un negocio muy rentable para una serie de empresas inmobiliarias, siendo «tiempos prolíficos para la iniciativa privada [...] el tipo de vivienda que se sostuvo por los promotores privados respondía a conceptos que no pasaban de ser meramente económicos» (Bilbao, 2016: 107).

- Segundo gran florecimiento de cooperativas de vivienda, posiblemente favorecidas por la Ley de Viviendas de Renta Limitada de 1956. 
La interpretación de esta tabla lleva a detectar cinco constantes que vienen a confirmar algunas cuestiones avanzadas. En primer lugar, y tal y como se puede observar en la columna relativa al contexto de la problemática de la vivienda, esta ha sido efectivamente una constante estructural en el periodo analizado. Aunque en determinados periodos fuertemente agravada y sostenida por un aumento de población rápido y descontrolado incapaz de ser gestionado por las instituciones, otros factores parecen ser clave para ello. Uno de ellos es la segunda constante detectada. En este caso, se trata de la permanente exclusión del grueso de una clase obrera y de rentas bajas de una supuesta política de vivienda orientada a dicho sector social. Las fuentes consultadas indican que muchas de las medidas tomadas desde la esfera tanto pública como privada y apuntadas en la tabla están diseñadas, de facto, para una clase obrera ascendente, si no directamente para una clase media floreciente. La tercera constante es también un factor determinante para el mantenimiento de la situación de crisis constante de vivienda. Se trata de la intervención de agentes en la gestión inmobiliaria con un objetivo lucrativo y meramente comercial, que ven en la construcción de vivienda -orientada a una clase obrera o no- una oportunidad de acumulación de capital. En este sentido, son paradigmáticos algunos casos señalados, en escalas y esferas muy diversas. Como aquellas industrias que, de ofrecer vivienda en exclusiva al personal empleado en la misma, pasan a abrir una línea de actividad - directa o indirectamente- centrada en el negocio inmobiliario, o los casos de subarriendo y realquiler de habitaciones a familias enteras, provocando el hacinamiento y una alta rentabilidad económica de la vivienda arrendada.

La cuarta constante detectada se refiere al papel de las instituciones. Se ha de señalar que, la insuficiencia de la respuesta pública a la crisis descrita y señalada en la Tabla 4.1 no se justifica por una falta de interés por parte de ciertos agentes de la administración. A pesar de que posiblemente los esfuerzos realizados no han venido siendo ni suficientes ni del todo acertados, desde los inicios del periodo analizado se observan testimonios y muestras de interés y preocupación por la necesidad de responder a una grave situación habitacional. Igualmente, se han venido dando diversos ensayos y ejecución de actuaciones para intentar solucionar el problema. Lo cual indica que la complejidad del asunto no puede simplificarse a una cuestión de supuestos bandos enfrentados con posicionamientos claros, si no que muchos y diversos agentes, intereses, afecciones, limitaciones y condicionantes entran en juego. Por último, se observa una quinta constante y esta hace referencia al hecho de que las respuestas que con mayor o menor éxito se han venido dando a la problemática residencial a lo largo de este periodo, lo han hecho desde muy diversos organismos y esferas, a diferentes escalas, y con muy diversos objetivos, como se acaba de apuntar -asegurar la productividad empresarial, desarrollo de una actividad económica, respuesta a una necesidad social,...-. 


\section{Las geografías de las contradicciones en procesos de gobernanza urbana como línea de investigación}

En este apartado se han presentado las principales motivaciones y justificaciones, los síntomas, que han llevado a la elección de esta dimensión social de la vivienda como objeto de estudio. El fin último es colaborar en la comprensión y la transformación de un sistema de organización socio-espacial dominante y excluyente centrado en un fin principal: la acumulación de capital. Se apunta, por tanto, a una dimensión social que busca la consecución última del acceso a la vivienda entendida como un derecho humano fundamental al cual no todas las personas tienen todavía acceso. El estado actual de desarrollo de esta dimensión se enmarca en el contexto más amplio ya apuntado, propio de un carácter estructural de este y otros retos urbanos. Esto, junto con algunas cuestiones clave para esta investigación -que se desarrollan más adelante- como la naturaleza interna y transversal de ciertas contradicciones, una gobernanza desigual, o las herencias y retos propios del AMB, permiten plantear el estudio de las geografías de las contradicciones en procesos de gobernanza urbana como la línea de investigación. En este caso, centrada en los usos residenciales en un contexto de crisis urbana.

El cruce que el trabajo plantea, en siguientes capítulos, de esta problemática con el soporte socio-espacial del AMB y la crucial variable de la gestión y los agentes que la protagonizan, supone un aterrizaje de todo ello en la realidad, buscando la aplicación y transmisión del conocimiento generado. Se piensa en modelos de gestión que abarquen también, por supuesto, algunas de las dimensiones no incluidas en el trabajo, y que serán los agentes clave para aprovechar las oportunidades que se van a señalar. Si bien es una investigación parcial y no trata todas las dimensiones y ámbitos de influencia de la vivienda, también es un trabajo de temática heterogénea y multiescalar que intenta conectar varias de las mismas con una mirada poliédrica. Bajo todo ello, hay una inquietud y una llamada de atención por recuperar la vivienda como un elemento, no solo básico para el desarrollo vital, si no también de gran complejidad y cuyas múltiples facetas difícilmente pueden ser separadas en su totalidad. El enorme peso que la variable económica de la vivienda tiene en el sistema urbanístico e inmobiliario español ha hecho que, desde que se produjera la explosión de la burbuja inmobiliaria, en ocasiones parezca que los problemas anteriores a la misma hayan quedado relegados a segundo plano. $Y$ no por que se hayan conseguido solucionar, si no porque toda la atención se ha centrado en el seguimiento de la compra-venta, los precios, y los puestos de trabajo perdidos; y sin embargo, la verdadera problemática de fondo de la vivienda se sigue sin resolver mientras cuestiones como la crisis financiera no hacen si no recrudecer algunas de sus características (Etxezarreta, 2010: 5). 


\section{$-1.2-$ \\ Un marco para la comprensión y la búsqueda de respuestas}

Lo desarrollado en el apartado 1.1 lleva a identificar este fenómeno de la ciudad residencial excluyente como una contradicción propia de un sistema que pretende, por un lado, dotar a todas las personas de una vivienda digna y adecuada mientras, paralelamente, despliega un método de producción del espacio residencial, no solo excluyente, si no dependiente del mantenimiento de esa exclusión para su supervivencia. La necesidad y el deseo tanto de analizar y comprender los fenómenos detrás de esta contradicción, como de buscar y señalar posibles respuestas, lleva a esta investigación a seleccionar una serie de trabajos enmarcados en la teoría urbana crítica como apoyo teórico. El objetivo primero es argumentar y dotar de un marco a la afirmación anteriormente planteada: la situación problemática en el $\mathrm{AMB}$, brevemente presentada y que será desarrollada en el siguiente capítulo, tiene una naturaleza estructural propia, no solo del modelo urbanístico e inmobiliario residencial hegemónico, si no de un contexto más amplio propio de un sistema capitalista y neoliberal establecido como forma dominante de organización social. Un sistema que, como ha sido ampliamente estudiado y argumentado a lo largo de sus últimas décadas de existencia, tiene como fin último la acumulación de capital a través de complejos e imbricados arreglos espacio-temporales provisionales que permiten la búsqueda $y$ generación de excedentes de capital, materiales y humanos para una reproducción geográficamente desigual (Harvey, 2014). Las fuerzas enredadas y diversas que actúan abarcan muchos intereses y posturas y generan diferentes contradicciones, pero el (des)equilibrio resultante se decanta generalmente hacia dicha acumulación produciendo importantes situaciones de exclusión y desigualdad social. Las contradicciones tienen aquí un papel fundamental: no son un efecto colateral, pues más bien es su permanencia la que permite precisamente esa reproducción del capitalismo.

Sin embargo, a esta posición crítica se suma una intención constructiva y transformadora. La cual se formaliza en la creencia de que existen ciertas oportunidades, debidas a ciertas características del modelo actual y su contexto heredado -que serán en su momento desarrolladas-, que permiten de una manera alternativa luchar para lograr avances en la superación de la problemática. Para ello, la investigación se apoya en un marco teórico que permite dos 
movimientos. En primer lugar, el marco permite contextualizar, desgranar y comprender las lógicas que sostienen y fortalecen los conflictos apuntados. Lo cual será desarrollado en el presente apartado 1.2, y permitirá construir en el 1.3 el planteamiento general de la investigación y la hipótesis principal de partida. En segundo lugar, a partir de dicho marco se ha construido una herramienta de análisis, presentada y aplicada en el capítulo segundo, a partir de la cual se ha concretado la hipótesis de partida y se han identificado esas potenciales alternativas que serán analizadas en el cuerpo de la investigación.

De cara a la construcción de dicho marco teórico, la pregunta que se busca responder es la siguiente: ¿cuáles son las ideas, los principios, las herramientas, agentes, espacios de decisión, intereses, condicionantes, conflictos, acciones,... existentes hoy en día y que conforman el contexto hacia la consecución de un acceso digno y adecuado a la vivienda? En definitiva, ¿cuál es la realidad en la que encaja esta investigación, y sobre la que definir una hipótesis de trabajo?. De manera previa a poder responder a dichas preguntas, es necesario dar alguna breve pincelada sobre lo que es la teoría urbana crítica y cuáles son los fundamentos que de ella se toman. El resto del apartado se divide en las dos grandes líneas de trabajo consultadas para la posterior construcción de la herramienta para el análisis: el carácter contradictorio de la condición urbana como elemento clave de la consolidación del capitalismo, y su desarrollo a través de una gobernanza urbana desigual .

\section{La teoría urbana crítica como herramienta de investigación}

Frente a posiciones y corrientes más conformistas o pesimistas, la evolución de la teoría crítica ha buscado no solo identificar las contradicciones internas del capitalismo, sino también señalar y explorar las alternativas al mismo. Un posicionamiento que ha sido mantenido y desarrollado por diferentes contribuciones al pensamiento marxista desde la geografía, la filosofía y el urbanismo, entre otras disciplinas (Harvey, 2014; Lefebvre, 2013; Marcuse, 1985), utilizando la teoría urbana crítica como instrumento para la transformación social. En su artículo ¿Qué es la teoría urbana crítica? Brenner (2017b) resume algunos de los elementos clave para comprender la posición desde la cual esta nace y desarrolla su labor. Tal y como el autor plantea, es una expresión que con frecuencia se utiliza para hacer referencia tanto a cierta obra teórica urbana radical o de izquierdas en los años posteriores a 1968 de autores como Henri 
Lefebvre, David Harvey, Manuel Castells, o Peter Marcuse, así como a otros inspirados por estos.

Una corriente que se distingue de la teoría urbana dominante ${ }^{5}$, pues en «vez de reafirmar la situación actual de las ciudades como expresión de leyes transhistóricas de organización social, racionalidad burocrática o eficiencia económica, la teoría urbana crítica enfatiza el carácter política e ideológicamente mediado de espacios urbanos que están abiertos a la disputa social» (Brenner, 2017b: 234). Se enfrenta así a saberes urbanos heredados y formaciones urbanas existentes insistiendo en que «otra forma de urbanización socialmente justa, sostenible y más democrática, es posible, aunque actualmente esté siendo reprimida por los mecanismos institucionales y las prácticas e ideologías dominantes» (Brenner, 2017b: 234). Brenner revisa los orígenes del concepto moderno de crítica y los sitúa principalmente en la Ilustración, si bien identifica -apoyando esta afirmación en otros trabajos (Postone, 1993) - un momento clave en el que este adquirió un nuevo sentido: el desarrollo de la crítica de la economía política en la obra de Marx:

«Marx entendía la crítica de la economía política no sólo como una crítica de las ideas y discursos sobre el capitalismo, sino como una crítica del capitalismo en sí mismo, y como una contribución al esfuerzo por superarlo [...] un medio para explorar, tanto en la teoría como en la práctica, la posibilidad de forjar alternativas al capitalismo [...] para mostrar cómo las contradicciones inherentes al capitalismo socavan el propio sistema y, al mismo tiempo, apuntan a su superación con otros modos de organizar las capacidades sociales» (Brenner, 2017b: 237).

El autor atribuye a la Escuela de Frankfurt de teoría social crítica la exploración más sistemática de este concepto, que fue trabajado desde diferentes perspectivas y autores a lo largo de varias décadas. Aunque aquí interesa lo que cataloga como «la visión más politizada de la teoría crítica» (Brenner, 2017b: 239) planteada por Herbert Marcuse en El hombre unidimensional (1985), quien «recela de esa astuta integración que el sistema hace de todo aquello que se le opone, y [...] constata que, a pesar de todo, existen nuevas alternativas» (Elorza, 1985: VII). Efectivamente, Marcuse enfatiza que una teoría crítica de la sociedad contemporánea tiene entre sus propósitos examinar sus alternativas históricas, pues la «forma establecida de organizar la sociedad se mide enfrentándola a otras formas posibles, formas que se supone podrían ofrecer mejores oportunidades para

\footnotetext{
${ }^{5}$ Entendida como aquella no solo desarrollada en el ámbito académico, si no también -O principalmente- como la que sustenta y explica las posiciones, ideologías, acciones y motivaciones predominantes en ámbitos técnicos, políticos y empresariales dedicados a la práctica cotidiana del urbanismo, la planificación espacial, el desarrollo de políticas urbanas, y que en general conforma la norma común de intervenir, pensar, opinar o percibir los sistemas urbanos por parte de una gran mayoría social.
} 
aliviar la lucha del hombre por la existencia» (Marcuse, 1985: 20). De esta manera la teoría social crítica queda irremediablemente «relacionada con las alternativas históricas que amenazan a la sociedad establecida como fuerzas y tendencias subversivas» (Marcuse, 1985: 22). Se trata de una corriente que busca luchar contra lo que el propio Marcuse denomina conciencia feliz, reflejo del conformismo y que se formaliza en una forma de conducta social que impide la comprensión de las contradicciones y las alternativas (Marcuse, 1985: 109, 114).

Pero para que esas fuerzas y esas alternativas sean desarrolladas y construidas con la capacidad suficiente de enfrentarse a los sistemas de organización existentes, se ha de dar un paso previo crucial, compuesto de cuatro fases: la identificación, asimilación, análisis y comprensión de las contradicciones internas. En la medida en que son fuerzas a desarrollar por sujetos dentro de esos sistemas, se necesita primeramente asumir que «la negación existe antes que el cambio mismo, la idea de que las fuerzas históricas liberadoras se desarrollan dentro de la sociedad establecida es un punto clave de la teoría marxista» (Marcuse, 1985: 53). De tal manera, que Brenner concluye que hay «una conexión directa entre el proyecto de Marcuse y un aspecto central de la crítica de la economía política planteada originalmente por Marx: la búsqueda de alternativas emancipatorias latentes en la actualidad, partiendo de las contradicciones de las relaciones sociales existentes (como ha enfatizado sistemáticamente Postone, (1993)» (Brenner, 2017b: 239). Se trata, en definitiva, de una visión de la crítica con un espíritu constructivo de fondo. Algunos otros estudiosos de Marx se han decantado también por este tipo de posturas, planteando que «tiene que haber una forma de examinar el presente que muestre en su interior cierto futuro como potencialidad; de otro modo, sólo se hace a la gente desear infructuosamente[...]» (Eagleton, 2011: 69).

Para mostrar un ejemplo de lo anterior, es posible acudir a otro autor firmemente dedicado al estudio de las contradicciones propias del capitalismo avanzado, como David Harvey. Este planteaba la realización de ciertas afirmaciones universales por parte del movimiento zapatista mexicano como afirmaciones que «descansan firmemente en la experiencia local, pero operan más dialécticamente en relación con la globalización [aprovechando] la contradicción implícita vigente en la actual aceptación en todo el mundo de ciertas normas y formas de "hacer negocios" y de definir "las libertades" y el derecho a elegir» (Harvey, 2003: 107). El autor argumenta que el mantenimiento del «mundo seguro para la democracia y la libertad de expresión se consideraba y se considera íntimamente unido a mantener el mundo libre para el capital, y viceversa. Ésta es la raíz de toda una serie de paradojas y contradicciones contemporáneas que crean oportunidades y potencialidades para formas progresistas de acción política» (Harvey, 2003: 107). Es decir, el sistema actual presenta entre sus instrumentos y formas de desarrollo grietas que 
permiten actuar en contra de sus intereses principales. Para concluir, se señalan las cuatro proposiciones que Brenner plantea como constitutivas e indisolublemente entrelazadas que conforman una concepción común de la teoría crítica, bajo las cuales podrían encajar las diferentes visiones existentes dentro de dicha teoría (Brenner, 2017b).

\section{Es teoría}

El autor hace referencia a la naturaleza abstracta de la misma, situándola en el momento previo a la búsqueda de respuestas. Con ello, plantea que a pesar de que puede «construirse sobre investigaciones concretas, es decir sobre una base empírica», no busca «servir como fórmula para un camino concreto hacia el cambio social; no es un mapa estratégico para el cambio social; y no es un manual del tipo "¿cómo hacer...?” para movimientos sociales» (Brenner, 2017b: 241). Es este el punto en el que más fricción se genera con los planteamientos de la presente investigación, pues esta busca pretendidamente unos resultados que puedan ser comprendidos y aplicados con cierta facilidad para reconducir la situación problemática. Si bien no se buscan respuestas concretas ni se proponen soluciones específicas, y el objeto del trabajo es la identificación y la comprensión de determinados fenómenos existentes y potenciales- en torno a la gestión de la vivienda, sí hay una deriva intencionada hacia una teoría aplicada. Como el propio Brenner recuerda que dijo Marcuse, «los conceptos teóricos culminan en el cambio social» (1985: 22).

\section{Es reflexiva}

Situarse en la teoría crítica supone hacerlo desde una posición de plena consciencia en un contexto espacio-temporal históricamente específico; es un conocimiento «intrínsecamente contextual» (Brenner, 2017b: 241). Por otro lado, esta reflexividad busca poner en evidencia el «carácter fragmentado, fracturado o contradictorio del capitalismo como una totalidad social» (Brenner, 2017b: 242). En este sentido, el autor recuerda que la ausencia de este carácter contradictorio significaría la ausencia y falta de necesidad de una conciencia crítica. Esta surge, precisamente, por la existencia de conflictos internamente generados y sufridos por la propia sociedad. La presente investigación puede calificarse de reflexiva en los términos que Brenner propone, en la medida en que busca abordar una situación problemática determinada -identificada y asumida- en un contexto social, espacial y temporal concreto.

\section{Implica una crítica de la razón instrumental}

La crítica de la razón instrumental elaborada en la Escuela de Frankfurt estaba dirigida a confrontar una racionalidad centrada en 
conectar «eficazmente los medios y los fines, sin cuestionar los fines en sí mismos» (Brenner, 2017b: 242). La teoría crítica rechaza por lo tanto los planteamientos de las ciencias sociales «destinados a hacer más eficientes y efectivos los arreglos institucionales existentes, a manipular y dominar el mundo físico y social y, por lo tanto, a reforzar las formas vigentes de poder [exigiendo] cuestionar los fines últimos del conocimiento, y por lo tanto [...] un compromiso explícito con cuestiones éticas» (Brenner, 2017b: 243). Esto lleva a evitar posiciones excesivamente tecnocráticas centradas en un correcto desarrollo de los instrumentos, pero alejadas de un análisis profundo del objeto trabajado y analizado; como el autor apunta, en la medida en que el agente investigador forma parte del contexto social estudiado, «las cuestiones éticas se vuelven inevitables» (Brenner, 2017b: 243). Así, y respetando la objetividad y el rigor científico que el marco académico de un trabajo como este exige, la presencia en él de una orientación ética determinada, una inquietud y una preocupación por una problemática sensible y urgente es, desde la responsabilidad social de la disciplina, inevitable.

\section{Enfatiza la separación entre lo presente y lo posible}

La teoría crítica supera el mero análisis de las fuerzas de poder y las contradicciones del capitalismo moderno, para «ahondar en el potencial emancipatorio intrínseco a, y simultáneamente reprimido por, este mismo sistema [lo que] implica la búsqueda de un sujeto revolucionario, es decir, la preocupación por encontrar un agente de cambio social radical que pueda materializar los potenciales despertados pero, al mismo tiempo, reprimidos por el capitalismo» (Brenner, 2017b: 244). Desde un punto de vista urbano, puede decirse que engloba a trabajos que buscan «ahondar en las posibilidades de formas de urbanismo alternativas y radicalmente emancipatorias que están latentes, aunque sistemáticamente reprimidas, en las ciudades contemporáneas» (Brenner, 2017b: 246). Este espíritu constructivo en busca de potenciales latentes en el contexto actual está en el fondo de esta investigación, condicionando su diseño y sus objetivos.

$-1.2 .2-$

\section{El contradicción como característica de la condición urbana}

\section{E1 capitalismo como sistema internamente contradictorio}

La primera de las dos grandes líneas de investigación de la teoría urbana crítica en las que se apoya la investigación ofrece un contexto 
de carácter genérico, en el marco de un enfoque transformador, propio de diversos trabajos centrados en el estudio del capitalismo como sistema internamente contradictorio y simultáneamente generador de alternativas. La condición estructural que desde aquí se defiende que presentan determinados conflictos como necesarios para la supervivencia del modelo inmobiliario español, supone la argumentación -y aceptación-, de que se trata de un modelo contradictorio. Este fenómeno puede ser comprendido y confirmado desde un análisis más general del sistema capitalista en el que se enmarca.

La existencia de una serie contradicciones en las sociedades capitalistas ha sido argumentada y analizada por diversos autores $\mathrm{y}$, como se ha señalado más arriba, puede ser identificada en la obra de Marx, o en autores que beben de ella. Recientemente, algunas de las principales han sido sintetizadas por Harvey (2014) clasificando estas en fundamentales, cambiantes y peligrosas. En cualquier caso, estas se comprenden como conjuntos de fenómenos sociales que estructuran diversos aspectos de su organización. Este planteamiento se puede enmarcar hoy en día en una corriente de pensamiento que identifica un contexto socio-político y un proyecto ideológico global común bajo lógicas de neoliberalización. Una de las más significativas peculiaridades del mismo es que las «múltiples discrepancias (entre ideología y práctica, doctrina y realidad, visión y consecuencia) que han acompañado la expansión transnacional del neoliberalismo no son meros efectos secundarios accidentales de este proyecto disciplinario [...] sino más bien algunos de sus rasgos más importantes» (Brenner et al., 2015: 215). Tal y como los autores señalan -reforzando lo sugerido en otros trabajos (Peck y Tickell, 2002) - se trata, no de un sistema coherentemente delimitado, sino de un proceso vivo, en desarrollo e internamente contradictorio. Al aplicar este enfoque a la dimensión social de la vivienda, el modelo de ciudad residencial de las sociedades post-industriales se ha catalogado como de sistémicamente excluyente (Madden y Marcuse, 2018; Smith, 2015), a pesar de tratarse de un derecho humano fundamental aparentemente asumido.

Se pueden por lo tanto considerar los conflictos aquí apuntados como algunas de las problemáticas implícitas e indisociables a un modelo residencial enmarcado en y compartiendo la ideología de un contexto denominado por algunos como neoliberalismo realmente existente (Brenner et al., 2015; Brenner y Theodore, 2017). Un concepto que busca rebatir el carácter supuestamente inmutable de unas leyes de mercado que se plantean como independientes al lugar donde se desarrollen, y pone el énfasis en las interacciones de los proyectos de reestructuración neoliberal con su contexto -espacial, institucional, social,...-, las cuales son además dependientes de la trayectoria heredada (Brenner et al., 2015: 213). Y que tiene entre sus objetos «poner de relieve el carácter contradictorio y destructivo de las políticas neoliberales» (Brenner y Theodore, 2017: 119). Se trataría así 
la aquí abordada de una relación de dependencia de doble sentido: estos conflictos señalados para el caso del modelo residencial español no existirían, o no hubiesen alcanzado tal nivel de conflictividad, con otro modelo diferente; por otro lado, este no podría haber alcanzado el nivel de desarrollo al que ha llegado sin la generación de los mismos. Existen algunos ejemplos muy aclaratorios de este tipo de contradicciones propias del sistema global actual y de las que este depende, que pueden ayudar a confirmar las aquí señaladas como tales:

«Considérese, por ejemplo, la idea de que todos los trabajadores deberían ser tratados con dignidad y que debería pagárseles un "salario digno" que les garantice una seguridad económica mínima y una acceso adecuado a las oportunidades de la vida. Esa concepción universal, claramente coherente con la Declaración Universal de 1948, es completamente contraria a las condiciones de desarrollo geográfico desigual de las que el capital se ha alimentado y que, en muchos casos, ha producido activamente. Se enfrenta de una manera fundamental al neoliberalismo, porque interfiere de una manera fundamental con el funcionamiento de los mercados de trabajo» (Harvey, 2003: 114).

De la misma manera, la idea de que toda persona debe contar con una vivienda digna y adecuada es coherente con esa misma Declaración Universal, así como con otros muchas normativas de diversa naturaleza y escala. Pero, al igual que en el ejemplo citado por Harvey, se trata de una concepción universal totalmente contraria a las características y el funcionamiento de un modelo inmobiliario -en este caso el español- cuya subsistencia depende de una constante producción de ciudad residencial y de la generación de plusvalías mediante esta, lo que conlleva en última instancia a la búsqueda de la mayor ganancia económica posible con la venta o alquiler de la vivienda, expulsando a toda persona que no tenga la capacidad para hacer frente a los precios finales a aquellas zonas y viviendas más degradadas y/o alejadas de los espacios urbanos con mayor calidad y centralidad:

«...la ideología neoliberal presupone que la autorregulación de los mercados generará una distribución óptima de inversiones y recursos; sin embargo, en la práctica, la política neoliberal produce fallos de mercado generalizados, nuevas formas de polarización social y una dramática intensificación del desarrollo desigual en todas las escalas espaciales» (Brenner y Theodore, 2017: 117-118).

\section{El fundamental papel del espacio}

Como se ha avanzado en algunos fragmentos de los párrafos anteriores, es imprescindible señalar la inherente dimensión espacial de este sistema capitalista como la que posibilita en gran medida el 
mantenimiento de sus contradicciones. El desarrollo espacial desigual, junto con la expansión geográfica propia de un modelo basado en el crecimiento urbano, y la reorganización espacial son tres elementos clave que han permitido el funcionamiento del capitalismo como sistema político y económico (Harvey, 2003). Un recurso que el propio autor ha identificado como una «solución espacial a las contradicciones internas del capitalismo» (Harvey, 1996: 38) que se reproduce y expande a través de una serie de fijaciones/soluciones espacio-temporales provisionales (Harvey, 2014: 154). De esta manera, se plantea que el neoliberalismo en el que se enmarca el modelo urbanístico hegemónico actual en España «se basa y se materializa a través del desarrollo desigual; esto es, su 'estado natural' se caracteriza por una topografía desigualmente desarrollada y persistentemente inestable» (Brenner et al., 2015: 216).

El re-escalamiento global que el capitalismo avanzado ha desarrollado en las últimas décadas ha hecho que, desde algunos análisis parciales, se interpreten ciertas situaciones aparentes de orden y estabilidad logradas a través de determinados arreglos institucionales como la consecución de soluciones a algunos de los retos existentes. Sin embargo, otras lecturas realizadas con mayor profundidad y perspectiva afirman que dicha estabilidad está construida sobre el desplazamiento de los problemas en el espacio y/o su aplazamiento en el tiempo (Jessop, 2017: 101). Así, se trata en definitiva de arreglos espaciotemporales que, bajo la garantía de una coherencia estructural relativa, completa y provisional de un orden concreto, esconden una externalización de costes sociales, económicos, ambientales o de otra naturaleza que supera los límites espaciales, temporales y sociales que conforman el marco de dichos arreglos y generan una estabilidades dependientes de otras inestabilidades (Jessop, 2017: 206).

Estos arreglos se dan de manera simultánea en muy diversas escalas y ámbitos, entre las que pueden encontrarse la global o la propia de la ciudad, pasando por grandes metrópolis, regiones o incluso una escala de barrio. En este marco, la permanencia y evolución en el tiempo, así como la extensión y diversificación en el espacio, del dramático choque que se da entre la vivienda como derecho humano fundamental y su utilización como medio de acumulación de capital, o de importante generador de empleo, con graves consecuencias en forma de exclusión social y deterioro ambiental, justifica este primer enfoque.

En conclusión, la relevancia que la componente espacial en general, y urbana en particular en un contexto de urbanización planetaria $^{6}$, tiene en el desarrollo del capitalismo como sistema político

\footnotetext{
${ }^{6}$ Concepto que aborda con un enfoque abierto y con la intención de confrontar viejas categorías una condición urbana que no es si no un proceso que desborda la concepción tradicionalmente morfológica y poblacional de lo urbano como aquello limitado a la ciudad, que desdibuja los límites de los asentamientos humanos afectando a muy diversos espacios y territorios, y que genera fuertes interdependencias escalares y temporales al servicio del desarrollo del capitalismo (Brenner, 2017a; Lefebvre, 1976).
} 
y económico ha permitido señalar que el sistema neoliberal -en el que se enmarca el modelo urbanístico español- se apoya en un desarrollo geográfico desigual. Lo urbano se ha de entender entonces no como un soporte fijo, si no como un proceso (Brenner, 2017a; Harvey, 1996) de territorialización a través del cual se produce la apropiación y transformación socio-espacial de un espacio determinado (Jessop, 2017: 195). Así, puede afirmarse que la condición urbana propia de los muy diversos espacios que forman parte de ese proceso de territorialización de relaciones sociales complejas, como pieza clave del desarrollo del capitalismo $-\mathrm{y}$ en lo que interesa a este trabajo intrínseca a la cuestión residencial-, es de igual manera, además de dinámica en el tiempo y en el espacio, internamente contradictoria.

\section{$-1.2 .3-$}

\section{Una gobernanza urbana desigual}

Si bien el marco utilizado se centra sobre todo en el estado, también aborda la gobernanza urbana como elemento clave en la transformación del primero. Ambas cuestiones son por lo tanto de necesaria revisión para los objetivos del trabajo. Por otro lado, las características del sistema de organización territorial español y las competencias propias de la Comunidad Autónoma de Euskadi hacen que muchas de las consideraciones a tratar sean aplicables a la gobernanza de esta autonomía, así como de la región metropolitana existente en torno a Bilbao que como se mostrará es, con diferencia, su principal aglomeración urbana.

\section{Una aproximación relacional}

La segunda gran línea de investigación en la que se ha apoyado la construcción del marco teórico aborda un tema más concreto, una vez establecida la contradicción como elemento estructural de la condición urbana. En este caso, se ha buscado un marco para abordar la problemática desde un enfoque relacional. Cobra aquí importancia la manera en que se desarrolla esta relación social compleja que es la urbanización, en la medida en que los fenómenos analizados se dan en un espacio social. Entendido este como un producto social que es instrumento y medio de reproducción del capitalismo como sistema dominante (Lefebvre, 2013: 86). Así, se ha tomado como referencia una serie de trabajos en torno a la naturaleza desigual de la gobernanza de los sistemas urbanos contemporáneos. La multiplicidad de agentes e intereses intervinientes en el proceso de generación de dispositivos residenciales -desde la identificación de la necesidad, a la demanda, la toma de decisiones, pasando por la ordenación urbana, el diseño arquitectónico, la producción, o la comercialización- se ve reflejada en una enorme diversidad de 
fuerzas, posiciones y niveles de poder. Esta compleja red de relaciones justifica este segundo enfoque del trabajo.

Por lo tanto, el siguiente paso ha sido identificar el contexto en el que los diferentes agentes intervinientes llevan a cabo su actividad, hacen explícita su necesidad o demanda, aplican sus instrumentos regulatorios, y construyen sus relaciones. La razón de buscar respuestas estudiando la gobernanza se debe a que, frente a los conflictos arriba señalados para el caso de la ciudad residencial, se vienen desarrollando y enfrentando desde hace tiempo no pocos esfuerzos con el objetivo de reducirlos o eliminarlos. Ni tampoco se reducen estos a unos pocos agentes, existiendo una rica variedad de organismos públicos, privados y civiles trabajando en ese sentido. $\mathrm{Y}$ sin embargo, como se ha defendido previamente, estos persisten. Sin embargo, lo anterior no debe entenderse como el reflejo de una lucha entre dos bloques claramente diferenciados. Plantear que el poder está en exclusiva en manos de unas instituciones - públicas o privadasy/o en las de los agentes gestores de las mismas, «enmascara un complejo conjunto de relaciones sociales que se extiende mucho más allá del sistema $[\ldots]$ y de sus capacidades diferenciadas» (Jessop, 2017: 101):

«El actual modelo inmobiliario no ha resultado de aplicar ningún plan teórico premeditado, sino de la configuración histórica de un marco institucional en el que se solapan aspectos e instrumentos (políticos, económicos, jurídicos, ...) orientados por el poder de determinados intereses oligárquicos. Es este poder oligárquico el que se impone y da unidad al modelo en toda nuestra geografía, trascendiendo la casuística de las legislaciones autonómicas» (Naredo, 2015: 77).

\section{Acotando la gobernanza}

A continuación se expone una breve, pero necesaria, acotación de lo que se ha tomado como gobernanza. Sin entrar en debates sobre las diferentes visiones que de este concepto existen, para el fin de esta investigación la revisión y definición que de este concepto hace Jessop (2017) sirve como referencia. En ellas, gobernanza y complejidad se plantean como conceptos inseparables. Como recuerda el autor, se trata de un concepto que no cuenta con un núcleo jurídico-político o punto de referencia institucional relativamente fijo, y su práctica se relaciona no tanto -o no sólo- con el gobierno, como con la política y la práctica política (Jessop, 2017: 229). De tal manera, que su alcance va más allá del sistema de gobierno y hace mención al ejercicio de la política pública en lo que se refiere a la gestión de asuntos públicos (Larsson, 2013: 107). La definición propuesta por Jessop queda de la siguiente manera:

«En términos generales, la gobernanza se refiere a mecanismos y estrategias de coordinación de cara a la interdependencia recíproca compleja entre agentes, 
organizaciones y sistemas funcionales operativamente autónomos. Las prácticas de gobernanza van desde la expansión de regímenes internacionales y supranacionales, pasando por asociaciones nacionales y regionales públicoprivadas, a redes de poder y de toma de decisiones más localizadas [...]» (Jessop, 2017: 230).

Además de la complejidad y diversidad de agentes, escalas y sistemas a los que hace mención, coordinación e interdependencia son dos aspectos de esta definición que centran especialmente el interés en el marco de este trabajo. La coordinación implica la necesidad de un cierto nivel de consenso para poner en práctica la mencionada gestión de asuntos públicos. En este sentido, la gobernanza no se reduce a una cuestión técnica acotada a una serie de problemas definidos por aquellas fuerzas sociales con el poder de hacerlo y que pueden resolverse por expertos gestores, si no que incorpora por definición objetivos, técnicas y sujetos reacios a la propia gobernanza que promueven proyectos con los que esta entra en conflicto, de tal manera, que afecta al equilibrio de fuerzas (Jessop, 2017: 241-242). En cuanto a la interdependencia, Jessop recuerda que -propia de las interconexiones materiales existentes entre diversas situaciones problemáticas de un mundo complejo- debido a esta «la gobernanza supera la separación convencional entre lo público y lo privado y puede involucrar "jerarquías enmarañadas", redes de poder paralelas u otras vinculaciones a través de niveles de gobierno o dominios funcionales» (Jessop, 2017: 241). Puede plantearse, por lo tanto, que interdependencia y coordinación quedan así estrechamente ligadas, dado que el permanente cambio en el equilibrio de fuerzas generado por la interconexión e interrelación entre problemáticas, agentes, prácticas, escalas, instrumentos o tiempos requiere constantes esfuerzos de coordinación entre estos. Lo central del argumento hasta aquí desarrollado es que se reafirma la complejidad de la problemática, la cual hace necesaria la búsqueda de herramientas que permitan ofrecer una visión más completa y profunda de los conflictos existentes en su trasfondo. Esta cuestión es abordada en el capítulo segundo. Definida la gobernanza, se repasa a continuación algunas de sus principales características que afectan a su desarrollo más o menos eficaz.

\section{Una apertura desequilibrada y re-jerarquizada de la toma de decisiones}

Este enfoque centrado en el aspecto relacional de la gobernanza urbana puede ser cercano al que Poulantzas planteaba para el Estado, en el sentido de entenderlo como una relación social desigual. Una relación de fuerzas que privilegia a ciertos agentes e intereses por encima de otros, cuyo resultado dependerá del equilibrio variable de dichas fuerzas, de sus estrategias y sus tácticas (Poulantzas, 2000). Esta perspectiva ha sido desarrollada y definida, también en torno a la 
teoría del estado, como la de un enfoque estratégico-relacional (Jessop, 2007). Se trata de un planteamiento que deja de lado análisis centrados en la gobernanza como algo unificado y propio de un sujeto unitario -y por lo tanto más orientados al aparato de poder en sí mismo-, y busca desarrollar herramientas para estudiar la variación de sus formas, sus funciones, así como el ejercicio y los efectos de un poder repartido entre un cambiante equilibrio de fuerzas que luchan por sus respectivos intereses dentro, a través y en contra del sistema que aglutina dicha gobernanza (Jessop, 2017: 98). Esto lleva a Jessop a plantear que las acciones llevadas a cabo por los agentes implicados dependen en gran medida del contexto estratégico y de las capacidades transformadoras. El autor plantea que las limitaciones y oportunidades son estratégicamente selectivas, y no absolutamente restrictivas. De manera que al igual que hay margen para que las acciones superen las limitaciones, no hay garantía de alcanzar la totalidad de los objetivos.

Aquí caben señalar tres cuestiones. Primero, la evolución y creciente complejidad de la gobernanza urbana a lo largo de las últimas décadas, debido a diversos procesos de apertura de esta. Se ha evolucionado así desde modelos muy centralizados, jerarquizados y vinculados a territorios considerablemente limitados, a sistemas de organización más abiertos, en los que participan diferentes agentes, así como repartidos e influidos por diversas escalas interrelacionadas. Segundo, el carácter desequilibrado de este proceso de apertura, en muchas ocasiones bajo la apariencia de una mejora democrática de los procesos de toma de decisiones. La participación de más y diversos agentes esconde cierta exclusión, jerarquía oculta y un reparto desigual del poder. Tercero, el importante papel que dentro de esa relativa apertura siguen jugando actores tradicionalmente poderosos con estructuras de funcionamiento consolidadas. De tal manera, que se sigue manteniendo en el fondo una jerarquía más o menos fuerte entre los agentes involucrados. Se desarrollan con más detalle estos tres fenómenos a continuación.

El fin de las formas de gobierno considerablemente cerradas, unidas a espacios geográficos claramente delimitados ha sido ampliamente estudiado y referenciado. La evolución y proliferación de nuevas formas de gobierno -especialmente a lo largo de las últimas décadas- que han dejado atrás una relación entre poder y sociedad muy jerárquica y casi unidireccional han dado paso a articulaciones algo más abiertas en las que se han ido incluyendo a otros agentes institucionales - de naturaleza y escala muy diversa, desde la Unión Europea a entidades de carácter mixto destinadas al desarrollo urbano y metropolitano-, así como organizaciones de la sociedad civil y agentes del mercado privado. Un proceso que ha llevado a la proliferación de nuevas formas institucionales de gobierno con muy diversas características, mediante arreglos multi-escalares e institucionales o cuasi-institucionales, dando pie a una diferente articulación entre el poder y la ciudadanía (Brenner, 2004: 7; 
Swyngedouw, 2005: 1992, 1994). Además, la descentralización del gobierno se ha dado mediante diferentes fases de externalización de responsabilidades, a menudo a través de la privatización y desregulación (Jessop, 2017: 244; Swyngedouw, 2005: 1998).

Esta evolución del gobierno a la gobernanza conlleva que los tradicionales organismos de poder y control pasen a ser casi una más entre las partes interesadas (Jessop, 2017:249), al pasar de un esquema estado-céntrico a un proceso de integración global fundamentalmente económica- y a su vez de resurgimiento de las regiones urbanas y las grandes ciudades, eso sí, con los propios estados jugando un papel clave en todo ello ya que lejos de desaparecer, se transforman (Brenner, 2004). Han ido surgiendo así nuevas formas de gobernanza multinivel altamente interdependientes por encima, dentro y por debajo del ámbito geográfico sobre el que predominaban las anteriores formas de gobierno, generando e intensificando las redes horizontales y la coordinación entre diversos agentes (Brenner, 2004: 6; Swyngedouw, 2005: 1998).

Todo ello sugiere el paso a una gobernanza 'más allá del estado', entendida como el surgimiento, proliferación y fomento activo de arreglos institucionales de gobierno que dan un importante papel tanto a actores privados económicos en el desarrollo, administración e implementación de políticas, como a la sociedad civil en la autogestión de lo que hasta hace poco era provisto y organizado por el gobierno, local o estatal (Swyngedouw, 2005: 1992). Según Swyngedouw, ha sido en la escala urbana donde estos arreglos han proliferado y materializado especialmente. Como señala el autor, esta aparente dispersión del poder se presenta habitualmente como un modelo ideal que implica la existencia de un propósito, unos valores y una acción compartidas, así como una interacción continua para alcanzar una serie de logros colectivos que no pueden ser satisfechos en el caso de actuar por separado. Pero la supuesta horizontalidad, interactividad y funcionamiento en red entre los diversos agentes choca con una serie de conflictos propios de diferentes agendas, ideologías y fuerzas (Swyngedouw, 2005: 1995). Ya que estos nuevos modos de gobernanza se sitúan en y son apoyados por un contexto ideológico de racionalidad neoliberal que supone la re-estructuración de las relaciones de poder en la sociedad más que su desaparición y la aparición de nuevos actores en ellas (Lemke, 2002: 50). Pero simultáneamente, son apoyados por actores como ONGs, movimientos sociales o agentes de la planificación con una visión más alternativa y progresista (Swyngedouw, 2005: 1993).

Esto último lleva a la segunda cuestión: el desequilibrio existente entre los diversos agentes que conforman estos nuevos modelos de gobernanza más abiertos. Como concluye Swyngedouw (2005: 2003), se trata de procesos contradictorios en los que se da una fuerte tensión entre, por un lado, un proceso de apertura hacia la democratización, el empoderamiento, la participación y la transparencia asociadas a interdependencias horizontales en red y, por 
otro, tendencias autocráticas y tecnocráticas propias de cierta élite ${ }^{7}$, la consolidación de ciertos agentes externos a las instituciones con poder para intermediar, y una serie de relaciones de gobernanza informales jerárquicamente articuladas. En definitiva, estas formas de 'gobernanza más allá del estado' se han teorizado en torno a la promesa de relaciones horizontales y regulares -constantes en el tiempo- entre todos los agentes, y la garantía de un acceso desde las fases iniciales al proceso de toma de decisiones. Sin embargo, estas relaciones se han construido de manera contradictoria a través del empoderamiento de algunos de los agentes y la exclusión de otros. Se han reestructurado algunos parámetros de la representación política, alcanzando un importante déficit democrático. Todo ello lleva a afirmar que «los arreglos socialmente innovadores de la gobernanza más allá del estado son fundamentalmente hipócritas, especialmente bajo condiciones en las cuales el carácter democrático de la esfera política está siendo cada vez más erosionado por imposiciones invasivas de fuerzas del mercado que establecen las 'reglas del juego'» (Swyngedouw, 2005: 1993). La gobernanza en red no es por lo tanto un modelo simétrico y no jerárquico, si no que sus asimetrías están enraizadas y a su vez alimentan las contradicciones propias del capitalismo vistas arriba, reproduciendo desiguales concentraciones de poder y riqueza, altos niveles de competencia y una inestabilidad crónica (Davies, 2011). Se trata, por lo tanto, de un sistema de gobernanza liderado por una coalición de élites económicas, socioculturales o políticas que no es neutral en su re-estructuración y reescalamiento, pues mientras algunos actores emergen y/o consolidan su posición -con frecuencia de manera 'oculta', encargándose de las necesidades del capital y del neoliberalismo, y no de la vida cotidiana (Jessop, 2017: 96)-, otros son excluidos y marginados del proceso (Swyngedouw, 2005: 1999, 2001). Es este marco precisamente sobre el que sitúa Naredo (2015) el desarrollo del modelo residencial español:

«La crisis de la planificación territorial y urbana, permitió instalar un laissez faire de los poderosos. Es decir que se instaló, no el laissez faire igualitario y democrático que predica el liberalismo, sino un laissez faire elitista que permitió a los nuevos caciques desarrollar sin trabas sus lucrativas "operaciones" inmobiliarias en el conjunto del territorio» (Naredo, 2015: 77).

Davies (2011) afirma que el fracaso de esta coordinación en red degenera en una coordinación jerárquica hacia tendencias de dominación, lo cual enlaza con la tercera y última cuestión: la existencia, dentro de esa apertura desequilibrada, de una establecida

${ }^{7}$ Como señala Jessop (2017: 90), el arte de gobernar no se reduce «al ejercicio del poder soberano», siendo uno de sus aspectos clave la manera en que se «(re)definen ciertas cuestiones como privadas, técnicas o de gestión, eliminándolas de la toma de decisiones abiertamente políticas». 
jerarquía en la toma de decisiones. Como se ha señalado, existen argumentaciones para defender que, frente a quienes afirman la desaparición de las formas tradicionales de gobierno con el auge de estos nuevos modelos de gobernanza y de los procesos de globalización de las últimas décadas, estas no han muerto, si no que han evolucionado (Brenner, 2004; Jessop, 2017; Swyngedouw, 2005: 2002). Esos gobiernos más centralizados que antecedían a estos nuevos modelos juegan un papel fundamental en la formación de las actuales configuraciones institucionales de regulación, pues estas son en gran medida creadas, articuladas y directa o indirectamente controladas por ellos (Swyngedouw, 2005: 2002). Según Jessop (2017), esta «influencia indirecta que pueden ejercer los estados sobre otros agentes o fuerzas en la sociedad política y civil a través de la amenaza real o imaginada de una acción ejecutiva o legislativa que recurra a las capacidades y poderes singulares del Estado, incluida la coerción» queda sintetizada con la expresión 'a la sombra de la jerarquía' (Scharpf, 1993). De manera que, analizando la cuestión con mayores matices, se puede afirmar que no se ha pasado de un gobierno a una gobernanza, si no a un «gobierno + una gobernanza a la sombra de la jerarquía» que logra el consenso activo de la población gobernada (Jessop, 2017: 240). Gobierno y gobernanza quedan de esta manera unidas mediante un constante reequilibrio de las fuerzas y formas de gobernanza que se dan tanto dentro de los modelos tradicionales, como fuera de ellos, aunque reservándose los primeros cierto «derecho de abrir, cerrar, distorsionar y rearticular la gobernanza» (Jessop, 2017: 236, 241, 243). Como se verá, esto es aplicable a la gestión de la vivienda. Los mercados no son organismos autónomos que se organizan a sí mismos, pues el papel -limitado, pero poderoso- del Estado ha sido y es clave en el proceso de transformación de la vivienda de una necesidad fundamental a una mercancía disponible en el mercado (Madden y Marcuse, 2018: 67). Sin embargo, tampoco se puede entender -como plantean los mismos autores para el Ayuntamiento de New York- la política de vivienda de una administración pública como «un aparato complejo que se resiste al cambio» (Madden y Marcuse, 2018: 199), pues esta, a pesar de su poder y capacidad, es en realidad parte de un proceso de gobernanza más amplio y complejo. Los propios autores identifican páginas más adelante, en el caso de las políticas estatales, al Estado como parte del problema a la vez que absolutamente necesario para lograr cualquier solución (2018: 212).

El resultado es el de un marco re-jerarquizado, pero lejano y diferente al propio de esas formas originarias de organización centralizada, relativamente simple y geográficamente acotada. Las instituciones y agentes en posiciones altas de la jerarquía han de enfrentarse a nuevos, más diversos y en ocasiones fuertes agentes, y a unas contradicciones, interconexiones e interdependencias en aumento. Se ven así en el compromiso de dejar que las crisis surgidas en dichos contextos sigan su curso, o de desplazar y aplazar sus efectos (Jessop, 2017: 302). Se trata, en definitiva, de un contexto que 
Tabla 1.2. Principales procesos dados en la evolución de la gobernanza urbana. Elaboración propia a partir de Brenner (2004), Davies (2011), Jessop (2017) y Swyngedouw (2005). aglutina simultáneamente prácticas de apertura en el proceso de toma de decisiones, relaciones desequilibradas de poder, así como «jerarquías enrevesadas y una interdependencia compleja» (Jessop, 2017: 251), configurando una suerte de equilibrio inestable (Tabla 1.2).

\begin{tabular}{|c|c|}
\hline Proceso & Aspectos clave \\
\hline \multirow{4}{*}{ Apertura } & $\begin{array}{l}\text { - Inclusión de ‘nuevos’ agentes privados, económicos y } \\
\text { civiles en la administración, implementación y gestión de } \\
\text { políticas públicas. Externalización de responsabilidades. } \\
\text { · Imprecisión y re-escalamiento de los límites geográficos } \\
\text { sobre los que se gobierna: disgregación en unidades } \\
\text { menores hacia abajo, integración en estructuras } \\
\text { superiores hacia arriba, influencia de fenómenos } \\
\text { transversales (a veces globales) no institucionales. }\end{array}$ \\
\hline & $\begin{array}{l}\text { - Re-estructuración de las relaciones de poder: de una } \\
\text { relación unidireccional poder-ciudadanía a una dispersión } \\
\text { del poder sobre una red compleja de fuerzas } \\
\text { interdependientes. }\end{array}$ \\
\hline & $\begin{array}{l}\text { - Mayor horizontalidad y coordinación; interacción } \\
\text { continua para lograr objetivos comunes. }\end{array}$ \\
\hline & $\begin{array}{l}\text { - Un modelo ideal que choca con conflictos debidos a } \\
\text { diferentes agendas, ideologías y fuerzas. }\end{array}$ \\
\hline \multirow{4}{*}{ Desequilibrio } & $\begin{array}{l}\text { Tensiones entre tendencias hacia la democratización, } \\
\text { horizontalidad y transparencia, y tendencias autocráticas } \\
\text { y tecnocráticas con apoyo de relaciones informales de } \\
\text { poder. }\end{array}$ \\
\hline & $\begin{array}{l}\text { Re-estructuración, re-escalamiento y desarrollo } \\
\text { contradictorio y no neutral de la gobernanza: } \\
\text { empoderamiento de algunos agentes y exclusión de } \\
\text { otros. }\end{array}$ \\
\hline & $\begin{array}{l}\text { - Carácter democrático erosionado por imposiciones y } \\
\text { contradicciones enraizadas en el capitalismo neoliberal. }\end{array}$ \\
\hline & $\begin{array}{l}\text { - El fracaso de la coordinación en red lleva a la } \\
\text { coordinación jerárquica con tendencias de dominación. }\end{array}$ \\
\hline \multirow{4}{*}{$\begin{array}{l}\text { Re- } \\
\text { jerarquización }\end{array}$} & $\begin{array}{l}\text { Las formas previas de gobierno no han desaparecido, } \\
\text { han evolucionado a formas de 'gobierno + gobernanza a } \\
\text { la sombra de la jerarquía'. }\end{array}$ \\
\hline & $\begin{array}{l}\text { - Mantienen un papel central en las formación de las } \\
\text { nuevas configuraciones, pero condicionado y limitado } \\
\text { por múltiples jerarquías enrevesadas y una } \\
\text { interdependencia compleja. }\end{array}$ \\
\hline & $\begin{array}{l}\text { Ejercen una influencia directa o indirecta, a través de } \\
\text { supuestos reales o imaginarios, sobre agentes privados, } \\
\text { políticos y civiles logrando un relativo consenso activo. }\end{array}$ \\
\hline & $\begin{array}{l}\text { - Se da un constante re-equilibrio de fuerzas y formas de } \\
\text { gobernanza dentro, fuera y a través de las formas } \\
\text { tradicionales, pero conservando estas cierta capacidad de } \\
\text { rearticulación. }\end{array}$ \\
\hline
\end{tabular}




\section{$-1.2 .4-$}

\section{La transversalidad de las contradicciones}

Con lo visto hasta aquí, se puede afirmar que el mantenimiento de una situación problemática propia de este y otros retos urbanos, puede explicarse desde dos lecturas diferentes. Una de ellas plantearía que el motivo de esa permanencia es el choque tanto de planteamientos a la hora de explicar y justificar los orígenes y causas de la problemática en cuestión, como de posibles soluciones y respuestas a adoptar para combatirla:

«No se puede explicar las estructuras del espacio en función del "impulso vital" de la comunidad urbana [...] Es el resultado de una historia que debe concebirse como la obra de "agentes" o "actores" sociales, de "sujetos" colectivos, que operan por impulsos sucesivos, emitiendo y formando de manera discontinua (relativamente) capas de espacio. Estos grandes grupos sociales, que comprenden clases y fracciones de clases, pero que comprenden también instituciones que no se pueden definir únicamente por su carácter de clase (la monarquía o la municipalidad, por ejemplo), actúan con y/o en contra los unos de los otros. Las cualidades y "propiedades" del espacio urbano son resultados de sus interacciones, de sus estrategias, de sus éxitos y fracasos» (Lefebvre, 1976: 133).

$\mathrm{Y}$ es en parte cierto; la falta de unidad en las respuestas o la diferente capacidad de ejecución, a pesar de existir un amplio consenso a la hora de asumir la existencia y urgencia de la situación, dificulta en gran medida alcanzar logros importantes para equilibrar los conflictos. Pero el marco presentado lleva a plantear que existe una segunda lectura para intentar comprender y abordar este tipo de retos urbanos complejos. Esta parte de una idea: habitualmente las respuestas incorporan la importante carencia de actuar desde la superficie, centrando la mirada en los efectos más que en las causas. Y plantea que, leyendo la situación desde la teoría urbana crítica y observando la complejidad y el nivel de interconexiones, interdependencias y jerarquías actuales, los conflictos existentes surgen y se mantienen debido a un marco estructural de organización socio-espacial internamente contradictorio, conducido por una gobernanza relativamente abierta, pero desequilibrada y rejerarquizada.

En base a lo anterior, se cree que las razones contradictorias que generan y/o refuerzan la situación problemática presentada pueden enmarcarse en un contexto similar. En este sentido, la complejidad de un marco así lleva a plantear que no debe achacarse el origen y mantenimiento de dicha situación a un esquema de fuerzas simple y coherente. Es decir que, yendo a ejemplos extremos, esta situación relativa a la vivienda no se ha de entender exclusivamente causada por 
una mala gestión pública, ni por un mercado privado devorador de recursos y derechos; los conflictos y las contradicciones surgen y se reproducen en un contexto más complejo, diverso y difuso en el que, entre otras cuestiones, se dan casos como esos. La idea que se pretende defender aquí es que los conflictos entre los grandes objetivos en relación al acceso a la vivienda y las fuerzas y condicionantes con afecciones negativas sobre dicho acceso pueden encontrarse con diferente intensidad, no tanto $-\mathrm{O}$ además de- entre diferentes agentes, si no especialmente dentro de múltiples agentes, incluso en aquellos luchando por el derecho a la vivienda de manera más militante:

«...en la medida en que los agentes están involucrados en diferentes conjuntos de relaciones o tienen varias subjetividades o identidades, pueden tener conjuntos contradictorios de intereses. [...] Los intereses enfrentados pueden conducir a problemas severos (o "indecidibles") en la elaboración de estrategias y políticas y en la toma de decisiones» (Jessop, 2017: 147).

Lo que se plantea en definitiva es que la problemática abordada se debe y se mantiene gracias a un marco propio de una gobernanza urbana trabajando a dos niveles. Mientras reproduce determinados conflictos y contradicciones de una manera menos visible -pues implican relaciones complejas no siempre fáciles de detectar, y que de hecho por naturaleza no desean ser detectadas-, simultáneamente regula y reforma parcialmente y de una manera más perceptible -para mostrar los esfuerzos y las herramientas desarrolladas para ello, en este caso buscando activamente su percepción- los efectos más superficiales de esas causas de origen. La imagen global resultante no refleja por tanto la realidad: poderosas fuerzas y tensiones quedan ocultas, mientras los esfuerzos por reducir la problemática quedan sobredimensionados. Al aplicar esta perspectiva a la dimensión social de la vivienda, en ocasiones se observa que los debates en torno a la problemática de la vivienda parecen dar por sentado que los orígenes de las fuerzas generadoras de las contradicciones internas se sitúan en el enfrentamiento de agentes clásicos, supuestamente homogéneos e inalterables en sus posicionamientos -gobierno y administración pública, sociedad e iniciativa privada-. Algo que puede identificarse incluso en aquellos discursos críticos que abordan la complejidad de la situación (Madden y Marcuse, 2018: 135-142). Una idea que en su nivel más simplificado reduce la cuestión a un conflicto entre dos grandes agentes opuestos y bajo el ideal de ser totalmente coherentes en sus argumentos y acciones: aquellos favorables exclusivamente al desarrollo de la función social de la vivienda -habitualmente en una posición de debilidad-; y aquellos defensores de la vivienda solamente como objeto de acumulación de capital -habitualmente en una posición de poder-. 
Sin negar la existencia de perfiles que pueden asimilarse en cierta manera con esos dos extremos, lo que se plantea, como se acaba de exponer, es que para llegar a desgranar mínimamente la complejidad oculta tras visiones simplistas de la problemática se han de enfocar las contradicciones existentes como transversales al proceso de gobernanza. De tal manera que pueda estudiarse cómo estas se pueden dar, y de hecho se dan, a través y dentro de múltiples momentos y periodos, espacios, escalas y agentes -incluyendo en estos últimos a aquellos dedicados a la gestión pública (Jessop, 2017: 86)-. Será entonces el profundizar en este diverso y desigual ecosistema de agentes, tiempos, escalas y relaciones lo que permitirá identificar diferentes niveles de participación, exclusión, poder, responsabilidad social, competencias, o potencialidades, entre otras cuestiones. En definitiva, esa idea simplificadora debe ser sustituida por una mirada que permita estudiar la complejidad de la realidad.

Para ello, se habrá no solo de incorporar los diversos agentes que pueden encontrarse en cada una de las grandes categorías, si no también identificar esos diferentes momentos, intereses y reacciones que los afectan en el proceso de gobernanza que engloba la generación y gestión de vivienda. Por lo tanto, este énfasis en la transversalidad no ha de desplazar del centro una cuestión clave: el desequilibrio de la participación en la toma de decisiones. No se trata de desviar la atención ni de minimizar la alta responsabilidad que algunos agentes tienen en la generación de las contradicciones, ni de olvidar la exclusión y el des-empoderamiento de otros muchos; pero sí de asumir dos cuestiones. La primera, que dichas responsabilidades están -desigualmente- repartidas a lo largo de los diversos agentes participantes en el proceso de gobernanza. La segunda, y consecuencia directa de la primera, que las posibilidades de éxito se verán incrementadas si se entienden los retos urbanos complejos como una problemática colectiva y no como una lucha de bandos enfrentados y autónomos. Todo este planteamiento refuerza la idea de entender la urbanización como una relación social o, más concretamente, como el resultado en permanente cambio de un proceso de territorialización de una relación social compleja. Lo que encaja a su vez en esa visión antes señalada de la cuestión urbana como proceso y no como objeto, en línea con aquellas lecturas que la identifican con una cuestión de la 'urbanización' (Brenner, 2017a; Harvey, 1996). Es este, por tanto, un proceso conducido por una gobernanza urbana en permanente evolución. 


\title{
$-1.3-$ \\ Planteamiento de la investigación
}

\author{
$-1.3 .1-$ \\ Necesidades, enfoque y objetivos
}

\section{La necesidad de realizar "correcciones"}

«Hay que asumir que estamos sufriendo las consecuencias de un modelo inmobiliario agotado, que no resuelve los problemas que tiene planteados el país en estos momentos, lo que pide a gritos su reconversión» (Naredo, 2015: 81).

¿Puede el modelo inmobiliario predominante en España en general, y en Euskadi -tomando el Área Metropolitana de Bilbao como caso de estudio- en particular, responder a la necesidad de vivienda en un marco caracterizado por un sistema de organización social internamente contradictorio y una gobernanza urbana desigual? Es la principal pregunta a la que los apartados anteriores conducen. De lo visto hasta aquí, se pueden hacer dos lecturas. Primero, los conflictos propios de la dimensión social de la vivienda señalados pueden, efectivamente, no solo considerarse como indisociables del modelo residencial actual, si no parte de un contexto más amplio y complejo de organización social. El hecho de que en diferentes épocas y contextos estos puedan verse rebajados en función de la coyuntura económica o de la capacidad de las administraciones públicas para satisfacer este derecho, no hace imposible distinguir una línea de continuidad y evolución de esta problemática ya desde los inicios de la ciudad moderna industrial hasta el presente. Segundo, además de en unos efectos finales sobre los que hay una identificación y un diagnóstico común relativamente extendido -en este caso la situación problemática apuntada-, de cara a una posible reducción de los mismos interesa poner el foco en las causas que los generan. Es decir, centrar los esfuerzos en la resolución de unos conflictos de fondo fuertemente arraigados en la sociedad, sobre los que ya no hay tanto consenso a la hora explicar sus fundamentos, orígenes ni posibles soluciones.

Interpretando todo lo desarrollado previamente, el planteamiento del que parte este trabajo es que si se mantiene el modelo actual, la respuesta mayoritaria a la necesidad de vivienda muy probablemente seguirá reproduciendo, con pequeñas variaciones, un sistema que se 
ha visto ineficaz para alcanzar un acceso digno y adecuado a la vivienda por parte de los sectores y colectivos de población con mayores dificultades para hacerlo. Una respuesta que alcanzará un precio final de venta lejos de las capacidades de compra o alquiler de una gran parte de la población; que continuará manteniendo y produciendo un espacio doméstico que choca con las necesidades de muchas unidades de convivencia; y que se formalizará a través de nuevos crecimientos u operaciones de sustitución de ciudad que dejen de lado una actuación profunda y transformadora del parque existente. Es decir, seguirá siendo de facto «un derecho débil» que no hace referencia a los conflictos y las causas de fondo que están detrás de la problemática (Madden y Marcuse, 2018: 208). Y todo ello será posible, siempre que se den las condiciones suficientes de viabilidad económica y financiación de las operaciones, y estas cuenten con la demanda suficiente de un producto específico que tenga además la capacidad económica para hacerla realidad; lo cual en los últimos años se ha visto complicado. Pero, chasta cuándo se va a dar esta continuidad? Cuándo va a encontrar este modelo unos límites que inevitablemente existen, si no lo ha hecho ya?. El reciente desarrollo y posterior pinchazo de la burbuja inmobiliaria ha sido en ocasiones interpretado como uno de los episodios más relevantes y condicionantes para el territorio y el urbanismo español, y a la vez como una oportunidad y un llamamiento para que todo este sistema inmobiliario se resitúe y redefina (Naredo, 2015). Sin embargo, sus raíces profundamente arraigadas en dinámicas y estructuras rígidas, y su peso en la economía parecen haber descartado esta reestructuración. Pasados los peores años post-burbuja, muchos indicadores y prácticas vuelven a valores y hábitos propios de décadas pasadas. Con todo, la necesidad de cambio por algunos ya señalada en momentos previos a la crisis, persiste:

«En mi opinión, en estos momentos nos encontramos en una fase clásica de utilización del entorno construido como un sumidero para el capital excedente en un momento de sobreacumulación, y la única pregunta que cabe hacerse es cuánto puede durar esta situación sin que la burbuja inmobiliaria estalle y si, cuando esto ocurra, habrá otras salidas disponibles que permitan aprovechar toda esta capacidad o si nos veremos abocados a una recesión deflacionaria (una versión a escala mundial de lo que le sucedió a Japón en los años 90). No puedo prever el porvenir, pero estoy prácticamente seguro de que en un futuro no muy lejano tocará realizar ciertas "correcciones" difíciles en el negocio de la inversión inmobiliaria» (Harvey, 2004).

La reflexión que se pretende lanzar es la siguiente: estas "correcciones", extensibles al modelo en su totalidad más allá de su vertiente inversora, se habrán de apoyar, fomentar e implantar a través de otros $-y$ no necesariamente nuevos- planteamientos urbanísticos e inmobiliarios que incorporen métodos de planificación, 
gestión, promoción, intervención o construcción, compra y alquiler de vivienda diferentes a los comúnmente utilizados para hacer extensivo el acceso a la misma. La viabilidad de la transformación del modelo deberá por lo tanto centrarse, en gran medida, en la dimensión social aquí abordada. Consecuentemente, se plantea que la política de vivienda actual debe -seguir buscando- eliminar el desequilibrio entre necesidad y oferta de vivienda en una sociedad en precarización y transformación habitando una ciudad residencial heredada de y diseñada para tiempos diferentes. Para ello, se ha de continuar diversificando y buscando nuevas maneras de responder a la necesidad, más allá de las respuestas tradicionales del mercado inmobiliario español: asumiendo las características, pero aprovechando y exprimiendo al máximo las oportunidades del parque edificatorio heredado bajo una ordenación social y ambientalmente responsable; fomentando un cambio de valores hacia la responsabilidad social en los múltiples agentes implicados en la generación y gestión de la vivienda; e impulsando una divulgación de cultura doméstica espacial entre la sociedad en su conjunto como generadora y a la vez destinataria final de este derecho, para su empoderamiento como agente demandante de vivienda.

\section{Posibles vías y posicionamiento}

«Hay un tiempo y un lugar en el incesante esfuerzo humano por cambiar el mundo en el que visiones alternativas, no importa lo fantásticas que puedan ser, son útiles para modelar poderosas fuerzas políticas de cambio. Creo que estamos precisamente en ese momento» (Harvey, 2003: 225).

«Nosotros hablamos mucho de que nuestra legislación tiene defectos; deficiencias y defectos. Es cierto, pero a mi no me gustaría que eso termine por echar abajo la poca legislación que tenemos $[\ldots]$ entonces, yo no quisiera que se piense que son los instrumentos todos malos, porque entonces se posterga el problema a cuando tengamos un instrumento bueno» (Márquez, 2012).

«...no se trata de ceder terreno al mantra TINA ${ }^{8}$ de "No hay alternativa"; se trata de resaltar las fracturas y las fricciones que generan el espacio para esas alternativas» (Jessop, 2017: 322).

«Puede que no sea posible resolver el problema de la vivienda en el contexto del capitalismo, pero sí que es posible alterar, modificar y cambar la configuración del sistema habitacional actual» (Madden y Marcuse, 2018: 32).

${ }^{8}$ Se refiere a la expresión 'There is no alternative' por sus siglas en inglés, popularizada por la primera ministra del Reino Unido Margaret Thatcher en la década de 1980 como eslogan y respuesta ante las críticas a la estrategia neoliberal desarrollada bajo su mandato. 
Estas cuatro citas, entre otras muchas, ejemplifican diferentes posturas a la hora de responder a situaciones problemáticas complejas como la que en este trabajo se aborda. Se pretende a continuación reflexionar sobre dos posibles maneras o perspectivas -a priori opuestas y llevadas a su extremo- desde las que se podría hacerlo, y desde las que buscar caminos para reducirla o eliminarla. La intención es dibujar un marco sobre el que colocar y justificar el posicionamiento de la investigación. Por un lado, se podría plantear redefinir desde cero el sistema y las herramientas existentes a partir de esas visiones fantásticas que señalaba Harvey. Sin miedo de hacerlo con aspiraciones ambiciosas y ampliamente transformadoras, para expulsar todos los vicios y malas prácticas, diseñando un modelo acorde a los criterios que se han venido estableciendo como adecuados a través de múltiples análisis y trabajos a lo largo de años de experiencia. Una postura quizás frecuente en ciertas posiciones políticas de izquierda, en búsqueda de una pureza del sistema, siempre imperfecto. Es este un ritmo lento, que necesita de cambios estructurales, destinado a ser planteado a largo o muy largo plazo. A la hora de imaginar actuar así, surgen inevitablemente ciertas dudas y retos. La dificultad a la hora de establecer un plazo de tiempo aproximado en el que sería posible un cambio tan profundo es solo uno de ellos. Posiblemente, el mayor obstáculo a salvar serían las dificultades que el contexto político, social, económico, cultural, legal, ambiental, pero también el urbanizado, el construido, plantean. Por otro lado, a la vez que se busca redefinir, trabajar y luchar por un cambio sustancial como este, cabe reflexionar sobre qué pasa mientras tanto; si no seguirá ganando poder y presencia el modelo hegemónico actual. En cualquier caso, el planteamiento ofrece un gran aliciente: el de la promesa de una respuesta integral a esta y otras problemáticas, incorporando todo el conocimiento aprendido durante décadas de experiencia, práctica e investigación. Pero una redefinición de cero del sistema urbanístico parece impensable si no es partiendo de una tabula rasa. Por otro lado, las interconexiones entre las diferentes esferas del sistema de organización social actual son enrevesadas; ¿se trata de una utopía?. El propio Harvey apunta algunos de estos retos:

«Cuestionar el papel dominante del valor de cambio en el suministro de un valor de uso como la vivienda, por ejemplo, supondría cambiar la forma y el papel del dinero y modificar, si no abolir, el régimen de derechos de propiedad privada que tan bien conocemos. La búsqueda de una alternativa anticapitalista parece por consiguiente una tarea bastante ardua. Tendrían que producirse transformaciones simultáneas en muchos frentes» (Harvey, 2014: 29).

Frente al anterior y un extremo opuesto, podría plantearse un camino aparentemente más corto en el tiempo, desde una perspectiva quizás más pragmática, a la vez que conformista. Sería aquella que acepta sin cuestionamiento alguno el contexto, las herramientas, las 
dinámicas y las condiciones supuestamente dadas y asumidas de manera generalizada, trabajando dentro del marco predominante. Dejando fuera de este supuesto aquellas posturas que no cuestionan el statu quo, se trataría este de un posicionamiento -en el que se podría enmarcar la cita señalada de Márquez- con una intención parcialmente transformadora, aunque consciente de las limitaciones de actuar bajo un paradigma que ha demostrado poca eficacia. Una postura que suele basarse en "prescindir del ideal [de la vivienda como derecho] y conformarse con introducir reformas en los márgenes. $\mathrm{O}$ peor incluso [...] esperar sin hacer nada a que llegue una revolución mesiánica que nos solucione el problema y abandonar todo esfuerzo por cambiar las cosas mientras tanto» (Madden y Marcuse, 2018: 212). Con todo, se trata de un enfoque con sus ventajas: la búsqueda $-\mathrm{y}$ por lo tanto en ocasiones desarrollo exitoso- de soluciones a problemas y personas de ahora. Sin embargo, las fuertes limitaciones y contradicciones entre las que se ha de desarrollar esta posición, junto con su débil esfuerzo transformador, hace que sus posibilidades de éxito se vean fuertemente dañadas. En cualquier caso, estos dos caminos presentados como idealmente enfrentados y extremos, no se reflejan normalmente en la realidad. Esta no suele caracterizarse por fenómenos y posiciones tan nítidamente definidas y libres de afecciones y dependencias externas. Por otro lado, podría decirse que ambos planteamientos son necesarios y enriquecedores, y sería muy positiva su coexistencia. La practicidad de uno se ve alimentada por la ensoñación del otro, y viceversa; la experiencia sobre el terreno de la mirada a corto plazo alimenta y genera conocimiento para la apuesta a largo plazo, mientras esta dota de grandes objetivos a la primera:

«...las viviendas experimentales y los movimientos emancipadores tienen una gran relevancia como demostraciones vivas del potencial de la vivienda. Deberíamos considerarlas como modelos que apuntan hacia una posibilidad más general [...] Hoy en día lo difícil es imaginar un sistema de vivienda que permita a los residentes enfrentarse al poder, la desigualdad social y la violencia estructural de una manera más significativa» (Madden y Marcuse, 2018: 132).

Una posible vía intermedia sería la de buscar, en el contexto actual, estrategias para intervenir y activar sub-sistemas minoritarios dentro del hegemónico, que aprovechen ciertos vacíos o grietas de este para introducir valores y principios progresistas apuntando hacia la transformación social. Es este enfoque precisamente el que desarrolla la teoría urbana crítica arriba presentada, y el que encajaría en la postura sintetizada en las citas de Jessop (2017) y Madden y Marcuse (2018): pasar del "no hay alternativa" y una actitud conformista, a dirigir los esfuerzos hacia la búsqueda y la puesta en valor del espacio a menudo oculto en el que nacen las alternativas dentro de un sistema que se pretende transformar -como señalaba Marcuse (1985: 53)-, lo que sin duda conlleva grandes dificultades. Sin caer en ejercicios exclusivamente utópicos o excesivamente soñadores que hagan 
olvidar el presente, pero sin desviar la mirada del futuro. Afinando el argumento, se podría concretar que se propone una mirada «en el sentido de futuros presentes más que en el de futuros futuros, pues los primeros se centran en potencialidades del sistema «tal y como está actualmente organizado», mientras que el contenido de los segundos «es ahora mismo materia para la especulación» (Jessop, 2017: 318). Un enfoque similar al de Madden y Marcuse al definir unas demandas transformadoras, realizables en el mundo actual, que apunten a hacia un cambio más profundo, y que desarrollen potenciales existentes aunque limitados en su desarrollo por las condiciones actuales (Madden y Marcuse, 2018: 212, 213). Lo que se busca desde este tipo de posturas es la identificación de oportunidades rupturistas. Para lo cual es imprescindible profundizar en el contexto sobre el que se estén dando, o puedan darse, esas rupturas. Lo cual en el marco de una investigación sobre el modelo residencial hace imprescindible contar con el parque edificado, el mercado, los sistemas de vivienda públicos, y los agentes actualmente jugando un papel en todo ello, para mitigar sus debilidades y explotar sus fortalezas. Se trataría, en definitiva, de complementar y exprimir algunos de los instrumentos ya existentes con una «reimaginación radical de las herramientas y marcos legales empleados hasta ahora» (Sevilla, 2015). Es este un ritmo más rápido que el del primer supuesto, pero más lento que el del segundo, y en el que se dan acciones simultáneas y parciales de ajuste de y adaptación a la realidad.

Por supuesto, en este caso también se identifican dudas e inconvenientes, en gran parte compartidos con o provenientes de las dos posturas extremas. Uno de los principales es que se trata de una respuesta parcial con altas intenciones de transformación dentro de un sistema, como se ha visto, con fuertes conexiones, interdependencias y complejas relaciones entre sus muy diversas esferas. Otro gran obstáculo puede ser que se plantean una serie de cambios que requieren desequilibrar la relación de fuerzas actuantes en los procesos de gobernanza, con las consecuentes resistencias que ello puede acarrear. Con lo cual, los propios límites y obstáculos del modelo actualmente predominante impedirán con frecuencia un correcto desarrollo de este tipo de estrategias, haciendo difícil el equilibrio social buscado. Pero ante la posible crítica -desde una estrategia utópica como la primera- de una falta de purismo e integridad, podría decirse que la heterogeneidad del marco y soporte heredados, y las contradicciones de las sociedades actuales dificultan enormemente el desarrollo de caminos tan idealmente imaginados. Y frente a una supuesta crítica -desde un posicionamiento conformista como el segundo- que señale lo ilusorio de transformar desde dentro el sistema actual, se podría argumentar que las condiciones generadas por las propias contradicciones del sistema hacen que sea en cierta manera posible abordar la problemática desde la intervención y actuación alternativas. 
Será en este tercer camino donde se posiciona la investigación. Sin embargo, no por ser menos ambiciosa que la primera opción se trata esta de una vía sencilla y carente de cierto posicionamiento utópico, ya que el carácter estructural de las contradicciones hacen que cualquier planteamiento que busque anularlas suponga también «una voluntad, aunque solo sea en el mundo del pensamiento, de superar o anular las fuerzas socioecológicas impuestas por la acumulación de capital descontrolada, los privilegios de clase y las enormes desigualdades del poder político y económico» (Harvey, 2003: 230). Todo ello se deberá llevar a cabo, por lo tanto, a través de la riqueza -aunque también dificultad- que implica un obligado proceso de consenso y negociación, y aprovechando lo existente en todo sus sentidos.

Quizás podrían clasificarse estos tres tiempos de otra forma. Lefebvre (1976:150) planteaba tres términos, lo 'real', lo 'posible' y lo 'imposible', proponiendo que un análisis excesivamente centrado en lo real se queda en «una acepción trivial y corriente del término» y «acepta el oportunismo político», mientras que al profundizar demasiado en lo imposible se tiende a fracasar de antemano. Entre ambos, abogaba por un acercamiento dialéctico a los tres términos que hiciera posible lo que parecía imposible. Existen otros ejemplos que aportan mayores matices, y sitúan los tres tiempos en un gran proceso único, como apunta Sevilla (2015), diferenciando entre el corto, el medio y el largo plazo. Este sitúa en el primero un momento 'recuperador' en el que «deberían integrarse todas esas políticas que antes refería como obvias y en torno a las cuales existe un consenso general tanto técnico como, crecientemente, ciudadano. Una agenda de políticas urbanas para acabar con la ciudad especulativa y la mercantilización del espacio social». En el medio plazo sitúa un momento 'progresista' donde poner «en marcha una serie de iniciativas encaminadas a rearticular selectivamente los marcos y técnicas de planeamiento heredados [...] y a idear nuevas herramientas que permitan acabar con las desigualdades socioespaciales». Finalmente, en el largo plazo coloca un momento 'diferencial' apoyado en una democracia radical para «garantizar la cesión de prerrogativas a la ciudadanía, protegiendo y propiciando la proliferación de espacios autónomos que pongan en marcha sus propios urbanismos populares. Se trataría de articular el marco para una paulatina colonización del estado por la sociedad civil a nivel local y sub-local, $[. .$.$] en la que el Ayuntamiento operaría como 'guardia$ nocturno', actuando sólo como escudo institucional para proteger ese común de las distintas agresiones que pudiera sufrir por parte de mercados, agentes desestabilizadores, etc.». Podría decirse que el camino intermedio propuesto para esta investigación estaría en algún punto entre los momentos 'recuperador' y 'progresista' que planteaba Sevilla (2015), y en línea con los futuros presentes planteados por Jessop (2017) para lograr ese 'posible' al que hacía referencia Lefebvre (1976) (Tabla 1.3). 


\begin{tabular}{|c|c|}
\hline Fase / estrategia & Características \\
\hline \multirow{8}{*}{$\begin{array}{l}\text { Corto plazo } \\
\text { Momento 'recuperador' } \\
\text { Lo 'real' }\end{array}$} & . "No hay alternativa". \\
\hline & - Pragmatismo y conformismo. \\
\hline & - Aceptación del marco dado. \\
\hline & $\begin{array}{l}\text { - Entre el reformismo leve y el abandono del } \\
\text { esfuerzo por cambiar las cosas. }\end{array}$ \\
\hline & · Logros parciales ‘aquí y ahora’. \\
\hline & $\begin{array}{l}\text { - Alto condicionamiento por el contexto y baja } \\
\text { tasa de éxito. }\end{array}$ \\
\hline & - Acumulación de experiencia sobre el terreno. \\
\hline & $\begin{array}{l}\text { - Integración de políticas en torno a las que hay } \\
\text { un consenso técnico y ciudadano. }\end{array}$ \\
\hline \multirow{8}{*}{$\begin{array}{l}\text { Plazo intermedio } \\
\text { Futuros presentes } \\
\text { Momento 'progresista' } \\
\text { Lo 'posible' }\end{array}$} & $\begin{array}{l}\text { Demandas parcialmente transformadoras, } \\
\text { pero que apuntan hacia un cambio más } \\
\text { profundo. }\end{array}$ \\
\hline & $\begin{array}{l}\text { Activación y aprovechamiento de grietas, } \\
\text { potencialidades latentes y espacios de } \\
\text { oportunidad alternativos y rupturistas dentro } \\
\text { del sistema actual. }\end{array}$ \\
\hline & $\begin{array}{l}\text { - Ajuste de y adaptación a la realidad de manera } \\
\text { simultánea. }\end{array}$ \\
\hline & . Exige un conocimiento profundo del marco \\
\hline & $\begin{array}{l}\text { heredado y actuar sobre múltiples } \\
\text { dimensiones. }\end{array}$ \\
\hline & - Importantes limitaciones y fuerzas en contra. \\
\hline & $\begin{array}{l}\text { - Necesidad de consenso, negociación, } \\
\text { educación. }\end{array}$ \\
\hline & $\begin{array}{l}\text { - Rearticulación selectiva de marcos y técnicas, } \\
\text { diseño de nuevas herramientas. }\end{array}$ \\
\hline \multirow{10}{*}{$\begin{array}{l}\text { Muy largo plazo } \\
\text { Futuros futuros } \\
\text { Momento 'diferencial' } \\
\text { Lo 'imposible' }\end{array}$} & - Visiones alternativas fantásticas. \\
\hline & - Redefinición desde cero del sistema. \\
\hline & - Ambicioso y profundamente transformador. \\
\hline & $\begin{array}{l}\text { Aplicación del conocimiento acumulado } \\
\text { durante años de experiencia, investigación, y } \\
\text { prueba-error. }\end{array}$ \\
\hline & - Grandes obstáculos debidos a las \\
\hline & características del marco heredado y las \\
\hline & fuertes interrelaciones de sus dimensiones. \\
\hline & - Incertidumbre por el 'mientras tanto'. \\
\hline & - Especulativo. \\
\hline & $\begin{array}{l}\text { - Empoderamiento ciudadano, democracia } \\
\text { radical, colonización del estado por la } \\
\text { sociedad civil. }\end{array}$ \\
\hline
\end{tabular}

Tabla 1.3. Tres posibles grandes fases de gobernanza urbana en un proceso de transformación social. Elaboración propia a partir de Harvey (2003, 2014), Jessop (2017), Lefebvre (1976), Madden y Marcuse (2018) y Sevilla (2015). 
Pero más allá de estas cuestiones, hay en común entre los discursos analizados un consenso de que muchas de las herramientas de planificación espacial están obsoletas, fueron diseñadas en otro contexto y ahora no pueden responder de manera adecuada a los retos actuales. Es por ello que desde aquí se aboga también por que deben ser replanteadas, adaptadas y transformadas. No obstante, debido a lo largo que puede ser ese proceso, es de la misma manera importante actuar en dos frentes hasta que haya unos instrumentos y un marco nuevos.

El primero trata de buscar la manera de sacar el máximo partido a los instrumentos actuales; el segundo, localizar, analizar y explotar esos espacios y grietas en los que se pueden dar alternativas transformadoras. Los plazos y tiempos para cambios profundos pueden demorarse lo suficiente como para que cobre interés buscar la máxima eficacia y el mayor rendimiento posibles a los instrumentos vigentes pese a no ser los óptimos. Además, el esfuerzo por activar y sacar el potencial latente en el marco urbano y social actual a la superficie permitirá estudiar sus carencias y sus puntos fuertes. Todo ello puede aportar además una serie de criterios que podrían aprovecharse de cara a una redefinición futura de las herramientas.

\section{Objetivos de la investigación}

El carácter académico del trabajo implica dejar de lado esfuerzos propositivos; este se centra en investigar una serie de oportunidades, primeramente intuidas -a través del desarrollo de una carrera profesional en la arquitectura y el urbanismo, de la trayectoria y formación previas en torno a los estudios urbanos, de la observación, de la lectura y consulta de otros trabajos previos, de inquietudes personales,...-, y posteriormente suficientemente reveladas como para plantear un proyecto investigador en el marco de una tesis doctoral. A partir de lo presentado en apartados anteriores, pueden establecerse dos grandes niveles de objetivos:

- En un primer nivel y con un carácter más general, hay una inquietud por responder al enquistamiento generado por el habitual choque de estrategias en la cuestión residencial y su actuación frecuentemente superficial, a pesar de existir un relativo consenso en torno a la urgencia y relevancia de los problemas existentes. Lo cual lleva a intentar profundizar en las causas de fondo que generan la situación problemática, y no tanto en sus efectos. Estos han sido ampliamente analizados y discutidos; en cambio, la comprensión de las causas llevará, al menos de una manera parcial, a hacer posible relacionar unos con otros superando el mero análisis descriptivo y acercándose a la comprensión (Marcuse, 1985: 149). 
- De una manera también general, está la manera en que se posiciona el trabajo en las tres fases de gobernanza que posibilitarían una transformación social sintetizadas en la Tabla 1.3. De forma que, poniendo la mirada en esos futuros presentes de un momento 'progresista', no se pretenden analizar posibles formas para una transformación total y directa del sistema predominante -como se ha señalado, de dudosa viabilidad o incluso existencia-. Pero sí se busca -sin desviar del todo la mirada de esa transformación final- identificar, poner en valor y analizar las potencialidades y los retos de ciertas realidades e iniciativas que puedan ser, como parte de un movimiento de reforma rupturista para reducir la desigualdad social, «la punta de lanza para una transformación revolucionaria» (Harvey, 2014: 180).

- Entrando en un segundo nivel de objetivos más concretos, y cogiendo cierta perspectiva temporal, se cree que continuar sin una reacción más o menos profunda ante la situación actual de la dimensión social de la vivienda no tiene gran recorrido. Tanto si esta se mantiene, como si sigue evolucionando a una versión más mercantilizada del modelo actual, diferentes análisis apuntan que los niveles de desigualdad residencial y consumo de suelo alcanzados pueden llegar a hacer peligrar la propia reproducción del mismo. Parece que -incluso por la propia supervivencia del modelo actual- cualquier respuesta racional debería contar con, al menos, dos factores cruciales: un parque residencial heredado considerablemente obsoleto e infrautilizado, y una realidad social en fase de precarización, transformación y estancamiento demográfico. Así, el objetivo principal del trabajo, o más bien su marco social y político, se puede considerar como el deseo de avanzar hacia el acceso total a una vivienda digna en lo que se refiere a su dimensión social adecuada económica y tipológicamente-, con el añadido de hacerlo posible en un entorno construido eficazmente utilizado.

\section{$-1.3 .2-$ \\ Estado de la cuestión}

\section{Revisión de trabajos existentes}

Si bien lo desarrollado hasta aquí se ha centrado especialmente en el carácter contradictorio del capitalismo y en una gobernanza desigual como el camino a través del cual se construyen las relaciones para la reproducción del mismo, no son ninguna de estas dos cuestiones el objeto de estudio de la investigación. Pero sí conforman 
un marco a tener en cuenta necesariamente para abordar, de la manera que se propone, el verdadero objeto de estudio: la potencialidad de avanzar en el acceso a la vivienda en el AMB en un contexto como ese. Por lo tanto, la revisión del estado de la cuestión previa al diseño de la investigación se ha centrado en, aunque no limitado a, aquellos trabajos que cumplen dos requisitos: abarcar un ámbito geográfico compartido con el de la presente investigación con mayor o menor concreción, pero siempre abarcando, o dentro de, la Comunidad Autónoma de Euskadi-, y centrar su mirada en el acceso a la vivienda -desde diferentes perspectivas e inquietudes-. Algunos de los trabajos más relevantes para el fin de esta investigación serán citados a lo largo de la misma; otros no son citados, pero se abordan en cambio asuntos y temas por ellos trabajados. Por lo que en este apartado no se va a profundizar en su contenido.

Puede afirmarse, en general, que existen estudios de gran interés. Comenzando por el amplio abanico de trabajos realizados desde una perspectiva histórica, algunos de los cuales abordan el análisis de la problemática de la vivienda incluso ya desde la primera mitad del siglo XX (Bastida, 1924). En trabajos más recientes, algunos autores han tomado los primeros años de la posguerra como marco para el estudio de algunas propuestas habitacionales que se hicieron entonces (Pérez de la Peña, 2004), mientras que otros lo hicieron en una franja de tiempo más amplia, analizando la disponibilidad de vivienda durante los años de desarrollo del pasado siglo (Bustillo, 2004). La calidad de la vivienda y el higienismo en la vivienda obrera han sido también temas a tratar, tanto durante la segunda mitad del siglo XIX (Pacho, 2010), como a comienzos del XX (Urrutia, 1993). Y los estudios en torno a las diferentes tipologías arquitectónicas y morfologías urbanas desarrolladas para responder a la necesidad de vivienda del siglo pasado son numerosos (Beascoechea, 2007; Domingo, 2005; Gómez, 2004, 2009; Muñoz, 2009; Pérez Castroviejo, 1994; Pérez, 1997; Ruiz de Azúa, 1978; Santas, 2007). También se han desarrollado trabajos que recogen la evolución del parque residencial (Rodríguez, 2001) tomando el periodo entre los años 1950 y 2000, si bien el mencionado está exclusivamente basado en los datos de los censos demográficos ofrecidos por el Eustat.

En cuanto a lo que aquí se ha venido a llamar la dimensión social de la vivienda propiamente dicha, existen diversos aportes desde el mundo académico. Tanto buscando métodos para la construcción de un índice de precios de la vivienda en Bilbao que permita comprender el mercado con mayor precisión (Bárcena et al., 2011), como los que mediante estudios comparados buscan demostrar que el aporte de más oferta de suelo urbano residencial no colabora en el descenso del precio final de la vivienda (Azpiri, 1997). Los intentos de comprender los motivos que han generado el auge de los precios de la vivienda en los años de la burbuja inmobiliaria también fueron analizados en su día para el caso de Euskadi (Sasigain et al., 2004). Pueden a su vez 
encontrarse trabajos que han tratado algunos de los graves efectos que los desequilibrios estructurales han generado y generan en la sociedad vasca. Como los desahucios (Etxezarreta et al., 2013), las personas sin hogar (Moreno, 2009, 2013), las peculiaridades y retos para responder a las necesidades de alojamiento de las personas mayores (Mondragon et al., 2011), el coste de la emancipación en la juventud vasca (López, 2014) o, desde un punto de vista más general, la problemática de la exclusión residencial (Duque, 2014) o el repaso a la política de vivienda en España en el contexto Europeo como un estado incapaz de garantizar el acceso a la vivienda a toda su población (Rodríguez Alonso, 2009).

Desde el análisis de las políticas e instrumentos para la gestión de la vivienda, las aproximaciones al tema se dan -aunque con el foco puesto en cuestiones sectoriales- en torno a las tendencias más recientes en la política de vivienda española (Leal y Martínez del Olmo, 2017), la vivienda vacía (Etxezarreta, 2010), el marco existente para el desarrollo de cooperativas de vivienda (Bilbao, 2014; Burón, 2014; Etxezarreta y Etxezarreta, 2007; Gondra, 2004; Observatorio Vasco de la Vivienda, 2015e) u otras fórmulas de vivienda colectiva (Observatorio Vasco de la Vivienda, 2014c, 2015c, 2015d), o el papel y los retos de los instrumentos de planificación urbana dentro del marco normativo vasco 9 (Maguregui, 2007). Se hace necesario hacer referencia especialmente -debido a su gran conocimiento del tema en general, y del sistema y modelo vasco de vivienda en particular, tras su experiencia tanto en el sector público como en el privado- a los aportes realizados durante los últimos años por Javier Burón al desarrollo de un debate sobre el futuro de la vivienda en la región (Burón, 2005, 2008, 2010, 2011, 2015b, 2015c, 2016).

\section{Posición crítica y aporte de la investigación}

La base de conocimiento e información existente en torno a un tema tan diverso, complejo y amplio como la vivienda tanto en Euskadi como en el AMB es de gran valor. Sin embargo, el camino por avanzar es todavía largo y con numerosos retos. Muchos de los trabajos citados comparten objetivos con este, pero su ámbito de estudio se queda en una escala nacional, autonómica o provincial; y en el caso de analizar un caso de estudio más concreto, lo hacen en otra área urbana. Por otro lado, hay otros trabajos en los que, a pesar de estar centrados más precisamente en la región del $\mathrm{AMB}$, por diversos motivos - profundizan en otros temas, ha pasado un tiempo suficiente como para justificar un nuevo enfoque, o simplemente han dejado algunos aspectos fuera- no han abordado el tema como desde esta investigación se plantea. Se quiere, por lo tanto, hacer hincapié en una serie de puntos sobre los que se ha detectado cierta carencia en la

${ }^{9}$ Mención especial merece el análisis y enriquecimiento de los debates sobre esta cuestión realizado por autores como Tejerina y Cerezo, disponibles en la web www.orbenismo.es. 
producción tanto académica como divulgativa, así como la aspectos sobre los que la presente investigación pretende aportar algo de luz al debate:

- Asimilar que se está enfrentando un modelo estructuralmente desigual: son pocos los estudios y trabajos que abordan la dimensión social de la vivienda aquí planteada entendiendo que, como ya se ha mencionado, el modelo urbanístico residencial actual se ha apoyado en la problemática identificada en ella para sobrevivir; como una cuestión que ha demostrado ser estructural del modelo.

- Enfoque geográfico y espacial transversal: al tratarse de un acercamiento al tema desde la arquitectura y el urbanismo, el protagonismo recae sobre la perspectiva espacial; eso sí, enriquecida por otras disciplinas y conocimientos. Habitualmente los trabajos tienden a limitarse a un ámbito muy concreto: políticas y gestión, estudios morfológicos, análisis demográficos,... sin cruzar algunas de estas variables para una visión algo más integral.

- Análisis profundo: en general, los trabajos revisados se quedan en un análisis más genérico o menos detallado, por lo que se busca profundizar, en lo posible, en la realidad local del caso de estudio que se está estudiando, mediante una recogida de información con considerable nivel de detalle.

- Búsqueda de una investigación aplicada: se echan en falta trabajos sobre esta temática orientados a una aplicación directa y relativamente rápida del conocimiento aportado; una vez aclarada la posición - puede decirse casi que política- de este trabajo al seleccionar un camino a corto y medio plazo con intenciones transformadoras a largo, la posible aplicación del conocimiento generado es uno de los objetivos fundamentales.

- Mirada abierta y fresca al parque heredado: en cuanto al soporte sobre el que se ha de trabajar, queda un gran trabajo por hacer en torno al análisis de la complejidad de las necesidades y retos, y de la riqueza del potencial que la ciudad residencial existente presenta.

- Agentes alternativos de gestión: si bien son cada vez más frecuentes los trabajos en torno a nuevas o diferentes fórmulas de gestión para el desarrollo del derecho a la vivienda, se precisan estudios que crucen los aspectos espaciales de dicho soporte residencial existente con las características socio-demográficas de la población objetivo y con las capacidades y los posicionamientos de los agentes disponibles para llevar a cabo esa tarea mediante esas otras fórmulas alternativas. 


\section{Hipótesis}

«Vale la pena recordar que al igual que el neoliberalismo explotó la crisis del Estado de bienestar keynesiano, y se alimentó de ella, puede anticiparse que en las crisis cada vez más profundas dentro del mismo proyecto neoliberal, y en torno a las mismas, se abrirán nuevas oportunidades estratégicas para movimientos tanto reformistas como antihegemónicos. Por supuesto, nada hay de predeterminado en tales luchas, pero parece indudable que el terreno urbano será un campo de batalla decisivo. Las luchas locales en torno a la vivienda digna $[\ldots]$ plantean ya pertinentes alternativas progresistas al neoliberalismo. No obstante, revertir el neoliberalismo también implicará una amplia re-regulación de la ciudad misma, con medidas destinadas a hacer frente a los corrosivos efectos de la competencia interurbana y la redistribución regresiva. Una de las claves para trascender al neoliberalismo es, por lo tanto, la construcción de nuevas formas de solidaridad urbana, entre ciudades y dentro de ellas» (Brenner et al., 2015: 240).

Esta cita de Brenner, Peck y Theodore sintetiza de manera muy eficaz algunas de las principales cuestiones presentadas en este capítulo: la esperanza en un resurgimiento de alternativas progresistas dentro de un sistema altamente limitador, el carácter tanto reformista como profundamente transformador de estas, el entorno urbano (existente) como espacio clave para su desarrollo, y la necesidad de hacerlo desde iniciativas solidarias con altas dosis de responsabilidad social. Jessop (2017: 182) puede ayudar a contextualizar esta cuestión, al afirmar que «las configuraciones espaciales heredadas y sus estructuras de oportunidad son lugares en los que se puede establecer, disputar y modificar la gobernanza». Todo ello permite construir la hipótesis de partida de la investigación, si bien se hace en dos tiempos. Una primera se presenta a continuación, como resultado del marco hasta aquí desarrollado, y por lo tanto desde un punto de vista más genérico. Esta se completa en el capítulo segundo detallando y contextualizando en el AMB y el objeto de estudio esta primera formulación. La hipótesis se define de la siguiente manera:

Tal y como afirma la teoría urbana crítica, existe la posibilidad de construir alternativas transformadoras a partir de reformas rupturistas ante las problemáticas estructurales de los retos urbanos. Sin embargo, para desarrollar y aprovechar con cierto éxito esas alternativas surgidas de entre las grietas del sistema y corregir la situación problemática abordada, será necesario abordar de forma transversal las causas y las contradicciones de fondo para buscar en ellas y de manera 
conjunta (1) espacios de oportunidad para adecuar y adaptar las obsolescencias heredadas en el contexto urbano actual y (2) espacios de poder para desarrollar relaciones más horizontales y colectivas en las formas actuales de gobernanza urbana desigual.

$-1.3 .4-$

\section{De la teoría urbana crítica al análisis empirico: aproximación metodológica}

A pesar de la naturaleza abstracta de la teoría crítica arriba señalada (Brenner, 2017b), el propio autor -entre otros- señala que sobre la base empírica del trabajo investigador también puede construirse la teoría crítica, a pesar de situarse esta en un momento de abstracción (Brenner, 2017b: 241; Roch, 2009: 183). Igualmente, Marcuse apuntaba que «en una sociedad dada, existen posibilidades específicas para un mejoramiento de la vida humana y formas y medios específicos para realizar esas posibilidades. El análisis crítico tiene que demostrar la validez objetiva de estos juicios, y la demostración tiene que realizarse sobre bases empíricas» (Marcuse, 1985: 21). En este caso, la investigación empírica cumple una doble función. Ya que es, además de una vía para una investigación aplicada que permita arrojar algo de luz hacia algunas posibles alternativas, una herramienta para intentar ir más allá y hacer un aporte teórico crítico.

Por un lado, se pretende reflexionar, aportar datos para el debate y confirmar, en última instancia, la naturaleza estructural y sistémica de algunos conflictos y contradicciones propias del modelo de vivienda casi global, aterrizándolas sobre el caso español en general, y vasco en particular. Esto se hace ahondando en el por qué de su existencia, buscando la comprensión de la generación de estas contradicciones en procesos desiguales de gobernanza urbana. A su vez, esto permitirá demostrar que, precisamente, las contradicciones identificadas son las que originan y posibilitan esas alternativas. A ello van dirigidos los dos primeros capítulos de la investigación, sobre lo que ya se han avanzado algunas cuestiones fundamentales. Por otro lado, los capítulos tres y cuatro se centran en demostrar que, más allá de la crítica estructural y la búsqueda de la redefinición total del modelo, existen y/o es posible poner en marcha y activar espacios y alternativas transformadoras dentro del sistema actual. No para cambiar el mismo de manera drástica a corto plazo, pero sí para lograr ciertos avances y facilitar una vida digna a parte de la población con necesidad de una vivienda adecuada; esto a su vez permitirá difundir, fortalecer y extender algunas alternativas rupturistas. Para todo lo cual, se utiliza el caso del AMB como objeto de estudio. El diseño de la investigación se plantea mediante la proposición de algunos - de los muchos posibles- caminos para aportar conocimiento con tal fin. 
A pesar del marco introductorio presentado, se parte de una actitud optimista y constructiva. Se defiende que el AMB, aún habiendo sufrido los efectos de un modelo de desarrollo urbano y territorial que está inevitablemente en vías de extinción -pero de desarrollo y plazo incierto, según sea abordada de una manera anticipada y más amable, o se estire la situación ideal hasta un momento de colapso forzoso-, no está aún totalmente hipotecada. Se cree que existen una serie de espacios y agentes sociales que ofrecen margen de maniobra y potencial de mejora en el marco y contexto actual, para avanzar hacia el objetivo propuesto. Pero ese gran objetivo de acceso a la vivienda se ha de concretar en fases y pasos de la investigación propiamente dichos. En este sentido, esta se plantea como un ejercicio -casi experimental- de búsqueda de oportunidades de mejora con el fin de demostrar la hipótesis. Así, son cuatro los principales pasos metodológicos ${ }^{10}$; el primero ha sido ya desarrollado $\mathrm{y}$ es el que ha llevado a la definición de este planteamiento investigador; los dos siguientes pasos se desarrollan en el capítulo segundo, y hacen referencia a la primera parte de la hipótesis -la existencia de alternativas a partir de las contradicciones-; mientras que el último paso se desarrolla a través de los capítulos tercero, cuarto y quinto -en los que se desarrolla el resto de la hipótesis-, quedando el capítulo sexto para las conclusiones. En síntesis, los pasos establecidos en la investigación han sido, en este orden:

- Acotar el tema y la situación problemática a investigar, señalando sus principales retos y características, y enmarcándolo, a través de la teoría urbana crítica, en un contexto más amplio que ayude a su comprensión, a la búsqueda de respuestas, y a la formulación de una hipótesis de partida general.

- Sobre el caso de estudio elegido, el AMB, localizar las principales contradicciones transversales a diferentes momentos, escalas y agentes propias de la situación problemática, y situarlas en un contexto sistémico más amplio. Con este fin, se presenta $-\mathrm{y}$ aplica al AMB- una herramienta de análisis de diseño propio que busca conceptualizar e identificar la generación de contradicciones en procesos de gobernanza urbana.

- Una vez localizadas las contradicciones principales para el caso de estudio, se busca identificar posibles alternativas locales -potenciales o existentes- surgidas de esas contradicciones y actuando - o con capacidad de hacerlo- en

10 Se presenta aquí el marco metodológico general sobre el que se ha desarrollado el trabajo investigador. Para facilitar la comprensión del mismo y por comodidad de lectura, el desglose y los detalles -material y métodos- de cada uno de estos pasos se exponen al inicio de cada capítulo. Así mismo, una vez situada y completada la hipótesis en el AMB en el capítulo segundo, se concretan en mayor medida estas cuatro fases en pasos metodológicos más detallados. 
contra de ellas con un espíritu transformador; esto permitirá aterrizar la hipótesis general en el caso de estudio.

- Por último, estudiar el origen, promoción, nivel de desarrollo e implantación, ámbito de actuación, características, territorialización, potencialidades, debilidades, retos y otras cuestiones de interés de dichas alternativas.

\section{Abstracción, concreción, y aplicación del trabajo}

Aunque atravesado por diversas disciplinas, este trabajo se considera propio de las ciencias sociales, por lo que la posibilidad de aplicar sobre una realidad social específica sus resultados cobra una importancia fundamental para poder tener un efecto transformador en el ámbito y objeto analizado. Pero la aplicabilidad de los aportes académicos puede variar en base a su naturaleza: desde aquellos que tratan cuestiones muy bien acotadas y muy específicas con una aplicación directa de sus resultados en soluciones concretas -O incluso aportando estas-, a otros que se enmarcan en cuestiones más difusas y multidimensionales cuyos resultados pueden ser aplicados de manera parcial en diferentes procesos, pero que necesitan de otros agentes, tiempos y medios para llegar a conformar esas soluciones concretas. Es en esta segunda categoría en la que se sitúa la presente tesis doctoral.

Se ha pretendido -lo que no garantiza haberlo logrado en su totalidad- desarrollar el trabajo entre la investigación teórica y la investigación aplicada, buscando el enriquecimiento mutuo de ambas áreas. Esta investigación busca conocer y comprender, más allá de lo evidente, una problemática concreta para identificar fenómenos que originen oportunidades de corregirla. Para lograr ambas cuestiones, se ha considerado fundamental contextualizar la misma en un marco urbano, físico, económico, social, ambiental, normativo y regulador presente en el capítulo segundo especialmente, si bien el tercero y cuarto añaden información relevante en este sentido-. El nivel de profundización en este contexto, yendo de lo abstracto a lo concreto, está entre el considerado necesario para el desarrollo de la investigación y el posible debido a los medios disponibles. No se han buscado soluciones detalladas y precisas aplicables directamente a instrumentos, elementos, colectivos o localizaciones específicas del ámbito geográfico de estudio. Lo contrario, en este caso, supondría un ejercicio ambicioso de difícil consecución. Por otro lado, la complejidad y diversidad de variables, afecciones, agentes y personas involucradas hace necesario que a dicho nivel de concreción y aplicación se llegue a través de procesos de toma de decisiones colectivos y abiertos, con información más rica y actualizada que la aquí trabajada. Sin embargo, los resultados sí podrán tenerse en cuenta para ser incorporados a dichos procesos. 


\section{Parte I. \\ Contexto, marco de análisis \\ y planteamiento}

Parte II.

Material, métodos y resultados

Parte III.

Discusión y

Conclusiones 



\section{CAPÍTULO 2}

\section{Contradicciones, efectos y respuestas en procesos de gobernanza urbana}

«Las contradicciones de los aspectos políticos de la vivienda son el resultado de las propias contradicciones de la sociedad contemporánea. Solo es posible entender esta situación si sacamos a la luz el proceso por el que se produce la opresión en la vivienda, las personas y los intereses responsables de ella, las fuentes de resistencia a dicha resistencia y el potencial liberador que también tiene la vivienda. Las cuestiones fundamentales sobre la vivienda hoy en día no son las relativas a las restricciones de altura ni a los cambios en la zonificación, pese a lo importantes que son todos estos temas. Las cuestiones esenciales son para qué y para quién es la vivienda, a quién oprime y a quién empodera».

(Madden y Marcuse, 2018: 133) 



\section{$-2.1-$ \\ Una herramienta de análisis}

La contextualización del objeto de estudio y de la situación problemática brevemente presentada en un marco más amplio ha permitido plantear que un análisis que profundice más allá de los efectos que la conforman, con el fin de intentar identificar cuáles son las causas -las fuerzas sociales e ideológicas que la generan-, permitirá una definición y una comprensión suficiente de las contradicciones existentes que facilite la identificación y/o construcción de alternativas. A partir de esa argumentación, y en sintonía con el posicionamiento de la teoría urbana crítica, se ha trabajado en la búsqueda de una herramienta teórica con aplicación empírica que ayude a realizar dos labores. En primer lugar, identificar y comprender las causas de fondo que hay detrás de la generación -y la permanencia- de conflictos complejos con una determinante dimensión espacial y urbana, generadores de contradicciones. En segundo lugar, buscar, encontrar y analizar alternativas surgidas de las anteriores, a las cuales se enfrentan, y que permitan corregir algunos de sus efectos. Para ello, el principal foco se ha de poner en el espacio social, en la medida en que son las relaciones sociales diversas, desiguales y complejas que lo conforman las que generan y reproducen, internamente, ese panorama contradictorio. Por todo ello, la intención ha sido el diseño de un esquema con especial énfasis en la componente relacional de los fenómenos analizados. Pues, tal y como Lefebvre (2013: 86) señala para las relaciones sociales contenidas en este espacio (social), además de identificarlas se ha de comprender su motivación y su funcionamiento. La naturaleza transversal y compartida, antes planteada, de las contradicciones entre muchos de los agentes participantes en el proceso de gobernanza se considera clave en este sentido, y hace que uno de los principales esfuerzos -si no el principal- haya sido diseñar una herramienta que permita situar, simultáneamente, a los diversos agentes en diferentes momentos y espacios de la gobernanza. Precisamente, por dicho carácter transversal de las contradicciones.

Siendo, como se ha planteado, esta continuidad en el tiempo y este carácter estructural de los conflictos que impiden un adecuado acceso a la vivienda extensible a otras problemáticas urbanas, la cuestión del derecho a una vivienda digna y adecuada sirve aquí como referencia para el desarrollo de una propuesta que busca ser aplicable a otros fenómenos propios del espacio social. Por lo tanto, se ha planteado un objetivo ambicioso que va más allá de responder a la problemática 
de esta investigación; se ha buscado aportar una herramienta aplicable en otros trabajos futuros a otras cuestiones contradictorias, a las que abordar desde la gobernanza de los entornos urbanos. Se propone así como herramienta para el objeto de este capítulo la construcción de un esquema que busca conceptualizar la generación de contradicciones en procesos de gobernanza urbana. Habiendo señalado ya que en el AMB existe una situación considerablemente conflictiva respecto a la dimensión de la vivienda a trabajar, el objetivo es identificar y proponer un esquema conceptual que ayude a estructurar las causas que la motivan.

\section{$-2.1 .1-$}

\section{La generación de contradicciones}

La base utilizada en el proceso de diseño de esta herramienta la constituyen dos cuestiones fundamentales, cuyos efectos no se limitan a este apartado, si no que conforman la estructura de la investigación: el análisis empírico y profundo de la situación problemática y de su contexto, y el apoyo teórico para comprender e interpretar el mismo. A partir de esa primera labor empírica se han obtenido tres principales resultados. En la búsqueda de claridad en la redacción y la estructuración de las ideas, y una vez presentada con una breve pincelada la problemática en cuestión (apartado 1.1.3), estos se han distribuido en diferentes partes del trabajo. En primer lugar, se ha construido un marco teórico capaz de explicar, acotar y acompañar algunas de las interpretaciones más relevantes obtenidas en dicho análisis empírico. Este se ha presentado en el capítulo anterior. En segundo lugar, fruto del ejercicio deductivo y apoyado en trabajos teóricos, se ha diseñado una herramienta con intención de conceptualizar algunas de las interpretaciones realizadas en el análisis empírico. Lo cual se desarrolla seguidamente. En tercer lugar, se ha aplicado dicha herramienta al objeto y caso de estudio de esta investigación, lo que centra la principal atención del resto de este segundo capítulo. Este tercer paso incluye, al ser uno de los elementos que conforman la herramienta, una revisión más profunda de la situación problemática antes anunciada. Se trata, por lo tanto, de una herramienta teórica -teoriza sobre la naturaleza de ciertas relaciones sociales-, nacida de un fuerte trabajo empírico y sustentada por un marco teórico sólido, con clara vocación de ser aplicada empíricamente -con el objetivo de contrastar ese ejercicio de conceptualización sobre casos concretos- para a su vez alimentar la teoría -confirmando o corrigiendo lo planteado-.

El esquema de conceptualización planteado para la detección y comprensión de las contradicciones relaciona algunas de las cuestiones clave: la situación problemática, la respuesta que esta genera en la sociedad, las metas definidas como fin último, y los 
principales mecanismos ideológicos del modelo hegemónico que se contraponen a las mismas (Esquema 2.1). Se ha de insistir en que no se trata de un esquema que refleje un mapa de agentes, pues busca identificar posiciones, actos y relaciones; algunos de sus protagonistas podrán ver reflejada parte de su actividad en diferentes elementos del mismo de manera simultánea. Se define, como planteamiento inicial, que en las sociedades actuales pueden identificarse tres grandes fases de gobernanza en la búsqueda de lograr una serie de metas, como respuesta ante la identificación de una situación problemática concreta. Una respuesta que es heterogénea y en la cual los diferentes agentes juegan papeles diversos según su posición, poder, naturaleza u objetivos. Más aún, la distinción entre unos y otros agentes puede llegar a ser muy porosa, y los intereses y presiones ejercidos y sufridos por estos son diversos, a pesar de la poderosa presencia del capital entre ellos (Harvey, 2014: 158). Estas tres fases pueden resumirse, y así se han sintetizado, como las fases del Contenido, los Instrumentos y la Ejecución. Teórica e idealmente se desarrollarían cronológicamente en ese orden, pero realmente se presentan en continua retroalimentación, en función tanto de los resultados y los aprendizajes a lo largo del proceso, como de las afecciones externas que luego se señalan.

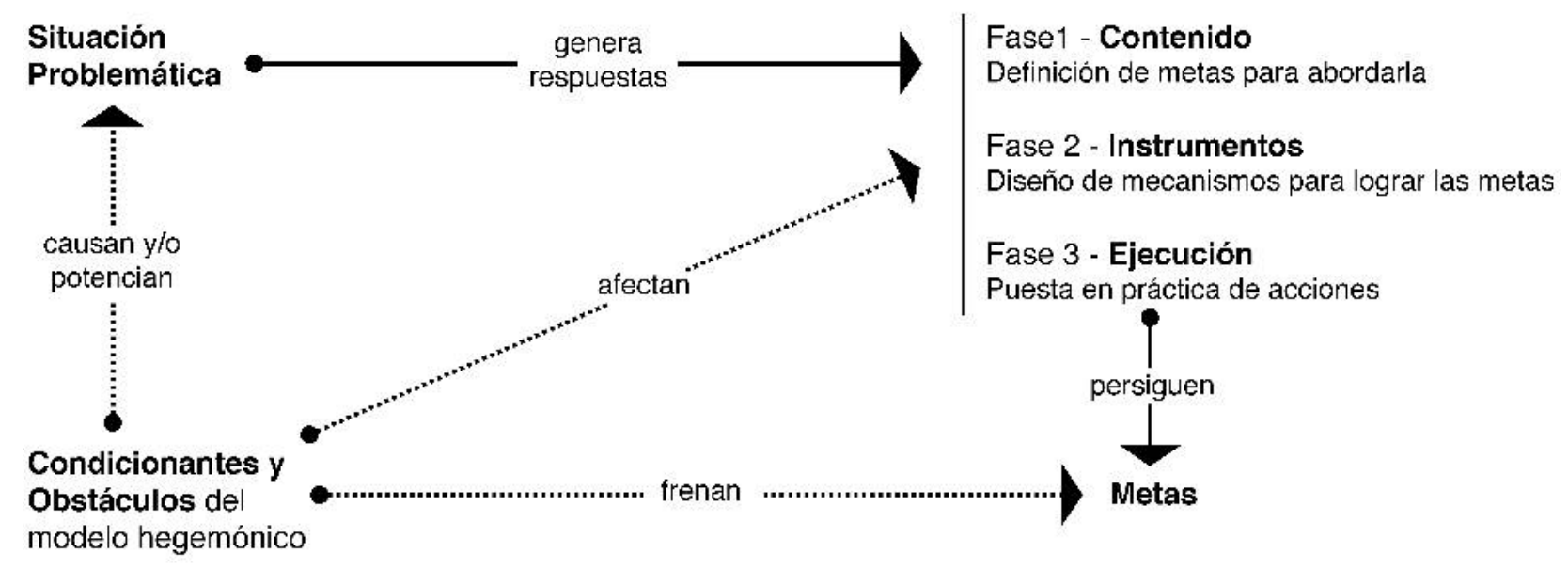

Así, detectada y conocida la problemática en cuestión, la primera es la fase de la generación de conocimiento de una manera colectiva no necesariamente actuando como un colectivo consciente, si no colectivamente como sociedad diversa y contradictoria-. Es este el tiempo para la discusión, el debate, el consenso y la definición de necesidades ante dicha problemática. Es aquel punto de partida en el que se discuten y se asientan las bases de las ideas y los principios, de los derechos y los objetivos. Se establecen las razones por las que fijar una meta concreta para una temática concreta. Lecturas y visiones enfrentadas se ven aquí expuestas las unas a las otras, llegando a consensos en algunas cuestiones, quedando debates abiertos en otras. Juegan un importante papel en esta fase-aunque diverso en cuanto a

Esquema 2.1. Esquema conceptual de la generación de contradicciones en procesos de gobernanza urbana. Elaboración propia. 
su fuerza y el tipo de contribución (Jessop, 2017:237)- muy diferentes agentes; desde la sociedad civil organizada o la sociedad anónima -con muy diversos intereses e ideologías-, la empresa privada -con posturas e intereses que pueden ser opuestos, desde visiones desreguladoras a actitudes solidarias del tercer y cuarto sector-, pasando por otro tipo agrupaciones, colectivos y asociaciones, hasta el mundo académico o, por supuesto, las propias instituciones. Es lo que aquí se ha definido como Contenido:

«Las luchas por el reconocimiento, el respeto, la auténtica igualdad ante la ley, los derechos ciudadanos, las libertades culturales y religiosas, las representaciones políticas adecuadas, las oportunidades educativas y el acceso al empleo, o incluso sobre el derecho a la pereza. Muchas de esas luchas son colectivamente emprendidas por sectores particulares de la población que tratan de enderezar las cosas u obtener ventajas según el caso (por ejemplo mujeres, grupos LGBT, minorías raciales, étnicas o religiosas, ciudadanos de la tercera edad, sindicatos, cámaras de comercio, por no hablar de las instituciones sociales y políticas que tratan de defender los intereses de los trabajadores). El flujo y reflujo de esas luchas sociales da lugar a diversos resultados» (Harvey, 2014: 168).

La segunda fase sería aquella en la que todo ese conocimiento, bajo una hipotética situación ideal, es incorporado al proceso de diseño de un amplio abanico de herramientas llevado a cabo desde determinados espacios y por agentes concretos -teóricamente en representación del interés general-, y puestas a disposición de la sociedad para alcanzar las metas definidas. Es este el espacio de las leyes, ordenanzas, y demás artefactos normativos, así como de planes de ordenación, planes estratégicos, o planes de acción. También es el momento de la puesta en marcha de programas, públicos o privados, o en definitiva de cualquier tipo de iniciativa que busque la aplicación directa de ese contenido inicial. Se ha venido a llamar a esta segunda fase la de los Instrumentos, y es la que sirve como marco de actuación para la gestión, la planificación, la intervención o la regulación.

Por último, la tercera y última fase de este planteamiento es la de la aplicación y puesta en práctica propiamente dicha de ese conocimiento a través de esas herramientas. Es en última instancia el nivel real de consecución, con mayor o menor éxito, de las metas originalmente establecidas; el resultado definitivo y último logrado por la puesta en práctica de los instrumentos para llevar a cabo actuaciones en base al contenido definido. Se la ha definido como la fase de Ejecución. Esta a priori se formaliza y queda reflejada, cerrando el círculo, en una nueva versión de la situación problemática identificada en un inicio, y que ha generado todo este proceso de gobernanza como respuesta. Dicha problemática se verá alterada, regulada, intervenida y corregida en mayor o menor medida en función precisamente del nivel de éxito de estas tres fases, 
especialmente la de ejecución. Lo cual a su vez iniciaría un nuevo ciclo de definición de necesidades, adaptación de instrumentos, y ejecución de los mismos.

Aparentemente, este planteamiento de fases puede parecer que encaja, en cierta medida, con otros planteamientos existentes que han buscado conceptualizar la respuesta que la sociedad da a sus necesidades de gobernanza. Como es el caso de los tres órdenes de gobernanza que algunos autores han propuesto como necesarios, al menos teóricamente, para abordar este concepto (Jessop, 2002a, 2002b; Kooiman, 2002): meta, primer y segundo orden. Tal y como lo interpreta Swyngedouw (2005), la meta-gobernanza hace referencia a aquellas instituciones y arreglos donde los 'grandes principios' de la gubernamentalidad, o la capacidad de gobierno desigualmente descentralizado, son definidos; el primer orden de gobernanza consiste en la codificación y la formalización de esos principios; mientras que el segundo orden es el propio de la implementación real de los mismos. Así, según el autor, existe una clara jerarquía entre estos tres órdenes de gobernanza. Los paralelismos son importantes, especialmente entre el denominado Primer Orden de gobernanza y la fase de Instrumentos, y entre el Segundo Orden y la fase de Ejecución. Pero frente a lo anterior, el esquema aquí propuesto plantea algunos matices, entendidos como necesarios debido al enfoque y objetivos de este trabajo.

En primer lugar, la Meta-gobernanza se entiende como el proceso en el que, entre otras cuestiones, las autoridades políticas a diferente nivel proporcionan las reglas de base para la gobernanza, aseguran la compatibilidad de los diferentes mecanismos y regímenes de gobernanza, o asumen la responsabilidad en caso de fallos de gobernanza (Jessop, 1997:575). Pero la transversalidad de las contradicciones que aquí se busca aclarar hace que, en este caso, la fase del Contenido se plantee abierta a todos aquellos agentes que aportan conocimiento, y no solo a las autoridades políticas. Es decir, si bien igualmente se entiende como aquel proceso en el que se definen esos 'grandes principios', quedan fuera del mismo el resto de aspectos de control y regulación sobre la gobernanza -ya que el interés no se centra tanto en la naturaleza y formas de la gobernanza en sí, como en la generación de contradicciones dentro de la misma-. En segundo lugar, la jerarquía existente entre los órdenes deja paso aquí a una mirada que estudia la jerarquía, no solo entre las tres fases, si no también a la existente dentro de las mismas -como apunta brevemente Swyngedouw (2005: 2001). Ya que no solo el papel de cada agente en la trayectoria de esos principios a lo largo de los órdenes o fases hasta su implementación final es desigual, si no que también tanto su capacidad y voz para establecer los grandes principios, su papel e influencia en el diseño de los instrumentos, como su libertad a la hora de ejecutarlos o de defenderse ante los mismos, es muy desigual. Con todo, en ambos casos puede decirse que se trata de un esquema que puede, y de hecho opera, en todas las 
Tabla 2.1. Síntesis de las dos aproximaciones analíticas a la gobernanza señaladas. Elaboración propia a partir de obras citadas. escalas espaciales (Swyngedouw, 2005). Se trata, en definitiva, de dos planteamientos similares que comparten determinados conceptos y algunas de las relaciones entre estos. Pero con una cuestión clave que les diferencia: sus fines analíticos diferentes (Tabla 2.1).

\begin{tabular}{|c|c|c|}
\hline & Órdenes de gobernanza & Fases de gobernanza \\
\hline Fuente & $\begin{array}{l}\text { Jessop }(1997,2002 a, 200 b) \text {, } \\
\text { Kooiman }(2002) \text { y } \\
\text { Swyngedouw (2005) }\end{array}$ & Elaboración propia \\
\hline \multirow{3}{*}{$\begin{array}{l}\text { Procesos de } \\
\text { gobernanza }\end{array}$} & $\begin{array}{l}\text { Meta-gobernanza: } \\
\text { control de la gobernanza } \\
\text { por parte de las autoridades } \\
\text { políticas (establecimiento } \\
\text { de reglas y principios, } \\
\text { compatibilidad de } \\
\text { mecanismos, respuesta ante } \\
\text { fallos,...). }\end{array}$ & $\begin{array}{l}\text { Contenido: desarrollo de } \\
\text { debates, establecimiento de } \\
\text { prioridades, definición de } \\
\text { metas ante una situación } \\
\text { problemática identificada. }\end{array}$ \\
\hline & $\begin{array}{l}\text { Primer orden: } \\
\text { codificación y } \\
\text { formalización de los } \\
\text { principios establecidos. }\end{array}$ & $\begin{array}{l}\text { Instrumentos: diseño y } \\
\text { desarrollo de herramientas } \\
\text { para alcanzar esas metas. }\end{array}$ \\
\hline & $\begin{array}{l}\text { Segundo orden: } \\
\text { implementación final de } \\
\text { principios, planes, } \\
\text { programas. }\end{array}$ & $\begin{array}{l}\text { Ejecución: aplicación y } \\
\text { puesta en práctica de } \\
\text { instrumentos. }\end{array}$ \\
\hline Jerarquías & Entre órdenes & Entre y dentro de fases \\
\hline Escalas & \multicolumn{2}{|c|}{ A todas las escalas } \\
\hline Fin analítico & $\begin{array}{l}\text { Estudio de la naturaleza, } \\
\text { los cambios y la evolución } \\
\text { de los procesos de } \\
\text { gobernanza y los nuevos } \\
\text { espacios de gobernanza. }\end{array}$ & $\begin{array}{l}\text { Identificación y } \\
\text { comprensión de la } \\
\text { generación de } \\
\text { contradicciones en } \\
\text { procesos de gobernanza } \\
\text { urbana. }\end{array}$ \\
\hline
\end{tabular}

Otra de las diferencias relevantes respecto a la idea de órdenes, y fundamental en el caso de la herramienta de esta investigación, es el siguiente elemento del Esquema 2.1. Ya que este supuesto sintetizado hasta aquí de una manera abstracta y simplificada, se ve sin embargo profundamente enfrentado y afectado por una serie de limitaciones y fuerzas, internas de la sociedad, que atienden «a la que es quizá la contradicción más importante: la que se da entre realidad y apariencia en el mundo en que vivimos», y que animan a «reconocer la posibilidad general de que a menudo atendamos a los síntomas más que a las causas subyacentes y de tener que desenmascarar lo que sucede verdaderamente bajo múltiples capas de apariencias superficiales a menudo engañosas» (Harvey, 2014: 20). La 
complejidad de los sistemas sociales contemporáneos hace inevitable la existencia de poderosas y complejas afecciones sobre estas tres fases de gobernanza definidas $y$, en última instancia, sobre la capacidad que el conjunto de agentes institucionales y extrainstitucionales tiene de dominar la formación social (Jessop, 2017: 140). Es aquí donde entra en juego en el esquema la señalada transversalidad de las contradicciones, sobre la que se pretende poner el foco de análisis. Ya que, lejos de tratarse de afecciones externas generadas por agentes y fuerzas ajenos a esas tres fases idealmente planteadas, son en realidad otras facetas internas de un sistema de organización social complejo y contradictorio. Jessop trabaja sobre esta cuestión, como ya se ha señalado antes (2017: 147), y puede ampliarse ahora al recordar que «diversos agentes con diversos intereses compiten para promover estrategias de acumulación competitiva que puedan reconciliar, de maneras diferentes, potencialmente contradictorias y conflictivas la tensión entre $[\ldots]$ una "voluntad general" integradora y la prosecución de intereses particulares que podrían culminar en una inconsistente "voluntad de todos"» (Jessop, 2017: 168).

Se trata, por lo tanto, de una serie de dificultades, a veces imprevistos, que pueden llegar a impedir una correcta definición de metas, generar carencias en el diseño de instrumentos, o dificultar la puesta en práctica de la que estos podrían ser capaces de desarrollar en condiciones óptimas. Un punto en el que confluyen -desde distintos orígenes, pero dentro de ese espacio social que es instrumento, objeto y promotor de gobernanza por la que se ve a su vez afectado- múltiples y poderosos intereses y límites. Se pueden encontrar aquí desde lógicas profundamente establecidas en la sociedad y actuando en sentido contrario a los objetivos marcados en el contenido, a carencias culturales o una cierta obsolescencia normativa fruto de una mala gestión pública, entre otras cuestiones. Todo ello se ha identificado y definido como una serie de Condicionantes y Obstáculos que afectan a las tres fases anteriores, que favorecen por tanto la ejecución parcial y limitada de las metas, y alimentan -si no originan- la situación problemática inicial. Se trata por tanto de una contradicción elemental, entendiendo esta como la convivencia de «dos fuerzas aparentemente opuestas simultáneamente presentes en una situación, una entidad, un proceso o un acontecimiento determinado» (Harvey, 2014: 17). Así, el anterior supuesto circular en el que, sucesivamente, la Ejecución corregía la situación problemática inicial para iniciar un nuevo ciclo de gobernanza, se ve distorsionado y complejizado por una serie de conflictos. Estos generan determinadas contradicciones internas, y pueden llevar a que esa corrección no solo se retrase o se alargue, si no incluso que no se dé, haciendo que la problemática inicial se extienda, crezca y/o evolucione. El capitalismo, «en su conjunto, está plagado de tales conflictos y enfrentamientos» (Harvey, 2014: 169). 


\section{Reflexiones previas a su aplicación}

Antes de su aplicación sobre un caso concreto, es posible obtener alguna lectura de interés y, paralelamente, una primera validez teórica de la herramienta. Esta ofrece un interesante marco conceptual para una mejor comprensión del carácter estructural y transversal de ciertos conflictos propios de las sociedades urbanas y/o urbanizadas. Por un lado, una de las cuestiones que hacen interesante el plantear esta problemática como fruto de una serie de contradicciones, es que se evita una lectura simplista que reduzca el conflicto a la existencia de dos posturas opuestas, impermeables y desigualmente empoderadas actuando, en este caso, a favor y en contra del acceso a la vivienda. Como se viene insistiendo, la complejidad socio-espacial supera con creces tal planteamiento, a pesar de que haya agentes concretos colocados prácticamente en alguno de esos extremos. Por lo que, más allá de la propia naturaleza contradictoria del sistema, en muchos casos la herramienta planteada ayudará a identificar contradicciones dentro de un mismo agente, al permitir situarlo en diferentes elementos del esquema de manera simultánea. Esta propuesta de conceptualización de la generación de contradicciones pretende señalar -y comprender los fenómenos que están detrás- que de manera frecuente hay agentes grandes y pequeños, poderosos y modestos, con diversas ideologías, que defienden y/o acometen acciones - por supuesto con muy diversa naturaleza, intensidad y motivación- con efectos y sentidos contradictorios en torno a la consecución del derecho a una vivienda digna. Entender y conocer esta realidad se plantea como fundamental para abordarla con garantías transformadoras.

Por otro lado, si se partiese de un supuesto hipotético en el que no existiesen los condicionantes y obstáculos apuntados -al extraerlos del esquema planteado-, con el tiempo y el afinamiento de las tres fases de respuesta de la sociedad se podría defender que estas tendrían la capacidad de reducir, o incluso eliminar, la situación problemática inicial. Es decir, en un esquema circular, la ejecución iría paulatinamente corrigiendo la problemática, a partir de cuya versión actualizada se generarían nuevas respuestas de gobernanza que producirían a su vez una nueva fase de ejecución, sucesivamente hasta la desaparición del conflicto. Pero el hecho de que esta se mantenga y evolucione en el tiempo puede interpretarse como una primera confirmación de que esas afecciones transversales se dan. Por último, el esquema permite también una interesante lectura sobre dos ejes: el formado por los elementos de las Fases de Gobernanza y los Condicionantes y Obstáculos por un lado, y el formado por la Situación Problemática y las Metas por otro (Esquema 2.2). 


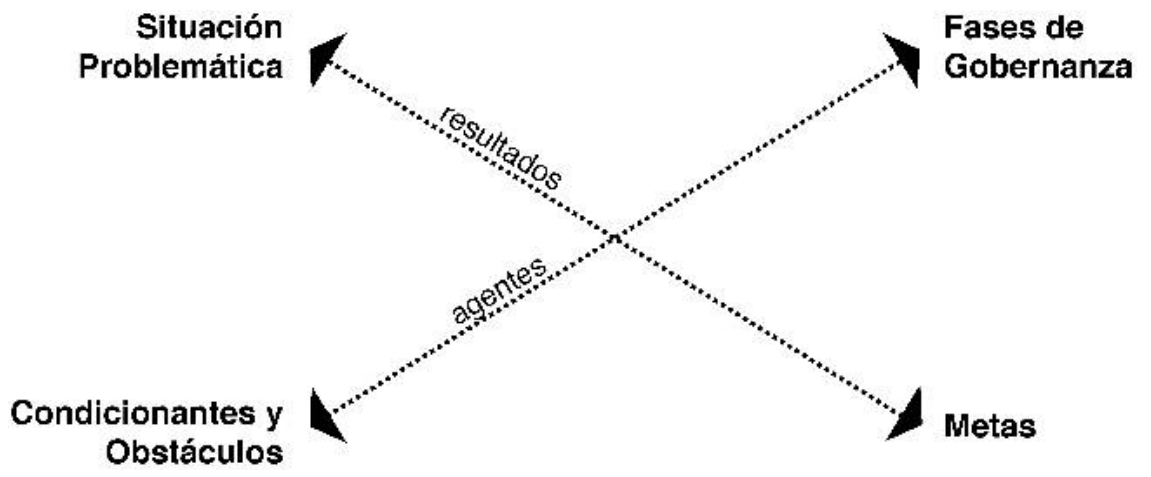

Si de alguna manera fuese posible sintetizar algo tan complejo en un valor, en una escala, en el primer eje se podrían colocar y distribuir los agentes que participan de manera desigual en el proceso, en función de cómo su posicionamiento, pero sobre todo sus acciones, favorecen a la construcción y reproducción de esos condicionantes y al correcto desarrollo de las tres fases de gobernanza. Según lo hasta aquí defendido, es poco probable que ninguno de los agentes se sitúe en los extremos, pues siempre se darán perfiles con combinaciones de equilibrio diverso. En el segundo eje se podría situar el 'resultado final' de ese proceso de gobernanza, en función del éxito alcanzado en la ejecución del mismo. Así, en la medida en que se logren abordar y corregir los condicionantes y obstáculos -es decir, que haya un mayor peso de agentes repartidos hacia el extremo de las fases de gobernanza del esquema-, la situación problemática se vería reducida y por lo tanto el resultado se acercaría en el otro eje hacia las metas. En una situación contraria, con unas fases débiles de gobernanza y/o con un mayor peso de aquellos agentes generadores de condicionantes poderosos y profundamente establecidos, dicho resultado quedaría más cerca de la problemática. Como en el primer eje, en este difícilmente llegará a posicionarse el resultado final en uno de sus extremos; se darán de manera simultánea y cambiante avances y retrocesos, fruto del choque de fuerzas y acciones -en ocasiones internas a los agentes- a favor de un acceso digno a la vivienda frente a movimientos en búsqueda de la acumulación de capital y la generación de plusvalías apoyados en estrategias para usar el parque residencial como objeto de inversión económica.

Las contradicciones quedan así de manera abstracta reflejadas en un esquema que pretende, sobre todo, facilitar la reflexión, la lectura inicial y la aproximación a situaciones de gobernanza. El objetivo no es desarrollar un instrumento cuantitativo que traduzca fenómenos sociales a valores numéricos, si no una herramienta para ayudar a pensar. Pero aún sin llegar a ese ámbito cuantitativo, la herramienta sí permite en esta lectura de dos ejes facilitar el apoyo a la reflexión y el análisis. Tanto al aplicarla sobre un solo agente, si se desea estudiar el nivel de su contradicción interna y analizar su posicionamiento y cómo este afecta al resultado final, como sobre el conjunto del ecosistema de agentes (Figuras 2.1-2.4). En el primer caso, puede
Esquema 2.2. Ejes internos del esquema de generación de contradicciones en procesos de gobernanza urbana propuesto. Elaboración propia.

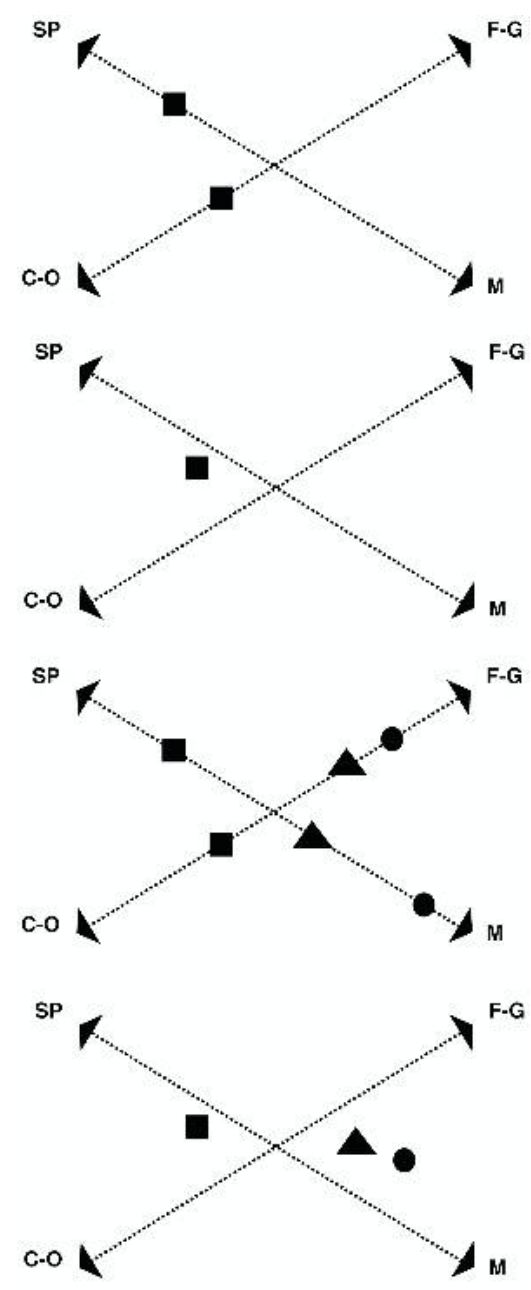

Figuras 2.1 a 2.4. De arriba abajo, situación en el esquema de un agente (dos variables o valor unificado), o de un mapa de agentes (dos variables o valor unificado). Elaboración propia. 
trasladarse el análisis de dos maneras: colocando en cada eje su variable correspondiente, u obteniendo un 'valor' unificado que se situaría en el espacio conformado por el esquema, según el peso de cada eje. En el segundo caso se abren consecuentemente también dos opciones: sintetizar el proceso global bien como una superposición de todas las variables de cada agente en los dos ejes, o bien como superposición de los valores unificados de todos ellos, a modo de nube de valores distribuidos por el espacio del esquema. En cualquier caso, sin dejar de ser una herramienta orientada a la reflexión y la aproximación a situaciones socio-espaciales complejas, esta lectura a partir de ejes relaciona eficazmente el posicionamiento y la acción de los agentes con los resultados obtenidos. Además, puede leerse en sentido contrario: conocido el nivel de desarrollo, la conflictividad o la urgencia de una problemática urbana concreta -los efectos-, se podría anticipar en una primera lectura hacia qué lado y de qué manera se decanta el equilibrio de los agentes participantes en su gobernanza, aún desconociendo su número y naturaleza -las causas-. Es, de hecho, de esta manera como se ha elaborado el presente capítulo: comenzando por una revisión de la problemática, a partir de la cual se han identificado y situado en este esquema teórico e instrumental un amplio ejemplo de los agentes y fuerzas que lo conforman, lo que ha llevado a detectar las causas de fondo que alimentan y que son parte de esa unidad contradictoria final. La naturaleza contradictoria del contexto no hace infructuoso combatir el mismo, ni debe llevar a perder toda esperanza de alcanzar logros; pero sí parece que hace imprescindible y fundamental, para tener cierta garantía de éxito, abordar esos condicionantes y obstáculos internos del propio proceso de gobernanza, y no solo los efectos. Un éxito que tendrá siempre el peligro de ser relativo, pues la mitigación de los conflictos no siempre supondrá su desaparición: estos pueden haber sido desplazados a otro lugar en el tiempo y/o en el espacio (Harvey, 2014: 149-164; Jessop, 2017: 101).

Para una segunda validez de esta herramienta aquí propuesta, esta vez empírica, ha sido necesario aplicarla sobre una realidad concreta. Para ello, se ha tomado como caso de estudio el Área Metropolitana de Bilbao. Esto ha permitido comprobar el carácter estructural de los conflictos señalados en la vivienda en España en general, y en la región en particular, así como contextualizarlos en unas contradicciones sistémicas concretas, e identificar algunas alternativas en marcha $-\mathrm{y}$ potenciales- para frenarlos. No se buscan con este estudio respuestas concretas ni proponer soluciones específicas. El objetivo final, además de dar por válida la herramienta para ser utilizada sobre otros retos urbanos, es la aplicación de este esquema sobre un caso real que permita identificar y comprender determinados fenómenos -existentes y potenciales- en torno a la gestión de la vivienda. De las características de las relaciones, posiciones y fuerzas existentes entre los agentes, y del contexto y soporte sobre las que construirlas, dependerá en gran medida la consecución de una vivienda digna y adecuada. En lo que resta de capítulo, además de 
Contradicciones, efectos y respuestas en procesos de gobernanza urbana

presentar brevemente el ámbito geográfico elegido para el desarrollo del trabajo, se buscará desarrollar y demostrar esta construcción teórica a partir de la aplicación local de la misma. 


\section{E1 Área Metropolitana de Bilbao como ámbito}

La selección y delimitación, con mayor o menor nivel de concreción, del espacio físico y social sobre el que desarrollar una investigación dentro de los estudios urbanos es tanto necesaria como indeseada. Las señaladas y cambiantes interconexiones $e$ interdependencias entre escalas y fuerzas geográficas desigualmente distribuidas parecen exigir una delimitación difusa, cambiante y flexible de los ámbitos sobre los que trabajar. Por otro lado, la intención de realizar un trabajo empírico como el propuesto conlleva la decisión de acotar un ámbito concreto, que choca con esa compleja red de relaciones. Existe por lo tanto un conflicto previo e implícito al diseño metodológico de la investigación: la selección -en primer lugar- y la acotación geográfica -en segundo- de ese ámbito espacial a investigar. El Área Metropolitana de Bilbao es el marco geográfico seleccionado para el desarrollo de este trabajo; tanto de cara a la puesta a prueba de la herramienta de análisis de la generación de contradicciones en procesos de gobernanza urbana, como de cara a la identificación de dichas contradicciones y de las alternativas surgidas de las mismas, así como el estudio de estas últimas.

\section{Justificación de la elección}

Esta decisión viene motivada principalmente por tres razones bien diversas. La primera de ellas es contar con un importante conocimiento previo del territorio que se investiga. Lo cual ha permitido detectar, al menos parcialmente, la situación problemática abordada y por lo tanto puede considerarse el origen del trabajo. El autor ha nacido, crecido y desarrollado gran parte de su trayectoria vital y profesional en el ámbito de estudio. Ello supone, además del aliciente generado por la inquietud personal de aportar conocimiento para la mejora del funcionamiento de esta región, un importante bagaje construido a lo largo de años de observación y trabajo en el área. Así mismo, no de menor importancia es que ello añade un interesante ahorro de tiempo y esfuerzo en labores logísticas, como la obtención de información, o la identificación y localización de agentes y lugares. Por supuesto, se trata de un conocimiento limitado y con 
mucho por aprender, pero indudablemente ha aportado una valiosa base sobre la cual iniciar la investigación.

La segunda razón es la relevancia que, en diferentes ámbitos socioespaciales, tiene el ámbito en cuestión desde una perspectiva tanto autonómica y nacional como, en menor medida, europea. A pesar de ser un área pequeña si se compara con otras grandes metrópolis globales, las características demográficas, su papel económico y productivo, su evolución histórica, o su encaje en una serie de fenómenos urbanos globales, entre otras cuestiones, hacen del AMB una región metropolitana que puede generar interés más allá de sus límites y que justifican el desarrollo de la investigación. El contexto geográfico y administrativo de este área es la Comunidad Autónoma de Euskadi, una de las diecisiete comunidades autónomas que conforman el estado de España, y que está formada por tres provincias: Araba, Bizkaia y Gipuzkoa. Esta comunidad se encuentra en la zona norte de la Península Ibérica, en la costa atlántica de Europa, y su litoral da al Mar Cantábrico, en el Golfo de Vizcaya. El ámbito de estudio en el que se desarrolla la presente tesis doctoral es el área metropolitana formada por una serie de municipios situados en torno a Bilbao, capital de la provincia de Bizkaia. También es conocida como el Gran Bilbao o Gran Bilbao Metropolitano. Es la principal aglomeración urbana de Euskadi morfológica, económica y demográficamente hablando $-\mathrm{y}$ una de las principales españolas- $\mathrm{y}$ cuenta con una población que, en función la manera de delimitar el área, ronda el millón de habitantes. Abarca una extensión de más de 39.000 hectáreas alcanzando en la costa la desembocadura de los ríos Nervión e Ibaizabal en la denominada Abra de Bilbao (Mapas $2.1 \mathrm{y}$ 2.2).

La tercera razón fundamental para tomar esta región como ámbito de trabajo es la intención de revertir el apoyo económico recibido por el Gobierno Vasco para el desarrollo de la presente investigación. Se ha pretendido así orientar el proceso formativo del doctorado al desarrollo de conocimiento sobre el propio territorio de la comunidad autónoma de Euskadi en general, y del AMB en particular. Por supuesto, sin cerrar la puerta a que el trabajo pueda enriquecer también situaciones similares de otras áreas urbanas. Se pretende también de esta manera poner en valor y señalar la urgencia de mantener y extender este tipo de iniciativas para la investigación académica, bajo cuyo Programa de Formación de Personal Investigador No Doctor se ha realizado una parte sustancial de este trabajo. Especialmente, cuando se trata de un campo no tecnológico -siendo habitualmente el que recibe una mayor atención de iniciativas y ayudas públicas, y medios de comunicación-, y más cercano a una visión de la planificación espacial como ciencia social -posición con frecuencia olvidada y desplazada por visiones más tecnocráticas e instrumentales de la ordenación de la ciudad y el territorio-.

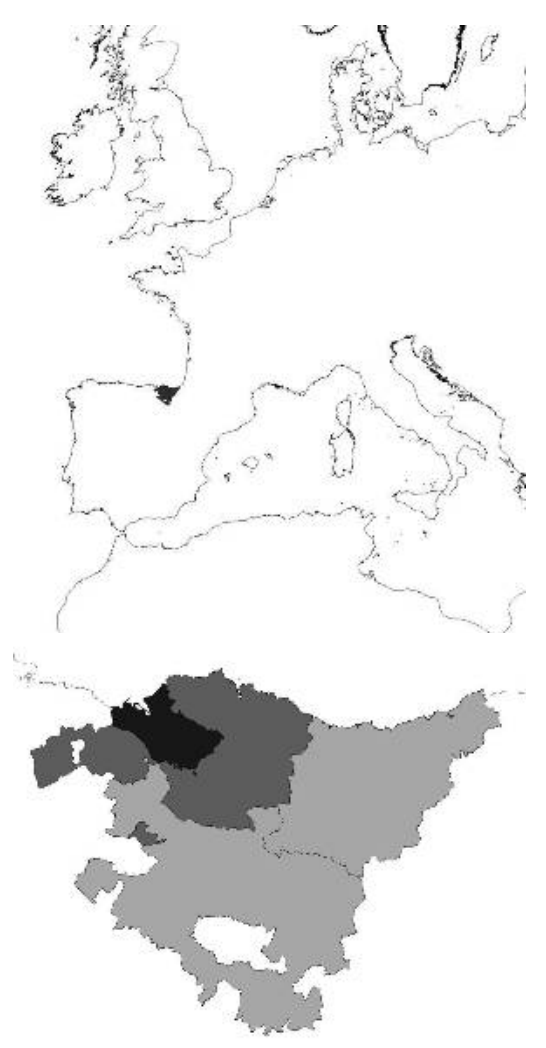

Mapas 2.1 y 2.2. Localización del Área Metropolitana de Bilbao en Europa, España, Euskadi y Bizkaia. Elaboración propia a partir de GeoEuskadi.

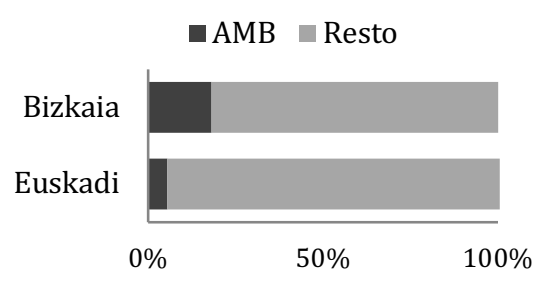

Gráfica 2.1. Superficie de suelo del AMB respecto del total de Euskadi y Bizkaia. Gobierno Vasco, 2016.

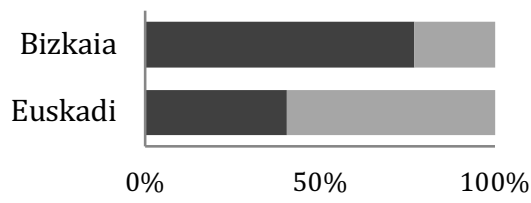

Gráfica 2.2. Población del AMB respecto del total de Euskadi y Bizkaia. Padrón Municipal, 2015. 
$\square$ AMB $\square$ Resto

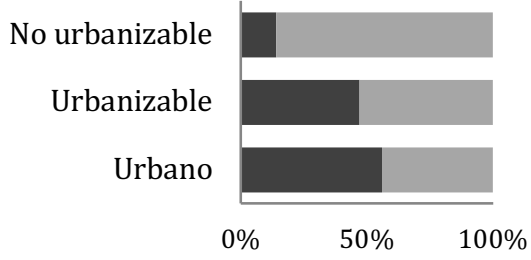

Gráfica 2.3. Superficie de suelo del AMB respecto del total de Bizkaia, según su clasificación urbanística. Gobierno Vasco, 2014.

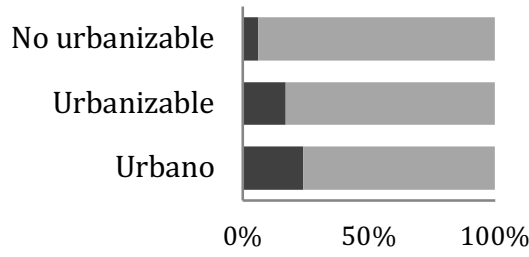

Gráfica 2.4. Superficie de suelo del AMB respecto del total de Euskadi, según su clasificación urbanística. Gobierno Vasco, 2014.

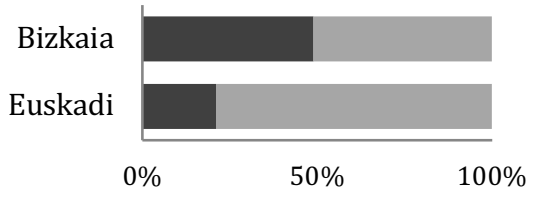

Gráfica 2.5. Superficie de suelo artificializado del AMB respecto del total de Euskadi y Bizkaia. GeoEuskadi, 2014.

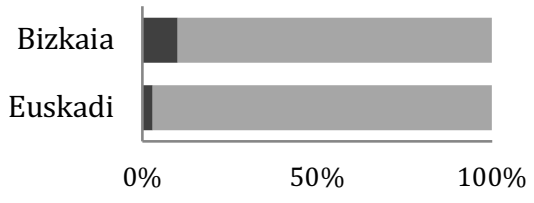

Gráfica 2.6. Superficie de suelo no artificializado del AMB respecto del total de Euskadi y Bizkaia. GeoEuskadi, 2014.

\section{Un territorio denso y urbanizado}

La segunda razón que llevaba a elegir esta región como ámbito espacial donde analizar el objeto de estudio propiamente dicho apuntaba a su relevancia y peso como conglomerado urbano supramunicipal. Efectivamente, la de Bilbao es un área metropolitana con un peso relevante en diferentes escalas de administración política del territorio -en mayor o menor medida, pero destacable a su manera en cada una de ellas-. A escala provincial es donde ejerce una influencia más obvia y directa, pues se trata de la principal y mayor concentración urbana de la provincia de Bizkaia, que incluye además su capital, Bilbao. Desde un punto de vista demográfico, a pesar de que sus más de 39.000 hectáreas de suelo suponen el 18\% de la superficie de Bizkaia (Gráfica 2.1), en el Área Metropolitana de Bilbao residen alrededor de 878.000 habitantes, un $77 \%$ de la población bizkaina (Gráfica 2.2). A escala autonómica, esta región destaca claramente sobre el resto de comarcas de Euskadi, habiendo solo otras dos que superan los cien mil habitantes -las que incluyen a las otras dos capitales de provincia-: el Área Funcional de Donostia-San Sebastián con más de 400.000 y la correspondiente a Álava Central que supera los 275.000 (Gobierno Vasco, 2016d). Ambas muy por debajo de la población del AMB. Así, esta ronda el 5,5\% de la superficie total de Euskadi y alberga al $40,4 \%$ de su población (Gráficas 2.1 y 2.2).

En cuanto a las características de su territorio desde una perspectiva urbanística, en concreto desde la clasificación global del suelo, los datos arrojan si cabe más luz sobre la idea de que se trata de la principal aglomeración urbana de la provincia y de la comunidad autónoma. El suelo clasificado como urbano en el AMB a fecha de diciembre de 2014 -datos de Udalplan-suponía más de la mitad del suelo urbano de Bizkaia (Gráfica 2.3) y casi un cuarto del de Euskadi (Gráfica 2.4). El urbanizable alcanzaba un $47 \%$ de su clase en la primera y un $16,5 \%$ en la segunda. Sin embargo, en el suelo no urbanizable se invertían las proporciones, mostrando que se trata de un territorio fuertemente urbanizado si se compara con su contexto más próximo: este no llegaba al 14\% del suelo no urbanizable total de Bizkaia y apenas superaba el 5\% del de Euskadi. En este sentido, los datos con misma fecha de consulta sobre la cobertura del suelo disponibles en la Infraestructura de Datos Espaciales de Euskadi (GeoEuskadi), en concreto sobre la artificialización del mismo, lo confirmaban: prácticamente un $50 \%$ del suelo artificializado de Bizkaia se encontraba en el Área Metropolitana de Bilbao -lo que representaba un 21\% del de Euskadi- (Gráfica 2.5) y, sin embargo, el no artificializado suponía un 10\% del mismo en la provincia y un 3\% en la comunidad autónoma (Gráfica 2.6).

Se presentan tres mapas para apoyar este primer acercamiento morfológico a la complejidad y relevancia del área en general, y de sus usos urbanos en particular. En el primero de ellos, se puede apreciar la complicada orografía de una región formada por una red de valles y 

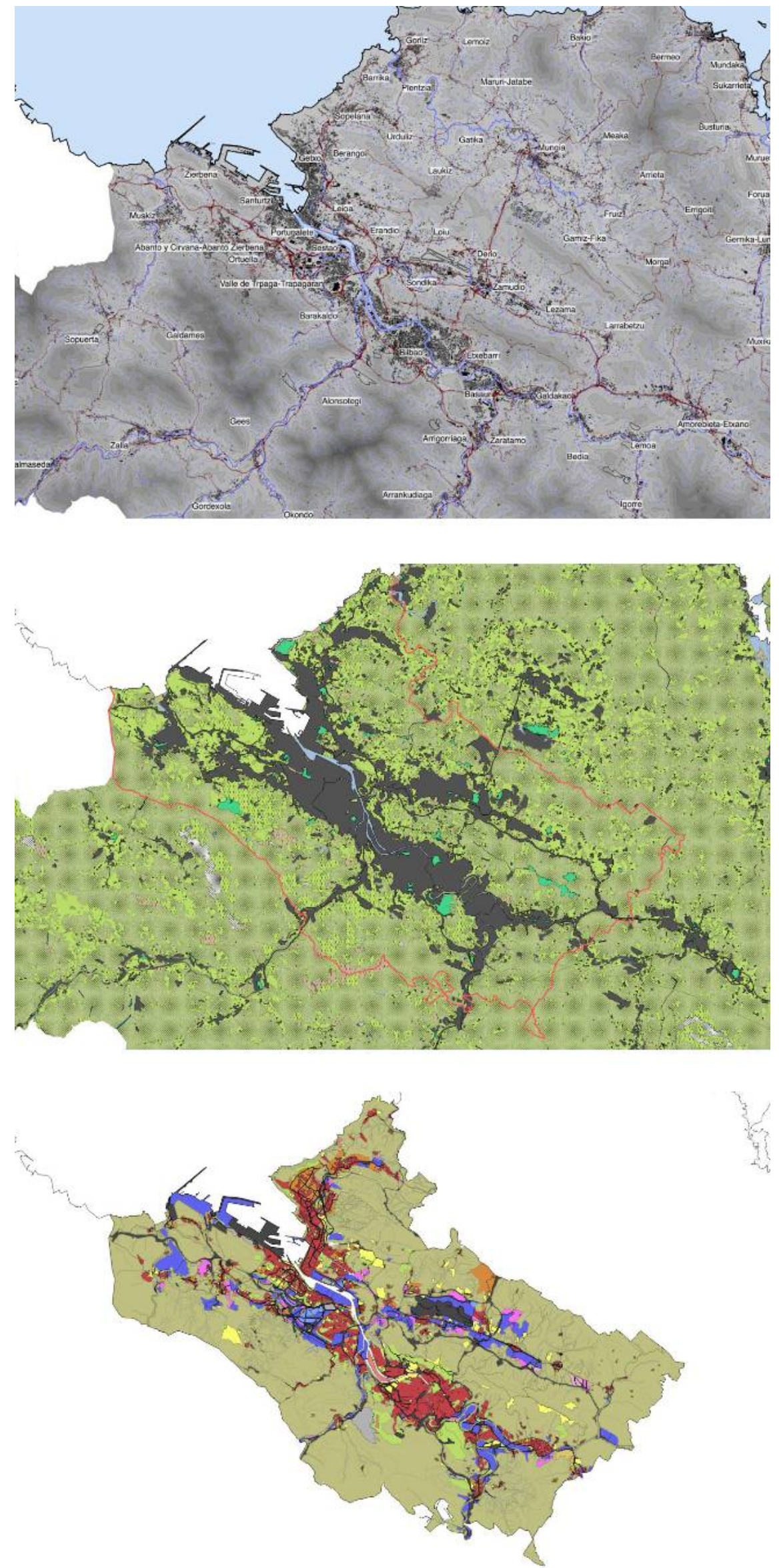

Mapa 2.3. El área metropolitana de Bilbao y su entorno inmediato. Elaboración propia a partir de GeoEuskadi, 2016.

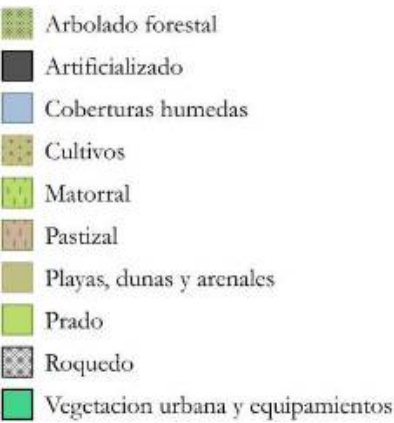

Mapa 2.4. Cobertura de los usos del suelo en el Área Metropolitana de Bilbao. Elaboración propia a partir de GeoEuskadi, 2016.

\footnotetext{
Suelo no urbanizable

Suelo no urbanizable SS. GG. Equipamientos

Infraestructura basica

Espacios libres

Residencial

Urbano consolidado

Urbano no consolidado

Urbanizable

Urbanizable no sectorizado

No urbanizable núcleos rurales Industrial

Urbano consolidado

Urbano no consolidado

Urbanizable

Urbanizable no sectorizado

No urbanizable
}

Mapa 2.5. Clasificación urbanística de los usos del suelo en el Área Metropolitana de Bilbao. Elaboración propia a partir de GeoEuskadi, 2016. 
pequeños montes, que históricamente ha estructurado sus usos y crecimientos urbanos, su distribución socio-demográfica y el desarrollo de infraestructuras (Mapa 2.3). El segundo, relativo a la cobertura de los usos del suelo, permite observar el enorme peso de los suelos artificializados -más de un tercio del suelo total-, y cómo han ocupado casi en su totalidad los espacios de ribera y zonas llanas o de baja pendiente de la región (Mapa 2.4). Y por último un tercero, el de la clasificación urbanística del suelo, donde puede apreciarse la importante presencia de los suelos con un uso característico residencial, y cómo estos en determinadas áreas de la región conviven en diversos (des)equilibrios con los destinados a la industria y a diversas actividades económicas de naturaleza, ocupando en muchos casos espacios de enorme centralidad y reflejando la relación entre la desigual distribución de usos, rentas y clases sociales (Mapa 2.5).

Según los datos recogidos es dichos mapas, un 16,31\% del territorio está clasificado como suelo urbano $-10 \%$ residencial y $6 \%$ de actividades económicas-, y un 3,26\% urbanizable $-1,97 \%$ y $1,29 \%$ respectivamente-. Los suelos no urbanizables suman el $75 \%$ de la superficie total -dentro de los cuales más de un $6 \%$ son sistemas generales, con una importante presencia de grandes infraestructuras como el puerto comercial, el aeropuerto, o vías de comunicación férrea y rodada, entre otras- y se caracterizan por estar en un nivel alto de transformación y afección por parte de los usos tradicionalmente entendidos como urbanos, además de contar con zonas de altas pendientes y desniveles. El resto de suelos lo conforman los equipamientos $-2,89 \%$, los espacios libres $-4,21 \%-y$ las infraestructuras básicas $-0,88 \%$ - La densidad total de habitantes es de unos 22 por hectárea, mientras que las expectativas de edificabilidad de superficie de techo construida es de unas 653 hectáreas de uso residencial y 484 de actividades económicas. Se trata, por tanto, de una región claramente urbana, con una importante masa de población, un territorio complejo y una serie de interesantes $-\mathrm{y}$ urgentes- retos. Algunos de los cuales se desarrollan más adelante.

\section{Un modelo ¿exitoso? de regeneración y reconversión}

A escala estatal y europea, sin entrar a evaluar el peso de este área dentro del sistema de ciudades y regiones españolas y frente a ciudades, regiones y países europeos, es desde luego un lugar de importancia e interés en diversos aspectos. Más allá de su masa demográfica, Bilbao y su entorno han tenido desde los inicios de la industrialización en España un papel singular con un desarrollo a la cabeza del estado. No en vano, fue el origen y desarrollo de uno de los principales puntos de la industria del metal en el Estado, con una fuerte conexión directa -vía marítima- con el proceso de industrialización inglés. Las evoluciones de esta economía fueron generando un tejido industrial fortísimo que aún hoy perdura, a su manera. Esto, sumado a la naturaleza comercial que ya tenía esta zona gracias a su puerto marítimo y su ría navegable, y al desarrollo de 
otras industrias generó, más allá de un fuerte impacto en el crecimiento económico, fuertes oleadas de inmigración y un rápido crecimiento urbano (García, 1987; Labayru, 1970; Ugarte, 1999; Ybarra, 2002). Así, la capital de provincia y sus municipios próximos pasaron de tener, según los datos del Instituto Nacional de Estadística (INE), 53.755 habitantes censados en 1857, a ser un área urbana continua con 411.375 habitantes en 1950, y 893.655 en 2011. Todo lo cual generó un enorme impacto en la conformación del carácter y la condición urbana de la región, tanto por la desigual localización, preocupación y empeño puesto en el desarrollo de los usos principales -extracción de recursos, producción, transporte y vivienda- como por la calidad y cantidad de dichos crecimientos.

La metrópolis creció priorizando los mejores y más accesibles suelos para usos industriales y para la residencia de las clases sociales que se habían ido situando en posiciones de poder a lo largo de este proceso socio-económico, encajando los residenciales de la masa trabajadora entre los accidentes orográficos de la región y el propio tejido industrial (González, 2001). De esta manera, «tan sólo el mercado laboral fue capaz de absorber sin mayores problemas la llegada masiva de mano de obra. El espacio urbano y el tejido social sufrieron una alteración de una dimensión descomunal [...] el nuevo Bilbao de finales del siglo XX, a pesar de la espectacularidad de sus realizaciones arquitectónicas presenta aún importantes focos de deterioro urbanístico y evidentes bolsas de marginación, algunas de las cuales -como en el caso de Sestao- giran en torno a los antiguos pueblos industriales» (Pérez, 2002). Este fenómeno se ha sintetizado también en la Memoria del Plan Territorial Parcial del Bilbao Metropolitano, del que se reproduce a continuación un extracto:

«El modelo actual de implantación de actividades económicas en el Bilbao Metropolitano es un modelo cronológico, en el que las diferentes tipologías productivas y terciarias fueron ocupando los espacios que iban dejando vacantes las precedentes. Es un modelo en el que los primeros que llegaron se hicieron con los mejores suelos y los que han llegado después han debido adecuarse a lo que quedaba libre.

La primera industria que se implantó desde mediados del siglo XIX fue una industria productiva de grandes factorías gran consumidora de suelo- surgida a partir de la introducción de los últimos descubrimientos técnicos en la siderurgia tradicional y la consiguiente explotación masiva del mineral de hierro de Somorrostro. A ella pronto se le unió una pujante industria naval. Por sus propias necesidades estas actividades ocuparon las vegas fluviales y fueron dotando a toda la ría de una intensidad fabril que situó al País Vasco a la cabeza del Estado, diversificando el modelo económico con otras actividades como el transporte marítimo, las industrias eléctricas, industria química, etc. 
Bilbao, como capital del área, vio surgir una intensa actividad de servicios vinculada a estos activos industriales. Bancos, compañías de seguros, sociedades de inversión fueron desplegando sus oficinas por el ensanche bilbaino, convirtiendo a la ciudad en un centro financiero de primer orden. Las diferentes oleadas industrializadoras colmataron los espacios de la Ría y demandaron nuevos suelos, ocupando la segunda línea primero y las vegas de los valles adyacentes después. El crecimiento industrial a lo largo de las márgenes de la Ría, de Basauri a Portugalete, atrajo a una abundante mano de obra y aceleró el proceso de urbanización, no siempre en las condiciones higiénicas adecuadas. Acosados por la actividad que los circundaba, estos núcleos ocuparon los suelos despreciados por la industria y crecieron de manera simple, indiferenciada y funcional, intentando cerrarse al entorno omnipresentemente industrial de la Ría. El nuevo impulso industrializador del desarrollismo estatal de los años 50 y 60 del siglo XX encontró los bordes fluviales colmatados y hubo de buscar nuevas áreas en los valles del Txorierri y el Ballonti» (Decreto 179/2006, de 26 de septiembre, Anexo I-Memoria, 2006: 81).

El omnipresente sector de la industria minera y sus derivados, así como sus evoluciones posteriores, crecieron, se desarrollaron, prosperaron y posteriormente, con especial relevancia en el último cuarto del siglo XX, perdieron peso en el marco de una transformación de la economía global apoyada en cambios sustanciales de los diversos puntos de producción y reproducción locales. Esta crisis, declive y debilitamiento de la base productiva de la región principalmente viene siendo explicada por «el impacto de la crisis Fordista y las dificultades de adaptación a las nuevas condiciones de la competencia globalizada» (Rodríguez, 2002: 73), así como por «la entrada de España en la CEE en 1986 [que] supuso el desarme arancelario» (Decreto 179/2006, de 26 de septiembre, Anexo I-Memoria, 2006: 82). A la desaparición de mucha de la industria afectada por este cambio, se sumaba la ya existente evolución del puerto comercial. En su origen localizado en el municipio de Bilbao aguas arriba de la ría del Nervión, fue -a medida que se expandía el volumen de transacciones comerciales- fue ampliándose y llevándose hacia la desembocadura en la costa a través de consecutivas operaciones de ampliación. El principal hito de este proceso se dio a través del desarrollo del puerto exterior del Abra de Bilbao, que hoy en día sigue en expansión. Este puerto es a día de hoy uno de los puntos de acceso y logística de la ruta atlántica comercial para acceder al mercado europeo. Además de las correspondientes actividades propias de dicho carácter comercial, alberga otros usos y grandes infraestructuras relacionadas con la generación y gestión de la energía. Con todo, aún se siguen manteniendo ciertas funciones portuarias activas a lo largo de la ría prácticamente hasta la propia capital, y esto 
ha ido dejando una impronta morfológica y simbólica en muchos espacios a lo largo de la región. Así, Ambos fenómenos dejaron a su paso suelos sobre los que realizar importantes operaciones de transformación y regeneración urbana.

Hoy en día, el sector terciario ocupa gran parte de la actividad económica del ámbito de estudio y los centros industriales dejan paso a centros de servicios. El Área Metropolitana de Bilbao, tanto desde la empresa privada como desde las instituciones, apuesta por el desarrollo y crecimiento de dicho sector con la proclama y bajo la bandera de la competitividad urbana global. Buscando colocar a Bilbao y su entorno en la pelea por la acumulación de inversiones y capital tanto local como extranjero. A medida que ha ido evolucionando en las últimas décadas, también este área urbana como tantas otras- ha sufrido cambios en lo que respecta al turismo nacional y extranjero. Cada vez existen más elementos que ayudan a construir un perfil adecuado para introducirse en un circuito turístico amplio bajo lógicas de mercado, como son la difusión de manera activa de una imagen de ciudad renovada y moderna, el desarrollo de oferta hotelera $-\mathrm{y}$ su deriva en conflictos relativos a los alojamientos turísticos en viviendas privadas-, una oferta cultural en auge, importantes infraestructuras de comunicación, fuertes campañas de captación, o una explotación del entorno existente, como la oferta costera vacacional.

Esa crisis y evolución del modelo productivo convivía además con un parque urbano altamente deteriorado en muchas de sus áreas debido a los crecimientos rápidos y de baja calidad ejecutados. A finales del siglo pasado, diversas políticas y estrategias de regeneración y reconversión urbana fueron tomando forma con diferente resultado. Algunos de sus movimientos y jugadas más espectaculares han alimentado el discurso de un modelo global de regeneración que llegó a categorizarse como de efecto Bilbao. Este modelo de regeneración se ha centrado en tres principales ejes, como son, una clara estrategia de renovación física a través de diferentes figuras de planeamiento urbano y territorial, el desarrollo de grandes operaciones urbanísticas y de infraestructuras «permitiendo la captura de plusvalías y la puesta en valor de suelos funcionalmente obsoletos y degradados», y la «adopción de un modelo de gestión competitiva y emprendedora orientado por la búsqueda de una mayor agilidad, flexibilidad, eficacia y rentabilidad [...] en el que el sector público emula, a través de estas sociedades de gestión urbanística, el funcionamiento del sector privado» (Rodríguez, 2018). Tras un proceso de regeneración iniciado hace tres décadas, este se presenta desde las instituciones como finalizado y consolidado, dando paso a una nueva etapa de reflexión en la que la región «presuntamente, estaría dando los primeros pasos de su particular "revolución del conocimiento", una refundación de su modelo urbano en términos menos urbanísticos y más socioeconómicos y funcionales [...] la nueva visión es hacer de Bilbao "una ciudad donde los sueños se 
hacen realidad" propulsada por los éxitos de la metamorfosis urbanística y su establecimiento como modelo de ciudad» (Rodríguez, 2018).

El modelo se difunde con determinación, a escala local, nacional e internacional, y por instituciones públicas locales y regionales, como una referencia y un ejemplo exitoso; como una batería de buenas prácticas disponibles para otras regiones en proceso de reconversión con orígenes industriales. Las mejoras desarrolladas en estas décadas son muchas, y la transformación de la región, además de ser relativamente rápida, ha permitido una mejora en la calidad de vida de parte de su población. Sin embargo, no todo marcha por la senda del desarrollo económico, la alta calidad urbana y la mejora social. En el $\mathrm{AMB}$ son muchas las áreas urbanas y sectores sociales con una herencia urbana compleja de gestionar, e importantes carencias.

\section{Herencias conflictivas, carencias y desigualdades}

La elección del AMB no es por lo tanto azarosa, más allá de los datos de población, morfología, o densidad mostrados anteriormente. Este sintetizado modelo de regeneración y reconversión urbana, tomado en algunos foros como de referencia (Vegara, 1999; Vidarte, 2007), permite ser cuestionado y desmitificado si se contempla con una mirada crítica y menos sesgada que incorpore variables no relacionadas con cuestiones de rentabilidad económica (Antolín et al., 2010; Rodríguez, 2002; Rodríguez et al., 2001; Swyngedouw et al., 2002; Vicario y Rodríguez, 2005; Zubero, 2012). Una mirada que permite levantar el velo de pretendida naturalidad de un proceso de regeneración que es fundamentalmente político, social y económico (Smith, 2015: 267), y dudar del insistentemente difundido éxito de Bilbao como modelo global. $\mathrm{O}$ al menos, de contraponer a sus éxitos parciales otras muchas realidades en forma de desplazamientos forzados de población, exclusión social, afecciones ambientales, fomento de un modelo de ciudad orientado al consumo y la competitividad con evidentes afecciones globales, o la polarización socio-espacial, bajo un modelo de ciudad neoliberal abierta al capital global.

Las huellas que los dos últimos siglos han dejado en este territorio son tremendas tanto desde el punto de vista físico, como social e identitario -puntos de extracción de materiales, grandes áreas dedicadas a la manipulación y transformación del metal, zonas industriales en estado de abandono y fuerte degradación, grandes expansiones urbanas carentes de planificación debidas a un fuerte crecimiento demográfico, suelos contaminados en localizaciones urbanas clave,...-. Como se mostrará para el caso de la vivienda, las vulnerabilidades y desigualdades sociales existentes son en algunos casos crecientes y tendentes a la polarización. Señalando estas cuestiones no se pretenden negar muchas de la mejoras acometidas en las pasadas décadas. Pero múltiples son los análisis que vienen a 
poner el foco en que la visión parcial y el excesivo interés por actuar en áreas centrales de los procesos de regeneración urbana aplicados en el AMB han dejado de lado y no han favorecido la necesaria mejora de muchas otras áreas o asuntos de la ciudad (Antolín et al., 2010; Vicario y Martínez, 2003).

Los diagnósticos coinciden en que son muchos los retos que quedan por afrontar. Algo que no se ha conseguido solucionar, o más bien no se ha sabido afrontar en su integridad, a pesar de contar con diferentes instrumentos y herramientas de planificación a escala territorial. Como el Plan Estratégico para la Revitalización del Bilbao Metropolitano impulsado desde la Asociación Bilbao Metrópoli-30 presentado en 1992, y que se ha ido complementando con reflexiones periódicas en 1999, 2001, 2005, 2011 y 2016-, o el Plan Territorial Parcial de Bilbao Metropolitano -aprobado en 2006, modificado en 2010 y en actual revisión-. Una reflexiones territoriales que según ciertos analistas «no responde más que a necesidades sectoriales» adoleciendo de unna concepción física clara para Bilbao y su Área Metropolitana en un futuro» (Mas Serra, 2010).

Aún siendo la vivienda el objeto de estudio de este trabajo, se cree imprescindible la contextualización de esta cuestión en un marco que está demostrando la imposibilidad de ser reproducido - por su propia naturaleza e inviabilidad, más allá de haber errado en la estrategia-. Algunas de las grandes operaciones urbanísticas desarrolladas en las últimas décadas hacen necesaria una reflexión sobre los posibles caminos para continuar con la necesaria regeneración de la metrópoli, tal y como evidencia Rodríguez (2002) en un acertado análisis del quizás caso más paradigmático del modelo en el área de Abandoibarra de Bilbao. Esta renovación urbana todavía en marcha con algunos de sus últimos coletazos en fase incipiente -Zorrotzaurre, Punta Zorroza, Bolueta,...- ha dado como resultado un modelo de luces y sombras que es necesario revisar, valorar y corregir si se pretende avanzar hacia una región más cohesionada y equilibrada:

«...oculto tras las luces del nuevo Bilbao y la retórica triunfal, aparecen las sombras de un modelo que ha consolidado una regeneración a dos velocidades, con un centro renovado y dinámico, espacio privilegiado de las élites locales y de visitantes foráneos y una periferia (especialmente los barrios altos) ajena y de espaldas al impulso regenerador de las décadas de los 90 y 2000 y duramente castigada en la última etapa por la crisis económica. Un modelo que pese a la materialización de áreas de nueva centralidad y de clara recuperación física y ambiental, no ha sido capaz de impulsar una reconversión económica y funcional, una nueva base productiva urbana que sustente la creación y distribución de riqueza y bienestar para la población bilbaína; un modelo que pese al triunfalismo y la retórica del éxito anticipado tiene en la operación Abandoibarra un ejemplo claro del fracaso de la estrategia direccional y su transformación, por la lógica del mercado inmobiliario, en un 
espacio predominantemente residencial y de infraestructuras culturales al servicio de los sectores más privilegiados de la ciudad» (Rodríguez, 2018).

Esta breve mirada al estado y evolución del proceso de transformación de esta región no pretende sustituir una revisión del estado del arte, pero sí apuntar dos cuestiones posteriormente desarrolladas y argumentadas. Primero, la región del AMB puede contextualizarse en el marco urbano presentado en el capítulo anterior: complejo, excluyente, y con retos estructurales. Segundo, este puede abordarse desde la teoría urbana crítica situándolo en una realidad socio-espacial contradictoria que afecta profundamente a su condición urbana, y planteando que su evolución y transformación se da bajo un proceso de gobernanza urbana que compagina la apertura en la toma de decisiones con un fuerte desequilibrio y rejerarquización. Todo ello conforma la base de un análisis de la gestión de los usos residenciales en un contexto de crisis urbana.

\section{$-2.2 .2-$}

\section{Justificación de la delimitación}

Aunque no se trata de una cuestión sustancial en este caso debido a la naturaleza del objeto de estudio y los propios objetivos de la investigación, se ha considerado de interés y relevancia la revisión de los diferentes nombres y delimitaciones espaciales de este área metropolitana, según la fuente y el fin con que la defina. Por lo que antes de presentar lo que en este trabajo se entiende por Área Metropolitana de Bilbao, se pasa a hacer un breve repaso a algunas de las delimitaciones que de esta región se han hecho.

\section{Delimitaciones existentes}

Exceptuando algunas aproximaciones a la cuestión en la primera mitad del siglo $\mathrm{XX}^{11}$, el primer movimiento realizado con el objetivo de agrupar en único instrumento de planificación espacial Bilbao y los municipios de su entorno para abordarlos de manera conjunta es la creación en 1946 de la Corporación Administrativa del Gran Bilbao ${ }^{12}$.

${ }^{11}$ Las Leyes de Grandes Ciudades que gozaron los planeamientos de Madrid, Bilbao y Valencia buscaban, superando los límites municipales, planificar su entorno inmediato (Urkidi, 2009: 227). Con este mismo objetivo, el entonces arquitecto municipal de Bilbao Ricardo Bastida desarrolló en 1923 el "Plan de Enlaces de Bilbao con los pueblos circundantes", con la intención de abordar desde una visión conjunta la planificación de los sistemas de transportes y usos del suelo en la región (Mas Serra, 2010).

12 Decreto del Ministerio de Gobernación de 1 de marzo de 1946, que completa la Ley de 17 de julio de 1945 sobre bases para la ordenación urbanística y comarcal de Bilbao y su zona de influencia. 
Esa corporación es el marco del Plan de Ordenación Urbanística y Comarcal de Bilbao y su zona de influencia aprobado en 1946, y su ámbito comprende veintidós municipios (Tabla 2.2). Ese mismo ámbito se mantuvo en la revisión del plan en 1964 con el nombre de Plan General de Ordenación Urbana de Bilbao y su Comarca. Hubieron de pasar varias décadas hasta que se produjera una nueva propuesta de delimitación del área. La Ley 4/1990 de Ordenación del Territorio del País Vasco definía tres instrumentos para la gestión del territorio de esta comunidad autónoma: las Directrices de Ordenación del Territorio (DOT), los Planes Territoriales Parciales (PTP) y los Planes Territoriales Sectoriales (PTS). Las DOT son jerárquicamente superiores al resto y ordenan a escala de toda Euskadi; por debajo de estas se sitúan los planes territoriales, y en el último escalón, el planeamiento municipal. En las directrices se pueden encontrar dos diferentes delimitaciones del AMB. En su fase de diagnóstico, con un carácter analítico y sin ninguna implicación para futuras propuestas, definían el concepto de Área Urbana Integrada. Esta se establecía como aquellos «asentamientos que operan en el sistema de ciudades de la Comunidad Autónoma como si fueran una sola ciudad en cuanto a su tamaño funcional y en relación con su papel en la jerarquía urbana» (Decreto 28/1997, de 12 de febrero, Suplemento, 1997: 203). Este ejercicio venía en parte motivado por la intención de promover la compatibilización del planeamiento municipal de algunas áreas de Euskadi, ya que el desarrollo y la expansión urbana en un territorio estructurado por estrechos valles había llevado a que se fusionasen diversos municipios en un único y complejo conjunto urbano. Tal fue el caso de Bilbao y su entorno, quedando así delimitaba el Área Urbana Integrada de Bilbao como el área constituida por dieciocho municipios (Tabla 2.2).

Con una finalidad esta vez sí instrumental para su aplicación en la futura planificación, y de carácter impositivo para los instrumentos jerárquicamente inferiores, las DOT hacen una subdivisión del territorio íntegro de la comunidad autónoma de Euskadi buscando una escala intermedia para la aplicación y desarrollo de las orientaciones definidas. Una escala que busca ser un eslabón integrador entre el planeamiento municipal y las propias DOT, y que permita «el análisis de problemas y la implantación adecuada de programas de Ordenación Territorial en cada uno de los territorios diferenciados de escala comarcal» (Decreto 28/1997, de 12 de febrero, Suplemento, 1997: 47). De esta manera, dividieron el espacio en quince Âreas Funcionales, correspondiendo al ámbito en cuestión el Ârea Funcional de Bilbao Metropolitano, que se compone de treinta y cinco municipios (Tabla 2.2). Esta misma delimitación la comparte el Ministerio de Fomento en su Atlas Estadístico de las Áreas Urbanas y su Sistema de Información Urbana. Si bien las DOT afirman que se trata de «un tamaño físico y funcional adecuado», la tradición y el sesgo físico y morfológico de la ordenación territorial desarrollada en Euskadi desde los que se impulsó esta disciplina -con considerables influencias de la escuela alemana, frente a una tradición
Tabla 2.2 (página siguiente).

Delimitaciones del área metropolitana de Bilbao en función del instrumento o fuente de consulta. Elaboración propia a partir de fuentes citadas. 


\section{CORPORACION ADMINISTRATIVA DEL GRAN BILBAO}

Fuente: Plan de Ordenación Urbanística y Comarcal de Bilbao y su zona de influencia, 1946.

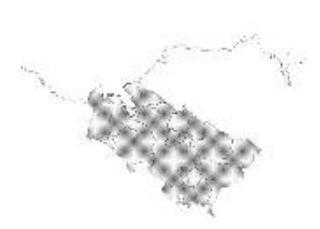

Abanto-Zierbena, Arrigorriaga, Barakaldo, Basauri, Berango, Bilbao, Derio, Erandio*, Etxebarri, Galdakao, Getxo, Larrabetzu, Leioa, Lezama, Loiu, Ortuella, Portugalete, Santurtzi, Sestao, Sondika, Trapagaran, Zamudio, Zaratamo, Zierbena** (*parte de Bilbao ** parte de Abanto-Zierbena)

\section{AREA URBANA INTEGRADA DE BILBAO}

Fuente: DOT, 1997

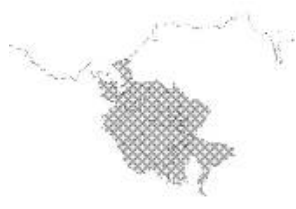

Alonostegi, Arrigorriaga, Barakaldo, Basauri, Bilbao, Derio, Erandio, Etxebarri, Galdakao, Getxo, Leioa, Loiu, Portugalete, Santurtzi, Sestao, Sondika, Trapagaran, Zamudio

\section{AREA FUNCIONAL DE BILBAO METROPOLITANO}

Fuente: DOT, 1997

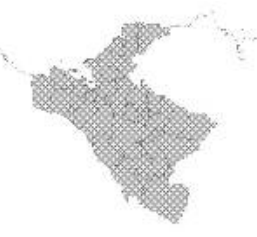

Abanto-Zierbena, Alonsotegi, Arrankudiaga, Arrigorriaga, Barakaldo, Barrika, Basauri, Berango, Bilbao, Derio, Erandio, Etxebarri, Galdakao, Getxo, Gorliz, Larrabetzu, Leioa, Lemoiz, Lezama, Loiu, Muskiz, Ortuella, Plentzia, Portugalete, Santurtzi, Sestao, Sondika, Sopela, Trapagaran, UgaoMiraballes, Urduliz, Zamudio, Zaratamo, Zeberio, Zierbena

\section{COMARCA DE GRAN BILBAO}

Fuente: Eustat, 2013

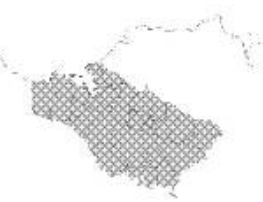

Abanto-Zierbena, Alonsotegi, Arrigorriaga, Barakaldo, Basauri, Berango, Bilbao, Derio, Erandio, Etxebarri, Galdakao, Getxo, Larrabetzu, Leioa, Lezama, Loiu, Muskiz, Ortuella, Portugalete, Santurtzi, Sestao, Sondika, Trapagaran, Zamudio, Zaratamo, Zierbena

\section{BILBAO METROPOLITANO}

Fuente: Bilbao Metrópoli-30, 2013

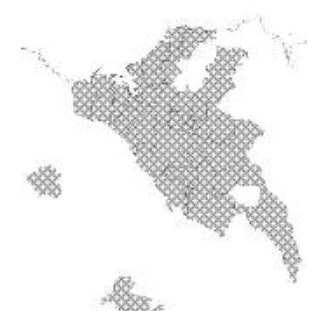

Abanto-Zierbena, Alonsotegi, Arantzazu, Arrankudiaga, Arrigorriaga, Balmaseda, Barakaldo, Barrika, Basauri, Bedia, Berango, Bilbao, Dima, Derio, Erandio, Etxebarri, Galdakao, Getxo, Gorliz, Larrabetzu, Leioa, Lemoa, Lemoiz, Lezama, Loiu, Mungia, Muskiz, Orduña, Ortuella, Plentzia, Portugalete, Santurtzi, Sestao, Sondika, Sopela, Trapagaran, UgaoMiraballes, Urduliz, Zamudio, Zaratamo, Zeberio, Zierbena

\section{BILBAO METROPOLITANO}

Fuente: Evaluación de los Ecosistemas del Milenio en Bizkaia, 2010

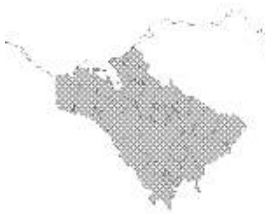
Abanto-Zierbena, Alonsotegi, Arrankudiaga, Arrigorriaga, Barakaldo, Basauri, Berango, Bilbao, Derio, Erandio, Etxebarri, Galdakao, Getxo, Larrabetzu, Leioa, Lezama, Loiu, Muskiz, Ortuella, Portugalete, Santurtzi, Sestao, Sondika, Sopela, Trapagaran, Ugao-Miraballes, Zamudio, Zaratamo, Zierbena 
francesa más apoyada en la ordenación económica- hacen que la parte 'funcional' se vea debilitada por una mirada parcial y geográficamente acotada. A pesar de que desde las instituciones vascas es tratada, o al menos difundida, como una disciplina muy técnica e instrumental, la verdadera naturaleza política de la ordenación territorial plantea numerosos retos (Etxabe, 2012; Urteaga, 2011).

Se cierra esta revisión con tres ejemplos más de las diferentes posibilidades de delimitación del AMB. El Instituto Vasco de Estadística (Eustat) desarrolla buena parte de su labor en base a una subdivisión comarcal de Euskadi, según la cual esta se divide en veinte comarcas -siete de ellas dentro de Bizkaia-. Le corresponde al ámbito de trabajo la Comarca de Gran Bilbao, formada por veintiséis municipios (Tabla 2.2). Aunque no se trata de una delimitación con fines administrativos, este organismo presenta parte de sus estudios estadísticos bajo este formato. Con unos objetivos más ejecutivos y estratégicos, desde la Asociación Bilbao Metrópoli-30 ${ }^{13}$, constituida en 1991 con el objetivo principal, pero no único, de impulsar la realización y puesta en práctica del Plan Estratégico para la Revitalización del Bilbao Metropolitano, se hizo al menos indirectamente una nueva delimitación. A pesar de no realizar una acotación espacial de su área de acción, pues define el Bilbao Metropolitano como «la realidad económica y social que representa la concentración urbana del Bajo Nervión y los valles contiguos» (Bilbao Metrópoli 30, 1992: 8), cuenta con una serie de municipios como socios ordinarios de la misma, que fueron treinta en sus inicios, pero que a día de hoy son cuarenta y dos en total (Tabla 2.2). Por último ${ }^{14}$, y como muestra de la diversidad de enfoques posibles, se recoge una delimitación desde una mirada ecosistémica. En la provincia de Bizkaia, desde la Cátedra UNESCO de Desarrollo Sostenible y Educación Ambiental de la Universidad del País Vasco / Euskal Herriko Unibertsitatea, en el marco del Programa de Naciones Unidas para el Medio Ambiente y como continuación al Programa de Evaluación de los Ecosistemas del Milenio, se desarrolla dicha estrategia global a través de evaluaciones locales. Uno de los casos de estudio del proyecto de investigación 'Evaluación de los Ecosistemas del Milenio en Bizkaia' es el denominado Cinturón Verde de Bilbao Metropolitano. Más allá de la acotación del propio cinturón, el trabajo señala la importancia de incorporar a su reflexión la realidad urbana y poblacional a la que los servicios de los ecosistemas propios de esta

\footnotetext{
13 Bilbao Metrópoli-30 es una sociedad mixta formada por una enorme lista de entidades diversas y de muy diferentes escalas de actuación, tanto públicas como privadas. Su papel en la transformación de la región ha sido muy relevante, aunque no carente de conflictos (Larrea y Gamarra, 2007; Mas Serra, 2010).

14 No se contemplan otras delimitaciones administrativas existentes como pueden ser los partidos judiciales, pues estas unidades territoriales para la administración de la justicia dividen la provincia de Bizkaia en seis partidos, ninguno de ellos coincidiendo remotamente con el área de interés. De hecho, habría que juntar tres de ellos -Barakaldo, Bilbao y Getxopara acercarse a una delimitación similar.
} 
infraestructura verde puede responder; en ese sentido, se incluyen veintinueve municipios dentro del área metropolitana (Tabla 2.2).

\section{Delimitación propuesta}

Ante las diferencias existentes entre estas delimitaciones, a la hora de aterrizar la investigación sobre el ámbito seleccionado surgen dos preguntas: ¿qué ámbito territorial utilizar? y, ¿es alguno de los descritos válido para los intereses de este trabajo?. Antes de responderlas conviene centrar la mirada un instante en la región y su entorno, una vez se ha introducido más arriba su espacio físico, para desarrollar posteriormente sobre esta base las argumentaciones de la delimitación propuesta. El área metropolitana sobre la que se va a trabajar está formada, como se ha dicho, por una serie de municipios concentrados principalmente a lo largo de la segunda mitad de los cauces de los ríos Nervión e Ibaizabal -así como en torno a algunos de sus afluentes- hasta su desembocadura en el Abra de Bilbao, extendiéndose a su vez por la costa, sobre todo hacia el este. Ambos ríos confluyen en el ámbito de estudio, y forman a partir de Bilbao la Ría del Nervión o de Ibaizabal. Así, independientemente del detalle de las diferentes delimitaciones posibles, y de dejar fuera o dentro algunos de esos municipios, este área toma forma en un territorio con una evidente condición urbana ${ }^{15}$ que puede diferenciarse con relativa claridad de otras áreas limítrofes, igualmente urbanas -aunque con diferentes formas de territorializar dicha condición- y que toman como centro un núcleo urbano diferente a Bilbao. Así ocurre con Mungia al noreste, Gernika al este, Durango e Igorre al sureste, Laudio/Llodio al sur y la comarca de Encartaciones al oeste, que linda con la Comunidad Autónoma de Cantabria. Todo ello no implica que la fuerza de atracción que ejerce Bilbao en muy diversas esferas, y tanto en la provincia como en Euskadi e incluso en Cantabria -muy próxima a este área metropolitana-, sea por supuesto superior en escala a esas otras áreas funcionales que son en definitiva también periféricas de Bilbao en muchos aspectos.

Teniendo esto en cuenta, y asumiendo la complejidad -y cierta subjetividad- de cualquier ejercicio de delimitación espacial como este, pueden descartarse algunas de las propuestas arriba presentadas, tanto por dejar fuera algunos municipios que se creen parte de esa 'unidad urbana' que forma el área metropolitana, como por incluir otros que pueden entenderse más fuertemente relacionadas con otros polos geográficos. Tal es el caso de la Corporación Administrativa del Gran Bilbao y del Área Urbana Integrada de Bilbao, que no incluyen, sobre todo la segunda, a ciertos núcleos urbanos claramente integrados en el funcionamiento de este artefacto urbano. Casos

15 Entendiendo esta como ese proceso de territorialización de relaciones sociales complejas apuntada en el capítulo primero, que desborda las dicotomías de ciudad-campo y urbano-rural -estáticas y ajenas a una realidad compleja-, y no como categoría urbanística o puramente morfológica (ver nota número 6). 
como Lezama o Larrabetzu al final del Valle de Asúa, Berango, Sopela y Urduliz en la zona noreste junto a la costa, o Zierbena, Muskiz, Abanto-Zierbena y Ortuella en el lado opuesto junto a la costa noroeste y tras la Margen Izquierda. Por el contrario, el caso del Bilbao Metropolitano delimitado por la sociedad Bilbao Metrópoli-30 incluye una serie de municipios que, si bien como se ha apuntado es verdad que se ven influidos por Bilbao como clara cabecera de provincia, podrían no ser considerados como parte de su área metropolitana. Así ocurre con Gorliz, Plentzia, Lemoiz o la propia Mungia, que pueden entenderse como dentro del área de influencia de esta última. $O$ con municipios como Dima, Balmaseda y Urduña/Orduña, que incluso se encuentran separados del área metropolitana con otros municipios de por medio.

Las tres delimitaciones restantes -Área Funcional, Comarca y Bilbao Metropolitano (definido por el programa de los Ecosistemas del Milenio)-, están más ajustadas a lo que se cree que podría definirse como Área Metropolitana de Bilbao. Ciertamente, son las tres muy similares entre sí. Al retomar la pregunta de cuál podría ser de entre ellas el ámbito territorial a utilizar, se intenta responder mediante la comparación de una serie de indicadores básicos y que permiten hacer un análisis de algunas variables relacionadas con el tema de la investigación. A saber: población, número de municipios, superficie de suelo total, viviendas existentes y viviendas por ejecutar previstas en los correspondientes documentos de planeamiento. Los datos existentes muestran que las diferencias entre ellas no son en ningún caso muy significativas teniendo en cuenta las características del objeto de estudio y los objetivos de la investigación. Es probable que no se produjesen cambios significativos en los resultados obtenidos en este trabajo por el hecho de tomar una u otra delimitación. Podría esto cambiar si la investigación se centrase con mayor profundidad en los usos del suelo o si trabajase los servicios ecosistémicos, para lo cual debería plantearse una delimitación en base a elementos naturales y no basada en delimitaciones administrativas (Daily, 1997; España, Ministerio de Vivienda, 2010; Naredo, 1997). Algunos planes de ordenación ya lo vienen haciendo, especialmente aquellos dirigidos a la planificación de espacios naturales como la Biosfera de Urdaibai en Bizkaia -delimitada a partir de la unidad hidrográfica del río Oka-, o la Huerta de Valencia delimitada en base al sistema de regadíos históricos-. Existen también ejemplos de planes de ordenación urbana que han incorporado ciertos criterios en este sentido como el de Vitoria-Gasteiz, si bien en este caso, puede que en parte se deba a que «el anillo verde ha llegado antes» que el PGOU (Orive, 2006). Para el caso de este trabajo, siendo la vivienda por un lado un objeto de gestión en gran parte municipal, aunque también bajo la influencia de competencias de las diputaciones forales, gobierno autonómica y estatal, y por otro lado sujeto a fuertes afecciones extra-administrativas, se ha entendido adecuado y no excesivamente conflictivo mantener una delimitación administrativa basada en la agregación de municipios.
Tabla 2.3 (página siguiente). Comparativa de diferentes delimitaciones del área metropolitana de Bilbao, y su peso respecto a Euskadi y Bizkaia. Elaboración propia a partir de las Directrices de Ordenación del Territorio de Euskadi, Eustat, Programa de Evaluación de los Ecosistemas del Milenio en Bizkaia, y Udalplan. 


\begin{tabular}{|c|c|c|c|}
\hline Euskadi & & \% Euskadi & $\%$ Bizkaia \\
\hline población 2015 & 2.173 .210 & 100 & \\
\hline $\mathrm{n}^{\mathrm{o}}$ de municipios & 251 & 100 & \\
\hline superficie total (Ha.) & 723.492 & 100 & \\
\hline viviendas existentes 2015 & 1.015 .096 & 100 & \\
\hline viviendas por ejecutar 2015 & 201.231 & 100 & \\
\hline \multicolumn{4}{|l|}{ Bizkaia } \\
\hline población 2015 & 1.141 .442 & 52,52 & 100 \\
\hline $\mathrm{n}^{\circ}$ de municipios & 112 & 44,62 & 100 \\
\hline superficie total (Ha.) & 221.485 & 30,61 & 100 \\
\hline viviendas existentes 2015 & 533.208 & 52,53 & 100 \\
\hline viviendas por ejecutar 2015 & 88.194 & 43,83 & 100 \\
\hline \multicolumn{4}{|c|}{ Área Funcional de Bilbao Metropolitano } \\
\hline población 2015 & 895.373 & 41,20 & 78,44 \\
\hline $\mathrm{n}^{\mathrm{o}}$ de municipios & 35 & 13,94 & 31,25 \\
\hline superficie total (Ha.) & 50.936 & 7,04 & 23,00 \\
\hline viviendas existentes 2015 & 412.150 & 40,60 & 77,30 \\
\hline viviendas por ejecutar 2015 & 59.077 & 29,36 & 66,99 \\
\hline \multicolumn{4}{|l|}{ Comarca de Gran Bilbao } \\
\hline población 2015 & 859.907 & 39,57 & 75,34 \\
\hline $\mathrm{n}^{\mathrm{o}}$ de municipios & 26 & 10,36 & 23,21 \\
\hline superficie total (Ha.) & 37.558 & 5,19 & 16,96 \\
\hline viviendas existentes 2015 & 391.825 & 38,60 & 73,48 \\
\hline viviendas por ejecutar 2015 & 53.121 & 26,40 & 60,23 \\
\hline \multicolumn{4}{|c|}{ Bilbao Metropolitano (Ecosistemas del Milenio) } \\
\hline población 2015 & 877.404 & 40,37 & 76,87 \\
\hline $\mathrm{n}^{\mathrm{o}}$ de municipios & 29 & 11,55 & 25,89 \\
\hline superficie total (Ha.) & 41.182 & 5,69 & 18,59 \\
\hline viviendas existentes 2015 & 400.082 & 39,41 & 75,03 \\
\hline viviendas por ejecutar 2015 & 55.844 & 27,75 & 63,32 \\
\hline \multicolumn{4}{|c|}{ Área Metropolitana de Bilbao (elaboración propia) } \\
\hline población 2015 & 877.928 & 40,40 & 76,91 \\
\hline $\mathrm{n}^{\mathrm{o}}$ de municipios & 29 & 11,55 & 25,89 \\
\hline superficie total (Ha.) & 39.928 & 5,52 & 18,03 \\
\hline viviendas existentes 2015 & 402.603 & 39,66 & 75,51 \\
\hline viviendas por ejecutar 2015 & 57.087 & 28,37 & 64,73 \\
\hline
\end{tabular}


Como refleja la Tabla 2.3, no hay grandes variaciones en los valores relativos de estos indicadores respecto al total de la provincia o de la comunidad autónoma, si no que más bien se mantienen en torno a unas cifras similares. Las diferencias no superan los tres puntos respecto a los datos globales autonómicos, ni los siete respecto a los provinciales. Este hecho lleva a afirmar que podría servir cualquiera de estas tres delimitaciones como base para acotar el ámbito de estudio. Pero igualmente, sería válido argumentar la definición de una nueva delimitación, similar a estas tres, que se ajuste más a lo que se cree que es la realidad de la región. Dado el carácter académico del trabajo, se toma la licencia de elegir la segunda opción, sirviendo así como ejercicio de reflexión sobre la definición oficial de este área metropolitana.

Tomando como base estas tres últimas delimitaciones y las consideraciones previamente desarrolladas, se ha definido lo que en esta investigación se toma como Área Metropolitana de Bilbao (AMB), y que queda reflejada en el Mapa 2.6 y la Tabla 2.4. Al sur, se han dejado fuera los municipios de Arrankudiaga y Zeberio, que pueden ser incorporados a los ámbitos de influenci de Laudio/Llodio e Igorre respectivamente. El Área Funcional de Bilbao Metropolitano los incorpora a ambos, mientras que el programa de los Ecosistemas del Milenio cuenta solo con Arrankudiaga. Al noreste, por un lado se han descartado Gorliz, Lemoiz y Plentzia al considerar la existencia de una fuerte red de relaciones con Mungia; los tres están dentro del Área Funcional de Bilbao definida por las DOT. Por otro lado, en esta misma zona se han añadido Sopela, Urduliz y Barrika -el Área Funcional ya lo hace, pero la Comarca no, y el Bilbao Metropolitano solo incorpora a Sopela-. El municipio de Barrika, también bajo la influencia de y con altas relaciones con Mungia, se ha incorporado al AMB. En la Tabla 2.3 puede apreciarse que los valores de la delimitación propuesta respecto a los de las otras tres analizadas son intermedios. En el trabajo se denominará con este nombre (Área Metropolitana de Bilbao) a este área geográfica, salvo en aquellas ocasiones en las que la fuente lo haga explícitamente de otra manera basada en una delimitación diferente.

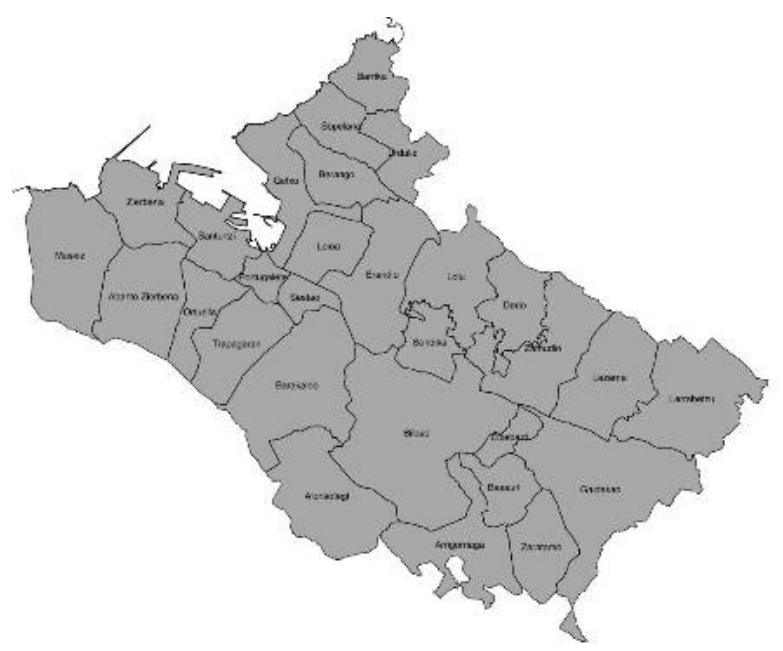

Abanto Zierbena

Alonsotegi

Arrigorriaga

Barakaldo

Barrika

Basauri

Berango

Bilbao

Derio

Erandio

Etxebarri

Galdakao

Getxo

Larrabetzu

Leioa

Lezama

Loiu

Muskiz

Ortuella

Portugalete

Santurtzi

Sestao

Sondika

Sopela

Trapagaran

Urduliz

Zamudio

Zaratamo

Zierbena

Mapa 2.6 y Tabla 2.4.

Municipios que conforman la delimitación del Área Metropolitana de Bilbao empleada en este trabajo. Elaboración propia. 


\section{$-2.3-$ \\ Situación problemática y metas}

Acotado el objeto y ámbito de estudio tanto conceptual como geográficamente, el siguiente paso es identificar y conocer las principales características de esos conflictos sociales a los que se ha hecho referencia, poniendo el énfasis en los que están relacionados y afectan al proceso de un acceso digno a la vivienda. Es decir, se procede a acotar la situación problemática a la que se enfrenta la investigación como punto de inicio para la aplicación de la herramienta propuesta. A pesar de que el punto de partida es una problemática global -la de la vivienda- mayor y más compleja de lo que este trabajo podría abordar, su desarrollo es local y en este sentido se han seleccionado algunos de los aspectos considerados como de mayor urgencia en el ámbito de estudio; con la atención centrada siempre en aquellos claramente vinculados con la dimensión social aquí trabajada. Como ya se ha apuntado, la motivación sustancial de la investigación es la de enfrentarse a una situación social con necesidad de mejora, con el objetivo de realizar un ejercicio de observación, reflexión, comprensión y búsqueda de aportes a su resolución.

Teniendo en cuenta que el acceso a la vivienda constituye un eje fundamental de la dimensión social de la misma definida en el capítulo anterior, podría como primera aproximación apuntarse que la gran problemática que aborda el trabajo es un alto coste económico de dicho acceso para una parte importante de la población del AMB. Sin embargo, y como se ha planteado anteriormente, se entiende que a pesar de su ya de por sí gran complejidad esta cuestión económica no debe abordarse de manera aislada, por dos razones. Por un lado, al formar parte de una problemática global mucho más compleja de variables y dimensiones interrelacionadas, un análisis parcelario dificultaría su resolución parcial. Por otro, la apertura del análisis a otros aspectos de la vivienda y la incorporación de sus conflictos al estudio puede, más allá de aumentar la complejidad y dificultad de la investigación, ofrecer una mirada más transversal que identifique oportunidades y posibilidades mutuamente enriquecedoras para la resolución de algunos de los conflictos existentes. De esta manera, asumiendo el inconveniente de profundizar menos en una sola variable para abarcar de una manera más somera varias, y asumiendo igualmente que en cualquier caso sigue siendo este un trabajo que aborda de una manera parcial y sectorial un complejo tema, se completa la cuestión económica con otras dos de gran relevancia. 
Para, como decía Alguacil (1995: 78), impregnar la primera de otras «expresiones y experiencias disciplinarias» y viceversa, así como buscar «la potencialidad y capacidad de ofrecer el apoyo en otros sectores y, a la vez, obtenerlo de las intervenciones en los mismos». Siempre, se recuerda, con las limitaciones de los medios disponibles en una tesis doctoral -un trabajo individual y de carácter formativo-. Las cuestiones añadidas en este trabajo son por lo tanto dos: los conflictos espaciales propios puestos en evidencia en dicho proceso de acceso, y el contexto de un parque residencial existente infrautilizado. En gran parte existentes como efecto de una normalización de la vivienda como objeto de mercado y de inversión que ha generado y genera, como se desarrollará a continuación, graves consecuencias sociales.

Una mirada rápida al contexto local permite constatar que los puntuales parches y ayudas del sistema capitalista que en esta materia se han ejecutado no han evitado que siga siendo una cuestión no cubierta para un amplio porcentaje de la población, para el cual el acceso conlleva un alto coste económico muchas veces inasumible. El complejo devenir socioeconómico de los últimos años ha llevado a que, a pesar de contar Euskadi con «una política de vivienda relativamente progresista y pionera [que] ha destacado en pleno auge inmobiliario por su impulso a la política de viviendas protegidas» (Etxezarreta et al., 2013: 67), y ser el AMB una de las regiones menos vulnerables del España a la crisis iniciada en $2007^{16}$ (Méndez et al., 2015), no carece esta de conflictos ni de problemas de acceso al parque residencial. Se verá a continuación cómo cada vez hay más personas que, necesitando una vivienda, no pueden acceder a ella por motivos económicos: el aumento de la necesidad de vivienda con dificultades de ser cubierta toma forma en una extendida incapacidad económica de demanda en la sociedad; frente a lo anterior, una oferta tanto pública como privada inadecuada -que no insuficiente- para satisfacer esa necesidad, y una ciudad existente que urge ser intervenida y adaptada, completan una situación problemática por la que «el derecho a la vivienda, lejos de acercarse a toda la población, se extiende como un problema que cada vez afecta a sectores y segmentos más amplios de la sociedad, y que a su vez la crisis económica e inmobiliaria no parece vaya a contribuir a mejorarlo» (Etxezarreta, 2010: 23).

Cuestiones todas que alimentan lo que algunos han venido a llamar la alienación residencial, entendida como lo opuesto a sentir que la

16 Resultado de un estudio a nivel nacional sobre el impacto de la crisis multinivel aflorada en la década pasada a partir del análisis de 15 indicadores económicos, sociales, demográficos e inmobiliarios en el periodo 2007-2013 sobre 363 municipios de más de 20.000 habitantes. Los principales resultados muestran que según dichos indicadores, aquellas regiones con una economía más diversificada, industria renovada, cierta capacidad exportadora, y menor desarrollo del sector inmobiliario, sufrieron en menor medida los efectos. Ocho de las diez ciudades menos vulnerables en este sentido se sitúan en Euskadi, cinco de ellas en el AMB. 
vivienda en que uno vive es su hogar, y consecuentemente a entenderla como otro espacio más dentro de un mundo caracterizado por la precariedad, la inseguridad y el desempoderamiento (Madden y Marcuse, 2018: 75-102). Y que encajan en el concepto de precariado acuñado como clase social emergente con enormes dificultades para acceder y desarrollar muchos derechos políticos, civiles, sociales y económicos en un contexto de desigualdad e inseguridad creciente (Standing, 2013). De esta manera, es muy importante señalar que, además de las afecciones económicas y ecológicas sobre la población de un modelo residencial y urbanístico muy mercantilizado que ha priorizado la adquisición antes que la producción de riquezas olvidando en muchas ocasiones el bienestar social, existen consecuencias psicológicas caracterizadas por el estrés, la crispación social, la frustración, el miedo, o la bancarrota moral, arrasando los sentimientos de amistad y solidaridad (Naredo y Montiel, 2011: 6062).

Con todo, la problemática no es nueva. Las carencias del modelo de vivienda de las sociedades modernas para satisfacer este derecho humano básico se van reproduciendo a lo largo de las décadas (Engels, 1974); a pesar de que en cada tiempo las causas y las características del fenómeno varíen. La preocupante continuidad de esta problemática en el tiempo añade si cabe un mayor carácter de urgencia, y la necesidad de una mayor responsabilidad social. En periodos relativamente recientes, pero todavía antes de las grandes expansiones urbanas de las pasadas décadas, la gravedad del asunto en el AMB era palpable:

«El problema de la vivienda, lo podemos encontrar como uno de los principales que afectaron al tejido urbano de Bilbao en todas las fuentes documentales que desde 1940 hasta el primer quinquenio de los años setenta han llegado hasta nosotros. Informes de todas clases y de orígenes muy diversos, Diputación, Ayuntamiento, Gobierno Civil, Falange, Cáritas, parroquias, Consejo Económico e Industrial de Bizkaia, archivos patronales de empresas diversas, testimonios literarios, orales, etc., etc» (Bustillo, 2004: 290).

De esta manera, se pasa a continuación a desarrollar y estudiar la situación desde una escala local y regional a partir de la recopilación de sus elementos más relevantes. La intención no es traer aquí una ingente cantidad de datos e información existente, si no mediante pequeñas pinceladas exponer y argumentar la existencia de dicha problemática. 
$-2.3 .1-$

\section{Necesidad de vivienda alta e incapacidad económica de demanda}

La necesidad de vivienda se puede entender como aquella situación en la cual existe una carencia e incapacidad de acceso al derecho básico de alojamiento, o a uno adecuado. La Ley de Vivienda de Euskadi establece que «una persona, familia o unidad convivencial tiene necesidad de vivienda cuando, no disponiendo de alojamiento estable o adecuado, tampoco cuenta con los medios económicos precisos para obtenerlo, encontrándose por ello en riesgo de caer en situación de exclusión social» (Ley 3/2015, de 18 de junio, 2015). Efectivamente, como recoge la memoria del Plan Territorial Parcial del Bilbao Metropolitana, la «necesidad real tiene como objetivo su ocupación» (Decreto 179/2006, de 26 de septiembre, Anexo IMemoria, 2006: 57) y está directamente unida a los procesos demográficos naturalmente lentos que subyacen bajo los flujos de aparición de unidades de convivencia (Vinuesa, 2013).

\section{Unidades convivenciales con necesidad de vivienda}

Para abordar este «problema vigente y no resuelto» (Etxezarreta, 2010: 5), contar con los datos del número de unidades de convivencia ${ }^{17}$ con necesidad de vivienda es una variable fundamental. Las series de la Encuesta sobre Necesidades y Demanda de Vivienda muestran en el periodo 2005-2015 un máximo en 2009, con un $14,81 \%$ de las unidades totales de Bizkaia con necesidad de acceso (Gobierno Vasco, 2015a). Desde entonces, el porcentaje ha ido disminuyendo importantemente hasta el 6,55\% cuantificado en 2013, observándose un leve repunte en los últimos datos disponibles de 2015 con un 7,76\% (Gráfica 2.7). Sin embargo, la metodología utilizada puede llevar a distorsionar considerablemente la realidad. Por un lado, se refiere exclusivamente a población entre 18 y 44 años. Por lo que deja fuera a situaciones que se verán luego, como los numerosos casos de familias con hipotecas ejecutadas o con rentas de alquiler pendientes y en peligro de ser, o habiendo sido, expulsadas de sus viviendas. Por otro lado, la disponibilidad de ingresos constituye uno de los requisitos para considerar que existe necesidad de acceso a

\footnotetext{
17 Frente a conceptos habitualmente utilizados como 'hogar' o 'familia' para referirse a las personas que habitan una vivienda, se utiliza y se cree más acertado para este trabajo la 'unidad de convivencia', entendida como aquel conjunto de personas que cuenta con un deseo, proyecto o situación de convivencia en una vivienda o parte de la misma fruto de las relaciones -familiares o no- existentes entre las personas que la conforman, en caso de ser más de una, y no por verse forzadas a convivir por motivos económicos o de otra naturaleza. La mención a hogares y familias se respetará cuando sea necesario al presentar datos directos de fuentes consultadas que así lo hagan. Algunos documentos, como la Ley de Vivienda de Euskadi, utilizan este concepto.
}

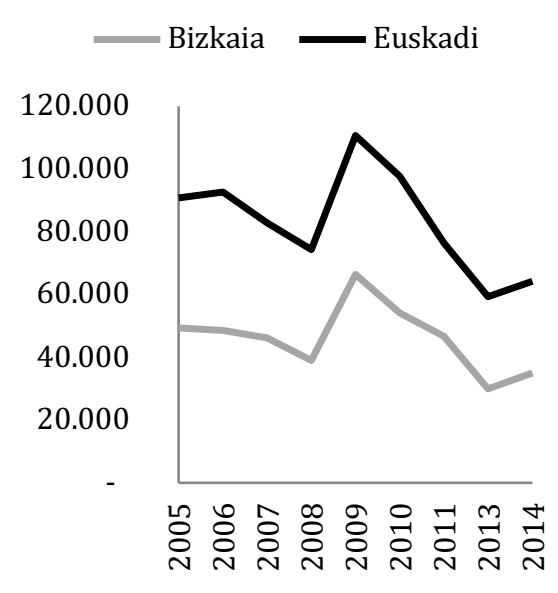

Gráfica 2.7. Evolución de la necesidad de vivienda en Euskadi y Bizkaia (hogares). Encuesta sobre Necesidades y Demanda de Vivienda. Gobierno Vasco, Departamento de Empleo y Políticas Sociales. 


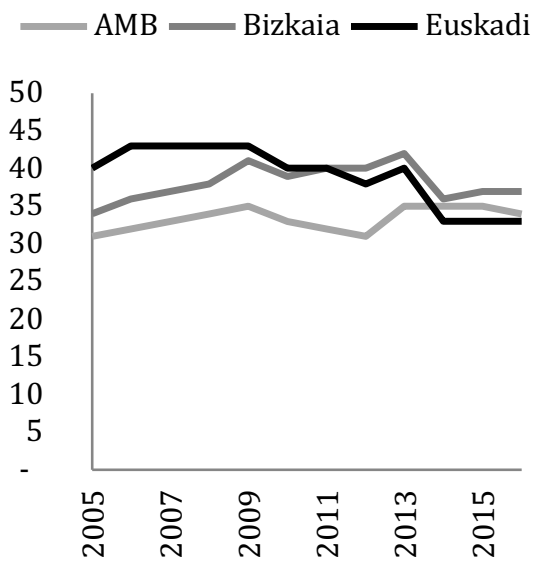

Gráfica 2.8. Solicitudes de vivienda que constan en Etxebide (por cada 1.000 habitantes). Open Data Euskadi. una vivienda; algo que viene siendo además habitual en los estudios realizados desde el Gobierno Vasco (Observatorio Vasco de la Vivienda, 2013: 23, 2014a: 13). Lo cual deja fuera a múltiples colectivos de la población en situación de desempleo y, de manera más preocupante, a aquellas personas en situaciones de especial vulnerabilidad. Estas carencias en la metodología de la encuesta lleva a plantear una posible relación entre la disminución de la capacidad económica que muchas unidades han sufrido en los últimos años y la disminución de la necesidad de vivienda reflejada en la gráfica.

Como novedad, en la encuesta de 2015 se aportó de manera complementaria la cuantificación de la necesidad de acceso a una primera vivienda según los ingresos o rentas propias disponibles. Es decir, se presentaba la imagen completa -siempre con los márgenes de error propios de la estadística- incluyendo esta vez personas con ingresos insuficientes, o sin ellos. Así, los datos de Bizkaia pasaban del $7,76 \%$ anterior a un $11,06 \%$, posiblemente más cercano a la realidad. Mostraban además matices muy importantes: del total de unidades estimadas con necesidad de acceso, tan solo un 14,64\% tenía ingresos suficientes; el 55,53\% los tenía de manera insuficiente o irregular, y el 29,83\% restante no tenía ingreso alguno. Es decir, más de un $85 \%$ de estas tenían dificultades para costearse la vivienda. En cualquier caso, y sin despreciar la aparente tendencia a la baja de los últimos años, estas cifras indicaban que en 2015 eran 49.807 las unidades de convivencia en Bizkaia con necesidad de vivienda, de las cuales 42.515 tenían dificultades económicas de diversa magnitud para afrontarla; 27.656 con ingresos insuficientes o irregulares, y 14.859 sin ninguno.

\section{Aumento de las situaciones de urgencia}

Se pueden encontrar más pistas sobre este asunto en el número de expedientes de solicitud de vivienda protegida existentes en el servicio vasco de vivienda, Etxebide. Los datos generales para Euskadi ofrecidos por el avance del Plan Director de Vivienda 2018-2020 son positivos, pues el número de solicitudes respecto de años anteriores ha bajado (Open Data Euskadi, 2017a). Sin embargo, tanto en Bizkaia como en el AMB la evolución de estas es relativamente estable desde hace años, con puntuales episodios de incremento y descenso (Gráfica 2.8). Algo que el Plan Director anterior de 2013-2016 ya constató, al observar que «Bizkaia, el territorio histórico con mayor número de solicitudes continúa en una fase de crecimiento con un aumento del $+2,5 \%$ respecto al año anterior» (Gobierno Vasco, 2013a: 125). Efectivamente, desde 2005 hasta 2013, las solicitudes en la provincia incrementaron, según los datos oficiales. En 2014 se redujo considerablemente la cifra global, pero desde entonces esta se mantiene en torno a las 37 solicitudes por cada 1.000 habitantes. En cuanto al Área Metropolitana de Bilbao, la pauta es similar, alcanzando en 2009 el máximo, reduciéndose luego hasta 2012. A partir de ese año, sube tres puntos manteniéndose más o menos 
estable hasta 2016, año en el que el AMB tenía 34,94 solicitudes por cada 1.000 habitantes. Desde 2005 a 2016 los indicadores han subido más de 2 y 3 puntos respectivamente para la provincia y la región. Esto se traduce en más de 42.000 solicitudes en Bizkaia, de las cuales cerca de 30.000 se engloban en el AMB. Lo que se asemeja mucho a los datos de necesidad de vivienda citados antes -42.515 unidades de convivencia con dificultades económicas en necesidad de vivienda fueron estimadas en 2015 para Bizkaia-.

Otro posible indicador es el relativo a las unidades convivenciales perceptoras de Ayudas de Emergencia Social, que reflejan claramente una evolución similar a la de la necesidad antes mostrada con la Encuesta de Necesidades y Demanda de Vivienda (Gráfica 2.9). De manera paralela, se produce en 2009 un pico máximo de unidades perceptoras, que va bajando hasta 2011; a partir de ese año y hasta 2015 vuelven a subir, con un incremento total desde 2008 igualmente superior a los 2 y 3 puntos en Bizkaia y el AMB respectivamente (Open Data Euskadi, 2017b). Las 11,76 unidades de convivencia por cada 1.000 habitantes existentes en 2015 dentro del área metropolitana suponían en torno a unas 10.000 unidades dentro de estos programas. En esta misma línea de perfiles con mayor urgencia, existen otros mucho más minoritarios -y más extremos- como son las personas $\sin$ hogar ${ }^{18}$ que, como en otros casos, no han de entenderse como ajenos a las políticas de vivienda a pesar de sus peculiaridades y de converger en ellos conflictos propios de otras esferas:

«El problema del sinhogarismo es consustancial al actual sistema de vivienda, no algo excepcional que se produce en sus márgenes. Lo mismo sucede con el crecimiento inusitado de los rearriendos, de las familias en pensiones temporales, las ocupaciones y otras formas de acceso informal y precario a la vivienda» (Madden y Marcuse, 2018: 18).

Las cifras dadas por la ONG Cáritas Bizkaia no son favorables (Gráfica 2.10): de las 847 personas atendidas por su Área de Intervención Sin Hogar en 2010, se ha pasado a atender 1.388 en 2016 (Cáritas Bizkaia, 2010, 2011, 2012, 2013, 2014, 2015b, 2016). Con todo ello, lo que se pretende señalar más allá de sintetizar la situación del acceso, es el peligro de simplificar la lectura de la necesidad de vivienda a la cifra global de unidades de convivencia en dicha situación según la metodología de la Encuesta de Necesidades y Demanda de Vivienda. Por supuesto, es positiva la reducción global de la cifra en los últimos 10 años recogidos por las encuestas. Desde 2005 a 2015 estas indican que existen en Bizkaia 14.000 unidades menos con dicha necesidad. Pero, como se ha apuntado, en el estudio de los matices reside la posibilidad de comprender con mayor profundidad el problema y actuar en consecuencia. Los datos

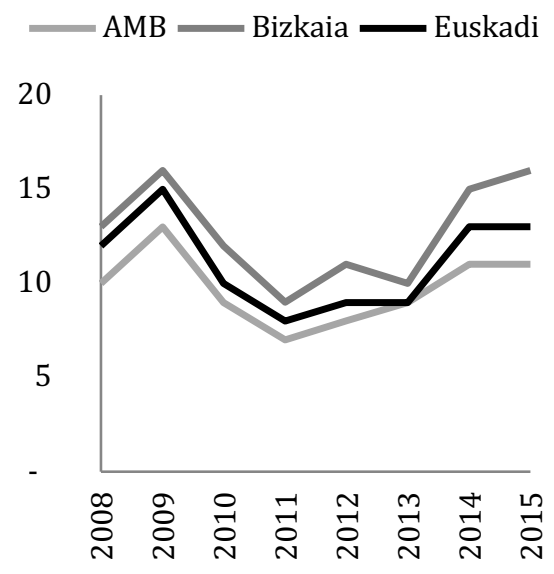

Gráfica 2.9. Unidades de convivencia perceptoras de Ayudas de Emergencia Social (por cada 1.000 habitantes). Open Data Euskadi.

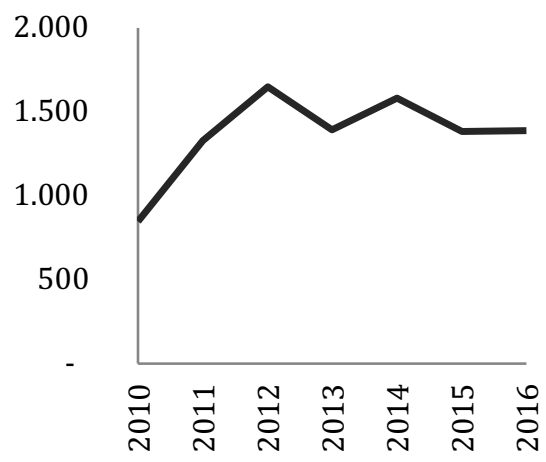

Gráfica 2.10. Evolución de las personas atendidas por el Área de Atención Sin Hogar de Cáritas Bizkaia. Cáritas Bizkaia.

${ }^{18}$ El hogar hace mención aquí al dispositivo habitacional, al espacio doméstico. 
reflejados muestran que si bien la necesidad global parece disminuir, esta no contempla algunas situaciones de especial y verdadera necesidad que completan un panorama en gran medida precario y cada vez con mayor tendencia a generar situaciones de vulnerabilidad y exclusión social.

Si hasta este punto se ha abordado la necesidad, a partir de aquí el interés radica en las razones que llevan a dicha situación. Este fenómeno de una alta y en proceso de precarización necesidad de vivienda, se pone en evidencia al constatarse en gran parte de la población una considerable incapacidad económica de generar demanda de vivienda tanto en el mercado libre como en el sistema público de vivienda. El gasto medio por unidad de convivencia destinado a la vivienda en Euskadi en la segunda década de este siglo supera el máximo del 30\% tolerable y aconsejado por diversos organismos (López, 2014), aumentando respecto a años anteriores (Flores y Ubrich, 2014). Como consecuencia, muchas unidades de convivencia se han visto obligadas a tomar medidas, dado que la exclusión residencial no solo afecta a la ausencia de vivienda, «sino que nos habla de situaciones sociales más complejas, compuestas de más factores y que no puede explicarse únicamente por motivos de privación y accesibilidad económica. Al hablar de exclusión residencial, se recogen también las situaciones relativas a accesibilidad, inadecuación, habitabilidad e inestabilidad de la vivienda» (Flores y Ubrich, 2014: 64). Según el citado trabajo, casi 3 de cada 10 personas en Euskadi han reducido sus gastos de calefacción y otros suministros. Algunos colectivos están especialmente afectados por esta situación, como por ejemplo los de diferente nacionalidad -hasta un $54 \%$ de las unidades formadas por personas de nacionalidad diferente a la española o de la Unión Europea son vulnerables a la exclusión residencial según el estudio-, o los jóvenes:

«La emancipación de las personas jóvenes se está viendo fuertemente frenada por problemas económicos, configurándose el acceso a la vivienda como el principal obstáculo para la constitución de un hogar independiente» (Ley 18/2008, de 23 de diciembre, 2008).

\section{Precios en aumento (o búsqueda del mismo)}

Tomando como ejemplo la ciudad de Bilbao dentro del AMB, puede observarse que el problema del precio como obstáculo para el acceso no es algo nuevo, si no más bien, como se ha apuntado en el capítulo inicial, de un problema estructural. Ya en siglos anteriores y durante «mucho tiempo la ciudad se tuvo que desarrollar exclusivamente en los espacios delimitados en el interior de dicha muralla, ya que todo lo exterior carecía de los beneficios de los que disfrutaban los habitantes de la villa. Esa limitación dio lugar a numerosos problemas, como las frecuentes inundaciones y un alto precio de la vivienda» (Ayuntamiento de Bilbao, 2012:1). Pero la 
evolución y los cambios en los precios de la vivienda pueden verse afectados por muy diversos factores. La vivienda presenta, frente a otros muchos bienes, una serie de características con implicaciones territoriales que afectan en la decisión y capacidad de acceder a la misma (González et al., 2003: 145). La localización fija en el espacio que le impide ser trasladada de un punto a otro -no existiendo dos localizaciones iguales-, y el tratarse de una mercancía de la que ninguna persona puede prescindir, suponen dos aspectos fundamentales que condicionan la elección de la persona consumidora (Harvey, 1977: 164).

En cualquiera de los casos, el elevado precio que alcanzó la vivienda en la década de 2000 en España excluyó a un conjunto de la población muy grande (Beltrán, 2009); esto afectó de igual manera a Euskadi -y a su vez al AMB- con «un fortísimo incremento [...], tanto en régimen de alquiler como de propiedad, que ha determinado que la vivienda se convierta en uno de los principales problemas de las familias vascas» (Ley 18/2008, de 23 de diciembre, 2008). En los últimos años, el precio medio de la vivienda en España ha descendido considerablemente -el Índice de Precios de la Vivienda del INE situaba la media de 2013 en un 64\% del precio de 2007-, siendo Euskadi una de las comunidades en las que el descenso ha sido más pronunciado -en este caso el índice estaba en un 61\%-. Y aunque proporcionalmente ha descendido más el precio en esta autonomía, ha sido y es uno de los lugares con los precios más altos del estado. Los datos y series estadísticas del precio del metro cuadrado de vivienda libre ofrecidos tanto por el Ministerio de Fomento como por los Registradores de la Propiedad muestran que tanto Euskadi, como concretamente el AMB, están siempre a la cabeza a lo largo de los últimas décadas.

En cuanto a la evolución de estos precios, las características de esta bajada en la venta (Gráfica 2.16 más abajo), y en el alquiler (Gráfica 2.11) señalan cómo el mercado muestra una importante resistencia a una clara bajada y ajuste de los precios a la capacidad económica de las personas con mayor necesidad, estando siempre en la búsqueda de un aumento de estos dentro de lo que el contexto permite para una adecuada reproducción del sector. En el caso del alquiler en Bilbao, la bajada entre 2009 y 2014 vino precedida por una clara subida a partir de ese año. Algo que viene siendo confirmado por los informes institucionales publicados: el descenso es lento, tiende a estabilizarse e incluso a aumentar en determinadas situaciones (Observatorio Vasco de la Vivienda, 2015b, 2017a). Y con todo, la situación de aquellos sectores más excluidos no deja de empeorar y engullir a más gente. En consecuencia, aunque la bajada de precios en general ha sido palpable, el problema de acceso no ha desaparecido ${ }^{19}$. En muchos

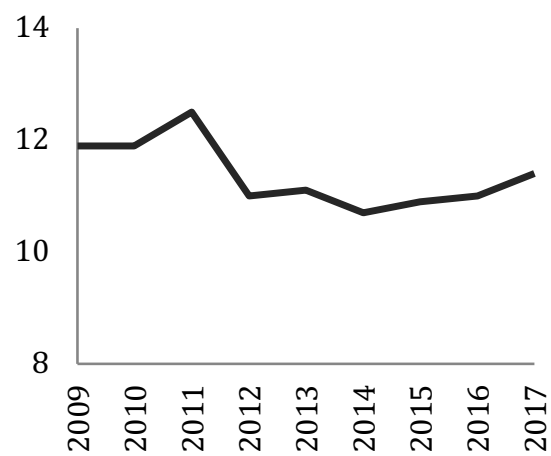

Gráfica 2.11. Evolución de la oferta de los precios de alquiler en Bilbao $\left(€ / \mathrm{m}_{2}\right)$. Idealista.

${ }^{19}$ El Diario.es (2017): «La caída del precio de los pisos es un espejismo para los precarios que siguen sin acceso a la vivienda», disponible en http://www.eldiario.es/economia/ mercado-vivienda-reactiva-lastrado-empleo_0_647785353.html. 


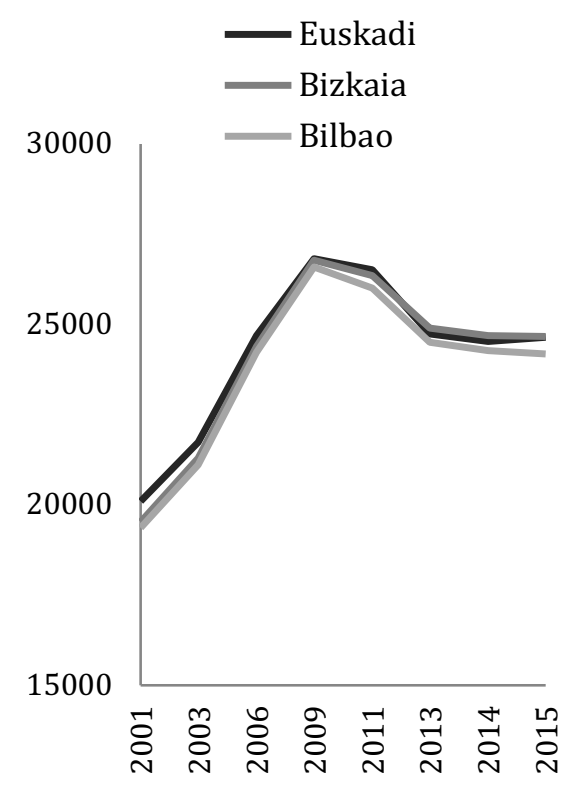

Gráfica 2.12. Evolución de la renta de trabajo familiar media.

Eustat. casos, el problema de la desproporción de los precios frente a las rentas motiva la elección forzada del alquiler -generalmente compartido- como régimen de tenencia, dado que solo así es viable el gasto de la vivienda ${ }^{20}$. La evolución de los precios ha de ser por lo tanto analizada junto a la de los salarios, el paro, la calidad del empleo, o las condiciones de acceso a la compra de una vivienda, entre otras variables.

\section{Salarios y desempleo}

Si tanto el AMB como Euskadi tienen uno de los precios medios de venta y alquiler de vivienda más altos de España, también existe una diferencia de renta media personal y familiar entre las comunidades autónomas, siendo las de Euskadi unas de las más altas. Tanto la Encuesta de Presupuestos Familiares como la de Condiciones de Vida elaborada por el INE sitúa a esta comunidad siempre en los primeros puestos. La relación entre precio y renta será la que decante en gran medida la capacidad de acceso, lo cual se analiza más abajo. Por otro lado, así como el AMB presenta un precio medio del metro cuadrado de vivienda libre en venta superior al de Euskadi y Bizkaia, su renta media familiar y personal es ligeramente inferior tanto a la de la comunidad autónoma como a las de sus tres provincias, según datos del Instituto Vasco de Estadística EUSTAT. Lo cual se confirma al observar que en los últimos años, tanto a nivel autonómico, provincial y metropolitano las rentas medias de trabajo personales y familiares presentan una subida desde 2001 hasta 2009, año en que comienza una clara bajada que dura hasta 2013 (Gráfica 2.12) -coincidiendo con la bajada de pecios de las Gráficas $2.11 \mathrm{y}$ 2.16-. Pero a partir de ahí, en Euskadi la tendencia comienza a invertirse, en Bizkaia sigue bajando aunque lentamente, y con algo más de fuerza en el AMB.

Pero más allá de la evolución de las rentas medias, la diversidad de casos puede esconder situaciones muy dispares. En cuanto a la juventud vasca, por ejemplo, el aumento de la accesibilidad al mercado de trabajo que parecían reflejar las cifras de años como el de 2015 «se traduce en una fuerte precarización del empleo joven» (Consejo de la Juventud de España, 2016: 1). Y es que como en otras áreas de España, «ha habido una devaluación interna, en vez de devaluar la moneda hemos devaluado los salarios» (Burón, 2016). Esta devaluación se ve reflejada en algunos de los sectores de la sociedad más sensibles en cuanto a su capacidad de acceso a la vivienda, como es el caso de las personas demandantes de vivienda protegida ${ }^{21}$. El

20 El Salto (2018): «Alquilar es de pobres, y cada vez más», disponible en https://www.elsaltodiario.com/vivienda/mercado-inmobiliario-alquilar-pobres-airbnbgentrificacion.

${ }^{21} \mathrm{El}$ Correo (2018): «Tres de cada cuatro demandantes de un piso social en Euskadi gana menos de 20.000 euros», disponible en http://www.elcorreo.com/sociedad/tres-cuatrodemandantes-20180203222021-nt.html. 
Plan Director de Vivienda 2013-2016 identificaba una disminución del nivel de ingresos medios de la población inscrita en el servicio de vivienda Etxebide alcanzando el valor más bajo de la serie analizada desde 2008 (Gobierno Vasco, 2013a: 46). El avance del Plan de Vivienda 2018-2020 constata cómo con los años la situación se sigue agravando, ya que el «nivel de ingresos ponderados de la población demandante de vivienda protegida de Etxebide ha descendido considerablemente, hasta situarse en el primer trimestre de 2017 en 16.845 euros de media (un 22\% menos que en 2013)»(Gobierno Vasco, 2017: 117).

Desde una perspectiva comparada con el resto del estado, Euskadi y Bizkaia son también unas de las comunidades y provincias con menor tasa de desempleo. Lo cual no les libra de situaciones de vulnerabilidad y exclusión. Con su mejor dato en 2008, este ha ido subiendo paulatinamente hasta alcanzar su máximo en 2014 (16\% y $18 \%$ respectivamente), año a partir del cual está descendiendo, pero siempre con niveles por encima de la serie 2002-2011. La problemática es claramente más grave en colectivos como el de las mujeres, las personas jóvenes, las migrantes -especialmente de fuera de la Unión Europea-, o la combinación de alguno de ellos (Gráfica 2.13). Son estos unos de los más vulnerables al acceso a la vivienda.

\section{Deudas hipotecarias y desahucios}

«Poseer una casa ha aportado seguridad económica a algunas personas. Para los pudientes, pagar una hipoteca a plazos durante los años de su vida laboral sirve como forma de ahorro para la vejez. Pero para muchas familias de la clase trabajadora y de clase media, el compromiso con un título de propiedad como única forma viable de acceder a una vivienda digna resulta opresivo. La constante carga de las cuotas de la hipoteca representa una adversidad económica que los obliga a dedicar a la vivienda una parte mucho mayor de sus ingresos de lo que deberían, a trabajar horas extras o a tener varios empleos a la vez» (Madden y Marcuse, 2018: 114).

La primacía de la propiedad como régimen de tenencia principal en el AMB -se abordará esta cuestión más adelante- esconde una realidad compleja y delicada, más si cabe en tiempos de crisis. La Encuesta Continua de Hogares del INE muestra que a pesar de que en torno a un $85 \%$ del parque residencial de Euskadi está identificado como en propiedad por compra de la vivienda, cerca del 30\% de este tiene pagos pendientes, con lo que algo más de la mitad del parque es el que realmente está en propiedad y en principio libre de riesgos por impago -los datos hacen referencia a la serie 2013-2016-. El sistema de créditos de vivienda a través de entidades privadas establecido entre 1975 y 1978 supuso el cambio de una economía dirigida a una de mercado, con la desaparición de la obligación para cajas de ahorros y otras entidades financieras de dedicar parte de sus fondos a

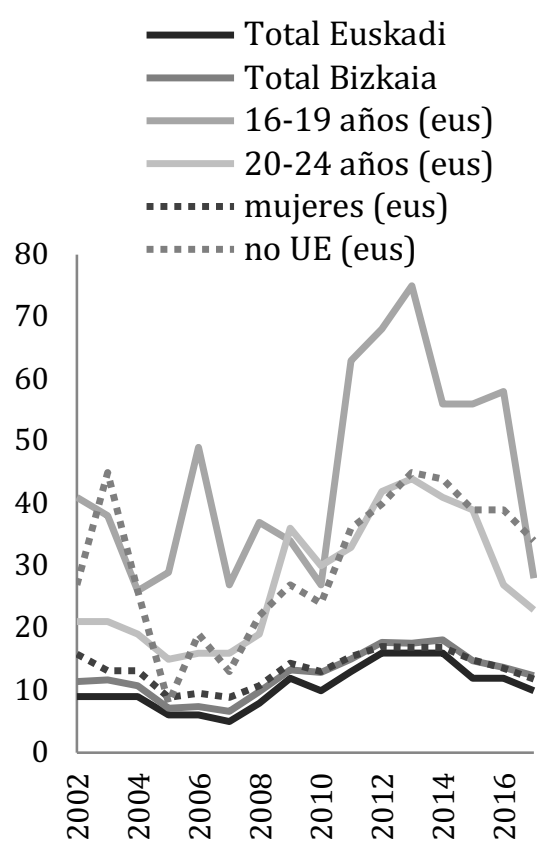

Gráfica 2.13. Evolución del desempleo en Euskadi (\%). INE. 
préstamos de vivienda (Beltrán, 2009: 456). El elevado precio de las viviendas, o mejor dicho, el elevado porcentaje que han de destinar muchas unidades de convivencia al pago de la vivienda, hace que sean muchos los casos sin capacidad para el pago completo de la misma directamente. Quien está en una situación así «dispone de dos opciones básicas: o bien la alquila de un propietario que se especializa en la compra especulativa de viviendas construidas para vivir de sus rentas, o puede endeudarse para comprarla, bien consiguiendo préstamos de los amigos y parientes o contratando una hipoteca con una institución financiera» (Harvey, 2014: 34). Cabría sumar a estos perfiles otro habitual en el AMB: el de una propiedad con pocas o incluso una sola vivienda en alquiler -proveniente de alguna herencia o adquirida como inversión- que complementa las rentas de trabajo con las provenientes de dicho inmueble. En cualquier caso, los efectos sobre la persona arrendataria son los mismos, por los deseos de obtener el máximo beneficio posible que están generalmente detrás de esos tres caminos. La escasa oferta de alquiler y una cultura de la propiedad fuertemente arraigada hacen que la segunda opción, la relativa a la compra y habitual endeudamiento, sea muy generalizada. Pero si la financiación hipotecaria es, como dice Harvey, una transacción muy peculiar que implica la adición de una importante prima extra para poder adquirir un inmueble con un valor económico inferior, es «difícil entender el provecho de esa transacción. ¿Por qué decidimos hacerla? La respuesta es, por supuesto, que necesitamos el valor de uso de la vivienda como lugar donde vivir...» (Harvey, 2014: 35).

En los últimos años se vienen observando múltiples ejemplos de dramas personales y familiares, así como contradicciones, consecuencia de los riesgos adquiridos a través de este sistema de financiación $^{22}$. La enorme escalada de precios de las décadas pasadas, pieza fundamental de un modelo residencial excluyente ya señalado someramente en el capítulo primero, hizo que muchos personas y unidades de convivencia se vieran forzadas a la compra de inmuebles a precios altos con un importante endeudamiento. Esto ha supuesto que, tras el desinflamiento de la burbuja inmobiliaria, los que así lo hicieron posean una vivienda que actualmente en el mercado vale mucho menos de la cantidad por la que se endeudaron y que todavía no han terminado de pagar. Por lo que el drama de la deuda vigente se ve incrementado por la imposibilidad de deshacerse de esa vivienda sin sufrir una pérdida sustancial (Harvey, 2014: 37). Esto ha favorecido el nacimiento de movimientos sociales con una gran relevancia y fuerza como la Plataforma de Afectados por la Hipoteca, cuya proliferación y expansión por toda España no es si no una muestra de la gravedad del problema. Esta cuestión ha afectado también a Euskadi, aunque se ha podido resistir al mejor la situación:

22 El Diario.es (2017): «Condenada a 45 días de arresto domiciliario en una casa que le obligan a desalojar por estar ocupándola», disponible en http://www.eldiario.es/madrid/ ocupacion-arresto_domiciliario-sentencia_0_630287111.html. 
«se observan muchas similitudes en el proceso de boom inmobiliario y en la generación de riesgos del sistema de hipotecas, si bien las relativamente más bajas tasas de desempleo y su mayor cobertura social han hecho que la incidencia de la crisis de las ejecuciones y los lanzamientos sea menor» (Etxezarreta et al., 2013: 74). En este sentido, según los datos ofrecidos por la Estadística del Consejo General del Poder Judicial, al comienzo de la serie 2007-2016 se produjo en Euskadi un importante incremento de ejecuciones y lanzamientos con máximos en 2012 y 2009 respectivamente, años a partir de los cuales se han ido reduciendo, pero siempre manteniéndose por encima de las cifras iniciales de la serie (Observatorio Vasco de la Vivienda, 2017b: 5). En cualquier caso, el riesgo y la afección no solo los sufren aquellas personas con vivienda en propiedad y pagos pendientes, si no que afecta también a aquellas en régimen de alquiler. Las estimaciones en Euskadi para 2015 eran de unas 29.663 familias con problemas para pagar la hipoteca y unas 31.338 con dificultades para afrontar el pago del alquiler $-18.860 \mathrm{y}$ 19.756 con problemas graves respectivamente- (Observatorio Vasco de la Vivienda, 2017b: 7). Los efectos de todo ello sobre la proliferación de los desahucios ha sido palpable en los últimos años. Con todo, se ha señalado en alguna ocasión que los datos de los desahucios finalmente ejecutados pueden esconder muchas unidades de convivencia que, forzadas por la gravedad de la situación, dejan la vivienda antes de que se complete el proceso (Madden y Marcuse, 2018: 83).

\section{Gasto destinado a la vivienda}

La imagen mostrada por algunos de los indicadores mostrados hasta aquí, como el hecho de que Euskadi sea una de las comunidades autonómicas con menor índice de vulnerabilidad (Méndez et al., 2015), no implica que en esta comunidad autónoma el esfuerzo necesario para acceder a una vivienda sea menor. Como se ha visto, a una de las mayores rentas medias anuales del estado le acompaña uno de los índices de precios más altos. Tal y como se ha apuntado previamente, será al cruzar ambas variables cuando se pueda empezar a tener información válida para evaluar la situación; por ejemplo, en el caso de la juventud, «la rigidez del mercado inmobiliario del País Vasco viene limitando el acceso a la independencia residencial de la mayoría de la población joven. En la actualidad, el esfuerzo económico que debiera realizar una persona joven asalariada para acceder a la compra de vivienda es el segundo más alto de España y en el caso del alquiler el cuarto más restrictivo» (Consejo de la Juventud de España, 2016: 1).

El Plan Director de Vivienda 2013-2016 señalaba una caída en la construcción de vivienda protegida en 2012 motivada por la disminución de demandantes con medios para comprar, debido a la dificultad de crédito y el empeoramiento de la situación personal en general, lo que generaba situaciones de gran incertidumbre vital 
(Gobierno Vasco, 2013a: 77). La situación cinco años después no había hecho si no empeorar, ya que «en los últimos años han surgido nuevos colectivos a los que atender desde las políticas de vivienda, como las víctimas de los desahucios y lanzamientos de alquiler, familias que teniendo ingresos no pueden hacer frente al pago de sus viviendas e incluso personas adjudicatarias de VPO que no tienen acceso a crédito hipotecario. Esta situación se ha visto agravada además por las importantes restricciones presupuestarias de las Administraciones en un contexto de crisis» (Gobierno Vasco, 2017: 34).

En este sentido, interesa sintetizar aquí los resultados obtenidos de una fuente muy útil para este trabajo, de gran interés y actualidad. Dado que uno de los objetivos de la investigación es analizar la accesibilidad económica de la población a la oferta de vivienda disponible, es de gran ayuda un informe sobre el coste de la emancipación residencial para la juventud en Euskadi entre los años 2007 y 2013 (López, 2014). Está centrado en el colectivo con mayor necesidad de emancipación -de 18 a 34 años-, en el que se identificó un salario medio mensual de $1.400 €$ y que sirvió de base de cálculo para los indicadores que desarrolla. Aunque no es este colectivo el único objeto de estudio del presente trabajo, sí es uno de los perfiles con mayor necesidad de alojamiento; en cualquier caso, las lecturas pueden extenderse a otros colectivos no jóvenes pues las situaciones de renta y desempleo son similares a las de otros colectivos, dado que «la vulnerabilidad y precariedad en las condiciones de empleo y trabajo $[\ldots]$ ha pasado a definir la vida laboral de muchas generaciones, jóvenes o no» (Consejo de la Juventud de España, 2013: 3). Con lo cual, se puede considerar una referencia válida en lo que al coste de la emancipación respecta.

Así, muchos de los indicadores presentados en dicho estudio son muy valiosos para el cometido de esta investigación. Principalmente o que hace es fijar los límites del gasto personal que debe dirigirse al pago de la vivienda, y alrededor de ese concepto construyen una serie de parámetros que relacionan precio, régimen de propiedad, salarios, tipo de vivienda y superficie de la misma. Todo su desarrollo se apoya en la necesidad de que el esfuerzo económico para asegurar el alojamiento personal no debe superar el 30\% del salario neto mensual. Cifra en la que parece hay un consenso general entre muy diferentes agentes, incluso financieros, pues «a la hora de conceder una hipoteca es el umbral máximo de endeudamiento tolerable» (López, 2014: 3). Dado el caso, recuerdan en el informe que la oficina estadística de la Comisión Europea indica que no se debiera de rebasar el $40 \%$ del salario pues supone ya un sobre esfuerzo económico «que aboca a quien accede en estas condiciones a la vivienda a una situación de precariedad» (López, 2014: 42). Los resultados que ofrece son verdaderamente preocupantes, a pesar de que la tendencia dentro del periodo analizado va mejorando (Tabla 2.5). Se observa a partir de los indicadores analizados por López que 
la accesibilidad a la vivienda para cualquier persona con un salario medio similar al de la base de cálculo es casi una utopía: o bien los salarios debieran ser el doble, o bien el precio medio de la vivienda debiera reducirse drásticamente. Algo que se podrá confirmar más adelante a partir del trabajo de campo realizado en esta investigación.

\begin{tabular}{|c|c|c|c|}
\hline Año & 2007 & 2011 & 2013 \\
\hline Sueldo base de cálculo & $1.286 €$ & $1.461 €$ & $1.400 €$ \\
\hline \multicolumn{4}{|c|}{ Compra } \\
\hline $\begin{array}{l}\text { Coste de acceso a la vivienda libre en } \\
\text { propiedad }\end{array}$ & $98,9 \%$ & $68,2 \%$ & $62,8 \%$ \\
\hline $\begin{array}{l}\text { Coste de acceso para la compra de un } \\
\text { piso libre de obra nueva }\end{array}$ & $105,8 \%$ & $78,6 \%$ & $76,9 \%$ \\
\hline $\begin{array}{l}\text { Coste de acceso para la compra de un } \\
\text { piso libre de segunda mano }\end{array}$ & $91,3 \%$ & $61,1 \%$ & $57,0 \%$ \\
\hline $\begin{array}{l}\text { Coste de acceso para la compra de una } \\
\text { vivienda unifamiliar libre, nueva o } \\
\text { usada }\end{array}$ & $152,5 \%$ & $106,2 \%$ & $92,4 \%$ \\
\hline $\begin{array}{l}\text { Precio máximo tolerable de compra de } \\
\text { la vivienda libre }\end{array}$ & $84.842 €$ & $110.089 €$ & $98.644 €$ \\
\hline $\begin{array}{l}\text { Diferencia entre el precio de venta de } \\
\text { la vivienda libre y el precio de } \\
\text { máximo tolerable de compra }\end{array}$ & $195.860 €$ & $140.252 €$ & $107.965 €$ \\
\hline $\begin{array}{l}\text { Superficie máxima tolerable de compra } \\
\text { de vivienda libre }\end{array}$ & $27,1 \mathrm{~m}^{2}$ & $39,6 \mathrm{~m}^{2}$ & $41,9 \mathrm{~m}^{2}$ \\
\hline $\begin{array}{l}\text { Diferencia entre la superficie media de } \\
\text { la vivienda libre y la superficie } \\
\text { máxima tolerable de compra }\end{array}$ & $64,6 \mathrm{~m}^{2}$ & $53,5 \mathrm{~m}^{2}$ & $48,6 \mathrm{~m}^{2}$ \\
\hline $\begin{array}{l}\text { Ingresos mínimos para la compra de } \\
\text { una vivienda libre }\end{array}$ & $238 \%$ & $135 \%$ & $116 \%$ \\
\hline \multicolumn{4}{|c|}{ Alquiler } \\
\hline $\begin{array}{l}\text { Coste de acceso a la vivienda libre en } \\
\text { alquiler }\end{array}$ & $69,2 \%$ & $61,4 \%$ & $59,0 \%$ \\
\hline $\begin{array}{l}\text { Renta máxima tolerable de alquiler de } \\
\text { una vivienda libre }\end{array}$ & $386 €$ & $438 €$ & $420 €$ \\
\hline $\begin{array}{l}\text { Diferencia entre la renta de mercado y } \\
\text { la renta máxima tolerable de alquiler }\end{array}$ & $504 €$ & $458 €$ & $405 €$ \\
\hline Superficie máxima tolerable de alquiler & $32 \mathrm{~m}^{2}$ & $36 \mathrm{~m}^{2}$ & $38 \mathrm{~m}^{2}$ \\
\hline
\end{tabular}

La cuestión es que el porcentaje de salario que deben destinar a la vivienda en Euskadi las personas con un sueldo en torno a los $1.400 €$, tanto en propiedad como en alquiler, no solo sobrepasa tanto el $30 \%$ y el $40 \%$, si no que alcanza valores mucho mayores, del $60 \%$ en
Tabla 2.5. Indicadores del coste de emancipación de la población joven en Euskadi para los años 2007, 2011 y 2013. López, 2014. 
adelante. La situación se agrava sobremanera al considerar el salario mínimo interprofesional, que para el año 2013 estaba en 645,30€, o incluso peor todavía al considerar los altos niveles de desempleo -en Euskadi solo el $40 \%$ de la población objetivo del informe estaba ocupada-. Según datos del Eustat, en la Comarca del Gran Bilbao la renta media personal disponible en 2011 era de $1.347 €$, por debajo aunque cercana a la base de cálculo del informe desarrollado por López con la coordinación del Observatorio Vasco de la Juventud, lo cual muestra que una importante proporción de población se enfrenta a dificultades como las mostradas en el mismo, y por lo tanto esos indicadores no solo son reflejo de la población joven. Por supuesto, los valores medios son precisamente eso, referencias que borran o diluyen la heterogeneidad y los extremos. Serán muchas las personas que pueden acceder a la vivienda en la situación en la que actualmente está el mercado. Pero aquí la intención es centrarse en la población que no tiene asegurado ese derecho por carecer de medios económicos suficientes para ello. Algo que, como se ha pretendido demostrar a lo largo de este apartado, no es un tema menor en Euskadi o en el AMB.

Si se vuelve a los resultados de la Encuesta de Necesidades y Demanda de Vivienda en Euskadi para 2015, se pueden identificar tres fenómenos en relación con lo anterior, que evidencian una vez más un desfase existente entre la necesidad y la oferta de vivienda. Primero, en la serie de 2009 a 2015, casi la mitad de las personas encuestadas tienen un perfil de necesidad de acceso a la vivienda protegida individual, con lo que se han de enfrentar ellas solas a unos gastos que no pueden repartir entre una unidad de convivencia. Segundo, entre un $70 \%$ y un $80 \%$ de ellas no puede destinar una cifra superior a los $600 €$ al mes al pago de la vivienda -algo más de la mitad no superaría los $450 €$ de gasto, y en torno a un tercio se queda por debajo de los $300 €$ - Tercero, apenas una tercera parte de las personas encuestadas pertenecen a una unidad de convivencia en la que hay dos personas con capacidad de participar en la financiación de dicho gasto. Enfrentadas estas realidades con cualquier mínimo estudio de la oferta de vivienda existente, tanto libre como protegida, se evidencia la clara exclusión que todos estas unidades de convivencia y personas sufren de un parque residencial mercantilmente obsoleto para gran parte de la población. Con todo, se ha de tener en cuenta que, como ya se ha insistido, la citada encuesta deja fuera de la estadística a aquellas personas sin ingresos, con lo cual los datos reales serían probablemente peores. Ante esta situación, las alternativas de estas personas pasan, bien por diferentes situaciones de precariedad, o por el aplazamiento de su emancipación y la consecuente deformación de sus biografías vitales. Porque incluso la búsqueda de fórmulas temporales para compartir vivienda con otras unidades de convivencia queda lejos de aliviar la presión económica de estas personas en ciudades como Bilbao, donde los 
precios del alquiler suponen un gasto en la vivienda superior al $30 \%$ recomendado ${ }^{23}$.

Como se viene apuntando, por desgracia la problemática, aunque evolucionada, no es novedosa. Algunos estudios revelan cómo en la primera década del siglo XX en Bilbao «en ningún caso se planteó una política de alquileres ajustada a las posibilidades de los sectores sociales con menos recursos, que era la única alternativa de acceso a la vivienda para muchos individuos. En consecuencia, las casas baratas tan sólo estuvieron al alcance de aquellos ciudadanos con un sueldo estable y algunos ahorros con los que poder [hacer] frente a la propiedad de su vivienda» (Muñoz, 2009: 790). Más cercano en el tiempo y en el contexto español, Ráfols denunciaba en 1982 que «la coexistencia de un alto porcentaje de la población carente de vivienda o mal alojada junto con un alto porcentaje de viviendas sin ocupar muestra la fuerte ineficacia social del sistema» (Beltrán, 2009: 471). El propio Ayuntamiento de Bilbao apuntaba en 1995 a una serie de fenómenos que «deben ser tenidos en cuenta en la planificación en materia de vivienda, ya que hoy por hoy la oferta no parece responder a las necesidades de los citados grupos de población» (Ayuntamiento de Bilbao, 1995: 20). Ni siquiera en los años de mayor vorágine constructora el problema fue resuelto, pues «podemos traer a colación las 11.987 Viviendas Libres iniciadas en Euskadi en el año 2005 y que tampoco ayudan a solucionar el problema del acceso a la vivienda de los ciudadanos vascos, como consecuencia de sus altos precios» (Burón, 2008: 6), si bien gran parte de ese esfuerzo constructor se dirigió a la ciudad de Vitoria-Gasteiz.

Por todo lo visto hasta aquí, se puede confirmar la inaccesibilidad económica al mercado de vivienda libre $-\mathrm{y}$ cada vez más a la propia oferta de vivienda protegida- de una nada despreciable parte de la población demandante de vivienda. Lo que lleva a cuestionar que el desarrollo de nuevas áreas urbanas residenciales, al menos bajo sistemas de ordenación y lógicas inmobiliarias convencionales, vaya a solucionar el problema. A pesar de la caída de precios tras el periodo más álgido de la burbuja inmobiliaria, una parte importante de la población sigue encontrándose con una gran dificultad de satisfacer la accesibilidad económica a la vivienda, pues se cuenta con pocos ahorros para afrontar el gasto. Tanto el de la renta mensual de un alquiler, como al de una hipoteca, en caso de conseguir contratarla. Posiblemente, en varias de las zonas urbanas pertenecientes al ámbito de estudio las generaciones de jóvenes con edad de emancipación actuales formen parte de un movimiento de población inverso al protagonizado por su generación anterior. Una formada por parejas que hace 30 o 40 años accedieron a un mercado de trabajo en alza, estable y con posibilidades de progreso salarial, que se movieron hacia áreas residenciales de calidad y de nueva construcción, y que tienen

${ }^{23}$ El País (2015): «El alquiler de una habitación 'se come' la mitad del salario», disponible en https://elpais.com/economia/2015/09/03/vivienda/1441292528_745068.html. 
hoy en día descendientes que, a pesar de haber adquirido una formación superior de calidad -en muchos casos mejor preparados que sus progenitores-, ven muy complicada la inserción en el mercado laboral y, por consiguiente, se ven forzados a salir de dichas áreas residenciales porque el precio de la vivienda en ellas es inalcanzable. Así, la meta de una accesibilidad espacial planteada en algunos foros centrados en la ordenación territorial como la idea de alcanzar un territorio que permita «elegir dónde vivir» ${ }^{24}$, se ve drásticamente condicionada por una inaccesibilidad económica. Existe por tanto la necesidad de una respuesta multi-escalar y coordinada entre todos los agentes participantes para poder avanzar hacia el derecho a la vivienda.

\section{$-2.3 .2-$}

\section{Oferta inadecuada, pero no insuficiente}

Ante la situación anterior, extensible a otras comunidades autónomas, muchas son las voces que vienen denunciando y poniendo sobre la mesa una de las grandes contradicciones del modelo inmobiliario residencial español:

«Mientras sobran muchísimas viviendas, cada vez más segmentos de la población quedan excluidos del mercado de la vivienda, porque la vivienda libre les es inaccesible y la VPO es prácticamente inexistente. Ello, me parece, refleja el fracaso de las políticas urbanística y de vivienda y de vivienda social de la década de 2000, que han ido a rastras de un desmedido e injustificado crecimiento inmobiliario» (Beltrán, 2009: 469).

Euskadi no es, por diversos motivos, la comunidad autónoma española en la que con mayor fuerza se ha dado este fenómeno. Es de hecho, según algunos estudios comparados, una de las modélicas en política de vivienda; lo que lleva a afirmar que «es innegable que los efectos del pinchazo de la burbuja inmobiliaria están siendo menores en Euskadi que en otras CCAA. Pero, que seamos cabeza de ratón, no quiere decir que esta sea la situación ideal» (Burón, 2015a). Así, podría decirse que unas políticas y unos agentes privados centrados en la gestión de la vivienda realmente centrados en la función social de la misma, deberían haber conducido y coordinado al sector de la construcción para que las nuevas viviendas construidas aumentasen o decreciesen en función de si la necesidad lo hacía (Madden y Marcuse, 2018: 149). Como se intenta desarrollar en este apartado, esto no ha sido así por diversos motivos y con diferentes consecuencias.

${ }^{24}$ Defendida por ejemplo por Natxo Izeta en su ponencia dentro del congreso Euskal Hiria 2015. 


\section{Primacía de la propiedad en un contexto de reducción de rentas}

La generalización y el fortalecimiento del régimen de tenencia en propiedad a lo largo de las décadas de dictadura bajo el régimen franquista, transformando una sociedad que vivía principalmente de alquiler en busca de una sociedad conservadora financiera $y$ geográficamente atada (Naredo y Montiel, 2011:27-34) es una herencia que está siendo difícil de gestionar y transformar ante la situación de crisis de alojamiento que viven muchas personas:

«Hay que buscar las raíces de nuestro "propietarismo" y alergia al alquiler en los años 50 del pasado siglo -el franquismo entendió que un país de propietarios era mucho menos susceptible de derrocar al régimen que un país de inquilinos - y en el pacto que desde 1956 (nuestra primera ley del suelo) se ha mantenido entre la Administración, el sector financiero y la propiedad del suelo para hacer extraordinariamente rentable la venta de vivienda y muy poco atractivo el alquiler. Las razones de nuestra anorexia arrendaticia no son culturales o técnicas, sino políticas y mercantiles [...] Buena parte de los partidos y medios españoles, como ya he señalado, defienden que la propiedad privada es sagrada. No se sabe si desconocen el contenido de nuestra Constitución en este punto o si se hacen interesadamente los despistados. La realidad es que, como hemos reseñado, nuestra Carta Magna constitucionaliza la función social de la propiedad, la subordinación de toda forma de riqueza al interés general y la intervención pública en la economía» (Burón, 2012).

Pero no fue ese un movimiento pionero. En otros países ya se había reflexionado sobre estas cuestiones a principios del siglo XX (Veiller, 1905: 52-53), y años antes de que se estableciesen con rotundidad las raíces de ese modelo actualmente heredado, en Euskadi ya se habían plantado algunas semillas:

«...el nacionalismo asoció la vivienda unifamiliar con la tradicional familia rural. De ahí que se quisiera extrapolar la familia tradicional rural al mundo obrero moderno, donde la casa propia y barata, el caserío, era valorado como un pilar esencial para la conservación de la estructura tradicional vasca cimentada en la familia, la propiedad y la religión. El mundo rural se oponía también a la ciudad, que era considerada foco de inestabilidad y de fuertes conflictos sociales que destruían la familia y el hogar. La propiedad de la vivienda unifamiliar se entendió además como un elemento de bienestar, independencia y de estabilidad del proletariado urbano; a la vez que era una forma de hacer frente al socialismo y el sindicalismo de izquierdas, que supuestamente era contrario a la 


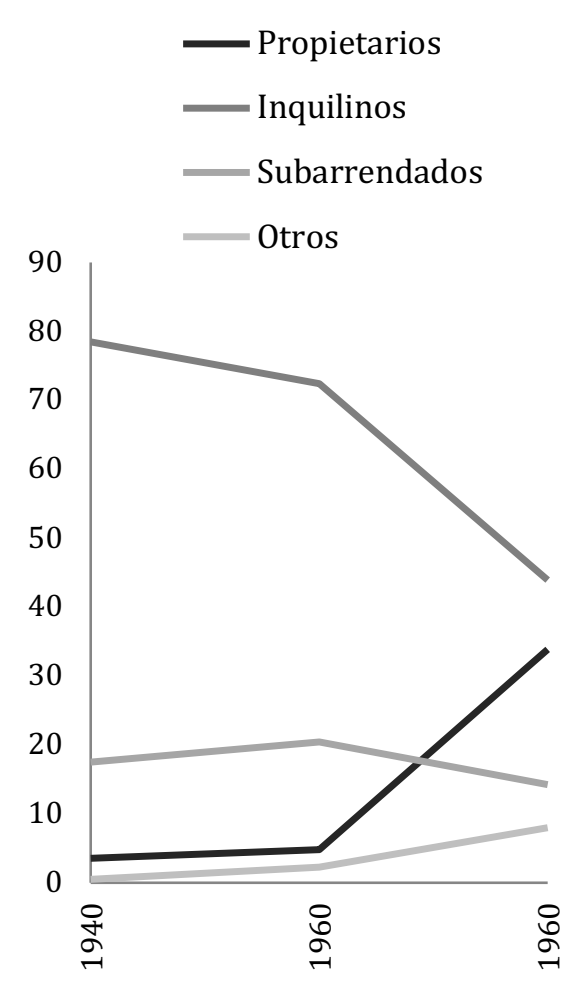

Gráfica 2.14. Porcentajes de régimen de tenencia de la vivienda por población total, Bilbao 19401960. Bustillo, 2004. idiosincrasia vasca por ser ateo, enemigo de la familia cristiana y contrario a la propiedad» (Muñoz, 2009: 784).

Como desarrolla Muñoz, el estado se limitó a ayudar al capital privado a desarrollar vivienda en propiedad, sin plantearse una política de alquileres ajustada a las posibilidades sociales de los sectores con menos recursos. La clase media fue la principal beneficiada de las leyes de casas baratas, así como las cooperativas, que entendieron estas leyes como un negocio inmobiliario. La cuestión es que en apenas dos décadas se produjo una convergencia de los regímenes de tenencia, el inicio del paso de una sociedad arrendataria a una propietaria -o con intenciones de serlo- (Gráfica 2.14). Hasta llegar a una distribución de regímenes como la actual, en la que según datos de 2015 en Bizkaia un 89,90\% de las viviendas eran en propiedad, y tan solo el 8,7\% en alquiler (Gobierno Vasco, 2015a).

Frente a lo anterior, se lleva varios años constatando que la demanda de vivienda en alquiler va en aumento, al menos con total claridad es el régimen de tenencia predominante en las solicitudes de vivienda protegida (Gobierno Vasco, 2013a: 128, 135, 148, 2017: 112). Posiblemente, debido a una reducción en las rentas de muchas unidades de convivencia y el efecto de esta en su incapacidad de endeudamiento, o a los estragos que las altas hipotecas contratadas en la década de 2000 están produciendo en muchas familias, más que por un cambio cultural. Lo que no quita para que sí se den algunas muestras de cierto cambio de mentalidad sobre el asunto ${ }^{25}$. Esto se refleja también en el mercado libre, en el que se está dando un incremento, más o menos fuerte según el área urbana, de la demanda de alquiler. Por otro lado, una de las ideas substanciales que subyace bajo la construcción social y política de ese 'propietarismo' que planteaba Burón ha sido desmontada al analizarla desde una perspectiva crítica. Como señalan Madden y Marcuse (2018: 93-100), se tiende habitualmente a plantear la tenencia en propiedad de la

${ }^{25}$ Las declaraciones de los hermanos Jesús y Fernando Encinar, cofundadores del portal inmobiliario Idealista, son claras y en cierta medida paradóiicas en este sentido, siendo dicho portal una de las puntas de lanza del cambio en el sector de las agencias de gestión inmobiliaria, pero que no deja de ser una pieza clave en la reproducción del modelo residencial basado en la propiedad:

«Hay dos grandes mantras en el sector inmobiliario español, falsedades que a fuerza de repetirlas la gente acaba creyendo. Una ya se ha desmontado: 'los pisos nunca bajan' [...] La otra es "alquilar es tirar el dinero" [...] a mí lo que me parece tirar el dinero es pagar intereses al banco $[\ldots]$ sigo pensando que no se debe incentivar la compra, nos habría ido mejor si no se hubiese hecho» en El País (2010): «La historia inmobiliaria de Jesús Encinan», disponible en https://elpais.com/economia/2010/10/24/actualidad/1287905574_850215.html.

«La crisis económica ha dejado una huella en la corteza mental de la gente, muchas personas piensan que comprarse una casa es una inversión de alto riesgo. Hay otras que quieren comprar pero no pueden. Y luego están miles de jóvenes que comparten piso y ni se plantean comprar casa. Debería estar prohibido que alguien con menos de 30 años se compre una casa» en El País (2017): «Debería estar prohibido que alguien con menos de 30 años se compre una casa», disponible en https://elpais.com/economia/2017/03/10/actualidad/ 1489178654_561309.html. 
vivienda como garantía y paso previo para alcanzar una situación de seguridad y estabilidad, como si la primera cuestión condujese a la segunda. Pero, acertadamente, apuntan los autores que las situaciones de precariedad se han de entender en un contexto social más amplio, de tal manera que no es un fenómeno causal, si no más bien que aquellas personas en situaciones cómodas y seguras son las que pueden tener una vivienda en propiedad sin riesgo de verse peligrosamente endeudadas. Esto no ha de confundirse con aquellos planteamientos que ponen el acceso -bajo diversas formas y no exclusivamente en propiedad- a la vivienda como paso fundamental para la construcción adecuada de una trayectoria vital digna - bajo el modelo Housing First-, ni supone que el régimen de alquiler no pueda generar igualmente situaciones de vulnerabilidad e inseguridad. Pero sí pone el foco en «negar que la adquisición de una vivienda sea la fórmula para reducir la alienación residencial en toda la sociedad» (Madden y Marcuse, 2018: 100).

A todo ello se ve añadida una cuestión clave: una de las ventajas del régimen de alquiler, u otros que no impliquen la propiedad individual tal y como se ha extendido en España, es la flexibilidad a la hora de cambio de domicilio - por ejemplo en búsqueda de una renta más barata-, o la no dependencia de una deuda hipotecaria y la dificultad implícita de conseguir contratarla. La paulatina precarización y el aumento de la incapacidad económica recién vistas, son razones de peso para que muchas personas se decanten por el alquiler, aún no siendo su régimen deseado. Sin embargo, la escasa oferta existente en alquiler frente al predominio de la propiedad, en un mercado liberalizado y orientado al lucro hace que ese movimiento de demanda de un tipo de régimen a otro -junto con fenómenos añadidos como el alquiler turístico de viviendas privadas, ya empezando a mostrar algunos efectos en el AMB-, conlleve un claro incremento de los precios, y por lo tanto un mantenimiento de la presión y la vulnerabilidad sobre esas unidades de convivencia.

\section{Oferta privada orientada al lucro}

Un conflicto añadido a esa primacía de la propiedad es que el mercado libre no responde según un modelo económico básico y teóricamente equilibrado a los cambios en la demanda. De manera que, lejos de aportar la solución, es parte del problema, pues no ofrece el producto que demanda la mayoría de la sociedad: viviendas a precios asequibles. Así, «construye aquello que la gente no necesita porque no puede pagarlo» (Burón, 2008: 5). En España, y de la misma manera también en Euskadi y en el AMB -se recuerda que son unas de las áreas con los mayores precios de vivienda del estado-, la política de vivienda pública ha tenido que pelear en la pasada década con una elevadísima rentabilidad del mercado libre y un consecuente alto precio del suelo, provocando que la promoción privada huyese de la vivienda protegida (Beltrán, 2009: 470). La enorme trascendencia de la cuestión -no se debe olvidar que se trata de un derecho humano 


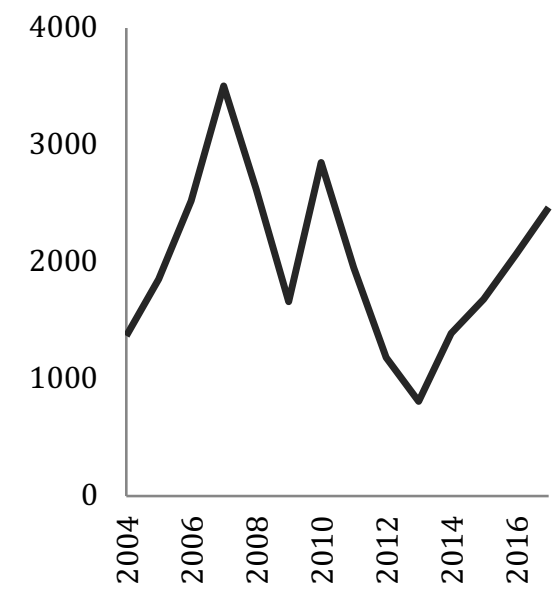

Gráfica 2.15. Número de transacciones inmobiliarias de vivienda libre en Bizkaia. España, Ministerio de Fomento.

Gráfica 2.16. Evolución de la oferta de los precios de venta en Barakaldo, Basauri, Berango, Bilbao, Galdakao, Getxo, Leioa, Portugalete, Santurtzi, Sestao y Sopela $\left(€ / \mathrm{m}^{2}\right)$. Idealista. fundamental- exige respuestas desde el ámbito privado, tanto desde la autogestión (Gondra, 2004: 108), como mediante un mercado «más sensible a las necesidades y posibilidades de la demanda» (Burón, 2008: 28).

El desajuste existente en los últimos años entre la oferta privada y la demanda de vivienda debida a la necesidad puede observarse atendiendo a algunos indicadores. El Plan Director de Vivienda 20132016 ya identificaba un incremento en el tiempo necesario para vender una vivienda y una reducción de la demanda con capacidad de pago (Gobierno Vasco, 2013a: 147, 152). Si se atiende al número de transacciones realizadas en Bizkaia, el ritmo con el que se inició el siglo paró en 2006, año a partir del cual cayeron hasta 2013 (Gráfica 2.15). Desde entonces hasta los últimos datos consultados de 2017, estas han vuelto a coger un ritmo ascendente, pero más lento y pausado. Si se observa en paralelo la evolución histórica de los precios de venta desde 2007 hasta 2017 a partir de una muestra de algunos de los principales municipios del AMB (Gráfica 2.16), el descenso casi continuado de estos en ese periodo lleva a plantear que el número de transacciones de viviendas libres comenzó a disminuir cuando las condiciones de renta y financiación alcanzaron situaciones límite en un contexto heredado de precios altos e inflados. Lo que produjo un descenso de los precios.

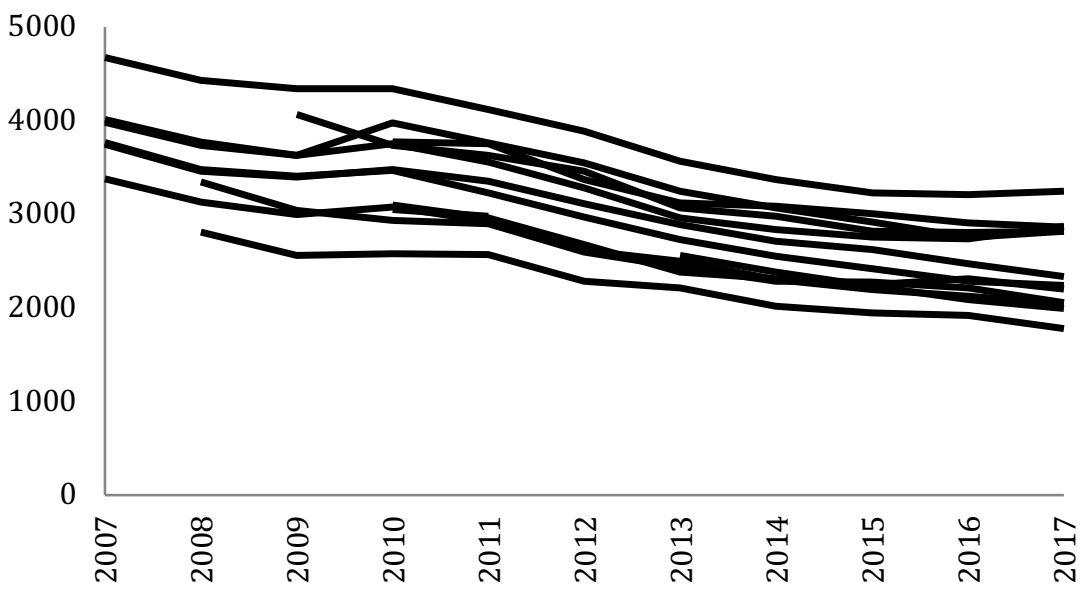

Pero la idea defendida aquí es que esta adaptación parcial de la oferta no debe entenderse como un comportamiento equilibrado del mercado tal y como se defiende desde posiciones a favor de la liberalización del mismo. Una vez que los precios alcanzaron ciertos rangos -en torno a 2013- las transacciones volvieron en varios de los municipios a aumentar gracias a que parte $-y$ este matiz es importante- de la población se pudo permitir afrontarlos. Esto generó un lento aunque patente cambio en la tendencia del mercado en propiedad, observándose un punto de inflexión en la Gráfica 2.16 a partir del año 2015, e igualmente, aunque más claro para el alquiler 
(Gráfica 2.11). Ambas gráficas pueden estar relacionadas, en la medida en que la subida de precios de venta pudo movilizar a parte de la población demandante al mercado del alquiler, y consecuentemente generar en este una anterior recuperación en la escalda de precios.

En cualquier caso, de ser así, sigue respondiendo a lo que se pretende desarrollar: que se trata de un mercado devorador de recursos, no centrado en la función social de la vivienda. El mercado, forzado a bajar precios ante el riesgo de poner en peligro su reproducción, a la primera oportunidad disponible pasa a alimentarse del alquiler en primer lugar para recuperarse, y algo más tarde y más lentamente, empieza a retornar a la venta como principal obtención de ganancias. Así se evidencia que se trataba de una bajada, no para adaptarse a las características de la demanda, si no forzada ante una falta de liquidez y de crédito a la espera de que se diesen las condiciones para volver a inflar dichos precios con independencia de la necesidad de acceso existente en la población. Todo ello pone de relieve la fuerte rigidez del mercado privado por ajustar los precios a la demanda real, que está en cambio orientado a la obtención de la máxima plusvalía posible a través de la compra-venta y alquiler de viviendas.

\section{Oferta pública incapaz de satisfacer la necesidad}

Ante un mercado libre en el que predomina el ánimo de lucro y la propiedad como régimen de tenencia, la apuesta por el alquiler social es uno de los principales caminos a seguir por las políticas públicas de vivienda (Burón, 2008: 21). En Euskadi ya desde el Plan Director de Vivienda 2013-2016 se produjo un importante giro de estas en ese sentido; el avance del Plan 2018-2020 confirma dicha apuesta. También en esta comunidad autónoma la Ley de Suelo y Urbanismo de 2006 supuso un fuerte avance en política de vivienda protegida con la obligatoriedad por parte del planeamiento de realizar una reserva considerable de suelo para vivienda protegida en los nuevos crecimientos. Sin embargo, «la conjunción de diversos factores ha hecho que los ambiciosos objetivos no siempre hayan podido cumplirse» (Gobierno Vasco, 2017:33). De tal manera que estos avances positivos no la sitúan fuera de una coyuntura estatal común ${ }^{26}$, en la que en general «sigue manteniéndose un sistema de protección oficial que se ha demostrado inaccesible para gran parte de la población con necesidades habitacionales» (Elorduy y García, 2014).

Las instituciones y administraciones públicas vascas con competencia en asuntos de vivienda conocen las dificultades para satisfacer la necesidad de vivienda a aquellas personas más

\footnotetext{
${ }^{26}$ La Vanguardia (2015): «La VPO queda fuera de mercado por los altos precios y la falta de crédito», disponible en http://www.lavanguardia.com/pr/economia/20150615/ 54432829352/la-vpo-queda-fuera-de-mercado-por-los-altos-precios-y-la-falta-decredito.html.
} 


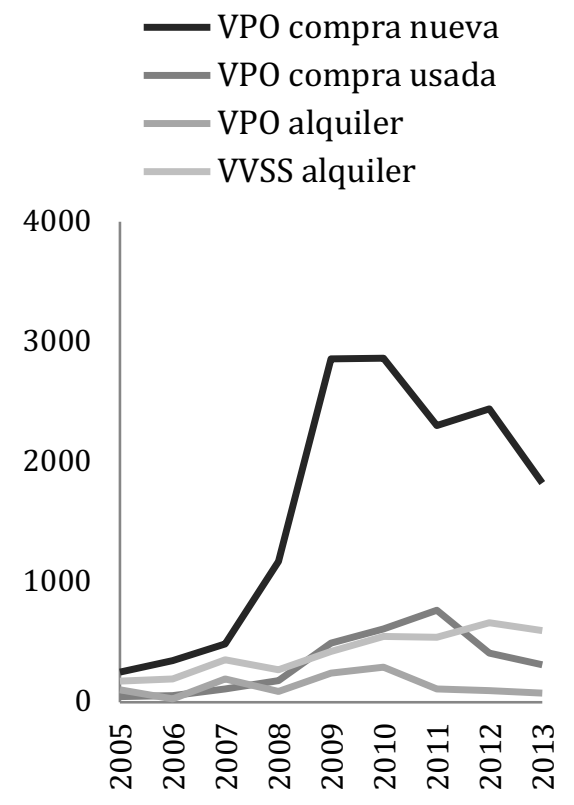

Gráfica 2.17. Evolución del número de renuncias a viviendas adjudicadas por Etxebide. Observatorio Vasco de la Vivienda. vulnerables. La Ley de Vivienda de Euskadi de 2015 reconocía en su exposición de motivos ser consciente de la insuficiencia del parque de vivienda de protección pública y alojamientos dotacionales existente para cubrir la necesidad a corto plazo. Los dos últimos planes directores de vivienda vienen identificando la falta de atractivo que tiene la promoción de vivienda protegida por parte de agentes privados por su falta de rentabilidad debido a la importante cantidad de recursos requeridos (Gobierno Vasco, 2013a: 23, 77, 94, 100, 2017: 43). Ya en 2011, se constataba que la promoción de viviendas protegidas en alquiler «requiere una estructura de apoyo económico exigente, difícil de conseguir en las circunstancias actuales» (Visesa, 2011: 5).

Las evidencias de la incapacidad de adaptación y respuesta por parte del parque público de vivienda a las necesidades de las personas solicitantes de vivienda son palpables observando la evolución en el número de renuncias a las viviendas adjudicada por el sistema público de vivienda (Observatorio Vasco de la Vivienda, 2014b). Hasta 2007, las renuncias se centraban principalmente en las viviendas de alquiler, en torno a un $30 \%$ motivadas por la renta mensual necesaria, y alrededor del $40 \%$ por la localización de la vivienda. Sin embargo, las renuncias a viviendas protegidas en régimen de compra estaban aumentando y a partir de ese mismo año en adelante, sufrieron un gran aumento pasando a ser las predominantes (Gráfica 2.17). Las principales razones - un $77,2 \%$ en la nueva y un $52,3 \%$ en la usadaeran los problemas para obtener financiación. En cuanto al ratio de renuncias globales, estas pasaron de un 7,8\% del total de contratos firmados en 2005 a un 43,1\% en 2013 -con un máximo del 68,1\% en 2012 . Incluso los programas que se han puesto en marcha en los últimos años desde el Gobierno Vasco para incorporar viviendas infrautilizadas del parque privado a la oferta de vivienda protegida en alquiler, cuentan -además de con otros problemas de mantenimiento y éxito que se abordarán con mayor detenimiento más adelante- con un elevado porcentaje de renuncias debidas a la cuantía de la renta. Concretamente, un $54 \%$ en el programa ASAP y un $37,1 \%$ en Bizigune, en el periodo 2005-2013 (Gobierno Vasco, 2013a, 2013b).

\section{Una evolución socio-demográfica sin atender}

Se ha sintetizado hasta aquí el estado de la necesidad de vivienda en Euskadi, y en la medida de lo posible en el AMB, en lo relativo al nivel de acceso y la capacidad económica de la población, las exclusiones generadas, o las respuestas dadas desde el sector público y privado, entre otras cuestiones. Pero, ¿qué está detrás de esa necesidad?. Dos son las principales cuestiones a tener en cuenta en este sentido, una cuantitativa -a cuántas personas hay que satisfacer con alojamiento en términos globales, no solo la estricta necesidad- y la otra cualitativa -cómo se ha de satisfacer, cómo ha de ser ese alojamiento-. La primera suele estar muy presente en los análisis, reflexiones, debates y políticas de vivienda, y se puede responder a 
través de los datos disponibles de población. Someramente, se puede decir que el número de habitantes totales del AMB -tomando en este caso los datos del Eustat para el Gran Bilbao- en las dos últimas décadas se mantiene relativamente estable. Los datos de 2019 858.236 habitantes- representan 6.000 personas menos respecto a los de 2001, habiéndose dado entre medias una leve bajada entre 2001 y 2004 -con un mínimo de 857.012- y una posterior subida de población entre 2005 y 2009 -hasta alcanzar los 875.560- para seguidamente bajar de nuevo por debajo de 860.000 (Gráfica 2.18). Pero además de los números globales, y sin profundizar en la cuestión, es de gran interés reflejar los grandes fenómenos que están detrás de esta situación demográfica. La Gráfica 2.18 muestra cómo el porcentaje de personas nacidas en Euskadi que viven en el AMB es muy estable, el de las nacidas en otras provincias de España lleva descendiendo en todo el periodo analizado, mientras que es con claridad el porcentaje creciente de personas nacidas en el extranjero el que logra la estabilidad final de los números globales de población.

La segunda cuestión, de carácter cualitativo, suele estar más ausente tanto en el diseño y ejecución de planes y políticas de vivienda, como sobre todo en el desarrollo y evolución del mercado inmobiliario. Este determina las características principales de un producto, la vivienda, en función de unas expectativas de venta y reduciendo a niveles seguros el riesgo de 'experimentar' con otras tipologías residenciales, de manera que el espacio doméstico ofertado no responde a las necesidades de quien habita en él (Madden y Marcuse, 2018: 80). Por ello, y por su propia complejidad, se centrará aquí el análisis de este apartado. Como se mostrará en el capítulo siguiente para el caso del AMB, una mirada crítica a la oferta de vivienda actual permite afirmar que la gran mayoría de las promociones de viviendas existentes $-\mathrm{y}$ futuras a corto y medio plazo- en Euskadi responden a un diseño espacial basado en unos esquemas familiares en declive: una familia nuclear blanca heterosexual y de cultura occidental con $n$ hijos y/o hijas viviendo según las costumbres de la primera mitad del siglo XX; el marido encargado del sustento económico, y la mujer a cargo tanto de los trabajos reproductivos domésticos habitualmente no remunerados y frecuentemente situados en un segundo plano del espacio doméstico, así como de los hijos e hijas. El resultado es una oferta muy homogénea, jerárquica y rígida basada en una vivienda compuesta con gran frecuencia por un recibidor, un pasillo de distribución, una cocina -con o sin espacio para comer-, una zona para tender la ropa, uno o dos baños completos, una sala más o menos amplia con posibilidad de albergar zona de comedor, y unas habitaciones bajo una estructura jerárquica destinadas principalmente a dormir y encabezadas por una principal con baño y vestidor propios, siendo el resto menores (se volverá sobre esta cuestión y se muestran algunos ejemplos en diferentes momentos del trabajo). Una oferta muy alejada de una realidad social en continua transformación que genera una «progresiva diversidad de los sistemas de vida» (Paricio y Sust,

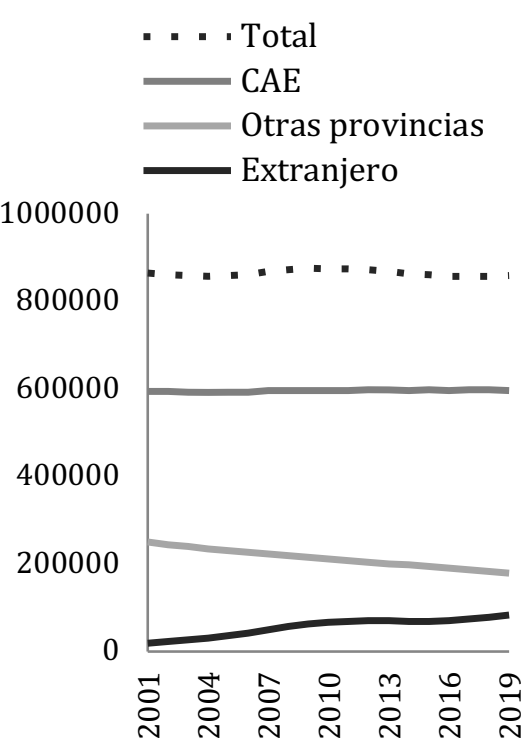

Gráfica 2.18. Población total en el Gran Bilbao, por lugar de nacimiento. Eustat. 
2000: 49). Esto relega a la mujer, a la población migrante -como se ha visto, con una creciente presencia en la región (Gráfica 2.18)-, a las parejas y familias no heteronormativos y a otros colectivos y perfiles diferentes al masculino en buen estado de salud y con un trabajo fuera de casa, a un papel secundario en el proceso de diseño y, consecuentemente, en la propia manera de habitar una vivienda que no es neutral en la configuración de sus espacios (Greene et al., 2013; Muxí, 2009). A pesar de que las propuestas generadas desde este tipo de aproximaciones haya podido, y siga haciéndolo, funcionar para determinados grupos sociales, una parte cada vez más importante de la población no encuentra soluciones técnicamente adecuadas a sus necesidades (Romero y Mesías, 2004: 15), viéndose obligadas a adaptar su vida doméstica y reproductiva.

Por todo ello existe, entre muchos de los diferentes tipos de unidades de convivencia actuales y la mayoría de viviendas del parque existente y por desarrollar, una brecha de desajuste de necesidades, una «inadecuación a las tipologías y superficies demandadas» (Burón, 2016: 6). En definitiva, una necesidad que «no encuentra eco en la oferta de vivienda» (Paricio y Sust, 2000: 49). Consecuentemente, se trata de un parque que está infrautilizado o mal aprovechado en la medida en que, ni está diseñado ni se ha ido en grandes rasgos adaptando a una parte importante de la población actual, la cual se ve forzada a habitarlo. Lo cual no debe llevar a entender que esta vivienda tipo más común es el único instrumento válido para responder a las diversas necesidades espaciales que se dan en torno a ella. De hecho, si se observa desde una perspectiva global, el abanico de posibles soluciones que puede adoptar una vivienda en función de las características de sus ocupantes es de una enorme riqueza. La diversidad de la arquitectura vernácula así lo ha demostrado, al igual que los esfuerzos de algunos agentes -ya sea sus propios ocupantes o profesionales del diseño espacial- por desarrollar soluciones contemporáneas con la búsqueda del mismo fin: generar un espacio doméstico adaptado a sus habitantes. La evolución y adaptación de la arquitectura residencial ha configurado un interesantísimo catalogo y base de datos de la diversidad de la vida y el espacio doméstico del ser humano.

Una de las tendencias más claras en las políticas y promociones de vivienda actuales extensible a toda España es la de homogeneizar y simplificar las características y categorías de las viviendas, como se tiende a hacer al diferenciar la oferta según el número de habitaciones. Este fenómeno, entre otros, deja fuera una suma de factores sociales, culturales, individuales, ambientales,...- que pueden abarcar múltiples combinaciones y requisitos. Lo que interesa aquí es poner el énfasis en las cualidades espaciales de la vivienda, las que facilitan o entorpecen en mayor o menor medida su utilización y que la hacen «parte inseparable de las vivencias familiares» (Vinuesa, 2013: 8). Aquellas que deberían buscar optimizarla en función de las necesidades específicas de las personas que la habitan. Es decir, 
aquellas relativas a su programa, tipología o distribución, que aglutinan aquellos «factores que configuran el universo de la vivienda moderna» (Monteys y Fuertes, 2002: 9) y que tienen como fin último la habitabilidad de la vivienda, su utilidad como tal. Lo que aparentemente puede parecer un planteamiento obvio, esconde detrás una necesidad de reivindicar el derecho de los habitantes de una vivienda a apropiarse de ella y transformarla, sin prejuicios ni condicionamientos sociales ni culturales externos que vayan en su contra $^{27}$. Algo que no se ve favorecido por las imágenes relativas a la arquitectura doméstica difundidas tanto por sus autores, como por medios de comunicación, sean especializados o no. Con demasiada frecuencia, se tiende a tratar la vivienda como un artefacto casi escultórico o museístico -acabado, completo intocable ni transformable-, perdiendo de vista su función y las personas destinatarias finales. Sobre esto ya se ha reflexionado en diferentes épocas $^{28} \mathrm{y}$, sin embargo, parece todavía una asignatura pendiente, de manera que «la gente, las personas que habitan los edificios, siguen siendo, en el fondo, los grandes olvidados de la arquitectura residencial» (Monteys y Fuertes, 2001:14). Afortunadamente, existen casos contemporáneos aislados en los que de una manera consciente se presenta la arquitectura realizada una vez esta ha sido tomada, probada e incluso transformada por sus ocupantes. Tal es el caso de algunas viviendas realizadas por los arquitectos franceses Lacaton\&Vassal, que muestran sin prejuicio la domesticidad generada en los espacios diseñados desde su oficina (Imagen 2.2).

Podría decirse que hoy en día se ha de reivindicar con urgencia, todavía, al habitante de la vivienda como el objetivo final de la misma, siendo en todo caso quien la utilizará y la manipulará (Gili, 1999: 8). Pero toda esta carencia programática, espacial y de diseño no ha de entenderse como un olvido, una trayectoria cultural, o una consecuencia más o menos arbitraria. Más bien, puede decirse que está estrechamente ligada al contexto social, político e ideológico planteado en el capítulo primero:

«...la vivienda hace mucho que ha dejado de tener como objeto el disfrute de la vida para convertirse en un medio de acumulación económica en el que lo importante no es el modo de vida que uno elige, sino mejorar nuestro nivel de renta, eligiendo por la optimación económica de la inversión, y no por el tipo de vida que esa vivienda y su entorno nos van a permitir vivin» (Hernández Aja et al., 1997: 12).

${ }^{27}$ Es paradigmático el fotomontaje realizado por Jean -Pierre Junker (Imagen 2.1), en el que se plantea una hipotética apropiación de la vivienda por una familia.

28 Años antes, Adolf Loos ya apuntó hacia esta misma cuestión: «quien quiera hacerse un hogar, deberá decidirlo todo por sí mismo. Si no, nunca aprenderá. Seguro que saldrá lleno de errores. Pero serán vuestros propios errores. Con recato y sin vanidad, reconoceréis inmediatamente esos errores. Los cambiaréis y corregiréis. Vuestro hogar se hará con vosotros y vosotros con vuestro hogan» (Loos, 2016).

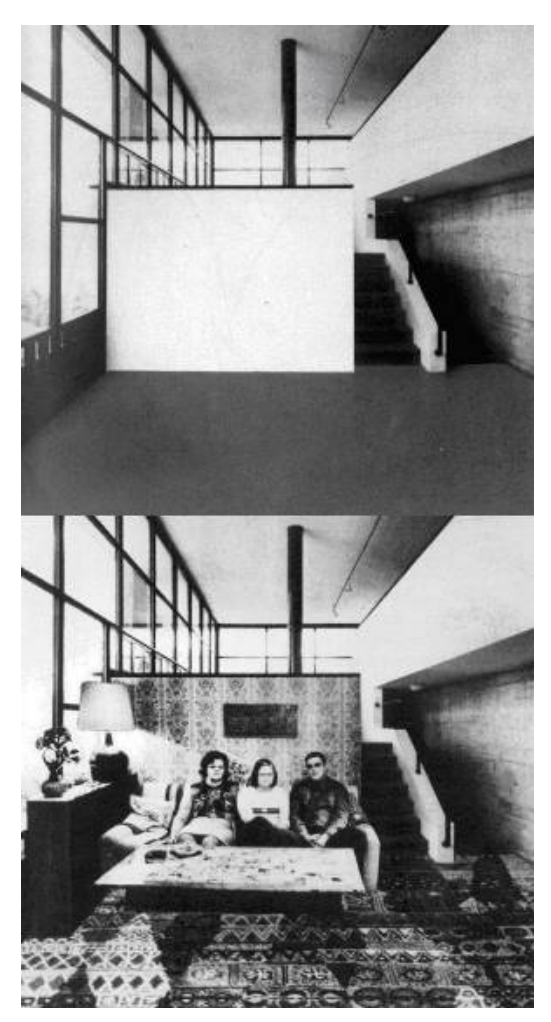

Imagen 2.1. Original y montaje sobre la casa Bianchetti de Luigi Snozzi hecho por Jean-Pierre Junker para el primer curso de Sociología en el ETH de Zurich en 1990. Monteys y Fuertes, 2001. 
Imagen 2.2. Vivienda en Coutras, Francia, de Lacaton\&Vassal. La imagen publicada por la propia oficina ofrece una estampa totalmente doméstica, sin miedo de mostrar la manera en que sus habitantes han personalizado el espacio.

Parece incluso que se busca intencionadamente eso mismo, ofrecer una escena de vida cotidiana, pasando la obra arquitectónica totalmente a segundo plano. Philippe Ruault.

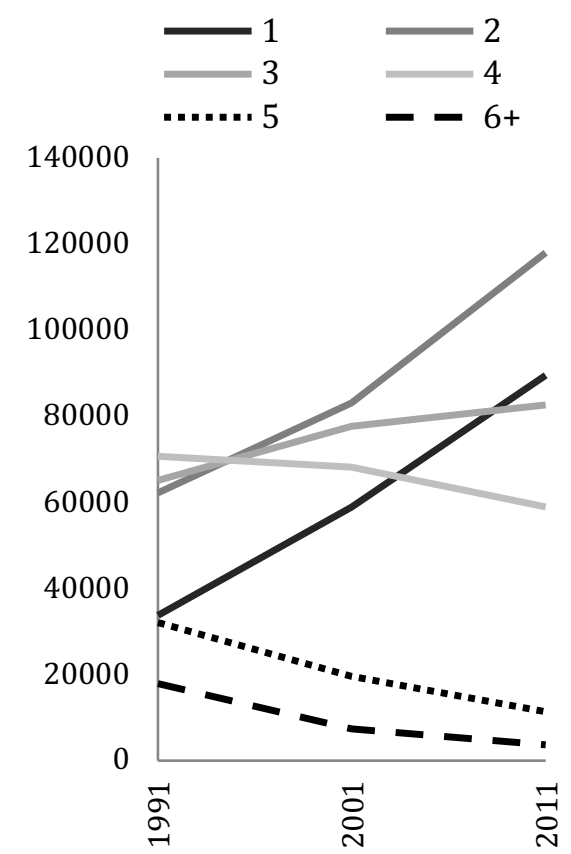

Gráfica 2.19. Evolución del tamaño de hogar en el Área Metropolitana de Bilbao (19912011). INE, 2014.

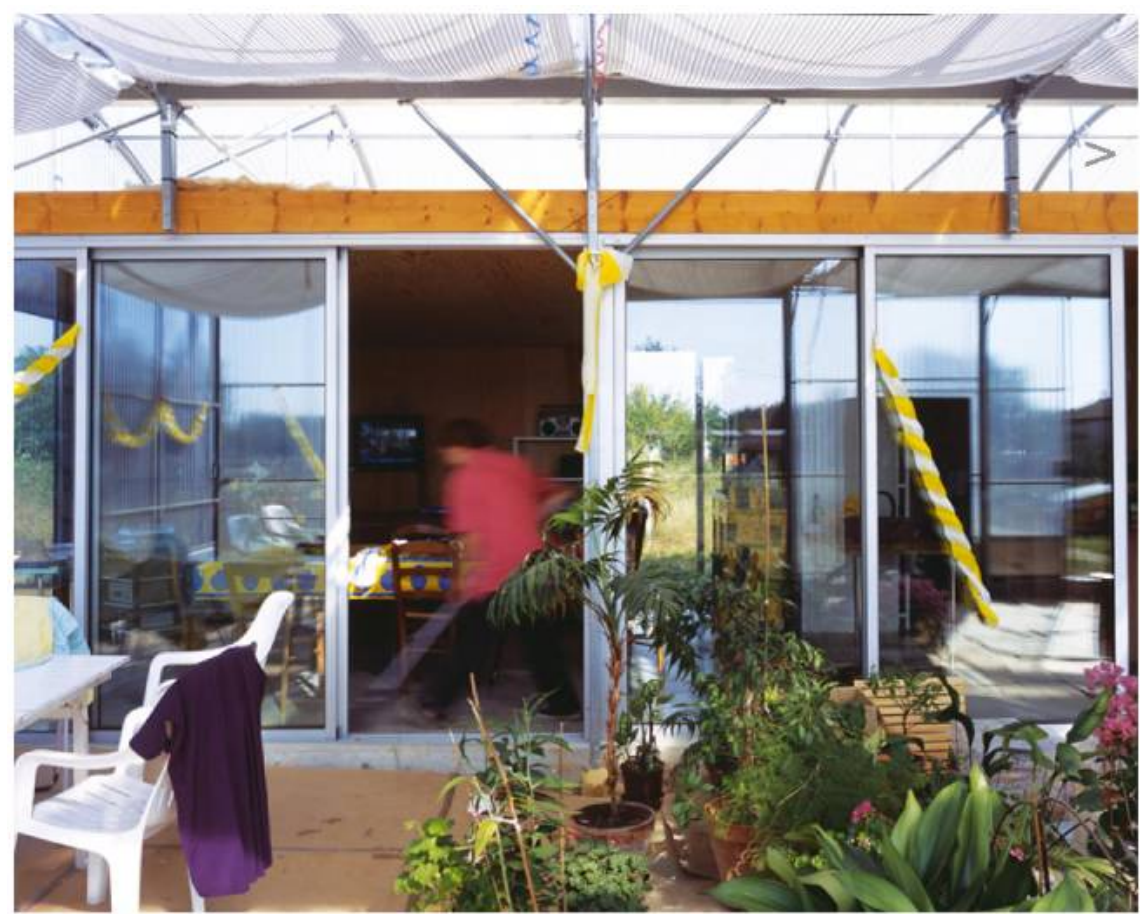

Una vez más, se trata de un reto urbano en parte estructural y que no es reciente; la diversidad de unidades de convivencia existentes que no ven satisfechas - de manera consciente o no- sus necesidades habitacionales no ha surgido de la nada en la última década. Los cambios desarrollados en las unidades convivenciales durante los últimos, al menos 25 años, han llevado a una creciente diversidad en los tipos y estructuras de estos. De la cual su tamaño es solo una de las múltiples pistas que lo constatan (Gráfica 2.19). Esto supone, de manera implícita, la existencia de cada vez más diferentes formas de convivir y diferentes exigencias y demandas espaciales. Mientras las unidades formadas por una o dos personas han incrementado su número hasta llegar a más del doble, los de cinco, seis o más han evolucionado de manera inversamente proporcional. Pero, como se señalaba, quedarse exclusivamente en el análisis del tamaño sería cerrar la puerta a una realidad heterogénea y compleja, cuya complejidad puede atisbarse algo más analizando las estructuras de esas unidades de convivencia o al menos a los datos disponibles más actualizados (Tabla 2.6).

Efectivamente, las unidades de convivencia formadas por una pareja con descendientes aún formando parte de la misma -principal objetivo de las tipologías de vivienda más habituales- apenas alcanza una tercera parte del total. Una cuarta parte son unidades unipersonales, de las cuales casi la mitad son personas mayores de 65 años, principalmente mujeres. La décima parte la forman unidades monoparentales con hijos e hijas, y la décima parte restante la forman parejas o núcleos monoparentales con hijos e hijas y otras personas, 
así como otros tipos de unidades de convivencia fuera de las categorías anteriores. Como apuntan diferentes informes y estudios del INE, la estructura de las unidades de convivencia en España lleva al menos 40 años cambiando y evolucionando hacia un tamaño medio cada vez menor; las unidades unipersonales se multiplicaron casi por dos entre los censos de 1991 y 2001, (Instituto Nacional de Estadística, 2014: 2). En 2014 conformaban el segundo tamaño más común con un $24 \%$ de todas las unidades, detrás de las formadas por dos personas que suponían el 30\%, mientras que las de 3, 4 y 5 personas decrecían respecto a los valores anteriores (Instituto Nacional de Estadística, 2015).
Tabla 2.6. Estructura del hogar en el Área Metropolitana de Bilbao, por número de hogares. INE, Censo de Población y Viviendas 2011.

\begin{tabular}{|c|c|c|}
\hline Total & 364.045 & $\%$ \\
\hline Hogar con una mujer sola menor de 65 años & 23.630 & 6,49 \\
\hline Hogar con un hombre solo menor de 65 años & 26.460 & 7,27 \\
\hline Hogar con una mujer sola de 65 años o más & 31.525 & 8,66 \\
\hline Hogar con un hombre solo de 65 años o más & 7.880 & 2,16 \\
\hline Hogar con padre o madre que convive con algún hijo menor de 25 años & 16.215 & 4,45 \\
\hline 2 personas & 9.070 & 2,49 \\
\hline 3 personas & 6.040 & 1,66 \\
\hline 4 personas & 830 & 0,23 \\
\hline 5 personas & 170 & 0,05 \\
\hline 6 o más personas & 105 & 0,03 \\
\hline Hogar con padre o madre que convive con todos sus hijos de 25 años o más & 21.505 & 5,91 \\
\hline 2 personas & 17.705 & 4,86 \\
\hline 3 personas & 3.300 & 0,91 \\
\hline 4 personas & 410 & 0,11 \\
\hline 5 personas & 85 & 0,02 \\
\hline 6 o más personas & 5 & 0 \\
\hline Hogar formado por pareja sin hijos & 79.705 & 21,89 \\
\hline $\begin{array}{l}\text { Hogar formado por pareja con hijos en donde algún hijo es menor de } 25 \\
\text { años }\end{array}$ & 87.085 & 23,92 \\
\hline 3 personas & 38.825 & 10,66 \\
\hline 4 personas & 42.235 & 11,6 \\
\hline 5 personas & 5.205 & 1,43 \\
\hline 6 o más personas & 820 & 0,23 \\
\hline $\begin{array}{l}\text { Hogar formado por pareja con hijos en donde todos los hijos de } 25 \text { años o } \\
\text { más }\end{array}$ & 30.575 & 8,4 \\
\hline 3 personas & 23.515 & 6,46 \\
\hline
\end{tabular}




\begin{tabular}{lrr}
4 personas & 6.260 & 1,72 \\
5 personas & 600 & 0,16 \\
6 o más personas & 195 & 0,05 \\
\hline Hogar formado por pareja o padre/madre que convive con algún hijo menor & & \\
de 25 años y otra(s) persona(s) & 13.695 & 3,76 \\
3 personas & 2.190 & 0,6 \\
4 personas & 5.250 & 1,44 \\
5 personas & 4.125 & 1,13 \\
6 o más personas & 2.130 & 0,59 \\
\hline Otro tipo de hogar & 25.765 & 7,08 \\
2 personas & 11.490 & 3,16 \\
3 personas & 8.750 & 2,4 \\
4 personas & 3.940 & 1,08 \\
5 personas & 1.165 & 0,32 \\
6 o más personas & 420 & 0,12 \\
\hline
\end{tabular}

Como se ha dicho, los cambios demográficos que están detrás no son recientes, ni las consecuentes lecturas que de ello se hacen para que el parque residencial se adapte; hace más veinte años ya se señalaba -entre otros tantos análisis- que existen «factores sociales y demográficos que justifican la existencia de una mayor diversidad de alternativas de alojamiento. Las demandas de alojamiento son cada vez más diversas, en parte como consecuencia de los distintos tipos de familias y la disminución de sus tamaños, y las ofertas deberían adecuarse a esas demandas» (León, 1995: 61). Siendo entonces el desfase evidente, el enfrentar más de dos décadas de cambios sociales, económicos y demográficos que afectan a la conformación y tipos de unidades de convivencia, a una mínima evolución de las tipologías residenciales en ese mismo periodo pone en evidencia el alcance del desfase actual. Pero dentro de cada categoría de unidad de convivencia definida por el INE según su estructura, se abre un abanico de diversos sub-tipos debido a los tamaños y consecuencia del número de hijos, hijas y otras personas asociadas a esa unidad. Así, las anteriores son solo algunas cifras cuantitativas, bajo las cuales existen multitud de matices que refuerzan la idea de un parque residencial desfasado respecto a las necesidades de sus ocupantes, enfocado a una familia tipo cada vez menos común. Algunos ejemplos a nivel nacional que lo fundamentan: más de una cuarta parte de las unidades tiene como sustentador principal a una persona mayor de 64 años, y las personas mayores formando unidades unipersonales son frecuentemente mujeres (Instituto Nacional de Estadística, 2012: 1). Más del 80\% de las unidades monoparentales lo forman madres (Instituto Nacional de Estadística, 2014: 4), y el 40\% de las unipersonales tienen 65 años o más (Instituto Nacional de 
Estadística, 2014: 6). Por otro lado, uno de cada tres jóvenes de entre 25 y 34 sigue sin emanciparse (Instituto Nacional de Estadística, 2014: 7). Tan solo con estos pocos ejemplos se evidencia que la información de la Tabla 2.5 se queda lejos de una realidad rica y en evolución. Más allá de las categorías del INE, la diversidad de perfiles familiares, laborales, estados de salud, vínculos comunitarios, ... vitales en definitiva, es múltiple.

El abanico de casos diversos podría extenderse enormemente: desde el desarrollo de diferentes actividades profesionales en la vivienda, como las 'madres de día" ${ }^{29}$-actividad ya regularizada en Navarra-, o los programas de acogida de refugiados en pisos compartidos, pasando por la vuelta de adultos a la casa de los progenitores mayores debido a situaciones de vulnerabilidad ${ }^{30}$, el crecimiento del subarrendamiento de habitaciones ${ }^{31}-\mathrm{y}$ aumento de la edad media de la persona inquilina tipo- muy focalizado en personas migrantes y con rentas bajas (Leal, 2018), los pisos compartidos por jóvenes y mayores intercambiando alojamiento por compañía y ayuda, adultos compartiendo una vivienda en la que además trabajan, viviendas de paso y temporales, unidades de convivencia con rutinas y componentes cambiantes, nuevas relaciones convivenciales más allá del espacio doméstico que abordan otras concepciones de los espacios comunes,.... Todo ello confirma el fin de la hegemonía de la que podría denominarse como la 'familia moderna' basada en una estructura jerárquica con un núcleo central heterosexual e inalterable en el tiempo, en torno al cual crecen varios descendientes:

«...la diversidad es innegable, por razones de origen diverso:

- Diversidad de programas de ocupación, que difícilmente se pueden resumir en la familia convencional con hijos.

- Diversidad de los sistemas de vida, que evolucionan vertiginosamente a causa del cambio en las relaciones entre los miembros de la familia en la historia y en la vida del mismo grupo.

- Diversidad en las relaciones con la vivienda misma, por la diferente manera de asumir la evolución técnica, tanto en el equipo de la vivienda como en su control» (Paricio y Sust, 2000: 49).

29 eldiario.es (2016): «Madres de día, una alternativa a las guarderías sobrecargadas», disponible en https://www.eldiario.es/sociedad/Madres-dia_0_510599130.html.

30 eldiario.es (2018): «Tengo 30 años y una nómina más que decente, pero tengo que volver a casa de mi madre», disponible en https://www.eldiario.es/economia/historiasdelal quiler/anos-nomina-decente-volver-madre_6_803579637.html

31 El País (2007): «Habitación con derecho a salón y cocina», disponible en https://elpais. com/economia/2007/11/16/actualidad/1195201975_850215.html. 
Pero, ¿para quién se están diseñando y construyendo nuevas viviendas? cómo se adaptan estas unidades de convivencia a las viviendas existentes?. Ya en el año 2012, el 70\% de las solicitudes totales del conjunto de la comunidad autónoma en el Servicio Vasco de Vivienda Etxebide se debían a unidades convivenciales de una persona (Observatorio Vasco de la Vivienda, 2012a). Si bien es cierto que no esto quiere decir que el total de esas demandas individuales se deba a unidades unipersonales -ha sido habitual, al menos durante un tiempo, darse de alta por separado en las parejas para tener más posibilidades de adjudicación-, indica un alto porcentaje de este tipo de unidades de convivencia en la demanda de vivienda protegida. Las unidades de dos personas suponían un 15\%, las de tres o cuatro un $12 \%$ y las de cinco o más no llegaban al 3\%. Así, la idea de unidad convivencial asociada a una unidad familiar formada por una pareja con hijos debe ser desplazada del centro de la planificación y políticas de vivienda, pues esta no es más que una de las múltiples realidades. Además, ni siquiera ese tipo de unidades siguen reproduciendo la dinámicas de las familias del siglo pasado, pues «el desarrollo de la vida familiar ya no es lineal, sino que se convierte en una serie de secuencias» (Inurrieta et al., 2013: 26).

Por otro lado, es necesario resaltar que no todos los tipos de unidad de convivencia censada según las clasificaciones del INE lo son por voluntad propia ${ }^{32}$; en muchos casos, la situación económica personal o familiar y los elevados precios de venta o alquiler lleva forzadamente a compartir vivienda entre varias (Leal, 2018). Situaciones que se ven llevadas al extremo cuando se añaden variables de discriminación y exclusión; el informe Ser negro en la UE desarrollado por la Agencia de Derechos Fundamentales de la Unión Europea a finales de 2018 indicaba que el 45\% de las personas de orígenes africanos o afroamericanos «vive en condiciones de hacinamiento, en comparación con el $17 \%$ de la población general, lo que pone de relieve la necesidad de que los Estados miembros mejoren la calidad de la vivienda y erradiquen la exclusión en este ámbito» (European Union Agency for Fundamental Rights, 2018). Lo que, por otro lado, es un síntoma evolucionado de una problemática vieja, pues «irse a vivir a una habitación una familia completa fue algo

32 El siguiente pasaje, ficticio y ambientado en la ciudad de New York, podría encajar a la perfección en las biografías vitales de muchas personas del AMB: «Bing prosigue su exposición diciéndole que suelen desayunar y cenar juntos porque todos andan cortos de dinero y tratan de gastar lo menos posible. El hecho de poner en común sus recursos los ha ayudado a salir adelante, y ahora que Miles se ha incorporado a la casa, sus gastos se reducirán en buena medida. Todos se beneficiarán de su presencia, y con eso no se refiere sólo al dinero, sino a todo lo que Miles aportará al espíritu de la casa, y Bing quiere que sepa lo contento que está de que al fin haya vuelto al sitio en donde debe estar. Miles se encoge de hombros, diciendo que espera poder integrarse, pero en el fondo se pregunta si está hecho para esa especie de vida en grupo, si no sería mejor que buscara un sitio para él solo. El único problema es el dinero, el mismo al que se enfrentan todos los demás. Ya no tiene trabajo, y los tres mil dólares que se ha traído no son en realidad más que unos centavos. Le guste o no, pues, de momento no puede hacer otra cosa, y a menos que surja algo que cambie radicalmente las circunstancias, tendrá que aguantar como pueda» (Auster, 2010: 119). 
habitual durante los años cincuenta y parte de los sesenta para muchos de los inmigrantes recién llegados a la ciudad, pero también para muchos jóvenes matrimonios de nativos cuyas economías precarias no les permitían acceder a una vivienda propia» (Bustillo, 2004: 299). Existe en definitiva un conflicto generado por un modelo de vivienda en decadencia, que no aborda esta como el concepto universal de formalización individual que es (Guidotti y Arroyo, 2004); en la medida en que cada unidad de convivencia es un mundo, la vivienda anónima debe ser en consecuencia versátil. El reto es por lo tanto plantear la vivienda como un espacio cambiante al ritmo de sus habitantes, otorgándole el derecho de ser planificada en el tiempo (Monteys y Fuertes, 2002).

\section{Un parque con alta capacidad de alojamiento}

Como se viene intentando argumentar, la ineficacia del modelo residencial para satisfacer las necesidades habitacionales de su población tiene múltiples caras y se percibe, entre otras cuestiones, al observar los problemas tanto cuantitativos como cualitativos para un aprovechamiento eficiente del parque residencial existente. Como se acaba de apuntar y se verá más tarde, desde un punto de vista cualitativo hay una ineficiencia en parte alimentada por la falta de adaptación espacial de este parque a muchas de las unidades de convivencia actuales. Desde un punto de vista cuantitativo y sin ánimo de realizar una cuantificación minuciosa, pero sí de hacer una breve reflexión, se plantean a continuación dos pequeños ejercicios de cálculo como mera aproximación a esta cuestión. El primero toma como ámbito la provincia de Bizkaia, pero la proporción demográfica y construida que el AMB supone dentro de la misma hace que los resultados sean relevantes para el estudio de la región. En 2011, se estimaba en la provincia una necesidad de vivienda total no cubierta para 43.476 unidades de convivencia -se ha de recordar que la metodología excluía las personas sin recursos-; 21.246 buscaban el acceso a su primera vivienda, mientras que 22.230 tenían una necesidad de cambio por diferentes motivos (Observatorio Vasco de la Vivienda, 2013).

Si por otro lado, se comparan los datos relativos a unidades de convivencia censadas ese año en el AMB con el total de viviendas existentes, se observa que había 34.519 viviendas de más -número cercano al de las viviendas desocupadas, estimado en 37.024 viviendas por el Censo de Población y Viviendas del Instituto Nacional de Estadística en 2011-. Al descontar de esta última cifra un 5\% del parque total para facilitar los movimientos normales de intercambio dentro del parque bajo las dinámicas el mercado - un porcentaje más o menos consensuado que supondría unas 20.000 viviendas, aunque algunos trabajos estiman un 2\% como suficiente (Etxezarreta, 2010)-, podrían suponerse unas 17.000 vacías sin justificar. Lo cual estaría a 4.000 de satisfacer la necesidad de primera vivienda. En cuanto a las viviendas ocupadas por las más de 22.000 unidades de convivencia 
con necesidad de cambio, estas no dejan por ello de ser utilizables por otras personas y por lo tanto incorporables en el mercado, por lo que no hay motivos para que toda la necesidad de vivienda estimada deba estar respondida por la construcción de nuevas viviendas. A primera vista y tras una aproximación superficial que no incluye la segunda residencia ni otros fenómenos, parece que cuantitativamente el parque tiene una considerable capacidad de responder a las necesidades de alojamiento de la población. Con todo, esas 17.000 vacías supuestamente disponibles estarían a 26.000 viviendas de la necesidad conjunta en la provincia, tanto de primera residencia como de cambio de la actual. Frente a estos números rápidos, sorprenden las previsiones del planeamiento urbanístico en el $\mathrm{AMB}$, que según datos de 2013 eran de 79.288 nuevas viviendas a construir. Previsiones que, vista la situación socio-demográfica previamente sintetizada, puede decirse que no abordan el fondo del asunto, si no que añaden más viviendas a un modelo inmobiliario disfuncional.

La segunda reflexión planteada se aborda desde el tamaño de las unidades de convivencia. Según la base de datos del planeamiento urbanístico de Euskadi, en 2015 se contabilizaban en el AMB 402.603 viviendas, lo cual cruzado con el total de población censada arroja un ratio de 2,18 habitantes por vivienda. Descontando de ese parque las cerca de 26.000 viviendas desocupadas estimadas en 2015 (Observatorio Vasco de la Vivienda, 2015a), el ratio quedaría en 2,33 habitantes. En cualquier caso, un ratio que queda por debajo del tamaño medio de hogar o unidad de convivencia, estimado para ese año por el Eustat en 2,5 personas. Los datos disponibles muestran que el tamaño medio de las unidades convivenciales continúa descendiendo, a la vez que las proyecciones de población ofrecen tendencias decrecientes o muy estabilizadas. Tras estos breves números, se podría volver afirmar que, aparentemente, el parque residencial actual del AMB puede, cuantitativamente, responder en gran medida a la necesidad de vivienda de su población. Como se verá más tarde, la cuestión clave es si este está preparado cualitativamente para albergar a unas unidades de convivencia diferentes de las que se tuvieron y se tienen en cuenta a la hora de diseñar esas tipologías residenciales.

Pero la realidad es bien diferente y, aunque físicamente hay viviendas potencialmente disponibles, a lo largo del análisis de esta problemática se han podido observar dos fenómenos que evidencian desequilibrios e irregularidades. Por un lado, la necesidad de vivienda está bien lejos de ser satisfecha debido a los obstáculos económicos para su acceso, insalvables para gran parte de la población y algunos de los cuales se han presentado en apartados previos. Por otro lado, las previsiones de los planes urbanísticos municipales siguen planteando nuevas viviendas -57.087 en diciembre de 2015 en el AMB - justificándose, al menos como argumento político, en la inaccesibilidad económica al parque actual y en el descenso del tamaño medio de la unidad de convivencia. Pero se trata de una 
estrategia de creación de nueva ciudad residencial -con sus consecuentes afecciones y consumos energéticos, materiales, ambientales,...- que como se ha podido comprobar en los últimos años no garantiza un producto final asequible, y basado en una visión demográfica y tipológica extremadamente simplistas, como se argumentará más tarde. En suma, se siguen reproduciendo las lógicas del urbanismo que ha venido desarrollándose durante las pasadas décadas.

Se confirma así que el mercado inmobiliario no sigue las leyes básicas del modelo económico de la oferta y la demanda: teniendo miles de 'clientes' necesitando y deseando comprar o alquilar, consumir en definitiva, no se adapta a la realidad para que estos puedan acceder al mismo. Y sin embargo, el gran volumen de 'producto' existente podría cuantitativamente satisfacer gran parte de la necesidad de vivienda actual. Las perversiones de este mercado inmobiliario hacen que se solapen en el tiempo y el espacio varios fenómenos que convergen en un drama social: personas sin poder acceder a la vivienda, la existencia de un stock vacío y/o infrautilizado, y la producción de nuevas unidades. Se trata al fin y al cabo de la mercantilización fallida de un derecho humano básico y fundamental. De todo ello, se extrae una conclusión directa: la oferta de vivienda existente en la actualidad es inadecuada, pero no insuficiente. Es inadecuada porque no consigue responder a las necesidades económicas ni tipológicas de vivienda de gran parte de la población. No es insuficiente porque los números globales indican un ratio de vivienda por habitante considerablemente razonable, apuntando así a un problema de redistribución y acceso, más que de producción. La convergencia de ambas cuestiones lleva a la tercera pata analizada de esta problemática: la necesidad de intervenir y transformar el parque como respuesta conjunta a las dos anteriores.

\section{$-2.3 .3-$}

\section{Ciudad existente con necesidad de intervención integradora}

Más allá de las carencias tipológicas recién apuntadas que muchos de los edificios residenciales del AMB presentan, la necesidad de intervención que aquí se pretende señalar se centra en una escala superior a la doméstica, y no se refiere tampoco a las posibles carencias físicas - pertenecientes a una dimensión constructiva de la vivienda sobre la que existe, como se ha señala en el primer capítulo, un consenso amplio y que abarca cuestiones como la accesibilidad espacial, la eficiencia energética o el estado de conservación, entre otros-. En este caso la necesidad identificada viene también motivada por una infrautilización parcial del parque de viviendas y edificios no 
residenciales, así como de algunos suelos urbanizados y sin puesta en carga alguna. Una realidad social y ambientalmente cuestionable, y que afecta a la calidad urbana de la ciudad. Alberga además ciertas contradicciones, y pide abordar estos espacios en toda su complejidad y afrontar sus retos desde una planificación global y racional. Una cultura de la intervención urbana planteada como la sustitución de un tejido por otro -en gran parte motivada por un planteamiento centrado en la necesaria rentabilidad económica de las operaciones-, ha sido, salvo algunas excepciones, la norma aceptada desde hace varias décadas por muchos de los agentes intervinientes. El presidente de la Asociación de Constructores de Bizkaia afirmaba lo siguiente en 1996, en respuesta a la propuesta de un periodista de si la rehabilitación de pisos degradados podía ser una salida a los altos precios de la vivienda: «otro periodista me preguntó hace tres o cuatro años qué haría con Bilbao La Vieja, y a mí me salió del alma decir que quemarlo, como Nerón quemó Roma, y edificar algo nuevo. Quizá la frase fue excesivamente drástica, pero en este caso no valen rehabilitaciones puntuales, ya que todo está muy degradado» (Merodio, 1996).

Frente a esta visión extrema, toman valor y más interés las estrategias de regeneración y rehabilitación realmente planteadas como tales, partiendo de lo existente e incorporando más variables que la viabilidad económica de la operación, como la protección de la población que actualmente reside en los barrios afectados. Planteamientos que poco a poco se han ido asentando tanto en profesionales del urbanismo como en las instituciones públicas a través de la legislación, planificación y ejecución, y que en algunos casos se viene trabajando desde hace años. En 1994 -dos años antes de las declaraciones de Merodio- la Sociedad Urbanística de Rehabilitación de Bilbao (SURBISA), nacida en 1985, amplió su objeto social que originalmente abarcaba el Casco Viejo de Bilbao para incorporar los barrios de Bilbao La Vieja, San Francisco y Zabala. Precisamente, los que desde el colectivo de empresas constructoras parecía no tener salida. Hoy es el día en que, con sus aciertos y errores ${ }^{33}$, la intervención en estos barrios ha mejorado su calidad urbana y la calidad de vida de parte de sus habitantes sin grandes operaciones de sustitución y expulsión.

\section{Vivienda vacía}

El drama de las viviendas vacías ha sido abordado desde múltiples perspectivas. En este caso, el interés se centra en su carácter de

33 Algunas de las políticas promovidas y desarrolladas por las instituciones públicas en estos barrios, junto con la intervención de diversos agentes privados y personas particulares bajo agresivas dinámicas del mercado de vivienda libre y de lonjas comerciales pueden con facilidad ser categorizados como parte de un proceso de gentrificación más o menos orquestado (Vicario y Rodríguez, 2005), cuyas consecuencias llevan años generando problemas de expulsión, cohesión y marginación. 
patrimonio edificado infrautilizado. Una paradoja, la existencia de viviendas desocupadas, menos frecuente en Euskadi que en otras regiones españolas, y que viene siendo -como se verá más adelantecada vez abordada con mayor intensidad desde las instituciones. La existencia de excesiva vivienda vacía, dada la situación de difícil accesibilidad económica a la vivienda, los costes materiales y ambientales consecuentes de las nuevas construcciones, y la ocupación de suelo que estas suponen, es un grave problema de compleja gestión, ya que se trata de bienes privados cuya gestión está en mano de su propiedad (Gobierno Vasco, 2013a: 151). Los retos y deberes que plantea esta realidad son varios, que se han de solucionar con relativa urgencia. El primero, desde luego, es saber de qué se está hablando. Porque uno de los mayores problemas es la falta de una definición precisa y compartida del objeto de estudio. El Gobierno Vasco en sus encuestas de vivienda vacía categoriza esta en las que son segunda residencia, las que están en oferta, y por último, las 'gestionables' -que son las que interesa abordar en un primer momento-. Algunas personas profundizan algo más y la plantean como aquella «unidad residencial que está vacía en un determinado momento, es decir, en el preciso momento en que el censo o la encuesta se ha llevado a cabo. Esta definición incluiría las viviendas que estén vacías en el transcurso del cambio de ocupantes, viviendas que están siendo reformadas o remodeladas, viviendas que están esperando su demolición, y las viviendas que recién terminadas aún no hayan sido ocupadas» (Etxezarreta, 2010: 6). También se pueden distinguir, como plantea la propia autora, entre vacantes temporales o estacionales (segunda residencia), vacantes permanentes, y vacantes transicionales.

Esta última categoría es de gran interés, porque lleva a plantearse otra de las grandes cuestiones: saber cuál es la proporción adecuada del parque residencial que ha de estar vacío «en determinados momentos para posibilitar su compra, venta o proceso de reforma en condiciones adecuadas» (Etxezarreta, 2010: 6). Como se ha apuntado más arriba, la autora plantea una cifra cercana al $2 \%$ del stock de vivienda. Independientemente de si el porcentaje debe ser mayor o menor, la siguiente información a recabar es clara: ¿cuántas viviendas vacías hay? Las dificultades encontradas hasta ahora para obtener una cifra relativamente fiable son grandes. A pesar de que existen encuestas y estadísticas oficiales ${ }^{34}$, la metodología utilizada en cada una de las fuentes varía, y eso lleva a que las diferencias entre los resultados de unas y otras sean importantes. Lo cual no hace si no evidenciar la falta de precisión de todas ellas. Como ejemplo, frente a las 15.083 desocupadas detectadas en Bilbao por el Censo de Población y Viviendas de 2011, la Encuesta de Vivienda Vacía realizada desde el Gobierno Vasco en 2009 localizaba 5.519 vacías en

34 En el Censo de Población y Viviendas de 2011 publicado por el Eustat, se contabilizaban un total de 36.796 viviendas desocupadas en el AMB, un 9,25\% del total censado en 397.874 viviendas. 
el municipio. Más allá de posibles diferencias en la definición del objeto en sí, o la variación del total de viviendas desocupadas a lo largo de los dos años que separan ambos estudios, resulta evidente la imprecisión de los datos. Por otro lado, algunas experiencias con metodologías más precisas han devuelto datos mayores -hasta un tercio más- que los estimados por las encuestas (Naredo et al., 2008), con lo cual puede que el problema sea más grave aún. Estos conflictos pueden reflejarse en el caso del AMB. Algunos estudios han estimado para la comarca del Bilbao Metropolitano un 6,3\% del parque residencial como desocupado -26.036 viviendas-, un 4,9\% 20.250 viviendas - sin contar aquellas destinadas a segunda residencia o de temporada (Observatorio Vasco de la Vivienda, 2015a). Esta cifra contrasta, a pesar de la diferencia temporal y de usar otra delimitación espacial, con la ya citada del Censo de Población y Viviendas del Instituto Nacional de Estadística en 2011 que estimaba en 37.024 las viviendas vacías para el AMB.

Lo anterior lleva a la necesidad de desarrollar un trabajo más exhaustivo y coordinado de localización de vivienda vacía e impulso y desarrollo de medidas para lograr su introducción en el mercado, ya sea libre o protegido. Pero en algunos casos, parece que los pasos se dan para retroceder, en vez de para avanzar. El censo del INE de 2011 se realizó por primera vez con una muestra -rondaba el 12,3\% de la población y el 11,9\% de las viviendas- en lugar de hacer un recuento real (Elorduy y García, 2014). Esta poca fiabilidad también ha sido apuntada desde otras posiciones (Vinuesa, 2013: 13), aunque en este caso el análisis va más allá. El autor afirma que los datos disponibles normalmente están adaptados a las necesidades de quien los genera. Conviene detenerse un momento a analizar esta reflexión, pues ofrece perspectivas interesantes. La falta de información precisa impide desarrollar en profundidad cierto conocimiento sobre el estado del parque residencial para actuar sobre él adecuadamente; su hipótesis es que este desconocimiento es una condición necesaria ocultando el número real de viviendas vacías y de esta manera manipulando la supuesta necesidad de construir nuevas- para el mantenimiento de un modelo urbano desarrollista que necesita, como ya se ha apuntado, una constante demanda de nueva vivienda (Vinuesa, 2013: 14). Lo que lleva al autor a preguntarse si realmente es técnica y logísticamente imposible -en un tema tan crucial como el habitacional y en una sociedad con un nivel de desarrollo suficiente para ello como se demuestra para otro tipo de informacionesdesarrollar una fuente de datos precisa y en constante actualización. Se trata, según Vinuesa, de una cuestión fuertemente influenciada por presiones e intereses externos y sectoriales.

Las maneras de abordar esta problemática son diversas. En las políticas de vivienda españolas se ha venido dando tradicionalmente dos vías a los fondos públicos: «destinar fondos a la oferta de vivienda, o sea a los promotores (lo que se conocía como 'ayuda a la piedra'), y destinar fondos a la demanda de vivienda (las ayudas a los 
adquirentes o arrendatarios)» (Beltrán, 2009: 461). En un contexto como el actual, con relativamente altas cantidades de vivienda desocupada, el autor propone como más adecuado reducir los fondos destinados a la promoción de nuevas viviendas para dirigirlos más a la activación de la demanda y en la puesta en el mercado de esas viviendas vacías. En este sentido, los movimientos por parte de las administraciones vascas competentes en el tema para frenar esta grave situación se comenzaron a dar años atrás con la puesta en marcha de programas de impulso al alquiler protegido a través de la movilización de vivienda libre. Como se verá, a pesar de que un considerable número de viviendas se han acogido a estos, presentan importantes retos y un bajo éxito, y son proporcionalmente muy pocas las viviendas movilizadas.

\section{Edificios obsoletos no residenciales}

A toda esta problemática se suman, por motivos diferentes, otros muchos edificios no residenciales, infrautilizados y con posibilidades de ser adaptados e incorporados a la oferta residencial ${ }^{35}$. Muchos de ellos están localizados además en ámbitos de planeamiento con previsión de vivienda nueva, a la espera de operaciones de sustitución. El pasado -y todavía en parte presente- industrial del AMB ha dejado en muchos de sus municipios, gracias a la extensa red de pequeñas y medianas empresas y talleres, una importante herencia edificada de inmuebles de uso industrial y de actividades económicas (Imagen 2.3). Frecuentemente, la ubicación en el momento de su construcción dentro del casco urbano ha hecho que el desarrollo y la expansión urbana de las décadas siguientes los sitúe en áreas de gran centralidad. Esta alta presencia de edificios industriales en desuso, o con una baja carga de utilización y aprovechamiento, es muy frecuente en determinadas zonas de Bizkaia y Gipuzkoa. Muchos mantienen, desde un punto de vista funcional, un enorme potencial para albergar nuevos usos, algo que por otro lado se enriquece por «la carga emocional que tienen muchas de estas construcciones en desuso, tanto por sus cualidades estéticas como el componente épico de su pasado industrial» (Collantes et al., 2013: 125). En este sentido, la diversidad urbana en lo relativo a su paisaje no está enfrentada con el cambio de uso.

Pero en el marco de un urbanismo muy enfocado a la obtención de plusvalías que ha olvidado la importancia cultural o ambiental, entre otras, del aprovechamiento del patrimonio heredado, como recuerda Capel (1997) la ciudad postindustrial ha acelerado los procesos de reconversión de suelo industrial a otros usos, de manera que numerosos edificios con frecuencia se abandonan, degradan, y

\footnotetext{
${ }^{35}$ Se pretende señalar aquí un potencial interesante, sin que ello signifique orientar hacia este uso residencial todo aquel inmueble en estas condiciones. La mezcla de usos para una adecuada diversidad urbana y las necesidades de cubrir carencias dotacionales son cuestiones a tener en cuenta de manera paralela.
}

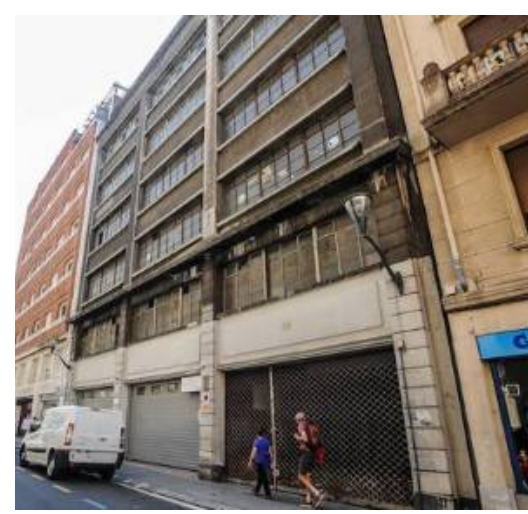

Imagen 2.3. Edificio industrial en el barrio de Castaños, Bilbao. Fuente: http://www.elcorreo.com /bizkaia/cadena-abba-abrira20170928193805-nt.html. 
acaban derribándose para albergar crecimientos de la ciudad residencial. El autor identifica varias posibles razones para esta pérdida del uso original (Capel, 1997: 26). Desde un punto de vista privado, tanto las nuevas exigencias de la producción, como las presiones de economía de escala o las plusvalías obtenidas por la venta del suelo tras el traslado de la empresa a nuevas áreas periféricas pueden haber motivado muchas de estas situaciones. Desde un ámbito público, la aceleración del proceso ha podido deberse a la aprobación de ordenanzas y normativas en favor de una mayor seguridad y convivencia de usos en la ciudad, o una política de vivienda reestructuradora de barrios degradados. De esta manera, «los rígidos planes urbanísticos llevados a cabo en las últimas décadas en nuestro entorno, no han favorecido la recuperación de estructuras obsoletas como los edificios industriales en desuso. Estos planes [...] han favorecido la tabula rasa de la trama urbana más que la reutilización y regeneración de estructuras existentes. La consecuencia ha sido la irremediable pérdida patrimonial e identitaria de muchos núcleos urbanos, así como un despilfarro desde el punto de vista energético» (Collantes et al., 2013: 125).

Las razones del interés por incorporar estos bienes a los procesos de planificación urbana en general, y de vivienda en particular, principalmente son históricas, culturales y educativas -para recuperar y poner en valor la memoria de las formas de actividad productiva del pasado-, económicas y ambientales -la reutilización de materiales ya extraídos y transformados, energía ya consumida, residuos ya generados, medios económicos ya gastados,...-, así como por el necesario fomento de la diversidad del paisaje urbano, y la alta capacidad que tienen muchos de esos edificios para satisfacer necesidades actuales y futuras por sus propias características (Capel, 1997: 36). Con todo, y ante el anteriormente citado desfase existente entre tipos de unidades de convivencia y tipologías de viviendas predominantes en el parque residencial, las posibilidad de flexibilidad y distribución que ofrecen algunos de estos edificios industriales, junto a su excelente ubicación en la ciudad, son un valor añadido más para aprovechar este patrimonio edificado. En parte se están dando pasos en este sentido. Es el caso del Avance del Plan General de Ordenación Urbana de Bilbao, actualmente en revisión, en el que se han identificado algunas zonas de la ciudad con este tipo de edificios con la intención de ser reutilizados. Lo cual no impide que desde algunos sectores se esté pidiendo mayor firmeza para evitar precisamente lo que en otras ocasiones ha sucedido en la propia ciudad: su derribo y sustitución por nuevos edificios de viviendas bajo un modelo orientado a la obtención de plusvalías, más que a responder a la necesidad de vivienda ${ }^{36}$. Aunque los intereses en

36 «UdalBerri-Bilbao en Común pide la puesta en valor del patrimonio industrial de Rekalde, Amezola e Irala», disponible en http://www.europapress.es/euskadi/noticiaudalberri-bilbao-comun-pide-puesta-valor-patrimonio-industrial-rekalde-amezola-irala20180108152635.html. 
búsqueda de la acumulación económica a través del parque residencial pueden dibujar en ocasiones otros destinos para este tipo de edificios. Planteando su conservación, pero anulando la posibilidad de destinarlos a cubrir la necesidad de primera vivienda. El paulatino, pero fuerte, desarrollo de un sector residencial orientado al turismo que se está viviendo recientemente en el AMB, y en Bilbao en especial, puede en ocasiones adelantarse y aprovechar la fuerza inversora de determinados agentes para orientar estos inmuebles hacia esos usos (Imagen 2.4).

\section{Suelos urbanizados infrautilizados}

Así mismo, existen ciertos espacios urbanizados y no edificados pertenecientes a la mancha urbana que están infrautilizados y/o degradados y sin aprovecharse en todas sus posibilidades. Espacios sobre los que se ha realizado una inversión de recursos económicos y naturales al dotar a esos suelos de las dotaciones necesarias, y que presentan en numerosos casos una localización céntrica en áreas urbanas activas. Las transformaciones y crecimientos de los sistemas urbanos han ido dejando suelos clasificados como urbanos que por diversas razones no están aprovechándose en todo su potencial. Vacíos urbanos, suelos con usos abandonados, suelos con planeamientos no desarrollados en su totalidad...son realidades existentes en las ciudades españolas, y también los son en el AMB. Frente a esto, se siguen planificando y desarrollando nuevos crecimientos generando situaciones de una baja eficiencia funcional de la ciudad como sistema complejo.

Sin descartar otras situaciones que han originado suelos urbanizados infrautilizados, se expone un ejemplo de este tipo de espacios en el AMB. En el área en general, y en el entorno de la ría en particular, la transformación del principal motor económico de la región -pasando de una economía industrial a una de servicios- dejó entre otras herencias grandes áreas industriales obsoletas y/o en desuso. Más allá de los motivos de base debidos a la crisis y posterior transformación económica, una de las principales razones de la existencia de estas grandes superficies de suelo de uso industrial es la figura de la gran empresa -que empleaba a más de 500 personascomo expresión más destacada de la revolución industrial llevada a cabo en la ría de Bilbao desde sus orígenes a finales del siglo XIX:

«En los Astilleros del Nervión en 1890 trabajan cuatro mil obreros; en 1894 trabajan mil obreros en la citada San Francisco; en Chavarri, Petrement y Compañía lo hacen quinientos en 1901; en ese mismo año 2.850 en Altos Hornos de Bilbao y 2.700 en la Sociedad Anónima de Metalurgia y Construcciones Vizcaya. Junto a las empresas citadas, masas importante de obreros trabajan en las minas: 13 mil mineros en 1910, y en el Puerto: más de 2 mil obreros trabajan en la carga y descarga de los barcos» (Egido, 2000).

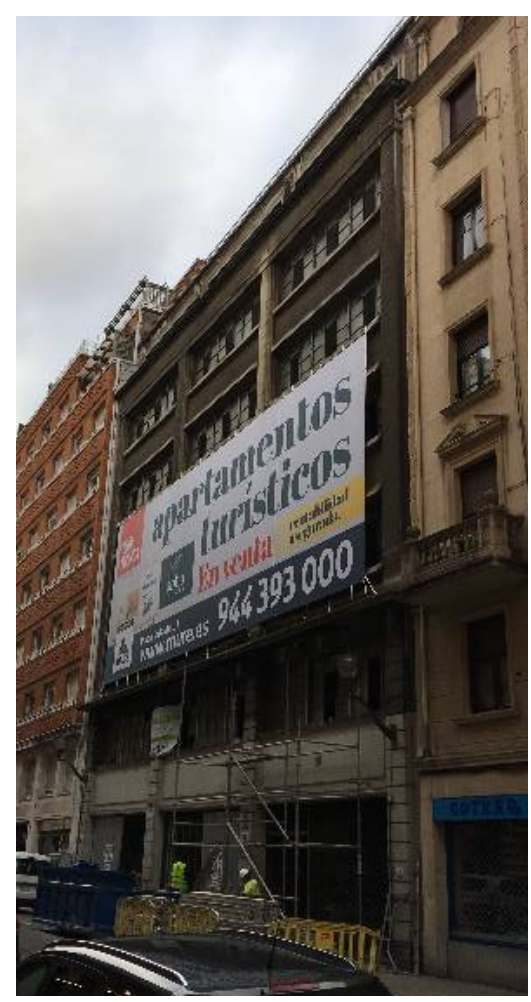

Imagen 2.4. Edificio mostrado en la Imagen 2.3 en fase de transformación en apartamentos turísticos.

Como afirma la publicidad, se trata de una operación con una «rentabilidad asegurada». La vivienda, en este caso temporal, como objeto de inversión desplaza otros posibles destinos más urgentes y menos rentables económicamente. 
Tabla 2.7. Empresas y personas empleadas en Bizkaia según $n^{\circ}$ de empleados en 1971. Egido, 2000.
Tal y como el autor desarrolla, este tipo de empresas fueron un potente eje del conjunto de la organización social y determinaron de diversas maneras la evolución urbana de parte de este territorio. Ocuparon, como ya se ha mencionado antes, los mejores terrenos junto a la ría y confinaron las zonas residenciales de ciertos municipios en el poco espacio disponible, mediante la construcción de "casas baratas" asociadas a las empresas. Hasta la década de 1970, la presencia de estas grandes empresas se mantuvo tal y como muestra la Tabla 2.7. A pesar de tratarse de datos provinciales, la gran mayoría de las citadas empresas se concentraban en el AMB. Aún en 1996, de las 35 empresas con 500 o más trabajadores existentes en Bizkaia -empleando a 41.000 personas- 33 estaban situadas en dicho ámbito (Egido, 2000).

\begin{tabular}{lccc}
\hline $\mathbf{N}^{\mathbf{o}}$ trabajadores & 50 a 100 & 501 a 1.000 & $>1.000$ \\
\hline $\mathbf{N}^{\mathbf{o}}$ empresas & 274 & 14 & 13 \\
\hline Trabajadores & 261.000 & 14.359 & 44.706 \\
\hline
\end{tabular}

Pero es en esa década de 1970 cuando estalla una crisis multidimensional en el AMB, y las grandes empresas entran una tras otra en crisis ejerciendo una enorme influencia en la región. Las decisiones tomadas como respuesta y reacción ante esta situación por las personas propietarias de estas empresas las clasifica el autor en tres: intentar vender al Estado o a multinacionales, deslocalizar las nuevas inversiones industriales a territorios más cómodos, accesibles, limpios y fiscalmente favorables, o proceder a la liquidación de las mismas. Se produce así un abandono progresivo de un esquema fordista propio de la concentración espacial de todas las fuerzas productivas, a otra organización basada, entre otras cosas, en la fábrica difusa. Mientras se mantiene una centralización del capital, se externalizan muchas de las funciones productivas y de gestión. Así, en las dos décadas siguientes se produce una reducción progresiva de empleo en las empresas de gran tamaño y comienza la proliferación de empresas pequeñas. El cierre o reducción de plantilla de muchas de las grandes empresas localizadas en el Área Metropolitana de Bilbao se produjo de esta manera en un periodo de tiempo relativamente corto y con un coste social elevado. Concluye Egido que las aglomeraciones urbanas y municipios que estaban más ligados a dichas fábricas son las que más sufren los efectos de este cambio en ámbitos como el desempleo, pobreza, exclusión y marginación, emigración, y por lo que interesa en este caso, deterioro y degradación urbana. A este fenómeno se pueden sumar otros, como los tiempos desacompasados de la ordenación y la ejecución urbanística o los fallos de previsión en la planificación urbana. Todos ellos, junto con el abandono de usos ya mencionado, son en ocasiones motivo de la existencia de solares y parcelas no edificadas sin uso y en un estado 
degradado, o con usos urbanos auxiliares como depósitos al aire libre o aparcamientos informales.

\section{Coste y dificultad de la intervención}

A los retos anteriores, tanto el parque edificado existente -sea residencial o no, vacío o en uso- como los espacios urbanizados no aprovechados, suman un importante obstáculo de cara a su aprovechamiento y adaptación: la dificultad para el desarrollo de las obras necesarias. Las dificultades de la intervención principalmente son dos: la económica y la constructiva. La primera tiene dos principales puntos desde los que ser abordada. Uno, el de la capacidad de pago, y que puede enmarcarse en la previamente sintetizada situación de precarización en la que se sitúa gran parte del colectivo con necesidad de vivienda. El otro sería el del coste relativo a las obras necesarias para adaptar el parque a esas unidades de convivencia que no ven satisfechas sus necesidades de alojamiento, o el relativo a la construcción de viviendas en aquellos solares infrautilizados. Lo que enlaza con la segunda dificultad: los sistemas constructivos generalmente utilizados no favorecen transformaciones económicas, fáciles, rápidas, limpias ni respetuosas con el entorno ruidos, residuos,...-. Además, «la industrialización de algunos de sus componentes ha mejorado la calidad, pero no ha hecho bajar los costes» (Paricio y Sust, 2000: 20). Los elementos y componentes constructivos que han de ser renovados o alterados habitualmente a la hora de reformar y adaptar un espacio para un uso residencial, tuviese o no ese mismo uso antes, son en general los que mayor coste unitario tienen. Frente a otros que, a pesar de ser grandes partidas, distribuyen mejor su coste entre la totalidad del edificio -cimentación, estructura,...-, los acabados, sanitarios y demás equipamientos de la vivienda, las carpinterías exteriores, o el imprescindible capítulo de las instalaciones - de climatización, electricidad o iluminación, que puede llegar a acaparar una tercera parte del coste total (Fumadó y Paricio, 1999: 7)-, suponen aún en pequeñas intervenciones un considerable gasto muchas veces inasumible por las unidades de convivencia interesadas en adquirir la vivienda. Indirectamente, si se trata de generar una oferta de alquiler, el coste de la intervención repercutirá probablemente en la renta final, con lo cual los efectos pueden llegar a ser similares.

Por otro lado, está el estado de conservación del parque actual. A pesar de que, «a diferencia de otras mercancías, la vida útil de la vivienda es prolongada y se puede modificar, tanto en su estructura física (superficie construida y acabados), como en su tenencia (Rothenberg, et. al.1991)» (González et al., 2003: 145), algunos datos indican que una parte relevante de las viviendas no habitadas no son susceptibles de ocupación inmediata por su deficiente estado de conservación o equipamiento (Gobierno Vasco, 2013a: 151). Efectivamente, algunas encuestas a personas que buscan piso en alquiler lo confirman, estimando que alrededor del $22 \%$ de la muestra 
encuentra que el mal estado de estos es uno de los principales problemas (Fotocasa, 2016). Y aunque no es el caso de Euskadi, en otras comunidades autónomas de España algunas administraciones públicas están rechazando viviendas cedidas por la Sociedad de Gestión de Activos procedentes de la Reestructuración Bancaria (Sareb) debido a que la inversión necesaria para la puesta al día de las mismas van más allá de una puesta a punto, necesitando en muchos casos de reformas integrales cuyo coste supera el máximo estipulado por convenio ${ }^{37}$.

\section{$-2.3 .4-$ \\ Respuestas en marcha: metas para enfrentar la situación}

El enorme peso que la variable económica tiene en el sistema urbanístico e inmobiliario residencial español ha hecho que desde que se produjera la explosión de la burbuja inmobiliaria buena parte de la atención se haya centrado en el seguimiento de la promoción y compra-venta, los precios, y los puestos de trabajo perdidos; y sin embargo, la verdadera problemática de fondo de la vivienda se sigue sin resolver mientras la crisis financiera no hace si no recrudecer algunas de sus características (Etxezarreta, 2010: 5). Como reacción, es posible identificar la definición, por parte de ese conjunto heterogéneo de relaciones, intereses y fuerzas que es la sociedad, de ciertas metas nada recientes ni novedosas, consecuencia directa de la lectura crítica de una tampoco novedosa situación problemática, con el fin de alterar un sistema dominante y excluyente centrado en un fin principal: el flujo y la acumulación de capital. Con todo, y sin negar otras posibilidades, el problema no parece tanto la mercantilización de la vivienda en sí -existen modelos de gestión y producción de vivienda en el mercado socialmente responsables o, por ejemplo, modelos de relaciones entre agentes productores de alimentación o productos textiles y destinatarios finales bajo un sistema de mercado con criterios justos, sostenibles y equilibrados para todas las partes-, como que esta es excesiva y desequilibrada. Lo que lleva a desfigurar el derecho de acceso a una vivienda digna y adecuada y a dificultar extremadamente su consecución por parte de una parte importante de la población. Estas metas presentes en la sociedad se enmarcan a su vez en ese objetivo concreto de la presente investigación, definido en el capítulo primero -avanzar hacia un acceso total y digno a la

\footnotetext{
37 «Ayuntamientos y Comunidades Autónomas rechazan uno de cada cuatro pisos sociales de la Sareb», disponible en https://www.eldiario.es/economia/AyuntamientosComunidades-Autonomas-rechazan-Sareb_0_850765213.html.
} 
vivienda aprovechando para ello de manera eficaz el entorno construido heredado-, y pueden resumirse en tres:

- Trabajar por un más extendido y digno acceso económico a la vivienda. Las dificultades existentes en una parte importante de la población para ser capaz de demandar un alojamiento en el mercado libre, para poder aceptar y costear una vivienda protegida o para, contando con vivienda habitual, destinar un porcentaje digno y asumible de las rentas de trabajo al pago de la misma sin alimentar situaciones de vulnerabilidad social, expulsión o desahucio, ni afectar al pago de otras necesidades básicas, hacen de esta la principal y más urgente meta.

- Intensificar la adecuación tipológica de las viviendas a las necesidades de las unidades de convivencia actuales y por venir. El desfase entre el mantenimiento y la consolidación de las características espaciales habituales -tanto de las viviendas existentes como las que se están realizando y/o planificando-, y la evolución de los tipos y formas de vida de las unidades convivenciales, plantea el reto de sacar de la esfera e iniciativa particular y privada la adecuación del espacio doméstico para incorporarla a las políticas públicas de vivienda.

- Aprovechar el parque y la ciudad existentes para el desarrollo de las anteriores y reducir la presión sobre el suelo no urbanizado. La convergencia, en el caso del AMB, de un territorio con una orografía complicada y un alto porcentaje de urbanización y artificialización de los suelos aptos para ello, una ciudad con necesidad de ser intervenida y actualizada, una población en estancamiento o muy ligero crecimiento, y un modelo urbanístico residencial estructuralmente expansionista que ha venido respondiendo a la necesidad de vivienda mayormente con la construcción de nuevos edificios y ocupación de suelos y generando como herencia un parque infrautilizado, lleva a tomar el parque residencial heredado como soporte para la consecución de las dos metas anteriores. 


\section{$-2.4-$}

\section{Generación de contenido}

Los siguientes tres grandes apartados, del 2.4 al 2.6, representan un recorrido por el resto de elementos que conforman la conceptualización propuesta de generación de contradicciones en procesos de gobernanza urbana (Esquema 2.1): las tres fases de gobernanza como respuesta de la sociedad -Contenido, Instrumentos y Ejecución- y los Condicionantes y Obstáculos internos enfrentados a las mismas. El repaso toma como caso de estudio el AMB y muestra una serie de ejemplos significativos, identificados en diferentes categorías dentro de cada uno de los grandes elementos del esquema, para argumentar y contrastar la herramienta. No es por lo tanto un recorrido exhaustivo por el universo existente en torno a la misma, si no un intento de demostrar su validez en base a dichos ejemplos. A su vez, la fuerte interconexión e influencia que hay entre diferentes escalas geográficas o administrativas, o entre diferentes esferas y ámbitos vitales, hace que en ocasiones este análisis recoja casos externos al AMB, o no propiamente centrados en la vivienda, pero con afección directa o indirecta en ambas. En el caso del Contenido y los Instrumentos, aunque no hay motivos para pretender una mirada equitativa ni comparativa, por motivos de claridad y comprensión la redacción se estructura, dentro de lo posible, analizando dentro de cada categoría la respuesta que se ha dado por separado a cada uno de los tres conflictos seleccionados de la situación problemática en la búsqueda de cada una de las tres metas que la sociedad ha definido como reacción. Se trata en definitiva de una breve aproximación al estado de este esquema, en el momento concreto de esta investigación, y en el marco del objeto de estudio escogido. El contexto analizado es en parte el español, con algunas necesarias referencias internacionales, y concretando en el vasco y el regional del $\mathrm{AMB}$ en la medida de lo posible -el peso demográfico del AMB respecto a Euskadi y Bizkaia permite ese margen-. Todo ello ayudará a comprender con mayor precisión la situación problemática a la que se enfrenta el trabajo, a confirmar el marco teórico previamente propuesto, y a completar y enriquecer -en una escala local- la hipótesis de investigación previamente formulada.

En lo que respecta al Contenido, una revisión del estado actual en el AMB permite afirmar, a modo de síntesis, que los objetivos y horizontes hacia los que avanzar en la dimensión social de la vivienda abordada en este trabajo gozan de un a priori extendido consenso y una legitimidad relativamente amplia entre numerosos agentes. La contundencia con la que esta problemática afecta a la realidad social genera aparentemente pocas dudas respecto a su urgencia. Sin embargo -se verá al analizar los Condicionantes y Obstáculos-, y 
como corresponde a un panorama contradictorio como el previamente presentado, existe un violento choque entre esa urgencia ampliamente consensuada y ciertos intereses y fuerzas. De manera que aparecen matices, discrepancias, actuaciones hipócritas, dramáticos daños colaterales, o agentes con objetivos enfrentados, que fortalecen las raíces de un reto urbano estructural y permanente, dentro de su evolución. Para el análisis de la generación de este contenido, entre otros muchos agentes que participan de diversa manera en esta compleja gobernanza, se han estudiado ejemplos propios de la sociedad civil 'anónima' -como agente sin una representación concreta ni públicamente identificada-, de la sociedad civil organizada y representada -bajo diferentes formas y esta vez sí con una identificación pública concreta-, de las instituciones públicas, y del mundo académico.

\section{$-2.4 .1-$}

\section{Sociedad civil 'anónima'}

\section{Percepción de la necesidad de vivienda}

Socialmente, es una necesidad claramente percibida y palpable, debido a su papel fundamental en el desarrollo vital. Como se ha esbozado previamente, una parte importante de la sociedad vasca choca brutalmente con ella, con unas consecuencias drásticas. Podría decirse que, en general y sin entrar en los detalles de cómo formalizarlo, no hay mucha discusión sobre la necesidad de ofrecer a toda persona un acceso básico a la vivienda bajo unas condiciones económicas aceptables. Así lo demuestran distintas encuestas realizadas sobre la percepción de las principales preocupaciones de la sociedad, como las series realizadas por el grupo de investigación Euskobarometro de la Universidad del País Vasco/Euskal Herriko Unibertsitatea (Gráfica 2.20). En ellas, la vivienda está presente de manera continua y directa, en mayor o menor medida, analizados los datos desde 1999 hasta 2016. Con un claro aumento de presencia entre los años 2003 y 2008, posiblemente cuando mayor dificultad de acceso económico hubo. Pero indirectamente, hay otros temas que pueden repercutir en la capacidad de acceso a la misma, como son las desigualdades y el bienestar, la situación económica, o el paro. En este sentido, resulta llamativa la relación inversa que se observa entre la preocupación por la vivienda y el paro. Según crece la primera se reduce la segunda. Podría entenderse como un reflejo de la escalada de precios de las viviendas en los años de mayor bonanza económica, con menores tasas de paro. En cualquier caso, son temas todos ellos que predominan en los primeros puestos de las series analizadas. Resultados similares ofrecen otras encuestas internacionales, como la realizada por GlobeScan para Oxfam Internacional entre 2013 y 2014. 
- otras

- inmigración

situación política

drogas

pacificación

violencia

- situación económica

- desigualdades y bienestar

- paro

uivienda

- vivienda / sanidad / educación

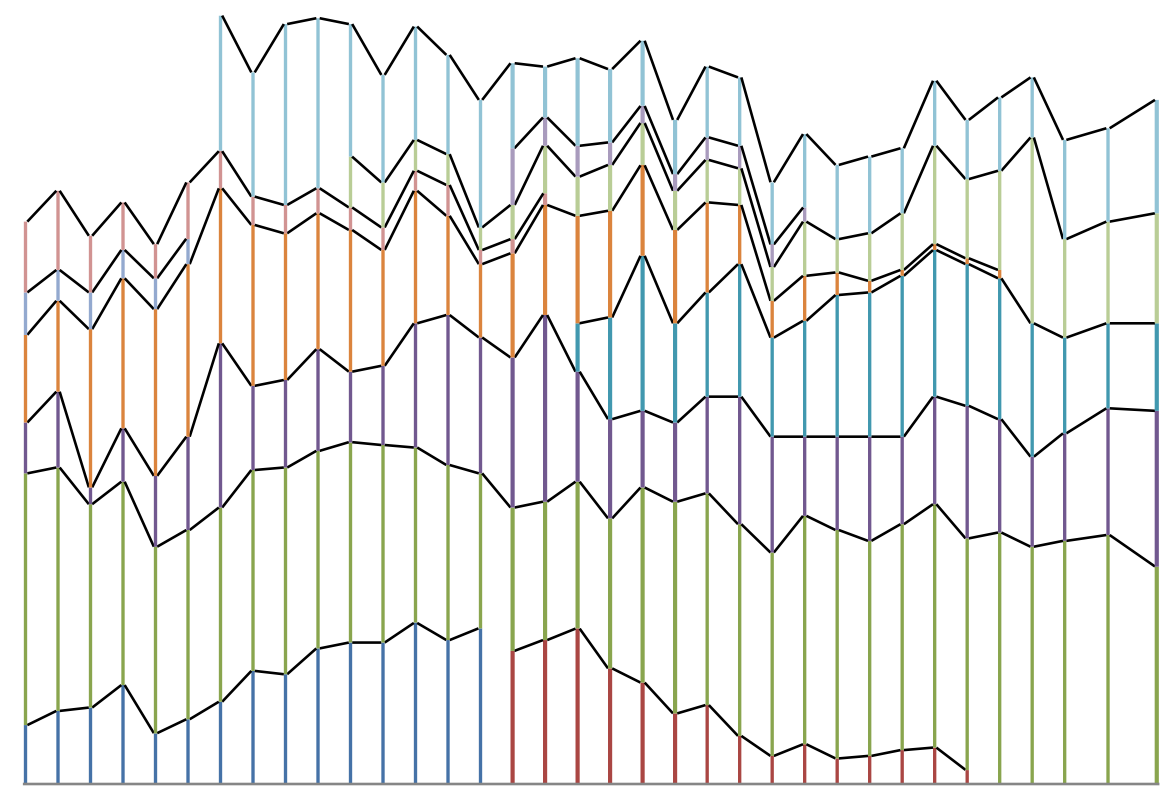

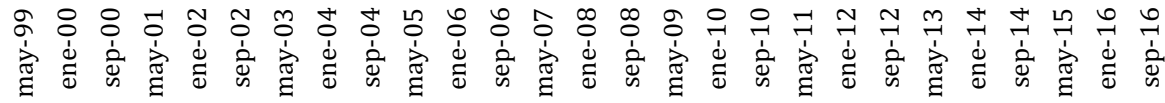

En ella se recogen datos de 24 países, entre ellos España, y la pobreza y el acceso a la vivienda aparecen como las principales preocupaciones en más de la mitad. Cuestiones que están al mismo nivel que otras como la delincuencia, la violencia, el desempleo o el aumento del coste de los alimentos y la energía. Todo indica que pobreza y acceso a la vivienda son preocupaciones en aumento, pues en la mitad de estos países el nivel de preocupación por ellos ha aumentado desde los datos de 2012. Así ha sido en España, con un aumento del $10 \%$.

\section{De la percepción a la acción}

Puede afirmarse por tanto que existe un considerable consenso social en torno a la urgencia e importancia de avanzar hacia un acceso a la vivienda. Algo, por otro lado, que no se trata de un fenómeno exclusivamente actual, en la medida en que la problemática es sistémica. En España hay una historia reciente de lucha vecinal y movimientos asociativos en relación con la necesidad de vivienda. Ejemplo de esto, entre otros, sería la «conquista del derecho a permanecer en los barrios» (Inurrieta et al., 2013: 10) por parte de la movilización vecinal surgida de los barrios de viviendas autoconstruidas en las décadas de los cincuenta y sesenta en numerosas ciudades como consecuencia de los fuertes flujos migratorios. Conquista que supuso, entre otras cosas, la aprobación por parte del Ministerio de Obras Públicas en 1979 de la operación de Barrios en Remodelación. Las respuestas, reacciones y reivindicaciones de la propia sociedad ante esta situación pueden 
llegar a tomar múltiples formas. Incluyendo la conformación de asociaciones vecinales en defensa de viviendas, dotaciones y servicios adecuados - muy presentes en el AMB, con ejemplos paradigmáticos como la Asociación de Familias de Otxarkoaga constituida en dicho barrio en 1968 (López, 2016), repartidas por numerosos barrios de la región y organizadas en ocasiones en federaciones en red, como el caso de Bilbao $^{38}-$, acciones menos habituales como las huelgas de alquileres -con casos internacionales ya desde inicios del siglo XX (Madden y Marcuse, 2018: 170, 201) y otros más recientes como las de las residencias de estudiantes de la University College London en 2015 o Parkdale, Toronto, en $2017^{39}$-, o movimientos de ocupación cercanos como los existentes en el barrio de Errekaleor en VitoriaGasteiz.

Desde una posición anónima, la canalización de esta preocupación en el AMB se observa, entre otras, en pequeñas aunque reveladoras acciones simbólicas de marcado carácter político. Aquí se van a mostrar dos acciones locales que evidencian una de las múltiples facetas que el problema del acceso a la vivienda presenta en la región: la situación de exclusión en la que se encuentra una parte considerable de la juventud que ha visto como la escalada de precios de la vivienda en sus municipios ha hecho que no pueda permitirse el acceso a la misma. Y viéndose así obligada a buscar alternativas precarias en esos mismos municipios, o a desplazarse a otros cercanos con precios más asequibles. El primer ejemplo se dio en el municipio de Getxo; como se verá más adelante, con uno de los precios medios de vivienda más altos del estado. En él, la ausencia de una política de vivienda eficaz orientada al colectivo de jóvenes en edad de emancipación ha generado en los últimos años cierto clima de crispación e impotencia por no poder residir en el municipio donde se ha crecido. A finales de 2008 apareció, sobre la fachada de una sede social del Partido Nacionalista Vasco -partido tradicionalmente gobernante no solo en Getxo, si no en la Diputación Foral de Bizkaia y el Gobierno Vasco, y por lo tanto con una alta responsabilidad en la política de vivienda municipal-, una pintada haciendo alusión al tema (Imagen 2.5). Si bien las fuentes consultadas no permiten aclarar si se trata de una pintada realmente ejecutada sobre la fachada o de un montaje sobre una fotografía, la cuestión de fondo es la fuerza del mensaje y la considerable difusión que logró, cumpliendo con el objetivo que buscaba. En la imagen se observa una pancarta colocada en dicha sede social con un fragmento del poema de Gabriel Aresti Nire aitaren etxea defendituko dut (defenderé la casa de mi padre). Dicho poema, publicado en 1964, pretendía mediante el paralelismo de la casa paterna hacer alusión a la defensa del País Vasco. Sobre esa imagen

\footnotetext{
38 La Federación de Asociaciones Vecinales de Bilbao agrupa 27 asociaciones federadas y
} 18 asociaciones observadoras.

${ }^{39}$ El Salto (2018): «Las cinco huelgas de alquileres que cambiaron las reglas del juego», disponible en https://www.elsaltodiario.com/vivienda/cinco-huelgas-alquileres-cambiaronreglas-juego.

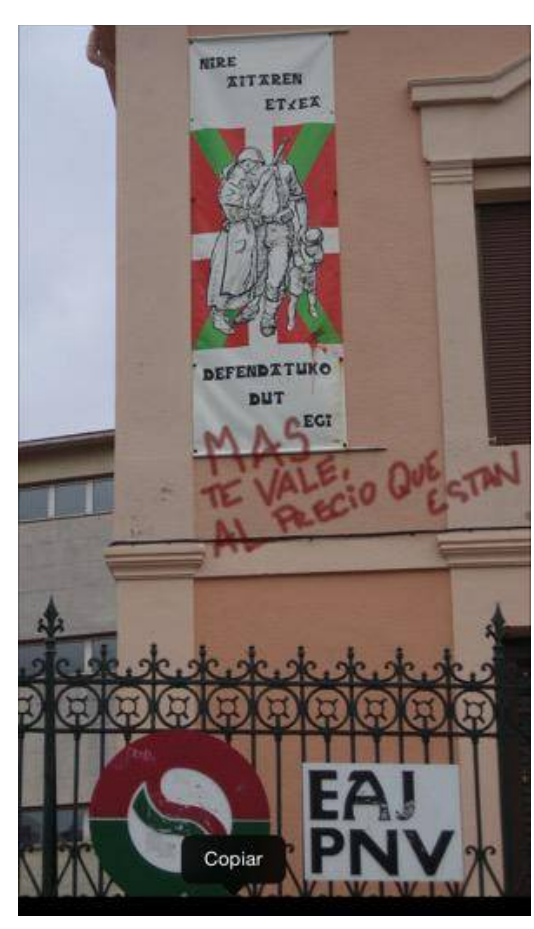

Imagen 2.5. Pintada (física o digital) sobre la fachada de una sede social del Partido Nacionalista Vasco en Getxo, Bizkaia. Disponible en: http://elciudadanocabreao.blogsp ot.com/2008/12/batzoki-dealgorta-pintada.html. 
colocada en la fachada -irónicamente firmada por EGI, movimiento de las juventudes del Partido Nacionalista Vasco-, la pintada decía «más te vale, al precio que están». La acción puede tener una lectura interesante. Más allá de la literalidad de las dos frases enfrentadas, de por sí ingeniosa, existe un choque de realidades y una fuerte contradicción de fondo: por un lado está el desfase de un nacionalismo conservador con poca evolución en sus mensajes a lo largo de las últimas décadas, que se ve abordado por una cruda problemática local de acceso a la vivienda. Por otro lado, resulta paradójico y contradictorio en lo que se refiere a la vivienda, que el Partido Nacionalista Vasco - con una importante responsabilidad, ya sea solo por las cuotas de poder y la capacidad de influencia que viene acumulando, en el mantenimiento de una política de vivienda y un modelo inmobiliario excluyentes- sea el más votado en el AMB. Evidentemente, otras muchas variables entran en juego a la hora de ejercer el voto. Sobre esta cuestión se volverá más tarde.

El segundo ejemplo es una acción que se realizó, también de manera anónima, en el municipio de Portugalete. El 23 de diciembre de 2014 aparecieron una serie de falsos bandos del ayuntamiento colocados en numerosos portales del municipio ${ }^{40}$. En ellos, se anunciaba la puesta en marcha con carácter inmediato de un programa de alquiler social. Un programa que consistía en la apropiación, por parte del ayuntamiento, de las viviendas desahuciadas por la banca y de las viviendas vacías en el municipio, para su posterior puesta en alquiler con precios bajos. En enero de 2015 se difundió en internet un video anónimo asumiendo y explicando la acción, indicando que se trataba de un ejercicio de reivindicación debido a la precariedad que el modelo actual de vivienda generaba en varios colectivos del municipio -jóvenes, personas desempleadas o inmigrantes, entre otros-. Como crítica a la respuesta municipal ante esa situación, el video cuestionaba los nuevos crecimientos en marcha y la falta de una política social potente. Con todo, por aquel entonces el gobierno local estaba trabajando en la elaboración de un censo oficial de viviendas vacías. Sin embargo, este caso muestra cómo a veces el ritmo de la administración pública ante determinados problemas se ve ampliamente superado por las exigencias y necesidades reales de la población, poniendo en evidencia a la misma con acciones como esta.

\section{Reivindicaciones territoriales de corte político}

En comparación con la meta del acceso económico, podría decirse que sobre la necesidad de lograr dicho acceso a través de una

40 Tele7 (2015): «Los falsos bandos de Portugalete causan decepción a vecinos que han acudido al ayuntamiento para interesarse por el falso programa de viviendas, disponible en http://www.tele7.tv/index.php/2388-los-falsos-bandos-de-portugalete-causan-decepcion-avecinos-que-han-acudido-al-ayuntamiento-para-interesarse-por-el-falso-programa-devivienda-2388. 
planificación espacial racional, eficiente y eficaz con el parque heredado, y que reduzca el crecimiento de la ciudad y la ocupación de suelos no artificializados, no hay una percepción tan clara, asumida ni reivindicada en la sociedad. En torno a la primera, no parece haber debate sobre el papel fundamental que un alojamiento digno juega en el desarrollo de la calidad de vida -lo que no evita la existencia de acciones contradictorias que van en contra de lograr ese alojamiento-. Sin embargo, es posible que la toma de conciencia sobre la necesidad de desarrollar la ciudad bajo los principios de un urbanismo racional que incluya una perspectiva integral del territorio, se dé con mayor probabilidad en perfiles personales concretos, con trayectorias formativas o culturales específicas. Circunstancias como una cultura y concienciación medioambiental y ecológica, o la existencia de lazos de identidad, económicos o productivos- con los suelos y/o formas de vida afectadas por el desarrollo urbano, entre otras, llevan a generar ese tipo de inquietudes y preocupaciones. Al igual que antes, en este caso se pueden encontrar acciones ciudadanas de ámbito local y carácter anónimo en el AMB con una marcada intención política detrás, reivindicando una intervención más equilibrada en el territorio por parte de la planificación residencial. Si bien la mirada se pone más sobre los suelos no ocupados, indirectamente hay una inquietud por actuar sobre la ciudad existente.

Un ejemplo de ello es el conflicto generado en torno a la construcción de un aparcamiento disuasorio junto a la futura parada de Ibarbengoa en la Línea 1 del metro de Bilbao, en el municipio de Getxo. Se trata esta de una nueva parada ejecutada en los últimos años, a día de hoy sin puesta en funcionamiento, en un entorno periurbano y semi-rural a medio camino entre los centros urbanos de Getxo y Berango. Ejecutadas las obras, su apertura está condicionada -según el Consorcio de Transportes de Bizkaia- a la construcción del citado aparcamiento contiguo. Las obras de la estación se iniciaron en 2009 y lleva desde 2011 acabada, pero sin uso. La justificación de la construcción de esta parada y el consecuente aparcamiento viene motivada, según el citado consorcio, por la necesidad de dotar a los habitantes de la zona de una parada que les permita conectar con el resto del área metropolitana. El ser un entorno semi-rural de baja densidad es la justificación utilizada para la localización de un aparcamiento disuasorio como equipamiento que permita la intermodalidad. Esta parada se encuentra a unos 1.000 metros de la más cercana en cada uno de los dos sentidos de la línea. Desde septiembre de 2011 un grupo de jóvenes ocupa y cultiva alimentos bajo una agricultura extensiva en los suelos previstos para el aparcamiento, como acto de protesta contra la ejecución del mismo. Si bien son varias las razones que les llevan a la lucha en contra del mismo -dañino para los acuíferos, innecesario para las necesidades actuales de la zona, presunta ausencia de estudio de impacto ambiental, y carencia de un proceso de toma de decisiones abierto a la ciudadanía-, puede afirmarse que este movimiento tiene su origen en un movimiento popular más amplio surgido años antes por razones 
más poderosas. En esta zona de Getxo se fomentó desde el Gobierno Vasco y Diputación Foral de Bizkaia a principios de la década de 2000 $-y$ trasladado frustradamente a la escala municipal con un avance de modificación puntual del Plan General de Ordenación Urbana en 2007, sin aprobación definitiva- un desarrollo urbano de unas 8.000 viviendas con un importante porcentaje de vivienda protegida. Cifra que finalmente fue reducida considerablemente.

Con todo, sí es cierto que esta zona alberga una de las mayores previsiones de crecimiento urbano de la región. Y aunque como se ha señalado más arriba, Getxo es un municipio con un problema de acceso a la vivienda considerable en ciertos colectivos, estos saben que los nuevos crecimientos difícilmente van a ser económicamente accesibles para ellos. Todo ello ha llevado a que, desde que se conociesen las intenciones de la Consejería de Vivienda del Gobierno Vasco, haya surgido y se mantenga vivo un movimiento ciudadano en defensa de esta zona periurbana -último gran espacio verde del municipio, con una considerable presencia de usos rurales, cercana a la ciudad y de gran valor ecológico y cultural-. Y en el que puede enmarcarse este movimiento puntual de lucha contra el aparcamiento de la estación de metro de Ibarbengoa, bajo el nombre de Tosu Betirako. No en vano, entre sus razones de existencia incluyen la creencia de que esta estación y el aparcamiento son una punta de lanza de la urbanización posterior de este barrio con la consecuente expansión de la ciudad. Efectivamente, pueden observarse importantes carencias en el proceso de planteamiento, decisión, diseño y comunicación de esta planificación urbana y territorial con importantes consecuencias ecosistémicas y cuestionables objetivos sociales. Igualmente, puede detectarse cierta inconsistencia en algunos de los argumentos del colectivo de personas trabajando en contra de la misma.

Imagen 2.6. Barricada levantada en la estrada de Tosu, Getxo, como protesta y acto de protección ante la inminencia de

las obras de ejecución del aparcamiento. Disponible en: tosubetirako.wordpress.com

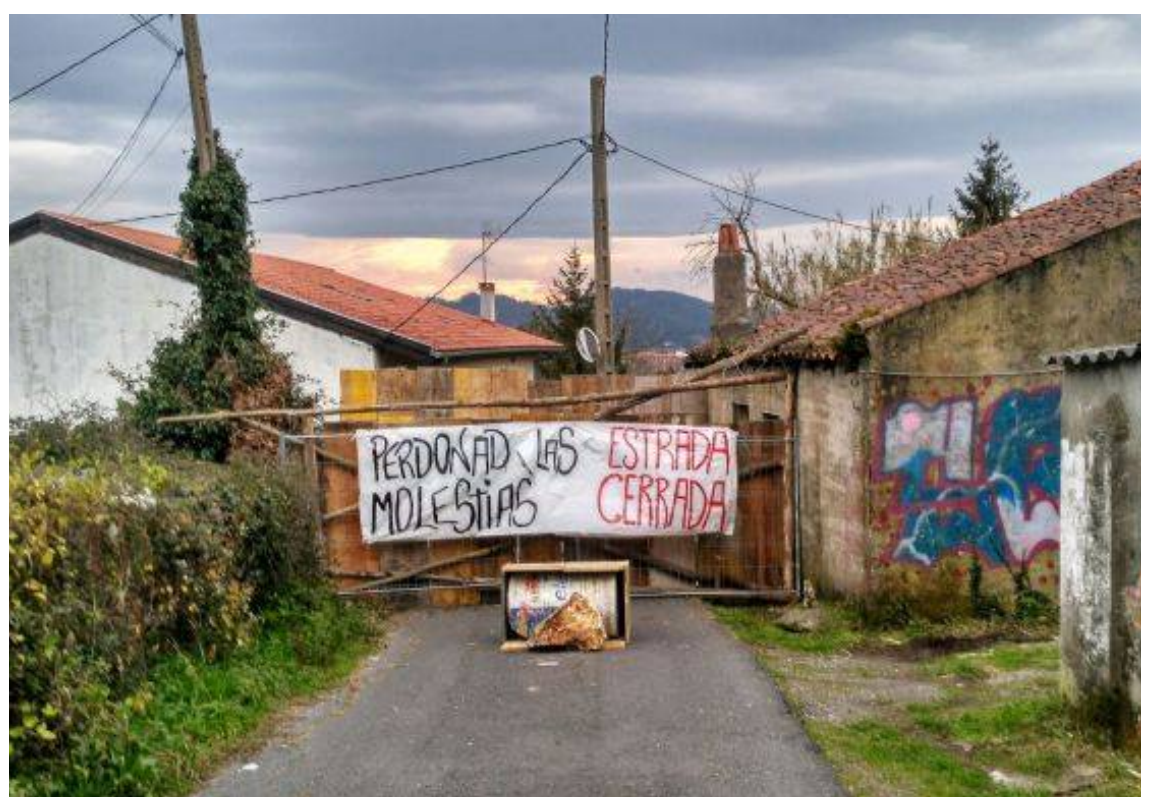


En cualquier caso, lo que interesa aquí es poner en valor no tanto el fondo si no la identificación de una activación ciudadana relativamente anónima en defensa de una ordenación y gestión racional de los suelos residenciales, colaborando a la generación de contenido -con mayor o menor éxito y rigor- dentro del Esquema 2.1. Una activación social que llevó incluso a intervenciones de cierto calado (Imagen 2.6). En enero de 2017, y observada cierta actividad previa a la obra del aparcamiento -posiblemente acciones de replanteo-, una serie de personas decidieron como acto simbólico proteger físicamente los suelos en cuestión. Y lo llevaron a cabo mediante el corte de los accesos al solar por carretera a través del levantamiento de barricadas. Es este caso un claro ejemplo en el que pueden identificarse los citados lazos de identidad como motivadores de la movilización ciudadana. Es cierto que existen sinceras razones de carácter ecológico y ambientalista detrás de esta lucha. Pero por los mensajes y las acciones de este movimiento ciudadano se observa que la cuestión del aparcamiento se queda en segundo plano, reforzando la idea de que las raíces del mismo se encuentran en la identificación con una supuesta forma de vida y un paisaje local, el cuestionamiento de un modelo de planificación urbana, e incluso en un posicionamiento político en contra del gobierno local, del Partido Nacionalista Vasco.

Lo que surgió como una acampada de ocupación y protesta como reivindicación de la necesidad de plantear un desarrollo urbano racional en Getxo, parece haber evolucionado a un espacio físico y social para la reflexión, el debate y la lucha de una serie de ideas y actividades con intenciones ${ }^{41}$ progresistas. En este sentido, la actividad de este grupo de personas es de gran interés y merecedora de atención y reconocimiento por su esfuerzo y motivación. Acampadas de resistencia, puesta en marcha de huertos comunitarios -algunos de ellos llegando a comercializar sus productos en el municipio- y difusión de la agricultura periurbana con talleres y charlas, realización de murales y teatralizaciones de los procesos de urbanización como acto de protesta y divulgación, organización de debates y encuentros de carácter político con el tratamiento de múltiples temas, encuentros con agentes sociales de otros lugares para la puesta en común de luchas por el territorio, o acciones simbólicas de plantación de hortalizas en espacios públicos y sedes de organismos inmersos en el proceso, como el Consorcio de Transportes de Bizkaia, son algunas de las muchas acciones llevadas a cabo a lo largo de los años desde el inicio del movimiento.

${ }^{41}$ Es posible identificar ciertas carencias por parte de esta movilización ciudadana, principalmente la de una visión más global del territorio y de los diferentes intereses, inercias, lógicas e instrumentos que lo afectan, imprescindible para una mejor comprensión del mismo. Por otro lado, parece no tenerse en cuenta la posibilidad de que el aparcamiento se utilice como equipamiento para el fomento de la intermodalidad con el transporte público. Especialmente en una región con un importante uso del vehículo motorizado privado. 
Como se ha comentado, en torno a la meta del acceso económico a la vivienda podría encontrarse un mayor consenso social. Sin embargo, en este caso -puede que por el hecho de que la necesidad de un desarrollo urbano y territorial racional y equilibrado no goce de un reconocimiento social tan amplio-, es posible identificar ciertas discusiones o enfrentamientos de ideologías y planteamientos. Los cuales, en lo que aquí interesa, llevan en última instancia a la reflexión $\mathrm{y}$ al debate y son también generadores de contenido dentro de la sociedad. Una muestra de ello son los espacios de participación ciudadana que, con mayor o menor fortuna, se dan en torno a estos procesos urbanos. $\mathrm{Y}$ sin salir del municipio de Getxo, puede presentarse un ejemplo. En el proceso de revisión de su actual Plan General de Ordenación Urbana, aprobado en 2001 y con alrededor de treinta modificaciones puntuales hasta la fecha, se puso en marcha en 2011 un grupo de trabajo para incorporar a la ciudadanía en el proceso. Concretamente, en las fases de Estudios Previos, Preavance y Avance. En dicho grupo de trabajo, en torno a la mitad de las cuarenta personas participantes decidieron abandonar el mismo al constatar la baja calidad y el condicionamiento previo del debate. La principal razón fue la «ausencia de un verdadero proceso participativo y un dirigismo del equipo redactor hacia un plan de desarrollo en Getxo preconcebido mucho antes incluso de la creación» del grupo (Asociación de Vecinos de Andra Mari, 2014). Aparentemente, las sesiones no permitieron un debate integral sobre el plan vigente ni sobre el modelo territorial futuro. En parte debido a cierto desconocimiento de los participantes de la legislación y los instrumentos de ordenación del territorio, pero también porque los instrumentos jerárquicamente superiores -Plan Territorial Parcial y, sobre todo, Directrices de Ordenación del Territorio- establecen una cuantificación residencial mínima. Así, los debates se centraron especialmente en el número de viviendas con las que la ciudad debía, sí o sí, crecer.

Todo ello llevó al hartazgo y desencanto de un grupo de personas, viendo la imposibilidad de plantear un debate serio que cuestionase la continuación de un modelo urbanístico en declive. Parece que tampoco se trató el estructural cambio socio-demográfico, y cómo este debería hacer cuestionar instrumentos de ordenación aprobados en las décadas de 1990 y 2000. De esta manera, tomaron la decisión de abandonar el grupo de trabajo, sacando a la luz una discusión que enfrentaba a un desarrollismo continuista con la prioridad puesta en el desarrollo económico del territorio, con un enfoque más integrador y holístico del mismo. Lo que aquí se quiere resaltar es cómo un grupo de personas anónimas puede generar, impulsar y fortalecer mediante este tipo de acciones un discurso concreto, y sacar a la luz, al menos parcialmente, un debate urgente. Una inquietud social que gira, en este caso, en torno a una preocupación por la necesidad de plantear un modelo territorial racional con la mirada puesta en el futuro a medio y largo plazo, cuyo eje central se sitúa en la necesidad de vivienda, el acceso a la misma, y la manera de resolverla. 


\section{Sociedad civil organizada y representada}

\section{La lucha por el derecho a la vivienda}

«Afortunadamente, grupos casi heroicos, como la Plataforma por una Vivienda Digna y VdeVivienda de antaño; y hoy el movimiento 15M, Democracia Real Ya y, sobre todo, la Plataforma de Afectados por la Hipoteca, han contribuido a que parte de la población en España considere que un país con millones de viviendas vacías, casi sin viviendas de alquiler, sin parque público de vivienda y con cientos de miles de personas desahuciadas es un país enfermo que debe ser sanado» (Burón, 2012).

Otra de las vías para la generación de este contenido al que se ha hecho referencia en el Esquema 2.1, en este caso en torno a la lucha por el derecho del acceso económico a la vivienda, son las asociaciones, colectivos, movimientos sociales, observatorios y otros entes sociales. Al contrario que en los casos previos, aquí ya no hay un anonimato, sino que más bien se busca una visibilidad pública. Quizás algunos de los más importantes son los colectivos de naturaleza reivindicativa y de origen ciudadano. Es el caso de la Plataforma por una Vivienda Digna, que lleva desde el año 2003 acumulando acciones, desarrollando documentos de información y difusión, elaborando guías y poniendo en contacto a personas en torno a la lucha por erradicar «todas las problemáticas que afectan al mercado de la vivienda y el urbanismo desde el punto de vista de los ciudadanos afectados» (Plataforma por una vivienda digna, 2017) tal y como se presentan en su página web. De manera similar, existen otras plataformas con objetivos y luchas similares. Como Opinión Pública, convocante el 15 de febrero de 2004 de una manifestación general en Barcelona en contra del abuso en el precio de la vivienda, por un alquiler justo, y que permitiera una calidad de vida digna. O la plataforma Juventud Sin Futuro, creada a iniciativa de varios colectivos universitarios de Madrid en 2011. Nacida como reacción ante las consecuencias que en la juventud estaban generando las medidas de salida de la crisis desarrolladas por el Gobierno de España bajo criterios de la Unión Europea, el Banco Central Europeo y el Fondo Monetario Internacional, y entre cuyas preocupaciones estaba el alto precio de la vivienda.

Desde otro ámbito de lucha, sin olvidar la incidencia política aunque más centrados en la observación, la investigación, la difusión y la formación, pueden encontrase espacios de reflexión y reivindicación como el Observatori DESC. Un espacio acumulador de entidades y personas independientes que lleva desde 1998 trabajando por el desarrollo de los derechos económicos, sociales y 
culturales. $\mathrm{Y}$ en los que el derecho a la vivienda tiene un lugar primordial como derecho fundamental. Otro ejemplo de colectivo ciudadano orientado a la reflexión y la generación de contenido en torno al problema del acceso a la vivienda es la plataforma Casastristes.org. En este caso se trata de un proyecto colectivo nacido en 2007 de desarrollo abierto a la ciudadanía, con el objetivo de desarrollar herramientas para la visualización de la problemática de la vivienda. Más allá de la identificación y localización de viviendas vacías en España, la plataforma ofrece síntesis muy reveladoras y de fácil difusión sobre la complejidad existente en torno a esta cuestión. Como por ejemplo, comparativas de la burbuja inmobiliaria española frente a la de los Estados Unidos de América, la evolución de las constructoras en la bolsa de valores, o mapas de nuevos habitantes frente a viviendas construidas, entre otros.

Aunque la propia temática hace que en el origen de estas plataformas haya una inquietud política, es de destacar cómo algunas de ellas han evolucionado y desarrollado especialmente ese ámbito de acción. Llevándoles desde una posición reivindicativa a pasar a ser movimiento político, formando parte del germen de la llamada 'nueva política' que ha irrumpido en España con fuerza desde 2011. La antes citada plataforma de Juventud sin Futuro participó junto a otras organizaciones en la convocatoria de la manifestación del 15 de mayo de 2011 en Madrid, formando más tarde parte -como lo hicieron muchos de sus integrantes a título individual- del movimiento $15 \mathrm{M}$, en cuyo seno se gestó la creación del partido político Podemos. Quizás uno de los ejemplos más paradigmáticos de esta evolución pueda ser la de la Plataforma de Afectados por la Hipoteca, que lucha para salir de las consecuencias de la burbuja inmobiliaria y encaminar a sus miembros hacia el derecho a la vivienda. Su presencia política es y ha sido innegable. $\mathrm{Y}$ ha sido el origen, al menos como personaje público a nivel nacional, de la carrera política de la actual alcaldesa de Barcelona, Ada Colau. Aunque todos estos ejemplos aquí expuestos se pueden inscribir en una escala nacional, muchos de ellos tienen o han tenido presencia y actividad en el AMB, y en cualquier caso su aportación al debate, al Contenido, es extensible a todo el estado en la medida en que hay un modelo y una problemática residencial compartida.

\section{Divulgación de otras tipologías de vivienda}

Así como desde la sociedad civil 'anónima' no se han podido detectar espacios de generación de contenido en torno a la necesidad de adaptar el espacio doméstico a esa diversidad de unidades de convivencia existente, a nivel de colectivos y asociaciones sí hay una serie de organizaciones interesadas en potenciar e investigar otras vías para la generación de tipologías residenciales que respondan con eficacia a las necesidades de sus habitantes, y diferentes a las convencionales y más comúnmente visibles en la oferta residencial actual. Muchos de estos grupos están principalmente formados por 
profesionales cuyas disciplinas están en contacto directo con el proceso de diseño, construcción o gestión de la vivienda. Si bien también es posible encontrar a personas usuarias con cierta inquietud y conocimiento en torno a alternativas y otros modelos de gestión, e incluso construcción, de vivienda. Esto último no es de sorprender, ya que la apertura de miras en una de las dimensiones puede llevar a la búsqueda de alternativas más interesantes en el resto.

Ejemplo de ello es la plataforma web Más que una Casa, que busca «desarrollar guías teóricas de propuestas y modelos alternativos de organización y desarrollo de proyectos de vivienda colectiva, potenciando la colaboración y la no especulación» (Más que una Casa, 2017). Su funcionamiento consiste en recopilar, difundir y promover nuevas experiencias colectivas, realizadas, para «hacer ver que hay otras maneras posibles de hacer vivienda y convivencia» (Más que una Casa, 2017). Se trata, por tanto, de un muy interesante generador de contenido desde la sociedad organizada en relación con la meta aquí planteada. Además, esta plataforma tiene un gran valor añadido, ya que trabaja para la búsqueda de un hábitat más cooperativo e igualitario, y siempre bajo un entendimiento de la vivienda colectiva como «todos aquellos casos y procesos de producción de vivienda colectiva en los que los habitantes hayan tomado un papel activo» (Más que una Casa, 2017). Siendo esto posible tanto en la fase de organización previa, como en la del diseño y construcción, o en la del propio uso y vida útil del inmueble. A un nivel más local, pueden encontrarse casos como el de M-etxea, un colectivo con origen en la Escuela Técnica Superior de Arquitectura de San Sebastián (Universidad del País Vasco/Euskal Herriko Unibertsitatea) e interesado y centrado en la investigación de la arquitectura desde un punto de vista de su uso y funcionalidad. Aunque su objetivo actual es investigar el uso del espacio arquitectónico y urbano de una forma proactiva, a partir del uso directo del mismo y mediante pruebas de ensayo-error, en sus orígenes la vocación de este grupo de docentes y estudiantes de la arquitectura era la de desarrollar una serie de talleres en torno a la reflexión del uso de la vivienda. Se ponía así el énfasis «en el usuario y los modos en los que ocupa y utiliza el espacio en el que habita» (M-etxea, 2017). Dentro de estos primeros talleres se trabajaron -desde una perspectiva experimental y algo excepcionalalgunos conceptos de interés buscando usos alternativos, potencialidades y cambios de paradigma en la vivienda colectiva contemporánea.

\section{Tradición de movimientos sociales en defensa del territorio}

Las agrupaciones sociales formales y con representación pública trabajando por avanzar hacia la meta de una utilización y ocupación racional del territorio muestran en general un perfil claramente reivindicativo, muy cercano a una ideología que se podría tildar de 
izquierda comprometida. Son movimientos que nacen de la inquietud de la sociedad civil y que tratan la reflexión del modelo territorial con rigor y profundidad. Una manera de abordar la problemática generalmente con poca presencia en los medios de comunicación generalistas o la agenda política. En Euskadi existe lo que podría denominarse cierta tradición de lucha social organizada en defensa de un modelo territorial cercano al conservacionismo, y que en ocasiones aborda la cuestión residencial. Muy relevante en este sentido fue el movimiento anti-nuclear activado en la década de 1970 como reacción al plan eléctrico nacional que proyectaba tres centrales nucleares en la costa vasca: Lemoiz e Ispaster en Bizkaia, y Deba en Gipuzkoa. Paralizados los proyectos de Deba e Ispaster gracias a la oposición antinuclear, el de Lemoiz fue el marco de un complicado proceso de intento, finalmente fallido, de puesta en marcha de la central allí planteada. A la masiva movilización social encabezada por agrupaciones ecologistas y algunos partidos políticos en contra del proyecto se sumaron ciertos gobiernos locales, enfrentándose a la empresa promotora y a los gobiernos provinciales, vasco y central. Todo ello adquirió un carácter dramático con la entrada en escena de la banda terrorista ETA, actuando con consecuencias mortales del lado del rechazo a la central. Finalmente, en 1984 el gobierno central decretó una moratoria nuclear y la central ya construida quedó, hasta el día de hoy, sin uso alguno. Aunque localizado en la comunidad autónoma de Navarra, igualmente relevante y con un gran poso en la memoria colectiva vasca fue el movimiento social contra la construcción del embalse de Itoiz. Este estaba planteado sobre la inundación de una serie de asentamientos, y afectaba a varias reservas naturales. Colectivos como Coordinadora de Itoiz, Greenpeace y Solidari@s con Itoiz encabezaron desde la década de 1980 todo un movimiento con acciones de protesta, judiciales, e incluso de sabotaje de las obras, que llegó a tener alcance internacional, si bien en este caso sí se llegó a desarrollar el proyecto. Como ejemplo más reciente, existe en la actualidad un movimiento contra la construcción de una incineradora de residuos domésticos en Zubieta, Gipuzkoa, con gran número de adhesiones y abogando en paralelo por un modelo alternativo de su gestión que sea menos perjudicial para la salud y el ambiente local.

Dirigiendo la mirada a casos más centrados en el debate del modelo territorial y el desarrollo de las ciudades, existe en Euskadi -al igual que en otros puntos de España ${ }^{42}$ - un fuerte movimiento social de reflexión crítica constructiva, organizado en grupos de trabajo, sobre las Directrices de Ordenación del Territorio del País Vasco. Aprobadas en 1997 y con apenas cambios desde entonces, a pesar de

42 Por citar un ejemplo, es de relevancia el caso de la ONG Per l'Horta, surgida a partir del esfuerzo y trabajo colectivo de numerosas asociaciones y colectivos, así como ciudadanía, en torno a la protección de la huerta valenciana frente a la inminente revisión del PGOU de Valencia que se iba a llevar a cabo en 2015 manteniendo un modelo de territorio definido en 2004. 
configurar en su día ciertos pasos positivos en materia de protección de los suelos no urbanizables, evidencian una obsolescencia considerable, ya que fueron desarrolladas sobre la base de un análisis territorial que cuenta con un total desfase respecto a la situación social, económica y ambiental actual (Etxabe, 2012). Este grupo de trabajo está promovido principalmente por las correspondientes ramas dedicadas al tema de los colectivos de Ekologistak Martxan y Desazkundea $^{43}$. Su producción y fomento del debate es de gran interés, habiendo realizado diversos procesos participativos e informes, presentado alegaciones ante diversas modificaciones puntuales propuestas por el Gobierno Vasco, y manteniendo un constante debate en torno al modelo territorial deseado para Euskadi. En lo que respecta a esta investigación, es de destacar-como ya se ha apuntado- que este instrumento de ordenación territorial cuyo ámbito es toda la comunidad autónoma de Euskadi, es el que marca las previsiones y la cuantificación residencial de cada municipio. Por lo que en el centro del debate de este movimiento ciudadano está muy presente el modelo residencial, y la manera de responder a la necesidad desde la ocupación de nuevos suelos y desde el aprovechamiento del parque existente.

Por otro lado, uno de los aspectos más interesantes de este caso es que, además de tratarse de un movimiento profundamente comprometido, no se reduce a una reflexión sobre la planificación urbana y territorial. Sus debates y acciones se enmarcan dentro de una posición más global, que aglutina cuestiones sobre el modelo energético o alimentario, entre otros. Consciente del tamaño y dificultad de los cambios necesarios, lo es también de la necesidad de que estos se den de manera integral y holística. Lamentablemente, existe el peligro de que los debates planteados por este tipo de movimientos, organizados o no, en torno a cuestiones territoriales y/o ecológicas se tiendan desde algunas esferas a utilizar como herramienta para la confrontación entre diferentes partidos políticos. Un caso claro de esto se ha podido ver en los últimos años en Gipuzkoa con el modelo de gestión de residuos domésticos, habiéndose simplificado el apoyo a uno u otro modelo al apoyo indirecto a un partido político u otro, y que «ha dejado un escenario de conflictividad y división social y política que ha de ser superada» (Belaustegui, 2016). Algo similar podría llegar a identificarse en el caso anteriormente presentado del aparcamiento de Ibarbengoa en Getxo.

43 Ecologistas en Acción y Decrecimiento, respectivamente, en castellano. 


\section{$-2.4 .3-$ \\ Instituciones públicas}

\section{E1 acceso a la vivienda en la agenda pública}

En cuanto al papel de la administración y las instituciones públicas a la hora de definir y acotar metas y objetivos, este es fundamental. En este sentido, la presencia del acceso económico a la vivienda como preocupación y objetivo en la agenda política es grande. Otra cuestión, como se verá más adelante, es si dicha presencia es suficiente para alcanzar los objetivos necesarios. En cualquier caso, este tema es abordado y el debate es alimentado desde documentos de organismos muy diversos con ámbitos de actuación igualmente diferenciados, como a continuación se expone a través de una serie de ejemplos. Desde una escala global, el Programa de las Naciones Unidas para los Asentamientos Humanos ONU-Habitat identifica como una de las cuestiones clave para el abastecimiento de una vivienda adecuada la cada vez mayor dificultad de alcanzar la asequibilidad de la misma (ONU-Habitat, 2016: 48). Desde este propio órgano de las Naciones Unidas, concretamente desde su Consejo de Derechos Humanos, el Relator Especial Miloon Kothari realizó una misión a España en 2008 para analizar el desarrollo del derecho básico del acceso a una vivienda digna y adecuada. En ella observó ciertos aspectos negativos en la consecución del mismo, como «que factores económicos y financieros, entre los que cabe mencionar la especulación generalizada, han tenido efectos negativos en el derecho a una vivienda adecuada» (Naciones Unidas, 2008). Así mismo, reflexionó sobre las graves consecuencias que el modelo de propiedad predominante y la escasez de un parque público de alquiler ejercen en todo ello, abogando por la intervención del Estado en la cuestión y formulando una serie de recomendaciones a su juicio «necesarias para dar cumplimiento a las obligaciones constitucionales e internacionales de España» (Naciones Unidas, 2008).

En un marco europeo, fue su Parlamento a través de la Resolución de 11 de junio de 2013 sobre la vivienda social en la Unión Europea, el que entre otras cuestiones puso el acento en los graves problemas existentes para el acceso económico a la vivienda. Un acceso cuya garantía es obligación internacional de los Estados miembros de la Unión, y que se plantea como una herramienta para lograr la justicia y la cohesión social. Se constata además en dicha resolución que «la combinación de las crisis económica y financiera, las medidas de austeridad, el aumento de los precios de la vivienda y la caída de los ingresos de las familias ha incrementado el desempleo y la exclusión social en la UE», y viendo que la vivienda «representa ya el gasto principal de las familias europeas, el aumento de los precios relacionados con la vivienda $[\ldots]$ constituye un motivo de 
inestabilidad y ansiedad y debe considerarse una preocupación prioritaria» (Parlamento Europeo, 2013: 7).

Desde una escala nacional, puede observarse cómo en las instituciones públicas existe una identificación de la gravedad del problema -siempre en esta fase inicial de definición de contenidos- si se analizan las exposiciones de motivos de algunos textos legislativos. Es el caso del Real Decreto 233/2013, de 5 de abril, por el que se regula el Plan Estatal de fomento del alquiler de viviendas, la rehabilitación edificatoria, y la regeneración y renovación urbanas para los años 2013-2016. En él se echa la vista atrás a los planes previos y se plantea la necesidad de una reorientación de políticas en la materia. Se ponía sobre la mesa el contraste entre el enorme stock de vivienda generado sin vender, y «las dificultades de los ciudadanos, especialmente de los sectores más vulnerables, para acceder a una vivienda $[\ldots]$ a lo que se une la restricción de la financiación proveniente de las entidades crediticias» (Real Decreto 233/2013, de 5 de abril, 2013). Así, entre sus objetivos se señalaban la adaptación del sistema de ayudas sociales a las necesidades reales y la contribución al pago de las deudas hipotecarias de aquellas personas propietarias de una vivienda protegida. Otro ejemplo es el Real Decreto Legislativo 6/2012 de medidas urgentes de protección de deudores hipotecarios. En él, se califica de dramática «la realidad en la que se encuentran inmersas muchas familias que, como consecuencia de su situación de desempleo o de ausencia de actividad económica, prolongada en el tiempo, han dejado de poder atender el cumplimiento de sus obligaciones derivadas de los préstamos o créditos hipotecarios concertados para la adquisición de su vivienda» (Real Decreto-ley 6/2012, de 9 de marzo, 2012). Lo cual llevaba a constatar que la puesta en marcha de los procesos de ejecución hipotecaria hacen que se esté privando de la vivienda, ese derecho fundamental, a un importante sector de la población -principalmente debido a que la facilidad de obtención de crédito en la década pasada hizo que el acceso al mismo se popularizase enormemente-.

En una última escala administrativa, la autonómica, la consideración del acceso económico a la vivienda por parte de las administraciones e instituciones públicas vascas como cuestión fundamental, y como aporte a un debate público, puede verse reflejada en dos ejemplos. El primero vuelve a remitir a la exposición de motivos de un texto legislativo, esta vez la Ley 3/2015 de Vivienda de Euskadi; una de las pioneras en esta materia en el Estado. Aunque se analizará más adelante parte de su contenido, en dicha exposición se refleja clara y directamente las motivaciones que están detrás de la ley: la dimensión social de la vivienda como eje que debe vertebrar las políticas públicas en torno a la misma. No en vano el texto comienza afirmando que «el derecho a disfrutar de una vivienda constituye una necesidad vital para el ser humano por cuanto condiciona el disfrute de otros derechos esenciales», y consecuentemente el derecho y «su realización efectiva facilitan y permiten al ser humano llevar una vida 
digna», estableciendo más abajo que corresponde «precisamente a esta ley concretar los términos más o menos abstractos y genéricos de las normas reseñadas» (Ley 3/2015, de 18 de junio, 2015). El segundo ejemplo lo conforman los dos últimos Programas de Legislatura del Gobierno Vasco. En ellos, desde el ejecutivo se marcan una serie de objetivos relacionados con el tema. En el caso de la X Legislatura, de 2012 a 2016, el programa se estructura en tres compromisos: empleo y personas; paz y convivencia; y un nuevo estatus político para Euskadi. Dentro del primero de ellos, se plantean dos ejes: empleo y desarrollo humano; y es bajo el paraguas de este segundo eje en el que se enmarcan las estrategias para afrontar la problemática en torno al acceso a la vivienda. Previo diagnóstico de la situación social al respecto:

«El acceso a la vivienda sigue siendo uno de los problemas de gran preocupación para la sociedad vasca. Al elevado precio de la vivienda se une, en estos momentos, la dificultad de obtener financiación. Esta imposibilidad de acceso a la vivienda da origen a otros muchos problemas relacionados con el desarrollo normal de las personas, lo que requiere de una política eficaz que ayude a mitigar las desigualdades que se generan» (Gobierno Vasco, 2013c).

Se constata en la redacción de este documento la estrecha relación existente entre el acceso a una vivienda y el soporte que ello supone para el desarrollo de una vida digna. Así, una vez hecho el análisis, se plantearon objetivos como la cooperación y la colaboración entre las diferentes administraciones públicas; la revisión de los sistemas de adjudicación de vivienda protegida para favorecer a las personas y colectivos más necesitados; la coordinación de las políticas de vivienda con otras políticas sociales; el fomento del régimen de alquiler tanto en el parque público como en el privado; la ayuda a la emancipación de las personas jóvenes mediante el alquiler social o los pisos compartidos, o el apoyo a las personas sin vivienda y en riesgo de exclusión. Otro detalle de considerable interés en el desarrollo del contexto y los principios que inspiraron estos objetivos es la identificación de diversos perfiles con problemas de acceso a la vivienda:

«[...] se han sumado recientemente nuevas realidades sociales: las personas que no pueden hacer frente a la hipoteca, quienes no pueden hacer frente a un alquiler de mercado y quienes no pueden hacer frente a un alquiler social; provocando que queden sin hogan» (Gobierno Vasco, 2013c).

Para la siguiente -y actual en el momento de redacción- legislatura entre 2016 y 2020, el Programa de Gobierno de Euskadi se estructura en cuatro pilares: empleo, reactivación y sostenibilidad; desarrollo humano, integración social, igualdad y servicios públicos de calidad; convivencia y los derechos humanos; y más y mejor autogobierno. Dentro del segundo, uno de los ejes es la agenda social para la 
integración y la igualdad. En el cual se integran los objetivos y compromisos relacionados con el acceso a la vivienda. Y cuyos principios inspiradores recogen de manera similar a la legislatura anterior, un diagnóstico de la urgencia y prioridad que plantea la cuestión:

«Compartimos la necesidad de impulsar una política de vivienda que facilite el acceso a una vivienda digna a las personas que no pueden disponer de ella, dando respuesta al derecho subjetivo a la vivienda y favoreciendo prioritariamente el acceso a la vivienda en régimen de alquilen» (Gobierno Vasco, 2016a).

«Nos comprometemos a favorecer la emancipación de la juventud, impulsando oportunidades para la formación, el empleo y el acceso a la vivienda. Desde una actitud de escucha y respeto a la juventud, vamos a sumar esfuerzos para que las personas jóvenes puedan desarrollar un proyecto de vida independiente, favoreciendo su acceso a una primera oportunidad laboral y a la vivienda» (Gobierno Vasco, 2016a).

Estos compromisos tan clara y firmemente definidos plantean cuestiones tales como el fomento y desarrollo del IV Plan Joven, en el que se incluyan actuaciones para la emancipación y el acceso a la vivienda por parte de este colectivo; la atención a las personas sin hogar y los apoyos para su autonomía, calidad de vida e inclusión social; trabajar por el acceso de las personas inmigrantes a la vivienda digna; el desarrollo del derecho subjetivo a la vivienda reconocido en la Ley 3/2015 de Vivienda, o priorizar el régimen de alquiler. De esta manera, los programas de legislatura son un claro ejemplo de presentación de intenciones y de un posible contenido de políticas públicas por parte de la administración, dentro del Esquema 2.1 propuesto. En un contexto donde es sabido y asumido como más que cuestionable la consecución de todos esos objetivos en una sola legislatura, la redacción de esos programas se queda en una declaración de intenciones coja desde su propio nacimiento. Por ello, han de entenderse como parte del sistema contradictorio y paradójico que se pretende desgranar en este capítulo, y como fases de esa gobernanza urbana desigual. El componente políticamente estratégico que tiene todo ello es probablemente considerable. Por otro lado, más allá de este tipo de documentos, la innegable preocupación institucional por el acceso a la vivienda puede observarse en otros formatos, como la prensa. El director de Vivienda y Arquitectura del Gobierno Vasco rechazaba una visión coyuntural de la problemática, afirmando que «para un sector muy importante de la sociedad la crisis ha introducido una precariedad y una incertidumbre que han venido para quedarse y es obligación de las administraciones combatir esa situación y por tanto ayudar a la gente con más dificultades de acceso a la vivienda» (García, 2018: 9). 


\section{Escasa, pero creciente, preocupación por aspectos tipológicos}

En los entes públicos se hace más difícil encontrar documentación, propuestas o pistas de una inquietud o preocupación profunda por las características tipológicas de la vivienda. Pero sí se hace mención a ello, como por ejemplo desde la agencia ONU-Habitat al identificar los cambios en los patrones familiares como uno de los retos urbanos a nivel global -con toda la diversa casuística local que eso implica(ONU-Habitat, 2016: 2). Se trata de una cuestión que no es menor desde un punto de vista ya no solo puramente arquitectónico, si no que puede tener una considerable influencia también en el planeamiento urbano. Las nuevas ordenaciones a desarrollar con un uso característico residencial pueden incorporar a su proceso de planificación unas tipologías de vivienda adecuadas a las necesidades de las diversas unidades de convivencia existentes y por venir. La agrupación de nuevas tipologías en edificios de vivienda colectiva podría exigir cambios tanto en la morfología urbana -dimensiones de parcelas, ocupación de la edificación, profundidad de crujías,...como en aspectos normativos con influencia directa en la edificación - dimensiones de patios, usos permitidos en plantas superiores,...-. Es algo sobre lo que desde ciertos sectores de la administración pública ya se ha reflexionado y publicado, como quedó reflejado en el Libro Blanco de la Sostenibilidad en el Planeamiento Urbanístico Español. En él se identificaron como algunos de los temas a considerar por el planeamiento urbanístico el claro envejecimiento de la población y la nueva composición familiar, «siendo mayoritaria la construcción de viviendas de las llamadas "de dos o tres habitaciones" muy alejadas de los requisitos» que los citados fenómenos demográficos plantean (España, Ministerio de Vivienda, 2010: 23). También pueden encontrarse reflexiones cercanas a esta cuestión en la exposición de motivos de la Ley 3/2015 de Vivienda de Euskadi, pues adelanta las intenciones que esta ley tiene para buscar la coexistencia de unidades de convivencia de distinto nivel de renta, edad y composición; lo cual parece que debería ir en paralelo a una oferta de tipologías diversa y flexible. Algo necesario si se quiere, como se expone en el citado documento, «incorporar los cambios sociales que impulsan el favorecimiento de las tareas de cuidado (trabajo que se desarrolla fundamentalmente en el ámbito doméstico y su entorno) y el desarrollo de proyectos vitales personales, combinando, en definitiva, una mejor organización social basada en la corresponsabilidad y conciliación del trabajo remunerado y no remunerado» (Ley 3/2015, de 18 de junio, 2015). Se trata en definitiva, como el texto sintetiza, de lograr la adecuación funcional de la vivienda en el marco de su función social.

También se están dando pasos de gran interés desde perspectivas más sectoriales, como es el caso de la iniciativa Euskadi Lagunkoia y «que tiene como objetivo incentivar la participación de las personas mayores y de la ciudadanía en general para la mejora de barrios y 
entornos en los municipios de Euskadi para que podamos seguir haciendo nuestra vida a medida que envejecemos» (Euskadi Lagunkoia, 2018) y basada a su vez en la iniciativa Age-friendly Environments Programme promovida por la Organización Mundial de la Salud. Entre sus ocho áreas de investigación y acción está la vivienda, y parte de una metodología basada en cuatro fases: diagnóstico y plan de amabilidad, implementación de acciones, evaluación, y mejora continua. En la primera de ellas, se prevía una recogida de información a base de encuentros ciudadanos y entrevistas en profundidad en las que se buscaba saber cómo son las viviendas en las que viven esas personas, y en caso de darse cambios en sus necesidades domésticas, saber si está adaptada a posibles situaciones de dependencia, o las posibilidades y facilidades que les ofrece su municipio para la adaptación o el cambio de vivienda (Euskadi Lagunkoia, 2017: 37, 42).

\section{Reconocimiento institucional del suelo como recurso finito}

En lo respectivo a la meta de avanzar hacia una ordenación más racional de los sistemas urbanos, la cual engloba un aprovechamiento eficaz del parque heredado, se localiza con facilidad cierto contenido en diversos documentos de las variadas administraciones públicas. Se trata de un tema claramente presente en documentos de trabajo a escala mundial, aunque con diferentes matices y peculiaridades según el contexto y nivel de desarrollo del país o continente correspondiente (ONU-Habitat, 2016). En cualquier caso, a nivel europeo son varios los documentos institucionales que han hecho una llamada de atención sobre la necesidad de contener ciertos crecimientos no ordenados y sobredimensionados de las ciudades, debido a las consecuencias que ello tiene en muchas esferas de la sociedad. La Estrategia Territorial Europea acordada en Postdam en 1999 -el propio título del documento, Hacia un desarrollo equilibrado y sostenible del territorio de la UE, dejaba claras sus intenciones- identificaba como uno de los temas importantes a abordar para el desarrollo territorial el progresivo crecimiento disperso de las ciudades. Hasta el punto en que se llegaba a afirmar que en «muchas áreas urbanas de la UE, la presión del desarrollo urbanístico sobre la periferia representa un grave problema $[y]$ deben encontrarse soluciones y modelos sostenibles para la planificación y el control de la expansión urbana» (Comisión Europea, 1999: 70). Sin salir de la escala continental, y más recientemente, la Comunicación de la Comisión al Consejo y al Parlamento Europeo sobre una Estrategia temática para el medio ambiente urbano de 2006 señalaba como uno de los principales retos medioambientales de las ciudades el crecimiento urbano desordenado. Apuntando además lo complejo del reto, pues «el hecho de que las causas de los problemas que aquejan a las ciudades estén relacionadas entre sí los hace particularmente complejos. Las iniciativas locales para resolver un problema pueden ocasionar otros en otros campos o 
pueden estar reñidas con otras políticas a nivel nacional o regional» (Comisión Europea, 2006).

Algunas de estas cuestiones han sido recogidas por algunas la administración estatal nacional, al menos en una primera fase de generación de contenido. Desde las instituciones se han impulsado textos de gran interés sobre el tema, como lo fue el Libro Blanco de la Sostenibilidad en el Planeamiento Urbanístico Español (España, Ministerio de Vivienda, 2010). En él, entre otras cuestiones, se abordaba la compleja problemática que generaba el dogma del crecimiento urbano descontrolado, y la ciudad dispersa y fragmentada que este ha generado en muchas regiones del país. El trabajo identificaba al suelo como un «stock patrimonial de primer orden» que debía por ello ser gestionado «en régimen de escasez y en beneficio de toda la colectividad» (España, Ministerio de Vivienda, 2010: 9). De esta manera, se planteaba que desde «el punto de vista territorial el principal reto a corto y medio plazo apunta a reorientar las grandes bolsas de suelo ya comprometido, que en muchos casos supera varias veces a las del suelo ya construido, y a reorganizar las superficies de aprovechamientos agrarios y paisajes que se ven presionadas por potenciales expectativas de recalificación. El objetivo primordial exige pues, pasar a un segundo plano la ocupación expansiva del suelo, y primar la reutilización y rehabilitación del patrimonio construido y del entorno urbano y periurbano degradado. Todo ello, además, con los menores daños económicos, sociales y ecológicos posibles» (España, Ministerio de Vivienda, 2010: 9).

Algo de esto se puede ver, ya en un marco legislativo, reflejado en el citado Real Decreto 233/2013 que regulaba el Plan Estatal de fomento del alquiler de viviendas, la rehabilitación edificatoria, y la regeneración y renovación urbanas para 2013-2016. En su exposición de motivos se señala la centralidad que los planes anteriores daban a la ocupación de nuevos suelos y al crecimiento de las ciudades, así como la «fuerte expansión promotora de los últimos años» (Real Decreto 233/2013, de 5 de abril, 2013) cuya herencia ha sido en parte ese gran stock sin vender. También en la exposición de motivos del texto refundido de la Ley del Suelo estatal de 2008 -documento legislativo base para el actual texto refundido vigente de la Ley de Suelo y Rehabilitación Urbana de 2015-, se plantea que las competencias relacionadas con la materia de dicha ley deben contribuir a una «utilización racional de los recursos naturales y culturales, en particular el territorio, el suelo y el patrimonio urbano y arquitectónico, que son el soporte, objeto y escenario necesario de aquéllas al servicio de la calidad de vida» (Real Decreto Legislativo 2/2008, de 28 de mayo, 2008). Pocos párrafos después, se reconoce el carácter desarrollista del modelo urbanístico español contemporáneo, volcado en la creación de nueva ciudad. Tal ejercicio de autocrítica es desde luego positivo, adecuadamente complementado con la idea de que «el urbanismo debe responder a los requerimientos de un desarrollo sostenible, minimizando el impacto de aquel crecimiento y 
apostando por la regeneración de la ciudad existente [...] El suelo, además de un recurso económico, es también un recurso natural, escaso y no renovable. Desde esta perspectiva, todo el suelo rural tiene un valor ambiental digno de ser ponderado y la liberalización del suelo no puede fundarse en una clasificación indiscriminada» (Real Decreto Legislativo 2/2008, de 28 de mayo, 2008).

Apenas dos años antes, en Euskadi se había aprobado la Ley del Suelo y Urbanismo con competencias a escala autonómica. En su exposición de motivos, se identificaban con acierto algunos problemas que debían ser abordados con urgencia para una planificación urbana racional. Entre ellos, una «tendencia a la extensión de la práctica urbanística de crecimiento urbano en desarrollos esponjados y en baja densidad, en una comunidad autónoma que carece de suelo apto para urbanizar en grandes partes de su territorio» (Ley 2/2006, de 30 de junio, 2006). Motivo que llevaba a plantear la necesidad de «una utilización racional e intensiva del suelo», evitando «los crecimientos dispersos, que, además de consumir gran cantidad de territorio, recurso siempre escaso y de carácter no renovable, generan modelos urbanos poco funcionales y, por lo tanto, poco sostenibles» (Ley 2/2006, de 30 de junio, 2006). Todo ello se apuntalaba con la preocupación manifiesta por la correcta conservación y uso racional del suelo no urbanizable. Sin salir de esta comunidad autónoma, y más recientemente, también ha sido posible comprobar la preocupación de ciertos agentes legisladores por estas cuestiones. En la exposición de motivos de la reciente Ley 3/2015 de Vivienda de Euskadi se recogen líneas de una posible actuación pública, como intervenir menos en el territorio. Así mismo, identifica el suelo destinado a uso residencial como un bien escaso y aboga por «el establecimiento de mecanismos que incentiven el modelo de ciudad compacta frente a la ciudad expansiva, respetando las singularidades propias de cada lugar y de forma armonizada con el entorno, lo que llevará a una ocupación más racional del suelo, propiciando un crecimiento más sostenible, homogéneo y armonizado» (Ley 3/2015, de 18 de junio, 2015).

Pero existen otros espacios de generación de contenido en relación a la búsqueda de un desarrollo racional de los suelos urbanos por parte de la administración pública vasca. El Gobierno Vasco aprobó en julio de 2011 la primera Estrategia de Desarrollo Sostenible planteada en esta comunidad autónoma, con la intención de formalizarse en «el instrumento de referencia para la elaboración de todas las políticas públicas» (Gobierno Vasco, 2011b: 5). En su misión, identificaba los recursos naturales y la biodiversidad de la comunidad como capital natural enriquecedor de la calidad de vida de la ciudadanía, de manera que «la urbanización, las vías de comunicación o las actividades productivas deben ser compatibles con su preservación y desarrollo» (Gobierno Vasco, 2011b: 19). Lo cual sentaría las bases para el desarrollo del objetivo estratégico número cuatro del documento: 
«La expansión de las actividades urbanas (residenciales, productivas y de servicios), la multiplicación de infraestructuras de transporte y el abandono progresivo de las prácticas agrícolas han supuesto un alto consumo de suelo y un fraccionamiento de los hábitats naturales que pone en peligro la supervivencia de nuestra biodiversidad e introduce cambios radicales en el paisaje natural. Las actividades humanas necesitan ciertamente de suelo para llevarse a cabo, pero el suelo debe gestionarse como un capital valioso y escaso a optimizar, posibilitando el desarrollo de sus funciones naturales, minimizando el impacto sobre los ecosistemas y recursos naturales» (Gobierno Vasco, 2011b: 27).

Y llevaba a la definición de tres líneas de actuación: impulso del modelo de ciudad compacta, reducción de la presión sobre los ecosistemas y recursos naturales (suelo, agua, aire y paisaje) mejorando la calidad de los mismos, y la promoción del desarrollo rural integral para promover los valores naturales del territorio. Todos ellos, directa o indirectamente, relacionados con la meta de lograr un desarrollo racional de los usos residenciales en las ciudades abordada en este trabajo. También en esa misma época, se publicaron a instancias del ejecutivo vasco los resultados de un estudio directamente relacionado con la ordenación urbana y territorial que incorporaba algunos objetivos cercanos. En este caso centrados en el desarrollo de estrategias para la mitigación y adaptación al cambio climático en la planificación espacial (Gobierno Vasco, 2010, 2011a). En ellos, pueden encontrase algunas estrategias a incorporar en el marco de la Ley de Suelo y Urbanismo de Euskadi y el desarrollo de Planes Generales de Ordenación Urbana, como son la consideración del potencial de los suelos como sumideros de $\mathrm{CO}^{2}$, la localización de usos en función de su accesibilidad, o la posibilidad de desclasificar suelo de urbanizable a no urbanizable por su improcedencia ${ }^{44}$. Sirvan estas cuestiones como ejemplo de que, como se ha señalado al inicio de este trabajo, muchas son las posibles dimensiones a abordar y que se ven afectadas por la planificación residencial.

\section{Academia}

El último colectivo o grupo social a analizar, y que junto a la sociedad civil anónima, la organizada, y la administración pública viene a completar este repaso parcial propuesto a los agentes y espacios de la gobernanza urbana generadores de debate y contenido para actuar como respuesta a una situación problemática acotada, es el mundo académico. El repaso en este caso va a ser más superficial

44 Algo que, como se verá más adelante, ya se está empezando a hacer en algunas revisiones de planeamiento urbano actualmente en marcha. 
que en las anteriores categorías, tanto porque un análisis riguroso del mismo requiere de un esfuerzo fuera del alcance y medios de esta investigación, como porque parte del material y el conocimiento generados ya han sido citados en esta investigación. Por otro lado, se ha de recordar que el objetivo de este apartado no es tanto entrar a analizar el fondo, como argumentar y sostener que hay una heterogénea generación de contenido desde diversas esferas de la sociedad, tal y como se ha propuesto en el Esquema 2.1. No obstante, es posible presentar una visión parcial, pero representativa, de la relevancia del objeto de estudio, y del interés e inquietud que en el mundo académico ha generado y genera.

\section{Derecho de acceso a la vivienda}

Así lo muestra, comenzando por la meta del acceso económico, la evolución del número de publicaciones científicas encontradas resultado de una búsqueda en Google Scholar. Es cierto que la presencia de trabajos en el buscador puede estar condicionada por el aumento de una digitalización y presencia en la red de este tipo de publicaciones en paralelo al desarrollo de la propia internet, especialmente en los primeros años analizados. Pero también lo es que en los últimos años, con la red de redes ya bien asentada en las sociedades desarrolladas, el número de publicaciones ha seguido aumentando (Gráfica 2.21). Respecto al contenido de las mismas, existe una gran diversidad de perspectivas, investigaciones $y$ contenido a lo largo de los años, y no se trata de un tema tan solo abordado hoy en día. Pueden encontrarse desde trabajos de mediados de siglo XIX (Engels, 1974) en un contexto de industrialización de la sociedad y de transformación de su geografía urbana, hasta otros más recientes en la búsqueda de las causas del no desarrollo del derecho a la vivienda establecido en la Constitución Española, con una aportación de posibles vías desde derecho y el urbanismo para lograrlo (González, 2013). Lo que es evidente es que se trata de una problemática que genera preocupación e interés, aún hoy sin resolver y con importantes retos por delante. Lo demuestran hechos como que el citado derecho a la vivienda viene siendo trabajado desde hace años (Pisarello, 2003) sin lograr grandes avances. O que las consecuencias en el mismo de la burbuja inmobiliaria desarrollada en España venían siendo anunciadas desde sus orígenes y, sin embargo, no se pudo o quiso evitar la explosión de la misma (Gaja, 2003; Nolla, 2003; Roch, 2003), ni se están abordando después (Inurrieta et al., 2013; Naredo y Montiel, 2011). Definitivamente, el acceso a la vivienda es y ha sido tratado desde la academia como el verdadero problema social que supone (Leal, 1995), tanto en España como en estudios comparados con casos internacionales (Orueta y Seoane, 2005). Como recuerdan algunos autores, «no se han tomado medidas que garanticen el acceso a la vivienda, que es "un espacio vital imprescindible para la socialización y un factor de inclusión social de primer orden", según Paniagua. Para éste, los planes de vivienda

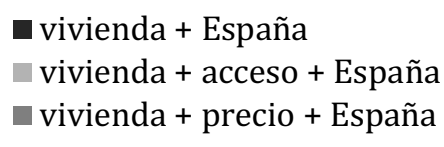

45.000

40.000

35.000

30.000

25.000

20.000

15.000

10.000

5.000

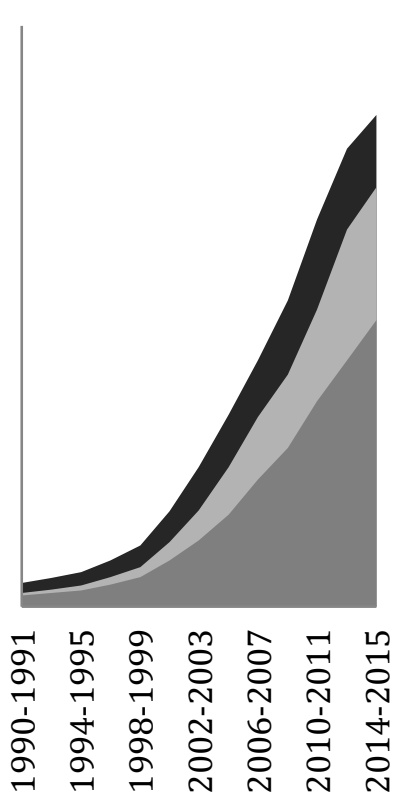

Gráfica 2.21. Número de publicaciones académicas según palabra clave y periodo de publicación. Google Scholar. 
- vivienda + España

vivienda + diseño + España

vivienda + tipología + España

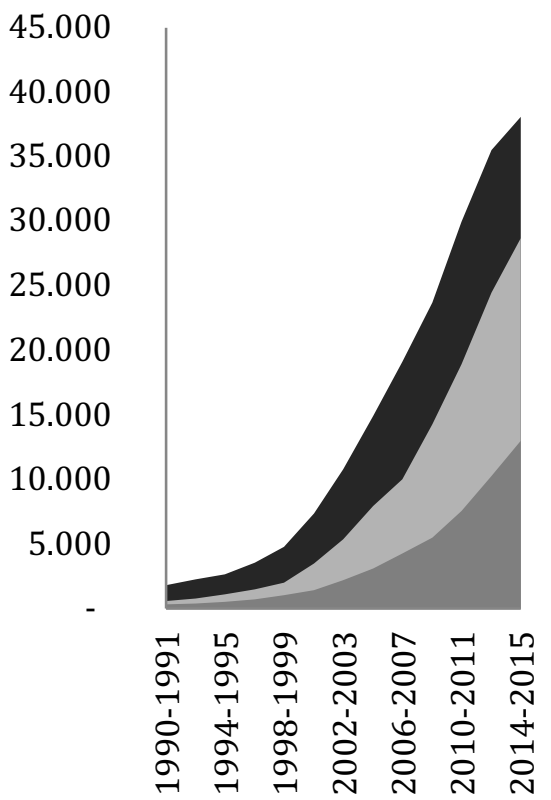

Gráfica 2.22. Número de publicaciones académicas según palabra clave y periodo de publicación. Google Scholar. mantienen "mecanismos continuistas, desfasados e inservibles para responder a las necesidades de alojamiento"» (Elorduy y García, 2014). Sirvan estas breves referencias como muestra de la extensa y rica producción académica existente en torno al tema.

\section{Diversidad de tipologías residenciales}

De igual manera, y aún con los mismos posibles sesgos de la fuente, al estudiar cuantitativamente las referencias devueltas por el buscador Google Scholar puede verse que los estudios tipológicos presentan una creciente presencia en publicaciones y por lo tanto, un aumento de investigaciones (Gráfica 2.22). Los estudios, miradas y propuestas en torno a la tipología residencial han sido un campo de trabajo e investigación que ha generado un gran interés prácticamente ininterrumpido, con épocas de mayor o menor augeen la arquitectura contemporánea. Podrían citarse numerosos trabajos en este sentido. Fueron relevantes los aportes que hicieron ciertos equipos en la década de 1970, como el desarrollo de la teoría de los soportes (Habraken, 1972), o aquellos que pusieron el foco en la habilidad de las personas para una autogestión del espacio doméstico y comunitario (Turner, 1977). En cuanto a estudios más actuales, pueden encontrarse acercamientos a las necesidades tipológicas desde perspectivas diferentes, lo cual enriquece el conocimiento global del tema. Desde la mirada más tecnológica y constructiva (Paricio y Sust, 2000; Peremiquel et al., 2000), hasta la más puramente habitacional (Montaner et al., 2011; Monteys y Fuertes, 2002), pasando por trabajos centrados en cuestiones de género en el marco de la arquitectura doméstica (Amann, 2005; Muxí, 2009). En cualquier caso, las perspectivas y puntos de vista son muy amplios, y se han trabajado y trabajan diversos campos que tienen una influencia y una relación directa con el potencial avance y formalización de nuevas tipologías residenciales. Temas como el género, la construcción, la eficiencia en el consumo y gestión de recursos, la evolución de los equipamientos domésticos o el trabajo en casa son solo algunos ejemplos de ello.

\section{Desarrollos residenciales racionales}

Realizando el mismo ejercicio de cuantificación del número de publicaciones académicas presentes en el buscador de Google Scholar que en los casos anteriores, puede observarse que igualmente estas han seguido creciendo en los últimos años (Gráfica 2.23). Vuelve a ser una visión parcial, pero representativa, del interés académico que el tema genera. Algunas de las bases fundamentales del estudio y comprensión de los sistemas urbanos y su incidencia en el territorio pueden buscarse en obras con varias décadas de antigüedad (Mumford, 1956; Odum, 1969). Y a pesar de que «las partes más coyunturales de ambos textos han sido sobrepasadas por los acontecimientos, en particular nuestros problemas son ahora 
muchísimo más graves que hace medio siglo [...] el diagnóstico de ambos autores, anterior a la primera crisis del petróleo y a la preocupación general sobre una posible crisis ecológica, todavía no ha sido plenamente incorporado a las estrategias políticas y culturales dominantes» (Vázquez, 2010). Con una visión más integral, pero poderosamente relevante para la meta del desarrollo racional de los suelos urbanos residenciales, también marcaron un importante hito los estudios académicos que se desarrollaron desde el Massachusetts Institute of Technology sobre los límites del crecimiento (Meadows, 1972). Entre la amplia producción más reciente, y en lo que se refiere al modelo español, se ha aportado gran conocimiento. Algunos autores vienen ya desde hace tiempo trabajando y hablando sobre la necesidad de equilibrar el uso del suelo por parte de las actividades urbanas (Ávila, 1998; Fariña, 2004; Naredo, 1994), abogando por una racionalidad en su uso -o, incluso, en su no uso (Fariña, 2004: 12)-. La defensa de unos criterios de racionalidad han llevado a ciertos autores a la llamada de una integración entre ciudad y ambiente, especialmente en sus espacios de borde donde el conflicto de intereses es permanente (Orive, 2006). Desde una escala europea, la preocupación por el creciente desarrollo urbano no planificado -O erróneamente planificado- se ha trabajado también desde un punto de vista académico, generando trabajos de considerable interés (European Environment Agency, 2006).

En definitiva, y a pesar de la brevedad del recorrido presentado, se cree que ha quedado argumentada la existencia de diversos agentes, ámbitos y esferas sociales -con diferente perfil, motivación, posicionamiento, trayectoria, intereses, capacidad de influencia, o posiciones de poder, y de las que aquí se ha mostrado parte-desde las que se debaten y generan ideas, principios y objetivos a modo de marco hacia el que dirigir los esfuerzos de una gobernanza urbana para avanzar hacia unas metas que permitan reducir y afrontar la situación problemática presentada anteriormente. Sobre la base de este contenido generado y en una hipotética situación ideal, el Esquema 2.1 plantea que se van desarrollando diferentes instrumentos que definen, con propuestas y acciones concretas, maneras de poner en práctica dicho contenido.

$$
\begin{aligned}
& \text { - vivienda + España } \\
& \text { vivienda + suelo + España } \\
& \text { vivienda + expansión + España }
\end{aligned}
$$

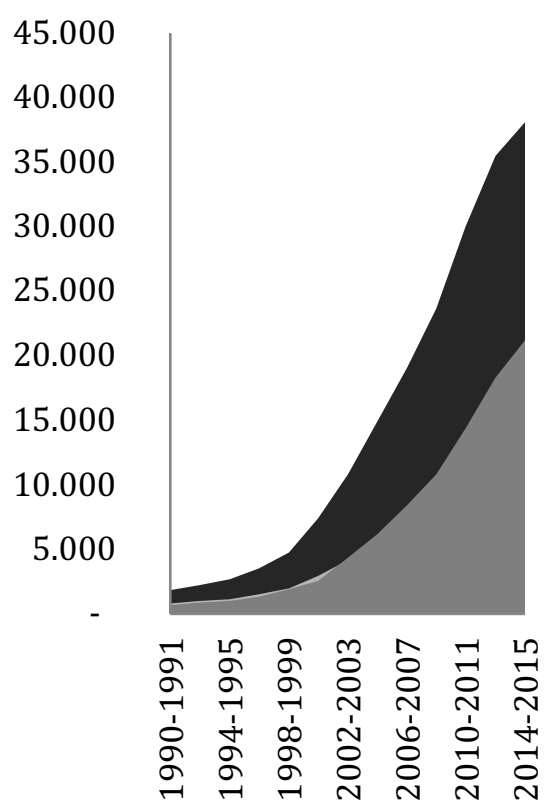

Gráfica 2.23. Número de publicaciones académicas según palabra clave y periodo de publicación. Google Scholar. 


\section{$-2.5-$}

\section{Desarrollo de instrumentos}

Tanto en el contexto español como en el vasco, y ya sea por promoción propia como por la ratificación de otros superiores estatales o internacionales, según el caso-, existen una serie de instrumentos de diversa naturaleza y escala que buscan poner en práctica buena parte del contenido generado por diferentes agentes de la sociedad, parte del cual ha sido identificado en el apartado anterior. Lo que no evita que, como se verá, se den conflictos debidos a ciertas discrepancias a la hora de dar forma y definir dichos instrumentos. Quedando en muchos casos parte de las metas y del contenido fuera de ellos. Como en el apartado previo relativo al contenido, se tratará de demostrar esto a través de la presentación de varios ejemplos adecuadamente clasificados.

\section{$-2.5 .1-$}

Declaraciones, firmas, pactos y cartas

\section{Intención de avanzar hacia la vivienda como derecho}

Se encuentran con cierta facilidad documentos de este tipo al respecto. Por supuesto, buena parte del marco de referencia serían los ya citados anteriormente en el apartado 1.1.1: la Declaración Universal de los Derechos Humanos de 1948 y el Pacto Internacional de Derechos Económicos, Sociales y Culturales de 1966, ambos bajo el paraguas de la Asamblea General de Naciones Unidas. U otros no mencionados, como la Carta Social Europea firmada inicialmente en 1961 y revisada en 1996, que establece tanto una serie de derechos y libertades, como un mecanismo para supervisar el respeto a los mismos por los Estados firmantes. En lo que a la vivienda concierne, hay dos artículos de esta carta que la tratan. El 16, sobre el derecho de la familia a protección social, jurídica y económica, con un compromiso del fomento -entre otros- del apoyo a la construcción de viviendas adaptadas a las necesidades de las familias como parte de los objetivos para lograr las condiciones de vida indispensables para su pleno desarrollo. Y especialmente el 31, sobre el derecho a la vivienda: 
«Para garantizar el ejercicio efectivo del derecho a la vivienda, las Partes se comprometen a adoptar medidas destinadas:

1 a favorecer el acceso a la vivienda de un nivel suficiente;

2 a prevenir y paliar la situación de carencia de hogar con vistas a eliminar progresivamente dicha situación;

3 a hacer asequible el precio de las viviendas a las personas que no dispongan de recursos suficientes» (Consejo de Europa, 1996: 44).

En este sentido, es fundamental la apuesta por y el desarrollo de un trabajo transversal y coordinado entre instituciones públicas, agentes sociales y privados para alcanzar un consenso en la definición de las estrategias de actuación, desde los mismos inicios del proceso. Hecho que facilitará una mejor ejecución final de las herramientas. Algo de esto hay por ejemplo en el Pacto Social de la Vivienda suscrito en 2010 por el Gobierno Vasco y una larga y diversa lista de entidades -financieras, constructoras, agentes de la propiedad inmobiliaria, universidad, sociedades de gestión urbanística públicas y privadas, asociaciones sociales, colegios profesionales,...-. Lista en la cual, sin embargo, pueden detectarse numerosas ausencias, como sindicatos y muchos colectivos sociales. Estos criticaron firmemente el contenido del citado pacto, aunque sobre esto se tratará más adelante. Pero el pacto sí acertó al menos en plantear en el documento las principales preocupaciones aparentes de sus agentes firmantes, pues "posibilitar el disfrute de una vivienda digna $y$ adecuada para aquellos ciudadanos que tengan necesidad de ella, es el referente principal de los retos y acciones propuestos» (Gobierno Vasco, 2010: 34). De esta manera, se buscó mejorar el actual acceso a la vivienda, «impulsando la vivienda protegida en sus distintas tipologías y fomentando el régimen de alquiler con carácter preferente» (Gobierno Vasco, 2010:40). Varias de las líneas de actuación se centraban en la promoción del acceso bajo diferentes regímenes, y se plantearon propuestas como la aplicación de precios diferenciados en la vivienda protegida en función de los niveles de renta de las personas destinatarias. Así mismo, también se establecieron posibles acciones para luchar contra la exclusión social residencial. Aunque este pacto no se trata de una herramienta al uso con una aplicación directa, y se sitúa en una difusa línea entre lo que aquí se ha venido a llamar contenido e instrumento, sí cabe considerarlo como lo segundo en la medida en que aún hoy sigue siendo marco de referencia para los agentes firmantes a la hora de plantear políticas y líneas de actuación concretas. Es decir, su firma viene exigiendo cierto compromiso. 


\section{Compromisos por la defensa del planeta}

Compromiso que, a otra escala, adquirieron también los Estados firmantes de diversos pactos y declaraciones sobre la sostenibilidad urbana, y que se han venido dando desde hace ya unas décadas. A escala global, pueden citarse dos documentos de vital importancia, entre otros. El primero es la Declaración de la Conferencia de Naciones Unidas sobre el Medio Humano, proclamada en Estocolmo en junio de 1972. En ella, se recoge el reconocimiento claro de la capacidad de transformación de la acción humana sobre el medio que le rodea; «de innumerables maneras y a una escala sin precedentes [...] vemos multiplicarse las pruebas del daño causado por el hombre en muchas regiones de la Tierra» (Naciones Unidas, 1972: 3). Dicho documento, aprobado el mismo año que veía la luz el citado informe sobre los límites del crecimiento (Meadows, 1972), planteaba ya la necesidad de que los recursos naturales, incluido el suelo, deben preservarse en beneficio de las generaciones presentes y futuras, planteando la necesidad de incorporar la idea de esta conservación en la planificación del desarrollo económico. El instrumento que se planteó como capaz de conciliar las posibles diferencias surgidas entre ambas cuestiones -desarrollo y conservación-, es la planificación racional de los asentamientos humanos y la urbanización. Quedó definido un marco general en el que encajar la meta del aprovechamiento del parque residencial existente. Tras los pasos de esta declaración, se situó la Declaración de Río sobre el Medio Ambiente y el Desarrollo celebrada en Río de Janeiro en junio de 1992 por la Conferencia de las Naciones Unidas sobre el Medio Ambiente y el Desarrollo. Fue este un documento clave para asentar y difundir a escala global el concepto de la sostenibilidad, y para definir instrumentos de gran interés para el avance hacia la misma como la Agenda 21, que más adelante se comentará. Se insistía en que la protección del medio ambiente debía ser parte inseparable de los procesos de desarrollo, debiendo reducir los modos de producción y consumo insostenibles, lo cual en lo que al suelo respecta supone inevitablemente enfocar la mirada en el modelo de planificación y gestión espacial de este, sea urbanizado o no.

A escala europea, existen ciertos hitos de relevancia como lo fue la Carta de las Ciudades Europeas hacia la Sostenibilidad, o Carta de Aalborg, aprobada en dicha ciudad danesa en mayo de 1994. En ella, ciudades, poblaciones menores y otras unidades territoriales de Europa se comprometían a participar en el programa de la Agenda 21 así como a avanzar «a largo plazo hacia un desarrollo sostenible» (VV.AA., 1994: 1). El documento perseveraba en otorgar al modelo de vida urbano gran parte de la responsabilidad de muchos de los problemas ambientales a los que se enfrenta la humanidad. Pero a su vez, identificaba a la ciudad como aquella entidad capaz de abordar muchos de estos desequilibrios, así como de resolver los problemas de manera integrada y holística, por su «función determinante en el proceso de cambio de los modos de vida, de la producción, del 
consumo y de las pautas de distribución del espacio» (VV.AA., 1994: 2). Entre los objetivos marcados estaba el mantener la calidad del suelo «a niveles suficientes para preservar la vida y el bienestar humanos, así como la flora y la fauna, para siempre» (VV.AA., 1994: 3). Su planteamiento de cara a la intervención en el capital natural, entre el cual está el suelo, consistía en su conservación, fomento de su crecimiento y alivio de la presión sobre el mismo. Entrando más específicamente en materia de suelo, se propuso la necesidad de aplicar "políticas eficaces de ordenación del territorio que impliquen una evaluación ambiental estratégica de todos los planes [y] equilibrar los flujos entre el campo y la ciudad e impedir a las ciudades una mera explotación de los recursos de las zonas periféricas» (VV.AA., 1994: 5). La relación de estas estrategias -en un contexto como el del AMB con escaso suelo adecuado disponible y una población con su crecimiento estancado-, con un uso eficaz de la ciudad existente como manera de reducir dicha presión sobe el suelo, es directa.

Una relación que podía observarse y tenía su continuidad en siguientes documentos, como la Carta de Leipzig de 2007, o la Declaración de Toledo de 2010. En esta última, si bien la centralidad del discurso fue la de la regeneración urbana integrada, no se dejó de dirigir la mirada también a las características de los nuevos desarrollos urbanos. Así, el reciclaje urbano propuesto servía de estrategia, entre otras cosas, para limitar el consumo de suelo, "previniendo la transformación innecesaria de suelo virgen o de zonas naturales en suelo urbanizado, y por tanto controlando y limitando la dispersión urbana» (VV.AA., 2010: V). El documento establecía la 'ecoeficiencia' de los nuevos desarrollos como condición necesaria, aunque no suficiente, para avanzar hacia la sostenibilidad de los sistemas urbanos. La regeneración planteada incluía en este sentido «la protección de los recursos naturales, paisajísticos, forestales, hídricos, agrícolas, etc. en el entorno de la ciudad y el refuerzo de sus conexiones o articulaciones con la misma (por ejemplo, mediante cinturones y/o cuñas verdes conectados y en continuidad con la red de parques y espacios públicos), el 'reverdecimiento' de la ciudad existente, etc» (VV.AA., 2010: 2). En paralelo, existen otro tipo de iniciativas, como la red internacional Compact of Mayors puesta en marcha en 2014, formada por una red internacional de ciudades y de la que Bilbao forma parte, que tiene el objetivo de reducir las emisiones de efecto invernadero a la atmósfera, así como reducir la vulnerabilidad y potenciar la resiliencia ante el cambio climático. Todo ello, mediante el trabajo en equipo y compartiendo valiosa información entre las ciudades participantes. Lo que engloba respuestas de mitigación y adaptación, entre las que pueden encontrarse estrategias de reducción de la construcción de nuevas viviendas redirigiendo el foco a la transformación y puesta en carga eficaz del parque existente -por suponer una reducción del consumo de recursos materiales y energéticos, y por tanto una menor emisión 
de gases, o por ir ligadas a la conservación de suelos vegetados que pueden hacer de sumideros de $\mathrm{CO}^{2}$, entre otras cuestiones-.

\section{Marco legislativo}

Posiblemente -siempre que estén alineados con sus mismos objetivos-, sea el legislativo uno de los instrumentos más poderosos y que más garantías puede ofrecer para avanzar hacia la consecución de las tres metas planteadas. Aunque también puede presentar una cara menos favorable: los tiempos de aprobación y modificación de este tipo de herramientas para su adaptación a la realidad social pueden llegar a ser muy lentos. Por otro lado, si el marco legislativo no comparte mismos objetivos que las metas, pasará de ser un gran aliado a un enorme obstáculo, como se analizará más adelante. Se muestran aquí algunos casos que sí trabajan a favor.

\section{Derecho aparentemente asumido}

En cuanto al acceso a la vivienda se refiere, la cobertura legal en España y Euskadi es a priori amplia. Desde un marco general, comenzando por la propia Constitución española, con el ya citado artículo número 47, o continuando con los también mencionados artículos 9.1 y 10.31 del Estatuto de Autonomía de Euskadi, quedó al menos definida la existencia del derecho a disfrutar de una vivienda. Ahora bien, como se ha mostrado al presentar la situación problemática, el desarrollo de los acontecimientos desde la aprobación de ambos documentos ha dejado clara la falta de firmeza de ese derecho, pues el alcance y acceso al mismo es bien desigual según el colectivo social, dependiendo en gran medida de la capacidad de pago económica. Pasando a la legislación más centrada en asuntos urbanísticos, la referencia a este derecho es también importante. El texto refundido de la Ley de Suelo y Rehabilitación Urbana de 2015 ya especifica en el primer artículo que su objeto es regular las condiciones básicas que garanticen:

«a) La igualdad en el ejercicio de los derechos y en el cumplimiento de los deberes constitucionales, relacionados con el suelo.

b) Un desarrollo sostenible, competitivo y eficiente del medio urbano, mediante el impulso y el fomento de las actuaciones que conducen a la rehabilitación de los edificios y a la regeneración y renovación de los tejidos urbanos existentes, cuando sean necesarias para asegurar a los ciudadanos una adecuada calidad de vida y la efectividad de su derecho a 
disfrutar de una vivienda digna y adecuada» (Real Decreto Legislativo 7/2015, de 30 de octubre, 2015).

Estableciendo con más precisión en su artículo 3.4 que los suelos destinados a un uso residencial por los instrumentos de planificación espacial están por definición destinados a hacer efectivo el derecho constitucional citado. Además, profundiza no solo en las características que la vivienda digna y adecuada debe tener -accesible, con un diseño adecuado, libre de contaminaciones,...- en su artículo 5 , si no también en las del contexto urbano en que está ha de estar seguro, salubre, accesible, integrado socialmente, equipado y dotado,...- en su artículo 3.3. De manera similar, la Ley de Suelo y Urbanismo de Euskadi de 2006 recoge ciertos preceptos relativos a esta cuestión. Como lo hace en su artículo cuarto, relativo al principio de subordinación al interés general, en el que establece que entre las garantías que la ordenación urbanística ha de garantizar al interés público está «el derecho de todas las personas a acceder a una vivienda digna y adecuada a sus necesidades» (Ley 2/2006, de 30 de junio, 2006). Adentrándose ya en asuntos más instrumentales, en su título cuarto -sobre la intervención administrativa en el mercado del suelo- establece como una de las posibles herramientas la obligada constitución, por parte de las autoridades locales, de patrimonio público de suelo ${ }^{45}$. El cual tienen como finalidad la regulación de los mercados del suelo y la vivienda, así como facilitar el desarrollo de suelo para, entre otras cuestiones, la construcción de viviendas sometidas a algún régimen de protección pública. La ley dejó establecidos a su vez los porcentajes de vivienda protegida a destinar en las nuevas promociones residenciales, fijados en un $75 \%$ del incremento de la edificabilidad urbanística de uso residencial en el caso del suelo urbanizable, y un $40 \%$ en el suelo urbano consolidado, lo que supuso un incremento de los anteriores ratios $-65 \%$ y $20 \%$ respectivamente-.

Una de las recientes novedades legales en torno a la vivienda de los últimos años es la Ley Vasca de Vivienda aprobada por el Parlamento Vasco en 2015. Es, junto con Andalucía, una de las comunidades autónomas pioneras en este sentido en el ámbito estatal. Su aprobación no ha estado falta de polémica, y todavía está por ver, como se desarrollará más adelante, hasta dónde va a ser capaz de actuar $^{46}$. Pero en cualquiera de los casos, es sin lugar a dudas un importante hito en el camino hacia la consecución de la meta aquí

\footnotetext{
45 Herencia y evolución de un instrumento por primera vez aparecido a nivel estatal en el Reglamento de Bienes de las Corporaciones Locales de 1955, el Patrimonio Municipal del Suelo, también incluido en la Ley de Régimen de Suelo y Ordenación Urbana de 1956 y desde entonces incorporado en las sucesivas leyes de suelo estatales, y en este caso, autonómica.

46 Se trata de una ley que fue promovida y finalmente aprobada 'desde fuera' del Gobierno Vasco, en manos del Partido Nacionalista Vasco (PNV), que vio sumado a su rechazo el del Partido Popular (PP), y que fue impulsada por el Partido Socialista de Euskadi (PSE), Euskal Herria Bildu y Unión, Progreso y Democracia (UPyD).
} 
señalada. El texto, que admite tener como una de sus referencias al ya citado Pacto Social por la Vivienda -mostrando con claridad en este caso la relación que aquí se pretende poner en evidencia entre la fase de la generación de contenido y la del desarrollo de instrumentos-, establece en su primer artículo que su objeto es regular el derecho a una vivienda digna y adecuada en el territorio autónomo. Objeto que desarrolla con mayor detalle en sus artículos séptimo y noveno. Entre los principios rectores de la política de vivienda que la ley define, es de señalar su artículo segundo, en el que se señala la «erradicación de cualquier discriminación en el ejercicio del derecho al disfrute de una vivienda o alojamiento protegidos, con el establecimiento de medidas de acción positiva a favor de los colectivos vulnerables y con la penalización de las conductas discriminatorias» (Ley 3/2015, de 18 de junio, 2015). Como documento instrumental, el texto pone sobre la mesa dos conceptos de gran relevancia: la acción pública y el derecho subjetivo. La primera se refiere al carácter público legítimo para exigir ante la administración y justicia el cumplimiento de la ley, así como los documentos que se generen para su desarrollo y ejecución. El segundo establece, a través de su artículo sexto, que «las personas que, con arreglo al artículo 9 de la presente norma legal y a las disposiciones que se dicten en su desarrollo, tengan derecho a acceder a la ocupación legal de una vivienda o alojamiento protegido podrán reclamar su cumplimiento ante el departamento competente en materia de vivienda del Gobierno Vasco, y las resoluciones de esta administración serán recurribles ante la jurisdicción contenciosoadministrativa» (Ley 3/2015, de 18 de junio, 2015). En este sentido, en el momento de la redacción está en fase de proyecto, y aprobado previamente, un proyecto de Decreto por el que se regula el derecho subjetivo, bien a la ocupación legal de una vivienda, o bien a la prestación económica de vivienda.

Otro paso de gran interés dado por esta ley es la definición que hace de la necesidad de vivienda por parte de una persona o unidad de convivencia. Son tres los casos que acoge, todos ellos identificados como perfiles con alto potencial de caer en exclusión social. El primero es el de aquellas unidades de convivencia que no disponen de un alojamiento estable o adecuado, ni de los medios económicos necesarios para lograrlo. El segundo es el de aquellas que, siendo titulares de su vivienda habitual, no tienen los medios económicos para hacer frente a los préstamos del crédito hipotecario y se encuentran en un proceso de desahucio por ejecución hipotecaria. El tercero, es el de aquellas unidades bajo régimen de alquiler que no disponen de los medios económicos para hacer frente a las rentas, y están bajo riesgo de desahucio. Por finalizar el breve análisis a esta ley, es de resaltar su propuesta, para un futuro desarrollo por vía reglamentaria, de instrumentos públicos de intervención administrativa en viviendas que no cumplen su función social. Se busca con esta vía garantizar el uso adecuado de las viviendas, y se adelanta al citado desarrollo con una batería de opciones de intervención, desde el desahucio administrativo, a la expropiación, 
pasando por venta o alquiler forzosos, o la imposición de sanciones. Tal y como se demostró en su proceso de proposición y aprobación, la ley una vez aprobada ha provocado y provoca importantes polémicas, rechazos y conflictos por su choque ideológico con un modelo inmobiliario residencial rígido, cimentado en un fuerte y parcial concepto del derecho a la propiedad privada que olvida que esta se ve condicionada por su función social según la Constitución. Por supuesto, existen otro tipo de textos normativos que abordan de una manera más o menos directa el tema del acceso económico a la vivienda. Por citar algunos ejemplos, están las medidas urgentes de protección de deudores hipotecarios sin recursos, definidas por el Real Decreto Ley 6/2012. En su anexo, se definió un Código de Buenas Prácticas para la reestructuración viable de las deudas con garantía hipotecaria sobre la vivienda habitual. Este incorporaba medidas previas a la ejecución, como la reestructuración de las deudas; complementarias, como la quita en el capital pendiente de amortización; y sustitutivas a la ejecución hipotecaria, como la dación en pago de la vivienda habitual. Todas ellas, podrían ayudar a evitar que una unidad de convivencia en situación de vulnerabilidad evite la exclusión social por falta de alojamiento digno y adecuado.

Otra posible vía de actuación frente a la inaccesibilidad económica, ya explorada en numerosos lugares, es el control del precio de los alquileres -en España eliminada por el Real Decreto Ley 2/1985-:

«Durante el siglo XX el control de alquileres ha sido el instrumento más común y de mayor tradición en la política de vivienda en Europa. El hecho de que los parques de vivienda de la primera mitad del siglo fuesen mayoritariamente de alquiler propició políticas sociales de protección basadas en sistemas de control de las evoluciones de los precios de los alquileres, especialmente en etapas inflacionistas, y en el establecimiento de garantías de permanencia en la vivienda para los inquilinos. A comienzos de siglo o en el período de entreguerras en casi todos los países se implantaron diversos sistemas más o menos rígidos de congelación de alquileres antiguos y de indización o fijación normativa de los nuevos contratos» (Trilla, 2002: 114).

Sin embargo, la propia autora plantea que, si bien tras la Segunda Guerra Mundial esta herramienta fue perdiendo peso paulatinamente hasta casi desaparecer por completo, «la función básicamente social de este instrumento hace que, a pesar de su práctica inexistencia, algunos gobiernos busquen, en los últimos tiempos, mecanismos parciales de reintroducción, para hacer frente a demandas sectoriales o de determinadas zonas, de vivienda a precio asequible y protegida de los movimientos inflacionistas de los mercados libres» (Trilla, 2002: 115). Medidas de este tipo se están experimentando recientemente en ciudades como Berlín y Paris, con respectivas leyes de control de alquileres puestas en marcha en 2015. Se trata este de un tema de gran actualidad, presente en los debates e iniciativas 
políticas tanto a escala nacional en el Congreso de los Diputados, como local. En la ciudad de Barcelona se está estudiando el poner en marcha instrumentos similares, desde la generación de un índice serio y respetable - pero no vinculante- que marque precios razonables según las características de la vivienda, hasta la propia limitación de los alquileres. Algo que busca «proteger a los consumidores, sí, pero también al mercado» (Burón, 2016), evitando espirales de inflación y especulación que puedan ir en contra de los intereses de la propiedad a futuro. Aunque motivado por razones muy concretas, de alguna manera algo similar busca el gobierno de las Islas Baleares con sus recientes movimientos legislativos para evitar que el grave problema de sobrecarga turística existente en dicha comunidad autónoma ejerza, como lo está haciendo de facto, un efecto de subida en los precios de los alquileres de viviendas.

\section{Concreción y diversificación de la vivienda 'digna y adecuada'}

En el caso de la adecuación tipológica de las viviendas existentes, no solo la cantidad de textos normativos localizados es inferior a los que tratan la meta del acceso económico, si no que la profundidad con que abordan el tema es mucho más superficial. En cualquier caso, sí existe cierta regulación, como se trata de mostrar aquí con algunos ejemplos. Quizás por donde se ha de empezar a escala nacional es por la mención que se hace en el artículo 47 de la Constitución Española a esa condición de 'digna y adecuada' que ha de tener la vivienda. Si bien no se desarrolla el concepto, un alojamiento con esas características podría entenderse como aquel que responde lo más acertadamente posible a las necesidades de las personas que lo ocupan y utilizan, entre las cuales están las espaciales y habitacionales de la vida doméstica, garantizando una calidad de vida suficiente para el desarrollo de las múltiples esferas vitales. Pero como en el caso de la Constitución, la tónica general de muchas de las herramientas que abordan de manera más o menos directa la cuestión es la de una referencia parca.

Así es en el Texto Refundido de la Ley del Suelo y Rehabilitación Urbana de 2015, que en su artículo tercero se limita a recoger lo establecido en el texto constitucional, refiriéndose a la necesidad de que «el suelo vinculado a un uso residencial por la ordenación territorial y urbanística está al servicio de la efectividad del derecho a disfrutar de una vivienda digna y adecuada, en los términos que disponga la legislación en la materia» (Real Decreto Legislativo 7/2015, de 30 de octubre, 2015). La Ley de Suelo y Urbanismo de Euskadi no especifica mucho más, pues en su artículo cuarto señala que la ordenación urbanística habrá de garantizar, entre otros, el derecho de toda persona al acceso a una vivienda digna y adecuada «a sus necesidades» (Ley 2/2006, de 30 de junio, 2006). Si bien no queda claro si está haciendo referencia solamente a las económicas o a todas 
las relacionadas con la vida doméstica. Desde otra perspectiva más cercana a la dimensión constructiva de la vivienda, la Ley de Ordenación de la Edificación, define en su artículo tercero los requisitos básicos de toda edificación con el fin de garantizar, entre otras cuestiones, el bienestar de la sociedad. En los relativos a la funcionalidad, se hace mención a la necesidad de satisfacer un requisito de utilización, «de tal forma que la disposición y las dimensiones de los espacios y la dotación de las instalaciones faciliten la adecuada realización de las funciones previstas en el edificio» (Ley 38/1999, de 5 de noviembre, 1999). Por lo tanto, hay que acudir a textos más específicamente centrados en esta cuestión para encontrar una mayor profundización en el tema, como es el caso de la Ley de Vivienda de Euskadi. En ella, el artículo primero desarrolla los criterios bajo los cuales debe desarrollarse el citado derecho a la vivienda digna y adecuada:

«Que la vivienda pueda constituir domicilio, morada u hogar estable en el que sus destinatarios o usuarios puedan vivir con dignidad, salvaguardar su intimidad y disfrutar de las relaciones familiares o sociales teniendo derecho legal a su ocupación y utilización.

Que resulte adecuada, en razón a su tamaño, para las características de la persona, familia o unidad de convivencia a que vaya destinada, respetando la igualdad de trato y de oportunidades entre hombres y mujeres y atendiendo, además, a las distintas etapas de su vida y a sus necesidades de residencia.

Que reúna las condiciones objetivas previstas al efecto en la legislación de ordenación de la edificación y normativa técnica aplicable, en lo que se refiere tanto a su funcionalidad como a su habitabilidad y a su seguridad y salubridad» (Ley 3/2015, de 18 de junio, 2015).

A los cuales suma, en su artículo séptimo, que la vivienda en cuestión debe ser accesible. Así, se ha dado con esta ley -todavía en periodo de asimilación y quedando por ver su efecto y los posibles conflictos con la realidad- un paso importante hacia la definición de un marco normativo para la meta de la adecuación tipológica. Aunque como se ha dicho, existe un marco legal previo que da cierta cobertura, aunque no de manera específica en los términos críticos aquí planteados, a la necesidad de adaptar tipológicamente las viviendas a sus ocupantes. $\mathrm{O}$ que al menos ofrece un contexto sobre el que desarrollar esta meta. Así sucede, con una ley que lleva unas décadas de vigencia: la Ley de Propiedad Horizontal. Esta establecía en su artículo séptimo que la propiedad de un inmueble de uso residencial puede «modificar los elementos arquitectónicos, instalaciones o servicios de aquél cuando no menoscabe o altere la seguridad del edificio, su estructura general, su configuración o estado 
exteriores, o perjudique los derechos de otro propietario, debiendo dar cuenta de tales obras previamente a quien represente a la comunidad» (Ley 49/1960, de 21 de julio, 1960). Incluso en su artículo décimo ofrece cierta flexibilidad al permitir, sin necesidad de acuerdo previo en la Junta de Propietarios, «los actos de división material de pisos o locales y sus anejos para formar otros más reducidos e independientes, el aumento de su superficie por agregación de otros colindantes del mismo edificio, o su disminución por segregación de alguna parte, realizados por voluntad y a instancia de sus propietarios, cuando tales actuaciones sean posibles a consecuencia de la inclusión del inmueble en un ámbito de actuación de rehabilitación o de regeneración y renovación urbanas» (Ley 49/1960, de 21 de julio, 1960).

En cuanto a los textos normativos que sí se centran específicamente en las cuestiones puramente espaciales y de diseño de las viviendas, más allá de una versión actualizada y evolucionada de los habituales mínimos de salubridad y habitabilidad heredados del movimiento moderno, no hay en el marco legal vasco instrumentos que superen dichos mínimos y ofrezcan herramientas para el desarrollo y transformación de viviendas hacia tipologías más diversas. Sí es posible, en cambio, encontrar en otras comunidades autónomas referencias interesantes a la flexibilidad, o a la adaptación y adecuación de las viviendas a sus habitantes. En Cataluña, por ejemplo, en 2012 se avanzó en esta cuestión con la redacción de la regulación de las condiciones mínimas de habitabilidad de las viviendas. Con un aporte especialmente importante: el de incluir una definición de lo que se entendía por una vivienda flexible, no solo para adaptarse a diferentes ocupantes, si no que hacía mención expresa a la propia naturaleza cambiante de cada unidad de convivencia. Esta vivienda flexible quedaba definida en su Anexo I como la «concebida de manera que facilite su adaptabilidad a las necesidades cambiantes de sus ocupantes y que quede abierta a la intervención de los usuarios en su compartimentación» (Decreto 141/2012, de 30 de octubre, 2012). Y precisamente los requisitos establecidos en torno a esta compartimentación, y aplicables tanto a obra nueva -incluidas las dotacionales públicas- como a las viviendas resultantes de procesos de intervenciones de rehabilitación, son otro claro avance en este sentido, como lo muestran alguno de sus puntos:

«3.3.1 La compartimentación de la vivienda será libre, con la única limitación de que los espacios destinados a las habitaciones puedan independizarse y que los destinados a cámaras higiénicas sean recintos independientes.

3.3.2 La compartimentación de la vivienda podrá ser concebida con criterios de flexibilidad, siempre que se mantengan inalterables, conforme al proyecto técnico original: la dotación obligatoria de carácter fijo consistente en el equipo de cocina y las cámaras higiénicas, los elementos que tengan 
una función estructural o sean elementos comunes al edificio y los que conformen el cierre con el exterior» (Decreto 141/2012, de 30 de octubre, 2012).

Si bien el fondo del asunto el texto no es novedad desde un punto de vista teórico ni desde el estudio de las tipologías residenciales como se ha visto previamente al resumir algunos de los trabajos académicos existentes sobre el tema, generadores de ese Contenido ahora aplicado a un Instrumento-, sí es de gran relevancia que una norma en forma de decreto lo recoja. Incluso cabe resaltar -aún tratándose de una cuestión muy concreta, pero como muestra de las intenciones progresistas y del cambio de mentalidad para dejar atrás esquemas rígidos- que este documento permite que el lavabo esté fuera de las estancias húmedas y en espacios de circulación. Hoy en día algo todavía impensable en una promoción de viviendas 'tipo' del mercado. Parece que si se buscan en Euskadi intenciones y hechos similares, estos quedan lejos de los catalanes. Tanto la Orden 12/02/2009 que establece las ordenanzas de diseño de viviendas de protección oficial, como las condiciones mínimas de habitabilidad de las viviendas establecidas para las actuaciones protegidas de rehabilitación del patrimonio urbanizado y edificado definidas en el Decreto 317/2002 se limitan principalmente, como se insistirá más adelante, a establecer mínimos de habitabilidad y máximos de superficie total de las viviendas. No obstante, sí se aprecia una escasa, pero creciente, preocupación por aspectos tipológicos desde las instituciones. Ejemplo de ello es que desde el año 2018 se está dando forma al proyecto de Decreto por el que se regula las condiciones mínimas de habitabilidad y las normas de diseño de las viviendas y de los alojamientos dotacionales en la Comunidad Autónoma del País Vasco, en desarrollo de la Ley 3/2015 de Vivienda. Tal y como recoge el documento para la consulta pública sobre el mismo, se pretende con él «incorporar criterios de salubridad, de accesibilidad, de género, de sostenibilidad y de equipamiento, sin olvidar la innovación, la flexibilidad y la adaptación de la vivienda a las distintas etapas de la vida y nuevos tipos de hogar, necesidades y formas de vida modernas» (Gobierno Vasco, 2018a: 4). Para abrir el debate y fomentar la participación de la población, el documento lanza algunas preguntas que demuestran un importante cambio de paradigma y una reflexión sobre la obsolescencia tipológica generalizada del parque actual. No obstante, el interesante debate que pueden llegar a abrir estas preguntas puede verse limitado y condicionado por la existencia, o no, de un factor clave para una participación pública y una toma de decisiones colectiva exitosas: que esta sea adecuadamente informada con anterioridad, que se prevea una fase previa de formación. Lo contrario podría hacer que ante el desconocimiento o los prejuicios se responda defensivamente, fortaleciendo aún más un esquema habitacional conservador, pero el único conocido:

«¿Qué es lo primero que cambiaría o incorporaría a su vivienda? 
$¿$ Cree que la vivienda debe ser flexible para acomodarse al cambio de las circunstancias de sus ocupantes o las personas deberían cambiar de vivienda?

¿Considera que las viviendas actuales son fáciles y económicas de mantener por su configuración, diseño y materiales?

¿Cuál sería para usted la relación idónea de número de personas por vivienda y superficie?

¿Se debería potenciar en los edificios de vivienda los espacios comunitarios en las viviendas, zonas de lavado o de tendido de ropa, por ejemplo?

¿Cree que se debería ofrecer viviendas con núcleos de servicio, y huecos de fachada y que después cada uno se distribuya la vivienda como quiera?

¿Qué opina de la distribución actual de la vivienda (salóncomedor, cocina, baños, dormitorio)? ¿Qué otras distribuciones haría? ¿Qué equipamientos pondría? ¿Considera que la cocina debería incorporar el espacio para comer o prefiere que este se incorpore al salón?

¿Cree imprescindible tener garaje y trastero con la vivienda?

$¿$ Cree que los espacios de tendedero se pueden sustituir por máquinas secadoras?» (Gobierno Vasco, 2018a: 7-9).

A escala local, existe un poderoso instrumento legal complementario a estos otros. La Ley del Suelo de 2006 de esta comunidad autónoma, en su disposición final segunda, establecía la obligatoriedad por parte de gobierno, diputaciones y asociación de municipios de elaborar un modelo básico de ordenanzas municipales de urbanización y edificación. Algunos años después se redactó este documento, de cumplimiento optativo por parte de los ayuntamientos, y aplicable «a obras de nueva planta, así como a la división de viviendas, reedificación y de reforma o rehabilitación cuando se menciona expresamente» (Gobierno Vasco, 2016b: 1). Puede observarse en parte del documento cierta intención de aprovechar la ocasión para actualizar este tipo de ordenanzas, incorporando criterios de flexibilidad para facilitar la transformación de las viviendas existentes, y responder a los nuevos tipos de unidades de convivencia. Entre uno de sus objetos está el «adaptar el modelo de vivienda a la realidad de los hogares actuales, actualizar el tipo vivienda mediante fórmulas flexibles, que las haga adaptables a las diferentes formas de habitar, al uso universal de la vivienda por colectivos con dificultades de movilidad temporal o permanente» (Gobierno Vasco, 2016b: 7). Pero de igual manera que en otros casos, 
y como se verá posteriormente, estas incorporaciones en el discurso se quedaron en meras intenciones, sin aportar nada nuevo en este sentido respecto a los dos documentos citados previamente (la Orden de 12 febrero de 2009 en la que se establecen las Ordenanzas de Diseño de Viviendas de Protección Oficial, y el Decreto 317/2002 de Actuaciones protegidas de rehabilitación del patrimonio urbanizado y edificado de Euskadi). Por finalizar, se desea mostrar con un breve ejemplo que desde la iniciativa municipal se dan también en ocasiones esfuerzos o gestos positivos muy interesantes como reflejo de una preocupación por esta cuestión tipológica. En su ordenanza de 2004 -hoy vigente- para la regulación de las viviendas de protección local, el ayuntamiento de Barakaldo, perteneciente al Área Metropolitana de Bilbao, añadía un anexo de recomendaciones para el diseño y la construcción de estas viviendas. Este incluía una serie de criterios de funcionalidad, entre los cuales se planteaba -aunque sin ahondar en cómo formalizarlo- que «siempre que se pueda se intentará una flexibilidad de espacios, lo que permitirá la adecuación de la vivienda a las distintas necesidades de los usuarios» (Ayuntamiento de Barakaldo, 2004: 7).

\section{Cambios recientes en el urbanismo y la ordenación del territorio}

Al igual que en el caso anterior, el desarrollo normativo que da cobertura legal a la meta de una ordenación urbana racional y responsable de los usos residenciales para reducir la presión sobre el territorio y aprovechar el parque existente, es menos amplio y preciso que el existente para satisfacer el acceso económico a la vivienda. Sin embargo, existen tanto en los textos antes analizados como en otros, referencias a esta cuestión. Uno de los principios que estructuran el Texto Refundido de la Ley del Suelo y Rehabilitación Urbana es el del desarrollo territorial y urbano sostenible planteado en su artículo tercero, de manera que «las políticas públicas relativas a la regulación, ordenación, ocupación, transformación y uso del suelo tienen como fin común la utilización de este recurso conforme al interés general y según el principio de desarrollo sostenible»; políticas que deben «propiciar el uso racional de los recursos naturales» (Real Decreto Legislativo 7/2015, de 30 de octubre, 2015). Como complemento a lo anterior, en el artículo cuarto se recuerda que «la ordenación territorial y la urbanística son funciones públicas no susceptibles de transacción que organizan y definen el uso del territorio y del suelo de acuerdo con el interés general» (Real Decreto Legislativo 7/2015, de 30 de octubre, 2015). En este marco, cabe interpretar el concepto de sostenibilidad en toda la complejidad del mismo, y el interés general como aquel que requiere de una ordenación equilibrada que incorpore análisis y propuestas multi-variables y multi-escalares.

Otra ley del suelo, en este caso la Ley 2/2006 de Suelo y urbanismo de Euskadi, ya había incluido también entre los principios 
generales de urbanismo el del desarrollo sostenible. Se apostaba por un urbanismo cuya función pública asegure el uso racional y sostenible de los recursos naturales como parte de un modelo territorial que incorpore procesos de producción y consumo adecuados, integre las necesidades ambientales que aseguren una transmisión intergeneracional del patrimonio natural, y se oriente hacia una ocupación racional del suelo. Sin embargo, y como algunos analistas han planteado al hacer estudios comparados de los modelos urbanísticos vigentes (Tejerina, 2016), la Ley de Suelo y Urbanismo de Euskadi es, en su contenido y en las herramientas que ofrece, clara heredera del modelo de planeamiento centrado principalmente en la creación de nueva ciudad apuntado previamente - con la citada Ley del Suelo Estatal de 1956 como origen y principal influencia-. De manera que, a pesar de la inclusión del principio del desarrollo sostenible en su articulado, no facilita un cambio de paradigma en la planificación urbanística. Por lo tanto, y en lo que a la intervención en el parque existente se refiere, sus capacidades y sus herramientas para intervenir sobre el patrimonio residencial en uso se ven limitadas por la necesaria viabilidad económica de unas operaciones que demandan la sustitución y redensificación de tejido urbano más que su regeneración -con habituales procesos de desplazamiento de habitantes, y subida de precios de la vivienda-. Frente a ello, la citada ley estatal de 2015, fruto de la unión de dos instrumentos legislativos previos como fueron el Texto Refundido de la Ley del Suelo de 2008 y la Ley de Rehabilitación, Regeneración y Renovación Urbanas, se posiciona claramente con la intención de actuar sobre la ciudad existente, y plantea un cambio relevante hacia otro modelo urbanístico (Tejerina, 2016). La primera de ellas introdujo ya algunos cambios de fondo respecto a ese modelo heredado de la ley de 1956 y sus versiones posteriores: la inclusión de la sostenibilidad, la mirada puesta en la necesidad de vivienda y los derechos de la ciudadanía, o cambios en los métodos de valoración del suelo. La segunda, conocida como la ley 3R, y enfocado específicamente a la intervención sobre áreas con necesidad de actuación, introdujo criterios de delimitación de estas por objetivos, la equidistribución plena, o la inclusión de todos los costes previstos -incluidos costes sociales- en la viabilidad de la operación. La vigente ley del suelo de 2015 refundó ambas leyes en una e incorporó esas y otras cuestiones. La ineficacia de las técnicas de intervención propias del modelo de 1956, y vigente en Euskadi con su ley de 2006, evidencian la necesidad de actualizar esta última por su total incompatibilidad con el modelo de la ley estatal vigente.

Pero en gran medida, es posible hablar ya de un lento, pero perceptible, giro real de intenciones en la última década y media de las políticas públicas urbanas hacia la gestión de la ciudad existente y no exclusivamente de la nueva como se venía haciendo hasta hace no tantos años (Matesanz, 2012). No son pocos los retos ni corto el camino que queda por andar, pero sí se ha producido claramente un cambio en las prioridades (Burón, 2011). Y en ese camino 
necesariamente compartido con otras disciplinas, también se ha dado forma a instrumentos para la gestión racional del territorio no urbanizado. Lo cual es un complemento de enorme valor para una correcta ordenación urbana $-\mathrm{y}$ viceversa-. Un ejemplo es el relativo a la conservación y fomento del uso del suelo agrario aprobado en Euskadi en 2012. Se trata de una herramienta con un enorme potencial, aplicable a no pocos espacios de borde y periferia de núcleos urbanos vascos y que ayudaría a activar un uso de gran interés en esos suelos. Viene a desarrollar algunas de las medidas que estableció la Ley 17/2008 de Política Agraria y Alimentaria, como la protección especial de los suelos de alto valor agrológico y la cesión obligatoria del uso del suelo en caso de incumplimiento de la función social de la propiedad por infrautilización de los mismos. Su finalidad se establecía en su artículo primero como la de «evitar el abandono y la perdida de superficies agrarias útiles y de promover un uso continuado y adecuado de dichos suelos para la actividad agraria» (Decreto 193/2012, de 2 de octubre, 2012). Para lo cual define toda una serie de medidas de detección, gestión, contraprestaciones, o sanciones, entre otras.

\section{$-2.5 .3-$ \\ Planificación}

\section{Planes de vivienda y acceso asequible}

La planificación como momento de gobernanza es una fase vital para el adecuado desarrollo de cualquier política. Jerárquicamente por debajo del marco legislativo, será a través de esta como se definan y se diseñen actuaciones pormenorizadas para poner en práctica algunas de las estrategias establecidas en las primeras. A nivel estatal, el Plan Estatal de fomento del alquiler de viviendas, la rehabilitación edificatoria, y la regeneración y renovación urbanas para el periodo 2013-2016 definía ocho programas, para los cuales serían subvencionables algunas de las actuaciones previstas. Uno de ellos es el programa de ayuda al alquiler de la vivienda, que «tiene por objeto facilitar el acceso y la permanencia en una vivienda en régimen de alquiler a sectores de población con escasos medios económicos» (Real Decreto 233/2013, de 5 de abril, 2013) tal y como establecía su artículo décimo. En el ámbito autonómico, el Plan Director de Vivienda 2013-2016 ahondaba más en esta misma cuestión. En su Eje 1, titulado muy aclaratoriamente 'Impulso decidido al acceso a la vivienda en régimen de alquiler', se hacía un breve análisis del contexto socioeconómico identificando, entre otras cuestiones, un mercado de alquiler reducido con un porcentaje de tenencia en propiedad muy alto, el aumento del desempleo, la dificultad de obtener financiación, o el aumento de la demanda de vivienda 
protegida en alquiler. Así, su línea de acción 1.1 apostaba por impulsar tanto el acceso como la promoción de vivienda nueva en alquiler. Para ello planteaba un alquiler con opción a compra más flexible, el fomento de la compra-venta con plazo aplazado, la colaboración con entidades privadas para el desarrollo y gestión de viviendas protegidas de alquiler -entre ellas algunas sin ánimo de lucro pertenecientes al ámbito de los servicios sociales-, o la fijación de precios, rentas y convenios con entidades financieras. En un ámbito más urgente, la línea 1.3 se centraba en orientar los recursos al alquiler social para personas con necesidad de vivienda. Mediante dos estrategias: la creación de una red de alojamientos públicos en alquiler para colectivos con especial necesidad de vivienda, y la gestión de una parte de las viviendas en alquiler social a través de convenios específicos con entidades sin ánimo de lucro pertenecientes al ámbito de los servicios sociales municipales.

Siguiendo con estas cuestiones, su Eje 2 se centraba en favorecer el acceso a la vivienda a los colectivos prioritarios, con el objetivo de «definir con mayor precisión la demanda real de vivienda, y redefinir y depurar el Registro de Demandantes de Vivienda adecuándolo a la necesidad real»(Gobierno Vasco, 2013b: 14). En su diagnosis se identifica la aparición de nuevos colectivos con vulnerabilidad residencial debida a la crisis estructural de la última década que se ven sumados a los ya existentes. Como ya se ha apuntado el desarrollar con más detalle la situación problemática, la novedad residía en «quienes teniendo ingresos y una vivienda adjudicada, no consiguen el crédito necesario para una vivienda de VPO», y aquellas «personas que, por su falta de ingresos, no pueden hacer frente a sus hipotecas y alquileres, y se quedan sin hogar» (Gobierno Vasco, 2013b: 14). Si bien también se centra en otros colectivos como «jóvenes, las víctimas de violencia de género, las personas con discapacidad, las familias numerosas, las personas separadas, y los colectivos con dificultades de inserción social, a los que tradicionalmente se ha atendido en sus dificultades de acceso a la vivienda» (Gobierno Vasco, 2013b: 14). Las principales líneas de trabajo planteadas para responder a esta situación eran el establecimiento de un sistema de adjudicación de vivienda protegida que favoreciese a todos estos colectivos prioritarios citados, y el fomento de medidas innovadoras y experiencias contrastadas en otros lugares para responder a las necesidades de vivienda. Como novedad, en el borrador presentado para el Plan Director de 20182020, y en clara relación con la Ley Vasca de Vivienda, una de sus cuatro líneas de trabajo es el impulso al desarrollo y la garantía del derecho subjetivo a la vivienda, así como la búsqueda y apoyo a fórmulas innovadoras de acceso a la vivienda como el co-housing o la propiedad en cesión de uso, entre otros. Es importante subrayar aquí la relación directa de este documento con el plan de gobierno correspondiente, en este caso el anteriormente citado Plan de Gobierno de la X Legislatura del Gobierno Vasco. Así, los ejes del Plan Director presentados aquí siguen los compromisos y objetivos del Plan de Gobierno. Es este un claro ejemplo -parcial- de ese 
proceso de respuesta de la sociedad ante la situación problemática que se pretende sintetizar en el Esquema 2.1, proponiendo desde ciertos Instrumentos diversas líneas de acción para alcanzar una serie de metas previamente establecidas en el Contenido.

\section{Visión parcial de la evolución de unidades de convivencia}

En la línea de los otros apartados analizados, en este caso ha sido también difícil encontrar material abundante que aborde la problemática del desfase tipológico existente entre gran parte del parque residencial y sus residentes. En el Plan Director de Vivienda 2013-2016 del Gobierno Vasco sí se identificaron algunas cuestiones en este sentido. La fase de diagnóstico menciona un aumento de los expedientes de solicitudes individuales de vivienda protegida en relación al total, «lo que se traduce en una adaptación de tipologías edificatorias a los nuevos tipos de demanda» (Gobierno Vasco, 2013a: 150). Esta evolución del tamaño de la unidad de convivencia que demanda vivienda se formalizó en estrategias concretas, como lo hizo su Eje 3, que buscaba, entre otras cosas, la adaptación de la edificación a las nuevas necesidades, e identificaba «una disminución del tamaño medio de la composición del hogar. La respuesta de la Administración debe optimizar los recursos, adaptando la oferta de viviendas, tanto en número como en características, a las demandas reales de la población» (Gobierno Vasco, 2013b: 16). Así, planteaba entre sus líneas de acción dos con este fin. La primera, consistente en adaptar las tipologías de viviendas a las necesidades actuales, contemplaba actuaciones como flexibilizar y favorecer la rotación y cambio de vivienda, el fomento de cooperativas de promoción -se entiende que por una mayor participación de los futuros habitantes en el proceso de diseño- o la implicación de la ciudadanía en el «análisis y posible modificación de las ordenanzas de diseño de las VPO para adaptarlas a las necesidades actuales» (Gobierno Vasco, 2013b: 18). $\mathrm{La}$ segunda línea en la que pueden identificarse algunos planteamientos de interés en relación a esta meta, buscaba entre otras cosas permitir combinaciones de tipologías distintas de vivienda protegida en una misma parcela. Como se verá más tarde, tanto el diagnóstico como las respuestas estaban muy centradas en la variable del tamaño de la unidad de convivencia y de las viviendas, dejando fuera otras muchas y fundamentales cuestiones.

\section{La planificación espacial y la ordenación racional}

En lo relativo al aprovechamiento del parque residencial existente, la planificación espacial ejerce un papel especial. Dentro de los programas definidos por el ya mencionado Plan Estatal de fomento del alquiler de viviendas, la rehabilitación edificatoria, y la regeneración y renovación urbanas de 2013-2016, son de interés tres de ellos por la manera en que abordan con mayor o menor énfasis 
dicha meta. Uno es el centrado en el fomento de la rehabilitación edificatoria como apuesta por poner en carga la ciudad existente, con directa influencia en la reducción de la demanda de ocupación de nuevos suelos. Su objetivo se definía en su artículo decimonoveno, siempre bajo ciertos requisitos, como «la financiación de la ejecución de obras y trabajos de mantenimiento e intervención en las instalaciones fijas y equipamiento propio, así como en los elementos y espacios privativos comunes, de los edificios de tipología residencial colectiva» (Real Decreto 233/2013, de 5 de abril, 2013). El programa de fomento de la regeneración y renovación urbanas, por razones similares al anterior, establecía en el artículo veinticinco el objetivo de financiar «la realización conjunta de obras de rehabilitación en edificios y viviendas, de urbanización de espacios públicos y, en su caso, de edificación en sustitución de edificios demolidos, dentro de ámbitos de actuación previamente delimitados. Estas obras se realizarán con la finalidad de mejorar los tejidos residenciales, y recuperar funcionalmente conjuntos históricos, centros urbanos, barrios degradados y núcleos rurales» (Real Decreto 233/2013, de 5 de abril, 2013). Un tercer programa compartía esta búsqueda de un desarrollo urbano racional de los suelos residenciales para el fomento de ciudades sostenibles. Dentro de este, se pretendía financiar la ejecución de proyectos de una trascendencia importante para la ciudad siempre que siguiesen líneas estratégicas como la mejora de barrios, la regeneración de centros históricos y cascos rurales, la renovación de áreas funcionalmente obsoletas, la renovación de áreas para la sustitución de infravivienda, la generación de ecobarrios, o la regeneración de zonas turísticas en procesos de degradación.

También el Plan Director de Vivienda de Euskadi 2013-2016 compartía algunas de las líneas hasta aquí avanzadas. En su fase de diagnóstico se detectaba el creciente stock de vivienda usada en venta como oportunidad para utilizarlo como vivienda protegida (Gobierno Vasco, 2013a: 150). Así mismo, el aumento del número de viviendas deshabitadas detectado -con repercusiones sociales negativas en ciertos barrios- y la posibilidad de obtener un rendimiento económico a partir de las mismas, se planteaba como oportunidad para diseñar políticas que hiciesen atractiva la incorporación de este parque privado a la oferta pública (Gobierno Vasco, 2013a: 151). Políticas que, de tener éxito, reducirían el número de viviendas nuevas protegidas a edificar. En cuanto a las estrategias, principalmente el interés se centraba en un eje que contribuía a reducir la presión sobre la urbanización de nuevos suelos. Se trata del Eje 4, que buscaba dar un impulso a un nuevo modelo de rehabilitación. El diagnóstico que llevaba a plantearlo era el deficiente estado de conservación de una gran parte del parque residencial edificado. De manera más indirecta, también se podía encontrar en otros ejes del plan estrategias cercanas al desarrollo racional de los suelos, como la línea 3.3 -aprovechar suelos disponibles para promover futuras actuaciones prioritarias-, o el propio Eje 5 que se centra en la disminución de las viviendas deshabitadas existentes para una más eficaz puesta en carga del 
parque existente y una reducción de la presión sobre nuevos suelos. Quedaban así establecidos los principios base sobre los que desarrollar una planificación espacial residencial.

Planificación espacial en la que, en el caso de esta meta, se pueden identificar algunos documentos de ordenación con planteamientos en favor de la consecución de un desarrollo racional de los suelos residenciales, tanto existentes o potencialmente afectados por la urbanización -cabiendo preguntarse si existe alguna influencia, algún proceso consciente de transmisión de Contenido, entre el Plan Director de Vivienda y aquellos más recientes-. Se van a presentar cuatro ejemplos, en escala geográfica y jerárquica descendente, y comenzando por las ya mencionadas Directrices de Ordenación del Territorio de Euskadi (DOT). Estas fueron aprobadas en 1997, y en su origen dieron un paso importante, aunque parcial, para la protección de ciertos suelos de la ocupación y transformación urbana. En las bases de su modelo territorial se planteaba como imprescindible «que el territorio se desarrolle dentro de una estrategia general de atención a la conservación, rehabilitación y puesta en valor del medio físico» (Decreto 28/1997, de 12 de febrero, Suplemento, 1997: 21). Proponían condicionar «el diseño del modelo territorial a la valoración de los recursos naturales» y abogaron por superar «la actitud centrada exclusivamente en evitar impactos negativos sobre el medio natural, y asumir una postura activa más comprometida» (Decreto 28/1997, de 12 de febrero, Suplemento, 1997:21). Se definían a sí mismas como «inspiradas en una nueva Cultura de la Ciudad y del Territorio [...] con un profundo interés por la recualificación urbana y por el redescubrimiento del territorio y sus valores para la vida cotidiana de los ciudadanos» (Decreto 28/1997, de 12 de febrero, Suplemento, 1997: 27).

Asentadas las bases del modelo, las DOT pasan a establecer las características del mismo. Conceptualmente este sigue la línea de una ordenación territorial tradicionalmente ligada al modelo alemán, centrado casi en exclusiva en la planificación física y sin entrar en consideraciones políticas o económicas. Modelo que en Europa se ha venido contraponiendo al modelo francés, contando este con una perspectiva más integral e incorporando variables económicas. Así, el denominado Medio Físico es el principal concepto que vertebra el documento, identificado como aquello que ha «constituido un elemento esencial para la configuración del modelo territorial» (Decreto 28/1997, de 12 de febrero, Suplemento, 1997: 41). Efectivamente, tal y como se indica en el texto, las características geográficas físicas de Euskadi han tenido un importante papel en el desarrollo y evolución de su sociedad y sus sistemas urbanos, a la par que el propio territorio ha sido gravemente damnificado por estos. Las DOT, a través de la gestión de lo físico, afirmaban centrarse en «el papel que deben jugar los recursos naturales y el suelo no urbanizable en un contexto de nuevas demandas sociales y modificaciones en la estructura económica y en el sistema de 
asentamientos» (Decreto 28/1997, de 12 de febrero, Suplemento, 1997: 42). La «escasa integración de las actividades humanas en el medio» llevaron a los agentes redactores a entender el Medio Físico «como una infraestructura de base» (Decreto 28/1997, de 12 de febrero, Suplemento, 1997: 42). Hay por tanto en las DOT cierta concienciación de las consecuencias que sobre el medio físico tiene la artificialización del territorio, y gracias a ella se propuso una relativamente alta protección de los suelos no urbanizables. La propuesta de protección, que tomó forma de matriz, fue definir para estos una serie de categorías de ordenación a las que se superpusieron ciertos condicionantes que «limitan no el uso sino la forma en que se pueden desarrollar sobre ellas determinadas actividades, según el tipo de riesgo o situación particular que se presenta en cada caso» (Decreto 28/1997, de 12 de febrero, Suplemento, 1997: 42). De la misma manera, se plantearon estrategias de protección frente a nuevos crecimientos, así como un seguimiento de la realidad territorial y la coordinación de planes municipales de municipios colindantes. Como complemento a este principal planteamiento, existen en este instrumento algunas iniciativas de apoyo para la reducción de la presión urbana sobre los suelos no transformados, orientadas a la renovación y recuperación de conjuntos urbanos degradados.

Se trata de un instrumento de ordenación que cuenta tanto con grandes defensores, como con intensos detractores; el contar con un instrumento único de ordenación espacial a escala autonómica es sin duda un aspecto positivo, y algunas de las técnicas de ordenación y distribución de usos en el territorio han favorecido cierta protección de la urbanización, aunque probablemente el papel de la orografía vasca ha sido fundamental en este sentido. Por otro lado, las DOT compaginan discursos enfrentados hacia el desarrollismo y hacia el conservadurismo, algunas de sus técnicas estrella para la limitación de la urbanización han fallado, y perpetúan en definitiva un modelo insostenible (Etxabe, 2012). Pero esto se abordará más adelante, continuando aquí con el objetivo de este apartado: mostrar cómo algunos de estos instrumentos se diseñan, al menos parcialmente, para intentar poner en práctica ese Contenido inicial. Años más tarde, en el documento de trabajo previo desarrollado en 2011 para la revisión de las DOT se confirmaba la escasez de suelo y se veía el crecimiento urbano como un riesgo y peligro (Taller de Ideas, 2011). Se planteaba además la necesidad de frenar el crecimiento y de actuar, densificar y reutilizar lo existente, en paralelo al desarrollo de estrategias de control de los nuevos crecimientos. Por otro lado, el documento optaba por mantener la alta protección de espacios singulares, y existía un deseo explícito de coordinación institucional y legislativa. Cabe también destacar la aprobación de una modificación puntual de las DOT en 2016 relativa exclusivamente a la cuantificación 
residencial que los planes urbanísticos deben incorporar ${ }^{47}$. En la metodología actualizada se incorporaba una nueva variable relativa a la vivienda vacía existente, y se reducía en general el número de viviendas nuevas a realizar respecto al cálculo previo. Por todo lo anterior, y limitando el análisis a sus aspectos más positivos, puede afirmarse que en este instrumento de ordenación territorial hay herramientas de control y una apuesta por un desarrollo racional ${ }^{48}$. Más adelante se mencionarán ciertas contradicciones insertas en algunos de sus propios planteamientos, contrarios a los aquí expuestos.

El siguiente instrumento en la escala espacial y jerárquica, dentro de la estructura de herramientas para la ordenación territorial vasca, es el ya citado Plan Territorial Parcial del Bilbao Metropolitano, aprobado en 2006. Entre algunas de las propuestas de interés que este planteó está la discriminación de suelos: el artículo 44 de su normativa expone que el plan «realiza una discriminación de los suelos actualmente vacantes estableciendo unos criterios que definen los suelos no susceptibles de ocupación y que, por tanto, quedarán excluidos en las nuevas propuestas de asentamientos» (Decreto 179/2006, de 26 de septiembre, Anexo I-Normativa, 2006: 47). Se trataba de suelos clasificados por el planeamiento municipal como residenciales, de actividades económicas o sistemas generales, y que cumplían con una serie de condiciones. Entre ellas, presentar pendientes superiores al 15\%, estar afectados por áreas inundables, o formar parte de espacios o categorías de suelos protegidos. Al igual que se ha visto con otros instrumentos, este plan presenta también otra línea de acción paralela para un desarrollo racional de los suelos, además de la protección de estos de la urbanización: la actuación en la ciudad existente para una puesta en carga eficaz de la misma y reducir así la presión sobre los suelos no urbanizados. En este caso, las propuestas de intervención con usos residenciales y de actividades

\footnotetext{
47 Movimiento del Gobierno Vasco ampliamente cuestionado desde diversos sectores, al separar en dos tiempos y formas la revisión de un instrumento estratégico de gran influencia. La anticipación de la revisión de la cuantificación residencial supuso no someter esta al procedimiento de evaluación ambiental estratégica, y de manera contradictoria se decía que, ante la urgencia de la planificación residencial, el resto del documento merecía ser revisado «de forma más pausada y con la apertura de un amplio proceso de participación» (Gobierno Vasco, 2014b: 3), como si la materia en ese momento abordada no mereciese tal proceso de reflexión y debate público. La lectura de todo ello era clarificadora: la cuantificación residencial era el interés principal de las DOT (Fernández de Betoño, 2014).

48 En el momento de la redacción está en proceso de aprobación el avance de la revisión de las DOT, en el cual parece que se van a incorporar una serie de aspectos de interés: el compromiso con la renovación y regeneración urbana priorizando el aprovechamiento de lo existente, y la limitación de los nuevos desarrollos a aquellas situaciones verdaderamente necesarias. Se pretende así sacar el máximo rendimiento a los suelos urbanos disponibles poniendo en segundo orden de prioridad suelos urbanizables que en algunos casos llevan lustros a la expectativa. Incluso se plantea corregir la fórmula de cálculo de la cuantificación residencial, de la que se va a eliminar -por exigencias de muchos municipios vascos- el mínimo obligatorio en la actualidad. Se trata de un gran paso, no carente de cierta trampa: al parecer las actuaciones en los suelos urbanos no van a contar como viviendas a descontar de la cuantificación obtenida por la fórmula de las DOT.
} 


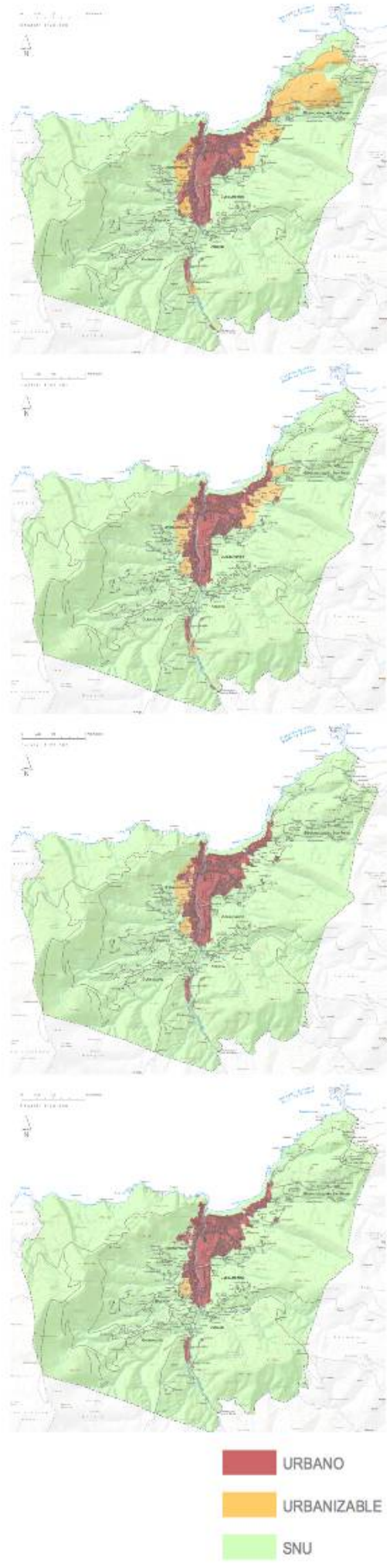

Mapas 2.7 a 2.10. Alternativas de planificación en Bakio, según el Avance del PGOU. De arriba a abajo: alternativa $0,1,2-$ finalmente seleccionada- y 3 . Ayuntamiento de Bakio, 2017. económicas se articulan a través de diferentes modos de intervención. Estos son la regeneración, la renovación, la actuación sobre el patrimonio edificado, la redensificación, y los nuevos desarrollos; la prioridad se enfocaba en los primeros, dejando los desarrollos en suelos no urbanizados como última alternativa.

En una tercera escala, la municipal, la casuística es amplia y diversa. Existen diferentes ejemplos en España de buenas prácticas de planificación espacial municipal desde un punto de vista de la racionalidad en la gestión de la ocupación de suelos - pueden citarse, entre otros, los reconocidos casos de Vitoria-Gasteiz, Girona o Lleida-. Y ello mediante el buen uso de, y también a pesar de, los instrumentos tradicionales de ordenación urbana. Casos que en las últimas décadas han planteado un crecimiento y una expansión contenida de la ciudad, clasificando nuevos suelos con cautela y bajo una previsión demográfica coherente. Pero aquí se quieren traer en concreto dos ejemplos locales, y además recientes, que han dado un paso de gran relevancia hacia un modelo más avanzado y necesario: el de la desclasificación de suelo urbanizable a no urbanizable. Es decir, no solo se reduce el ritmo de expansión, si no que se llega a invertir la tendencia; la superficie global municipal de suelo no urbanizable pasa a aumentar, frente a la reducción de la urbanizable. Se trata sin duda de un punto de inflexión importantísimo y que probablemente comience a ser común en muchas revisiones de planeamiento urbano municipal a corto y medio plazo.

El primer ejemplo -fuera del AMB, pero que merece la pena mencionar por su cercanía y su potencial aplicación a algunos municipios del área metropolitana- es el del municipio bizkaíno de Bakio, con una población estable de aproximadamente 2.500 personas, y una estacional, principalmente en verano, de 10.000. En el Avance de la revisión de su PGOU vigente, se han trabajado en el proceso participativo cuatro alternativas (Mapas 2.7 a 2.10). Es de resaltar que una de ellas, la que se corresponde con el modelo urbanístico del planeamiento vigente (alternativa 0), ha sido identificada como inviable por incumplimiento de la normativa actual. Las otras tres plantean, en mayor o menor medida, una reducción considerable del suelo urbanizable clasificado, habiéndose optado en el proceso participativo por la segunda más restrictiva en este sentido:

«Los suelos que están claramente al margen del proyecto territorial de Bakio y no tienen un grado de desarrollo urbanístico suficiente, cuya paralización no implica un riesgo para la gestión del Plan, se han desclasificado. La alternativa Bakio sin prisas implica poner todo el empeño en los procesos de rehabilitación y regeneración urbana, dejando las nuevas ocupaciones para operaciones con justificación estructural muy robusta [...] la pretensión de esta propuesta es recomponer la unidad orgánica del territorio, estableciendo relaciones más integradoras entre el poblamiento y el espacio rústico, entre el litoral y el interior, entre los espacios libres y los urbanizados y 
entre los ciclos naturales y las condiciones de habitabilidad» (Ayuntamiento de Bakio, 2017: 313).

El segundo ejemplo es de otro avance de PGOU, en este caso el del propio Bilbao, actualmente en proceso de revisión. Entre las propuestas previas planteadas en este documento de avance, desarrollado en gran medida para abordar el proceso de participación, y dentro del apartado del Medio Físico y Natural, se ha planteado una posible «desclasificación de suelos con desarrollos previstos por el Plan General 95 y que no han sido gestionados ni urbanizados» (Ayuntamiento de Bilbao, 2016a: 27). El documento propone cuatro grandes objetivos estratégicos, de los que interesa mencionar dos: los que buscan una ciudad en continua regeneración y renovación, y los que apuestan por una ciudad medioambientalmente sostenible. Las líneas de actuación del primero inciden una vez más en la apuesta por utilizar de manera óptima lo existente, conteniendo así la presión sobre suelos sin artificializar. El segundo contempla líneas de actuación como la protección del suelo natural, o la reducción del consumo de suelo:

«La sostenibilidad urbana y la preservación del suelo natural exige reflexionar sobre los límites de la urbanización en las laderas de los montes circundantes de la ciudad, a la vista de sus valores paisajísticos y de ocio. El suelo es un recurso escaso en nuestra ciudad, por lo que se impone una utilización racional e intensiva del mismo que genere crecimientos funcionales y sostenibles. Para ello, se proponen como objetivos pormenorizados evitar o minimizar el consumo de nuevos suelos y establecer densidades adecuadas en los nuevos desarrollos urbanos, abandonando las bajas densidades» (Ayuntamiento de Bilbao, 2016a: 19).

El cuarto ejemplo de planificación espacial, a pesar de su excepcionalidad, es propio de una escala de gran relevancia: la que aborda el barrio y los espacios urbanos que lo conforman desde la ordenación de usos de locales comerciales. El caso aquí reflejado tiene una limitada capacidad de actuación, pero la problemática y la estrategia que están detrás vienen siendo abordadas y aplicadas, con mayor o menor acierto, en numerosos municipios. La convergencia de una escasez de vivienda asequible con la dificultad de poner en uso muchos locales previstos para usos terciarios que se mantienen vacíos ha llevado a la proliferación, en muchas ocasiones de manera descontrolada, de la transformación de estos en viviendas. Desde el Gobierno Vasco se puso en marcha un plan piloto en 2018 con un doble objetivo: proporcionar viviendas a colectivos con dificultad de acceso al mercado libre, y revitalizar ciertos locales propiedad del propio gobierno, hasta entonces en desuso. Se trata de una estrategia de doble filo: si bien puede ampliar la oferta de vivienda asequible aprovechando además el parque edificado existente, puede también alimentar ciertos procesos de pérdida de diversidad y vitalidad urbana 
homogeneizando usos en zonas donde podría darse una mezcla de los mismos. Al igual que en muchos municipios se han desarrollado ordenanzas para regular este tipo de actuaciones, desde el Gobierno Vasco se editó una guía con recomendaciones para dichas transformaciones, a incluir en los pliegos de este tipo de iniciativas promovidas desde la institución. Entre los municipios previstos en este plan se incluían varios del AMB, como Barakaldo, Bilbao, Portugalete, Sestao y Santurtzi (Gobierno Vasco, 2018b). Para cerrar este apartado de repaso parcial $^{49}$ a algunos de los instrumentos de planificación espacial con capacidad de intervenir en el proceso de avance de las tres metas señaladas, se quiere apuntar la existencia de otro tipo de herramientas que vienen a complementar los diversos planes. Un ejemplo de ello es el proyecto de investigación 'Recuperando la ciudad' (Hernández Aja et al., 2016), que busca ayudar a determinar estrategias para planes y programas de Rehabilitación Urbana Integrada a través de una metodología de evaluación tanto previa como posterior a su ejecución. Se trata de un trabajo a medio camino entre el Instrumento y la generación de Contenido, mostrando que el Esquema 2.1 no es si no una síntesis y una abstracción de una realidad compleja y entrelazada.

\section{Otros}

Como cierre del apartado dedicado a los instrumentos, se quiere hacer un breve repaso a algunos otros posibles que igualmente buscan llevar a cabo la ejecución y la gestión del contenido generado previamente. Sirva también esto como muestra de la diversidad y del abanico de herramientas disponibles, así como de su diferente perspectiva y ámbito de actuación. En este caso, no se van a separar en sub-apartados por metas, si no que se comentarán en general por tipos de instrumentos, mencionando en cuáles de las metas actúan.

\section{Ayudas económicas}

Hay una variedad de programas, institutos, normativas y planes relacionados con la producción y oferta de vivienda protegida destinada a aquellos sectores sociales que no pueden acceder a la misma en el mercado libre que constituyen un potente abanico de instrumentos para el acceso económico. Aunque su ámbito de

\footnotetext{
${ }^{49}$ Como se ha apuntado previamente, el objetivo es argumentar el marco general propuesto a través de una serie de ejemplos, quedando fuera del análisis otros, no de menor importancia. Cabría señalar entre estos segundos el Plan Territorial Sectorial de Creación de Suelo para la Promoción Pública de Viviendas, promovido en 2003 por el Gobierno Vasco para su aplicación en toda la comunidad autónoma, pero que se quedó en fase de Avance.
} 
actuación va más allá y, entre otras cosas, incluso pueden abordar cuestiones relativas a la adaptación tipológica. En Euskadi, y desde las instituciones públicas, ese papel lo ejercen principalmente Etxebide, Visesa, Orubide, y otras sociedades públicas, así como algunos programas concretos más específicos - en general dependientes de las anteriores- y que se analizarán más adelante, como Bizigune o ASAP. No se pretende ahondar aquí en el funcionamiento de este sistema de ayudas porque ha sido, y es, tratado y analizado abundantemente por diversos autores y en numerosos trabajos. Este tipo de instrumento cuenta con programas que se dirigen tanto a la persona usuaria final de manera por lo tanto directa-, como a la construcción de la vivienda - de manera indirecta-. Todo ello, para rebajar el coste de acceso a la misma, ofreciendo una vivienda protegida tanto en propiedad -cada vez más razonablemente cuestionado- como en alquiler. En las primeras, se destina un importe económico a la persona para que sea esta quien gestione la búsqueda de alojamiento. Ayudas estas destinadas tanto al pago de la propia vivienda como de los consumos y gastos complementarios a la misma, y focalizadas en general en aquellos sectores de mayor riesgo de exclusión y vulnerabilidad. En Euskadi existe también, como se verá, un sistema público de este tipo, y considerablemente bien instaurado, a través de la Renta de Garantía de Ingresos, la Prestación Complementaria de Vivienda o las Ayudas de Emergencia Social.

El segundo caso es uno de los grandes instrumentos de generación de nueva vivienda protegida, no ya solo en España si no generalizable a toda Europa: la financiación a la construcción de alojamientos residenciales. Surgido principalmente en la etapa de posguerra entre 1945 y 1960, «el instrumento básico de actuación fue la inversión pública en forma de financiación directa de la construcción, o en forma de financiación subvencionada de la construcción realizada por agentes concertados. Es la etapa de las 'ayudas a la piedra' por excelencia: construcción generalizada para ser cedida (en alquiler o en acceso a la propiedad) a precios razonables al segmento más amplio posible de población. Entre 1950 y 1963, el 80\% de las viviendas construidas en Francia lo fueron con aportaciones importantes del Estado, y en el Reino Unido, las Local housing authorities y las New Towns fueron las promotoras del 60\% edificado entre 1945 y 1964» (Trilla, 2002: 120). También se dio en España a lo largo de buena parte del siglo XX otro tipo de financiación, orientada a la persona compradora, cuando las viviendas no tenían altos precios, pero sin embargo el precio de los préstamos bancarios para acceder a ellas sí lo eran. Esto tuvo su lógica hasta que los términos de la ecuación se invirtieron, estando el precio de la vivienda por las nubes y la financiación bancaria casi regalada (Burón, 2005: 125). Por ello, y entre otras razones, parece que el gasto público en vivienda no debe orientarse ni a la financiación bancaria, ni a la subvención de compra en propiedad, si no a la construcción de un parque de vivienda público de alquiler y preferiblemente en rotación, como lo vienen 
reclamando desde muchos sectores, y se viene desarrollando desde el Gobierno Vasco con éxito variable.

En cualquier caso, las posibilidades que ofrecen este tipo de actuaciones son diversas, y el límite con otras de las metas apuntadas es a veces difuso. Así lo ejemplifica un reciente plan puesto en marcha en Detroit. Aunque con otras singularidades, pero recordando algunas de las dificultades -especialmente económicas- anteriormente citadas para el AMB de cara a transformar y adaptar el parque existente, se trata de una iniciativa de gran interés. La abundante cantidad de edificios residenciales en un estado de conservación malo ha generado en dicha ciudad, entre otros, un grave problema de acceso económico. Aunque los créditos bancarios disponibles se ajustan al valor de mercado de esas viviendas, las personas interesadas en ellas con bajos ingresos- no disponen de capacidad económica para abordar la necesaria rehabilitación de las mismas. Con el doble fin de no solo activar la compra de viviendas y de productos financieros, si no también de ayudar al proceso de rehabilitación urbana tan urgente en la ciudad, en 2016 se puso en marcha el Detroit Home Mortgage. Este programa se basa en la colaboración de una serie de bancos y fundaciones locales, la autoridad estatal en materia de vivienda, y algunas asociaciones sin ánimo de lucro. El resultado es que el crédito se puede ampliar en hasta $75.000 \$$ por encima del precio de la vivienda para destinarlos a las intervenciones necesarias. Si bien el concepto va en contra de uno de los principios elementales de la financiación -que esta no supere el valor del bien a financiar-, «el mercado inmobiliario de Detroit es tan anómalo que las reglas tradicionales no siempre son aplicables» y «no hay necesidad de que sea un programa permanente, está pensado para corregir un fallo del mercado» (Spector, 2016). Por otro lado, se establecieron una serie de garantías tanto para las entidades financieras como para las personas deudoras, y se formaron órganos de asesoramiento orientados a las personas interesadas para que valoren los riesgos de esa ampliación del crédito.

\section{Fiscalidad}

Desde la fiscalidad es posible también plantear instrumentos de actuación para avanzar hacia las metas identificadas en este trabajo. Por un lado, desde la implantación de medidas de atracción, como puede ser la exención o rebaja fiscal en el Impuesto de Bienes Inmuebles (IBI) para aquellas personas propietarias que pongan en alquiler con un precio asequible una vivienda ${ }^{50}$. Por otro, medidas punitivas, como el aumento del citado impuesto en casos de viviendas desocupadas para movilizar el parque de vivienda vacía hacia el

${ }^{50}$ El NYU Furman Center realizó un estudio en 2015 en este sentido, analizando las posibilidades de utilizar un beneficio fiscal de este tipo para mantener los precios de los alquileres no protegidos a un nivel admisible en la ciudad de Nueva York (NYU Furman Center, 2015). 
alquiler. El debate sobre la implantación de este tipo de medidas no es nuevo, pues ya a principios de la década de 1990 se apuntaba desde el Gobierno de España la posibilidad de favorecer en el IRPF aquellas viviendas alquiladas frente a las vacías compaginando medidas ventajosas con penalizadoras (Leal, 1992).

Sobre estas últimas - con casos en España como los de Barcelona, Comunidad Valenciana o Aragón-, se tienen experiencias cercanas y recientes en Euskadi, ya que en los últimos tiempos se han venido implantando en algunos municipios de Gipuzkoa. La Diputación de dicho territorio foral aprobó en el año 2013 una serie de medidas fiscales entre las que se encontraba la posibilidad de aplicar un recargo en el IBI de hasta un 150\% sobre las viviendas que no constituyesen residencia habitual. El objetivo al menos era doble: en primer lugar, movilizar esas viviendas hacia el mercado -ya sea de venta o alquilercon lo que la demanda de nueva vivienda a construir se vería reducida; en segundo, aportar ingresos a los ayuntamientos. Entre estos, y dado que la norma foral dejaba en última instancia en manos de los gobiernos locales la implantación o no del recargo, en estos años de vigencia ha habido quien no la ha adoptado, quien planteó un recargo del 50-100\% y quien -los menos- aplicó el máximo del $150 \%$. No ha sido una herramienta carente de polémica y contestación social; se ha recurrido en diversas instancias hasta llegar en 2017 al Tribunal Constitucional, que finalmente ha avalado la norma. Algunos estudios señalan este tipo de medidas como eficaces para movilizar viviendas desocupadas hacia el alquiler, indicando el considerable peso que la fiscalidad puede tener a la hora de tomar dicha decisión (Bilbao y Prieto, 2007). En la provincia de Bizkaia se abrió la puerta a los ayuntamientos en 2016 para que incrementasen dicho impuesto hasta un $50 \%$, como se hizo posteriormente en Bilbao para incentivar esa movilización de viviendas desocupadas hacia el alquiler.

\section{...y más}

En cualquiera de los casos, muchos son los instrumentos disponibles para avanzar hacia la consecución de las metas aquí seleccionadas. Como cierre se van a citar dos más. La primera es la inclusión, en las medidas urgentes tomadas en España en 2012 para reforzar la protección a los deudores hipotecarios, de una llamada al gobierno a que promoviese junto «con el sector financiero la constitución de un fondo social de viviendas propiedad de las entidades de crédito, destinadas a ofrecer cobertura a aquellas personas que hayan sido desalojadas de su vivienda habitual por el impago de un préstamo hipotecario, cuando concurran en ellas las circunstancias previstas en el artículo 1 del presente real decreto-ley. Este fondo social de viviendas tendrá por objetivo facilitar el acceso a estas personas a contratos de arrendamiento con rentas asumibles en función de los ingresos que perciban» (Real Decreto-ley 27/2012, de 15 de noviembre, 2012). De manera similar, se han venido 
produciendo -con mayor o menor éxito y lucha de intereses- algunas cesiones de viviendas por parte de la Sociedad de Gestión de Activos procedentes de la Reestructuración Bancaria (SAREB) a algunos ayuntamientos para su gestión como vivienda social. Ello, a cambio de un pago mensual por debajo del precio del mercado y el cargo de ciertos gastos complementarios como el IBI. Pero se ha dado cierta rigidez tanto por parte de la propia SAREB como de cierta banca a la cesión de estos inmuebles, que ha venido siendo escasa. Lo cual ha venido a agravar el de por sí bajo incumplimiento de la función de esta institución ${ }^{51}$, cuyo fracaso volverá a tener importantes consecuencias públicas, ya que las «entidades rescatadas con dinero público han transferido a la Sareb sus activos tóxicos provenientes del sector inmobiliario (valorados en más de 51.000 millones de euros) y esta ha recibido ayuda pública proveniente del rescate europeo a la banca española. Los compromisos firmados indican que en un plazo de quince años desde su constitución, la Sareb debe vender todos estos paquetes inmobiliarios. En caso contrario, el Estado deberá asumir las pérdidas económicas que de ello se deriven» (Gutiérrez y Vives-Miró, 2018). En algunas comunidades autónomas incluso se han realizado movimientos normativos para buscar que buena parte de esas viviendas pasasen a una oferta temporal de alquiler social, en algunos casos a través de expropiaciones como en la Comunidad Valenciana o en Cataluña. Pero los avances siguen siendo lentos y complicados; en este último caso, el artículo de la Ley 24/2015 de medidas urgentes para afrontar la emergencia en el ámbito de la vivienda y la pobreza energética que dotaba de poder a la administración para resolver la cesión obligatoria de viviendas por parte de la propiedad bajo una serie de condiciones fue, entre otros, suspendido por el Tribunal Constitucional-suspensión que en el momento de la redacción sigue vigente-.

La última herramienta a nombrar, y cambiando de esfera de actuación completamente, es una de gran interés y relevancia que posiblemente se haya dejado demasiado de lado y no se le esté prestando la atención ni la estima que merece. Se trata del Programa 21 -que ha venido generalizándose como Agenda 21- fruto del acuerdo de las Naciones Unidas firmado en paralelo a la Declaración de Río sobre el Medio Ambiente y el Desarrollo en 1992. Es un programa que busca la promoción y generalización de un desarrollo sostenible global. Pero lo que aquí interesa es lo acertado de su planteamiento, que reside - en gran parte- en haber sabido diversificar los objetivos y actuaciones por escalas, siendo la local, la municipal, una de las más importantes debido al impacto directo que tiene en la sociedad y a la capacidad de abordar con éxito muchos de los objetivos. Efectivamente, el texto afirma que las autoridades locales de cada país deberán llevar «a cabo un proceso de consultas con sus

${ }^{51}$ El País (2018): «La Comisión Europea critica que el 'banco malo' siga en pérdidas desde 2012», disponible en https://elpais.com/economia/2018/04/16/actualidad/ 1523904732_388055.html. 
respectivas poblaciones y haber logrado un consenso sobre un Programa 21 Local para la comunidad» (Naciones Unidas, 1992). Se trata de un programa que no solo aborda la acción propiamente dicha, si no que además la ha sabido canalizar a través de la divulgación, con especial énfasis en los centros educativos aquellas franjas de edad pertenecientes a la infancia y la juventud. En el marco de este trabajo, es de interés porque muchos de los campos de actuación y reflexión de los Programas 21 locales tratan temas relativos a los espacios naturales en torno a la ciudad, a la biodiversidad de su territorio o incluso a la gestión y consumo de recursos. Todo ello, susceptible de ser introducido en un debate sobre la planificación racional de los suelos con destino a un uso residencial. En Euskadi, la red de programas inmersos en esta iniciativa, constituida en 2002, ha tomado el nombre de Udalsarea 21 - Red Vasca de Municipios hacia la Sostenibilidad. $\mathrm{Y}$ se define como «el foro de coordinación y cooperación que dinamiza las Agendas Locales 21 de los municipios vascos e impulsa la ejecución de los Planes de Acción» (Ihobe, 2017). 


\section{$-2.6-$ \\ Condicionantes y obstáculos}

Mediante una serie de ejemplos propios de la región, abordando también casos externos con afección en la misma -y estudiando otros no relacionados, pero con interés de cara a demostrar el fondo del argumento-, hasta aquí se ha pretendido poner de manifiesto la existencia en el Área Metropolitana de Bilbao de un relativo, aunque parcial- consenso en torno a un discurso, unas intenciones e inquietudes, que motivan y originan el diseño y desarrollo de una serie de herramientas promovidas por parte de diferentes agentes sociales, institucionales y privados de diverso tipo y ámbito de influencia. Agentes que, a pesar de algunas de las contradicciones internas que en este apartado se van exponer, comparten en gran medida el diagnóstico de la problemática aquí trabajada y buscan también, entre otras, las tres grandes metas señaladas en el contexto de esta investigación. Como resultado de todo ese proceso de gobernanza hasta aquí expuesto, la fase de la Ejecución final de los Instrumentos recién mostrados, y de tantos otros, puede plantearse como un reflejo corregido de la situación problemática inicial. En definitiva, los resultados efectivos que con mayor o menor éxito se obtienen de la aplicación de las herramientas disponibles -que pueden traducirse como los avances logrados en las metas buscadas-, y la evolución de la problemática en el tiempo, pueden verse como una misma cosa: en el marco de esta investigación, esta no es otra que el estado y condición, en un momento concreto, de la dimensión social de la vivienda. Como se ha planteado en el primer capítulo, más allá de las evoluciones, de los cambios, avances o retrocesos en las metas definidas, puede identificarse una permanencia en el tiempo de una problemática estructural en torno al acceso a la vivienda. Así, los tres primeros elementos del Esquema 2.1 analizados -situación problemática, fases de respuesta y metas- conforman a priori un círculo continuamente retroalimentado e interdependiente.

El panorama hasta aquí mostrado recoge, sintetiza y ordena un contexto conocido y profundamente estudiado en diversos trabajos. Por todo ello, el verdadero interés de la herramienta de análisis, además de las relaciones que establece entre todos sus elementos, reside en lo que sigue: el estudio e identificación de aquellos factores internos a la sociedad que -de manera oculta, o al menos, desplazados de los principales discursos y debates- forman parte de ese círculo como un elemento más. Un elemento fundamental, pues está formado por una serie de Condicionantes y Obstáculos que generan y 
alimentan fuertes contradicciones, y que pueden ayudar a explicar el por qué de esa permanencia y arraigo de los conflictos, o los motivos de no alcanzar unas metas que cuentan con un amplio respaldo.

Como se ha avanzado de manera general en el Esquema 2.1, se sintetiza y concreta en la Tabla 2.8 , y se procede a desarrollar en este apartado, se han identificado toda una serie de fenómenos internos que afectan negativamente a esas tres grandes fases de respuesta que la sociedad como conjunto heterogéneo y desequilibrado pone en marcha en los procesos de gobernanza urbana. Fenómenos que van desde inercias y construcciones sociales -más o menos conscientespropias de algunos de los agentes analizados, a intereses y presiones externas entre agentes, pasando por ocasiones en las que el propio contenido presenta carencias de fondo, o en las que los instrumentos presentan carencias de diseño o no acaban de utilizarse en toda su capacidad -incluso en ninguna, a veces-. Aunque, como se verá, en el contexto de la presente investigación muchos de estos obstáculos son en el fondo propios de una visión hegemónica que asemeja la ciudad a «una máquina que puede incrementar las rentas agregadas y capturar la riqueza asociada en provecho de aquellos que están en la posición adecuada» de tal manera que la búsqueda del «crecimiento genera amplios consensos entre una variedad de grupos de élite, independientemente de que en otros asuntos puedan estar divididos» (Logan y Molotch, 2015: 158). Todo ello hace que en muchas ocasiones los esfuerzos de las fases de Contenido e Instrumentos no lleguen a buen puerto; la Ejecución es por tanto parcial y limitada. A continuación, se pretende evidenciar - de nuevo a través de ejemplos puntuales- la existencia de diversos Condicionantes y Obstáculos, agrupados y clasificados en tres grandes categorías que afectan directamente, aunque sin obviar fuertes afecciones cruzadas, a cada una de las metas propuestas en el trabajo (Tabla 2.8). El objetivo es localizar los principales fenómenos y presiones que influyen en la correcta transición entre las fases de Contenido y Ejecución de cada meta, fortaleciendo e incluso originando la situación problemática.
Tabla 2.8. Relación entre los principales conflictos de la situación problemática, las metas definidas como respuesta y los condicionantes y obstáculos detectados. Elaboración propia.

\begin{tabular}{lll}
\hline \multicolumn{1}{c}{ Problemática inicial } & \multicolumn{1}{c}{ Meta } & Condicionante y Obstáculo \\
\hline $\begin{array}{l}\text { Necesidad de vivienda alta e } \\
\text { incapacidad económica de } \\
\text { demanda }\end{array}$ & $\begin{array}{l}\text { Trabajar por un más extendido y digno } \\
\text { acceso económico a la vivienda }\end{array}$ & $\begin{array}{l}\text { Poder económico por encima } \\
\text { de la justicia social }\end{array}$ \\
\hline $\begin{array}{l}\text { Oferta inadecuada, pero no } \\
\text { insuficiente }\end{array}$ & $\begin{array}{l}\text { Intensificar la adecuación tipológica de las } \\
\text { viviendas a las necesidades de las unidades } \\
\text { de convivencia actuales y por venir }\end{array}$ & $\begin{array}{l}\text { Visión conservadora del } \\
\text { espacio doméstico }\end{array}$ \\
\hline $\begin{array}{l}\text { Ciudad existente con } \\
\text { necesidad de intervención } \\
\text { integradora }\end{array}$ & $\begin{array}{l}\text { Aprovechar el parque y la ciudad existentes } \\
\text { para todo ello, reduciendo la presión } \\
\text { urbanizadora }\end{array}$ & $\begin{array}{l}\text { Fuerte inercia urbanizadora } \\
\text { heredada }\end{array}$ \\
\hline
\end{tabular}




\section{Poder económico por encima de la justicia social}

\section{Legitimidad del modelo de vivienda como bien económico y de inversión}

«...no acabo de entender las razones por las que España, un país que ha hecho docenas de convergencias sectoriales con la UE y que lidera algunas actividades a nivel planetario, es incapaz de converger con la UE en lo que se refiere a la vivienda vacía, el alquiler, la rehabilitación y la vivienda pública. Nuestro rechazo de la eficacia y la eficiencia es casi un asunto de salud mental colectiva. Mucho es el poder del complejo inmobiliario-financiero. Grande es el servilismo de nuestros políticos. No menor es la tentación de la inercia [...] aún está casi todo por hacer. Empezando por vencer en este debate que primero es cultural, después será político y finalmente requerirá financiadores, profesionales, empresarios, funcionarios $\mathrm{y}$ Administraciones a la europea en materia de vivienda» (Burón, 2012).

La centralidad que ha alcanzado lo económico en lo que respecta a la vivienda, y no solo en las sociedades occidentales post-industriales, no es algo que sorprenda. No, al menos, teniendo en cuenta la manera en que se ha dado la evolución y el desarrollo del sistema capitalista predominante. Pues «entre las creaciones de la mente humana que hoy gobiernan nuestra existencia destaca cada vez más la idea usual de lo económico, con la convención social del dinero que le da vida y sus afanes de crecimiento permanente, con la evidente incidencia en el territorio, el urbanismo y la construcción» (Naredo, 2004a: 13). Si al acotar el objeto de estudio de este trabajo se han apuntado algunos de los múltiples usos o diversas actividades a las que puede destinarse la vivienda, lo que en términos marxistas equivale a su valor de uso, la cuestión central ahora es su valor de cambio:

«En gran parte del mundo contemporáneo tenemos que comprar la vivienda o alquilarla a fin de disponer del privilegio de usarla, para lo que tenemos que emplear dinero. La cuestión es cuánto valor de cambio se requiere para procurarnos sus usos y cómo afecta ese «cuánto» a nuestra capacidad para disponer de los usos particulares que deseamos y necesitamos. Suena como una pregunta simple, pero de hecho su respuesta es bastante complicada» (Harvey, 2014: 32).

En aquellas situaciones en las que la unidad de convivencia a la que está destinada la vivienda promueve su diseño y construcción, las limitaciones económicas vienen establecidas por el coste del suelo, los 
materiales y los servicios necesarios para ello. Pero en el modelo existente de vivienda colectiva, esta es habitualmente diseñada y construida sin conocer las personas que van a habitarla y es además, aquí está la clave, planteada como una actividad económica en sí misma. Esto segundo, a pesar de ser algo evidente, normalizado y asumido, es fundamental que sea cuestionado para abordar la problemática, ya que su nivel de integración en las lógicas y comportamientos de la mayoría de esferas sociales es tal que en los debates parece olvidarse la cuestión principal: la función prioritaria de la vivienda como derecho humano básico. Por lo que a los costes anteriores, se ha de sumar una muy relevante variable: el margen de beneficio esperado por el agente que promueve la operación, adelanta el capital y paga los intereses de los créditos necesarios para ello (Harvey, 2014). En el Libro Blanco de la Sostenibilidad en el Planeamiento Urbanístico Español quedó bien reflejado y sintetizado el peso del factor económico en el pasado reciente del modelo urbanístico español. Un sistema "gobernado por el simple pulso de la coyuntura económica [...] con grandes requerimientos materiales y territoriales» en el que la construcción se convirtió «en el gran motor de la economía española, cuya importancia respecto a otros sectores se situó muy por encima de la media europea, pese a que en España se contaba ya con más viviendas y kilómetros de autopista por habitante que en la mayoría de los países de la Unión Europea» (España, Ministerio de Vivienda, 2010: 5).

Efectivamente, a partir de mediados del siglo XX en España se ha puesto en práctica y 'perfeccionado' hasta su último extremo, con consecuencias sociales, económicas, ambientales y geográficas devastadoras, un modelo inmobiliario -particularmente en su rama residencial- muy centrado en su papel como objeto y medio de inversión, al que le interesa un permanente desarrollo estable con continuos y suaves aumentos de precios, compra-ventas constantes y un mercado activo. Y que da la espalda a la realidad social y a las teorías económicas clásicas; la divergencia identificable entre el comportamiento de la evolución de los precios de oferta por un lado, y la evolución de la población y de la producción de viviendas a lo largo de los últimos años es una muestra más de que las supuestas leyes de la oferta y la demanda no regulan el mercado de la vivienda, que se guía por la búsqueda de la mayor acumulación de capital posible (Gráfica 2.24). Mientras población y parque aumentan progresivamente, los precios de oferta responden a ciclos de especulación, hinchamiento y pinchazo de la burbuja inmobiliaria. Una cuestión fundamental es que, aunque con diferente peso en la conformación de la problemática final, este predominio de la visión económica sobre la dimensión social se reproduce tanto a gran escala, en grandes promociones de vivienda llevadas a cabo por empresas privadas, como a escala pequeña e incluso familiar, en la compra de viviendas para la inversión como fuente extra de ingresos, o simplemente en los procesos de compra-venta de vivienda motivados por el cambio de la residencia habitual (Roch, 2009: 182-183).

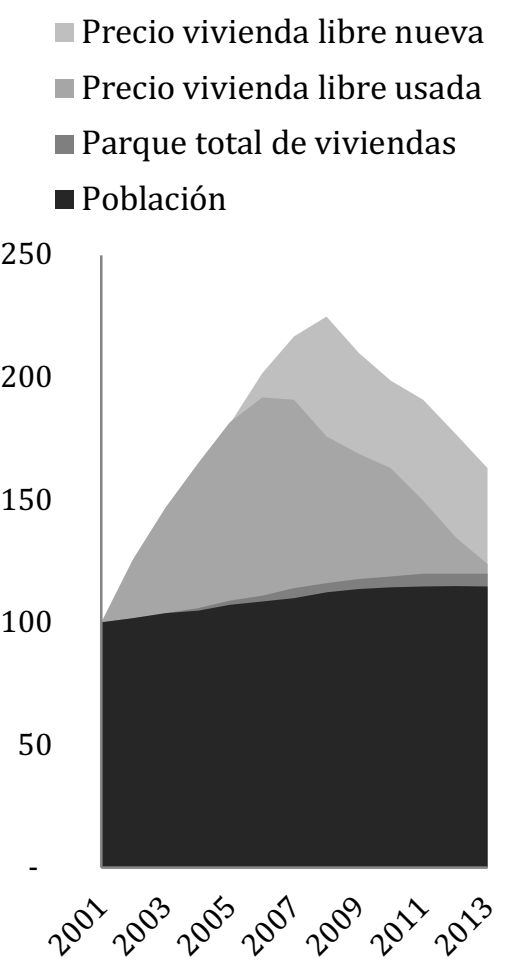

Gráfica 2.24. Evolución del parque, población y precio medio de oferta de la vivienda libre en España en el periodo 2001-2013 (base 100\% en 2001). Elaboración propia a partir de datos del Ministerio de Fomento, INE y el portal inmobiliario Idealista. 
Esta segunda escala de desarrollo del fenómeno, y los altos ingresos de rentas que ha supuesto para muchas personas por su alta rentabilidad -aparente si se observa con perspectiva, como se desarrollará más tarde-, ha sido probablemente una de las claves del asentamiento cultural y social de un proceso de acumulación que ha alcanzado la imaginación de ciudadanos comunes (Sevilla, 2015). Lo cual de alguna manera ha venido a legitimar o 'limpiar' socialmente las grandes operaciones inmobiliarias lucrativas al servir de modelo empresarial para pequeños negocios $u$ operaciones familiares $y$ particulares. La supuesta 'cultura' de la propiedad, que no es más que un comportamiento alimentado por incentivos económicos, refuerza este tipo de dinámicas y contradicciones internas: el interés de la pequeña propiedad por la bajada de los precios a la hora de adquirir una vivienda para poder acceder al mercado se torna en la búsqueda de la máxima subida posible en el momento de la venta. La transversalidad de las contradicciones entre los diversos agentes, e incluso a lo largo del tiempo, queda aquí claramente patente -con especial fuerza cuando se trata de vender una vivienda protegida con un sobreprecio en dinero negro ${ }^{52}$. Así, lo que es una necesidad está más cerca de ser un problema, estando la vivienda centrada de manera muy importante en su faceta de negocio económico y habiendo perdido peso su naturaleza como objeto de uso (Gondra, 2004: 109). El contexto social y actores civiles reclaman además que esta debe dejar de ser esa herramienta de inversión para retomar una de sus principales funciones: ser una herramienta de inclusión social (Bargos, 2017). Como se ha visto al presentar la situación problemática, esta utilización de la vivienda como bien de inversión y no como objeto de función social lleva en muchos casos a que demanda y necesidad discurran por caminos divergentes y muestren números lejanos entre sí, pues no toda persona con necesidad es capaz de generar demanda en un mercado excluyente -en ocasiones ni siquiera en un sistema público de vivienda protegida-. El nivel de sofisticación del modelo español ha llevado a que autores como Harvey lo utilicen para ejemplificar bajo una concepción marxista una de las contradicciones del capitalismo, la existente entre un valor de uso -marginado- y un valor de cambio -inflado- (Harvey, 2014: 31-40). La gravedad de la situación reside en que, a pesar de ser la vivienda un derecho fundamental, hay detrás de todo ello fuertes razones políticas para que no esté debidamente satisfecho:

«Mientras otros derechos sociales, como el acceso a la educación o a la sanidad, están razonable y universalmente cubiertos por lo público, el derecho a la vivienda no puede ser

52 El Diario.es (2019): «Picaresca con la vivienda protegida: frustrado un 'pelotazo' de 120.000 euros en la venta de un piso en Bilbao», disponible en: https://www.eldiario.es/norte/euskadi/Picaresca-protegida-frustrado-protegido-Bilbao_0_8 69663895.html. A pesar de ser minoritarios, la existencia de casos detectados en los que se ha intentado la venta de viviendas protegidas cobrando por un lado el precio máximo fijado por la normativa sectorial, y por otro un sobreprecio, muestra cómo el virus especulativo alcanza diferentes colectivos y clases (Naredo, 2004a). 
ejercido por una parte importante de la población. La explicación no es jurídica sino política ( $v g$. la sanidad y la vivienda, los dos, principios rectores de política social y económica recogidos en la Constitución de 1978 y uno está garantizado de forma universal -como si fuera un derecho subjetivo- y el otro no)» (Burón, 2008: 2).

Como apunta el autor, la formalización del derecho no depende solo de que quede recogido en la Constitución, si no también de la regulación legal y reglamentaria que lo desarrolle. Pero la legislación ha fomentado durante años un modelo «al servicio del lucro de la propiedad del suelo, reconociéndole un valor no por lo que es, sino por lo que puede llegar a ser (asumiendo, en definitiva las expectativas de carácter especulativo del suelo y realizando una capitalización casi exclusivamente privada de los efectos del planeamiento urbanístico público), dañando con ello el derecho de la ciudadanía a acceder a una vivienda digna a un precio razonable» (Burón, 2008: 3). Ha faltado así una determinación política a todos los niveles para intentar frenar la inercia especuladora y desarrollista que está detrás de la inaccesibilidad a la vivienda (Vinuesa, 2013: 108). Lo cual tuvo especial visibilidad en España a lo largo de la década de 2000, cuando «todas las administraciones públicas, de todos los signos políticos, se han limitado a ser espectadores y a contemplar esta realidad -que parecían considerar como inevitable y hasta como positiva, al generar riqueza- y han justificado con excusas más o menos serias su incapacidad para actuar» (Beltrán, 2009: 469). El diagnóstico es compartido por otros agentes y analistas como Burón, que ha dedicado gran parte de su trayectoria profesional al estudio e intervención en la materia:

«Partimos de una premisa: en España no se ha puesto nunca en marcha una auténtica política de vivienda. Al contrario, se ha entendido la vivienda como una palanca para el desarrollo económico del sector de la construcción; o, cuando se han impulsado políticas públicas en torno a la vivienda, estaban focalizadas en sectores desfavorecidos de la población. Es decir, estas políticas tenían carácter social. No hemos tenido políticas de vivienda con carácter transversal que tuvieran impacto industrial, laboral, social, civil, urbanístico, medioambiental y territorial» (Burón, 2015b).

De la misma manera, diversos agentes sociales afirman que las dificultades son en gran medida políticas, y precisamente estas motivaron en gran parte un dictamen de la Organización de Naciones Unidas a condenar la política de vivienda española y a plantear cuatro mandatos para ser cumplidos -con dificultades- por el gobierno 
español ${ }^{53}$. Motivaciones políticas parecen estar detrás de que la anteriormente citada Carta Social Europea no esté ratificada por España en su versión revisada de 1996, que entró en vigor en 1999 -y España firmó en 2000-. La gravedad del asunto está en que en dicha revisión se amplió la lista de derechos, estando entre ellos el de la vivienda. Esta legitimidad política del modelo puede verse también reflejada en el proceso de desarrollo y aprobación de la Ley 3/2015 de Vivienda de Euskadi. Fue un proyecto de ley promovido y elaborado desde fuera del gobierno del Partido Nacionalista Vasco -el primer proyecto se aprobó al final de la legislatura gobernada por el Partido Socialista de Euskadi, quien lideró desde la oposición en la siguiente legislatura el proceso hasta su aprobación-, lo cual ha generado no pocos conflictos y reticencias. Tanto, que desde el mismo Gobierno Vasco dos meses antes de su aprobación -y casi a la desesperada- su portavoz Josu Erkoreka alertaba y pretendía generar un clima de miedo y caos, poniendo más énfasis en las posibles consecuencias para el statu quo que en los objetivos sociales. Se afirmaba que había «motivos económicos, jurídicos y técnicos que aconsejan aparcar transitoriamente esta propuesta» y llamando a la «responsabilidad política a los grupos parlamentarios»; con argumentos como la incapacidad económica para abordar la propuesta, la generación de un efecto llamada «ya que cualquier persona podría venir a Euskadi y exigir una vivienda por ley», los efectos perjudiciales para «la ciudadanía vasca que tiene una segunda residencia en la CAV», o llevando el dramatismo al extremo, planteando que supondría «el fin del alquiler de vivienda privada en Euskadi» (Gobierno Vasco, 2015). La ley, vigente y en proceso de desarrollo reglamentario, no parece de momento haber generado tales consecuencias. Sus planteamientos han sido de hecho, como se ha vito previamente, asumidos en el Plan Director de Vivienda 2018-2020, y en general en las políticas de vivienda vascas.

Como en esta última ocasión en relación a la Ley de Vivienda, el Partido Nacionalista Vasco ha mostrado en más episodios -algunos previamente mencionados- una posición rígida de cara a realizar cambios estructurales en las políticas de vivienda, tanto municipales como provinciales o autonómicas. Sus políticas han mantenido un cierto equilibrio entre una visión liberal y desarrollista de la vivienda y la construcción de un sistema de bienestar social puntero en España; pareciera que en esta región, como en otros casos, las «motivaciones reales del Gobierno en el sector de la vivienda están más relacionados con el mantenimiento del orden político y económico que con la búsqueda de soluciones para la crisis habitacional [...] ha utilizado el

${ }^{53}$ El Salto (2017): «Un comité vigilará que España cumpla las exigencias de la ONU sobre vivienda», disponible en https://www.elsaltodiario.com/vivienda/comite-vigilaraespana-cumpla-exigencias-pah-onu-vivienda.

El Salto (2018): «España, condenada por vulnerar el derecho a la vivienda, responde con evasivas a la ONU», disponible en https://www.elsaltodiario.com/vivienda/espana-evasivasonu-desc-condena-vulnerar-derecho-vivienda. 
sistema de la vivienda para mantener la estabilidad política y sustentar la acumulación de beneficios privados» (Madden y Marcuse, 2018: 135, 136). Más allá de aspectos ideológicos, las conexiones empresariales y económicas de este partido político con el sector de la construcción han sido analizadas y cuestionadas desde diversos sectores, y el partido contaba hasta hace pocos años con varias sociedades destinadas al sector inmobiliario ${ }^{54}$. Con todo, sí puede afirmarse que se trata de un partido conservador que pivota alrededor de la búsqueda de una mayor autonomía vasca dentro de España, con valores demócrata-cristianos y liberales, y que puede situarse en el espectro del centro-derecha político. Esto hace que su dominio electoral en el AMB (Mapa 2.11) choque con la realidad social presentada en apartados previos -entre otros datos, el número de solicitudes en el sistema público de vivienda Etxebide (Mapa 2.12): la necesidad de un cambio profundo en las políticas de vivienda no se ve reflejada en el sentido del voto, cuando hay además formaciones con planteamientos progresistas dentro de sus programas en esta cuestión. Por supuesto, el comportamiento del electorado es complejo y no es este espacio para analizarlo. Pero sí se desea apuntar que este fenómeno es otro reflejo más de la complejidad de la problemática abordada, de su conflictiva intersección con otras cuestiones y preocupaciones, y de la transversalidad de unas contradicciones que atraviesan diferentes colectivos sociales.

Los ejemplos de esta concepción económica de la vivienda son numerosos. A escala estatal, en octubre de 2017 Partido Popular y Partido Socialista Obrero Español rechazaron la iniciativa del Grupo Unidos Podemos -En Comú Podem- En Marea para obligar a la mencionada Sociedad de Gestión de Activos procedentes de la Reestructuración Bancaria (SAREB) a ceder su parque inmobiliario al Fondo Social de Viviendas. El grupo que planteaba la iniciativa argumentaba que después de casi cuatro décadas desde la aprobación de la Constitución se puede afirmar que el acceso a una vivienda digna no ha sido una prioridad para los poderes públicos españoles. Algo de esto se criticó también en el proceso de desarrollo del Pacto Social por la Vivienda de Euskadi ya mencionado. Numerosos agentes cuestionaban el giro económico de la política de vivienda con dicho pacto, centrado no tanto «en la accesibilidad socio-económica de la vivienda (la vivienda como derecho ciudadano), sino en el crecimiento del PIB y en el empleo (la vivienda como una mercancía del mercado), con todo lo que ello supone» (Burón, 2010). Desde sindicatos y otras asociaciones -muchas de las cuales no fueron invitadas al proceso de diseño del documento- no se dudó en calificar al pacto como un instrumento de rescate para el sector de la construcción (Eusko Langileen Alkartasuna, 2010).

${ }^{54}$ El Mundo (2013): «El PNV liquida tres de las empresas bajo la lupa del Tribunal de Cuentas», disponible en https://www.elmundo.es/pais-vasco/2013/11/08/527d3d7263fd3 d7f3 d8b456c.html.

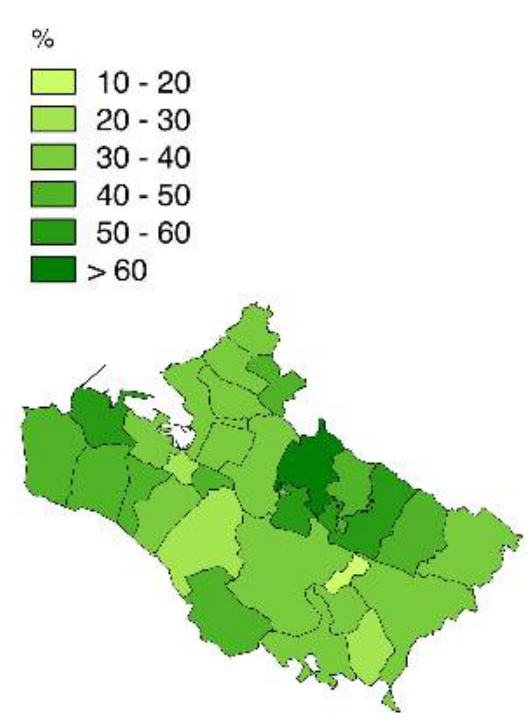

Mapa 2.11. Porcentaje de voto del Partido Nacionalista Vasco en las elecciones municipales de 2015 en el AMB. Elaboración propia a partir de datos del Gobierno Vasco.
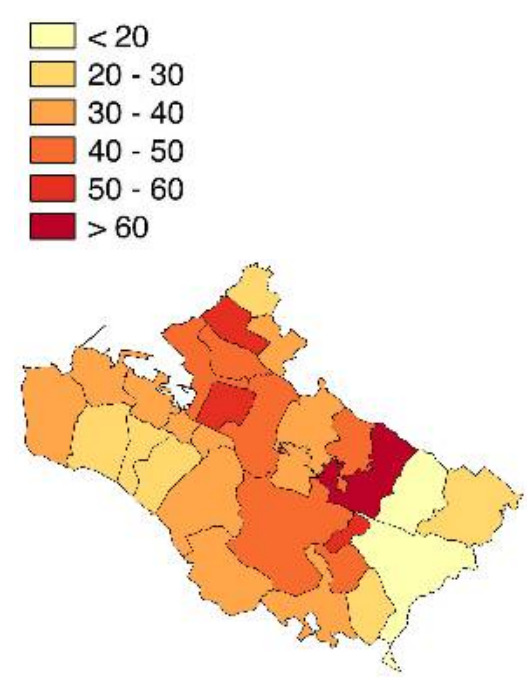

Mapa 2.12. Solicitudes de vivienda en Etxebide en 2015 en el AMB (por cada 1.000 habitantes). Elaboración propia a partir de datos del Gobierno Vasco. 
En otro ámbito, como se ha mencionado en el apartado de instrumentos, a lo largo de 2016 se trabajó para utilizar la fiscalidad como herramienta de movilización de la vivienda vacía, tanto en Bizkaia como en el Ayuntamiento de Bilbao, entre otros. Las medidas fueron aplaudidas por algunos sectores y agentes, pero discutidas por otros, dejando ver una fuerte reacción enfocada a la protección de una concepción parcial de la propiedad privada frente al interés general y su función social. Las declaraciones de las diferentes concejalías y portavocías del ayuntamiento de Bilbao mostraban muy diversos posicionamientos e ideologías:

«No tiene sentido agotar el escaso suelo que queda en la ciudad cuando contamos con un número tan alto de viviendas vacía. La prioridad debe ser esa. La clave es ayudar en la rehabilitación con una línea potente de subvenciones».

«Gravar con un 50\% el IBI a los pisos vacíos revela el fracaso de las políticas municipales [...] Esa mala gestión se intenta paliar gravando a los dueños de estos inmuebles, que se han podido recibir en herencia o que tal vez son el colchón de la jubilación tras invertir ahorros de una vida» (Reviriego, 2016).

Se trata de una legitimidad que también es apreciable a nivel judicial, empresarial e instrumental. En el primero, en 2013 se dio un caso paradigmático en el contexto español, con la sentencia contra el Decreto Ley 6/2013 de medidas para asegurar el cumplimiento de la función social de la vivienda aprobado por la Junta de Andalucía. En ella, el Tribunal Constitucional dictaminó en contra de la propia y numerosa jurisprudencia relativa a la vivienda, que hasta ese momento había reforzado el papel de función social de la propiedad que establece la Constitución. La sentencia considera que la competencia estatal de coordinación de la planificación general de la actividad económica -en este caso en forma de legislación hipotecaria y regulación bancaria- impide a las Comunidades Autónomas adoptar normas que pretendan tutelar el derecho a la vivienda de una forma más intensa que la fijada por el legislador estatal. Lanzando un «potente mensaje a navegantes: los derechos de los acreedores hipotecarios están por encima, no solo del derecho a la vivienda de la ciudadanía, sino de las competencias de vivienda de las Administraciones Públicas. Algo que no dice nuestra Constitución, ni los tratados internacionales que hemos ratificado, ni el derecho y la jurisprudencia europea» (Burón, 2015a).

Una legitimidad judicial que también está presente en Euskadi, como ejemplifica la Sentencia del Tribunal Superior de Justicia del País Vasco 1542/2017 sobre la Cuarta Modificación del PGOU de Eibar en la zona de Txonta. Sentencia que estimó un recurso contra dicha modificación por existir una «ausencia de válida y precisa justificación de la viabilidad económica» (Tribunal Superior de Justicia del País Vasco, 2017: 12). El objetivo municipal en esta zona con una muy alta densidad existente era hacer viable económicamente su 
renovación con la ayuda de una fuerte inversión pública por parte del Departamento de Vivienda del Gobierno Vasco, lo que ha quedado desestimado cuando el «promotor recurrente consideró que la comparación de usos lucrativos previstos y costes (fundamentalmente, indemnizaciones por supresión de preexistencias) no garantizaba que la actuación fuera rentable económicamente, convenciendo a la Sala que, en consecuencia, ha anulado la modificación» (Tejerina y Cerezo, 2017). Sin embargo, sorprendentemente el tribunal parece no tener en cuenta dos importantes hitos recientes en materia legislativa, como los dos autores citados evidencian. La Ley de Suelo de 2007 estableció un cambio en la configuración de la propiedad inmueble en relación con los planes urbanísticos según el cual los propietarios no tienen obligación de ejecutar en exclusiva los planes de la administración, ni el suelo se valora por lo que prevea el plan sino por lo que realmente es, a diferencia de lo que ocurría con el Texto Refundido de la Ley sobre Régimen de Suelo y Valoración Urbana de 1976:

«La exigencia de que el plan fuera rentable para los propietarios [...] se derivaba de que estos tenían la obligación de ejecutar el planeamiento. Como ha desaparecido la justificación de que el plan sea rentable para el propietario, la nueva legislación básica del estado ya no exige el estudio que demostraba la viabilidad para el propietario. Ahora se exige la viabilidad económica a largo plazo ( $\mathrm{y}$ no cuando se larga el promotor de la urbanización) y para la hacienda pública (y no para el propietario de suelo).

En 2013, la Ley de Rehabilitación, Regeneración y Renovación Urbanas culminó un proceso normativo que recuperó la obligación de la viabilidad económica a corto para el propietario pero revisó el concepto. Para que una actuación sea viable ya no hace falta que el saldo sea positivo, es viable aunque el saldo sea negativo con tal de que la aportación de los propietarios para cubrir el saldo neto negativo de la actuación no exceda del límite legal del deber de conservación (Art. 11.a, actual Art. 22.5.a del Real Decreto Legislativo 7/2015). Límite que se ha elevado convenientemente a lo que puede definirse como $50 \% \mathrm{VRB}$, unos $550 € / \mathrm{m}^{2} \mathrm{t}$ preexistente.

$$
[\ldots]
$$

Tenemos la sensación de que las leyes que afectan al urbanismo no entran en vigor tras su publicación en el Boletín Oficial, que tienen una vacatio legis especial porque, como El Cid, siguen ganando batallas después de muertas» (Tejerina y Cerezo, 2017).

Dentro del ámbito empresarial y financiero, y en el sector de la construcción en particular, existen también fuertes intereses por 
mantener este modelo de vivienda como bien económico y de inversión, con la búsqueda de precios al alza, generando presiones e incluso alianzas con las instituciones públicas para tal fin, y explorando nuevos caminos para continuar el modelo ${ }^{55}$. Desde una de las principales empresas constructoras de Euskadi se afirmaba desde una perspectiva mercantilista de la problemática, en relación a la evolución del sector a lo largo de los últimos años, que «la crisis ha sido muy dura. El precio de la vivienda, de media, en Euskadi ha caído un $30 \%$ y no se ha recuperado todavía. Una de las consecuencias directas de ello ha sido precisamente la desaparición de cantidad de empresas de la promoción y de la construcción. El mercado las expulsó directamente» (Salaberri, 2018: 13). Según algunas fuentes, durante el proceso de modificación de los métodos de valoración de suelo incluidos en la Ley 8/2007 de Suelo que buscaban eliminar las expectativas urbanísticas y basar el cálculo en la situación real del mismo:

«Los lobbys de la construcción y del sector inmobiliario trataron de impedir este avance, y casi lo consiguen, pues contaron con la inestimable ayuda del Ministerio de Economía, que no dudó en ponerse de lado de los que pretendían seguir especulando con el suelo. El texto final logró introducir algunas mejoras, aunque la crisis ha propiciado que las condiciones pactadas como transición hacia el nuevo régimen se hayan mantenido para las grandes operadoras de suelo, dado el enorme coste que hubiese significado su expropiación» (Inurrieta et al., 2013: 48).

Un interés privado que, por poner otro ejemplo, está dificultando la atracción de promociones privadas hacia el alquiler social en Euskadi -un alquiler con una renta máxima del 30\% de los ingresos de las unidades de convivencia-, más cuando se están empezando a hacer notar considerablemente ciertos agentes inversores buscando «productos inmobiliarios jugosos» para hacer negocio, tal y como transmitían desde el Gobierno Vasco en la jornada de presentación del Plan Director de Vivienda de Euskadi 2018-2020. A un nivel instrumental, el marco legal ha sido uno de los principales pilares en los que se ha apoyado precisamente este modelo. Las propias leyes del suelo, tanto el modelo de la ley del suelo estatal de 1956 como las que han ido heredando sus principios estructuradores, han supuesto un soporte para el modelo de planeamiento hegemónico, protegiendo más al promotor y garantizándole los beneficios de las operaciones inmobiliarias. Se trata de un sistema de herramientas en el que en muchos casos se pierden por el camino las prioridades, formalizándose en un desfase entre las leyes que definen un derecho básico y las normativas que lo regulan y desarrollan (Bargos, 2017).

${ }^{55}$ El Salto (2018): «Socimis y Sareb, la última vuelta de tuerca del capitalismo gorrón», disponible en https://www.elsaltodiario.com/vivienda/como-funcionan-socimis-sarebespeculacion-inmobiliaria. 
Frente a esto, ya se ha señalado que el modelo de la ley de 2013, afianzado en el texto refundido de 2015 , ha supuesto un cambio de perspectiva, introduciendo la solidaridad, mayores obligaciones a la propiedad y buscando la sostenibilidad de la ciudad existente.

Pero sobre todo preocupa la enorme y generalizada legitimidad social de la idea de vivienda como bien de inversión. Un fenómeno y unas consecuencias que ya se venían constatando (Fernández, 2009), antes incluso de que explotase el modelo: «España ejemplifica cómo, al extenderse por toda la población el virus de la especulación inmobiliaria, se está construyendo un patrimonio inmobiliario sobredimensionado de escasa calidad y se está originando una burbuja especulativa cuyas dimensiones resultan cada vez más amenazantes» (Naredo, 2004a: 15). De esta manera, se ha ido alimentando en muchos casos a lo largo de varias décadas una visión de la vivienda como garantía económica «frente a la vejez y un Estado Social débil» (Burón, 2008: 4). Y no pocas veces utilizada como moneda de cambio; "si durante el franquismo se utilizó como una de las principales políticas de afectación al régimen, posteriormente ha servido para amplificar en el imaginario social la idea de riqueza general y de la buena salud del país» (Inurrieta et al., 2013: 7). De tal manera que «la ciudadanía, consciente, pero también inducida, ha considerado la vivienda un bien de inversión, frente a su carácter de bien de uso en otras latitudes» (Inurrieta et al., 2013: 29). Una consideración que durante décadas no solo se vio cumplida, sino también alimentada por ciertos sectores; el presidente de la Asociación de Constructores y Promotores de Bizkaia afirmaba hace más de veinte años que un piso de promoción privada siempre se puede comprar, porque al día siguiente va a estar más caro. Un piso es lo único que yo conozco de la sociedad que se le maltrata, no se le mantiene y, sin embargo, se revaloriza» (Merodio, 1996: 9).

Esta legitimidad social del modelo puede incluso llegar a apreciarse con claridad en medios de comunicación públicos, lo cual es de gran gravedad. En noviembre de 2014 la televisión pública vasca daba una noticia que ofrecía «una de cal y otra de arena». Así, calificaba como positiva la subida en la venta de viviendas en los últimos meses; y sin embargo, entendía como negativo el hecho de que el precio de estas seguía bajando. Llama la atención que esta bajada de precios no se recibiese con los brazos abiertos por un ente público, más teniendo todavía muy recientes -en muchos casos todavía sufriendo- las consecuencias de la burbuja inmobiliaria de la década pasada. Pocos años más tarde daba otra: la alta rentabilidad del alquiler, entre un $6 \%$ y un $7 \%$, asegurando que «los expertos afirman que es buen momento para invertir en vivienda con intención de alquilarla». La razón era que existía una oferta de vivienda en venta barata, y la media del alquiler rondaba en Bizkaia los $970 €$ mensuales, haciendo incluso más rentable la operación cuánto más barata fuese la compra pues «no guarda relación el valor en venta con lo que se cobra del alquilen». La aparente neutralidad u objetividad formal de ambas noticias esconde 
una preocupante falta de reflexión sobre cómo pueden afectar esos fenómenos al acceso a la vivienda, y constata lo implantado que está socialmente esta visión mercantilista de la vivienda, al no hacer mención en dicha noticia a su carácter de derecho básico. La contradicción es una vez más fácilmente identificable. El mismo medio recoge habitualmente noticias sobre la dificultad de acceso a la vivienda por parte de determinados colectivos, pero ambas cuestiones parecen entenderse como independientes y no relacionadas, quizás bajo la lógica de que las carencias en la consecución del derecho son fallos puntuales de un modelo que funciona.

«Podemos concluir que la provisión de viviendas bajo el capitalismo se ha desplazado, de una situación en que dominaba la búsqueda de valores de uso, a otra en la que lo primordial es el valor de cambio. En una versión insólita, el valor de uso de la vivienda se convirtió cada vez más, primero en un medio de ahorro, y después en un instrumento de especulación tanto para los usuarios como para los constructores, financieros y demás implicados [...] que pretendían obtener ganancias de la situación de boom en el mercado inmobiliario. La provisión de valores de uso de vivienda adecuados (en el sentido convencional del consumo) para la gran mayoría de la población es rehén de esa concepción cada vez más arraigada del valor de cambio. Las consecuencias para la provisión de viviendas adecuadas y asequibles han sido desastrosas para un sector cada vez mayor de la población» (Harvey, 2014: 37).

\section{Carencias para enfrentar la situación}

El modelo inmobiliario español ha sido y es estudiado en numerosos trabajos debido a la enorme influencia que este ha tenido en el devenir de la economía, la sociedad y el territorio. Entre algunos de sus efectos más perversos está la incapacidad institucional de controlar el mercado de un derecho humano básico, y la incapacidad de ofrecer respuestas habitacionales a aquellas personas que se ven expulsadas del mismo. Algunos autores llevan años advirtiendo de las graves consecuencias de todo esto, antes incluso de que estas se produjesen, y han llegado a sintetizar con gran eficacia sus características (Inurrieta et al., 2013; Naredo y Montiel, 2011; Vinuesa, 2013; VV.AA., 2003). Pero en muchas de las revisiones realizadas se ha constatado con rotundidad que detrás de esa incapacidad hay en parte una gran carencia: la de admitir que se trata de un modelo inmobiliario que no cumple las leyes económicas básicas, si bien se pretende actuar como si lo hiciera:

«En España el sistema de provisión residencial se fundamenta principalmente en el mercado. La vivienda es considerada principalmente como un bien que se rige por las leyes del mercado, siendo escasa la intervención pública a través de políticas específicas» (Antón et al., 2007: 44). 
Que el negocio inmobiliario español no sigue, como se ha dicho, las leyes del modelo económico básico de la oferta y la demanda quedó ya suficientemente demostrado tras la maniobra realizada con la Ley 6/1998 sobre régimen del suelo y valoraciones, que determinaba «que todo el territorio español era susceptible de ser urbanizado exceptuando aquellas partes del mismo que expresamente figuraban en la ley» (España, Ministerio de Vivienda, 2010: 19). Esta ley, anunciada como maniobra para intentar frenar e invertir la subida de los precios de la vivienda se ejecutó desde una perspectiva equivocada, ya que «resulta evidente que tal cosa no sucedió, sino que sucedió la contraria: sin duda se urbanizó muchísimo suelo y se construyeron muchas viviendas, pero su precio no descendió sino que aumentó vertiginosamente» (Beltrán, 2009: 469). Hay quien ha enmarcado este fenómeno dentro de «la paradoja de los países mediterráneos, es decir, la combinación de ratios altos de vivienda vacía junto con precios altos en el mercado inmobiliario» (Etxezarreta, 2010: 6). Y Euskadi no es una excepción en esta situación -con menos viviendas vacías que otras regiones, pero unos precios muy altos-. Tras lo visto hasta ahora, todo indica que la clasificación de nuevos suelos urbanizables, su posterior urbanización y la construcción en ellos de nueva vivienda bajo el mismo modelo urbanístico e inmobiliario no va a hacer más accesibles los precios de las viviendas (Azpiri, 1997). Algunas mejoras en el marco normativo están ayudando a superar esta visión del modelo, pero desde muchos sectores -y desde una visión mercantilista- se tiende a seguir creyendo que el mercado regulará el desequilibrio entre necesidad y oferta, aunque estas posturas no sean capaces de explicar los episodios de subidas de precios «mientras el grupo social de siempre sigue sin vivienda» (Roch, 2003: 121).

Otras de las carencias identificadas tienen dimensiones conceptuales y se reflejan en conflictos y/o excesos de regulación en la redacción de instrumentos. Los conflictos entre derechos administrativos y derechos de necesidad son uno de ellos; dándose paradojas como situaciones de personas con necesidad de vivienda, sin papeles para poder exigirla, frente a personas con papeles, pero sin necesidad de vivienda (Bargos, 2017). Un fallo frecuente es el de no avanzar de manera coordinada con otras dimensiones vitales de las personas necesitadas de vivienda, como el arraigo en su entorno cercano, o la construcción de lazos de comunidad. Cuando a una persona migrante perceptora de ayudas sociales, con pocos -pero existentes- lazos locales sociales y ninguno familiar le es adjudicada una vivienda fuera de su entorno, se encuentra ante un difícil dilema. Aceptar la vivienda y perder las débiles redes sociales que ha podido ir construyendo durante su estancia, o renunciar a ella y perder las ayudas sociales (Bargos, 2017). Frente a una realidad compleja, se observan declaraciones que evidencian un desconocimiento, excesiva simplificación o falta de comprensión de la misma, como la realizada desde la concejalía de urbanismo de Bilbao en 2014, afirmando que en ocasiones el Ayuntamiento ha tenido que ofrecer «hasta tres veces» 
algún piso debido a las negativas a ocuparlo, lo que indica que en ocasiones la necesidad de alojamiento «no es tan real» ${ }^{56}$.

Se dan también errores de planteamiento que distorsionan por completo la realidad y ofrecen lecturas parciales que llevan a confusión. Alguno de estos ha sido ya mencionada previamente: las series de la Encuesta de Necesidades y Demanda de Vivienda en la CAPV se han centrado durante años en cuantificar dicha demanda y necesidad de acceso a la vivienda con una mirada parcial, siendo el objeto de estudio las personas de 18 a 44 años de edad residentes en Euskadi, que disponen de ingresos propios y que precisan acceder a su primera vivienda. Es decir, dejando claro que según la metodología planteada «la disponibilidad de ingresos constituye uno de los requisitos para considerar que existe necesidad de acceso a una vivienda» (Observatorio Vasco de la Vivienda, 2013: 23). Lo cual deja fuera a no pocas personas, como ya se ha argumentado. Pero más allá de las propias metodologías y planteamientos, el lenguaje utilizado puede también alterar considerablemente el discurso, o al menos la percepción del mismo. Se trata de un tema lo suficientemente relevante como para cuidar la precisión de las palabras. Al definir el Plan Director de Vivienda de Euskadi 2013-2016 sus principios inspiradores, afirmaba que «las personas merecen tener un lugar donde desarrollar su vida» (Gobierno Vasco, 2013a: 7). Pero la cuestión es que no se trata de hacer méritos, o de que una persona sea digna de premio $^{57}$, sino de que es un derecho básico universal.

Incluso en leyes de gran relevancia como la Ley 3/2015 de Vivienda de Euskadi, que ha supuesto un especial paso en la consecución del derecho a la vivienda, se dan no pocos errores de fondo y de forma, como han sido minuciosamente analizados. Así, algunos la han tachado de norma con una estructura inconsistente e incorrectamente escrita; con pretensión de regular toda la materia de vivienda incorporando las determinaciones del Estado. Afirmando que «no se ha limitado a tratar la problemática de vivienda o los aspectos de vivienda de la normativa sobre urbanismo y suelo sino que se ha abierto paso incidiendo en el marco normativo de la acción urbanística más de lo que se desprende de su título» (Tejerina y Cerezo, 2015a). Además, lo hace descendiendo a medidas concretas «impropias de la Ley, que se elevan al rango de ley formal y que le

56 El Mundo (2014): «Bilbao pide a todos los dueños de pisos vacíos que los cedan al alquilen», disponible en http://www.elmundo.es/economia/2014/04/02/533bc49f268e3e75 5e8b4572.html.

${ }^{57}$ Merecer (del latín vulg. merescere; conjugación actual agradecer):

1. Dicho de una persona: Hacerse digna de premio o de castigo.

2. Dicho de una cosa: Tener cierto grado o estimación.

3. Conseguir o alcanzar algo que se intenta o desea, lograr.

4. Hacer méritos, buenas obras, ser digno de premio.

Fuente: Real Academia de la Lengua Española. 
ponen más difícil al gobierno alcanzar los objetivos en materia de vivienda» (Tejerina y Cerezo, 2015b).

A estas carencias se pueden sumar otras, también identificadas por la propia administración pública, que afectan a la aplicación de programas y a la implantación de sistemas para la consecución del acceso económico a una vivienda. En algunos casos puede tratarse de una serie de debilidades que hacen de obstáculo para la implantación de un régimen de alquiler protegido: el fuerte arraigo del régimen de propiedad como opción más deseada, la complejidad del sistema de ayudas, o la falta de garantías a las propietarios (Gobierno Vasco, 2013a: 152). En otros, las carencias instrumentales se centran en dificultades financieras para la promoción de la vivienda de alquiler, o en dificultades de implantación de programas de incorporación de vivienda libre al alquiler social, bien por su elevado coste económico o por su falta de éxito (Gobierno Vasco, 2013a: 23). En otro ámbito, y tomando las viviendas vacías como herramienta para poder ofrecer un parque de alquiler -protegido o no- a un precio asequible, existen también grandes carencias para determinar con precisión cuántas hay y dónde se localizan. Lo cual impide desarrollar políticas eficaces al respecto. Euskadi es, según los datos habitualmente disponibles, una de las comunidades autónomas de España con menor porcentaje de vivienda desocupada. Pero la imprecisión -ya comentada- de estas estadísticas por sus carencias metodológicas hace «deseable contrastar la información del Censo con estudios que miden la vivienda vacía con otras metodologías (por ejemplo, el número de viviendas con contrato y sin consumo de agua o electricidad), ya que puede que las cifras lanzadas por el citado Censo estén infravaloradas. Por ejemplo, en un estudio alternativo en Madrid se recogieron un tercio más de viviendas vacías respecto del dato censal (Naredo et al., 2008), sin embargo, no existe ningún estudio homólogo para el caso de la CAPV» (Etxezarreta, 2010: 11).

$$
-2.6 .2-
$$

\section{Visión conservadora del espacio doméstico}

Tal y como se ha defendido previamente, desde un punto de vista espacial y tipológico la mayoría de la vivienda colectiva desarrollada en España en las últimas cuatro o cinco décadas refleja un recorrido hacia la simplificación de soluciones, construyendo una idea homogénea y conservadora de la vida doméstica (Amann, 2005; Monteys y Fuertes, 2002; Moya, 2007; Paricio y Sust, 2000). Lo cual ha ido de la mano de una falta de atención sobre la creciente complejidad propia de la esfera doméstica de la sociedad, y su necesario reflejo en el espacio doméstico, olvidando la enorme diversidad y heterogeneidad de necesidades habitacionales, y por consiguiente de respuestas posibles. Hecho que ha dejado de lado a 
todas aquellas unidades de convivencia que no respondían a la familia tipo de la segunda mitad del siglo XX, forzando a una gran parte de la población a vivir en viviendas diseñadas para otras personas (Guidotti y Arroyo, 2004). Como se verá más tarde, centrar parte del análisis de esta investigación en una esfera específicamente arquitectónica como la que aquí se retoma es una cuestión clave para alcanzar un acceso asequible a la vivienda y un aprovechamiento eficaz del parque residencial existente que se estiman latentes, pero potenciales. Ya se ha planteado que la naturaleza multidimensional de la vivienda hace que cualquier intento de arrojar luz sobre la problemática tenga mayor probabilidad de éxito si se hace desde un enfoque multidisciplinar, si bien en este caso limitado por los medios propios de una tesis doctoral. Las otras dos esferas analizadas en el contexto de la dimensión social de la vivienda -económica y urbanística-territorialson habitualmente abordadas desde una visión excesivamente cuantitativa -coste de acceso, y número de viviendas disponibles o por construir-. El estudio crítico de la esfera tipológica ofrece una perspectiva cualitativa fundamental que permitirá conectar las dos primeras, y establecer así -junto con el marco teórico presentado en el capítulo primero- las bases para el análisis de posibles alternativas que respondan de manera integral a los conflictos existentes en las tres esferas en el modelo actual.

\section{Limitaciones normativas}

Como herencia de todo ello, hoy en día las diferentes normativas que regulan las condiciones espaciales y de habitabilidad de la vivienda pecan de quedarse en unos criterios de mínimos parcialmente anticuados que no entran en consideraciones espaciales más complejas. Más allá de establecer las condiciones -básicas y necesarias- de superficie, altura, iluminación y ventilación para las estancias, así como la relación de estas entre sí, prácticamente no se enfrentan a otras variables. Por otro lado, algunas de las determinaciones que establecen ahondan en una rigidez, simplificación y restricción de la riqueza de posibilidades espaciales de la vivienda. En el caso de las Ordenanzas de Diseño de Viviendas de Protección Oficial de Euskadi de 2009, la definición del programa mínimo plantea una composición que deja fuera posibles funciones de gran necesidad -espacios específicos o versátiles para el trabajo en casa, o para los cuidados- y cuya carencia puede generar situaciones de conflicto. Algunos de los usos que exige se plantean desde una perspectiva rígida, como por ejemplo la necesidad de un cuarto de aseo completo, cuando al tratarse de un programa mínimo sería más interesante la disgregación de los elementos de este en más de un espacio que permitiese su uso simultáneo (Paricio y Sust, 2000: 39). La tipificación de las viviendas planteada en la orden se limita a una clasificación por número de dormitorios, ocultando así una homogenización total de las tipologías posibles. Se dejan de lado otras maneras de clasificación en base a necesidades concretas, o a tipos de 
unidades de convivencia, con la única excepción de aquellas que cuentan con alguna persona con movilidad reducida, cuya especificidad sí se ve reflejada y claramente regulada -aunque, con todo, queda formalizada en una versión accesible de la tipología habitual-. Se favorece por ejemplo, con este tipo de clasificaciones, el imaginario y la existencia de estancias destinadas y diseñadas casi exclusivamente para dormir, cuando la realidad de muchas unidades de convivencia necesita de unas estancias más flexibles con capacidad de albergar diversos usos en el tiempo. Incluso desde un punto de vista constructivo, la necesidad establecida en la orden de que la totalidad de los suelos, techos y paredes cuenten con un revestimiento acabado no da pie a poder dejar los espacios no húmedos a falta de los acabados finales, tanto para una posible personalización de dichos revestimientos por parte de sus usuarios, como para reducir costes de construcción y aumentar la viabilidad inicial de la edificación.

En la misma línea, el Decreto 317/2002 sobre actuaciones protegidas de rehabilitación del patrimonio urbanizado y edificado se centra no tanto en la adecuación espacial del patrimonio edificado, como en «promocionar y fomentar el sector de la vivienda principalmente en áreas de interés urbanístico [...] conseguir su puesta en valor y su más adecuada utilización». Este último objetivo sí es más cercano a la meta en la que se enmarca este apartado, si bien de una manera ambigua y difusa. Una vez más, la única mención de la adaptación del parque a una de las múltiples necesidades existentes en las unidades convivenciales es aquella relativa a personas con limitaciones de accesibilidad física. Quedan así el resto de las exigencias enmarcadas en unas condiciones mínimas de habitabilidad que las viviendas sujetas a este documento han de cumplir; estas son reflejadas en su Anexo IV y, como el anterior texto, se reducen a la definición de un programa, superficies, alturas, iluminación, ventilación e instalaciones mínimas. Igualmente, se estima como adecuado un acabado general de la vivienda cuando este está totalmente finalizado y rematado, sin dar pie como a una arquitectura perfectible. La existencia de otros normas similares en otras comunidades autónomas, como es el caso del ya citado Decreto de Condiciones mínimas de habitabilidad de las viviendas y la cédula de habitabilidad de Cataluña de 2012 que incorpora la definición de vivienda flexible y unos criterios de compartimentación mucho más progresistas, evidencia la obsolescencia de ciertas cuestiones del caso vasco.

La ya citada publicación en 2016 por parte del Gobierno Vasco de un modelo de Ordenanzas Municipales de Edificación en cumplimiento de la Disposición Final Segunda de la Ley 2/2006 de Suelo y Urbanismo de Euskadi «que deberá ser utilizado por los municipios del País Vasco como referencia para elaborar las citadas ordenanzas» no aportó nada nuevo -si bien es de cumplimiento optativo-, perdiendo una interesante oportunidad. En ella las condiciones espaciales relativas al diseño y habitabilidad de las 
viviendas reflejan lo establecido en las Ordenanzas arriba comentadas de diseño de VPO. Con lo cual, a pesar de que el propio documento cuente entre sus objetivos con «adaptar el modelo de vivienda a la realidad de los hogares actuales, actualizar el tipo vivienda mediante fórmulas flexibles, que las haga adaptables a las diferentes formas de habitar, al uso universal de la vivienda por colectivos con dificultades de movilidad temporal o permanente» (Gobierno Vasco, 2016b: 7), la realidad es que mantiene un modelo de ordenanza anticuado, rígido y que continua una tradición conservadora del espacio doméstico, tal y como se asumía desde la dirección de Vivienda y Arquitectura del Gobierno Vasco:

«...en vivienda, tanto privada como pública, [...] podemos decir que el panorama es quizás más aburrido y conservador en lo que a arquitectura se refiere. La normativa de diseño tiene mucho que ver con ello y es algo que vamos a abordar en breve» (García, 2018: 9).

Desde los instrumentos de planificación y ordenación espacial, tampoco se tiende a profundizar en la casuística y diversidad existente éntrelas unidades de convivencia. En la modificación puntual de las Directrices de Ordenación Territorial aprobada en 2016, se apunta «la conveniencia de diversificar la tipología de las viviendas» (Decreto 4/2016, de 19 de enero, 2016: 12), pero más adelante plantea este ejercicio como un mero cambio en la superficie y tamaño de estas. En cuanto a los instrumentos de ordenación urbana, frecuentemente los análisis del parque residencial se centran en su antigüedad y estado de conservación, eficiencia energética, o nivel de accesibilidad, dejando fuera cualquier variable propia de las tipologías existentes que permitiese abordar la problemática aquí enfocada. Mientras esos tres temas citados contienen aspectos de interés claramente público seguridad en la vía pública, reducción del gasto energético y posibilidad de acceso a cualquier persona-, lo que pasa dentro de la vivienda sigue considerándose una cuestión exclusivamente privada, y amparada además por una idea del derecho a la propiedad que excluye cualquier debate sobre el interés público y social que ello pueda tener. Por otro lado, las limitaciones que el propio planeamiento pone para una construcción residencial más racional impiden, por su excesiva precisión de los parámetros urbanísticos -principalmente la profundidad edificable y la altura de la edificación-, abaratar su coste, trabajar con una mayor lógica constructiva y diversificar los tipos de vivienda (Paricio y Sust, 2000: 28):

«Posiblemente, una medida oportuna para racionalizar la habitabilidad sería su desvinculación de la normativa urbanística, ya que el planeamiento, como se ha dicho anteriormente, al preocuparse preferentemente por la calificación y la estructuración del territorio, muy a menudo trata desinteresadamente y miméticamente los temas de habitabilidad. La importancia de estos temas aconseja que 
tengan un tratamiento independiente más preciso y mejor estudiado» (Paricio y Sust, 2000: 29).

\section{Falta de cultura arquitectónica}

Pero las carencias tipológicas de gran parte del parque residencial actual para satisfacer las necesidades habitacionales de la sociedad no se pueden justificar tan solo por un marco normativo limitado y con necesidad de renovación. El bajo conocimiento medio existente del amplio abanico de soluciones y la enorme riqueza de posibilidades que un buen diseño arquitectónico es capaz de aportar para responder a dichas necesidades es algo compartido por muchos de los múltiples agentes intervinientes en el proceso. De tal manera que, entre unos y otros, alimentan una situación a la que en muy contadas ocasiones como se ha podido evidenciar en apartados anteriores con la dificultad de localizar agentes generadores de contenido en este ámbito- se observan esfuerzos sinceros para conocer y afrontar la problemática. Desde aquellas personas con la responsabilidad de identificar desde el ámbito político la transformación y evolución demográfica de las unidades de convivencia, a las que han de redactar las normas y leyes que regulen y faciliten la adaptación y diseño espacial de la vivienda, pasando por agentes fundamentales como los encargados de la promoción y construcción residencial, del diseño, la venta y distribución en el mercado, así como por supuesto la propia sociedad demandante, en todas ellas puede identificarse un importante desconocimiento en la materia.

Probablemente, en este caso la falta de avance sea por una carencia de información en torno a la existencia de otras tipologías. Carencia fortalecida y alimentada por la predominante presencia en el parque existente de una tipología hegemónica levantada a lo largo de las décadas pasadas y en diferentes etapas de fuerte expansión urbana. Expansión iniciada por la necesidad urgente de vivienda durante las décadas de 1950 a 1970 y motivada por acelerados procesos migratorios del campo a la ciudad, cuyo legado arquitectónico y urbanístico -y retos de intervención y mejora- puede hoy encontrarse en prácticamente cualquier núcleo urbano de cierta entidad. Un panorama completado y rematado por el afianzamiento de un modelo inmobiliario voraz en la búsqueda del beneficio económico, que tuvo su mayor auge y eclosión en la primera década del siglo XXI. Y que no ha aportado en el campo del espacio doméstico, salvo casos concretos, otras tipologías, de manera que «en la mayoría de los casos, la vivienda racional incorporada desde los CIAM, es el elemento que mantenemos dentro de la propia disciplina de la arquitectura. Unas cuantas instalaciones se han superpuesto a los esquemas espaciales vigentes desde el Movimiento Moderno, pero todo sigue obedeciendo a los mismos patrones» (Amann, 2005: V). Así, como reflejo de las desigualdades sociales, muchas son las realidades excluidas en el proceso de diseño del espacio doméstico. Lo son todas aquellas ajenas a un esquema de vida marcado por el patrón de un hombre sin 
problemas de salud o movilidad, con un empleo estable fuera de casa, y apoyado en una o varias mujeres -tanto sin remunerar por ser familiares, como remuneradas aunque habitualmente bajo condiciones de trabajo precarias- que se responsabilizan de los trabajos domésticos y de cuidados (Amann, 2005; Muxí, 2009). Lo cual conforma una tipología predominante con un fuerte sesgo de género y de clase -todavía hoy existen muchas viviendas con acceso independiente y zonas destinadas al personal de servicio-. Existe por tanto una carencia cultural arquitectónica socialmente extendidacimentada principalmente en el simple desconocimiento de alternativas ${ }^{58}$ - que genera un enorme obstáculo para dar pasos hacia la adaptación tipológica tanto del parque residencial heredado como, más desconcertante si cabe, del que se está proyectando. Aunque el proceso de toma conciencia de esta situación es lento, hay señales de su existencia, tal y como se observaba por ejemplo en declaraciones del concejal del Área de Vivienda del Ayuntamiento de Bilbao: «Hemos puesto cara y ojos a esos demandantes de vivienda de Etxebide cuyas necesidades difieren mucho de unos a otros casos. No es lo mismo la necesidad que pueda tener una persona de veinticinco años que viva con sus padres que la de otra de 55 con cargas familiares. La casuística es variada y, si no la conocemos, difícilmente podremos poner solución a los problemas en esta materia» (Zurro, 2018: 19). En este sentido, existen diversos trabajos y esfuerzos para contribuir con una labor formativa y divulgativa en torno a una cultura de la vivienda y la casa desde una posición crítica. Frente al posible argumento de que la sociedad ya sabe qué vivienda quiere y necesita apoyado en la estrecha relación histórica de esta con la casa, hay otras miradas que defienden la existencia de un camino educativo por recorrer:

«Se podrá decir que la gente "ya vive" en una casa y, por tanto, no necesita saber nada más. Por el contrario, nosotros pensamos, razonando por la vía del ejemplo, que la gente come, pero no necesariamente todo el mundo guisa ni se alimenta bien, aún teniendo los medios para ello. Si no, ¿qué sentido tienen las campañas, los textos y los artículos de todo tipo que orientan el problema de la dietética y la alimentación para mejorar la calidad de vida y prevenir enfermedades? Vivir en una casa, al igual que comer, es algo que se puede enseñar» (Monteys y Fuertes, 2002: 9).

«...hace falta replantear una cultura de la vivienda, potenciando una labor pedagógica para que haya una masa crítica de usuarios que sean conocedores y críticos exigentes

58 «I did what everybody did. I was in commuter hell, I didn't know my neighbors, all that. There wasn't a choice, or we didn't know another choice existed»; Alice Alexander en CityLab (2015): «Can Boomers Make Cohousing Mainstream?», disponible en https://www.citylab.com/equity/2015/01/can-boomers-make-cohousing-mainstream/3846 $24 /$. 
con lo que el mercado privado y público les ofrece. Se necesita educar para que la vivienda sea entendida como parte de la ciudad y como lugar para habitar el presente, albergar nuestro pasado y proyectar el futuro; un lugar donde vivir cómodamente, que responda al deseo de valores simbólicos individuales y comunitarios, de privacidad y sociabilidad, y no solo como un producto de mercado, inversión y consumo [...] no se trata de ofrecer un recetario de soluciones definitivas sino de promover maneras de pensar críticas» (Montaner et al., 2011: 11).

Consecuentemente, hay una gran dificultad para conocer y documentar cuál es la idea e imagen general o más común de la vivienda que prevalece en la sociedad. Esta falta de información es en ocasiones llamativa y puede responder a la falta de interés, o precisamente a ese desconocimiento de la diversidad de necesidades y posibles soluciones fruto de una baja cultura de la vivienda ${ }^{59}$. Pero esta carencia de datos sobre las características de la vivienda demandada y/o necesitada -que contrasta con un apabullante y de fácil acceso mar de datos e informes centrados en aspectos económicos y financieros- puede en parte suplirse con una aproximación al tema mediante el análisis de la manera en que se ofertan y comercializan la gran mayoría de las viviendas por parte de las promotoras y agentes de la propiedad inmobiliaria. Sin querer plantear aquí que la oferta sea un completo y fiel reflejo de la demanda -en este caso la pobre diversidad de la primera no ha de leerse como una falta de necesidades y exigencias de la segunda, pero sí como el reflejo de una demanda latente-, sí es cierto que la mayoría de viviendas existentes, bajo un mismo patrón tipológico, lleva a apoyar la tesis de que una gran parte de la población probablemente tenga sobre él formalizado su concepto de vivienda. No se erraría por tanto demasiado al decir que la vivienda mayoritariamente demandada sería la ya planteada en la situación problemática -compuesta por un recibidor, un pasillo de distribución, una cocina con o sin espacio para comer, una zona para tender la ropa, uno o dos baños completos, una sala más o menos amplia con posibilidad de albergar zona de comedor, y unas habitaciones bajo una estructura jerárquica destinadas principalmente a dormir y encabezadas por una principal con baño y vestidor propios, siendo el resto menores-. Lo cual no significa que sea esa la vivienda más comúnmente necesitada.

\footnotetext{
${ }^{59}$ Como ejemplo de ello es paradigmático el hecho de que un organismo tan interesado en conocer este tipo de cuestiones como el Observatorio Vasco de la Vivienda, en su Encuesta sobre Necesidades y Vivienda realizada periódicamente para «conocer la evolución de necesidades y demanda potencial de vivienda» y definida como «fuente básica de información del sistema de indicadores de seguimiento de la política de vivienda» reduzca y simplifique su análisis de las características de las viviendas necesitadas a cuestiones como si es nueva o usada, al régimen de tenencia, a la superficie útil o a su localización, sin entrar en cuestiones programáticas de gran relevancia para el éxito de los programas de vivienda protegida vasca. Disponible en: http://www.garraioak.ejgv.euskadi.eus/informacion/en cuesta-sobre-necesidades-y-demanda-de-vivienda-endv/r41-ovpe01/es.
} 

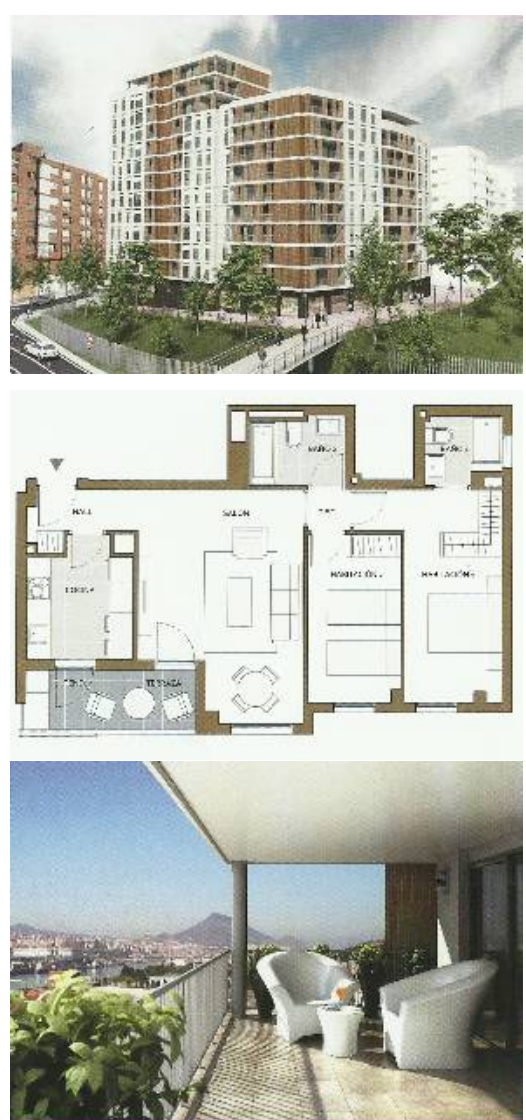

Imagen 2.7. Material publicitario de la promoción de un edificio de viviendas de nueva construcción en el municipio de Erandio.

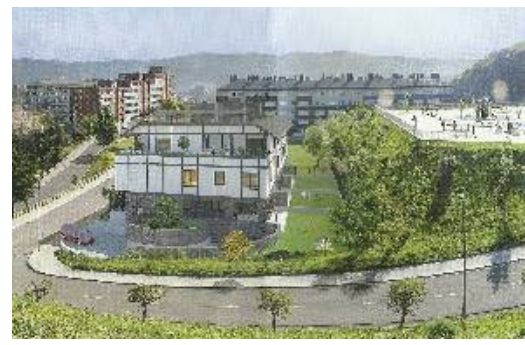

Imágenes 2.8 y 2.9. Material publicitario de la promoción de un edificio de viviendas de nueva construcción en el municipio de Bilbao.
Partiendo de lo anterior, un recorrido más o menos amplio por cualquier material publicitario destinado a la venta o alquiler de viviendas permite confirmar lo planteado. En primer lugar, llama la atención la poca presencia de material gráfico de planos y plantas de las viviendas. Ello muestra que en el proceso de estudio y selección de la vivienda, al menos en sus primeros pasos, no se echa en falta la información que ese tipo de lenguaje incorpora, dejando fuera de la conversación y por lo tanto de la decisión toda una serie de variables espaciales más que relevantes. Por lo demás, el tratamiento y clasificación que de las tipologías de vivienda ofertadas se realiza sigue la senda de las normativas antes citadas: la supuesta diversidad se limita a la variación del número de dormitorios entre una y otra, y a su consecuente alteración de la superficie útil total. Estos son los principales datos habitualmente ofrecidos cuando se habla de tipos de vivienda en documentos de comercialización y venta. En cambio, en la mayoría de promociones recientes publicitadas en el AMB sí se hace un especial énfasis en los equipamientos y calidades de la vivienda y el edificio -materiales, detalles y acabados, instalaciones, servicios comunes,...-, así como en su localización y dotaciones cercanas. Una incorporación que se ha extendido considerablemente en los materiales de difusión de promociones ha sido la favorecida por las herramientas para modelizar y renderizar espacios y materiales. Posibilitando la inclusión de infografías de una calidad alta que vienen a alejar más si cabe la posibilidad de incluir en este tipo de comunicaciones cuestiones espaciales y tipológicas más relevantes. Ya que en general, además de permitir mostrar imágenes globales exteriores del edificio en cuestión, se utilizan para ofrecer y vender una idea de calidad basada en las apariencias y en un imaginario acorde a la moda decorativa del momento. Todo lo cual queda rematado y confirmado al comprobar que en aquellas ocasiones en las que se aportan plantas de las viviendas están coinciden completamente con la descripción aquí realizada (Imágenes 2.7, 2.8 y 2.9).

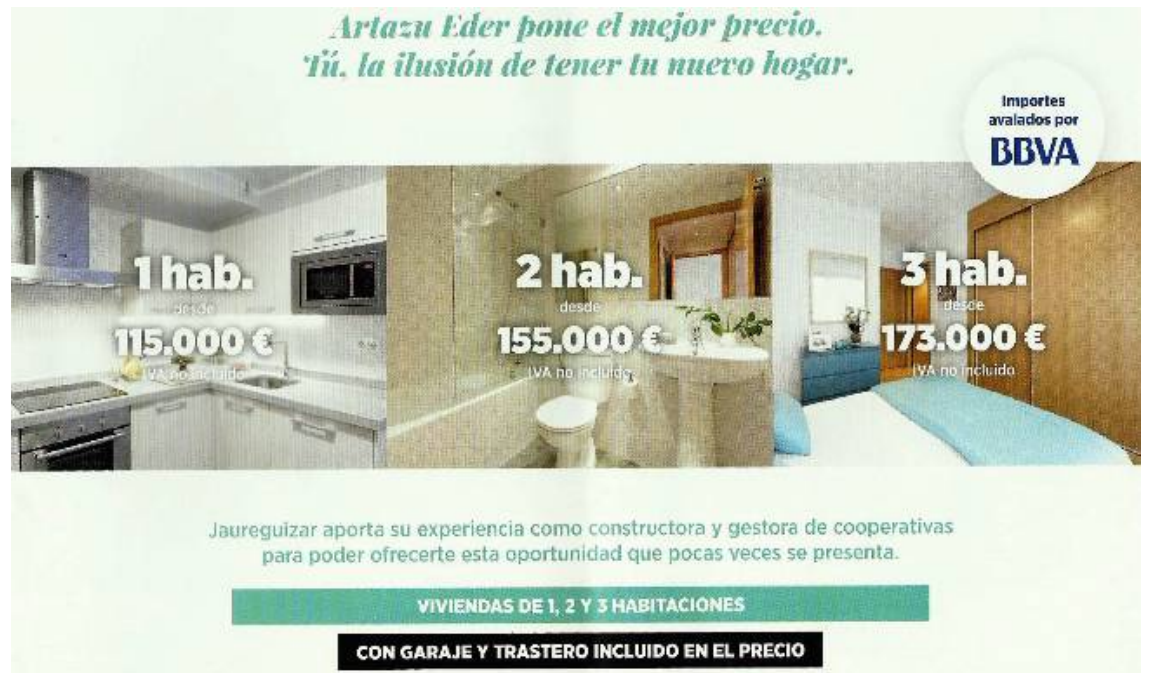


Al igual que el marco legislativo urbanístico español parece tomarse como norma y como único modelo posible cuando no lo ha de ser, el modelo de promoción inmobiliaria no es tampoco el único posible. Al contrario, como viene argumentándose, responde a una cultura arquitectónica y espacial carente de una educación y formación amplias. La prueba es que existen casos en los que el lenguaje y el contenido de los materiales publicitarios relacionados con la oferta residencial es totalmente diferente, y en los que la inclusión de material gráfico espacial está normalizado. Tal es el caso de algunos folletos del mercado inmobiliario de Tokyo, en Japón. En ellos, el esfuerzo dedicado a ofrecer una imagen superficial, a la primera impresión estética del folleto y el producto ofertado, a la apariencia de un bien que se trata de una necesidad básica -y que en los materiales estudiados en el ámbito de esta investigación parecen buscar una idea de lujo cuestionable-, se sitúa en el otro extremo. Se trata de material fotocopiado con una baja calidad gráfica de las escasas fotografías incorporadas en él. $\mathrm{Y}$ sin embargo, hay una constante y central presencia de la planta de la vivienda, hasta el punto de que en muchos casos es el único material gráfico. Es el plano el elemento principal del diálogo entre entidad que oferta y unidad de convivencia que demanda (Imágenes 2.10, 2.11, 2.12, 2.13, 2.14 y 2.15). Este diferente modelo de comunicación conlleva y es posible gracias una diferente capacidad de comprensión y análisis de la información por todas la partes; desde las personas demandantes de vivienda a los agentes que las comercializan.

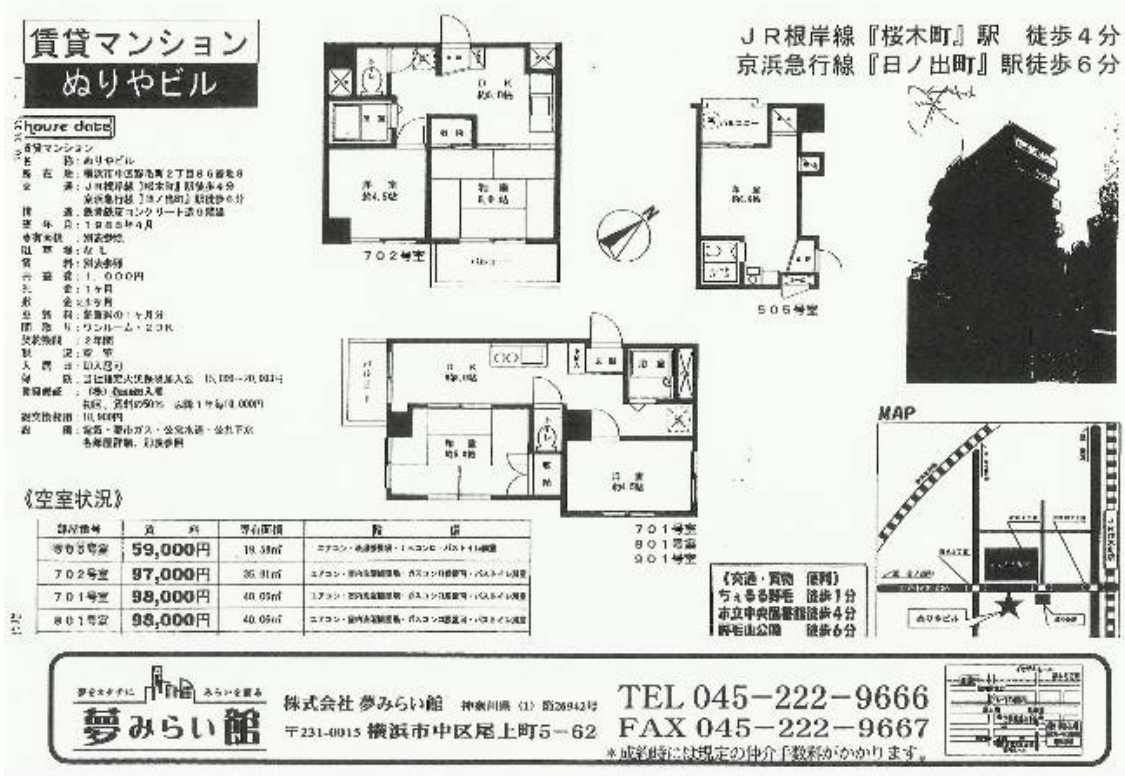

Esta idea aquí desarrollada se va reforzando según se analizan otras esferas desde las que se aborda la tipología residencial. El mismo tratamiento limitado y superficial de la tipología de vivienda identificado en normativa y material publicitario puede también
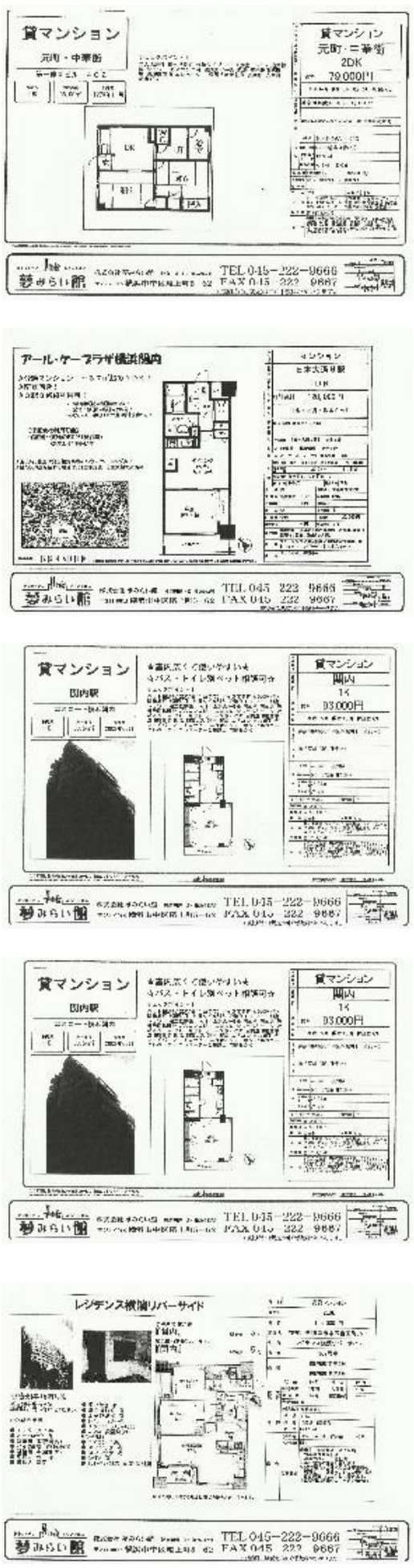

Imágenes 2.10 a 2.15. Ejemplos de folletos publicitarios de oferta inmobiliaria residencial en Tokyo, Japón. 
encontrarse en otros ámbitos, como por ejemplo el de las consultoras económicas y financieras. En informes publicados por estas puede comprobarse que sus estudios del mercado inmobiliario, en cuanto a la cuestión aquí tratada se refiere, se limitan a clasificar y diferenciar las viviendas por su número de dormitorios, superficie útil total o, en el mejor de los casos, por el número de personas que conforman la unidad de convivencia (Knight Frank, 2016; PricewaterhouseCoopers Internacional Limited, 2015; Servihábitat, 2017).

\section{Interpretación demográfica y sociológica simplista}

El tercer gran obstáculo del modelo urbanístico e inmobiliario hegemónico en lo relativo a la manera de abordar el espacio doméstico que se ha venido a analizar puede entenderse tanto desde una escala arquitectónica, como desde una territorial, pues tiene consecuencias en ambas esferas. Se trata de un asunto que engloba tanto al tamaño y tipo de unidad de convivencia, como a la cuantificación del número de viviendas necesarias para alojar a una población concreta, cruzando ambas cuestiones a través de la capacidad de transformación y adaptación tipológica del parque de viviendas debido a las variaciones socio-demográficas de esas unidades. En el desarrollo de la situación problemática ya se han apuntado algunas características del bajo crecimiento, o casi estancamiento, de población en el AMB, y de la diversidad de tipos de unidades de convivencia existentes. Aquí interesa reflejar una serie de lógicas instauradas en los discursos y textos destinados a la planificación espacial residencial, tanto en los agentes públicos como privados. El contexto es el de una disminución del tamaño medio de la unidad de convivencia -hogar es el término usado en las estadísticas- dentro de esa tendencia de descenso poblacional, con un considerablemente acertado diagnóstico de la situación por parte del Plan Director de Vivienda de Euskadi 2013-2016:

«Si atendemos a la tipología de los hogares, los procesos demográficos sufridos en la CAE en los últimos años han alterado profundamente la distribución de tipos de familias. Se constata que el número de familias ha aumentado a un ritmo mayor que el de población, lo que se traduce en una disminución del tamaño medio familiar.

Otro dato destacable es la disminución de la proporción de población que vive en una familia tradicional o pareja con hijos, mientras se ha producido un aumento de familias unipersonales y monoparentales. No obstante, el origen de estas últimas es diferente; si antiguamente la mayor parte de los núcleos se formaban por la defunción de uno de los cónyuges, en la actualidad en gran parte de ellos son producto del divorcio o separación de la pareja. 
En cuanto a la edad de abandono del hogar paterno, en los últimos años se ha producido un aumento de la misma, sobrepasando la cifra de los 30 años. Esta realidad tiene su respuesta en la situación socioeconómica actual. El paro y la eventualidad laboral han afectado profundamente a las dinámicas familiares de la población joven dificultando en gran medida las posibilidades de emancipación» (Gobierno Vasco, 2013a: 40).

Igualmente, en el proceso de modificación puntual de las DOT de Euskadi para redefinir la metodología de cálculo de la cuantificación residencial que debe ser aplicada por el planeamiento municipal, se recogía que «con una población prácticamente estabilizada, la demanda de vivienda principal se deriva casi totalmente de la reducción continua del tamaño medio familiar» (Gobierno Vasco, 2014b: 30). La importancia del fenómeno no es menor, y contiene multitud de posibles matices y consecuencias directas sobre las políticas de vivienda. No en vano, en el AMB se estimó que la necesidad de vivienda motivada por este hecho demográfico era unas diez veces mayor que la necesidad generada por el crecimiento poblacional (Gobierno Vasco, 2014b: 57).

Sin embargo, la interpretación de este diagnóstico y las estrategias planteadas como respuesta y adaptación al mismo -principalmente centradas en construir más viviendas justificadas por el incremento del número de unidades de convivencia debido a ese descenso del tamaño medio, bajo el argumento de que esto hace que, en un panorama demográfico estable, hacen falta más viviendas para las mismas personas- se enmarcan en una lógica enormemente influida por el modelo de planificación urbana expansiva y centrada en la urbanización y construcción permanente de nueva ciudad. Un discurso que anula planteamientos más racionales y responsables, tanto con el patrimonio urbano heredado, como con un territorio cercano deteriorado y enormemente presionado por la urbanización. En este último sentido podría parecer que se centraba el Plan Director de Vivienda de Euskadi 2013-2016 al establecer que la respuesta de la administración ante dicha disminución del tamaño medio de la unidad convivencial «debe optimizar los recursos, adaptando la oferta de viviendas, tanto en número como en características, a las demandas reales de la población»)(Gobierno Vasco, 2013b: 16). Pero la falta de concreción del texto queda aclarada al consultar el tratamiento del tema por otros instrumentos de planificación espacial. La mencionada modificación puntual de las DOT, tanto en su aprobación inicial como en la definitiva, afirman que «la continua contracción del tamaño familiar, el aumento de los hogares de una y dos personas, y el elevado coste de acceder a una vivienda (sea en propiedad o en alquiler) apuntan a la existencia de un segmento de demanda que podría ser proclive a viviendas más pequeñas, aunque también se aprecia una notable resistencia social y sectorial a iniciativas en este sentido. Se trata de un tema a analizar en 
profundidad, ya que permitiría reducir la superficie media por vivienda y moderar el consumo de suelo residencial» (Decreto 4/2016, de 19 de enero, 2016:12). Es esa última afirmación de reducción del consumo de suelo la que indica que la perspectiva desde la que se trabaja es la de responder a las viviendas demandadas con nuevas viviendas construidas, pero reduciendo su tamaño.

Es cierto que el método de cálculo establecido por las DOT lo que busca es cuantificar la necesidad de vivienda, con lo que aparentemente no adelanta cómo se ha de responder a esta -si mediante vivienda nueva o adaptando la existente-. Sin embargo, la realidad es que los instrumentos de ordenación municipal tienden a tomar la cifra obtenida como referencia para la planificación de su crecimiento residencial a base de nueva ciudad. Especialmente cuando en el nuevo método se incluyen variables para tener en cuenta la demanda de vivienda secundaria y la previsión de viviendas desocupadas. Es decir, la cifra final se refiere a viviendas nuevas. Una posición reafirmada desde otros agentes, como algunos profesionales del urbanismo y la ordenación territorial que asumen el discurso dominante sin cuestionar sus bases ideológicas o sin plantear un análisis más profundo y cualitativo de la situación que permita una respuesta desde la resiliencia por parte de la planificación espacial. Y que así lo transmiten al divulgar este complejo mecanismo de cálculo, afirmando que el tamaño medio familiar «se va reduciendo paulatinamente y supone que el mismo número de personas va a necesitar más viviendas para alojarse [siendo] el factor que más incidencia va a tener en el incremento de viviendas a plantear» (Sarria, 2015).

La confirmación de lo anterior se puede encontrar en los textos de aquellos planes a los que va dirigido toda esta justificación establecida desde instrumentos jerárquicamente superiores. En el proceso de revisión del PGOU de Bilbao - en marcha en el momento de la redacción de este trabajo- se ha ido transmitiendo de un documento a otro la idea de que «cada vez hay menos habitantes por vivienda lo que se traduce en el incremento del número de hogares y por ende en la necesidad de nuevas viviendas para albergar a la misma población» (Ayuntamiento de Bilbao, 2015:3). Lo paradójico es que en los propios documentos de avance aparecen pistas para abordar la cuestión desde una estrategia más responsable, pues tras constatar algunos de los cambios en la estructura demográfica -nueva tipología de familias, las necesidades de emancipación de los jóvenes y el aumento de la población de más de 65 años de edad-identifican una serie de «retos importantes en relación con las características de las viviendas y los edificios como [la] necesidad de pensar en nuevas tipologías y tamaño mínimo de las viviendas [o] posibilitar la división interior de viviendas actuales de gran superficie» (Ayuntamiento de Bilbao, 2015: 10). Es decir, aquí sí se está hablando de responder a parte de la necesidad de vivienda actuando sobre el parque existente para ajustar sus características a los perfiles de los nuevas unidades de 
convivencia mayoritarias. Lamentablemente, las categorías de tipos de vivienda a las que se hace referencia parece no salir, una vez más, de aspectos como el número de dormitorios o la superficie útil total de la misma (Ayuntamiento de Bilbao, 2012: 41).

Desde todas las esferas parece que se acepta sin dudarlo, y con un enfoque puramente cuantitativo, el dogma de que a mayor número de unidades de convivencia hace falta un mayor número de viviendas nuevas. Hay para quien es esta una excusa más para legitimar la continuidad de la producción de viviendas por parte del sistema inmobiliario (Roch, 2003: 121). Son posturas que, sin profundizar más en la cuestión, dan por correctamente analizados, interpretados y comprendidos los fenómenos y realidades demográficas, urbanas, y espaciales que hay detrás de todo ello. Se da por bueno un número de viviendas nuevas a construir generado por un método de cálculo diseñado en la década de 1990, que aunque revisado recientemente, deja fuera de la ecuación variables de gran interés ${ }^{60}$. Y la única reacción palpable a los cambios demográficos relativos a los tipos de unidades de convivencia es plantear que las nuevas viviendas a construir deben ser más pequeñas para adaptarse un tamaño de unidad medio menor -presumiblemente escalando la tipología habitual y/o eliminando dormitorios-. Pero este planteamiento puede ser corregido y complementado con variables cualitativas para arreglar y adaptar la ciudad a la sociedad que la habita. Y puede hacerse al menos centrándose en tres puntos, en el orden que sigue.

El primero sería relativo a las unidades de convivencia. Está suficientemente documentado el descenso progresivo desde hace años del tamaño medio de estas. Lo cual lleva a que, a pesar del estancamiento e incluso descenso de la población que viene formalizándose de manera estructural en Euskadi, el cómputo global del número de unidades puede incluso aumentar. El error del planteamiento política y técnicamente aceptado es quedarse en un análisis cuantitativo del fenómeno -en el que importa el tamaño, pero sobre todo el número de unidades de convivencia-. Este debe verse completado con otro cualitativo, para poder responder a preguntas sobre cómo son esas unidades, qué tipo de personas las forman (Guidotti y Arroyo, 2004), cuáles son sus biografías y proyecciones vitales y laborales, sus hábitos de vida, su origen, o si disponen de una comunidad local de apoyo y relación (Bargos, 2017). En definitiva, saber las características y necesidades de las cada vez -como se ha apuntado- más diversas unidades de convivencia que conforman la sociedad en lo que al espacio doméstico se refiere.

El segundo punto de análisis se debe centrar en las viviendas que estas personas necesitan, sin entrar a debatir -todavía- si han de ser nuevas o no. Al disponer de la información anterior sobre las

${ }^{60}$ Más abajo se profundiza sobre esta cuestión analizando cómo instrumentos como las Directrices de Ordenación del Territorio de Euskadi o el Plan Territorial Parcial del Bilbao Metropolitano abordan la cuestión. 
unidades convivenciales, se puede plantear cómo han de ser sus viviendas. No se trata aquí de plantear diseños personalizados, si no de que la diversidad creciente en los tipos de unidades exige tanto ampliar el reducido abanico de tipologías existente, como fomentar la generalización de una vivienda flexible y perfectible (Paricio y Sust, 2000), abierta y capaz de alojar diferentes tipos y número de unidades de convivencia en el tiempo. Con lo que, más allá de su superficie, se han de estudiar temas como los usos que se pueden prever -muchos de ellos históricamente excluidos de la tipología predominante actual, otros nuevos como reflejo de los cambios sociales-, los diferentes niveles de intimidad y comunidad en la vivienda y el edificio (Moya, 2009), la posibilidad de disgregar usos a lo largo del edificio (Monteys y Fuertes, 2002), o diferentes fórmulas de colectivizar los espacios domésticos y sus equipamientos complementarios (Más que una Casa, 2017).

Finalmente, recogida toda la información anterior, el tercer paso se centra en preguntarse cómo hacer realidad esas viviendas. La respuesta que directamente el discurso dominante y mayoritariamente extendido plantea es hacer una nueva aportación al parque actual mediante la nueva construcción de edificios residenciales. Ya sea en procesos de regeneración urbana por sustitución, o en operaciones de nueva urbanización y consumo de suelo no artificializado. Pero cabría primero preguntarse sobre las características del parque existente, y recoger información sobre las tipologías de las viviendas y las edificaciones residenciales con las que la ciudad ya cuenta. Sería razonable hacerlo así por la búsqueda de una gestión coherente y responsable tanto de los recursos de que se disponen -en este caso la ciudad residencial existente-, como por la puesta en valor de los que se consumieron para obtener los anteriores -recursos energéticos y materiales para la urbanización y construcción, emisión de contaminación al entorno para la obtención de los anteriores, generación de residuos,...-. Es decir, en plena situación de crisis global de recursos, se necesitan estrategias para la máxima eficiencia y aprovechamiento de los sistemas urbanos actuales, en todos los ámbitos posibles (Hernández Aja, 2008). En este sentido, los datos demográficos indican que las unidades de convivencia mayoritarias hoy en día son diferentes a aquellas para las que fueron diseñadas la gran mayoría de viviendas en uso. El planteamiento del dogma de 'a más unidades de convivencia, más viviendas nuevas', parece apoyarse en la fallida idea de que el parque actual va a estar eternamente ocupado por esas familias formadas por una pareja heterosexual con dos o más hijos o hijas. Viviendas a las que habría que ir sumando otras adaptadas a las nuevas necesidades. Pero si gran parte de las existentes se están quedando obsoletas tanto por motivos relacionados con su tipología como por su tamaño, parece razonable fomentar y abordar su segregación, transformación y adaptación para sacar el máximo rendimiento de dicho patrimonio -que cuenta en gran medida además con las infraestructuras, instalaciones y dotaciones urbanas básicas- a la par que se reduce la presión 
urbanizadora sobre los suelos libres que aún mantienen ciertas características naturales.

\begin{tabular}{ll}
\hline Para quién & $\begin{array}{l}\text { Análisis de la necesidad: biografías y proyecciones vitales y } \\
\text { laborales, hábitos de vida y culturales, nivel de integración en } \\
\text { la comunidad,... }\end{array}$ \\
\hline Cómo & $\begin{array}{l}\text { Plantear las viviendas más allá de su cuantificación, su } \\
\text { número de dormitorios o su superficie: usos previstos o } \\
\text { posibles y su evolución en el tiempo, niveles de intimidad y } \\
\text { comunidad, disgregación de usos por el edificio, o } \\
\text { colectivización de espacios. }\end{array}$ \\
\hline Dónde & $\begin{array}{l}\text { Antes de aumentar por defecto el parque actual, estudiar las } \\
\text { características tipológicas y estado de las viviendas y las } \\
\text { edificaciones residenciales con las que la ciudad ya cuenta, así } \\
\text { como el potencial para alterar la estructura de la propiedad } \\
\text { sobre la que se apoyan. }\end{array}$ \\
\hline
\end{tabular}

En función de los resultados obtenidos en cada uno de los tres puntos desarrollados (Tabla 2.9), la máxima de responder a la situación con nuevas viviendas podría verse cuestionada por contar con un parque obsoleto con capacidad de adaptación. $O$ por el contrario, podría darse el caso de contar con un parque residencial ya ajustado a las necesidades de las unidades de convivencia actuales, en el que el porcentaje de viviendas vacías fuese el tolerable tanto por el mercado como por los movimientos lógicos de población, y por lo tanto sí hicieran falta claramente nuevas viviendas. Como se ha podido ver en el capítulo previo, la realidad en el AMB se acerca más al primer supuesto. En cualquier caso, contar con una base de información demográfica, urbana y arquitectónica actualizada permitirá interpretar adecuadamente la situación y salir de la simplicidad del argumento que afirma que un mayor número de unidades de convivencia necesita siempre más viviendas nuevas, y diseñar políticas urbanas de vivienda en consecuencia. Lo cual depende, claro está, de que exista una clara voluntad por parte de las instituciones públicas para hacerlo (Vinuesa, 2013: 15). Como paso previo, sería necesario modificar algunas cuestiones de base como las propias definiciones de los conceptos tratados. Algo que en algunos ámbitos ya se ha hecho; mientras el Instituto Nacional de Estadística sigue definiendo el hogar como «la persona o conjunto de personas que residen en una vivienda familiar» (Instituto Nacional de Estadística, 2017: 9), otros trabajos han planteado definiciones más actualizadas y acertadas para abordar la problemática que aquí se plantea:

«En el presente estudio hemos considerado dos tipos de unidades residenciales: el hogar o grupo de convivencia y la vivienda o unidad residencial. El primero (hogar) se refiere a la persona o personas que constituyen una unidad de convivencia
Tabla 2.9. Consideraciones cualitativas para corregir la planificación residencial del AMB. Elaboración propia. 
y toma de decisiones, sea cual sea el espacio que habiten (una casa o piso, una habitación, en un albergue, etc.); la segunda (vivienda) alude a la unidad habitacional -piso o casa- donde pueden coincidir varios hogares o grupos de convivencia» (Pereda et al., 2005: 105).

Este hecho de desconectar número de hogares o unidades de convivencia y número de viviendas permite leer la situación desde la perspectiva que aquí se ha desarrollado. $Y$ existen cifras que evidencian la urgencia de hacerlo, como el propio trabajo citado muestra, ya que mientras «el mercado inmobiliario español se caracterizaba por tener muchas más viviendas (20,9 millones) que hogares (14,1 millones), entre los inmigrantes de países periféricos que residen en España se produce justamente lo contrario: las viviendas son prácticamente la mitad (626.000) que los hogares (1.150.000)》 (Pereda et al., 2005: 106). Es decir, unidades con vocación de habitar una sola vivienda se ven forzadas - por motivos económicos especialmente- a convivir con otras dentro de un espacio doméstico diseñado para una familia nuclear con menores a su cargo y pertenecientes a otra cultura.$$
-2.6 .3-
$$ \\ Fuerte inercia urbanizadora heredada}

La tercera gran pauta identificada, que se contrapone a la meta del aprovechamiento del parque residencial existente, es aquella que aglutina una serie de fuerzas diversas en torno a la idea del crecimiento urbano de los usos residenciales. Esto hace que ese parque heredado sea mayormente desatendido, no solo en cuanto a su mantenimiento y renovación -lo cual está en parte siendo revertido mediante políticas de rehabilitación y regeneración urbana en paralelo a un desarrollo normativo acorde-, si no también en cuanto a un análisis de las características de naturaleza más tipológica de este parque heredado y su entronque con las evoluciones demográficas, territoriales y económicas de la sociedad, como se acaba de exponer en el apartado inmediatamente anterior. Así, el modelo urbanístico predominante, del que ya se han señalado algunas características, ejerce una influencia negativa en esta tercera meta en la medida en que se trata de un modelo con una alta tendencia a priorizar $-\mathrm{y}$ dotarse de herramientas para- la construcción de nueva ciudad residencial. Una mirada sesgada, motivada por la búsqueda de unas plusvalías generadas por la actuación urbanística difícilmente alcanzables en operaciones de rehabilitación, que tiende a contagiar los instrumentos de ordenación y los discursos en torno a la misma. 


\section{Modelo inmobiliario generador de plusvalías}

El modelo urbanístico e inmobiliario común que subyace bajo las diferentes legislaciones autonómicas españolas hace que, con sus respectivas peculiaridades locales, se puedan identificar fenómenos prácticamente parecidos en todo el estado. Se han estado dando comportamientos similares que buscan la producción de nuevas viviendas mediante la expansión de la ciudad y el aumento del suelo urbanizado, dejando durante décadas de lado al estudio y la intervención en la ciudad existente. No por casualidad, pues aunque «la urbanización se expresa en el ámbito local, el marco político y económico que la hace posible es estatal y global» (Borja, 2011: 84). Se trata de un modelo gobernado por el negocio de la promoción inmobiliaria que priorizando la obtención de plusvalías a través de la recalificación de nuevos suelos y construcción de nuevas viviendas se ha impuesto a las lógicas de un planeamiento racional, configurando en última instancia el modelo urbano y territorial: un rápido e incontrolado crecimiento de la edificación residencial movido por las lógicas especulativas totalmente ajenas a las necesidades de la población (Naredo y Montiel, 2011: 53). Un modelo que además ha sido «justificado y aplaudido por la generación de empleo que suponía, alimentando la economía y, sobre todo, las finanzas locales» (Vinuesa, 2013: 48):

«Urbanismo y edificación se convirtieron en instrumentos generadores de actividad económica que el Estado fomenta por su esencial importancia para el país. La economía se impuso así sobre el urbanismo. Prevalecieron los beneficios "para todos», desde los titulares originarios del suelo hasta los propietarios de vivienda usada y, por supuesto, las administraciones públicas, a través del sistema fiscal. El derecho urbanístico, anómalo, quedó al servicio de la economía. [...] La ausencia de regulación adecuada resultaba clamorosa. La expansión proporcionaba plusvalías más rápidamente a los operadores inmobiliarios e ingresos fiscales a las Administraciones públicas» (Tejedor, 2015: 2).

Aunque cabe recordar que «la urbanización no es intrínsecamente perversa, sí lo es la forma que toma cuando la orienta el capitalismo especulativo y depredador, la complicidad política de los gobiernos, la sumisión ciega al todo mercado y la nocividad de la apropiación privada de las plusvalías urbanas» (Borja, 2011: 85). En este sentido, ni todos los usos urbanísticos planteados en un suelo son «nefastos para el mismo», ni todos los usos agrícolas posibles son «inocentes [...] será preciso valorar y estudiar cada caso concreto. Un suelo puede ser más o menos apto como soporte de la actividad constructiva dependiendo de múltiples factores» (Fariña, 2007: 239). La vivienda se ha convertido así, a través de su formalización como elemento de inversión y fuente de plusvalía, en una de las principales razones de la expansión urbana. Las plusvalías generadas en los 
procesos de urbanización y edificación del modelo urbanístico actual han puesto al planeamiento y la acción urbanística pública en el foco de muchos intereses y presiones. Como ya se ha mencionado, la propia Exposición de Motivos del texto refundido de la Ley del Suelo de 2008 recordaba que la historia del urbanismo español contemporáneo es desarrollista, volcada sobre todo en la creación de nueva ciudad. En un marco en el que «la legislación ha permitido a la propiedad del suelo obtener grandes rentabilidades anticipadas (sin necesidad de realizar actividad económica o profesional alguna sobre esos suelos) simplemente por la acción del planeamiento urbanístico público» (Burón, 2008: 3), las consecuencias expansivas y de ocupación del territorio son preocupantes:

«Desde hace tiempo vengo señalando que las reglas del juego económico habitual, guiado por la brújula del lucro, promueven modelos territoriales, urbanos y constructivos específicos, salvo que existan barreras mentales e institucionales que se lo impidan. Cuando estas barreras se diluyen dejando que el afán de lucro ordene y construya a su antojo la ciudad y el territorio, [...] tienden a desatarse patologías de crecimiento que fuerzan la expansión de los procesos de urbanización y sus servidumbres territoriales a ritmos muy superiores a los del crecimiento de la población y su renta disponible» (Naredo y Montiel, 2011: 18).

Este contexto llevó a generar una demanda de vivienda especulativa y artificial, alimentando un relativo olvido por el patrimonio edificado. Impulsada principalmente por la caída de los tipos de interés hipotecario, una rentabilidad inferior de los mercados financieros, un crecimiento económico mantenido, e incluso otras variables menos visibles como el lavado de dinero negro; lo que conllevó, además de un fuerte y rápido incremento del precio de la vivienda y el suelo, una gran actividad constructiva y expansiva (Beltrán, 2009: 464). Esta alta rentabilidad de la vivienda libre limita poderosamente las posibilidades de intervención y control de los poderes públicos, e incluso «cuando el suelo es tan caro (pero pese a ello su demanda aumenta, para conseguir grandes rentabilidades en la promoción), los municipios sucumben fácilmente a la tentación de especular con él en lugar de crear Patrimonios Municipales de Suelo» (Beltrán, 2009: 468). Sin embargo, al analizar esta situación con perspectiva es posible comprender que se trata de una rentabilidad no solo parcial y excluyente, si no que además en muchos casos es falsa.

Es parcial y excluyente porque se centra exclusivamente en la ya citada convención social del dinero (Naredo, 2004a), y mide los beneficios exclusivamente en variables económicas. No parece incorporar en la ecuación cuestiones sociales como la exclusión residencial de importantes sectores de la población ante la incapacidad de acceso a la vivienda, lo cual ya se ha expuesto en apartados anteriores. Ni tampoco lo hace respecto a variables ambientales como las capacidades ecosistémicas de los suelos 
anulados por la urbanización. Las plusvalías obtenidas en el proceso de urbanización y edificación de suelos naturales generan en diversos sectores de la población expectativas de lucro urbanísticas alimentadas por años de beneficios parciales a corto plazo y por la expansión en la sociedad de la idea de un posible -aunque falsolucro generalizado. Lo cual produce una presión desde el urbanismo sobre el resto de funciones y servicios del territorio que puede, y de hecho lo hace, desequilibrar el mismo: «las expectativas de urbanización contribuyen a desorganizar los sistemas agrarios próximos, al mismo tiempo que las demandas en recursos y residuos, en extracciones y vertidos, que plantea el modelo de urbanización imperante, extiende la "huella" del deterioro ecológico hacia puntos cada vez más alejados» (Naredo, 2004a: 15). Se trata de una exclusión de la complejidad y diversidad de los suelos del proceso de ordenación espacial a través de una visión parcelaria del suelo con una perspectiva económica e inmobiliaria. Algo especialmente determinante en los suelos periurbanos, en los que su «naturaleza de envolvente urbana los subordina al continuo crecimiento urbano, que lo convierte en expectante, paralizando su gestión y promoviendo su deterioro (Maldonado, 2008). La problemática se agrava cuando el suelo de estos espacios posee una alta capacidad agronómica» (Zazo, 2011: 212).

Esta rentabilidad económica es además en muchos casos aparente, con fuertes dosis de falsedad. La fuerte inversión en la construcción por parte de las familias de las dos pasadas décadas se dio a costa de reducir su inversión financiera, lo que generó «un comportamiento económico realmente insostenible, sobre todo cuando en los cuatro últimos años del boom las operaciones financieras netas de los hogares se hicieron negativas; es decir, que los hogares, en vez de aportar ya recursos al sistema financiero, se los demandaban para seguir invirtiendo en ladrillos; lo cual rompía con la normalidad enseñada en los manuales de economía, que da por supuesto que el ahorro de los hogares genera la capacidad de financiación que las instituciones financieras movilizan para satisfacer la tradicional necesidad de financiación las empresas» (Inurrieta et al., 2013: 17). Con todo, se viene constatando que hay miles de viviendas vacías o infrautilizadas con posibilidad de cubrir parte de la necesidad existente, pero que parte de ellas se encuentran fuera del mercado por diferentes motivos -incluso, estando en oferta, por estar fuera del rango de precios asumibles por gran parte de la población-. La respuesta principal frente a esa necesidad ha sido la construcción de nueva vivienda protegida o no-, y sin embargo parte de la sociedad no puede hacer efectivo el derecho de acceso a las mismas debido a las dificultades de acceso económico. El enorme consumo de suelo y recursos que la construcción de estas nuevas viviendas supone hace que la coexistencia de estos dos fenómenos sea en sí un drama social con directa repercusión territorial y ambiental. 


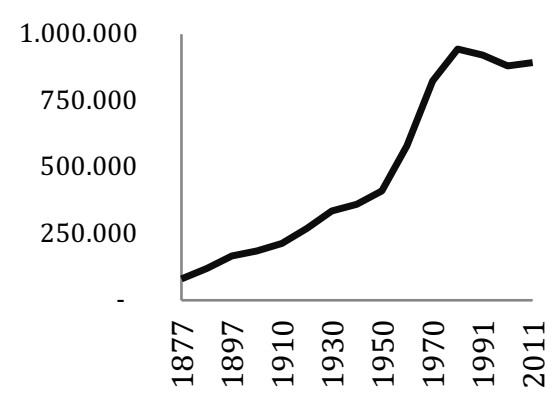

Gráfica 2.25. Evolución de la población en el Área

Metropolitana de Bilbao. INE, Censos de Población.

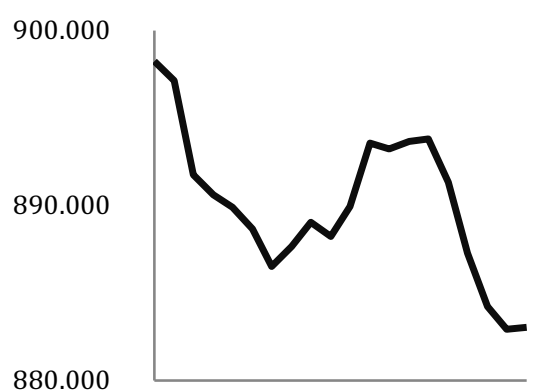

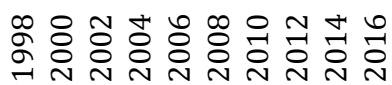

Gráfica 2.26. Evolución de la población en el AMB. INE, Padrón Municipal.

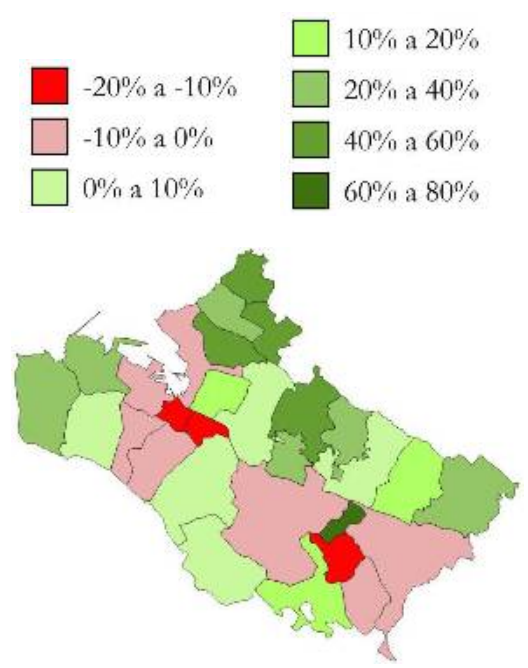

Mapa 2.13. Evolución del padrón municipal de habitantes entre 1998 y 2017. Elaboración propia a partir del INE.

\section{Nuevos desarrollos ¿`sobredimensionados?}

En lo que respecta a la vivienda, ¿qué es lo que amenaza concretamente con esa expansión de la ciudad residencial?. Ha quedado en diversos trabajos fundamentada la existencia en España y -aunque en menor medida- en el AMB de un sector de la edificación de viviendas artificialmente sobredimensionado, y habitualmente bajo modelos de ciudad expansivos basados en patrones insostenibles (Ozcáriz y Prats, 2009). En efecto, son muchos los indicios que llevan a definir el desarrollo inmobiliario de la década de 2000 como de «desmedido e injustificado» (Beltrán, 2009: 469). Continuar con nuevas ocupaciones de suelos y una mayor expansión de la ciudad residencial parece responder a un contexto similar al de las décadas de los grandes crecimientos demográficos en la región, entre 1950 y 1970. El rápido aumento de la población urbana obligó entonces a apresurados y con el tiempo cuestionados desarrollos residenciales por su baja calidad constructiva, su entorno urbano, o el déficit dotacional, entre otras cuestiones-. Sin embargo, en el contexto actual existen razones, algunas se presentan a continuación, que pueden hacer replantear la política de vivienda en lo que respecta a la ocupación de suelos.

Hoy en día las dinámicas demográficas son completamente diferentes pues la población total está, además de envejeciendo importantemente, en un estado de equilibrio si no de ligera reducción. Tomando como referencia los datos históricos de los Censos de Población del INE (Gráfica 2.25) para los municipios que conforman el AMB, puede apreciarse un incremento continuo de población que se remonta al censo de 1877, siendo especialmente fuerte ese aumento entre los censos de 1950 y 1981 -más de 500.000 personas-. Pero a partir de este hasta el de 2001 la población se redujo en unos 60.000 habitantes; los datos del último censo de 2011 muestran un aumento ligero de 11.000 habitantes desde el 2001. Pero los datos del Padrón Municipal de habitantes ofrecen datos más reveladores (Gráfica 2.26). Tomando como base el año de 1998, pueden identificarse cuatro grandes fases o épocas. Hasta 2004 la población total disminuyó en un 1,3\%-11.718 personas menos-. A partir de ese año hasta 2009, la tendencia se invirtió y hubo un aumento poblacional de unas 7.000 personas que suponía un 0,80\% más respecto a la de 2004. Tras tres años de relativa estabilidad hasta 2012 -un aumento de 242 personas-, desde entonces hasta 2016 vuelve a descender, y a mayor ritmo que en la primera fase. Esta vez se pierden 10.772 personas en menos tiempo que entonces; un 1,21\%. Los últimos datos de 2017 indican una mínima subida de población cuantificada en 117 personas. Por supuesto, estas variaciones no se han producido de la misma manera en todos los municipios del AMB (Mapa 2.13). Pero sí se ven ciertas pautas comunes: los grandes municipios que albergan a la gran parte de esta población, los mayores de 20.000 habitantes, son los que han sufrido pérdidas -exceptuando tres casos concretos como Barakaldo, Erandio y Leioa-. El resto, 
salvo alguna excepción, son los que han aumentado su población a lo largo de la serie analizada.

Como ya se ha señalado, el tamaño medio de las unidades de convivencia se va reduciendo cada vez más. Aunque, según los datos del Censo de Población y Viviendas del INE, el periodo de mayor descenso ha sido entre los años 1991 y 2001, pasando en Bizkaia de una unidad de convivencia media de 3,3 personas a una de 2,8 . Todo parece indicar que seguirá bajando, pero de manera más moderada, ya que el ritmo de reducción se ha frenado estando la media de 2011 en 2,47 . Con este panorama demográfico, en caso de mantener el ritmo de construcción de vivienda nueva hay quien incluso anuncia que «viene un desplome del acceso a la vivienda que bajará la demanda de vivienda de manera natural (sobre todo de la mano del escaso crecimiento vegetativo de la población española)» (Etxezarreta, 2010: 22). Y sin embargo, es importante establecer con claridad diferencias entre dos conceptos clave; como establecía el PTP del Bilbao Metropolitano, «es necesario realizar una puntualización respecto a la demanda y la necesidad real de vivienda. La necesidad real tiene como objetivo su ocupación, frente a la demanda, que pudiera incorporar un número de viviendas requeridas por otro tipo de causas como, por ejemplo, la de la inversión y que pudieran acabar engrosando el número de viviendas vacías. A la que hay que dar respuesta en definitiva, es a la necesidad de vivienda, independientemente de que se adopten criterios de esponjamiento con el fin de evitar la especulación» (Decreto 179/2006, de 26 de septiembre, Anexo I-Memoria, 2006: 57). Necesidad y demanda no van por lo tanto siempre en paralelo.

Este contexto demográfico hace que la necesidad de vivienda no se vea sometida a una presión extra debido a fuertes cambios ni aumentos poblacionales, si no que tendrá las características de una población estable con un tamaño medio de unidad de convivencia en relativo descenso. La necesidad existe -como se ha visto en el capítulo previo-, pero la respuesta repetida a lo largo de las últimas décadas, haciendo más vivienda bajo una misma fórmula, no ha solucionado el problema de acceso. Cuestionar que la construcción de nuevas viviendas sea el pilar y la estrategia principal de la política de vivienda no implica rechazar que hay un problema de vivienda. Pero centra el debate en cómo se responde a esa necesidad, y qué estrategias y lógicas sigue la planificación de vivienda. El Observatorio Vasco de la Vivienda identificaba a través de la Encuesta de Necesidades y Demanda de Vivienda la demanda para el año 2013 en la provincia de Bizkaia en 71.228 -de ellos, 41.283 se estimaban como cambio de vivienda habitual-. La base de datos del planeamiento urbano municipal Udalplan establecía en 2014 un total de 88.834 viviendas nuevas previstas (59.070 libres, 26.044 protegidas y 3.720 tasadas). Llama la atención que un porcentaje tal alto de la demanda de vivienda total se plantee para ser respondida con vivienda nueva. Efectivamente, siempre según los datos de la citada 
encuesta, para un 69,5\% de las unidades de convivencia demandantes de primera vivienda les era indiferente si esta es nueva o usada. Solo un 18\% deseaba una nueva. En el caso de las demandantes de cambio de vivienda, la indiferencia es mayor todavía: un $73,4 \%$ así lo indica, frente a un $14,1 \%$ que se inclinaba por un cambio a vivienda nueva. Dado que más de la mitad de la demanda de vivienda proviene de unidades de convivencia que ya cuentan con alojamiento, que no hay un crecimiento poblacional como para ocupar todas las viviendas que estas liberan, y que como se ha apuntado anteriormente la reducción del tamaño medio de la unidad de convivencia tampoco es justificación para un crecimiento de tales dimensiones, podría afirmarse que la necesidad real de nueva vivienda debería estar mucho más cercana a los datos de demanda de primera vivienda, que se establecía desde el Gobierno Vasco en torno a unas 30.000 unidades de convivencia, en Bizkaia. Por otro lado, el Censo de Población y Viviendas de 2011 del INE identificaba un total de 43.705 viviendas vacías en la provincia; una búsqueda de viviendas en venta en un solo portal inmobiliario -Idealista- ofrece un total de 19.857 en venta y/o alquiler. Son datos que muestran que el parque actual tiene un considerable potencial de respuesta a la demanda y la necesidad de vivienda para ser tenido en cuenta desde los instrumentos de planificación urbana y territorial.

Por todo lo anterior, resulta de interés acudir a las estimaciones establecidas por los documentos de ordenación territorial que definen la cuantificación residencial en Euskadi. Las Directrices de Ordenación del Territorio establecieron con su aprobación en 1997 un método de cuantificación de la oferta residencial municipal para ciclos de ocho años, que debe seguir el planeamiento. Este método tiene en cuenta, por un lado, datos directos relativamente cuantificables (población y estimaciones demográficas, estructura familiar, viviendas existentes) y por otro el propio documento establece una serie de variables más subjetivas (crecimiento selectivo, hábitat alternativo, segunda residencia prevista, corrección de la rigidez de la oferta). El resultado es una horquilla que establece un máximo de viviendas que no podrá sobrepasar en ningún caso el planeamiento urbanístico municipal, pero también un mínimo por encima del cual habrá de estar siempre el número de viviendas previsto para cada periodo. Esta metodología no tenía en cuenta en su cálculo las viviendas vacías existentes en cada municipio, y por lo tanto no se ha incorporado a lo largo de estas décadas de vigencia de esta herramienta de ordenación territorial una variable crucial para una adecuada planificación residencial. Con la aprobación de la modificación puntual de las DOT en 2016 en lo relativo a la cuantificación residencial, se ajustó el método de cálculo a la baja incorporando, entre otras cuestiones, la vivienda vacía en la ecuación. El método propuesto trata en definitiva de cuantificar una necesidad y una demanda volubles e influenciadas por otras variables externas. Aquí el análisis se va a centrar en dos de sus planteamientos. Una de las limitaciones que se establece en el cálculo «trata de asegurar una 
capacidad residencial mínima que permita una cierta capacidad de actuación a los agentes sectoriales y que no restrinja excesivamente el funcionamiento del mercado de suelo en una situación de contracción demográfica» (Decreto 4/2016, de 19 de enero, 2016), lo que efectivamente se entiende como el mantenimiento de un mínimo de viviendas a realizar. En cifras, esto se traduce en que todo municipio tendrá derecho a una capacidad residencial equivalente al $10 \%$ de su parque inicial de viviendas o a una capacidad mínima de 20 viviendas, independientemente del resultado de la cuantificación. Este planteamiento parece centrarse en la dimensión mercantil de la vivienda más que en la social. Y aunque la cifra mínima es pequeña, la obligatoriedad de esta parece generar cierto recelo, sobre todo en pequeños municipios, ya que puede llevar a situaciones no deseadas en las que las previsiones fallen y sin embargo se hayan clasificado e incluso desarrollado nuevos suelos residenciales. Generando a situaciones conflictivas de nuevos desarrollos legalmente legítimos, pero social y demográficamente injustificables.

Se introduce además en el método la cuestión de la vivienda vacía, aunque se trata de una primera incorporación conservadora, porque se siguen sin introducir variables de datos reales de viviendas vacías. Se establece un valor por municipio como «mínimo de un $2 \%$ del número total de viviendas existentes en el mismo sugiriéndose, como valor a incorporar, el $50 \%$ del número total de viviendas vacías» (Decreto 4/2016, de 19 de enero, 2016). Frente a esto, los datos del Censo de Población y Viviendas de 2011 señalaban que más de la mitad de los municipios del AMB tienen un porcentaje de vivienda vacía superior al $10 \%$; y con no pocos casos alcanzando porcentajes superiores al 15-20\%. La Encuesta sobre Vivienda Vacía realizada por el Gobierno Vasco en 2015 estimaba en torno a un 6,3\% -un 4,9\% al excluir la vivienda de temporada- el porcentaje del parque residencial del AMB deshabitado. Parece que reducir a la mitad de las viviendas vacías, o incluso a un $2 \%$, la cifra a incorporar al cálculo no se ajusta a la realidad local. Esto se debe entre otras razones a uno de los persistentes problemas en esta cuestión: se sigue sin contar con datos reales de viviendas vacías. En gran parte esto viene motivado por la dificultad de recoger dichos datos de una manera fiable, ya que las estadísticas existentes no acaban de ser del todo precisas (Gobierno Vasco, 2012: 147, 2014b: 22):

«Por otro lado, los supuestos generales que se proponen en este estudio deberán ser actualizados a medida que transcurra el tiempo y se disponga de nueva información. Especial interés tienen los aspectos relacionados con las viviendas secundarias y desocupadas, ya que la información general resulta poco fiable en estos apartados. Los municipios en los que estos fenómenos tengan especial relevancia deberían aportar la información pertinente y justificar los supuestos y coeficientes aplicados en relación a estos temas» (Gobierno Vasco, 2012: 156). 
Es decir, aunque corregido, el modelo de fondo sigue apoyado en la idea de continuar con nuevos desarrollos: la modificación de 2016 de las directrices, para el periodo 2014-2022 en el AMB, establecía el desarrollo de la ordenación urbanística necesaria para generar una capacidad máxima de 58.284 y una mínima de 29.149 viviendas nuevas. Desde ciertos ámbitos, y desde hace años, se viene defendiendo el excesivo dimensionamiento del parque residencial que esta metodología genera y su desfase con las necesidades reales de este territorio. Uno de los movimientos con mayor recorrido en este sentido es el grupo de trabajo nacido dentro del colectivo en favor de un cambio social hacia el decrecimiento en Euskadi, Desazkundea. Trabajan para hacer visible y llevar a la calle el debate sobre una ordenación del territorio desde una orientación decrecentista, y cuenta con el apoyo y adhesiones de numerosas organizaciones y colectivos sociales, ambientales y sindicales, así como personales de diferentes ámbitos. También desde diferentes ayuntamientos vascos, especialmente los pequeños o los que ven como su población se estanca o incluso decrece, se viene reivindicando la eliminación del mínimo de viviendas a planificar para cada periodo de ocho años establecido en las DOT. En el momento de la redacción de este trabajo, está en proceso de aprobación definitiva el documento de revisión total de las Directrices de Ordenación del Territorio. Se prevé que afecte también a la modificación residencial de 2016, y entre otros aspectos, elimine el mínimo que este establecía.

En cualquier caso, las DOT establecen unas previsiones que han de cumplir los planes urbanísticos municipales, pero que serán corregidas y concretadas en cada caso con la aprobación del Plan Territorial Parcial correspondiente. En el caso del AMB, esta cuenta con un PTP aprobado en el año 2006 -en el momento de la redacción, también, en proceso de revisión-. Este propone un método «adaptado a las necesidades concretas del Bilbao Metropolitano y sus peculiaridades» (Decreto 179/2006, de 26 de septiembre, Anexo I-Memoria, 2006: 63). En su memoria se hacen varias referencias a una planificación más coherente y racional, estando entre sus modos de intervención en la ordenación del suelo la regeneración, renovación, actuación sobre el patrimonio edificado o la redensificación. En sus estimaciones demográficas, y a pesar de que cuentan en sus tres escenarios con el mantenimiento de una entrada de población migrante que la realidad ha frenado, el descenso de población es evidente. En el escenario intermedio, el estable, la pérdida de población estimada entre 2008 y 2018 es de 18.000 habitantes. Lo cual viene a apoyar las consideraciones demográficas expuestas antes.

A primera vista se da una diferencia importante con lo planteado en las DOT, y de gran relevancia por lo que al problema que se analiza respecta. Y es que el PTP propone entre sus objetivos «frenar el consumo de nuevo suelo, invirtiendo la tendencia de los últimos años», y «optimizar el patrimonio edificado» (Decreto 179/2006, de 
26 de septiembre, Anexo I-Memoria, 2006: 60, 61). Por ello, trabaja sobre dos factores que maneja para la planificación residencial: la ya citada diferencia entre necesidad de vivienda y demanda de vivienda, y la gestión de la oferta. En cuanto a la gestión de la oferta, establece un interesante panorama pues propone tener en cuenta el patrimonio edificado, dentro del cual enmarca la posibilidad de articular mecanismos para la intervención sobre la vivienda vacía y el fomento de la rehabilitación, así como la capacidad del planeamiento vigente y los nuevos desarrollos propuestos para absorber parte de esa oferta. Sin embargo, el plan asume que la gestión del patrimonio edificado precisa de mecanismos de intervención y por lo tanto no introduce variables de vivienda vacía en el cálculo propuesto. Pero lo que si hace es identificar una serie de municipios que tienen el suelo para posibles desarrollos agotado, o cerca de su agotamiento, en los que no establece una horquilla de vivienda nueva. En ellos establece unas cantidades de vivienda orientativas que deberán satisfacerse mediante la optimización de su patrimonio edificado, operaciones de reforma interior o consolidación de su suelo urbano. Este método propone igualmente una horquilla con valores máximos y mínimos de vivienda nueva que los planes urbanísticos deben ofrecer. El valor máximo se justifica para no producir desarrollos urbanísticos desordenados como consecuencia de una sobrecalificación de suelo; el mínimo para evitar la escasez de suelo calificado. En cualquier caso, al igual que con el método propuesto en la revisión de las DOT, se vuelve a dar la situación de que expectativas erróneas pueden suponer el haber calificado e incluso desarrollado suelo para cumplir dicho mínimos, y sin embargo no adecuarse a la realidad municipal.

Las consideraciones previas que hace el PTP respecto a la diferenciación entre la demanda y la oferta residencial son de gran interés. La cuestión es si estas se plasman en la cuantificación que posteriormente realiza. A la cantidad total de vivienda nueva estimada se le resta la capacidad vacante del planeamiento, la optimización del patrimonio edificado, y la redensificación en los sectores de suelo urbanizable no desarrollados. Pero esa primera cifra obtenida pasa de las 44.208 viviendas calculadas como necesarias para satisfacer la necesidad de vivienda a, mediante un coeficiente de esponjamiento, 68.184 en el escenario mínimo y 88.633 en el máximo (Decreto 179/2006, de 26 de septiembre, Anexo I-Memoria, 2006: 62). La necesaria existencia de un margen de viviendas para favorecer un funcionamiento teóricamente correcto del mercado puede ser justificado. Pero que ese margen pueda llegar a duplicar la necesidad inicialmente calculada evidencia que las variables introducidas tienen más que ver con las lógicas del mercado inmobiliario que con las de la respuesta a un derecho fundamental como es el de la vivienda. Con todo, la cifra máxima de la horquilla propuesta con este concepto de esponjamiento no implica que deba ser la cifra definitiva. No obstante, esta sobre clasificación y las consecuencias que tiene sobre los suelos afectados -el paso a una situación expectante como se ha comentado antes (Zazo, 2011)-, puede llevar a menudo a la 
paralización de su desarrollo para otros usos o a la acumulación de suelos degradados infrautilizados.

\section{Obsolescencia del planeamiento}

Ante los retos espaciales que el modelo de organización social del capitalismo avanzado ha generado, son muchas las voces que desde diferentes posiciones y con diferentes intereses han puesto en duda la capacidad del planeamiento espacial tradicional para afrontarlos. Más allá de aquellas que buscan una pérdida, mayor si cabe, de capacidad y calidad de ordenación en búsqueda de la liberalización de la intervención privada, son de gran interés las que desde la crítica constructiva buscan recuperar y rediseñar unas herramientas de planificación eficaces. Una postura crítica que empieza por admitir que a lo largo de las últimas dos décadas las influencias de ciertas inercias neoliberales han logrado desprestigiar al planeamiento:

«Se ha querido acabar con el oficio de convertir en propuestas transformadoras y vivificadoras el conocimiento adquirido mediante el estudio concreto de los fenómenos sociales y urbanos, que en la actualidad se debate frente a una cuidadosamente elaborada urdimbre de falsos conceptos. Se ha obstaculizado la elaboración de esas propuestas bajo formas participativas que garanticen su legitimidad democrática. Cambios radicales en la demografía, en las estructuras sociales, en la división internacional del trabajo, en las relaciones entre modos de producción diversos, en las propias formas de reproducción social, todos ellos condicionantes profundos de nuestro futuro, han quedado fuera del alcance de la planificación. Se ha renunciado a considerar y gobernar el porvenir de nuestros territorios y, no contentos con ello, condenamos o ignoramos fuerzas positivas o renunciamos a imaginar alternativas, mientras acogemos con entusiasmo toda suerte de patologías que ni siquiera somos capaces de describir con un mínimo de rigor — nuevas centralidades, movilidad exacerbada con proliferación de infraestructuras cada vez más costosas y vulnerables, gentrificación, normalización-exclusión inmobiliaria, etc.- pero que alteran el tejido de relaciones sociales de nuestras ciudades y profundizan su sometimiento a un sistema económico sin futuro» (Roch et al., 2011: 6).

En esta línea, se puede afirmar que en el fondo de la planificación «subyace un problema político» (Fariña, 2007: 238). Y una de las consecuencias es la actual rigidez y obsolescencia de las herramientas de planificación espacial, de las que a continuación se muestran algunos ejemplos. Esto ha impedido que esta evolucione y se adapte al contexto cambiante mediante el enfoque en la reparación y recuperación de la ciudad existente, y ha supuesto la pérdida de capacidad de gestión del conjunto global del territorio, ligado más a intereses particulares que colectivos. A pesar de estar las 
competencias urbanísticas en manos de las Comunidades Autónomas, las bases del modelo asentadas en 1956 con la Ley sobre Régimen del Suelo y Ordenación Urbana son compartidas por todas las legislaciones autonómicas. Un modelo que se debía a las necesidades concretas de un tiempo y contexto particular, pero que «ha subsistido mucho más allá que la situación de emergencia que lo justificó, dando lugar a efectos contrarios a los que motivaron su alumbramiento» (Tejerina, 2016: 30). Efectivamente, se trata de una ley que «nació para dar respuesta a una necesidad perentoria, la creación de viviendas suficientes para que los polos de desarrollo industrial pudieran contar con la mano de obra que necesitaban y cuya satisfacción no podía ser atendida con fondos públicos» (Tejerina, 2016: 26), y cuyo objeto era la regulación de la propiedad privada. Esa falta de financiación fue lo que motivó la búsqueda de fórmulas que permitiesen hacer ciudad nueva trasladando la función pública del urbanismo a manos privadas. Para hacer atractiva dicha estrategia de cara a la promoción privada, la obligación de urbanizar se veía compensada por la garantía de un beneficio económico asegurado por las metodologías de valoración. De esta manera, el suelo era una garantía de acceso a la financiación. Quedó de esta manera, y bajo este modelo, eliminado el riesgo propio de toda apuesta empresarial, incluso llegando a ofrecer para casos excepcionales de operaciones costosas que la administración se hiciese cargo de parte de los costes originalmente correspondientes a la propiedad ${ }^{61}$.

Si con lo anterior quedaba asegurada la intervención privada en la expansión de la ciudad y en la urbanización de los suelos necesarios para albergar las viviendas demandadas, el sistema quedaba completo con una serie de maniobras para hacer atractiva, a la propiedad final, la compra de vivienda. Algunas de ellas fueron el blindaje del suelo urbano consolidado y la inmunidad de lo construido ante futuros nuevos planeamientos -hasta que se sustituyese el edificio- «a pesar de que la función social de la propiedad ya se había incorporado años atrás al derecho positivo español (art. 30 del Fuero de los Españoles de 18/07/1945)» (Tejerina, 2016:28). Lo cual sumado a otras herramientas como los incentivos fiscales, plantaron en la sociedad española la semilla de la supuesta 'cultura inmobiliaria de la propiedad' y el crecimiento continuo de la ciudad. El legado negativo de este modelo es, con mayor o menor intensidad según el ámbito geográfico, un excedente de viviendas, unos crecimientos

${ }^{61} \mathrm{El}$ Artículo 121 del texto refundido de la Ley sobre Régimen del Suelo y Ordenación Urbana de 1976 establecía que «Cuando la actuación en determinados polígonos o unidades de actuación no sea presumiblemente rentable, por resultar excesivas las cargas en relación con el escaso aprovechamiento previsto para las zonas edificables, el Consejo de Ministros, a propuesta del Ministro de la Vivienda y previo dictamen del Consejo de Estado, con audiencia, o en su caso, a instancia de los Ayuntamientos interesados, podrá autorizar, sin modificar las determinaciones del Plan, una reducción de la contribución de los propietarios a las mismas o una compensación económica a cargo de la Administración, procurando equiparar los costes de la actuación a las de otras análogas, que hayan resultado viables». 
desequilibrados, la destrucción y fragmentación del territorio, y una vivienda económicamente inaccesible.

Se trata de un modelo que se ha ido heredando de una ley a otra, con pequeños cambios, pero cuya estructura e ideología persiste. Así ha sido en los textos refundidos de 1976 y 1992 -este último anulado por el Tribunal Constitucional en 1997-, y en la Ley del Régimen del Suelo y Valoraciones de 1998. Hasta que, en cuanto a las competencias estatales se refiere, se han producido en los últimos años varios hitos importantes en lo relativo a un cambio en el fondo del asunto: la Ley del Suelo de 2007 y la Ley de Rehabilitación, Regeneración y Renovación Urbanas de 2013, refundidas ambas en la actual Ley de Suelo y Rehabilitación Urbana de 2015. Supusieron cambios positivos en cuanto a los derechos del ciudadano, la regulación de las obligaciones de la propiedad, la sostenibilidad de la ciudad existente, la eliminación de las expectativas a la hora de valorar los suelos, la redefinición del concepto de viabilidad económica de las operaciones urbanísticas, o el establecimiento de la obligación de actualización de la propiedad, por citar algunos. Sin embargo, en Euskadi la Ley de Suelo y Urbanismo de 2006 sigue enmarcada en el modelo de 1956, especialmente en el tratamiento del agente promotor y de la propiedad final. Una de las más graves consecuencias de todo ello es la necesidad de recordar que aunque «es frecuente considerar que este modelo es lo normal o natural, conviene advertir que el sistema urbanístico del periodo 1956-2006 puede considerarse único en el derecho comparado» (Tejerina, 2016: 29).

La permanencia en el tiempo del modelo se ha visto enfrentada a toda una serie de cambios y transformaciones sociales, las cuales «aparentemente no han afectado a las bases de los planes de urbanismo (la mayor parte de los grandes planes son los mismos y únicamente se han realizado en ellos modificaciones puntuales para posibilitar grandes operaciones de proyecto urbano)» (España, Ministerio de Vivienda, 2010: 23). En el AMB, en las últimas décadas puede estimarse una media de más de diez modificaciones puntuales de planeamiento al año sumando las de todos sus municipios. Analizados los datos absolutos por municipio, se observa una ingente producción de modificaciones, lo cual indica entre otras cosas una enorme obsolescencia e incapacidad de la herramienta para responder de manera flexible a las necesidades y cambios de su municipio:

«...la mayor parte de las ciudades españolas se están limitando a mantener sus planes generales, normalmente muy antiguos, y funcionan mediante modificaciones puntuales de planeamiento. Estas modificaciones puntuales de planeamiento en muchas ocasiones son tan importantes que cambian de forma determinante la imagen planteada en el plan sin tener en consideración las implicaciones que puedan incidir sobre el resto de la ciudad y su área de influencia. Esta situación, tanto en la planificación territorial como del planeamiento urbanístico, está sometiendo a una parálisis la ordenación 
racional de nuestros territorios que se están organizando y construyendo en función de intereses más particulares que colectivos. Esta falta de visión global del territorio y la escasa implicación de la ciudadanía en un proceso que se le escapa, ha traído consigo que no sea posible atender más que al corto plazo» (España, Ministerio de Vivienda, 2010: 27).

Quizás la existencia de ciertas «rutinas establecidas que, en parte, parecen entender el planeamiento urbanístico con la asignación casi discrecional (en el mejor de los casos) de valor económico al suelo» (España, Ministerio de Vivienda, 2010: 25), ayudan a que -hasta el cambio de modelo con la Ley de Rehabilitación, Regeneración y Renovación Urbanas de 2013- el planeamiento siga enfocado y diseñado para la creación de nueva ciudad sobre suelos no urbanizados pues «ya desde los primeros planes y leyes de ensanche el interés del planificador español se centraba en la extensión de la ciudad, de forma que nunca se han creado instrumentos que verdaderamente sirvieran para intervenir en el interior de los cascos, en la ciudad consolidada» (España, Ministerio de Vivienda, 2010: 20). Reflexión que, como ya se ha visto, ya venía reflejada en la Exposición de Motivos de la Ley del Suelo de 2007. El asunto se agrava porque además no se ha contado con la información ni los instrumentos necesarios para evaluar las consecuencias de un «aparato ideológico, cultural, profesional y de información [...] orientado al crecimiento» (Prats, 2007: 95). Estas herramientas se han convertido así en un instrumento dirigido casi exclusivamente a la clasificación y calificación de nuevo suelo a urbanizar según intereses económicos y dando la espalda a las necesidades actuales de las ciudades, que debieran estar más dirigidas a la gestión, mantenimiento y búsqueda de la eficiencia de la ciudad existente.

Este modelo expansivo desincentiva la actuación sobre la ciudad existente no solo por carecer de las herramientas adecuadas, si no porque además la protección del propietario final ha impedido en muchos casos dicha intervención. En otros, aún habiendo un interés en rehabilitar y regenerar no hay capacidad económica para afrontar dichos trabajos debido al alto endeudamiento necesario. Dado que hasta hace bien poco las únicas herramientas de actuación en lo consolidado disponibles trataban a estos suelos casi como urbanizables -con operaciones de tamaño medio o grande que seguían un esquema de derribo total y aumento de la edificabilidad, y que dependían de la viabilidad económica para su aprobación-, si el agente promotor no atisbaba beneficios la operación no se llevaba a cabo, por mucho que existiera una necesidad detrás. Además, el contexto social y ambiental llevan a plantear la obsolescencia de estos planteamientos. Con una población en proceso de reducción o estancamiento, no hay una demanda suficiente para cubrir toda la vivienda necesaria para financiar y hacer económicamente viables las operaciones bajo dichos esquemas. Por otro lado, cuestiones como el alto consumo de recursos materiales y energéticos propios de la 
construcción, la producción de residuos asociados, o los efectos de exclusión social que conllevan habitualmente estas operaciones hacen cuestionar el modelo. Por lo que «conseguir a través de los mecanismos urbanísticos vigentes ciudades y territorios más sostenibles pasa, necesariamente, por cambiar previamente algunas de las piezas clave del sistema actual» (España, Ministerio de Vivienda, 2010: 25).

Las nuevas herramientas de intervención en el parque existente hoy día vigentes con el Texto Refundido de la Ley de Suelo y Rehabilitación Urbana de 2015 suponen un gran avance y han introducido variables con un objetivo más solidario, una visión de comunidad y una mayor viabilidad de las operaciones. Sin embargo, mientras la Ley de Suelo y Urbanismo de Euskadi de 2006 no se actualice, la incompatibilidad entre ambas es absoluta. Las técnicas de la segunda -heredadas del modelo de 1956- son difícilmente aplicables en muchos casos de la ciudad existente, y las aportaciones al respecto de la Ley de Vivienda de Euskadi plantean un difícil encaje normativo. Las muestras de caducidad del marco normativo son por tanto diversas, ya sea presentado «cada vez menos capacidad de regulación del desarrollo territorial en espacios metropolitanos» con una ausencia de estructuras de gobernanza territorial eficaces relacionadas con la gestión del suelo y sus diferentes actividades a estas escalas (Valenzuela y Soria, 2012: 82), o debido a su lentitud de respuesta ante las dinámicas espaciales. En este sentido, los largos plazos del estudio, diagnóstico, redacción y aprobación de los instrumentos de ordenación hace que en ocasiones las reacciones lleguen tarde y desfasadas, por mucho que sean originalmente adecuadas. Es el caso del Plan Territorial Parcial del Bilbao Metropolitano -actualmente en revisión-. El documento presentaba una reflexión y diagnóstico acertados, identificando una colonización constante de suelo en ocasiones bajo modelos de asentamiento poco aconsejables para un área con limitaciones, proponiéndose frenar el consumo de nuevo suelo invirtiendo la tendencia de los años anteriores, buscando dar respuesta a la necesidad frente a la demanda de vivienda, y estableciendo unos criterios de intervención que dan prioridad a unos suelos sobre otros (Decreto 179/2006, de 26 de septiembre, Anexo I-Memoria, 2006).

Y sin embargo, se trata de un instrumento que inicia su tramitación en 1997, se aprueba inicialmente en 2003 y definitivamente en 2006. Es decir, pasan nueve años desde la redacción del primer avance hasta su puesta en vigor. El desfase respecto a la realidad con el que un documento así puede llegar a entrar en funcionamiento es considerable; pero incluso una vez aprobado, para que algunos de sus planteamientos se cumplan, los instrumentos de ordenación urbana municipales deben adecuarse al mismo. Observadas las fechas de aprobación de estos (Tabla 2.10), solo siete son posteriores al PTP. En el resto, aunque se hayan podido realizar modificaciones puntuales al respecto, no cuentan con una revisión estructural de todo su 
territorio siguiendo las directrices de reducción de consumo de suelo planteadas por el instrumento regional.

\begin{tabular}{lll}
\hline Municipio & Aprobación & Modificaciones \\
\hline Abanto Zierbena & 2012 & 1 \\
Alonsotegi & 1998 & 11 \\
Arrigorriaga & 1999 & 12 \\
Barakaldo & 2000 & 13 \\
Barrika & 1991 & 12 \\
Basauri & 2000 & 17 \\
Berango & 2011 & 0 \\
Bilbao & 1995 & 193 \\
Derio & 2003 & 9 \\
Erandio & 1992 & 43 \\
Etxebarri & 2002 & 8 \\
Galdakao & 1995 & 20 \\
Getxo & 2001 & 34 \\
Larrabetzu & 2017 & 0 \\
Leioa & 2001 & 29 \\
Lezama & 1988 & 8 \\
Loiu & 2011 & 0 \\
Muskiz & 1992 & 25 \\
Ortuella & 1985 & 24 \\
Portugalete & 2010 & 5 \\
Santurtzi & 1998 & 29 \\
Sestao & 2000 & 15 \\
Sondika & 1997 & 26 \\
Sopela & 1999 & 11 \\
Trapagaran & 2015 & 0 \\
Urduliz & 2000 & 9 \\
Zamudio & 2008 & 0 \\
Zaratamo & & 0 \\
Zierbena & 2016 \\
\hline & & 6 \\
\hline
\end{tabular}

Tabla 2.10. Año de aprobación del planeamiento vigente por municipio en el AMB, y número de modificaciones puntuales aprobadas desde entonces. Udalplan, 2017.

Por otro lado, existen posturas que abogan por caminos para la planificación e intervención espacial en la ciudad diferentes a los propios de los instrumentos habituales, especialmente ante retos de 
una escala y complejidad relevantes. Tales fueron las fórmulas bajo las cuales se han desarrollado las operaciones urbanísticas desarrolladas y promovidas por Bilbao Ría 2000. Esta «compañía sin ánimo de lucro» para la regeneración urbanística de Bilbao y su entorno (Bilbao Ría 2000, 2017) fue creada con el objetivo de impulsar una serie de grandes operaciones identificadas por el Plan General de Ordenación Urbana de Bilbao de 1987. Para ello, administraciones vascas y del estado participaron al 50\% con una aportación inicial de 1,8 millones de euros. La fórmula utilizada para las operaciones realizadas tanto en Bilbao como en otros municipios del AMB se basa en que «instituciones y empresas públicas, han cedido terrenos en desuso que poseían en zonas centrales de la metrópoli al tiempo que los correspondientes ayuntamientos modificaban los usos previstos para esos suelos [...] Las eventuales plusvalías que se generan con la venta de las parcelas se reinvierten en actuaciones urbanísticas y de infraestructuras -ferroviarias en muchos casos-, beneficiosas para los municipios y sus ciudadanos, que ven mejorado el entorno urbano y el transporte público» (Bilbao Ría 2000, 2017). Estratégicamente, su «forma jurídica de sociedad anónima de capital público se adoptó con el fin de agilizar la toma de decisiones, a pesar de que los socios son en su totalidad instituciones públicas» (Rodríguez, 2002: 89). Este urbanismo de proyectos a base de grandes intervenciones parciales en la ciudad ha tenido un importante auge en episodios recientes, favorecido por y a la vez alimentando una pérdida de confianza en el planeamiento, desplazando de facto a este como instrumento integrador:

«El traspaso de poderes de planificación y ejecución a la sociedad Bilbao Ría 2000 desplaza a las estructuras tradicionales fuera del núcleo duro de la gestión de las actuaciones estratégicas, lo que no está exento de conflictos y polémicas. [...] Ría 2000 actúa, de hecho, como una agencia pública con una importante capacidad de determinación de funciones de planeamiento en la medida que adopta decisiones sobre prioridades de intervención, disposición de suelo y otras propiedades y gestión de fondos públicos para el desarrollo de iniciativas. $Y$, aunque los instrumentos reguladores tradicionales son aún la referencia legal, las nuevas dinámicas de aplicación, ejecución y gestión han ido reduciendo su importancia como mecanismos de ordenación. La acción de Ría 2000 ha ido, de este modo, desplazando gradualmente los departamentos de planeamiento tradicionales a un segundo plano mediante la asunción de un número cada vez mayor de poderes relacionados con la revitalización urbana, incluyendo la gestión de las operaciones y proyectos más emblemáticos de la ciudad y del área metropolitana» (Rodríguez, 2002: 95).

Y sin embargo, como la propia autora plantea tomando como caso de estudio la operación de Abandoibarra en Bilbao -quizás uno de los casos más paradigmáticos de este modelo de actuación, no solo en el 
AMB-, se trata de un modelo de intervención que, emulando las lógicas del sector privado y confundiendo arquitectura y urbanismo, tiene grandes carencias que ella identifica en tres principales puntos. Primero, una enorme dependencia de la viabilidad económica que llevó a continuos y profundos cambios y ajustes en el contenido de la actuación, manteniendo la viabilidad a corto plazo por encima de los planteamientos estratégicos a medio plazo, lo cual choca con la imagen que se pretende dar de operación estratégica planificada. Segundo, se actúa desde una visión simplista y parcial de los procesos de revitalización urbana reducidos a cuestiones morfológicas y de viabilidad financiera que deja fuera de la ecuación múltiples variables y agentes sociales y económicos de una realidad diversa y compleja. Y por último, se trata de grandes proyectos que lejos de estar autofinanciados como se busca aparentar, necesitan de una enorme cantidad de recursos públicos que de una manera u otra son extraídos de otras áreas o destinos, logrando así un efecto de polarización y exclusión urbana y social. Se conforma por tanto una herramienta que no solo ha enfocado con cierta parcialidad las intervenciones en la metrópoli, si no que ha fomentado y asentado un modelo urbanístico especulativo con graves consecuencias y vienen a cuestionar su valide $^{62}$ para ser replicado en otros lugares.

En definitiva, son múltiples las voces que reclaman una mayor flexibilidad y capacidad de previsión y adaptación por parte de las herramientas de planificación espacial. Es fundamental «entender el plan urbanístico como un instrumento flexible en sus contenidos y propuestas, siendo capaz de anticiparse y de adaptarse a las cambiantes dinámicas metropolitanas, algo que como se ha podido comprobar, es una capacidad prácticamente nula» (Valenzuela y Soria, 2012: 101). La dimensión multiescalar de la crisis urbana y de recursos naturales lleva a plantear que «planes y proyectos deben hoy dar una respuesta innovadora a los nuevos desafíos sociales y ambientales. El "desarrollismo" crecimentista hoy no es viable materialmente ni aceptable moralmente. La austeridad y la recuperación de los recursos básicos contra el despilfarro, las energías blandas para substituir las que están en vías de agotamiento y la apuesta por la calidad de vida de todos y la reducción de las desigualdades sociales son hoy imperativos

62 A principios de la década de 2010 diversos medios se hicieron eco de la grave situación financiera por la que pasaba la sociedad Bilbao Ría 2000, como consecuencia de la falta de entrada de capital al no contar con operaciones urbanísticas en curso. Con una deuda en 2013 de cerca de 200 millones de euros, se despidió al 38\% de la plantilla y se iniciaron pasos para su disolución. Finalmente, gracias a pequeñas operaciones en 2017 la deuda se había reducido a 60 millones y las expectativas generadas por otras actuaciones mantienen a la sociedad con vida. Se trata, sin embargo, de una entidad que en palabras del entonces diputado general de Bizkaia tiene su modelo agotado, ya que es «una sociedad anónima con ánimo de lucro para generar beneficios contables, aunque otra cosa es qué hace con esos beneficios $[\ldots]$ esta falta de ingresos recurrentes agudiza la situación de la compañía, ya que prevén que, a partir de mediados de 2014, pudiera, si no se toman medidas, tener incluso problemas para pagar los gastos corrientes» (El Correo (2013): «"Bilbao Ría 2000 está abocada a un crack financiero o a un plan de cierre ordenado"», disponible en http://www.elcorreo.com/vizcaya/20130612/local/jose-luis-bilbao-bilbao-

201306121321.html). 
urbanos» (Borja, 2011: 87). Se trata de una llamada a la renovación de un planeamiento encorsetado y extremadamente enfocado casi con exclusividad a cuestiones que no abarcan todo lo que es el urbanismo, como la viabilidad económica, y que parece haber desplazado y aislado el interés enfocando sobre todo retos propios de las complejas herramientas a aplicar, dejando de lado lo que nunca debería: la capacidad propositiva del urbanismo más allá de las clasificaciones de suelo, las tramitaciones o los sistemas de actuación (Espuelas, 2007: 10). Lo que implica tomar medidas en cuestiones tan fundamentales como la recogida de información continua y compleja:

«...debería de existir una mayor implicación de la ciudadanía en los procedimientos de cambio y un sistema de información que permitiera analizar en tiempo real la situación de la ciudad o de los territorios afectados y proyectar tendencias y escenarios de futuro. Hay que considerar que la redacción de un plan general en la mayor parte de los casos, puede necesitar desde el momento en el que se produce la toma de datos (lo que se conoce como información urbanística) hasta que el plan se aprueba, como mínimo un plazo de cinco o seis años. En estas condiciones, los datos de partida en los que se ha basado la redacción del plan en muchos casos ya no coinciden con los reales. La planificación territorial debería contar con instrumentos que permitieran hacer de puente con el planeamiento urbanístico, adaptando el planeamiento municipal a determinaciones especificadas a una escala más amplia» (España, Ministerio de Vivienda, 2010: 27).

De forma que «contar con bases de datos específicas y espacializadas, conjuntamente con series temporales largas, es una tarea prioritaria con el fin de flexibilizar y adaptar el planeamiento urbanístico al desarrollo metropolitano» (Valenzuela y Soria, 2012: 101). Todo lo anterior refuerza «la vigencia del urbanismo como disciplina imprescindible no solamente para analizar la realidad urbana, sino para proyectarla y configurarla» (Espuelas, 2007: 9), y la necesidad de la existencia del planeamiento, eso sí, un planeamiento diferente al que se conoce ahora, con otras preocupaciones (Roch, 2007: 121). Todo ello, resulta un marco imprescindible para una adecuada gestión global de, en el caso de esta investigación, el parque residencial existente.

\section{Superficialidad e incompatibilidad del discurso}

Como se viene argumentando, el sistema de gobernanza urbana analizado es complejo y presenta múltiples interrelaciones y afecciones. En los propios instrumentos de ordenación espacial conviven planteamientos a menudo enfrentados, como reflejo de la diversidad de posturas, intereses y fuerzas de los agentes que los redactan y los influyen. Así, los retos que el contexto marcaba en ese Contenido inicial son progresivamente identificados, interiorizados e 
incorporados a los discursos y las herramientas para la puesta en marcha de políticas urbanas y territoriales. De alguna manera, se trata de una incorporación paulatina de intenciones para dar pequeños pasos hacia la adaptación de estos instrumentos en la búsqueda de respuestas adecuadas al entorno. Algunos ejemplos ya citados evidencian un lento, pero palpable, giro en el rumbo de las políticas espaciales. Sin embargo, en algunas ocasiones y ya sea por las inercias y lógicas enfrentadas dentro del propio modelo o por simple incompatibilidad -legal, temporal, estructural,...- la incorporación de estos discursos se queda en un mero ejercicio de redacción y sin llegar a la fase ejecutiva. No se logra regular adecuadamente, imponerse a determinados fenómenos, ni hacer cambios estructurales en el discurso, quedándose en actos superficiales y/o incompatibles. El resultado final refleja -como se viene demostrando en este apartadocómo el modelo reacciona colocando en modo stand-by una serie de planteamientos progresistas que de alguna manera ya han sido asumidos por los instrumentos. Y que cuentan con un fuerte respaldo social, político o académico -mostrado en la fase del Contenido-, pero con los que el sistema como conjunto no acaba de ser del todo consecuente. Desde la propia administración se han promovido trabajos que analizan y evidencian este desfase entre discurso y resultados, poniendo el énfasis en las carencias a la hora de ejecutar y poner en práctica criterios urgentes, como puede ser la incorporación de la sostenibilidad en el planeamiento urbano (España, Ministerio de Vivienda, 2010).

En el caso de Euskadi, existe un ejemplo paradigmático tanto por la facilidad con la que se puede identificar en él este problema, como por la escala de su ámbito de actuación e influencia. Se trata de las Directrices de Ordenación del Territorio ya citadas anteriormente. En ellas se planteaban objetivos como el de garantizar para cada punto del territorio la conservación de sus valores ecológicos, paisajísticos, productivos y científico-culturales. Pero estos convivían con un bajo nivel de vinculación de muchas de sus determinaciones, y con un planteamiento de fondo que seguía bajo la influencia de un modelo urbanístico marcado por el crecimiento y la dictadura del aumento del número de viviendas en todos los municipios vascos. Algunas de las personas cercanas al proceso de redacción de este instrumento, o que han estudiado el mismo, resaltan cómo a lo largo de las correspondientes redacciones y aprobaciones parciales fueron perdiendo fuerza algunas de sus principios más relevantes. Así, «la matriz de ordenación de usos para el suelo no urbanizable fue sustancialmente reducida tanto en lo referente a las Categorías de Ordenación propuestas como a las actividades y usos a ordenar así como a sus determinaciones vinculantes directas» (Urkidi, 2010: 194). En este contexto, el propio autor señala que uno de los principales planteamientos vinculantes de las DOT -orientado al control y la limitación del crecimiento difuso de la vivienda unifamiliar aislada en suelo no urbanizable - está viéndose debilitado de la mano de otros instrumentos de planificación territorial: 
«...las posteriores leyes de urbanismo (1998 y especialmente la del suelo de 2006) supusieron una modificación importante de la vía abierta por las DOT. Efectivamente, la ambigüedad que en esas leyes se ha tenido para definir el concepto de núcleo rural y su posible desarrollo e interpretación por parte de los municipios está permitiendo que, especialmente donde la presión de la demanda de este tipo de construcción es importante, se esté dando procesos de crecimiento urbano difuso que precisamente se estaba tratando de evitar con la determinación vinculante de las DOT, que muchas veces superan ampliamente al crecimiento unido al casco urbano de algunos municipios» (Urkidi, 2010: 195).

Dentro del propio documento, la incompatibilidad de algunos de sus planteamientos con la hegemónica prioridad del desarrollo económico hace que los primeros se hayan visto abocados al fracaso, la exclusión o un debilitamiento en su puesta en práctica. Las DOT propusieron allá por 1997 «conseguir los objetivos marcados en el ámbito económico a la vez que un cuidado y mejora del medio ambiente y de la calidad de vida, y el modelo de crecimiento en el que se apoya el sistema actual hace dudar de una verdadera compatibilidad de todo ello» (Etxabe, 2012: 30). Entre los retos y desafíos de futuro se planteaba la «máxima flexibilidad que sea posible combinado con el máximo control que sea necesario» (Decreto 28/1997, de 12 de febrero, Suplemento, 1997: 57) respecto al tratamiento del medio físico. Ejemplo que muestra con claridad una ambigüedad que abre la puerta a interpretaciones interesadas hacia uno u otro lado, y que se refuerza en otros apartados del texto: «la política de suelo deberá atender tanto a las demandas sociales de construcción de viviendas de baja densidad, como a las demandas existentes de parte de la población que desea habitar en el centro de las ciudades donde se precisa de un nuevo urbanismo que conlleva acciones de rehabilitación y dotación de equipamientos y de espacios de esparcimiento» (Decreto 28/1997, de 12 de febrero, Suplemento, 1997: 88).

En el largo proceso de revisión de esta herramienta de ordenación territorial, iniciado en 2011, aparece con fuerza un discurso aparentemente transversal hacia una pretendida sostenibilidad. Discurso del que tras la lectura y análisis de los documentos de trabajo se obtiene que «pretende añadir dicho concepto al modelo de base como una capa más, sin desplazar algunas cuestiones que debería hacer si se tratase de un planteamiento realmente consecuente con el verdadero significado del término. Además, se plantea el término de manera indisociable a la innovación, con el objetivo común de aumentar la competitividad del territorio [...] en un contexto de no crecimiento» (Etxabe, 2012: 31). Esta contradicción recuerda a la que algunos autores han identificado en otros instrumentos, como es el caso del ya mencionado Pacto Social por la Vivienda de Euskadi firmado en 2010: «no se puede ser a la vez productivista y 
medioambientalista, no se puede apostar por la construcción masiva de nueva vivienda protegida y a la vez decir que el centro de gravedad de la política de vivienda debe ser la rehabilitación y regeneración urbana» (Burón, 2010). Afirmación que sería aplicable al caso de las DOT al introducir una serie de relatos a favor del cambio, pero incompatibles con un discurso anterior que no se altera. Esto es posible en la medida que la «difusión y la efectividad de este lenguaje prueban el triunfo de la sociedad sobre las contradicciones que contiene: las mentiras son reproducidas sin que hagan estallar el sistema social. Y la franca, ostensible contradicción se convierte en constante del habla y la publicidad» (Marcuse, 1985:119). La relevancia de este condicionante y obstáculo es importante, y no se reduce a cuestiones formales. Al contrario, el discurso y el lenguaje son fuerzas fundamentales a la hora de conformar el imaginario político y, en consecuencia, a la hora de influir en la lucha y reivindicación política (Jessop, 2017:172). También en la escala intermedia de los PTP se pueden localizar este tipo de obstáculos. Existe un clara disociación al aparecer, por un lado, un discurso que acepta la escasez de suelo, la necesidad de modelos urbanísticos eficientes, la optimización del patrimonio edificado o la puesta en carga de las viviendas vacías, entre otras cuestiones. Y por otro, una materialización que no solo no se ve obligada por las diagnosis incorporadas en las memorias de estos documentos, si no que además generan profundas consecuencias:

«Incluso en el caso de que efectivamente los municipios opten finalmente por propuestas de nuevo suelo residencial sostenibles, el mero hecho de que se conciban tan amplias expectativas sobre posibles clasificaciones de suelo urbanizable genera tal cúmulo de efectos indeseados sobre el medio rural vasco que sólo por esa razón merece la pena replantearse la metodología seguida a la hora de estimar el suelo necesario para dar respuesta a la demanda de vivienda [...] No es suficiente con plantear plausibles objetivos en pro de la sostenibilidad, es necesario garantizar su implementación más allá de la retórica que a día de hoy impregna la declaración de intenciones de prácticamente cualquier Plan o Programa» (Ainz et al., 2008: 123).

Los condicionantes y obstáculos mostrados hasta aquí no son los únicos que ejercen una influencia negativa en el correcto desarrollo del proceso de gobernanza urbana planteado en el Esquema 2.1. Sin embargo, el objetivo de este recorrido parcial ha sido mostrar y desarrollar algunas de las principales fuerzas y razones que están detrás de la generación de contradicciones a la hora de dar forma e implementar políticas de vivienda en un contexto vasco en general, y centrado en el Área Metropolitana de Bilbao en particular. Todo el recorrido realizado a lo largo de este capítulo se sintetiza en el Esquema 2.3, que completa y desarrolla el 2.1. 


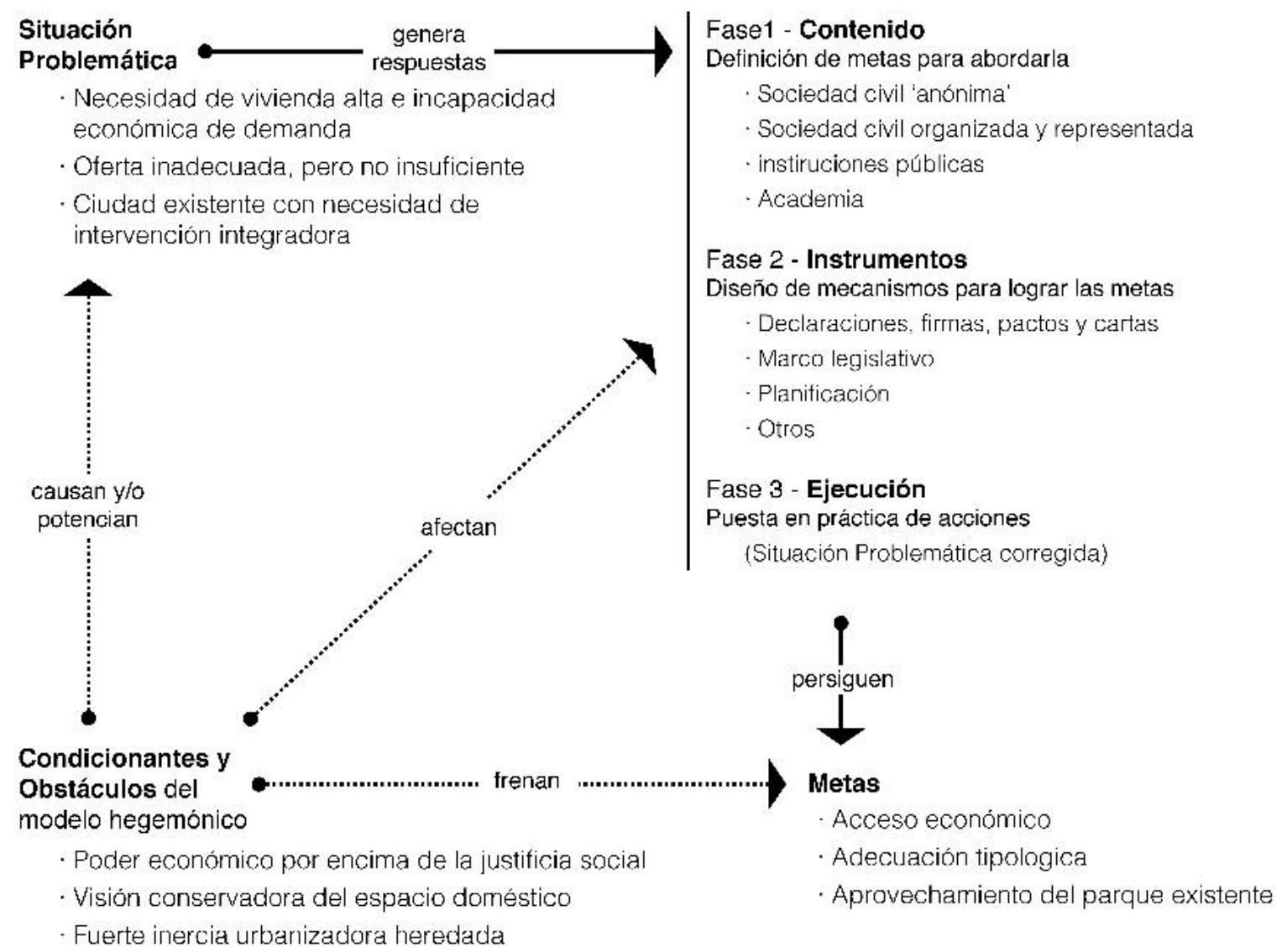

Esquema 2.3. Síntesis del desarrollo de la generación de contradicciones en procesos de gobernanza urbana planteada en

el Esquema 2.1 a partir del contenido elaborado en el capítulo. Elaboración propia. 


\section{$-2.7-$ \\ $¿$ ¿Hay alternativas?}

La aplicación de la herramienta propuesta para identificar y comprender la generación de contradicciones en procesos de gobernanza urbana al caso de estudio permite dar por buena la misma. Esta segunda validez empírica (para una primera teórica ver apartado 2.1.2) ofrece un mapa, y el papel en él desarrollado, de la diversidad de agentes que forman parte $-\mathrm{O}$ son excluidos- de esa gobernanza parcialmente abierta, desequilibrada y re-jerarquizada aquí parcialmente mostrada que evidencia un marco altamente contradictorio y desigual que alimenta la reproducción del modelo de vivienda predominante. En él, el desarrollo de ciertas políticas, iniciativas y debates de vivienda progresistas se enfrentan a una serie de condicionantes y obstáculos que, en muchas ocasiones, aparecen reflejados en los discursos, herramientas o acciones de los agentes que los intentan combatir. En este sentido, la aplicación del esquema propuesto ayuda a identificar conflictos contradictorios no solo entre agentes, si no dentro de los mismos. Plantear la lucha por la vivienda como una cuestión de bandos enfrentados -lo cual habitualmente se da a entender, si bien existen posiciones y colectivos con poderes $y / o$ con planteamientos en extremos opuestos- simplifica en exceso la cuestión y no permite abordar con rigor la complejidad de una problemática mucho más diversa. Corre el peligro de desviar la atención y los esfuerzos hacia objetivos parciales muy difíciles de lograr; de centrarse en los efectos en vez de en las causas.

Como principal interpretación de lo hasta aquí desarrollado, y en el marco de la herramienta, puede decirse que se necesitan vías para definir un Contenido con mayor consenso, diseñar unos Instrumentos más eficaces y acordes con el anterior, y enlazar todo ello con una Ejecución final más exitosa. Caminos que garanticen reducir la brecha existente entre un Contenido en muchos casos limitado a ejercicios discursivos y unas Metas que en ocasiones presentan síntomas de empeoramiento. Respuestas que logren una mayor consecución de las Metas iniciales salvando y reduciendo los Condicionantes y Obstáculos identificados. Esto puede lograrse tanto generando nuevos puentes para dichos caminos, como potenciando y fortaleciendo los ya existentes - en muchos casos débiles-, o influyendo directamente en el origen de las contradicciones de fondo. El peso que esta primera parte de la investigación toma se entiende como necesario para dotar a la misma de un marco analítico adecuado. Así, la herramienta de análisis anteriormente presentada y aplicada busca dotar a la investigación de una base a partir de la cual abordar la problemática desde la alternativa. En la medida en que la hipótesis preliminar establecía que esta surge por y de la contradicción 
existente, y que será a través de esta que podrán aprovecharse y desarrollarse espacios de oportunidad y de poder para reducir la situación problemática, un primer paso es contextualizar el análisis realizado en el sistema internamente contradictorio que es el capitalismo, del que forma parte este conjunto de conflictos. Los resultados de esta primera parte del trabajo permiten estudiar algunas contradicciones propias del sistema existente y plantear, tras el análisis del contexto que se ha presentado, la existencia de espacios de oportunidad en el marco urbano, normativo y socio-económico actual que estén siendo o puedan ser impulsados por determinados agentes participantes en una gestión no convencional de la vivienda para avanzar hacia las metas definidas.

A partir de la identificación de dos principales contradicciones estructurales del modelo residencial actual en las que situar todo el análisis arriba desarrollado, y del estudio y la interpretación de las mismas bajo una mirada crítica, es posible rearmar y concretar la hipótesis inicial planteando la existencia en el AMB de dos correspondientes alternativas que además son complementarias y mutuamente enriquecedoras. Puede leerse todo ello como un ejercicio intelectual que combina tres diferentes niveles de análisis con la intención de perseguir una serie de preguntas de la investigación: partiendo de un primer nivel abstracto -centrado en una generalidad teórica y en las principales características de un contexto capitalista-, atravesando un segundo nivel intermedio -que acota los arreglos institucionales, marcos regulatorios, configuraciones territoriales, $\mathrm{O}$ dinámicas socio-demográficas comunes a periodos más o menos amplios-, y terminando en un nivel concreto -aterrizando lo anterior en periodos y contextos geográficos específicos y diversos, mediante el trabajo empírico- (Brenner, 2004: 17-23).

$$
-2.7 .1-
$$

\section{Contextualizando las contradicciones en un marco estructural}

Las dos grandes contradicciones en las que el trabajo previo puede ser contextualizado son una visión parcial de ese carácter contradictorio de la condición urbana previamente señalado. Contradicciones que no solo juegan un papel clave permitiendo y alimentando la acumulación de capital y la búsqueda de excedentes para la reproducción del capitalismo mediante arreglos espaciotemporales provisionales (Harvey, 2014), si no que se consolidan y extienden precisamente gracias a que dicho sistema de organización social se reproduce. 


\section{$1^{\text {a }}$ contradicción: Oferta vs. Demanda}

«...la discrepancia entre la ideología de la autorregulación de mercado y la realidad cotidiana del estancamiento económico presente -la creciente desigualdad, la competencia destructiva entre ciudades y la inseguridad social generalizada- se ha tornado particularmente evidente, precisamente, en aquellos contextos económico-políticos en los que las doctrinas neoliberales se han impuesto de forma más extensiva» (Brenner y Theodore, 2017: 118).

La primera contradicción es la que se refiere a la existencia de un desfase de tipologías espaciales y precios entre la oferta del parque residencial existente - privado y público- y los cambios, la evolución y la diversificación de los perfiles de muchas de esas unidades de convivencia que presentan una alta necesidad de vivienda y una baja capacidad de demanda. En este sentido, no se cumplen las leyes del modelo económico básico en lo respectivo a la formación de precios y características de un producto puesto en el mercado, a través de una teórica autorregulación y ajuste entre oferta y demanda en un contexto de competencia perfecta -en el que supuestamente se enmarca el sistema capitalista según la escuela económica neoclásica y una visión neoliberal del mercado- (Palomera, 2018: 12). Un modelo que, a pesar de haberse evidenciado su imposible aplicación a la cuestión residencial, muchos agentes públicos y privados insisten en tomar como referencia para abordar la problemática del acceso a la vivienda (Roch, 2009). La enorme rigidez del mercado libre para ajustar sus precios a la realidad de la demanda ha sido ya mencionada, muy alejado del equilibrio que supuestamente atribuye dicha ley económica. Pero como se ha podido ver, los efectos de esta contradicción desbordan el espacio del mercado libre y afectan también a la oferta pública, que sigue y reproduce dinámicas del primero a la hora de diseñar tipologías residenciales, redactar los instrumentos normativos que las regulan, o establecer prioridades en la elaboración de planes y políticas de vivienda. También se ven afectados algunos programas de vivienda protegida que establecen sus rentas y precios tomando como referencia los propios del mercado libre.

Pero la naturaleza de la vivienda como derecho humano básico y necesario que no deja a la elección personal entrar o salir de ese mercado, las enormes y relativamente fáciles plusvalías que el proceso urbanizador ha demostrado ser capaz de generar en determinados contextos espacio-temporales, el hecho de que parte de estas terminasen en manos públicas, disponer de un marco capaz de dotar de rentabilidad a la vivienda como producto financiero, o la expandida idea de la posibilidad de riqueza generalizada a muy diversos esferas y escalas en un esquema de crecimiento exponencial sin fin, entre otras variables, distorsiona completamente tales suposiciones y deja sin capacidad de demanda a muchas unidades de 
convivencia, mientras paralelamente hay una parte del parque sin vender con precios fuera del rango de accesibilidad de las mismas. De tal manera que, lejos de ser el mercado de la vivienda reducible a la interacción matemática entre oferta y demanda, este es resultado de diferentes relaciones de poder entre las cuales el ejercido por las instituciones públicas no ha de considerarse externo, si no parte del mismo (Palomera, 2018: 13, 18).

En esta línea pueden entenderse algunos casos del AMB en los que esta contradicción puede identificarse de manera interna a determinados agentes, confirmando la transversalidad antes planteada. Como por ejemplo el papel que juega el conglomerado de agentes, entidades y programas del sistema vasco de vivienda, Etxebide. La misión principal del mismo es lograr un acceso digno y de calidad a la vivienda, y para ello trabaja y desarrolla instrumentos, alojamientos, o programas. Pero en su camino toma a su vez posiciones y realiza actos en contra de ese objetivo último, alimentado así esta contradicción: estableciendo franjas de rentas -que expulsan a ciertos colectivos de la posibilidad de demandar y por consiguiente de acceder a una vivienda protegida-, limitando estadísticamente la necesidad a las personas con rentas disponibles -alterando así los datos de la demanda de vivienda-, o desarrollando tipologías que beben de tendencias obsoletas y que no responden a nuevas necesidades de convivencia -manteniendo una oferta que no se ajusta a la demanda-.

También se da transversalmente al sobredimensionar las estimaciones de nuevas viviendas en los instrumentos de planificación espacial -al no contar por ejemplo con datos precisos de viviendas vacías y su potencial puesta en carga se está planteando la generación de nueva oferta sin conocer el stock existente-, al centrar las previsiones de necesidad de vivienda en aspectos cuantitativos dejando de lado otras variables cualitativas y reduciendo así la mirada al tamaño medio de las unidades de convivencia -sin tener en cuenta que más allá de ese tamaño hay fenómenos demográficos como que la estabilidad poblacional de la región se debe a la llegada de población migrante que en muchas ocasiones llega sola y procedente de otras culturas, y por lo tanto con otro tipo de demanda de vivienda-, o al incorporar en el proceso de planificación el parque existente sin valorar el desfase tipológico de este con la realidad socio-demográfica actual -es decir, manteniendo un producto en oferta que no encaja con la potencial demanda-. Pero es también fácilmente identificable en el sector privado: alimenta con su pobre oferta el imaginario de la vivienda racional jerarquizada como el tipo de vivienda 'adecuado' al que posteriormente se ven forzadas a encajar las diversas unidades de convivencia, y al reducir su público objetivo a aquel capaz de costear los precios del mercado libre están expulsando de este a una amplia parte de población que desea ser parte de esa demanda activa. 


\section{$2^{a}$ contradicción: Valor de uso vs. Valor de cambio}

«El derecho de propiedad privada sostiene la propiedad individual de las viviendas y los Estados capitalistas han apoyado sistemáticamente por diversos medios (desde los subsidios activos a la publicidad y la retórica en que se envuelven los sueños de propiedad de una vivienda) su extensión a sectores de la población cada vez mayores. Con ello se pretendía asegurar un crecimiento continuo del mercado inmobiliario como campo de acumulación activa y lucrativa de capital, pero también ha desempeñado una función ideológica crucial, consolidando el apoyo popular y populista a la estrategia de proporcionar valores de uso mediante mecanismos basados en el valor de cambio: con otras palabras, el apoyo a la vía capitalista» (Harvey, 2014: 63).

La segunda contradicción hace referencia a la convivencia de dos visiones de la vivienda: la generalizada y extendida como objeto de inversión y generación de capital -con un gran peso en la economía-, y la que a su vez -totalmente aceptada al menos como elemento discursivo- la plantea como derecho humano universal, así buscado y defendido de manera parcial desde diversos ámbitos. Este conflicto contradictorio puede definirse de diversas maneras: como la desconexión del aspecto económico de la vivienda respecto del social (Palomera, 2018: 14), como aquella «desigualdad entre quienes ven la vivienda principalmente como un hogar y quienes la tratan como una fuente de beneficios económicos» (Palomera, 2018: 18), o como aquel existente «entre la vivienda como espacio social en el que se vive y la vivienda como instrumento para obtener beneficios: el conflicto entre la vivienda como hogar y la vivienda como bien inmuebles) (Madden y Marcuse, 2018: 30). Todos ellos hacen mención al concepto de la mercantilización, cuya comprensión es clave para comprender correctamente la crisis de la vivienda (Madden y Marcuse, 2018: 73). Se trata de un discurso que contrapone de manera conflictiva el valor de uso y el de cambio de la vivienda, pues «la diferencia entre ambas formas de valor es significativa, y en la medida en que a menudo se enfrentan una con otra constituye una contradicción que puede dar lugar ocasionalmente a una crisis» (Harvey, 2014: 31). Como recuerda el autor, la vivienda es un ejemplo perfecto de cómo la diferencia entre ambos valores puede intensificarse de tal manera que las consecuencias de la contradicción pueden afectar $-\mathrm{y}$ de hecho así fue- a los sistemas financieros y económicos. Un desequilibrio en favor del «lado del valor de cambio que negaba a cada vez más gente el valor de uso adecuado de una vivienda, además de un nivel de vida decente» (Harvey, 2014: 38).

«En última instancia, el problema que supone convertir la vivienda en una mercancía es que, como tal, el espacio de habitación se distribuirá en función de la capacidad para pagar y se suministrará en la medida en que produzca beneficios. Pero 
la capacidad para pagar es desigual, mientras que la necesidad de tener un lugar en el que vivir es universal. Existe, por tanto, una contradicción inevitable» (Madden y Marcuse, 2018: 72)

En este caso, y acotando la cuestión a un contexto español, este desequilibrio supone además que no se cumpla la función social de la propiedad privada establecida en el artículo 33 de la Constitución ${ }^{63} \mathrm{y}$ que se extienda una concepción errónea de dicho derecho. Con excesiva frecuencia se puede observar como desde diferentes ámbitos sociales se sigue opinando desde la comprensión del derecho a la propiedad privada como un derecho individual y personal casi sin límites. Pero tal y como se recoge en la sinopsis del citado artículo constitucional realizada por Ruiz-Navarro en 2004 y actualizada por Sieira y Rastrollo en 2011 y 2017 respectivamente ${ }^{64}$, «la progresiva incorporación de finalidades sociales relacionadas con el uso y aprovechamiento de los distintos tipos de bienes» hace que «la propiedad, sobre todo, ha sido uno de los derechos que más ha evolucionado desde el punto de vista constitucional y legislativo» pasando «de entenderse como el derecho individual y personal por antonomasia a articularse como una institución jurídica objetiva, cargada de limitaciones impuestas por la función social a la que se encuentra sujeta». La propiedad ha pasado a ser un derecho estatutario, y así «lo tiene reconocido la ya constante jurisprudencia tanto del Tribunal Constitucional como del Tribunal Supremo». Según los autores, y apoyándose en dicha jurisprudencia, el contenido del mismo no se debe entender como la consideración de intereses individuales con una limitación externa impuesta por la función social, si no que esta debe entenderse «como parte integrante del derecho mismo»; «un derecho a la propiedad privada que se configura [...] como un conjunto de derechos y obligaciones establecido, de acuerdo con las leyes, en atención a valores e intereses de la comunidad...». La utilidad individual y la función social definen de esta manera «una doble dimensión de la propiedad privada [...] que ha afectado de forma singularmente intensa a la propiedad inmobiliaria». La contraposición de estos argumentos con la situación del acceso a la vivienda previamente analizada evidencia la existencia de una contradicción firmemente asentada en la sociedad. Los efectos de esta contradicción en esa errónea manera de interpretar el derecho a la propiedad privada se han podido ver, como por ejemplo, en

\footnotetext{
63 Artículo 33 de la Constitución Española:

Se reconoce el derecho a la propiedad privada y a la herencia.

La función social de estos derechos delimitará su contenido, de acuerdo con las leyes.
}

Nadie podrá ser privado de sus bienes y derechos sino por causa justificada de utilidad pública o interés social, mediante la correspondiente indemnización y de conformidad con lo dispuesto por las leyes.

${ }^{64}$ Disponible para su consulta en la página web del Congreso de los Diputados: http://www.congreso.es/consti/constitucion/indice/sinopsis/sinopsis.jsp?art=33\&tipo=2. 
algunas reacciones al recargo fiscal a las viviendas vacías en Bilbao que defendían el uso de estas como inversión (Reviriego, 2016).

A lo largo del capítulo se han visto en este caso también algunos ejemplos evidentes de la propagación social de esta contradicción, de ese virus especulativo que planteaba Naredo (2004a), y también de una manera interna y transversal a diversos agentes. Quizás uno de los más dramáticos sea el de aquellas personas que en el momento de la búsqueda de una vivienda en propiedad se ven forzadas a cierta movilidad geográfica por no poder acceder a un mercado local concreto, a endeudarse aumentando su potencial vulnerabilidad residencial, y en definitiva a buscar y negociar el menor precio de compra posible poniendo en el centro el valor de uso. Esas mismas personas en muchos casos, una vez convertidas en propietarias y llegado el momento de vender buscan el mayor precio de venta posible en el mercado, alimentadas por un contexto mercantilista que lleva a entender como fracaso la devaluación entre el precio de compra y de venta, que no contempla el no enriquecimiento con la venta, y que en última instancia reproduce un modelo excluyente que ellas mismas han sufrido en otro momento y situación, priorizando ante todo el valor de cambio. En el ámbito institucional, el contenido y crítica del mencionado Pacto Social por la Vivienda de Euskadi muestra cómo al centrarse más en el crecimiento del PIB, del empleo y el rescate de la construcción que en una lucha por el acceso a la misma (Burón, 2010; Eusko Langileen Alkartasuna, 2010) la apuesta decidida es por el valor de cambio frente al de uso. Igualmente, la televisión pública vasca es claramente contradictoria al transmitir como acontecimiento negativo la bajada del precio de la vivienda, a pesar de haber aumentado el número de operaciones, o al interpretar como positiva la alta rentabilidad del alquiler de vivienda libre, en un contexto de rentas de alquiler altas -evaluando el impacto de ambos fenómenos exclusivamente desde el valor de cambio-, mientras en paralelo da noticias relativas a la dificultad del acceso a la vivienda, la preocupante subida de los precios, la proliferación de procesos de ejecución hipotecaria y deshaucios, o prolongación de la edad de emancipación.

La diferenciación en dos contradicciones se debe a una intención analítica, y no niega una realidad en la que ambas «se cruzan, interactúan y crean interferencias entre sí de maneras fascinantes» (Harvey, 2014: 216). Las fuerzas e intereses que las generan son en su mayoría compartidos, lo cual hace que su interrelación e interdependencia sea constante y compleja. El desajuste del precio de oferta con la capacidad económica de la población que desea generar demanda se debe en gran parte a esa prioridad por el valor de cambio frente al de uso. Incluso el desajuste tipológico puede entenderse como altamente influenciado por la segunda contradicción: al centrar muchos de los agentes la mirada y los esfuerzos en lograr un mayor valor de cambio posible, la preocupación y el interés por hacer que el valor de uso se formalice con la mayor adecuación y calidad posible 
queda relegado a segundo plano. Este queda a merced de inercias de diseño, normativas y constructivas que aseguran el 'correcto funcionamiento' del mercado, y se rechazan innovaciones, cambios o recuperación de saberes espaciales olvidados que no garanticen un posicionamiento adecuado del producto en la oferta. Estas contradicciones cruzadas han llegado hasta el corazón de las unidades de convivencia, pues como señalaban Hernández et al. (1997 12), a la hora de optar por una vivienda la importancia del modo de vida -a través de un adecuado entorno doméstico y urbano- ha sido superada por las expectativas de mejorar el nivel de renta y la optimización de la inversión.

\section{Identificación de alternativas: una base para la investigación empirica}

Al presentar el diseño de la investigación en el capítulo inicial, se han planteado diferentes horizontes temporales dentro de los que responder a una problemática como la aquí abordada: desde el largo y estructural, al corto consistente en actuaciones parciales. En el caso de este trabajo, enmarcado en un punto intermedio, para que esas vías, esos caminos y puentes alternativos, permitan -desde un fortalecido consenso social- trasladar las necesidades que plantean los retos actuales en torno a la vivienda a un desarrollo instrumental progresista y eficaz capaz de sortear y luchar contra una serie de obstáculos internos y lograr un mayor nivel de consecución en las metas finales, tendrán que explotar de manera imaginativa la limitada flexibilidad del marco actual, buscar sus límites, activar las potencialidades latentes, y hacerlo en un plazo relativamente corto de tiempo. Algunas de las respuestas habituales dadas desde los poderes públicos a retos de esta complejidad suelen centrarse en acciones de tipo 'palo y zanahoria': estableciendo incentivos a determinadas situaciones o agentes, y castigos a otras. Sin negar la efectividad de este tipo de medidas en determinados contextos y tiempos, sí se puede decir que son acciones más tácticas que estratégicas. Su razón de ser responde a la búsqueda de logros a corto plazo - en ocasiones forzadas por situaciones de urgencia-, actuando sobre efectos más o menos superficiales de conflictos de fondo complejos generados por la reproducción de condicionantes, obstáculos y contradicciones específicas.

Ejemplos en este sentido, en el marco de las dos contradicciones recién señaladas, pueden ser las ayudas económicas para generar demanda de vivienda en el mercado libre -en forma de subvención directa o de beneficios fiscales, pero sin intervenir el mismo y alimentando su desajuste entre oferta y demanda-, o el 
establecimiento de límites en los precios de venta o alquiler regulando los máximos, pero sin actuar sobre el ánimo de lucro que prioriza el valor de cambio y la siempre justificada mercantilización que lo acompaña-. Por lo tanto, el interés del trabajo se centra en aquellas iniciativas que con mayor o menor intensidad van algo más allá, mirando y abordando en lo posible esas causas de fondo. Al acotar estas a ese plazo intermedio de los futuros presentes de un momento progresista como el planteado en el apartado 1.3.1, sus intenciones y capacidades transformadoras se verán limitadas y condicionadas por un contexto generalmente contrario a todo cambio que no vaya a favor de la acumulación de capital, en este caso hacia un proceso de des-mercantilización de la vivienda. De tal manera, que esa mirada profunda será parcial, ya que se hace desde dentro del sistema que se pretende intervenir. En cualquier caso, estas respuestas alternativas no solo surgen de y por las contradicciones existentes, si no que además luchan contra ellas; lo «que es especialmente interesante es cómo el modo de producción existente y sus actuales articulaciones políticas definen tanto los espacios como las estructuras de sus propias formas primarias de oposición» (Harvey, 2014: 272).

El trabajo pone el foco en dos grandes alternativas que pueden ser -o están siéndolo ya- esa punta de lanza de una reforma revolucionaria que mencionaba Harvey. Estas se han deducido e identificado a partir de todo el trabajo desarrollado hasta aquí en esta primera parte de la investigación; en lo que queda de capítulo, ambas van a ser formuladas y enlazadas a la hipótesis general de la investigación, para ser posteriormente demostradas en la segunda parte del trabajo. Son ejemplos de movimientos e iniciativas privadas, públicas y mixtas que generalmente de manera parcial $-\mathrm{y}$ no sin dificultades ni retos internos y externos- pueden ser capaces de poner lentamente en marcha una reforma radical -ya se le llame revolucionaria o reformista (Harvey, 2014: 64) - y contenida que, como sucede en las regatas a vela, desde una perspectiva estratégica ha de tener en cuenta las características cambiantes del contexto y entorno donde se pretende desarrollar para alcanzar el fin último -es lo que la diferencia de esos futuros futuros fantásticos, enormemente ambiciosos y especulativos con intenciones de transformación profunda señalados en el apartado 1.3.1-. La primera de ellas tiene la posibilidad de equilibrar el desajuste entre la oferta y la demanda de vivienda, adaptando la primera a la segunda, y no al revés; puede favorecer un contexto en el que se transforme la oferta ya que, como se busca demostrar más tarde, hay potencial en el parque actual del AMB para hacerlo. De manera paralela, la segunda alternativa tiene la posibilidad de equilibrar la relación contradictoria entre valor de uso y valor de cambio, priorizando el primero sobre el segundo, y no al revés; puede ayudar a extender el fortalecimiento del valor de uso ya que, como también se pretende demostrar, existen agentes con una vocación para ello actualmente trabajando en el AMB. Como se verá, en algunos casos estas alternativas se presentan de manera aislada - un parque potencialmente transformable, o agentes trabajando por el 
equilibrio de valores sin actuar en el parque-, en otros los agentes participan en la transformación del parque para ofrecer esas viviendas a unidades de convivencia con necesidad, e incluso se dan situaciones en las que la propia masa social capaz de constituir esa demanda de vivienda será la que a su vez transforme de manera colectiva la oferta a través de prácticas de gestión centradas en el valor de uso de la vivienda, relegando a un segundo plano el de cambio.

Finalmente, antes de pasar a exponer estas alternativas, es necesario acudir una vez más al análisis de Harvey sobre las contradicciones del capitalismo y sus potenciales respuestas para tener en cuenta dos aspectos relevantes. El primero es el hecho de que la identificación de determinadas alternativas, de la posibilidad de que estas se puedan desarrollar a partir de la comprensión de los fenómenos que están detrás de las contradicciones que reproducen los conflictos de la situación problemática, no presupone el éxito de las mismas. Pero sí se plantea esta vía como paso necesario para que puedan florecer y la reacción no se quede en una respuesta superficial que no ataca el fondo de la cuestión, ya que «señalar todas estas posibilidades no es afirmar que todas ellas darán frutos, sino sugerir que cualquier política anticapitalista tiene que ser diligente a la hora de rastrear entre las contradicciones para lograr encontrar su propio camino hacia la construcción de un universo alternativo utilizando los recursos y las ideas disponibles» (Harvey, 2014: 217). El segundo aspecto a tener en cuenta es que esas formas de oposición al sistema de organización predominante no surgen solo en un determinado espectro ideológico; la búsqueda de 'alternativas' puede estar motivada por diferentes intereses y objetivos que convergen en la idea común de desmontar las estructuras hegemónicas, «aunque la derecha lo haga en nombre del puro individualismo y la izquierda en nombre de algún tipo de asociacionismo» (Harvey, 2014: 272).

Consecuentemente, ni las alternativas aquí planteadas se entienden como únicas, ni son garantía absoluta de alcanzar la meta, ni si quiera son espacios para avanzar exclusivamente hacia las tres metas señaladas. Reflejan un análisis parcial de un abanico mayor de posibilidades, consideradas necesarias aunque no suficientes para la transformación del modelo residencial actual, y que además pueden favorecer y ayudar a la consecución de otras metas y objetivos incluidos los propios de algunos condicionantes y obstáculos señalados, como se verá en el capítulo tercero, reforzando la necesidad de actuar colectivamente para evitarlo-. La idea de fondo es aportar conocimiento para demostrar que, bajo el marco actual, tanto en lo relativo al espacio doméstico como en lo relativo a la gestión del acceso a la vivienda «el universo de las posibilidades habitacionales es más amplio e interesante de lo que pueda parecernos en un principio» (Madden y Marcuse, 2018: 221):

«Deberíamos reforzar estas iniciativas y fomentar que surjan muchas más. Estas formas de vivienda demuestran que las alternativas de tenencia de la vivienda que existen en la 
actualidad son mucho más variadas de lo que a menudo pueda parecer. Estos proyectos dan acceso a la vivienda y representan un antídoto creativo y comunal a la alienación residencial» (Madden y Marcuse, 2018: 223).

\section{Espacios de oportunidad en un sistema rígido y excluyente}

«La ecología nos enseña que las perspectivas de evolución de un sistema dependen de su flexibilidad para reaccionar ante nuevos acontecimientos en función de las señales que sobre ellos le envían sus circuitos de información. Pero la información ni se capta de modo homogéneo ni fluye por igual a todos los niveles. De ahí que "su capacidad para reaccionar como un sistema y su flexibilidad interna se deben precisamente a que no todas las conexiones imaginables están realizadas, a que muchas que serían posibles no se dan o están cortadas" (Margalef, 1992)» (Naredo, 2004a: 13).

Estas reflexiones de Naredo y Margalef ayudan a establecer el marco conceptual desde el que buscar soluciones imaginativas a la problemática aquí acotada, a partir de un conocimiento profundo del entorno en el que trabajar. Así, la primera alternativa identificada surge y conforma una potencial reacción y respuesta a la contradicción formada por ese desajuste existente entre la oferta y la demanda de un sistema de vivienda rígido y excluyente que, como se ha visto, trasciende al propio mercado y ejerce cierta influencia sobre el sistema de vivienda pública. Su deducción es posible gracias al estudio hasta aquí recogido de las características y potencialidades del soporte -el parque residencial heredado- y la población -las unidades de convivencia con necesidad de vivienda- que este debe acoger, de cara a lograr una vivienda digna y adecuada. La información recopilada, y el marco teórico sobre el que esta ha sido contextualizada, permite avanzar que la presencia de unidades de convivencia de tamaño cada vez menor y con unas pautas, biografías y necesidades vitales que difieren en gran medida de las de aquellas para las que fue $-\mathrm{y}$ es todavía- diseñado el parque actual, puede ser precisamente la que active una serie de espacios de oportunidad, buscando en las características del parque residencial heredado soluciones imaginativas. Ese desajuste entre las características tipológicas y las necesidades o perfiles habitacionales genera un margen, una grieta, que podría favorecer la aparición y/o expansión de estrategias que busquen romper las limitaciones tipológicas de las viviendas existentes, llegando incluso a transformar la estructura actual de la propiedad, para adaptar su oferta espacial a la demanda.

$\mathrm{Al}$ alterar el dogma de que a una vivienda existente le corresponde una única unidad de convivencia necesitada, y siendo estas generalmente menores, el reparto del coste económico del acceso en agrupaciones o colectivos de mayor o menor tamaño formados por 
varias unidades de convivencia puede además hacer todo ello posible a un coste razonable y accesible. Esto último lleva a deducir, adelantando en parte la segunda alternativa, que esta potencial adaptación del parque supera los límites y capacidades de acción individuales de las unidades de convivencia -acotados a una sola vivienda-, y necesita que se rompa el aislamiento en el que las mismas satisfacen habitualmente su necesidad de vivienda para actuar de una manera colectiva, en la medida en que las oportunidades deducidas afectan a y necesitan de múltiples agentes, ya sean otras unidades de convivencia para la generación de demanda, o más de una propiedad y/o vivienda actual desde el lado de la oferta. Para hacer posible este salto de una demanda individual a una colectiva capaz incluso de generar oferta, entra en juego -y de manera crucial- la gestión como elemento que permite activar estos espacios de oportunidad; sobre ella se centra la segunda alternativa. Por ello, como se aborda más abajo, es de gran interés el hecho de que las dos alternativas sean complementarias y mutuamente enriquecedoras, a la vez que interdependientes. Sobre el cruce de ambas se centra el capítulo quinto.

Pero esta alternativa planteada no se ha de entender y simplificar como una propuesta reducida a la segregación de viviendas en otras más pequeñas. Estas prácticas habitualmente son realizadas por un único agente -una unidad de convivencia, una empresa inmobiliaria-, reproduciendo la tipología común de vivienda en versiones reducidas, incorporándola posteriormente a la oferta residencial al mayor precio posible y logrando un mayor beneficio económico con la renta de alquiler o venta final del todo o de las partes - en ocasiones como forma de financiar la deuda para la adquisición de la vivienda original-. Tampoco se trata de una versión evolucionada de aquellos casos en los que una vivienda alberga varias unidades de convivencia, como los de familias y personas solas que se ven forzadas a compartir una vivienda pensada para una familia nuclear con descendientes menores, debido principalmente a factores de pobreza, precariedad laboral, e incluso agravadas por situaciones de indocumentación y exclusión legal, generando graves condiciones de hacinamiento y falta de habitabilidad. Ambas opciones no harían si no ahondar en la precarización espacial a fuerza de sometimiento a las imposiciones de precio y tipología del mercado.

El potencial detectado que se pretende demostrar es el de la generación de un mayor número de viviendas mediante una segregación y transformación que en muchos casos podrá idealmente desbordar los límites de la vivienda actual, alcanzando a parte o todo el edificio en cuestión, a través de tipologías diferentes y liberadas de una tradición de diseño doméstico conservadora, llegando a externalizar del espacio íntimo ciertos usos que podrán, sí en este caso, ser compartidos (Monteys y Fuertes, 2002; Paricio y Sust, 2000). Como se viene insistiendo, la estrategia que la potencial alternativa hace posible en este caso es otra: la adaptación tipológica y la 
reducción del coste final para cada unidad de convivencia, a través de una acción colectiva en algún momento del proceso. Una vez más, la necesaria convergencia con la gestión que se aborda en la segunda alternativa es fundamental. En este caso, una gestión socialmente responsable: se hace necesaria desde el inicio del proceso la intervención de agentes -sean públicos, privados o mixtos- que prioricen la función social de la vivienda para garantizar el aprovechamiento de estos espacios de oportunidad.

Antes de continuar, se hace necesario puntualizar a qué se está llamando aquí Espacio de Oportunidad. No se trata del concepto habitualmente utilizado desde las instituciones, ciertos agentes privados de la construcción y la promoción de viviendas, o algunos medios de comunicación. Aquel que hace referencia al crecimiento de la ciudad y a los nuevos desarrollos en exclusiva, ya sean estos sobre suelos no urbanizados, o mediante operaciones de sustitución de usos urbanos no residenciales bajo metodologías de suelo urbanizable (Imágenes 2.16, 2.17 y 2.18). El planteamiento aquí es el de intervenir en lo existente aprovechándolo de una manera más austera, justa, racional y eficiente, abordando su infrautilización. Se entienden como Espacios de Oportunidad la existencia de situaciones de desajuste como las apuntadas entre la oferta y la demanda, que tienen un potencial de mejora demostrable y suficientemente cuantificable; no tanto como unos lugares concretos hacia los que dirigir grandes operaciones, si no como idea o concepto aplicable a una buena parte del parque residencial del área metropolitana en su conjunto. La ciudad residencial generada a lo largo de las últimas décadas se ha hecho bajo una plantilla relativamente homogénea, anodina, sin la necesaria atención al lugar, a la población local, ni al clima. Aprovechar lo existente y contar con más variables que la económica, además de respetar la vida urbana existente, puede favorecer el mantenimiento de la identidad, la comunidad, la memoria, o la riqueza y diversidad urbana, así como facilitar la adaptación de un parque parcialmente obsoleto para hacerlo accesible a la población con necesidad de vivienda. Se trata, en definitiva, de reivindicar el sentido crítico y responsable de los conceptos 'oportunidad urbana' y 'espacio de oportunidad'; recuperarlos de un discurso expansionista que solo atiende a variables de acumulación económica utilizando la ciudad como «máquina de crecimiento» (Logan y Molotch, 2015). Una vía para «recuperar un lenguaje que nos permita comprender los conflictos de la vivienda e impugnar la injusticia residencial» (Madden y Marcuse, 2018: 30).

\section{Agentes alternativos de gestión residencial}

«Viendo que la necesidad de valores de uso adecuados quedaba insatisfecha, una pluralidad de fuerzas sociales, que iban desde patronos deseosos de mantener domesticada y asequible su fuerza de trabajo [...] hasta fervorosos radicales y utópicos [...] y el Estado local y nacional, han lanzado de vez
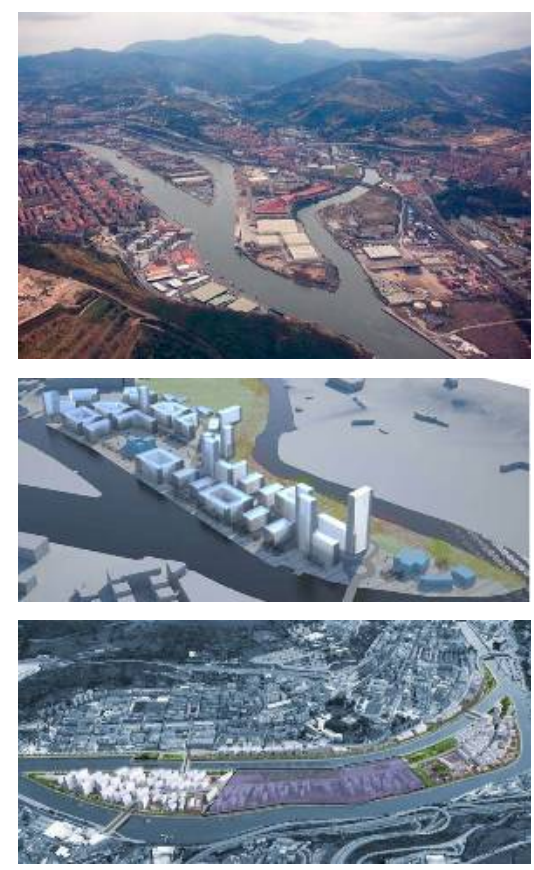

Imágenes 2.16 a 2.18 .

Zorrozaurre y Punta Zorroza, el paradigma de los espacios de oportunidad de Bilbao desde la óptica de la reproducción del urbanismo de las últimas décadas. Disponible en: https:// bilbaoenconstruccion.com. 
en cuando programas de alojamiento con financiación pública, filantrópica o paternalista para satisfacer las necesidades de clases más bajas con un coste mínimo. Si se acepta genéricamente que todo el mundo tiene derecho "a un hogar decente y un entorno vital apropiado" [...], entonces, obviamente, vuelven a primera línea de las luchas por el acceso a la vivienda las consideraciones sobre el valor de uso» (Harvey, 2014: 33).

«...puede anticiparse que en las crisis cada vez más profundas dentro del mismo proyecto neoliberal, y en torno a las mismas, se abrirán nuevas oportunidades estratégicas para movimientos tanto reformistas como antihegemónicos» (Brenner et al., 2015: 240).

Una vez identificados los espacios, estas reflexiones de Harvey, Brenner, Peck y Theodore son las que ayudan a contextualizar el marco conceptual sobre el que identificar las posibles respuestas para administrar e intervenir los mismos. Si la primera alternativa surgía de la identificación, en el soporte residencial existente y en la población con necesidad de vivienda, de ciertas oportunidades con potencial para permitir un acceso asequible y digno, esta segunda se centra en las formas de organización y gestión con intención y capacidad de lograr el mismo. Frente a la contradicción generada por el choque entre los valores de uso y de cambio propios de la vivienda en un sistema de organización social capitalista, en el que el segundo habitualmente predomina y condiciona la satisfacción de un derecho humano básico, en este caso se identifica como alternativa el surgimiento, como reacción y respuesta, de ciertos agentes con algún papel en el proceso de acceso a una vivienda digna y adecuada que incorporan un verdadero interés por lograrlo. Son agentes clave en la construcción de esos puentes necesarios para salvar los condicionantes y obstáculos y enlazar satisfactoriamente la definición de metas y prioridades con la ejecución final de los instrumentos diseñados para ello. El desequilibrio entre ambos valores y su consecuente exclusión residencial generan grietas en forma de ámbitos de gestión no cubiertos, fuera del sistema inmobiliario habitual. Estos ámbitos pueden ser potencialmente ocupados por agentes más o menos alternativos de gestión que, como resistencias surgidas a procesos de mercantilización (Madden, 2019), buscan a través de planteamientos de planificación, gestión, promoción, intervención, construcción, compra y alquiler de vivienda diferentes no necesariamente nuevos, pero sí distanciados del sistema inmobiliario y urbanístico hegemónicos- reducir el predominio del valor de cambio. Se cree que este papel puede ser jugado -o que lo está siendo en parte ya- por modelos públicos, privados o mixtos minoritarios que, lejos de seguir las inercias heredadas, buscan caminos diferentes para lograr sus metas. Algo que, sobre todo en el ámbito inmobiliario, parece fundamental para evitar reproducir o caer 
en lógicas y dinámicas pasadas pues, como señaló Harvey, «no deberíamos buscar un camino de retroceso pendular hacia donde ya estuvimos antes, sino que deberíamos esforzarnos por movernos en espiral a través de un nuevo estallido de energía en torno a los ideales de un gobierno democrático» (Harvey, 2004: 30).

Los modelos de gestión a los cuales se está haciendo referencia pueden formalizarse en muy diversos agentes o iniciativas, como ciertas empresas gestoras de comunidades residenciales, cooperativas de vivienda y grupos de co-housing, agentes de la propiedad inmobiliaria, empresas sin ánimo de lucro enmarcadas en el tercer sector, o ciertos programas y políticas públicas minoritarias, entre otros. Todos ellos, forman parte de ese concepto de modelo alternativo que busca enfrentarse a la problemática incorporando, en el desarrollo de su actividad, algunas variables y principios de fondo alineadas con las tres metas identificadas más arriba. Cuestiones y valores como la responsabilidad social y ambiental, la solidaridad, la holística, el pro-común, la incorporación al proceso de la toma de decisiones de los diferentes agentes implicados e interesados, o el no ánimo de lucro, hacen que compartan en general un enfoque de la vivienda y el suelo como un bien de interés y afección general, más allá de su titularidad. La necesidad de incorporar este tipo de agentes e iniciativas al sistema inmobiliario residencial viene siendo apuntada desde hace tiempo, en diferentes lugares y desde diversas esferas. Aunque pueden abarcar varios sectores, muchos análisis hacen hincapié en que, sin descargar de responsabilidad al poder público ni al mercado convencional, y asumiendo la fuerte interrelación entre los tres sectores, la sociedad civil ha de entenderse como «el terreno fundamental desde el que la transformación social y la acción innovadora emerge y donde se disputan y debaten las relaciones de poder social» (Swyngedouw, 2005: 1996). En este contexto han de entenderse propuestas como el llamamiento a «la entrada de nuevos actores en el monocorde panorama inmobiliario, gobernado por la vivienda libre y en propiedad» (Naredo, 2015: 82), o las afirmaciones de que «para conseguir auténticos avances ante los problemas de la vivienda será necesario desarrollar alternativas concretas a dicha mercantilización» (Madden y Marcuse, 2018: 73), dentro de las cuales encajan iniciativas de emprendizaje privado al servicio del interés general y de «un proceso de vivienda diferente e igualitario, en lugar de ser el motor de un proceso desigual y centrado en los beneficios, como ocurre en la actualidad» (Madden y Marcuse, 2018: 219).

La creencia de que algunos de estos modelos son capaces de generar cambios en las dinámicas rígidas y obsoletas características del sistema inmobiliario español y vasco no está falta de justificación ya que, como Burón y Rodríguez recuerdan, ningún estado europeo ha logrado grandes avances en materia de vivienda sin contar, entre otros, con un sector civil y privado fuertes en estrecha colaboración con la administración pública. Efectivamente, la tradición inmobiliaria 
local no ha dejado prácticamente espacio para el desarrollo de este tipo de iniciativas, frecuentes sin embargo en países cercanos:

«...empresas privadas sin ánimo de lucro o con ánimo de lucro que proveen alquiler asequible a clases populares y medias (housing associations) [...] en Euskadi no hay housing associations que operen en el mercado de la vivienda y ofrezcan alquileres asequibles. La sociedad civil auto-organizada es un proveedor clave de vivienda en ciudades europeas como Ámsterdam, Paris, Viena o Estocolmo y recibe apoyo del sector público, en virtud del interés general de sus actividades» (Burón, 2015c).

«El modelo vasco y español de solución de la carencia de viviendas ha tenido una escasa participación social y una intervención directa por parte de las administraciones limitada, frente a los modelos de los países del norte de Europa, en donde un fuerte movimiento cooperativo surgido de asociaciones de inquilinos, sindicales o religioso-asistenciales, junto con ayuntamientos y empresas, darán soluciones a los problemas generados por la industrialización en el ámbito de la vivienda» (Rodríguez, 2001: 59).

Esto hace necesario el florecimiento de «empresas y profesionales, con mentalidades muy distintas a las convencionales del sector» (Camino, 2016), pero siempre con un mínimo control público, ya que «sin intervención pública el derecho constitucional de la ciudadanía a la vivienda continuará siendo algo meramente semántico para las capas sociales menos poderosas económicamente, tanto en Euskadi como en el resto de España» (Burón, 2008: 17). Además, la complejidad de la cuestión hace deseable el establecimiento de mecanismos eficaces de gestión con un alto nivel de participación de la población residente final, no solo para conciliar diversos aspectos técnicos y sociales, si no para incorporar un mayor control y apego vecinal por todo el proceso (Alguacil, 1995). Por otro lado, un «aspecto fundamental que debe cuidarse con especial atención es el compromiso de esos profesionales con el vecindario [...], la necesidad de estricto control y el recomendable trato personalizado y cercano con los residentes» (Alguacil, 1995: 76). Un tipo de modelo inmobiliario aún por definir que algunas administraciones públicas ya están abiertamente aceptando que son necesarias. Tanto desde el Ayuntamiento de Bilbao (Ocio, 2018), como desde el Gobierno Vasco (Puerta, 2018), se apuntaba la necesidad de una promoción privada o público-privada para la intervención en determinadas situaciones de escala pequeña o intermedia -pequeños conjuntos de edificios, o incluso bloques individuales- de cara a la regeneración, renovación y rehabilitación urbanas, dado que las instituciones tienen puestos casi todos sus esfuerzos en las grandes operaciones en marcha, o previstas. Un reto que, admitían, todavía cuenta con numerosos obstáculos y un difícil encaje normativo. 
Esto último encaja a priori con las características de los espacios de oportunidad identificados en la primera alternativa, al plantearse como diseminados a lo largo del parque residencial en función del cruce entre características tipológicas y perfil de la población demandante. De tal manera que algunas de las características que suelen definir a este tipo de modelos o iniciativas - entidades de tamaño medio o pequeño, con relativa autonomía e independencia, dotados de una alta capacidad de adaptación y considerable velocidad de reacción al entorno; con una relativa baja necesidad de capital inicial, generadores de empleo, y respondiendo a las necesidades a corto plazo- parecen encajar adecuadamente con esa primera alternativa. Así mismo, al exigir estos espacios ser gestionados desde un ámbito que supere a la unidad de convivencia, estos modelos de gestión pueden suplir esa necesidad de actuar colectivamente, de «derribar (o "someter") las concepciones burguesas individualistas de riqueza y de valor a fin de liberar el potencial para una prosperidad humana creativa pero colectiva que nos rodea de forma latente en cada ocasión» (Harvey, 2014: 210), generando «la construcción de nuevas formas de solidaridad urbana» (Brenner et al., 2015: 240). Y viceversa, como se desarrollará más tarde, los espacios de oportunidad pueden ofrecer una posibilidad muy interesante a este tipo de iniciativas de gestión para alcanzar las metas que actualmente persiguen.

Con todo, algunas consideraciones son necesarias. La transferencia de modelos habitualmente calificados como de paradigmáticos en este tipo de políticas de vivienda, como el caso vienés, es compleja. Algunos de los factores que han favorecido el desarrollo de un tercer sector en torno a la generación de vivienda asequible en Viena son una apuesta decidida por él desde hace muchos años -logrando un rico ecosistema de empresas y asociaciones con un interés real en la misma-, y una población en crecimiento dentro del área metropolitana. Muchas de las empresas que allí actúan no se limitan exclusivamente a producir vivienda asequible, pero sí están obligadas a destinar a la misma parte de las ganancias logradas en el mercado libre -de manera similar, el marco legal autonómico vasco obliga a destinar un porcentaje importante de las nuevas promociones de vivienda a la oferta protegida-. Algo que se ve posibilitado por ese crecimiento de población que, sin embargo, no se da en el AMB. Por otro lado, la necesidad y el llamamiento por fomentar estas diferentes vías de gestión y generación de oferta residencial no se apoya solo en una cuestión ideológica y de principios, si no también por la pura insostenibilidad económica del modelo urbanístico actual que exige fuertes operaciones de redensificación, aumento de la edificabilidad y sustitución del tejido urbano como vía para la rentabilidad de las operaciones. Lo cual parece también ser cuestionado en un contexto de estancamiento y/o reducción demográfico, y precarización social.

Estos agentes e iniciativas alternativas se enfrentan a un sistema que tiene enormes conflictos entre los objetivos que pueda marcar la 
planificación, y una ejecución generalmente confiada a manos privadas con objetivos mayoritariamente incompatibles con el primero; marcados estos últimos por unos altos beneficios a corto plazo en un medio urbano de ritmos a medio y largo plazo (Tejerina, 2015). El autor enfatizaba esta incompatibilidad afirmando que el nivel de cumplimiento de objetivos es muy escaso, ya sea porque las medidas que se habían adoptado, es decir el plan, no era el adecuado, porque las circunstancias futuras alteran las situaciones iniciales -la ciudad es un artefacto que se modifica en el tiempo-, o porque «el contrario es listo y está muy motivado -cumplen la ley, pero no los objetivos del plan-». Todo ello enfatiza lo que ya en la primera alternativa se observaba: los agentes capaces de poner en marcha estas vías contrahegemónicas han de contar con una alta responsabilidad social y apostar por la función social de la vivienda como motivación para defender la prioridad de su valor de uso. Con la identificación de estas dos alternativas, se puede dar por demostrada la primera parte de la hipótesis formulada en el capítulo primero: existen posibilidades de construir alternativas transformadoras a partir de reformas rupturistas que parten de las contradicciones internas de la condición urbana. Una vez confirmado lo anterior, el trabajo cuenta con una sólida base sobre la que retomar y concretar el resto de la hipótesis general de la investigación, formulada en el apartado 1.3.3, para demostrar empíricamente la misma.

\section{La crucial relación entre transversalidady alternativas}

Pero antes de retomar la hipótesis, es necesario hacer otra reflexión. El planteamiento del trabajo ha permitido un proceso de investigación consistente, en primer lugar, en la identificación y acotación tanto de unos efectos formalizados en una situación problemática concreta en torno a la dimensión social de la vivienda, como de unas metas definidas como respuesta. A lo que ha seguido el diseño de una herramienta gracias a la cual: se han localizado algunas de las principales causas de fondo que generan dicha problemática; se han identificado dos grandes contradicciones estructurales generadas por el choque entre las causas de fondo y las metas buscadas; y se han identificado dos posibles alternativas al contrastar esas contradicciones con la problemática, la respuesta de la sociedad a esta, y el contexto general del AMB. Todo ello, ha permitido comprender cómo se generan ciertas contradicciones en procesos de gobernanza urbana. Pero el orden en el que se han presentado y abordado cada uno de estos elementos puede alterarse, interpretándolos de otra manera. La lectura puede iniciarse en la existencia de unos fenómenos 
causales de fondo, lo que aquí se han denominado Condicionantes y Obstáculos. Estos, generan unos efectos específicos y complejos que, como se ha indicado, se concentran y forman una Situación Problemática. La sociedad, como conjunto heterogéneo de agentes y fuerzas, detecta dicha problemática y responde a través de tres grandes fases de gobernanza -Contenido, Instrumentos y Ejecuciónpara alcanzar una serie de Metas. Tal y como se ha señalado, en la medida en que la respuesta se centre exclusiva o principalmente en esos efectos, y más allá de las discrepancias internas a la hora de establecer cómo responder, el margen de actuación se verá limitado a corregir parcialmente la situación problemática con mayor o menor éxito en función de múltiples variables coyunturales. Pero en paralelo, las causas de fondo seguirán alimentando una situación estructural que permanecerá en el tiempo mientras lo sea y lo hagan las primeras. Este panorama conforma una serie de contradicciones generadas por el citado choque entre el sistema causa-efecto -en el que toman protagonismo la oferta de vivienda y su valor de cambio- y el sistema respuesta-metas -en el que se busca priorizar la demanda y el valor de uso- (Esquema 2.4), que en gran medida impiden la visión y la identificación de esos condicionantes y obstáculos que conforman las causas, lo cual alimenta esa reacción centrada en los efectos. Y son precisamente contradicciones, pues se trata de un choque interno, ya que todo el proceso se desarrolla en el espacio social formado por relaciones sociales complejas.

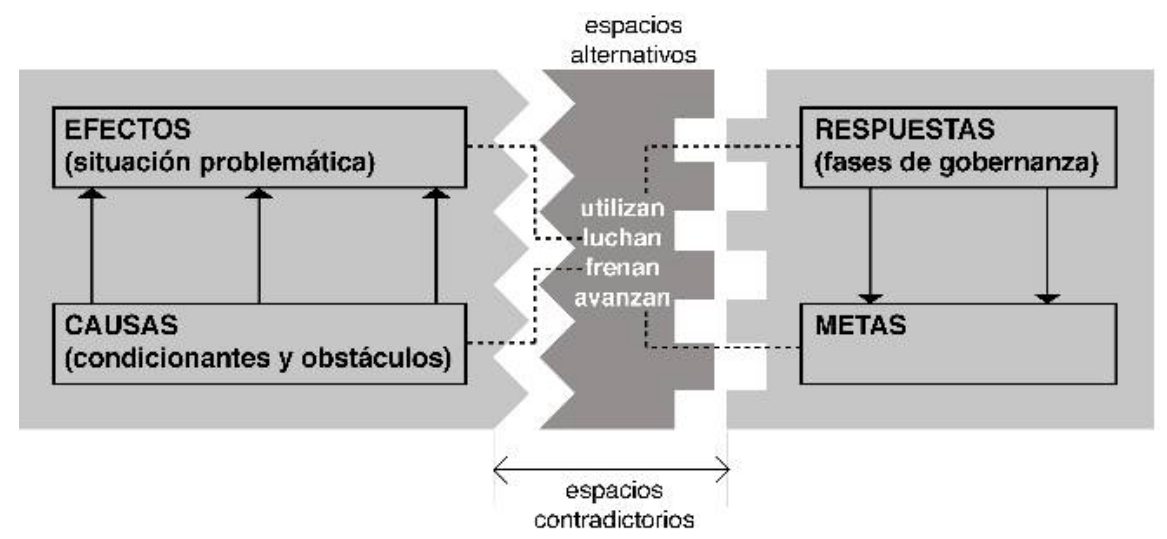

En este punto toma interés el concepto de transversalidad de esas contradicciones. Como se ha insistido, ese choque de fuerzas no se da entre bandos claramente enfrentados, cada uno con posiciones coherentes y metas opuestas, a desarrollar en espacios diferenciados y autónomos. Ya que, en ese caso, no se estaría hablando de contradicciones, si no de ataques y de defensas, de daños y de beneficios. Estos podrían darse en ambos sentidos, pero siempre serían acciones desde fuera, o hacia fuera. Pero la realidad -parcialmente presentada en este capítulo para el caso y objeto de la investigaciónmuestra que, usando esos mismos términos, en muchas ocasiones el
Esquema 2.4. Abstracción gráfica de la herramienta de análisis propuesta. Elaboración propia. 
agente que ataca también defiende; el que recibe daños también se beneficia. El matiz fundamental que diferencia ambas abstracciones está en que, en el segundo caso, todos esos choques son internos; de manera que al atacar, ese mismo agente debe defenderse de su propio ataque -puede que no en ese lugar ni en ese momento-. Ocurre así tanto porque en cada agente habitualmente se cruzan y superponen de manera conflictiva intereses opuestos, como porque los agentes están formados en definitiva por personas que pueden ser parte de más de un agente: aquellas que trabajan en las instituciones públicas encargadas de definir, desarrollar y llevar a la práctica políticas de vivienda con consecuencias excluyentes pueden verse luego afectadas por ellas; la propiedad de un inmueble en busca del mayor precio de venta posible puede estar alimentando un mercado excluyente que expulse a un familiar cercano, o a sí misma en un futuro; las personas que trabajan en una oficina técnica encargada de diseñar una promoción de viviendas, haciéndolo bajo un modelo tipológico obsoleto que deja fuera muchos tipos de unidades de convivencia, pueden estar reproduciendo una oferta que no responde a sus propias necesidades habitacionales,... Por eso el sistema es internamente contradictorio. Al ser contradicciones internas, al existir desajustes, hay un margen de maniobra para adecuar la oferta a la demanda, y para priorizar el valor de uso sobre el de cambio. Lo hay porque no son pocos los agentes interesados en que así sea, incluso aquellos que reproducen los condicionantes y obstáculos que alimentan las contradicciones -si fueran luchas externas todos los agentes estarían posicionados en exclusiva en uno u otro bando; no habría alternativa. El reto está en corregir y reducir de manera consciente esos conflictos de fondo, lo cual plantea como vía necesaria la transformación paulatina del sistema predominante.

Por supuesto, esta simplificación conceptual refleja una realidad muy diversa, con diferentes niveles e intensidades de choques internos repartidos a lo largo de un amplio gradiente en el que cual se reparte de manera no proporcional ni homogénea la población. Es decir, las contradicciones están desigualmente repartidas, tal y como se ha visto al situar la gobernanza en un contexto de apertura desequilibrada y re-jerarquizada. De manera que hay agentes con suficientes recursos y poder para ejercer ataques fuertes a favor de ciertos intereses, a la vez que le permiten absorber los efectos dañinos de ese ataque sobre otros intereses propios. Su situación le permite defenderse y en ocasiones desviar lo que le viene de vuelta hacia otros agentes, colectivos, espacios y tiempos. Pero en el fondo, lo que está es alimentando una contradicción sistémica que se expande a toda la sociedad. En el momento en que pierda recursos y poder, ese agente se verá damnificado por las consecuencias de sus propios ataques y no podrá defenderse adecuadamente. Todo este carácter interno y transversal es lo que ha permitido a la teoría crítica plantear la existencia de alternativas internamente generadas para la transformación social. Como se ha citado previamente, Marcuse (1985: 53) incidía en que la negación y el enfrentamiento es el paso 
previo al nacimiento de fuerzas transformadoras precisamente dentro de la sociedad que estas buscan transformar. Por todo ello, esa transversalidad de las contradicciones es la que hace que existan alternativas con el potencial de producir cuatro grandes efectos: poner en valor y utilizar el marco de respuesta ofrecido por las fases de gobernanza, luchar contra las causas de fondo, frenar sus efectos, y avanzar hacia las metas. Pues, si las fuerzas que producen esos choques son internas a ese conjunto heterogéneo que es el espacio social, también lo son las metas, y los instrumentos.

\section{- 2.7.4. - \\ Complementariedad de las alternativas: rearmando la hipótesis}

\section{De la abstracción a la realidad}

Hasta aquí, y siguiendo lo formulado en la hipótesis de partida de la investigación, el estudio de las contradicciones identificadas a partir de la aplicación en el AMB de la herramienta de análisis propuesta ha permitido señalar dos posibles alternativas. Pero estas se han formulado de una manera teórica y abstracta, apuntando oportunidades y potencialidades ideales. En este apartado, y partiendo de ese marco, lo que se hace es aterrizar esa formulación de lo posible al terreno de lo existente, para continuar con la demostración de dicha hipótesis inicial. Esto se hace encajando en el esquema de la herramienta las piezas obtenidas a partir del trabajo realizado en este segundo capítulo. Así, asumiendo que las oportunidades y potencialidades apuntadas al plantear ambas alternativas no van a reflejar en su totalidad las existentes en esta región, la reformulación de la hipótesis permite concretar y acotar la misma en torno a la dimensión social de la vivienda en el AMB: lo que se plantea es que existen ciertos espacios de oportunidad y alternativas de gestión que cuentan con algunas de esas características ideales. No son ejemplos paradigmáticos de las alternativas en el AMB, si no una mirada al estado actual de las mismas en dicha región. Son casos en los que se prevén ciertos potenciales, posicionamientos y objetivos que pueden favorecer el crecimiento de dichas alternativas y abordar las contradicciones de fondo, sin dejar por ello de estar inmersas en un sistema residencial dentro del cual reproducen muchos de los condicionantes y obstáculos internos ya señalados.

\section{Concreción de la hipótesis}

Sin negar otros posibles caminos que ayuden a dotar de respuestas a la problemática enfrentada, lo que se busca es demostrar una serie 
Esquema 2.6. Desarrollo de la hipótesis general a partir de las alternativas concretas identificadas completando el esquema de generación de contradicciones en procesos de gobernanza urbana. Elaboración propia. de oportunidades, a diferentes escalas y en diferentes esferas, existentes en el AMB para hacerlo. Identificadas las contradicciones estructurales en las que contextualizar el caso de estudio, y señaladas las posibles alternativas surgidas de las mismas, el espíritu constructivo y socialmente transformador que subyace a la presente investigación lleva a rearmar la hipótesis de partida para su demostración a través del trabajo empírico. Así, tanto la hipótesis como los Esquemas 2.1 y 2.2 se completan y queda la primera formulada en tres puntos -que serán desarrollados en los capítulos 3, 4 y 5 respectivamente- de la siguiente manera (Esquema 2.6):

En el AMB (1) puede darse un uso más eficaz al parque residencial heredado debido a ciertos espacios de oportunidad existentes por desajustes económicos, sociodemográficos y tipológicos entre la oferta y la demanda, transformando espacialmente el mismo, mejorando el acceso económico y alterando tanto su estructura de la propiedad como las correspondencias habituales entre unidades de convivencia y viviendas existentes; (2) existen en la región, aunque con baja presencia y nivel de desarrollo, agentes alternativos públicos, privados y mixtos -desde agentes y programas de gestión públicos a cooperativas privadas, pasando por agentes inmobiliarios éticos o empresas privadas orientadas a la consultoría urbana social-, actuando a diferentes escalas -desde la parcela al área metropolitana- y en el marco de gobernanza actual, que intervienen en el acceso a la vivienda y que buscan avanzar hacia las metas aquí señaladas, luchando contra la situación problemática identificada y trabajando por dar prioridad al valor de uso de la vivienda; (3) estos agentes, bajo el marco normativo y contexto actual, están aprovechando $-\mathrm{O}$ tienen potencial para hacerlo- los espacios de oportunidad mencionados para alcanzar dichas metas y salvar, al menos parcialmente, los condicionantes y obstáculos identificados.

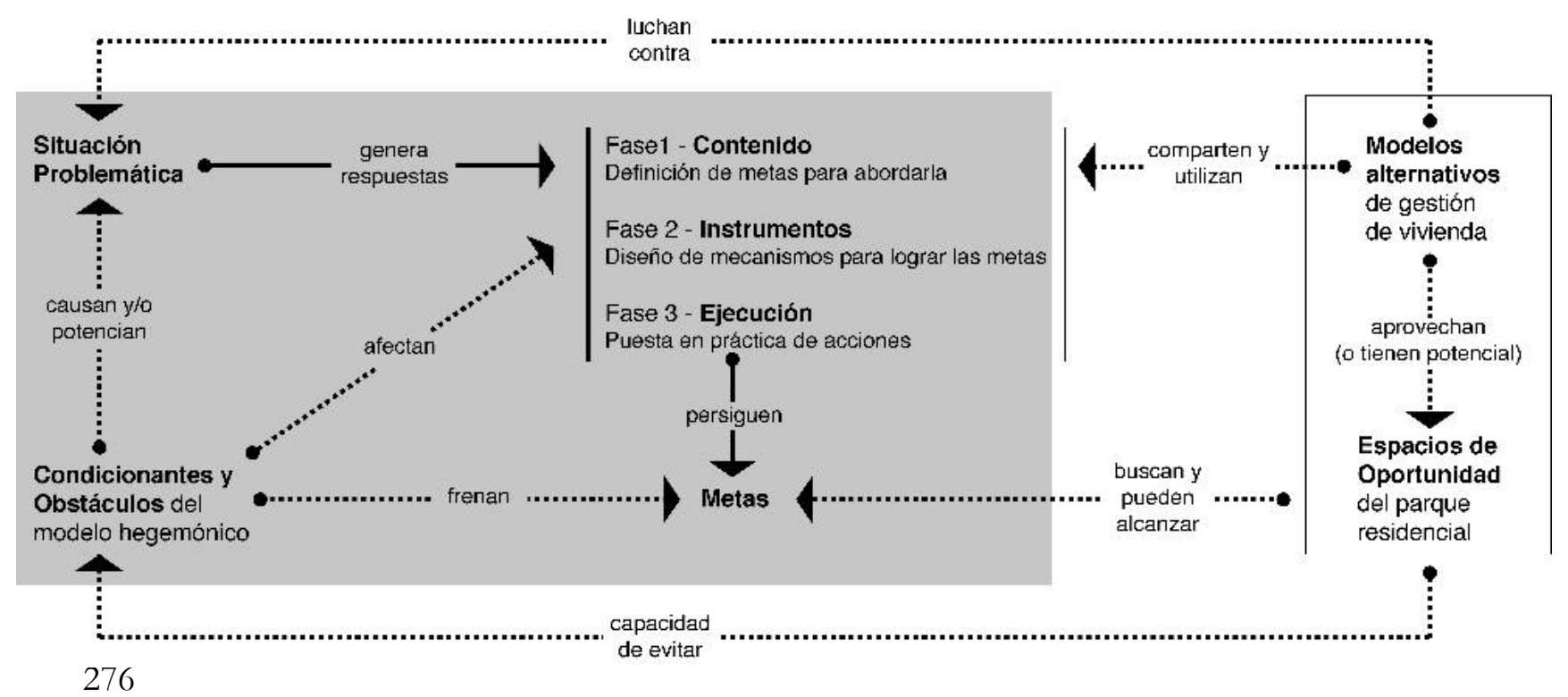




\section{Necesaria vinculación entre alternativas}

La ya mencionada complementariedad de ambas alternativas, para activarse y fortalecerse mutuamente, es una cuestión clave para esta re-definición de la hipótesis, pues en parte es la que permite formular que existen altas posibilidades de éxito. $\mathrm{Al}$ abordar simultáneamente espacios de oportunidad y alternativas de gestión, se podrá evitar que los primeros no sean absorbidos y pervertidos por un mercado devorador de recursos y oportunidades para la obtención de plusvalías - «no hay ninguna contradicción que no genere respuestas potencialmente contradictorias» (Harvey, 2014: 210)-, y se ofrecerá a las segundas una vía actualmente latente para el desarrollo de su actividad; los agentes de gestión podrían empoderarse si aprovechan el potencial de los espacios de oportunidad identificados. Lo cual hace que no se puedan entender los espacios sin los agentes, ni viceversa: aquellos que buscan fortalecer el valor de uso pueden aprovechar los espacios para ello y cambiar así la oferta adecuándola a la demanda. Jessop puede ayudar a contextualizar esto, si se entienden los Espacios de Oportunidad como lo que él denomina «configuraciones espaciales heredadas» y «estructuras de oportunidad», y se toman los agentes alternativos de gestión como actores clave en el desarrollo de la gobernanza:

«Como un producto de prácticas sociales que se apropia de los fenómenos físicos y sociales, los transforma y les confiere significado social, el espacio puede funcionar como lugar, objeto y medio de gobernanza. Las configuraciones espaciales heredadas y sus estructuras de oportunidad son lugares en los que se puede establecer, disputar y modificar la gobernanza. El espacio es un objeto de gobernanza en la medida en que resulta del establecimiento, manipulación, reorganización y eliminación de márgenes, límites, fronteras y espacios liminares materiales, sociales y simbólicos» (Jessop, 2017: 182).

\section{Acotando el trabajo empírico}

El planteamiento es también una manera de poner en valor ese camino intermedio antes señalado, apostando por buscar en el marco normativo, político, geográfico, construido o socio-económico actual alternativas y agentes para llevarlas a cabo. Planteada como una investigación empírica desde la teoría urbana crítica, en lo que sigue no entra el trabajo a desarrollar tareas propositivas, ni a plantear cuestiones concretas sobre aspectos inmediatos, prácticos $\mathrm{O}$ instrumentales (Brenner, 2017b: 246). El abordar, en cada caso, la formalización de las transformaciones de las viviendas y edificios para su adaptación a unidades de convivencia concretas con sus respectivos límites espaciales, normativos y económicos, o los detalles de la necesaria redefinición y adaptación de la actividad desarrollada por los diversos agentes analizados para alterar su modelo de gestión de manera que puedan aprovechar los espacios de oportunidad que se 
han detectado en el trabajo es propio de una fase posterior de aplicación del conocimiento y el debate aquí abierto.

Lo desarrollado hasta ahora ha sido un marco sobre la gobernanza y la contradicción en el contexto de la dimensión social de la vivienda -capítulo primero-, y la aplicación de una herramienta de análisis en el mismo, y sobre un ámbito geográfico concreto, para apuntar posibles alternativas -este segundo capítulo-. Estas pueden ser analizadas y demostradas de muy diversas maneras y vías. En esta investigación se van a plantear dos de ellas -capítulos tercero y cuarto-, para estudiar posteriormente su compatibilidad -capítulo quinto-. El resto de esta investigación se centra, por lo tanto, en un análisis parcial del parque residencial y de ciertos agentes participantes en el proceso de acceso a la vivienda del AMB. Es muy habitual, tanto en este como en otros temas, abordar las posibles soluciones a una problemática comenzando por hacer estudios comparados de las diversas respuestas que a conflictos similares se dan en otros lugares y contextos. La intención, comprensible, es la de partir de aquellas experiencias en marcha para poder obtener información sobre lo aprendido de cara a la transferencia, adaptación y aplicación de las mismas a los casos locales. Pero para que ese ejercicio de transferencia de conocimiento sea útil y tenga garantías de una correcta aplicación, se entiende como necesario un paso previo fundamental -existe otro aún anterior, ya recogido más arriba, que es la identificación de la problemática y la definición de metas-: observar, analizar y comprender el contexto local, sus contradicciones, sus potencialidades, sus retos, y los agentes que participan con mayor o menor poder en la gobernanza de esos espacios. Es este el contexto y el objetivo de este trabajo. Una vez generado este conocimiento, ya sí se abre el tiempo de dirigir la mirada hacia el exterior y buscar experiencias en contextos similares para enriquecer la situación local, sabiendo qué buscar. Hacerlo antes puede resultar en un esfuerzo infructuoso. Es decir, se plantea la búsqueda de un diagnóstico acertado y profundo que permita luego buscar eficazmente las respuestas y los remedios concretos. De esta manera, el resto del trabajo se centra en:

- Localizar los espacios de oportunidad, y demostrar su potencial de mejora en relación a las metas (Capítulo 3).

- Identificar modelos de gestión bajo los criterios definidos, y evaluar los avances logrados y los retos existentes en su búsqueda de las metas (Capítulo 4).

- Estudiar el potencial de encaje y aprovechamiento de los espacios de oportunidad por parte de los modelos y agentes analizados (Capítulo 5).

Se comenzará así por seleccionar un caso representativo de la existencia de dichos espacios de oportunidad en el parque de viviendas actual; se ha tomado para ello la vivienda libre a partir de una amplia muestra de viviendas en oferta en el mercado. No se están 
por ello validando ni dando por buenos dichos precios, ni las lógicas del mercado que los legitiman. Lo que se buscan son oportunidades transformadoras a corto plazo bajo esas reglas. La intención es satisfacer una necesidad relativamente urgente de vivienda, principalmente localizada en colectivos con mayor o menor riesgo de vulnerabilidad social. Una vez seleccionado el universo a analizar, el siguiente paso ha consistido en construir una buena base de información espacial relacionada tanto con la situación problemática como con las metas. Algo que viene siendo apuntado como imprescindible para desarrollar correctas políticas espaciales (España, Ministerio de Vivienda, 2010; Naredo y Montiel, 2011). Para ello, se ha acudido a diversas fuentes y herramientas, y se ha trabajado con el precio de oferta de estas viviendas, algunas de sus principales características espaciales -superficie y tipología-, y con su localización en el área metropolitana. Contar con una buena base de datos ha sido crucial para poder abordar con éxito los siguientes pasos: interpretar los resultados, identificar posibles estrategias de transformación, así como localizar y demostrar la existencia de las oportunidades que se vienen anunciando. En un primera fase se han identificado dichas situaciones potenciales en todo el AMB; en una segunda, se han comprobado mediante pequeños estudios comparativos entre diferentes áreas de la región.

Lo anterior no plantea soluciones concretas para acceder a la vivienda de una manera asequible, si no que identifica oportunidades económicas y espaciales en el mercado para ello, y analiza la territorialización de estas a lo largo del AMB. Es el cuarto capítulo el que estudia posibles maneras de gestionar ese acceso. Confirmados los espacios de oportunidad, el siguiente paso ha sido la búsqueda y selección de modelos de gestión alternativa en el AMB. Se ha tomado una muestra de modelos e iniciativas provenientes de diversas esferas y orientados a diversos momentos y actividades en el ámbito de la gestión de la vivienda. El análisis de su papel en dicho proceso ha permitido la evaluación de sus capacidades -efectivas o posibles- de aprovechamiento de los espacios de oportunidad identificados previamente. Para ello, se ha seguido una metodología tipo DAFO (estudio de Debilidades, Amenazas, Fortalezas y Oportunidades). Los resultados de esta parte ofrecen una visión -parcial- de gran interés de la red de agentes existentes actuando fuera de un circuito convencional bajo unos principios más responsables y racionales. Ambos capítulos han permitido desarrollar, en el capítulo quinto, las principales interpretaciones de la investigación, centradas en desarrollar algunas de las variables a tener en cuenta a la hora de evaluar el potencial encaje entre agentes alternativos y espacios de oportunidad. Por último, ya en el capítulo sexto, se confirma la hipótesis central de la investigación y se plantean algunas otras lecturas obtenidas, para cerrar finalmente con el apunte de algunas posibles líneas de trabajo como continuación de este. 


\section{Conflictos del proceso desigual de gobernanza urbana}

(Aps. 2.3 y 2.6)
Creciente diversidad de unidades de convivencia y situaciones vitales con alta necesidad de vivienda y sin capacidad económica de demanda.

$$
+
$$

Reproducción de unas tipologías conservadoras y en proceso de obsolescencia que no responden a la misma.
Modelo urbanístico e inmobiliario de la vivienda como bien económico y para la inversión.

Concepción de la vivienda como derecho humano fundamental, asumido y aceptado social y normativamente.

Contradicciones

(Ap. 2.7.1)

\section{oferta}

vs.

\section{demanda}

No se cumple la supuesta ley económica básica de equilibrio y autorregulación del mercado; la oferta no se ajusta a la demanda.

Ayudas económicas para generar

\section{Respuestas superficiales} (Aps. 2.4 y 2.5) demanda de vivienda en el mercado libre -en forma de subvención directa o de beneficios fiscales, pero sin intervenir el mismo y alimentando su desajuste entre oferta y demanda.

\begin{tabular}{|c|c|c|}
\hline Alternativas & $\begin{array}{l}\text { El desajuste entre el producto } \\
\text { ofertado y las características de la } \\
\text { necesidad puede favorecer la } \\
\text { transformación del primero } \\
\text { adaptándolo a un coste asequible. }\end{array}$ & $\begin{array}{l}\text { Dotar de herramientas para empoderar } \\
\text { a aquellos agentes luchando por } \\
\text { recuperar la posición prioritaria del } \\
\text { valor de uso de la vivienda como } \\
\text { derecho humano básico. }\end{array}$ \\
\hline & \multicolumn{2}{|c|}{$\begin{array}{l}\text { 1) el parque residencial actual del AMB puede transformarse y adaptarse a } \\
\text { las necesidades espaciales de muchas unidades de convivencia con necesidad } \\
\text { de vivienda a un coste asequible, alterando la correspondencia entre } \\
\text { viviendas actuales y unidades convivenciales. }\end{array}$} \\
\hline (Ap. 2.7.4) & \multicolumn{2}{|c|}{$\begin{array}{l}\text { (2) existen diversos agentes participantes en el proceso de acceso a la } \\
\text { vivienda actualmente trabajando en la región, con interés real en la } \\
\text { consecución de un acceso digno a esta. }\end{array}$} \\
\hline & \multicolumn{2}{|c|}{$\begin{array}{l}\text { (3) esa estrategia de transformación podría ser -o estar en parte siendo- } \\
\text { incorporada, activada y aprovechada por dichos agentes. }\end{array}$} \\
\hline
\end{tabular}

Tabla 2.11. Síntesis de la demostración parcial de la hipótesis general y construcción de la base para la demostración empírica y completa de la misma. Elaboración propia.
La Tabla 2.11 recoge y sintetiza, señalando los apartados de los que proviene la información, algunos de los principales aspectos desarrollados hasta aquí. La hipótesis previa apuntada en el apartado 1.3.4 queda así parcialmente demostrada, a la vez que ampliada para proseguir el trabajo. Enlazando con el marco teórico presentado, se señala la apuesta por el análisis de las causas contradictorias de fondo de los conflictos como vía para superar lecturas y respuestas superficiales centradas en sus efectos y abordar posibles alternativas transformadoras. 


\section{Alternativas espaciales: viviendas existentes infrautilizadas}

«En un punto, al menos, Marx y Unger hacen causa común. Ambos insisten en que es necesario construir el futuro, no con un fantástico molde utópico, sino mediante transformaciones tangibles de las materias primas que hemos recibido en nuestro estado actual».

(Harvey, 2003: 221)

«¿no puede surgir algo diferente, en el ámbito arquitectónico y urbanístico, del modo de producción existente, algo que nazca de sus propias contradicciones y las ponga de manifiesto en vez de cubrirlas bajo un velo?». 



\title{
- 3.1 - \\ Acotación del objeto de estudio
}

\author{
$-3.1 .1-$ \\ El drama de un parque de viviendas \\ infrautilizado
}

A partir de la problemática analizada, principalmente protagonizada por la incapacidad de una población con necesidad de vivienda y en proceso de precarización de generar demanda tanto en el mercado inmobiliario como en ocasiones en el sistema público de vivienda, y por una oferta que no responde al tamaño ni tipo de muchas de las unidades de convivencia que conforman esa población, se identifica dicha situación como la de un parque de viviendas, el del AMB, infrautilizado. No está este adaptándose a las necesidades domésticas espaciales de sus ocupantes -actuales y potenciales-, y no puede, a pesar de contar con un ratio global de unos 2,18 habitantes por vivienda, garantizar el acceso al mismo en condiciones dignas a toda su población. La contradicción entre la oferta y la demanda de vivienda en la que se ha podido contextualizar el trabajo analítico previo ha llevado a plantear la existencia de la siguiente alternativa: el parque actual de viviendas permite una ocupación, una adecuación y una versatilidad mayor de las que el uso y características actuales suponen. Se cree que este puede responder cuantitativa y cualitativamente a gran parte de la necesidad de vivienda existente bajo unos precios máximos tolerables de gasto. El planteamiento es que una de las posibles respuestas para avanzar hacia la meta de un acceso económico y espacialmente digno a la vivienda pasa por transformar y adaptar el parque existente a las necesidades espaciales de las unidades de convivencia actuales y futuras.

La justificación de la existencia de estas oportunidades bajo unos precios de acceso razonables descansa principalmente en tres cuestiones: la frecuente obsolescencia de sus tipologías, el haber descendido el tamaño medio de la unidad de convivencia, y el estar cambiando las pautas y dinámicas de vida y convivencia de parte de la población. Y es que más allá de la mera ocupación de una vivienda, hay cuestiones como el habitar y el vivir. Los esfuerzos por movilizar el parque residencial desocupado centrados exclusivamente en su puesta en carga, o por ofrecer nuevas viviendas bajo la reproducción de unas tipologías desfasadas de su contexto social, son planteados 
desde una óptica meramente cuantitativa muy extendida en la planificación y la política de vivienda (Romero y Mesías, 2004: 43). Urge por lo tanto incorporar al proceso otras variables cualitativas que permitan afrontar con mayor éxito la complejidad de la cuestión y poder así «restablecer las perspectivas críticas» (Slater, 2015: 131).

El objetivo del capítulo es por tanto demostrar este supuesto, sin entrar todavía en la gestión que ha de hacerlo posible; hacer evidente la existencia de este espacio de oportunidad en el parque existente, así como su potencial para corregir parte de la problemática, favoreciendo el avance hacia las metas del acceso económico a la vivienda, la adecuación tipológica de esta, y el aprovechamiento del parque existente. Se trata de un paso previo para ahondar posteriormente en dicha gestión. Es importante destacar que lo relevante no es la foto fija que se ha obtenido de las viviendas analizadas en este trabajo, cuya información se recogió en 2015. Como se ha establecido en el capítulo anterior, a pesar de estar en parte apoyada en un trabajo empírico, es esta una investigación con una fuerte componente teórica, y no tanto instrumental. No se busca dar soluciones concretas, si no pautas, pistas para comprender un fenómeno deducido y poder posteriormente actuar. El verdadero interés reside en el estudio y la comprensión de ese fenómeno que está detrás de la contradicción detectada y de las posibilidades de mejora que ofrecería la alternativa formulada.

Una vez finalizada la investigación, los datos recogidos ya no son vigentes, si no una imagen del pasado. Pero sí será en cambio valida la interpretación obtenida a partir de los mismos, que podrá ser aplicada al conjunto del parque residencial. Por supuesto, las dinámicas del parque varían con el tiempo, pero su ritmo es lo suficientemente lento como para que las aportaciones que se esperan hacer en la presente investigación puedan tener vigencia durante varios años. Las tipologías de vivienda predominantes apenas han evolucionado en décadas, con lo cual no es de esperar que lo hayan hecho durante el tiempo de redacción de este trabajo. En cuanto a los precios, estos no sufren grandes alteraciones -se mantienen en general estables con pequeñas variaciones según la zona (Gráficas 2.11 y 2.16)-, y la precariedad del colectivo necesitado de vivienda se mantiene o incluso aumenta (Gráficas 2.7, 2.8, 2.9 y 2.10). En cualquier caso, en las conclusiones finales se revisa la evolución de ambas cuestiones desde la realización del trabajo de campo hasta el cierre de la investigación, para evaluar posibles afecciones en los resultados obtenidos.

Así, el objeto de estudio de este capítulo es la totalidad del parque de vivienda libre existente en el AMB. La decisión de dejar fuera la oferta protegida se debe a que esta tiene mecanismos de gestión diferentes que la hacen incompatible con la metodología aquí propuesta, por lo que no permiten ser abordados desde el 
planteamiento utilizado ${ }^{65}$. La situación ideal para la investigación hubiese sido contar con información de la totalidad de las viviendas existentes. Por supuesto, ni los medios humanos ni temporales disponibles en este trabajo, ni siquiera la disponibilidad de datos sobre el tema, han hecho posible dicha labor. Por lo que se ha buscado la manera de trabajar con una muestra del parque existente que fuese representativa de su totalidad, y que ofreciese una visión lo más heterogénea y amplia posible de la diversidad existente. Una muestra parcial que debía ser asumible en cuanto a su dimensión para el manejo de datos $-\mathrm{y}$ poder ofrecer resultados tanto cuantitativos como cualitativos-, y accesible para poder recoger información de sus características espaciales y su precio de mercado. Estos condicionantes han llevado a seleccionar una muestra de la oferta de viviendas libres en venta y alquiler como la más adecuada para los fines buscados. Por otro lado, el hecho de trabajar con una muestra así no responde solo a la necesidad metodológica de contar con información accesible. Se ha seleccionado esta por tratarse de viviendas cuya propiedad está en un estado activo de búsqueda de su puesta en carga, lo cual además de facilitar enormemente el acceso a la información las sitúa en una posición muy favorable para su potencial ocupación y transformación. En el caso de que este trabajo haga un aporte de interés para gestionar e incorporar las viviendas libres a un mercado de oferta de vivienda accesible económicamente y adaptada tipológicamente, estas podrían hacer de elemento tractor para que se produzcan dos movimientos. Uno, que viviendas vacías pasen al mercado, y otro, que las ocupadas que no responden a las necesidades de diseño de sus habitantes sean, bien alteradas, bien puestas también en el mercado. Es decir, el éxito en el espacio de oportunidad formado por aquellas viviendas ya en el mercado podría generar un efecto dominó y activar esas mismas oportunidades en viviendas fuera del mismo. Al fin y al cabo, el objeto de estudio es, como se ha dicho, el parque en su totalidad.

\section{$-3.1 .2-$}

\section{Metodología para explotar datos de la oferta de vivienda libre}

El grueso de la información utilizada en el análisis presentado e interpretado en este capítulo es resultado de un trabajo de recogida de datos de uno de los principales portales inmobiliarios en el ámbito de

\footnotetext{
65 Sin embargo, como se desarrolla en el capítulo cuarto, algunos programas públicos de vivienda gestionan parque libre, por lo que la gestión pública no queda del todo desatendida en la investigación. En cualquier caso, posiblemente el enfoque de fondo y los resultados obtenidos tanto en este capítulo como en el siguiente serían en gran medida aplicables al parque protegido.
} 
estudio, Idealista. Se han recogido todas las viviendas existentes en este portal tanto para venta como para alquiler dentro del AMB en el momento de la toma de datos, realizada entre mayo y junio de 2015 . De cada una de ellas, se ha recogido su localización -a escala municipal o de barrio según la disponibilidad de este dato-, su precio, y su superficie. Para algunas de ellas se ha recogido también, como se verá más adelante, datos gráficos en forma de planos de distribución de los espacios que conforman la vivienda. En total, el universo analizado lo forman 17.415 viviendas en el caso de la venta y 2.071 en el del alquiler. Lo que respecto al total del parque residencial existente, suponen un $4,32 \%$ y un $0,51 \%$ respectivamente. Se ha de tener en cuenta que los datos de los precios no son de cierre, si no de oferta, por lo que es muy probable que los resultados reales varíen. Lo harán por la posible negociación a la baja de estos de cara al cierre de a venta o la firma del contrato de alquiler, y porque «en momentos de crisis los precios de mercado caen bien por debajo de los de los anuncios, pero no salen en la foto de nuestras precarias estadísticas» (Naredo, 2015: 80). En consecuencia, los precios de cierre finales serán con probabilidad más bajos que los utilizados en la investigación. El escenario real, por tanto, podrá suponerse como algo más favorable al que aquí se presenta. Sin embargo, al utilizarse como referencia una renta media, y dada la diversidad de realidades, la metodología utilizada sigue entendiéndose como valida, y ese desfase permite contar con cierto margen de seguridad.

En cualquier caso, existen antecedentes de estudios que se han basado en el análisis de las estructuras de los precios de oferta que, con sus limitaciones, validan y dan por buena esta fuente de información, y justifican la elección de esta metodología. La posibilidad de utilizar como fuente otras bases de datos como los «precios medios de las viviendas de una ciudad es una manera de ocultar cualquier información sobre su estructura y su morfología» (Roch, 2009: 185). En algunos de ellos incluso se ha utilizado la misma fuente de datos, el portal inmobiliario Idealista (Bárcena et al., 2011; Fernández y Roch, 2012). Esta afirmación podría ser aplicada a la decisión de tomar como referencia de capacidad de pago una renta media, pues esta oculta la estructura de rentas que hay detrás. La necesidad de acotar la investigación y hacerla viable ha llevado a tomar dicha decisión. No obstante, se apuntan algunas reflexiones sobre esto en el apartado 3.3.3.

La justificación de apoyar el estudio en la oferta del mercado libre, que podría ser cuestionada por aceptar las 'reglas' de un sistema que se pretende transformar, puede ser argumentada a partir del marco teórico previo. La situación problemática en torno a la vivienda no es, como se ha planteado, un reflejo de dos bandos enfrentados, si no de un sistema desigual de agentes, fuerzas y acciones contradictorias. Por ello, se ha planteado que el éxito de equilibrar dichas desigualdades dependerá en parte de abordar esa problemática como una cuestión colectiva y no como ataques de agentes externos. Esto lleva a leer los 
posibles agentes enemigos como compañeros a quienes reconducir. Todo ello podría ser respondido con una afirmación sencilla: si es una cuestión interna, el propio sistema podría por ejemplo bajar los precios de acceso a la vivienda. Aquí la naturaleza colectiva e interna cobran importancia, y dotan de complejidad a la situación. La cuestión se centra entonces en la manera de reformar este sistema colectivo desigual, transformando las pautas y las estructuras agresivas del capitalismo sin que este colapse de forma que se lleve por delante, precisamente, a aquellos colectivos más vulnerables. Esa vocación de transformación interna es la que justifica la decisión de tomar como base del estudio los precios y las tipologías del mercado libre. Porque es ese, y no otro, el principal soporte del que se dispone para hacer realidad el derecho a una vivienda digna y adecuada del que buena parte de la población carece.

Las tipologías de vivienda existentes son una variable cuya materialidad y rigidez es fácil de entender, y por lo tanto hacen rápidamente comprensible que se hayan tenido en cuenta. Pero el 'aceptar' los precios del mercado libre como base puede ser más cuestionado por su aparente mayor capacidad de alteración. Sin embargo, no es tanto los precios lo que se está tomando como base, si no la búsqueda de lucro propia de la mentalidad que está detrás. Esa es realmente la variable económica tenida en cuenta y que, como se ha mostrado en los condicionantes y obstáculos propios de la generación de contradicciones, no es material, pero presenta una fuerte rigidez y resistencia a su cambio. Por lo tanto, se ha entendido como necesario el abordar el acceso a la vivienda desde esta perspectiva. En consecuencia, los espacios alternativos deducidos son oportunidades para la ya citada reforma revolucionaria, generadas por unos espacios producidos obsoletos en su tipología e inaccesibles en su precio en un contexto de precarización y cambio sociodemográfico.

\section{Reparto y aporte de la muestra}

Antes de pasar a desarrollar los resultados obtenidos, se presenta la distribución cuantitativa de la muestra utilizada a lo largo de las áreas de análisis utilizadas. Estas no son áreas homogéneas ni responden a unos criterios ideales de delimitación, ya que la utilización del portal inmobiliario Idealista como fuente de datos conlleva ciertos condicionantes. Uno de ellos es la imposibilidad de geolocalizar con precisión cada vivienda, ya que en la mayoría de los casos los anuncios carecen de la información necesaria para ello. Así, la unidad espacial mínima de localización de estas, la que se ha utilizado en el trabajo, ha sido la que el propio portal utiliza. Esta varía; podrá coincidir con la totalidad de un municipio, con la suma de dos o incluso tres términos municipales completos o, por el contrario, llegar a la escala de barrio, acercándose a las delimitaciones realizadas por las secciones censales (Mapas 3.1 y 3.2). El conjunto de todas ellas suma un total de 98 áreas geográficas y su identificación, localización 
y delimitación puede ser consultada en los anexos. La mayoría de mapas y gráficas que se expondrán a lo largo del trabajo indicarán en general, salvo excepciones, porcentajes relativos dentro de cada una de estas áreas de territorio analizada, con el fin de comparar unas y otras a un mismo nivel. Por supuesto, hay áreas con muchas más viviendas que otras; si los mapas fuesen en números brutos serían estas las que mayores valores obtendrían en casi todos los casos, con lo cual se perdería la posibilidad de comparar las áreas entre sí. Pero como el objetivo es conocer mejor el parque residencial en cada área de manera comparada con el resto, se trabajarán también los porcentajes, pudiendo siempre acudir a los números y distribución globales para conocer donde se acumularán más viviendas.
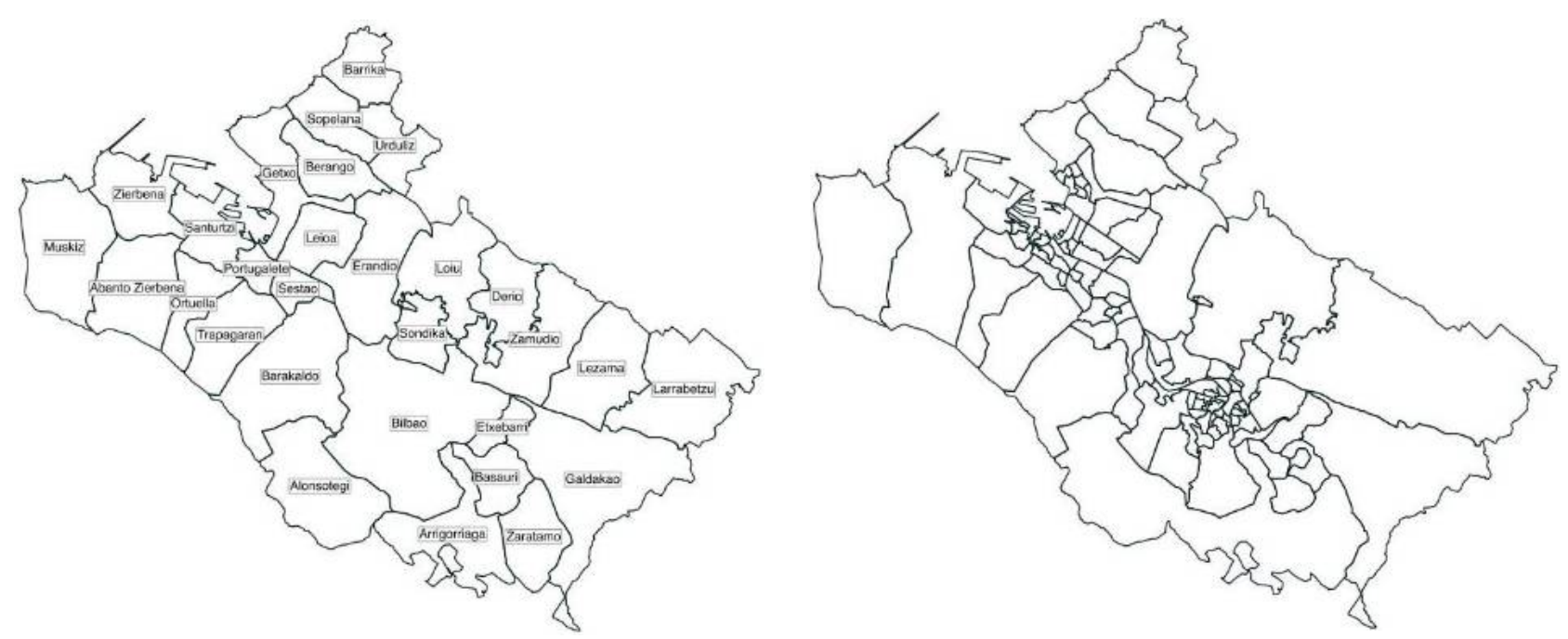

Mapas 3.1 y 3.2. Delimitaciones de los términos municipales del AMB (izquierda), y de las 98 áreas utilizadas por el

portal inmobiliario Idealista (derecha). Más información en los anexos del trabajo. Elaboración propia a partir de Idealista.com.

Dentro de cada área de recogida de datos, el porcentaje de viviendas analizadas respecto al total de viviendas existentes en la misma es relativamente similar en todas ellas (Tablas 3.1 y 3.2). Salvo algunos pocos casos concretos con pequeños desajustes por encima y por debajo, pero sin que suponga afección alguna al trabajo. En cuanto al aporte de viviendas que cada área hace al universo total de la muestra, los números no ofrecen anomalías ni indicios de desequilibrio. Este aporte se da de manera generalizada en una proporción algo menor que lo que su parque supone respecto al total de la región. Por supuesto, existen ciertos casos con variaciones mayores, y excepcionalmente, con un aporte proporcionalmente mayor. Hecho este último que se da en dos de las tres áreas con mayores parques residenciales de la región: Bilbao y Getxo. Presentada así la muestra, a continuación se exponen los materiales y métodos utilizados en las diferentes fases del trabajo para la demostración de la existencia de este espacio de oportunidad. 


\begin{tabular}{|c|c|c|c|c|c|}
\hline \multirow[b]{2}{*}{ Área geográfica } & \multicolumn{2}{|c|}{$\begin{array}{l}\text { VENTA } \\
\text { existentes }\end{array}$} & \multicolumn{3}{|c|}{ muestra } \\
\hline & viviendas & $\%$ AMB & viviendas & $\%$ área & $\%$ muestra \\
\hline AMB & 403.018 & 100 & 17.415 & 4,33 & 100 \\
\hline Abanto-Zierbena y Zierbena & 4.663 & 1,16 & 159 & 3,41 & 0,91 \\
\hline Alonsotegi-Arrigorriaga-Zaratamo & 7.413 & 1,84 & 194 & 2,62 & 1,11 \\
\hline Barakaldo* & 47.632 & 11,82 & 1.558 & 3,27 & 8,95 \\
\hline Barrika & 718 & 0,18 & 59 & 8,22 & 0,34 \\
\hline Basauri* & 18.018 & 4,47 & 183 & 1,02 & 1,05 \\
\hline Berango & 2.813 & 0,7 & 233 & 8,28 & 1,34 \\
\hline Bilbao* & 154.110 & 38,24 & 8.305 & 5,39 & 47,69 \\
\hline Erandio-Astrabudua & 10.502 & 2,61 & 238 & 2,27 & 1,37 \\
\hline Etxebarri & 7.940 & 1,97 & 78 & 0,98 & 0,45 \\
\hline Galdakao & 12.863 & 3,19 & 259 & 2,01 & 1,49 \\
\hline Getxo* & 32.640 & 8,1 & 2.358 & 7,22 & 13,54 \\
\hline Leioa* & 13.458 & 3,34 & 586 & 4,35 & 3,36 \\
\hline Loiu-Derio-Sondika & 5.812 & 1,44 & 221 & 3,8 & 1,27 \\
\hline Muskiz & 3.241 & 0,8 & 138 & 4,26 & 0,79 \\
\hline Ortuella & 3.869 & 0,96 & 137 & 3,54 & 0,79 \\
\hline Portugalete* & 20.811 & 5,16 & 779 & 3,74 & 4,47 \\
\hline Santurtzi* & 22.342 & 5,54 & 820 & 3,67 & 4,71 \\
\hline Sestao* & 13.357 & 3,31 & 385 & 2,88 & 2,21 \\
\hline Sopela & 6.243 & 1,55 & 380 & 6,09 & 2,18 \\
\hline Trapagaran & 6.049 & 1,5 & 160 & 2,65 & 0,92 \\
\hline Urduliz & 3.578 & 0,89 & 77 & 2,15 & 0,44 \\
\hline Zamudio-Lezama-Larrabetzu & 3.502 & 0,87 & 108 & 3,08 & 0,62 \\
\hline
\end{tabular}

* Disgregada en áreas inframunicipales

Tabla 3.1. Número de viviendas total existente en el AMB y número de viviendas utilizadas como universo de la muestra de venta para el análisis; sin desglosar en áreas inframunicipales en aquellos casos disponibles. Udalplan 2014 e Idealista.com. 


\begin{tabular}{|c|c|c|c|c|c|}
\hline & $\begin{array}{l}\text { ALQ } \\
\text { exist }\end{array}$ & $\begin{array}{l}\text { ILER } \\
\text { ates }\end{array}$ & & muestra & \\
\hline Área geográfica & viviendas & $\%$ AMB & viviendas & $\%$ área & $\%$ muestra \\
\hline AMB & 403.018 & 100 & 2.071 & 0,51 & 100 \\
\hline Abanto-Zierbena y Zierbena & 4.663 & 1,16 & 10 & 0,21 & 0,48 \\
\hline Alonsotegi-Arrigorriaga-Zaratamo & 7.413 & 1,84 & 5 & 0,07 & 0,24 \\
\hline Barakaldo* & 47.632 & 11,82 & 72 & 0,15 & 3,47 \\
\hline Barrika & 718 & 0,18 & 3 & 0,42 & 0,14 \\
\hline Basauri* & 18.018 & 4,47 & 12 & 0,07 & 0,58 \\
\hline Berango & 2.813 & 0,7 & 12 & 0,43 & 0,58 \\
\hline Bilbao* & 154.110 & 38,24 & 1.406 & 0,91 & 67,89 \\
\hline Erandio-Astrabudua & 10.502 & 2,61 & 23 & 0,22 & 1,11 \\
\hline Etxebarri & 7.940 & 1,97 & 26 & 0,33 & 1,26 \\
\hline Galdakao & 12.863 & 3,19 & 27 & 0,21 & 1,3 \\
\hline Getxo* & 32.640 & 8,1 & 299 & 0,92 & 14,44 \\
\hline Leioa* & 13.458 & 3,34 & 40 & 0,3 & 1,93 \\
\hline Loiu-Derio-Sondika & 5.812 & 1,44 & 15 & 0,26 & 0,72 \\
\hline Muskiz & 3.241 & 0,8 & 5 & 0,15 & 0,24 \\
\hline Ortuella & 3.869 & 0,96 & 7 & 0,18 & 0,34 \\
\hline Portugalete* & 20.811 & 5,16 & 23 & 0,11 & 1,11 \\
\hline Santurtzi* & 22.342 & 5,54 & 38 & 0,17 & 1,83 \\
\hline Sestao* & 13.357 & 3,31 & 11 & 0,08 & 0,53 \\
\hline Sopela & 6.243 & 1,55 & 24 & 0,38 & 1,16 \\
\hline Trapagaran & 6.049 & 1,5 & 3 & 0,05 & 0,14 \\
\hline Urduliz & 3.578 & 0,89 & 12 & 0,34 & 0,58 \\
\hline Zamudio-Lezama-Larrabetzu & 3.502 & 0,87 & 8 & 0,23 & 0,39 \\
\hline
\end{tabular}

* Disgregada en áreas inframunicipales

Tabla 3.2. Número de viviendas total existente en el AMB y número de viviendas utilizadas como universo de la muestra de alquiler para el análisis; sin desglosar en áreas inframunicipales en aquellos casos disponibles. Udalplan 2014 e Idealista.com. 


\section{Metodología para la Accesibilidad Económica}

El trabajo comienza por analizar las condiciones económicas de acceso a la muestra de viviendas, en el orden que sigue:

- Referencias previas: de manera previa y a modo de referencia, se fija un límite en forma de Precio Máximo Tolerable (PMT) de gasto a destinar a la vivienda. Este se ha obtenido a partir del estudio sobre el coste de la emancipación residencial en Euskadi para el año 2013 realizado desde el Observatorio Vasco de la Juventud (López, 2014), el cual se basó en un salario medio de $1.400 €$. El trabajo se centraba en la situación del acceso individual de la población joven de entre 18 y 34 años a la vivienda en Euskadi, pero en este caso los resultados del mismo se han aplicado a la totalidad de la población del AMB sin acotación de edad alguna. Los datos de la renta personal media del Eustat para ese mismo año eran de $1.584 €$ en el AMB, lo que valida la referencia anterior como buena y permite trabajar con un margen de error conservador del lado más desfavorable. Por supuesto, al tratarse de un dato medio son muchos los casos que se quedarán por debajo o por encima de esta. Sin embargo, se han de aclarar aquí dos cuestiones que justifica la utilización del citado estudio: la primera es que el enfoque del presente trabajo es precisamente aportar soluciones para aquellos sectores de población que están por debajo, o al menos en torno a esa renta de referencia. La segunda, es que este porcentaje de población no es nada despreciable. Atendiendo a los datos disponibles en Eustat de 2015, y que hacen referencia a la provincia de Bizkaia, un $57 \%$ de la población mayor de 18 años tenía rentas personales iguales o inferiores a $1.500 €$ mensuales. La distribución por estratos de rentas muestra dos realidades: hay un alto porcentaje de población sin renta y con rentas muy bajas -por debajo de los $1.500 €-$, y se trata de un colectivo especialmente protagonizado por la mujer -con una mayor vulnerabilidad, al sumar un $70 \%$ por debajo de los $1.500 €$, frente al $44 \%$ en los hombres- (Gráfica 3.1).

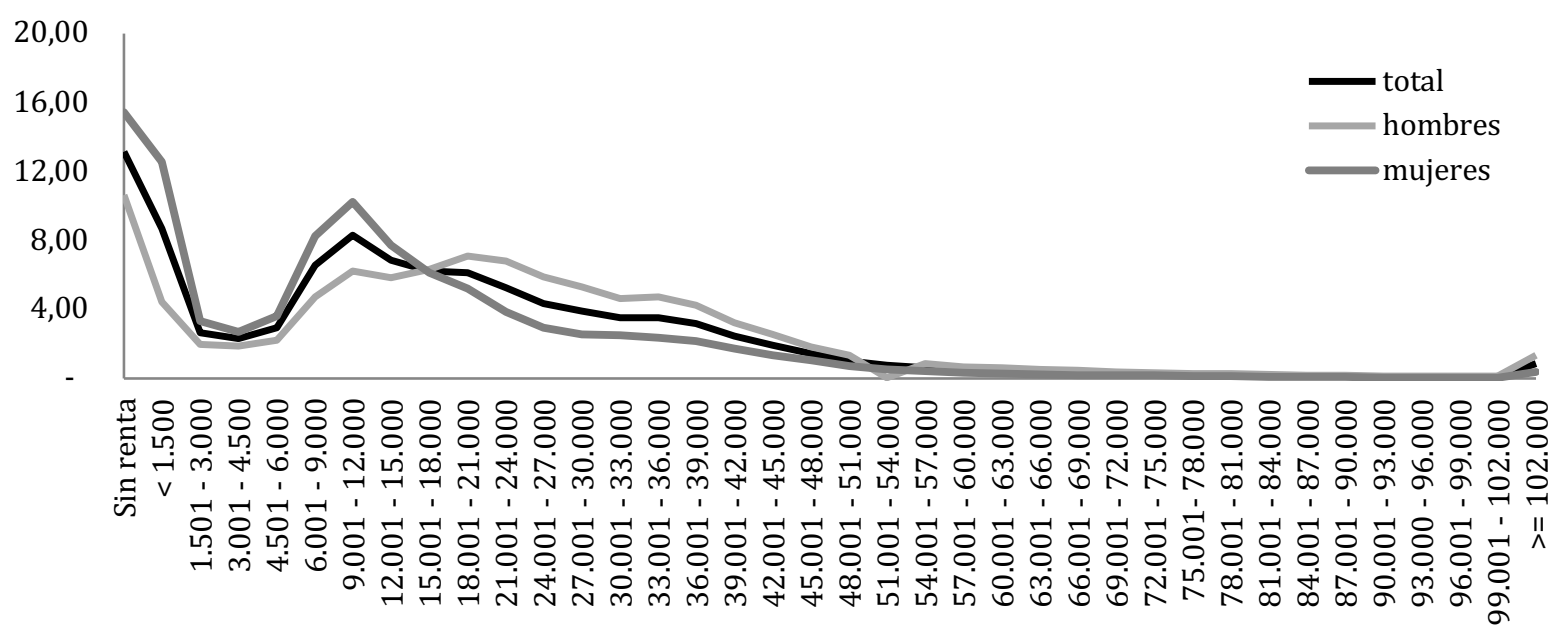

Gráfica 3.1. Población de 18 años y más por estrato de renta personal anual en Bizkaia. Eustat, 2015. 


1
entre 1 y 2
entre 2 y 3
entre 3 y 4
entre 4 y 5
entre 5 y 6
entre 6 y 7
entre 7 y 8
entre 8 y 9
entre 9 y 10
entre 10 y 15
entre 15 y 20
entre 20 y 40
más de 40

Tabla 3.3. Clasificación utilizada del número de personas o rentas medias de $1.400 €$ necesarias para un acceso económico digno a la vivienda. Elaboración propia.
Como en el citado informe se establece, «todo coste que supere el 30\% nos indica que se supera el umbral máximo de endeudamiento tolerable, tal y como lo consideran las entidades financieras a la hora de conceder una hipoteca. Por encima del $40 \%$, siguiendo la pauta establecida por la oficina estadística de la Comisión Europea (Eurostat), se consideraría sobreesfuerzo económico» (López, 2014: 3). Se ha tomado por lo tanto como PMT el fijado en el informe en $98.644 €$ para la venta y $420 €$ para el alquiler como máximos a admitir por debajo de un 30\% del salario de referencia, $1.400 €$.

- Características de la oferta: seguidamente, a partir de la generación de diferentes gráficas, se estudian las características de las estructuras de precios de las diferentes áreas y la distribución geográfica de estas en el área metropolitana. Se han analizado los precios medios, precios unitarios y franjas de precios más habituales en la oferta de vivienda en venta y alquiler, para realizar una primera aproximación y conocer el objeto de estudio en cuestión.

- Accesibilidad económica individual: mediante el cruce y comparación de los dos datos anteriores -el precio máximo tolerable frente a la muestra de la oferta seleccionada- se analiza la accesibilidad individual a la misma. Como se verá, esta es prácticamente inexistente si se plantea desde unos límites de acceso económicamente razonables para la renta de referencia. Si a lo anterior se le suman las situaciones de precarización ya presentadas en capítulos previos respecto a la calidad del empleo, o la ausencia de este, puede confirmarse la existencia de una crisis en el acceso a la vivienda.

- Accesibilidad económica por agrupación: por último, lo visto en el paso anterior lleva a plantear una estrategia teórica como marco para la gestión en el capítulo cuarto- de agrupación de personas con una renta de referencia de $1.400 €$ (Tabla 3.3). Una agrupación de momento solo económica; en este punto no se entran a debatir ni analizar cuestiones espaciales, de tamaño de la vivienda o tipológicas, ni si forman o no unidades de convivencia entre sí. El objetivo es comprobar en qué medida varía y sería posible alcanzar el acceso a la vivienda mediante la acumulación de salarios medios, manteniendo los precios de oferta de la muestra, y siempre por debajo de los límites de endeudamiento y sobre esfuerzo económico anteriormente fijados en los 98.644€ y $420 €$. Los resultados muestran el número de personas con capacidad de pago necesarias para afrontar esos precios bajo el PMT -más adelante se abordará está cuestión incorporando la variable de personas sin esa capacidad de pago, presentes en muchas unidades de convivencia-. 
Por supuesto, no se está negando la naturaleza individual del derecho a la vivienda. La justificación de esta decisión metodológica se apoya directamente en la ya comentada interpretación de la situación problemática. La de un parque residencial infrautilizado generado por un modelo de vivienda excluyente, en un contexto social de precarización económica y de reducción en el tamaño y diversificación del tipo de unidad convivencial. Que es lo que ha llevado a la formulación de un potencial no aprovechado de transformación y optimización del mismo para dar respuesta a gran parte de la necesidad de vivienda. El planteamiento es sencillo: al contar en general las viviendas con una mayor superficie mínima y/o unas características espaciales diferentes de las que muchas de las unidades de convivencia actuales necesitan, la adaptación de estas podría llegar a albergar en condiciones dignas de habitabilidad -ya sea en viviendas separadas, o no- a más de una unidad. Y posiblemente pasando por una intervención física en las mismas. Así, este punto lo que busca es desarrollar el primer paso lógico, que no es otro que comprobar cual sería la accesibilidad económica a esas viviendas en base a diferentes niveles de acumulación de rentas de referencia. Para ello, se divide el precio de oferta entre el PMT correspondiente, sea de venta o alquiler, obteniéndose un factor de accesibilidad económica. Este determina el número de personas con una renta de $1.400 €$ mensuales necesarias para acceder en condiciones económicas dignas a la misma.

\section{Metodología para la Accesibilidad Espacial}

Una vez comprobado que la estrategia anterior puede ser de interés como herramienta bajo un punto de vista económico, el siguiente paso aborda las condiciones espaciales de acceso a las viviendas que forman la muestra:

- Referencias previas: en este caso, la referencia que de manera previa se toma para garantizar una habitabilidad mínima o una ocupación máxima- será el concepto de Superficie Mínima por Persona (SMP) obtenido principalmente a partir de datos del INE. En el último censo de población y viviendas disponible, el de 2011, la superficie media por habitante en el AMB era de $33,35 \mathrm{~m}^{2}$, un metro menos que la media provincial. Por supuesto, la media esconde matices que pueden arrojar lecturas de mayor interés y riqueza y que, aunque previsibles en algunos casos, dan una imagen más real de la situación. Estos indican que, a mayor tamaño de hogar o unidad de convivencia, menor es la superficie media por persona (Tabla 3.4), algo que es justamente a la inversa en el caso de la superficie útil de la vivienda: a mayor superficie, mayor es la media por persona (Tabla 3.5). Lo que viene confirmado, desde otro punto de vista, si se analiza la estructura de los hogares (Tabla 3.6). Con todo, se ha decidido tomar, con la flexibilidad que permiten los valores medios, la superficie de

\begin{tabular}{ll}
\hline Total & $\mathbf{3 3 , 3 5}$ \\
\hline 1 persona & 74,36 \\
2 personas & 39,92 \\
3 personas & 27,64 \\
4 personas & 22,32 \\
5 personas & 19,31 \\
6 personas o más & 16,22 \\
\hline
\end{tabular}

Tabla 3.4. Superficie media por persona $\left(\mathrm{m}^{2}\right)$ según el tamaño de hogar en el AMB. INE, Censo de Población y Viviendas 2011.

\begin{tabular}{ll}
\hline Total & $\mathbf{3 3 , 3 5}$ \\
\hline Hasta $30 \mathrm{~m} 2$ & 12,91 \\
$30-45 \mathrm{~m} 2$ & 22,78 \\
$46-60 \mathrm{~m} 2$ & 26,2 \\
$61-75 \mathrm{~m} 2$ & 29,47 \\
$76-90 \mathrm{~m} 2$ & 32,71 \\
$91-105 \mathrm{~m} 2$ & 36,96 \\
$106-120 \mathrm{~m} 2$ & 40,42 \\
$121-150 \mathrm{~m} 2$ & 48,72 \\
$151-180 \mathrm{~m} 2$ & 57,59 \\
Más de $180 \mathrm{~m} 2$ & 83,34 \\
\hline
\end{tabular}

Tabla 3.5. Superficie media por persona $\left(\mathrm{m}^{2}\right)$ según la superficie útil media de la vivienda en el AMB. INE, Censo de Población y Viviendas 2011. 
Tabla 3.6. Superficie media por persona $\left(\mathrm{m}^{2}\right)$ según la estructura del hogar en el AMB.

INE, Censo de Población y

Viviendas 2011.
$30 \mathrm{~m}^{2}$ como Superficie Mínima por Persona. Esta decisión viene a su vez apoyada por otras referencias y trabajos (Moya, 2007), que establecen como adecuada dicha superficie como cifra de referencia para un alojamiento mínimo de calidad. Pero sin olvidar que se trata de una cifra de referencia aproximada, y nunca para plantear viviendas de esa superficie si pretenden reproducir «la vivienda habitual, achicada en su programa» (Moya, 2007: 11). Toda persona puede y debería lícitamente acceder a una vivienda de la superficie que guste; pero la urgente necesidad de responder a la necesidad de alojamiento es la razón para enfocar el trabajo hacia el cumplimento de mínimos.

\begin{tabular}{lc}
\hline Total & $\mathbf{3 3 , 3 5}$ \\
\hline Hogar con una mujer sola menor de 65 años & 72,57 \\
Hogar con un hombre solo menor de 65 años & 71,37 \\
Hogar con una mujer sola de 65 años o más & 77,54 \\
Hogar con un hombre solo de 65 años o más & 77,09 \\
Hogar con padre o madre que convive con algún hijo menor de 25 años & 31,82 \\
Hogar con padre o madre que convive con todos sus hijos de 25 años o más & 37,92 \\
Hogar formado por pareja sin hijos & 39,95 \\
Hogar formado por pareja con hijos en donde algún hijo es menor de 25 años & 23,62 \\
Hogar formado por pareja con hijos en donde todos los hijos de 25 años o más & 26,65 \\
Hogar formado por pareja o padre/madre que convive con algún hijo menor de 25 años y & \\
otra(s) persona(s) & 19,45 \\
Otro tipo de hogar & 29,83 \\
\hline
\end{tabular}

- Características de la oferta: definido lo anterior, se comienza por un análisis global de los tamaños de vivienda existentes en la muestra seleccionada, generando gráficas y mapas para su interpretación, y clasificándolas en las distintas franjas de superficie utilizadas por el INE, complementadas a partir de los $180 \mathrm{~m}^{2}$ por una clasificación propia para abarcar algunos casos excepcionales de grandes superficies, como grandes viviendas, edificios completos, o aquellos con usos no residenciales (Tabla 3.7). Se decide hacer de esta manera por dos motivos. El primero, para permitir posibles cruces y comparaciones con los datos de las estadísticas publicadas por dicho instituto. El segundo, porque no hay garantía de la exactitud en los datos de superficie de las viviendas de la muestra -no se especifica la fuente de obtención de la misma, ni si es útil o construida-, con lo que se considera una superficie aproximada. Así, con este método se permite cierta flexibilidad y absorber los márgenes de error posibles en dicha información. El objetivo de todo ello es realizar un primer 
acercamiento a las características espaciales de la muestra para ver cómo es su estructura de superficies.

\begin{tabular}{l}
\hline superficie \\
\hline$<30 \mathrm{~m}^{2}$ \\
$30-45 \mathrm{~m}^{2}$ \\
$46-60 \mathrm{~m}^{2}$ \\
$61-75 \mathrm{~m}^{2}$ \\
$76-90 \mathrm{~m}^{2}$ \\
$91-105 \mathrm{~m}^{2}$ \\
$106-120 \mathrm{~m}^{2}$ \\
$121-150 \mathrm{~m}^{2}$ \\
$151-180 \mathrm{~m}^{2}$ \\
$181-200 \mathrm{~m}^{2}$ \\
$201-250 \mathrm{~m}^{2}$ \\
$251-300 \mathrm{~m}^{2}$ \\
$301-400 \mathrm{~m}^{2}$ \\
$401-500 \mathrm{~m}^{2}$ \\
$501-600 \mathrm{~m}^{2}$ \\
$601-700 \mathrm{~m}^{2}$ \\
$701-800 \mathrm{~m}^{2}$ \\
$801-900 \mathrm{~m}^{2}$ \\
$901-1.000 \mathrm{~m}^{2}$ \\
$1.001-1.500 \mathrm{~m}{ }^{2}$ \\
$>1.500 \mathrm{~m}^{2}$ \\
\hline
\end{tabular}

\begin{tabular}{ll}
\hline superficie & $\mathbf{n}^{\mathbf{o}}$ de personas \\
\hline$<30 \mathrm{~m}^{2}$ & 1 \\
$30-45 \mathrm{~m}^{2}$ & $1-2$ \\
$46-60 \mathrm{~m}^{2}$ & 2 \\
$61-75 \mathrm{~m}^{2}$ & $2-3$ \\
$76-90 \mathrm{~m}^{2}$ & 3 \\
$91-105 \mathrm{~m}^{2}$ & $3-4$ \\
$106-120 \mathrm{~m}^{2}$ & 4 \\
$121-150 \mathrm{~m}^{2}$ & $4-5$ \\
$151-180 \mathrm{~m}^{2}$ & $5-6$ \\
$181-200 \mathrm{~m}^{2}$ & $6-7$ \\
$201-250 \mathrm{~m}^{2}$ & $7-8$ \\
$251-300 \mathrm{~m}^{2}$ & $8-10$ \\
$301-400 \mathrm{~m}^{2}$ & $10-13$ \\
$401-500 \mathrm{~m}^{2}$ & $13-16$ \\
$501-600 \mathrm{~m}^{2}$ & $16-20$ \\
$601-700 \mathrm{~m}^{2}$ & $20-23$ \\
$701-800 \mathrm{~m}^{2}$ & $23-26$ \\
$801-900 \mathrm{~m}^{2}$ & $26-30$ \\
$901-1.000 \mathrm{~m}^{2}$ & $30-33$ \\
$1.001-1.500 \mathrm{~m}{ }^{2}$ & $33-50$ \\
$>1.500 \mathrm{~m}^{2}$ & $>50$ \\
\hline
\end{tabular}

- Accesibilidad espacial por agrupación: a continuación, se hace una aproximación al límite máximo de ocupación de esas viviendas en función de su superficie total. La lógica de base es la división de la superficie de la vivienda entre la SMP, para tratar de ver qué tamaño aproximado de grupos de personas, así como el peso demográfico de estos en la estructura de unidades de convivencia existentes, permitiría alojar el parque actual. Siempre, bajo una habitabilidad de calidad en torno a los aproximadamente $30 \mathrm{~m}^{2}$ por persona establecidos. Así, se continúa con el mismo ejercicio teórico anterior de agrupación de personas, pero en este caso, en vez de centrarse en aspectos económicos, se hace en función de la superficie de la vivienda. Lo cual arroja interesantes resultados que permitirán descomponer la oferta y analizar sus posibilidades más en detalle. Como adelanto, se aclara que esta
Tabla 3.7 (izquierda). Franjas de superficies en las que se han clasificado las viviendas o inmuebles de la muestra según los datos disponibles de su superficie. INE y elaboración propia.

Tabla 3.8 (derecha). Número máximo de personas por vivienda definido según las franjas de superficie utilizadas y una superficie media por habitante de unos $30 \mathrm{~m}^{2}$. Elaboración propia. 
estrategia de agrupación no debe entenderse como sinónimo de una ocupación de una vivienda al uso por varias unidades de convivencia, viéndose obligadas a convivir y compartir un espacio que no está diseñado para sus necesidades. Se trata de un paso previo que forma parte de un planteamiento más ambicioso y complejo, adelantado en el capítulo anterior, que propone la adaptación y transformación de un parque parcialmente obsoleto a las demandas de muchas unidades convivenciales. Al no contar, como se ha dicho, con datos precisos de la superficie de cada vivienda, si no con una clasificación de estas por franjas de superficie, el método finalmente utilizado ha sido establecer, para cada una de estas franjas, un número máximo de personas según los criterios propuestos en el trabajo (Tabla 3.8). El trabajar con franjas de superficie supone que, en general, la variable de ocupación se defina a su vez también en franjas de grupos de personas $^{66}$. En este punto, no se entra a analizar las tipologías de las viviendas; esta variable condicionará en gran medida el éxito del planteamiento propuesto para este espacio de oportunidad, y se abordará en el siguiente paso. Aquí se estudia el potencial de la superficie de las viviendas, en bruto.

- Estudio tipológico: el último paso en el análisis de la accesibilidad espacial es un pequeño estudio de las tipologías residenciales frecuentes en la muestra utilizada. A partir de los planos del estado actual disponibles en 377 de las viviendas ofertadas, se comprueba cuál es su capacidad actual para acoger a diferentes unidades de convivencia, y cuáles sus potenciales posibilidades de adaptación física a otras configuraciones espaciales para responder a la estrategia planteada. Para ello, se han utilizado una serie de indicadores tomados de diversos trabajos de investigación desarrollados en las últimas décadas en torno al espacio doméstico. Con un abanico de referencias amplio -detalladas en los anexos- que van desde los estudios de los soportes de Habraken (1972), a los aportes de Zaida Muxí (2009) para avanzar hacia un hábitat doméstico no jerárquico ni androcéntrico, se abarcan algunas de las principales variables espaciales de la vida doméstica. En una situación ideal, las referencias para definir los criterios de una vivienda adecuada hubiesen podido estar centradas en las normativas de diseño de vivienda. Lamentablemente, como ya se ha avanzado en el capítulo previo, las existentes condicionan el desarrollo de unas viviendas a modo de estuche y con estancias especializadas.

\footnotetext{
${ }^{66}$ Como se viene diciendo, los objetivos generales del trabajo y la metodología en su conjunto permiten jugar con estos y otros márgenes, ya que el fin es identificar y comprender grandes pautas, fenómenos y oportunidades genéricas sin entrar en detalle de casos concretos.
} 


\section{Metodología para la Accesibilidad Total}

Hasta este punto se habrá visto confirmada, por separado, tanto una alta accesibilidad económica como otra espacial a la muestra de viviendas seleccionada, si se aborda desde una estrategia de agrupación de personas con una renta media de referencia de $1.400 €$ y una superficie mínima por persona de $30 \mathrm{~m}^{2}$-que se trata de un límite de seguridad, como se verá, superado por los resultados; es decir, no se está planteando una estrategia para dividir el parque de viviendas actual en unidades de dicha superficie-. Queda por abordar entonces el cruce de ambas variables y comprobar en cada caso si se dan las dos; ver si las viviendas de la muestra que son económicamente accesibles lo son también espacialmente, y viceversa. Se trata por lo tanto de identificar el número y tipo de viviendas que permiten esa agrupación:

- Accesibilidad total bruta: el primer ejercicio a realizar en este caso es la identificación de aquellas viviendas en las que el número mínimo de personas necesarias para acceder a la misma en función de su precio de oferta- bajo las condiciones de acceso económico dignas definidas, podrían habitarlas -en función de su superficie- bajo las condiciones espaciales de ocupación establecidas. Se hace necesario así definir un marco de incompatibilidad a partir de las categorías utilizadas en cada uno de los indicadores anteriores, para excluir aquellas viviendas que no cumplan las dos condiciones. Este es el definido en la Tabla 3.9. Al indicador resultante se le ha llamado Accesibilidad Total, y refleja de manera considerablemente directa las capacidades del parque actual para responder a la situación problemática mediante la hipótesis parcial de trabajo planteada para este capítulo. No obstante, se trata de una Accesibilidad Total Bruta, ya que hasta aquí no se han tenido en cuenta variables complementarias como el coste de las posibles transformaciones espaciales de esas viviendas, o la inclusión de personas sin capacidad de pago en el cálculo. Lo cual alterará las condiciones económicas de acceso, al incrementar el gasto total necesario o reducir la capacidad de pago total de la unidad de convivencia.

- Accesibilidad total neta: el segundo paso ha sido estimar un aumento del gasto total necesario para el acceso económico, incorporando al precio de oferta un incremento motivado por las obras de transformación de la vivienda, los honorarios de los agentes profesionales participantes en su gestión y desarrollo, o las tasas a aplicar, entre otras cuestiones. Con este ajuste, el ejercicio se acerca más a los supuestos en los que se lleven a cabo estas estrategias de agrupación de personas y adaptación del parque. Se define así la obtenida tras este ajuste como Accesibilidad Total Neta. Dado que la escala y profundidad de cada intervención puede variar, se han definido cuatro tramos de incremento, con el objetivo de ver si se producen cambios significativos entre uno y otro (Tabla 3.10). Este se calcula en

\begin{tabular}{ll}
\hline coste $\mathbf{m} \mathbf{2}$ & coeficiente \\
\hline $600 €$ & 1,2222 \\
$700 €$ & 1,2592 \\
$800 €$ & 1,2962 \\
$900 €$ & 1,3332 \\
\hline
\end{tabular}

Tabla 3.10. Coeficientes estimativos de incremento del precio de oferta según el coste de la intervención de transformación de la vivienda. Elaboración propia. 
Tabla 3.9. Marcadas con una $\mathrm{X}$, situaciones de incompatibilidad entre accesibilidad espacial y económica según los criterios establecidos de PMT y SMP para la identificación de la Accesibilidad Total Bruta. Elaboración propia. base a unos coeficientes medios obtenidos a partir del aumento de precio resultante en 369 de las 377 viviendas analizadas en el estudio tipológico -las que se ofertan para la venta-, según cuatro niveles de coste por metro cuadrado. Los coeficientes se han obtenido a partir de la media del coste añadido para cada una de las viviendas y para cada tramo de coste de intervención. Se ha considerado que serían intervenciones en lo fundamental y esencial de la vivienda, sin abordar lo accesorio. Este apartado se centra en la muestra en venta - por ser más directa su posible aplicación respecto al alquiler-, y una vez multiplicado el precio de la oferta por cada coeficiente, se ha repetido el ejercicio del paso anterior para el cálculo de la accesibilidad total.

\begin{tabular}{|c|c|c|c|c|c|c|c|c|c|c|c|c|c|c|c|}
\hline acc. Espacial & & & cesib & oilida & $\mathrm{d}$ eco & nóm & ica: $n$ & ${ }^{\circ} \mathrm{de}$ & perso & nas o & renta & is medi & as de 1 . & $400 €$ & \\
\hline superficie & personas & 1 & $1-2$ & $2-3$ & $3-4$ & $4-5$ & $5-6$ & $6-7$ & $7-8$ & $8-9$ & $9-10$ & $10-15$ & $15-20$ & $20-40$ & $>40$ \\
\hline$<30 \mathrm{~m} 2$ & 1 & & $\mathrm{X}$ & $\mathrm{X}$ & $\mathrm{X}$ & $\mathrm{X}$ & $\mathrm{X}$ & $\mathrm{X}$ & $\mathrm{X}$ & $\mathrm{X}$ & $\mathrm{X}$ & $\mathrm{X}$ & $\mathrm{X}$ & $\mathrm{X}$ & $\mathrm{X}$ \\
\hline $30-45 \mathrm{~m} 2$ & $1-2$ & & & $\mathrm{X}$ & $\mathrm{X}$ & $\mathrm{X}$ & $\mathrm{X}$ & $\mathrm{X}$ & $\mathrm{X}$ & $\mathrm{X}$ & $\mathrm{X}$ & $\mathrm{X}$ & $\mathrm{X}$ & $\mathrm{X}$ & $\mathrm{X}$ \\
\hline $46-60 \mathrm{~m} 2$ & 2 & & & $\mathrm{X}$ & $\mathrm{X}$ & $\mathrm{X}$ & $\mathrm{X}$ & $\mathrm{X}$ & $\mathrm{X}$ & $\mathrm{X}$ & $\mathrm{X}$ & $\mathrm{X}$ & $\mathrm{X}$ & $\mathrm{X}$ & $\mathrm{X}$ \\
\hline $61-75 \mathrm{~m} 2$ & $2-3$ & & & & $\mathrm{X}$ & $\mathrm{X}$ & $\mathrm{X}$ & $\mathrm{X}$ & $\mathrm{X}$ & $\mathrm{X}$ & $\mathrm{X}$ & $\mathrm{X}$ & $\mathrm{X}$ & $\mathrm{X}$ & $\mathrm{X}$ \\
\hline $76-90 \mathrm{~m} 2$ & 3 & & & & $\mathrm{X}$ & $\mathrm{X}$ & $\mathrm{X}$ & $\mathrm{X}$ & $\mathrm{X}$ & $\mathrm{X}$ & $\mathrm{X}$ & $\mathrm{X}$ & $\mathrm{X}$ & $\mathrm{X}$ & $\mathrm{X}$ \\
\hline $91-105 \mathrm{~m} 2$ & $3-4$ & & & & & $\mathrm{X}$ & $\mathrm{X}$ & $\mathrm{X}$ & $\mathrm{X}$ & $\mathrm{X}$ & $\mathrm{X}$ & $\mathrm{X}$ & $\mathrm{X}$ & $\mathrm{X}$ & $\mathrm{X}$ \\
\hline $106-120 \mathrm{~m} 2$ & 4 & & & & & $\mathrm{X}$ & $\mathrm{X}$ & $\mathrm{X}$ & $\mathrm{X}$ & $\mathrm{X}$ & $\mathrm{X}$ & $\mathrm{X}$ & $\mathrm{X}$ & $\mathrm{X}$ & $\mathrm{X}$ \\
\hline $121-150 \mathrm{~m} 2$ & $4-5$ & & & & & & $\mathrm{X}$ & $\mathrm{X}$ & $\mathrm{X}$ & $\mathrm{X}$ & $\mathrm{X}$ & $\mathrm{X}$ & $\mathrm{X}$ & $\mathrm{X}$ & $\mathrm{X}$ \\
\hline $151-180 \mathrm{~m} 2$ & $5-6$ & & & & & & & $\mathrm{X}$ & $\mathrm{X}$ & $\mathrm{X}$ & $\mathrm{X}$ & $\mathrm{X}$ & $\mathrm{X}$ & $\mathrm{X}$ & $\mathrm{X}$ \\
\hline $181-200 \mathrm{~m} 2$ & $6-7$ & & & & & & & & $\mathrm{X}$ & $\mathrm{X}$ & $\mathrm{X}$ & $\mathrm{X}$ & $\mathrm{X}$ & $\mathrm{X}$ & $\mathrm{X}$ \\
\hline $201-250 \mathrm{~m} 2$ & $7-8$ & & & & & & & & & $\mathrm{X}$ & $\mathrm{X}$ & $\mathrm{X}$ & $\mathrm{X}$ & $\mathrm{X}$ & $\mathrm{X}$ \\
\hline $251-300 \mathrm{~m} 2$ & $8-10$ & & & & & & & & & & & $\mathrm{X}$ & $\mathrm{X}$ & $\mathrm{X}$ & $\mathrm{X}$ \\
\hline $301-400 \mathrm{~m} 2$ & $10-13$ & & & & & & & & & & & $\mathrm{X}$ & $\mathrm{X}$ & $\mathrm{X}$ & $\mathrm{X}$ \\
\hline $401-500 \mathrm{~m} 2$ & $13-16$ & & & & & & & & & & & & $\mathrm{X}$ & $\mathrm{X}$ & $\mathrm{X}$ \\
\hline $501-600 \mathrm{~m} 2$ & $16-20$ & & & & & & & & & & & & & $\mathrm{X}$ & $\mathrm{X}$ \\
\hline $601-700 \mathrm{~m} 2$ & $20-23$ & & & & & & & & & & & & & $\mathrm{X}$ & $\mathrm{X}$ \\
\hline $701-800 \mathrm{~m} 2$ & $23-26$ & & & & & & & & & & & & & & $\mathrm{X}$ \\
\hline $801-900 \mathrm{~m} 2$ & $26-30$ & & & & & & & & & & & & & & $\mathrm{X}$ \\
\hline $901-1000 \mathrm{~m} 2$ & $30-33$ & & & & & & & & & & & & & & $\mathrm{X}$ \\
\hline $1001-1500 \mathrm{~m} 2$ & $33-50$ & & & & & & & & & & & & & & \\
\hline$>1500 \mathrm{~m} 2$ & $>50$ & & & & & & & & & & & & & & \\
\hline
\end{tabular}

- Personas sin capacidad de pago: la accesibilidad total a la vivienda que engloba tanto condiciones económicas como 
espaciales planteada hasta aquí se ha calculado contando con que todas las personas tienen capacidad de pago. Por lo que, por último y para aportar una mirada final a esta accesibilidad global alcanzada, queda pendiente reflexionar sobre aquellas unidades de convivencia en las que no todas sus personas cuentan con dicha capacidad. Lo cual, como se ha visto en los datos presentados sobre renta, desempleo y endeudamiento -entre otros- en el capítulo segundo, se trata de una realidad extendida. A partir de la Tabla 3.9, se genera una nueva en la que esta vez se indican aquellas situaciones en las que la superficie de la vivienda permite una ocupación máxima mayor que el número de personas con capacidad de pago mínimo necesario para su acceso económico. Es decir, casos en los que la vivienda permite espacialmente acoger más personas que el número de rentas medias de $1.400 €$ necesarias para su compra o alquiler (Tabla 3.11). Como se verá, los resultados son considerablemente positivos.
Tabla 3.11. Marcadas con un + , situaciones de accesibilidad espacial por encima de la SMP con posibilidad de acoger a personas sin capacidad de pago. Elaboración propia.

\begin{tabular}{|c|c|c|c|c|c|c|c|c|c|c|c|c|c|c|c|}
\hline acc. Espacial & & & de $\mathrm{p}$ & ersot & has o & renta & as me & dias & de 1. & $400 €$ & & & & & \\
\hline superficie & personas & 1 & $1-2$ & $2-3$ & $3-4$ & $4-5$ & $5-6$ & $6-7$ & $7-8$ & $8-9$ & $9-10$ & $10-15$ & $15-20$ & $20-40$ & $>40$ \\
\hline$<30 \mathrm{~m} 2$ & 1 & & $\mathrm{X}$ & $\mathrm{X}$ & $\mathrm{X}$ & $\mathrm{X}$ & $\mathrm{X}$ & $\mathrm{X}$ & $\mathrm{X}$ & $\mathrm{X}$ & $\mathrm{X}$ & $\mathrm{X}$ & $\mathrm{X}$ & $\mathrm{X}$ & $\mathrm{X}$ \\
\hline $30-45 \mathrm{~m} 2$ & $1-2$ & & & $\mathrm{X}$ & $\mathrm{X}$ & $\mathrm{X}$ & $\mathrm{X}$ & $\mathrm{X}$ & $\mathrm{X}$ & $\mathrm{X}$ & $\mathrm{X}$ & $\mathrm{X}$ & $\mathrm{X}$ & $\mathrm{X}$ & $\mathrm{X}$ \\
\hline $46-60 \mathrm{~m} 2$ & 2 & + & & $\mathrm{X}$ & $\mathrm{X}$ & $\mathrm{X}$ & $\mathrm{X}$ & $\mathrm{X}$ & $\mathrm{X}$ & $\mathrm{X}$ & $\mathrm{X}$ & $\mathrm{X}$ & $\mathrm{X}$ & $\mathrm{X}$ & $\mathrm{X}$ \\
\hline $61-75 \mathrm{~m} 2$ & $2-3$ & + & + & & $\mathrm{X}$ & $\mathrm{X}$ & $\mathrm{X}$ & $\mathrm{X}$ & $\mathrm{X}$ & $\mathrm{X}$ & $\mathrm{X}$ & $\mathrm{X}$ & $\mathrm{X}$ & $\mathrm{X}$ & $\mathrm{X}$ \\
\hline $76-90 \mathrm{~m} 2$ & 3 & + & + & & X & $\mathrm{X}$ & $\mathrm{X}$ & $\mathrm{X}$ & $\mathrm{X}$ & $\mathrm{X}$ & $\mathrm{X}$ & $\mathrm{X}$ & $\mathrm{X}$ & $\mathrm{X}$ & X \\
\hline $91-105 \mathrm{~m} 2$ & $3-4$ & + & + & + & & $\mathrm{X}$ & $\mathrm{X}$ & $\mathrm{X}$ & $\mathrm{X}$ & $\mathrm{X}$ & $\mathrm{X}$ & $\mathrm{X}$ & $\mathrm{X}$ & $\mathrm{X}$ & $\mathrm{X}$ \\
\hline $106-120 \mathrm{~m} 2$ & 4 & + & + & + & & $\mathrm{X}$ & $\mathrm{X}$ & $\mathrm{X}$ & $\mathrm{X}$ & $\mathrm{X}$ & $\mathrm{X}$ & $\mathrm{X}$ & $\mathrm{X}$ & $\mathrm{X}$ & X \\
\hline $121-150 \mathrm{~m} 2$ & $4-5$ & + & + & + & + & & $\mathrm{X}$ & $\mathrm{X}$ & $\mathrm{X}$ & $\mathrm{X}$ & $\mathrm{X}$ & $\mathrm{X}$ & $\mathrm{X}$ & $\mathrm{X}$ & $\mathrm{X}$ \\
\hline $151-180 \mathrm{~m} 2$ & $5-6$ & + & + & + & + & + & & $\mathrm{X}$ & $\mathrm{X}$ & $\mathrm{X}$ & $\mathrm{X}$ & $\mathrm{X}$ & $\mathrm{X}$ & $\mathrm{X}$ & $\mathrm{X}$ \\
\hline $181-200 \mathrm{~m} 2$ & $6-7$ & + & + & + & + & + & + & & $\mathrm{X}$ & $\mathrm{X}$ & $\mathrm{X}$ & $\mathrm{X}$ & $\mathrm{X}$ & $\mathrm{X}$ & X \\
\hline $201-250 \mathrm{~m} 2$ & $7-8$ & + & + & + & + & + & + & + & & $\mathrm{X}$ & $\mathrm{X}$ & $\mathrm{X}$ & $\mathrm{X}$ & $\mathrm{X}$ & $\mathrm{X}$ \\
\hline $251-300 \mathrm{~m} 2$ & $8-10$ & + & + & + & + & + & + & + & + & + & & $\mathrm{X}$ & $\mathrm{X}$ & $\mathrm{X}$ & $\mathrm{X}$ \\
\hline $301-400 \mathrm{~m} 2$ & $10-13$ & + & + & + & + & + & + & + & + & + & + & $\mathrm{X}$ & $\mathrm{X}$ & $\mathrm{X}$ & $\mathrm{X}$ \\
\hline $401-500 \mathrm{~m} 2$ & $13-16$ & + & + & + & + & + & + & + & + & + & + & + & $\mathrm{X}$ & $\mathrm{X}$ & $\mathrm{X}$ \\
\hline $501-600 \mathrm{~m} 2$ & $16-20$ & + & + & + & + & + & + & + & + & + & + & + & + & $\mathrm{X}$ & $\mathrm{X}$ \\
\hline $601-700 \mathrm{~m} 2$ & $20-23$ & + & + & + & + & + & + & + & + & + & + & + & + & $\mathrm{X}$ & $\mathrm{X}$ \\
\hline $701-800 \mathrm{~m} 2$ & $23-26$ & + & + & + & + & + & + & + & + & + & + & + & + & & $\mathrm{X}$ \\
\hline $801-900 \mathrm{~m} 2$ & $26-30$ & + & + & + & + & + & + & + & + & + & + & + & + & + & $\mathrm{X}$ \\
\hline $901-1000$ m2 & $30-33$ & + & + & + & + & + & + & + & + & + & + & + & + & + & $\mathrm{X}$ \\
\hline $1001-1500 \mathrm{~m} 2$ & $33-50$ & + & + & + & + & + & + & + & + & + & + & + & + & + & + \\
\hline$>1500 \mathrm{~m} 2$ & $>50$ & + & + & + & + & + & + & + & + & + & + & + & + & + & + \\
\hline
\end{tabular}


- Cruce con las estructuras de las unidades de convivencia: a modo de cierre de este apartado, se ha realizado un cruce entre los tamaños de unidades de convivencia que podrían albergar las viviendas con valores positivos en la accesibilidad total, y los datos de la estructura de los hogares existentes del INE. El objetivo ha sido identificar desfases entre ambos datos, lo cual ha permitido argumentar y reforzar la estrategia de agrupación de personas planteada para una gran parte de la muestra analizada.

\section{Metodología para el análisis de áreas geográficas}

Como se verá, todo lo que se desarrolla a lo largo del capítulo en los puntos hasta aquí presentados arroja un esperanzador resultado, que llevará a reivindicar que existe una oportunidad de diversificar y adaptar espacialmente una buena parte de la oferta de vivienda a las características de la necesidad de la misma. Y todo bajo parámetros de acceso económicos justos y racionales. Aunque los resultados de los puntos previos se van a presentar tanto a escala general del AMB, como desglosados a lo largo de las diferentes áreas de análisis tomadas del portal inmobiliario Idealista, se profundizará más en los primeros, relativos al conjunto del área metropolitana. No obstante, se ha querido añadir un apartado final comparativo de todas las unidades geográficas mínimas disponibles en la muestra. Ya que las ciudades no son espacios sociales homogéneos, es vital saber como se territorializan desigualmente estos espacios de oportunidad. Sin desarrollar el análisis al mismo nivel que se ha hecho en el conjunto del AMB -principalmente por la falta de medios humanos y temporales-, se han desarrollado los siguientes puntos:

- Estudio de las estructuras de la oferta: se han estudiado y comparado entre sí las diferentes estructuras de accesibilidad tanto económica como espacial de cada área geográfica. Aunque se han encontrado importantes diferencias, el ejercicio ha permitido identificar con claridad una serie de grupos con características similares en la oferta de vivienda en venta y alquiler analizada, síntoma de la existencia de pautas comunes y señales de homogeneización de la ciudad residencial. En concreto, son cuatro los grupos definidos en cada indicador.

- Análisis geográfico y espacial: al trasladar al espacio geográfico del AMB los resultados anteriores, ha sido posible identificar un desequilibrio en el reparto global de las áreas con características homogéneas a lo largo del área metropolitana. También se han identificado, a una escala mayor, varios ejemplos de una alta polarización de las condiciones de acceso económico y espacial al parque residencial entre áreas espaciales colindantes, lo que permitirá apoyar las tesis relativas a los procesos de jerarquización y desigualdad social existentes en un espacio urbano común. 
- Identificación de oportunidades: el cruce entre los resultados de la clasificación en cuatro grupos de la accesibilidad económica y espacial ha permitido -de una manera más estimativa que en el caso del conjunto del AMB antes analizado en el que se ha trabajado vivienda por vivienda-, obtener una aproximación a la accesibilidad total de cada área. A partir del abanico de combinaciones posibles se ha establecido, para cada una de las 98 áreas, una graduación -de más a menos favorabledel potencial de adecuación de la oferta para un acceso total según la estrategia de agrupación de personas propuesta. Todo ello permite identificar aquellas áreas con mayor potencial para el acceso a la vivienda mediante dicho planteamiento, e igualmente localizar aquellas con mayores impedimentos para el mismo fin. Por otra parte, ha permitido confirmar que la tendencia de un área hacia uno u otro sentido no está condicionada por un determinado rango de valores en alguno de los indicadores, si no por la combinación de ambos.

- Condicionantes del entorno local: como se habrá confirmado hasta aquí, el AMB, y como muchos otros sistemas urbanos de cierta entidad (Brenner y Theodore, 2017; Fernández y Roch, 2012; Harvey, 1977, 2014; Massey, 1995; Peck, 2015; Slater, 2015) no es un espacio urbano y territorial homogéneo y equilibrado, si no que a lo largo de su formación, desarrollo y transformación ha ido generando espacios tanto de acumulación de capital e inversiones, como de exclusión de sectores más desfavorecidos. Por lo que la obtención de resultados similares entre muchas de las áreas analizadas no implica que dos de ellas con valores similares tengan que presentar un potencial similar, ni una misma manera de ser abordadas. La idea aquí defendida es que la superposición de otras capas y variables, así como un estudio del contexto más local y cercano, ayudará a comprender con mayor precisión las diversas oportunidades y realidades de cada área, y definir las posibles estrategias. Sin pretender profundizar en esto, pero si hacer evidente esa diversidad y complejidad del contexto socio-urbano, para finalizar el capítulo se presentan algunos datos parciales que ayudan a visualizar su diversidad. En concreto, a partir de un estudio realizado por el Instituto Vasco de Estadística sobre tipos de secciones censales en Euskadi (Eustat, 2010), se presentan datos geolocalizados en cada área de análisis relacionados con la renta familiar media, el tamaño familiar y el año de construcción de los edificios residenciales.

Se plantea por lo tanto en este capítulo una respuesta cuantitativa, haciendo referencia a la ocupación -la puesta en carga-, otra cualitativa, al apuntar a la versatilidad -en forma de adaptación a las necesidades programáticas de sus ocupantes-, y una tercera económica -en lo relativo a la capacidad de pago-. Se cree 
imprescindible incorporar la variable económica a la investigación. Ya se ha expuesto en el segundo capítulo que el acceso a la vivienda actual está deformado por las consecuencias de un modelo inmobiliario con una visión muy parcelaria de su cometido, con unos precios fuera de la capacidad de demanda de parte de la población. Sin embargo, la urgencia de la problemática lleva a partir, a corto plazo y siempre en paralelo a un esfuerzo por transformar esa realidad, de las reglas de dicho modelo para buscar soluciones revolucionarias. Es así que un análisis únicamente espacial de la muestra trabajada se quedaría incompleto. 


\section{$-3.2-$ \\ Trabajos previos: indicadores de base}

En este apartado se exponen y desarrollan los resultados parciales relativos a las condiciones tanto económicas como espaciales de acceso que presenta la muestra de viviendas seleccionada, siempre por separado. Tras una introducción sobre las principales características de la oferta analizada en cada una de ellas, se presentan los resultados de mayor interés y relevancia obtenidos. Se cierra cada parte con la confirmación de haber detectado una oportunidad para avanzar hacia la meta del acceso a la vivienda, lo cual justifica y sirve de base para los resultados del apartado 3.3.

\section{$-3.2 .1-$}

\section{Condiciones económicas para el acceso}

\section{Características de la oferta}

A partir del universo consultado, el precio medio de venta de una vivienda en el mercado libre del Área Metropolitana de Bilbao ha quedado fijado en $308.646 €$, y en $925 €$ mensuales el del alquiler. Se trata, a la vista de los datos disponibles, de uno de los mercados inmobiliarios con los precios más altos de España (Tabla 3.12). Como se ha visto en el capítulo previo, aunque la renta media del ámbito de estudio es también una de las más altas del estado, la importancia radica en el cruce de ambos indicadores. Y Euskadi presenta, precisamente, entre todas las comunidades autónomas, uno de los costes más altos de acceso a la vivienda. Siendo, por ejemplo en 2013 y para la población joven, el más alto para la venta y el segundo para el alquiler por detrás de la Comunidad Autónoma de Madrid (Consejo de la Juventud de España, 2013). Por otro lado, más del 60\% de la población del AMB residía en 2010 en secciones censales cuya renta per cápita media estaba por debajo de la media de la comunidad autónoma (Eustat, 2010).

Siendo esta una investigación centrada en el AMB, y no de un estudio comparativo entre áreas metropolitanas o regiones, el precio medio global puede pasar a segundo plano. Pero sin dejar de lado los precios medios, parece adecuado e interesante en este primer acercamiento centrar la atención en los diferentes valores y la

\begin{tabular}{ll}
\hline Provincia & $\boldsymbol{€} / \mathbf{m}^{2}$ \\
\hline Gipuzkoa & 3.257 \\
Gran Bilbao (comarca) & 3.031 \\
Bizkaia & 2.915 \\
Madrid & 2.374 \\
Baleares & 2.220 \\
Barcelona & 2.179 \\
Ceuta & 2.130 \\
Araba & 2.090 \\
Girona & 2.049 \\
Málaga & 1.799 \\
Cantabria & 1.747 \\
Pontevedra & 1.615 \\
La Coruña & 1.593 \\
Asturias & 1.549 \\
Sevilla & 1.539 \\
Cádiz & 1.524 \\
Huesca & 1.515 \\
Salamanca & 1.480 \\
Navarra & 1.479 \\
Las Palmas & 1.465 \\
Tarragona & 1.446 \\
Zaragoza & 1.445 \\
Alicante & 1.433 \\
Almería & 1.418 \\
Santa Cruz de Tenerife & 1.403 \\
Huelva & 1.378 \\
Valladolid & 1.360 \\
Palencia & 1.291 \\
Córdoba & 1.279 \\
Segovia & 1.279 \\
\hline Burgos & 1.268 \\
\hline Tabia 312 & \\
\hline
\end{tabular}

Tabla 3.12. Posición del Gran Bilbao en las 30 provincias con el precio medio del $\mathrm{m}^{2}$ de vivienda libre en venta más alto de España. Idealista, 2014. 
Gráfica 3.2. Variación del precio medio de venta $(€)$ por área de análisis respecto a la media del AMB. Elaboración propia a partir de Idealista, 2015. Información detallada en anexos.

Gráfica 3.3. Variación del precio medio de alquiler $(€)$ por área de análisis respecto a la media del AMB. Elaboración propia a partir de Idealista, 2015. Información detallada en anexos. distribución espacial de estos en cada área geográfica analizada. Por supuesto, la estructura de precios de la región no es uniforme, si no que presenta una importante diversidad, como se va a ir viendo en el desarrollo del capítulo. Como primera aproximación a la misma, las 98 áreas analizadas muestran extremos bien alejados: desde 117.223€ a $718.183 €$ de precio medio en la oferta en venta, y desde $340 €$ a $1.637 €$ en alquiler. Al superponer al precio medio de cada una de las áreas el precio medio de la región se observa que la mayoría de estas, en torno a un $70 \%$ tanto para la venta como para el alquiler, tienen un precio medio inferior. Lo cual indica que aquellas con precios altos alcanzan valores muy por encima de los $308.646 €$ y $925 €$ medios del AMB respectivamente (Gráficas 3.2 y 3.3). Valores que pueden consultarse con detalle en los anexos del trabajo. Al tratarse de una investigación urbanística, la distribución geográfica y territorialización de los datos analizados es una cuestión clave. Como se ha indicado en la revisión crítica del estado de la cuestión del capítulo primero, uno de los objetivos que este trabajo pretende alcanzar es cubrir cierta carencia, en el ámbito de análisis, de estudios urbanos con un claro componente espacial. En este caso, en torno a las dimensión social de la vivienda. Así, al trasladar los datos de los precios medios a mapas, se pueden realizar unas primeras lecturas de las diferencias espaciales que el parque residencial presenta en el AMB (Mapas 3.3 y 3.4).
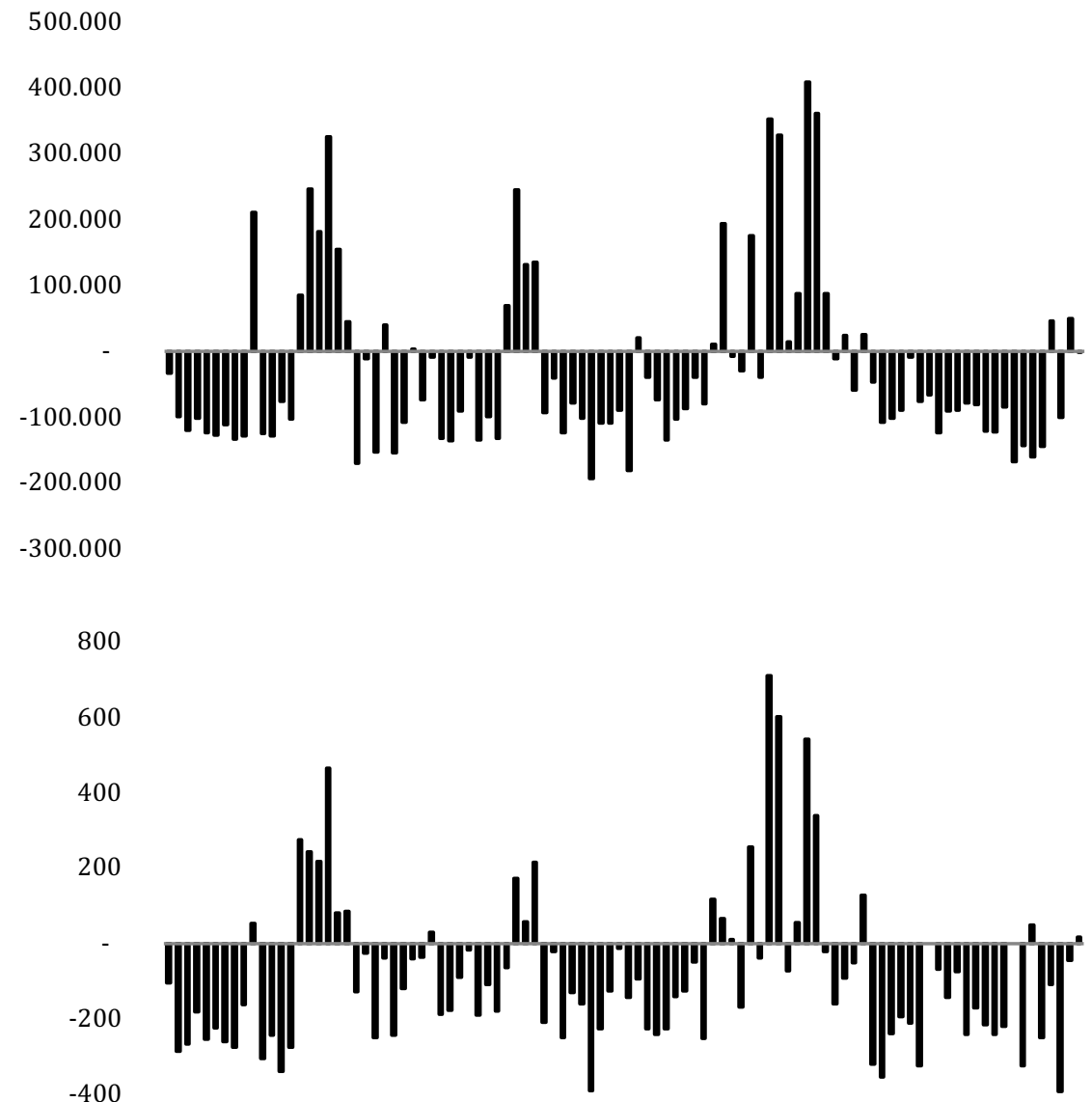

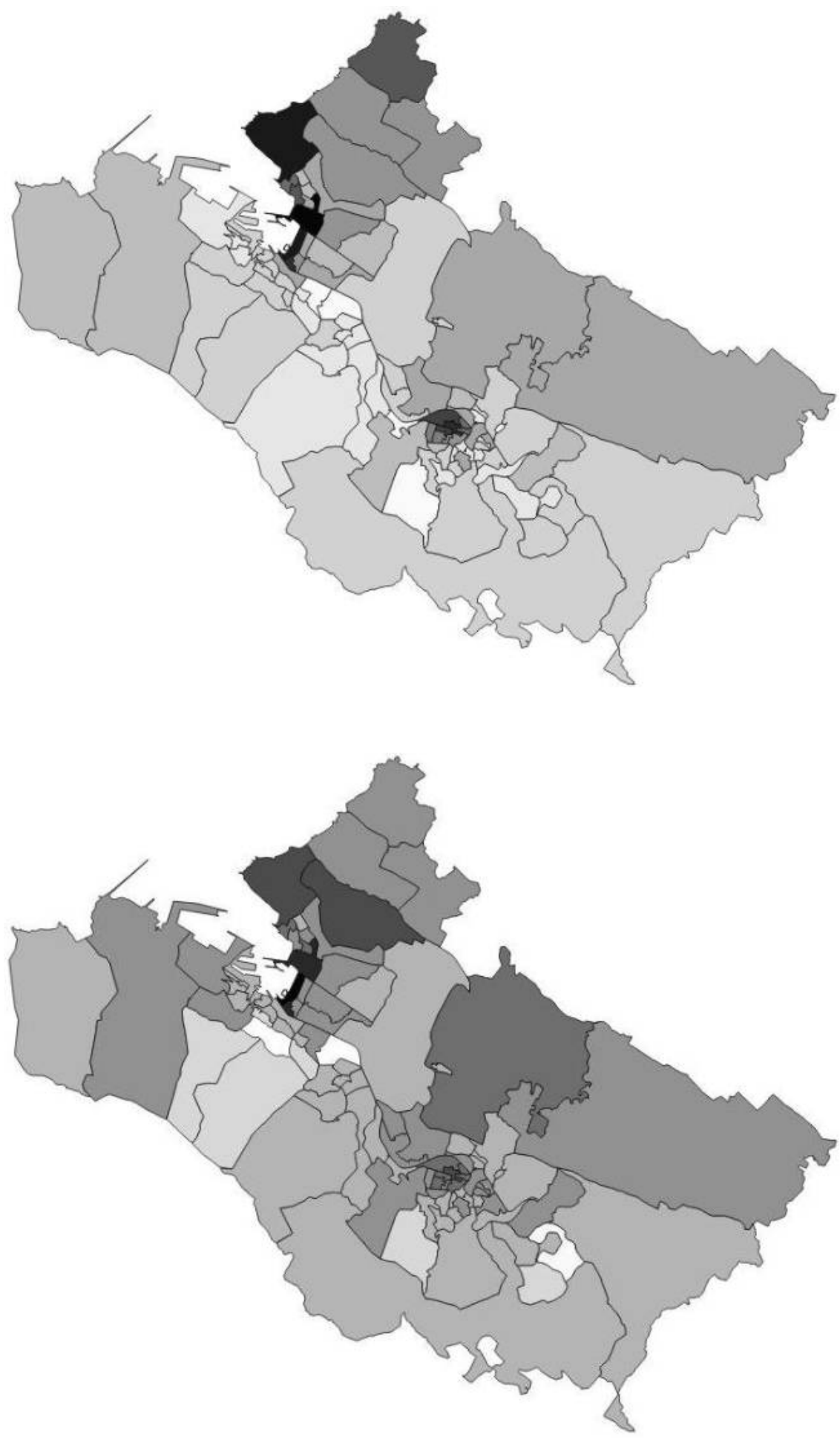

Las principales áreas con los precios medios más altos se localizan en torno al Ensanche de Bilbao y gran parte del municipio de Getxo, así como zonas de costa como Barrika, aunque en este último caso solo para la oferta de venta. Son, las dos primeras, zonas significativas por alojar desde su origen a las clases altas de la sociedad local. En cambio, aquellas zonas con los precios medios más bajos se

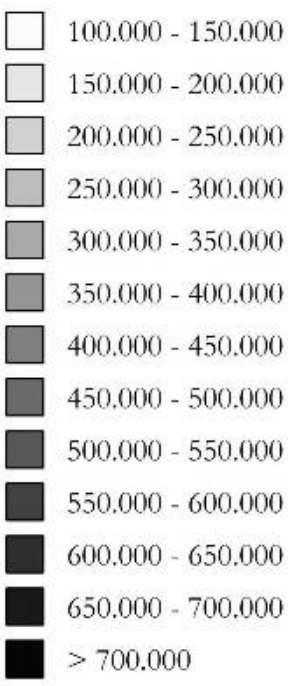

Mapa 3.3. Precio medio de la oferta en venta analizada. Elaboración propia a partir de Idealista, 2015.

Mapa 3.4. Precio medio de la oferta en alquiler analizada. Elaboración propia a partir de Idealista, 2015. 
7.000 .000

6.000 .000

$5.000,000$

4.000 .000

3.000 .000

2.000 .000

1.000 .000

Gráfica 3.4. Precios unitarios de venta $(€)$ de la muestra de viviendas ordenados de menor a mayor y precio medio, en el AMB.

Elaboración propia a partir de Idealista, 2015.

5.000

3.750

2.500

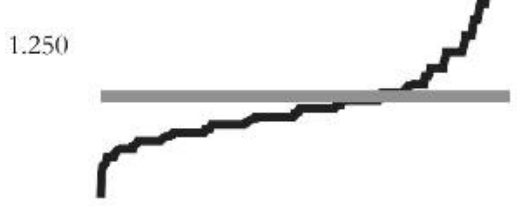

0

Gráfica 3.5. Precios unitarios de alquiler $(€)$ de la muestra de viviendas ordenados de menor a mayor y precio medio, en el AMB.

Elaboración propia a partir de Idealista, 2015. encuentran en parte de los municipios de la Margen Izquierda de la ría, Basauri y Erandio. Todos ellos han acogido, y lo siguen haciendo, el grueso de los grandes usos industriales desde los inicios del desarrollo industrial del AMB. También presentan precios medios bajos zonas de Bilbao como Peñascal, Zorroza, Rekalde, San Francisco, Atxuri o parte de Uribarri. El resto de áreas presentan precios medios cercanos a la media del AMB. Es el caso de gran parte del valle del Txorierri, (formado por Loiu, Derio, Sondika, Zamudio, Lezama y Larrabetzu), los municipios de la costa oriental (Berango, Sopela, Urduliz, Barrika -para el alquiler-), parte del municipio de Getxo con zonas más tradicionalmente de clase media y baja como Romo, los municipios de la costa occidental (Zierbena, AbantoZierbena, Muskiz), o los barrios de Bilbao de Deusto o Miribilla.

Como se desea analizar e interpretar el mercado con mayor detalle, se profundiza a continuación más allá del precio medio para ir progresivamente desgranando y presentando la información recogida. Un proceso de análisis de los datos obtenidos que tiene como objetivo lograr diferentes visiones y lecturas para su interpretación posterior. La lectura del conjunto de los precios unitarios y las diferentes estructuras que estos conforman para cada muestra local permite identificar ciertos aspectos de interés, que en este caso se presentan de manera similar para los dos regímenes de tenencia, la venta y el alquiler. Al igual que en los precios medios, los extremos son muy desiguales: con precios unitarios mínimos de $17.500 €$ y $300 €$, y máximos de $6.400 .000 €$ y $5.000 €$, respectivamente. En cualquier caso, uno de los aspectos de interés es la evolución de estas estructuras de precios unitarios, de un extremo al otro. La toma de datos individual de cada una de las viviendas de la muestra posibilita un gran detalle de análisis de precios, que permite un enfoque minucioso. Observadas la totalidad de las viviendas del AMB analizadas, y situadas en orden creciente según su precio de oferta, pueden obtenerse unas primeras lecturas; y es que en ambos casos la estructura de precios de oferta es muy clara. Los precios de las viviendas se acumulan principalmente y de manera considerablemente homogénea en una franja que va desde los $100.000 €$ a los $300.000 €$ para la venta y de los $600 €$ a los $1.000 €$ para el alquiler (Gráficas $3.4 \mathrm{y}$ 3.5). Por encima y por debajo de dichos límites, el número de viviendas disminuye considerablemente, de manera drástica por debajo y de manera primero progresiva y luego tajante también -a partir de los $500.000 €$ y los $1.200 €$ respectivamente- por arriba.

Así, podrían diferenciarse tres grandes grupos de viviendas según su precio. Por un lado está el gran núcleo central que conforma la masa de la muestra. Presenta un escalonamiento pausado y tendido desde los precios bajos a los más altos. Un posible reflejo de las pequeñas diferencias de superficies, calidades, localización y tipologías, entre otros aspectos, que son valoradas de diferente manera en el mercado y a modo de transición van diferenciando a estas viviendas. Este gran núcleo tiene en cada uno de sus dos 
extremos un grupo que, por lo que a su precio se refiere, muestra una pauta diferente. Tanto la franja de precios más bajos como la de los más altos agrupan un menor número de viviendas; inmuebles con unas peculiaridades aparentemente diversas a las de la mayoría. $\mathrm{O}$ al menos, con saltos cualitativos y/o cuantitativos en algunas de sus características lo suficientemente importantes como para influir en un incremento o descenso de precios igualmente significativo. Eso sí, es mucho menor el número de viviendas de precios muy bajos, que las que por sus características extraordinarias producen un incremento del precio de oferta muy destacado. Como se ha visto antes con los precios medios, esas viviendas con precios muy altos desvían el punto de intersección de las estructuras con los precios medios del AMB hacia la derecha de la gráfica, es decir, hacia precios más altos, por lo que cruza las líneas de precios dejando por debajo a una mayoría de la muestra. Los datos de los precios medios de cada área anunciaban una importante heterogeneidad de la oferta en el parque residencial. Una primera aproximación muestra que, aunque siguiendo en líneas generales una estructura relativamente similar a la gráfica del $\mathrm{AMB}$, en las gráficas de precios de oferta unitarios de cada área de análisis también existen diferencias notables. Efectivamente, tal y como se ha visto en las gráficas 3.2 y 3.3 para los precios medios, en el caso de los unitarios muchos áreas presentan un mayor porcentaje de viviendas por debajo del precio medio del AMB que por encima, aunque no todas. $\mathrm{Y}$ a su vez, esos porcentajes varían considerablemente, tal y como se puede observar en el punto de intersección de la línea de los precios unitarios de las diferentes áreas con la del precio medio (Gráficas 3.6 y 3.7).

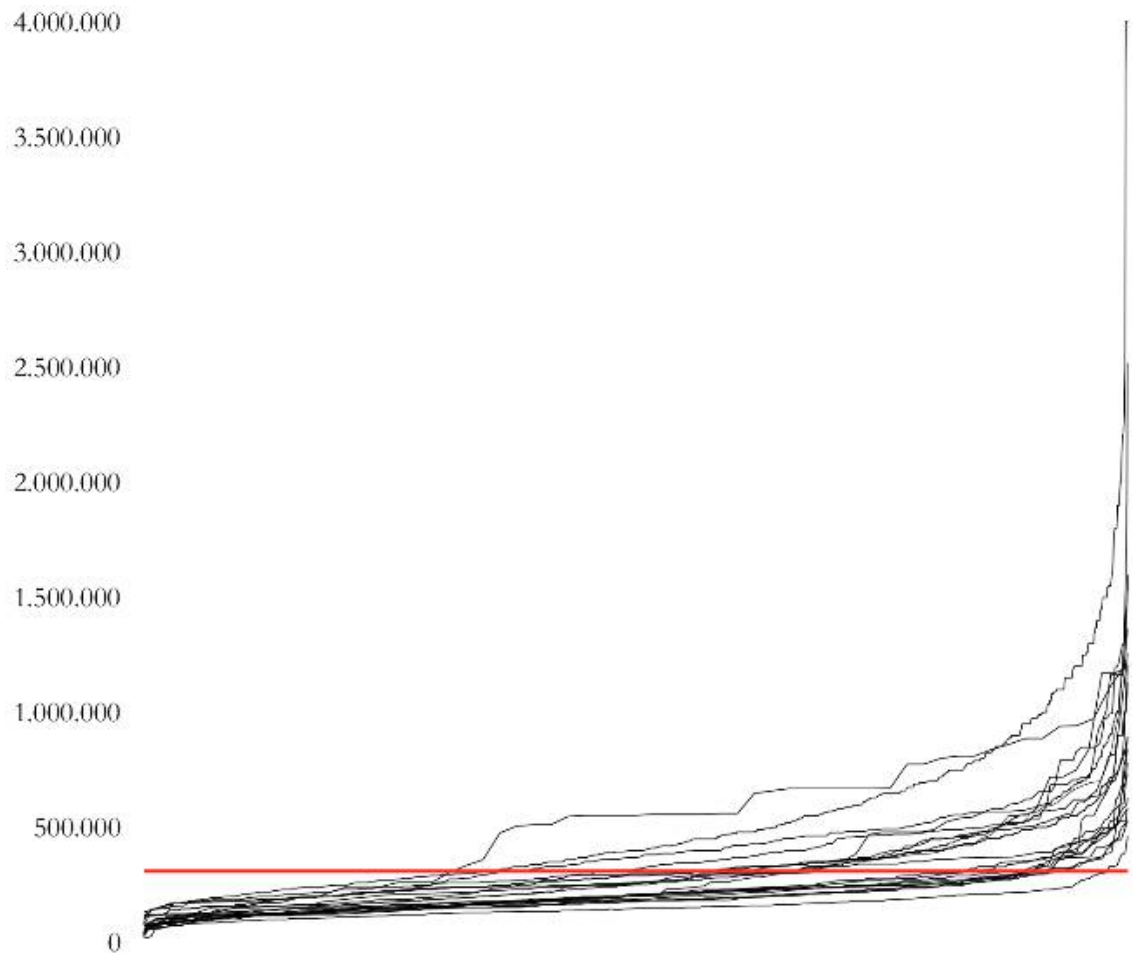

Gráfica 3.6. Precios unitarios de venta $(€)$ de la muestra de viviendas ordenados de menor a mayor, por área de análisis (sin incluir áreas inframunicipales), y precio medio del AMB. Elaboración propia a partir de Idealista, 2015. 
Gráfica 3.7. Precios unitarios de alquiler (€) de la muestra de viviendas ordenados de menor a mayor, por área de análisis (sin incluir áreas inframunicipales), y precio medio del AMB. Elaboración propia a partir de Idealista, 2015.

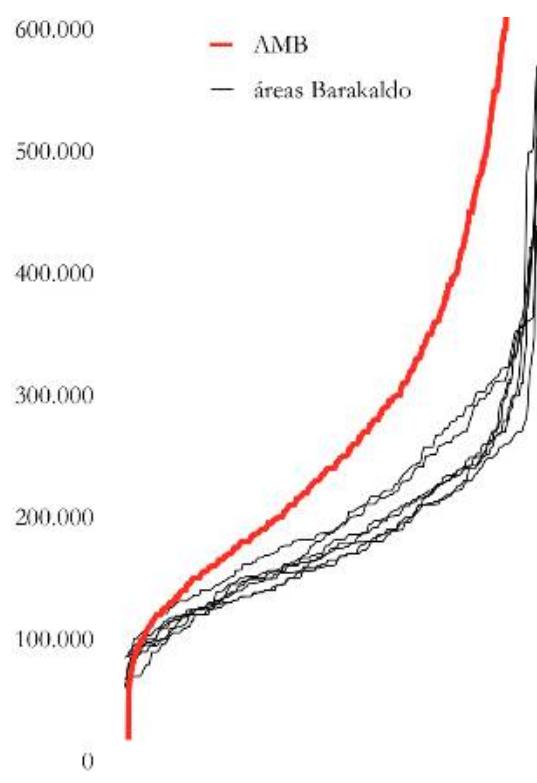

Gráfica 3.8. Precios unitarios de venta $(€)$ de la muestra de viviendas ordenados de menor a mayor en las áreas geográficas de Barakaldo, y estructura de precios unitarios total del AMB.

Elaboración propia a partir de Idealista, 2015.

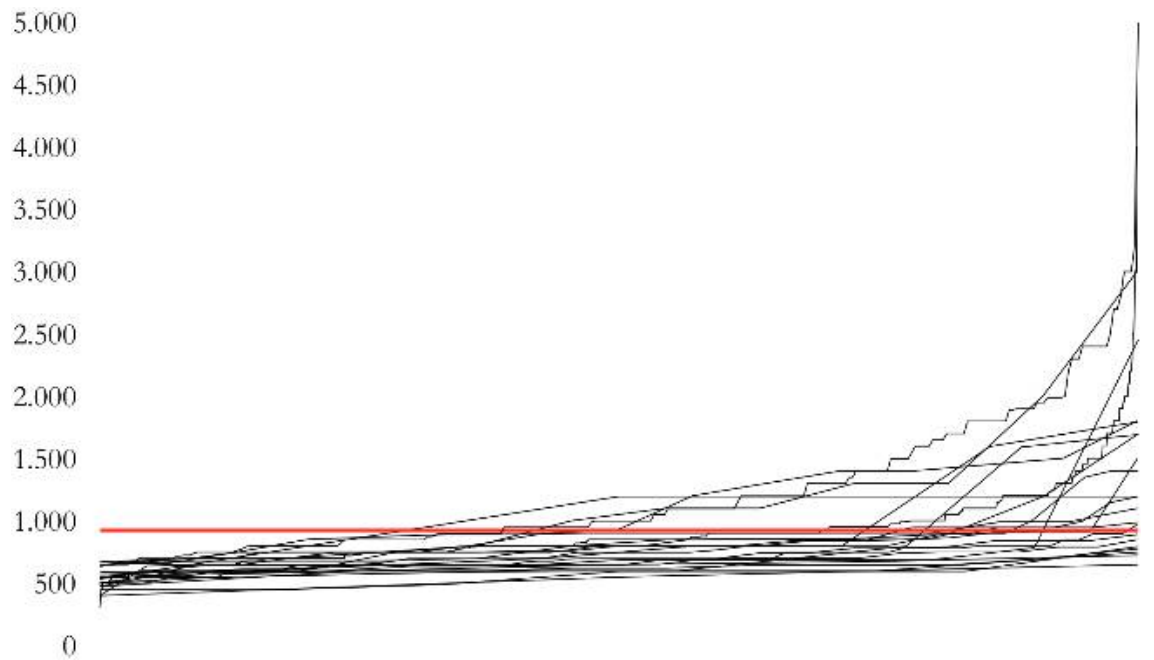

Por otro lado, si bien las gráficas tienen en la zona de precios más bajos un inicio similar, a medida que estos suben las gráficas se van separando y mostrando diferentes estructuras dentro del patrón común general. Las viviendas más baratas se sitúan en una franja de entre $30.000 €$ y $130.000 €$ en la venta, y entre $450 €$ y $650 €$ en el alquiler. Sin embargo, en la zona de precios altos -desde $450.000 €$ a $4.000 .000 €$, y de $800 €$ a $3.000 €$ o $5.000 €$, respectivamente-, el abanico de precios es mucho mayor. Hay, por tanto, una tendencia a la diversificación de los precios a medida que estos suben. Dado que cada línea corresponde a un área geográfica, esto indica la existencia de importantes desigualdades entre ellas. En cuanto a aquellas áreas correspondientes a una escala inframunicipal con datos disponibles ${ }^{67}$, al compararlas con el resto de áreas del municipio al que pertenecen, se observan cuatro claras pautas. La primera la forman aquellos municipios en los que todas sus áreas de análisis disponibles están claramente por debajo de la estructura de precios unitarios total del $\mathrm{AMB}$, es decir, presentan precios bajos en la mayoría de la oferta analizada (Gráfica 3.8). Esto ocurre en Barakaldo, Basauri, Portugalete, Santurtzi y Sestao. Los otros tres municipios con datos inframunicipales disponibles presentan tres características diferentes. En el caso de Getxo, la estructura es casi la opuesta a las anteriores, con la práctica totalidad de la oferta analizada por encima de la del AMB (Gráfica 3.9). Frente a esos dos extremos, Leioa muestra una oferta similar a la estructura general del AMB y cercana a la media de la región. Finalmente, el caso de Bilbao difiere del resto pues, debido a que se trata de un municipio con una mayor entidad y diversidad urbana, y cuenta con una mayor desagregación de su territorio por parte de Idealista, el conjunto de las estructuras de sus áreas secundarias de análisis abarca precios y tipos muy diversos, desde muy bajos a muy altos.

${ }^{67}$ Se recuerda que estas son las correspondientes a los municipios de Barakaldo (7 áreas), Basauri (4), Bilbao (37), Getxo (10), Leioa (4), Portugalete (5), Santurtzi (8) y Sestao (4). 
Esta primera mirada a las características de la oferta, en cuanto a su precio se refiere, permite obtener dos primeras lecturas. Primero, se hace evidente la diversidad -en este caso de precios de oferta de vivienda libre, pero como reflejo de una compleja realidad socioespacial que está detrás-, que desde una perspectiva geográfica y espacial, existe entre las diferentes áreas del AMB que se han tomado como ámbitos de análisis. A pesar del sesgo que toda delimitación espacial conlleva, y sin descartar que pudieran hacerse otras delimitaciones más adecuadas, dado que el espacio residencial en los sistemas urbanos es, entre otras cuestiones, un espacio desigual de diferentes niveles de acumulación de capital y rentas (Brenner et al., 2015; Fernández y Roch, 2012; Harvey, 1977), los datos aquí mostrados no son si no un reflejo de lo anterior. Segundo, aunque el precio medio de la oferta analizada es alto tanto para la venta como para el alquiler, la presencia de un número importante de viviendas con precios altos y muy altos traslada ese precio medio del centro geométrico de las gráficas de estructuras de precios. Lo cual indica que, más allá de los datos de los precios medios, existe un alto porcentaje de viviendas con precios inferiores. Concretamente, un $66 \%$ de las viviendas de la muestra en venta y un $68 \%$ de la relativa al alquiler están por debajo del precio medio total del AMB. Esta acumulación de viviendas por debajo del precio medio, puede ser un primer indicativo de que se pueden dar oportunidades para un acceso económico más favorable al existente en la actualidad, tal y como la hipótesis del trabajo plantea.

\section{Accesibilidad económica individual}

Realizado un primer análisis de las estructuras de los precios de oferta, se analiza a continuación la accesibilidad económica individual que una persona con una renta mensual de $1.400 €$ puede tener a la muestra trabajada. Este punto ayudará a comprender y justificar la hipótesis parcial que el trabajo plantea. Se entiende este como el primer paso necesario de cara a la argumentación que posteriormente se desarrolla sobre la agrupación de personas como estrategia para favorecer el acceso a la vivienda. La primera cuestión a resaltar es que esta accesibilidad individual es muy baja. Efectivamente, el precio medio del AMB representa 3,14 veces el Precio Máximo Tolerable ${ }^{68}$ de referencia en cuanto a la oferta de venta, y 2,2 veces en el caso del alquiler. Otra lectura de este dato es el reducido número de viviendas de la muestra que quedan por debajo de dichos límites de gasto aconsejados en caso de que el acceso sea individual. Pueden considerarse casi anecdóticas: tan solo un 3,07\% del total de la muestra en venta y un $0,19 \%$ en alquiler. Esto evidencia una preocupante situación de cara al acceso a este derecho básico

\footnotetext{
${ }^{68}$ Definidos ambos en el apartado 3.1 de este trabajo como el gasto máximo destinado a la vivienda no superior al $30 \%$ de una renta de $1.400 €$ : $98.644 €$ para la venta y $420 €$ mensuales para el alquiler.
}

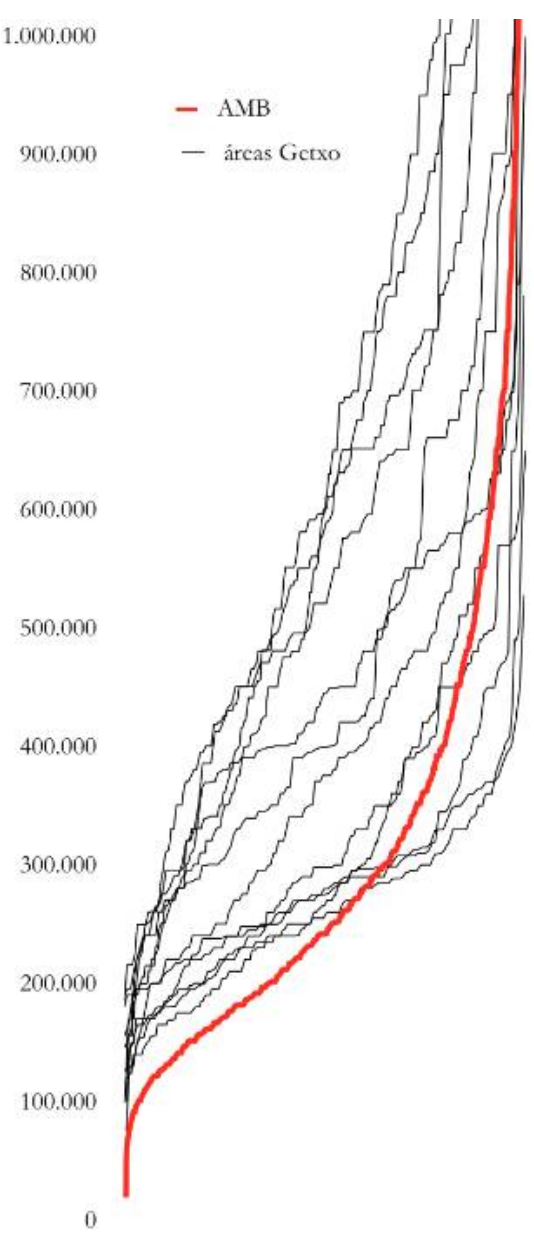

Gráfica 3.9. Precios unitarios de venta $(€)$ de la muestra de viviendas ordenados de menor a mayor en las áreas geográficas de Getxo, y estructura de precios unitarios total del AMB. Elaboración propia a partir de Idealista, 2015. 
universal que es la vivienda, al menos desde una perspectiva individual, y generalizada en las 98 áreas geográficas, salvando ciertas diferencias entre los porcentajes (Mapas 3.5 y 3.6).
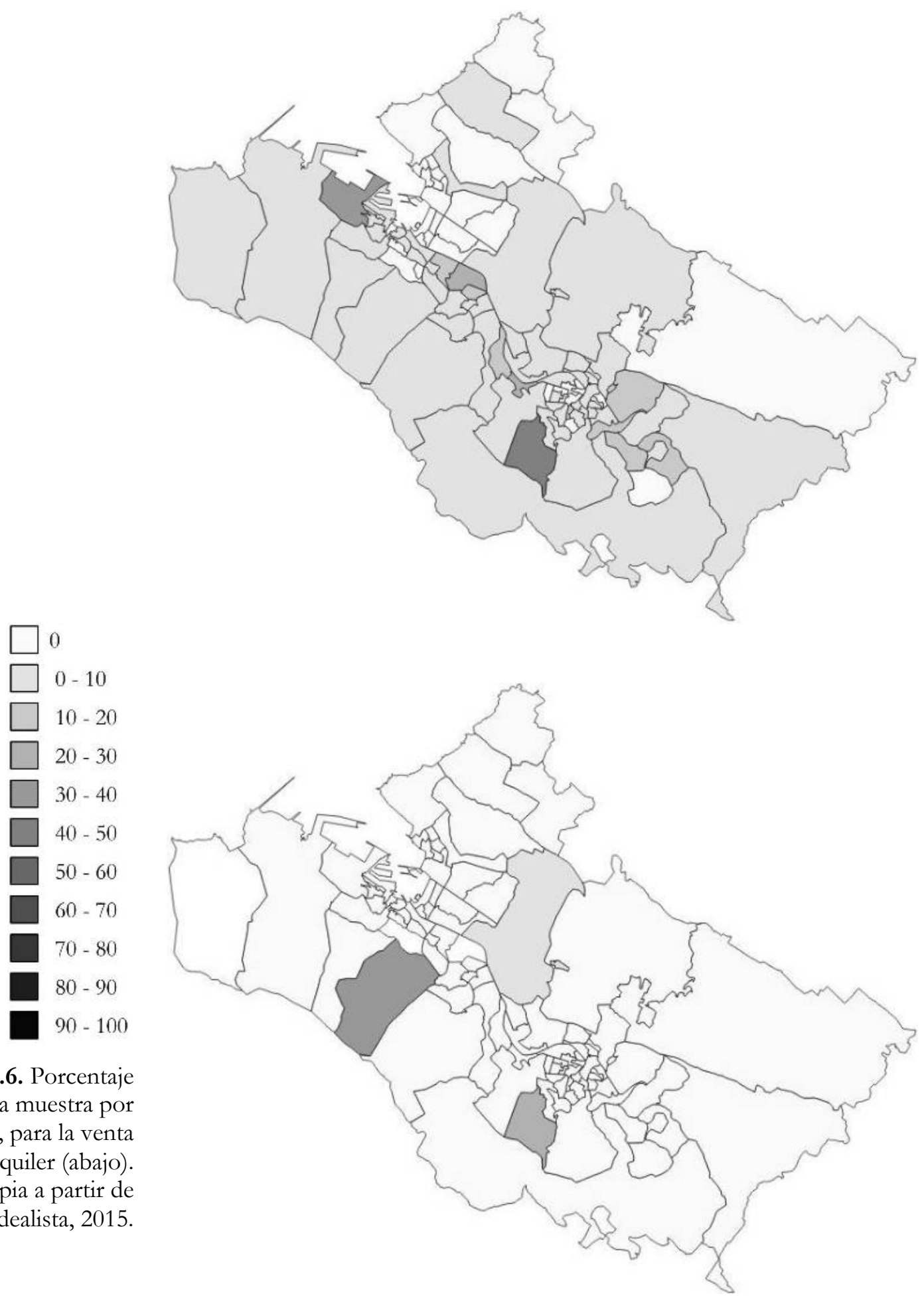
A pesar de la diversidad mostrada entre las estructuras de precios unitarios de cada área, respecto al PMT de referencia todas ellas, incluso las que presentan los precios más bajos, presentan el grueso de la muestra por encima del mismo. La práctica totalidad de áreas presentan un porcentaje de viviendas por debajo de ese precio razonable inferior al 10\%; algunas por debajo del 5\%, y en otras directamente no hay ninguna vivienda en tal situación. La salvedad se da en algunos áreas puntuales de Basauri, Santurtzi, Sestao, Trapagaran, o algunos barrios periféricos de Bilbao, donde la proporción de viviendas por debajo de dicho PMT es mayor. Las gráficas de precios unitarios antes mostradas no albergan gran interés interpretativo en este caso, pues la línea horizontal que marcaría el PMT queda sustancialmente baja en todas ellas y se pierde detalle. Por esta razón, se ha decidido alterar la mirada y generar otro tipo de gráficas. En este caso, agrupando las viviendas analizadas en franjas progresivas de precios, lo que ayuda a visualizar de una manera más clara estos mismos datos. La identificación de los tres grandes grupos antes citados - pocas viviendas con bajos precios, gran masa principal de precios en progresivo ascenso, y una cantidad considerable de viviendas con precios altos que se prolonga hasta los muy altos- es también muy clara. Son por tanto los mismos datos, pero representados de una manera diferente (Gráficas 3.10 y 3.11).

Se vuelven a poner en evidencia, quizás con mayor claridad, tres cuestiones. En general, aunque las diferentes áreas geográficas presentan una estructura de precios similar -rodeando y acompañando a la estructura global del AMB-, las variaciones y alteraciones en los porcentajes de acumulación de precios en una u otra franja son importantes. Es decir, todo apunta a una considerable diversidad y polarización socio-económica entre diferentes áreas urbanas de la región, aquí reflejada en las expectativas de acumulación de capital a través de las rentas obtenidas por productos residenciales -se ha de recordar que se trata de precios de oferta-. En segundo lugar, se observa también que los precios medios de la muestra -los $308.646 €$ y $925 €$ respectivos para cada régimen de tenencia- quedan a la derecha del grueso principal de las viviendas en ambos casos. Las franjas de precios con mayores porcentajes de viviendas son las existentes entre el PMT y el precio medio, con las principales acumulaciones situadas en precios que corresponden a un $60-75 \%$ del precio medio del AMB. En tercer lugar, queda constatado el reducido número de viviendas de la muestra que presentan un precio de oferta por debajo del precio máximo individual aconsejado según las referencias tomadas para el trabajo. En ambos casos, pero sobre todo en el alquiler, la disponibilidad de vivienda económicamente accesible bajo dichos parámetros de dignidad para una persona con una renta de referencia de $1.400 €$ es prácticamente inexistente. El precio medio de la muestra de alquiler está $505 €$ por encima del PMT. Esto supone que, para que el pago de la mensualidad media de $925 €$ represente un máximo del 30\% del salario, este debería alcanzar los 3.083€, $1.736 €$ por encima de la renta media disponible en la región. 


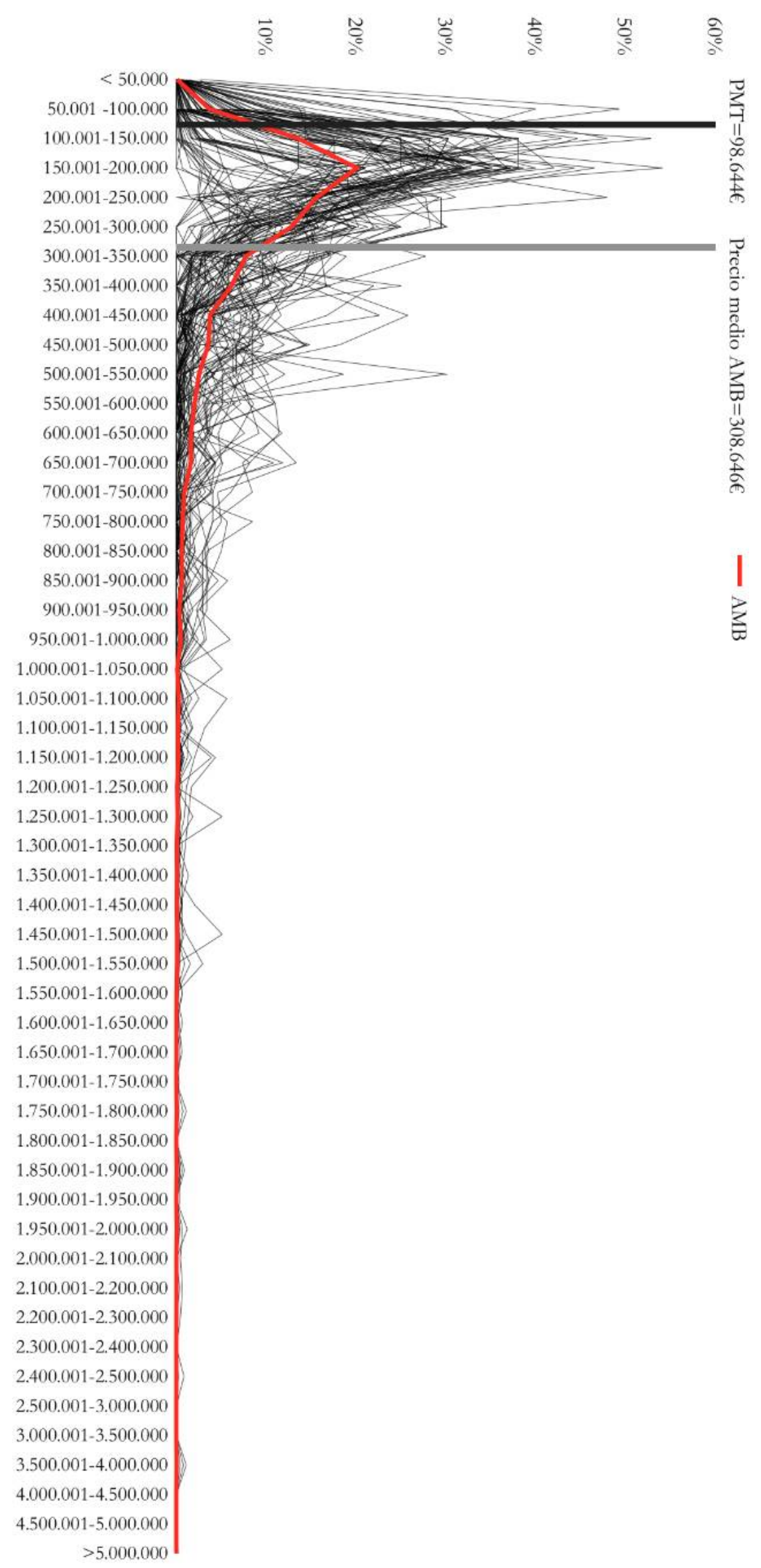

Gráfica 3.10. Porcentaje de viviendas de la muestra de la oferta de venta analizada en las áreas geográficas y el $\mathrm{AMB}$, por grupos de precios (€). Elaboración propia a partir de Idealista, 2015.

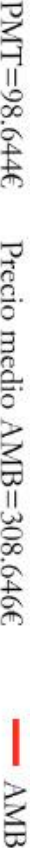




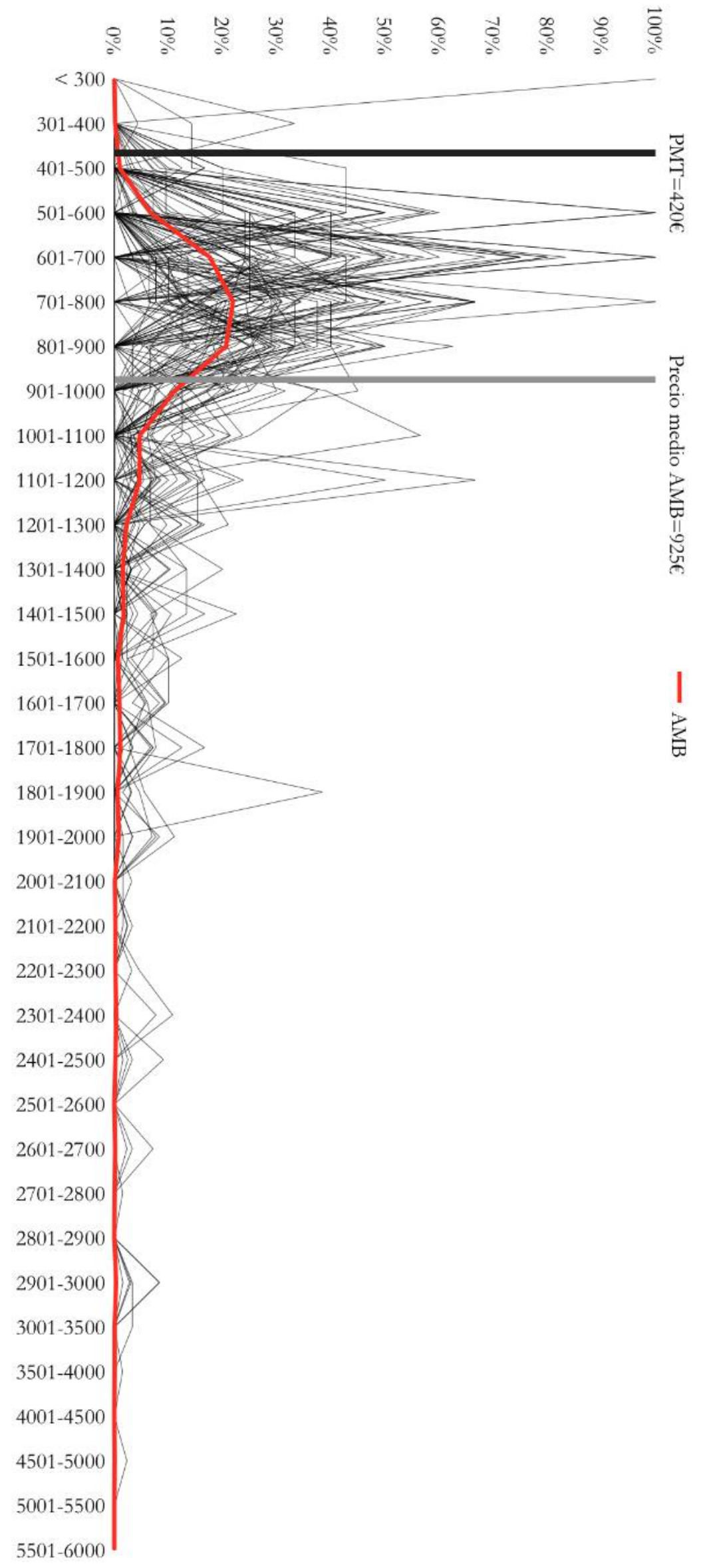

Gráfica 3.11. Porcentaje de viviendas de la muestra de la oferta de alquiler analizada en las áreas geográficas y el AMB, por grupos de precios $(€)$. Elaboración propia a partir de Idealista, 2015. 
La situación es alarmante, a pesar de que no se vea reflejada como tal en algunas encuestas e informes. Se recuerda que tal es el caso de la Estadística sobre Necesidades y Demanda de Vivienda en la CAPV, que durante años ha identificado a las personas que no disponen de rentas o ingresos propios para poder financiar el proceso de acceso a la vivienda como situaciones de «ausencia de necesidad» (Observatorio Vasco de la Vivienda, 2014a: 13), al considerar que no es posible bajo tales circunstancias un proyecto de acceso a primera vivienda. Como ya se ha señalado, a pesar de tratarse la cifra utilizada de $1.400 €$ de un dato medio que oculta la complejidad y diversidad socio-económica de la región, el porcentaje de población con rentas cercanas a esta cifra tomada como referencia es amplio, y por lo tanto los resultados mostrados se pueden considerar como relevantes. Es necesario puntualizar que estos datos de referencia no representan a los colectivos en peor situación, como personas en desempleo, riesgo o situación de pobreza, u otros tipos de vulnerabilidad. Si no que se trata de un supuesto de personas con empleo y salario, lo cual para parte de la sociedad está incluso lejos de su realidad. Se trata por tanto este de un colectivo potencialmente vulnerable, con empleo, que se suma a todas esas otras personas que en situación más grave todavía, no pueden acceder a la vivienda libre.

\section{Accesibilidad económica por agrupación}

Una vez comprendida y confirmada la gran inaccesibilidad económica individual a la vivienda para el perfil medio tomado como base, ya sea en propiedad o en alquiler, la investigación busca bucear en otras opciones. Hay que recordar que el citado informe del Observatorio Vasco de la Juventud plantea siempre las cifras de referencia de precios máximos tolerables para unidades de convivencia unipersonales. Es decir, se remite al derecho individual de contar con un alojamiento que, como tal, debería poder ser exigido por cualquier persona. No obstante, y aunque efectivamente se están dando pasos relevantes hacia la consecución de ese derecho -la reciente Ley de Vivienda vasca así lo hace-, la situación problemática y el marco teórico desarrollados previamente hacen dudar del posible éxito, al menos a corto plazo, que vaya a tener la continuación de las políticas públicas habituales para intentar favorecer el acceso. Como se ha visto en el capítulo segundo, la oferta de vivienda tiene dificultades para ofrecer -incluso la protegida- precios adecuados para satisfacer la necesidad; por otro lado, la tipología de vivienda predominante en el mercado y en la oferta pública está lejos de haber sido diseñada para la gran mayoría de unidades de convivencia demandantes de vivienda. Por todo ello, se desarrolla aquí la posibilidad de, desde la investigación y la apertura a nuevas perspectivas y modelos, explorar y articular otros caminos que la situación actual pueda ofrecer, siempre sin renunciar al carácter individual del derecho a la vivienda. 
El primer ejercicio a realizar es dejar de lado la idea hegemónica de la unidad de convivencia como sinónimo de familia tradicional jerarquizada con hijos e hijas, tal y como refleja la oferta de vivienda existente. La naturaleza de muchas de las unidades convivenciales existentes según datos del INE, vistas tan solo parcialmente en la Tabla 2.6, es de una diversidad tal que son muchas las voces que llevan años demandando la necesidad de que la oferta residencial se adapte a esos otros perfiles formados por personas que se ven obligadas a vivir «en casas diseñadas para otros» (Guidotti y Arroyo, 2004: 1). Dicha diversidad permite imaginar nuevas o diferentes maneras de convivir, y otras tipologías de vivienda más allá de la habitual formada por un salón-comedor, una cocina, dos o tres dormitorios y dos baños (uno de ellos integrado en el dormitorio principal). Lo que en este trabajo se pretende argumentar es que no solo gran parte de las viviendas actuales no responden a la mayoría de unidades de convivencia existentes y necesitadas de vivienda ${ }^{69}$, si no que estas podrían ser adaptadas a las mismas. Aunque sobre todo esto se profundizará más adelante, al abordar las condiciones espaciales de acceso, es necesario fijar este marco para desarrollar y justificar el presente apartado.

Por lo tanto, y volviendo a los precios de la oferta, estando estos en el mercado tan alejados de las posibilidades de acceso individual de una gran mayoría de la necesidad, y estando la tipología común de vivienda cada vez más lejos de la realidad social que exigen las unidades de convivencia, se plantea aquí una estrategia a modo de experimento y ensayo. Se trata de la posibilidad de compartir los gastos de acceso a lo que el mercado considera una única vivienda entre varias personas que no conforman una unidad convivencial, pero que podrían establecerse como grupo de compra o alquiler. Se ha denominado a esta como Estrategia de Agrupación, y así se le hará mención a lo largo del trabajo. Se ha de aclarar una vez más que lo que se propone no es una convivencia obligada en viviendas tradicionales, ni pisos compartidos por adultos que mantienen los inconvenientes y las dinámicas domésticas de un piso de jóvenes recién emancipados, ni de viviendas en situaciones cercanas al hacinamiento habitadas por personas de bajos recursos, habitualmente lejos de sus lugares de origen, y en general con problemas serios de convivencia y habitabilidad. Aunque en este apartado tan solo se va a analizar la variable económica, la estrategia en su conjunto -completada y desarrollada en apartados siguienteslo que plantea es, una vez comprobada la posibilidad de compartir los costes quedando todas las personas bajo un PMT, transformar y adaptar estas viviendas para lograr otras nuevas diferentes, ya sea

\footnotetext{
${ }^{69}$ Detrás y dentro de las categorías que el Censo de Población y Viviendas del INE establece, se esconde una enorme variedad de tipos de unidades de convivencia muy diversas. Más allá del número, género y edad de sus componentes, están las diferentes culturas, orígenes, entornos sociales, educativos y económicos, planteamientos y biografías vitales, o tipos y modelos de trabajo.
} 


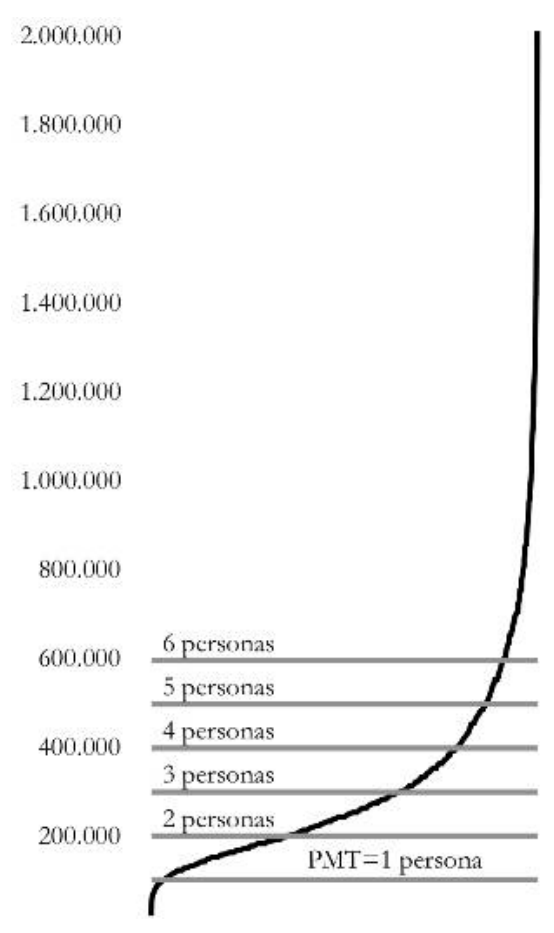

Gráficas 3.12 y 3.13. Precios unitarios ( $€$ ) de venta (arriba) y alquiler (abajo) en el AMB, y accesibilidad económica según tamaño de agrupación bajo el

PMT (gráfica limitada a un máximo de 2.000.000€).

Elaboración propia a partir de Idealista, 2015.

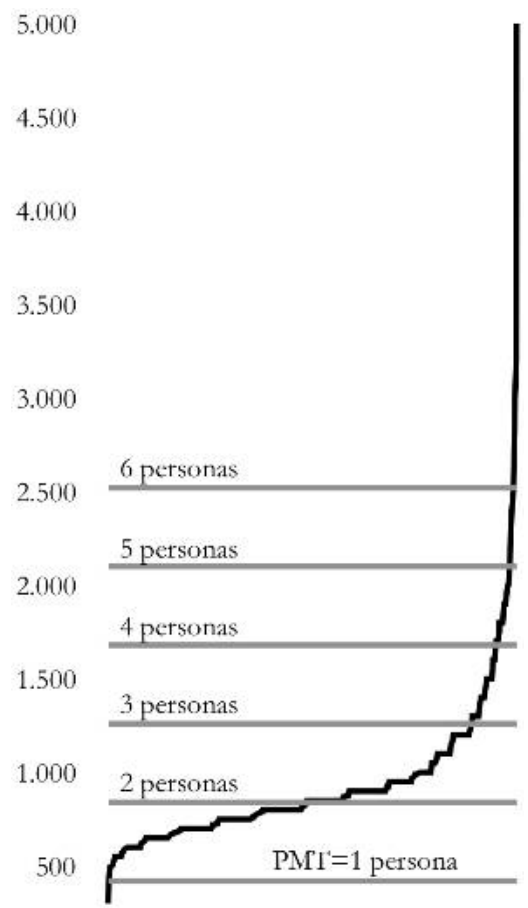

segregando una vivienda en varias o planteando otros modelos de convivencia mediante la articulación de espacios privados y semiprivados dentro de la vivienda o del edificio, en función de las unidades de convivencia que vayan a habitar el inmueble.

La hipótesis es que si se pudiesen adaptar las viviendas $-\mathrm{O}$ incluso edificios o partes de los mismos- existentes a nuevas maneras de convivir, a otras distribuciones o tipologías, logrando alojar a más de una unidad convivencial donde se preveía una única familia, la accesibilidad económica podría garantizarse y lograr así la consecución del derecho a la vivienda. Se dejan para más tarde las cuestiones espaciales, y en primer lugar se analizan -en base al precio de oferta- cuál es el número de personas que se habrían de agrupar para afrontar el pago de la compra o alquiler de la muestra de vivienda analizada, siempre bajo los límites máximos tolerables de referencia establecidos por el informe del Observatorio Vasco de la Juventud: 98.644€ para la compra y $420 €$ para el alquiler. Es decir, se va a analizar la accesibilidad económica por lo que se ha venido a denominar 'agrupación', evitando conscientemente los términos de 'hogar' o 'familia', ya que, tal y como se plantea la estrategia, las personas potencialmente agrupadas no han de formar en principio ninguna estructura que encaje con dichos términos. En un primer acercamiento, y retomando por un momento las estructuras de precios unitarios, la multiplicación del PMT tantas veces como personas formen el grupo correspondiente ofrece una rápida visión del sustancial cambio en la accesibilidad económica a la muestra (Gráficas 3.12 y 3.13). Es de relevancia el hecho de que con agrupaciones de 3 personas para la venta y 2 personas para el alquiler, cerca de la mitad de la muestra queda cubierta bajo las condiciones dignas de acceso tomadas como referencia. Alcanzadas las 5 o 6 personas, la práctica totalidad de las viviendas analizadas serían accesibles.

Esto mismo puede observarse más detalladamente en la Tabla 3.13, a la que se han trasladado numéricamente ambas gráficas. Igualmente, se puede observar en esta cómo un porcentaje muy alto de las viviendas permiten un acceso digno a agrupaciones de 2 y 3 personas. Especialmente sucede en el caso del alquiler, pues estas dos situaciones suponen más de un $88 \%$ de los 2.071 casos analizados. En cuanto a la venta, si bien ese tipo de viviendas superan el $60 \%$ de las 17.415 viviendas analizadas, también son de interés y relevancia aquellas viviendas que exigen agrupaciones de 4, 5 incluso 6 personas. Sin embargo, vista la mejor visibilidad que ofrecen gráficas como la 3.10 y 3.11, se estima interesante reflejar los resultados con ese otro tipo de visualizaciones. Para ello, se ha utilizado -como ya se ha avanzado- un método en el que se divide el precio unitario de cada vivienda entre el PMT correspondiente a su régimen de tenencia. El resultado es un índice del número de personas necesarias para acceder económicamente a la misma bajo los criterios definidos. Al tratarse de un índice con decimales, se han agrupado las viviendas en las franjas 
de personas definidas en la Tabla 3.3, y tomando el valor mayor como límite; aquellas clasificadas como accesibles para 1-2 personas, por ejemplo, tienen un precio de oferta superior al PMT de una, pero igual o inferior al de dos (Gráfica 3.14).

\begin{tabular}{llll|lll}
\hline \multirow{2}{*}{$\begin{array}{l}\mathbf{n}^{\mathbf{o}} \\
\text { pers. }\end{array}$} & \multicolumn{3}{c|}{ V PMT } & $\mathbf{\%}$ & \multicolumn{3}{c}{ aLQUTALER } \\
\hline 1 & 534 & 3,07 & & 4 & 0,19 & \\
2 & 5.596 & 32,13 & $35,20 \%$ & 1.002 & 48,38 & $48,58 \%$ \\
3 & 5.037 & 28,92 & $64,12 \%$ & 837 & 40,42 & $88,99 \%$ \\
4 & 2.499 & 14,35 & $78,47 \%$ & 123 & 5,94 & $94,93 \%$ \\
5 & 1.366 & 7,84 & $86,32 \%$ & 71 & 3,43 & $98,36 \%$ \\
6 & 810 & 4,65 & $90,97 \%$ & 20 & 0,97 & $99,32 \%$ \\
\hline
\end{tabular}

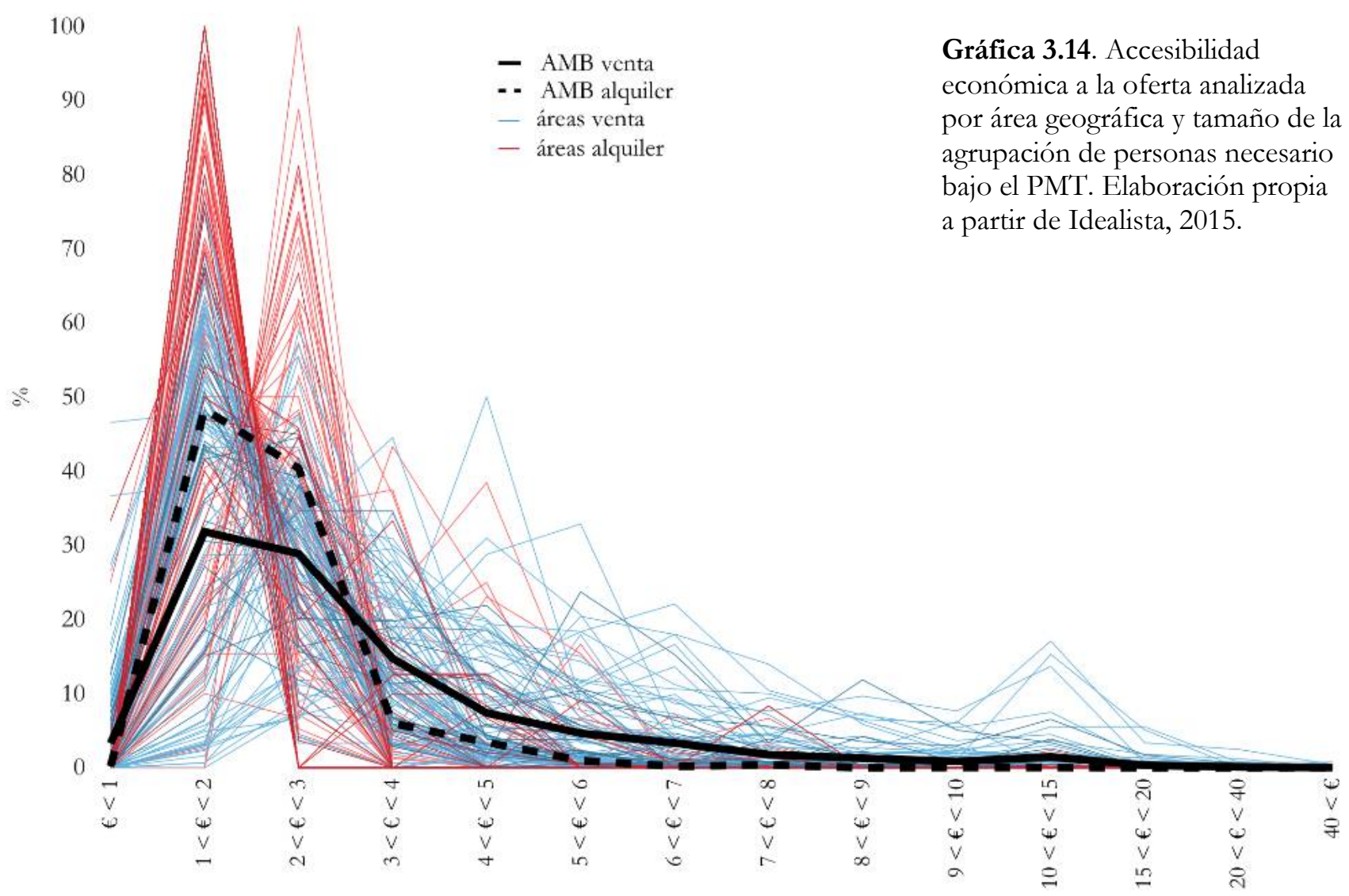

A priori, vista la distribución de los tipos de estructuras de unidades de convivencia ofrecida por el INE (ver Tabla 2.6), los valores obtenidos no son descabellados de cara a afrontar la estrategia de agrupación planteada. Probablemente tampoco lo son de cara a
Tabla 3.13. Accesibilidad económica a la muestra de la oferta en el AMB según tamaño de agrupación bajo el PMT. Elaboración propia a partir de Idealista, 2015.

Gráfica 3.14. Accesibilidad económica a la oferta analizada por area geográfica y tamaño de la personán de necesario ajo el PMT. Elaboración propia a partir de Idealista, 2015. 
abordar una transformación de dichas viviendas para unidades de convivencia individuales, como se verá más adelante. En cuanto a la interpretación de los resultados de cada área geográfica de análisis, al tratarse de un índice es posible comparar conjuntamente la oferta de venta y de alquiler. Una vez más, a pesar de que se puede identificar una estructura general de precios similar en la práctica totalidad de las áreas -con una acumulación generalizada de accesibilidad económica para 2 y 3 personas-, las variaciones y los matices son considerables. Tal y como muestran los datos globales del AMB, resulta de especial interés el hecho de que la accesibilidad económica al alquiler para los datos aquí analizados es sustancialmente mayor que la correspondiente a la oferta de venta. Algo que queda constatado al superponer las gráficas de accesibilidad económica de todas las áreas espaciales (Gráfica 3.14). Aunque este régimen de tenencia cuenta con una oferta mucho menor, estando el parque residencial del AMB caracterizado por el predominio de la propiedad. A pesar de la ya mencionada principal acumulación de viviendas en las franjas de entre 1-2 y 2-3 personas, y de que a medida que los precios exigen una agrupación mayor de estas con capacidad de pago bajo el PMT -a partir de 4, el número de viviendas con tales características se reduce, los porcentajes en esas franjas mayores no son despreciables. Por lo que las estrategias para avanzar hacia el acceso total al parque residencial a través de este camino apuntado deberán ser diversas. Al menos, en lo que a las condiciones de accesibilidad económica establecidas por las diferentes características de las estructuras de precios de las áreas urbanas estudiadas se refiere.

\section{Una oportunidad económica como paso previo}

Hasta ahora se ha visto que la oferta inmobiliaria de vivienda libre en el AMB está muy por encima de las posibilidades económicas individuales de la renta media per cápita de la región, y por lo tanto fuera del alcance de una gran parte de la población. Ha quedado en un primer paso demostrado que, de momento desde un punto de vista exclusivamente económico, y entre otras estrategias posibles, mediante la agrupación de personas con capacidad de pago y bajo unas condiciones de gasto dignas se podría combatir el encarecimiento de y las dificultades de acceso a este bien necesario que es la vivienda. Se recuerda que la idea de agrupación sobre la que se apoya el experimento no es la de una convivencia forzada. En este primer punto, se trata de la unión de personas para afrontar el pago de la vivienda. La identificación de una oportunidad en el ámbito económico es un paso previo y necesario para poder explorar oportunidades desde una variable espacial. De esta manera, en el siguiente punto se completa esta estrategia analizando las posibilidades de transformación del parque a unas unidades de convivencia más pequeñas que aquellas para las que suelen estar diseñadas las viviendas, y que a su vez cuentan con diferentes maneras de convivir -ambas cuestiones fundamentan esa adaptación espacial-. 
El interés del indicador planteado de la accesibilidad económica por agrupación, enfrentado al precio de la oferta, es que da una idea más directa de la capacidad económica necesaria para acceder a una vivienda en función del tamaño de la unidad de convivencia o grupo de acceso. Todo ello encaja en el planteamiento de actuación inicialmente acotado, con un horizonte a corto y medio plazo, desde una posición consciente de los límites de actuar dentro del modelo y sistema residencial actual, y sin pretender aportar una solución definitiva, pero sí transformadora. No se está afirmando que se haya de ver la sociedad obligada a pasar por los requisitos de precios que el modelo inmobiliario hegemónico plantea. Se trata más bien de un ejercicio de reflexión y búsqueda de resiliencia y adaptabilidad desde la investigación empírica, para fundamentar la existencia de alternativas surgidas de las propias contradicciones internas del modelo. Como se ha planteado más arriba, lo desarrollado en este capitulo no ha de interpretarse de manera separada a lo desarrollado en el siguiente, centrado en los modelos de gestión que pueden aprovechar estas oportunidades del parque actual.

\section{$-3.2 .2-$ \\ Condiciones espaciales para el acceso}

\section{Características de la oferta}

$\mathrm{Al}$ igual que se ha planteado con la estructura de precios, se quiere en primer lugar presentar una imagen global de la distribución de la muestra en diferentes franjas de superficie, para tener una primera aproximación general a algunas de las características espaciales de la misma. En el caso de la oferta en venta, más de la mitad de las viviendas de la muestra -unas 10.000 , alrededor de un 56\%- se sitúan en la franja entre 46 y $90 \mathrm{~m}^{2}$; otro $28 \%$ lo están entre 91 y $150 \mathrm{~m}^{2}$. Las cifras para el alquiler son similares: más del 63\% tienen entre 46 y 90 $\mathrm{m}^{2}$-esta vez sumando unas 1.320 viviendas-, y un $27 \%$ entre $91 \mathrm{y}$ $150 \mathrm{~m}^{2}$ (Tabla 3.14). Al pasar los datos a la gráfica, se observa por primera vez una aparente relación entre los precios y la superficie de las viviendas (Gráfica 3.15). El paralelismo con las estructuras de precios mostradas en las Gráficas 3.10 y 3.11 es evidente. La acumulación de unas pocas viviendas con precios bajos y muy bajos en la zona izquierda parece corresponderse aquí con aquellas de superficies pequeñas e incluso muy reducidas. Igualmente, aparece una gran masa de acumulación de viviendas con las superficies frecuentes ya citadas y señaladas en la Tabla 3.14. Y finalmente, la transición desde esa mayoría hacia superficies muy grandes se produce con un escalonamiento similar al de los precios, presentando en algunas de las franjas porcentajes más que considerables y relevantes.

\begin{tabular}{llll}
\hline sup. $\left(\mathbf{m}^{2}\right)$ & SMP & venta & alq. \\
\hline$<30$ & 1 & 11 & 2 \\
$30-45$ & $1-2$ & 286 & 61 \\
$46-60$ & 2 & 1.921 & 328 \\
$61-75$ & $2-3$ & 4.117 & 461 \\
$76-90$ & 3 & 3.855 & 531 \\
$91-105$ & $3-4$ & 2.220 & 270 \\
$106-120$ & 4 & 1.514 & 169 \\
$121-150$ & $4-5$ & 1.368 & 122 \\
$151-180$ & $5-6$ & 659 & 38 \\
$181-200$ & $6-7$ & 363 & 9 \\
$201-250$ & $7-8$ & 497 & 35 \\
$251-300$ & $8-9$ & 284 & 24 \\
$301-400$ & $10-13$ & 237 & 18 \\
$401-500$ & $13-16$ & 77 & 1 \\
$501-600$ & $16-20$ & 29 & \\
$601-700$ & $20-23$ & 12 & 1 \\
$701-800$ & $23-26$ & 8 & 1 \\
$801-900$ & $26-30$ & 2 & 1 \\
$901-1.000$ & $30-33$ & 6 & \\
$1.001-1.500$ & $33-50$ & 3 & \\
$>1.500$ & $>50$ & 1 & \\
\hline
\end{tabular}

Tabla 3.14. Clasificación de las viviendas analizadas según franja de superficie y régimen de tenencia. Elaboración propia a partir de Idealista, 2015. 
Gráfica 3.15. Superficie de las viviendas analizadas, por franjas, en el AMB. Elaboración propia a partir de Idealista, 2015.

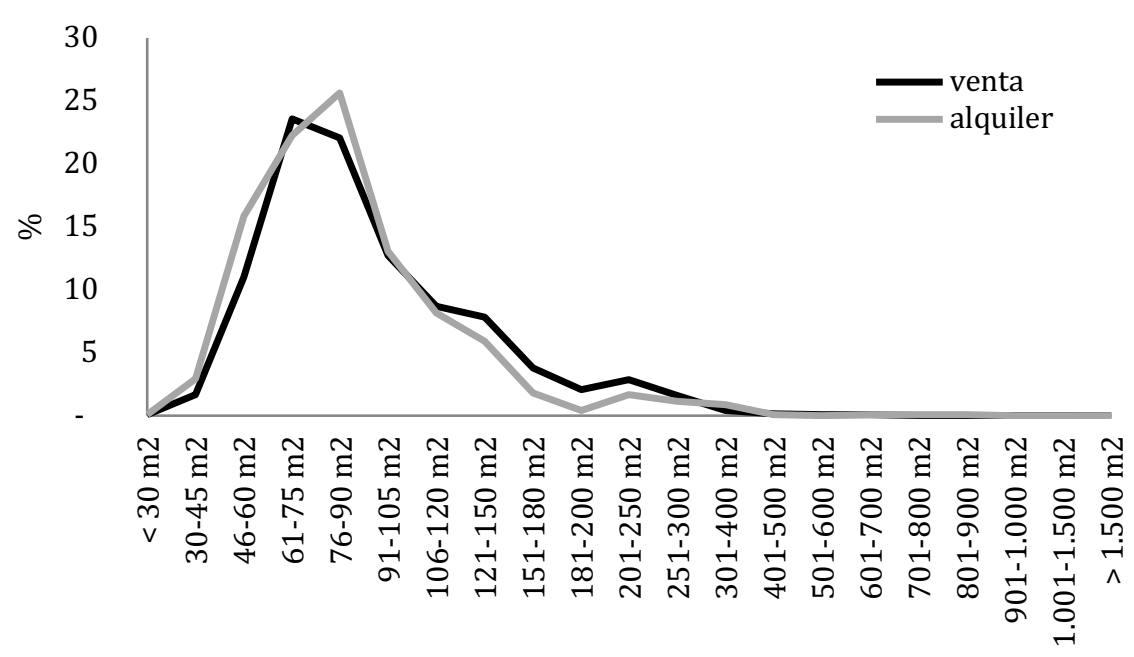

Más allá de los datos medios, la distribución geográfica de la oferta en función de su superficie a lo largo de las áreas en que se ha dividido el AMB permite observar posibles alteraciones. De manera paralela a los resultados de la accesibilidad económica, los mapas de los tramos de superficie de las viviendas analizadas ofrecen una pauta similar. $\mathrm{Y}$ vienen a reforzar el paralelismo observado con las estructuras de precios, aunque en este caso desde la perspectiva de la segregación y polarización espacial de los tamaños de las viviendas a lo largo del parque residencial (Mapas 3.7 y 3.8). Aquellas áreas con mayores porcentajes de viviendas en franjas de superficie pequeñas son las que se encuentran al suroeste de la ría que estructura buena parte de este territorio, y a medida que aumenta la presencia de viviendas con mayor tamaño, comienza a notarse una mayor agrupación de estas en el noreste. Como ya indicaban los mapas presentados antes, el patrón muestra que en aquellas áreas que históricamente han alojado a población con rentas más bajas, zonas donde se han establecido los principales y grandes usos industriales e infraestructurales de la región, el parque residencial presenta superficies menores. Frente a lo anterior, las viviendas de mayor superficie se dan con más frecuencia en áreas con un carácter principalmente residencial, zonas tradicionalmente rurales, o en polos de desarrollo de servicios y centros de actividades económicas no industriales.

Las primeras son zonas donde la presencia de grandes industrias asociadas al metal, grandes infraestructuras regionales como estaciones depuradoras de aguas residuales o el puerto comercial y todas sus actividades auxiliares, centrales térmicas de generación de energía y tratamiento de productos derivados del petróleo, vertederos y plantas de tratamiento de residuos, o zonas de explotación minera para la extracción de recursos minerales, han condicionado e influido enormemente en la configuración territorial de, entre otras cuestiones, la ciudad residencial de sus municipios. Tal y como se ha mencionado 

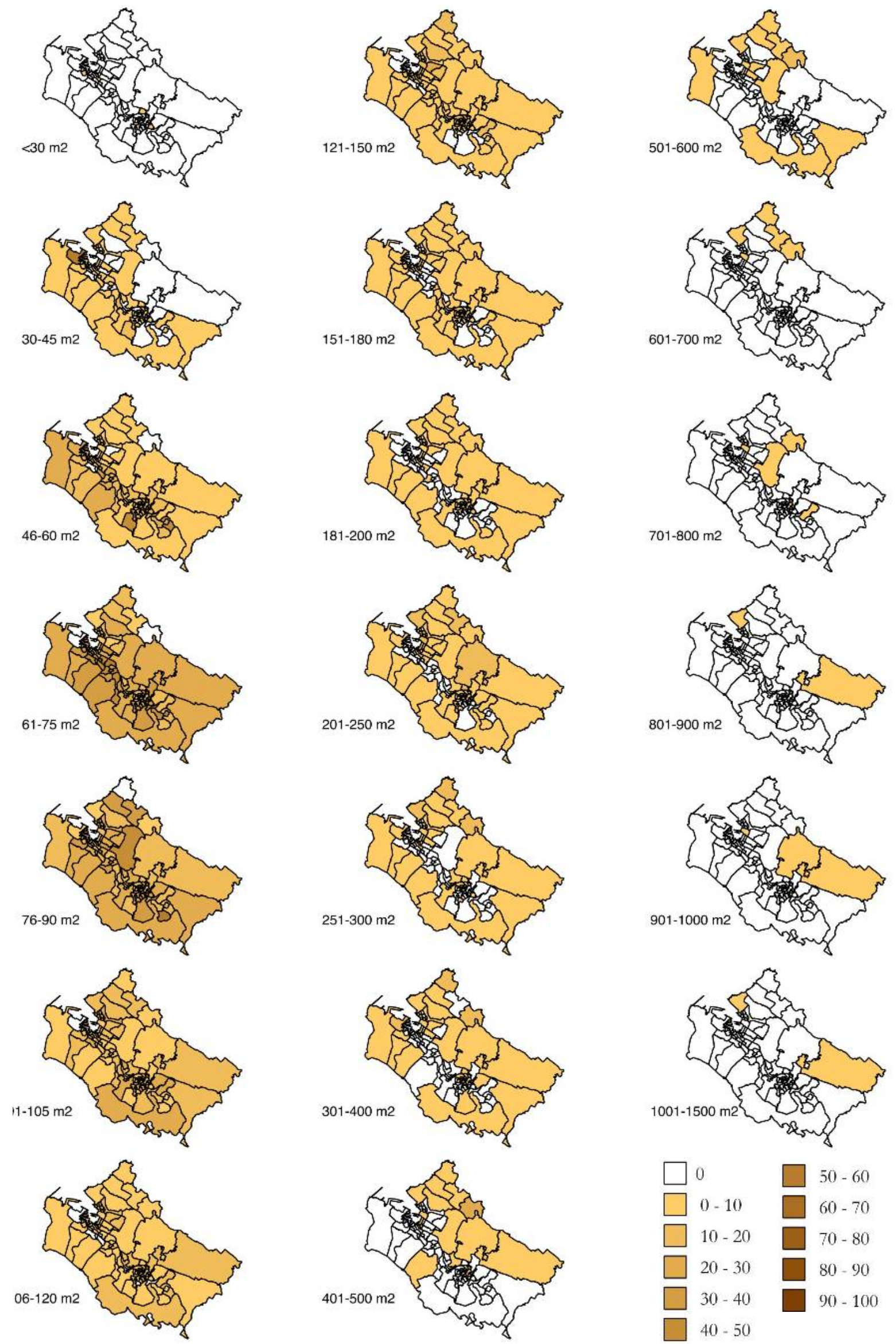

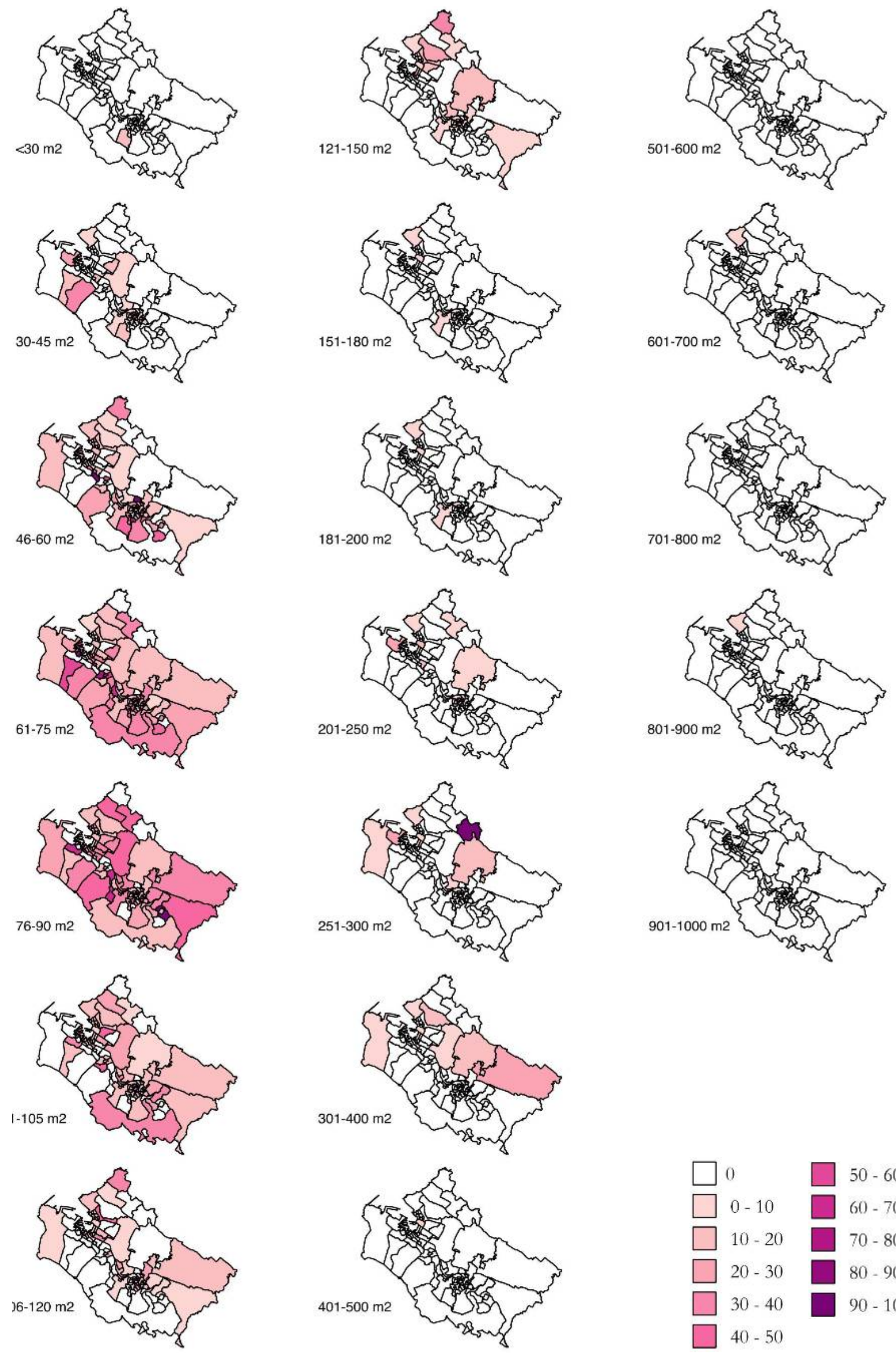
en capítulos previos, el propio Plan Territorial Parcial del Bilbao Metropolitano señala que estas zonas fueron, y siguen siendo, fuertemente afectadas por haber cedido la prioridad territorial a los usos de actividades económicas del suelo (Decreto 179/2006, de 26 de septiembre, Anexo I-Memoria, 2006), trasladando la planificación integral de la ciudad -y los usos residenciales por extensión- a un plano secundario. Gran parte del parque de vivienda desarrollado en ese entorno urbano agresivo y predominantemente destinado a las familias que trabajaban en todo ese entramado industrial, parece haber sido levantado bajo criterios de superficies mínimas. En cambio, las zonas de Uribe Kosta o el valle del Txorierri, así como determinadas áreas de Bilbao, entre otras, aunque presentan también zonas industriales y de infraestructuras de menor tamaño, albergan en muchos casos una ciudad específicamente residencial generalmente vinculada a una población de rentas mayores con perfiles profesionales orientados a la gestión empresarial o los servicios. Compaginada con polos de actividades económicas de un carácter más tecnológico, infraestructuras más amables como campus universitarios, centros de actividad deportiva, playas u otras zonas de esparcimiento natural, o el mantenimiento de explotaciones agrícolas y ganaderas, el parque residencial resultante, en su diversidad, tiende a presentar tipologías de mayor superficie.

\section{Accesibilidad espacial por agrupación}

Una vez vista la estructura general de superficies de la muestra y su distribución geográfica por áreas, se continúa con el planteamiento propuesto desde la perspectiva económica de agrupar personas formen o no unidades de convivencia entre ellas-. En este punto, la atención se centra en analizar el nivel de ocupación que permiten las viviendas estudiadas, en número de personas, según la superficie de referencia definida en el apartado 3.1 de aproximadamente $30 \mathrm{~m}^{2}$ por persona para una habitabilidad mínima digna. Tal y como se ha establecido en la Tabla 3.8 y reflejado en la 3.14, a cada franja de superficie le corresponde un número de personas máximo bajo esos criterios. Por lo tanto, los datos globales del AMB respecto a este indicador devolverían una gráfica idéntica a la 3.15, con una única variación: la unidad en este caso sería el número máximo de personas que podrían alojarse en dichas viviendas bajo la SMP. Pero si de igual manera que se ha hecho para la accesibilidad económica en la Gráfica 3.14, se superponen todas las estructuras de accesibilidad espacial de la oferta de venta y alquiler para cada área geográfica analizada, los datos revelan la diversidad oculta tras la media regional (Gráfica 3.16). Una vez más, la forma y estructura de base de las gráficas son similares, pero existen alteraciones importantes entre áreas. Las superficies que con mayor frecuencia se dan en la muestra son predominantemente aquellas que permitirían una ocupación máxima de la vivienda por parte de dos o tres personas. 


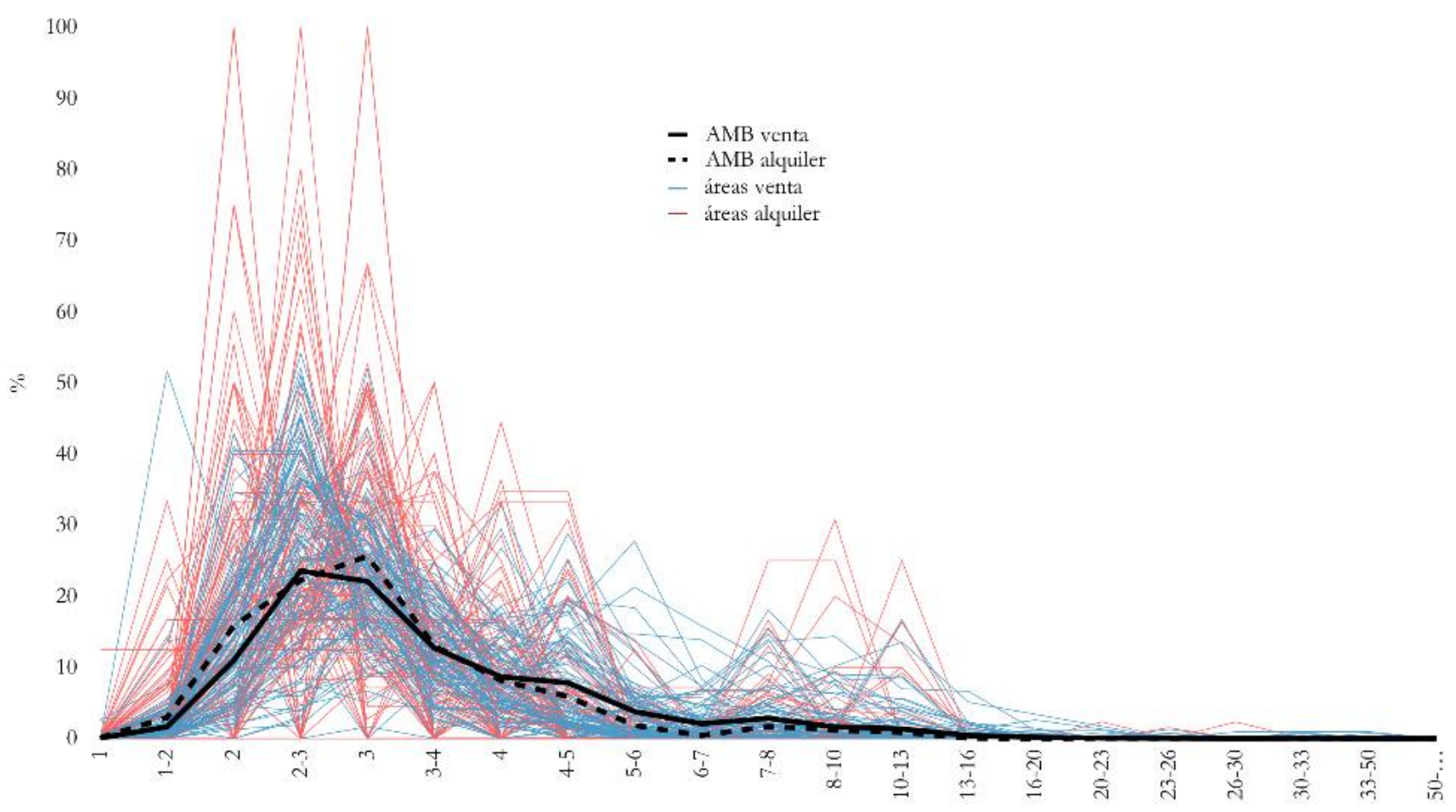

Gráfica 3.16. Accesibilidad espacial a la oferta analizada por área geográfica y tamaño de la agrupación de personas necesario bajo la SMP. Elaboración propia a partir de Idealista, 2015.
No obstante, hay casos en los que los porcentajes de parque residencial aparentemente apto en cuanto a su tamaño para una o dos personas es relevante, con valores que alcanzan el $20 \%$ y hasta el $40 \%$ de su muestra correspondiente. De la misma manera, y en el otro extremo de la gráfica, son numerosas las áreas con viviendas aptas para cuatro, cinco, ocho, diez y hasta trece personas. Mostrando valores que en algunos casos superan el $20 \%$ de su muestra. Otro aspecto a resaltar es que atendiendo a los regímenes de tenencia, en el caso del alquiler son varias las áreas geográficas en las que su oferta tiende a homogeneizarse. En ellas, más de la mitad del parque analizado presentan una superficie mínima apta para dos y tres personas, incluso en varios casos sustancialmente por encima de la mitad, llegando puntualmente en algunos casos a acumular la totalidad de la muestra. En el caso de la venta, las viviendas aparecen más repartidas a lo largo de las franjas de accesibilidad espacial. En cualquier caso, la superposición de estructuras ofrece otra visión más - de tantas posibles- de la diversidad del parque residencial del AMB. Lo que fortalece la idea de que esta heterogeneidad no se debe a cuestiones azarosas ni fortuitas, si no que responde a las lógicas de una distribución socio-espacial desigual debidas a la diferente acumulación de rentas y capital en la ciudad. Una de las consecuencias directas de dichas lógicas -y reflejadas en las Gráficas 3.14 y 3.16, y Mapas 3.7 y 3.8- es la de una diferente territorialización del derecho a la vivienda estrechamente ligada al variable acceso a las rentas. Por otro lado, se observa una relativa diversidad de precios y superficies que puede dar pie a diferentes tipos de intervenciones y accesos. 


\section{Compatibilidad tipológica de las viviendas}

Los datos hasta aquí presentados dan una imagen global de los tamaños de agrupaciones de personas más habituales a los que el parque actual condiciona de cara a habitar esas viviendas. Aunque se volverá más adelante a esta cuestión, se desea ahora dar un pequeño giro en este análisis del parque de viviendas del AMB, con el fin de abordar aspectos desde una componente más arquitectónica y explícitamente espacial. Probablemente, uno de los condicionantes más relevantes a la hora de abordar el ajuste espacial de la vivienda, más allá de una primera aproximación desde la variable de la superficie, es la adecuación de su tipología a las personas que la van a habitar. La correcta configuración del entorno doméstico de acuerdo a las necesidades y deseos de sus habitantes permitirá o dificultará, como se ha apuntado en capítulos previos, el óptimo desarrollo de su vida doméstica. En este sentido, la estrategia aquí planteada de la agrupación de personas como herramienta a corto y medio plazo para avanzar hacia el acceso a la vivienda necesita de un estudio de este tipo para afianzar su hipótesis, en la medida en que entre sus planteamientos incluye la transformación y adaptación tipológica de estas viviendas. Se ha considerado por tanto que la incorporación de información relativa a las características tipológicas de la muestra trabajada es indispensable para el correcto desarrollo de la misma, pues podrían surgir incompatibilidades relevantes.

Por lo tanto, sin profundizar en la teoría y la práctica del diseño y ejecución de tipologías residenciales, se entiende como necesaria una pequeña incursión en este campo para comprobar la compatibilidad, o no, del parque con el planteamiento de fondo de la investigación. Para ello, se ha planteado un ejercicio de análisis de parte de la muestra total, con el objetivo de comprobar el tipo de viviendas habitualmente existentes en la oferta residencial del AMB. El objetivo principal es doble. Por un lado, ver la flexibilidad actual que presentan estas viviendas para acoger formas de habitar diferentes a las que el mercado general se dirige. En paralelo, y en la medida en que ya se ha comprobado en el desarrollo del marco teórico la generalizada rigidez tipológica del parque existente, se evalúa su capacidad de adaptación y transformación a esas formas de habitar excluidas de la oferta convencional. Con tal fin, de entre las que cumplen las condiciones de accesibilidad económica y espacial anteriores, se han seleccionado 377 viviendas de la muestra inicial -disponibles en el Anexo III-. Estas presentan una diversidad de superficie, forma, localización, calidad, precio y edad considerables - la práctica totalidad construidas a lo largo del siglo XX-. En ellas se han estudiado estas dos cuestiones a través de la evaluación de 14 indicadores $^{70}$ (Tablas 3.15 y 3.16).

70 Obtenidos de trabajos y bibliografía especializada que han abordado estas cuestiones (Amann, 2005; Druot et al., 2007; Fonseca, 2014; Lleó, 2006; Montaner, 2015; Montaner y Muxí, 2009; Montaner et al., 2011; Monteys y Fuertes, 2002; Moya, 2007; Muxí, 2009; Paricio y Sust, 2000; Trovato, 2009). En el Anexo III se da más información sobre la metodología utilizada.
Tabla 3.15 (Página siguiente). Porcentaje de la muestra con valores positivos en los indicadores de flexibilidad actual utilizados en el análisis tipológico de las viviendas en oferta. Elaboración propia a partir de referencias señaladas. 


\begin{tabular}{cr}
\hline Indicador de flexibilidad actual & Cuentan con él \\
\hline Vestíbulo-recibidor-distribuidor a modo de filtro & $\mathbf{9 2 , 8 6 \%}$
\end{tabular}

La existencia de un espacio de transición entre las zonas comunes del edificio y la vivienda permite funciones como el almacenaje de elementos para su uso exterior, proteger la intimidad del espacio doméstico y la salud de sus ocupantes de visitas puntuales, además de hacer de elemento estructurador de la vivienda si es de cierta entidad.

Pasillos multifunción

Un dimensionado generoso de los pasillos y espacios distribuidores permite, de manera complementaria a su función de paso, la incorporación de otros usos y actividades en las zonas de tránsito, como el almacenaje o el juego. Incluso en ocasiones, si disponen de luz natural y ventilación, pueden acoger el estudio o el trabajo productivo y reproductivo.

\section{Circulación doble}

La existencia de alternativas de circulación y paso ofrecen la posibilidad de realizar zonificaciones temporales dotando de una mayor versatilidad a la vivienda.

\section{Cocina con posibilidad de actividades diferentes}

Un diseño y dimensionado específico de la cocina permite tanto liberar la sala de estar de ciertos usos (como el espacio de comedor), como acoger en ella otros diversos y temporales en condiciones de calidad: estudiar, realizar manualidades, o el desarrollo de trabajos reproductivos, además de poner en valor las labores propias de este espacio sin aislarla del resto de la vivienda.

\section{Baño(s) en zona común}

$94,97 \%$

Su disposición en zonas comunes favorece un acceso igualitario y no conflictivo con zonas de mayor nivel privado e íntimo que quedan liberadas de los condicionantes de tránsitos puntuales.

\section{Baños con funciones separadas}

La separación de los elementos del baño en diferentes espacios favorece su uso simultáneo.

\section{Habitaciones no jerárquicas}

$24,07 \%$

Evitar la habitual incorporación de dormitorios principales con baños incluidos que jerarquizan la vida de los habitantes de la vivienda favorece la convivencia y ofrece mayor adaptación a unidades de convivencia diferentes de la familia nuclear con hijas e hijos.

Espacios y/o zonas comodín

La presencia de espacios que permitan usos temporales auxiliares o secundarios, ya sean independientes o anexos a otro espacio y/o actividad, suman riqueza y versatilidad de uso.

\section{Estancias versátiles}

La presencia de estancias indefinidas, polivalentes, con compartimentaciones ambiguas, con más de una puerta, fácilmente divisibles y/o comunicables y de usos genéricos dota de versatilidad y flexibilidad a la vivienda sin necesidad de sistemas constructivos complejos ni costosos. Evita limitar las mismas a usos concretos debido a su diseño.

\section{Estancia junto a acceso}

La situación de una estancia cerca del acceso permite la desconexión temporal o fija de una parte de la vivienda para otros usos, como un posible apartamento-estudio independiente, o para complementar el uso residencial con el trabajo productivo favoreciendo las labores reproductivas de la persona que utiliza ese espacio, y reduciendo gastos de alquiler o compra de un espacio externo. 


\begin{tabular}{|c|c|}
\hline Indicador de adaptabilidad futura & Cuentan con él \\
\hline Acceso en punto central de la vivienda & $50,53 \%$ \\
\hline \multicolumn{2}{|c|}{$\begin{array}{l}\text { La localización estratégicamente central del acceso actual amplía las posibilidades a la hora de } \\
\text { transformar la distribución existente en otros espacios domésticos. }\end{array}$} \\
\hline Dos accesos a la vivienda & $7,41 \%$ \\
\hline \multicolumn{2}{|c|}{$\begin{array}{l}\text { La existencia de un doble acceso (uno 'principal' y otro para el personal de servicio, común en } \\
\text { algunas viviendas destinadas a perfiles de rentas altas hasta hace unas décadas) facilita posibles } \\
\text { segregaciones de la vivienda para separar unidades de convivencia o usos y actividades. }\end{array}$} \\
\hline Distribución racional de la estructura & $96,24 \%$ \\
\hline \multicolumn{2}{|c|}{$\begin{array}{l}\text { La disposición ordenada de los elementos estructurales favorece el cambio en la distribución de } \\
\text { los espacios actuales y amplía el abanico de opciones de transformación de la vivienda. }\end{array}$} \\
\hline Distribución racional de patinillos de instalaciones & $81,58 \%$ \\
\hline \multicolumn{2}{|c|}{$\begin{array}{l}\text { La disposición ordenada de estos elementos auxiliares favorece el cambio en la distribución de } \\
\text { los espacios actuales y amplía el abanico de opciones de transformación de la vivienda. }\end{array}$} \\
\hline Áreas húmedas agrupadas en la vivienda & $63,49 \%$ \\
\hline $\begin{array}{l}\text { La agrupación de aquellas funciones con necesidad de in } \\
\text { saneamiento de agua permite obtener mayor rendimientc } \\
\text { de instalaciones, y liberar la planta para posibles transfor }\end{array}$ & $\begin{array}{l}\text { niento y } \\
\text { no los patinillos }\end{array}$ \\
\hline
\end{tabular}

Los indicadores relativos a la flexibilidad actual hacen referencia a una versatilidad perceptiva del espacio, no debiendo esta necesariamente sostenerse en una flexibilidad física con elementos móviles (Paricio y Sust, 2000: 25). De los analizados, la presencia de un espacio de filtro y transición con el exterior que pueda hacer de principal distribuidor de acceso a zonas diferenciadas de la vivienda, $y$ de una cocina con la suficiente dimensión como para dotarla de versatilidad y capacidad de acoger usos diversos del cocinado y la alimentación, es muy común. Ambas cuestiones podrían llegar a facilitar la una futura transformación parcial, y la ocupación y uso de la vivienda por parte de pequeñas unidades de convivencia diferentes. Los elementos de distribución se limitan en gran medida a elementos monofuncionales con una sola alternativa de recorrido y unas dimensiones mínimas para el paso. Lo cual condiciona el posible cambio de uso de algunas de las estancias, e impide la utilización de esos propios espacios de conexión con otros fines complementarios. Es decir, rigidizan en gran medida la planta de cara a plantear otras maneras de convivencia diferentes a las propias de la familia nuclear.

La disposición general de los baños es positiva en la medida en que casi el 95\% de la muestra analizada dispone de al menos un baño en las zonas comunes de la vivienda -más del $27 \%$ tiene dos en la misma condición-. Sin embargo, la separación de los distintos aparatos sanitarios en diferentes espacios para permitir un uso simultáneo de los mismos es prácticamente inexistente. En cuanto a las
Tabla 3.16. Porcentaje de la muestra con valores positivos en los indicadores de adaptabilidad futura utilizados en el análisis tipológico de las viviendas en oferta. Elaboración propia a partir de referencias señaladas. 
características de las estancias, los resultados no muestran signos de flexibilidad ni versatilidad. La presencia de una estructura de estancias totalmente jerarquizada se observa en el $75 \%$ de la muestra, conteniendo habitaciones claramente destinadas a un uso de dormitorio y con proporciones rígidas y dimensiones mínimas. En muchos casos, tal situación se remata con un dormitorio principal amplio, con baño y vestidor incluidos -casi un $40 \%$ de las viviendas cuentan con una habitación de esas características-, tanto en viviendas con varias décadas de antigüedad como en nuevas promociones. En este sentido, la presencia de estancias con cualidades que favorezcan la flexibilidad, el cambio y/o compatibilidad de usos, como contar con más de un punto de acceso, o ser divisible en varias, es baja y apenas lo presenta un cuarto de las viviendas estudiadas. De igual manera, y como ya se ha señalado en el caso de los pasillos, la presencia de espacios -no necesariamente estancias- con un carácter multifuncional es muy baja, apenas del $9 \%$. Por último, la disponibilidad de espacios adecuados para el trabajo productivo en la vivienda $-\mathrm{y}$ la consecuente necesidad de recibir personas relacionadas con la actividad- que necesitan muchos perfiles laborales actuales, o la posible demanda de una estancia parcialmente segregada del resto de la vivienda para personas de paso, no se ven adecuadamente respondidas. Tan solo un 18\% de la muestra dispone de una estancia de dimensiones adecuadas, en un lugar cercano al acceso a la vivienda para no interferir en la vida doméstica.

En cuanto a la adaptabilidad futura, la metodología se ha basado principalmente en la identificación y localización en la planta de una serie de elementos soporte siguiendo algunos de los planteamientos teóricos de Habraken (1972). El objetivo ha sido plantear un supuesto de eliminación de todos los elementos secundarios de las viviendas, como particiones verticales y mobiliario. Y manteniendo los elementos esenciales de la misma para analizar las posibilidades de albergar otras tipologías diferentes a las existentes. Con excepción del indicador relativo a la presencia de dos accesos diferentes a la vivienda, que alcanza un valor del 9\% de la muestra, el resto arrojan valores altos y por lo tanto positivos. Alrededor de la mitad de las viviendas analizadas tienen el punto de acceso desde las zonas comunes del edificio en una zona relativamente central. Lo cual favorece posibles segregaciones o separaciones en zonas de la misma de cara a acoger unidades de convivencia diferentes. La distribución de los elementos de la estructura y los conductos verticales para las instalaciones es en general considerablemente racional y ordenada -en torno al $96 \%$ en el primer caso y más del $80 \%$ en el segundo-, sin condicionar la distribución y dimensionamiento de las diversas estancias en hipotéticas transformaciones futuras de esas viviendas. En la línea con lo anterior, más del $60 \%$ de la muestra dispone de sus zonas húmedas agrupadas, lo cual también es un elemento favorable de cara a transformar y redistribuir los espacios existentes. 


\section{Una oportunidad espacial prometedora}

A pesar de tratarse de miradas en cierta medida parciales, los datos mostrados en lo relativo a esta accesibilidad espacial a la vivienda en el AMB permiten confirmar algunas cuestiones. En primer lugar, la oferta actual no parece estar, en cuanto a sus superficies más habituales respecta, en proceso de adaptación a una sociedad cuya estructura de unidades de convivencia está en proceso de diversificación y reducción general del tamaño, con las unipersonales en continuo aumento. Por otro lado, los resultados muestran una considerable obsolescencia espacial en cuanto a su tipología respecta, para albergar unidades convivenciales diferentes a la pareja con dos o tres hijos ${ }^{71}$. Con un escenario socio-laboral que condiciona en gran medida las biografías vitales de parte de la sociedad a la hora de formar esas unidades, así como la posibilidad de encontrar unos espacios adecuados y asequibles de trabajo productivo y reproductivo, los resultados confirman que no se dan tipologías ajustadas a las necesidades de muchas de estas personas. Hay importantes carencias en lo relativo a la flexibilidad en su distribución actual como para permitir una ocupación de calidad por su parte.

Sin embargo, la flexibilidad potencial de muchas de las viviendas analizadas es tal que, mediante transformaciones en sus características espaciales, podría responderse adecuadamente a dichas necesidades. La convergencia de unas unidades de convivencia cada vez más pequeñas con un parque heredado en muchos casos superficial y tipológicamente obsoleto, genera también un potencial para adaptar esas viviendas a posibles agrupaciones de personas. Ya sea en lo que hasta ahora se entiende como una sola vivienda, o desbordando los límites de esta para tomar el edificio o parte del mismo como ámbito de actuación (Monteys y Fuertes, 2002). Precisamente, ese desfase entre tipos de unidades de convivencia y tipologías es una de las razones que impiden el acceso económico, pues el mercado está ofreciendo a una gran parte de la demanda un producto no diseñado para ella. Consecuentemente, se cree que las posibilidades de adaptación y transformación de lo que antes se ha etiquetado como un parque infrautilizado son considerablemente altas. Algo en lo que se sigue profundizando, y confirmando, en los apartados siguientes. Como se aborda más abajo, estas intervenciones conllevarían un sobrecoste por el que se verían afectadas las condiciones de acceso económico hasta ahora analizadas.

\footnotetext{
${ }^{71}$ Como se ha mostrado de manera breve al abordar la situación problemática, existe una rica y heterogénea variedad de unidades de convivencia y formas de vida que no se corresponden con ese perfil.
} 


\title{
$-3.3-$ \\ Un parque por adaptar
}

\author{
$-3.3 .1-$ \\ Accesibilidad total
}

En los apartados anteriores de este capítulo se ha podido ver de manera separada que, por un lado, en muchas de las viviendas de la muestra seleccionada el acceso económico digno a las mismas puede estar garantizado mediante una determinada agrupación de personas con capacidad de pago. Por otro lado, también se ha visto que espacialmente hay un abanico bastante diverso de posibilidades para que unidades de convivencia formadas por un diferente número de personas se agrupen y ocupen, en su caso mediante transformaciones ${ }^{72}$, algunas de estas viviendas. Entre ambos casos se observa un paralelismo: así como la mayoría de la oferta es accesible económicamente para grupos de dos o tres personas, la mayoría de viviendas se acumulan en franjas de superficie que permitirían una habitabilidad adecuada para dos o tres personas. Parece que aparentemente hay cierto encaje de precios y superficies que permitiría poner en práctica la estrategia planteada de agrupar personas para acceder a las viviendas del mercado. Sin embargo, ambas variables se han analizado por separado. En este apartado -con la motivación y la justificación de los datos positivos anteriores- para cada vivienda analizada se cruzan las dos condiciones, la económica y la espacial. El objetivo es ver cuántas de las viviendas económicamente accesibles bajo el PMT para un tamaño de agrupación de personas concreto permiten, a su vez, una ocupación de calidad por parte de ese mismo, o superior, número de personas. Siempre según la franja de superficie en la que estén clasificadas, y por encima de la SMP.

\section{Accesibilidad total bruta}

Entendiendo esta como el cruce antes mencionado, pero sin incorporar al cálculo costes complementarios relativos a la posible transformación de las viviendas -se hará más adelante-, se parte de los tamaños de grupos ya definidos para comprobar, de las viviendas que podrían pagar bajo un coste tolerable con una renta de $1.400 €$,

\footnotetext{
72 Intervenciones de transformación y adaptación que podrían en una situación ideal ir de la mano de otras actuaciones ya fomentadas por las políticas públicas en materia de eficiencia energética o accesibilidad.
} 
cuántas tienen una superficie admisible para que sean habitables. A mayor número de personas, mayor será la accesibilidad económica por la acumulación de rentas, pero más exigente será la espacial -al necesitar de más superficie-. Así, los datos globales de la región ofrecen resultados muy interesantes. Más de un $80 \%$-para la venta- y de un 95\% - para el alquiler- de la muestra manejada es accesible totalmente; es decir, que las personas necesarias para el acceso económico tolerable a esas viviendas pueden a priori habitarlas sin problema, al menos basándose exclusivamente en su superficie. Más allá de los datos medios, se observan franjas de accesibilidad total con porcentajes bien diversos (Tabla 3.17). En general, el nivel de acceso total aquí analizado muestra una pauta clara. Presenta sus niveles relativos más altos en aquellas viviendas asumibles económicamente con una sola renta de $1.400 €$, que en ambos regímenes de tenencia es del $100 \%$. Y va reduciéndose a medida que el tamaño de la agrupación de personas necesario para costear el gasto es mayor.

\begin{tabular}{|c|c|c|c|c|c|c|c|c|}
\hline \multirow{2}{*}{$\begin{array}{l}\text { Acc. } \\
\text { económica }\end{array}$} & \multicolumn{4}{|c|}{ VENTA } & \multicolumn{4}{|c|}{ ALQUILER } \\
\hline & Viv. & Acc. total & $\%$ franja & $\%$ total & Viv. & Acc. total & $\%$ franja & $\%$ total \\
\hline$€<1$ & 575 & 575 & 100,00 & 3,30 & 4 & 4 & 100,00 & 0,19 \\
\hline $1<€<2$ & 5.562 & 5.559 & 99,95 & 31,88 & 1.002 & 1.001 & 99,90 & 48,33 \\
\hline $2<€<3$ & 5.038 & 4.704 & 93,37 & 26,97 & 837 & 784 & 93,67 & 37,86 \\
\hline $3<€<4$ & 2.574 & 1.708 & 66,36 & 9,79 & 123 & 103 & 83,74 & 4,97 \\
\hline $4<€<5$ & 1.286 & 707 & 54,98 & 4,05 & 69 & 58 & 84,06 & 2,80 \\
\hline $5<€<6$ & 814 & 368 & 45,21 & 2,11 & 22 & 18 & 81,82 & 0,87 \\
\hline $6<€<7$ & 582 & 251 & 43,13 & $1,44 \%$ & 4 & 3 & 75,00 & 0,14 \\
\hline $7<€<8$ & 309 & 105 & 33,98 & 0,60 & 8 & 7 & 87,50 & 0,34 \\
\hline $8<€<9$ & 214 & 70 & 32,71 & 0,40 & 0 & & & \\
\hline $9<€<10$ & 146 & 52 & 35,62 & 0,30 & 1 & 1 & 100,00 & 0,05 \\
\hline $10<€<15$ & 256 & 31 & 12,11 & 0,18 & 1 & 1 & 100,00 & 0,05 \\
\hline $15<€<20$ & 58 & 5 & 8,62 & 0,03 & 0 & & & \\
\hline $20<€<40$ & 20 & 4 & 20,00 & 0,02 & 0 & & & \\
\hline $40<€$ & 6 & 3 & 50,00 & 0,02 & 0 & & & \\
\hline total & & & & 81,09 & & & & 95,61 \\
\hline
\end{tabular}

En el caso de la venta, este sigue siendo muy alto para aquellas viviendas que exigen de dos a tres rentas de $1.400 €$, y a partir de ahí el descenso del porcentaje de accesibilidad total es progresivo a medida que aumenta la exigencia económica. Con la salvedad de un salto cuantitativo para grupos de más de veinte personas, en los que la relación de viviendas accesibles totalmente respecto a la muestra sube hasta valores del $20 \%$ y hasta del $50 \%$-en este último caso el dato
Tabla 3.17. Accesibilidad total a la muestra de viviendas en oferta en el AMB, a partir del cruce de la accesibilidad económica y espacial en cada vivienda. Elaboración propia a partir de de Idealista, 2015. 


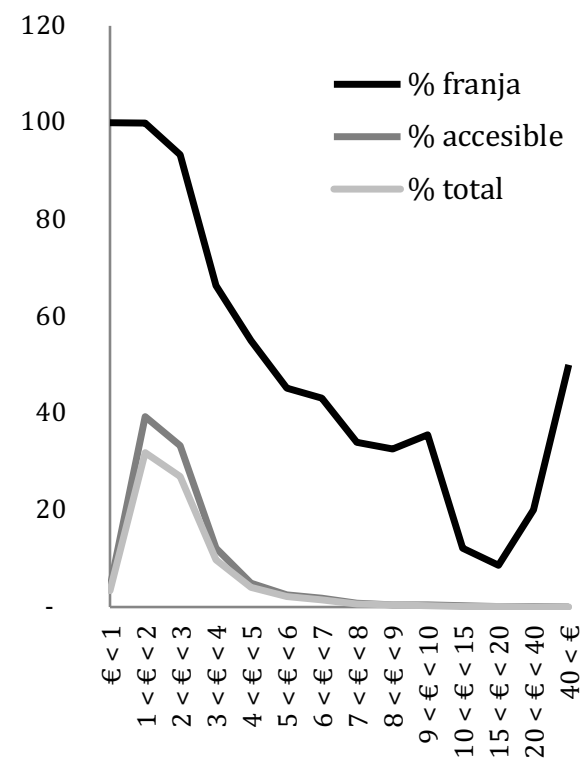

Gráfica 3.17. Accesibilidad total a la muestra de viviendas en venta en el AMB, a partir del cruce de la accesibilidad económica y espacial en cada vivienda. Elaboración propia a partir de Idealista, 2015.

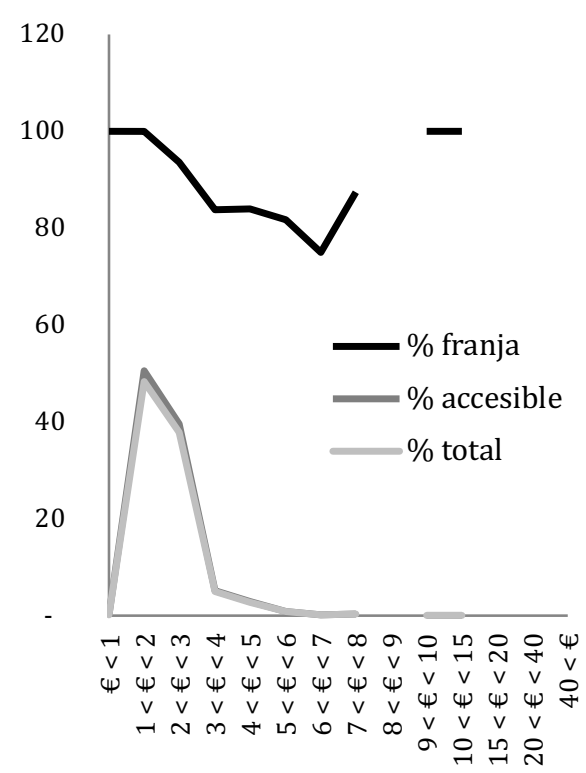

Gráfica 3.18. Accesibilidad total a la muestra de viviendas en alquiler en el AMB, a partir del cruce de la accesibilidad económica y espacial en cada vivienda. Elaboración propia a partir de Idealista, 2015. puede estar pervertido por el bajo universo de análisis correspondiente-. En cuanto al alquiler, los porcentajes de accesibilidad total se mantienen en valores altos incluso para aquellas viviendas con necesidad de agrupaciones de hasta siete u ocho personas con capacidad de pago. A partir de ahí, la falta de una muestra de calidad impide hacer una lectura adecuada. Son, en cualquier caso, resultados muy positivos que reflejan un alto potencial para avanzar hacia las metas de este trabajo. Estos altos porcentajes de viviendas relativos al cruce de las variables de espacio y precio permiten afirmar la existencia de unos espacios de oportunidad interesantes para el acceso a la vivienda acorde a las necesidades sociales. Eso sí, pasando probablemente en gran parte de los casos por la necesaria adaptación del parque a las mismas, a través de intervenciones en las viviendas, sin descartar la posibilidad de abarcar en dichas operaciones más de una vivienda actual, o espacios comunes del edificio. Este posible desborde de la estructura de la propiedad actual será, como se verá luego, una de las principales razones para que la incorporación a la estrategia global de una gestión colectiva empoderada se torne necesaria.

Al trasladar los datos de la Tabla 3.17 al formato de gráfica se observa que, tanto la estructura de la totalidad de la muestra de viviendas analizadas, como la relativa al conjunto de viviendas con accesibilidad total, reflejan con gran fidelidad las estructuras de las gráficas de franjas de precios y de superficies antes presentadas (Gráficas 3.17 y 3.18). Por lo que, en número absolutos, las viviendas aptas para dos y tres personas son sin duda las mayoritarias. Pero más allá de esa lectura, en este caso también son de interés los porcentajes de vivienda accesible relativos a cada franja de personas necesarias para pagar la vivienda: aparentemente, a menor tamaño de la agrupación necesaria, mayor será la accesibilidad total. Como ya se ha apuntado, para la venta los porcentajes son muy altos hasta 2-3 personas, medios y altos hasta 4-5, y siguen bajando hasta 9-10; a partir de ahí bajan mucho, con un repunte final para 20-40 y más de 40 personas. En el caso del alquiler, el porcentaje es muy alto en todas las categorías; pero la gran mayoría de viviendas accesibles totalmente podrían a priori pagarse y ocuparse por 2-3 personas.

\section{Accesibilidad total neta}

Como se ha venido anticipando, la metodología utilizada para el cálculo de la accesibilidad económica a la muestra de viviendas trabajada dejaba de lado los costes propios de las posibles transformaciones y adaptaciones del parque a las que se han ido haciendo alusión como parte de la estrategia de agrupación de personas planteada. Por esta razón, se propone aquí un ejercicio de análisis en el que abordar esta cuestión. La muestra utilizada en este caso deja de lado la oferta en alquiler y se centra en la de venta. Al precio de oferta de cada una de las viviendas se le ha sumado, planteando cuatro escenarios diferentes, un incremento económico 
por unidad de superficie tal y como se ha explicado en el apartado 3.1 y especificado en la Tabla 3.10. En dicho incremento se incluye, además de los costes de la obra, un porcentaje correspondiente a las tasas municipales, honorarios de proyecto y la gestión del proceso por un agente. Con todo, se trata de valores aproximados tendiendo hacia intervenciones básicas. En un supuesto real, cada caso presentará muy diversas necesidades y respuestas. Una vez aplicados los cuatro incrementos, se ha vuelto a calcular la accesibilidad económica de esas viviendas. Trasladados los resultados a una gráfica similar a la 3.14, que refleja la accesibilidad de las viviendas en función del número de personas necesarias para afrontar su pago bajo el PMT -limitada a un máximo de 6 personas para favorecer la visualización-, se observa que la estructura pivota sobre las viviendas accesibles para tres personas (Gráfica 3.19). El porcentaje de las accesibles para una persona baja más de la mitad, aunque al tratarse de pocas viviendas no se aprecia adecuadamente en la gráfica. El cambio más relevante en cuanto a número absoluto de viviendas se refiere es el de aquellas accesibles para 2 personas, que baja considerablemente. Mientras que las de cuatro, cinco y seis suben con moderación. Los porcentajes totales no varían demasiado: del $90 \%$ de viviendas accesibles económicamente para grupos de 6 o menos personas según los precios de oferta originales, este pasa a un $85 \%, 84 \%, 83 \%$ y $82 \%$ respectivamente por cada precio de intervención analizado.

Por supuesto, la accesibilidad espacial no varía, por lo que obtenida la económica, se ha vuelto a calcular la accesibilidad total para cada uno de los cuatro supuestos. El descenso en el número de viviendas accesibles que exigen la existencia de una y dos rentas de referencia de $1.400 €$ sigue la misma pauta adelantada en la Gráfica 3.19 , aunque más acusada, con una pérdida de entre el $35 \%$ y el $75 \%$ de la muestra. Lo que lleva a corregir la lectura realizada en la accesibilidad total bruta respecto a la existencia de un mayor acceso total inversamente proporcional al tamaño de la vivienda. Si se llevan a cabo transformaciones espaciales en esta, el incremento de los costes correspondientes expulsan a una gran parte de dichas viviendas fuera del rango de accesibilidad económica admisible definido en el trabajo (Gráfica 3.20). De ahí en adelante, la estructura de la accesibilidad total varía sustancialmente respecto a la de la económica. En cuanto a las viviendas accesibles totalmente para agrupaciones de dos y tres personas con una renta media de $1.400 €$, el descenso es claramente menor que en los casos anteriores, y se reafirman como el tipo de mayor relevancia en la muestra estudiada, si se tienen en cuenta tanto las cantidades absolutas como el ajuste por los costes de transformación. Estos resultados permiten sostener la propuesta estratégica aquí planteada de agrupar pequeñas unidades de convivencia para afrontar el coste de la vivienda mediante adaptaciones espaciales del parque. Para los casos con precios más altos, que exigen agrupaciones de cuatro, cinco, seis y hasta siete rentas medias, los resultados son inversos. Mientras que en la accesibilidad económica se incrementaba el porcentaje de viviendas

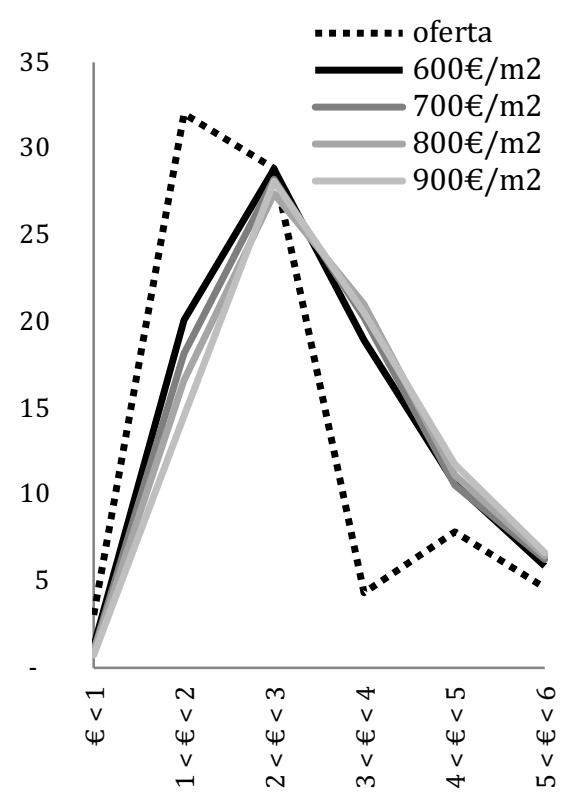

Gráfica 3.19. Accesibilidad económica a la muestra de viviendas en venta en el $\mathrm{AMB}$, según incremento de coste de transformación. Elaboración propia a partir de Idealista, 2015. 
- precio oferta $\%$ de la franja

- precio oferta \% de accesibles

- precio oferta total

- $600 € / \mathrm{m} 2$ total

- $700 € / \mathrm{m} 2$ total

- $800 € / \mathrm{m} 2$ total

- $900 € / \mathrm{m} 2$ total

$=-600 € / \mathrm{m} 2 \%$ de la franja

- - $700 € / \mathrm{m} 2 \%$ de la franja

- - $800 € / \mathrm{m} 2 \%$ de la franja

- - $900 € / \mathrm{m} 2 \%$ de la franja

- $600 € / \mathrm{m} 2 \%$ de accesibles

. $700 € / \mathrm{m} 2 \%$ de accesibles

- $800 € / \mathrm{m} 2 \%$ de accesibles

. $900 € / \mathrm{m} 2 \%$ de accesibles

Gráfica 3.20. Accesibilidad total a la muestra de viviendas en venta en el AMB, según incremento de coste de transformación. Valores relativos por franja, conjunto de accesibles y muestra total. Elaboración propia a partir de Idealista, 2015. relativas, en la total este desciende entre un 15\% y un 30\%. Aún así, no se deben despreciar, pues el número absoluto de viviendas en estas situaciones es considerable, y su mayor tamaño permitirá acoger a agrupaciones formadas por unidades de convivencia de otras características y de mayor tamaño que los casos anteriores. En el resto de viviendas, los resultados se mantienen prácticamente inalterados, con descensos muy pequeños en ciertos casos, e incluso aumentos relativos del número de viviendas accesibles totalmente para agrupaciones grandes de personas.

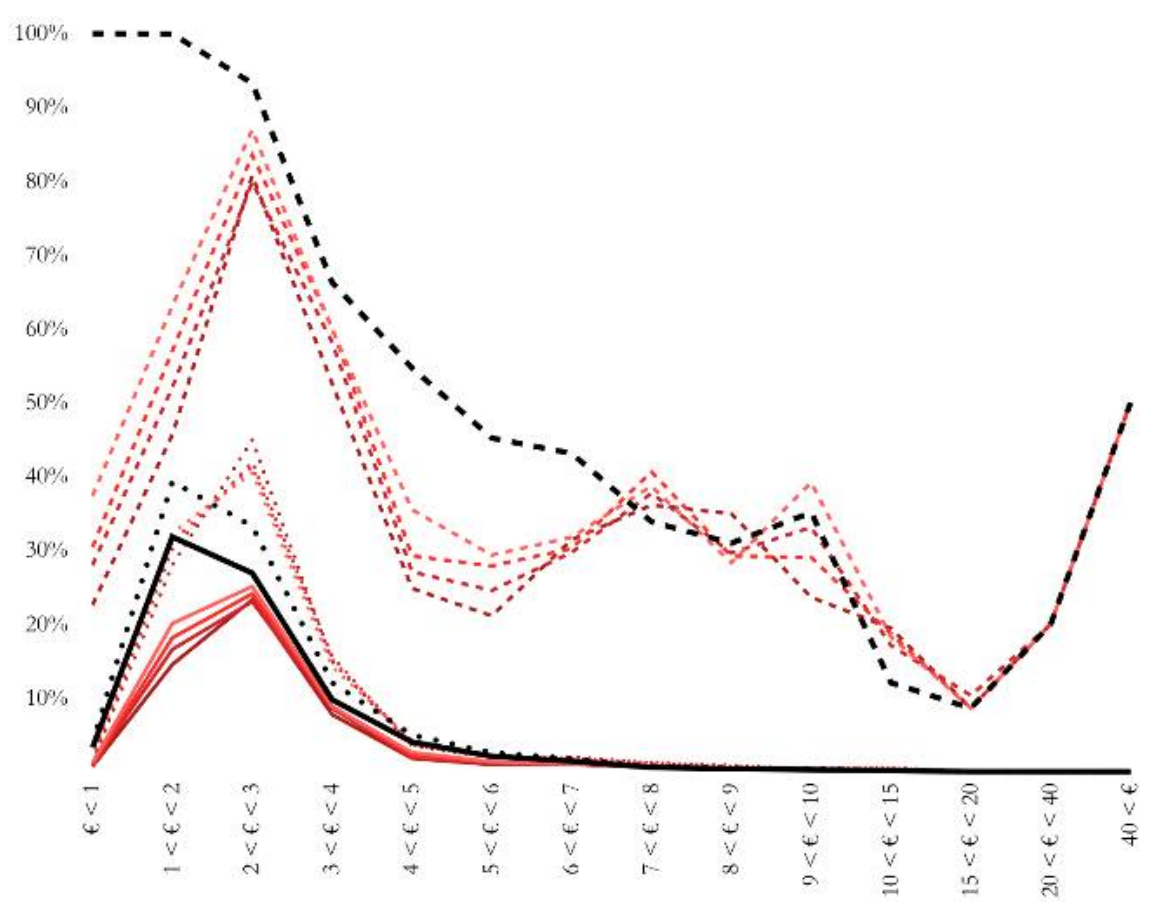

En conclusión, la ejecución de adaptaciones físicas en las viviendas para su adaptación -ya sea a las necesidades de una unidad de convivencia diferente a la familia nuclear, como para permitir la agrupación de estas- generan un incremento del gasto necesario para su acceso. Las principales consecuencias son, manteniendo este por debajo del PMT y considerando siempre a personas con capacidad de pago, las siguientes:

- Reducción drástica del acceso a viviendas aptas para una y dos personas.

- Valores similares o baja reducción del acceso a viviendas aptas para tres y cuatro personas.

- Reducción considerable de acceso a viviendas aptas para cinco, seis y siete personas. 
- Muy baja reducción, e incluso incremento, del acceso a viviendas aptas para siete y más personas ${ }^{73}$.

La reducción -tras este ajuste de los costes de acceso- en los porcentajes de viviendas accesibles totalmente en la muestra de oferta de venta estudiada es por supuesto importante. Pero aún así, del $81,09 \%$ estimado para una accesibilidad total bruta, la neta arroja unos esperanzadores porcentajes del $62 \%, 58 \%, 55 \%$ y $52 \%$ respectivamente por cada escenario de intervención definido (Tabla 3.18).
Tabla 3.18. Accesibilidad total neta a la muestra de viviendas en venta en el $\mathrm{AMB}$, según incremento de coste de transformación. Elaboración propia a partir de Idealista, 2015.

\begin{tabular}{|c|c|c|c|c|c|c|c|c|c|c|}
\hline \multirow{2}{*}{$\begin{array}{c}\text { Acc. } \\
\text { Económica }\end{array}$} & \multicolumn{2}{|c|}{ Total Bruta } & \multicolumn{8}{|c|}{ Acc. Total Neta } \\
\hline & $\mathrm{n}^{\circ}$ viv. & $\%$ & $600 € / \mathrm{m} 2$ & $\%$ & $700 € / \mathrm{m} 2$ & $\%$ & $800 € / \mathrm{m} 2$ & $\%$ & $900 € / \mathrm{m} 2$ & $\%$ \\
\hline$€<1$ & 575 & 3,30 & 215 & 1,20 & 175 & 1,00 & 161 & 0,90 & 130 & 0,80 \\
\hline $1<€<2$ & 5.559 & 31,90 & 3.511 & 20,10 & 3.171 & 18,20 & 2.897 & 16,60 & 2.540 & 14,60 \\
\hline $2<€<3$ & 4.704 & 27,00 & 4.387 & 25,20 & 4.214 & 24,20 & 4.028 & 23,10 & 4.074 & 23,40 \\
\hline $3<€<4$ & 1.708 & 9,80 & 1.544 & 8,90 & 1.551 & 8,90 & 1.499 & 8,60 & 1.355 & 7,80 \\
\hline $4<€<5$ & 707 & 4,10 & 459 & 2,60 & 378 & 2,20 & 350 & 2,00 & 321 & 1,80 \\
\hline $5<€<6$ & 368 & 2,10 & 239 & 1,40 & 227 & 1,30 & 200 & 1,20 & 172 & 1,00 \\
\hline $6<€<7$ & 251 & 1,40 & 185 & 1,10 & 176 & 1,00 & 173 & 1,00 & 183 & 1,10 \\
\hline $7<€<8$ & 105 & 0,60 & 120 & 0,70 & 126 & 0,70 & 117 & 0,70 & 112 & 0,60 \\
\hline $8<€<9$ & 70 & 0,40 & 64 & 0,40 & 66 & 0,40 & 67 & 0,40 & 79 & 0,50 \\
\hline $9<€<10$ & 52 & 0,30 & 58 & 0,30 & 43 & 0,30 & 49 & 0,30 & 35 & 0,20 \\
\hline $10<€<15$ & 31 & 0,20 & 47 & 0,30 & 48 & 0,30 & 44 & 0,30 & 50 & 0,30 \\
\hline $15<€<20$ & 5 & 0,00 & 5 & 0,00 & 5 & 0,00 & 6 & 0,00 & 5 & 0,00 \\
\hline $20<€<40$ & 4 & 0,00 & 4 & 0,00 & 4 & 0,00 & 4 & 0,00 & 4 & 0,00 \\
\hline $40<€$ & 3 & 0,00 & 3 & 0,00 & 3 & 0,00 & 3 & 0,00 & 3 & 0,00 \\
\hline total & & 81,10 & & 62,20 & & 58,40 & & 55,00 & & 52,00 \\
\hline
\end{tabular}

\section{Margen para personas sin capacidad de pago}

Como se ha ido apuntando a lo largo del capítulo, la metodología aplicada a la investigación ha abordado una estrategia de agrupación de personas con una renta de referencia en torno a los $1.400 €$ mensuales. Es decir, los cálculos de la accesibilidad económica, y consecuentemente la total, se refieren a personas con capacidad de pago. Sin embargo, la realidad social es que muchos de las unidades de convivencia con necesidad de vivienda no cuentan, parcial o

\footnotetext{
${ }^{73}$ La razón de los incrementos en el último caso se deben al paso de viviendas de una franja de acceso económico a la superior debido al incremento de los costes, con el consecuente aumento del número total de viviendas disponibles en la segunda.
} 


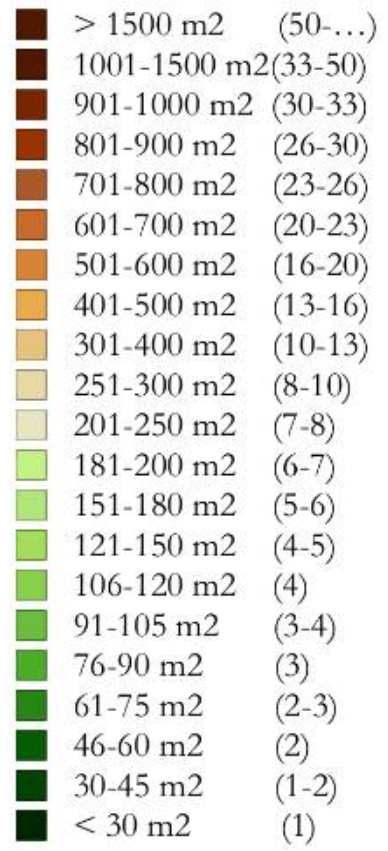

Gráfica 3.21. Desglose en franjas de superficie de la accesibilidad total bruta a la muestra de viviendas en venta y alquiler en el AMB. Elaboración propia a partir de Idealista, 2015. totalmente, con dicha capacidad. Ahora bien, se ha de tener en cuenta que la accesibilidad total calculada sitúa un límite mínimo de superficie, la SMP, pero no un límite máximo. Es decir, con los datos hasta aquí presentados, se puede afirmar que las viviendas accesibles totalmente permiten una ocupación con un ratio de treinta o más metros cuadrados por persona, pero no se ha analizado el margen de superficie existente por encima de esa cifra. Margen que, en determinados casos, permitiría la compatibilidad de lo hasta aquí desarrollado con situaciones en las que una o varias personas de la unidad o unidades de convivencia que accedan a esa vivienda puedan no tener ingresos, que tengan todas ingresos aunque por debajo de la referencia de los $1.400 €$, o combinaciones de las dos anteriores. A partir de los datos de la accesibilidad total bruta se puede presentar una primera aproximación a esta cuestión. Profundizando en el detalle de las franjas de superficie de las viviendas a las que pueden acceder los diferentes tamaños de grupos de personas, se observa que no siempre la superficie de las viviendas se ajusta al número de personas mínimas para el pago que exige su precio de oferta (Gráfica 3.21). Al contrario, la proporción de viviendas con una superficie por encima de la SMP es considerable y variado, según la franja de accesibilidad económica correspondiente.

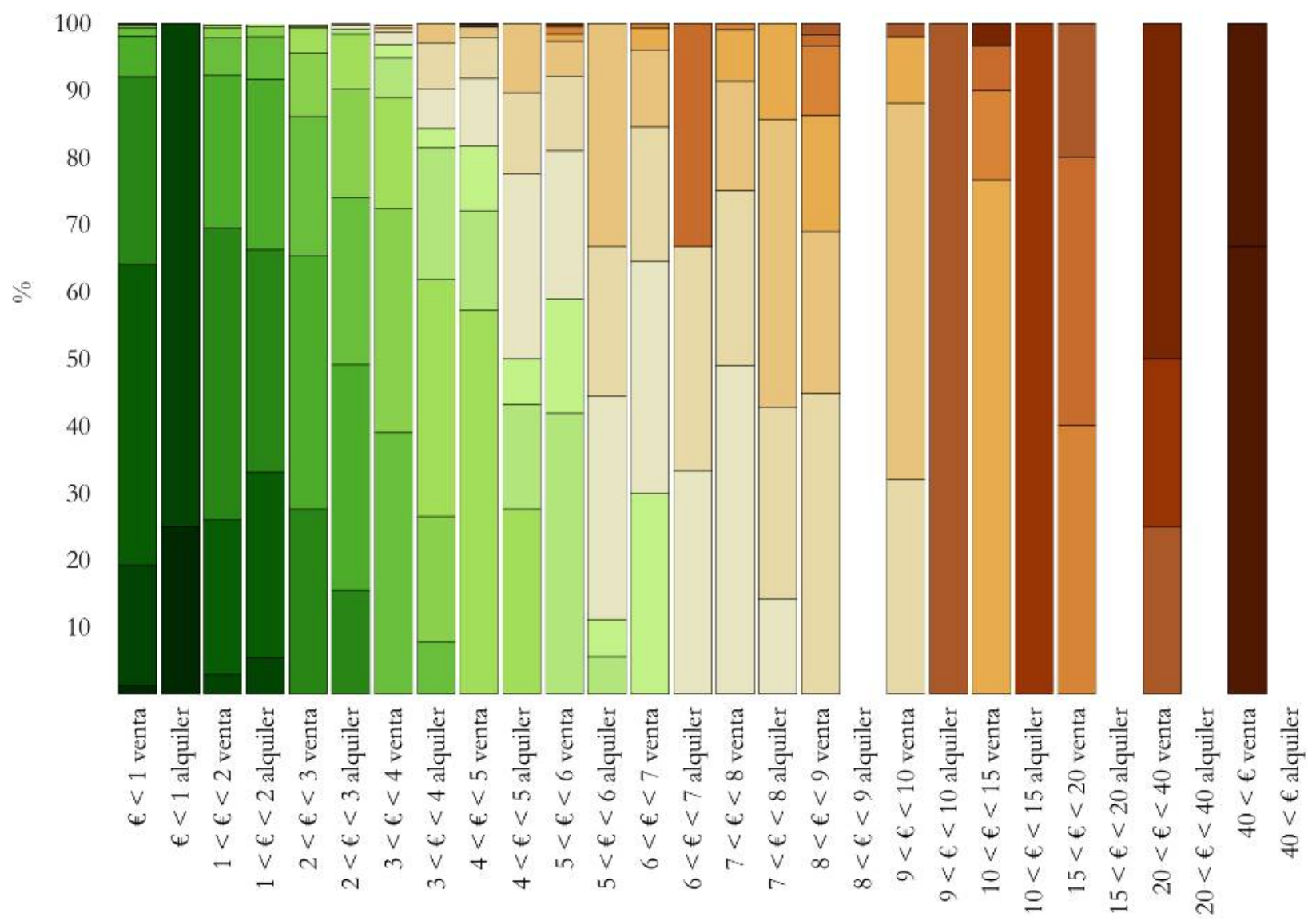


Para ilustrar esto con algunos ejemplos: entre aquellas viviendas que pueden ser costeadas con una sola renta de $1.400 €$, hay casos en la muestra de venta con superficies entre $61-75 \mathrm{~m}^{2}$-un $28 \%$ de la muestra- y de hasta $76-90 \mathrm{~m}^{2}$-en un 6\% de la misma-. Para aquellas viviendas que exigen un mínimo de tres rentas de $1.400 €$, más del $9 \%$ de la muestra tiene entre 106 y $120 \mathrm{~m}^{2}$, y más del 3\% entre 121 y 150 $\mathrm{m}^{2}$. El 10\% de las que tienen una accesibilidad económica mínima de 5 rentas de referencia está entre 201 y $250 \mathrm{~m}^{2}$, y más del $11 \%$ con necesidad de siete rentas tiene entre 301 y $400 \mathrm{~m}^{2}$. Es decir, todo apunta a que el margen espacial para albergar a más personas de las que se han incluido en el cálculo es considerablemente alto en el parque de viviendas del $\mathrm{AMB}$, o al menos en muchos casos superior al ratio mínimo de $30 \mathrm{~m}^{2}$ estimado. Efectivamente, el número de viviendas accesibles totalmente que cuentan con una superficie aproximada por encima de la $\mathrm{SMP}^{74}$ es alta. Con una media del $43 \%-$ en el caso de la venta- y del $58 \%$-en el alquiler- respecto a la muestra total, y con variaciones de entre el $27 \%$ y el $100 \%$, la flexibilidad de este parque residencial para acoger a unidades de convivencia cuyas personas integrantes no cuenten en su totalidad con capacidad de pago es alta (Tabla 3.19).
Tabla 3.19. Accesibilidad total bruta a la muestra de viviendas en venta y alquiler en el AMB para viviendas con superficie por encima de la SMP correspondiente a su franja de accesibilidad total. Elaboración propia a partir de Idealista, 2015.

\begin{tabular}{l|llll|llll}
\hline \multicolumn{1}{c|}{$\begin{array}{c}\text { Acc. } \\
\text { económica }\end{array}$} & \multicolumn{5}{c|}{ VENTA } \\
muestra & \multicolumn{1}{c|}{ Acc. total } \\
bruta & $>$ SMP & \% & muestra & $\begin{array}{c}\text { Acc. total } \\
\text { bruta }\end{array}$ & > SMP & \% \\
\hline$€<1$ & 575 & 575 & 464 & 80,70 & 4 & 4 & 0 & 0 \\
$1<€<2$ & 5.562 & 5.559 & 4.114 & 74,01 & 1.002 & 1.001 & 669 & 66,83 \\
$2<€<3$ & 5.038 & 4.704 & 1.630 & 34,70 & 837 & 784 & 399 & 50,89 \\
$3<€<4$ & 2.574 & 1.708 & 472 & 27,67 & 123 & 103 & 76 & 73,53 \\
$4<€<5$ & 1.286 & 707 & 300 & 42,80 & 69 & 58 & 42 & 72,41 \\
$5<€<6$ & 814 & 368 & 214 & 58,15 & 22 & 18 & 17 & 94,44 \\
$6<€<7$ & 582 & 251 & 176 & 70,12 & 4 & 3 & 3 & 100 \\
$7<€<8$ & 309 & 105 & 53 & 50,96 & 8 & 7 & 6 & 85,71 \\
$8<€<9$ & 214 & 70 & 58 & 82,85 & 0 & 0 & 0 & 0 \\
$9<€<10$ & 146 & 52 & 34 & 68,00 & 1 & 1 & 1 & 100 \\
$10<€<15$ & 256 & 31 & 30 & 100 & 1 & 1 & 1 & 100 \\
$15<€<20$ & 58 & 5 & 5 & 100 & 0 & 0 & 0 & 0 \\
$20<€<40$ & 20 & 4 & 3 & 75,00 & 0 & 0 & 0 & 0 \\
$40<€$ & 6 & 3 & 3 & 100 & 0 & 0 & 0 & 0 \\
\hline
\end{tabular}

${ }^{74}$ Los criterios para la determinación de los casos en los que la franja de superficie supera el número de personas condicionado por la accesibilidad económica se ha definido en la Tabla 3.11. 


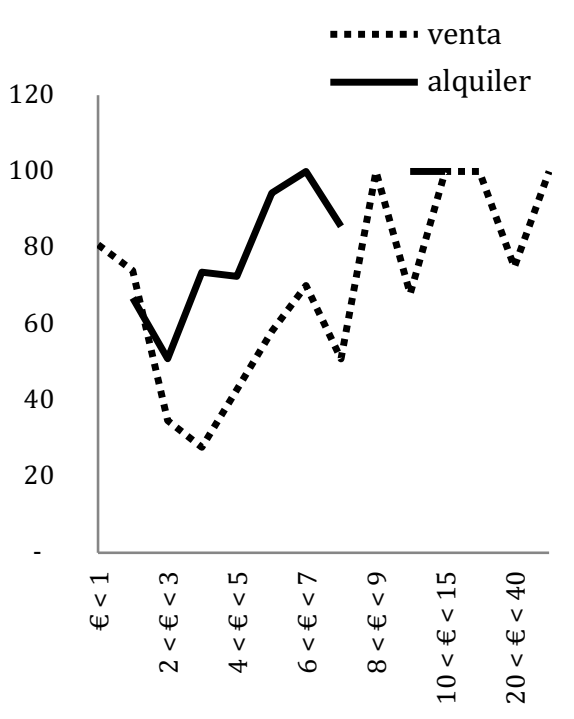

Gráfica 3.22. Porcentaje de viviendas de la muestra del AMB con accesibilidad total bruta y con una superficie por encima de la SMP. Elaboración propia a partir de Idealista, 2015.

Gráfica 3.23. Porcentaje de viviendas de la muestra del AMB con una superficie por encima de la SMP según accesibilidad total neta. Elaboración propia a partir de Idealista, 2015.
En general, y salvo para aquellos precios que exigen una y dos rentas de $1.400 €$, puede deducirse que mientras mayor tamaño de agrupación permita la accesibilidad total a la vivienda, mayor probabilidad habrá de que ocurra lo siguiente: se darán más posibilidades de acceso para unidades de convivencia con personas sin capacidad de pago, o se dispondrá de mayor superficie por persona, o más barato será el acceso a la misma si el aumento de la agrupación mínima de personas se da mediante perfiles con capacidad de pago (Gráfica 3.22). Si bien los datos mostrados hacen referencia a la accesibilidad total bruta, los relativos a la neta en esta cuestión no cambian la pauta de manera relevante. No al menos para el fin de este trabajo, que no es otro que abordar desde miradas diferentes un análisis del parque para apuntar posibles estrategias alternativas desde las que abordar su actual infrautilización. En ningún caso el énfasis se pretende poner en la precisión ni el detalle de los datos pues, como se ha mencionado, no ofrecen un reflejo detallado y exhaustivo de la realidad, ya que provienen de la recogida mediante el trabajo de campo en un momento concreto. En todo caso, con los datos de la accesibilidad neta disponibles se observa que baja el porcentaje de viviendas accesibles totalmente con una superficie aproximada por encima de la SMP para grupos pequeños, y sube algo para grupos intermedios, mientras que para grupos grandes las variaciones son diversas, pero sin grandes cambios (Gráfica 3.23). Con todo, este ejercicio ofrece mayor información para poder planificar diversas estrategias según el tamaño de las unidades de convivencia y de las viviendas.

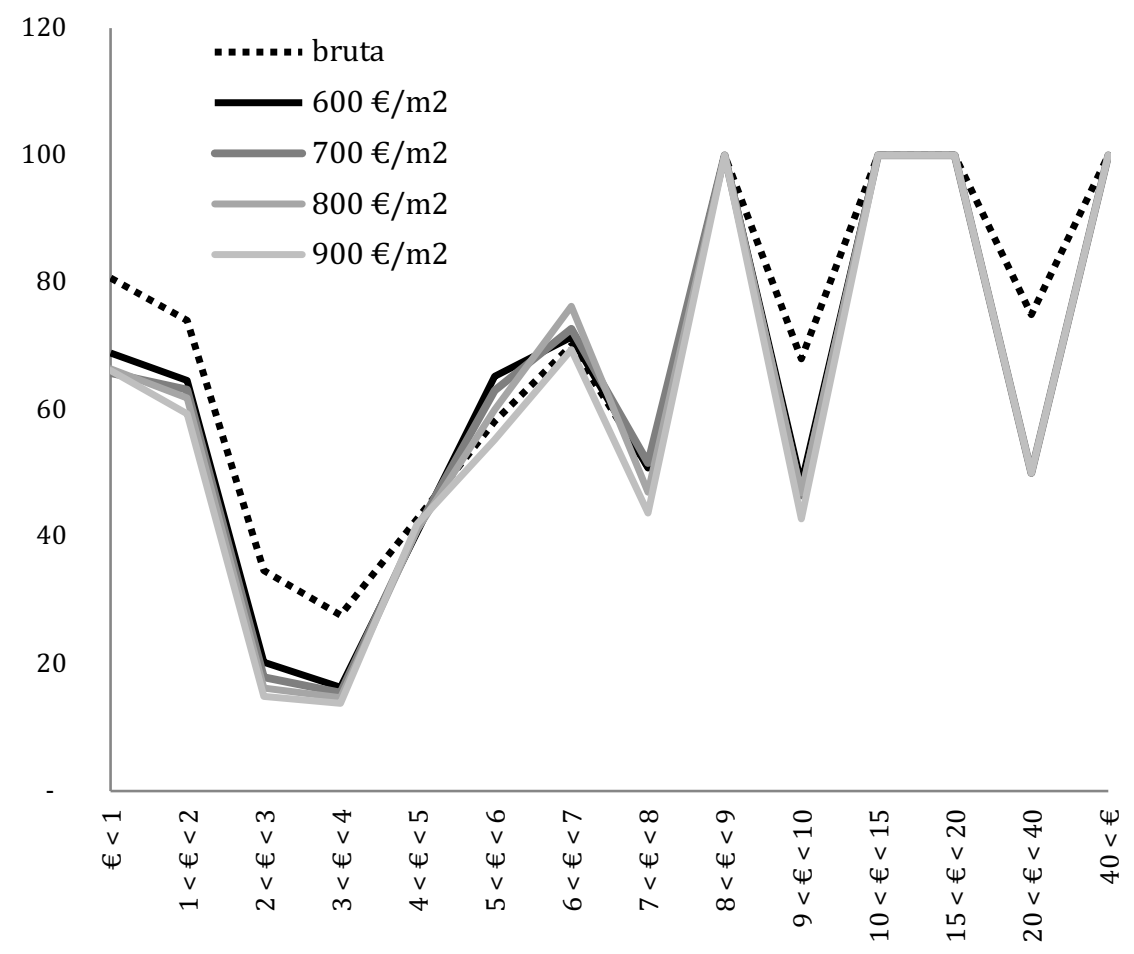




\section{Encaje con la estructura de unidades de convivencia y viviendas}

Antes de pasar a analizar los resultados obtenidos a una escala más detallada por áreas geográficas, se ha realizado un último ejercicio de profundización en los resultados a escala global del AMB. Se trata de un cruce entre los tamaños de las unidades de convivencia existentes según los censos de población y viviendas del INE, y las estimaciones de ocupación máxima de las viviendas con accesibilidad total identificadas en este trabajo. El objetivo es visualizar el desfase existente entre ambos para reforzar el planteamiento propuesto en torno a la idea de la agrupación de personas y unidades de convivencia a los que adaptar el parque actual. Al sintetizar los datos de la Tabla 2.6 según el número de personas que conforma cada unidad de convivencia, la distribución de las seis categorías que define el INE muestra que las formadas por dos personas son las mayoritarias, seguidas de las unipersonales y las formados por tres personas (Tabla 3.20). Las de cuatro tienen una frecuencia algo menor, siendo ya mucho más minoritarias las de cinco, seis y más personas. Por otro lado, se han clasificado las viviendas con acceso total identificadas en los apartados previos en las diferentes franjas de superficie del propio INE, -utilizadas para el cálculo de la accesibilidad espacial, y a partir de las cuales se ha definido una ocupación máxima aproximada como se ha explicado en el apartado 3.1-. Así, se puede obtener una síntesis de la disponibilidad, según la adecuación al tamaño de unidad de convivencia, que el parque actual ofrece para acoger a estas bajo las condiciones económicas y espaciales dignas definidas. Pero, eso sí, sin realizar ningún cambio ni transformación en las mismas (Tabla 3.21).

Aunque las categorías no sean las mismas y por lo tanto no puedan compararse directamente, el cruce de los datos de la Tabla 3.20 con los de la 3.21 permite obtener al menos dos claras conclusiones. La primera es que, mientras que aproximadamente una cuarta parte de las unidades de convivencia existentes según los datos de 2011 eran unipersonales -también en Euskadi, se trata de un tamaño de unidad cada vez más común, como vienen anunciando las estadísticas-, el parque actual apenas ofrece viviendas accesibles para aquellas con una renta media cercana a la de referencia, en torno a los $1.400 €$. En el supuesto más optimista, apenas alcanza el 1,5\% o $2 \%$ de las viviendas de la muestra. La segunda lectura es que mientras que las unidades de convivencia formadas por cinco, seis o más personas son con diferencia las minoritarias -sumando ambas un 4,13\% del total en 2011-, la muestra analizada ofrece en torno a un $8-10 \%$ de viviendas accesibles para unidades de esos tamaños, bajo los criterios económicos y espaciales exigidos. Es decir, podría decirse que existe, en el marco de este trabajo, un exceso de oferta de vivienda de gran tamaño. Respecto al resto de tamaños intermedios, los datos son menos claros y directos, pero podría interpretarse que el grueso de la muestra analizada se ajusta con mayor o menor éxito, en cuanto a la

\begin{tabular}{lll}
\hline Personas & Viviendas & \multicolumn{1}{c}{$\%$} \\
\hline 1 & 89.495 & 24,58 \\
2 & 117.970 & 32,4 \\
3 & 82.620 & 22,69 \\
4 & 58.925 & 16,18 \\
5 & 11.350 & 3,11 \\
6 o más & 3.675 & 1,02 \\
\hline
\end{tabular}

Tabla 3.20. Tamaño del hogar en el AMB. INE, 2011. 
Tabla 3.21. Viviendas de la muestra en venta y alquiler con accesibilidad total en el AMB, clasificadas por franja de superficie y tamaño máximo de la unidad de convivencia por encima de la SMP. Elaboración propia a partir de Idealista, 2015. superficie de la vivienda se refiere, a unidades convivenciales formadas por dos, tres o cuatro personas. Aunque con mayor carencia de oferta en el caso de las primeras, un pequeño exceso de oferta para las segundas, y algo más ajustada proporcionalmente en el caso de las terceras.

\begin{tabular}{llll}
\hline \multicolumn{1}{c}{ superficie } & tamaño ud. convivencial & \% venta & \% alquiler \\
\hline$<30 \mathrm{~m}^{2}$ & 1 & 0,05 & 0,05 \\
$30-45 \mathrm{~m}^{2}$ & $1-2$ & 1,53 & 2,80 \\
$46-60 \mathrm{~m}^{2}$ & 2 & 8,80 & 13,37 \\
$61-75 \mathrm{~m}^{2}$ & $2-3$ & 22,18 & 21,91 \\
$76-90 \mathrm{~m}^{2}$ & 3 & 17,56 & 24,95 \\
$91-105 \mathrm{~m}^{2}$ & $3-4$ & 11,25 & 12,84 \\
$106-120 \mathrm{~m}^{2}$ & 4 & 6,29 & 7,77 \\
$121-150 \mathrm{~m}^{2}$ & $4-5$ & 5,07 & 5,79 \\
$151-180 \mathrm{~m}^{2}$ & $5-6$ & 2,17 & 1,79 \\
$181-200 \mathrm{~m}^{2}$ & $6-7$ & 1,44 & 0,39 \\
$201-250 \mathrm{~m}^{2}$ & $7-8$ & 1,87 & 1,69 \\
$251-300 \mathrm{~m}^{2}$ & $8-10$ & 1,23 & 1,11 \\
$301-400 \mathrm{~m}^{2}$ & $10-13$ & 0,76 & 0,87 \\
$401-500 \mathrm{~m}^{2}$ & $13-16$ & 0,35 & 0,05 \\
$501-600 \mathrm{~m}^{2}$ & $16-20$ & 0,13 & 0 \\
$601-700 \mathrm{~m}^{2}$ & $20-23$ & 0,03 & 0,05 \\
$701-800 \mathrm{~m}^{2}$ & $23-26$ & 0,03 & 0,05 \\
$801-900 \mathrm{~m}^{2}$ & $26-30$ & 0,01 & 0,05 \\
$901-1.000 \mathrm{~m}^{2}$ & $30-33$ & 0,02 & 0 \\
$1.001-1.500 \mathrm{~m}^{2}$ & $33-50$ & 0,02 & 0 \\
$>1.500 \mathrm{~m}^{2}$ & $50-\ldots$ & 0,01 & 0 \\
\hline total & & $\mathbf{8 1 , 0 9}$ & $\mathbf{9 5 , 6 1}$ \\
\hline & & & \\
\hline
\end{tabular}

Este cruce de datos, de manera complementaria a lo desarrollado a lo largo del capítulo, viene a reafirmar la estrategia de agrupación propuesta como posible vía, entre otras, para una adecuada puesta en carga de un parque de viviendas infrautilizado como el del caso de estudio. Ya que, por un lado, hace patente la existencia de una carencia de oferta de vivienda adaptada en tamaño, tipología y precio a aquellas unidades de convivencia más pequeñas y con cada vez más peso en la estructura demográfica. Por otro, permite identificar la posibilidad de responder a dicha carencia mediante la intervención, 
transformación y adaptación de un parque fundamentalmente dirigido a unidades de tamaños medianos y mayores, cada vez menos habituales. Es decir, mientras que los resultados de los apartados anteriores muestran que hay potencial y capacidad para adaptar una parte importante del parque según los criterios económicos y espaciales establecidos, esta comprobación final demuestra que también hay una importante necesidad de ello. Se trata de una estrategia que podría favorecer cierto equilibrio en el desfase y la contradicción señalada entre la oferta y la demanda residencial. Aunque muchas serán las unidades de convivencia que podrían encontrar, bajo la situación actual, una vivienda acorde a sus deseos y necesidades, muchas otras que actualmente no lo logran $-\mathrm{u}$ otras con una necesidad no consciente, pero latente de ello-, podrían hacerlo a través de la unión con otras unidades para abordar estrategias de transformación tipológica del mismo bajo unas condiciones económicas que no superen el 30\% de una renta cercana a los $1.400 €$ por persona.

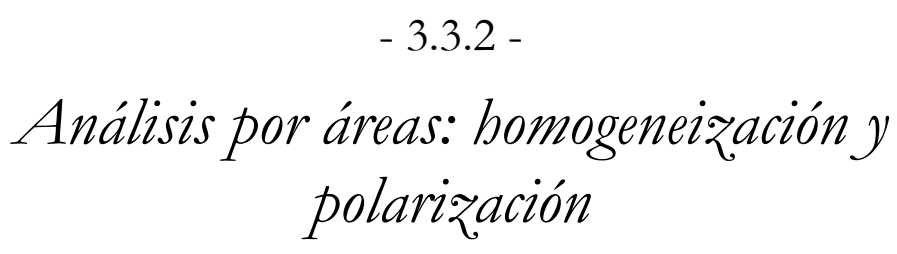

Una vez demostrado el potencial global del parque existente en el $\mathrm{AMB}$, se pretende a continuación ofrecer un análisis similar al anterior, esta vez centrado en las 98 áreas geográficas tomadas como unidad mínima de segregación a partir de la delimitación que hace el portal inmobiliario Idealista, fuente de los datos utilizados. Dado que el objetivo de este apartado se centra en la comparación entre áreas, y que la exacta repetición del mismo estudio hecho a escala global en el apartado 3.3.1 conllevaría el tratamiento y cálculo de una cantidad de datos inasumible para los medios disponibles, el apartado es resultado de un análisis parcial a partir de la accesibilidad económica y la espacial, sin calcular la total. Se cree que el marco presentado para el conjunto de la región ofrece suficiente información como para contextualizar lo que sigue, asumiendo por otro lado que la falta de un estudio detallado de la accesibilidad total en cada área impide conocer con una mayor profundidad el potencial específico en cada una de ellas.

\section{Homogeneización de las condiciones de acceso}

La diversidad de precios entre áreas mostrada al comienzo del capítulo tiene un reflejo geográfico, ya apuntado en los mapas $3.3 \mathrm{y}$ 3.4, que puede ayudar a identificar las zonas con mayor o menor accesibilidad y oportunidades. Se cree por lo tanto conveniente buscar 
Gráficas 3.24 y 3.25.

Accesibilidad económica a la muestra de viviendas en venta y alquiler del AMB de los municipios del Grupo 1 (arriba) y 2 (abajo). Elaboración propia a partir de Idealista, 2015. lógicas y pautas comunes entre algunas de estas áreas para identificar fenómenos concretos; buscar similitudes entre los parques ofertados que permitan abordar sus oportunidades mediante estrategias similares. En cuanto a la accesibilidad económica, se ha visto que aquellas viviendas aptas para agrupaciones de dos o tres rentas de referencia $-1.400 €-$ son las predominantes. Pero por otro lado, y como ya se ha mostrado de manera conjunta en la Gráfica 3.14, la diversidad en las estructuras de precios de las áreas analizadas es importante. Con todo, si se toma dicha gráfica como base y se agrupan las áreas en ella visualizadas por estructuras de precios similares, pueden con cierta claridad observarse cuatro grupos (Gráficas 3.24 a 3.27).
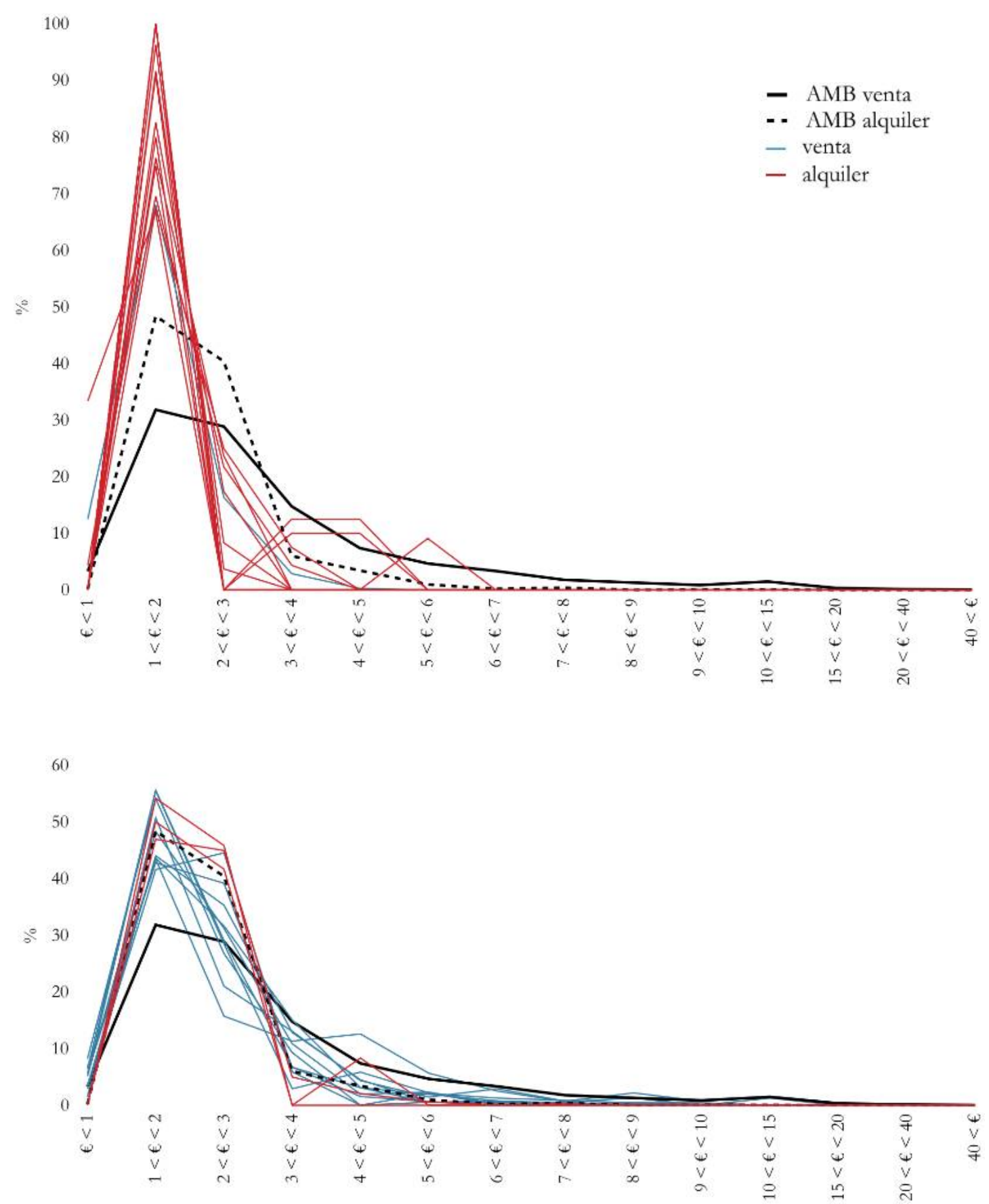

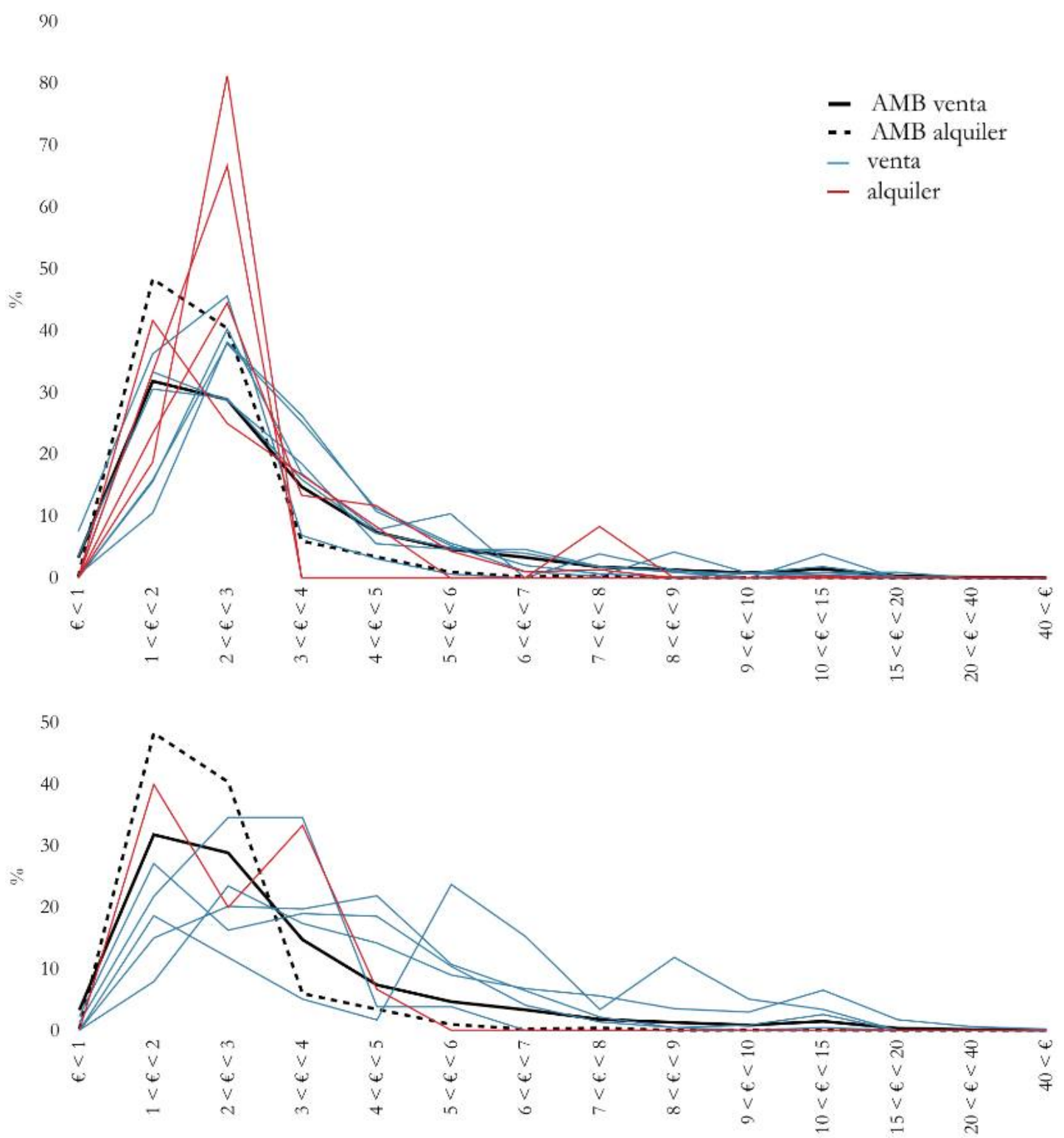

En el primero de ellos, el Grupo 1, predomina claramente la oferta en alquiler, y hay una mayoría de viviendas accesibles económicamente para una o dos personas; entre un $60 \%$ y un $100 \%$ de la muestra. Puntualmente, y de manera más excepcional, se dan casos con porcentajes en torno al $10 \%$ y al $20 \%$ de viviendas que exigen tres, cuatro, cinco y hasta seis rentas de $1.400 €$. Es el caso de las ofertas de alquiler de Abanto-Zierbena, Alonsotegi, Arrigorriaga, Barakaldo, Basauri, Erandio, Galdakao, Larrabetzu, Leioa, Lezama, Muskiz, Ortuella, Portugalete, Santurtzi, Sestao, Trapagaran, Zamudio, Zaratamo y Zierbena, así como la oferta de venta de Sestao (Gráfica 3.24). En el Grupo 2 la oferta de vivienda en venta es ya mayoritaria, y aunque las viviendas aptas para una o dos personas siguen predominando con valores entre el $40 \%$ y el $55 \%$, hay muchas viviendas que necesitan de dos o tres. Es decir, los precios suben. De la misma manera, se dan casos fuera de la norma que exigen
Gráficas 3.26 y 3.27 .

Accesibilidad económica a la muestra de viviendas en venta y alquiler del AMB de los municipios del Grupo 3 (arriba) y 4 (abajo). Elaboración propia a partir de Idealista, 2015. 
- AMB venta

- AMB alquiler

- venta

- alquiler
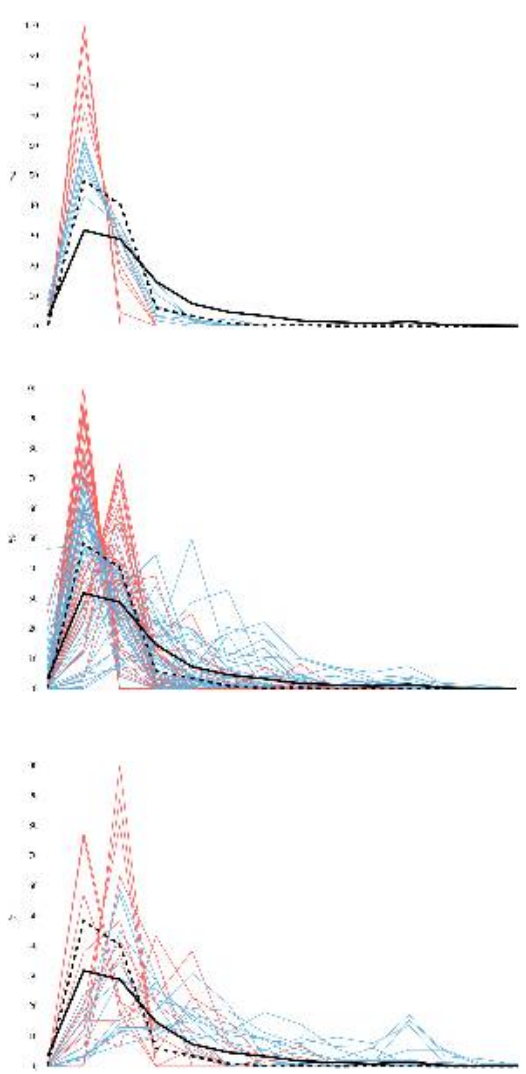

Gráfica 3.28. Accesibilidad económica a la muestra de viviendas en venta y alquiler por áreas inframunicipales de Barakaldo (arriba), Bilbao (centro)

y Getxo (abajo). Elaboración propia a partir de Idealista, 2015. agrupaciones de cuatro y cinco personas bajo las condiciones económicas fijadas, pero difícilmente superan el 10\%. Esta pauta se da en la oferta de alquiler de Bilbao, Sopela y Urduliz, así como en la de venta de Abanto-Zierbena, Alonsotegi, Arrigorriaga, Barakaldo, Basauri, Erandio, Galdakao, Muskiz, Ortuella, Portugalete, Santurtzi, Zaratamo y Zierbena (Gráfica 3.25). El Grupo 3 presenta una presencia similar de ofertas de venta y alquiler. En cuanto a la estructura tipo del mismo, el cambio respecto a las anteriores es claro. Aunque se mantiene un porcentaje relevante de viviendas accesibles para una o dos personas -entre el $10 \%$ y el $40 \%$-, la mayoría necesitan ya de dos o tres. Los casos excepcionales que suponen la necesidad de agrupaciones mayores de rentas medias son cada vez más numerosos, y empezando a darse casos desde cinco, seis, hasta ocho e incluso quince personas. Los municipios que así lo reflejan son Barrika, Berango, Etxebarri y Getxo en cuanto al alquiler, y Bilbao, Larrabetzu, Leioa, Lezama, Sopela, Trapagaran, Urduliz y Zamudio en lo que respecta a la venta (Gráfica 3.26). En cuanto al cuarto y último caso, en el Grupo 4 predomina el régimen de venta, y aunque no deja de haber una alta proporción de viviendas accesibles para una o dos personas, el centro de las gráficas se desplaza claramente hacia viviendas que exigen agrupaciones mayores, y más variadas. No hay un grupo predominante como antes, y los porcentajes son considerables para grupos de entre dos y siete personas. Es el caso de Barrika, Berango, Derio, Etxebarri, Getxo, Loiu y Sondika para la venta y Derio, Loiu y Sondika para el alquiler (Gráfica 3.27).

En aquellos casos en los que la fuente de datos utilizada ofrece datos inframunicipales, se puede realizar el mismo ejercicio. Así, se comprueba si los diversos barrios siguen una estructura de precios similar a la del grupo al que pertenece su municipio o si, por el contrario, algún barrio destaca en uno u otro sentido. Partiendo de la gráfica conjunta de todas las áreas geográficas de cada municipio, es posible agrupar estas en función de su pertenencia a uno de los cuatro grupos previamente definidos. Lo cual permite identificar naturalezas muy diversas de ofertas de vivienda entre los ocho municipios de los que se disponen datos detallados. En algunos de ellos hay una enorme homogeneidad de la accesibilidad económica del parque, con todas sus áreas encajando en los grupos primero y segundo. Es el caso de Barakaldo (Gráfica 3.28-a), Basauri y Sestao, en los que tanto las ofertas en venta como en alquiler de sus barrios reflejan casi a la perfección la misma dinámica del grupo al que pertenece el municipio. Se deduce, por tanto, una cierta homogeneidad en la estructura de precios de su parque residencial. Es decir, con precios bajos y accesibles para unidades de convivencia pequeñas. Otros casos, como Bilbao (Gráica 3.28-b) o Leioa, presentan una cierta heterogeneidad, con sus áreas geográficas repartidas de manera más o menos equilibrada entre los cuatro grupos. Lo cual refleja una importante diversidad y diferenciación entre zonas de la ciudad. En el extremo opuesto a los primeros casos está Getxo (Gráfica 3.28-c), en 
el que la mayoría de sus áreas con información inframunicipal se enmarcan en las pautas de los grupos tercero y cuarto, que es donde se localiza la oferta total del municipio. Lo que indica precios altos con necesidad de agrupaciones de personas grandes. Por último, tanto en Portugalete como en Santurtzi se observan varias alteraciones respecto al grupo global, con áreas que puntualmente presentan una accesibilidad económica que exige mayor tamaño de agrupaciones de personas.

Si se analiza la accesibilidad espacial de las 98 áreas, el predominio de las viviendas aptas para dos o tres personas ya visto esconde igualmente una diversidad adelantada en la gráfica 3.16. Se han encontrado también en este caso cuatro grandes grupos de estructuras de accesibilidad espacial por municipio (Gráficas 3.29 a 3.32). En el Grupo 1 el predominio de las viviendas accesibles para dos y tres personas es claro y, aunque existe oferta tanto de venta como de alquiler, la segunda acumula porcentajes mayores para ese tamaño. También se da una considerable presencia, aunque menor, de aquellas que lo son para una o dos personas; a partir de cuatro o cinco los casos son muy pocos. Esta pauta se da en las ofertas en venta de Barakaldo, Basauri, Portugalete, Santurtzi, Sestao y Trapagaran, y en las de alquiler de Barakaldo, Basauri, Muskiz, Ortuella, Santurtzi y Trapagaran (Gráfica 3.29). En el Grupo 2 empiezan a tomar más presencia viviendas de mayor tamaño, con una mayoría accesibles espacialmente para tres personas, y con un aumento en las que lo son cuatro y cinco personas. Las aptas para dos y tres siguen sin embargo presentando valores considerables. Así ocurre en el caso de la venta en Alonsotegi, Arrigorriaga, Erandio, Galdakao, Leioa, Ortuella y Zaratamo, y en el caso del alquiler en Bilbao, Erandio, Galdakao, Leioa y Sopela (Gráfica 3.30).

En el Grupo 3 la gráfica se extiende hacia los tamaños grandes de vivienda, los porcentajes son más bajos en general y no hay una franja que destaque. Mientras que las aptas por superficie para dos y/o tres personas se mantienen en valores que rondan el 30\% y 40\%, las que lo son para tres y cuatro también alcanzan esos mismos valores. De ahí en adelante la proporción baja, pero con cada vez mayor presencia de viviendas grandes. Tal es el caso de las ofertas de venta de AbantoZierbena, Bilbao, Etxebarri, Larrabetzu, Lezama, Zamudio y Zierbena, y las de alquiler de Alonsotegi, Arrigorriaga, Etxebarri, Portugalete, Sestao, Urduliz y Zaratamo (Gráfica 3.31). Finalmente, en el Grupo 4 la presencia de áreas con oferta de viviendas grandes que permiten agrupaciones de personas de mayor tamaño es ya clara. Aún así, vuelve a no destacar una franja sobre las demás, es una gráfica extendida en la que es posible ver con facilidad áreas en las que en torno al 10\%, incluso por encima del $20 \%$ y $30 \%$ de las viviendas analizadas admiten de cuatro a seis y de siete a trece personas. Con todo, los casos de viviendas admisibles para dos y tres personas siguen alcanzando valores nada despreciables cercanos al $10 \%$ y $20 \%$. Esto ocurre en los municipios de Barrika, Berango,
Gráficas 3.29, 3.30 y 3.31 (página siguiente). Accesibilidad espacial a la muestra de viviendas en venta y alquiler del AMB de los municipios del Grupo 1 (arriba), 2 (centro) y 3 (abajo). Elaboración propia a partir de Idealista, 2015. 
Derio, Getxo, Loiu, Muskiz, Sondika y Urduliz para la venta y Abanto-Zierbena, Barrika, Berango, Derio, Getxo, Larrabetzu, Lezama, Loiu, Sondika, Zamudio y Zierbena (Gráfica 3.32).
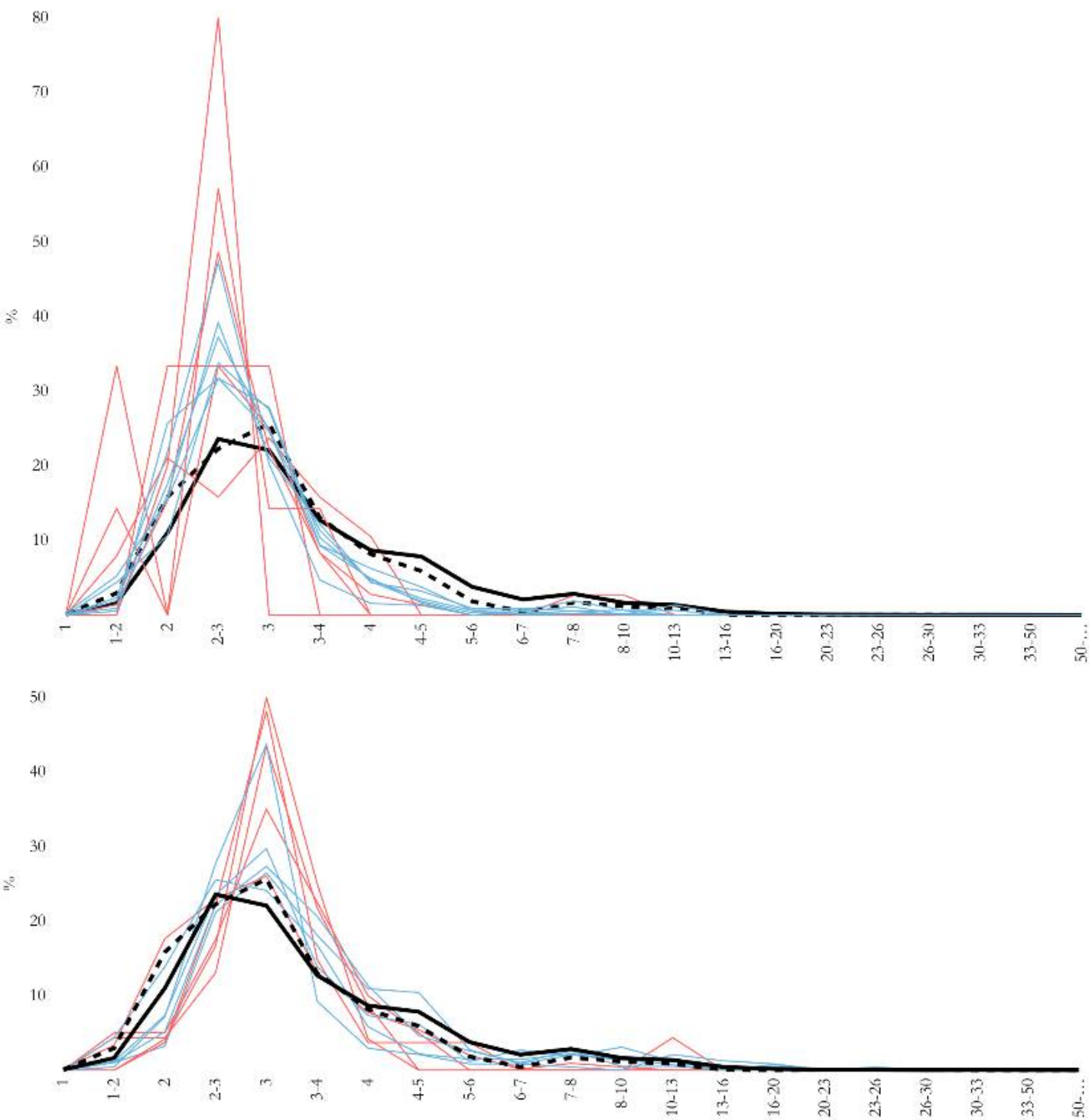

50

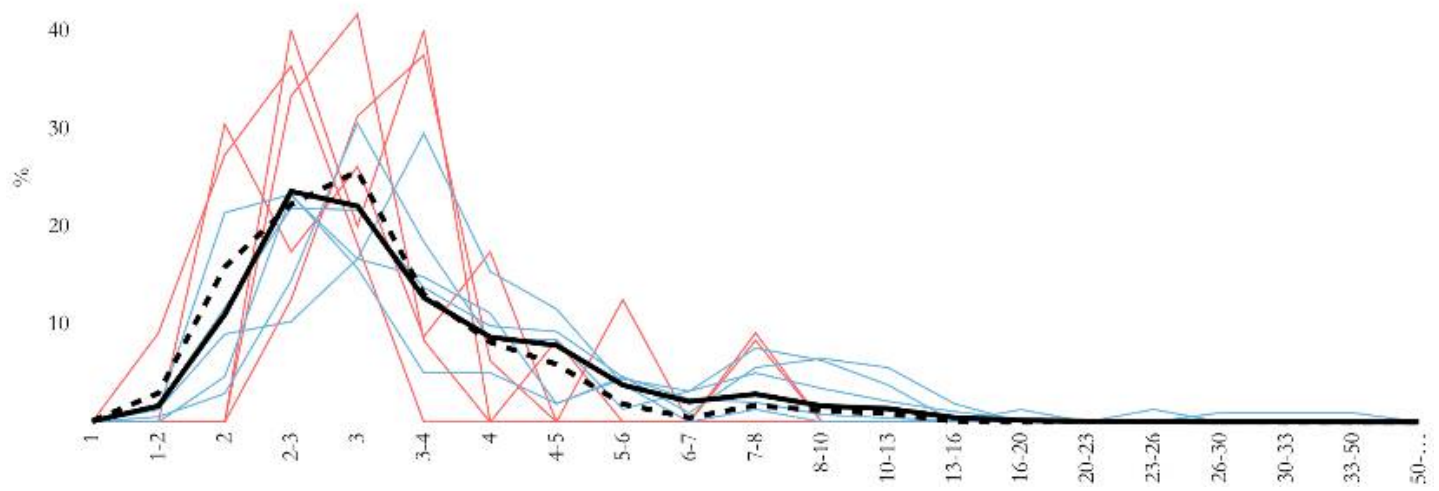




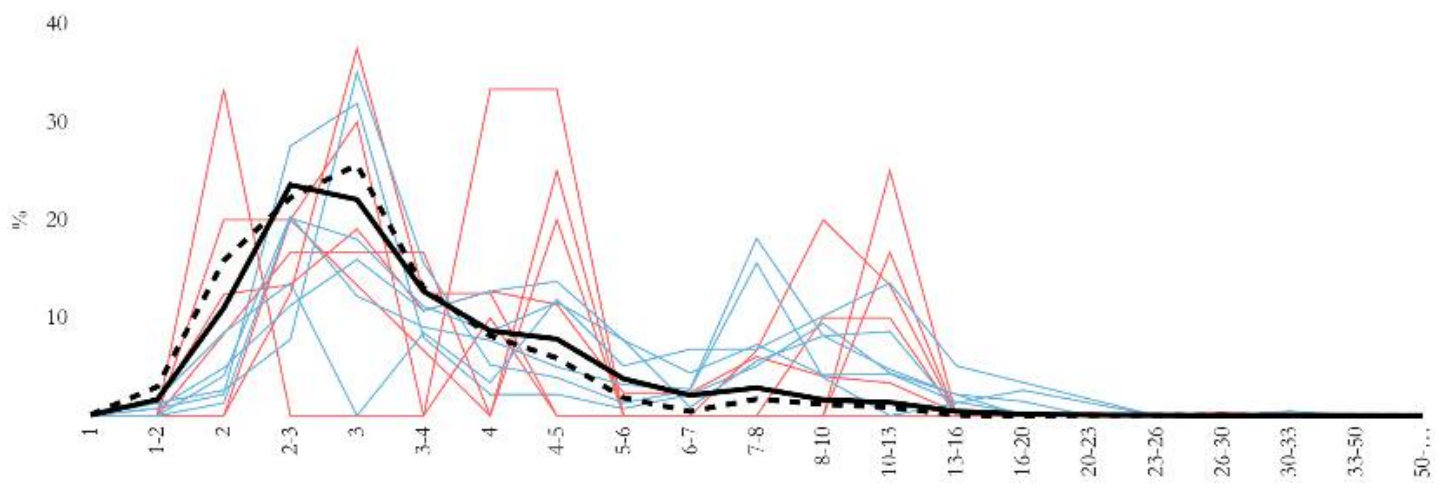

Para la accesibilidad espacial, en los casos en los que hay información inframunicipal, las áreas agrupadas por municipio no muestran pautas similares tan claras como en el caso de la económica, pero sí se ven ciertas dinámicas comunes. En casos como Barakaldo (Gráfica 3.33-a) y Sestao, hay un gran predominio de viviendas de tamaños medios y pequeños, aptos para dos o tres personas, por lo que se da una considerable homogeneidad del parque. En otros, como en Basauri, Santurtzi o Bilbao, aunque se mantiene ese tipo de viviendas y son también mayoría, hay cantidades considerables tanto de viviendas menores como mayores. En Leioa y Portugalete, el centro de la gráfica se desplaza hacia viviendas habitables para tres personas -manteniéndose una presencia relevante de aquellas que lo son para dos o tres-, y aparecen ya casos frecuentes para cuatro y cinco. Con una estructura muy diferente, en Getxo (Gráfica 3.33-b) hay una gran presencia de viviendas de mayor tamaño a lo largo de varias franjas, hasta aquellos casos disponibles para trece personas.

Como se ha planteado al inicio del trabajo, uno de sus objetivos es abordar la situación problemática desde una perspectiva espacial y geográfica. A través de los resultados presentados a lo largo del capítulo se ha podido constatar que se produce un fenómeno a dos escalas. Por un lado, manifestándose a escala global del AMB y reflejado en las gráficas 3.14 y 3.16, se observa que a pesar de que puede identificarse una estructura de precios y tamaños similar en casi todas las áreas analizadas, la superposición de las estructuras de las 98 áreas delata que en apariencia existe una considerable diversidad en ambos indicadores -económico y espacial-. Una lectura parcial de lo anterior podría llevar a afirmar que las características de la oferta de vivienda posibilitan cierta capacidad de decisión de las unidades de convivencia con necesidad de la misma, a la hora de seleccionar localización, precio y tamaño. Sin embargo, como se ha avanzado y se desarrolla a continuación, esa aparente libertad de elección no es tal. La distribución geográfica de dicha diversidad presenta, a una escala inferior a la metropolitana, una homogeneización de las condiciones de acceso, según el área geográfica, que permite que sean clasificadas en grupos similares. Lo cual es el reflejo de una distribución desigual de la población en función de las rentas, y muestra los condicionantes y las limitaciones que ello establece en el acceso residencial.
Gráfica 3.32. Accesibilidad espacial a la muestra de viviendas en venta y alquiler del AMB de los municipios del Grupo 4. Elaboración propia a partir de Idealista, 2015.

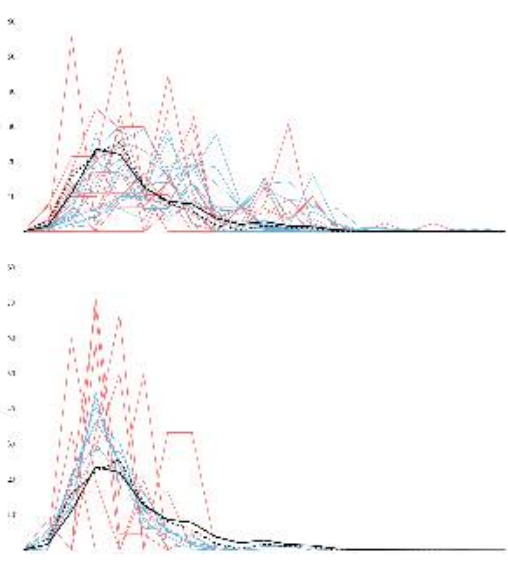

Gráfica 3.33. Accesibilidad espacial a la muestra de viviendas en venta y alquiler por áreas inframunicipales de Barakaldo (arriba) y Getxo (abajo). Elaboración propia a partir de Idealista, 2015. 


\section{Polarización espacial de la distribución geográfica}

Esta segunda escala de análisis, que no es si no otra cara de la primera, permite la identificación de un fenómeno que se percibe si se acerca la mirada a una escala más local y de manera comparada; en algunos casos, será suficiente con abordarlo desde la escala municipal, y en otros, se podrá profundizar hasta una dimensión de barrio o incluso a delimitaciones de ciudad más pequeñas. Se trata de la identificación de ciertas pautas comunes, en lo relativo a las estructuras de accesibilidad económica y espacial, a muchas de las áreas (Gráficas 3.24 a 3.33). Hasta el punto de haber podido clasificarlas en cuatro grupos: es entonces cuando la relativa diversidad global aparente se revela en una polarización espacial del acceso a la vivienda entre las diversas áreas geográficas, a través de la homogeneización de la ciudad residencial dentro de cada una de ellas, tendente a alcanzar un abanico muy reducido de situaciones similares. Lo cual viene a reforzar las tesis de algunos autores que plantean que «la ciudad moderna inmobiliaria consiste realmente en la construcción de espacios homogéneos, y esa construcción implica también la simplificación de los espacios históricos heredados que contenían una complejidad social mayor debido a que la exclusión social no era tan acusada y no utilizaba la renta inmobiliaria como operador en los términos actuales» (Roch, 2003: 127). Es decir, cada «vez hay un proceso mayor de homogeneización de los espacios, que en última instancia nos va a llevar a una mala gestión y convivencia en la ciudad [...] el espacio es muy discriminante desde el punto de vista de cuál es la posición social» (Leal, 2018):

«La tendencia a la desigualdad es una constante a lo largo de la historia de la ciudad y resulta inseparable de ella. De hecho, la desigualdad ha pasado a ser considerada uno de los mayores retos de las áreas urbanas contemporáneas. En los últimos años se ha detectado, además, que esta desigualdad va pareja a una creciente segregación social que unida a la fragmentación funcional (segregación de los usos en la ciudad, hipertrofia de las infraestructuras de movilidad) configura un espacio urbano en creciente simplificación: mosaico de piezas segregadas social y funcionalmente» (González y Gayoso, 2018).

Frente a lo anterior, desde algunas instituciones y posiciones políticas se pretende difundir una imagen de Bilbao, núcleo de esta área metropolitana, como una especie de paradigma de la igualdad social. Con el trasfondo del proyecto 'Bilbao, Ciudad de Valores' puesto en marcha en 2017 como soporte, el alcalde Juan Mari Aburto ha mostrado su intención de «que nos conozcan por nuestros propios valores, por aquellos que nos hacen ser así...por nuestra esencia», incluso afirmando que la ciudad de Bilbao es referente europea en igualdad. Si bien el proyecto plantea un interesante camino por andar mediante el desarrollo de diecisiete valores en la ciudad, carece de una autocrítica al modelo de ciudad neoliberal generadora de 
desigualdades que se mantiene y refuerza desde las propias administraciones públicas ${ }^{75}$. Tal y como viene denunciándose desde diversos colectivos civiles, grupos políticos y esferas académicas, algunos ya citados en el capítulo segundo. Sin ánimo de detenerse en cada área, pero sí de ofrecer una imagen representativa de todo ello, se repasan a continuación algunas de las situaciones más llamativas de una zonificación social que lleva a que se conviva "con sus semejantes... en renta, naturalmente» (Roch, 2009: 179). Para lo cual se parte de una serie de mapas en la que se representa el grupo en el que ha quedado clasificada cada área según el trabajo antes desarrollado y presentado (Mapas 3.9 a 3.12).
Mapas 3.9 a 3.12. Clasificación de las 98 áreas geográficas por grupo de accesibilidad económica (arriba) y espacial (abajo), para la oferta en venta (izquierda) y alquiler (derecha). Elaboración propia a partir de Idealista, 2015.
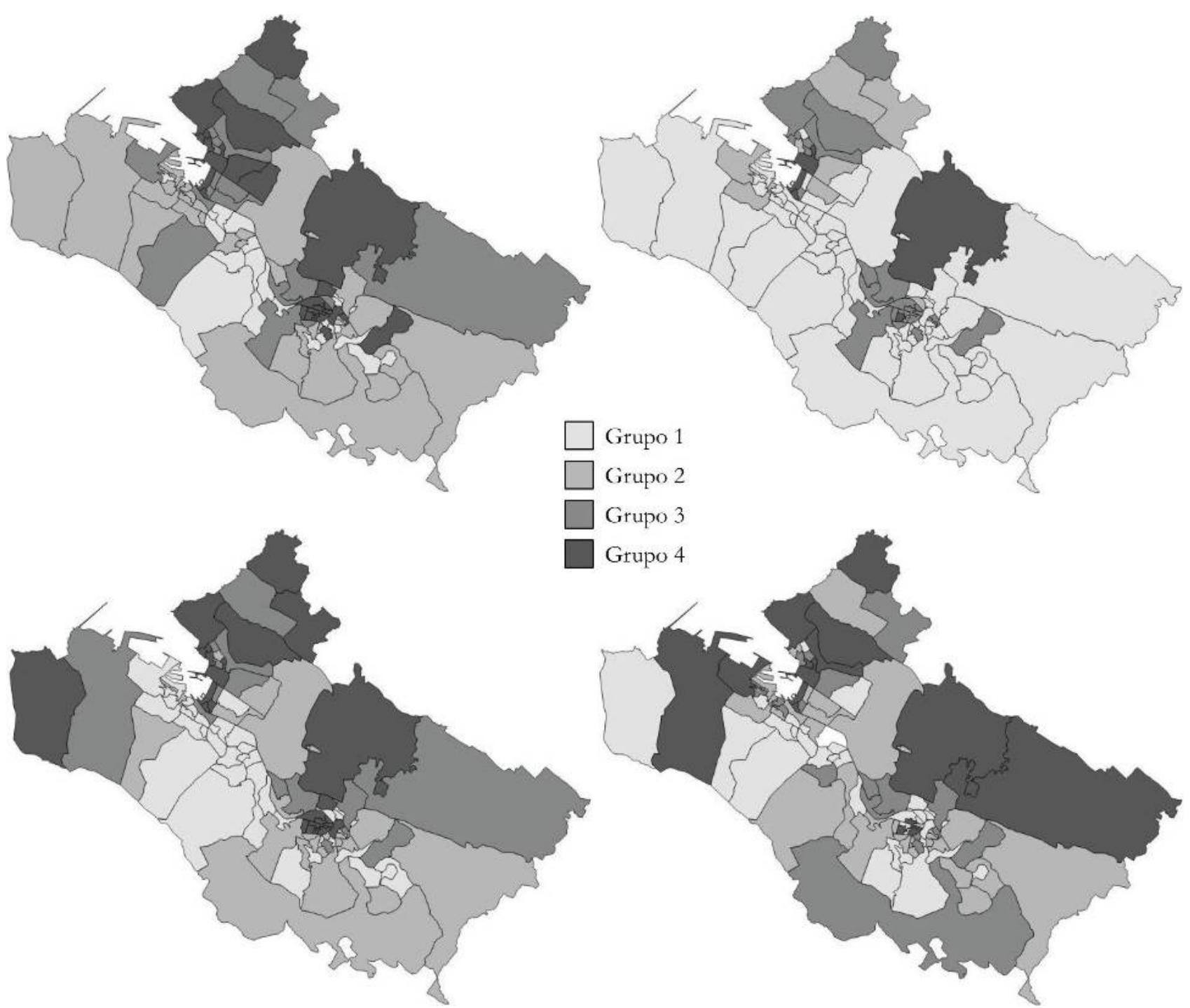

Grupo 3
Grupo 4
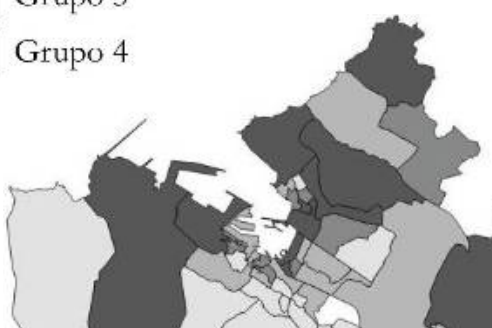

r
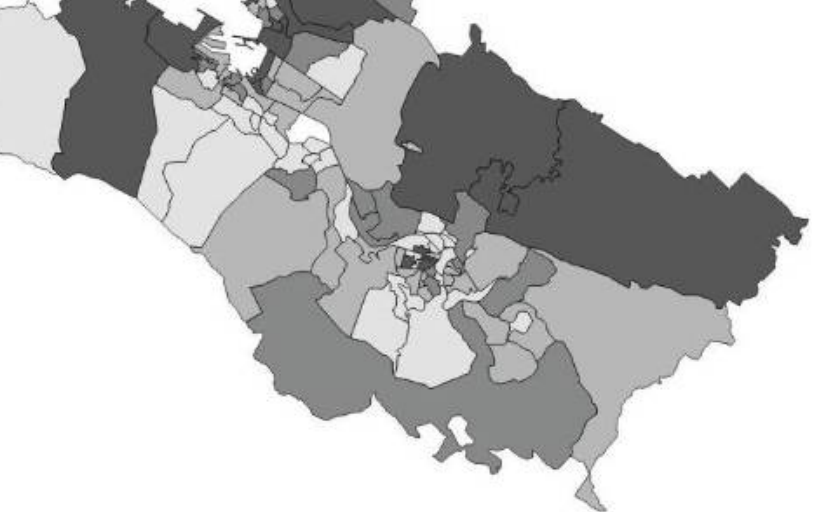

${ }^{75}$ Naiz (2018): «Los pisos turísticos y el alto precio del centro desplazan el alquiler a los barrios de Bilbo», disponible en https://bilbotarra.naiz.eus/eu/info_bilbotarra/20180314/ los-pisos-turisticos-y-el-alto-precio-del-centro-desplazan-las-vivienda-de-alquiler-a-losbarrios-de-bilbo. 
Antes de pasar a una escala de análisis más pequeña, cabe sintetizar la interpretación conjunta de los resultados trasladados a los mapas. En cuanto a la distribución global del acceso a la muestra analizada, poco hay que añadir a lo que se ha interpretado en casos anteriores (Mapas 3.3, 3.4, 3.7 y 3.8). Si se observa la distribución de las áreas del ámbito en función de su clasificación en uno u otro grupo, un análisis del conjunto permite observar que el primero y el segundo tienen en ambos casos -accesibilidad económica y espacial- una mayor presencia en aquellas zonas que históricamente han albergado gran parte de la gran industria e infraestructuras pesadas de la región, tanto a orillas de la ría como en el interior. Las zonas de la Margen Izquierda o el entorno del río Nervión aguas arriba de Bilbao son ejemplos claros de ello. En el lado opuesto, los grupos tercero y cuarto, con precios más altos y viviendas más grandes, se concentran en zonas históricamente reservadas a la ciudad residencial y de servicios, o a los usos rurales, como el centro de Bilbao, parte del valle del Txorierri y sobre todo en los municipios de la Margen Derecha de la desembocadura de la ría, desde Leioa hasta Barrika. Sí se da un cambio en esta pauta en la muestra de vivienda en alquiler. En este caso la diversidad entre áreas en la accesibilidad económica es menor, muchas presentan bajos precios, menos la costa noreste desde Getxo a Barrika, parte de Bilbao y parte del valle del Txorierri, en los municipios de Derio, Loiu y Sondika. No obstante, la baja oferta generalizada en este régimen de tenencia impide obtener lecturas tan representativas como en el caso de la venta.

En cualquier caso, el desigual reparto del parque residencial no se limita a estas diferencias identificadas a escala global del AMB, si no que al profundizar con detalle en los mapas es posible identificar zonas que incluyen áreas colindantes en las que se da, por un lado, una gran homogeneización interna, y por otro, una alta polarización entre ellas. Se pueden entender estas situaciones como el reflejo de los procesos de creciente desigualdad social, en este caso bajo la máscara de la disponibilidad de renta para acceder a la vivienda. Lo cual puede enmarcarse en un «modelo de campo de rentas en mosaico jerarquizado [que] va penetrando lentamente las viejas estructuras históricas de las ciudades, en un proceso de depuración y de elitización que terminará por suprimir los últimos reductos de biodiversidad y de complejidad, el último refugio de lo urbano» (Roch, 2003: 129). Con ánimo de demostrar que en el AMB se produce tal fenómeno y de que, como Roch defiende, se trata de una relación estructural y fundamental entre los precios del mercado inmobiliario residencial y la producción del espacio social (Roch, 2009: 183), se presentan a continuación cuatro breves ejemplos en los que se han identificado dichas situaciones. Probablemente, uno de los más evidentes y más fuertemente fijados en el imaginario colectivo es la desigualdad que el desarrollo del AMB, a partir de la industrialización, generó entre las dos márgenes de la desembocadura de la ría. Como ya se ha avanzado, la estratégica localización desde finales del siglo XIX y a lo largo del XX de las principales actividades 
e infraestructuras industriales y portuarias en base a criterios de rendimiento económico, marcó todo el desarrollo urbano y territorial posterior. Así, la Margen Izquierda pasó a albergar los primeros centros de transformación del mineral extraído en las cercanas minas, o las infraestructuras necesarias para el transporte del mismo. Con el tiempo, también fue lugar de implantación de grandes industrias siderúrgicas, astilleros, desarrollo y ampliación del puerto de mercancías, o grandes infraestructuras de transporte o servicios auxiliares de los usos urbanos -estaciones depuradoras, vertederos,...-. Muchas de estas actividades perduran hoy en día. Consecuentemente, como se ha señalado, gran parte de la ciudad residencial allí desarrollada, en un entorno poco agradable, y cercano a los centros de trabajo, ha estado dirigida a una población obrera de rentas medias y bajas, en buena parte procedente de otras comunidades autónomas del estado a lo largo de diversos procesos migratorios del siglo pasado.

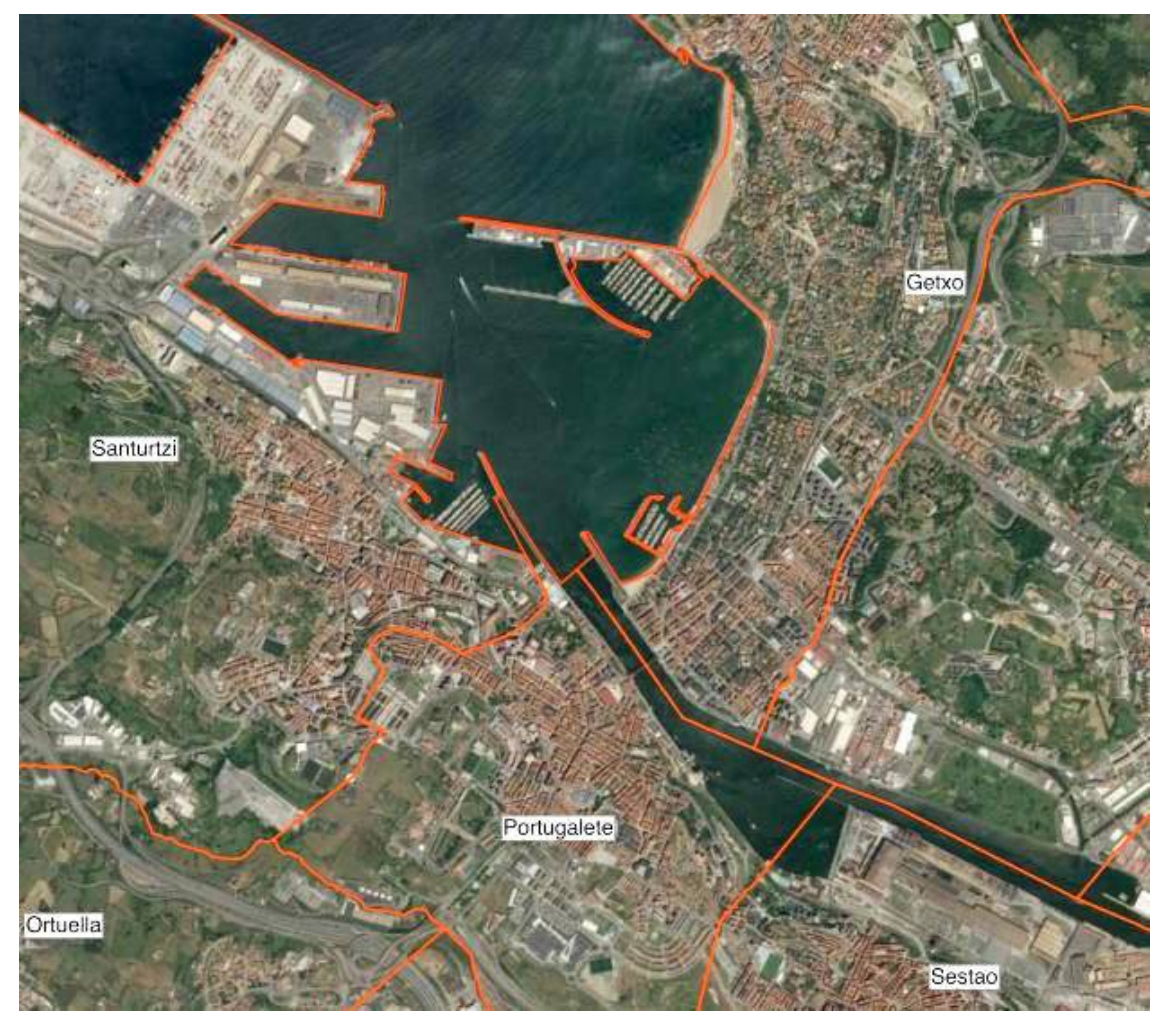

Paralelamente a lo anterior, la Margen Derecha vivió un desarrollo urbano muy marcado por el establecimiento -temporal o permanente- de una población con rentas altas. Entre las que se encontraba gran parte de la clase dirigente de las grandes industrias funcionando en el AMB, así como de las entidades de un sector financiero y comercial en crecimiento, e incluso ciertas figuras de la nobleza española. La expansión de la mancha urbana en este lado ha sido principalmente residencial -con ciertas zonas bajo un modelo
Imagen 3.1. Vista parcial de la desembocadura de la ría del Ibaizabal. Elaboración propia a parir de Bing Maps. 


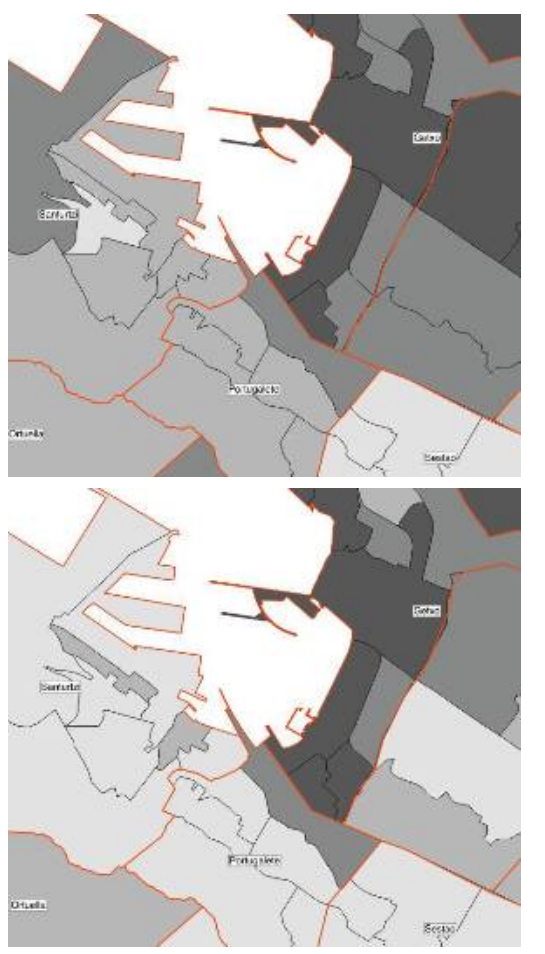

Mapas 3.13 y 3.14.

Accesibilidad económica (arriba) y espacial (abajo) a la oferta en venta de las áreas espaciales en la desembocadura de la ría del

Ibaizabal. Elaboración propia a partir de Idealista, 2015.
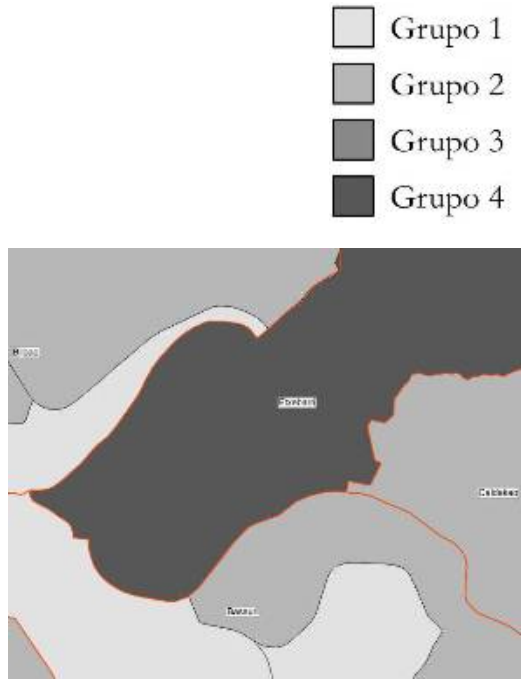

Mapa 3.15. Vista parcial de la accesibilidad económica a la oferta en venta de las áreas geográficas de los municipios de Etxebarri,

Basauri y barrio de Bolueta en

Bilbao, correspondiente a las imágenes 3.2 y 3.3. Elaboración propia a partir de Idealista, 2015. segregador y elitista mediante complejos de urbanizaciones privadas-, dotacional y de servicios. Por supuesto, en ambas márgenes hay cierta diversidad y pueden encontrarse ejemplos propios de la contraria, pero en líneas generales el desequilibrio del reparto espacial de usos del suelo ha sido evidente. Hoy en día, las diferencias entre ambas zonas se mantienen en gran medida identificables. Y así lo confirman los resultados obtenidos en el análisis de la oferta de vivienda en venta, en lo que a la polarización de la accesibilidad económica y espacial a la misma se refiere. El parque residencial del barrio de Las Arenas, en Getxo, mantiene todavía las características de una ciudad residencial de rentas altas y muy altas. Al otro lado de la ría, municipios como Santurtzi o especialmente Sestao, son testigos de la permanencia de las grandes industrias e infraestructuras que invadieron la ciudad y el territorio (Imagen 3.1). Analizados los resultados de la accesibilidad económica y espacial a la oferta en venta de la muestra trabajada, puede apreciarse que las áreas señaladas de la Margen Derecha pertenecen al grupo cuarto en ambos indicadores, mientras que en las de la izquierda predominan el primero y el segundo (Mapas 3.13 y 3.14). Se dan algunas salvedades como el frente del muelle y parte del casco antiguo de Portugalete, con valores dentro del tercer grupo, reflejo y herencia de haber sido la residencia de un sector de población con un importante pasado comercial y naviero.

El segundo ejemplo se da también en torno al río, pero ya aguas arriba de la capital. En este caso, se trata de una zona en la que, aunque con un pasado feudal y rural de relevancia, no se dan las diferencias históricas del caso anterior. Todas ellas presentaban en 2010 rentas medias por debajo de la media autonómica (Eustat, 2010), y la industria y las actividades económicas monopolizadoras del suelo han tenido y tienen un peso territorial enorme en toda la zona. Desde el barrio de Bolueta en Bilbao, pasando por los municipios de Etxebarri, Basauri y continuando tanto hacia Galdakao como hacia Arrigorriaga y Zaratamo, existe un corredor formado por polígonos industriales, pabellones, grandes fábricas, talleres y otros usos como infraestructuras de comunicación o grandes equipamientos regionales, que han condicionado el desarrollo de la ciudad residencial. Sin embargo, los resultados muestran que mientras Etxebarri tiene una accesibilidad económica a la oferta de venta propia del grupo cuatro, con precios altos que exigen agrupaciones de personas más grandes, Basauri y el barrio de Bolueta representan con claridad estructuras de precios de venta del primer grupo (Mapa 3.15). Esta diferencia posiblemente se deba, entre otras cosas, a las diferentes características y evoluciones de sus correspondientes parques de viviendas. El principal núcleo urbano, Basauri, está limitado geográficamente por el monte Malmasín al oeste, y desde hace varias décadas por elementos territoriales de gran consideración como grandes industrias -Sidenor con más de 50 hectáreas de suelo ocupadas o ArcelorMittal con más de 36-, o infraestructuras y equipamientos como la autopista A8 o Mercabilbao. Sin facilidades para la expansión urbana, ha mantenido 
en gran parte un parque residencial envejecido y con pocas operaciones de renovación y crecimiento. Un 80\% del mismo está construido entre 1950 y 1980 según el último censo de viviendas del INE, mientras que aquellas construidas de 1990 en adelante apenas alcanzaban el 10\%. Sin embargo, en Etxebarri se llegó a la década de 1990 con una relativa cantidad de suelo destinado a uso rural y una localización relativamente central (Imagen 3.2). Lo cual ha permitido que el censo de 2011 arrojase un porcentaje de viviendas edificadas a partir de 1990 del 57\% -un 29\% se hicieron entre 1950 y 1980-. Así, en las últimas dos décadas Etxebarri ha llevado a cabo un desarrollo residencial importante (Imagen 3.3) apoyado en gran medida en los avances de las infraestructuras de movilidad de la región. Con una entrada de población de otros municipios y -sobre todo- con otros perfiles demográficos, este desarrollo es probablemente parte de un proceso que ha permitido la ampliación y evolución de un parque hacia precios más altos que los de su entorno inmediato:

«Como consecuencia de la nueva expansión urbanística y de la movilidad residencial en torno a Bilbao, se observó un nuevo repunte en los 90. En torno al año 2000 y especialmente, desde su entrada en el mapa del metro en 2004, no ha dejado de crecer gracias a la llegada de parejas jóvenes atraídas por la tranquilidad de un lugar que está cerca de Bilbao. El crecimiento de su población en la última década alcanza prácticamente el 40\%» (Ayuntamiento de Etxebarri, 2018).

Pero si en los dos primeros ejemplos se ha mostrado una polarización residencial entre áreas pertenecientes a municipios diferentes, en los dos segundos se presentan casos de desigualdad y cercanía dentro de un mismo municipio. Para el primero de ellos, se vuelve al municipio de Getxo, ya comentado en el caso de las márgenes de la ría, y se analiza la accesibilidad económica a la oferta en alquiler. Una vez más, parte de este ejemplo lo conforma el barrio de Las Arenas. Es, como se ha dicho y junto con el de Neguri-que linda con el primero por el noreste-, una zona que tradicionalmente ha albergado a población de rentas muy altas. Con la consecuente presencia de un parque residencial en el que predominan las grandes viviendas de cierta calidad constructiva, muchas de ellas bajo una tipología unifamiliar. En clara contraposición, el barrio de Romo, apenas separado de los anteriores por el cauce de un pequeño río, el Gobela, es una zona residencial con un marcado carácter obrero y con predominio de rentas bajas. Desde su origen albergó pequeñas fábricas y talleres, así como viviendas para sus trabajadores, empleados ferroviarios e incluso todavía entre sus calles hay un bien conservado ejemplo de 'casas baratas'. La construcción del ferrocarril que unía esta parte de la región con Bilbao se hizo en paralelo al cauce del Gobela, lo que contribuyó a fortalecer la barrera física del río, asentando y rematando una existente barrera social (Imagen 3.4).

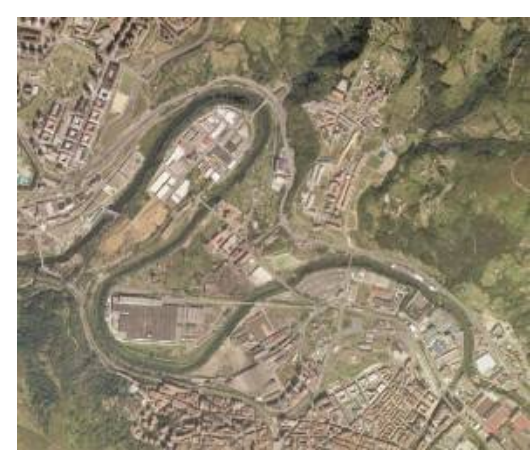

Imagen 3.2. Vista parcial de los municipios de Etxebarri, Basauri y barrio de Bolueta en Bilbao en 2001. En la zona formada por el meandro central se pueden apreciar los suelos agrícolas. Gobierno Vasco.

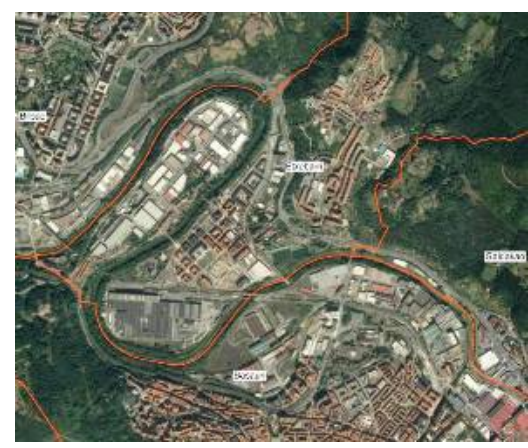

Imagen 3.3. Vista parcial de los municipios de Etxebarri, Basauri y barrio de Bolueta en Bilbao en 2017. El meandro central ha sido urbanizado y edificado.

Elaboración propia a partir de Bing Maps. 
Imagen 3.4. Vista parcial de los barrios de Las Arenas, Neguri y Romo, en Getxo. Elaboración propia a partir de Bing Maps e Idealista.

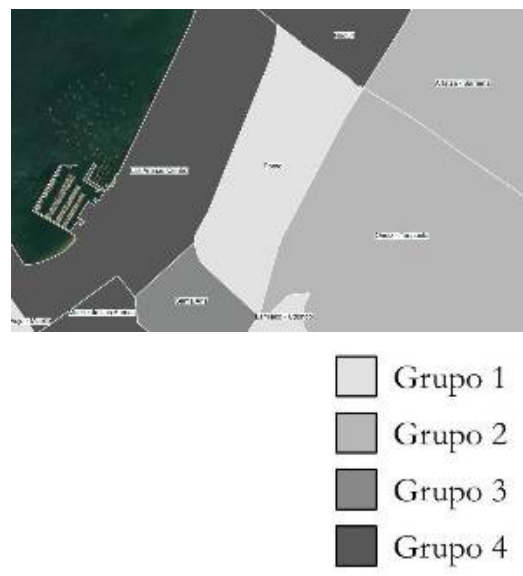

Mapa 3.16. Accesibilidad económica a la oferta en alquiler en los barrios de Las Arenas, Neguri y Romo, en Getxo. Elaboración propia a partir de Idealista, 2015.

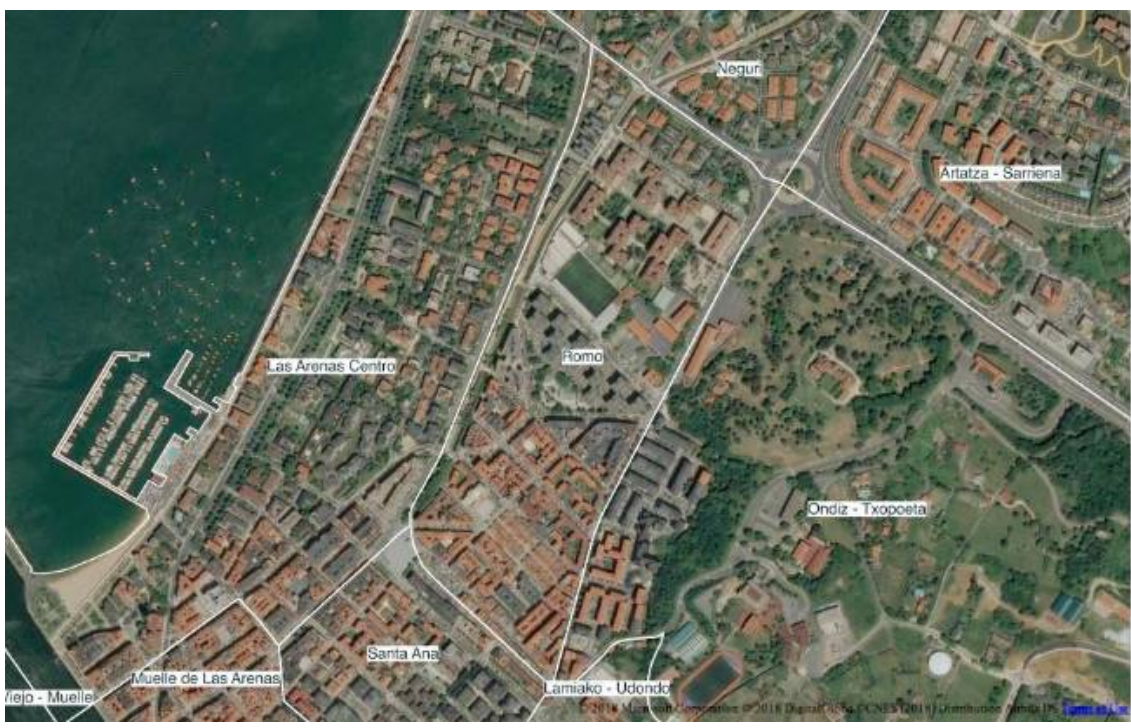

Ambos barrios cuentan con un extendido y fuerte sentimiento de pertenencia. Existen, aunque con muy diferente forma $y$ pertenecientes a esfera sociales opuestas, importante lazos de identidad entre su población. En Romo el tejido asociativo y vecinal ha sido y es muy importante, parte construido en torno al principal centro religioso del barrio. En Las Arenas y Neguri, existen otros espacios de socialización y formación de comunidad, como son el histórico club social dedicado principalmente a las actividades náuticas, o los lazos empresariales y familiares. Como reflejo de todo ello, los mapas obtenidos en este trabajo muestran una alta polarización entre Romo y los otros dos barrios colindantes. Especialmente extrema en el caso de la accesibilidad económica a la oferta en alquiler (Mapa 3.16). Mientras que el primero presenta una estructura de precios dentro del primer grupo, con un rango adecuado para unidades de convivencia pequeñas con una renta media personal de $1.400 €$, los otros dos se enmarcan en el cuarto grupo, con precios altos que precisan de agrupaciones de varias unidades de convivencia con idéntica renta para acceder a la oferta bajo un PMT.

Por último, y también dentro de un mismo municipio, en Bilbao se dan varias situaciones similares en las que coexisten con una gran cercanía espacial áreas urbanas con estructuras de precios y tamaños de vivienda opuestas. Síntoma de la falta de cohesión social de su población. Una de ellas es la existente entre la parte sureste del Ensanche y el barrio de San Francisco. El primero es parte de la principal extensión de la ciudad desarrollada entre finales del siglo XIX y principios del XX bajo una típica trama de manzanas ordenadas. Expansión que fue principalmente ocupada por la burguesía de la ciudad, y que hoy sigue siendo una de las zonas de acumulación de mayores rentas de la misma. Al otro lado de las vías del ferrocarril -una vez más-, el barrio de San Francisco alberga una población muy diferente. Originado como arrabal del Casco Viejo en torno al convento de su mismo nombre, el barrio creció y se 
desarrolló hasta los límites definidos por la ría al norte y las minas de Miribilla al sur. Aunque albergó parte de una burguesía de clase media, históricamente su población se ha caracterizado por el predominio de una clase trabajadora de rentas bajas y por ser uno de los destinos de acogida de colectivos migrantes. Hoy en día es uno de los barrios con mayor diversidad de nacionalidades, y sigue albergando a una población de rentas predominantemente bajas. Aunque dicha situación convive, dese hace años, con un proceso de regeneración urbana que está, entre otras cosas, incorporando al tejido social población de rentas más altas que está accediendo a un parque residencial deteriorado y de precios asequibles, mediante intervenciones de reforma y rehabilitación en las viviendas. Lo cual, en paralelo, está también generando ciertas pautas identificables con fenómenos de gentrificación urbana y expulsión de residentes. A estas dos diferentes realidades se suma una cuestión morfológica fundamental. La entrada del ferrocarril a Bilbao divide ambos barrios con una extensa playa de vías y edificaciones auxiliares limitando a un solo punto la comunicación peatonal y rodada entre uno y otro lado (Imagen 3.5).

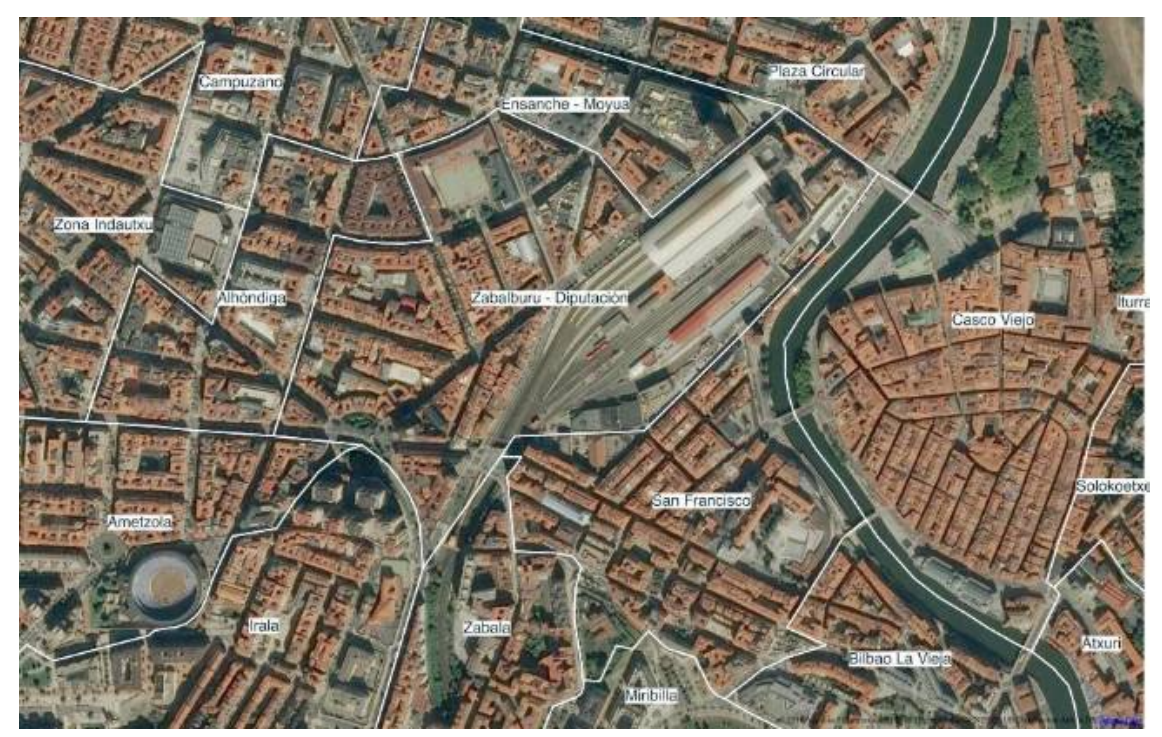

Esta cuestión dificulta en gran medida la cohesión de dos poblaciones diversas habitando dos tipos de ciudad muy diferentes. Si bien es cierto que esta parte del Ensanche alberga cierta mezcla social, lejos de la mayor homogeneidad existente en el resto del mismo. Así, la accesibilidad económica y espacial obtenidas para esta zona muestran una gran polarización en ambos indicadores, como claro reflejo de la desigualdad entre barrios, y la homogeneización interna en cada uno de ellos (Mapas 3.17, 3.18 y 3.19). Se trata de un buen ejemplo de «la convergencia de una morfología urbana y una morfología social a través de una imagen socialmente elaborada sobre patrones monetarios» (Roch Peña, 2009:191).
Imagen 3.5. Vista de la zona sureste del Ensanche y el barrio de San Francisco, en Bilbao. Elaboración propia a partir de Bing Maps e Idealista. 

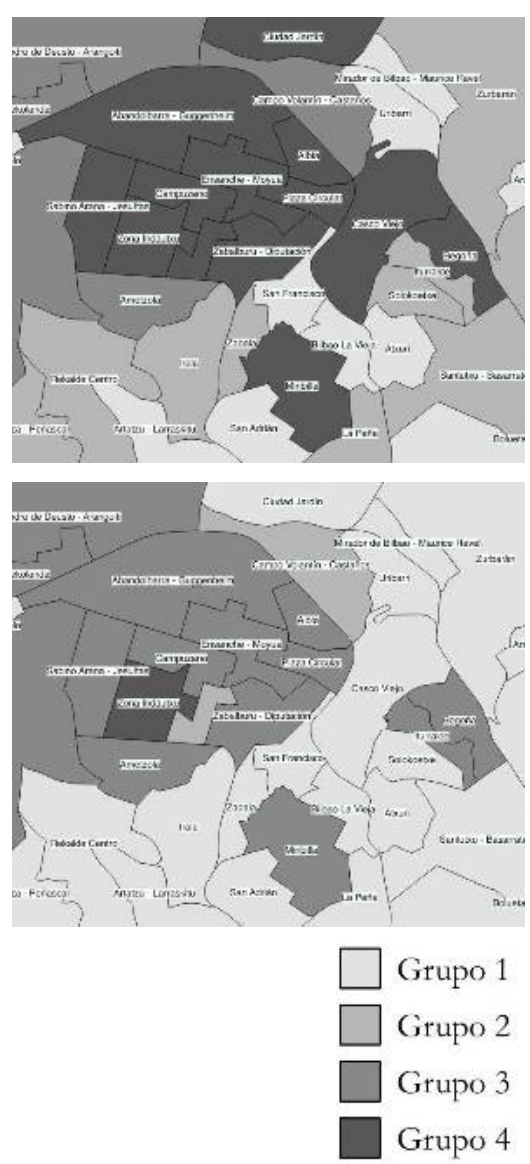

Mapas 3.17 y 3.18. Vista parcial de la accesibilidad económica a la oferta en venta

(arriba) y alquiler (abajo) de

Bilbao. Elaboración propia a partir de Idealista, 2015.

Imagen 3.6. Evolución del barrio de Miribilla en Bilbao, desde su origen como punto de extracción de mineral en abandono (1991), pasando por su urbanización (2002) y su estado completado (2017). Gobierno Vasco.
La segunda situación de polarización socio espacial identificada en Bilbao, en lo que al acceso a la vivienda respecta, es la existente entre el barrio de Miribilla y sus alrededores. Se trata de un barrio residencial de nueva construcción desarrollado en el antiguo emplazamiento de una zona de extracción de mineral. Ha sido una de las últimas expansiones urbanas de cierta escala en Bilbao, y se caracteriza por haber acogido a una población principalmente formada por familias relativamente jóvenes con hijos e hijas de corta edad, tanto de Bilbao como de otros municipios. Las características de su parque residencial difieren en gran medida de las de sus barrios colindantes. Una tipología de manzana edificada a lo largo de las últimas dos décadas que contrasta con barrios como el ya mencionado San Francisco y la prolongación de este en Bilbao La Vieja, al norte, Zabala al oeste, y San Adrián y La peña al sur. Todos ellos con un parque considerablemente más viejo y de peor calidad constructiva, generado en otra época y bajo otros criterios. Como resultado, Miribilla aparece como una isla de precios tanto para la venta como para el alquiler, con una accesibilidad económica necesitada de agrupaciones de personas mayores que las áreas espaciales cercanas (parte inferior de los Mapas 3.17 y 3.18). Una vez más, estos indicadores hacen referencia a una diferente capacidad de acumulación de rentas entre las poblaciones de estos barrios. De tal manera, que la limitación de su capacidad económica -en el caso de los pertenecientes a áreas de los grupos primero y segundo-, o la falta de una oferta de igual o superior calidad en el caso del área de Miribilla -que pertenece al grupo cuarto o tercero, según el régimen de tenencia-, dificulta la movilidad y la mezcla de estas personas. En este caso, el origen de esta polarización está probablemente en una gran operación de remodelación urbano-territorial que ha introducido en un 'vacío' de la ciudad existente una ciudad residencial considerablemente homogénea y a la vez diversa respecto a su contexto social y edificado inmediato (Imagen 3.6). Es decir, fortaleciendo mediante estos procesos de homogeneización del parque la polarización socio-espacial.

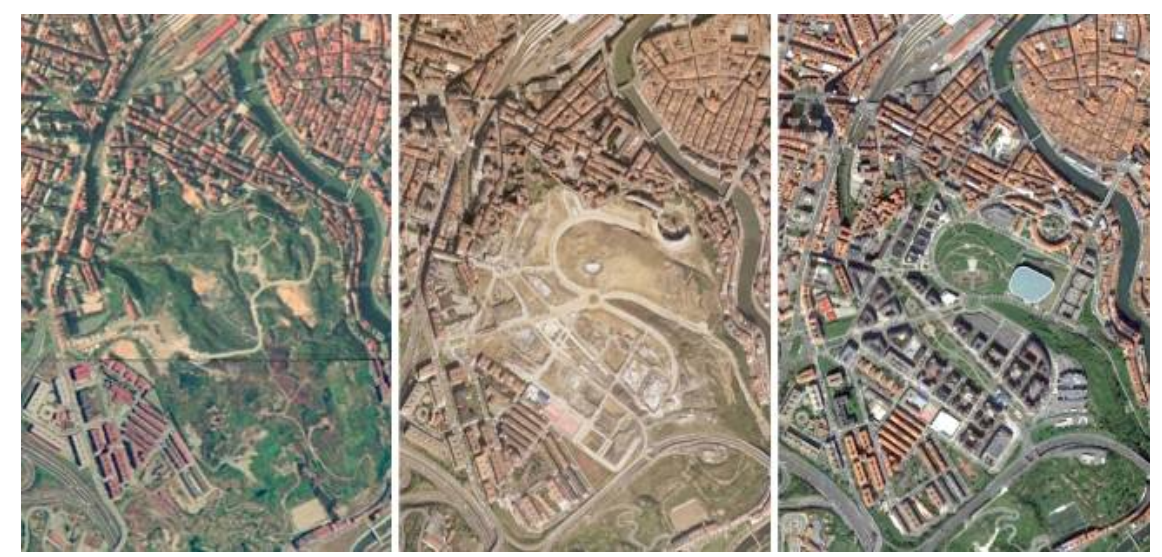


Este tipo de situaciones de desigualdad son habituales, y en el mismo Bilbao pueden identificarse con facilidad otros casos, como el del barrio de Begoña para la accesibilidad económica, con características del grupo cuarto rodeado de áreas del segundo en el caso de la venta, y del tercero rodeado del primero en el alquiler (Mapas 3.17 y 3.18). Igualmente ocurre en el barrio de Ciudad Jardín en lo que respecta a la oferta en venta; tanto en la accesibilidad económica como en la espacial este barrio destaca con precios y superficies que exigen un número mayor de personas para un acceso total digno, frente a las necesarias en el colindante barrio de Uribarri (Mapas 3.17 y 3.19). Es de señalar que en este último caso, y otros como el propio Ensanche o el Casco Viejo, se dan valores muy diversos al comparar los resultados obtenidos dentro del propio área para la venta y el alquiler. En la Ciudad Jardín y el Casco Viejo, la accesibilidad -económica y espacial- a la oferta en venta presenta una estructura de precios propia del grupo cuarto, mientras que la correspondiente al alquiler encaja en el primer grupo (Mapas 3.17 a 3.20). Es decir, parece que son zonas con un parque menos homogéneo y que ofrece en régimen de alquiler de viviendas de menor tamaño a menor precio. Sin embargo, en el caso del Ensanche, mientras las diferencias en la accesibilidad económica son leves, en la espacial sí se presentan, sobre todo en su zona norte (Mapas 3.19 y 3.20). Esto puede indicar que mientras la oferta en venta ofrece viviendas grandes a precios altos, la oferta de alquiler ofrece pequeñas a precios altos. Lo cual, como se verá en el siguiente apartado, tendrá directas consecuencias en la potencialidad de dicha oferta de cara a la estrategia de acceso por agrupación planteada en este trabajo. Todas estas diferencias socio-espaciales aquí parcialmente reflejadas, se pueden entender como un reflejo sectorial -en este caso a partir de datos de acceso a la vivienda- de un fenómeno mayor: la dimensión geográfica y espacial de la desigualdad como uno de los principales retos actuales que, además de transversal a la condición urbana, es cambiante:

«Los patrones resultantes de polarización centro-periferia y de desigualdad socio-espacial se reproducen en todas las escalas; sus contornos nunca se inscriben "para siempre" en cierto paisaje geográfico sino que se rehacen permanentemente a través de la dinámica del desarrollo desigual del capital (Harvey, 1982; Massey, 1985)» (Brenner et al., 2015: 219).

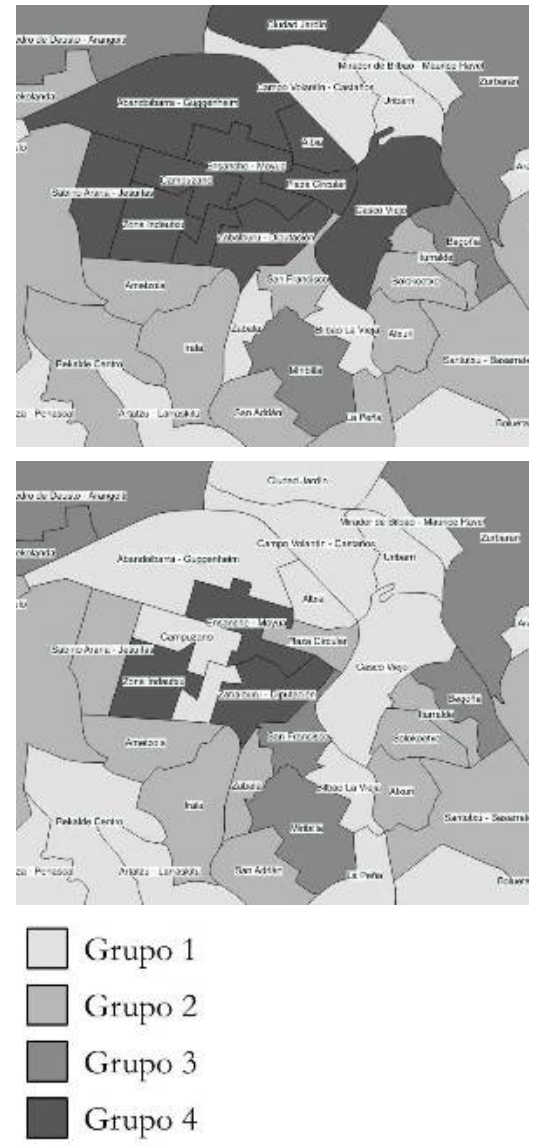

Mapas 3.19 y 3.20. Vista parcial de la accesibilidad espacial a la oferta en venta (arriba) y alquiler (abajo) de Bilbao. Elaboración propia a partir de Idealista, 2015. 


\section{- 3.3.3 - \\ Territorialización del potencial}

\section{Identificación y distribución de oportunidades}

Todas estas lecturas sobre la diversidad, la homogeneización y la polarización, si se hacen desde un análisis exclusivamente limitado a los precios o a las superficies disponibles, pueden ayudar a comprender algunos de los fenómenos socio-espaciales que están detrás, pero no permitirían comprender las potencialidades que también esconden. Si se observan por separado los mapas relativos a los cuatro grupos identificados para cada accesibilidad (Mapas 3.9 a 3.12), la lectura es parcial y no permite identificar oportunidades. La clasificación de cada área geográfica según los diferentes tamaños de agrupación de personas necesarios para el acceso total a la vivienda bajo los criterios definidos en el trabajo -que es en definitiva y a grandes rasgos lo que diferencia a cada grupo-, podría llevar a planteamientos erróneos si se deja una de las dos variables fuera económica o espacial-. Sin embargo, como se ha apuntado al final del apartado anterior, de una lectura cruzada se puede desprender cuáles de esas áreas presentan situaciones más o menos favorables para albergar casos de accesibilidad total bajo una estrategia de agrupación de personas para la transformación y adaptación del parque a sus necesidades económicas y espaciales.

Para facilitar precisamente esa empresa, y a pesar de no profundizar con el detalle que se ha hecho para el conjunto del AMB, a partir de los resultados recién expuestos se ha realizado una lectura de la accesibilidad total de cada área geográfica. Mediante un análisis cruzado de los grupos a los que estas pertenecen en cada indicador de accesibilidad, se ha estimado si las características de la oferta residencial analizada favorecen o no el acceso, y de qué manera, teniendo en mente la estrategia de agrupación de personas planteada. Se ha de advertir que al poner en paralelo los cuatro grupos identificados en ambas variables se observa que, en general, en cada emparejamiento de grupo -el primero de la accesibilidad económica con el primero de la espacial, y así sucesivamente- la accesibilidad económica exige un número de personas para el acceso por debajo del PMT inferior al número máximo de personas que pueden ocupar cumpliendo la SMP. Es decir que, por ejemplo, un área en la que predominase el segundo grupo en la accesibilidad económica y el primero en la espacial presentaría una situación favorable para el acceso total. Dicho esto, el cruce de los resultados en cada área se enmarca en una de tres posibilidades:

- Acc. Económica < Acc. Espacial: aquellos casos en los que coexisten la posibilidad de agrupaciones pequeñas en la accesibilidad económica con la posibilidad de albergar agrupaciones mayores en la espacial; precios pequeños con 
viviendas grandes. Se trata de una situación ideal que permitiría un acceso más barato al poder albergar a más gente -hacen falta menos personas para pagar que las máximas que puede albergar en condiciones dignas-, un acceso a más superficie con un gasto dentro del límite del PMT, o incluir a personas sin capacidad de pago en las unidades de convivencia.

- Acc. Económica $\approx$ Acc. Espacial: situaciones en las que en ambos tipos de accesibilidad el tamaño de la agrupación de personas predominante marcados por los indicadores es similar; precios pequeños, pero viviendas pequeñas o precios altos, pero viviendas grandes. Aunque algo más ajustada, en principio se trataría de una situación también favorable, con una oferta cuya ocupación espacial máxima permitiría alojar al número de personas con capacidad de pago necesarias para el acceso económico digno a la misma.

- Acc. Económica > Acc. Espacial: situación inversa que la primera, se trata del supuesto en que el tamaño de las agrupaciones exigidas por los precios en la accesibilidad económica fuese mayor que el condicionado por la ocupación máxima por encima de la SMP; precios altos con viviendas pequeñas. Se trataría de una situación desfavorable que no permitiría el acceso bajo los criterios de este trabajo, porque harían falta más personas para pagar la vivienda con rentas de $1.400 €$ que las que podrían ocuparla bajo una habitabilidad mínima de $30 \mathrm{~m}^{2}$ por persona.

Por supuesto, los tres supuestos se definen como paradigmas para las cifras globales de cada área. En todas ellas habrá, como se ha visto en las gráficas anteriores, mayor o menor diversidad para acoger casos de uno u otro tipo. Pero el objetivo es buscar e identificar pautas comunes y predominantes en cada área que ayuden al diseño posterior de estrategias para luchar contra la infrautilización del parque y la exclusión residencial existente. En base a lo anterior, y recordando que en igualdad de grupos la económica se veía favorecida, se han definido diferentes grados de adecuación al cruzar los grupos de cada accesibilidad, abarcando todo el abanico de posibilidades que se podrían llegar a dar (Tabla 3.22). Aún tratándose de una aproximación estimativa a partir de todo el trabajo previo realizado, los datos resumidos en la tabla son en cualquier caso muy esperanzadores, y llevan a pensar que es posible la hipótesis parcial planteada. Una gran mayoría de las áreas geográficas presentan un cruce de las dos variables favorable de cara a implantar la estrategia de agrupación de personas para lograr el acceso a la vivienda de una manera asequible y con posibilidades de adaptar el parque a sus necesidades. Los resultados permiten además afirmar que el potencial existente no se reduce a áreas de precios bajos, si no que se deben a la combinación de precios y tamaño de viviendas, mostrando que incluso en no pocas áreas de precios altos es posible plantear estrategias como la que se propone. Sin ánimo de infravalorar otros 
posibles obstáculos a salvar, esto supone que podría utilizarse esta estrategia de agrupación de personas para favorecer la cohesión social del espacio residencial de la ciudad.

\begin{tabular}{|c|c|c|c|c|}
\hline \multirow{2}{*}{$\begin{array}{c}\text { Grupo de Acc. } \\
\text { Económica }\end{array}$} & \multirow{2}{*}{$\begin{array}{l}\text { Grupo de Acc. } \\
\text { Espacial }\end{array}$} & \multicolumn{3}{|c|}{ Adecuación } \\
\hline & & grado & venta & alquiler \\
\hline \multicolumn{5}{|c|}{ favorables } \\
\hline \multicolumn{5}{|c|}{ Acc. Económica < Acc. Espacial } \\
\hline 1 & 4 & A1 & 0 & 2 \\
\hline 2 & 4 & A2 & 1 & 1 \\
\hline 1 & 3 & A3 & 0 & 10 \\
\hline 3 & 4 & A4 & 2 & 8 \\
\hline 2 & 3 & A5 & 3 & 3 \\
\hline 1 & 2 & A6 & 3 & 23 \\
\hline 1 & 1 & A7 & 20 & 29 \\
\hline 2 & 2 & A8 & 14 & 6 \\
\hline 3 & 3 & A9 & 10 & 8 \\
\hline \multirow[t]{2}{*}{4} & 4 & A10 & 21 & 5 \\
\hline & & total áreas: & 74 & 95 \\
\hline \multicolumn{5}{|c|}{ Acc. Económica $\approx$ Acc. Espacial } \\
\hline 2 & 1 & B1 & 18 & 2 \\
\hline 3 & 2 & B2 & 6 & 6 \\
\hline \multirow[t]{2}{*}{4} & 3 & B3 & 4 & 0 \\
\hline & & total áreas: & 28 & 8 \\
\hline \multicolumn{5}{|c|}{ desfavorables } \\
\hline \multicolumn{5}{|c|}{ Acc. Económica > Acc. Espacial } \\
\hline 3 & 1 & $\mathrm{C} 1$ & 4 & 3 \\
\hline 4 & 2 & $\mathrm{C} 2$ & 1 & 0 \\
\hline \multirow[t]{2}{*}{4} & 1 & $\mathrm{C} 3$ & 0 & 0 \\
\hline & & total áreas: & 5 & 3 \\
\hline
\end{tabular}

Estos resultados generales, en gran medida extensibles a la práctica totalidad del AMB, pueden trasladarse de la Tabla 3.22 al espacio geográfico, aportando una lectura de gran interés (Mapas 3.21 y 3.22). Como se ha apuntado, el indicador conjunto de la accesibilidad total no se ve condicionado por los precios o por los tamaños de las viviendas, si no por el cruce de ambas variables. 


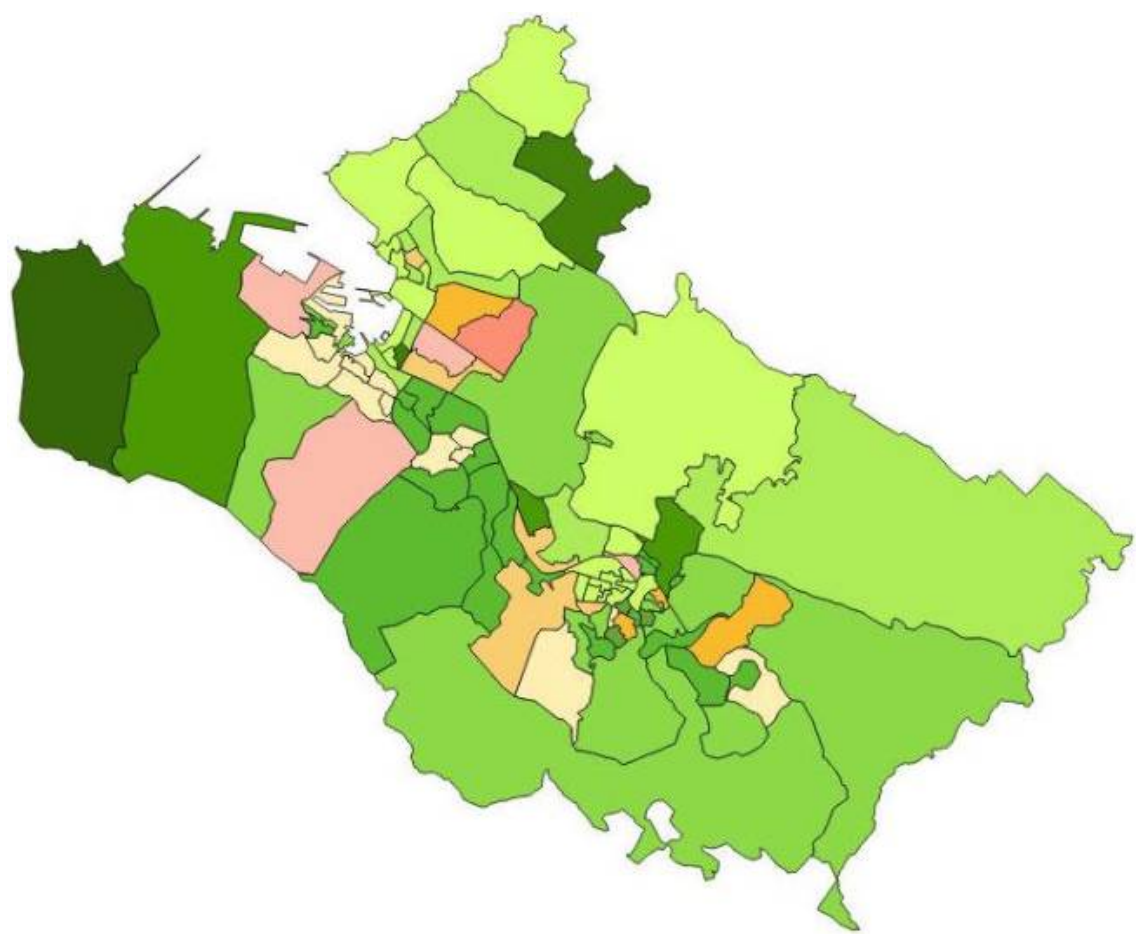

$\square$ A1
$\square$ A2
A3
$\square$ A4
$\square$ A5
$\square$ A6
$\square$ A7
$\square$ A8
$\square$ A9
$\square$ A10
$\square$ B1
$\square$ B2
$\square$ B3
$\square$ C1
C2

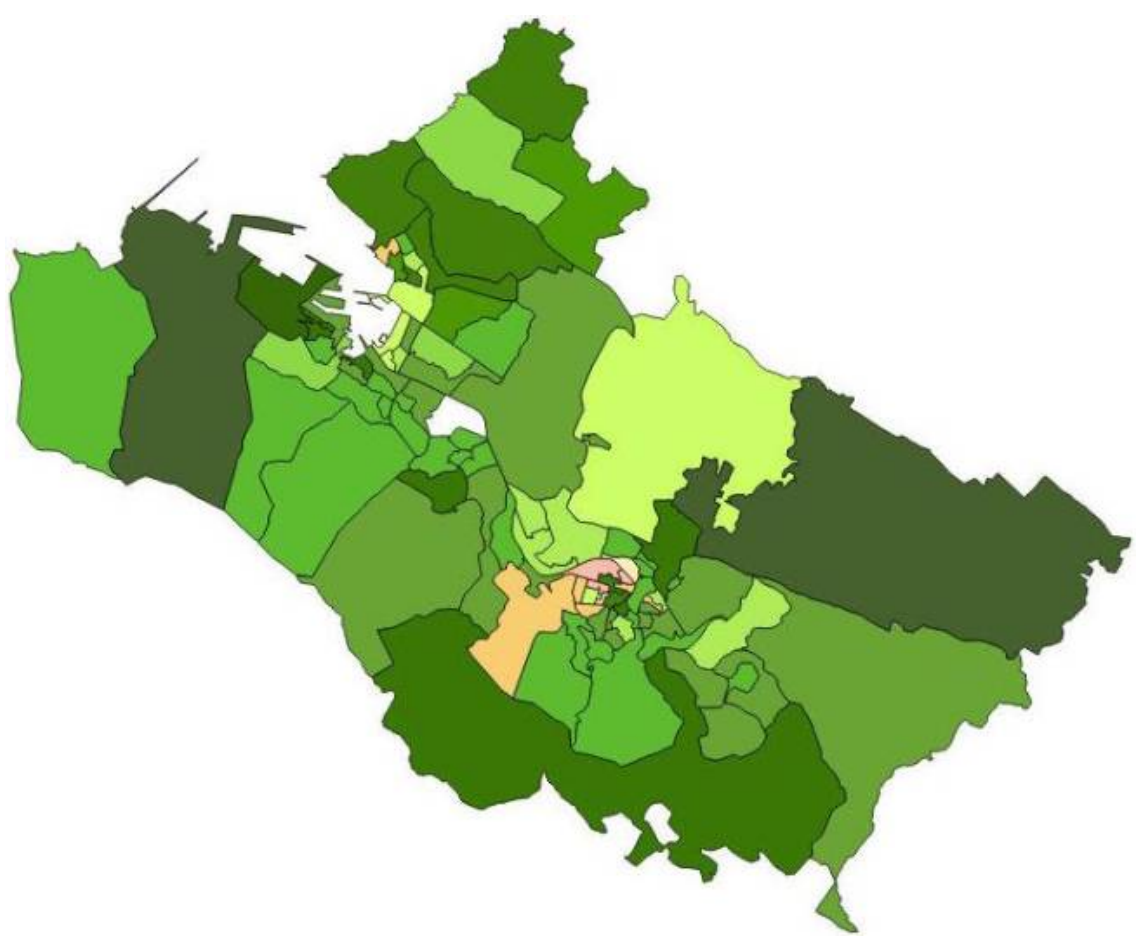

Mapas 3.21 y 3.22. Clasificación de las 98 áreas geográficas por grado de adecuación del cruce entre la accesibilidad económica y espacial según lo establecido en la Tabla 3.22, para la venta (arriba) y alquiler (abajo). Elaboración propia a partir de Idealista, 2015.

Así, numerosas áreas espaciales con precios altos y muy altos en ambos regímenes de tenencia resultan considerablemente favorables para un acceso a la vivienda según los criterios definidos. Es el caso de gran parte de Getxo -incluso en sus zonas de mayores precios, al contar también con viviendas de gran tamaño-, Barrika, o el Ensanche y el Casco Viejo de Bilbao. Por otro lado, y confirmando lo 
ya adelantado, en algunos otros casos, como en la oferta de alquiler de la zona norte del Ensanche, los resultados confirman que el desajuste entre precios y tamaños de viviendas hacen este área -al menos mientras se mantengan las características de la oferta de esta maneradesfavorable para la implantación de este tipo de estrategias (Mapa 3.22). Aunque el análisis tipológico desarrollado anteriormente ha sido sobre una muestra parcial, la diversidad de tipologías de la muestra utilizada y los resultados obtenidos permiten deducir que el alto potencial de adaptación es generalizable al conjunto del parque residencial. En conclusión, se deduce que el desarrollo de una política de vivienda como la actual no profundiza en los tipos de unidades de convivencia ni en las tipologías, y no contempla alternativas de transformación y adaptación del parque orientadas a estrategias de agrupación de personas como las planteadas aquí. Continuar bajo el ya mencionado dogma de 'una unidad de convivencia actual $=1$ vivienda actual' sin plantear soluciones imaginativas bajo nuevos enfoques puede dejar fuera muchas y ricas posibilidades para avanzar hacia un mayor acceso a la vivienda. Aunque, como se desarrollará más adelante, todo ello dependerá en gran medida -aunque no solode la capacidad que la sociedad civil tenga para actuar colectivamente y de influir en la toma de decisiones, pues «de la recuperación de un proyecto verdaderamente cívico y de profundas transformaciones en la composición del bloque local de poder depende que podamos soñar con vivir en algún sitio mejor y más barato, también que todos tengan un alojamiento digno» (Roch, 2003: 129).

De momento, y mientras se mantenga la supremacía ejercida por los condicionantes y obstáculos internos identificados en el capítulo segundo, un planteamiento a medio y corto plazo como el presente para explotar ciertos espacios de oportunidad del sistema inmobiliario y urbanístico actual representan una esperanza razonable ante un modelo cuyos «agentes más osados se atreven a dar golpes de estado para mantener intactas sus opciones de poder y sus interminables proyectos inmobiliarios al servicio de la acumulación del dinero. El precio de la vivienda no es otra cosa» (Roch, 2003: 129). Algunas muestras recientes de un aparente cambio de paradigma en este sentido, parecen todavía lejanas a la urgencia de la situación. El positivo enfoque desarrollado en la revisión del PGOU de Bilbao, por ejemplo, que plantea ocupar poco suelo y centrarse en la ciudad ya urbanizada no supone forzosamente un cambio de paradigma. Las lógicas e intereses que hay detrás en cuanto a la búsqueda de plusvalías económicas generadas por la ciudad residencial siguen siendo los mismos, aunque bajo una mirada más consciente del territorio y la ciudad. Por lo tanto, las consecuencias en cuanto a la exclusión residencial se refiere van a verse mantenidas.

\section{La importancia del entorno local}

En los dos apartados anteriores, se ha visto que puede ser de gran interés cruzar, no solo los indicadores relativos a la accesibilidad 
económica y espacial digna, si no también los relacionados con otras variables del contexto en el que se enmarca la oferta de vivienda analizada. La incorporación de determinada información sociodemográfica, así como urbana -calidad del entorno y las dotaciones, de la edificación,...- probablemente facilitará una respuesta más adecuada al acceso a la vivienda desde los planteamientos aquí desarrollados. Como proceso social que es, la producción del hábitat residencial forma parte de un sistema complejo abierto en constante interacción con su entorno (Romero y Mesías, 2004: 16). Es decir, la óptima utilización y aprovechamiento de los resultados aquí obtenidos dependerá en gran medida de saber contextualizarlos. Como se viene insistiendo, el AMB es, al igual que otros sistemas urbanos, un reflejo del desarrollo espacial desigual de las sociedad capitalista. Por ello, ya se ha señalado que dos áreas geográficas con valores similares en los indicadores generados no tienen porque presentar un potencial similar, ni por lo tanto una misma manera de ser abordadas. El estudio del contexto más local y cercano ayudará a definir estas. Con el objetivo de evidenciar esto, y sin pretender ahondar ni presentar una imagen completa de la complejidad de capas que podrían llegar a identificarse, se presentan unos ejemplos a partir de un estudio sobre tipologías de secciones censales en Euskadi (Eustat, 2010). Algunos de los indicadores que el citado estudio analizó fueron la renta familiar media, el tamaño familiar y el año de construcción de los edificios residenciales. Para, posteriormente, clasificar las secciones censales de toda la comunidad autónoma en doce tipos, señalando en cada una de ellas los valores predominantes para cada indicador. Es decir, categorizando las secciones en función de aquellos valores que más destacaban, lo que no implica la inexistencia de otras realidades aunque sea en menor proporción. Las tres variables aquí seleccionadas podrían, en su caso, ser muy relevantes de cara a plantear una adaptación del parque residencial en la búsqueda de la accesibilidad total ya que dan pistas sobre la naturaleza de la población, o las características del parque construido predominante en cada área. En lo que sigue, dado que se trata de un ejercicio para la argumentación, se va a hacer referencia en exclusiva a los resultados de la investigación relativos a la oferta en venta.

En el caso de las rentas familiares, es posible identificar con claridad una masa social heterogénea, con una mayoría de secciones por debajo de la renta media de Euskadi $^{76}$, y con el eje de la ría marcando la herencia de la mencionada división histórica: por un lado la localización de la industria y la fuerza de trabajo, al otro las clases altas y dirigentes y áreas rurales con mayor poder adquisitivo (Mapa 3.23). Se observan dos zonas de rentas muy altas, la mitad norte del Ensanche y parte del Casco viejo en Bilbao, y la práctica totalidad del municipio de Getxo con pequeñas continuidades hacia Berango y

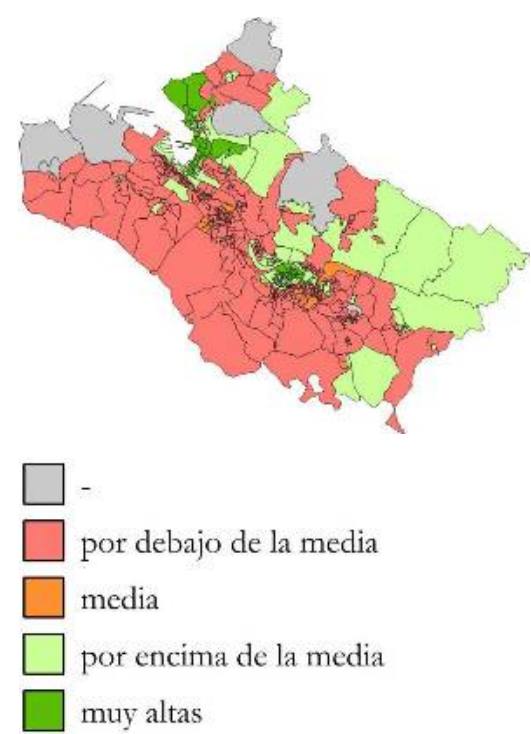

Mapa 3.23. Renta media familiar predominante por sección censal en el AMB. Elaboración propia a partir de Eustat, 2010.

\footnotetext{
${ }^{76} \mathrm{La}$ referencia a toda la comunidad autónoma es válida pues, según datos del Eustat, la renta media familiar del Gran Bilbao, de $42.179 €$ en 2010, era similar a la de Euskadi, de
} $42.720 €$. 


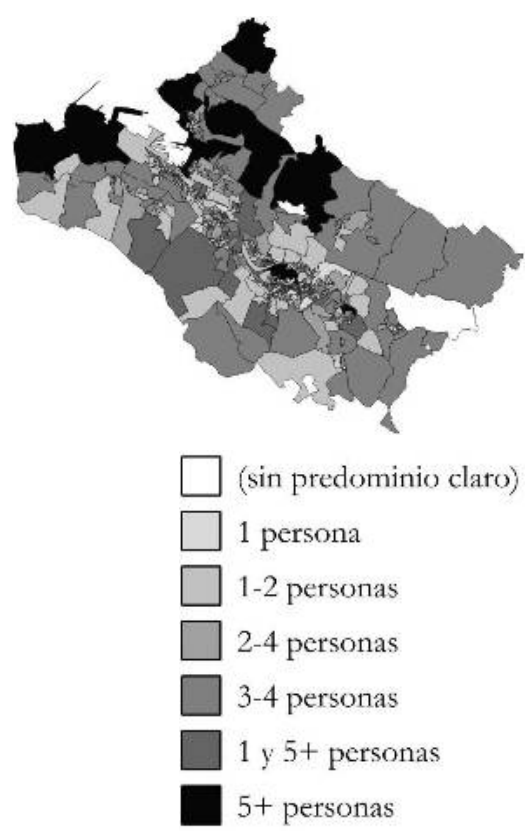

Mapa 3.24. Tamaño medio del hogar predominante por sección censal en el AMB. Elaboración propia a partir de Eustat, 2010.
Leioa. Las secciones con rentas por encima de la media comprenden casi todo el resto del centro de Bilbao y del municipio de Getxo, la totalidad de Lezama y Zamudio, y parte de municipios como Santurtzi, Portugalete, Leioa, Sopela, Erandio, Sondika, Galdakao, Zaratamo o Arrigorriaga. Las pocas secciones censales con una renta familiar cercana a la media se localizan en algunos barrios periféricos de Bilbao y Barakaldo. Por último, las secciones censales con una renta familiar por debajo de la media, conforman la totalidad o práctica totalidad de los municipios de Santurtzi, Ortuella, Trapagaran, Barakaldo, Sestao, Alonsotegi, Arrigorriaga, Basauri, Etxebarri, Derio y Sopela. Por otro lado se localizan en parte de los municipios de Portugalete, Erandio, Leioa, Berango, Sondika, Galdakao, Bilbao en gran parte de sus barrios periféricos, así como en pequeñas áreas de Getxo y Zamudio. No obstante, y a modo de ejemplo, no será lo mismo abordar las posibilidades de transformación y adaptación de un parque con un resultado favorable de grado A9 según la Tabla 3.22, como el del municipio de Sopela que tenía según la fuente una renta familiar media por debajo de la media de Euskadi-, que hacerlo en los municipios de Zamudio, Lezama y Larrabetzu -con ese mismo grado A9, pero con una renta familiar por encima de la media-. Tampoco lo será en aquellas áreas geográficas de Getxo y Bilbao con un grado favorable A10 que presentan secciones censales de rentas muy altas, o en los municipios de Loiu, Derio o Sondika que con un mismo grado presentan rentas por debajo y por encima de la media. La capacidad de acceso de la población con necesidad de vivienda será en cada caso diferente, lo que exigirá ajustar los resultados globales obtenidos en la investigación hacia otros tamaños de agrupaciones de personas. El enfoque, en caso de llevarse a cabo este tipo de estrategias, habría de ser adaptado en consecuencia.

De igual manera ocurre con el segundo indicador tomado del citado estudio del Eustat. Si el anterior influía mayormente en la accesibilidad económica, este segundo, relativo al tamaño de los hogares o unidades convivenciales, lo hará en la espacial. Así, con un mismo nivel de adecuación favorable entre la accesibilidad económica y la espacial de grado A9, Sopela o el área de Polígono Rojo-Aldapa en Getxo albergan unidades de convivencia con un tamaño predominante de entre tres y cuatro personas. Mientras, en el área de Casco Viejo-Muelle, en Portugalete, con ese mismo grado de adecuación el tamaño predominante es de una o dos personas (Mapa 3.24). Las necesidades de superficie que pueden llegar a tener unidades de convivencia de tales tamaños variarán considerablemente. Lo cual afecta directamente a la manera en que habrá de adaptarse el parque, permitiendo incorporar más o menos unidades de convivencia en una agrupación destinada a ocupar y adaptar una vivienda existente, o un conjunto de varias.

Un parque que, por otro lado, presentará dentro de la homogeneidad tipológica ya tratada anteriormente diferentes 
variaciones de la misma. La familiar nuclear formada por una pareja con hijos e hijas ha sido y es el público objetivo al que se ha dirigido la gran mayoría del parque residencial existente. A pesar de ello, la evolución y los cambios sufridos en las tendencias arquitectónicas, en los criterios de habitabilidad, o en la normativa y los condicionantes urbanísticos, entre otras cuestiones, han influido en dotar de cierta diversidad al parque. Así, la edad o antigüedad de un edificio residencial -el tercer indicador tomado del Eustat para esta reflexiónpuede adelantar información de interés en relación a una diferente morfología urbana y arquitectónica. En este sentido -de igual manera que con los dos indicadores anteriores-, las estrategias deberán probablemente diferir en lo que a la transformación de la tipología existente respecta, en función de las características del parque heredado. Si se abordan algunas de las áreas geográficas analizadas en Sestao como Asilo-Rebonza-Urbinaga o Centro-Albiz-Markonzaga, con un grado de adecuación favorable A7 y un parque mayoritariamente construido entre 1951 y 1970, predominará un tipo de vivienda, de sistema constructivo y de estado de conservación seguramente diferente al que se encontraría en el área de Arteagabeitia-Retuerto-Kareaga, en Barakaldo, en la que con el mismo grado A7 predominan los edificios residenciales construidos de 1971 en adelante, con una proporción alta de los edificados posteriormente a 1990 y 2000 (Mapa 3.25).

Los casos pueden ser múltiples y diversos, y la riqueza y complejidad del contexto se va constatando si se van sumando variables a las lecturas realizadas en los dos indicadores anteriores. Si en el caso de las rentas familiares medias se identificaba entre Sopela y parte del Txorierri -Zamudio, Lezama y Larrabetzu- una adecuación igual de grado A9 sobre una población de diferente renta media -por debajo de la media en el primer caso y por encima en el segundo-, en lo relativo a la edad de la edificación también se detectan importantes diferencias. En Sopela predomina un parque construido entre los años 1981 y 2000 en su centro urbano, y posterior a 1990 en las diferentes expansiones urbanas desarrolladas y actualmente en desarrollo en el resto del municipio. En cambio, en los otros tres municipios, y posiblemente por la conservación de una actividad y edificaciones agrícolas, el parque residencial predominante según el estudio del Eustat de 2010 había sido edificado, bien antes de 1900, o bien después de 1990. Casos similares pueden encontrarse entre gran parte de Getxo y Barrika -ambos con un grado de adecuación favorable A10, pero el primero con muchas de sus áreas albergando un parque edificado entre 1900 y 1940 o entre 1981 y 2000, y el segundo antes de 1900 y después de 1990-, o entre el área de Uretamendi-Betolaza-Peñascal en Bilbao y gran parte de Portugalete comparten un grado de adecuación favorable B1, pero el primero con un parque construido entre 1951 y 1970 o antes de 1961, y en el segundo principalmente levantado a partir de 1971, mucho del cual lo fue entre 1981 y 2000 o a partir de 1990-.

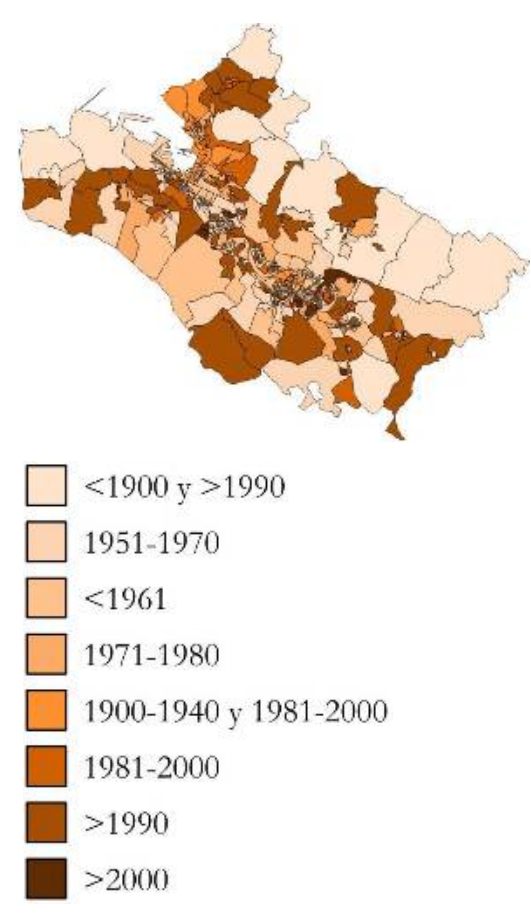

Mapa 3.25. Año de construcción de los edificios residenciales predominante por sección censal en el AMB. Elaboración propia a partir de Eustat, 2010. 
Estos tres indicadores son solo una muestra de un abanico mucho mayor de posibles variables complementarias para el análisis: tipos de unidad de convivencia, edad, nivel formativo, ocupación, nacionalidad y cultura, desempleo,... A mayor riqueza del análisis, más ajustada será la respuesta a la hora de aprovechar los espacios de oportunidad detectados. Para ello, la recogida de información puede ser crucial de cara a identificar correctamente las características y los retos de las viviendas a poner en carga, y las necesidades de la población con necesidad de vivienda. Retos como los propios de la necesaria transformación de un producto común y de difícil venta en algunas áreas del AMB, como las grandes viviendas de $200 \mathrm{~m}^{2}, 300 \mathrm{~m}^{2}$ y más sobre lo que ya se observan debates e inquietudes desde las instituciones públicas locales-, o la frecuente existencia de viviendas deterioradas y con falta de un mantenimiento y un equipamiento correctos, lo cual complica también su puesta en carga. Todo ello, para lograr viviendas que permitan, no solo el acceso de una población que incluso ni con una renta de trabajo es capaz de costear bajo un límite de gasto razonable el alojamiento, si no para adaptarlas a las tipologías que las unidades de convivencia diferentes a la familia nuclear con hijas e hijos requieren en el presente, y requerirán en el futuro. 


\section{- $3.4-$ \\ Conclusiones parciales}

\section{Potencial latente de un parque infrautilizado}

A partir de una muestra de datos, en gran parte cuantitativos ${ }^{77}$, se ha buscado ofrecer unos resultados orientados a la reflexión cualitativa. Observando los resultados obtenidos y extrapolando los mismos al total de viviendas principales de la región se puede afirmar que, con una baja calidad espacial del parque, pero una considerable adaptabilidad para albergar unidades de convivencia diversas bajo un límite máximo de gasto razonable, queda demostrado el punto primero de la hipótesis general de la investigación: la existencia de un enorme potencial de transformación en el parque residencial existente en el $\mathrm{AMB}$ para responder, en número y tipología, a una parte considerable de la necesidad espacial y económica de vivienda. Estas pueden ir unidas o no, pues habrá unidades de convivencia con rentas altas que habitan viviendas diseñadas para otros, o unidades con problemas económicos que desean acceder a una vivienda tal y como está, sin transformarla. Este caso de estudio ha permitido comprobar que, no solo cuantitativamente hay un gran número de viviendas existentes capaces de responder a una importante parte de la necesidad actual en cuanto al acceso económico con una ocupación adecuada, si no que además sus características espaciales y tipológicas (cualitativas) permiten en gran medida adaptarlas a las necesidades de muchas unidades de convivencia demandantes.

Se ha visto que la enorme inaccesibilidad económica individual a la vivienda -que precisa ser abordada y eliminada- y la obsolescencia espacial generalizada del parque residencial existente, esconden un abanico de posibilidades de acceso para muchas unidades de convivencia bajo criterios económicos dignos, y sobre una arquitectura heredada cuyos soportes básicos permiten una transformación con una considerable libertad. Y con todo, se insiste en que no debe ser esto un argumento para obligar a convivir, en una vivienda existente diseñada a una familia nuclear, a personas que no conforman una única unidad convivencial. Lo que sirve es para argumentar la necesidad de investigar y analizar en mayor profundidad el posible potencial de transformación espacial de esas viviendas en el mercado, para que puedan responder a otros tipos de unidades de convivencia, en plural. Para ver si mediante intervenciones a medida - cada vivienda requerirá de un proyecto diferente- puede plantearse la subdivisión o agrupación de viviendas,

${ }_{77}$ Principalmente aquellos obtenidos del INE, de Idealista, o del Observatorio Vasco de la Vivienda. 
o la generación de otras formas de compartir el espacio doméstico y convivir en lo que hasta ahora se ha considerado una vivienda convencional. Para ello, el primer paso básico, una vez vista la posibilidad de superar la barrera económica, ha sido introducir la variable de superficie. De nada sirve que una vivienda sea económicamente accesible para tres personas si su superficie es inferior a lo que tres personas necesitan para un alojamiento digno y de calidad. En segundo lugar, se han analizado aspectos tipológicos y espaciales. A la habitual postura de aceptar como inamovible el número de viviendas que actualmente conforman el parque existente, se pueden contraponer las posibilidades de adaptar el mismo a la diversidad de unidades de convivencia, tipos de vida doméstica y entornos laborales. Más aún en una región con un crecimiento de ciudad limitado por sus características físicas y orográficas. Pueden ser de interés estrategias de aumento de la densidad urbana en determinadas zonas que así lo admitan, segregando y/o albergando más unidades de convivencia por vivienda, sobre todo en aquellos ámbitos con grandes viviendas, muchas de ellas a la venta y de difícil encaje con la población con necesidad y/o demandante de vivienda. $\mathrm{U}$ otras estrategias enfocadas en la adaptación de inmuebles a una escala mayor, alcanzando la totalidad o parte del edificio para ofrecer de una manera más radical diferentes tipologías residenciales con espacios comunitarios complementarios.

\section{La agrupación como estrategia}

Como se ha definido en el apartado 3.2.1 al desarrollar la Accesibilidad Económica por Agrupación, la estrategia de agrupación propuesta como herramienta para avanzar hacia un acceso económico y espacialmente digno, está más cerca de ser un experimento teórico que de un planteamiento instrumental detallado. Es un ejercicio de investigación desarrollado para confirmar las previsiones planteadas en la hipótesis. Y sin embargo, se cree que puede ser una interesante base para desarrollar sobre la misma propuestas concretas de transformación del parque residencial en el marco en el que se ha desarrollado. El lujo de mantener un patrimonio edificado infrautilizado, mientras se producen situaciones de vulnerabilidad residencial, refleja una sociedad desequilibrada y contradictoria, propia de un diverso y complejo mapa de agentes con diferentes intereses, prioridades, y capacidades de actuar, decidir e intervenir. Una situación alimentada en gran medida por ese carácter transversal que estas y otras contradicciones internas del capitalismo presentan, como se ha desarrollado en el capítulo segundo. En este sentido, la estrategia de agrupación estudiada puede ser el origen de una herramienta válida para abordar el fondo de una de esas contradicciones, la existente entre la oferta y la demanda de vivienda, para facilitar el acceso al parque a través de su transformación. No se pretende por lo tanto dar una respuesta instrumental, ni un manual para ser aplicado directamente por diversos agentes sobre el parque 
residencial edificado - la teoría crítica permanece en lo abstracto, es teoría (Brenner, 2017b: 241)-; se trata de ofrecer un estudio para argumentar una oportunidad. La intención de lo desarrollado en este capítulo es aportar información, conocimiento e ideas para la reflexión y el debate de cara a un proceso abierto de toma de decisiones en torno a la problemática.

La interpretación de los resultados antes presentados de la accesibilidad total neta también ayudan a defender la estrategia de agruparse. Mientras que las viviendas aptas para unidades de convivencia pequeñas son accesibles con menos frecuencia -aplicado el ajuste por los costes propios de la transformación muchas quedan por encima del PMT-, en el caso de aquellas accesibles para grupos a partir de siete personas las posibilidades de que lo sigan siendo son muy altas (Gráfica 3.20). No se ha de olvidar que este trabajo busca una respuesta a la necesidad básica de vivienda, y por eso se ha planteado como razonable un ratio de unos $30 \mathrm{~m}^{2}$ de vivienda por persona. Por supuesto, no todas las personas que habitan una vivienda son susceptibles de tener unos ingresos, y por lo tanto de aportar capital para el acceso económico. Sin embargo, dado que se ha trabajado con datos estadísticos de salarios medios, y que los precios de la oferta se engloban en un abanico amplio, se comprende que cada caso concreto podrá, según su situación y su contexto particular, acceder a más o menos superficie. Además, ya se ha visto que un porcentaje considerable de las viviendas ofrecen una SMP por encima del tamaño de unidad de convivencia o agrupación necesario para costearla. Es decir, permiten la inclusión de personas sin renta en la ecuación. Por otro lado, es también necesario recordar que los datos manejados parten del salario medio con el que se ha realizado el estudio del Observatorio Vasco de la Juventud, estimado en $1.400 €$ netos en 2013. Esto supone que, aunque se ajusta con relativa precisión al salario medio del AMB, la diversa realidad social alberga colectivos con rentas más bajas para los cuales los resultados obtenidos en este trabajo no son directamente aplicables, si no que estarían algo por encima de sus posibilidades económicas.

Se considera que los datos ofrecidos son válidos como abstracción de una oportunidad real existente en el AMB, aunque sin lugar a dudas compleja y más diversa que lo aquí presentado. En cualquier caso, el objetivo ha sido poner en valor la existencia de un potencial para una solución digna de mínimos básicos a un problema urgente. La idea central es que un porcentaje muy alto de las viviendas es accesible económica y espacialmente, eso sí -y he aquí la clave del trabajo-, en función del tamaño del grupo que acceda, lo cual conlleva también ampliar la mirada más allá de la correspondencia entre una vivienda y una unidad de convivencia. Es desde este planteamiento que debe entenderse el espacio de oportunidad detectado. La alternativa a la realidad recogida en la situación problemática, vistos los resultados hasta aquí obtenidos y las oportunidades de acceso que el parque ofrece, es dejar a un lado la 
idea de que la necesidad de vivienda de una persona deba responderse con una vivienda de las ofertadas actualmente. Y pasar a la transformación de las viviendas existentes en espacios de vida adaptados al tamaño y tipo de las unidades de convivencia necesitadas. Ello exige una estrategia más allá de la renovación y rehabilitación energética del parque residencial, del desarrollo de una accesibilidad física al mismo, y de otras políticas que se están desarrollando ya desde hace un tiempo, para incorporar a lo anterior la rehabilitación tipológica del mismo. Si bien esto ya se está haciendo mediante actuaciones aisladas -ya sea por particulares reformando una primera vivienda, o agentes con fines más lucrativos como grupos de inversión con intención de sacar rendimiento económico a la vivienda-, lo interesante es que sea planteada desde la óptica del acceso a la vivienda como derecho fundamental, bajo una visión global y una planificación más o menos conjunta del parque.

Recapitulando, se ha planteado hasta ahora que la necesidad de intervención habitacional en el parque residencial construido, debido al desfase existente tanto entre precio y capacidad de pago como entre la necesidad de vivienda de unas unidades de convivencia diversas y las tipologías existentes, ha llevado a plantear la mencionada estrategia de agrupación. Pero esta no debe entenderse exclusivamente como una opción temporal para acceder a un derecho -la vivienda- que no puede hacerse individualmente, y que se deje de lado, para volver a un acceso individual, si las unidades de convivencia van aumentando su capacidad de pago. Tampoco debe entenderse como una variante de una consecuencia vigente y en crecimiento de la exclusión residencial en marcha: la vivienda compartida por adultos. Casos que se ven forzados a convivir por encontrarse en situaciones vulnerables o de incapacidad de acceso como unidad de convivencia ${ }^{78}$, sea dando continuidad a pisos de antiguos estudiantes ya en etapa laboral, o como suma de varias unidades no unipersonales. Las oportunidades detectadas ofrecen, además de la adecuación tipológica, el potencial de una serie de valores añadidos propios de la acción colectiva - de organización y formación de comunidad, de cuidados,...- que el acceso individual no tiene, y que harían interesante mantener esas prácticas de agrupación de personas aunque haya capacidad económica, puesto que se habría podido garantizar el espacio personal e íntimo dentro de un inmueble más o menos compartido. Por lo tanto, y sin infravalorar el enorme valor de la política de vivienda pública vasca desarrollada hasta la actualidad, sería interesante buscar y analizar otros modelos alternativos de acceso a la vivienda que aprovechen los espacios de oportunidad detectados y mostrados. Estos pueden ser seguramente abordados desde la propia administración pública, pero también

${ }^{78}$ El País (2018): «Los jóvenes españoles ya no pueden ni comprar ni alquilar vivienda», disponible en https://elpais.com/economia/2018/11/22/actualidad/1542902550_758805 .html. 
desde la intervención privada, o a través de modelos mixtos de colaboración público-privada.

\section{Riesgos de su apropiación y simplificación por el modelo hegemónico}

Avanzando en la propuesta, su desarrollo ideal alcanzaría una agrupación de personas, no como casos puntuales independientes en torno a un inmueble, si no como una red de estos, un tejido de iniciativas en comunicación y preferentemente con apoyo institucional -no necesariamente económico, subvencionado, pero sí dando prioridades, facilitando procesos, reduciendo fiscalidad,...-. Esta cuestión es de gran importancia, pues lo primero podría incluso entenderse como favorecedor de un modelo en búsqueda de la mayor acumulación de capital posible a través de la renta de la vivienda, y cuyas consecuencias podrían ser el aumento de los precios de las viviendas del mercado libre dado que serían más unidades de convivencia las que demanden un inmueble. Lo segundo, en cambio, se trata de una manera de empoderamiento y fortalecimiento colectivo consciente en un contexto inmobiliario generalmente hostil. No es por lo tanto el de este trabajo un planteamiento neoliberal que llame a sacar de la esfera pública la obligación de satisfacer la necesidad de vivienda. Se ha de entender como una aproximación a una herramienta de mejora de las políticas públicas de vivienda, ampliando el horizonte y el radio de acción e influencia de estas a ámbitos privados y mixtos. La postura de fondo no es arrodillarse ni claudicar ante el mercado, si no saber leer sus contradicciones y aprovechar sus oportunidades con unos límites de dignidad claros. No obstante, lo anterior no impide que pueda intuirse cierto peligro en una explotación neoliberal de estos espacios detectados; se habrá de estar vigilante porque si bien «una de las eventuales salidas de una contradicción es la innovación», -como puede ser este caso- las primeras «tienen la desagradable costumbre de no ser resueltas sino simplemente desplazadas» (Harvey, 2014: 19).

De hecho, ya se están dando situaciones de algún modo cercanas, pero que se plantean con un enfoque exclusivo de la vivienda como objeto de inversión ${ }^{79}$. Existen diversos agentes -determinadas agencias inmobiliarias, entidades financieras $y$ medios de comunicación- que están identificando situaciones de gentrificación, con su consecuente y frecuentemente invisibilizado proceso de expulsión de población (Slater, 2015), como una oportunidad para poner en marcha una línea de negocio orientada, precisamente, a las unidades de convivencia que están siendo presionadas hacia el desplazamiento de sus barrios. El planteamiento de estas iniciativas es

${ }^{79}$ El Salto (2018): «iSegrega tu casa! La nueva estrategia inmobiliaria para precarizar aún más la vivienda», disponible en https://www.elsaltodiario.com/burbuja-inmobiliaria/segregatu-casa-nueva-estrategia-precarizar-vivienda. 
fomentar la segregación de viviendas -vendiendo o alquilando una parte y manteniendo como residencia principal la otra- como una manera de generar rentas y evitar así ser expulsadas. El modelo viene motivado por la apertura de una nueva posibilidad de acumulación de capital en forma de comisiones por la gestión inmobiliaria y de intereses por la contratación de créditos bancarios -ya sea por parte de la propiedad original para financiar la obra de transformación, o por la nueva propiedad de la parte segregada en caso de compra-. Sin embargo, este tipo de prácticas, aunque comparten con la estrategia de agrupación planteada en esta investigación la idea de hacer corresponder una vivienda actual a más de una unidad de convivencia, chocan en muchos otros aspectos.

Destaca, por encima de todo, lo perverso de exprimir y buscar un nicho de mercado a costa de personas en situaciones de vulnerabilidad y fragilidad. Pero más allá de ese ya inicialmente alejado planteamiento, hay tres puntos de divergencia. Primero, no se busca la agrupación, la colaboración entre unidades convivenciales con dificultades de acceso a la vivienda, como herramienta de empoderamiento para lograr el mismo en unas condiciones dignas. Su agrupación es vista como una oportunidad para la venta de servicios de gestión y productos financieros. Segundo, no hay ninguna reflexión sobre la adaptación tipológica de las viviendas, si no que las resultantes de la segregación se plantean como una versión más pequeña de la tipología habitual -lo que en muchos casos supondrá una pérdida de calidad habitacional, al perder superficie y no responder a esa reducción con otras soluciones espaciales-. Tercero, no se plantea el proceso como un instrumento para el acceso económico digno a la vivienda. Si bien para la propiedad original sí supone una mejora de su situación económica, esta se apoya en la búsqueda del mayor valor posible de alquiler o venta para la parte segregada, manteniendo así una visión de la vivienda como objeto de inversión y rentabilidad económica. Se trata, en definitiva, de trasladar la presión a la nueva unidad de convivencia que está por llegar, que se verá forzada a responder a un crédito hipotecario o una renta de alquiler probablemente alta si se trata de barrios en proceso de gentrificación. Al igual que ocurre con otras experiencias y vías alternativas exploradas, $-\mathrm{y}$ de ahí la importancia de contemplar la hipótesis de esta investigación en su conjunto, y de unir estos resultados con lo abordado en el siguiente capítulo-:

«Estos proyectos podrían convertirse con demasiada facilidad en el dominio exclusivo de las familias pudientes y corren el riesgo de ser reintegrados en la lógica de la mercantilización. Para evitar esto, los experimentos de tenencia alternativa de la vivienda deberían estar lo más vinculados posible a otros esfuerzos de mayor escala, a grupos de personas marginadas y a las agencias de vivienda pública, con el objetivo de evitar que se limiten a ser excepciones interesantes en un 
panorama residencial que por lo demás sigue igual» (Madden y

Marcuse, 2018: 223).

\section{Hacia un aumento de la planificación y del ritmo de transformación}

Entre un modelo político basado en una serie de gobiernos estatal, autonómico y locales como único agente responsable y activo en materializar este derecho a la vivienda, con todos los obstáculos -por ejemplo la carencia de medios humanos y económicos para llevar a cabo todo lo deseado- y limitaciones - por ejemplo algunas de las inercias y rigideces que condicionan los planteamientos de base, frenan una apertura de miras más amplia y fresca, y generan las contradicciones señaladas- que pueden darse, y un modelo radicalmente neoliberal sin regulación ni intervención pública alguna en materia de vivienda, que dejase en manos del mercado y las presiones capitalistas el acceso al alojamiento digno -con la evidente exclusión y expulsión de la población incapaz de pagar la vivienda a otros lugares más asequibles, en caso de que los haya-, hay un amplio espectro de variantes y matices. De hecho, el modelo existente en el AMB -en España, puede decirse- podría comprenderse como una variante intermedia, pues la política de vivienda accesible está en su casi totalidad en manos exclusivamente públicas, quedando el resto de opciones bajo un mercado feroz y altamente enfocado hacia la vivienda como inversión y fuente de acumulación. Como otra variante intermedia, se puede plantear y fomentar un mayor compromiso público y, tal y como se da en otros países cercanos, el renacimiento y fortalecimiento de una sociedad civil activa $y$ comprometida para participar en el desarrollo y gestión de una oferta, para sí misma o para otras personas, siempre con el apoyo y constante comunicación institucional, que no es -o debería ser- si no un brazo representativo de esta (Burón, 2014). Se está pensando en fórmulas de gestión de edificios completos o partes de los mismos, e incluso, por qué no, de conjuntos residenciales, que permitan por ejemplo intercambiar las viviendas entre las personas que las habitan a lo largo del tiempo, o adaptar el edificio a las necesidades cambiantes de la comunidad de vecinos - cambios en el tamaño familiar, en las pautas de vida, en la movilidad,...-. Para ello, existen diferentes fórmulas suficientemente testadas y comprobadas como para poder afirmar que es posible otro modelo de gestión residencial, cuyo éxito dependerá de la intersección de cuestiones e intereses económicos, políticos, culturales y legales. Las diferentes cooperativas de vivienda, o la masovería urbana son algunas de estas posibles fórmulas.

En cierta medida, la política pública de vivienda vasca ya ha mostrado un, de momento tímido, giro hacia este tipo de fórmulas. En el Plan Director de Vivienda 2013-2016 se hacía mención a algunas de las líneas de trabajo a futuro planteadas en el Informe de Evaluación de la Política de Vivienda 2012 (Observatorio Vasco de la 
Vivienda, 2012b). La estrategia de fomento del alquiler allí establecida identificaba como «necesaria la búsqueda de fórmulas imaginativas e innovadoras que ofrezcan soluciones, tratando de superar el actual binomio propiedad-alquiler. Estas fórmulas alternativas (propiedad compartida, propiedad temporal, modelo Andel de cooperativas, etc.) podrían ser una oportunidad de acceso a la vivienda para las personas con menores recursos económicos» (Gobierno Vasco, 2013a: 36). El reflejo de esto en propuestas algo más concretas se formalizó en acciones del propio plan director. Así, se propuso el estudio, para su posible implantación en la comunidad autónoma, de «modelos existentes en otros países basados en compartir la propiedad de la vivienda para facilitar el acceso a la misma en este régimen» (Gobierno Vasco, 2013b: 16), de «un conjunto de medidas de apoyo que faciliten el alquiler para jóvenes de 18 a 35 años, por un periodo máximo a determinar, y con rentas mensuales no superiores al $30 \%$ de los ingresos, como programas de pisos compartidos o nuevos modelos de convivencia entre personas mayores y jóvenes» (Gobierno Vasco, 2013b: 17), el análisis de «la viabilidad de implantar en el parque vasco de vivienda pública la masovería urbana, comercial y empresarial, para las personas que rehabiliten viviendas o locales a cambio de poder disfrutarlos durante un tiempo determinado» (Gobierno Vasco, 2013b: 21), o «un tratamiento fiscal ventajoso que resulte atractivo para que los propietarios privados pongan en el mercado de alquiler las viviendas que se encuentren deshabitadas» (Gobierno Vasco, 2013b: 25), entre otras. En el Plan Director de Vivienda 2018-2020, además de dar cierta continuidad a estas líneas de trabajo, se planteaba afrontar una rehabilitación profunda y la búsqueda de habitabilidad de un parque existente con una gran necesidad de ello, para ponerlo a punto y estudiar la manera de integrarlo en los programas de movilización de vivienda vacía libre hacia el alquiler social ${ }^{80}$. Lo que se pretende evidenciar aquí es la enorme vigencia de los planteamientos desarrollados en esta tesis, y su total encaje con la evolución progresiva de la política de vivienda vasca, poniendo en valor el aporte transformador que esta investigación puede llegar a suponer al converger con dichas estrategias autonómicas.

Detectadas las oportunidades espaciales que el parque ofrece, la naturaleza de las iniciativas y de los procesos de gestión a través de los cuales estas son, o pueden ser, aprovechadas es de gran relevancia. Por lo tanto, la idea defendida es que con detectar dichas oportunidades presentadas en este capítulo no basta; hace falta activar y/o ayudar a agentes públicos y privados. Dos son los principales motivos. El primero es que no se discute que las intervenciones puntuales y aisladas de reforma y rehabilitación de viviendas realizadas por particulares probablemente estarán, en muchos casos,

80 Tal y como se afirmó en la jornada Nuevo Plan Director de Vivienda 2018-2020: Un paso más hacia el acceso efectivo y sostenible a la vivienda celebrada en Bilbao el 23 de noviembre de 2017. 
adecuando ese espacio doméstico concreto a sus necesidades espaciales y dentro de un gasto económico razonable. Sin embargo, el interés de los resultados obtenidos -para que lo aquí planteado tenga efectos relevantes- radica en que estos espacios de oportunidad detectados sean identificados, asumidos, e intervenidos a una escala y a un ritmo mayores. Que haya iniciativas poniendo en marcha y activando estas oportunidades de una manera planificada, coordinada y global en el AMB. Dado que, lejos de ser una estrategia temporal para responder a un contexto de crisis coyuntural, se trata de un planteamiento a largo plazo que responde a una problemática estructural, con valores añadidos más allá del acceso económico.

El segundo motivo se apoya en lo planteado en el apartado 3.3.3: la observación, e incorporación al proceso, de diversas variables del entorno local puede permitir contar con otras múltiples facetas y dimensiones de la cuestión. Del adecuado tratamiento de todas ellas, dependerá en gran medida el éxito de la aplicación de la estrategia de agrupación planteada. La complejidad que supone tal ejercicio es un motivo más para defender la necesidad de que la gestión de la misma venga, al menos en parte o como acompañamiento, de la mano de múltiples y diversos agentes especializados en la materia. Para que esto suceda, se deberá dar la condición previa de la existencia de un interés por avanzar sinceramente hacia las metas planteadas. Este interés habrá de estar presente en las instituciones públicas frecuentemente bajo unas lógicas de funcionamiento rígidas, limitadas por diferentes marcos normativos y jerárquicos-, en forma de políticas que fomenten este tipo de estrategias. Pero también en el sector privado -mayoritariamente orientado a una actividad principalmente lucrativa, que no incorpora en la misma medida otras variables de corte social ni ambiental-, ofreciendo servicios de gestión y dinamización del parque para una vivienda asequible. $Y$ por supuesto, lo habrá de estar en la propia sociedad civil, asimilando las carencias culturales propias, las espaciales del parque, y reivindicando una utilización racional y justa de este último.

\section{Los retos de la re-colectivización}

El papel de estos muy diversos agentes puede centrarse, bien en una intervención externa a las personas que van a activar dichos espacios de oportunidad, bien en la formación de colectivos de personas usuarias con el fin de fortalecer su posición y adquirir mayor capacidad de acción e intervención. En cualquier caso, cabría saber si la sociedad está preparada para actuar de manera colectiva en este ámbito de la vivienda, tradicionalmente familiar ${ }^{81}$. Por lo que se

\footnotetext{
${ }^{81}$ Es necesario aclarar que se hace alusión a la acción, y no necesariamente a la convivencia en una misma vivienda. Se plantea una estrategia de agrupación y actuación colectiva como camino para el empoderamiento y la toma de control de ciertos procesos y decisiones en torno al acceso a la vivienda, lo cual no debe confundirse con la posibilidad de compartir una vivienda, que podrá o no formar parte de la estrategia.
} 
añaden, sin subestimar el valioso trabajo que desde hace tiempo vienen haciendo algunos movimientos sociales, dos importantes retos. En primer lugar, se podría decir que la sociedad ha perdido prácticas cotidianas $-\mathrm{O}$ no ha avanzado lo suficiente en ellas- para el funcionamiento colectivo. Las lógicas capitalistas han ido aislando e individualizando a la sociedad, y favoreciendo el desarrollo de prácticas orientadas a la competitividad, lo cual puede identificarse en diferentes esferas y escalas:

«En una sociedad neoliberal como la actual, el modelo es el ser humano empresario. El dueño de sí mismo, que diría Foucault, es un ser humano que lo que hace es invertir en sí mismo para luego, en ese mercado capitalista, intercambiar por un buen puesto laboral, por posiciones sociales, salario, consumo, etc. Es ese ser que está todo el día acumulando cosas, compitiendo con los demás, para convertirse en eso. Pero claro, en una sociedad más democrática, en un Estado de bienestar más fuerte... En una sociedad socialista, hablando claramente, más igualitaria, donde se contempla el nosotros, donde somos iguales unos a otros, lógicamente la finalidad es otra: es construir ese nosotros y educar a las personas viendo su interdependencia con los demás seres humanos, no solo de su país sino de otros pueblos y con el entorno, porque todos nos necesitamos. En la otra sociedad no, porque, si yo me baso en la cultura del esfuerzo, mi obsesión es construirme yo, educarme yo a mí mismo y los demás no importan, allá cada uno porque cada uno es responsable de lo que hace con su vida...» (Torres, 2018).

En segundo lugar, y de alguna manera unido a lo anterior, en las últimas décadas con frecuencia se ha tendido a jugar desde la sociedad civil un papel pasivo frente a los derechos y las reivindicaciones. Se trata de una consecuencia perversa y negativa del estado de bienestar, generando una actitud de espera a que las instituciones satisfagan las necesidades bajo un enfoque que admite un único sentido de acción. $\mathrm{Al}$ ser, desde el presente planteamiento, la agrupación y acción común de personas una condición necesaria para aprovechar la alternativa identificada y demostrada, esta estrategia conlleva actuar colectivamente. De modo que es posible identificar un tercer gran motivo para la existencia de agentes más o menos externos orientados a la gestión de la vivienda: la atomización e individualización generalizada de la sociedad. Estos agentes pueden cumplir el papel de difundir, fomentar, facilitar, fortalecer, acompañar y/o acelerar estos procesos. Incluso también en casos de una mayor autonomía, en los que las personas usuarias finales se organicen desde la autogestión, pues en estos casos tendrá gran importancia una labor de acompañamiento $\mathrm{y} / \mathrm{o}$ de trabajo previo especializado para la identificación de oportunidades y retos. Agentes que deberán, ante la naturaleza y la fuerza del poder ejercido por los condicionantes y obstáculos presentados, ante las contradicciones mostradas, compartir 
una serie de principios y valores como arma de lucha frente a los anteriores: el no ánimo de lucro, o la responsabilidad social, entre otros. Es este contexto, este trabajo pretende aportar un primer marco general estratégico.

Recientemente, se están dando a conocer en el AMB iniciativas de gran interés en este sentido, como se mencionarán más adelante: cooperativas de cesión de uso, o plataformas de intercambio de conocimiento colaborativo sobre modelos de vivienda alternativos, entre otras. Sin embargo, puede que sean todavía casos excesivamente aislados y desconocidos por el grueso de la población con necesidad de vivienda. Fuera de ellos, existen también ciertos programas públicos de vivienda que llevan varios años explorando vías alternativas fuera y dentro del mercado libre, así como empresas privadas con un enfoque diferente del sistema inmobiliario. Todo ello plantea la necesidad, desarrollada en el siguiente capítulo, de analizar algunos de estos modelos alternativos de gestión para conocer su potencial de aprovechar -si no lo están haciendo ya- las oportunidades espaciales aquí identificadas. 



\section{CAPÍTULO 4}

\section{Alternativas de gestion: ¿modelos locales más allá del mercado?}

«En otros países, como Alemania o Dinamarca, la existencia de promotoras de vivienda sin ánimo de lucro y de estrategias de integración social en la construcción de los edificios y en la constitución de los grupos ha tenido cierto impacto al fomentar la existencia de un número creciente de viviendas fuera del mercado especulativo, y al facilitar el acceso a este tipo particular de viviendas a todos los colectivos sociales. En estos países, los proyectos de vivienda reciben apoyo público, pero a cambio de que un porcentaje de las viviendas del bloque sea para colectivos sociales vulnerables, y los servicios sociales se reservan el derecho de asignar directamente esas plazas a personas que tienen especiales necesidades.

[...] También en ciudades como Hamburgo, se están integrando los proyectos de viviendas colaborativas en alquiler o en cesión de uso, en las fases de planeamiento, y en la rehabilitación barrios. Tal es el caso de la rehabilitación de barrios como Saint Pauli o de la zona nueva del puerto. Para ello tienen una oficina de vivienda cooperativa que informa a los grupos de personas interesadas de los plazos, procedimientos y necesidades para embarcarse en un proyecto de estas características. La intención sería, además de favorecer el acceso a la vivienda, que la inversión en la mejora de los barrios no se traduzca en un incremento de los alquileres que acabe expulsando a las personas de más bajos recursos del barrio» 



\title{
$-4.1-$
}

\section{Acotación del objeto de estudio}

\author{
$-4.1 .1-$ \\ Islas en un modelo inmobiliario hegemónico
}

Los resultados obtenidos en el capítulo previo permiten afirmar que las tres metas perseguidas por parte del mapa de agentes que participan de la gobernanza en torno a la dimensión social de la vivienda, e identificadas en este trabajo -acceso económico, adaptación tipológica y aprovechamiento del parque existente-, pueden ser alcanzadas, al menos parcialmente, a través de una utilización consciente del potencial detectado en los espacios de oportunidad. Para ello, se ha analizado como una posible estrategia la agrupación de personas y rentas, es decir, el actuar colectivamente para que la capacidad total del grupo vaya más allá de la suma de las capacidades económicas individuales -esfera en la que se ponen los principales esfuerzos, tanto por parte de las políticas públicas como por las propias personas interesadas-. Esto permitiría tanto un acceso asequible, como romper con la limitación de hacer corresponder una vivienda del parque existente a una unidad de convivencia demandante y/o necesitada; el soporte habitacional en esta estrategia puede abarcar una vivienda actual, o puede ir más allá gracias a ese agrupamiento de unidades de convivencia y abarcar más de una vivienda, o un edificio entero, alterando la estructura de la propiedad heredada.

La estrategia facilitaría también un ajuste de un parque residencial considerablemente obsoleto, en cuanto a su tipología se refiere, a los perfiles de estas unidades de convivencia. Una esfera esta, la espacial, que como se ha señalado en el capítulo segundo, es frecuentemente olvidada y/o desconocida por la falta de una cultura extendida sobre la misma. Mientras que abordar esta esfera de manera individual es complejo debido a limitaciones económicas, medios personales, o conocimiento, al actuar colaborativamente el proceso puede facilitarse, según lo visto en el capítulo anterior. Pero para ello, se ha entendido como imprescindible el papel que puedan jugar diversos agentes participantes en la gestión de la vivienda, de manera que 
puedan promover, fomentar, apoyar, y acompañar procesos $y$ estrategias de agrupación como las planteadas.

Dada la compleja problemática enfrentada, estos agentes deberán estar dotados de cierta sensibilidad hacia la misma, e incorporar una serie de principios y valores en línea con la responsabilidad social, así como unas estrategias y prácticas de trabajo transversales, abiertas y colaborativas. Se trataría, en definitiva, de agentes buscando la solidaridad, la lucha por el interés general, el cooperativismo o el procomún, entre otras cuestiones. Por supuesto, no todos los casos seleccionados en este capítulo cumplen con la totalidad de estas condiciones. La historia reciente muestra que la prioridad por la búsqueda de ganancias y plusvalías económicas, propia del modelo inmobiliario y urbanístico residencial español, viene expulsando a través de los condicionantes y obstáculos ya desarrollados, y desde hace décadas, objetivos, intereses y necesidades propios de dimensiones como la social, territorial, ambiental o cultural. Y limita enormemente, y en ocasiones por afecciones internas, la capacidad de respuesta desde las políticas públicas de vivienda. A través de la aplicación en el AMB de la herramienta de análisis presentada en el capítulo segundo, lo anterior ha podido ser contextualizado en una contradicción estructural del sistema de organización social capitalista: la contraposición entre el valor de uso y de cambio que la sociedad da a la vivienda, con un claro predominio del segundo sobre el primero. Lo cual llevaba a plantear la existencia de una alternativa como reacción a la misma, y como parte de la hipótesis general. Esta afirma que en el $\mathrm{AMB}$, tanto en el ámbito público como en el privado y desde posiciones minoritarias, se han dado y se dan experiencias en el proceso de acceso a la vivienda con un planteamiento diferente, en defensa del valor de uso de la misma y con la intención de incorporar la responsabilidad social en el negocio privado inmobiliario y urbanístico, o de implantar programas públicos innovadores en cuestión de vivienda.

Esta afirmación de que actualmente existen en esta región metropolitana algunas iniciativas similares, desarrolladas por agentes diversos, viene justificada por el conocimiento de la misma, y por haber realizado de manera previa un pequeño estudio del estado de la cuestión. Fruto de este estudio del panorama local, sin embargo, se cree también que todavía estos agentes e iniciativas son reducidos en número, y que cuentan con ciertas carencias en su nivel de desarrollo e implantación. Por otro lado, se estima que se enfrentan a muchas y diversas trabas -tanto endógenas como exógenas- para desarrollar en condiciones óptimas su labor y lograr avanzar hacia sus objetivos. En definitiva, se plantea que el crecimiento de este tipo de iniciativas permitiría explorar otros modelos de gestión de vivienda -públicos, privados y mixtos-, y encauzar y activar la estrategia de agrupación de unidades de convivencia desarrollada en el capítulo anterior, favoreciendo así la construcción de una red de iniciativas, el 
empoderamiento social y la mejora de las políticas públicas de vivienda.

El objetivo de este capítulo es analizar una muestra del ecosistema de agentes existente, para estudiar hasta dónde está siendo capaz de actuar -y hasta dónde podría llegar-, y para demostrar que existe como tal en la actualidad y en el AMB una red de agentes de muy diversa naturaleza, dimensión y escala de actuación, con un papel alternativo en el acceso a la vivienda. Una red que está trabajando, con mayor o menor coordinación y comunicación entre sí, en búsqueda de las tres metas seleccionadas. El objeto de estudio queda definido, por lo tanto, como aquellos agentes, tanto públicos como privados, que participan en alguno de los procesos de gestión residencial centrados en el avance hacia un acceso económica y espacialmente digno, aprovechando para ello el parque residencial existente. Agentes que muestran a través de su trabajo y su planteamiento un posicionamiento socialmente responsable, alejado del modelo urbanístico e inmobiliario hegemónico. Ante dicho universo, la muestra seleccionada es resultado de una búsqueda local a partir de documentos y textos en torno a la materia. De todos los agentes localizados con previsión de que encajasen en las condiciones anteriores, la selección final ha dependido del interés de cada caso, de abarcar experiencias diversas, y de la disponibilidad de información sobre ellas. Para que este análisis sea completo se considera que, como toda alternativa, ha de ser comparado y estudiado en paralelo a lo que se opone -en este caso, el modelo inmobiliario convencional, habitual y mayormente establecido- para que los aportes sean eficaces y para poder evaluar con calidad las mejoras, las diferencias o simplemente las inercias que unos ejercen sobre otros. Este ejercicio ha quedado asegurado con el trabajo anteriormente desarrollado en los capítulos primero y segundo.

$$
-4.1 .2-
$$

\section{Desarrollo de un mapa de agentes con capacidad de transformación}

\section{Localización y selección de experiencias}

El primer paso ha sido localizar aquellas iniciativas activas en el $\mathrm{AMB}$ que, desde diferentes posiciones y esferas, tengan algún tipo de papel en la gestión de la vivienda y el acceso digno a la misma, y sea previsible que puedan incorporar algunos de las características mencionadas con anterioridad. El principal filtro a aplicar ha sido estudiar si cada una de las experiencias seleccionadas incorpora en mayor o menor medida las tres metas aquí trabajadas. La variedad de iniciativas seleccionadas va desde algunas de las principales 
Tabla 4.1. Principales funciones relacionadas con el acceso a la vivienda de los casos seleccionados en el AMB. Elaboración propia. herramientas de las políticas públicas de vivienda, a programas públicos más concretos para la movilización de vivienda libre vacía hacia el alquiler social, pasando por inmobiliarias éticas, cooperativas de vivienda, o empresas del tercer sector orientadas a la consultoría y gestión de proyectos de intervención residencial. Esto otorga tal diversidad al objeto de estudio analizado, que implica una complejidad y dificultad enorme a la hora de clasificar, categorizar y compara r los casos y agentes estudiados. Pese a ello, se dan similitudes y aspectos en común entre unos y otros que permiten dicho trabajo. Así, más que forzar una ordenación, lo que se ha realizado para ayudar a plantear un mapa de estos casos es una matriz con algunas de las principales funciones y características de los mismos (Tabla 4.1). Sin negar la posibilidad de haber dejado fuera del estudio algunos casos de relevancia, la diversidad de iniciativas lograda aporta una riqueza e interés considerable al trabajo.

\begin{tabular}{ccccc}
\hline caso & Promoción & Gestión $\begin{array}{c}\text { Movilización de } \\
\text { vivienda vacía }\end{array}$ & $\begin{array}{c}\text { Acompañamiento } \\
\text { y/o asesoramiento }\end{array}$ & $\begin{array}{c}\text { Exclusión y } \\
\text { vulnerabilidad }\end{array}$ \\
\hline esfera pública \\
\hline
\end{tabular}

Vivienda y Suelo de

Euskadi, S.A. (Visesa)

Alokabide, S.A.

Bizigune

$\mathrm{x}$

$\mathrm{X}$

Alokairu Segurua,

Arrazoizko Prezioa

(ASAP)

Jóvenes Solidarios

$\mathrm{x}$

$\mathrm{x}$

$\mathrm{x}$

Ayudas de Emergencia

Social (AES)

Prestación

Complementaria de

$\mathrm{X}$

Vivienda (PCV)

\section{Etikalia}

Urbania ZH Gestión

Sumae Coop.

Marco cooperativas de vivienda Euskadi

Etxekoop

Egunsentia Aurora

Eguzkilore

Barriztu

Renta Vitalicia

\section{esfera privada}

$\mathrm{x}$

$\mathrm{x}$

$\mathrm{X}$

$\mathrm{X}$

$\mathrm{X}$
$\mathrm{X}$

X $\quad$ X

$\mathrm{X}$

$\mathrm{X}$

$\mathrm{X}$

$\mathrm{X}$

$\mathrm{X} \quad \mathrm{X}$ 
En conclusión, el mapa que a continuación se va a presentar es, en cierta manera, una versión evolucionada y actual del marco presentado en el capítulo primero. Ya que, las iniciativas seleccionadas, trabajan en el mismo contexto y con las mismas cinco constantes obtenidas de la Tabla 1.1 para aquellos ejemplos señalados entre finales del siglo XIX y finales del XX: una problemática estructural, la permanente exclusión de clases y colectivos vulnerables, el predominio de los intereses económicos, las dificultades tanto propias como contextuales de las instituciones públicas para abordar la cuestión, y el hecho de que son múltiples y diversos los agentes que intervienen en el proceso.

\section{Fuentes utilizadas}

En un segundo paso, una vez identificadas y seleccionadas las iniciativas a estudiar, se ha analizado en cada caso de qué manera abordan -si lo hacen- cada una de las tres metas trabajadas, y con qué obstáculos se encuentran en el camino. Para ello, se ha desarrollado un proceso de trabajo centrado en el análisis documental -un análisis que ha permitido a su vez, de cara al capítulo quinto, estudiar el potencial que tienen de aprovechar los espacios de oportunidad detectados en el capítulo anterior-. Debido a la dimensión que el conjunto de experiencias seleccionadas para el análisis de esta parte del trabajo, la recopilación del material y de la información se ha limitado a documentación ya existente. Posiblemente, la realización de entrevistas a algunos de los agentes analizados podría aportar nueva y rica información sobre el papel de estas experiencias en el acceso a la vivienda, y su potencial de aprovechamiento de los espacios de oportunidad. Sin embargo, los esfuerzos y los recursos a dedicar a la investigación tienen un límite, y se ha creído que dichas entrevistas estaban más allá de él, por la dedicación que supone la preparación, desarrollo, y análisis de tanto material. El objetivo en el momento del diseño y la planificación de esta investigación ha sido lograr dibujar un mapa parcial, pero lo más general posible, del estado de este tipo de iniciativas en el AMB, aún si ello conllevase una menor profundización en cada una de ellas. Con todo, se cree que el trabajo elaborado y desarrollado en el presente capítulo constituye una interesante base sobre la que, ya sí, poder en un futuro profundizar e indagar con más detalle y nivel cualitativo en aquellos puntos y casos que interesen.

La fuente del material analizado puede clasificarse, según su tipo, en las siguientes categorías. Por un lado, está el material propio de cada caso, ya sea para su difusión, su regulación o su planificación:

- Normativa: ciertos casos estudiados están regulados por su correspondiente normativa en formato de ley, decreto, orden y/o reglamento, así como estatutos en los casos en que se trata de sociedades, asociaciones o cooperativas. A través de la misma se establecen $-\mathrm{y}$ siempre según el caso- desde los objetivos, el 
alcance, o las competencias hasta las herramientas, los criterios y condiciones de adjudicación, o el alcance de las ayudas ofrecidas.

- Documentos publicados: algunas más que otras, pero en general la mayoría de iniciativas analizadas cuentan con diverso material generado internamente que ofrece información relativa al trabajo desarrollado, su enfoque, o los servicios ofrecidos. Este tipo de documentos abarcan desde memorias anuales, documentos diversos de planificación estratégica, material de difusión, guías de funcionamiento, o cartas de servicios.

- Páginas web: una de la principal y más común fuente de datos en todos los casos es la página web, pues sintetiza mucha de la información en torno a los mismos. Se trata de una herramienta presente en la gran mayoría de ellos, y en ciertos casos se ve completada por un espacio tipo 'blog' en el que se desarrollan pequeños artículos de opinión o se exponen experiencias propias, de gran valor para el fin de este trabajo.

Por otro lado, se han utilizado otros documentos que tratan sobre los diversos casos analizados, pero esta vez están generados desde fuera de ellos de manera independiente a los mismos:

- Prensa: la recopilación de artículos de prensa comprende tanto aquellos que recogen sucesos, novedades o noticias relativas a las experiencias analizadas, como los que incorporan entrevistas o declaraciones de personas pertenecientes a dichas iniciativas, logrando así el acceso a relatos en primera persona.

- Artículos de opinión: de la misma manera que se han consultado artículos de opinión en espacios tipo 'blog' dentro de las propias iniciativas estudiadas, también se han consultado aquellos escritos desde espacios similares, pero fuera de ellas. Al tratarse de un tema de una gran relevancia social y política, la producción en este sentido es considerable.

- Artículos académicos: aunque en menor medida, también se ha localizado material académico que de forma más o menos directa hace mención a algunos de los casos, aportando así una reflexión más pausada y de mayor rigor que permite enriquecer, en los citados casos, el análisis.

Es importante recalcar que la gran parte del material analizado corresponde a la primera categoría, es decir, se trata de producción propia de las experiencias seleccionadas. El material externo localizado es cuantitativamente menor y, por lo tanto, el conjunto de información disponible ha quedado posiblemente desequilibrado hacia las primeras. Esto supone que existe la posibilidad de que, en ciertos casos, dicho material lo que exponga se trate más de intenciones o visiones algo sesgadas de logros ejecutados, ocultando o minimizando conflictos o errores en el desarrollo de su actividad. Por esta misma razón, aunque proporcionalmente ha sido una fuente más limitada, la información externa localizada ha resultado de 
considerable importancia en cuanto que ha ofrecido cierta independencia de opinión, ha permitido incorporar una visión crítica a algunos casos, $y$ ha equilibrado cierta resistencia a la crítica constructiva interna de los modelos de gestión de vivienda analizados.

\section{Metodología para el análisis de los casos}

La principal herramienta utilizada para realizar la aproximación a cada una de las diferentes iniciativas ha sido el método DAFO. Se trata de una herramienta ampliamente conocida cuyo origen se remonta a la planificación estratégica empresarial en la segunda mitad del siglo XX. Sus siglas hacen mención a cuatro atributos que son Debilidades, Amenazas, Fortalezas y Oportunidades (SWOT en inglés, de Strengths, Weaknesses, Opportunities, y Threats), y es un instrumento de gran utilidad para «estructurar el diagnóstico y como un método para conocer la situación de partida [...] antes de formular la visión estratégica» (Fernández, 2006: 199). Consta de cuatro pasos principales: los dos primeros son un análisis interno -en el que se recogen las debilidades y fortalezas-, y otro externo -para las amenazas y oportunidades-. Una vez se cuenta con dicha base de información, el siguiente paso es la confección de la matriz de cuatro celdas en la que se incluyen los aspectos seleccionados para cada atributo. El interés del método reside, especialmente, en las diferentes relaciones que se establecen entre los cuatro atributos, retroalimentándose y generando relaciones de causa-efecto entre los múltiples emparejamientos posibles (Fernández, 2006: 200). Por último, el cuarto paso es la definición de la estrategia a emplear como consecuencia del análisis cruzado anterior. A pesar de su origen empresarial y estar orientada a la mejora de la competitividad económica, se trata de una herramienta versátil con una gran capacidad de ser incorporada en procesos de reflexión y análisis de cualquier organización o proyecto, que ayuda a visualizar la situación presente y definir una estrategia futura.

Las razones para elegir esta metodología han sido principalmente dos. Por un lado, permite aglutinar en una única matriz los casos seleccionados -tanto por separado como el conjunto de ellos- y las tres metas u objetivos en los que se desea profundizar dentro de cada iniciativa. Por otro, las características de esta metodología facilita el análisis comparativo y paralelo de casos tan diversos como los estudiados, que se enmarcan tanto en la iniciativa privada como pública, se centran tanto en la gestión de la compraventa como en la autopromoción de vivienda, o abarcan tanto pequeñas futuras comunidades residenciales como políticas de vivienda autonómicas. Es decir, se ha considerado una metodología adecuada tanto por la diversidad del propio objeto de estudio, como por el deseo de abarcar tres metas de manera simultánea. Así, el trabajo se ha iniciado con una primera aproximación a cada caso, para el que se han generado las correspondientes matrices DAFO. Estas han consistido en la generación de una matriz subdivida en los cuatro grandes cuadrantes 
Esquema 4.1. Adaptación de la matriz DAFO a la investigación. Elaboración propia. establecidos por la metodología. Estos organizan la entrada de información de los casos de estudio para cada meta analizada, para lo cual cada cuadrante se ha subdividido en tres columnas, una por meta (Esquema 4.1). En este punto, el análisis se ha centrado en el posicionamiento de cada caso ante las tres metas; tanto en la definición de objetivos y propuestas para alcanzarlas, como en los obstáculos tanto internos como externos que se han ido encontrando. El trabajo anterior ha posibilitado un segundo paso, que es un análisis cruzado de las diferentes iniciativas. Para ello, todas estas matrices se sintetizan en una única común, con la intención de buscar relaciones y similitudes, así como divergencias, entre los casos. Se trata de una matriz similar a las anteriores, con la peculiaridad de que cada cuadrante quedaba subdividido en tantas filas como casos a analizar.
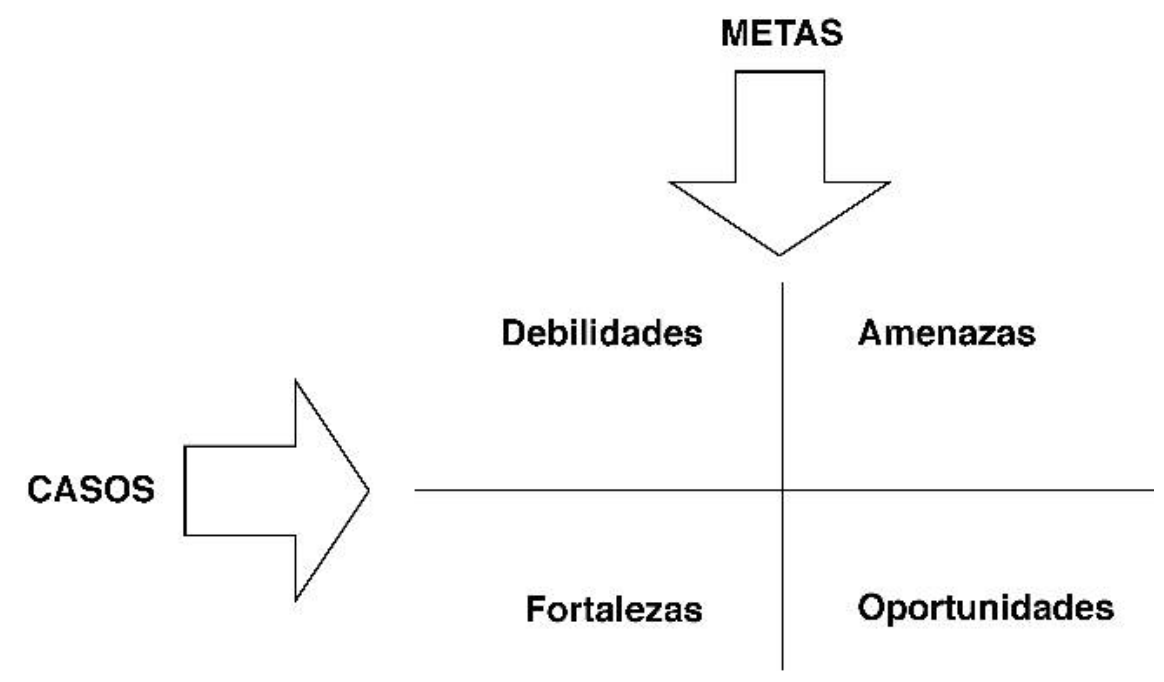

Los resultados presentados son una síntesis de las cuestiones de mayor interés detectadas de cara a la demostración de la hipótesis parcial planteada. No se plantea como una revisión descriptiva de datos sobre las viviendas manejadas, o sobre las intervenciones realizadas, si no como una revisión analítica de esas matrices. En cada caso, por lo tanto, se ha ido sintetizando el análisis diferenciando en la fase de redacción por la meta a la que se hace referencia. De esta manera, las cuestiones resaltadas no siempre hacen mención a los mismos temas. Es decir, mientras que en ciertos casos se hablará de aspectos instrumentales, en otros se hará de alianzas y colaboraciones interinstitucionales e ínter-empresariales; mientras que en unos se destacarán retos económicos para desarrollar sus objetivos, en otros se señalará un cierto posicionamiento ideológico como obstáculo interno; habrá casos en los que se crea conveniente destacar su capacidad de adaptación y evolución al contexto, y en otros será digno de mención su encaje con las políticas públicas de vivienda. Todo ello no es si no un reflejo de la ya mencionada diversidad existente en el conjunto de experiencias seleccionadas (Tabla 4.1). 


\section{$-4.2-$ \\ Características principales de las iniciativas}

El presente apartado se plantea como una primera aproximación a los casos que van a ser estudiados y desgranados a lo largo del capítulo; como forma de presentación y síntesis de sus principales características. En siguientes apartados el análisis profundizará en los aspectos que para la investigación interesan -principalmente el mayor o menor encaje de todos ellos con las tres metas planteadas, y su nivel de éxito alcanzado-. Por lo que, primeramente, se van a presentar datos más generales; información relacionada con el tipo de iniciativa de la que se trata, su misión, la institución que la promueve, su escala de intervención, un breve repaso a su trayectoria, y sus principales valores y principios. Algunas cuestiones apuntadas aquí se argumentan y demuestran en apartados posteriores. Como se ha indicado anteriormente, no se ha visto la necesidad de establecer una clasificación o categorización de estas experiencias analizadas. Pero sí ha parecido conveniente agruparlas, en esta fase del trabajo al menos, en función de ciertas similitudes propias del tipo de iniciativa correspondiente.

\section{$-4.2 .1-$}

\section{Sistema público de vivienda}

En cuanto a las políticas públicas orientadas a los tres objetivos identificados -acceso económico, adaptación tipológica y aprovechamiento de un parque infrautilizado-, estas se despliegan en diversas áreas de actuación, escalas, instrumentos, o instituciones públicas para su gestión. No se va a analizar aquí el mapa completo de las mismas, pero sí se ha creído conveniente incorporar entre los modelos y agentes locales que participan en la gestión de la vivienda con alguna influencia en uno o varios de los tres objetivos, dos importantes casos que pueden ser considerados como unos de los principales pilares de dichas políticas públicas. Se trata de las sociedades públicas Visesa y Alokabide. 


\section{Visesa}

Visesa es una sociedad publica dependiente del Gobierno Vasco, enmarcada actualmente en el Departamento de Medio Ambiente, Planificación Territorial y vivienda -según la legislatura ha ido variando, pues antes lo estuvo en el de Empleo y Políticas Sociales-. Es una de las partes principales del entramado institucional que constituye el servicio público vasco de vivienda. Su labor es participar en el desarrollo de la política territorial de vivienda y suelo en la comunidad autónoma, en colaboración con otras instituciones. Aunque también se encarga de gestionar suelo ${ }^{82}$, la principal función que aquí interesa de Visesa es la promoción y adjudicación de vivienda de protección pública destinada a aquellos colectivos con necesidad de la misma. El sistema utilizado para ello es el sorteo o la adjudicación directa, según el caso, bajo diferentes fórmulas -venta, alquiler, alquiler con opción a compra, venta con pago aplazado,... si bien en los últimos años se viene desde la política general de vivienda pública haciendo un mayor énfasis en el alquiler como herramienta-.

Alrededor de un $80 \%$ de la sociedad está participada por el propio Gobierno Vasco, estando el restante en manos de las entidades financieras Kutxabank y Caja Laboral-Euskadiko Kutxa. Su creación se remonta al año 1989, y su escala de actuación es la autonómica. Atendiendo a la presentación que de ella misma hace la sociedad en su página web, esta incorpora una serie de valores declarados, como son la responsabilidad social, la colaboración/cooperación, la transparencia, el trabajo en equipo, la adaptabilidad o la innovación, entre otros. Una responsabilidad social que aparentemente constituye «una de las líneas estratégicas de Visesa»(Visesa, 2009: 18), que se supone basada, entre otras premisas, en un "comportamiento ético» (Visesa, 2006: 28), y enmarcada en una «triple perspectiva económica, social y ambiental» (Visesa, 2012:10). Y sin embargo, algunos conflictos propios del sistema público de vivienda que chocan con estas afirmaciones han sido ya apuntados previamente: no cuantificar a las personas sin capacidad de demanda como necesidad de vivienda, o la incapacidad económica, por parte de muchas unidades de convivencia que han resultado adjudicadas, de costear la compra o alquiler de una vivienda protegida.

En cuanto a la colaboración, la cooperación, el trabajo en equipo o la innovación -en lo que a los objetivos analizados se refiere- se verá que, efectivamente, se trata de valores incorporados en el funcionamiento de Visesa en diferentes esferas. Pero también que los resultados obtenidos y la prácticas realmente desarrolladas ofrecen un gran margen de mejora en estas cuestiones. No se pone en duda que todos estos valores no cuenten con un alto nivel de apoyo y sean

${ }^{82}$ Lo hace desde que en 2016 se fusionaron Visesa y Orubide, absorbiendo la primera a la segunda. Orubide era una sociedad pública igualmente dependiente del Gobierno Vasco y orientada a la adquisición, gestión y urbanización de suelo residencial para la construcción de vivienda protegida, cuyas competencias pasaron a integrarse en Visesa. 
ambicionados con sinceridad desde la sociedad pública. Sin embargo, lo que en este capítulo se va a pretender plantear es que sus estructuras internas de funcionamiento, sus métodos y el marco de sus actuaciones, simultáneamente, están inmersas con profundidad en, forman parte de, y dependen totalmente del modelo hegemónico analizado en la primera parte del trabajo. Con lo cual, muchos de estos valores se van a ver reducidos a meras intenciones o van a ver sus logros minimizados por los obstáculos y condicionantes -muchos de ellos internos- ya presentados con anterioridad.

\section{Alokabide}

Al igual que Visesa, Alokabide es otra parte sustancial del entramado del sistema público vasco de vivienda. Y por lo tanto, igualmente dependiente del Gobierno Vasco. En este caso, su labor fundamental es el desarrollo de la función social de la vivienda a través de la política de alquiler. Esto se concreta principalmente en la gestión del parque propio o de terceros, siempre en dicho régimen de tenencia, y en la coordinación de los programas de movilización de vivienda libre vacía. El método utilizado para las adjudicaciones y puesta en carga de dichas viviendas sigue un sistema de puntuaciones y criterios en orden de preferencia que evalúan la antigüedad de la inscripción, el número de miembros de la unidad convivencial, y si existe, la especial necesidad de vivienda según unos perfiles tipificados. El recorrido y experiencia de Alokabide es menor que el de Visesa, pues la sociedad fue constituida en el año 2000. Su escala de intervención es igualmente la totalidad de la comunidad autónoma vasca.

Entre los valores que en el Marco Estratégico 2013-2016 se adscribían a la entidad, estaban la orientación al cliente - «dando respuesta a sus necesidades y considerando de forma específica aquellos colectivos con especiales dificultades» (Alokabide, 2012: 7)-, la innovación, la flexibilidad « «que se adapta a los nuevos cambios, garantizando el nivel de servicio y dando respuesta en cada momento a los retos que a la organización se le plantean» (Alokabide, 2012: 8)-, la coordinación, o la colaboración - estas dos últimas principalmente entre las diferentes sociedades públicas, y también con otras instituciones privadas-. Al igual que en el caso anterior, la a priori asunción de estos y otros valores en el trabajo desarrollado por Alokabide no implica que todos sus resultados puedan enmarcarse en actuaciones que los incorporen. Como se ha venido y se continuará argumentando, las necesidades de muchas unidades de convivencia con necesidad de vivienda no están ni económica ni tipológicamente cubiertas por un modelo de vivienda que no es capaz de reducir los costes de acceso, ni acaba de mirar más allá de la superficie del inmueble, el número de dormitorios o de componentes de la unidad convivencial. La flexibilidad e innovación defendidas no parecen suficientes para resolver los problemas existentes en los programas de movilización de vivienda vacía que se nombran a continuación, y que 
se detallarán más adelante. Problemas con un dudoso éxito y un alto coste económico.

\section{Bizigune}

El primer programa para la movilización de vivienda libre vacía hacia la oferta de alquiler protegido puesto en marcha desde las instituciones públicas vascas a escala autonómica fue Bizigune. Con el objetivo planteado en el Plan Director de Vivienda 2002-2005 de movilizar 5.000 viviendas en su periodo de vigencia -decisión motivada por los datos disponibles en aquel momento, que estimaban más de un $10 \%$ del parque residencial de Euskadi vacío o desocupado-, por iniciativa de la Consejería de Vivienda y Asuntos Sociales se aprobó en 2002 esta iniciativa, originalmente llamada Programa de Vivienda Vacía. El procedimiento de adjudicación es similar al general establecido por el sistema de vivienda pública, debiendo como requisito fundamental formar parte del registro de solicitantes de vivienda de protección oficial -y por lo tanto cumplir las condiciones para considerar que hay una necesidad de vivienda no cubierta por el mercado-. Para acceder al programa en cuestión como solicitante de vivienda, se ha de solicitar expresamente el interés de participar en él.

Teniendo por un lado la base de datos de las personas y unidades de convivencia interesadas, y por otro las viviendas procedentes de particulares o entidades privadas que desean poner a disposición de la administración pública sus viviendas deshabitadas, esta se encarga tras la correspondiente cesión en usufructo- de gestionar y adjudicar las mismas. Y lo hace según un sistema de baremación a partir de los datos disponibles en el registro de solicitantes, a cambio de una renta proporcional a los ingresos de la unidad de convivencia correspondiente. En origen, la gestión del programa estuvo en manos de Visesa, tal y como quedó establecido en el Decreto que lo promovió, impulsó y estableció su régimen jurídico. Esto fue hasta el año 2007, cuando se creó la Sociedad Pública de Gestión de Vivienda en Alquiler (SPGVA), a la cual fue traspasada la competencia de dicho programa. Desde 2011, con la fusión de la SPGVA con Alokabide, es esta última la sociedad que viene gestionando el programa Bizigune hasta la actualidad. Es, por tanto, un programa orientado a la totalidad de la comunidad autónoma, si bien existen definidas por el Gobierno Vasco ciertas áreas prioritarias, ya sea motivadas por el número de viviendas vacías que albergan, o por el número de solicitantes de vivienda protegida existentes en las mismas.

Podría decirse que el principal valor que incentiva este programa es la función social de la vivienda, pues a través de él se pretende responder a dos problemas: la necesidad de vivienda de aquellas personas con dificultades económicas para satisfacerla en el mercado libre, y la socialmente difícil de asumir existencia de viviendas vacías en un contexto de conflictos demográficos, territoriales, ambientales y 
económicos que hacen cuestionar la nueva construcción de ciudad residencial -habitualmente, además, bajo modelos urbanos poco amables y con una baja mezcla de usos-. Aunque se podrían identificar algunos otros valores de interés: la colaboración y convergencia público-privada bajo intereses no lucrativos, la eficiencia del patrimonio construido, o la sensibilización de la problemática por parte de la sociedad.

\section{ASAP}

Como se detallará más adelante, por motivos de sostenibilidad económica y relativo éxito del programa Bizigune, diez años después se puso en marcha un segundo, denominado ASAP (Alokairu Segurua, Arrazoizko Prezioa ${ }^{83}$ ). Cuenta con un mismo ámbito de actuación autonómico, un fundamento y un fin similar -la incorporación de vivienda vacía privada a un mercado de alquiler asequible, destinada a aquellas personas inscritas en el registro de solicitantes de vivienda protegida y con una voluntad expresa de participar en el programa-. Pero la diferencia sustancial entre este y el anterior radica en que, mientras en Bizigune se subvenciona parte de la renta a la unidad de convivencia, en ASAP se hace un llamamiento a que la propiedad se sensibilice ofreciendo una renta asequible, a cambio de lo cual la administración ofrece una serie de garantías y una gestión completa del proceso. Gestión que puede ser desarrollada, bien por Alokabide, o bien por una figura creada al efecto como son los Agentes Colaboradores en la Intermediación. Así mismo, en este caso el contrato de arrendamiento lo firman la propiedad y la unidad convivencial, mientras que en el caso anterior lo hacía Alokabide como usufructuaria de la vivienda.

\section{$-4.2 .2-$ Agentes privados}

Hasta este punto, han sido citados algunos de los instrumentos con los que cuenta la administración pública, diseñados y en activo, para el desarrollo de sus políticas de vivienda protegida. Pero, por supuesto, las instituciones públicas no son el único agente en busca de y con capacidad para generar una oferta de vivienda adecuada y asequible. Así, una búsqueda local ha permitido localizar e identificar otros agentes que desde la esfera privada -aunque con una escala y capacidad de influencia claramente menor no comparable a las estructuras, medios humanos y recursos económicos del Gobierno Vasco-, trabajan con la firme creencia de que la vivienda como

83 Alquiler Seguro, Precio Razonable, en castellano. 
derecho básico no está plenamente garantizado por el modelo inmobiliario-urbanístico actual. Por lo que desarrollan diversas estrategias y ofrecen diferentes servicios en búsqueda de la materialización de dicho derecho bajo unas condiciones económicamente dignas y espacialmente adecuadas.

\section{Sumae Coop.}

En primer lugar se han identificado dos casos de empresas de servicios profesionales. La primera de ellas es Sumae, una pequeña cooperativa «especializada en asesoría y gestión de proyectos para el sector público, el tercer sector y el cuarto sector emergente» (Sumae, 2016). Su oferta de servicios contempla la consultoría, gestión, formación y asistencia técnica en cinco áreas de trabajo: economía, gestión pública, sociedad, vivienda y sostenibilidad. Su posicionamiento es, según el mensaje transmitido en su estrategia de comunicación, el de una empresa social y ambientalmente comprometida, consciente del contexto complejo y las desigualdades sociales reflejadas en el mercado de trabajo, la convivencia y la necesidad de intervención socio-urbanística. A pesar de que se observan algunas contradicciones habituales de un lenguaje que incorpora conceptos complejos sin una aparente comprensión ni asunción profunda de su significado ${ }^{84}$ (Naredo, 2004b), cuentan con un planteamiento de valores de gran interés, tanto por el ya citado posicionamiento responsable, como por tratarse de una cooperativa sin ánimo de lucro.

\section{Urbania ZH Gestión}

El segundo caso en este tipo de agentes es el de Urbania ZH Gestión. Se trata de una empresa creada en 2012, pero que cesó su actividad en 2015-2016 -formaba parte del Grupo Zahoz, inmerso en un concurso de acreedores y que cuenta con deudas, quiebras, impagos y otros conflictos ${ }^{85}$ - y dedicada a la prestación de servicios

${ }^{84}$ Desde su área de sostenibilidad y medio ambiente ofrecen «políticas y prácticas capaces de generar empleo estable y de calidad sin comprometer la conservación del medioambiente. Proponemos alternativas de crecimiento basadas en la participación de la sociedad y en promover el conocimiento y el respeto por el medioambiente» (Sumae, 2016). Pero un planteamiento sincero de la sostenibilidad parece poco compatible con el mantenimiento, aún incorporando medidas alternativas, de un crecimiento en el sistema social y económico actuales.

85 Crónica Global (2019): «El turbio pasado empresarial de Javier Burón, gerente de Vivienda de Colau», disponible en: https://cronicaglobal.elespanol.com/politica/buronpasado-empresarial-gerente-vivienda_218673_102.html.

El Telescopio Digital (2019): «Ganar Torrejón estudiará si se ha podido cometer un delito contra la Hacienda Pública en la gestión de la EMVS», disponible en: http://www.eltelescopiodigital.com/index.php/politica-torrejon/49339-ganar-torrejonestudiara-si-se-ha-podido-cometer-un-delito-contra-la-hacienda-publica-en-la-gestion-de-laemvs.html. 
de gestión, consultoría y formación a entidades del sector público, cooperativas y la economía social. Su objetivo era el de mejorar la eficacia y la eficiencia de los servicios públicos, cooperativos y sin ánimo de lucro, y gestionaban todo tipo de operaciones urbanoresidenciales tanto en la zona cantábrica como a lo largo del corredor del Ebro. Su principal valor añadido era su planteamiento de facturación por sus servicios: esta se producía «en la medida en que conseguimos mejoras contrastables en la gestión: aumento de la satisfacción de los usuarios, a través de reducciones de costes, generación de ingresos adicionales, ampliaciones de servicios, etc» (Urbania, 2016a). Su posicionamiento era, por lo tanto, el de no acceder a las plusvalías generadas por los servicios prestados en el ámbito urbanístico y residencial, actuando desde la cooperación público-privada. Enmarcada en un modelo de empresa de ánimo de lucro limitado, no realizaba reparto de dividendos, si no que los beneficios se reinsertaban en la propia empresa, con la intención de fomentar la responsabilidad social corporativa de las empresas privadas (Urbania, 2016b). Así mismo, entre los principios en los que se enmarca la labor de esta empresa, según su material de difusión, está el trabajo en red, el fomento de lo común, la ética del trabajo, el trabajo abierto, colaborativo y cooperativo, la convergencia de la acción pública y la privada, la triple cuenta de resultados o la búsqueda del beneficio público.

\section{Marco para cooperativas de vivienda en Euskadi}

Continuando en la esfera privada, otro de los modelos a estudiar va a ser el marco existente para la formación de cooperativas de viviendas en Euskadi. No se trata de una iniciativa concreta, pero se ha creído conveniente incorporar al análisis este contexto, por su relevancia de cara a otras posibles alternativas de gestión. Como se desarrollará más adelante, algunas personas con experiencia en este tipo de fórmulas residenciales en España detectan con facilidad dos tipos de cooperativas, diferenciando las 'falsas' de las 'verdaderas'. Las primeras son iniciativas que aprovechan ciertas ventajas económicas que ofrece el modelo cooperativo para acceder a un producto inmobiliario que, más allá de su precio, poco tiene de interés respecto a la oferta libre habitual en el mercado. Mientras que las segundas se identifican por contar con una creencia profunda en los valores cooperativos, y por incorporar y mantener estos en todo la vida útil de un proyecto a largo plazo. Como tales, las cooperativas de viviendas siguen un modelo de «sociedad constituida por personas que se asocian, en régimen de libre adhesión y baja voluntaria $[. .$. encaminadas a satisfacer sus necesidades y aspiraciones económicas y sociales, con estructura y funcionamiento democrático»; en este caso,

Cuellar7.com (2016): «Se agrava el conflicto de las trabajadoras de la limpieza de los colegios de Cuéllar», disponible en: http://cuellar7.com/las-trabajadoras-de-la-limpieza-delos-colegios-siguen-sin-cobrar-sus-salarios/38111/. 
«asocian a personas físicas que precisen alojamiento y/o locales para sí y las personas que con ellas convivan» (Ley 27/1999, de 16 de julio, 1999). Pueden tener como objeto desde la promoción y edificación de viviendas y locales hasta la adquisición, parcelación y urbanización de terrenos, pasando por la rehabilitación de inmuebles. El modelo que en el contexto de este trabajo interesa es aquel que, más allá de buscar un acceso económico digno a la vivienda, tiene entre sus objetivos otras cuestiones como la formación, el cuidado y el desarrollo de una comunidad de personas con deseo de compartir una serie de espacios e inquietudes, el fomento de la convivencia, y las relaciones de cercanía. Además, muchos de los proyectos que siguen estas pautas incluyen con frecuencia otros valores de gran interés de ámbito social, medioambiental, educativo.

\section{Etxekoop}

En esa precisa línea es donde se enmarca uno de los proyectos de cooperativa residencial existentes en la actualidad en el AMB. Se trata de Etxekoop, una asociación que busca fomentar la creación de cooperativas de vivienda en régimen de cesión de uso bajo el modelo Andel ${ }^{86}$. Aún sin haber logrado formalizar sus intereses en un proyecto concreto, el grupo lleva varios años trabajando, aprendiendo, organizando charlas y pequeños encuentros formativos sobre el tema, y manteniendo el contacto con otras iniciativas similares del Estado como SostreCivic - de la que es socio-. Por otro lado, a pesar de su pequeño tamaño, está participando como agente social en el diseño de las políticas públicas de vivienda del Gobierno Vasco, con la intención de cambiar el modelo predominante actual. En los textos de difusión y divulgación generados por este grupo se pueden encontrar conceptos como la facilitación grupal, la interculturalidad e intergeneracionalidad, el apoyo mutuo, o el presumo colaborativo. Se trata de una iniciativa sin ánimo de lucro, con un alto componente social, y una asimilación profunda de determinados objetivos de sostenibilidad y convivencia.

86 Un modelo de creciente aceptación y desarrollo en España: «Los ANDEL no son sino un modelo de cooperativas de cesión de uso desarrollado en Dinamarca y que parece estar teniendo buena aceptación en otras partes de Europa, fundamentalmente. Las cooperativas de cesión de uso, sin embargo, no solo se contemplan ya en nuestra legislación cooperativa y de protección pública a la vivienda como forma de acceso a una vivienda sino que responden mejor que ningún otro modelo a los principios cooperativos regulados en el artículo 7 del Reglamento de la Alianza Cooperativa Internacional: puerta abierta, democracia, participación económica, autonomía e independencia, educación, cooperación e interés por la comunidad. Y subrayamos que es el modelo cooperativo que mejor encaja en el espíritu cooperativo por cuanto permanece en el tiempo, al contrario que las cooperativas ad hoc que pierden su objeto social, desapareciendo, con la adjudicación de las viviendas a sus socios en propiedad». Obtenido de Una nueva cultura de la vivienda: el modelo ANDEL, disponible en https://sostrecivic.coop/modelo-andel. 


\section{Egunsentia Aurora}

Como una variante de este tipo de proyectos, o como una opción específica para un perfil de personas concreto, existen los habitualmente denominados 'co-housing senior'. De lo que se trata, en la mayoría de los casos, es de cooperativas de viviendas en régimen de cesión de uso con la salvedad de que están orientadas -y por lo tanto específicamente adaptadas para responder a sus necesidades concretas- a personas mayores, entendiendo estas como aquellas comprendidas entre los 50 y los 70 años. En el AMB se pueden encontrar casos de este tipo, como el de Egunsentia Aurora. Tal y como se autodefinen, se trata de una asociación sin ánimo de lucro cuyo fin es promover o adquirir conjuntos de viviendas, en inmueble único, para personas mayores en régimen de cesión de uso, como instrumento para la provisión de atención y asistencia integral de dichas personas, mediante la creación de un centro residencial y asistencial. Y todo ello bajo el modelo Andel. Al igual que en el caso anterior, todavía no han logrado formalizar su proyecto en un inmueble concreto, pero llevan un tiempo formándose, estudiando diferentes opciones, y colaborando con otros agentes -públicos y privados- que permiten facilitarles el proceso. Precisamente, es la colaboración uno de los principios clave que puede identificarse en la documentación disponible sobre su proyecto, junto con la participación, comunicación, ayuda mutua, la creación de comunidad, la búsqueda de una estructura no jerárquica, una gestión democrática, el no ánimo de lucro, el respeto, la tolerancia e incluso la libertad.

\section{$-4.2 .3-$}

\section{Programas de urgencia social}

De vuelta a la esfera pública, en el proceso de análisis de agentes participantes en la gestión del acceso a la vivienda también se ha analizado el papel de ciertas estructuras públicas de respuesta a situaciones de alta vulnerabilidad social con incidencia en el ámbito residencial.

\section{AES}

Una de ellas es las denominadas Ayudas de Emergencia Social (AES), definida como una prestación económica subvencional del Sistema Vasco de Garantía de Ingresos e Inclusión Social. Está orientada a la cobertura de gastos no periódicos de aquellas personas integradas en una unidad de convivencia cuyos recursos resulten insuficientes para hacer frente a gastos específicos, de carácter ordinario o extraordinario, necesarios para prevenir, evitar o paliar situaciones de exclusión social. Aunque, en la práctica, se han 
destinado frecuentemente a sufragar el gasto de la vivienda. Este programa viene establecido por su normativa correspondiente a través de la Ley 18/2008 para la Garantía de Ingresos y para la Inclusión Social, y el Decreto 4/2011 de las Ayudas de Emergencia Social, así como las correspondientes órdenes y normativa complementaria. Un marco que establece, además del propio funcionamiento y motivación de las mismas, las condiciones y criterios para acceder a ellas, las cuantías máximas o el límite presupuestario anual, entre otras cuestiones.

\section{PCV}

En el mismo marco de la Ley 18/2008, y desarrollada en el Decreto 2/2010, existe otra herramienta que también puede categorizarse como para responder a situaciones de urgencia social, que es la Prestación Complementaria de Vivienda (PCV). En este caso, se trata igualmente de una prestación económica de derecho del Sistema Vasco de Garantía de Ingresos e Inclusión Social aunque, a diferencia de las AES, es periódica y complementaria. Su finalidad es facilitar a las personas más necesitadas -es decir, a las titulares de la Renta de Garantía de Ingresos ${ }^{87}$ - el acceso a la vivienda. De este modo, se intenta a su vez devolver a las AES su carácter original ya que, aunque estas fueron diseñadas como un instrumento de cobertura de gastos principalmente extraordinarios, se ha producido «una deriva que, por razones de necesidad, había llevado, con el curso de los años, a que las Ayudas de Emergencia Social adquirieran, en la práctica, un carácter periódico y se destinaran, en una elevadísima proporción, a la cobertura de gastos de vivienda» (Decreto 2/2010, de 12 de enero, 2010).

En este sentido, la PCV busca aportar una respuesta estable, aunque transitoria, a un problema de naturaleza estructural hasta que pueda ser este susceptible de un abordaje más integral desde una política pública de vivienda, y queden de esta manera las AES y la RGI como elemento fijo del propio sistema de garantía. Es decir, que «esta prestación sólo permanecerá integrada en el Sistema Vasco de Garantía de Ingresos e Inclusión Social en tanto no se articulen, en el marco de la política pública de vivienda, medidas análogas o de otra naturaleza que den cobertura a la misma necesidad de acceso a la vivienda de los colectivos más vulnerables y desfavorecidos» (Ley $18 / 2008$, de 23 de diciembre, 2008). Con todo, el sistema funciona desde una perspectiva global, y lo anterior no significa que bajo este marco regulatorio los gastos relacionados con la vivienda no tengan cabida en las AES, «sino que sólo podrán atribuirse para la cobertura de dichos gastos a personas que no sean titulares de la Renta de Garantía de Ingresos» (Decreto 2/2010, de 12 de enero, 2010). Entre

\footnotetext{
${ }^{87}$ La conocida como RGI es otra de las piezas fundamentales de la estructura del Sistema Vasco de Garantía de Ingresos, a su vez desarrollada por el Decreto 147/2010.
} 
los principios por los que se rige el Sistema Vasco de Garantía de Ingresos e Inclusión Social, tal y como queda establecido en la Ley 18/2008, están la responsabilidad pública, universalidad, igualdad, equidad, solidaridad, participación o la perspectiva de género.

\section{Eguzkilore}

Dentro del ámbito de los programas e iniciativas destinadas a luchar contra la exclusión social residencial y orientadas a situaciones de urgencia, también se dan en el AMB casos fuera de la esfera pública, promovidos y gestionados por entidades privadas de diferente naturaleza. Eguzkilore es un buen ejemplo de las mismas. Se trata de una fundación perteneciente a Cáritas Bizkaia y creada en 2013. Su fin es la extensión del derecho humano básico y fundamental de la vivienda a aquellas personas con mayor situación de vulnerabilidad, y en proceso de inclusión social. Ofrecen asesoramiento en materia de vivienda, la posibilidad de alojamiento en un parque propio o cedido, y acompañamiento social y familiar. A pesar de contar con unos medios limitados y una capacidad de respuesta cuantitativamente mucho menor que la estructura de garantía pública del Gobierno Vasco, cuenta con el respaldo de una organización asentada, con experiencia y de relativa fortaleza local como es Cáritas, asociada a la Iglesia Cristiana. Por lo que es capaz de ofrecer una respuesta cualitativamente interesante, y lleva varios años trabajando con grupos de personas en situación de vulnerabilidad para avanzar hacia su inclusión. Los valores en los que se centra Eguzkilore son la prioridad en las personas, la solidaridad -algunas de las viviendas con las que cuenta son cedidas gratuitamente o a cambio de una cantidad económica simbólica-, el enfoque comunitario, y una perspectiva transformadora de la sociedad.

\section{Barriztu}

También bajo la promoción y gestión de Cáritas Bizkaia -en este caso por el Área de Personas Mayores- el programa Barriztu es uno de los casos seleccionados. En este caso, el objeto del mismo difiere del que comparten la mayoría de iniciativas estudiadas en este trabajo. Mientras las anteriores buscan el acceso a una vivienda para aquellas personas con dificultades económicas, a las que en ocasiones se suman carencias tipológicas, el fin último del programa Barriztu es la intervención en situaciones de vulnerabilidad residencial de personas mayores que, aún contando ya con una vivienda propia, su situación personal y/o económica impiden adecuarla o mantenerla en unas condiciones dignas de habitabilidad y seguridad. De manera coordinada con otros agentes públicos y privados, la iniciativa trabaja a lo largo de un proceso de detección e identificación, estudio de propuestas, ejecución de las obras necesarias y acompañamiento tanto durante el propio proceso como después de la propia intervención. Como en el caso anterior, a pesar de ser un programa humilde, de 
escala reducida y local, sus resultados son de gran interés, pues desde sus inicios en 2008 hasta 2016 se intervinieron 132 viviendas -99 de ellas habitadas por mujeres-.

\section{Otros caminos}

Por último, se han analizado también una serie de casos que, aunque no encajan de manera clara en las categorías anteriores, presentan unas características de considerable interés de cara a avanzar hacia las metas principales de esta investigación.

\section{Jóvenes Solidarios}

Uno de estos es el programa Jóvenes Solidarios. Se trata de una iniciativa que comenzó a funcionar en 2010 -y desde entonces lo hace cada año-, promovida por la Universidad del País Vasco/Euskal Herriko Unibertsitatea y el Ayuntamiento de Bilbao, y llevado a cabo a través de la sociedad pública Viviendas Municipales de Bilbao. Con el apoyo del programa europeo Rehabitat, el programa ofrece viviendas de bajo coste a estudiantes de posgrado menores de 35 años, a cambio de su integración positiva y constructiva en la vida de los barrios y las comunidades en las que se lleva a cabo el programa; concretamente, en Otxarkoaga y Bilbao La Vieja. Con esto se actúa en dos frentes. Por un lado, el acceso a la vivienda por parte de un sector de población que, en muchos casos, carece de medios suficientes para acceder a un mercado de alquiler -el de Bilbaolimitado y de baja calidad. Por otro, la construcción de una comunidad de barrio más cohesionada. Así, valores como la solidaridad, la integración, la convivencia o el intercambio de intereses con un fin social, pueden encontrarse en este tipo de propuestas.

\section{Etikalia}

Otro de los agentes locales del AMB que presenta un gran atractivo y un alto potencial para hacer aportes a las metas de acceso económico y espacial dignos es Etikalia. Puesta en marcha en 2014 por personas que, entre otras experiencias, venían de dirigir durante diez años desde el sector público el programa Bizigune-, se autodefinen como una empresa privada de servicios inmobiliarios apoyada en principios éticos e innovadores, que busca facilitar el derecho a tener una vivienda digna desde dicho sector, introduciendo la visión ética en el mismo. Su planteamiento está basado en la triple cuenta de resultados, es decir, en buscar un equilibrio entre los resultados económicos -es una empresa sin ánimo de lucro y por lo tanto las ganancias se reinserten en la propia actividad; «No pagamos 
por invertir dinero, sino por trabajar. A partir de ahí, los resultados económicos no son un fin, sino un medio para tener un impacto positivo en la sociedad y en el medio ambiente. Como nos ha dicho algún amigo, somos una empresa "con ánimo de sueldo"» (Etikalia, 2016)-, el aporte a la sociedad facilitando el acceso a una vivienda digna y generando empleo de calidad, y la reducción del impacto ambiental de la propia actividad centrándose en el aprovechamiento del parque construido.

Esta propia estructura de trabajo ya muestra cuáles son los principales valores que acompañan el proyecto, a los que se suman otros. Como la responsabilidad social y empresarial de no participar en operaciones especulativas, y el hecho de renunciar a obtener beneficios económicos a costa de sus trabajadores. También, la búsqueda de acuerdos entre iguales evitando posiciones de poder combinando «el problema de quien necesita una vivienda con el de quien tiene una vivienda vacía y buscamos soluciones que permitan anular mutuamente ambos problemas dando soluciones satisfactorias para todas las partes implicadas» (Etikalia, 2016)-, la innovación y la búsqueda constante de la mejora en los servicios ofertados a través del diálogo con la clientela, el fomento de la inversión privada con una sensibilidad social incorporada, o una estrategia basada en el código abierto - «compartimos nuestras ideas y formas de trabajo de forma abierta con quienes piensan como nosotros: no tenemos miedo a que nos copien, sino que deseamos que lo hagan para tener un mayor impacto positivo en la sociedad, abarcar un mercado mayor y generar más puestos de trabajo» (Etikalia, 2016)-. Como se verá más tarde, el camino que han elegido no es desde luego fácil en un mundo generalmente muy distante de dichos principios y valores. Las dificultades y los obstáculos detectados les han llevado a ir adaptando el modelo de negocio, pero siempre manteniendo de una manera clara sus objetivos iniciales fundamentales.

\section{Renta Vitalicia y Alquiler Garantizado}

Por último, se ha analizado también un modelo de gestión de la vivienda privada que, a pesar de abordar esta desde una perspectiva inversora, ofrece posibilidades de mejorar la calidad de vida residencial de ciertos perfiles de unidades de convivencia. Se trata de

la denominada Renta Vitalicia Inmobiliaria y la Compraventa con Alquiler Garantizado, dos opciones que comparten un fundamento común: la compra de la vivienda de una persona mayor de 65 años, de manera que esta pueda seguir habitando la que hasta entonces ha sido su vivienda y a su vez acceda al valor económico estimado para la misma. Valor que puede servir en determinados casos para afrontar situaciones de posible vulnerabilidad o exclusión social debido a situaciones económicamente precarias. Esto posibilita el uso de la vivienda habitual con una calidad de vida digna. En el AMB existen algunos agentes dedicados a la gestión de este tipo de servicios, poniendo en contacto a la parte inversora con la parte usufructuaria, 
como es el caso de la empresa Grupo Retiro -activa desde 1996-, que es de la cual se ha obtenido y analizado la información correspondiente, u otras como Kategora o Inverpremium.

La opción de la renta vitalicia consiste en la «compra de la nuda propiedad de la vivienda de un Persona Mayor de 65 años, reservándose esta persona el derecho de usufructo de la vivienda hasta su fallecimiento, momento en el que el Inversor pasa a disponer de la plena propiedad del inmueble» (Grupo Retiro, 2016). No obstante, existen diferentes opciones que van desde la compra a cambio del pago de una renta mensual, del pago durante un tiempo diferente establecido, o a cambio de un pago único. La persona o entidad inversora se hace cargo de los gastos inherentes a la nuda propiedad, quedando en manos de la persona usufructuaria los propios de la comunidad y los consumos de suministros de la vivienda. La opción del alquiler garantizado plantea la compra de este tipo de viviendas con el objetivo de rentabilizarlas económicamente mediante el alquiler, pero contando desde el primer momento con una persona inquilina, que en este caso es la anterior propietaria de la misma. De manera que «de forma simultánea a la firma de la Escritura de Venta, se formaliza un Contrato de Alquiler con el comprador hasta su fallecimiento (modalidad vitalicia) o por el plazo que la Persona Mayor estime oportuno» (Grupo Retiro, 2016).

A pesar de contar con un evidente potencial de mejora de la calidad de vida de ciertos perfiles de población, se trata de un modelo que ha de analizarse con cautela, pues ante todo busca la rentabilidad de la inversión inmobiliaria -en la documentación de Grupo Retiro se anuncia como una inversión que «proporciona unas magníficas rentabilidades» (Grupo Retiro, 2016)-. Con lo que pueden darse casos en los que la presión de la parte inversora para rebajar al máximo los precios de las viviendas a una propiedad en situación de precariedad económica -y necesidad relativamente urgente de generar ingresos-, pueda convertirse en una herramienta para infravalorar la vivienda. En el caso de la Compra con Alquiler Garantizado, la presión queda patente en el propio planteamiento del modelo: «a partir de los precios de venta y de alquiler de la vivienda, se analiza la rentabilidad que tendrá la operación para el comprador, garantizando que la misma se ajuste al máximo a las rentabilidades medias de alquiler de viviendas en la zona. Esto implica que en determinadas operaciones, los precios de venta de estos inmuebles lleven un descuento de entre un $10 \%-25 \%$ respecto al precio de mercado, para alcanzar las rentabilidades demandadas por los inversores» (Grupo Retiro, 2016).

La estructura del resto de los apartados, del 4.3 al 4.6, se ha planteado a modo de primera presentación de los resultados obtenidos y como un repaso del posicionamiento y la actividad desarrollada por los agentes seleccionados en relación a las tres principales metas identificadas. Se trata de una síntesis de los 
resultados generados a partir de la aplicación del método DAFO apuntado al inicio del capítulo. Es posible que llame la atención un cierto desequilibrio cuantitativo respecto al contenido presentado en las diferentes iniciativas. Esto se debe al hecho de haber contado con más o menos información y datos para el análisis. Sin embargo, los resultados logrados se cree que alcanzan un nivel suficiente de profundidad como para dar por válido el ejercicio, teniendo en cuenta que este se plantea como el desarrollo de un mapa de agentes y no un estudio comparado de casos. La clasificación realizada en este apartado en cuatro grandes grupos se refleja en los siguientes, al final de cada cual se sintetizará y reflexionará sobre lo encontrado en cada categoría. 


\section{$-4.3-$ \\ Sistema público de vivienda}

Como ya se ha avanzado, el entramado, competencias y alcance del sistema vasco de vivienda es amplio y diverso. Para el fin de esta investigación, se han analizado de manera parcial y específica algunas de las instituciones que lo conforman, o algunos de los programas que este desarrolla. No son estas las únicas herramientas que el citado sistema tiene para avanzar hacia los objetivos aquí marcados. Pero probablemente sí son una buena representación de la fortaleza y éxito alcanzados a lo largo de los años.

\section{$-4.3 .1-$ \\ Visesa}

\section{Mirando hacia un derecho constitucional no resuelto}

Dentro del objeto social de esta sociedad pública se contempla que las actuaciones y servicios ofrecidos dentro de su competencia serán adecuadas a las exigencias sociales de Euskadi (Decreto 96/2011, 2011: 4), de lo que se interpreta que en materia de vivienda esta institución tiene una predisposición por abordar, con cierta sensibilidad y capacidad de adaptación al contexto, la problemática residencial correspondiente a cada tiempo. A la hora de analizar las fortalezas adquiridas por esta sociedad -y en ese marco de actuaciónen lo que al acceso económico se refiere, se ha de comenzar señalando que parte de su misión es generar las condiciones necesarias para proporcionar, a aquellas personas que lo necesiten, viviendas a unos precios y a unas condiciones de financiación asequibles, con el objetivo de hacer efectivo el derecho constitucional de acceso a una vivienda (Visesa, 2006: 28). Este horizonte no ha dejado de ser prioritario en la empresa, ya que tal y como se afirma «es el motor que no podemos perder de vista en cada una de las tareas que desarrollamos [...] es la razón de ser de nuestro trabajo» (Visesa, 2009: 18). Consecuentemente, ha desarrollado en los últimos años herramientas como el Plan Estratégico 2013-2016, en sintonía con instrumentos de gobierno y desarrollo de políticas públicas superiores como fueron el Plan Director de Vivienda 2013-2016 y el propio Programa de Gobierno 2012-2016 del Gobierno Vasco. En dicho plan, se marcaba la estrategia de esta sociedad pública para esos 
cuatro años, y el primero de los cinco ejes de trabajo, «marcados por la coyuntura económica y social vivida en los últimos años y que afecta de forma directa a su actividad» (Visesa, 2013a: 5), se centraba en responder a las necesidades de vivienda de la ciudadanía vasca para facilitar el acceso a la misma.

\section{La promoción asequible como línea de trabajo}

De una manera más concreta, Visesa dispone de instrumentos específicos para intentar llevar a cabo ese ambicioso objetivo constitucionalmente sustentado. Una de ellos es la competencia otorgada a la sociedad pública para la gestión, en régimen de alquiler, de viviendas; tanto las que conforman el patrimonio social como las «que le fueren adscritas por cualquier título de cesión, para esta misma finalidad locaticia» (Decreto 96/2011, 2011: 4). Aunque esa labor de gestión del alquiler pasará a manos de otra sociedad pública creada precisamente para tal fin en 2002, Alokabide, que se analizará más adelante. Los servicios principales que ofrece Visesa, por tanto, se centran en la promoción y edificación de vivienda pública, que pasará luego a través de los correspondientes sorteos y/o adjudicaciones directas a ser habitadas por aquellas personas con necesidad de vivienda que cumplan los requisitos establecidos por el Gobierno Vasco. Entre las obligaciones con las que cuenta Visesa en el camino para favorecer el acceso económico a las viviendas ofertadas, y que habrá de condicionar enormemente el proceso de planificación y edificación de las mismas, está la de «fijar los precios de venta de forma que no puedan exceder los límites establecidos en normativa de vivienda pública protegida» (Visesa, 2016: 5). Tal es así, que a modo de garantía quedaba establecido que las personas adjudicadas con una vivienda tienen el derecho de «instar la resolución del contrato en caso de que el precio final de la vivienda resultara superior al 25\% sobre el pactado en el contrato, en cuyo caso se reintegrarán las cantidades abonadas incrementadas con el interés legal más 1.000 euros en concepto de indemnización» (Visesa, 2016: 6).

\section{De la propiedad al alquiler}

A lo largo de los últimos años, Visesa ha demostrado tener claro que el acceso económico a la vivienda es uno de los pilares fundamentales para el desarrollo vital de las personas y la sociedad. Prueba de ello es la evolución y adaptación que ha sufrido esta sociedad pública, al menos en la manera en que dirige la mirada a la problemática residencial de su contexto cercano. Según se afirmaba en su memoria anual de 2012, hasta esa fecha «las políticas de vivienda que se han venido desarrollando desde el Gobierno Vasco, y también desde otras administraciones locales y territoriales, estaban destinadas a corregir y dar respuesta a las graves distorsiones del mercado de la vivienda» (Visesa, 2012: 4). Políticas que se centraban, entre otras cosas, en facilitar el acceso a una vivienda en propiedad. 
Pero en el documento se reconocía que la sociedad vasca estaba inmersa en una crisis económica, por lo que el objetivo para la legislatura entrante era «un cambio de modelo» para centrar las políticas de vivienda en todas aquellas situaciones de necesidad de vivienda no satisfecha causadas o potenciadas por la citada crisis. Para ello, una de las grandes apuestas que se planteaban era priorizar el alquiler por encima de la propiedad. Con todo, la oferta de regímenes de tenencia se ha diversificado para satisfacer también a aquellas unidades de convivencia con deseo de acceder en propiedad. En la búsqueda de fórmulas de acceso adaptadas a las diferentes situaciones que se pueden llegar a dar en el colectivo de personas solicitantes de vivienda protegida, en el año 2013 se diseñaron y pusieron en marcha opciones de comercialización como el alquiler con opción a compra, o la compra con pago aplazado. Lo cual supone importantes pasos para favorecer la accesibilidad económica a la vivienda protegida.

\section{Acuerdos interinstitucionales}

Visesa parece aprovechar adecuadamente algunas oportunidades externas que se le presentan para ampliar, en la medida de lo posible, su oferta de vivienda asequible. Tal fue el caso del convenio firmado entre Gobierno Vasco, las sociedades públicas Visesa y Orubide (esta última centrada en la adquisición y urbanización de suelos) con el Ayuntamiento de Bilbao en 2006. En virtud del mismo, el consistorio municipal se comprometió a permutar el aprovechamiento urbanístico que la ley de suelo le atribuye como cesión obligatoria por viviendas a edificar por Visesa en el ámbito de Bolueta (Visesa, 2010: 23).

\section{Exceso de confianza en su ámbito de influencia}

Lamentablemente, la respuesta a la necesidad de vivienda por parte de Visesa a lo largo de las últimas décadas ha sido parcial, pues existen no pocos colectivos sin capacidad de acceder a la misma. Como se ha presentado en capítulos anteriores, la precarización social está dificultando más si cabe ese acceso en los últimos años, y hace patente que el sistema en el que esta sociedad se enmarca no es capaz de responder a la totalidad de la necesidad. Por supuesto, se han realizado muy importantes avances, y las promociones finalizadas y entregadas a lo largo de los años desde su creación son numerosas, pero en algunos momentos parece que desde una perspectiva política se ha caído en un exceso de confianza en los métodos y herramientas de que se dispone. Así se entiende tras una lectura actual de lo que se afirmaba en su informe anual de 2006:

«Pero por encima de los datos económicos, Visesa ha mantenido el objetivo de crecer "socialmente". Poco a poco, confiando en el valor de nuestro trabajo, estamos empezando a dar una respuesta definitiva al problema de la vivienda. Estamos 
generando espacios para vivir para muchas personas que, de otra manera, no tendrían posibilidad de acceder a una vivienda. $\mathrm{Y}$, como consecuencia, nuestro esfuerzo empieza a reflejarse también en el mercado, ya que la presión de la demanda se reduce y los precios tienden a estabilizarse.

Somos conscientes de que estamos ante una tarea ardua y de largo recorrido, pero estamos convencidos de que hemos tomado el camino correcto porque tenemos vocación de servicio hacia las personas. En Visesa creemos en las personas $y$, apoyados precisamente en un excelente conjunto de profesionales, vamos a seguir trabajando para que la vivienda deje de ser una de las principales preocupaciones de la sociedad» (Visesa, 2006: 7).

\section{Abriendo tímidamente la mirada a otras tipologías}

En cuanto al objetivo de la adecuación de la tipología de las viviendas a las necesidades y características de las unidades de convivencia necesitadas -identificada como necesaria para llevar a cabo la estrategia aquí estudiada de la agrupación de personas-, en Visesa sí se ha trabajado en cierta manera esta cuestión. En el ya mencionado Plan Estratégico 2013-2016, y dentro de ese primer eje centrado en la respuesta a las necesidades y el acceso relacionados con la vivienda, una de las líneas de acción se concretaba en el objetivo operativo de "adecuar la promoción de vivienda a las necesidades actuales (tipo de vivienda, modalidades de acceso, etc.) y proponer el producto más adecuado para dar respuesta a dichas necesidades» (Visesa, 2013a: 29).

\section{Comunicación, participación y enriquecimiento del proceso de diseño}

De entre las herramientas desplegadas para ello, con la intención de hacerlo sobre la base de una información actualizada en relación a las características de la demanda (Visesa, 2012: 5), destacan dos. La puesta en marcha de diversos canales de participación y comunicación con las personas demandantes, y la conformación de equipos técnicos que desarrollen y planifiquen las respuestas en base a la información recogida. La primera de ellas se da en dos tiempos. Por un lado, se facilitan espacios de intercambio con futuros clientes de Visesa, interactuando «directamente con ellos para conocer de primera mano sus necesidades y expectativas» (Visesa, 2005: 18). Dentro de este planteamiento, se han realizado diversos grupos de debate con diversos perfiles de personas demandantes. Así mismo, en el año 2007 se puso en marcha un espacio de participación en la página web de la sociedad pública para recoger opiniones sobre algunos aspectos del diseño de las viviendas que esta promueve. Continuando con esta estrategia, el año siguiente se realizó un experimento piloto para una 
promoción concreta en el municipio de Mutriku, en Gipuzkoa. Tras lanzar una convocatoria a las personas demandantes en dicha localidad, se realizaron cuatro reuniones de diseño colaborativo entre las interesadas y el equipo de arquitectura encargado de su desarrollo. El objetivo, que todos ellos «interactuasen en la definición del proyecto de la promoción logrando un enriquecimiento del mismo y una mejor adecuación a las necesidades de los clientes» (Visesa, 2008: 34). Por otro lado, existe también una intención de construir canales de comunicación posteriores a la entrega y ocupación de las viviendas. En el año 2009, y con el objetivo de detectar aquellos aspectos positivos y negativos percibidos por las personas usuarias de Visesa en relación tanto al producto como al servicio ofrecido, se realizaron una serie de dinámicas de trabajo para «conocer sus demandas, percepciones, expectativas e imagen existente respecto a Visesa y respecto a los productos y servicios que prestamos» (Visesa, 2009: 31). Según la propia sociedad, se trató de un ejercicio que permitió completar y mejorar la información obtenida anualmente a través de la encuesta de satisfacción. Cualitativamente supuso un salto adelante, pues se desarrollaron doce encuentros a lo largo de las tres provincias. Así, «el análisis del estudio realizado, nos ha permitido detectar algunos puntos débiles, para los que hemos puesto en marcha acciones concretas de mejora» (Visesa, 2009: 32).

La segunda herramienta a señalar es el establecimiento en 2003 de un Comité de Producto para la explotación, por parte de Visesa, de toda esa valiosa información recogida. Este órgano es el encargado de concretar, materializar y desarrollar una Política de Producto permanentemente actualizada. Y trata de prever la tendencia a futuro de las necesidades de la demanda a partir de los datos recogidos a través de los canales de participación mencionados. Entre sus objetivos está, por lo tanto, «ofrecer un producto diversificado que responda a la demanda de la sociedad en cuanto a sus precios, características de las viviendas y régimen de propiedad [así como] adaptar los productos y servicios a los nuevos colectivos y a la realidad social»(Visesa, 2013a: 57). Los objetivos son desde luego ambiciosos pues, según la propia sociedad, es compromiso de este comité ser ejemplo dentro del sector «por la acertada respuesta social en cada una de sus actuaciones, por su sensibilidad arquitectónica (integración urbana, respuesta social, calidad arquitectónica...), tecnológica y medioambiental y, en definitiva, por ser motor de la innovación» (Visesa, 2013a: 58).

\section{Enorme inercia cultural reproduciendo una tipología obsoleta}

A priori, las intenciones demostradas a la hora de adecuar tipológicamente la oferta de vivienda promocionada y edificada por Visesa a las necesidades del contexto social a lo largo de los últimos años son positivas. Sin embargo, a tenor de lo visto en los dos 
primeros capítulos, los horizontes que en esta materia se han planteado una vez se profundiza en ella son poco ambiciosos y limitados. La adaptación del producto que se afirma haber realizado, de cara a las necesidades de los clientes, parece limitarse a cuestiones como el número de dormitorios (Visesa, 2016: 12), el tamaño de las estancias, la disposición o no en una única estancia del salón y la cocina o, ya en una esfera más superficial, el tipo de acabados de la vivienda (Visesa, 2007: 36). La simplificación de las categorías de vivienda en la cantidad de dormitorios que ofrecen no altera en absoluto una tipología que en su estructura sigue diseñada para una familia nuclear formada por pareja y uno o más descendientes. Las únicas unidades de convivencia verdaderamente diferentes a esa familia tipo en el que se aglutina la enorme diversidad ya vista anteriormente, y para las que parece que sí se ofrecen tipologías algo más adaptadas, son las formadas por alguna persona con movilidad reducida, o las consideradas familias numerosas (Visesa, 2013a: 58).

Se observa una falta de comprensión más profunda de la riqueza que puede aportar un proceso verdaderamente participativo en el que aglutinar a las personas demandantes y a los agentes encargados de la gestión y desarrollo de la vivienda protegida. Un proceso en el que debiera existir, en primer lugar y vistas las carencias en torno a la cultura arquitectónica ya mencionadas, una fase de formación y educación dirigida a ambas partes (administración y unidades de convivencia demandantes), que divulgue las posibilidades de la diversidad de tipologías contrastadas a lo de la historia de la arquitectura y en múltiples investigaciones. Esta falta de visión puede comprobarse al ver cómo desde la sociedad pública Visesa se publicita como un éxito el compromiso aceptado de "poner a disposición de la ciudadanía la visita a un piso piloto para todas las promociones de venta a particulares al menos 3 meses antes del inicio de entrega de la misma» (Visesa, 2016: 13); es decir, cuando están ya las cuestiones espaciales más determinantes y que configuran el espacio residencial, decididas. En ciertas ocasiones, se han realizado experiencias con futuros habitantes de las viviendas consistentes en visitas guiadas a las promociones en fase de construcción, «con el objetivo de que nuestros clientes pudieran comprobar cómo se realiza, qué materiales y cómo se ejecuta la construcción de su vivienda» (Visesa, 2005: 13). Una vez más, no se discute el interés que pueda tener tal iniciativa para otros fines, pero no aporta ningún valor en cuanto a la adaptación de la vivienda al cliente.

Si la adaptación de la vivienda se asimilase verdaderamente y en profundidad, desde el inicio del proceso de gestión y diseño, estas visitas a obra podrían llegar a ser un excelente instrumento para poner en práctica un ajuste a las necesidades espaciales domésticas mucho más satisfactorio. Lo serían, si el proyecto arquitectónico fuese ideado incorporando planteamientos como los de Habraken (1972) en torno a un sistema de soportes del edificio, de modo que las futuras personas que vayan a habitar las viviendas pudiesen en la fase de obra 


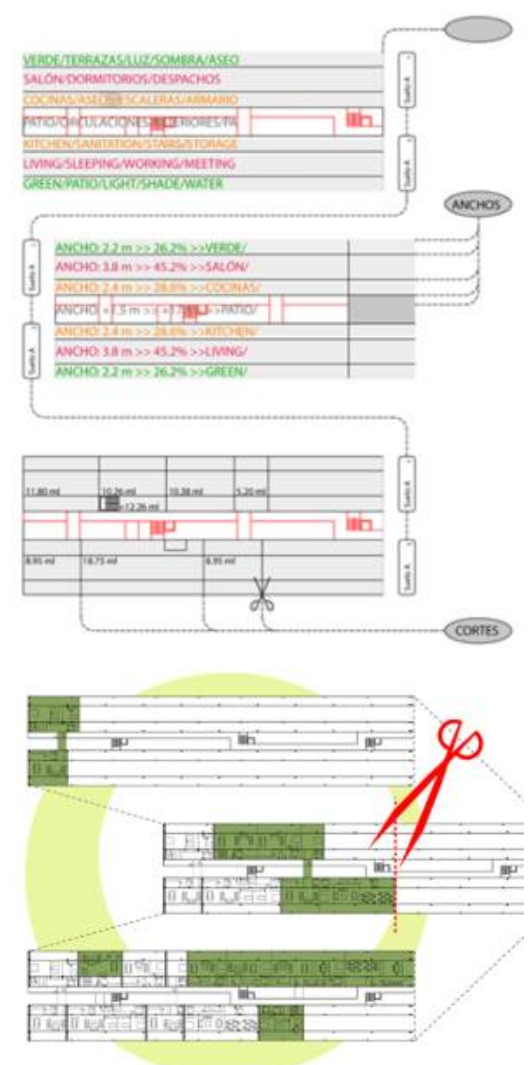

Imagen 4.1. Esquemas conceptuales del Ecobarrio de

Toledo en Santa María de Benquerencia. Disponible en: www.carlosarroyo.net ir delimitando las porciones del edificio a ocupar según sus necesidades. Con el tiempo, los sistemas constructivos facilitarían una transformación futura acorde a la evolución de esas mismas u otras unidades de convivencia. Algunos ejemplos de gran interés en este sentido ya han sido planteados, como es el caso del llamado Ecobarrio de Benquerencia de Toledo, propuesta desarrollada por Carlos Arroyo, Eleonora Guidotti y Manuel Pérez Romero dentro del concurso Europan 6 y que resultó ganadora en 2001. En ella, el equipo realizaba un acertado diagnóstico de la situación:

«Más de la mitad de los españoles vive en casas diseñadas para otros. La práctica totalidad de las viviendas disponibles está pensada para albergar un modelo en el que ellos ya no encajan: el de la familia nuclear tradicional. Su distribución impide compatibilizar los espacios de trabajo y vivienda, o generar estancias que faciliten la independencia de sus habitantes si se decide compartir piso. La vida de los nuevos modelos familiares no encaja en la rígida y jerarquizada estructura de estos pisos, mientras que las personas mayores, solas o en grupo, sufren las consecuencias de vivir en una casa no adaptada, demasiado grande y costosa de mantener» (Arroyo, 2002).

La definición de una serie de volúmenes con ciertos parámetros fijos y otros abiertos al crecimiento, mediante el establecimiento de unas dimensiones transversales fijas y otras longitudinales variables, permitía, gracias a la definición de bandas paralelas con usos más o menos idóneos, «que las personas adquirientes puedan elegir el tamaño de su espacio con total libertad. Pueden también compartimentar según sus deseos, su forma de vida, o las necesidades de su trabajo. La libertad de crecimiento se extiende en planta y en sección, permitiendo múltiples opciones de colonización» (Arroyo, 2002). Se lograba, con el sistema constructivo propuesto, no solo unas auténticas viviendas al corte, si no también un espacio interior que dotase a las unidades de convivencia que lo ocupasen de la capacidad de adaptar el mismo en paralelo a la evolución de la unidad convivencial, con unas intervenciones constructivas relativamente sencillas y económicas (Imagen 4.1). La realización de las visitas a obra planteadas por Visesa, con una estructura levantada básica similar a esta, podría ser una excelente oportunidad para que las personas adjudicadas con una vivienda protegida pudieran ir acotando los límites en los que posteriormente definir y planificar su espacio doméstico personalizado y transformable en el tiempo.

\section{La importancia creciente del patrimonio edificado}

Sobre el nivel de aprovechamiento del parque existente por parte de Visesa, las intenciones -al igual que en los otros dos objetivos anteriores- son altas. Tal y como queda reflejado en su carta de servicios, es parte de su misión el impulsar, colaborar, promover y 
participar activamente tanto en la regeneración y renovación urbana como en la rehabilitación de viviendas (Visesa, 2016: 2). Así, en los estatutos de la sociedad se establecía como uno de sus principales objetos sociales, además de la promoción de nueva vivienda, «todas las actuaciones de rehabilitación con destino a operaciones de vivienda, ya se refieran a adquisición y preparación de suelo, ordenación y conservación de conjuntos históricos o arquitectónicos, etc., y, en particular, la rehabilitación, bajo cualquier forma de promoción viviendas ya existentes» (Decreto 96/2011, 2011:4). A pesar de todo, una acertada lectura del contexto tanto edificado como territorial no edificado llevó en 2012 a un cambio de estrategia. Se estableció en su memoria anual que el mayor esfuerzo del propio Departamento de Empleo y Políticas Sociales del que dependía la sociedad pública en los años siguientes debía hacerse «sobre "lo edificado" y no en lo que está por edificar. Hay que impulsar y estimular la demanda, es necesario ocupar, alquilar, vender, reducir el stock de viviendas teniendo en cuenta la variable territorial» (Visesa, 2012: 5). Todo lo cual se enmarcaba en un anunciado impulso decidido por la rehabilitación y regeneración urbanas.

Efectivamente, ese impulso es el que enmarcaba el segundo eje del Plan Estratégico 2013-2016, con objetivos operativos como el análisis e identificación de áreas con necesidades de intervención, el diseño de un modelo de gestión global para la rehabilitación y, por supuesto, planificar y ejecutar por sí misma actuaciones de renovación del parque edificado (Visesa, 2013a: 29). Pero no solo se podían encontrar líneas de acción relacionadas con un mayor y mejor aprovechamiento del parque en el eje orientado al impulso de la rehabilitación, regeneración y renovación urbanas. El tercer eje del plan, centrado en el desarrollo de Visesa como una sociedad pública eficiente y sostenible financieramente -entre otros objetivos-, planteaba entre sus aspiraciones el lograr maximizar la rentabilidad de sus recursos. Entre ellos, se trataba de optimizar el rendimiento del stock de vivienda ya edificado (Visesa, 2013a: 30). Un año después, la memoria anual de 2014 afirmaba que «todas las personas que hacemos Visesa hemos dirigido nuestro trabajo a prestar el mejor servicio a la sociedad vasca en el ámbito de la Rehabilitación, Regeneración y Renovación Urbana» (Visesa, 2014: 4).

\section{Despliegue de herramientas de intervención en la ciudad existente}

Las herramientas que los estatutos de la sociedad definen para la rehabilitación del parque se centran principalmente en la capacidad de adquirir y vender inmuebles públicos o privados, «bajo cualquier forma y procedimiento [...] que sean precisos o convenientes a cualquiera de los fines y actividades» objeto de Visesa (Decreto 96/2011, 2011: 4). Lo cual, a su vez, se ve complementado con la potestad de adjudicar y contratar «toda clase de» estudios, proyectos, 
obras y trabajos de mantenimiento que tengan relación con dicha rehabilitación (Decreto 96/2011, 2011: 4). Otro instrumento de gran valor es la predisposición y búsqueda activa de alianzas y colaboraciones con otras entidades, mediante la participación en proyectos de regeneración urbana previstos. El Plan Estratégico 2013-2016 preveía esto mismo en casos como Zorrozaurre, Bolueta, o la vega del Galindo, todos ellos en el AMB. Este tipo de alianzas no se limitan a agentes externos al sistema vasco de vivienda pública, si no que se busca activamente la creación de sinergias entre diferentes sociedades y programas del mismo -algunos de los cuales se estudiarán a continuación-, como Bizigune, Orubide o Alokabide. Así, se integraron procesos de unos en otros, y pasaron a ser clientes mutuos. Una cuestión de gran importancia en este sentido, es el encaje de los objetivos de Visesa en las políticas públicas de rango superior definidas por el Gobierno Vasco. Así ocurrió con el Plan Renove de Rehabilitación de Vivienda 2013-2016, autodefiniéndose como actor fundamental y colaborador del mismo dentro de «un amplio consenso social en la necesidad de impulsar el cambio de la cultura urbanística a favor de la rehabilitación, renovación y regeneración del parque edificado ya existente y de los espacios consolidados, frente a la del crecimiento y expansión urbana de edificios de nueva planta» (Visesa, 2013b: 27). Igualmente, el ya mencionado segundo eje del Plan Estratégico de la sociedad pública, centrado en la rehabilitación del parque, colgaba directamente de los objetivos del Plan Director de Vivienda de Euskadi 2013-2016; como ocurría en los otros dos objetivos aquí analizados.

$$
\text { - 4.3.2 - }
$$

\section{Alokabide}

\section{La función social del alquiler: control de la renta, gestión de parques de terceros y cesiones}

Según el documento de definición de su marco estratégico para el periodo 2013-2016, el núcleo central de la actividad de esta sociedad pública es el que constituye el primero de sus cuatro ejes de actuación: el «dar cobertura a las necesidades de vivienda en alquiler favoreciendo la cohesión social»(Alokabide, 2012: 10). Afirmando que, por encima de todo, la prioridad para la empresa era orientar el parque de viviendas hacia una función social. Así, queda constatada una intencionalidad clara por parte de Alokabide de avanzar hacia la consecución del derecho de acceso -económico- a la vivienda. Uno de los instrumentos más potentes con que cuenta esta sociedad es la de establecer la renta mensual del alquiler dentro de los límites máximos establecidos para la vivienda protegida. Con la interesante peculiaridad de que, en caso de que la totalidad de los doce meses de 
renta supere el 30\% de los ingresos anuales de la unidad de convivencia, la renta mensual a pagar tendría como límite dicho porcentaje, tal y como el contrato de arrendamiento base disponía en el año 2016. En algunos casos, la renovación de la renta se hará conforme a la evolución del IPC, pero en otros contratos se hará en base a la evolución de los ingresos de las personas habitantes de la vivienda arrendada, manteniendo así una flexibilidad acorde a situaciones más vulnerables. Al igual que lo hace Visesa, Alokabide ha sabido ver la oportunidad y las ventajas de colaborar con otras entidades para, de manera unida, avanzar hacia el acceso a la vivienda.

El año 2006 supuso un hito, al decidir desarrollar en profundidad su segunda línea de negocio, la gestión de parques de vivienda de terceros. Aquí encajan viviendas tanto del propio Gobierno Vasco, de ayuntamientos, de particulares -estas a través de programas como Bizigune y ASAP-, o de otras entidades privadas (Alokabide, 2013: 4). De manera quizás más excepcional, participa -siempre dentro del objetivo del acceso económico a la vivienda- en iniciativas de gran relevancia social. En 2014 el Gobierno Vasco, a través de esta sociedad pública, cedió el uso temporal de varias viviendas a asociaciones con fines sociales y sin ánimo de lucro como ALCER orientada a mejorar la calidad de vida de la personas con enfermedades renales crónicas- y Bizitza Berria - esta segunda buscaba crear una red de viviendas destinadas a personas en riesgo de exclusión social- (Alokabide, 2016). Otro caso de interés es el del convenio firmado en 2016 con la delegación en Euskadi de la Comisión Española de Ayuda al Refugiado y la Cruz Roja, para la cesión de viviendas por parte de Alokabide; viviendas que serían destinadas a la acogida de personas refugiadas desplazadas por las crecientes crisis humanitarias de los últimos años (Alokabide, 2016). En otros casos, las cesiones han sido en el otro sentido; también en 2016, la Diputación Foral de Bizkaia cedió temporalmente a Alokabide -mediante un convenio de tres años prorrogable de manera indefinida- 42 viviendas para que esta se encargara de su gestión, y las destinase «al alquiler social para cubrir las necesidades de vivienda derivadas de situaciones de vulnerabilidad, tales como ejecuciones hipotecarias, desahucios, acogida de refugiados u otras necesidades específicas» (Alokabide, 2016). Tanto esta acción como la anterior, se enmarcaban en el Plan Director de Vivienda 2013-2016.

\section{Carencias económicas internas y externas}

$Y$ sin embargo, no son pocas las dificultades que se dan para el logro de todos esos objetivos de acceso a la vivienda. Los obstáculos de naturaleza económica son en general los que más condicionan esta labor. Por un lado, personal técnico de la propia empresa admitía en 2016 que «los motivos de dificultad de una mayor apuesta por el alquiler son fundamentalmente económicos» (Etxabe, 2016). Por otro lado, los efectos en la adjudicación y la entrega final de la vivienda a las personas demandantes de la misma son palpables: uno de los 
motivos principales de renuncia a las viviendas adjudicadas en 2014 era el precio de la renta mensual (Alokabide, 2014: 25).

\section{Adecuación de la oferta a las necesidades de la demanda}

En lo que respecta a la adaptación tipológica del parque, en su marco estratégico para el periodo 2013-2016 la sociedad pública Alokabide definía su visión como la de aspirar «a ser un agente fundamental para el Gobierno Vasco en el desarrollo de la política de vivienda y referente en la gestión del alquiler protegido» (Alokabide, 2012: 5), para lo cual establecía como medio el adecuar la oferta para dar respuesta a las necesidades de la demanda y contribuir así a optimizar el uso social de la vivienda. Aunque se trata de una formulación un tanto abierta y susceptible de ser interpretada de diferentes maneras, se podría entender que dicha visión incluye la adecuación espacial y tipológica de esa oferta a las correspondientes necesidades de la demanda.

\section{Identificación de necesidades y potencial intervención en el parque}

Para ello, en ese mismo documento se establecían algunos ejes y objetivos estratégicos. El primero, centrado en la ya mencionada búsqueda de cobertura a las necesidades de vivienda para favorecer la cohesión social, incorporaba entre sus objetivos el «adecuar el modelo de gestión del parque en función de las tipologías de vivienda (por tipo de propiedad, destinatario, usos, plazos, etc.)» (Alokabide, 2012: 11). Para ello, se propuso «realizar un diagnóstico de necesidades de gestión en función de los diferentes parques de vivienda para proponer y poner en marcha alternativas que optimicen el modelo de gestión» (Alokabide, 2012: 15). El potencial de estos objetivos, para sumar bajo su ámbito de acción acciones de adaptación tipológica, es remarcable. A dicho potencial se suma la capacidad que la sociedad tiene, según el artículo segundo de sus estatutos y al igual que ocurría en el caso de Visesa, de adjudicar y contratar toda clase de estudios, proyectos, obras y trabajos de mantenimiento en las viviendas promovidas, así como de controlar las posibles obras por parte de las personas inquilinas, a través de la autorización necesaria de Alokabide y la Delegación Territorial de Vivienda correspondiente (así se establecía en su página web en el momento de la consulta y en el modelo de contrato tipo facilitado). También es de destacar el interés que puede llegar a tener, como herramienta de detección de necesidades habitacionales concretas, la creación en el año 2006 del Área de Seguimiento Especial de Arrendatarios/as, «que persigue atender a aquellas personas arrendatarias que presentan situaciones personales y/o sociales 
especiales» (Visesa, 2006: 52) y que puede constituir un canal de comunicación relevante entre sociedad de gestión y personas usuarias.

\section{Carencias de una mirada parcial al problema}

Frente a lo anterior, se han detectado ciertas debilidades que Alokabide presenta a la hora de intentar avanzar hacia el objetivo aquí analizado de adecuar al máximo posible la tipología de las viviendas arrendadas a la diversidad y evolución de las necesidades que la demanda presenta. En primer lugar, hay que destacar que el otro principal motivo de renuncia -junto con el ya mencionado del precio- en las adjudicaciones de vivienda protegida en alquiler era el tamaño de la vivienda. Algo que de manera más o menos directa está relacionado con la tipología que cada unidad de convivencia aspira a ocupar. Por otro lado, hay una cuestión de gran relevancia en un colectivo como el demandante de vivienda protegida. En muchas ocasiones puede necesitar destinar parte de su vivienda -al menos de manera temporal- al desarrollo profesional, implantando en ella fiscalmente una actividad económica, ya sea como empresa autónoma o por cuenta ajena. Hay una cada vez mayor diversidad de oficios y trabajos que son compatibles, no solo con las correspondientes normativas urbanísticas, si no con el propio uso residencial, sin causar afecciones a las viviendas colindantes, y que se trata de una realidad ampliamente instalada en la sociedad. En muchos de esos casos, la potencial reducción de los gastos implícitos al inicio de una actividad -al desarrollar esta en el propio domicilio- es tal, que podría en los primeros años de la misma ayudar a conseguir cierta estabilidad económica. Permitir este tipo de situaciones en las viviendas de protección pública podría ser un interesante valor añadido del sistema público de vivienda, y un apoyo a la emancipación económica de las unidades de convivencia respecto al sistema de ayudas. Lo cual favorecería en última instancia la buscada rotación de esos inmuebles con nuevas personas con una necesidad de vivienda sin cubrir. Sin embargo, tal y como se establece en el modelo de contrato tipo de Alokabide, la persona arrendataria «no podrá instalar y/o desarrollar, actividad industrial, comercial o de servicios» en la vivienda. Rechazar la totalidad y agrupar como iguales actividades industriales y de servicios no parece una estrategia adecuada.

El bajo aprovechamiento de la capacidad que Alokabide tiene para poder intervenir espacialmente y transformar algunas de las viviendas -propias o de terceros- para generar tipologías que se adapten a los modos de vida cambiantes de muchas de las unidades de convivencia con necesidad de vivienda se ve reflejado en algunos de los datos estadísticos recogidos por la propia institución. Como ejemplo, a lo largo del año 2013 tan solo un 5\% de las incidencias registradas -que se corresponden en general con llamadas de personas que habitan una vivienda gestionada por Alokabide al centro de atención al cliente y que comprenden cuestiones como averías, mantenimiento, temas comerciales y administrativos o reclamaciones, entre otras- se debían 
a solicitudes de reforma (Alokabide, 2013:29). Es probable que la falta de solicitudes en este sentido sea una más de las razones por las que se sigue manteniendo una tipología habitual de vivienda según los esquemas en los que ya se ha enfatizado con anterioridad. En este caso, la influencia de la citada falta de cultura arquitectónica puede ser clave para comprender el porqué de dicha carencia en las exigencias de las propias unidades convivenciales. Sin embargo, la predisposición de la administración tampoco parece la adecuada pues los criterios de adjudicación y el esfuerzo del sistema se centra quizás excesivamente en la variable económica. Sin tener en cuenta otras variables como un estudio tipológico en profundidad que, como en este trabajo se pretende recalcar, son de urgente relevancia, no solo por su importancia aislada, si no por las posibilidades indirectas que abren una vez se contemplan otro tipo de aproximaciones y estrategias a la cuestión desde una mirada más integral. Desde la propia sociedad se han hecho declaraciones en este sentido Como el propio Etxabe afirmaba desde la dirección de atención y comunicación externa de la sociedad pública Alokabide, igual de importante es tener en cuenta el número como la tipología de viviendas ofertadas, pues se pueden estar orientando esfuerzos a movilizar viviendas que no se necesitan, o que no tienen demandantes:

«...los criterios de baremación y la propia Ley de Vivienda hacen que la posibilidad de acceso a una VPP en alquiler se escore hacia cuestiones fundamentalmente económicas, dejando de lado importantes capas de la población que también necesitan vivienda (jóvenes, personas mayores, familias monoparentales con pocos miembros, repatriadosinvestigadores, parados puntuales, etc.). Es por ello que sería positivo disponer de más programas/cupos/tipología de viviendas para cubrir esas necesidades, y ahí sí que sería necesaria la colaboración con otras instituciones a nivel educativo, municipal, del tercer sector, etc» (Etxabe, 2016).

\section{Hacia la puesta en carga del parque}

En lo que a las iniciativas promovidas por Alokabide para lograr un aprovechamiento del parque de viviendas existente se refiere, sea propio o no, dentro de sus objetivos se puede encontrar la rehabilitación de viviendas para destinarlas al arrendamiento, sin descartar la venta a sus arrendatarios o a terceras personas o entidades, tal y como definen sus estatutos al establecer su objeto social. En esta línea, el marco estratégico 2013-2016 definía como uno de sus objetivos el fomento de la mejora de los inmuebles en alquiler protegido, facilitando tanto la rehabilitación de viviendas de terceros orientándolas hacia el alquiler protegido, como la adecuada conservación del parque propio (Alokabide, 2012: 15).

Para lograrlo, la sociedad se ha ido dotando de una serie de instrumentos, desde la adquisición y transformación de inmuebles 
para destinarlos a los fines establecidos -definidos en sus estatutos, y entre los que se contempla el derecho de tanteo y retracto en representación del Gobierno Vasco sobre las viviendas de protección oficial-, al impulso de la movilización de viviendas deshabitadas «como recurso adecuado para facilitar el acceso a la vivienda» en Euskadi (Alokabide, 2012: 12). En este sentido, se busca la mejora de la eficiencia de los programas existentes colaborando con ellos, el estudio de otras iniciativas diferentes para aumentar dicha movilización mediante la identificación y análisis de alternativas y buenas prácticas existentes, así como la definición de un mapa de agentes públicos y privados de interés en esta cuestión (Alokabide, 2012: 16). Algunos de estos agentes tienen en sus manos un número de viviendas nada despreciable, como puede ser la Sociedad de Gestión de Activos Procedentes de Reestructuración Bancaria (SAREB), con quien Alokabide firmó un contrato en 2015 por el cual la primera cedía a la segunda diez viviendas a incluir en el parque público de alquiler social. Aunque puntual y limitado a tan solo diez viviendas, este convenio, con cuatro años de duración y prorrogable por periodos de un año, es un ejemplo más de las oportunidades y posibilidades de mejora todavía sin aprovechar que ofrece la colaboración interinstitucional.

\section{Dificultades propias de un contexto exigente}

Pero una vez más, existen debilidades y/o obstáculos que el contexto y marco institucional presentan. En opinión de algunos agentes la cuestión de los recursos -económicos, pero no solo- es el principal reto a superar, ya que:

«...es de remarcar que no está siendo tan fácil movilizar viviendas, y estimo que sería necesario un impulso decidido en cuanto a la dedicación de los recursos necesarios para ello y en cuanto a la colaboración interinstitucional [...] es algo a todas luces evidente que con los recursos actuales (tanto económicos, como humanos, como de viviendas disponibles, como de coordinación interinstitucional, como de otros tipos) no es posible cumplir con las exigencias que plantea una Ley tan potente como la de Vivienda ${ }^{88}$. El importante desarrollo reglamentario que exige tiene que venir acompañado de la correspondiente dotación presupuestaria, dado que en caso contrario, la efectividad de la Ley se resentirá» (Etxabe, 2016).

Entre las alternativas, mientras no se dispongan de dichos recursos, el autor citaba una: la financiación de la rehabilitación de viviendas deshabitadas a cambio de que la propiedad devuelva el importe incorporando durante un tiempo establecido la vivienda en

${ }^{88}$ Se refiere a la Ley 3/2015 de Vivienda de Euskadi. 
uno de los programas de movilización de vivienda vacía sin contraprestación económica alguna.

\section{Una transición hacia la vivienda protegida}

El objetivo de lograr el acceso económico a la vivienda del programa Bizigune es compartido con las sociedades públicas vistas hasta ahora. Su objeto es ofrecer las viviendas movilizadas a aquellas personas con necesidad de la misma y que cumplan con los requisitos establecidos para poder ser catalogadas como demandantes de vivienda protegida, tal y como se establece en el Decreto 316/2002 que promueve e impulsa dicha iniciativa. Cabe resaltar que se plantea como un programa de transición para las unidades de vivienda adjudicadas, y no como una solución permanente; las condiciones de cesión y el procedimiento diseñados establecen que a efectos de la unidad de convivencia adjudicada, esta sigue de alta como demandante de una vivienda protegida: «la adjudicación y alquiler de una vivienda en régimen de alquiler con arreglo al «Programa de Vivienda Vacía» conllevará únicamente su eliminación del referido programa, sin que ello afecte a su inscripción como demandante de vivienda de protección oficial en Etxebide» (Orden de 22 abril de 2003, del Consejero de Vivienda y Asuntos Sociales, 2003).

\section{Subvención para lograr una renta digna}

En este caso, las herramientas diseñadas para satisfacer la necesidad de vivienda mediante esta iniciativa son varias. La primera permite garantizar que el destino de estas viviendas movilizadas sean aquellos colectivos con dificultades de acceso económico y es, como ya se ha dicho, el establecimiento de la condición previa de que hayan de estar, las personas físicas o unidades convivencia, inscritas como solicitantes en el registro del servicio vasco de vivienda protegida. En sus inicios, dentro de los tres criterios de adjudicación de estas viviendas estaba la «acomodación del nivel de ingresos de la persona o unidad convivencial, respecto de la renta prevista para el alquiler correspondiente» (Orden de 22 abril de 2003, del Consejero de Vivienda y Asuntos Sociales, 2003) ${ }^{89}$. Renta que se mantendrá dentro de unos límites razonables y adecuados según algunas referencias citadas anteriormente, ya que «ascenderá al 30\% de los ingresos anuales ponderados de la persona o unidad convivencial arrendataria

${ }^{89}$ Como se señalará más adelante, esta variable se eliminó y sustituyó por otra. 
calculados con arreglo a la normativa sobre viviendas de protección oficial, con un límite de 450 euros [y] se actualizará, al alza o a la baja, en la fecha en que se cumpla cada año de vigencia, previa comprobación de dichos ingresos anuales ponderados» (Decreto 466/2013, de 23 de diciembre, 2013). El procedimiento establecido para alcanzar la renta acordada con la propiedad de la vivienda vacía a movilizar establece que la persona arrendataria recibe, por parte de Visesa, una subvención consistente en la diferencia entre la renta anual del alquiler previsto y el 30\% de los ingresos brutos anuales. Se trata de una subvención que se concede en el mismo momento en que se cierra el contrato de arrendamiento, y que se revisa anualmente según la variación de los ingresos anuales de la persona o unidad convivencial, siempre que se mantengan dos condiciones: que sus ingresos brutos no superen el umbral de ingresos máximos previstos en la normativa correspondiente a las viviendas de protección oficial, y siempre que la renta del alquiler supere el $30 \%$ de estos.

\section{Orientación hacia situaciones de mayor necesidad económica}

Es de resaltar que a lo largo de los años el programa se ha ido enfocando paulatinamente hacia colectivos más vulnerables o, al menos, ha sido desechado para aquellas unidades de convivencia que, aún cumpliendo los requisitos genéricos de ingresos para poder solicitar una vivienda protegida, se encuentran en la parte alta de la horquilla. Así, en el año 2004, tan solo dos años después de su creación, se modificó el techo máximo de ingresos para acceder al mismo, situándose en los 21.000€ anuales (Decreto 100/2004, de 1 de junio, 2004). Por otro lado, también se realizó en 2013 un cambio en los criterios de adjudicación con un giro hacia aquellas situaciones más necesitadas. Como se ha avanzado antes, se eliminó el criterio de acomodación de ingresos y rentas, sustituyéndose por una puntuación de cada expediente según tres variables, una de las cuales otorgaba diez puntos a aquellos en los que algunas de las personas titulares formasen parte de uno o más colectivos con necesidad especial de vivienda -en cuyo caso se conceden diez puntos por cada colectivo al que se pertenece hasta un máximo de treinta- (Decreto 466/2013, de 23 de diciembre, 2013).

\section{Un muro cultural en búsqueda de la acumulación}

Como contrapunto, una de las principales amenazas del programa en lo que al acceso económico se refiere ha sido apuntada al inicio del trabajo. Se trata de la arraigada cultura existente, a muy diferentes escalas, de entender la vivienda como objeto de inversión y no como elemento de desarrollo vital con una clara función social -en este caso aplicada a la propiedad privada, cuya función social viene establecida por la Constitución en su artículo 33-. Las aspiraciones de la propiedad de la vivienda por ingresar las mayores rentas del alquiler 
posible llevan en muchos casos a que no considere suficiente la renta ofrecida por el programa Bizigune, que está por debajo del mercado, y no se anime a incluir su vivienda en el mismo, o la retire una vez dentro del mismo, con graves consecuencias para las unidades de convivencia que las habitan. Dichas unidades, formadas por «personas y sus familias -que no pueden ganar más de 21.100 euros al año- tendrán que mudarse a otra parte si el inmueble donde han residido sale del arrendamiento social y el propietario aspira a cobrarles un alquiler de mercado libre, algo que muchas veces está fuera de sus posibilidades» (Muñoz, 2014).

\section{Predisposición a una adecuación tipológica}

Con mayor o menor profundidad, el objetivo de que las viviendas movilizadas se adjudiquen según cierta adecuación entre tipología y perfil de la unidad de convivencia está presente entre las bases de definición de Bizigune. Desde su origen, uno de sus principios rectores ha sido la búsqueda de la «máxima adecuación de la vivienda disponible a las necesidades de las personas o unidades convivenciales» (Decreto 316/2002, de 30 de diciembre, 2002). Y uno de sus criterios de adjudicación, la «acomodación de la persona o unidad convivencial a las características de las viviendas disponibles en el correspondiente municipio» (Orden de 22 abril de 2003, del Consejero de Vivienda y Asuntos Sociales, 2003). Lo cual se mantuvo en el Decreto 466/2013, al establecer la necesidad de que la vivienda se adecue a las necesidades de la unidad de convivencia.

\section{Facilidades de transformación espacial}

Para garantizar - $\mathrm{O}$ al menos intentar lograr- dichos objetivos, se plantea como un filtro inicial la no aceptación en el programa de aquellas viviendas que no cumplan los requisitos ni condiciones básicas de habitabilidad. Una de las herramientas de mayor interés, en lo que al objeto de adaptar las viviendas a las unidades de convivencia se refiere, fue el contemplar en la normativa reguladora del programa la posibilidad de realizar reformas en las viviendas movilizadas, ya fuesen promovidas por la sociedad pública Visesa o por la propiedad del inmueble -en este caso bajo la supervisión de la primera-. Las intervenciones serían costeadas por Visesa para posteriormente deducir el importe de las mismas de la renta o canon que este institución abona a la propiedad de las viviendas (Orden de 22 abril de 2003, del Consejero de Vivienda y Asuntos Sociales, 2003). Así, la compensación recibida por incorporar una vivienda en el programa quedaba complementada por la posibilidad de financiar sin intereses una reforma no superior a los $18.000 €$. 


\section{Un potencial transformador subestimado}

A pesar de las intenciones positivas que tiene el programa, los resultados parecen quedar lejos de la necesidad espacial y habitacional de las unidades convivenciales participantes en el mismo. Efectivamente, uno de los principales motivos de renuncia a una vivienda del programa Bizigune en 2013 fue que esta no se ajustase a las necesidades de la persona arrendataria (Alokabide, 2013:25). A esta realidad han podido ayudar cuestiones como que las obras de reforma que Visesa está capacitada para efectuar, gestionar y/o controlar en estas viviendas se plantean con unos objetivos mínimos de adecuación constructiva y estructural, así como de habitabilidad básica (Decreto 61/2009, de 10 de marzo, 2009), pero que no entran a analizar ni responder conflictos referentes a la tipología de las mismas. Desde otro punto de vista, y pensando en las posibilidades que ofrece la estrategia de agrupación de personas desarrollado en el capítulo anterior, tampoco parece favorecedor dejar fuera del programa a aquellas viviendas de más de 120 metros cuadrados -si bien esta condición fue eliminada en la modificación de 2009-. Puede que se tratase de un requisito que se correspondía con una visión simplificadora de la cuestión que no contemplaba la posibilidad de ubicar en una vivienda más de una de convivencia $-\mathrm{y}$ consecuentemente transformarla-, que consideraba que ofrecer una vivienda de gran tamaño a una unidad de convivencia dentro del sistema de vivienda protegido era algo fuera de lugar. En cualquier caso, dicho criterio fue eliminado ofreciendo mayores posibilidades y flexibilidad de adecuación entre tipología y tipos de unidades de convivencia.

Quizás uno de los movimientos que más ha perjudicado al potencial que ofrecía el programa con este fin -a pesar de que no se haya aprovechado- fue la eliminación en la normativa aprobada en 2013 de los preceptos relacionados con la posibilidad de desarrollar reformas en las viviendas incluidas en el programa Bizigune, precisamente justificada «por su escasa utilización práctica» (Decreto 466/2013, de 23 de diciembre, 2013). Motivo a pesar del cual, probablemente, si hubiese por parte de la administración pública una visión más amplia de las posibilidades que estas obras abren -como se ha visto en el capítulo anterior-, no se habrían eliminado los preceptos correspondientes, si no que se hubiese puesto más énfasis en difundir y divulgar el potencial que ocultan. Con ellos, quedó eliminada también la citada posibilidad de financiar las obras:

«...otra cosa que aportaba Bizigune y de lo que no se solía hablar mucho era la posibilidad de financiar sin intereses la reforma de la vivienda hasta un importe máximo de $18.000 €$. Esa medida suponía un coste ridículo para la Administración, porque lo iba recuperando del cobro de la renta durante los 5 años que duraba el contrato, y permitió que unas 1.000 viviendas pudieran ponerse en el mercado de alquiler (aproximadamente el 20\% de las viviendas se acogían a esta 
financiación). Esa medida fue suspendida en la legislatura de Iñaki Arriola (PSE) y en la actual incluso se ha suprimido de la normativa. En muchas ocasiones no es posible alquilar porque no reúne condiciones suficientes de habitabilidad y requiere de una inversión económica cuyos propietarios no pueden realizar. En esos casos, una financiación pública sin intereses condicionada a la puesta en alquiler de la vivienda sería una solución barata y eficaz» (Cacho, 2016d).

\section{La puesta en carga del parque actual como eje principal}

Aunque, si hay que recalcar un objetivo principal del programa Bizigune, este es el de «conseguir que las viviendas de titularidad privada, que se hallen deshabitadas en el ámbito de la Comunidad Autónoma de Euskadi, sean puestas en el mercado de la vivienda de alquiler en beneficio de quienes las necesitaren y fueren calificados como beneficiarios con arreglo a la normativa propia de las viviendas de protección oficial» (Decreto 316/2002, de 30 de diciembre, 2002). Es decir, se trata de una iniciativa que tiene como razón de ser el aprovechamiento del parque ya edificado, en un encaje total con uno de los tres objetivos que esta investigación ha identificado como esenciales para llevar a cabo la estrategia de agrupación de personas planteada que posibilite una acceso económica y espacialmente digno a la vivienda.

\section{Apuesta por una gestión total del proceso}

A pesar de las dificultades que el programa viene presentando como se apuntará más adelante- para alcanzar los objetivos marcados, se han diseñado y puesto en marcha un abanico de instrumentos e iniciativas de gran interés. A fecha de enero de 2015 se preveía la captación de viviendas para el mismo en cerca del $80 \%$ de los municipios del AMB, con lo que es una herramienta de gran interés para los intereses de la región. La manera en que se establece la relación y la gestión de la vivienda por parte de Alokabide, que es la sociedad que finalmente gestiona los inmuebles, es -como se especifica en el modelo de contrato consultado- haciendo a esta titular de un derecho de usufructo a su favor, sobre la vivienda objeto del contrato. Aunque, aparentemente, se goza de cierta flexibilidad probablemente con el fin de abarcar la mayor diversidad de situaciones posibles-, pues la cesión se podrá realmente «formalizar utilizando cualquier figura contractual que faculte a Alokabide, S.A. para arrendar o subarrendar posteriormente las viviendas» (Decreto 466/2013, de 23 de diciembre, 2013). Es decir, que no se descartan figuras como «la cesión del contrato de arrendamiento, mediante arrendamiento o, tal y como se especifica en el artículo 4 del Decreto 316/2002 de 30 de Diciembre, por cualquier título válido en 
Derecho» (Orden de 22 abril de 2003, del Consejero de Vivienda y Asuntos Sociales, 2003).

A la hora de hacer atractiva a la propiedad la cesión de estas viviendas y abarcar el máximo posible de situaciones, son varias las estrategias a seguir. El programa ha demostrado en este sentido cierta capacidad de retroalimentación y mejora a partir de la experiencia inicial. Si en origen se estableció como condición necesaria que los inmuebles hubiesen tenido la condición de vacíos durante al menos doce meses, en la modificación de 2009 este periodo bajó a nueve, a la vez que se ajustó la definición de vivienda vacía. De tal manera que no se consideran viviendas ocupadas aquellas que ya vengan de estar incorporadas al programa Bizigune, ni las que queden vacías por ingreso de sus titulares en alguno de los servicios sociales residenciales para la tercera edad. En la modificación de 2013 se mantuvieron estas condiciones, si bien se eliminó otra de considerable interés social aportada en 2009. Se trataba de la posibilidad de incluir en el programa aquellas viviendas cedidas por unidades de convivencia cuando sus titulares tuviesen más de 70 años, habitasen una que no reuniese las condiciones mínimas de accesibilidad, cuando el ratio fuese inferior a $15 \mathrm{~m}^{2}$ por persona, o cuando algún miembro de la unidad de convivencia tuviese una movilidad reducida permanente. En todos esos casos, hasta 2013 la solicitud y adjudicación de una vivienda protegida posibilitaba la inclusión de su vivienda actual en el programa Bizigune.

Aunque, con toda probabilidad, el principal aliciente para la propiedad de este tipo de viviendas sea la ya mencionada contraprestación económica que en este caso la sociedad pública Visesa ofrece a cambio de su movilización y puesta en carga. Se trata de «un canon o renta periódica o, en su caso, un importe capitalizado, a calcular en función de los precios medios de mercado sin que, en ningún caso se supere la renta de mercado tasada por VISESA. En este caso podrá tenerse en cuenta el importe de la rehabilitación efectuada» (Decreto 316/2002, de 30 de diciembre, 2002). De esta manera, para cada caso se fija -a partir de los precios de mercado de la zona próxima al inmueble- el canon o renta que la propiedad recibiría una vez deducidos los gastos de gestión y, en su caso, de las obras de reforma necesarias. El resultado es que, en general, la propiedad recibe una renta mensual de entre el $65 \%$ y el $75 \%$ de la habitual en el mercado libre. En cierto modo, la evolución del programa parece confirmar lo apuntado sobre las aspiraciones existentes en el colectivo propietario de viviendas por ingresar la mayor renta posible, pues si en el momento de la creación del programa en 2002 la renta de mercado tasada tenía como límite máximo los 660€ mensuales (Decreto 316/2002, de 30 de diciembre, 2002), en 2009 esta subió hasta los $750 €$, con el objetivo de atraer a más agentes propietarios (Decreto 61/2009, de 10 de marzo, 2009).

El despliegue de garantías es también diverso, según los fines buscados. Por un lado, están aquellas que persiguen devolver la 
vivienda a la propiedad, al final del periodo de cesión, en similares condiciones en las que se encontraba al inicio de la relación. Unas garantías que, en los inicios del programa, aportaban un valor añadido de gran interés por el poco hábito de ese tipo de prácticas en el mercado libre (Visesa, 2005: 44). De este modo, Alokabide es la entidad que «responde por el valor de reposición en caso de desaparición o deterioro del mobiliario y electrodomésticos inventariados debidos al dolo o culpa de las personas arrendatarias, sin perjuicio de repetir contra éstas en caso de dolo» (Decreto 466/2013, de 23 de diciembre, 2013). Este mismo decreto establece también que será Alokabide quien se hará cargo, subsidiariamente, de las labores de mantenimiento que la legislación aplicable establece, en los casos en que las personas titulares de las viviendas no puedan o quieran hacerlo. En cuyo caso, se descuenta el importe de dichas intervenciones del canon que reciben estas. Aunque también existen otro tipo de garantías o elementos en la búsqueda de un adecuado funcionamiento del programa, como es el caso de las medidas tomadas para fomentar el compromiso de las personas solicitantes: en 2003 se estableció que tras dos renuncias consecutivas se procedería a la expulsión del mismo durante dos años. Ahora bien, este tipo de medida implica que el sistema debería a cambio ofrecer una suficiente y adecuada información de las características de la vivienda.

En definitiva, lo que se busca desde Alokabide para el programa Bizigune es la gestión total del proceso. Lo cual, por una lado, permite alcanzar mayores niveles de eficacia, y por otro ofrece un mayor atractivo a la propiedad que reduce su labor a la mera cesión de la vivienda. La sociedad pública se compromete a elaborar «un documento específico para cada una de las viviendas ofrecidas, en el que se contendrá, como mínimo, el resultado de la tasación efectuada, el presupuesto completo de las obras necesarias, el plazo preciso para ejecutarlas, y la propuesta de cesión que la mencionada sociedad realiza al titular o titulares de la vivienda» (Orden de 22 abril de 2003, del Consejero de Vivienda y Asuntos Sociales, 2003). Así mismo, también se encarga del inventario, el pago de la renta a la propiedad, la contratación de un seguro, o la devolución de la vivienda en buen estado.

\section{Pionero en el Estado}

Como resultado de los esfuerzos destinados a este programa por parte de la administración vasca, algunos expertos en el tema lo han calificado como uno de los más avanzados en esta materia en el estado, ya que aunque «ciertamente otras Administraciones Públicas han realizado presuntas copias del Programa Bizigune -por ejemplo la Bolsa de Alquiler Joven de la Xunta de Galicia- las diferencias son tan evidentes (no ofrecer a los inquilinos alquileres sociales sino de mercado, no movilizar viviendas vacías sino simplemente introducir en esquemas pseudo públicos a viviendas que ya estaban en alquiler, no crear nuevos nichos de mercado de alquiler sino esquilmar el ya 
raquítico mercado privado de alquiler, etc) que no guardan relación alguna con este programa» (Burón, 2008: 31).

\section{Un bajo éxito a un alto precio}

$\mathrm{Y}$ sin embargo, los niveles de movilización alcanzados han sido y son cuestionados, debido a varias razones. Una de las más importantes, por lo que directamente atañe al objetivo principal de Bizigune, es la baja captación de viviendas vacías. A pesar de ser alabado y haber generado esperanzas en ciertos sectores catalogándose como de exitoso en sus primeros años (Burón, 2008: 12), se ha quedado lejos de las cifras y aspiraciones originales y se ha señalado -tanto desde fuera como desde dentro de las instituciones públicas- su incapacidad de constituirse como herramienta para responder a la amplia necesidad de vivienda:

«El programa Bizigune, de hecho, tenía como objetivo cuando lo creó el ejecutivo anterior movilizar unas aproximadamente 26.700 viviendas vacías de las 54.500 que estimaba el Dpto. de Vivienda y Asuntos Sociales en 2006 en el conjunto de la Comunidad Autónoma del País Vasco, pero desde el inicio de su andadura en 2003 hasta 2006 había movilizado mil novecientas viviendas, y en torno a unas cinco mil viviendas hasta 2009, según fuentes del propio Departamento.

Así, el citado programa valorado como exitoso en el Plan director 2006-2009 (quien preveía más recursos y su conversión en sociedad), e incluso considerado en el apartado de buenas prácticas por el Consejo de la Juventud de España, pudiera ser ciertamente un paso adelante en la ampliación del sector del alquiler, pero con resultados insuficientes y extraordinariamente caros (frente a las necesidades de la sociedad vasca; 87.115 personas necesitadas de acceso según estudios del Dpto. de vivienda y asuntos sociales en 2008). Tanto es así, que el nuevo gobierno ha anunciado una progresiva desaparición de dicho programa» (Etxezarreta, 2010: 17).

En los sucesivos planes directores de vivienda habidos desde la creación del programa, se ha planteado la cifra de 5.000 viviendas a movilizar en sus correspondientes periodos de vigencia, pero entre 2002 y 2005 se lograron movilizar 869 viviendas, entre 2006 y 2009 se alcanzaron 3.157, entre 2010 y 2012 se alcanzó la cifra de 545, y entre 2013 y 2016 se perdieron 603 respecto a las acumuladas hasta entonces (Gobierno Vasco, 2013a: 35, 2017: 35). A pesar de que en diversos documentos, como las memorias anuales de algunas de las sociedades públicas implicadas en la gestión de Bizigune, se ofrecen cifras que pueden llevar a la confusión -citando el número de contratos de arrendamiento firmados con personas arrendatarias, pero no de los formados con propietarias (Visesa, 2007: 43, 

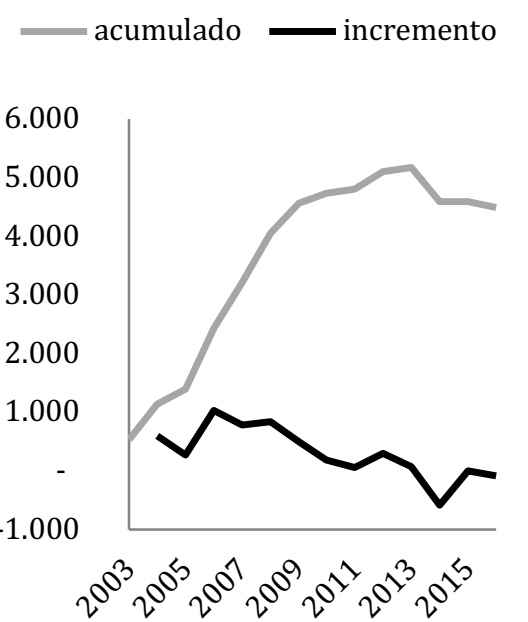

Gráfica 4.1. Número de viviendas libres movilizadas por el programa Bizigune entre 2003 y 2016. Elaboración propia a partir de Gobierno Vasco, 2013a y Gobierno Vasco, 2017.
2008: 44)-, en aquellos que se ofrece una mayor transparencia queda patente lo alejadas que quedan las cifras de los objetivos iniciales (Visesa, 2009: 65). Así, los datos recogidos por el propio Gobierno Vasco para la elaboración del Plan Director de Vivienda 2018-2020 ofrecen una realidad clara: la del estancamiento e incluso pérdida de viviendas movilizadas (Gráfica 4.1).

El principal motivo que está, aparentemente, detrás de lo anterior es el alto coste del programa para los presupuestos públicos, algo de lo que se era consciente ya desde sus inicios (Visesa, 2005: 43). Un problema que se ha mantenido a lo largo de los años, ya que «el motivo fundamental de la reducción en el volumen de nuevas viviendas incorporadas al programa Bizigune fue la limitación de presupuesto, provocada por la situación económica general» (Visesa, 2009: 66). Efectivamente, se trata de una «reducción de la aportación económica a las personas propietarias de vivienda del Programa Bizigune (particulares y entidades) que unido a un incremento en otras exigencias, ha hecho imposible cumplir con el objetivo establecido» (Etxabe, 2016). Así, en 2013 se decidió volver a disminuir la retribución destinada a la propiedad de las viviendas incorporadas al programa -como se ha señalado antes, en 2009 se subió la establecida originalmente en 2002-. Este cambio fue justificado por dos motivos: la reducción de la renta media de alquiler en Euskadi en un 10\% según datos de 2012, y la intención de «incidir desde la esfera pública en las rentas que se abonan en el mercado libre de alquiler, de manera que sigan adecuándose aún más a las actuales necesidades de los demandantes de vivienda» (Decreto 466/2013, de 23 de diciembre, 2013). Frente a esto, el exdirector de Suelo y Urbanismo del Gobierno Vasco, Iñigo Maguregui, afirmaba que la bajada había sido superior a la que el mercado libre había sufrido, con lo que dicha maniobra de «reducir de 650 euros a 450 el máximo mensual que reciben los dueños de los pisos puede disuadir a muchos de ellos de continuar en el programa de arrendamiento social o de apuntarse a él por primera vez» (Muñoz, 2014). Según Maguregui, dicha rebaja le llevaba a aventurar que solo aquellas personas propietarias de viviendas en mal estado de mantenimiento, mala localización, u otras características por las que sean expulsadas o relegadas a un segundo plano del mercado libre, se mostrarían dispuestas a entrar o renovar en Bizigune.

Según datos de 2013, Alokabide facturó a las unidades de convivencia inquilinas de las viviendas del programa Bizigune 16.406.183€, con una renta media mensual cercana a los $260 €$. El pago de las rentas a la propiedad se calculó en 36.807.510€. Se trata de un programa que «supone un importante coste presupuestario para el Gobierno Vasco que financia esa diferencia» (Burón, 2008: 22). Lo cual fue, en gran medida, la motivación para la búsqueda de un nuevo modelo de movilización de vivienda vacía -que se verá a continuación-, para funcionar en paralelo a este. En palabras del Consejero de Vivienda y Transportes del Gobierno Vasco en 2010, 
Iñaki Arriola, con los inmuebles del programa Bizigune «pagas y pagas, pero nunca son tuyos. Ese programa seguramente irá decreciendo a medida que surjan otras alternativas» (Muñoz, 2010). Las consecuencias de todos estos obstáculos económicos han llevado a situaciones como la «paralización del Programa Bizigune en VitoriaGasteiz, donde curiosamente la oferta de vivienda para este programa es muy importante al haber empujado el elevado número de VPP en alquiler existente, los precios de alquiler privado a la baja» (Etxabe, 2016).

\section{La dificultad de definir, cuantificar y localizar la vivienda vacía}

Pero no todo se ha de achacar a cuestiones presupuestarias. Pueden al menos detectarse dos debilidades más de este programa que afectan directamente a la cantidad de viviendas vacías movilizadas, y que además están relacionadas entre sí. Por un lado, está la metodología utilizada para la captación de estas. La orden que regulaba en 2003 el procedimiento a seguir establecía que Visesa realizaría «como mínimo, una convocatoria o llamamiento público a los titulares de viviendas vacías que reúnan las condiciones previstas en el Decreto 316/2002 de 30 de diciembre al objeto de que los mismos puedan contactar con la referida sociedad para concertar y, en su caso, otorgar el correspondiente contrato de cesión temporal» (Orden de 22 abril de 2003, del Consejero de Vivienda y Asuntos Sociales, 2003). Y en el más reciente decreto para regular este programa se fijaba que «las personas titulares de viviendas libres vacías interesadas en incorporarlas al Programa de Vivienda Vacía «Bizigune» deberán solicitarlo por escrito a Alokabide, S.A.» (Decreto 466/2013, de 23 de diciembre, 2013). Sin restar importancia ni capacidad de difusión y activación a las campañas publicitarias desarrolladas desde el Gobierno Vasco para el impulso de esta iniciativa, al tratarse de una serie de inmuebles específicos, la apuesta por una metodología basada en una captación directa, orientando los esfuerzos y recursos estrictamente a aquellas personas o instituciones propietarias, podría ser más eficaz y eficiente.

Lo cual lleva a la segunda cuestión: sin un detallado y actualizado censo e inventario de este tipo de viviendas desocupadas y/o con potencial de ser puestas en carga, no es posible tal estrategia. A lo largo de los años, son varios los municipios vascos -algunos dentro del AMB - en los que se están desarrollando experiencias para generar este tipo de bases de datos. De manera que los propios ayuntamientos pueden, una vez conocida la ubicación de las viviendas con condición de no ocupada, dirigirse a la propiedad correspondiente para intentar movilizarla hacia el alquiler protegido (Lujambio, 2009). Sin embargo, se trata de una tarea no exenta de dificultades que, siendo asumible en poblaciones pequeñas (Imagen 4.2), exige unos medios importantes para poblaciones mayores. 

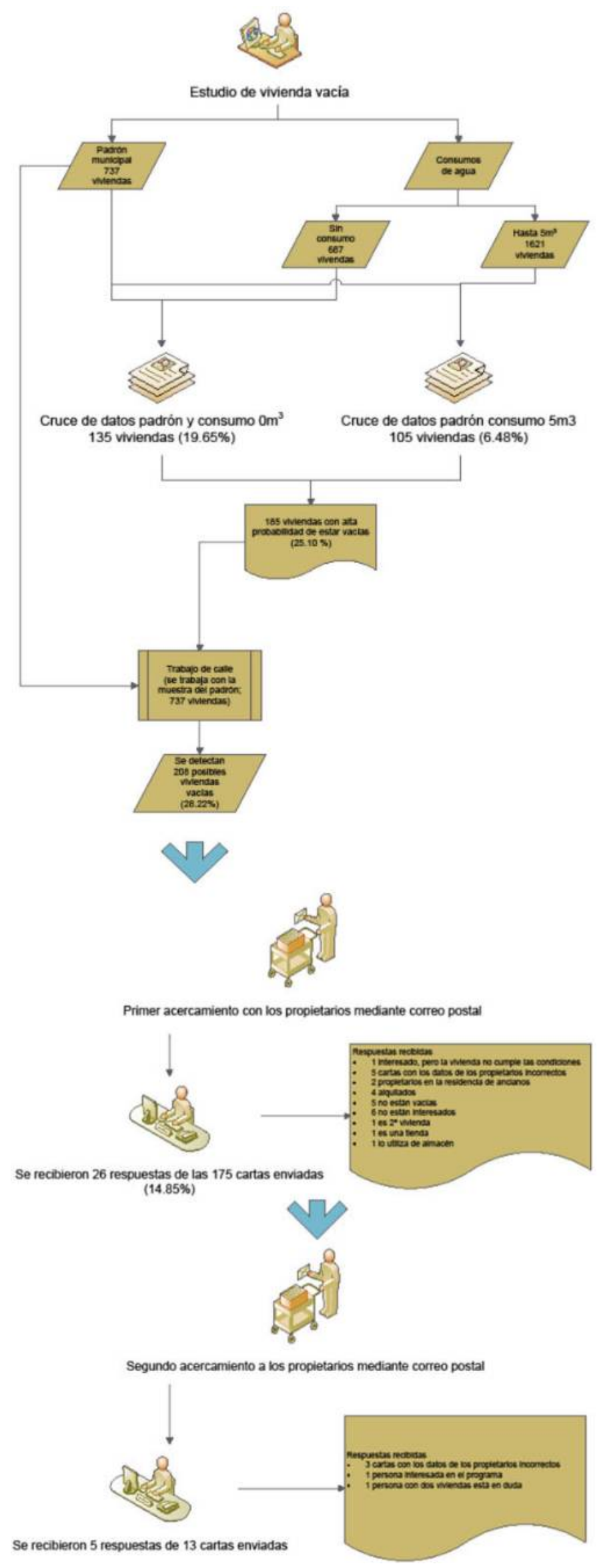
«Una vez cruzados los dos datos anteriores (padrón y consumo de aguas) se realizó un listado de las casas que tienen alta probabilidad de que estén vacías. Faltaba verificar si realmente esas casas estaban vacías. Para ello, se decidió acudir a las mismas casas para poder obtener información de primera mano. Primero se tocaba el timbre de la casa que supuestamente estaba vacía, para ver si respondía alguien. Si fuese así, se les explicaba el motivo de la visita y del estudio, y se les preguntaba si vivía alguien en esa casa. En la mayoría de los casos, no respondía nadie, por lo tanto, se les preguntaba a los vecinos. Una vez explicado el motivo de la visita y del estudio, se les preguntaba por la casa que supuestamente está vacía, y si sabía si vivía alguien o no. La mayoría de los vecinos mostraron una actitud positiva y colaboradora» (Lujambio, 2009: 37).

El citado estudio realizado en Andoain muestra también algunas lecturas de interés que reflejan la complejidad y diversidad de un parque que no puede ser, como se viene apuntando en los debates sobre esta materia, clasificado en categorías simples como viviendas vacías y ocupadas. Tal es el caso de la existencia de viviendas ocupadas sin personas empadronadas -sea por error del propio padrón o por estar empadronadas en otro municipio o vivienda(Lujambio, 2009: 38). En definitiva, el desarrollo de este tipo de censos ayudaría no solo a la eficacia de un programa como Bizigune, si no también a conocer, con más exactitud, la problemática que se está afrontando. Ya que, en algunos casos, los diversos motivos finalmente identificados por los que están vacías las viviendas ha hecho que el trabajo de campo haya devuelto unas cifras de viviendas desocupadas y susceptibles de ser movilizadas al alquiler social considerablemente por debajo de las estimaciones previas -un 28\% de las previstas en el caso de Andoain, y cerca de un tercio también en el caso de Bilbao $^{90}-$.

Por último, es de destacar otra debilidad de Bizigune -y también del programa ASAP analizado seguidamente-. Las garantías en su día ofrecidas por estos programas a la propiedad de la vivienda movilizada eran, como se ha dicho, un valor añadido poco común en el mercado y que podía ejercer una atracción e interés por participar en el mismo. Sin embargo, dichas garantías se están generalizando en el mercado libre, «por lo que cualquier persona que desee garantías las puede contratar. Desde ese punto de vista, Bizigune y sobre todo ASAP no aportan ya el valor que aportaban hace diez años, más allá

${ }^{90}$ Deia (2016): «Bilbao quiere captar las 5.453 viviendas vacías para impulsar el alquiler social», disponible en: http://www.deia.eus/2016/11/18/bizkaia/bilbao/bilbao-quierecaptar-las-5453-viviendas-vacias-para-impulsar-el-alquiler-social.

Es, sin embargo, necesario apuntar que la prudencia exige no tomar tampoco estas cifras para Bilbao como definitivas pues, además de ser una realidad cambiante, la metodología utilizada puede variar considerablemente los resultados. 
de que esas garantías son gratuitas para el arrendador, con el coste que eso supone para lo público, lo cual puede ser un argumento más para suprimirlas» (Cacho, 2016d).

\section{Ampliando la oferta de vivienda protegida}

En gran parte motivado por el alto coste del modelo de funcionamiento de Bizigune, el Gobierno Vasco puso en marcha un segundo programa paralelo de movilización de vivienda libre vacía, denominado ASAP. Las características principales del mismo han sido ya presentadas en apartados anteriores, pero a modo de síntesis, se recuerda que la diferencia principal, frente al primero, es que el programa ASAP lo que ofrece son unas garantías a la propiedad a cambio de fijar un precio máximo de alquiler. Es decir, se trata de un programa de intermediación, sin entrar a subvencionar la renta de alquiler a las personas arrendatarias. En cualquier caso, uno de los objetivos sigue siendo lograr incorporar al mercado de alquiler viviendas a un precio asequible, destinadas a aquellas personas con dificultades económicas para acceder al mismo. De manera que «las personas demandantes de vivienda en alquiler que, por sus circunstancias socio-económicas, quedan fuera de este mercado libre, tendrán mayores opciones de acceso a la vivienda en alquiler en este mercado intermediado por el programa ASAP» (Gobierno Vasco, 2016c: 3). Para lo cual, se garantiza que las viviendas incorporadas al programa no superan los precios máximos establecidos para cada municipio (Decreto 43/2012, de 27 de marzo, 2012). En un origen, en el citado decreto se estableció que las personas inscritas en el registro de solicitantes de vivienda protegida quedaban automáticamente incorporadas a la base de datos de demandantes de viviendas en ASAP, siempre que su demanda fuese en régimen de alquiler y cumpliesen ciertas condiciones de empadronamiento, carecer de vivienda en propiedad. Como se verá más adelante, este mecanismo de compartir base de datos sin filtro alguno fue un error que se tuvo que corregir.

\section{Fijación de un precio máximo de alquiler}

Las herramientas dispuestas para lograr lo anterior y poder orientar el programa hacia la demanda identificada, fueron en general las habituales en los sistemas de vivienda protegida. Por un lado, se establecieron unos límites máximos y mínimos de ingresos anuales para poder participar como unidad convivencial en el programa, en este caso, debiendo estar entre los 7.000€ y los 39.000€. Respecto a 
las rentas mensuales a pagar, los precios máximos admisibles fueron clasificados en ese mismo decreto en cinco escalones. En el caso del AMB, a Bilbao le correspondía un límite de $600 €$, mientras que el resto de municipios se distribuían entre los $550 €$ y los $475 €$. Mediante el cruce de ambas variables, ingresos y precios, el programa se asegura que la suma de las doce mensualidades de las viviendas a las que se puede acceder en cada caso no supere el 30\% de los ingresos anuales ponderados de la unidad de convivencia. Así, uno de los criterios para ordenar y dar preferencia a las unidades de convivencia que soliciten una vivienda en el programa tiene en cuenta la «correlación entre ingresos anuales ponderados de la unidad convivencial y renta de la vivienda» (Decreto 43/2012, de 27 de marzo, 2012).

\section{Dependencia de la responsabilidad social privada}

Este programa presenta algunas diferencias en la capacidad y el potencial de responder a la necesidad de vivienda, en comparación con Bizigune. Al tratarse de una intermediación, y no de una ayuda económica, mientras que en casos anteriores si la renta mensual superaba el 30\% de los ingresos esta podía de cara a la parte arrendataria ajustarse y verse reducida a través de la subvención pública de la misma, en este caso la superación de dicho límite supone directamente el descarte de la correspondiente vivienda. Es decir, la intervención del Gobierno Vasco en este caso es menor; se limita a ofrecer unas condiciones de seguridad y garantía a la propiedad a cambio del interés de esta por realizar un ejercicio de responsabilidad social. En otro orden de cosas, con la modificación del decreto que regula el programa realizada en 2014, la horquilla de ingresos mínimos para poder acceder al mismo subió desde los 7.000€ a los $12.000 €$, probablemente porque por debajo de estos difícilmente se puede asumir las rentas fijadas, que en el AMB rondan los 500-600€ al mes. Por otro lado, llama la atención la alta cifra superior de la horquilla, ya que con unos ingresos incluso inferiores a esos puede accederse al mercado libre no intermediado ni intervenido.

\section{Pequeños avances hacia una adaptación espacial}

$\mathrm{Al}$ igual que en otros procedimientos de adjudicación de vivienda analizados, entre los criterios de asignación de viviendas en el programa ASAP está el «máximo ajuste entre las características de la vivienda y el número de miembros de la unidad convivencial» (Decreto 43/2012, de 27 de marzo, 2012). A partir de 2014, el espacio de decisión sobre la adecuación o no de una vivienda a las necesidades de una unidad de convivencia se desplaza desde la administración -que era quien notificaba de la existencia de una vivienda apropiada - a la propia unidad interesada, al ofrecerse en la página web del programa una herramienta de búsqueda de viviendas disponibles, con filtros de búsqueda relacionados con algunas de sus características (Decreto 180/2014, de 23 de septiembre, 2014). Por 
otro lado, y como se ha mencionado al presentar el programa, este incluía la figura de los Agentes Colaboradores, cuya intervención, entre otras cosas, ofrece el potencial de tener la potestad dada por el decreto regulador del programa de uproponer la realización de las obras de adecuación que sean precisas para la inclusión de las viviendas en el Programa y revisarlas una vez concluidas» (Decreto 43/2012, de 27 de marzo, 2012). Se configuran así como posibles actores de detección de oportunidades tipológicas como las analizadas en el capítulo anterior, e impulso de transformación y adaptación del parque a unidades de convivencia con carencias habitacionales.

\section{Continuidad a una clasificación tipológica simplificada}

A pesar de contar con la intención de adecuar las características de la vivienda a las de la unidad de convivencia demandante, la metodología utilizada se basa en el número de miembros de la unidad convivencial. Se trata, una vez más, de una visión simplista del espacio doméstico en el que las viviendas se clasifican por número de dormitorios, y las unidades de convivencia por su tamaño. Dejando de lado otras variables de gran importancia ya señaladas, como el perfil de los miembros de dicha unidad convivencial -edad, origen, modo de vida, tipo de trabajo,...-u otras configuraciones espaciales que vayan más allá del dormir, el estar y los trabajos reproductivos. Así, la persona dada de alta en ASAP no recibirá ofertas de viviendas disponibles si esta «no cumple con la adecuación habitacional (relación entre miembros-habitaciones según la vigente normativa de Etxebide)» (Gobierno Vasco, 2015c). Por otro lado, si bien la capacidad de los agentes para proponer obras de adaptación es un valor muy positivo, el coste de las mismas es posiblemente un freno para la propiedad, siempre y cuando no haya algún tipo de facilidad en forma de ayuda o financiación- económica desde las instituciones públicas.

\section{La apuesta por el Agente Colaborador para movilizar viviendas}

Al igual que lo es para Bizigune, en el caso de ASAP el objetivo principal de la iniciativa es la movilización de viviendas desocupadas del parque libre existente para su aprovechamiento. Para lograr este objetivo concreto, de las herramientas desplegadas aquí se destacan dos. La primera es la creación de la ya mencionada figura de los Agentes Colaboradores. El interés de la misma radica en el empoderamiento que se ha planteado de los mismos. En efecto, se trata de una red de profesionales externos a la administración pública que «asumirá una serie de funciones trascendentales para la puesta en marcha y funcionamiento del referido programa» (Decreto 43/2012, de 27 de marzo, 2012). Entre las principales funciones de estos 
agentes, además de la ya mencionada potestad de proponer obras de reforma, están las de informar y difundir el programa entre posibles grupos de interés -tanto personas arrendadoras como arrendatarias-, captar aquellas viviendas libres de ser incorporadas al programa, y recoger las solicitudes de inclusión en el programa presentadas por los anteriores para presentarla a su vez al Gobierno Vasco. Así mismo, el decreto establece que corresponde a estos mismos agentes la asignación de las viviendas a las unidades de convivencia correspondientes, según los criterios definidos, lo cual probablemente ayude a reducir los plazos de respuesta al reducir la labor a realizar por la administración pública. Como contraprestación, y lo cual puede servir de aliciente para que estos agentes participen activamente en el programa, la propiedad del inmueble movilizado debe retribuir al agente correspondiente por los servicios desarrollados. Concretamente, deberá entregar el importe equivalente a una mensualidad de alquiler al inicio de cada contrato, y media con cada renovación, además de una comisión mensual máxima del 3\% de la renta y la obligación de atribuir la exclusividad a dicho agente de al menos seis meses para la gestión de su alquiler (Decreto 180/2014, de 23 de septiembre, 2014).

La segunda herramienta destacada, y utilizada como principal aliciente para atraer a aquellas personas o entidades propietarias de viviendas sin ocupar, es la oferta de una serie de garantías a cambio de la incorporación de estas al programa. En concreto se garantiza, a través de la contratación de pólizas de seguros -esta vez sí mediante la subvención directa a la propiedad-, el cobro mensual de la renta acordada, la defensa jurídica en caso de que se requiera debido a posibles conflictos generados, un seguro de responsabilidad civil, asistencia en la vivienda y la reparación de aquellos desperfectos y daños materiales causados en viviendas y mobiliario. También existe otro tipo de garantía, si se quiere ver así, que puede favorecer la atracción de personas propietarias al programa. Esta se formaliza en que, una vez el Agente Colaborador ha entregado en la administración la solicitud de inclusión de una vivienda en el programa ASAP, pasados los tres meses de plazo para notificar la resolución del expediente este se considera como aceptado y la vivienda quedará incluida en el mismo (Decreto 43/2012, de 27 de marzo, 2012).

\section{Autocrítica y mejoras del programa}

A pesar de contar con pocos años de vida, las instituciones responsables del programa han sabido detectar sus principales errores de planteamiento, ante algunos de los cuales se ha buscado responder y adaptarse. Creado en 2012, ya en 2013 y 2014 se observaban dificultades para una correcta adjudicación (Alokabide, 2013: 24, 2014: 24). El cambio llegó a finales de 2014 con el Decreto 180/2014, de 23 de septiembre, en el que se pasó de incorporar automáticamente a todas aquellas personas inscritas en el sistema 
vasco de vivienda que cumpliesen las condiciones de ASAP a su base de datos, a establecer una plataforma web en la que las propias personas interesadas $-\mathrm{y}$ dadas de alta como solicitantes de vivienda protegida- fuesen quienes analizasen la oferta de viviendas disponible y solicitasen aquellas de su interés. Las viviendas quedan asignadas así por orden de solicitud. Con ello se buscó simplificar la gestión, reducir drásticamente el número de renuncias, y acortar los plazos de adjudicación, lo cual era causa de desincentivo para ambas partes. $\mathrm{Al}$ igual que se ha visto con el programa Bizigune, también en ASAP la colaboración y unión de esfuerzos se muestra y se ha identificado por parte de los agentes interesados como una herramienta de gran interés y potencial. En este caso, entre el departamento competente del Gobierno Vasco en materia de vivienda, y los gobiernos de escala municipal -con una mayor capacidad de conocer y gestionar el entorno local- con el objetivo de sacar el máximo partido al parque residencial existente.

\section{Escaso éxito y repetición de errores de Bizigune}

Pero de la misma manera, también se han identificado ciertos puntos débiles e inconvenientes en el planteamiento del programa. Algunos de los cuales vienen repitiéndose respecto a su predecesor, Bizigune. En primer lugar, destaca que la estrategia para captar viviendas sigue enfrentándose a un mismo reto: la inexistencia de un censo actualizado y preciso de las viviendas desocupadas. Con lo cual, el principal engranaje del programa queda en manos de que la diversa propiedad de este tipo de viviendas, a partir de las campañas de divulgación y publicidad que desde Gobierno Vasco se hacen, se active, sensibilice, y ponga a disposición del mismo sus viviendas desde una posición de responsabilidad social. Es decir, la iniciativa ha de salir del lado de la propiedad, quedando en la administración pública la gestión. Este primer obstáculo es uno de sus grandes inconvenientes y la principal razón del escaso éxito alcanzado. Se trata, según algunas personas, de un programa que «se ha mostrado claramente ineficaz» (Cacho, 2016b), y que «no ha cumplido con las expectativas, debido al complejo encaje de necesidades e intereses de los agentes colaboradores, las personas propietarias y los demandantes de vivienda» (Etxabe, 2016). Efectivamente, el número de viviendas finalmente logrado a lo largo de los años se ha quedado muy lejos de los objetivos planteados. Con lo cual el actual gobierno plantea la necesidad de reflexionar y analizar los errores de esta iniciativa:

«Por su parte, el Programa ASAP se planteaba como una importante alternativa para captar viviendas para el arrendamiento protegido con un ambicioso objetivo de 2.330 viviendas en los 4 años del PDV 2010-2013. Sin embargo, este nuevo programa de intermediación en el mercado de alquiler se ha quedado muy por debajo de las expectativas ya que únicamente han sido captadas 254 viviendas (grado de 
cumplimiento del 11\%). Estos bajos resultados plantean la necesidad de realizar una reflexión sobre el programa, analizando en profundidad aquellos lugares en los que ASAP ha tenido éxito de cara al aprendizaje y traslación a otros municipios de estas buenas prácticas» (Gobierno Vasco, 2017: 37).

Además del bajo número de viviendas incorporadas, lo que ha sido también determinante durante al menos los primeros años de vida de ASAP ha sido el bajo nivel de ocupación de estas, resultando un programa ineficiente. En el periodo que va desde 2012 -el año de su puesta en funcionamiento- hasta 2014, el mayor índice de viviendas adjudicadas y habitadas fue del 30\% (Cacho, 2016b). Es decir, durante esos años más del 70\% de las viviendas incorporadas al programa no eran adjudicadas. De esta manera, los esfuerzos realizados por lograr movilizar viviendas del parque privado -que, como se ha visto, supone una tarea difícil en un contexto social que percibe erróneamente la soberanía de la propiedad privada olvidando su función social- se ven con frecuencia perdidos ante una ineficacia de gestión. La razón parece estar en el planteamiento, ya comentado, de compartir de manera automática la base de datos general del servicio de vivienda protegida.

En 2014 se aprobó una modificación con el objetivo de afrontar dicho problema, una vez constatado que se estaba muy lejos de los objetivos marcados. Efectivamente, se apuntaba desde el Gobierno Vasco como causa de esta ineficacia a «el procedimiento de adjudicación de las viviendas, que registra numerosas renuncias y se alarga durante varios meses, lo que acaba por desincentivar a los propietarios», para lo cual se estimaba oportuno «agilizar dicho procedimiento e introducir una serie de mejoras en el programa que lo hagan atractivo para las personas titulares de viviendas vacías como para las personas demandantes de alquileres asequibles» (Decreto 180/2014, de 23 de septiembre, 2014). La estrategia fue, como ya se ha mencionado, hacer que sean las propias personas interesadas en arrendar una vivienda dentro del programa las que a través de una plataforma web específica, estudien la oferta existente y soliciten la vivienda que deseen. Se trata de una maniobra que en teoría agiliza el proceso y reduce los plazos de adjudicación desde que una vivienda es incorporada al programa. Sin embargo, como ya se mencionado, el informe realizado en 2017 para la redacción del Plan Director de Vivienda 2018-2020 apunta a que los objetivos han seguido quedando muy lejos de lo esperado. Por último, al igual que ocurre con Bizigune, las garantías ofrecidas a la propiedad por parte de ASAP a través de la contratación de pólizas de seguros no supone hoy en día un valor añadido, ya que en los inicios del programa no existían en el mercado, pero hoy esas garantías ya están disponibles en él. 


\section{Reproducción de una estructura de unidades de convivencia atomizada}

El servicio vasco de vivienda es uno de los referentes en el Estado respecto a otras comunidades autónomas. Pero como se ha mostrado hasta aquí en los capítulos primero, segundo y este mismo, y pese a sus éxitos, se trata aún de un sistema con carencias que no logra satisfacer el derecho de acceso a una vivienda digna de una parte de la población. Es este, de hecho, un problema que se está complejizando y agravando cada vez más, en la medida en que el precio de la vivienda parece que vuelve a subir, disminuye la capacidad de pago de los gastos propios de la vivienda de muchas unidades de convivencia, y aparecen diferentes formas de precariedad y vulnerabilidad residencial ${ }^{91}$. Una muestra de la incapacidad que las diversas herramientas públicas analizadas tienen para dar solución a estas situaciones, la ofrecen los precios máximos de alquiler establecidos por el Gobierno Vasco en sus programas de incorporación de vivienda libre a la oferta de vivienda protegida en alquiler. En un contexto en el que las unidades de convivencia unipersonales van en aumento, estas rentas de alquiler quedan por encima de la renta máxima tolerable calculada por el informe del Observatorio Vasco de la Juventud utilizado como referencia metodológica en el capítulo previo, que eran $420 €$ para una renta media de $1.461 €$ en el año 2013; la renta media disponible por municipio para ese mismo año estaba en muchos casos por debajo de la misma (Tabla 4.2).

Como se ha apuntado, las limitaciones presupuestarias del Gobierno Vasco y la propia inviabilidad económica de estos programas condicionan en gran medida el éxito de los mismos. En cuanto al aprovechamiento del parque existente, la política pública vasca de vivienda viene dando desde hace varios años un giro hacia una puesta en carga y utilización eficaz de este como estrategia prioritaria frente a los nuevos crecimientos. Las motivaciones que hay

${ }^{91}$ A lo largo del verano de 2018 se pudieron leer titulares relativos a estas cuestiones:

Eldiario.es (2018): «El precio de la vivienda crece en Euskadi un 6,1\% en el primer trimestre del año», disponible en: https://www.eldiario.es/norte/euskadi/precio-viviendaEuskadi-primer-trimestre_0_779722119.html.

Eldiario.es (2018): «El número de familias con problemas para pagar el alquiler y otros gastos básicos se duplica desde 2008», disponible en: https://www.eldiario.es/ norte/euskadi/familias-problemas-alquiler-basicos-duplica_0_777622527.html.

Eldiario.es (2018): «Se busca piso para refugiado», disponible en: ,https://www.el diario.es/norte/euskadi/busca-piso-refugiado_0_775172994.html.

En este caso último caso, es de gran relevancia el dato de que el Ararteko (Defensoría del Pueblo del País Vasco) «reclama al Gobierno vasco más mano dura con los dueños de viviendas en el mercado libre que se niegan a alquilar viviendas a determinados colectivos, incluso a pesar de disponer de ingresos por trabajo o por prestaciones sociales». 


\begin{tabular}{|c|c|c|c|c|}
\hline Municipio & $\begin{array}{l}\text { Renta } \\
\text { media } \\
(2013)\end{array}$ & $\begin{array}{c}\text { Diferencia } \\
\text { respecto a } \\
1.461 €\end{array}$ & $\begin{array}{c}\text { Renta } \\
\text { máxima } \\
\text { ASAP }\end{array}$ & $\begin{array}{c}\text { Renta } \\
\text { máxima } \\
\text { Bizigune }\end{array}$ \\
\hline Abanto-Zierbena & 1.180 & -233 & 475 & 450 \\
\hline Alonsotegi & 1.543 & 130 & 475 & 450 \\
\hline Arrigorriaga & 1.447 & 34 & 475 & 450 \\
\hline Barakaldo & 1.058 & -355 & 550 & 450 \\
\hline Barrika & 1.177 & -236 & 475 & 450 \\
\hline Basauri & 1.908 & 495 & 550 & 450 \\
\hline Berango & 1.333 & -80 & 550 & 450 \\
\hline Bilbao & 1.309 & -104 & 600 & 450 \\
\hline Derio & 1.360 & -53 & 475 & 450 \\
\hline Erandio & 1.326 & -87 & 550 & 450 \\
\hline Etxebarri & 1.356 & -57 & 475 & 450 \\
\hline Galdakao & 1.409 & -4 & 550 & 450 \\
\hline Getxo & 1.465 & 52 & 550 & 450 \\
\hline Larrabetzu & 1.300 & -113 & 475 & 450 \\
\hline Leioa & 864 & -549 & 550 & 450 \\
\hline Lezama & 1.882 & 469 & 475 & 450 \\
\hline Loiu & 1.543 & 130 & 475 & 450 \\
\hline Muskiz & 1.573 & 160 & 475 & 450 \\
\hline Ortuella & 1.881 & 468 & 475 & 450 \\
\hline Portugalete & 1.426 & 13 & 550 & 450 \\
\hline Santurtzi & 1.467 & 54 & 550 & 450 \\
\hline Sestao & 1.205 & -208 & 550 & 450 \\
\hline Sondika & 1.156 & -257 & 475 & 450 \\
\hline Sopela & 1.064 & -349 & 550 & 450 \\
\hline Trapagaran & 1.445 & 32 & 475 & 450 \\
\hline Urduliz & 1.241 & -172 & 475 & 450 \\
\hline Zamudio & 1.217 & -196 & 475 & 450 \\
\hline Zaratamo & 1.186 & -227 & 475 & 450 \\
\hline Zierbena & 1.345 & -68 & 475 & 450 \\
\hline
\end{tabular}

Tabla 4.2. Renta media personal y alquileres máximos protegidos $(€)$ en el AMB para los programas ASAP y Bizigune. Elaboración propia a partir de Eustat, Decreto 43/2012, de 27 de marzo del Gobierno Vasco y web de Bizigune (2015).

detrás de ello son diversas -el derroche de recursos materiales y energéticos, la carencia de suelo fácilmente urbanizable en una región con una orografía accidentada y suelos accesibles prácticamente ocupados, el drama de contar con viviendas infrautilizadas en un contexto de necesidad habitacional, la intervención socio-espacial con 
operaciones de rehabilitación integral en ámbitos urbanos degradados,...-, y aunque la inercia urbanizadora sigue presente y alimenta intereses en múltiples esferas públicas y privadas, la reflexión del deber social de aprovechar el parque existente se va extendiendo. Desde los programas de movilización de vivienda libre vacía, a las operaciones de rehabilitación por parte de las sociedades públicas como Visesa y Alokabide, los avances en este sentido son significativos. Sin embargo, se han podido identificar ciertos obstáculos que los limitan. La dificultad de sensibilizar y atraer a la propiedad privada para incluir sus viviendas en dichos programas, o una vez más- la carencia de medios económicos públicos para cubrir los objetivos marcados, por ejemplo.

En lo que a la cuestión tipológica se refiere, se ha visto que existen diferentes esfuerzos y caminos abiertos con la intención de adecuar las características espaciales de la oferta de vivienda protegida a las necesidades cambiantes de un abanico de unidades de convivencia diverso. La inquietud por responder a ello y la identificación de una evolución de los tipos de unidades de convivencia -y una consecuente reflexión en torno a la misma- es palpable en los agentes públicos analizados. Sin embargo, ante el marco y las carencias presentadas en los capítulos previos, estos esfuerzos se quedan cortos de miras y no acaban de despegarse de una visión simplista y conservadora del espacio doméstico. La apertura de canales de diálogo y el desarrollo de análisis de datos estadísticos no son aprovechados en todo su potencial. Se limitan en gran medida a identificar las variaciones demográficas desde la óptica del número de estancias necesarias destinadas a dormitorios, o al número de personas que conforman cada unidad de convivencia. Y siempre bajo la premisa de que a una vivienda existente le ha de corresponder una, y solo una, unidad convivencial demandante.

Como una de las posibles maneras de abordar esta compleja problemática, aquí se pretende hacer una reflexión transversal guiado por la cuestión tipológica -como antes ya se ha hecho al plantear el sentido y el motivo de la existencia de los espacios de oportunidad detectados-. Los resultados presentados llevan a plantear que mientras se mantenga en el papel ejercido por la administración pública la inercia, consciente o no, de seguir reproduciendo las condiciones habitacionales para una idea de familia o unidad de convivencia heredada que cada vez es más minoritaria -una pareja heterosexual con uno, dos o tres descendientes-, será muy difícil desbloquear las otras dos cuestiones aquí analizadas: el acceso económico digno y la puesta en carga del parque infrautilizado. Pero como se ha visto en el capítulo previo, existen ciertos márgenes de maniobra -previo cambio sustancial en la manera de abordar la problemática- para que ciertos tipos de unidades de convivencia puedan ver satisfecha su necesidad, a un precio asequible y aprovechando el parque actual. Se trata, como ya se ha indicado, de un potencial latente propio del contexto actual para re-escalar y 
adaptar el parque residencial existente a unas unidades de convivencia diversas en tamaño, necesidades y hábitos, logrando así salvar los obstáculos propios de un mercado inmobiliario muy homogéneo tipológicamente. Lo cual abre a su vez la posibilidad de reducir el gasto necesario al repartir este entre varias de estas unidades, gracias a que su tamaño es inferior al de aquellas para los que fueron diseñadas muchas de las viviendas actuales.

La necesidad de no dejar exclusivamente en manos del mercado y los intereses puramente empresariales esta estrategia implica caminar hacia la agrupación y la acción colectiva, no solo a escala de la vivienda, que fortalezca estos planteamientos y defienda los intereses de las personas demandantes. Por todo ello, es de resaltar que desde las políticas públicas y sus programas y herramientas de vivienda protegida se está en una situación privilegiada para incorporar este planteamiento e implantarlo en sus actuaciones -al menos de manera experimental en un inicio-, ofreciendo una excelente oportunidad para ponerlo en práctica. Aunque cuenta con grandes retos y fuertes presiones tanto internas como externas, la dimensión y fortaleza propias de la administración pública son un enorme aliciente y una gran ventaja que colocan a esta en una posición muy favorable para desarrollar esta estrategia aquí esbozada. Su ámbito de actuación e influencia permite actuar en su propio parque, en el de terceros agentes a través de la gestión subrogada, o difundir y acompañar en el proceso a la propiedad privada interesada. Para ello, es necesario comenzar por dos cuestiones estrechamente unidas: cambiar radicalmente el enfoque de la unidad de convivencia como familia 'convencional', y romper con una estructura de la propiedad residencial rígida que formaliza espacialmente lo anterior. 


\section{Alternativas en búsqueda de lo colectivo}

Una primera mirada fuera de las herramientas públicas se dirige hacia aquellas iniciativas del ámbito privado que, compartiendo algunos de los objetivos tratados en la investigación, incorporan en su naturaleza principios de acción colaborativa, colectiva $\mathrm{y} / \mathrm{o}$ cooperativa. El motivo de ello es que este tipo de iniciativas pueden establecer un contexto muy favorecedor para el acompañamiento y la puesta en práctica de la estrategia identificada en el capítulo anterior de agrupar unidades de convivencia. Lo hacen en ocasiones, además, yendo más allá del trabajo con grupos de personas asociadas en exclusiva para un inmueble determinado, para abordar la cuestión desde una escala por encima de estos. $\mathrm{Y}$ es que en todos ellos se observa una dimensión política, una inquietud proveniente de la responsabilidad social y la defensa del interés general -en este caso el derecho a al vivienda- frente a las presiones y desigualdades propias del modelo inmobiliario residencial actual. En algunos casos, esto es patente cuando se busca activamente también la colaboración como instrumento para avanzar hacia las metas marcadas; concretamente, la colaboración entre los agentes privados y la administración pública.

Sumae Coop.

\section{Una gestión de calidad como garante del acceso}

A pesar de haber contado con poca información sobre esta sociedad cooperativa, su posicionamiento respecto al papel social de la vivienda es claro, pues en los documentos consultados establecían que sus esfuerzos van encaminados a «que el acceso a la vivienda sea una realidad y se gestione correctamente» (Sumae, 2016). Son conscientes de las carencias económicas de una gran parte de la población demandante y así lo transmiten en su carta de servicios. Y es precisamente en la gestión del proceso para llevar a cabo este derecho donde esta empresa pone el énfasis, afirmando que dicho acceso a la vivienda social solo es posible cuando se cuenta con una buena gestión y un adecuado asesoramiento. 


\section{Unos servicios específicamente orientados a las metas}

Desde la premisa anterior, ofrecen diferentes servicios que tienen algunos de los objetivos aquí trabajados como fin último. Por un lado, ofrecen servicios de asesoramiento y acompañamiento a proyectos de co-housing y otros tipos de comunidades residenciales no habituales, destinados «a grupos de familias, o personas solas, con voluntad de crear comunidades vecinales, a promover y diseñar ex-novo edificios de viviendas que faciliten la existencia de positivas relaciones de convivencia entre las unidades familiares» (Sumae, 2016). Iniciativas que están planteadas desde una mirada abierta a otras tipologías de vivienda fruto de este tipo de relaciones comunitarias y que, a pesar de que a priori parece limitarse el servicio a proyectos de nueva planta, bien podría ser desarrollado en la rehabilitación y transformación de edificios existentes, sean estos residenciales o no. Por otro lado, Sumae aborda la problemática de un parque infrautilizado. Ofrecen a las administraciones públicas servicios para la movilización de vivienda vacía hacia el alquiler asequible mediante la «detección y elaboración de mapas y censos de viviendas desocupadas o infrautilizadas en cada municipio, e implementación de un plan de medidas normativas, económicas y de gestión pública» (Sumae, 2016). Dentro de los cuales, engloban la necesidad de que dicha oferta sea a su vez acorde a las necesidades de las personas demandantes; si bien no queda claro a qué tipo de necesidades se está haciendo referencia -económicas, tipológicas,...-. Este tipo de servicios podría cubrir la ya mencionada carencia de censos e información precisa y actualizada sobre las viviendas vacías que afectan a la eficacia de programas como Bizigune ASAP. La limitación de la información recogida sobre este caso impide profundizar más en su actividad, e igualmente reduce la capacidad de analizar sus posibles debilidades.

\section{$-4.4 .2-$}

\section{Urbania ZH Gestión}

\section{Servicios para el acceso económico y la adaptación tipológica}

En cuanto al objetivo de la accesibilidad económica, esta empresa enmarcaba sus servicios residenciales en actuaciones con un componente social. Para lo cual trabajaban en la gestión de parques públicos, de planes de vivienda, o el fomento de viviendas en régimen de cesión de uso, promoviendo cooperativas que optimicen sus recursos propios y puedan acceder a una vivienda a un menor coste. La variable tipológica estaba presente en muchos de estos proyectos, sobre todo actuando como agente de acompañamiento de 
comunidades residenciales diversas. Acumularon experiencia con grupos de co-housing denominados 'senior', formados por personas mayores que buscan una alternativa a la respuesta que la sociedad les ofrece -normalmente limitada a residencias de mayores, a vivir con otros familiares en las viviendas de estos, o a situaciones de soledad en sus propias casas-. A este tipo de perfiles ofrecían «herramientas de consultoría y gestión profesionalizada que permite viabilizar proyectos de vivienda a residentes senior que serán los que planifiquen su vivienda y espacios comunes, marcando sus necesidades y servicios. La toma de decisiones es completamente asumida por los propios residentes» (Urbania, 2016).

\section{Movilización de vivienda vacía desde una postura colaborativa}

Esta empresa ofrecía también servicios de consultoría y gestión para movilizar vivienda vacía hacia el alquiler asequible, mediante «proyectos adaptados a las necesidades de cada administración, coordinando la publicidad y la información, la localización de viviendas vacías susceptibles de ser alquiladas, estableciendo garantías para los propietarios y localizando a los demandantes de vivienda de alquilen» (Urbania, 2016). Han colaborado con varios ayuntamientos del AMB -incluso fuera de esta, con la Diputación de Barcelona- en la implantación de este tipo de programas, desarrollando censos previos y estudiando las posibilidades reales de poner en carga dichas viviendas. Unas experiencias que les ha permitido constatar que «muchas viviendas vacías tienen restricciones de habitabilidad o bien sus propietarios no quieren o no pueden alquilarlas. Por eso es necesario conocer cuál es la disponibilidad real de vivienda vacía [...] cuál es la realidad exacta de las viviendas vacías y cuáles son los motivos reales para que sus propietarios no puedan o no quieran alquilarlas. Una vez que se tiene un conocimiento exhaustivo del parque de vivienda vacía, se propone a los propietarios diferentes alternativas para su inclusión en el mercado de alquiler asequible» (Urbania, 2016). Desde la empresa se insistía en que no importa tanto conocer la cantidad de vivienda vacía, si no el potencial real de ser alquilada a precios asequibles. Para lo cual se defendía que el ejercicio de detección e información solo se podía hacer desde lo local, desde la escala municipal.

Estas iniciativas desarrolladas fueron para Urbania «un magnífico ejemplo de cómo la colaboración público-privada -realizada con criterios de gestión subordinada al interés público- puede mejorar las condiciones objetivas de la ciudadanía para acceder a una vivienda» (Urbania, 2016). Su experiencia les llevó a identificar tres pilares fundamentales en este tipo de programas: detectar las viviendas cuantitativa y cualitativamente-, movilizarlas -mediante diversos instrumentos, medidas e incentivos-, y gestionarlas -cooperando con instituciones de escalas superiores como diputaciones o gobiernos 
autonómicos, gestionando directamente desde el gobierno local las viviendas movilizadas, y fomentando la aparición y puesta en marcha de empresas sin ánimo de lucro del denominado tercer sector enfocadas a dicha gestión-. Todo ello, para ser «orientado al fomento de una vivienda alineada con la economía, lo social, el desarrollo sostenible y el refuerzo de las redes comunitarias civiles» (Urbania, 2016). Por otro lado, es de destacar que su planteamiento iba más allá de la vivienda vacía, enfocando también la mirada hacia bienes públicos en desuso que podrían ser reconocidos hacia, entre otros, un uso residencial. Quedaban estos identificados como bienes susceptibles de gestión, catalogados como activos públicos ociosos por falta de financiación o por falta de especialistas, para los que ofrecían soluciones dentro de sus objetivos con un componente social.

\section{Empresa pública total}

Una de las propuestas de interés de esta empresa es el concepto que denominaban 'empresa pública total'. Se trataba de una manera de colaboración novedosa entre las esferas pública y privada con el objetivo común de la defensa del interés general. El origen está en la detección de una serie de disfunciones en el modelo habitual de gestión pública -ya sea a través de la gestión directa, la creación de empresas públicas, el contrato de prestación de servicios, o la concesión administrativa-. Disfunciones como la «dependencia presupuestaria de la matriz, cultura funcionarial de control y no de impulso de proyectos, escaso incentivo de la innovación y creatividad, insuficiente atención a la eficiencia y la eficacia, pésima provisión de los puestos de trabajo, etc» por parte del modelo público de trabajo, y la «búsqueda del beneficio a corto plazo, empeoramiento de las condiciones laborales del personal, nulo incentivo para la inversión a largo plazo, etc» de un sector privado adjudicatario que suele enfocar excesivamente hacia el lucro privado (Urbania, 2016). Frente a ello, se proponía un modelo con el objetivo «crear actividad económica pública susceptible de generar ingresos adicionales a la matriz administrativa» (Urbania, 2016), a la vez que garantizase empleo de calidad y de larga duración. Una propuesta de empresa de titularidad totalmente pública, con una gestión profesionalizada mediante la contratación de su gestión, y con unos objetivos bajo un modelo empresarial con plazo y coste determinados. Se proponía así una plantilla totalmente privada que «implica relaciones laborales de derecho privado y una cultura organizacional volcada en los objetivos empresariales y la excelencia profesional» (Urbania, 2016), una actividad exclusivamente financiada por el sector financiero, y unos beneficios exclusivamente públicos, que serían «transferidos a la matriz, a la administración propietaria de la empresa» (Urbania, 2016)

(Urbania, 2016):

«Este modelo permite llevar adelante proyectos inequívocamente de interés general, buscando la producción de 
una serie de bienes y servicios públicos, así como la dinamización de la economía y el empleo local, con una combinación de lo mejor de lo público (empresa de propiedad pública), lo profesional y la economía social/cooperativa. El modelo de Empresa Pública Total que nosotros proponemos crea el mismo o más valor añadido y empleo que el de muchas empresas privadas, pero el lucro que se pueda producir no acaba en mano privadas, sino que revierte a la matriz administrativa (y con ello, al conjunto de la ciudadanía). Y lo más importante, mantiene y mejora el servicio público que recibe la ciudadanía» (Urbania, 2016).

Más allá de su planteamiento teórico, parece que el modelo existe y viene funcionando en varios municipios españoles desde hace más de diez años. Lo cual llevaba a que desde Urbania se defendiese el potencial de aplicarlo a cuestiones tales como la movilización de vivienda vacía, o la rehabilitación integral de barrios. El limite de este planteamiento puede quizás situarse cerca de ciertas corrientes de privatización de los servicios públicos, aunque en esta ocasión parecen darse elementos que lo sitúan fuera de objetivos lucrativos y bajo la búsqueda del interés general. En cualquier caso, como ocurre con Sumae Coop., la escasez de información disponible impide profundizar en estos y otros planteamientos de esta iniciativa privada, quedando el análisis limitado a su propio material de difusión. Lo cual no permite estudiar sus posibles inconvenientes o debilidades.

\section{Marco para cooperativas de vivienda en Euskadi}

\section{Posibilitando un acceso asequible a la vivienda}

Las ventajas y valores que las cooperativas aportan al proceso de acceso residencial son abiertamente conocidas, por «lo positivo que supone trasladar los principios del cooperativismo al ámbito de la promoción de vivienda» (Bilbao, 2014: 11). El interés de las soluciones residenciales que este tipo de iniciativas son capaces de generar en múltiples agentes, desde los puntos de vista social y medioambiental, es alto y suele superar los niveles alcanzados en estos ámbitos por el modelo convencional de promoción de viviendas (Burón, 2014). Incluso su aporte a la esfera pública, en lo que se refiere a las relaciones con su entorno comunitario cercano, suele ser de gran valor:

«Las cooperativas traen muchos efectos positivos consigo.

Gracias a la colaboración de las diferentes personas aportan variedad urbanística y se oponen a la monotonía, a menudo criticada, de las zonas de nueva construcción [...] Mediante un 
proyecto comunitario y un compromiso personal a menudo se crean intensas relaciones entre vecinos y con ello una estructura social estable que tiene consecuencias positivas en el entorno» (Liese, 2009: 277).

Aunque, con frecuencia, es la ventaja económica la que suele destacar. Probablemente, porque se trata en definitiva del principal y más generalizado obstáculo de acceso a la vivienda entre los colectivos con necesidad de la misma. Al fin y al cabo, las cooperativas son en general modelos que reducen gastos e intermediarios, obtienen ventajas fiscales y conllevan, en definitiva, un precio final inferior al del mercado por un producto de similares características (Etxezarreta y Etxezarreta, 2007:156). Esto se ve enriquecido por la posibilidad de que este tipo de formas de propiedad pueda ofrecer viviendas protegidas a sus socios (Gondra, 2004: 109). Consecuentemente, el desarrollo e implantación de este tipo de iniciativas extiende y posibilita, bajo determinadas condiciones, la existencia de parques de vivienda a precios asequibles gestionados por entidades que podrían clasificarse como dentro del tercer sector, ya sean cooperativas al uso o empresas tipo 'housing associations' (Burón, 2014). Por supuesto, no están carentes de dificultades. Una de las debilidades que el sistema cooperativo presenta, en cuanto a la dimensión económica se refiere, es la dificultad de encontrar en muchos casos «una banca que ofrezca financiación a largo plazo a tipos de interés moderados para este tipo de viviendas, edificios y parques», así como la disposición, por parte de la administración pública, de suelo y ayudas para iniciativas de esta naturaleza (Burón, 2014).

\section{Empoderamiento aplicado al diseño}

El funcionamiento bajo un modelo cooperativo facilita -aunque no siempre se consiga- el empoderamiento de las personas que la integran. De manera que cuentan con mayor información, disfrutan de un proceso de aprendizaje, y desarrollan una mayor implicación en la toma de decisiones. Esto es de especial interés, entre otras cuestiones, en el aspecto tipológico y espacial:

«...el mercado de la vivienda, en especial el de pisos, ofrece sólo viviendas de tamaños y tipologías estándar, que apenas responden a las crecientes necesidades individuales del público: los promotores confían más en proyectos clásicos y conformes al supuesto mercado en lugar de experimentar con nuevas formas de vivienda. Sin embargo, los miembros de las cooperativas tienen ideas concretas sobre la vivienda que no pueden verse reflejadas en los pisos llave en mano ni en las viviendas unifamiliares aisladas» (Liese, 2009: 277).

La integración y la participación de sus integrantes en el proceso de planteamiento y desarrollo de la cooperativa desde el inicio 

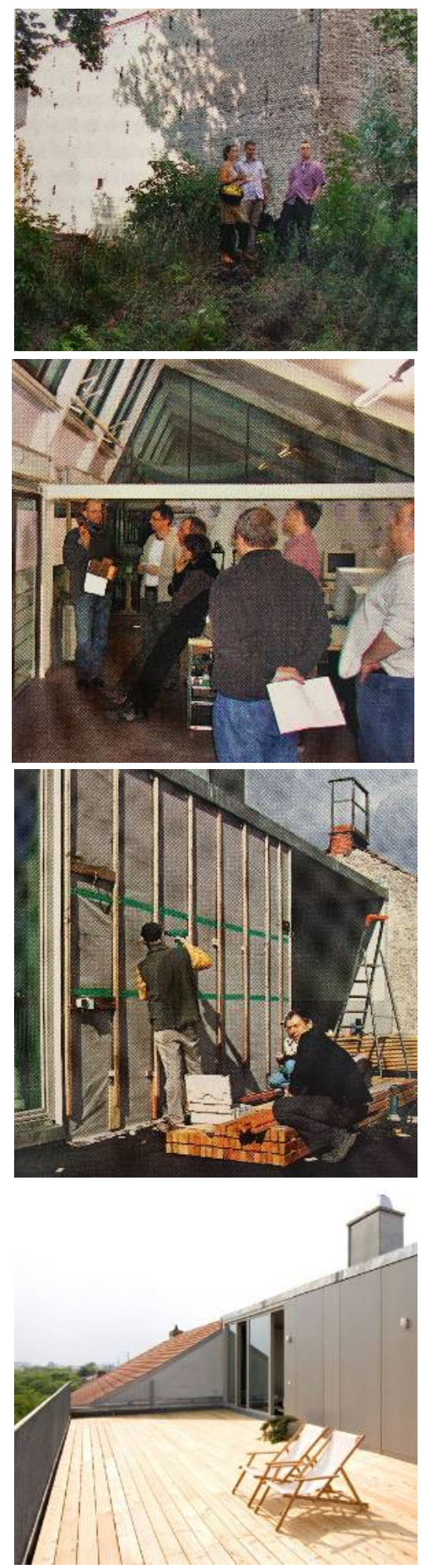

Imágenes 4.3 a 4.6. Visitas al solar, talleres de diseño, participación en la construcción, y resultado final de una cooperativa

de viviendas en Berlín. Roedig Schop Architekten, 2009. permite conocer sus necesidades y deseos -también sus limitaciones y condicionantes-, para posteriormente tomar decisiones de diseño (Imágenes 4.3 a 4.6). En algunos casos se han llevado «a cabo talleres durante días enteros antes de comenzar la obra. Por la tarde se colgaban los resultados en la pared y así todo el mundo podía imaginarse su piso [...] Muchos aprendieron gran cantidad de cosas gracias a toda la información que les llegaba» (Roedig Schop Architekten, 2009: 346). De esta manera, los espacios se adaptan dentro de lo posible- a cada situación y a cada unidad de convivencia, además de consensuar entre las personas socias las características y los programas de los espacios comunes, o los usos y soluciones a priorizar. Si en el proceso se cuenta con la presencia y el apoyo de personas con el conocimiento técnico necesario, se produce una transmisión de conocimiento que ayuda a identificar necesidades y seleccionar soluciones tipológicas concretas que conducirán a una experiencia habitacional mucho más satisfactoria. El desarrollo conjunto del proyecto en ocasiones «ha ayudado a generar una mayor identificación con el proyecto, ya que hemos proyectado, debatido, y decidido juntos. Contribuir de manera personal ha sido una gran experiencia. Hemos desarrollado una buena relación y una cultura del acuerdo» (Roedig Schop Architekten, 2009: 352). Por otro lado, es patente el efecto en una vida en comunidad más rica, pues en las viviendas anteriores «sólo habíamos llegado a conocer a nuestros vecinos inmediatos, pero aquí existe un genuino espíritu de comunidad, una estructura semejante a la de un pueblo, en el corazón de la ciudad $[\ldots]$ quedamos en la terraza para ver el fútbol o hacer una barbacoa; esto es calidad de vida» (Roedig Schop Architekten, 2009: 352).

\section{Un modelo dependiente de una sociedad civil organizada y fortalecida}

En cuanto al aprovechamiento del parque existente como bien infrautilizado, el modelo cooperativo tiene -al igual que en el caso de la adaptación tipológica- potencial y capacidades para ello. En el segundo caso, como se acaba de apuntar, porque las personas socias se establecen como individuos con capacidad de decidir y consensuar aspectos programáticos y de diseño. En el primero, porque de las intereses de la cooperativa y de la oferta disponible dependerá también la posibilidad de desarrollarla sobre un inmueble existente, o no. Pero en cualquier caso, ambas cuestiones dependen del enfoque de la propia iniciativa, y no se trata de cuestiones tan estructurales e incluso motivadoras como la económica. Por esto último, es habitual encontrar casos en los que, más allá de un ahorro económico, no se diferencian del modelo inmobiliario residencial convencional en cuanto a las tipologías de viviendas desarrolladas, ni en cuanto al modelo de ciudad impulsado a través de la nueva construcción en parcelas de reciente urbanización. Con todo, algunos profesionales con conocimiento de este modelo residencial llevan tiempo 
identificando las carencias que la sociedad y el sistema actual presentan para un mayor desarrollo del mismo. Por un lado, la necesidad de que la sociedad civil se fortalezca en la materia; por otro, que desde las esferas de gestión pública «vean en la sociedad civil organizada en materia de vivienda un instrumento privilegiado de ejecución de sus políticas, y no solo como un fenómeno difícil de encajar en las existentes rígidas normativas administrativas» (Burón, 2014).

Desde una perspectiva interna, y en el marco vasco, en ocasiones se dan conflictos y fricciones entre los dos principales órganos de gestión de las cooperativas: el consejo rector y la asamblea general. Estos choques están alimentados por cuestiones como el desconocimiento del sector de la promoción y construcción residencial por parte de las personas socias, la presión de algunas entidades gestoras para que las decisiones se tomen en el primero de los órganos por razones de agilidad y plazos, o el condicionamiento de entidades financieras para trabajar bajo esta figura de propiedad. Todo ello lleva a algunos autores a proponer instrumentos que «permitan ejecutar los procesos de decisión interna de manera perfectamente armonizada, ofreciendo, de este modo, mayor resistencia a las influencias externas que puedan afectarles de manera indeseada» (Bilbao, 2014: 10).

\section{La expansión de las falsas cooperativas}

A pesar de todo, algunos de los retos mencionados son propios de aquellos casos en los que la cooperativa no se toma como fin, si no como medio temporal para un acceso algo más económico al mismo producto inmobiliario ofertado en el resto del mercado (Etxezarreta y Etxezarreta, 2007: 161). Es decir, todo el potencial que este tipo de estrategias colectivas ofrece para generar vivienda queda desaprovechado, desvirtuando la figura en sí misma. Es lo que algunos vienen a llamar 'falsas cooperativas de vivienda':

«Por lo general, en las últimas décadas un proyecto cooperativo de vivienda es aquel en el que un conjunto de compradores de vivienda se agrupan en una cooperativa de promoción. La idea es que ellos van a ser los empresarios de su propia construcción. Van a contratar a un gestor de cooperativas. Van a comprar un suelo (o rehabilitar un edificio ya existente). Y cuando termine el proceso de promoción o rehabilitación van a dividir la propiedad del edificio, de forma que cada cooperativista va a ser propietario de una vivienda y de un porcentaje de los espacios comunes. Esto es lo que se entiende por cooperativa de vivienda en nuestro país, al menos de forma casi hegemónica. Yo a esta especie la llamo FALSAS COOPERATIVAS. Y les doy este nombre por la siguiente razón: cuando se hacen con limpieza, formalmente son cooperativas, pero materialmente es poco mas que el traslado 
del riesgo financiero del promotor (propietario del suelo o del edificio y, a veces, incluso gestor de cooperativas) al comprador. No hay elementos de propiedad compartida. Más allá de mancomunar el riesgo financiero y, en algunos casos, conseguir una rebaja de precio (control de los costes por los cooperativistas) y/o cierta adaptación del programa constructivo de las viviendas a las demandas de los cooperativistas.

\section{$[\ldots]$}

En los últimos años ha surgido otro género de cooperativas de vivienda que también forma parte de las auténticas falsas cooperativas. Yo las llamo FALSAS COOPERATIVAS DEFENSIVAS. Carecen casi por completo de elemento cooperativo alguno, incluso en fase de promoción. Pues lo que mueve estas operaciones es que el propietario del suelo, promotor y gestor de cooperativas (aunque cambien los nombres, suelen ser la misma entidad o entidades aliadas) no asuma ningún riesgo financiero y que sean los compradores finales los que financien con sus medios la operación desde el minuto cero. Una prueba clara de si estamos ante una cooperativa de vivienda verdadera o impostada es comprobar quien realiza la captación de futuros cooperativistas. Si el propietario de suelo, promotor o gestor de cooperativas hace publicidad para encontrar cooperativistas es casi seguro que estamos ante una cooperativa defensiva» (Burón, 2014).

Efectivamente, en Euskadi en los últimos años es muy habitual observar este tipo de situaciones de comercialización de promociones en régimen de cooperativa en búsqueda de socios, promovidas por grandes empresas que aglutinan la gestión, la promoción y la construcción. Algunas fuentes señalan que desde «el estallido de la burbuja, los grupos promotores no son lo suficientemente solventes para acceder a los créditos bancarios, por lo que buscan en la figura de la cooperativa una forma de viabilizar sus inversiones» (Rodríguez Alonso y Fernández, 2016). Tal es el nivel de normalización y falta de cuestionamiento de este modelo cooperativo que la propia Confederación de Cooperativas de Euskadi afirma que «el objeto de las Cooperativas de Vivienda es promover viviendas para sus propios/as socios/as cooperativistas. Ser socio/a de una cooperativa de vivienda significa convertirse en promotor/a de las viviendas para posteriormente acceder a una de estas viviendas en propiedad o alquiler [...] Una vez finalizada la promoción es habitual la disolución de la sociedad cooperativa» (Konfekoop, 2016). Es decir, sin hacer especial mención a los valores y principios positivos que un modelo cooperativo puede conllevar en el tiempo, relacionados con la convivencia, la comunidad y la colaboración, la participación en el proceso de diseño del programa y necesidades, o la definición de los espacios. Y asumiendo como normal el paso de un régimen de raíces 
democráticas como el cooperativo a otro capitalista como el de la propiedad horizontal, que valora a cada persona o unidad de convivencia por lo que posee.

El enfoque de ese planteamiento es el de utilizar el régimen cooperativo de manera temporal como acceso más seguro y económico a un mismo producto y modelo de ciudad residencial $-\mathrm{O}$ como vía para mantener la actividad promotora y constructora en el caso de ciertos agentes de gestión-. Se trata, en definitiva, de cooperativas estrictamente de promoción y construcción, no de uso o convivencia (Gondra, 2004: 109), con una vida media no superior a los cinco años desde que se registran hasta que se liquidan una vez finalizada la obra, y con una clara apuesta por un régimen final de propiedad individual de cada vivienda, desechando no solo el régimen cooperativo si no también el alquiler (Etxezarreta y Etxezarreta, 2007). Así, lo frecuente es encontrar promociones bajo este tipo de planteamientos reproduciendo no solo las tipologías residenciales conservadoras ya mencionadas -jerarquizadas, destinadas a familias nucleares con de uno a tres descendientes-, si no un bajo nivel de aprovechamiento del parque existente -con algunas excepciones- al desarrollarse frecuentemente en parcelas de nueva urbanización.

\section{- 4.4.4 - \\ Etxekoop}

\section{Luces en la noche inmobiliaria}

Al contrario que en otros países y ciudades, las iniciativas que Burón califica como 'auténticas cooperativas de vivienda' resultan escasas y difícilmente localizables en el AMB. Se trataría de «una asociación de personas que promueven, usan y gestionan de forma colectiva uno o varios edificios. La diferencia fundamental es que el edificio una vez entregado no divide su propiedad entre los usuarios, sino que sigue siendo un bien y solo uno. Eso implica que el cooperativista es primero financiador, después propietario colectivo del bien en su conjunto, así como usuario de una de sus viviendas (una suerte de inquilino de un bien del que es propietario colectivo) y usuario de los espacios y servicios comunes que el edificio tiene a disposición de sus propietarios (comedor, lavandería, huerta, servicio médico, gimnasio ... -lo que los cooperativistas hayan considerado de interés para si mismos y pueden sufragar-)» (Burón, 2014). Se trata de proyectos que, con cierta frecuencia, suelen incorporar valores complementarios más allá del estrictamente económico, buscando mejoras ambientales y sociales en su entorno cercano, así como promoviendo una adecuada y rica convivencia entre sus habitantes. Es un modelo muy extendido en países escandinavos, así como Reino Unido, Alemania, Canadá, Estados Unidos o Uruguay. 
A pesar de ser casi excepcionales, hay en el AMB iniciativas que se enmarcan totalmente en este modelo 'auténtico', en línea con unos valores cooperativos sinceros. Una de ellas es el proyecto Etxekoop, de creación reciente, con la intención de enfrentarse a un modelo urbanístico residencial centrado en el individualismo y la no colaboración. A pesar de su corto recorrido, entre sus logros está el haber presionado en la fase de redacción de la Ley de Vivienda de Euskadi para incluir en la misma la figura de las cooperativas de vivienda en régimen de cesión de uso -recogida en la disposición adicional tercera-, así como «el compromiso autoadquirido a instancias del Parlamento Vasco de una experiencia piloto» (Desazkundea, 2016).

\section{Transversalidad y conciencia de su entorno}

El objetivo del acceso económico está claramente definido en la documentación consultada, y se le concede la importancia que le corresponde como principal variable para el acceso a la vivienda. Eso sí, este viene siempre acompañado por otros valores a los que se les atribuyen también un lugar prioritario. De tal forma que el fin del proyecto es «facilitar el acceso a la vivienda como problema o necesidad social no resueltas y creando valor social o ambiental» a través de la misma (Más que una Casa, 2017), ofreciendo así a las personas socias una vivienda de carácter social, a un precio asequible y ambientalmente sostenible (Barandiaran, 2015). Esta interseccionalidad del proyecto queda reflejada, por ejemplo, cuando los criterios establecidos para la búsqueda de financiación exigen que esta sea a través de una banca ética solidaria. La apuesta que en Etxekoop se hace por la autogestión, y el compromiso de mantener a lo largo del proceso una participación real de las personas socias en el diseño, gestión y -en definitiva- en la toma de decisiones, supone una base inmejorable para que los espacios tanto privados como comunitarios sean diseñados acorde a las necesidades y deseos de sus habitantes. El grupo de personas que conforma esta iniciativa lo hace además desde el conocimiento y la inquietud por afrontar algunos de los problemas y conflictos de las áreas urbanas contemporáneas, planteando que su objetivo es lograr desarrollar el proyecto en uno o varios edificios dando preferencia a las oportunidades de hacerlo en edificios existentes. Su intención es demostrar que se trata de un modelo posible y generalizable; que pueda responder a problemáticas como la de la vivienda vacía (Desazkundea, 2016). Para ello, se pretende «investigar, mapear y relacionar instituciones públicas y privadas en el ámbito de la vivienda que puedan apoyar la rehabilitación y remodelación de edificios en viviendas dentro del formato de cooperativas en cesión de uso» (Más que una Casa, 2017). La principal debilidad del proyecto está en la reducida disponibilidad de capital para la adquisición de edificios o solares en los que desarrollar el mismo. 


\section{Egunsentia Aurora}

\section{Un colectivo mayor proactivo en búsqueda de alternativas}

También con una reciente aparición en el AMB, y siguiendo el ejemplo de casos existentes en otros lugares, se está comenzando a observar el nacimiento de una variante dentro de las cooperativas de vivienda en régimen de cesión de uso, orientada a grupos de personas mayores, y denominadas en ciertos círculos como co-housing senior. La iniciativa Egunsentia Aurora se enmarca en este tipo de proyectos. $\mathrm{El}$ acceso a una vivienda a un precio asequible e inferior al disponible en el mercado es una de las razones de la creación de esta agrupación. Aunque no la única, pues este colectivo detecta una importante carencia de soluciones habitacionales en el sistema de cuidados de personas mayores actual. Entre las razones de su existencia está el evitar un envejecimiento en soledad en su propia vivienda -con los problemas crecientes de autonomía y dependencia que ello conlleva-, el no tener la posibilidad o no desear que sea la familia quien desarrolle dichos cuidados, o el rechazo al modelo habitual de residencias para la tercera edad. Se trata de un proyecto que busca una solución adaptada a sus necesidades, que permita una convivencia y apoyo comunitario compatibles con un espacio más íntimo y personal.

Así, dado que los integrantes de este proyecto de co-housing no aspiran a obtener ningún lucro con la operación, si no que tratan de responder a una necesidad no cubierta, «en el caso de obtener beneficios (hay cohousings que alquilan vivienda a terceros, que ofrecen servicios no solo a sus usuarios, sino al público en general, etc), estos se reinvierten en el propio cohousing» (Urbania, 2016). En definitiva, se trata de una variante del régimen de cooperativa en régimen de cesión de uso, pues «este tipo de empresas (técnicamente es lo que son) no solo no reparte beneficios, sino que no divide horizontalmente la propiedad. Los cohousers no son propietarios de una vivienda o espacio concreto, sino de un porcentaje de la empresa, participación que es vendible en el mercado»(Urbania, 2016). La sintonía entre algunos de los agentes analizados en el trabajo es patente al observar que Urbania ZH Gestión, empresa anteriormente analizada, fue contratada por Egunsentia Aurora para desarrollar servicios de asesoramiento y acompañamiento en el proceso de búsqueda de un espacio y el desarrollo del propio proyecto. Este está además abierto a la adquisición y reforma de un edificio ya construido, con lo que podría enmarcarse en una estrategia de aprovechamiento del parque existente. Además, la citada consultoría realizada por Urbania ZH Gestión se centra, entre otras cosas, en el asesoramiento en la búsqueda de ubicación. 


\section{Una demanda tipológica no ofertada}

Debido a la propia naturaleza del proyecto, la adaptación tipológica de los espacios privados y comunes está prácticamente asegurada, dependiendo ya de la capacidad de comunicación y entendimiento entre la agrupación de personas que lo forma y el personal técnico que desarrolle el proyecto arquitectónico. La garantía de esta adecuación espacial se debe principalmente a que, en este caso, la motivación primordial que mueve la iniciativa no es tanto la económica, si no la tipológica. Las soluciones actuales no satisfacen ni sus demandas, ni el modelo de convivencia que busca este colectivo, por lo que entre los fines de esta asociación está el «facilitar y organizar colectivamente la respuesta a las distintas necesidades de las personas residentes» (Egunsentia Aurora, 2016). Tal es así que sus propios estatutos reflejan, entre las actividades a realizar, el estudiar las necesidades de las personas mayores y las distintas alternativas para afrontarlas. La estrategia que inicialmente se ha planteado como solución espacial es «que cada persona socia disponga de un espacio privado modulable de unos $30 \mathrm{~m}^{2}$, de forma que pueda unirse con el de otra persona si desean compartir $60 \mathrm{~m}^{2} »$ (Egunsentia Aurora, 2016).

\section{Apuesta por la colaboración}

Entre los aspectos positivos comunes a los tres objetivos aquí analizados, está la búsqueda de colaboración con otras entidades, tanto publicas como privadas, «en la promoción de esta alternativa residencial, especialmente en el caso de que estén dirigidas a personas mayores» (Egunsentia Aurora, 2016). Lo cual apunta a la disposición hacia una actitud colaborativa de los diversos agentes participantes como uno de los instrumentos clave para alcanzar y generar soluciones habitacionales fuera del modelo hegemónico residencial. Y que no solo abarcaría a los usuarios finales; desde las instituciones públicas a las entidades financieras, pasando por empresas constructoras, el cambio de una mentalidad dirigida al lucro planteada por la visión estrictamente económica e inversora de la vivienda parece un requisito indispensable para poder hacer realidad proyectos con una mayor transversalidad. En este sentido, parte del camino ya se ha recorrido, pues desde el Gobierno Vasco ya se ha incluido, como se ha avanzado, este tipo de figuras en la Ley de Vivienda. Por otro lado, se ha de destacar que la conformación de Egunsentia Aurora como asociación parece haber facilitado el diálogo y la atención por parte de la administración pública ${ }^{92}$.

92 Deia (2015): «Sesenta vizcaínos promueven la primera cooperativa de pisos autogestionados», disponible en http://www.deia.eus/2015/10/04/bizkaia/sesentavizcainos-promueven-la-primera-cooperativa-de-pisos-autogestionados\#Loleido. 


\section{Lecciones de experiencias cercanas}

Esta iniciativa está en activo y sigue en búsqueda de poder hacer realidad el proyecto que llevan años desarrollando. Los retos no son pocos, tal y como han podido comprobar las personas integrantes de una iniciativa similar, Housekide, en este caso ubicada en Donostia/San Sebastián, y que tras varios años intentándolo decidieron cerrar el proyecto por falta de viabilidad. Igual que en el caso de Egunsentia, las razones que les llevaron a agruparse se deben a aspectos relacionados con la convivencia y la falta de soluciones específicas en el mercado o en el sistema público:

«Estamos convencidos de que proyectos como Housekide, donde las personas mayores unen esfuerzos para preparar su futuro en convivencia y solidaridad son necesarios en esta sociedad donde la familia ya no puede ser, ni queremos que lo sea, quien se haga cargo de nosotros, y donde no podemos esperar hoy por hoy, de los poderes públicos una implicación en proyectos vanguardistas o innovadores» (Housekide, 2016).

Pero igualmente que en la anterior, la dimensión económica era una variable de gran importancia, ya que «además de lo que se puede ahorrar con una financiación conjunta a la hora de construirlo, en la vida del cohousing vamos a poder compartir numerosos gastos de mantenimiento, de calefacción, de servicios de ayuda y sanitarios, de transporte, de comida, etc» (Housekide, 2016). Por otro lado, en sus escritos y comunicaciones quedaba igualmente clara la carencia detectada y la necesidad identificada de unos espacios específicamente diseñados para unas situaciones concretas y poco atendidas en el parque residencial existente. Así, declaraban que «somos los que decidimos (en la medida que se pueda) el lugar de emplazamiento, el diseño, y la construcción [...] nosotros mismos habremos decidido qué espacios y servicios comunes tendremos, en qué régimen, cómo nos organizaremos para la vida en el co-housing» (Housekide, 2016). Pero quizás la lectura más interesante que se pueda hacer de esta iniciativa disuelta por sus propias socias, en cuanto a su aporte constructivo para otros casos presentes o futuros -como Egunsentia Aurora-, es el análisis de las razones que llevaron a dar por cerrado el proyecto. Desde la propia agrupación se identificaban estas como «muchas y complejas», entre las que se daban «nuestras propias limitaciones como grupo» (Housekide, 2016). La situación general de la que partía el colectivo era que cada persona socia contaba con una vivienda en propiedad y totalmente pagada, tras cuya venta estimaban que podrían acceder a la oferta de parcelas a edificar o edificios a rehabilitar. Sin embargo, este planteamiento se vio enfrentado a dos obstáculos. Por un lado, el precio de los escasos suelos disponibles en aquellas zonas en las que el colectivo estaba interesado resultó ser más alto del esperado, hasta el punto de ser «inabordables para economías como las nuestras» (Housekide, 2016). Y es que no hay que olvidar 
que la capital guipuzcoana es una de las ciudades del estado con los precios más altos.

Por otro lado, el planteamiento inicial se vio afectado por la incapacidad de vender sus actuales viviendas; reduciendo así sus posibilidades de financiación a la búsqueda de esta en entidades financieras de las que parece que no obtuvieron apoyo. En este punto cabría reflexionar sobre el rango de precios al que se intentó vender dichos inmuebles, de lo que no se tiene información, y si el mismo grupo fue víctima de un mercado alimentado o compartido por sus propias expectativas. En cuanto a su relación con las instituciones públicas, a pesar de autodenominarse como un proyecto autogestionado e independiente, desde el colectivo de Housekide se ha detectado una falta de apoyo y atención por parte de la administración, ya que «no esperábamos ayudas económicas de la administración, pero sí que pensábamos que un proyecto innovador, y con fuerte componente social como el nuestro merecía un poco más atención y apoyo por parte de las autoridades, que nos han dado muchas buenas palabras y elogios, pero ninguna ayuda efectiva» (Housekide, 2016). Son todas estas valiosas lecciones a tener en cuenta en experiencias como la de Egunsentia Aurora. Más cuando una de las principales debilidades o retos del proyecto puede estar en la aportación inicial necesaria de $60.000 €$ planteada por el grupo promotor. Esto puede ser un obstáculo considerable para muchas personas que no tienen la capacidad económica de hacerlo.$$
\text { - 4.4.6 - }
$$ \\ Agrupación de unidades de convivencia como fundamento del proyecto}

La búsqueda de una oferta de vivienda económicamente accesible es sin duda una de las principales líneas de trabajo compartidas por las experiencias privadas aquí analizadas. Sin embargo, y a diferencia de los programas y políticas públicas anteriormente presentadas, en estos casos esta variable se ve acompañada, en importancia y dedicación, por las otras metas tratadas en el trabajo. Especialmente, aquella centrada en la adecuación del parque a las necesidades espaciales. La búsqueda sincera y real de esta adaptación, de generar un producto final acorde a las características propias de sus habitantes, conlleva forzosamente -como se ha visto- el desarrollo de un proceso de toma de decisiones abierto e informado, con el consecuente empoderamiento de las personas participantes y la necesidad de alcanzar consensos entre diferentes. En cuanto a los esfuerzos por poner en carga un parque residencial ya existente, aunque se trata de un objetivo menos prioritario, se ha podido ver que varias de las iniciativas se plantean como opción el desarrollo de su proyecto en un 
inmueble ya construido. Algunas de las razones que lo motivan son la búsqueda de un entorno social y/o ambiental de su agrado.

La idea que aquí interesa rescatar de este apartado, con la estrategia de agrupación del capítulo previo en el horizonte, es que la principal herramienta para lograr los tres objetivos planteada por estas diversas experiencias es la agrupación de unidades de convivencia. En este sentido, se ha visto como Sumae identifica a los grupos de unidades como su público objetivo, para facilitar «positivas relaciones de convivencia» entre ellos. Los casos de Etxekoop y Egunsentia Aurora centran gran parte de su planteamiento en el trabajo colectivo como herramienta de enriquecimiento del proyecto en su fase de diseño y en su vida útil. Lo que implica la creencia de que es desde una posición colaborativa como se logrará un espacio -individual y compartido- adecuado a sus necesidades, construir unas relaciones comunitarias ricas basadas en el consenso, el respeto o los cuidados, y desarrollar en todo el proceso un rico conocimiento en torno a la vida en comunidad, la construcción o la ciudad. Y todo, asumiendo que esta agrupación de unidades de convivencia es la vía para lograrlo bajo un coste económico razonable y accesible, y el camino para evitar que muchas de ellas queden fuera del mercado libre -puede que también del protegido-. El ejemplo citado de la cooperativa de viviendas en Berlín es una de tantas muestras de que así puede llegar a ser. En los casos de los co-housing senior, la carencia actual de soluciones a medida para este colectivo con unas legítimas aspiraciones que van más allá de un envejecimiento precario, se ve contrarrestada por el enorme potencial que otorga su agrupación y trabajo colectivo para trabajar bajo la auto-gestión y desarrollar soluciones tipológicas específicas.

Pero esta unión de unidades de convivencia como camino de empoderamiento hacia el acceso a una vivienda digna, también se observa que abarca otros fines y escalas. Varias de las experiencias mostradas integran en sus discursos objetivos más ambiciosos, que van más allá de su propio proyecto residencial. Así, se busca generar efectos positivos tanto en su entorno social más cercano -tal y como afirman desde Etxekoop y Egunsentia Aurora-, como en la sociedad en su conjunto -ambas iniciativas han presionado y favorecido la incorporación en la Ley de Vivienda de Euskadi este tipo de figuras cooperativas-. Esta interacción de agentes privados -como lo son estas cooperativas- con las instituciones públicas son la prueba de que, compartiendo un mismo fin, la aplicación de un espíritu de colaboración y gestión abierta puede suponer grandes aportes a la cuestión. En ese sentido, algunos casos como el de Urbania ZH Gestión o la propia Egunsentia Aurora insisten en la necesidad de generar y fortalecer este tipo de relaciones público-privadas. Se trata por tanto, este ejercicio de unión de unidades de convivencia, de una oportunidad de gran interés para lograr los tres objetivos aquí analizados. Sin embargo, esto exige un cambio de mentalidad. Tal y como afirmaban desde Sumae, este planteamiento necesita de 
unidades de convivencia con voluntad de crear comunidad. Es decir, ha de haber un espíritu proactivo por parte de una sociedad civil que, como insiste Burón -que ha desarrollado parte de su actividad profesional en Urbania ZH Gestión-, ha de estar organizada y debe contar con el apoyo de las instituciones públicas. Una sociedad que mire más allá de satisfacer sus necesidades individuales de vivienda, y trabaje en paralelo por defender al colectivo demandante de la misma. Con todo, los retos y dificultades de este tipo vías no son pocos. Entre ellos, la necesidad de romper con la rígida estructura de la propiedad del modelo inmobiliario local y su reflejo en la mentalidad 'propietarista' de la sociedad. Lo que podría abrir la puerta a iniciativas colectivas no necesariamente acotadas a un inmueble único, si no a una red de diversos inmuebles distribuidos por el parque existente. 


\section{$-4.5-$ \\ Programas de urgencia social}

Aunque destinados a unidades de convivencia y situaciones con una mayor vulnerabilidad residencial y una más urgente necesidad de vivienda que las hasta ahora analizadas -sobre todo comparado con los casos de co-housing senior que, aparentemente, cuentan con un capital de partida relevante-, los agentes, programas e instituciones dirigidas a cubrir casos habitacionales urgentes merecen también un breve repaso. Desde su especificidad, buscan responder también a las tres metas acotadas e identificadas en el presente trabajo. Por supuesto, el primer y principal fin es lograr un acceso económicamente digno y factible para estas personas. En algunos casos esto puede llegar a suponer un coste cero para estas; en otros, se tratará de reducir mediante subvenciones el gasto en vivienda de dichas unidades de convivencia. Pero, como se verá, también es posible detectar cierta inquietud y preocupación porque estas soluciones, habitualmente temporales $\mathrm{o}$ de transición hacia situaciones más estables, se adecuen también espacial y tipológicamente a las necesidades de las personas demandantes de estos programas. Necesidades que, en muchos casos, se alejan considerablemente de las unidades de convivencia más habituales de la demanda de vivienda protegida, debido precisamente a que son colectivos especialmente vulnerables -personas migrantes $\mathrm{y} / \mathrm{o}$ refugiadas, socialmente excluidas por otras razones que llevan a serlo también residencialmente, situaciones diversas de dependencia,...-. Igualmente, el intento de responder a estas situaciones desde la puesta en carga y la renovación del parque residencial existente es patente en varios de los casos, incorporando medidas para que las viviendas destinadas a estas situaciones sean rehabilitadas y mantenidas en un estado de habitabilidad digno.

\section{Ayudas de Emergencia Social}

\section{Cubrir los gastos mínimos para un alojamiento digno}

Entre los destinos a los que pueden dirigirse estas ayudas sociales están varios gastos relacionados con la vivienda habitual. Desde el coste de la renta mensual del alquiler, a aquellos «derivados de 
intereses y de amortización de créditos contraídos con anterioridad a la situación de emergencia social como consecuencia de la adquisición de una vivienda o alojamiento» (Decreto 4/2011, de 18 de enero, 2011), pasando por los correspondientes a los suministros básicos, el impuesto sobre bienes inmuebles, o los propios para garantizar un equipamiento y habitabilidad dignos -mobiliario, electrodomésticos básicos, reparaciones, instalaciones,...-. Es decir, su objetivo es aligerar o cubrir, en mayor o menor medida, las dificultades económicas que ciertas unidades de convivencia presentan para poder acceder, bajo unas condiciones mínimas, al alojamiento digno que constitucionalmente está establecido. El máximo de los costes subvencionados por este tipo de instrumentos en 2015 eran $250 €$ al mes para gastos de alquiler o amortización de créditos, $1.110 €$ anuales para suministros e impuestos de bienes inmuebles, $925 €$ anuales para mobiliario y electrodomésticos, $1.850 €$ para reparaciones y mantenimiento, o $3.000 €$ anuales para cubrir gastos de endeudamiento previo. Es decir, según la finalidad de la ayuda y el perfil de la unidad de convivencia que habita la vivienda, la cuantía se establece en diferentes cantidades.

Las garantías que permiten que estas ayudas sean dirigidas a aquellas personas con mayor urgencia vienen incorporadas en la legislación correspondiente. El aprovechamiento de otras estructuras del sistema público de vivienda permite adelantar ciertos trámites en este sentido; para poder recibir la subvención de las AES dirigida a la cobertura de los gastos del alquiler de la vivienda, la persona o unidad de convivencia solicitante debe estar inscrito como solicitante de vivienda en Etxebide. Por supuesto, hay ciertas excepciones: los casos en que no cumplen los requisitos del anterior por cuestión de residencia o de renta mínima, o ciertos casos de personas mayores de 65 años. Así mismo, se establecen ciertas incompatibilidades para garantizar un correcto reparto de los recursos económicos con estos fines. Las ayudas de emergencia social destinadas al pago del alquiler no son compatibles con la Renta de Garantía de Ingresos -en ninguna de sus modalidades-, y en ningún caso lo serán las destinadas al acceso y mantenimiento del alojamiento habitual con la Prestación Complementaria de Vivienda.

\section{Un instrumento limitado y rígido}

En algunos casos, el sistema autonómico de ayudas se ve limitado por la dotación presupuestaria destinada para ello, y los gobiernos locales disponen de programas complementarios bajo criterios prácticamente idénticos, unas «prestaciones económicas similares a las establecidas por la Ley 18/2008» (Ayuntamiento de Barakaldo, 2009):

«Teniendo en cuenta que los recursos en concepto de ayudas de emergencia social competencia del Gobierno Vasco se tornan insuficientes para atender la demanda de ayudas a los vecinos del municipio, el Ayuntamiento de Barakaldo establece 
anualmente una partida económica con el objetivo de poder atender las solicitudes que no han podido ser satisfechas con la consignación presupuestaria del Gobierno Vasco» (Ayuntamiento de Barakaldo, 2009).

Es precisamente el anterior uno de los potenciales puntos débiles de este tipo de programas. Al tener una naturaleza subvencional, y a pesar de que «el Gobierno Vasco y los Ayuntamientos, en su calidad de administraciones públicas competentes, consignarán con carácter anual las cantidades suficientes para hacer frente a los gastos relacionados con las mismas [queda] su concesión sujeta a la existencia de crédito consignado para esa finalidad en los Presupuestos Generales de la Comunidad Autónoma de Euskadi» (Decreto 4/2011, de 18 de enero, 2011). Por otro lado, en ocasiones los plazos máximos de resolución y carácter del silencio administrativo establecidos en la normativa sectorial podrían seguir favoreciendo estas situaciones de exclusión, al ser los primeros de dos meses, y el sentido del silencio negativo; es decir, si no hay respuesta se dará la solicitud por denegada.

También existe la posibilidad de que aparezcan conflictos para la adjudicación de estas ayudas en ciertas situaciones de sobreocupación de viviendas que pueden darse en algunos colectivos con baja capacidad económica. El citado decreto establece en un máximo de dos las ayudas a destinar a una misma vivienda, independientemente del número de unidades de convivencia que en ella se alojen. Esto implica una limitación de los recursos económicos disponibles por algunas unidades para el acceso y disfrute de la vivienda. Frente a lo anterior, sí se observa cierta adaptación de la norma a aquellas situaciones existentes en los denominados alojamientos colectivos, en los que el número máximo de AES queda limitado por el número máximo de plazas que legalmente dispongan. Así, siempre que sean utilizadas de forma independiente, la norma considera vivienda a las partes propias de establecimientos de alojamiento turístico, hotelero o extrahotelero, y de centros de acogida temporal -públicos o de entidades privadas sin ánimo de lucro- como «los pisos de acogida, los centros residenciales para personas en situación de exclusión, así como los centros residenciales para mujeres víctimas de maltrato doméstico y otros servicios de acogida para mujeres» (Decreto $147 / 2010$, de 25 de mayo, 2010). De esta manera, se abre una puerta a la flexibilidad y a una potencial adaptación tipológica de un parque considerablemente homogéneo para permitir, mediante las figuras anteriores, dos acciones importantes. Primero, transformar ciertos inmuebles a la realidad de unas unidades de convivencia con necesidades y recursos ciertamente diferentes a lo habitual. Segundo, hacer posible solicitar ayudas de emergencia para salir de dichas situaciones de vulnerabilidad. 


\section{Prestación Complementaria de Vivienda}

\section{Orientada exclusivamente al pago del alquiler}

El objetivo de este instrumento es facilitar el acceso a la vivienda a colectivos vulnerables y desfavorecidos. Así como la subvención de las AES podía ser destinada a diversos fines, en este caso se trata de una ayuda que complementa la Renta de Garantía de Ingresos, para lo que «tendrán la consideración de necesidades relacionadas con la vivienda los gastos de alquiler de la vivienda o del alojamiento habitual, en cualquiera de sus modalidades de arrendamiento, subarriendo, coarriendo, hospedaje y alquiler de habitaciones» (Decreto 2/2010, de 12 de enero, 2010). Para ello, se establece en la normativa correspondiente una cuantía máxima de $250 €$ «dirigida a cubrir los gastos de alquiler [...] tanto cuando se trate de casas particulares como cuando se trate de alojamientos colectivos» (Decreto 2/2010, de 12 de enero, 2010). No obstante, se prevén ciertos casos en los que dicha cantidad puede verse incrementada hasta los $320 €$-cuando la unidad de convivencia tiene dos o más hijas o hijos a su cargo, o cuando algún miembro de la misma realiza una actividad laboral remunerada-.

Como se ha avanzado antes, el sistema ha dispuesto ciertas garantías para buscar una igualdad de acceso a este tipo de ayudas. $\mathrm{Al}$ constituir «la última red de protección $[\ldots]$ no podrán ser complementadas por otras prestaciones o ayudas, evitando que se produzcan situaciones de desigualdad» (Ley 18/2008, de 23 de diciembre, 2008). Por esta razón, esta prestación es incompatible con cualquier otra ayuda de emergencia social destinada a sufragar gastos relacionados con la vivienda habitual, ni podrán acceder a la misma aquellas unidades de convivencia que se encuentren habitando una vivienda protegida, sea esta en régimen de alquiler o en propiedad. De manera similar que el caso anterior, para acceder a esta prestación no solo se ha de contar con la RGI, si no que además se ha de contar con una necesidad demostrable de ayuda para costear los gastos propios del arrendamiento de la vivienda, y se ha de haber solicitado una vivienda protegida en el sistema vasco de vivienda pública -con las mismas excepciones que el caso anterior-. Aquellas unidades de convivencia que son perceptoras de esta prestación tendrán, por parte de las políticas de vivienda protegida, un acceso preferente respecto a otros casos generales. Es de interés, en contraste con lo visto en las AES, la garantía que supone para la unidad de convivencia solicitante que tras el plazo de resolución de dos meses, en este caso el silencio administrativo tiene sentido positivo y por lo tanto la prestación se da por concedida. En cuanto a la rigidez del número de ayudas máximas, los condicionantes, debilidades y potenciales detectados son los mismos que en las AES: al límite máximo de dos PCV por vivienda se 
enfrenta un marco más laxo en lo que se refiere a los alojamientos colectivos definidos por la norma.

\section{$-4.5 .3-$ \\ Eguzkilore}

\section{Una iniciativa privada abierta a la colaboración}

Pero más allá del paraguas público, existen ciertas instituciones privadas que trabajan hacia la consecución de objetivos compartidos con los programas institucionales de emergencia social vistos hasta ahora. Una que cuenta con un importante arraigo en el AMB es la delegación de Cáritas en Bizkaia, que trabaja desde la Iglesia católica en la búsqueda de la justicia social. Entre sus diferentes instrumentos está la fundación Eguzkilore, cuyo objetivo fundamental es la promoción y desarrollo del derecho humano a una vivienda digna y adecuada. Para ello, generan recursos habitacionales y residenciales, y desarrollan labores de acompañamiento centradas en personas y familias en riesgo de perder su vivienda como consecuencia de procesos de exclusión social, desempleo, enfermedad o crisis económica (Fundación Eguzkilore, 2016). Su posicionamiento es claro: el de luchar contra el modelo de mercado de la vivienda vigente, «en el que ésta aún prevalece como bien de inversión antes que como un derecho que resuelve necesidades básicas de las personas» (Fundación Eguzkilore, 2016).

Su público objetivo es por tanto el que sufre situaciones de precariedad o precarización residencial. Y esto incluye no solo las mencionadas situaciones con dificultades para mantener la vivienda derivadas del sobre-endeudamiento o la falta de recursos, si no también las que carecen por completo de ella, o las que están en situación de infravivienda. Las herramientas desplegadas son diversas y paralelas: desde la oferta de un espacio donde vivir, al acompañamiento del proceso de reinserción e inclusión social. Se parte de un sistema de precios asequibles para facilitar el acceso económico a aquellas unidades de convivencia con estos perfiles de vulnerabilidad social y residencial. La referencia inicial es un importe de $350 €$ al mes en concepto de renta, con el objetivo de que este gasto sea sostenible y equilibrado respecto a otras variables como la renta destinada a la propiedad del inmueble, el coste de las posibles obras y reparaciones, el equipamiento de la vivienda, o los riesgos de impago. No obstante, la prioridad es siempre que la persona usuaria de estos dispositivos temporales solo deba destinar el 30\% de sus ingresos en concepto de alquiler -una vez más, se confirma el consenso generalizado sobre esta cifra como referencia digna-, y «si los ingresos son cero lo que tienen que pagar es cero» (Fernández, 2015). El acompañamiento en la transición desde la situación de 
exclusión a una más normalizada es de gran importancia. Para ello, Eguzkilore dispone de instrumentos como el cobro mensual a las personas usuarias, para generar un fondo acumulable que queda a su disposición en el momento de la salida del dispositivo habitacional. Esta se da cuando están en situación de acceder con plena autonomía a una situación residencialmente estable, y dicho fondo facilita precisamente ese proceso de incorporación al mercado libre.

A pesar de desarrollar instrumentos y espacios para una gestión propia y específica de estas soluciones residenciales, es de gran interés la predisposición y búsqueda activa por parte de Eguzkilore de la colaboración -por otra parte necesaria- con otras entidades y agentes públicos o privados para una mejor respuesta a las situaciones de emergencia social a las que se dirigen. Así, parte de su público objetivo se pone en contacto con la fundación derivado de la propia Cáritas, o por los servicios sociales de diversas entidades públicas u otras entidades sociales. Aunque se trata de una iniciativa defensora del papel protagonista que debe jugar la administración pública, defiende también que para un correcto desarrollo de las política públicas residenciales la primera ha de contar «con la colaboración de la ciudadanía y el tercer sector de acción social [y] el proceso de acompañamiento ha de ser cooperativo con entidades sociales e instituciones (en especial con los Servicios Sociales de Base)» (Fundación Eguzkilore, 2016).

\section{Potencial de transformación y adaptación tipológica}

Aunque los principales esfuerzos de Eguzkilore se dirigen a lograr y facilitar el acceso económico de su público objetivo, la iniciativa cuenta también con algunas herramientas que potencialmente podrían favorecer la preparación de las viviendas utilizadas para hacer la estancia temporal de estas personas lo más digna y satisfactoria posible. El programa prevé la acometida, cuando se considera necesario, de trabajos de adecuación y reforma de las viviendas incluidas en el mismo, mediante la "preparación técnica para la habitabilidad y/o rehabilitación y puesta a punto» (Fundación Eguzkilore, 2016). Es probable que estos trabajos se limiten a reproducir el modelo tipológico habitual ya apuntado en este trabajo, pero los esfuerzos dirigidos a ello podrían enfocarse en dotar a las unidades de convivencia que habitan estas viviendas de un espacio doméstico más adecuado a sus características -lejanas a las de esa familia tipo cada vez más minoritaria para la que se han diseñado y diseñan las gran mayoría de viviendas del parque actual-.

\section{Fomentando la solidaridad de la propiedad del parque existente}

La que sí supone una labor fundamental e indispensable en el proyecto, en paralelo al logro de un acceso económico, es la captación 
de viviendas existentes para ser incluidas en el mismo. Aunque también motivada por la escasa disponibilidad de recursos económicos, la estrategia principal en este sentido es la de aprovechar el parque existente infrautilizado. Se busca desarrollar «una línea de actuación en el ámbito de la rehabilitación de vivienda» (Fundación Eguzkilore, 2016), y una gestión integral del parque movilizado para lograr una respuesta tanto rápida como de proximidad con las personas necesitadas. Para ello, Eguzkilore se encarga de la totalidad del proceso: desde la misma captación inicial, a la gestión del contrato y/o convenio por el que la vivienda queda incorporada al programa, el desarrollo y supervisión de las obras necesarias, la contratación de suministros y pólizas de seguros, o el seguimiento del arrendamiento $\mathrm{y}$ las posibles incidencias que surjan, entre otras cuestiones. La contraprestación a la propiedad a cambio de que esta movilice viviendas al programa viene a ser similar a las que se han visto en los programas públicos de movilización de vivienda, si bien en este caso al tratarse de una fundación de marcado carácter solidario, se dan situaciones excepcionales:

«Hay quienes las han cedido gratuitamente, hay entidades que las ceden pidiendo una retribución básica y también hay particulares a los que les pagamos un canon que llamamos de lucro tasado, no pagamos lo que se puede pagar en el mercado, pero nos asemejamos al programa Bizigune, en ese aspecto, que paga un máximo de 450 euros. Lo que pasa es que nosotros no nos dirigimos a toda la población, sino a un núcleo concreto» (Fernández, 2015).

En cuanto a las garantías de recibir la renta mensual -en los casos que así se haya convenido- o de devolver la vivienda en condiciones adecuadas una vez esta sale del programa, al igual que en iniciativas anteriores todo ello queda garantizado mediante la contratación de un seguro. Como se ve, esto es cada vez más habitual en el mercado de alquiler residencial, y sirve tanto para lograr la tranquilidad de la propiedad, como para alcanzar unas condiciones más atractivas para que más viviendas sean movilizadas y pueda este programa responder a un mayor número de personas en situaciones de exclusión socioresidencial.

\section{$-4.5 .4-$}

\section{Barriztu}

\section{Más allá del acceso: una habitabilidad digna}

Este interesante aunque minoritario programa, que también es participado por Cáritas, presenta ciertos aspectos que merece la pena resaltar, por el planteamiento de fondo que en ellos reside. A pesar de 
que actúa sobre unidades de convivencia que ya cuentan con una vivienda y el acceso a la misma está por lo tanto satisfecho, su objetivo es mantener o recuperar el contexto para que el disfrute de la misma se siga dando bajo unas condiciones dignas (Cáritas Bizkaia, 2015a). Algo que, como el propio programa pone en evidencia, en muchas situaciones de infravivienda no se da, siendo una realidad considerablemente oculta que esconde situaciones con riesgo de exclusión y vulnerabilidad social. El objetivo de Barriztu es, por tanto, detectar situaciones con un importante desfase entre la necesidad concreta de la unidad convivencial y las características de una vivienda con carencias que impiden una mínima habitabilidad básica. El público objetivo son aquellas unidades de convivencia con rentas bajas y muy bajas, o incluso aquellas sin capacidad de generarlas. Se trata de actuaciones básicas, con un límite de gasto para las intervenciones de $6.000 €$ (sin incluir IVA ni tasas municipales).

El programa lleva, de esta manera, implícita la variable económica. Pero su objetivo claro es la adaptación tipológica de estas viviendas a unas necesidades cambiantes debido al envejecimiento $\mathrm{y} / \mathrm{o}$ a situaciones de dependencia. Por supuesto, no se trata de transformaciones en profundidad como las que se han venido mencionando en el trabajo para la adaptación de una tipología convencional a la agrupación de unidades de convivencia de pequeño tamaño. Son intervenciones de menor escala, como la renovación de una cocina, la eliminación de pequeñas barreras arquitectónicas en la propia vivienda, o el saneado de ciertos espacios. Pero en el fondo de todo ello, está el facilitar que esas personas puedan continuar habitando la vivienda en la que viven, bajo unas condiciones económicas dignas, sin necesitar de un endeudamiento que les condicione el futuro -en caso de que pudiesen llegar a acceder al mismo-, y a través de la adaptación de la misma a sus necesidades actuales.

\section{Valores añadidos de gran interés}

Lo cual implica que, por su propia naturaleza, Barriztu suponga un valioso aporte - desde su pequeña escala y capacidad de influencia- al debate sobre las políticas de aprovechamiento y búsqueda de una utilización eficaz y óptima del parque residencial existente. El hecho de que su actividad se fundamente en conseguir que sus actuales habitantes lo sigan siendo, y lo hagan además en unas mejores condiciones de habitabilidad, es de destacar. Por último, se han de señalar dos cuestiones que le otorgan un mayor valor a la iniciativa. Por un lado, uno de los mayores logros de este programa posiblemente sea el haber conseguido la colaboración de diferentes agentes a lo largo de sus fases. En la inicial, de detección, participan tanto los servicios sociales de base, como el personal de la Sociedad Urbanística para la Rehabilitación de Bilbao (Surbisa); el acompañamiento tanto durante la fase de intervención, como el seguimiento tras la misma lo realiza el voluntariado de Cáritas y el 
personal de los servicios sociales municipales; para la realización de la obra se contratan empresas constructoras con políticas de reinserción social; por último, cuenta con el apoyo económico de Kutxabank (Cáritas Bizkaia, 2015a). Por otro lado, se trata de una iniciativa de la que otras podrían en gran medida copiar y aplicar estrategias. A pesar de contar por ahora con un número de intervenciones pequeño hasta 2015 se habían intervenido 132 unidades de convivencia, 99 de ellos formados por mujeres y los otros 33 por hombres (Cáritas Bizkaia, 2015a)-, se trata de un colectivo probablemente en aumento debido a la conjunción de dos fenómenos: el envejecimiento de la población, y la creciente precarización de esta.

\section{$-4.5 .6-$ \\ Colaborar para incluir situaciones de vulnerabilidad}

La urgencia y la compleja especificidad de este tipo de situaciones hace que, en muchos casos, abordar solamente la cuestión económica no sea suficiente para lograr que las personas afectadas salgan de las mismas. Son casos en los que el proceso de acompañamiento y el seguimiento en la transición hacia una situación autónoma resulta vital, entendido este como una «atención social personalizada y continuada que brinda oportunidades de incorporación social a las personas mediante el fortalecimiento de sus competencias» (Fundación Eguzkilore, 2016). Por lo tanto, el éxito del proceso va a depender, en gran medida, del nivel de aislamiento o de acompañamiento de estas unidades de convivencia. Para lograr lo segundo, la colaboración entre agentes resulta indispensable. Así lo demuestran casos como los de las iniciativas de Eguzkilore y Barriztu, en los que dicha colaboración y solidaridad es la clave para lograr detectar los casos de mayor urgencia mediante el trabajo de los servicios sociales de base, recibir o gestionar inmuebles de terceros personas o entidades diversas- a bajo coste, transformar los mismos para adecuarlos a las situaciones de las unidades de convivencia necesitadas, financiar las intervenciones, o realizar todo el acompañamiento -previo y posterior- gracias a las personas voluntarias.

Instrumentos como las AES y la PCV son desde luego de gran valor y constituyen una potente garantía para evitar, o reducir, situaciones de vulnerabilidad residencial. Sin embargo, cuando estas no conllevan el necesario acompañamiento y seguimiento, se corre el riesgo de que estén ayudando a reproducir unas situaciones en precarización, atomizados y aislados, habitando además viviendas en muchos casos no adecuadas a sus necesidades. Cualquier situación fuera de esta no tiene a priori casi cabida en este tipo de ayudas 
sociales, pues el número máximo de estas por vivienda es, como se ha dicho, dos. La excepción en el marco actual, y por tanto el potencial, está en los llamados alojamientos colectivos. Tal y como la normativa indica, en estos el límite de ayudas lo marca el número de plazas legales disponibles. Dentro de este tipo de alojamientos están los diversos centros de acogida temporal, que son el marco perfecto para reproducir el trabajo colectivo y colaborativo desarrollado en experiencias como Eguzkilore. Esta línea de trabajo, con la mirada puesta en este tipo de centros incluidos en el marco normativo, tiene el potencial de favorecer las metas señaladas en la investigación: el acceso económico a un dispositivo de alojamiento temporal, la puesta en carga de viviendas existentes, o su transformación en tipologías residenciales específicas para generar unas instalaciones que favorezcan el proceso de seguimiento y empoderamiento de las personas residentes. 


\section{$-4.6-$ \\ Otros caminos y alternativas}

Finalmente, se revisan otras iniciativas y agentes participantes, desde diferentes ámbitos, en la gestión de la vivienda y con capacidad para influir en alguno o varios de los tres objetivos analizados. Quizás son experiencias más excepcionales, pero como se verá, con características de interés.

\section{- 4.6.1 - \\ Jóvenes Solidarios}

\section{Un programa a medida con beneficios comunitarios}

La primera de ellas es el programa Jóvenes Solidarios puesto en marcha mediante la colaboración de Viviendas Municipales de Bilbao y la Universidad del País Vasco/Euskal Herriko Unibertsitatea. Una vez más, queda patente que la unión y colaboración entre agentes diversos y con esferas de gestión diferentes puede tener como resultado una política de vivienda de interés que además, como en este caso, genera aportes de gran valor comunitario a una escala de barrio. Uno de sus objetivos es posibilitar a estudiantes de posgrado de la UPV-EHU el acceso a un alojamiento asequible, para lo cual se ofertan viviendas de propiedad municipal y compartidas con más estudiantes, durante el curso académico. A cambio, se busca un segundo objetivo como parte de este programa: que estas personas se integren y participen en la vida de los barrios -en este caso Otxarkoaga y Bilbao La Vieja-, fomentando la cohesión y la convivencia.

El programa se enmarca en la búsqueda, por parte de la institución municipal, de resolver la necesidad de vivienda de aquellos colectivos con dificultades para acceder a la misma en el mercado libre. Así, a la situación de un colectivo estudiantil que se enfrenta «habitualmente a especiales dificultades añadidas a las generales de acceso a la vivienda, en cuanto que a la escasez y precariedad económica, se une la necesidad de alojamiento temporal y económico, adaptado a sus recursos, para completar su formación durante un cierto tiempo, en las mejores condiciones» (Ayuntamiento de Bilbao, 2016b). El acceso económico queda así garantizado para las personas participantes en la 


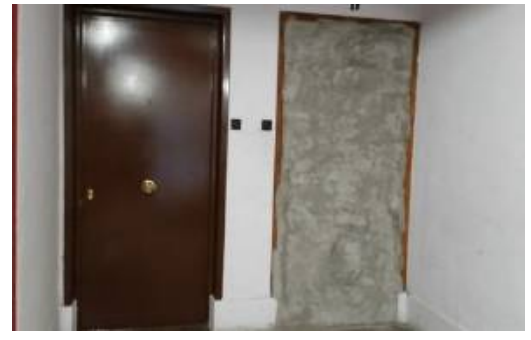

Imagen 4.7. Inmueble propiedad de Viviendas Municipales de Bilbao tapiado tras el desalojo de las personas que la llevaban ocupando más de dos años. Naiz (2018): «El

Ayuntamiento tapia una vivienda municipal que había estado 'ocupada' durante dos años», disponible en:

https://bilbotarra.naiz.eus/eu/inf o_bilbotarra/20180626/elayuntamiento-tapia-una-viviendamunicipal-que-habia-sidoocupada.

Como cita el artículo, concejales de EH Bildu denuncian

la falta de previsión del Ayuntamiento para hacer frente a este tipo de situaciones y consideran que Viviendas

Municipales no cuenta con los medios suficientes para gestionar sus propiedades. iniciativa, que deberán abonar una renta de $55 €$ mensuales, excluidos los gastos relativos al suministro de luz y agua. Se trata de un programa que parece gozar de éxito dentro de su limitado margen de acción, ya que para el curso 2018/2019 se abrió la novena convocatoria. A priori no parece haber una reflexión de interés en torno a la tipología de vivienda que más podría favorecer a este tipo de agrupaciones de unidades unipersonales, si bien es patente que habitan viviendas que no están diseñadas para una convivencia desjerarquizada y horizontal, si no todo lo contrario. En cuanto al aprovechamiento del parque existente, este es uno de los ejes intrínsecos del programa, ya que se nutre de viviendas que son propiedad del organismo local. Además, la incorporación entre sus objetivos de la exploración de «nuevas posibilidades de colaboración futura entre Viviendas Municipales de Bilbao y la UPV-EHU» (Ayuntamiento de Bilbao, 2016b) otorga un interesante potencial a la iniciativa para seguir aumentando ese aprovechamiento.

\section{Dificultades para una adecuada gestión del parque propio}

Quizás una de sus debilidades es el bajo número de plazas que las instituciones que promueven el programa ofrecen, ya que estas se limitan a 45. La oferta se nutre de viviendas propiedad del organismo autónomo local de Viviendas Municipales de Bilbao, que contaba en diciembre de 2016 con un parque total de 4.127 viviendas y 20 alojamientos dotacionales. Un parque que, a pesar de presentar uno de los mayores ratios de vivienda social por habitante del estado según fuentes municipales, no es capaz de acoger a las más de 9.000 solicitudes recibidas en 2017. Hay quien además denuncia la falta de previsión e incapacidad de la institución para gestionar sus propiedades causando que algunas de ellas permanezcan vacías durante mucho tiempo (Imagen 4.7), pero desde el gobierno local parece argumentarse que se debe tanto a la necesidad de poner a punto dichas viviendas, como a los trámites propios del proceso de solicitud y adjudicación de las mismas (Altuna, 2018). Es posible que una mejor gestión de este parque pueda favorecer la ampliación del número de plazas del programa Jóvenes Solidarios. Incluso el carácter temporal de este -son estancias acotadas dentro de un curso académico- podría encajar con los tiempos y plazos de adjudicación mencionado para el resto de necesidades y solicitudes -más estables en el tiempo- de viviendas sociales municipales. 


\section{Una revolución en la gestión inmobiliaria por el acceso a la vivienda}

El siguiente agente a destacar es de especial relevancia, principalmente por el giro que vienen planteando en lo relativo a los valores y principios habituales en su ámbito profesional. Se trata de un agente de la propiedad inmobiliaria fuera de lo común, con una profunda integración de funciones sociales y ambientales en el planteamiento de su actividad económica. Su objetivo, en lo que respecta al acceso económico a la vivienda, es la promoción del alquiler como principal fórmula de acceso a la misma, para lo cual Etikalia ha tratado de «poner en marcha una actividad innovadora y cumplir con un sueño: facilitar el derecho a tener una vivienda digna desde nuestra propia empresa privada, introduciendo la visión ética en el sector inmobiliario privado» (Etikalia, 2016). Esta empresa sin ánimo de lucro busca facilitar el acceso a la vivienda, en paralelo a la creación de empleo de calidad.

Para ello, las personas integrantes de este proyecto empresarial han desarrollado varias herramientas a través del afianzamiento de ese posicionamiento. Una de ellas, es ofrecer a la clientela que busca vivienda solo aquellas viviendas que consideran adecuadas a sus ingresos, para evitar situaciones de endeudamiento o presión financiera que lleven a posibles situaciones de vulnerabilidad. Al plantear la actividad bajo el diseño de una triple cuenta de resultados, los económicos no son un fin, si no un medio para lograr un impacto positivo en la sociedad. Su planteamiento inicial fue el ofertar a las personas arrendatarias una gestión gratuita y unos precios éticos. Sin embargo, pocos años de trayectoria les han bastado para replantearse algunas partes del modelo de negocio, y confirmar otras. La estrategia de la triple cuenta de resultados, así como el mensaje dirigido a la propiedad de que se puede acumular rentas en paralelo al desarrollo de una labor social, parecen haber funcionado. En el lado opuesto, el reparto de cargas planteado entre la figura arrendadora y arrendataria no parece haberlo hecho, lo cual les llevó a reflexionar sobre cuestiones como la idea de mantener una gestión gratuita a la segunda, o sobre si debía y podía Etikalia subvencionar la renta de alquiler (Fundación Eguzkilore, 2015).

\section{Capacidad de autocrítica y evolución}

Pero precisamente uno de lo valores de interés de este proyecto es que, más allá de los principios éticos que incorpora, demuestra una capacidad de análisis y reflexión continua de su actividad, para adaptarse en función de los resultados del mismo. Así, tras dos años 
de actividad y mediante la metodología del Balance del Bien Común, un estudio de los resultados obtenidos en la triple cuenta social, ambiental y económica planteada «no solo nos ha hecho conscientes de que debemos mejorar los resultados en todos ellos, sino que nos ha dado ideas sobre cómo conseguirlo» (Cacho, 2016a). Una de las principales consecuencias, y de gran relevancia dada su estrategia de empresa de corte social, fue el cambio en su política de honorarios. Se dejó de ofrecer una gestión gratuita a la parte arrendataria; «uno de los elementos que nos diferenciaba de la competencia y uno de los argumentos en los que justificábamos nuestra aportación social» (Cacho, 2016a).

El análisis de los resultados previos permitió detectar que dicha estrategia supuso ciertos obstáculos económicos y sociales. Por supuesto, se trataba de una posición que permitió captar más clientela potencial, y reducir plazos de puesta en carga, pero afirman desde la empresa que no ha sido un elemento clave a la hora de facilitar vivienda y que, sin embargo, planteó efectos negativos. Como un escaso margen económico que dificultaba la sostenibilidad de la empresa, y un escaso impacto real en las personas en búsqueda de una vivienda en alquiler. En este último caso, las principales dificultades residen en el pago mensual de la renta, más que en el pago puntual de los honorarios a la empresa inmobiliaria. Así, el escaso beneficio económico impedía revertir el mismo en la empresa para que esta pudiese ofrecer mejores soluciones residenciales a colectivos desfavorecidos. A partir de 2016, por lo tanto, pasaron a cobrar un importe tanto a la parte arrendadora como a la arrendataria, y pusieron en marcha acciones para construir colaboraciones con entidades del tercer sector en las que «invertiremos parte de nuestros beneficios y que nos va a permitir aportar soluciones de inclusión residencial a personas usuarias de estas entidades» (Cacho, 2016a).

\section{Convergencia y colaboración para la adaptación del parque}

En cuanto a la búsqueda de una adecuación tipológica de las viviendas ofertadas, la apuesta por la innovación en los procesos y por la colaboración entre agentes involucrados en la gestión de la vivienda supuso el desarrollo de un servicio que podría permitir dicha adaptación. Etikalia llevaba tiempo detectando que la información ofrecida a la clientela potencial respecto a las posibilidades de reforma de las viviendas era muy mejorable (Cacho, 2016b). Con el objetivo de facilitar la venta de aquellas viviendas cuyo estado hace difícil la visualización de sus posibilidades por parte de las personas interesadas, la alianza de la empresa con un estudio de arquitectura local ha permitido ofrecer un servicio que puede facilitar la transformación y adaptación del parque a las necesidades de unidades de convivencia diversos, a la par que realizan una interesante labor divulgativa y educativa: 
«...consiste en dar una información lo más completa posible sobre la vivienda, su estado actual, qué cosas hay que reparar o reformar, qué distintas posibilidades tiene de reforma, etc. En la visita entregaremos al posible comprador un dossier con toda esa información, incluyendo fotografías del estado actual, plano actual, distintas distribuciones posibles [...] una vista 3D de la vivienda una vez reformada, simulaciones de decoración y hasta tres presupuestos de reforma con diferentes calidades de materiales [...] De esta forma el posible comprador tiene información muy precisa de lo que le va a costar el piso, no solo la compra, sino la reforma posterior» (Cacho, 2016b).

Esta innovación en los servicios habituales de los agentes de la propiedad inmobiliaria supone un interesante potencial para facilitar la estrategia de agrupación analizada en el capítulo anterior. De manera que un hipotético grupo de personas dispuestas a unir sus esfuerzos -no solo económicos- para adquirir y transformar una vivienda del mercado en un espacio doméstico adecuado y con el nivel de convivencia deseado, que puede ser ninguno, podría encontrar en este servicio el acompañamiento perfecto para hacerlo realidad.

\section{La movilización del parque vacío con una doble visión}

El aprovechamiento del patrimonio edificado es también una de las líneas de trabajo principales de Etikalia, ya que es el mayor fundamento para dotar de contenido a la parte ambiental de su actividad:

«Impulsamos la utilización del parque de viviendas construido. Esto supone una menor necesidad de construcción de nueva vivienda, lo cual tiene un impacto positivo en el medio ambiente reduciendo las emisiones de $\mathrm{CO}_{2}$ y el uso de materiales de construcción procedente de la explotación de canteras y otras fuentes de extracción de áridos» (Etikalia, 2016).

Igualmente, y comprensiblemente al haber jugado su fundador Roberto Cacho un papel clave en el diseño y dirección del programa Bizigune antes analizado, la movilización de viviendas vacías existentes es otro gran objetivo de Etikalia. Buscan activamente localizar y captar este tipo de viviendas para incorporarlas al mercado de alquiler. Así, en 2015, tras un año de actividad, un 40\% de las operaciones realizadas se enmarcaban en esta línea. Su enfoque, como se ha señalado antes, es claro: poner en paralelo los dos problemas, el de aquellas personas necesitadas de vivienda y el de la propiedad que posee una vacía. El considerar a ambas situaciones como tales problemas es ya un ejercicio de cambio de mentalidad considerable, dejando de lado la perspectiva más común en la que la propiedad está en una posición negociadora privilegiada, de poder, frente a una 
unidad de convivencia con necesidad o demanda de vivienda que puede verse como vulnerable. Para lograr lo anterior, el abanico de herramientas utilizadas por Etikalia es diverso. Como ya se ha avanzado, buscan trasladar el mensaje de que es posible participar como propiedad en el negocio inmobiliario desde la responsabilidad social, y por ello buscan con especial interés a «personas con sensibilidad social [que] puedan participar en el mercado inmobiliario de forma ética y en coherencia con sus valores personales» (Etikalia, 2016). Ofrecen también, en este sentido, servicios de asesoramiento a agentes inversores para invertir su dinero de manera que obtengan beneficios tanto económicos como sociales. Al igual que otras iniciativas vistas previamente, ofrecen como aliciente a la propiedad una gestión integral en búsqueda de la profesionalidad y la rapidez en las operaciones, así como garantías ante posibles conflictos y un acompañamiento tanto en el proceso de cierre de contrato como a lo largo de la vigencia de este.

La permanente búsqueda de la innovación en la gestión y en las fórmulas de acceso a la vivienda les ha llevado a ofrecer servicios de 'venta express' - haciendo un estudio de mercado y diseñando un plan de marketing y acciones exclusivo para el inmueble concreto-, o a escuchar a la propiedad para idear y ofrecer soluciones a medida de sus necesidades (Etikalia, 2016). Prueba de esa búsqueda, es la declaración de explorar vías para poner en carga y movilizar viviendas actualmente fuera del mercado por razones diversas, como estar en un mal estado de conservación (Fundación Eguzkilore, 2015). Con todo, la propia empresa ha ido detectando algunas de las debilidades propias del modelo de negocio. Por un lado, parece que el mensaje ético no siempre funciona y que incluso les ha llegado a perjudicar en ciertas ocasiones; por otro, han detectado limitaciones propias del seguro de alquiler, ya que no siempre el alquiler garantizado parece resolver los conflictos aparecidos (Fundación Eguzkilore, 2015). En cualquier caso, se trata de una experiencia de gran valor. Por la naturaleza social y no lucrativa de la misma, en un sector donde la búsqueda del máximo beneficio - propio de las agencias de gestión y de la propiedad- parece haber sido la pauta habitual en el desarrollo del sector en las últimas décadas, y por el potencial para ayudar en la consecución de la tres metas analizadas.

\section{Renta Vitalicia y Alquiler Garantizado}

\section{Los peligros de la rentabilidad económica}

Por último, aunque se trata de un fenómeno minoritario, existe un modelo de negocio privado que tiene entre sus objetivos el facilitar o adelantar capital a personas propietarias y usuarias de viviendas con 
dificultades de acceso al mismo por otros métodos de los vistos hasta ahora. Al igual que ocurría con el programa Barriztu, se dirige a personas que ya cuentan con una vivienda, pero cuya situación puede ser potencialmente vulnerable. Principalmente dirigido a personas mayores sin renta de trabajo, las denominadas soluciones de Renta Vitalicia y Alquiler Garantizado pueden verdaderamente posibilitar una mejor calidad de vida a personas que no cuentan con recursos económicos para responder a necesidades cambiantes derivadas de procesos de envejecimiento o dependencia. Este tipo de inversión ofrece varias fórmulas para dar estabilidad económica a la parte que vende el inmueble, con la garantía de retorno si la parte que adquiere la vivienda falla en el pago de las rentas establecidas en el contrato (Grupo Retiro, 2016).

Aunque podría entenderse como una alternativa privada a iniciativas como Barriztu, existen algunos factores que hacen cuestionar el componente social de este tipo de actividades económicas. Por un lado, las operaciones están siempre condicionadas a una rentabilidad económica para la persona o sociedad que compra la vivienda. Con lo cual no todas las situaciones serán económicamente viables y, por lo tanto, no todas atraerán el interés de este modelo. Por otro lado, junto con el valor del inmueble, la esperanza de vida de la persona previamente propietaria de la vivienda son las dos principales variables de las que depende el cálculo de las condiciones económicas de la operación. Además, «se establece la obligación por parte del usufructuario de acreditar su fe de vida cada seis meses al propietario. No obstante, tanto los familiares como personas allegadas al mayor comunican siempre el posible fallecimiento, y además Grupo Retiro mantiene una comunicación permanente con las Personas Mayores y/o sus entornos familiares» (Grupo Retiro, 2016). Lo cual incorpora una sombra siniestra al modelo, con cierta presión por parte de la entidad mediadora y la nueva propiedad por ver cuándo fallece la persona que ha vendido su vivienda. En cuanto a la adaptación tipológica, se da a entender, en la información consultada, que podrían llegar a establecerse cláusulas en el contrato de compra-venta para la adecuación de las viviendas a las nuevas necesidades de su anterior propiedad -que con la operación pasa a ser parte arrendataria y, por lo tanto, sin capacidad plena de decidir sobre el inmueble-. Necesidades que esa persona no podía cubrir económicamente y que serán en muchos casos las que motiven la elección de este modelo de transacción inmobiliaria. Pero la realidad parece ser que se publicita este modelo como una opción para no actualizar ni reformar el inmueble recién adquirido:

«Olvídese de tener que actualizar o reformar la vivienda para comenzar a alquilarla, de buscar al inquilino, perdiendo meses sin poder cobrar, o de ir sufriendo los permanentes cambios de arrendatarios y con ello los nuevos gastos de "lavado de cara" de la vivienda $[. .$.$] se garantizará la rentabilidad de la vivienda$ 
adquirida desde el primer momento y de forma continuada, sin tener que sufrir periodos sin ingresos» (Grupo Retiro, 2016).

Se trata de una visión excesivamente mercantil que aborda la vivienda como objeto de inversión, y que aprovecha las debilidades económicas de un colectivo vulnerable para garantizar unas condiciones de rentabilidad seguras. En cuanto al aprovechamiento del parque, y de manera similar al programa Barriztu, este tipo de operaciones tienen el potencial de evitar una posible desocupación de viviendas habituales por parte de un colectivo que se ve en muchas ocasiones forzado a dejarlas para trasladarse a centros residenciales especializados o a viviendas familiares en las que recibir sus cuidados. 


\section{- 4.7 - \\ Síntesis del DAFO}

Lo desarrollado hasta aquí en este capítulo es el resultado de un análisis documental a través del método DAFO. En lo que a cada experiencia concreta respecta, se ha creído conveniente no estructurar estos resultados en las cuatro categorías del método -debilidades, amenazas, fortalezas y oportunidades-. Las razones para ello han sido tanto por buscar unos títulos de subapartados más aclaratorios, como por la conveniencia de hilar diferentes temas correspondientes a diferentes categorías, o por la diversidad de los casos y las situaciones detectadas. En definitiva, por una mayor facilidad de lectura. En cualquier caso, todo lo presentado en los apartados 4.2.3, 4.2.4, 4.2.5 y 4.2.6 proviene de dicho análisis y hace referencia, aunque no se haya dicho explícitamente, a alguna de esas cuatro cuestiones. Dada la extensión del capítulo y la diferente naturaleza de las iniciativas estudiadas, se presenta a continuación una síntesis de los resultados con la intención de ayudar a cerrar conceptualmente el mismo. Ahora sí, siguiendo la estructura del DAFO, se tratan algunas de las principales lecturas y conclusiones obtenidas para cada una de las cuatro categorías de la metodología, muchas comunes a varios de los casos. Las menciones que se hacen a casos concretos se presentan a modo de ejemplo -y a riesgo de repetir lo ya dicho- para apoyar la argumentación de esta síntesis del DAFO, y no pretenden abarcar todo el abanico de supuestos identificados en cada apartado.

\section{$-4.7 .1-$ \\ Debilidades}

\section{Una gestión ineficaz}

En no pocas ocasiones, una voluntad positiva y unas intenciones orientadas a la consecución de las metas aquí estudiadas no significa que se alcancen a un nivel deseable. En algunas de esas ocasiones los obstáculos y los retos son internos, propios de una gestión con margen de mejora que todavía no es capaz de aprovechar todo el potencial que la iniciativa correspondiente alberga:

- Las garantías ofrecidas de forma pionera por los programas de movilización de vivienda vacía Bizigune y ASAP, que en su día aportaban un valor añadido de cara a atraer a la propiedad de esas viviendas vacías, dejan de ser una variable diferenciadora en el momento en el que el mercado libre comienza a incluir las 
Tabla 4.3. Tasa de ocupación en las viviendas movilizadas por el programa ASAP en el AMB. Gobierno Vasco, 2014. mismas. De tal manera, que el público objetivo para incorporar sus viviendas al programa se limita a comparar las rentas que puede obtener en el mercado libre frente a las máximas establecidas en estos dos programas.

- La administración pública desarrolla importantes esfuerzos económicos dentro de una estrategia pedagógica y de incentivación para que algunas grandes empresas participen en los programas de movilización de vivienda vacía, mientras la pequeña propiedad no acaba de ser atraída a los mismos. Como recuerda Cacho, la sociedad pública Alokabide y la entidad financiera Kutxabank firmaron hace pocos años un acuerdo para que la segunda incluyera en el programa Bizigune 100 viviendas de su propiedad. Algo en principio positivo, fue cuestionado por el autor ya que las condiciones en las que se realizó aplicaban «la zanahoria a una gran entidad que debería alquilar las viviendas por sí misma en lugar de a los pequeños propietarios, cuyas viviendas están quedando fuera de Bizigune» (Cacho, 2016d). Así, Kutxabank cobraba una renta inferior al mercado, pero en la franja alta de las previstas en el programa; la gestión por parte de Alokabide era gratuita; se reducían los riesgos de rotación para la entidad, cobrando la renta esté la vivienda ocupada o no una vez firmado el primer contrato; y la garantía frente a impagos y daños la asumía Bizigune.

- El programa ASAP, además de haber alcanzado un bajo número de viviendas inscritas en el mismo, presentaba otra preocupante realidad: la baja tasa de ocupación de dichas viviendas disponibles. En respuesta a la solicitud realizada por un parlamentario del Partido Socialista de Euskadi, en mayo de 2014 el Gobierno Vasco presentó los datos de ocupación hasta la fecha, en los que se podía observar unas bajas tasas de ocupación (Tabla 4.3).

\begin{tabular}{ccc}
\hline Fecha & $\mathbf{N}^{\mathbf{o}}$ viviendas & Ocupación \\
\hline $31 / 12 / 2012$ & 19 & $5 \%$ \\
$31 / 03 / 2013$ & 57 & $7 \%$ \\
$30 / 06 / 2013$ & 105 & $10 \%$ \\
$30 / 09 / 2013$ & 118 & $14 \%$ \\
$31 / 12 / 2013$ & 144 & $21 \%$ \\
$31 / 03 / 2014$ & 140 & $29 \%$ \\
\hline
\end{tabular}

- Falta de adaptación de los programas de ayudas AES y PCV a la realidad extendida en ciertas situaciones de pisos compartidos por varias unidades de convivencia, no necesariamente unipersonales, por motivos económicos o de situaciones de 
ilegalidad. La limitación de dos ayudas por vivienda habitual no refleja este tipo de situaciones.

- La existencia, como viene denunciando parte de la oposición en el ayuntamiento bilbaíno, de inmuebles propiedad de Viviendas Municipales de Bilbao vacíos y/o en malas condiciones de habitabilidad que no pueden ser destinados a su fin social, manteniéndose en dicha situación durante un tiempo prolongado mientras hay una importante necesidad de vivienda sin cubrir en la ciudad.

\section{Inviabilidad económica}

Se ha podido ver en varios de los casos cómo la carencia de medios económicos supone uno de las principales debilidades. Ya sea para llevar a cabo la propia experiencia en sí, para alcanzar objetivos más ambiciosos que los logrados, o para hacer sostenible la iniciativa en el tiempo, los motivos principalmente se reducen a dos:

- La dificultad de acceso a financiación por parte de pequeños grupos de personas con intención de adquirir un inmueble en propiedad para su gestión de manera cooperativa. Se ha visto en casos como Egunsentia Aurora, Etxekoop, o Housekide.

- El alto coste para los presupuestos públicos que plantea el diseño actual de ciertos programas, como es el caso de los públicos de movilización de vivienda vacía hacia el alquiler social, los hace inviables en el tiempo y es parte del motivo de su bajo éxito. Como se ha hecho referencia a lo largo del capítulo, se trata de una cuestión de la que desde las propias instituciones se es plenamente consciente, y es de hecho la motivación por la que se siguen estudiando nuevas fórmulas de poner en carga ese parque vacío privado con un coste público más reducido. En este sentido, en octubre de 2018 el Tribunal Constitucional ha avalado la capacidad del Gobierno Vasco para actuar sobre las viviendas desocupadas de la manera que prevé la Ley 3/2015 de Vivienda, con el establecimiento de un canon a las viviendas desocupadas, el alquiler forzoso o, en última instancia, la expropiación aspectos que fueron recurridos por el gobierno central en 2016-.

\section{Mantenimiento de la vulnerabilidad residencial}

Las limitaciones económicas están precisamente detrás de muchos de los fenómenos que tienden a que algunas de las iniciativas analizadas ayuden a reproducir, en contra de sus objetivos, situaciones de precariedad y vulnerabilidad residencial:

- Como se ha podido ver en la Tabla 4.2, los precios de alquiler fijados en los programas Bizigune y ASAP para el AMB superan el precio máximo de referencia establecido en el informe del Observatorio Vasco de la Juventud utilizado como fuente para el 
análisis del capítulo tercero, que eran $420 €$ (López, 2014). Tal y como ya se ha apuntado, esa renta máxima está calculada en base al límite del 30\% de un salario medio de 1.461€. Lo cual indica que serán muchos las unidades de convivencia con rentas inferiores, y con dificultades para que las rentas de los citados programas estén por debajo del $30 \%$ de su renta mensual.

- En algunas ocasiones, los propios criterios o limitaciones de los programas hacen que ciertas personas se vean directamente expulsadas de los mismos. En el caso de ASAP, la franja de rentas anuales mínimas para poder solicitar una vivienda pasó de los $7.000 €$ a los $12.000 €$.

- De igual manera, la bajada de la retribución económica a la propiedad en el programa Bizigune hace que, como mencionaba Maguregui, no solo se salgan propiedades del programa, si no que las que queden sean aquellas con peores características (Muñoz, 2014).

\section{Falta de respuesta a necesidades espaciales}

Es cierto que las carencias culturales generalizadas apuntadas en capítulos previos son un gran obstáculo a salvar para que cualquier iniciativa incorpore una reflexión profunda en torno a la necesidad de plantear alternativas a la tipología de vivienda habitual. Tanto en el parque existente, como en las nuevas promociones en marcha. Sin embargo, algunos de los casos analizados presentan un marco más favorable para que se dé dicho proceso de reflexión -algunos de hecho lo incorporan-, mientras que otros mantienen todavía esquemas y lógicas anclados en la reproducción de dicha tipología como única opción. En general, la pretendida adaptación del parque a las necesidades de las unidades de convivencia se limita a un margen de cambio siempre dentro de dicho esquema tipológico:

- De manera muy extendida, y sobre todo entre las políticas y programas públicos, existe una simplificación de las tipologías de vivienda posibles que reduce el abanico a cambios en el número de dormitorios o en la superficie total de la misma. Pero manteniendo de manera inamovible una estructura espacial rígida y permanente que consta de salón-comedor, cocina, tendedero, dos baños - uno de ellos en uno de los dormitorios-, y un número variable de dormitorios. De igual manera, el rico espectro de unidades de convivencia existente se simplifica drásticamente al clasificarlos por el número de personas que las forman, o introduciendo otras variables solo en los casos con algún tipo de movilidad reducida.

- Las cooperativas de vivienda, a pesar de contar con un contexto más favorable a la adecuación de sus espacios a las necesidades y deseos de sus integrantes, no siempre desarrollan dicha capacidad. Especialmente en aquellos casos que Burón 
califica como de 'falsas cooperativas de vivienda', el modelo encubre, bajo una gestión diferente, una reproducción de la habitual promoción de viviendas desarrollada en las últimas décadas, incluida una pobre diversidad tipológica.

- En el contrato tipo para el alquiler de una vivienda gestionada por Etxebide se prohíbe expresamente la instalación y/o desarrollo de cualquier actividad comercial o de servicios. Con esta cláusula, que incluye otras cuestiones, se pretende que la persona inquilina haga un uso del inmueble que garantice el adecuado mantenimiento del mismo, así como una correcta convivencia y respeto de cara al resto de la comunidad residente en el edificio. Sin embargo, al no permitir ningún tipo de actividad económica, sea cual sea la misma, deja fuera muchas actividades totalmente compatibles con el uso residencial, y que puede ser de gran interés desarrollar en la propia vivienda para el colectivo que disfruta de una vivienda protegida, precisamente por el consecuente ahorro de costes que supone no tener que contar con otro inmueble para la actividad profesional. De esta manera, la transición hacia una situación de mayor autonomía y la salida y consecuente rotación de la vivienda podría acelerarse.

- Algunos de los principales motivos de renuncia a las viviendas adjudicadas por Alokabide -tanto directamente como a través del programa Bizigune- han sido una falta de ajuste de la superficie y/o de las características de la vivienda a las necesidades de las unidades de convivencia demandantes.

- A pesar de haber desplegado desde la administración pública una interesante variedad de herramientas con potencial para que esta y las personas con necesidad de vivienda dialoguen y establezcan las bases de los aspectos tipológicos más importantes que las diversas unidades de convivencia necesitan, no parece que se tenga consciencia del alcance real que dichos instrumentos pueden llegar a ofrecer. Los espacios de participación desarrollados, las líneas de comunicación abiertas, o los departamentos creados expresamente para recabar información y transformar el diseño del producto ofertado, siguen planteando la vivienda como una copia, sin casi alteraciones, de la tipología predominante en el mercado y de la que ya se ha hablado anteriormente.

- En este sentido, incluso la incorporación de herramientas y la previsión de realizar obras en las viviendas gestionadas -que podrían facilitar la transformación y la adaptación de dichas viviendas- no vienen siendo aprovechadas. En el caso de Bizigune, por ejemplo, la posibilidad de financiar sin intereses intervenciones de hasta $18.000 €$ parece que tuvo muy poco éxito y las solicitudes para ello fueron escasas. Una vez más, es posible que la carencia de información de las posibilidades espaciales que 
pueden llegar a plantearse sea el principal condicionante para esta limitada demanda.

\section{Bajo nivel de participación}

Para salvar el desfase existente entre las necesidades espaciales de muchas de las unidades de convivencia con necesidad de vivienda no cubierta y las características de la oferta actual se necesita, especialmente, un verdadero ejercicio de apertura hacia el colectivo demandante. Solo conociendo su realidad, los motivos que los han llevado a esa situación, sus orígenes culturales, su forma de vida, o sus aspiraciones, podrá adecuarse el parque a esas unidades convivenciales. Hasta entonces, los intentos de participación y recogida de información, tal y como se vienen planteando en su gran mayoría y por mucho que vengan movidos por buenas intenciones e intereses, seguirán facilitando la reproducción de un modelo de vivienda en proceso de obsolescencia tipológica:

- Los ya mencionados canales de comunicación entre la administración pública y usuarios -futuros o presentes- de las viviendas gestionadas por alguna de sus sociedades, no acaban de plantearse desde una perspectiva profunda y radical del concepto de participación. En una parte importante, la recogida de información del colectivo demandante se nutre de información estadística. Por otro lado, algunas de las experiencias llevadas a cabo siguen reproduciendo un esquema jerárquico en el que la administración asienta las bases principales de la oferta y el proceso participativo se limita a concretar cuestiones secundarias y poco estructurales. En 2007 Visesa creó un espacio de participación en su página web, en el que las personas usuarias de alguna de las viviendas gestionadas por la sociedad opinaba sobre «temas como el tamaño de las estancias de la vivienda, el diseño del salón vs salón-cocina, la preferencia en cuanto al tipo de suelo y carpintería interior de la vivienda, su opinión sobre el parquet industrializado flotante...» (Visesa, 2007: 36). Otro ejemplo es el ya mencionado anteriormente, consistente en visitas a promociones en fase de ejecución para que las personas que las iban a habitar viesen su construcción. Una ocasión perdida para tomar decisiones de diseño a pie de obra.

- Las denominadas 'falsas cooperativas de vivienda' (Burón, 2014) son también un espacio de toma de decisiones desperdiciado. Frente a la rica experiencia que puede suponer un verdadero proceso cooperativo -como se ha visto en la experiencia citada de Berlín-, estas suelen constar de un órgano de decisiones ajeno a las personas socias -que viene a ser el verdadero agente promotor del proyecto-, con una limitada comunicación. Si bien es cierto que la capacidad de realizar cambios y tomar ciertas decisiones de diseño es mayor que en promociones habituales, estos suelen ser limitados, ya que en 
muchas ocasiones la comercialización para la búsqueda de socios se realiza con el diseño del proyecto ya planteado.

\section{$-4.7 .2-$ \\ Amenazas}

A las amenazas propias de la situación problemática y los condicionantes y obstáculos internos apuntados en el capítulo segundo, se suman otras variables que afectan directamente al desarrollo de las experiencias estudiadas.

\section{Un modelo de gobierno paternalista y una sociedad pasiva-individualista}

La enorme distancia existente entre la administración y la persona administrada es en muchos casos motivo para obstaculizar o dificultar la puesta en marcha de otros modelos de gestión de y acceso a la vivienda. Algunos de los casos aquí analizados se encuentran encallados y sin perspectivas de salvar complejos retos, como su viabilidad económica. Abriendo la mirada a experiencias frecuentes en otros países, puede observarse cómo un modelo mixto con mayor participación y empoderamiento civil, con más autonomía, pero sin perder el necesario apoyo público, puede favorecer el avance hacia las tres metas aquí estudiadas (Burón, 2015c):

- Las dificultades existentes para la captación de vivienda libre por parte de los programas de movilización de vivienda vacía son un ejemplo de la falta de concienciación y responsabilidad social de cierto sector de la población, así como de determinado tejido empresarial y financiero. Su participación en estas y otras iniciativas relacionadas con la búsqueda del acceso a una vivienda digna, ya sean públicas, privadas o mixtas, dependerá en gran medida de su sensibilización hacia esta problemática. Como los esfuerzos realizados por la inmobiliaria Etikalia desde el ámbito privado, o el programa ASAP desde lo público muestran, hay otro modelo posible, en el que la propiedad privada puede generar rentas a partir de sus inmuebles, sin un ánimo de lucro excesivo y permitiendo así el acceso a la vivienda.

- Tal y como insiste Burón (2014), hay una carencia de organización en la sociedad civil para la auto provisión de vivienda. Aquí pueden estar afectando tanto actitudes pasivas que tienden a dejar la responsabilidad por completo en manos del gobierno correspondiente- como individualistas -en la búsqueda de esa auto provisión siguiendo el camino habitual, pero solo hasta ver satisfecha su propia necesidad, y no como una 
problemática colectiva-. En el segundo caso se pueden enmarcar fenómenos sociales contradictorios ya señalados en el capítulo segundo: el cambio de actitud y posicionamiento que puede acompañar el paso de una situación de necesidad a otra de propiedad puede, en ocasiones, alimentar el sistema excluyente frente al que se estaba luchando. Algunos autores plantean la necesidad de un modelo intermedio, con una sociedad activa apoyada por las instituciones, siendo imprescindible para el adecuado desarrollo de las políticas públicas contar con la colaboración de la ciudadanía y el tercer sector de acción social (Fundación Eguzkilore, 2016).

- La ausencia de experiencias en ese término medio puede haber favorecido el fracaso de algunos casos pioneros en Euskadi, con una sociedad todavía sin experiencia en estas cuestiones, y una administración sin saber apreciar el valor de las mismas para el desarrollo de sus políticas de vivienda. Algunos experimentos piloto desarrollados desde la iniciativa privada, como la cooperativa de personas mayores Housekide, han visto como la búsqueda de modelos con un alto nivel de autonomía, pero con la necesidad de cierto apoyo institucional, han contando con una considerable dificultad de puesta en marcha.

- Otra amenaza del sistema público en relación al gasto dirigido a iniciativas relacionadas con la vivienda proviene de la denominada regla de gasto establecida por el Ministerio de Hacienda. Esta permite, en algunos casos, a aquellos ayuntamientos con superávit destinar parte del mismo a nuevas inversiones en vez de al pago de la deuda que la corporación local tenga. Sin embargo, la vivienda no se contempla entre esas actuaciones; la Asociación Española de Gestores Públicos de Vivienda y Suelo solicitó al ministerio en noviembre de 2018 que la vivienda pueda ser contemplada como Inversiones Financieramente Sostenibles, entendiendo como «inconcebible que existan ayuntamientos con una elevada demanda de vivienda social por parte de los ciudadanos que contando con suelo del patrimonio municipal suficiente y superávit presupuestario no lo puedan emplean (AVS, 2018).

\section{Rigidez del sistema normativo relativo al diseño}

El marco regulatorio que afecta a la formalización de la vivienda viene establecido por la correspondiente normativa de carácter técnico-constructivo, la relativa a la habitabilidad y el diseño de los espacios, y la urbanística (Paricio y Sust, 2000). En diferentes aspectos, este marco suele presentar una rigidez y unos condicionantes que dificultan una mayor diversidad de tipos de vivienda $\mathrm{y}$, consecuentemente, una mayor variedad de hábitos y formas de vida: 
- Aunque ya ha sido apuntado en el capítulo segundo, conviene insistir en que la normativa relativa al diseño de las viviendas protegidas, en el caso de Euskadi las Ordenanzas de Diseño de Viviendas de Protección Oficial aprobadas en 2009, refleja una vivienda que sigue unos parámetros conservadores, continuando con la tradición de imitar parcialmente una distribución de la vivienda racional moderna orientada a una familia. Como muestra, la única distinción que realiza entre tipos de vivienda se basa en el número de dormitorios, en la superficie total y en la de sus estancias. Quedan así «demasiado sujetas a unos predeterminados tipos compositivos y obstaculizan, por tanto, el desarrollo de soluciones alternativas diferentes a las mayoritarias y también la introducción de concepciones evolutivas acerca de la composición de la vivienda» (Paricio y Sust, 2000: 22). Esto afecta no solo a las viviendas protegidas, si no también a las libres en la medida en que en numerosas ocasiones las ordenanzas urbanísticas municipales en materia de vivienda hacen mención a, o se basan en, esta normativa sectorial. De tal manera que «la gente, las personas que habitan los edificios, siguen siendo, en el fondo, los grandes olvidados en la arquitectura residencial» (Monteys y Fuertes, 2002: 14).

- Precisamente el citado marco urbanístico podría ser aprovechado para, cumpliendo los requisitos mínimos de las citadas ordenanzas de vivienda protegida, ir más allá y dotar de un instrumento normativo que favoreciese esa necesaria diversidad de tipologías residenciales. El ámbito de acción es adecuado, ya que las limitaciones espaciales para transformar o proponer otras soluciones muchas veces dependen de factores como la anchura o profundidad de las parcelas edificables, las alturas libres permitidas, la disposición y características de los patios interiores y de manzana, o la morfología de las propias manzanas edificatorias. Sin embargo, con demasiada frecuencia se trata de una sección de las normativas urbanísticas «que queda incluida en un documento de planeamiento que, generalmente, no tiene como principal preocupación la regulación de la edificación sino la ordenación del territorio. Así, los principales esfuerzos en la redacción no se destinan a una regulación cuidadosa de la edificación y, en especial, de las condiciones de habitabilidad» (Paricio y Sust, 2000: 22). De esta manera, se limitan, como se ha señalado, a repetir o trasladar lo establecido en normativas anteriores, incorporando igualmente las limitaciones de estas.

\section{Ausencia de información detallada y actualizada}

Como en otros múltiples aspectos de la planificación espacial, «no cabe hablar seriamente de gestión sin información» por lo que «el compromiso público-institucional ha de concretarse, en primer lugar, 
en instalar de modo permanente un sistema de información mínima» (Naredo, 2003). Aunque estas palabras de Naredo hacen mención a la gestión y evaluación de los sistemas urbanos desde el punto de vista de la sostenibilidad, son plenamente aplicables a la temática de este trabajo. Dos son al menos los ámbitos en los que sería deseable contar con una mayor y más actualizada información para ser incorporada a la actividad de las iniciativas analizadas:

- Tal y como se ha apuntado, no tanto el número, si no su naturaleza cambiante, sus características, su localización y, sobre todo, los motivos que llevan a que haya miles de viviendas vacías y/o infrautilizadas es todavía una cuestión sobre la que se debe investigar. Los diferentes estudios, encuestas y estadísticas sobre esta problemática arrojan resultados poco esclarecedores, salvo en aquellos casos a pequeña escala en los que se ha realizado un verdadero estudio pormenorizado, prácticamente vivienda por vivienda. Como apunta Vinuesa (2013), la información relativa a la vivienda -número de viviendas vacías, stock de pisos sin vender, o evolución de precios- aparecida en prensa, en organismos públicos o entidades privadas varias suele ser contradictoria y en muchos casos sin aclarar la metodología y fuentes de dichos datos. Según dicho autor, los motivos no son de ninguna manera técnicos o por falta de medios. De igual manera, sería de enorme interés contar con información relativa a las viviendas que sí están ocupadas, para recoger datos sobre el nivel de satisfacción de sus habitantes con las características espaciales de las mismas. E ir así construyendo un conocimiento sobre el nivel de adecuación del parque existente a la población residente:

«Es completamente escandaloso que en un país con un nivel de desarrollo como el nuestro, con un peso importante de los sectores inmobiliario y de la construcción en nuestra economía, y con las dificultades que un importante segmento de la población tiene para disponer de un alojamiento digno, siendo la vivienda algo fácilmente visible e inmóvil, ni los ayuntamientos, ni las administraciones regionales o la estatal, en el ámbito territorial de sus respectivas competencias, sean capaces de contestar correctamente a preguntas del tipo: ¿cuántas viviendas hay? ¿Cuál es su estado y uso? ¿Cuál es su precio? ¿Cuántas y qué viviendas se necesitan? ¿Cuántas se están construyendo?» (Vinuesa, 2013: 15).

- Además de abordar el continente, se ha de hacer lo propio con el contenido. En este caso, las personas que conforman las unidades de convivencia que habitan o van a habitar esas viviendas. A pesar de la rica y extensa variedad de datos que ofrecen fuentes como los censos de población y viviendas elaborados por el Instituto Nacional de Estadística, la diversidad y la evolución de las diferentes unidades están lejos de ser 
acotadas y descritas con dichos datos. A la información cuantitativa se han de sumar estudios cualitativos que recojan pautas y formas de vida, y aquellos conflictos concretos generados por el desfase tipológico relativos al género, la movilidad, la edad, las relaciones personales, o el trabajo productivo y reproductivo fruto de un parque heredado diseñado por y para una población masculina, que trabaja fuera de casa, sin problemas de salud y con familiares $-u$ otras personas- que realizan las labores domésticas. Las categorías del tamaño y estructura familiar de las estadísticas existentes se quedan lejos de una realidad diversa y cambiante, cuyo conocimiento será crucial para la adecuación del parque a los mismos:

«...no podemos pensar, como ocurría antes de la década de los setenta, en una solución única de vivienda para una familia nuclear, de jóvenes que salían de casa de sus progenitores para formar un nuevo hogar, réplica del que dejaban. El abanico de elecciones de formas de vida se ha ampliado considerablemente. [...] La vida de cada persona en nuestro tiempo es cada vez más larga e indeterminada, $y$ pasa por fases muy diversas: a cada una le ha de poder corresponder una forma distinta de vivienda. Hoy los presupuestos de modos de vida muy estables ya no existen, y no solo por rupturas y recomposiciones, sino porque incluso la misma familia modifica sus componentes, sus relaciones y sus necesidades a lo largo de la vida. Sin embargo, la distribución espacial y el concepto de vivienda han variado poco en relación a estos cambios sociales» (Montaner et al., 2011: 21, 29).

\section{$-4.7 .3-$}

\section{Fortalezas}

\section{Apuesta por la función social de la vivienda}

La práctica totalidad de las experiencias analizadas en la investigación incorporan de alguna manera la búsqueda y fortalecimiento de la función social de la vivienda como eje estratégico. La manera en que desarrollan dicha labor, o participan en el proceso para que se lleve a cabo es diversa, según su naturaleza, escala, objetivos, o ámbito de influencia:

- Muchas de las experiencias analizadas cuentan entre sus principales objetivos, si no es su misión prioritaria, con la consecución de una manera directa o indirecta -participando en alguna de las fases del proceso- del acceso a una vivienda digna y adecuada por parte de aquella población con una necesidad no 
cubierta. Por supuesto, muchas de las debilidades internas propias y amenazas externas ajenas identificadas condicionan el éxito de lo anterior. Pero existe ese elemento común de fondo en búsqueda del interés general.

- Hay un esfuerzo extendido de fomentar y extender otros regímenes de tenencia diferentes a la propiedad, muy arraigada en Euskadi. Desde las políticas públicas de vivienda, el Gobierno Vasco viene en los últimos años dando un importante giro hacia la apuesta por el alquiler, algo claramente presente en los Planes Directores de Vivienda de 2013-2016 y 2018-2020. Lo cual tiene su reflejo en el trabajo de Alokabide -íntegramente orientada a la gestión del alquiler, propio o de terceros-, o en los programas de movilización de vivienda vacía hacia el alquiler social gestionados por la anterior, como Bizgune y ASAP. Desde la esfera privada, se observa también la extensión de un interesante posicionamiento que apuesta no ya solo por el alquiler -como hace en parte Etikalia-, si no por otras fórmulas de copropiedad en régimen cooperativo y de cesión de uso. Por este tipo de alternativas apuestan algunas iniciativas como Etxekoop y Egunsentia Aurora, y son las que pretenden fomentar empresas de servicios como Sumae Coop. y Urbania ZH Gestión.

- El papel de estas últimas es fundamental en la divulgación y el impulso de este tipo de modelos que pueden, como se ha visto, ayudar a avanzar hacia las tres metas estudiadas. Uno de los aspectos clave en este sentido es la manera en que, iniciativas privadas como las mencionadas, incorporan de una forma sincera y consecuente la responsabilidad social corporativa en su actividad económica. Aunque lo hacen en diversas esferas -desde las condiciones del personal y calidad de empleo, a posibles afecciones ambientales- son de especial interés aquellas que tienen efectos en la gestión de la vivienda. En algunos casos, lo hacen desde un ámbito de trabajo más cercano a las situaciones de urgencia con un importante componente solidario, como Eguzkilore. Otros, como Etikalia, trabajando para transformar una actividad tradicionalmente enfocada al lucro y la acumulación de rentas como principal fin, como son los Agentes de la Propiedad Inmobiliaria. Desde su posición, buscan atraer a la propiedad y posibles agentes inversores con sensibilidad para que desarrollen una función social sin dejar de generar rentas, aunque estas sean menores a las habituales del mercado, y lograr la utilización responsable del patrimonio edificado de sus clientes.

\section{Giro hacia la intervención en el parque existente}

Que contar con un parque residencial que no está aprovechado ni utilizado en toda su capacidad es algo que no se puede admitir socialmente, se está paulatinamente asentando en diversas esferas. Aunque de manera lenta, muchas son las pequeñas propiedades que 
incorporan sus viviendas a los programas de movilización de vivienda vacía, o que las ponen en el mercado libre. También hay agentes que invierten en la compra de inmuebles para su puesta en alquiler a unos precios razonables, equilibrando la búsqueda de rentas con la función social de la vivienda. Y por supuesto, son muchos los ayuntamientos que ven la necesidad de elaborar censos rigurosos del estado de la vivienda vacía en sus correspondientes municipios, para poder llevar a cabo una adecuada gestión y ocupación de la misma:

- En este marco, es de destacar la aparición de empresas privadas de servicios de consultoría como Sumae Coop. y Urbania ZH Gestión, que ofrecen trabajos de detección, planificación y gestión del parque residencial infrautilizado. En la misma línea se puede entender la preocupación y prioridad de algunas de las experiencias analizadas, como el proyecto cooperativo Etxekoop o la iniciativa Eguzkilore, por formalizar sus diversos proyectos de vivienda a partir de uno o varios inmuebles existentes, desarrollando estrategias concretas de intervención y transformación para la adaptación de los mismos a sus necesidades.

- Tanto Visesa como Alokabide, ambas sociedades públicas con competencias en la gestión del acceso a la vivienda protegida, recogen en sus estatutos y/o normativa que dentro de su objeto social está la adquisición de inmuebles - públicos o privadosbajo cualquier forma y procedimiento para destinarlos a la promoción y alquiler de viviendas. Esta competencia, unida a un cambio de estrategia a principios de la década de 2010 para poner mayor énfasis en la rehabilitación y regeneración del parque existente, dota de una capacidad de gran interés a estas sociedades para poner en carga y aprovechar el patrimonio residencial construido.

- A pesar de los obstáculos y las debilidades vistas en los programas creados para la movilización de vivienda libre vacía hacia el alquiler social, puede afirmarse que existe ya una línea de trabajo constante en este sentido por parte del Gobierno Vasco. Son ya más de quince los años que lleva en marcha Bizigune, y seis ASAP. La experiencia va poco a poco facilitando la mejora del servicio ofrecido. La apuesta es firme, pues se es consciente de que ante la incapacidad de generar con medios exclusivamente públicos una respuesta residencial, la inclusión del parque privado en la fórmula es una cuestión fundamental. En ese sentido, además de dar continuidad a los programas analizados, se siguen analizando desde el Observatorio Vasco de la Vivienda casos y métodos utilizados en otros lugares.

- El tratamiento que Etikalia hace de las viviendas vacías como un problema de la propiedad al que hay que buscar solución es una manera innovadora y positiva de abordar la situación. Por un lado, centra parte de su línea de negocio en el aprovechamiento y 
uso eficaz del parque existente. Por otro, equilibra las relaciones y negociaciones entre la propiedad que vende y la que compra, o entre arrendataria y arrendadora. Ya que plantea dichos acuerdos de compraventa o alquiler como estrategias para soluciones dos problemas: la existencia de vivienda vacía y la necesidad de alojamiento. Además, a todo ello le suma una componente medioambiental, al considerar la puesta en carga de las viviendas ya construidas como una prioridad frente a los nuevos crecimientos, permitiendo el ahorro de recursos materiales y energéticos.

- El programa Barriztu y -aunque quizás de una manera indirecta y cuestionable, pues ya se ha visto que se trata de un modelo de gestión más orientado a la obtención de rentabilidad económica y no destaca por sus objetivos sociales- las fórmulas de la Renta Vitalicia y el Alquiler Garantizado, facilitan la permanencia en sus viviendas de personas con dificultades físicas y/o económicas en situaciones -potenciales o reales- de vulnerabilidad residencial. Anticipándose así al problema de la vivienda vacía, pues en muchos casos el motivo de la desocupación es el abandono de esta por personas mayores, y una falta de gestión adecuada por parte de la familia que la hereda.

\section{Adaptación tipológica relativa}

A pesar de los mencionados retos culturales que llevan a que la oferta tipológica residencial sea todavía muy pobre en diversidad, existen ciertos agentes que son conscientes de la necesidad de abrir la oferta a otro tipo de modelos. Ya sea ofreciendo servicios para asesorar en dicho proceso, o actuando de manera autogestionada:

- Aunque de manera quizás demasiado paulatina, hay por parte de las instituciones una lenta toma de conciencia de la importancia de incorporar información sobre las necesidades cambiantes de la población con necesidad de vivienda. A los diferentes canales de comunicación y participación abiertos se suman las herramientas dispuestas para poder intervenir físicamente en los inmuebles, propios o de terceros, gestionados. Lamentablemente, todavía no parece haberse detectado el potencial que puede llegar a tener una estrategia basada en la transformación del parque como punta de lanza para favorecer el acceso económico, como la que se ha analizado en el capítulo previo, ni se cuenta con una normativa sectorial lo suficientemente flexible que lo facilite.

- El programa Barriztu es un claro ejemplo, aunque parcial, de la necesidad extendida entre diferentes perfiles y colectivos de adecuar las viviendas a sus situaciones vitales concretas. Si bien el citado programa se limita a unas situaciones específicas de 
especial vulnerabilidad y urgencia, y se reduce a intervenciones mínimas, la estrategia de fondo podría aplicarse a otras escalas, situaciones y perfiles.

- La comprensión del desfase existente y de la gradual obsolescencia tipológica de las viviendas en un contexto demográfico cambiante es quizás lo que ha llevado a Etikalia a buscar alianzas externas y ofrecer de manera conjunta un servicio orientado a esta cuestión. A la actividad de gestión inmobiliaria habitual suman una información considerablemente detallada de las posibilidades espaciales del inmueble, de su capacidad de adecuarse a las necesidades de la potencial clientela, y de los costes de todo ello.

- También desde el asesoramiento y la consultoría, empresas como Urbania ZH Gestión y Sumae Coop. creen en la incorporación de procesos de toma de decisiones abiertos y colectivos en torno al diseño de los espacios residenciales. Por esta razón, ofrecen servicios de fomento, apoyo y acompañamiento a proyectos cooperativos de vivienda de diversa naturaleza, para que respondan a las necesidades y deseos de sus futuros habitantes.

- Entre otras motivaciones, la demanda todavía minoritaria de unas soluciones habitacionales diferentes a las habituales, y que no encuentra una oferta adecuada en el mercado -que reproduce un esquema conservador y jerárquico entre parte de la población con necesidad de vivienda- es la que lleva a parte de ella a agruparse en colectivos cooperativos de distintos perfiles como Etxekoop y Egunsentia Aurora. La necesidad y búsqueda de otras soluciones y esquemas tipológicos resultan ser ejes estratégicos de dichos proyectos.

\section{Control del coste final de acceso a la vivienda}

El papel que las dificultades de carácter económico juegan en el proceso de acceso a la vivienda es, con diferencia, uno de los aspectos mayormente abordados por todos los casos. No en vano, es el principal impedimento para la consecución de este derecho fundamental. La naturaleza que tiene la vivienda de necesidad básica hace que se planteen, orientados a determinados sectores sociales, instrumentos para reducir el precio final de la misma. Pero no solo por una cuestión de acceso, si no también para limitar el posible endeudamiento y/o sobrecarga sobre las rentas disponibles:

- Los agentes y programas públicos analizados establecen límites máximos para los precios finales de venta y alquiler de las viviendas promovidas o gestionadas por ellos. De igual manera, agentes privados como Eguzkilore fijan también unos máximos para que las personas a las que enfocan su labor puedan acceder de una manera digna a las viviendas temporales ofertadas. 
- En algunos casos, como en las promociones de nueva construcción llevadas a cabo por Visesa, se cuenta con ciertas garantías en caso de que, por los motivos que fueran, el precio final acabe superando en un porcentaje determinado el acordado en el contrato. En dichos casos, este puede resolverse.

- Para la protección y prevención de posibles situaciones de endeudamiento excesivo, algo que ha sido muy frecuente en años previos con hipotecas a muy bajo precio, pueden observarse diversos mecanismos - se ha de recordar que diversos estudios y fuentes establecen un 30\% como el máximo aconsejado de las rentas personales a destinar al pago de la vivienda-. Desde el establecimiento de una renta mínima para poder solicitar una vivienda protegida de régimen general, a la fijación del citado límite del 30\% -sea cual sea el salario de referencia, si es que lo hay- a la hora de calcular las rentas por parte de Eguzkilore, pasando por la política de Etikalia de ofrecer a su clientela solo aquellas viviendas adecuadas al nivel de ingresos de la unidad de convivencia interesada.

- Desde una estrategia de autogestión, los proyectos cooperativos también nacen en gran parte de una necesidad o carencia económica. Por ello, en sus planteamientos tienen una importante presencia cuestiones como la reducción de gastos gracias a la eliminación de ciertos intermediarios, el desarrollo interno de ciertas tareas en la fase de construcción y en la vida útil del inmueble, o las posibles ventajas fiscales en proyectos cooperativos. En algunos casos, sin descartar la autoconstrucción (Etxekoop), ni la reinversión de posibles beneficios en el propio proyecto (Egunsentia).

\section{Trabajando por la convivencia y la cohesión social}

Desde diferentes puntos de vista, y con objetivos diversos, en muchas de las iniciativas se observa una preocupación y un interés por avanzar hacia otras metas de gran relevancia. Como la integración de un sector de población con dificultades de acceder a la vivienda en un modo de vida autónomo y digno. Como algunos agentes con gran experiencia en esta problemática afirman, la vivienda es el primer paso para un desarrollo personal completo ${ }^{93}$ :

- De una manera puntual e indirecta, los programas de movilización de vivienda vacía pueden aportar además, aunque a pequeña escala, cierta cohesión social y mezcla de perfiles socioeconómicos. Dado que la localización y características de las

93 Este es el principal planteamiento del modelo Housing First, que da la vuelta a un modelo de atención en escalera a situaciones vulnerables en el cual el último escalón, una vez superados otros conflictos y necesidades, era la vivienda habitual. Este otro comienza, precisamente, por dotar a las personas atendidas con el acceso a una vivienda. 
viviendas incorporadas responden más a la incierta y variable participación de la propiedad privada que a una planificación detallada de estas -a pesar de que desde el Gobierno Vasco se han definido ámbitos prioritarios de movilización-, la casuística puede poner en relación a unidades de convivencia participantes en el programa con un contexto de comunidad y barrio diferente del que provienen.

- Los casos de Barriztu, Eguzkilore y Jóvenes Solidarios tienen estas temáticas como ejes clave en su definición y trabajo diario. La primera de las tres experiencias integra en el proceso de renovación de la vivienda a diferentes agentes para profundizar más allá de la mera intervención física y detectar situaciones de exclusión social sobre las que trabajar. La segunda pone especial énfasis en la fase de acompañamiento, a través de los dispositivos residenciales que gestiona, para lograr la salida de las situaciones de vulnerabilidad en las que están inmersas las personas atendidas. La tercera, en una escala más cercana a las comunidades vecinales y al propio barrio, pretende fortalecer y generar lazos de convivencia en barrios con ciertos conflictos y carencias en dicha materia.

- La mediación en los conflictos vecinales es también una cuestión fundamental para la mejora de la convivencia y la cohesión. Algunos de los agentes analizados ofrecen servicios orientados a ello. Alokabide, por ejemplo, ofrece a las comunidades que habitan viviendas gestionadas por ella un servicio de gestión de conflictos. Desde la esfera privada, Urbania ZH Gestión ofrecía servicios de intermediación y gestión de conflictos en espacios vecinales y comunitarios, y el asesoramiento en materia de intervención e integración social en parques públicos de alquiler.

- La transversalidad frecuentemente detectada en muchos proyectos cooperativos de vivienda, posiblemente dado el perfil político de algunas de las personas que las conforman, se ve reflejada también en los objetivos que en esta materia tienen los proyectos de Etxekoop y Egunsentia Aurora. En ambos casos se plantea que el proyecto debe abarcar más allá de la propia vida dentro del inmueble, y buscan abrirlo al entorno próximo y realizar aportes a la comunidad cercana. 


\section{Oportunidades}

\section{Alianzas vigentes y potenciales}

Como se ha venido incidiendo, la colaboración entre agentes parece resultar una estrategia fundamental para el desarrollo exitoso de los objetivos marcados en torno a la gestión residencial. Esta se da actualmente a diferentes escalas, aunque existe capacidad para que se vea fortalecida por las relaciones ya existentes, y extendida y ampliada por otras nuevas:

- Las alianzas entre las diferentes sociedades y organismos públicos relacionados en mayor o menor medida con la gestión residencial es patente y rica. Se da entre instituciones de diferente rango y competencia territorial y sectorial, y puede observarse entre Gobierno Vasco -a través de agentes como Visesa o Alokabide, por ejemplo- y ayuntamientos, entre estos y la universidad pública vasca, o entre las propias sociedades dependientes del gobierno autonómico.

- Otra de las fórmulas de colaboración es la que afecta a instituciones públicas y entidades privadas. Merecen una especial mención aquellas cesiones y convenios puntuales por los que las primeras destinan por periodos concretos de tiempo, y bajo determinadas condiciones, viviendas de su propiedad a entidades privadas del tercer sector. El objetivo, cubrir necesidades de sectores en riesgo como personas refugiadas, o con enfermedades crónicas, entre otros.

- Se dan también casos en un sentido contrario, es decir, cuando las viviendas pertenecen a entidades privadas y estas son cedidas a instituciones públicas para su gestión y puesta en alquiler social. Tal es el caso de la colaboración de Alokabide con la Sareb.

- Desde la óptica del desarrollo de servicios profesionales, también se dan relaciones de interés entre algunos de los agentes estudiados, que no hacen si no enriquecer todos los procesos y alimentar el conocimiento mutuo de la problemática. Así se ha dado en aquellos proyectos desarrollados por Urbania $\mathrm{ZH}$ Gestión en diversos ayuntamientos del AMB, en los que la empresa fue contratada para la planificación de una política que abordase la situación de la vivienda vacía. O en el asesoramiento que esta misma empresa realizó al proyecto de Egunsentia Aurora para el diseño y desarrollo de su cooperativa residencial.

- En otro marco relacional, los servicios sociales de base municipales trabajan en estrecha colaboración con iniciativas sociales como Eguzkilore y Barriztu para la detección de aquellas 
situaciones de exclusión social y el seguimiento de los procesos de mejora de su situación residencial.

\section{Encaje (e influencia) en grandes políticas públicas de vivienda}

La convergencia de intereses entre diferentes agentes -civiles, privados y públicos- ha quedado ya patente en el planteamiento del marco teórico propuesto en el capítulo segundo. En ese contexto, las experiencias en este capítulo seleccionadas son parte de ese mapa de agentes que aportan, desde su ámbito competencial y con los medios con los que cuentan, su grano de arena en la consecución de las tres metas aquí trabajadas:

- Un repaso a los objetivos y al trabajo desarrollado por las diversas experiencias locales seleccionadas permite identificar con facilidad la multitud de diagnósticos, objetivos, y estrategias que comparten con algunos de los principales instrumentos propios de las políticas públicas de vivienda. Tales como los diversos Planes Directores de Vivienda de Euskadi, el Pacto Social por la Vivienda, o las políticas de Rehabilitación y Regeneración Urbanas.

- Además del encaje en dichas políticas, se ha de destacar el papel que desde su ámbito de influencia limitado ejercen en las mismas algunos de los agentes. Así fue en el caso de Etxekoop, pues su participación en el proceso de aprobación de la Ley 3/2015 de Vivienda favoreció la inclusión de la figura de cooperativas de cesión de uso en la misma, y logró el compromiso de apoyar el desarrollo de una experiencia piloto por parte del Gobierno Vasco.

A todas estas oportunidades, se puede añadir la propia de los espacios de oportunidad identificados en el capítulo tercero; es decir, la posibilidad de que los agentes estudiados en este capítulo desarrollen la estrategia de agrupación de unidades de convivencia como vía para alcanzar las tres metas analizadas. En el estudio de este potencial se centra el capítulo quinto. 


\section{$-4.8-$}

\section{Conclusiones parciales}

\section{Agentes por una gestión y un acceso alternativos}

Lo desarrollado a lo largo del capítulo permite confirmar la hipótesis parcial formulada. Tal y como se planteaba, y con sus limitaciones internas y externas -pero también con un cierto interés general compartido-, existen en el AMB una serie de agentes participando desde diferentes ámbitos, con diferentes estrategias y planteamientos, en diferentes fases del proceso de acceso a la vivienda, y desde un posicionamiento alternativo al modelo inmobiliario predominante, con interés sincero por solucionar la problemática desde la responsabilidad social. En mayor o menor medida, tienen entre sus objetivos las tres metas abordadas: el acceso a la vivienda a un coste digno, la adecuación de esta a las necesidades propias de las diversas unidades de convivencia actuales, y el aprovechamiento del parque existente como estrategia para lo anterior. Aunque de una manera tímida, se comienzan a distinguir movimientos institucionales, civiles y empresariales hacia un modelo de gestión de la vivienda enfrentado a la visión de esta como mero elemento económico y de inversión, trabajando por equilibrar la relación contradictoria entre el valor de uso y de cambio de la misma. Sociedades públicas de gestión de vivienda protegida, programas específicos gestionados por estas, empresas privadas orientadas a la consultoría, iniciativas diversas de autopromoción de vivienda, programas de urgencia social públicos y privados, o iniciativas con otros planteamientos. Se ha comprobado que es posible identificar un rico e interesante mapa de agentes con un considerable espíritu de colaboración a diversas escalas y con diferentes fines: interno, entre agentes, para ofrecer un servicio más eficiente, o para empoderar a las personas que integran la experiencia.

La inclusión de figuras como las cooperativas en régimen de cesión de uso en la Ley 3/2015 de Vivienda de Euskadi y en los Planes Directores de Vivienda, el incipiente interés ciudadano por promover desde la autogestión este tipo de proyectos, o la oferta de servicios privados para el acompañamiento y asesoría en su puesta en marcha son una prueba de ello. Los ya más de quince años de recorrido del Gobierno Vasco buscando la mejor fórmula para poner en carga las viviendas libres vacías y orientarlas al alquiler social, la colaboración entre el ayuntamiento de Bilbao y la universidad pública vasca para ofertar vivienda asequible al colectivo estudiante aportando el valor añadido de enriquecer la convivencia y la cohesión social de 
ciertos barrios de la ciudad, la intervención privada en colaboración con los servicios sociales de base para responder a situaciones de mayor vulnerabilidad residencial, o la aparición en 2014 de una inmobiliaria ética con la intención de revolucionar el sector de los APIs, también lo confirman. Y hacen evidente la amplia diversidad y heterogeneidad del público objetivo, las estrategias planteadas, y los ámbitos de actuación.

\section{Amenazas abordables desde las instituciones}

Una de las interpretaciones obtenidas a partir de la metodología DAFO es que varias de las amenazas detectadas podrían ser abordadas y reducidas desde las instituciones. La generación de un marco regulador, de difusión y de información podría facilitar el desarrollo y crecimiento de estas prácticas. El contraste existente entre, por un lado, las limitaciones planteadas por las diversas normativas que afectan a la problemática -constructiva, de condiciones de habitabilidad, urbanística, fiscal,...algunas han sido mencionados en el trabajo-, una tradición administrativa paternalista, o una sociedad civil pasiva y poco organizada, y por otro, los espacios de oportunidad detectados en la investigación, podría motivar y animar al desarrollo de un marco que favorezca, impulse y fortalezca iniciativas como las analizadas en el presente capítulo. Iniciativas que pueden originarse desde la promoción pública de las mismas, desde modelos mixtos, o bajo esquemas totalmente privados. Y que pueden verse favorecidas por instrumentos como reducciones fiscales, la adaptación y renovación de ciertas normativas heredadas de contextos pasados, la divulgación y educación sobre el tema, o el fomento de la creación de iniciativas ciudadanas de autopromoción bajo fórmulas verdaderamente cooperativas. Igualmente, en manos de las instituciones públicas está el desarrollo y la apertura de información detallada y en continua actualización relativa a toda esta cuestión. Contar con más datos sobre la realidad del parque -su ocupación o no, las razones de ello, las características espaciales del mismo, la estructura de su propiedad, su localización,...-, o sobre las unidades de convivencia con necesidad de vivienda -la evolución y el abanico de sus pautas y desarrollos vitales, sus tiempos y espacios de producción y reproducción, sus formas de convivencia,...- es un paso necesario para abordar con rigor y una base mínimamente sólida la presente problemática. Se trata, por tanto, de colocar sobre la administración pública una buena parte de la responsabilidad de acelerar -o iniciar, según el caso- un cambio social y empresarial que comienza a evidenciarse a través de pequeños $-\mathrm{y}$ no tan pequeñoscasos aislados.

\section{Parque como objeto, acceso como fin}

De una u otra manera, todos los agentes tienen en común dos cuestiones: que entre sus objetos de trabajo está, directa o 
indirectamente, el parque residencial existente, y que entre sus objetivos está avanzar hacia un acceso digno a la vivienda por parte de aquellas personas con mayores dificultades para lograrlo en el mercado libre. Lo cual hace que sea de gran interés saber en qué medida encaja cada caso con la estrategia de agrupación de unidades de convivencia identificada en el capítulo tercero para aprovechar los espacios de oportunidad detectados; cuáles son las variables y los condicionantes a tener en cuenta para que la incorporen a su actividad; y cuáles son las capacidades y las limitaciones para ello. Todas estas cuestiones se desarrollan a continuación. 


\section{Parte I. \\ Contexto, marco de análisis \\ y planteamiento}

Parte II.

Material, métodos y resultados

Parte III.

Discusión y

Conclusiones 



\section{CAPÍTULO 5}

\section{Agentes locales ante espacios de oportunidad y agrupaciones}

«Los procesos sociales, entre ellos los que están relacionados con la producción del hábitat, son partes de un sistema abierto, ya que suponen la interacción de personas, grupos sociales y objetos, y están siempre sujetos a intervenciones e interferencias diversas, estrechamente vinculadas con su entorno».

(Romero y Mesías, 2004: 16) 



\section{$-5.1-$ Variables y condicionantes a tener en cuenta}

Los resultados obtenidos en el cuerpo de la investigación capítulos segundo, tercero y cuarto que conforman la Parte II del trabajo- llevan, entre otras cuestiones, a proponer un principal ejercicio de interpretación en esta tercera parte del trabajo. Este consiste en una aproximación analítica al potencial que los agentes de gestión alternativos estudiados presentan, desde una posición en defensa por el valor de uso de la vivienda, para llevar a cabo la posible estrategia identificada en el capítulo tercero. Esta consiste en abordar la problemática de la vivienda en el AMB desde el aprovechamiento de unos espacios de oportunidad existentes en el parque residencial actual. Espacios que han sido identificados como consecuencia de ciertos desfases entre la oferta y la demanda, y pueden ser explotados a través de la agrupación de unidades de convivencia como herramienta para adaptar -y aprovechar- dicho parque, y así lograr un acceso económica y espacialmente digno.

A modo de síntesis, se recuerdan a continuación las principales características y resultados de los espacios de oportunidad detectados. El análisis del parque residencial, a partir de la muestra seleccionada, ha mostrado una Accesibilidad Económica individual prácticamente inexistente. Aunque el acceso se incrementa muy notablemente en la medida en que se suman personas con capacidad de pago, sin necesidad de alcanzar grupos grandes (ver Tabla 3.13). En cuanto a la Accesibilidad Espacial, esta se caracteriza por una baja flexibilidad actual para albergar, en condiciones adecuadas, a unidades de convivencia diferentes del modelo tomado como base para el diseño de la vivienda habitual. Pero cuenta con una adaptabilidad futura considerable de cara a realizar transformaciones espaciales en la misma (ver Tablas 3.15 y 3.16). El cruce de ambos indicadores, ya sea como Accesibilidad Total Bruta o Neta, arroja unos esperanzadores resultados. Un alto porcentaje de las viviendas analizadas son accesibles bajo condiciones espacial y económicamente dignas para diferentes tamaños de grupos de personas -especialmente para aquellos de dos y tres- (ver Tablas 3.17 y 3.18). La estrategia de acceder al parque existente a través de la agrupación de unidades de convivencia, y de la transformación del mismo a sus perfiles, se ha visto además que es compatible con la inclusión de personas sin capacidad de pago en esos grupos (ver Tabla 3.19 y Gráficas 3.22 y 
3.23). Lo oportuno de su planteamiento ha quedado demostrado al observar el desfase entre la diversa estructura de unidades de convivencia actuales y los tamaños de viviendas habituales (ver Tablas 3.20 y 3.21$)$.

El presente apartado desarrolla un análisis del encaje que se está dando, o puede llegar a darse, entre los agentes locales estudiados y esos espacios de oportunidad detectados. Es decir, estudia si los primeros pueden estar aprovechando, o no, dichas oportunidades, y cuál es el potencial que presentan, bien para hacerlo, bien para optimizar ese aprovechamiento. En definitiva, una vez confirmados los principales elementos de la hipótesis general en el cuerpo de la investigación, lo que se busca en este capítulo es confirmar el último punto de la misma. La metodología propuesta para dicha labor es un nuevo análisis de ambas cuestiones -agentes locales y parque existente- desde la óptica de la gestión del acceso a la vivienda. Siempre con las tres metas del acceso económico, la adecuación tipológica, y el aprovechamiento del parque infrautilizado como telón de fondo, pero esta vez especialmente centrado en evaluar el encaje entre ambos objetos de estudio. Para ello, se han evaluado en cada caso una serie de variables que se han considerado clave para que se dé ese adecuado aprovechamiento y permiten hacer una previsión del nivel de encaje de estas iniciativas con las características del contexto socio-económico y tipológico residencial analizado anteriormente. Las diferentes respuestas a estas variables condicionarán o habilitarán en gran medida la capacidad de aprovechar las oportunidades identificadas. La selección de las variables viene justificada porque, además de reflejar algunos de los principales aspectos y conflictos detectados y analizados a lo largo de la investigación, se cree que pueden aportar información relevante para facilitar una interpretación de interés de cara al cierre de la investigación. Sin perjuicio de que puedan añadirse más, las analizadas son las siguientes.

\section{$-5.1 .1-$}

\section{Estructura y escala de la propiedad}

Dado que se plantea una alteración espacial y una reorganización de la ocupación del parque residencial, y se hace desde la búsqueda de una intervención planificada que abarque el máximo de viviendas posibles, cabe saber si se gestionan conjuntos de inmuebles, y la relación de estos entre sí. Se centra la mirada en la organización y las relaciones existentes, de haberlas, entre los inmuebles donde se ejerce la propiedad, el derecho de usufructo, o la gestión propia de cada experiencia analizada. Se diferencian situaciones que van desde aquellas iniciativas que engloban una sola vivienda, un edificio o una parcela, pasando por sistemas más complejos que incluyen una red de viviendas, parcelas, edificios, e incluso áreas urbanas de cierta entidad 
distribuidas sobre una ciudad, el área metropolitana o incluso toda la comunidad autónoma vasca. No se entra a valorar cómo se plantean estas unidades de vivienda ni cómo están ocupadas, lo cual se analiza en variables posteriores. Es su estructura y su escala lo que interesa.

\section{Una única vivienda}

Aunque con un peso menor, son varias las experiencias analizadas cuya actividad tiene como resultado la gestión puntual en el tiempo sobre una sola vivienda. En el sentido en que esta se trata de manera aislada, y una vez desarrollado el servicio se pierde seguidamente el contacto y toda gestión con la misma, su propiedad y/o sus habitantes. No hay un control continuado del destino de la misma, ni forma parte de un parque bajo una misma gestión. Habitualmente afecta a una sola unidad de convivencia, la que ocupa dicha vivienda. En esta categoría se sitúan los casos de la Renta Vitalicia y el Alquiler Gatantizado, Etikalia -siempre y cuando se trate de operaciones de compra-venta-, y Barriztu -esta última en menor medida, pues sí hay cierto seguimiento posterior a la intervención y adaptación de la vivienda-.

\section{Viviendas sueltas distribuidas en el parque libre o protegido}

Se trata, probablemente, de la estructura más habitual dentro de las gestionadas por los diferentes casos, y que forma conjuntos de inmuebles por los que pueden llegar a pasar muchas unidades de convivencia. Puede ser resultado de la generación de un parque propio a lo largo del tiempo a partir de un goteo intermitente de adquisición o donación puntual de viviendas. Situaciones de este tipo se dan en el parque público de vivienda protegida gestionado por Alokabide -aunque en menor medida, pues no es esta su principal manera de generar oferta-, o en iniciativas bien diferentes como Eguzkilore, que va captando viviendas de orígenes y mediante acuerdos diversos para formar poco a poco un parque propio. Pero la formación de un parque en propiedad no es la única manera de participar en el proceso de acceso a una vivienda digna, como se ha podido comprobar en el capítulo anterior. La gestión y administración continuada en el tiempo de viviendas pertenecientes a terceros es también habitual. Ya sea mediante pequeños o medianos conjuntos de viviendas dispersas, pero pertenecientes a grandes propietarios como el caso de la cesión temporal de viviendas por parte de la SAREB a Alokabide-, o mediante la gestión de muchas viviendas provenientes de pequeñas propiedades. Esta opción es más frecuente y es en la que están basados los programas Bizigune y ASAP, pero también Barriztu, Eguzkilore, y por supuesto Etikalia en las operaciones de arrendamiento, pues es esta la base de su actividad. 
En cuanto a las escalas manejadas, estas son muy diversas, con medios y objetivos también diferentes. Si el programa de Jóvenes Solidarios incluía en la convocatoria de 2016 un total de 45 plazas, las viviendas gestionadas por los programas de movilización de vivienda vacía rondaban las 5.000 -en toda la comunidad autónoma-. Este tipo de estructura formada por un conjunto de mayor o menor tamaño, de viviendas dispersamente distribuidas a lo largo del parque de vivienda colectiva, presenta tanto inconvenientes como ventajas. Entre los primeros, está la dificultad de que se generen redes formadas por las unidades de convivencia que ocupan dichas viviendas, y que pueden facilitar actuar como colectivo. Esto es interesante tanto para un enriquecimiento de la experiencia, como para la defensa de sus intereses. La creación de sindicatos de personas arrendatarias en algunas ciudades no es algo nuevo -aunque sí reciente en España, con poca tradición en este aspecto $^{94}-$, y sería comprensible que las unidades de convivencia participantes en los programas Bizigune y ASAP, por ejemplo, decidiesen construir este tipo de asociaciones. Sin embargo, el diseño de estos programas está planteado desde la perspectiva, como se ha apuntado en la síntesis del $\mathrm{DAFO}$, de una administración pública con ninguna delegación de funciones en la sociedad civil. Se gestiona así desde arriba un servicio que hace imposible el contacto entre las personas beneficiarias. De la misma manera, esta característica dispersa de este tipo de estructuras dificulta también el contacto y la relación entre pequeñas propiedades, que podrían actuar como grupo. No ya solo para la defensa de sus intereses, si no incluso para lograr una gestión unificada y más eficaz de sus inmuebles a la hora de incorporarlos a la oferta gestionada por agentes tan diversos como Etikalia, Bizigune, ASAP o Eguzkilore. Entre las ventajas de este tipo de propiedad dispersa, en el caso de agentes con varias viviendas, está la posibilidad de rotar estas entre sus habitantes en función de sus necesidades habitacionales cambiantes. Por otro lado, como ya se ha apuntado con anterioridad, en casos como Bizigune, ASAP y Eguzkilore, las viviendas gestionadas en bloques de vivienda colectiva tienen una localización heterogénea. Al estar distribuidas en zonas y barrios de diferente perfil socio-económico, podrían llegar a favorecer la mezcla y la cohesión social; la normalización de la convivencia con perfiles socioeconómicos en ciertos casos rechazados o evitados.

\section{Parcelas y/o edificios completos}

Frente a la estructura anterior, y aunque probablemente acumulando un menor número de viviendas, está aquella conformada

${ }^{94} \mathrm{El}$ nacimiento de este tipo de sindicatos en Barcelona o Madrid se enmarca en un movimiento internacional como respuesta a una problemática común de creciente incapacidad de compra y subida de precios de alquiler. Hay casos con un interesante recorrido y logros como Kotti \& Co u Otto Suhr Siedlung en Berlín, Living Rent en Escocia, Dublin Tenants Association en Irlanda, o London Renters Union en Inglaterra, entre otros muchos ejemplos. 
por uno o varios edificios completos -o una parte importante de ellos-, ya sea por la promoción de estos dentro de una parcela urbanizada, o por la adquisición de los mismos una vez edificados. Es importante aclarar que de lo que se está hablando es de aquellos casos en los que esta escala más amplia que abarca varias viviendas es un planteamiento de continuidad, y no solo un proceso temporal de promoción y venta de viviendas. Pues el resultado de lo segundo sería precisamente alguna de las categorías anteriores. En esta se incluyen solamente aquellas situaciones en las que una estructura de la propiedad mayor que conecta la gestión de todos esos inmuebles entre sí permanece en el tiempo, de diferentes maneras posibles. De cara a los objetivos e intereses de este trabajo, esta otra estructura de la propiedad ofrece varias ventajas que se apuntan a continuación. Suele permitir, casi por su propia naturaleza debido a que es un ejercicio planificado previamente, la anticipación y el conocimiento previo de los perfiles y tipos de unidades de convivencia a los que el proyecto está dirigido. Sería el caso de las promociones públicas de vivienda protegida desarrolladas por Visesa. Incluso en algunos casos, se llega a conocer con exactitud quienes son las personas que los van a habitar -como en los proyectos verdaderamente cooperativos-. Esto supone que, con mayor o menor precisión y ajuste, se cuente de manera previa con un programa de necesidades definido al cual el proyecto ha de responder. $\mathrm{Y}$ que permite enriquecer el mismo y reducir los posibles desfases tipológicos.

Por otro lado, para un mismo número de personas finales a alojar, la concentración de los inmuebles y de las unidades de convivencia, sean estas propietarias o inquilinas de los primeros, es previsible que permita una mayor eficiencia de recursos si se compara con la distribución de estos a lo largo del parque. El coste económico de adquisición -en el caso de que estén ya construidos, y con unas características similares- será seguramente inferior cuando estén agrupados. Si se trata de una obra nueva colectiva, la comparación con la adquisición de viviendas sueltas usadas es más desequilibrada, aunque igualmente podría situarse en una posición más atractiva, sobre todo si el periodo analizado incluye la vida útil futura. En este sentido, los recursos económicos, personales y temporales a destinar a la administración y gestión de la vida del inmueble serán inferiores si hay una concentración que facilite la reducción y la localización de los esfuerzos.

En el punto anterior se ha hecho mención a la dificultad que puede ofrecer, para actuar de manera colectiva, el hecho de que las viviendas estén dispersas por el parque y alejadas unas de otras. Pero en este otro caso, es de interés señalar que las propiedades de mayor escala que engloben varias viviendas favorecen precisamente lo anterior, favoreciendo -que no garantizando- la generación de comunidades vecinales con un significativo nivel de convivencia y relación. Ya sean comunidades formadas y gestionadas de manera autónoma, o nacidas bajo el impulso de la administración pública, la 
cercanía física es una variable crucial para el fortalecimiento de las relaciones comunitarias. En el primer caso, algunos proyectos cooperativos en marcha han permitido comprobar el alto nivel de riqueza que se puede alcanzar a través de ciertos procesos de diseño y toma de decisiones abiertos. En el segundo, y aunque como se ha visto hay todavía grandes retos que salvar para alcanzar niveles de empoderamiento similares a los casos anteriores, se puede afirmar que hay una serie de intenciones y herramientas desplegadas desde las instituciones públicas con un alto potencial para lograr una participación y una retroalimentación de calidad por parte las unidades de convivencia destinatarias de vivienda protegida.

\section{Conclusiones y estrategias de mejora}

Dado que el propio objeto de estudio es el parque de viviendas existente, y tomando como referencia la muestra de viviendas seleccionada para la demostración de la hipótesis parcial del capítulo tercero, la vivienda como un elemento inmueble individual de propiedad independiente y distribuido por el parque es el tipo de estructura de propiedad mayoritaria sobre la que trabajar y desarrollar la estrategia de agrupación de unidades de convivencia planteada. Lo cual obliga a que, si este no pertenece a una red mayor de inmuebles sean propiedad del agente que los gestiona o de terceros-, si no que está administrado por una entidad que solo cuenta con esa vivienda a ofertar, la iniciativa de poner en marcha la estrategia de transformar la vivienda para alojar a un grupo de unidades de convivencia reside, bien en la propiedad de la vivienda, bien en un grupo de unidades convivenciales interesado en la misma. A la hora de divulgar, fomentar y apoyar externamente esta manera de aprovechar las oportunidades detectadas en el parque -como podría ser el caso de la administración pública-, haría falta un esfuerzo considerable y la necesidad de destinar importantes recursos para un ámbito de acción pequeño, puntual y a priori anónimo, con una baja eficiencia. Como ocurre con programas como Bizigune y ASAP, el desarrollo de campañas de divulgación y el lanzamiento de mensajes de sensibilización parten con la incertidumbre de no saber a cuánto público objetivo llega y a cuánto influye.

Por otro lado, la complejidad del proceso que conllevaría el desarrollo de esta estrategia de agrupación de unidades de convivencia - la comprensión de la problemática y la estrategia propuesta, tomar la iniciativa, la búsqueda de apoyo técnico y administrativo, de financiación, la definición del programa tipológico, el diseño del espacio, el desarrollo de la intervención, la oferta y/o comercialización, la selección de personas demandantes,...- conlleva también importantes esfuerzos de gestión. Y en el caso de viviendas independientemente administradas, este proceso debería iniciarse desde cero en cada uno de los casos. Así, en aquellos casos en los que la gestión de estas viviendas heterogéneamente repartidas por la ciudad está unificada en un agente, la administración centralizada de 
estos favorecería una mayor eficiencia de recursos para una misma cantidad de inmuebles. Por otro lado, al ser en general casos que gestionan viviendas en regímenes de alquiler, o como dispositivos habitacionales de urgencia, la naturaleza de rotación de estas hace que esos esfuerzos se distribuyan a un importante número de unidades de convivencia a lo largo del tiempo. En cuanto a las experiencias que se enfocan al desarrollo de viviendas a una escala de parcelas y/o edificios, estas se ven fuertemente limitadas por la escasa oferta de suelos o edificios disponibles para ello. Ya que, apuntar a esta mayor escala espacial implica contar con soportes que lo permitan. Desde una mirada urbanística y territorial, el $\mathrm{AMB}$ es una región con muy escasas posibilidades de desarrollar este tipo de actuaciones en suelos previamente no urbanizados. Se trata de un territorio con una orografía compleja, cuyos suelos con unas características más favorables para la urbanización han venido ocupándose intensamente desde el desarrollo industrial de la región. A pesar de contar con un porcentaje de suelo no artificializado alto, el desequilibrio ecosistémico es patente, la necesidad de frenar el impacto ambiental sobre el entorno natural viene siendo apuntada desde hace tiempo, y los diferentes instrumentos de planificación espacial van paulatinamente asumiendo la prioridad de actuar sobre lo construido y proteger y recuperar lo no urbanizado ${ }^{95}$. Sin embargo, lo anterior no significa que no sea posible la implantación de proyectos a estas otras escalas. Ya que el AMB es también una región con una importante herencia de espacios y zonas degradadas o en proceso de reconversión. Lo cual permite apuntar a la construcción en lugares anteriormente destinados a otros usos, a la sustitución de edificios, o a la reutilización de estos, ya sea por un cambio de uso en aquellos no residenciales, o por la transformación y rehabilitación en aquellos residenciales en un estado obsoleto - por su estado de conservación, por sus características tipológicas,...-. Estas situaciones se darán con mayor o menor frecuencia según las zonas a regenerar. Como puede ser, en el caso de Bilbao, la ya convertida en isla de Zorrozaurre, barrios con una amplia presencia de edificios industriales como Rekalde, o edificios y parcelas puntuales en zonas claramente residenciales y de servicios, como los barrios de Castaños o Begoña.

Puede concluirse que las tres categorías identificadas en esta variable referida a la estructura y la escala de la propiedad cuentan con el potencial de incorporar avances sustanciales hacia las metas de esta investigación a través del aprovechamiento de los espacios de oportunidad mediante la estrategia de agrupación. Pero según las interpretaciones recién desarrolladas, la acumulación de inmuebles bajo un mismo órgano gestor es deseable tanto por una mayor eficiencia de recursos, como por un mayor alcance de los esfuerzos de

95 Así lo reflejan, con mayor o menor énfasis, desde el Plan Territorial Parcial del Bilbao Metropolitano, a los documentos de Avance de la revisión del PGOU de Bilbao, pasando por los estudios elaborados por la Cátedra UNESCO sobre Desarrollo Sostenible y Educación Ambiental en relación a la Evaluación de los Ecosistemas del Milenio en Bizkaia. 
divulgación, difusión y puesta en práctica de esta estrategia. Ante la escasa oferta de grandes inmuebles y suelos no edificados, el papel de aquellos agentes que gestionan viviendas existentes dispersas por el parque es por lo tanto importante.

\section{$-5.1 .2-$ \\ Soporte elemental buscado}

Esta variable se diferencia de la estructura y escala anteriormente definidas en que aquí se analiza la manera en que se conceptualiza y comprende la unidad espacial básica con la que se trabaja, sea cual sea la estructura en la que se enmarca. Puesto que la estrategia de agrupación propone que será con frecuencia posible que un número determinado de unidades de convivencia adapten y ocupen un número inferior de lo que ahora son viviendas diseñadas para una sola unidad, se busca saber cuál es el planteamiento desde el que se busca generar dispositivos residenciales. Ya sea mediante la promoción y gestión directa, o a través de otros procesos indirectos, la participación de cada uno de los agentes analizados en el proceso de ofertar y/o generar el acceso al parque residencial se desarrolla a través de una unidad espacial base. Según la utilizada con mayor frecuencia por cada iniciativa, se pueden diferenciar principalmente aquellos casos que no cuestionan el modelo actual -entendiendo la vivienda como unidad indivisible y destinada a una única unidad de convivencia-, frente a aquellos otros que, o bien están abiertos a plantear la vivienda como espacio compartido por diversas unidades de convivencia, o bien incluso van más allá e identifican al edificio entero, parte del mismo, o un conjunto de edificios, como soporte espacial vital de una vecindad capaz de transformarse y adaptarse a sus necesidades.

\section{Vivienda como elemento independiente e indivisible destinada a una unidad de convivencia}

Puede decirse que es el planteamiento mayormente compartido por las experiencias analizadas. Y sin entrar en cuestiones propias de la tipología espacial, será posiblemente el planteamiento más extendido y deseado por las unidades de convivencia con necesidad de vivienda. Pero a esta argumentación cabe enfrentar tres cuestiones, ya que la rigidez del modelo y de la cultura urbanística-inmobiliaria residencial ampliamente extendida reproduce un soporte habitacional atomizado, individual, y únicamente destinado a su ocupación por una única unidad de convivencia. Primero, el abanico de posibilidades de convivencia entre personas es muy amplio y no todas pasan por que conformen una única unidad, sea esta familiar o de otro tipo. Hay otras formas de vida y hábitos domésticos más allá de ese dogma 
ampliamente extendido. Ya sea por decisión propia -grupos de personas adultas sin núcleo familiar o varias familias nucleares que desean compartir un espacio doméstico con diferentes niveles de intimidad-o como resultado indirecto de diversas experiencias vitales -mujeres provenientes de situaciones de violencia machista, personas con enfermedades crónicas, mayores que no desean vivir en soledad,...- son muchas las razones y situaciones que pueden necesitar o desear la convivencia entre varias unidades de convivencia, ante lo cual el soporte residencial habitual no responde adecuadamente.

Segundo, como se ha venido planteando, muchas de las unidades de convivencia actuales - un mapa cada vez más diverso y cambianteque sí pueden desear habitar una vivienda en 'soledad' ven cómo sus necesidades espaciales tampoco son adecuadamente respondidas por la tipología residencial mayormente extendida. Sobre lo cual se profundizará en su variable correspondiente. Y tercero -y de manera más grave-, el contexto de crisis, precarización social y precios al alza genera numerosas situaciones de conflicto y desfase económico entre muchas unidades de convivencia y las viviendas disponibles. Por lo que muchas, deseando habitar una sola vivienda sin compartirla con otras personas se ven obligadas de manera forzada a habitarla y compartirla con más personas que no forman parte de su unidad convivencial, lo cual puede generar situaciones de conflicto, mala calidad de vida e incluso hacinamiento ${ }^{96}$. La ausencia total de un cuestionamiento de todo lo anterior - por falta de interés, o por desconocimiento-, sumado al mantenimiento y escasa transformación y adaptación de un parque heredado así formulado y formalizado, ayuda a mantener estas situaciones. Un reflejo del enorme trabajo que todavía queda por hacer para favorecer una apertura a otros esquemas tipológicos y de convivencia.

Este modelo que toma la vivienda existente como unidad independiente e indivisible es el que fortalecen, con sus estrategias y herramientas para satisfacer la demanda y la necesidad de vivienda, los agentes y programas del sistema vasco de vivienda -Visesa, Alokabide, Bizigune y ASAP-, en los que no se ha detectado en las fuentes consultadas ninguna reflexión profunda de este tipo. Desde la esfera privada también se afronta muy habitualmente la gestión residencial bajo esta idea conservadora y rígida de la vivienda como unidad incuestionable. Quizás sea Etikalia un buen ejemplo de ello, pues, a pesar de ser un caso innovador con aportaciones transformadoras al sector, ejemplifica como desde los APIs se favorece la reproducción de este modelo, siendo además unos agentes

96 El Periódico (2017): «Nuevas 'familias' unidas por un mismo techo», disponible en https://www.elperiodico.com/es/sociedad/20170929/nuevas-familias-unidas-mismo-techopiso-compartido-6288967.

20 minutos (2007): «Los jóvenes españoles, obligados a compartir piso si quieren independizarse», disponible en https://www.20minutos.es/noticia /274346/0/jovenes/al quiler/independencia/. 
clave en la evolución de la gestión y potencial transformación del parque. En todos ellos puede distinguirse un posicionamiento de fondo, sea de manera consciente o no, por el cual la correspondencia entre una vivienda del parque existente y una unidad de convivencia demandante parece ser un dogma incuestionable. Desde otras aproximaciones, casos como Barriztu o los modelos de Renta Vitalicia y Alquiler Garantizado también podría decirse que reproducen estos esquemas. Sin embargo, en estos casos hay una mayor justificación por mantener dicha correspondencia, pues se trata de unidades de convivencia actualmente habitando dichas viviendas, y en ambas iniciativas se busca -con mayor o menor interés y sensibilidad socialuna mejora en las condiciones de vida de las personas mayores y con escasez de recursos económicos a las que se dirigen.

\section{Vivienda diseñada para una unidad de convivencia, a compartir entre varias}

En el punto anterior se ha hecho referencia a cómo diversas razones suelen llevar a muchas unidades de convivencia a asumir, de una manera forzada, la necesidad de compartir una vivienda como única opción posible para contar con un alojamiento. Una vivienda que, con frecuencia, no ha sido planteada para tal fin. En algunas de las experiencias locales analizadas sucede algo similar. Aunque la decisión de compartir el espacio doméstico entre varias unidades de convivencia sí es parte de la actividad desarrollada, son casos en los que el contexto y las capacidades y/o limitaciones propias de las experiencias llevan a que la unidad o el soporte edificado utilizado no se elija, si no que se asuma. Principalmente esto es debido a dos razones, ampliamente diseccionadas en el trabajo. Por un lado, está la obligatoriedad de trabajar sobre un parque heredado con las características ya indicadas. Por otro, la incapacidad de demandar económicamente una vivienda por parte de muchas de estas personas. Todo ello lleva a que se ocupen y habiten de manera forzosa viviendas planteadas como unidades indivisibles para una única unidad de convivencia, por varias.

Así ocurre en el programa de la Fundación Eguzkilore, para el cual los medios de que dispone y las viviendas que les son cedidas por diferentes agentes son limitaciones fundamentales dentro de las cuales desarrollan sus esfuerzos por ofertar dispositivos habitacionales temporales a personas en situaciones de exclusión y vulnerabilidad social. En este caso, el compartir las viviendas es algo intencionado, pues su objetivo es el acompañamiento en el proceso de salida de dichas situaciones. Para lo cual, es imprescindible el trabajo en la convivencia y la presencia de agentes sociales en las viviendas. Pero esto no debe llevar a error: son viviendas pensadas para una unidad de convivencia muy concreta y falta de conflictos; ahora están ocupadas por diferentes personas con necesidad de acompañamiento y con situaciones personales difíciles. En otro marco totalmente 
diferente, el programa Jóvenes Solidarios se encuentra también con unas limitaciones similares. Su soporte son viviendas pertenecientes a la entidad de Viviendas Municipales de Bilbao, cuyo parque se ha ido conformando a lo largo de décadas ${ }^{97}$. Un parque que, generalmente, ha ido reflejando las evoluciones de la vivienda social y protegida, pero que en todo caso reproduce la idea apuntada de que a una vivienda le corresponde una unidad de convivencia. Por ello, la acertada e interesante búsqueda de soluciones como las de este programa dirigido a jóvenes del ámbito universitario -con habituales problemas para encontrar vivienda asequible de alquiler-, con el valor añadido del fomento de la convivencia de barrio, se enfrenta a la rigidez propia de este parque municipal heredado.

\section{Edificio entero como soporte vital de una comunidad real}

Frente a los dos supuestos anteriores, y aunque de manera minoritaria, se observa otra manera de abordar la situación, rompiendo con las pautas habituales del sector inmobiliario. La principal diferencia es la escala del soporte base. En los diversos modelos enmarcados en un sistema cooperativo, aunque el producto final sigue siendo la vivienda, esta no es un elemento aislado sino que forma parte de un soporte mayor que la complementa y enriquece. Pasa de ser una vivienda individual dentro del parque residencial, a abarcar una parte o la totalidad de uno o varios edificios; de ser un inmueble de propiedad 'individual' a otro de propiedad colectiva con diferentes derechos de uso. De esta manera, no solo cambia la escala, si no que dicho cambio lleva implícito -en las anteriormente consideradas 'verdaderas cooperativas'- una intención de organizarse como grupo, de una toma de decisiones abierta y una voluntad de consenso y convivencia. Es decir, la generación de otro tipo y calidad de relaciones personales entre los habitantes del inmueble, así como de espacios comunes diversos. Pero el cambio de escala hace que también cambie el propio proceso, en un sector donde lo común es que la unidad de convivencia que va a ocupar finalmente la vivienda se incorpore al mismo en el momento final, sin participación alguna en las fases previas -localización, programa de necesidades, identificación de prioridades presupuestarias, planteamiento y diseño del inmueble,...-. Así, en estos casos la incorporación se hace en mayor o menor medida al inicio o en fases previas del proceso, facilitando la participación en decisiones clave para que el proyecto se adecue a las necesidades de sus futuros habitantes. Esto puede verse en la manera en que empresas como Urbania ZH Gestión abordan

\footnotetext{
${ }^{97}$ En 2018 la entidad cumplió 100 años desde que se creara, en 1918, la Junta de Viviendas, organismo delegado del Ayuntamiento de Bilbao. Tras varias renovaciones, actualizaciones y modificaciones jurídicas y organizativas, desde 2008 permanece como Organismo Autónomo Local, un instrumento jurídico para el desarrollo de la política de vivienda municipal.
} 
los servicios de consultoría que ofrecen a este tipo de proyectos. Haciendo especial hincapié en que la planificación, la identificación de necesidades y la toma de decisiones esté plenamente bajo control de las futuras personas residentes.

Por supuesto, lo habitual será que en este tipo de fórmulas el resultado final busque corresponder a cada unidad de convivencia con una vivienda. Sin embargo, frente a los casos anteriores, aquí se dan una serie de matices. Las unidades de convivencia participantes en este tipo de proyectos lo suelen hacer por haber detectado una carencia determinada en la oferta residencial convencional. Ya sea por motivos económicos, tipológicos, por la búsqueda de una vida en comunidad rica, o por la combinación de varios de ellos, entre otros, hay una reflexión, un cuestionamiento del modelo predominante y una apertura a otras alternativas. Por otro lado, el orden de la correspondencia es importante. Si antes se hacía mención a que ciertos modelos hacen corresponder a una vivienda existente una unidad demandante, aquí se plantea corresponder a una unidad de convivencia existente una vivienda. El resultado es una vivienda adecuada a las necesidades de esa unidad, en vez de verse las personas que la forman mejor o peor adaptadas a las características de una vivienda. Con lo cual, es frecuente que sobre dicha base y alimentados por unos procesos de desarrollo enriquecedores, las unidades de convivencia integrantes del grupo logren unas viviendas que respondan con considerable éxito a sus necesidades concretas. Esto significa que no siempre -aunque sí habitualmente- dichas viviendas reproducirán los esquemas habituales del mercado. Como ejemplo, la estrategia asumida en el proyecto de Egunsentia Aurora: módulos individuales de $30 \mathrm{~m}^{2}$ con posibilidad de combinarse para compartir entre dos personas $60 \mathrm{~m}^{2}$. Para que, en caso de que se den situaciones en las que varias unidades de convivencia compartan un espacio doméstico, sea por voluntad propia y este haya sido planteado y diseñado en función de tal situación. En definitiva, a la hora de partir de un soporte inmueble mayor como agregación de varias viviendas y otros espacios comunes, la correspondencia final no será tanto una vivienda convencional para una unidad de convivencia, si no una vivienda expresamente diseñada para una situación concreta.

\section{Conclusiones y estrategias de mejora}

La oferta mayoritaria de vivienda actual se enmarca rotundamente en la primera categoría de esta variable, obligando a corresponder a cada vivienda actual una unidad de convivencia. Como se ha mencionado, en un supuesto en el que no se diese el desfase entre unidades y tipologías este hecho no debería generar mayores conflictos. Sin embargo, la tipología rígida y muy específica que abunda en el mercado libre y la oferta protegida impide el correcto desarrollo de una vida doméstica de calidad para muchas unidades de convivencia del marco socio-demográfico actual y por venir. Unidades que no encajan en la idea de vivienda tenida en cuenta en el 
diseño de la gran mayoría del parque residencial edificado. En cuanto a la demanda de alojamientos para aquellas situaciones en las que varias unidades de convivencia desean compartir un espacio doméstico común a la que hace mención la segunda categoría, no es habitual. Los casos que se den, sin embargo, como ocurre con las experiencias analizadas de Eguzkilore y Jóvenes Solidarios, se verán probablemente enfrentados a entornos domésticos muy alejados de las necesidades de este tipo de agrupaciones. Pero este desencuentro es en definitiva una de las piezas clave que llevan a plantear que, más allá de casos específicos como los dos citados, la estrategia de agrupación de unidades de convivencia diversas para el acceso a la vivienda debe incorporar por definición la transformación espacial de esta. Por último, la vía de desarrollar proyectos tomando un edificio, o una parte sustancial del mismo, como soporte elemental presenta un potencial ya mencionado. Sin embargo, la escasa oferta ya apuntada de este tipo de inmuebles en el AMB lleva a que cobre mayor relevancia la estrategia de transformar las viviendas dispersas por el parque para alojar a grupos de unidades de convivencia. Como se ha visto, una parte muy importante del parque residencial del AMB puede satisfacer las necesidades espaciales de dos y tres personas a un precio digno, y otra parte nada despreciable cuenta con viviendas actuales de grandes superficies con una difícil salida en el mercado libre. Es decir, todas estas viviendas pueden ser reformadas para ser segregadas, o para disponer de diferentes niveles de privacidad e intimidad, y alojar a unidades de convivencia pequeñas con posibilidad de compartir ciertos espacios y/o equipamientos.

En cualquiera de los casos, estas tres categorías en las que puede clasificarse el soporte elemental utilizado por los agentes analizados confirman la existencia de un planteamiento predominante. Este reafirma la carencia de una lectura crítica del parque existente y de un análisis profundo de la necesidad de vivienda. Una cuestión preocupante de este desfase y desajuste entre unidades de convivencia y tipologías de viviendas es que, a pesar de ser una realidad considerablemente extendida entre colectivos de muy diferente perfil y renta, y de venir prolongándose y evolucionando a lo largo de varios años, no parece generar un debate visible ni reflexiones en torno a ello, ni mucho menos una demanda concreta palpable de otro tipo de soportes habitacionales ${ }^{98}$. Parece asumirse de manera resignada como una situación temporal que se sufre y de la que se pretende salir, con el objetivo común e inamovible de acceder, algún día, a una vivienda -como si solo hubiese un solo tipo de vivienda-, sin tener que compartirla con otras unidades de convivencia y que cumpla con el ideal imaginado de la vivienda adecuada. El desconocimiento del potencial de agruparse puede entenderse como una de las razones

\footnotetext{
98 En este sentido hay espacio para cierta esperanza pues, como se ha mencionado anteriormente, el proyecto de Decreto que regula las condiciones mínimas de habitabilidad en Euskadi parece que incorpora este tipo de reflexiones.
} 
para que no se estén aprovechando los espacios de oportunidad mediante la estrategia aquí planteada.

\section{$-5.1 .3-$ \\ Tipología de vivienda ofertada}

Cada iniciativa de gestión estudiada ayuda, en mayor o menor medida y a través de su participación en el proceso de acceso a la vivienda, a la formalización o el mantenimiento de un soporte residencial concreto. En el marco de la estrategia de agrupación de unidades de convivencia, y debido al desfase generalizado entre la tipología residencial predominante y las necesidades cambiantes de un abanico de unidades en evolución respecto a la idea de familia convencional que ya no es mayoritaria, se estudia la manera en que se aborda esta cuestión para ver el nivel al que las posibles agrupaciones pueden ver satisfechas sus necesidades habitacionales. La distinción principal detectada en esta variable se centra en si la iniciativa se limita a mantener un modelo tipológico en gran medida obsoleto, forzando la adaptación delas unidades de convivencia a unos espacios domésticos diseñados para otros perfiles, o si por el contrario abre puertas - $O$ intenta hacerlo- a fórmulas para que sea el soporte construido el que se adapte a las necesidades cambiantes de una población con una necesidad de vivienda distinta de la del público objetivo para el que se diseñó gran parte del parque analizado.

\section{Mantenimiento y baja alteración de las tipologías existentes}

$\mathrm{El} \mathrm{AMB}$ es una región cuyo suelo potencialmente urbanizable en gran medida ya es de facto urbano - no en términos de clasificación urbanística, pero sí geográficos-. Las áreas para la expansión y/o creación de nueva ciudad residencial son pocas y reducidas. Lo cual, sumado a una calidad y estado de conservación bajos de parte de la ciudad residencial existente lleva a que la prioridad sea la intervención en la misma, a través de operaciones de regeneración, renovación y rehabilitación. Como ya se ha mencionado, las políticas públicas ya están trabajando en esa dirección con cierto éxito, aunque también con múltiples exclusiones socio-espaciales. Y en ese marco, muchos de los agentes de gestión de la vivienda analizados orientan sus esfuerzos y su trabajo precisamente al parque residencial existente. Sin embargo, frente a la obra nueva, adaptar espacialmente el mismo supone una mayor complejidad puesto que a los condicionantes propios de la primera -que se citan más abajo- se suman otros con importante afecciones negativas. 
A pesar de que el ratio precio/superficie de una vivienda de segunda mano es generalmente inferior a la obra nueva, una supuesta transformación y adaptación de esta en los términos en los que aquí se plantea supone una carga adicional de costes añadidos considerable. Por otro lado, se darán en ocasiones también otro tipo de limitaciones. Estas pueden ser normativas, condicionando la segregación o la unión de propiedades, la apertura de huecos en fachada, o el incremento de edificabilidad, entre otras. Pero también pueden ser espaciales, como la disposición de la estructura portante preexistente, la distribución de las instalaciones, o la propia forma de la vivienda. En este sentido, Paricio y Sust propusieron a modo de idea-fuerza una oportuna y aclaratoria clasificación de las viviendas según su forma. Diferenciando por un lado la vivienda-caja, «una envoltura protectora indiferenciada en la que se puede disponer una gran cantidad de objetos $[\ldots]$ si tiene compartimentos serán jerarquizaciones del espacio interior, sin demasiada especificidad y siempre la forma general será mucho más importante que el dibujo de las divisiones interiores, que, en muchos casos, se podrán alterar o eliminar» (Paricio y Sust, 2000: 77). En ella se sintetizan conceptos como la atención al diseño de la unidad de la propia vivienda, la importancia de la percepción del espacio global interior, las ventajas de la indiferenciación del perímetro exterior, la cuidadosa consideración de las proporciones entre los lados de la caja, fachada y profundidad edificable, las posibilidades de la localización periférica de los elementos comunes, o las perspectivas de ciertas previsiones sobre las modificaciones de la compartimentación (Imagen 5.1). Frente a esta, identificaban la vivienda actual predominante como una vivienda-estuche (Imagen 5.2), "una envoltura protectora que se adecua exactamente a las formas del objeto protegido [...] nuestras viviendas no sólo contienen una única forma de ocupación, sino que la evidencian en la misma fachada [...] cristalizadas por unas separaciones amovibles que definen espacios pensados para un uso concreto, y por la presencia de estructuras e instalaciones que dificultan la inserción de un uso imprevisto» (Paricio y Sust, 2000: 77).

A todo lo cual, se añaden otras afecciones propias del régimen de alquiler. La hoy en día escasa tradición y arraigo de este tipo de régimen de tenencia es rígida y basada en la precarización de la vida doméstica de la parte arrendataria. Habitualmente, se ha de habitar con el mobiliario y la decoración que la propiedad de la vivienda mantiene en la misma, la sustitución y/o retirada del mismo requiere importantes esfuerzos de negociación, y no cabe casi plantear por la parte arrendataria la realización de una obra de modificación de la distribución espacial. A esto se suma una extendida incertidumbre económica, laboral y personal que hacen de estas viviendas en régimen de alquiler lugares más o menos temporales, tanto para las unidades de convivencia que las ocupan como para la propiedad que las arrienda -como puede ser el caso del programa de Jóvenes Solidarios implantado en viviendas municipales del Ayuntamiento de Bilbao, cuyo fin último probablemente sea el alojar a familias que
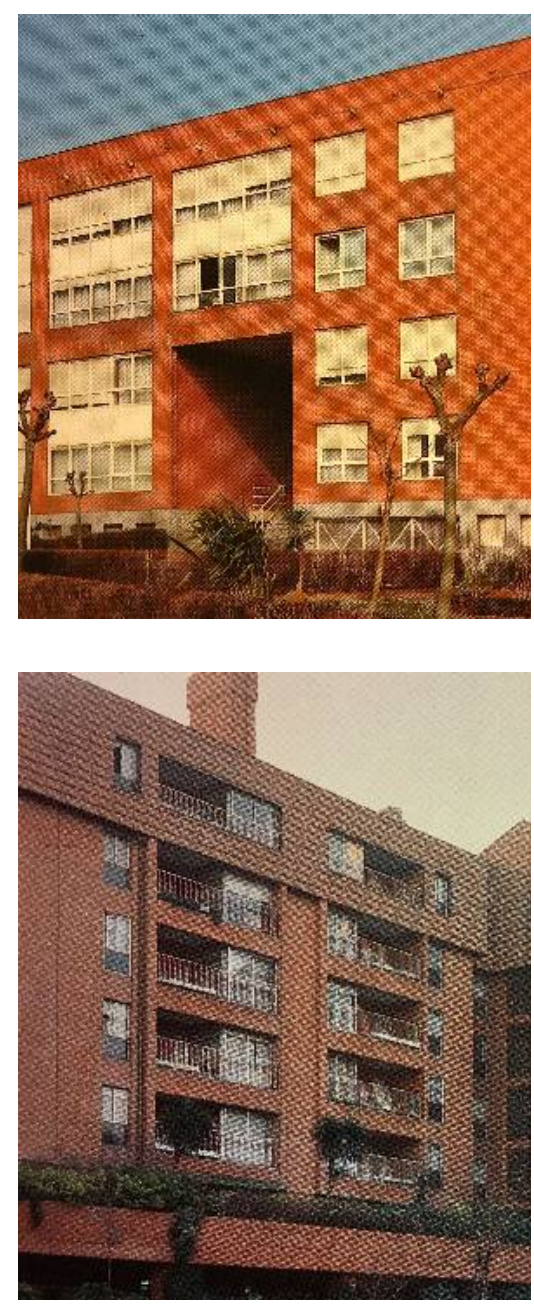

Imágenes 5.1 y 5.2. Ejemplo de edificios de vivienda colectiva en el AMB (Sopela y Getxo, respectivamente) que encajan con la categoría de vivienda-caja (arriba) y vivienda-estuche (abajo) de Paricio y Sust. A pesar de no contar con información de la planta, la fachada puede ser buen reflejo, como señalan los autores, de sendas categorías. Mas Serra y Brea Ruiz, 1990. 


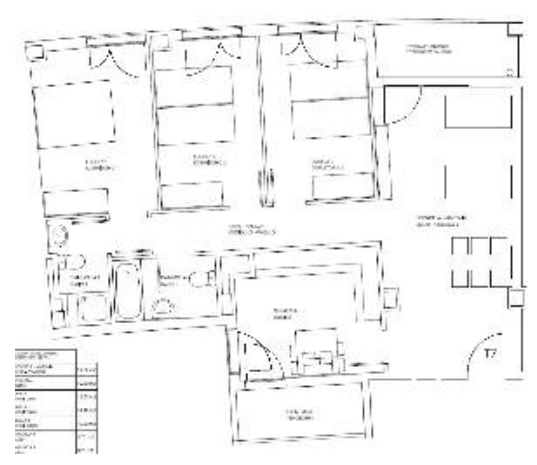

conforman una sola unidad-. Así, los esfuerzos económicos y de gestión a destinar para la posible transformación de estas viviendas se miden con cautela, al no saber el destino de las mismas a corto plazo.

Por todo ello, cuando una unidad de convivencia ocupa una vivienda se enfrenta a un espacio en el que, por todos esos motivos culturales, económicos y espaciales, en aquellas ocasiones en las que se interviene y altera se hace de una manera limitada. Muchas serán intervenciones superficiales y pequeñas alteraciones centradas en la renovación de acabados o de equipamientos de la vivienda eliminación de particiones a lo sumo-, que no cambian en lo fundamental las características conservadoras y jerarquizadas. Lo harán sin una reflexión profunda en torno a si existen necesidades y/o usos domésticos no cubiertos, manteniendo de esta manera y dando continuidad a un 'monocultivo' tipológico. Se trata, en definitiva, de un círculo que se alimenta y reproduce de generación en generación. En la medida en que es esta vivienda-estuche el tipo mayoritario existente, es aquella que se conoce -eliminando del abanico de opciones por lo tanto las soluciones espaciales no conocidas-, conformando así el imaginario colectivo de la vivienda a la que se desea acceder, y en definitiva, la que se acaba habitando con mayor o menor esfuerzo en el intento.

\section{Reproducción de una tipología conservadora y jerarquizada}

Es posible encontrar este tipo de modelo en aquellas promociones de obra nueva, tanto las realizadas por Visesa y Alokabide a través de las cuales se amplía el parque de vivienda protegida vasco, como en las soluciones planteadas desde la promoción privada de vivienda libre más reciente Pero también, en operaciones de rehabilitación integral de edificios en los que la escala de intervención es profunda y las nuevas viviendas planteadas parten de una planta considerablemente nueva, salvo los principales elementos estructurales, o en intervenciones puntuales de reforma integral de viviendas, con condiciones similares. Bajo una tradición cultural y un marco normativo fuertemente condicionantes -ya desarrollados en el capítulo segundo-, se sigue en muchos casos generando una vivienda con una estructura distributiva muy concreta. Un esquema base formado por un hall y un espacio de distribución variable que conducen a una cocina, una sala de estar y comedor, dos o tres dormitorios, uno o dos baños - uno de ellos dentro de un dormitorio en el segundo caso- y un tendedero, que varía exclusivamente en términos de superficie útil total y número de dormitorios, respondiendo de manera simplista a una clasificación de las unidades de convivencia demandantes basada en el número de personas que lo forman (Imágenes 5.3 a 5.8).

Por supuesto, no todas las promociones públicas ni privadas responden perfectamente a este planteamiento. A pesar de todo, 
algunas intervenciones sobre lo existente probablemente planteen ciertas transformaciones más profundas tras un proceso consciente de análisis de las necesidades habitacionales y del reflejo espacial que están deberían o podrían llegar a tomar; pero a un coste considerable requerido por una reforma integral de la vivienda. En algunos casos de obra nueva, se observa la introducción de planteamientos orientados hacia una menor jerarquización y mayor versatilidad de algunas estancias, con dos baños en zonas comunes, así como una localización de la estructura y las zonas húmedas considerablemente ordenada y racional liberando el resto de la vivienda de dichos condicionantes (Imágenes 5.9 y 5.10).
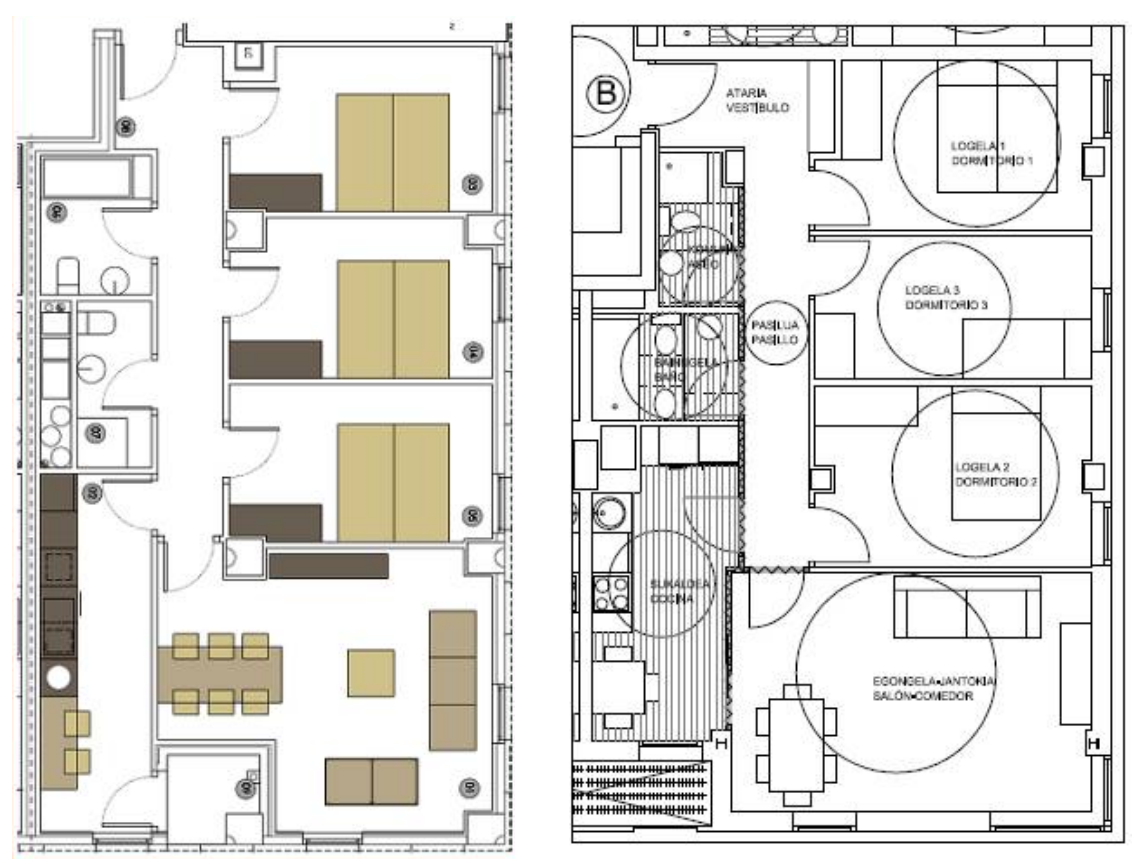

Como se ha venido insistiendo, una buena parte del parque residencial actual presenta un desfase y una obsolescencia espacial para satisfacer con calidad las necesidades habitacionales de muchas unidades de convivencia. Esto está parcialmente justificado por la propia antigüedad de esas viviendas. Muchas fueron diseñadas y construidas en otra época, y para otros perfiles de personas. Algunos estudios centrados en casos concretos, como por ejemplo los polígonos residenciales construidos en España entre 1950 1976, evidencian que el «perfil de la persona actualmente demandante de vivienda no tiene nada que ver con aquel grupo humano, lo que apunta la importante cuota de responsabilidad que las tipologías arquitectónicas tienen en la actual obsolescencia de los polígonos», detectando «desencuentros existentes entre las viviendas de los polígonos y las necesidades contemporáneas» en ámbitos relacionados con la dimensión, la funcionalidad, los cambios culturales y las formas de vida (García-Vázquez, 2015: 5). Las bases de esta estructura tipológica, asentadas a mediados del siglo pasado, no han
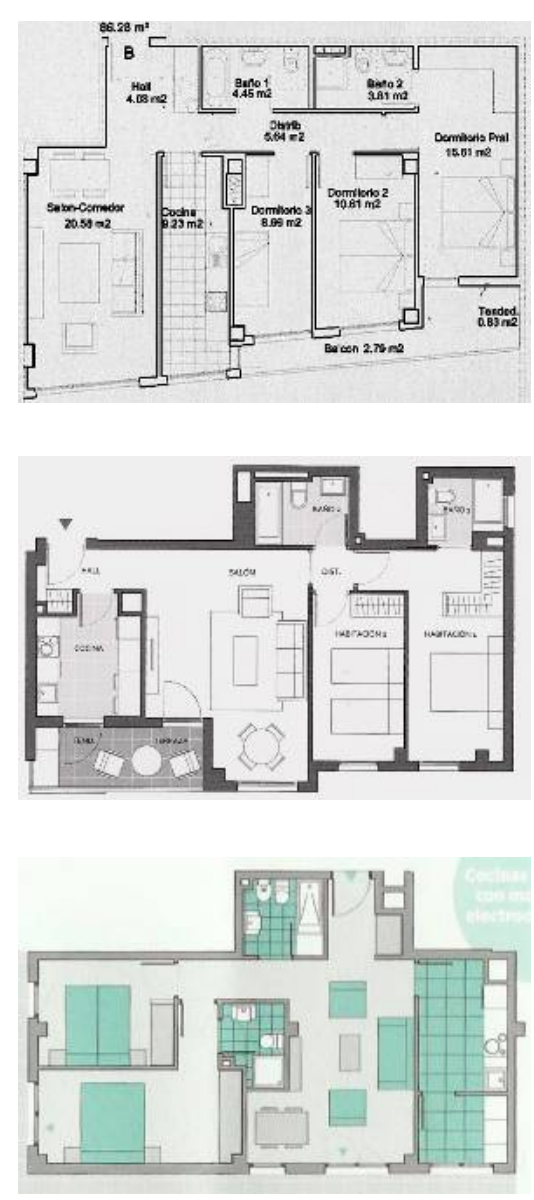

Imágenes 5.6, 5.7 y 5.8 (arriba). Ejemplos de promociones de vivienda libre recientes o en marcha en el AMB, en Erandio y Bilbao. Obtenidos de diversos folletos publicitarios en 2017.

Imágenes 5.9 y 5.10 (izquierda). Ejemplos de promociones de vivienda protegida recientes o en marcha en el AMB en Barakaldo, Bilbao y Sondika. Visesa, 2018. 
acompañado a las evoluciones sociales y familiares de la sociedad. De esta manera, se sigue hoy en día reproduciendo dicho modelo, añadiendo nuevas viviendas con una tipología ya desfasada desde origen; forzando a familias de hábitos y formas de vida nuevas a vivir en viviendas de protección oficial con planteamiento viejos (Etxabe, 2010).

\section{Diseño adaptado y adecuado a las necesidades}

Frente a las dos maneras anteriores de afrontar el tipo de hábitat residencial, hay otra en la que el punto de partida es claramente opuesto a estas: la percepción de que la oferta generalizada actual no responde a unas necesidades concretas. Necesidades que pueden limitarse a una escala puramente doméstica, relativa a una única unidad convivencial, o abarcar a toda una comunidad de unidades diferentes, incorporando cuestiones relativas a los espacios comunes, elementos, equipamientos y usos compartidos, las relaciones personales, o los cuidados. Esta forma de abordar la cuestión puede surgir y nacer de la propia autopromoción de vivienda -en casos como Etxekoop-, o pueden ofertarse como asesoramiento externo para el desarrollo de cooperativas -como lo hacía Urbania ZH Gestión con Egunsentia Aurora-. En cualquier caso, la iniciativa no nace siempre de los propias unidades de convicencia que van a habitar las viviendas. En el caso de Etikalia, el servicio que ofrecen en colaboración con la oficina técnica externa se plantea como un elemento diferencial de la competencia y un valor añadido para la posible clientela. En este caso, es a través de estos agentes que se plantea la posibilidad de adaptar y transformar las viviendas en función de las necesidades programáticas y formas de habitar de las unidades de convivencia contactadas.

La evolución de los tipos y estructuras de estas, y algunas de las posibles y diversas características y situaciones que generan necesidades habitacionales no cubiertas por el parque residencial actual, han sido ya comentadas en apartados previos. Algunas de estas se reflejan en experiencias analizadas en el capítulo anterior: la convivencia temporal de personas en proceso de salida de situaciones de exclusión social -Eguzkilore-, la convivencia de jóvenes estudiantes -Jóvenes Solidarios-, colectivos de mayores con deseos de organizar una comunidad de cuidados y convivencia -Egunsentia Aurora-, o agrupaciones heterogéneas de unidades de convivencia de diferente perfil y tamaño con intención de formar una cooperativa vecinal -Etxekoop-. A estas posibilidades se han de sumar muchas otras: jóvenes adultos con deseo de compartir algunos espacios domésticos, pero complementados con zonas privadas y con el desarrollo de una actividad profesional en la vivienda; familias desestructuradas y/o reubicadas; o migrantes con bajos recursos en situaciones complejas de integración local y con necesidad de una red de apoyo cercana, por citar algunas. En general, lo habitual y frecuente es que todos estos casos se vean obligados a vivir en un 
espacio diseñado para una familia nuclear con una, dos o tres personas menores a su cargo.

Pero las posibles respuestas que desde la arquitectura pueden darse a estas situaciones son también diversas. $\mathrm{Y}$ el nivel potencial de especificidad es alto. Este puede tomar forma en el diseño de viviendas con perspectiva de género, como ya plantearon en los siglos XIX y XX diversas mujeres -imaginando la reorganización del trabajo doméstico, la equiparación de tareas, la generación de espacios comunes para el trabajo compartido, la remuneración de las tareas domésticas o el cuidado socializado (Madden y Marcuse, 2018: 129)-, y como el caso de las viviendas sociales de Frauen-Werk-Stadten Viena (Imagen 5.11). Se trata de un grupo de edificios residenciales desarrollados siguiendo los planteamientos de la Oficina de la Mujer de Viena. Además de importantes medidas de diseño para dotar de una seguridad perceptible y real en los espacios exteriores y de transición, se dotó al proyecto de una gran diversidad de tipologías, y «las viviendas atienden a los requerimientos de la igualdad de géneros (desjerarquización, espacio de almacenaje, cocinas para el trabajo de varias personas, vistas directas del espacio público, etc) y de la flexibilidad (para adaptar las viviendas a diferentes fases de la vida y estructuras familiares) [...] son una lección de planta libre y flexible» (Montaner, 2015: 183).

Las respuestas pueden también estar destinadas a un colectivo de jóvenes en búsqueda de viviendas en alquiler; unidades de convivencia unipersonales o formadas por dos personas con ninguna necesidad de contar con dos baños duplicados, o tres habitaciones jerarquizadas. Tal es el caso de unas viviendas promovidas por el Ayuntamiento de Mataró, en las que a partir del sistema de soportes de Habraken se dispone una franja central de usos fijos húmedos con cocina y baño, con dos franjas laterales más libres y poco concretas (Imagen 5.12). En cuanto a aquellas agrupaciones de carácter temporal formadas por varias unidades de convivencia de reducido tamaño, aún cuando se vean forzadas a habitar y compartir una vivienda planteada siguiendo un programa relativamente habitual, esta puede facilitar mucho la convivencia si está planteada de una manera no jerarquizada. Lo cual puede alcanzarse de diversas maneras. Bien con unas estancias de similares proporciones, localizando las zonas de aseo y baño en las zonas comunes de paso y favoreciendo diferentes opciones de comunicación y recorrido (Imagen 5.13), o bien dotando a unas estancias de iguales características de zonas de baño y dimensiones generosas para la vida íntima, complementadas con una franja de uso colectivo para la convivencia en común (Imagen 5.14). En definitiva, las posibilidades son múltiples, sin olvidar muchas otras no citadas que rompen con el programa de estancias común, como la tipología de vivienda sin cocina colectivizando esta función en espacios comunes. Más allá de los habituales clichés que asocian este tipo de tipología con políticas socialistas y comunistas, existen hoy en día propuestas muy variadas que la desarrollan (Puigjaner, 2018).
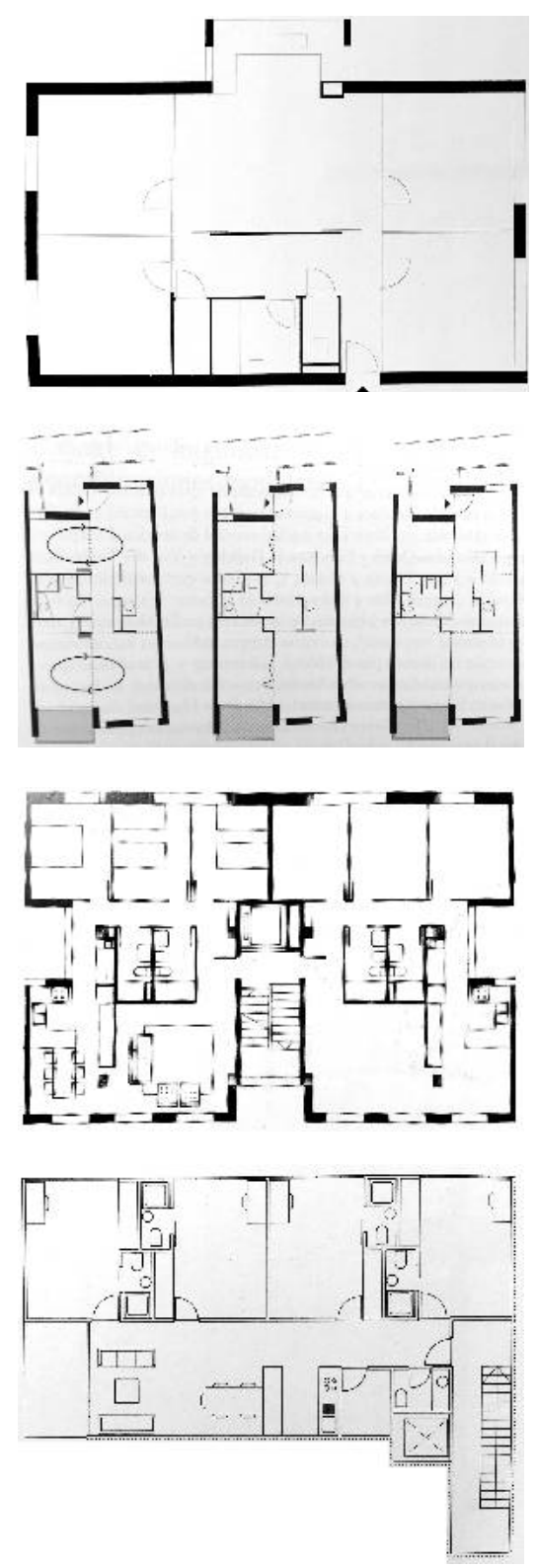

Imágenes 5.11 a 5.14. De arriba abajo, algunos de los tipos de vivienda planteados en el grupo Frauen-Werk-Stadten, Viena (Montaner et al., 2011), vivienda tipo del edificio de viviendas en alquiler en Mataró (Montaner et al., 2011), planta tipo de edifico de viviendas en Gavà, Barcelona (Paricio y Sust, 2000), y una de las tipologías presente en un edificio de viviendas para jóvenes y mayores en Sevilla (Lleó, 2006). 


\section{Conclusiones y estrategias de mejora}

Ha quedado comprobado el predominio de una estructura de la propiedad altamente dispersa y atomizada, y la arraigada idea de hacer corresponder a cada vivienda existente -como soporte elementaluna única unidad de convivencia. Esto lleva a que la tipología de vivienda más habitualmente ofertada, y así ocurre con los agentes en este trabajo estudiados, suponga el mantenimiento -con simbólicas alteraciones no sustanciales- de las tipologías predominantes en el parque residencial del AMB. La superficialidad de las transformaciones habituales probablemente no se deba tanto a las limitaciones propias de los inmuebles, como a la falta de demanda de intervenciones más profundas. En definitiva, a la falta de conocimiento de que la vivienda más frecuente no es ni la única posible, ni en muchos casos la que mejor se adapta a cada unidad de convivencia. Dado que el objeto de estudio se limita al parque existente ya edificado, la lectura del encaje de esta variable se limita a aquellas operaciones de rehabilitación e intervención profunda en inmuebles existentes, en los que las viviendas planteadas parten de unas posibilidades espaciales amplias. Dejando fuera de este análisis, por lo tanto, a las promociones de obra nueva.

Así, incluso en las intervenciones que se están dando en el AMB limitadas a una vivienda y en las que participan profesionales de la arquitectura que podrían favorecer una lectura crítica de la situación y un ejercicio divulgativo de otras soluciones para el hábitat doméstico, aún abordando una reforma integral de la misma son en general planteadas dentro del esquema anterior, reproduciendo en mayor o menor medida la tipología habitual. No aprovechan la oportunidad histórica que supondría la toma de conciencia, por parte de la población que ya está realizando importantes esfuerzos y desembolsos económicos para renovar un parque envejecido y aprovechando el favorable contexto de las políticas públicas en favor de la rehabilitación y renovación de la ciudad residencial, para adaptar esta a un futuro $-\mathrm{y}$ un presente- que requiere de otras respuestas habitacionales a precios asequibles. Estas intervenciones que solo afectan a una única vivienda cuentan con importantes limitaciones espaciales que van más allá de las categorías de vivienda-caja y vivienda-estuche citadas. Como la obligada disposición de las zonas húmedas cerca de las bajantes y patinillos de instalaciones, las afecciones propias de la forma de las particiones que limitan dicha vivienda con sus colindantes, o la obligatoriedad de mantener el punto de entrada actual, entre otras. Limitaciones que superan el ámbito espacial, pues también suponen, por ejemplo, un mayor gasto en sistemas de aislamiento térmico al colocar este en suelos y techos, lo cual además duplica el mismo en caso de que las viviendas superiores o inferiores cometan trabajos de este tipo. Algo habitual en edificios de cierta antigüedad con eficiencia energética baja, en los que se viene desde hace años dando un goteo intermitente de reformas integrales de viviendas dado el mal estado de conservación de las 
mismas, como puede ser el caso del Casco Viejo, San Francisco y Bilbao La Vieja en Bilbao.

En lo que respecta a las actuaciones que engloban todo el edificio, en general este tipo de viviendas generadas no suelen aprovechar la gran oportunidad que supone actuar en el parque existente a tal escala. Cuando la intervención alcanza todo el edifico, muchos de los condicionantes apuntados para las intervenciones puntuales en viviendas quedan eliminados o muy debilitados, y las posibilidades de alterar las disposiciones de los diferentes espacios y usos de las viviendas aumentan considerablemente. Sin embargo, al igual que ocurre en las promociones de obra nueva, en muchos casos las tipologías buscadas y generadas siguen las pautas ya comentadas. Con todo, en ocasiones son precisamente los condicionantes propios del edificio -como el tamaño y forma de la parcela, la disposición y características de los edificios colindantes, la forma de la envolvente del edificio, el sistema y la disposición estructural,...- los que llevan a que las tipologías convencionales buscadas por parte de la promoción se alteren en mayor o menor medida. $O$ incluso se sepa leer la situación como una oportunidad para generar otras disposiciones espaciales que saquen mayor provecho al espacio, y consecuentemente sean más atractivos para cierto tipo de unidades de convivencia. Por otro lado, se dan entre las experiencias analizadas algunas que son conscientes de los conflictos existentes, de la falta de respuestas espaciales a precios asequibles ofrecidas por el mercado libre y el sistema de vivienda protegida. Lo cual les lleva a plantear, o al menos buscar conscientemente, un diseño adaptado y adecuado a las necesidades previstas de las unidades de convivencia. Presentan así un enfoque muy apropiado para aprovechar la oportunidad que se plantea al intervenir en el parque actual. Existe una predisposición, una sintonía y una apertura de mente que puede facilitar la comprensión del potencial de la estrategia de agrupación aquí planteada para responder a sus intereses.

En este contexto, los importantes esfuerzos desarrollados por las administraciones vascas de escala autonómica, provincial y local para satisfacer la necesidad de vivienda puede decirse que no están orientando los recursos económicos públicos de la manera más adecuada. Resulta por tanto recomendable reconducir los criterios de diseño y formalización del parque de vivienda protegida y libre. Con más urgencia si cabe, dado que muy acertadamente las políticas públicas de vivienda de Euskadi se han orientado con decidida energía hacia el alquiler como principal régimen de tenencia a ofertar. Ya que las unidades de convivencia a las que se adjudica una vivienda protegida -sea de propiedad pública, o privada bajo gestión públicapasan por la misma a modo de transición hacia una situación en la que puedan demandar una vivienda en el mercado libre -con las dificultades y retos que ello implica-. Así, a lo largo de la vida útil de este parque de alquiler, la diversidad de unidades de convivencia con sus respectivas necesidades espaciales que pueden pasar por él es 
considerable. Lo cual conlleva a la necesidad de plantear tipologías con una mayor flexibilidad y versatilidad, pero no necesariamente mediante elementos móviles de alto coste. La compartimentación ambigua de las piezas de la vivienda, y una polivalencia de usos sin necesidad de transformar los espacios que la conforman ha sido una estrategia habitualmente adoptada en la historia reciente de la arquitectura residencial (Paricio y Sust, 2000: 25).

En definitiva, se vuelve a confirmar que la estrategia planteada de agrupación de unidades de convivencia para el acceso a la vivienda lleva implícita por definición -debido a las características del parque y de muchas de esas unidades con necesidad de vivienda- la adaptación del mismo a las diversas realidades de dichas unidades. Pero hay, tal y como se ha desarrollado en el trabajo, poderosas inercias y obstáculos -muchos de ellos internos- de diversa naturaleza muy difíciles de combatir que requieren probablemente cambios normativos, pero sobre todo un importante trabajo divulgativo e incentivador. Este debería alcanzar todo tipo de esferas, apuntando tanto a las instituciones públicas como a empresas de la construcción, a agentes inmobiliarios como al colectivo de personas con necesidad de vivienda, a agentes del tercer sector $\mathrm{y}$ a inversores de diversa escala. $\mathrm{Y}$ sin infravalorar el potencial de introducir en estos conocimientos a un público heterogéneo en edad y condición ${ }^{99}$.

\section{- 5.1.4 - \\ Modo de participación en el proceso}

El sistema de agentes que participan en el complejo proceso para acceder a dicho soporte edificado, sea cual sea la escala y el tamaño de la estructura de la propiedad, es diverso y puede ser complementario. $\mathrm{Y}$ juega diferentes papeles en el mismo. Las posibles fórmulas para llevar a cabo el acceso a la vivienda pueden variar en función de la naturaleza del agente en cuestión. Dependiendo de si este es parte del sistema vasco de vivienda, es un ente privado empresarial, religioso o de otro tipo, o se trata de un grupo de la sociedad civil; de si su objetivo es cubrir uno de los pilares de un sistema público a priori orientado al cubrimiento del estado del bienestar, si desarrolla su labor con ánimo de lucro, con fines sociales, o ambos, o si simplemente lo que busca es auto-abastecerse del derecho a una vivienda digna; los caminos elegidos y a la vez condicionados serán múltiples. Entre los presentes en los casos analizados en el capítulo previo, las principales fórmulas se pueden clasificar en la promoción

99 Tal es el caso del proyecto Familia Milakolore (Familia Multicolor) del trío de payasos Pirritx, Porrotx eta Marimotots, que busca desde el humor educar al colectivo infantil en la diversidad de las familias y de las personas, trabajando temas como la transexualidad infantil, las familias monoparentales, la adopción, o la muerte. 
propia, la adquisición, el alquiler u otro modo de subarriendo, la gestión de parques de terceros, la participación en las fases iniciales del proceso, e incluso hay casos en los que su aporte en este sentido es la mera subvención o ayuda económica sin participar en el proceso de gestión del inmueble.

\section{Promoción propia}

En la medida en que una de las características del objeto de estudio ya ha quedado definida al inicio del trabajo como la vivienda colectiva, la promoción de esta implica forzosamente una estructura y una escala de la propiedad grandes. Esto supone, entre otras cosas, tres cuestiones de interés de cara al análisis que aquí se está realizando. En primer lugar, por pequeña que esta sea, una promoción de vivienda colectiva necesita de una serie de medios y recursos a los que habitualmente no es fácil de acceder. Como se ha visto, la falta de recursos económicos es una de las grandes debilidades transversales a muchas de las experiencias analizadas. Ya sea por limitaciones en la distribución de los presupuestos públicos, la baja disponibilidad de rentas, o la necesidad de ofrecer un proyecto serio y viable para ganarse la confianza de las instituciones financieras. No obstante, la frecuencia con que los obstáculos económicos limitan o incluso anulan proyectos desde su inicio no implica que no haya otro tipo de recursos necesarios e imprescindibles para llevar a cabo una promoción completa con éxito. Como se ha visto en el caso del co-housing senior de Housekide, una de las razones para su disolución sin haber logrado formalizar su proyecto fue su limitación como grupo. La organización y la gestión de un proyecto así, sobre todo cuando este nace de una agrupación civil ajena al sector inmobiliario, urbanístico y/o arquitectónico, requiere de ciertas capacidades, conocimientos, tiempos y actitudes.

En segundo lugar, la promoción propia de vivienda colectiva es, entre las encontradas en los casos analizados, la fórmula con más posibilidades para abrirse a otras configuraciones espaciales. El control directo o indirecto de la totalidad del inmueble, así como de su proceso de diseño y construcción, es de facto un potencial control de la planificación de todas sus viviendas, de sus espacios comunes, y de grandes afecciones y condicionantes como el diseño y distribución de la estructura portante o las instalaciones. Aunque, como se ha visto, la realidad de las promociones recientes suele estar lejos de aprovechar esta oportunidad para ofrecer soluciones espaciales diferentes -se ha visto especialmente en el caso de Visesa, cuya principal actividad se ha centrado en la promoción propia-. El potencial y las ventajas de llevar a cabo esta manera más abierta y participativa de abordar el proyecto en promociones de obra nueva o en grandes rehabilitaciones integrales-, comparado con actuar sobre el parque existente de manera puntual, son muy destacables. En tercer lugar, ese control es precisamente lo que abre la puerta también a la posibilidad de ofrecer una serie muy diversa de características 
complementarias al conjunto del inmueble, y por lo tanto a sus habitantes. Ya sea para su propio uso o porque se desarrolla el proyecto para otras personas, contar con estas en el proceso desde el inicio ha demostrado ser un instrumento eficaz para enriquecer el resultado final. Estos complementos poco comunes en las promociones habituales pueden tomar forma, por ejemplo, en una vivienda en el ático, disponible para toda la comunidad como alojamiento para personas invitadas, o como lugar de reposo para el vecindario (Roedig Schop Architekten, 2009). Todo bajo una adecuada planificación y un reparto de tiempos a través de un calendario común -es el caso de la cooperativa mostrada en las Imágenes 4.3, 4.4, 4.5 y 4.6-. Como se ha apuntado previamente, una correcta organización y convivencia es indispensable para este tipo de opciones.

Aunque se ha hablado aquí de promociones nuevas, el fondo de la cuestión permite clasificar dentro de esta categoría aquellos proyectos que se orienten a la adquisición y la intervención de edificios existentes para su transformación integral y completa. Es decir, casos en los que la dimensión de la intervención hace que haya también un control muy grande del conjunto, de los elementos que lo conforman, y del programa de necesidades a satisfacer. Así, aunque se deban mantener ciertos condicionantes espaciales -envolvente, estructura,...- la libertad y la capacidad de redistribuir los espacios y de añadir o sustituir usos es grande. En este contexto se podrían enmarcar aquellos casos que, buscando una estructura de la propiedad grande, por diversos motivos se inclinan hacia la adquisición de grandes o medianos inmuebles. Ya sea por contar el proyecto con una serie de valores y principios alineados con la sostenibilidad de recursos para aprovechar el parque construido y enriquecer además la vida de los barrios donde se quieren ubicar -como el caso de Etxekoop-, o por no descartar esta opción debido en gran medida a una escasa oferta de suelos edificables que dificulta el desarrollo de una obra de nueva planta -en el caso de Egunsentia Aurora-. Algunos ejemplos así planteados, como numerosas cooperativas desarrolladas en las últimas décadas en Uruguay, «muestran las cualidades de la rehabilitación de edificios antiguos: el aprovechamiento de su centralidad, la capacidad de recuperar saberes constructivos tradicionales, la diversidad de viviendas que se propician y se adaptan a las distintas familias y grupos de convivencia, y la posibilidad de disfrutar de patios, espacios comunes y equipamientos singulares» (Montaner, 2015: 224). La cooperativa de viviendas y servicios Sargfabrik, en Viena, es otra prueba de ello. Lo que «se ahorra con la rehabilitación se puede invertir en la eficiencia energética, la creación de espacios comunitarios [...] se introducen jardines y huertos a nivel de suelo y en las cubiertas [...] el nivel de equipamientos y servicios compartidos es muy alto» (Montaner, 2015: 234). 


\section{Adquisición de viviendas o edificios a terceros agentes}

La primera interpretación evidente de esta otra manera de alcanzar el acceso a la vivienda es que carece de las ventajas y valores añadidos que se acaban de comentar para la promoción propia. Sin embargo, cuenta también con sus ventajas, observadas en algunos de los casos analizados. La generación de un parque propio diseñado a medida para lograr los objetivos de acceso concretos de cada experiencia, más si esta responde a unos perfiles y unas relaciones de convivencia muy concretas como puede ser en el caso de Eguzkilore, podría ser un ideal muy atractivo y deseable. Pero las limitaciones de los medios económicos disponibles y el depender en gran medida de la solidaridad externa hacen que, aunque a largo plazo el gasto económico total sea mayor, la adquisición de viviendas existentes sueltas y distribuidas por el parque sea con probabilidad la única opción viable y factible de que Eguzkilore se vaya haciendo con un parque propio que satisfaga sus necesidades con mayor o menor éxito. En cualquier caso, las razones para optar por este camino pueden ser bien diversas, como en los casos bajo un modelo de Renta Vitalicia o de Alquiler Garantizado, ya que este precisamente se basa en la adquisición de viviendas de manera individual. Así, para los agentes que deciden participar en este tipo de adquisiciones, el no contar con los valores comentados de las grandes promociones propias no supone desventaja alguna. Como ya se ha comentado, la obtención de rentabilidad económica es el objetivo principal de esas iniciativas.

Se trata de una estrategia que no solo se aborda desde el ámbito privado. El Gobierno Vasco ha sido durante años un importante promotor de vivienda protegida a través de sus sistema de vivienda. Pero desde hace ya tiempo, la intervención en el patrimonio construido ha ido paulatinamente pasando a ser una prioridad en la agenda política. Como en el resto de España, tras «la explosión de la burbuja inmobiliaria, pero no solo por esa razón, la realidad económica y financiera del país ha convertido en prioridad lo que era una necesidad, abordar con nuevos planteamientos el tratamiento de la ciudad y la edificación, promoviendo su regeneración integrada y energéticamente eficiente, impulsando un nuevo paradigma normativo» (Tejedor, 2015: 1). Pueden apuntarse dos importantes motivos. El primero es el estado del parque, especialmente el habitado por las capas sociales y los colectivos socialmente más vulnerables, en lo relativo a situaciones de infravivienda, de baja eficiencia energética, o problemas de accesibilidad física, entre otros. El segundo, las limitaciones territoriales y ambientales para continuar con la expansión urbana residencial iniciada hace más de un siglo. Un ejemplo de ello es el citado giro que dio Visesa en 2012 hacia la rehabilitación, en línea además con el Plan Director de Vivienda 2013-2016, definiendo así mismo un documento estratégico propio. Este giro en las políticas de vivienda supone entre otras opciones, por necesidad, pasar de la promoción como principal instrumento a la 
adquisición de inmuebles. Esto último se puede hacer tanto mediante la compra de grandes inmuebles -probablemente preferible- o de viviendas sueltas a lo largo del parque según surjan oportunidades para ello -a través de instrumentos y capacidades como el tanteo y retracto de viviendas protegidas en propiedad, por ejemplo-. Para ello, se ha visto que tanto Visesa como Alokabide cuentan con la capacidad de adquirir, bajo diversas formas y procedimientos, inmuebles de cualquier tipo que puedan ser destinados a los objetivos de ambas sociedades.

\section{Gestión de viviendas o edificios de terceros agentes}

Las iniciativas seleccionadas y estudiadas que trabajan este tipo de modalidad para lograr el acceso a la vivienda se diferencian, en una primera aproximación, por la línea de actividad que desarrollan. Se pueden distinguir aquellas que lo hacen con el fin último de ofrecer la gestión total del inmueble -por lo que la propiedad delega en estas toda la gestión-, de las que ofrecen un servicio más acotado y específico $-\mathrm{y}$ por lo tanto la propiedad sigue con la necesidad de atender ciertos aspectos-. Entre los primeros están, por ejemplo, la sociedad pública Alokabide, que busca destinar los inmuebles pertenecientes a otra propiedad al mismo fin que los propios: el alquiler protegido. Para ello, firma convenios y contratos para que dichas viviendas de terceros agentes pasen a englobar temporalmente el parque que gestionan, incorporando además estrategias de movilización de vivienda libre vacía. Esta gestión de inmuebles externos pasó en 2006 a ser la segunda línea de negocio de esta sociedad. Desde entonces, han gestionado viviendas pertenecientes a entidades financieras, ayuntamientos, diputaciones forales, $\mathrm{y}$ particulares - estas últimas a través de los programas Bizigune y ASAP-. También dentro de esta categoría, pero como variante de la misma línea de actividad, estaría Eguzkilore. Algunas de las viviendas que utiliza como soporte para lograr que las personas usuarias salgan de las situaciones de vulnerabilidad y exclusión social en las que están inmersas son igualmente cedidas temporalmente por diversos agentes, con diferentes contraprestaciones.

Entre las experiencias que ofrecen un servicio de gestión de viviendas no propias más limitado, está como ejemplo paradigmático Etikalia. Se trata en definitiva de un agente de la propiedad inmobiliaria (API), y como tal lo que ofrece como modelo de negocio es la gestión de los procesos de compra-venta y alquiler. Más allá de que puedan complementar los servicios habituales de una API con un seguimiento y acompañamiento postventa, la propiedad no queda tan desvinculada de la administración de su inmueble como en los casos anteriores. Pero una de las cuestiones principales, común a todos los casos, es la búsqueda de métodos diversos para lograr captar las viviendas a gestionar. La solución vendrá condicionada especialmente por el tipo de servicio ofrecido, el destino al que se pretenden orientar las mismas, y el público objetivo al que se dirigen para que este se 
interese por cederlas. En el caso de las instituciones públicas, las viviendas gestionadas a través de sociedades u otro tipo de instrumentos provienen principalmente de pequeñas propiedades particulares, de grandes empresas privadas, o de otras entidades públicas. Para lograr que las primeras se interesen en este tipo de modalidades, más allá de que deba existir una mínima sensibilización hacia la problemática del acceso a la vivienda, la contrapartida que reciban a cambio -en forma de renta mensual, de garantías, u otrasdeberá ser atractiva. Lo suficiente como para combatir la cultura extendida de comprender la vivienda como objeto de inversión económica, ya desarrollada al inicio del trabajo. Además de este reto, la naturaleza anónima y dispersa del público al que se han de dirigir los esfuerzos dificulta en gran medida los logros, debiendo invertir recursos en campañas de publicidad y divulgación.

Los motivos por los que grandes empresas -como aquellas entidades financieras que en los últimos años han ido acumulando un importante patrimonio inmobiliario surgido por causas como la ejecución de desahucios- se interesen en ceder viviendas a la gestión pública son similares, pero con matices. Se trata de una estrategia que fomenta igualmente la puesta en carga de inmuebles existentes no ocupados, y deberá existir con probabilidad una contraprestación económica a cambio. Pero en estos casos, el llamamiento desde las administraciones al desarrollo de una responsabilidad social como valor corporativo añadido puede ser una potente herramienta para lograr acuerdos. En cuanto a las viviendas cedidas entre instituciones públicas diversas, el paso previo debe ser la existencia de una buena relación y coordinación institucional. Más allá de eso, el interés en principio compartido de ofrecer soluciones habitacionales de diferente naturaleza y de dar salida a inmuebles que por una u otra razón no se están gestionando adecuadamente para su fin social, debería facilitar la colaboración para la cesión de los mismos. Tanto en este como en el anterior caso, al tratarse el público objetivo de agentes concretos y conocidos que además acumulan cantidades importantes de inmuebles, la necesidad de publicidad abierta desaparece, centrándose los esfuerzos en una negociación más acotada y dirigida.

Si el agente que busca la gestión de las viviendas de terceros es un API como Etikalia, su principal público será la propiedad particular de viviendas. Su objetivo, como parte fundamental de su modelo de negocio, será por tanto lograr transmitir a dicho público la confianza para que cedan la gestión del alquiler o venta de su inmueble, y hacerlo con una relativa rapidez, profesionalidad y capacidad de gestión. Al igual que con la movilización de vivienda vacía hacia el alquiler social, el anonimato inicial de su público hace que necesite desarrollar una publicidad abierta. Pero en el caso de una entidad privada como Eguzkilore, el abanico de posibles agentes que cedan viviendas se amplia considerablemente. Algunos siguen siendo particulares, aunque con una sensibilidad social importante que no 
buscan una contraprestación económica -y si lo hacen, esta es baja-. En el caso de que empresas privadas o instituciones públicas se interesen por la cesión a este tipo de iniciativas, el interés social es profundo por la misma razón, e igualmente en muchos casos no se buscará un intercambio económico. Esta vez la publicidad es también prescindible, ya que la naturaleza de la iniciativa hace que los convenios se consoliden con contactos más directos y puntuales.

\section{Asesoramiento y acompañamiento en la planificación e intervención}

Las posibilidades de participar en el proceso de acceso a la vivienda son por lo tanto diversas, pues se trata de un camino complejo con diferentes condicionantes, responsabilidades y retos. Así, más allá de la gestión directa de los inmuebles a través de una promoción propia, o de la adquisición o el alquiler a terceros agentes, existe un espacio de trabajo paralelo para el acompañamiento a los procesos anteriores. Especialmente interesante, en aquellos casos en los que hay una carencia de conocimiento, recursos personales o tiempo, entre otras cuestiones. Aquellos agentes que desarrollan este tipo de labor resultan un importante apoyo a la hora de lograr alcanzar las metas de algunos proyectos e iniciativas de vivienda concretas. Entre los casos analizados, se ha visto cómo Urbania ZH Gestión ofertaba servicios de asesoramiento para la formación y puesta en marcha de viviendas en régimen de cesión de uso, fomentando la creación de cooperativas bajo este régimen. Incluso se ha de recordar que existía en convenio entre esta empresa y la cooperativa senior Egunsentia Aurora para ayudar en la puesta en marcha de la misma.

Este asesoramiento abre la puerta a otras posibilidades, por un lado relativas a diferentes regímenes de tenencia, y por otro espaciales. Desde Urbania planteaban que los residentes senior «serán los que planifiquen su vivienda y espacios comunes, marcando sus necesidades y servicios» con una toma de decisiones «completamente asumida por los propios residentes» (Urbania, 2016). A una escala inferior y a través de la gestión de una estructura de la propiedad de terceros más disgregada, Etikalia oferta -a través de su colaboración con una oficina técnica de arquitectura- un servicio de asesoramiento previo a la compra de un inmueble para conocer las posibilidades y limitaciones espaciales, y los costes añadidos de posibles transformaciones. Juegan estos dos agentes aquí un papel relevante, aportando una experiencia y conocimiento en un contexto que presenta una baja diversidad en las fórmulas de acceso a la vivienda y una considerable carencia de cultura arquitectónica en cuanto a las tipologías de vivienda posibles. Por otro lado, más allá de buscar un modelo de negocio sostenible y viable económicamente, estos casos analizados muestran inquietudes y planteamientos alineados con una responsabilidad social importante, añadiendo valor a su papel asesor. 
Incorporan valores éticos y sociales, dentro de lo que podría identificarse como un tercer sector económico en expansión en el AMB. Muestra de ello es que para el cierre de contratos de compraventa o alquiler, en el caso de Etikalia, no basta con el interés por parte de ambas partes bajo la intermediación de este API. Dentro de sus criterios está el control de las rentas de la futura unidad de convivencia arrendadora o propietaria, estableciendo unos límites máximos de pago por encima de los cuales no le ofrecen inmuebles. El objetivo de esta medida es proteger a dicha unidad ante posibles situaciones de endeudamiento y consecuente vulnerabilidad y exclusión económica y residencial.

\section{Capacitación para la rehabilitación de inmuebles}

Resulta de gran interés que, de manera transversal a las diferentes modalidades de participación en el proceso de acceso a la vivienda analizadas, haya entre los casos estudiados una extendida capacitación de desarrollar actuaciones de rehabilitación de inmuebles. Especialmente, dado el estado de conservación y características físicas de gran parte del parque de viviendas -tanto su construcción como su urbanización, su accesibilidad física, su comportamiento energético,...-, la colmatación de los suelos con posibilidad de ser urbanizados, el desfase tipológico entre viviendas y unidades de convivencia y, sobre todo, la existencia de los espacios de oportunidad detectados en el capítulo tercero que podrían explotarse mediante la intervención y transformación del parque residencial. Con dos excepciones. La primera la forman las empresas aquí categorizadas como de asesoramiento y acompañamiento (Sumae Coop., Urbania ZH Gestión y Etikalia) pues, pudiendo aconsejar y ayudar, la labor de dicha rehabilitación no es competencia suya. En cualquier caso, pueden llegar a jugar un papel importante precisamente como agentes tractores que la fomenten. La segunda excepción son aquellos casos cuya finalidad es ofrecer una ayuda económica a la unidad de convivencia para destinarla a diversos gastos relacionados con la vivienda. Los programas públicos AES y PCV orientados especial, o exclusivamente, a destinar una ayuda económica a aquellas unidades de convivencia en diversas situaciones de vulnerabilidad tienen en general poca interferencia con cuestiones aquí tratadas, ya sean tipológicas, de régimen de tenencia, o de ayuda en la gestión a través de un asesoramiento, entre otras. Al tratarse como alguna de ellas se autodenomina- de la última red de protección, conforman entre todas una herramienta que busca garantizar unos mínimos dignos en relación al derecho a una vivienda. Quizás, debido precisamente a esa naturaleza, se limitan sin más ambiciones a ese ya de por sí complejo reto.

Esta capacidad de intervención en el parque, formalizada a diversos niveles y desde diferentes perspectivas y planteamientos, se puede entender como una respuesta a las necesidades y las exigencias de un contexto construido que, a pesar de llevar años bajo diversas 
intervenciones de regeneración, cuenta todavía con muchos retos para su renovación. Un contexto al cual se han ido adaptando y han ido respondiendo las políticas públicas con competencias en urbanismo y vivienda, entre otras, y en las que encajan positivamente algunos modelos locales de gestión de la vivienda analizados. Los caminos por los que estos pueden desarrollar esta rehabilitación del parque residencial - $\mathrm{y}$ el alcance de esta- varían, en gran medida, en función de las tres categorías previamente establecidas: la promoción propia, la adquisición de inmuebles ya construidos y la gestión de inmuebles de terceros agentes.

\section{Conclusiones y estrategias de mejora}

Tanto la promoción propia como la adquisición de viviendas o edificios a terceros son dos situaciones ideales para aprovechar las oportunidades identificadas en esta investigación. Ya que de esta manera el control y la autonomía sobre el inmueble residen en la propiedad. Ya sea una promoción originada a partir de la rehabilitación integral de uno o varios edificios completos, o la reforma de una vivienda en un edificio de uso residencial colectivo, el desarrollo de estrategias como la aquí identificada está en su mano y dependerá de su conocimiento al respecto, del interés y la voluntad que esta muestre, y la disponibilidad de recursos. Todo ello, enmarcado en un contexto de afecciones normativas o culturales ya apuntadas antes, a las que se suman otras posibles dificultades añadidas. Es el caso de la necesidad de realojar a las unidades de convivencia que en el momento habiten el inmueble, ya sean estas las propietarias, por estar este arrendado -puede suceder en experiencias públicas como Visesa o Alokabide-, o por estar destinado a otros usos habitacionales más específicos -en el caso de Eguzkilore, en sus dispositivos de alojamiento de transición hacia la salida de situaciones de exclusión social-.

En cuanto a aquellos modelos orientados a la gestión de inmuebles que no sean de su propiedad, estos agentes pueden aconsejar, asesorar y animar a esta para que desarrolle trabajos de transformación y adaptación de la vivienda a las necesidades delas unidades de convivencia que vayan a habitarla -como en ocasiones hace Etikalia-, y pueden ofrecer la gestión completa de todo el proceso de intervención: el diseño y el control de las obras, garantizar respuestas económicas y jurídicas en caso de conflictos, e incluso financiar la intervención -algunos de los servicios que ofrecen Alokabide, Bizigune y ASAP-. Sin embargo, la decisión final está siempre en manos de la propiedad del inmueble. Se considera así de gran relevancia la labor de difundir desde las instituciones públicas y desde los agentes profesionales del sector algunos de los resultados de este trabajo. Ya sea con el argumento de lograr un mayor ajuste del producto inmobiliario final a la demanda diversa y cambiante -en los casos en los que se busque cierta rentabilidad para la empresa o para la clientela, como Etikalia-, de lograr una mayor movilización de la 
vivienda vacía en los programas públicos destinados a ello al ofrecer viviendas que se adaptan más a las necesidades de las personas demandantes - caso de Bizigune y ASAP, en los que dicho desajuste es una de las razones de renuncia-, de alcanzar un mayor ajuste del servicio público de vivienda a la necesidad habitacional existente destinando así con mayor eficacia recursos públicos-Alokabide-, o de ofrecer unos dispositivos habitacionales de mayor calidad espacial y por lo tanto funcional en el caso de aquellos agentes con una actividad muy específica -como Eguzkilore-. Todos estos casos lo hacen además bajo el paraguas de una mínima responsabilidad social y cierta sensibilidad hacia la problemática de la vivienda.

Por otro lado, los agentes analizados cuya actividad se acota al asesoramiento y acompañamiento, pero que ni cuentan bajo su propiedad con viviendas ni gestionan otras, juegan un papel fundamental en todo este proceso y tienen un gran potencial para poner en marcha esa estrategia de agrupación de unidades de convivencia. La razón es que mantienen una posición que facilita el fomento, la difusión y la divulgación de la misma entre el diverso público objetivo. Además, con sus servicios son capaces de suplir carencias y limitaciones que pueden existir en algunas unidades convivenciales y/o propiedades. Tanto estos agentes como los que gestionan propiedades de terceros tienen el reto de saber trasladar a la propiedad de las viviendas que gestionan, las ventajas de orientar su parque a agrupaciones de unidades de convivencia para transformar y comercializar este a un precio asequible, con el objetivo de extender el derecho a una vivienda digna y adecuada. Para lo cual pueden aprovecharse los espacios de oportunidad detectados.

En conclusión, la extendida competencia y capacidad de muchos de los agentes de acometer labores de rehabilitación de inmuebles es un gran valor añadido y un interesante potencial a explotar para fortalecer el encaje entre estos y los espacios de oportunidad. Pero los resultados aportados en el trabajo permiten afirmar que ese potencial está latente, y hay todavía necesidad de una importante labor de fomento y divulgación tanto entre agentes de gestión como entre la propiedad. Pues la intervención resulta una cuestión imprescindible para poder llevar a cabo una estrategia que, como se ha planteado, lleva implícita por definición la necesidad de acometer obras de adaptación y reforma. Es esa rehabilitación o reutilización del parque existente, un requerimiento necesario para poder aprovechar los espacios de oportunidad detectados. 


\section{Utilización de estrategias colaborativas}

La importancia de la existencia de estrategias colaborativas de diferente naturaleza en los agentes analizados radica en que la colaboración y la actuación colectiva puede ser considerada como una condición crucial para el adecuado aprovechamiento de los espacios de oportunidad identificados. Ya sea mediante la colaboración entre unidades de convivencia para adaptar una o más viviendas actuales en otras ajustadas a sus necesidades, la colaboración entre estas y algunos de los agentes para que los segundos les asesoren y acompañen, o la colaboración entre agentes - públicos y privados- para un desarrollo más exitoso de sus servicios y objetivos, se ha considerado conveniente repasar el estado actual de esta variable en el marco estudiado, así como sus afecciones, ventajas y limitaciones. Estas estrategias se pueden entender a diferentes escalas, esferas, tiempos y con diversos objetivos. Desde la creación de espacios de diálogo y comunicación entre la sociedad gestora y las personas que van a habitar las viviendas ofertadas, a la búsqueda de colaboraciones entre diferentes administraciones púbicas o entre estas y entidades del tercer sector, pasando por proyectos de autopromoción con un alto componente democrático en la toma de decisiones, o aquellas experiencias que fomentan el desarrollo de la responsabilidad social de la empresa privada o la pequeña propiedad inmobiliaria.

\section{Canales de comunicación entre promoción y habitantes}

De entre los casos analizados, estos canales se dan especialmente en el marco del sistema vasco de vivienda; son los generados y puestos en marcha por Visesa y Alokabide, y ya desarrollados en el capítulo previo. A modo de síntesis, estos pueden diferenciarse según el momento en el que se abren, lo cual implica diferentes objetivos y metodologías. En un tiempo previo a la promoción de las viviendas, dos son los grandes fines buscados. El primero, conocer las características o principales rasgos de la demanda de vivienda protegida dada de alta en el registro público correspondiente. Tal y como se ha apuntado antes, se ha partido durante años con cierto sesgo, al no considerar necesidad de vivienda a aquellas unidades de convivencia sin capacidad económica de demandarla. Pero dejando de lado dichas limitaciones, con este objeto se desarrollan desde el Gobierno Vasco -principalmente a través del Observatorio Vasco de la Vivienda- encuestas y estudios periódicos para recoger algunos datos relativos a los perfiles socio-demográficos de este colectivo heterogéneo. El segundo fin, ya en una fase más avanzada, es ir concretando esas necesidades más generales en casos concretos, a través de procesos de participación más o menos profundos 
destinados a las unidades de convivencia que están en espera de ser adjudicadas -a través de una página web-, o a los que se han adjudicado algunas viviendas protegidas $-\mathrm{a}$ través de talleres presenciales-. Estas segundas herramientas están menos desarrolladas $\mathrm{y}$ extendidas, $\mathrm{y}$ de momento se han realizado algunos experimentos piloto en contadas promociones.

Una vez adjudicadas y habitadas las viviendas, se abre un tercer canal de comunicación entre la administración, como promotora de las viviendas, y las personas que las habitan. En este momento la información que interesa recoger es la relativa al uso de los inmuebles. Se tratan cuestiones tanto propias del nivel de satisfacción con el producto final, como de la percepción general de los servicios prestados. Todo esta estructura de comunicación pasa en última instancia por, en el caso de Visesa, el Comité de Producto, que es quien tiene la responsabilidad de adaptar el mismo a las necesidades y las experiencias de usuario analizadas. Existen, no obstante, una serie de limitaciones internas ya apuntadas que reducen la capacidad de este sistema para ofrecer unas viviendas adecuadas a los tipos de unidad de convivencia demandantes. Destacan la simplificada clasificación que se hace de estas y de las viviendas, la superficialidad de algunas de las cuestiones tratadas en los canales abiertos para la participación sin cuestionar la estructura de fondo de un programa residencial anticuado-, o el momento tardío en que se abren los mismos - con las principales cuestiones ya decididas-. Así mismo, la información recogida de aquellas unidades de convivencia que ya habitan viviendas protegidas puede resultar parcial y subjetiva en la medida en que tanto la administración como la sociedad comparten la falta de cultura arquitectónica argumentada con anterioridad. A pesar de todo, el camino iniciado es positivo y esperanzador. Los esfuerzos parecen ir destinados a un progresivo avance en la materia, si bien aún se está lejos de una participación real y profunda, tanto por parte de las instituciones públicas -todavía aparentemente reticentes a perder gran parte del control de los procesos y a abrir realmente la toma de decisiones- como por parte de la sociedad civil -con carencias para recuperar la capacidad de debate y consenso, y con limitaciones de tiempo e información-.

Por otro lado, hay otra gran dificultad para lograr que estos canales abiertos, y otros futuros, alcancen con éxito el objetivo final de adecuar las viviendas a sus habitantes. Se trata de la limitación estructural de un sistema de vivienda que debe aportar soluciones habitacionales para el alojamiento de un público en gran medida anónimo y desconocido, más allá de las estadísticas y las encuestas de que se dispone. Un condicionante reforzado además por el hecho de que son viviendas destinadas a la rotación de las unidades de convivencia que las ocupan, al menos a partir de los últimos años en los que la política pública de vivienda se centra en el alquiler. De esta manera, cobra si cabe más relevancia la estrategia ya planteada de que el parque de vivienda pública en alquiler es un territorio adecuado 
para el desarrollo de tipologías versátiles, poco concretas, de distribuciones neutras y polivalentes que faciliten la apropiación y personalización del espacio doméstico por parte de cada unidad de convivencia en función de sus gustos, necesidades y situaciones cambiantes en el tiempo. Se trata de estrategias que, como se ha visto, vienen planteándose desde hace tiempo, desde el sistema de soportes de Habraken a las viviendas 'al corte' del Ecobarrio de Benquerencia, Toledo, de Carlos Arroyo y Eleonora Guidotti.

\section{Espacios y procesos de participación internos}

Las bondades de este tipo de planteamientos, en caso de alcanzar los objetivos marcados -cabe recordar el fracaso de experiencias cercanas como la cooperativa de mayores Housekide-, incluyen una mayor y mejor adecuación de los espacios a los usos y formas de vida de las personas que los van a habitar, así como el favorecer la construcción de una comunidad más conectada, con mayor preocupación por el cuidado de las personas que la forman y del inmueble que ocupan, como ha podido verse en el ejemplo de la cooperativa de Berlin, y en las inquietudes y motivaciones de los proyectos cooperativos de Etxekoop y Egunsentia Aurora. En este tipo de casos, la búsqueda de cierta calidad de vida suele trascender el espacio doméstico personal y alcanza a los espacios comunes de convivencia, al entorno social local, a la comunidad y el barrio en el que se ubique el proyecto e incluso a un entorno ambiental de mayor escala.

Sin embargo, abordar la ocupación de una vivienda desde la aceptación de este desfase frecuente entre las necesidades personales y las características espaciales, supone abordar también una serie de retos de no poca importancia. Por un lado, en aquellas situaciones en las que la escala de intervención es amplia y engloba varias unidades de convivencia dentro de uno o varios inmuebles, están las dificultades para lograr un adecuado y fructífero proceso de toma de decisiones como colectivo. Proceso en el que se deberán consensuar desde el concepto y la organización general del inmueble y la comunidad, el establecimiento de unos límites de gasto o la definición de prioridades, al reparto de los inmuebles -que puede ser temporal e ir intercambiándose en el caso de un régimen de cesión de uso-. Las experiencias de Etxekoop y Egunsentia se verán en este tipo de situaciones. Un correcto funcionamiento como grupo será por tanto indispensable para el éxito de la iniciativa. En aquellos casos en los que se trata de una sola unidad de convivencia formada por varias personas, este obstáculo se reduce, pero no desaparece pues la necesidad de consenso y puesta en común de las decisiones se mantiene entre los miembros que lo conformen.

Por otro lado, está el reto - esta vez común, sea cual sea el número de unidades de convivencia-, debido a la ya mencionada baja cultura arquitectónica en torno al conocimiento de las ricas y variadas 
posibilidades de solucionar o responder espacialmente a las necesidades de habitar; de lograr ampliar la concepción e imagen habitual de lo que es y puede ser una vivienda. En este sentido, se ha de plantear como fundamental el papel que ha de jugar la participación de agentes de perfil técnico, suficientemente capacitados y sensibilizados, para dirigir el diseño en diálogo con las unidades de convivencia promotoras y/o inquilinas (Imagen 5.15) - sean estas una sola o una agrupación de varias- quienes en última instancia serán quienes deban controlar el proceso (Turner y Fichter, 1976). El reparto del peso de las decisiones será uno de los aspectos clave para el éxito de un proceso de por sí complejo y difícil, evitando confundir un correcto proceso de diseño colaborativo con el hecho de que se hayan de decidir absolutamente todas las cuestiones de manera abierta. La búsqueda del equilibrio entre un extremo donde el personal técnico asume una posición superior de imposición tecnológica y otro donde a los futuros habitantes se les da total credibilidad será clave para una adecuada transferencia tecnológica (Romero y Mesías, 2004).

En este punto la confianza en el equipo técnico será fundamental; en la ya citada cooperativa de viviendas en Berlín, aunque se debatieron todas las decisiones con la futura comunidad, «algunas cosas las decidimos nosotros si eran demasiado complejas para ellos. Sin embargo, hay cooperativas que lo quieren decidir todo, incluso el tipo de pintura, y con ello no hacen si no complicarse la existencia. En muchos casos las conversaciones se reducían al diseño, ya que en el caso de los detalles técnicos teníamos vía libre. Los propietarios confiaban en nosotros» (Roedig Schop Architekten, 2009: 347). En este caso, el hecho de que el propio equipo de arquitectura encargado del diseño fuese a la vez parte de la comunidad vecinal facilitó la generación de dicha confianza. Se trata, en definitiva y como se ha apuntando en el marco teórico al plantear la carencia de cultura arquitectónica, de desmontar la homogénea y rígida idea de vivienda habitual existente y de «formar en los usuarios una cultura crítica sobre la casa» (Monteys y Fuertes, 2002: 9). Una formación que, sin olvidar los aspectos y las evoluciones técnicas que pueden mejorar la calidad del hábitat, se centre en las experiencias y en los modos de habitar, algo que como defienden estos autores, es posible.

\section{Convenios y alianzas externas}

En la medida en que la gestión del acceso a la vivienda es un proceso complejo en el que participan multitud de agentes de diferente naturaleza, parece inevitable que se den -con mayor o menor frecuencia, intencionalidad y éxito- colaboraciones y alianzas entre muchos de ellos. El abanico de las relaciones posibles es por lo tanto amplio y diverso. En este contexto, el análisis realizado y presentado en el capítulo previo ha permitido constatar que el nivel de desarrollo e implantación de actuaciones compartidas y estrategias de colaboración entre los agentes para avanzar hacia las metas

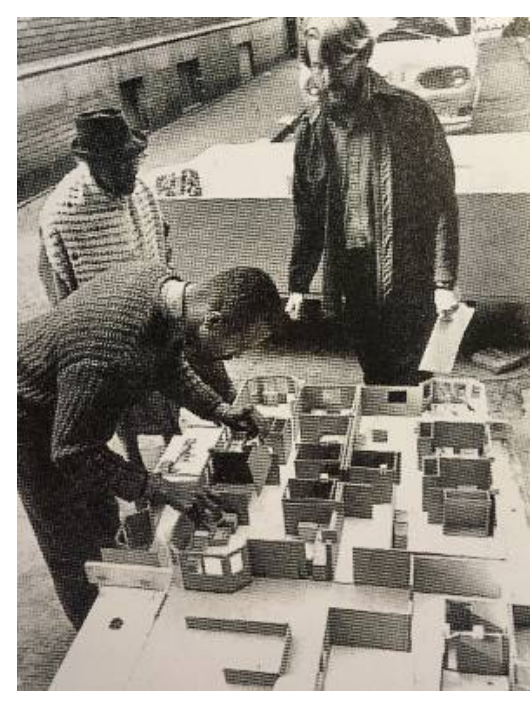

Imagen 5.15. Un integrante de un equipo técnico colabora con miembros de una asociación de inquilinos a planificar y diseñar el reacondicionamiento de sus viviendas. Turner y Fichter, 1976. 
comunes es bajo. Sin embrago, existen en el AMB algunas de estas alianzas ya en marcha. Y aunque algunas sean fruto de la normalidad y cotidianidad propia del desarrollo de la actividad por parte de estos agentes, se pretende poner en este punto un especial énfasis en esta realidad de carácter colaborativo, como ejercicio para subrayar positivamente estos fenómenos, para su puesta en valor, así como para fomentar nuevas alianzas. A modo de ejemplo, y sin perjuicio de otros posibles, se apuntan a continuación algunos ejemplos agrupados según tres categorías. En la primera están aquellos acuerdos realizados entre instituciones públicas. Es el caso de los convenios puestos en marcha entre Alokabide con diferentes ayuntamientos o gobiernos provinciales de Euskadi por los que estos ceden a la primera inmuebles de su propiedad, de forma que esta pasa a controlar su gestión orientada al alquiler social. Así mismo, se enmarcaría en esta categoría la satisfactoria relación, con varios años de recorrido ya, entre la Universidad del País Vasco/Euskal Herriko Unibertsitatea y la sociedad Viviendas Municipales de Bilbao gracias a la cual existe el programa Jóvenes Solidarios.

Una segunda categoría englobaría aquellas alianzas que combinan instituciones públicas y privadas. Aquí también se dan situaciones bien diversas. Como la identificación e intervención en unidades de convivencia en situación de vulnerabilidad y exclusión residencial desarrollada por Cáritas -a través de la fundación Eguzkilore y el programa Barriztu- junto a los servicios públicos sociales de base y la Sociedad Urbanística de Rehabilitación de Bilbao (SURBISA), entre otros agentes. Con el foco en otro tipo de situaciones de exclusión y vulnerabilidad, la sociedad pública Alokabide ha colaborado con diversos agentes privados del tercer sector. Así lo hizo con la Comisión Española de Ayuda al Refugiado (CEAR) y la Cruz Roja para la acogida de refugiados en viviendas bajo su gestión. Y con las entidades ALCER y Bizitza Berria, a las que cedió de manera temporal viviendas para destinarlas a sus actividades. Pero la colaboración en este ámbito también puede incluir actividades remuneradas, bajo unos criterios orientados tanto hacia el interés general como a la generación de empleo y/o rentas. Esto es lo que puede llegar a darse cuando un gobierno local contrata a empresas como Sumae Coop. o Urbania ZH Gestión para el desarrollo de planes de identificación, localización y movilización de vivienda vacía, o para la gestión de operaciones socio-urbanísticas. Pero si en el ámbito privado la sensibilidad hacia la problemática puede tomar forma en una responsabilidad social corporativa, también puede hacerlo en una responsabilidad social particular. Esto mismo es lo que buscan los programas públicos de movilización de vivienda vacía Bizigune y ASAP, animando a aquellas pequeñas $\mathrm{o}$ grandes propiedades a colaborar e incorporar sus inmuebles vacíos al alquiler social a precios razonables. Luchan así por debilitar las lógicas del mercado libre en búsqueda de la máxima renta de alquiler posible. 
Por último, la tercera categoría agrupa las relaciones entre agentes exclusivamente privados. Una vez más, la diversidad de posibilidades va desde la creación de convenios entre empresas de consultoría como Urbania ZH Gestión y proyectos de cooperativas como Egunsentia Aurora para acompañar y asesorar a esta en el proceso de puesta en marcha, hasta la participación de empresas de construcción con políticas de reinserción social en las intervenciones y reformas desarrolladas en el marco del programa Barriztu. Sin olvidar la búsqueda por parte de Etikalia y Eguzkilore - de manera similar a Bizigune y ASAP- de una propiedad privada con inmuebles infrautilizados y sensible a la problemática de la vivienda que opte por destinar estos, bien a un alquiler a precios dignos para la parte arrendataria, bien a utilizarlos como dispositivos de reinserción social. O la colaboración entre diferentes agentes como Etikalia y una oficina de arquitectura, con el objetivo común de ofrecer a las unidades de convivencia la mayor información posible relativa a las posibilidades de adaptación de las viviendas a sus necesidades.

\section{Conclusiones y estrategias de mejora}

El camino iniciado - principalmente con el cambio de siglo- por Visesa y Alokabide, desarrollando diferentes espacios de comunicación e intercambio de información entre el sistema vasco de vivienda protegida y la población registrada como demandante en el mismo, lleva ya varios años de recorrido. Desde la puesta en marcha del Área de Seguimiento Especial de Arrendatarios/as, a la creación de espacios web de participación y recogida de demandas tipológicas, la elaboración de experimentos de diseño colaborativo entre equipos de arquitectura y personas adjudicatarias de viviendas, o la puesta en marcha del Comité de Producto, los esfuerzos muestran un interés y una preocupación institucional por intentar alcanzar un sistema de vivienda pública que responda a las necesidades de la población con necesidad de la misma. En este sentido, los avances no son menospreciables, y el potencial de seguir mejorando estos cauces es alto siempre que se mantenga dicho interés. Sin embargo, reflejo de los condicionantes y obstáculos internos planteados en la herramienta teórica de la investigación, se ha visto que los planteamientos de fondo son todavía lejanos a los aquí presentados. El nivel de colaboración efectiva en el diseño de las políticas de vivienda por parte de la población afectada es considerablemente bajo. Su participación está condicionada por los límites del debate establecidos desde la administración pública -generalmente sin entrar en el fondo de la problemática-, el hecho de tratarse de un proceso cuya puesta en marcha depende de la iniciativa pública -de arriba a abajo-, y la calidad y cantidad de la información previa recibida -escasa, dado que hay una importante falta de conocimiento sobre el asunto-. Así mismo, los tiempos en los que se plantean este cruce de información no son siempre los deseados. Todo ello dificulta la apertura de las 
políticas hacia una estrategia colectiva de agrupación y transformación como la desarrollada en este trabajo.

Cuando se trata de procesos de participación y colaboración más horizontales, estos pueden suponer una herramienta fundamental para poder aprovechar los espacios de oportunidad. Algo que puede verse en algunos proyectos de viviendas cooperativas. La apertura de la toma de decisiones suele ir de la mano de un cuestionamiento de las tipologías habituales y la posibilidad de abrir el abanico de soluciones tipológicas, adaptando estas a las necesidades delas unidades de convivencia participantes en el proceso. Así mismo, un mayor control desde el origen favorece el control del gasto económico. Con todo, los retos para aplicar este tipo de prácticas de colaboración en otros ámbitos son importantes. Como puede ser el contar con una fuerte, jerarquizada y rígida estructura administrativa con procesos y tiempos burocráticos que lo dificultan -como puede pasar con Visesa, Alokabide, Bizigune o ASAP-, o desconocer la identidad y características de las unidades de convivencia que finalmente van a habitar las viviendas -también habitual en las cuatro citadas, pero también en viviendas libres en alquiler-. A lo cual se suman algunas cuestiones como el reto de aprender a participar, a debatir y a llegar a consensos.

Pero las dificultades encontradas y el todavía bajo nivel de colaboración entre agentes llevan a plantear como imprescindible el fomento y aumento de esta. Lo cual ayudará a compartir planteamientos, metodologías de trabajo, información y conocimiento, para en última instancia favorecer la puesta en práctica de la estrategia de agrupación de unidades de convivencia y transformación del parque. Las posibilidades de colaboración son considerables: las lecciones aprendidas en los procesos de participación abiertos en cooperativas podrán ser de gran utilidad a las instituciones públicas para incorporar metodologías similares; la fortaleza y disponibilidad de medios humanos y económicos de estas, al menos en comparación con otros agentes analizados, puede favorecer tareas de divulgación, gestión, e intervención en el parque; la cercanía con la población en búsqueda de vivienda de agentes como Etikalia puede servir para recoger y compartir información de gran interés en torno a las necesidades, deseos, preocupaciones, limitaciones y capacidades de esta para acceder a la vivienda. En definitiva, el análisis lleva a concluir que si las prácticas colaborativas están poco extendidas en general, el proceso de acceso a la vivienda no es excepción. Se convierte así en un proceso personal o familiar complejo, difícil y traumático en muchos casos, enfrentado a una realidad con una enorme inercia que dificulta la transformación desde lo individual. Por ello, la creación de redes activas de agentes públicoprivados y unidades de convivencia con necesidad puede favorecer a colectivizar la gestión de la vivienda y lograr mejores resultados. 
- 5.1.6 -

\section{Agrupación de personas como estrategia de empoderamiento}

Uno de los resultados de mayor interés presentados en el capítulo tercero, es la oportunidad que brindan las características de la oferta y la necesidad de vivienda analizadas para lograr un acceso alternativo a esta a través de una estrategia de agrupación de personas y rentas en paralelo a una transformación espacial del parque. En este sentido, se ha considerado relevante analizar si los casos de gestión seleccionados integran, con mayor o menor nivel, alguna pauta o intención hacia esta agrupación. El objetivo, distinguir si se trata de agrupaciones conscientes de su capacidad con una intención similar a la aquí planteada, o son consecuencias indirectas motivadas por otras razones, como la mera reducción del coste del acceso, o la limitación de los medios disponibles para ofertar vivienda. Dado que ya se han desarrollado las principales características de estos modelos locales de gestión de vivienda, esta última variable se presenta sintetizada pues en gran medida hace mención a aspectos ya tratados (Tabla 5.1).
Tabla 5.1. Análisis de la utilización de una estrategia de agrupación de unidades de convivencia como herramienta para el acceso digno a una vivienda por los diferentes agentes de gestión de vivienda analizados en el capítulo 4. Elaboración propia.

¿agrupación de personas como estrategia de empoderamiento?

casos

NO:

Se reproduce un modelo de unidad de convivencia y/o familia 'tradicional' formado por una pareja heterosexual con uno a tres descendientes menores de edad, a pesar de ser un tipo de unidad en proceso de reducción cuantitativa frente a otros y más variados tipos. La manera en que este se reproduce es a través de las propias tipologías ofertadas, la simplicidad de lectura de las características sociodemográficas de la población con necesidad de vivienda, el propio sistema de registro y adjudicación de viviendas en el caso de la vivienda protegida, o la limitación del número de ayudas económicas -y por lo tanto unidades de convivencia- por vivienda.

Visesa

Alokabide

Bizigune

ASAP

AES

PCV

Etikalia

Sumae Coop.

\section{NO:}

Son iniciativas destinadas a intervenir en viviendas ya ocupadas por una única unidad de convivencia - generalmente unipersonal-formada por personas mayores -especialmente mujeres-, y plantean la continuidad de esa persona en la

Barriztu

Renta Vitalicia misma.

\section{NO:}

Hay una agrupación de unidades de convivencia en la vivienda, pero no se plantea como herramienta para alcanzar un acceso económica y espacialmente digno. Se debe a otras razones, como la utilización de esas viviendas a modo de dispositivos temporales para facilitar el acompañamiento a personas en proceso de reinserción social provenientes de situaciones de vulnerabilidad y exclusión, o la utilización de un parque de viviendas ya existente -previsto para destinos propios de la vivienda protegida convencional- para un uso temporal de alojamiento de estudiantes.

Eguzkilore Jóvenes Solidarios 
SÍ:

Indirectamente, pues no son gestores de vivienda. Ofrecen servicios de consultoría y acompañamiento a proyectos de vivienda colectiva,

Urbania ZH Gestión generalmente cooperativas, y fomentan y difunden las ventajas y los potenciales de este tipo de iniciativas colectivas.

\section{Sí:}

Es el fundamento más o menos implícito y la razón de ser de estas experiencias. La agrupación de unidades de conviviencia bajo estas fórmulas permite un acceso normalmente más económico a la vivienda en comparación con el mercado libre, libera de algunas condiciones restrictivas de las viviendas protegidas, y da pie a procesos de diseño y toma de decisiones colectivos que Marco de Coop. Etxekoop

Egunsentia Aurora suelen favorecer un mayor sentimiento de identificación con el proyecto y las personas que lo conforman.

\section{Conclusiones y estrategias de mejora}

En aquellos casos en los que las viviendas ofertadas son destinadas a una única unidad de convivencia, no por el momento encaje alguno con los espacios de oportunidad planteados en el trabajo. Los planteamientos y la inercias que están detrás de este modelo son precisamente algunos de los obstáculos para su aprovechamiento. Pero es este tipo de práctica el principal objetivo al que apunta la estrategia de agrupación planteada: esta tiene un alto potencial de influir en las dinámicas hegemónicas del sistema inmobiliario residencial actual, abriendo las posibilidades de acceso y desmontando la idea fuertemente arraigada de que la estructura de la propiedad y la tipología de las viviendas actuales es una variable fija e inalterable. Las experiencias de Barriztu, Renta Vitalicia y Alquiler Garantizado, si bien continúan dichos planteamientos al intervenir en las viviendas manteniendo las unidades de convivencia que las ocupan, podrían en este sentido ser una oportunidad para plantear iniciativas de adaptación de las mismas con el objetivo de incorporar -en aquellas casos en los que el tamaño y las características de la vivienda lo permita- una nueva unidad de convivencia añadida. Lo cual supondría una entrada de rentas de alquiler -para unas personas habitualmente con pocos recursos económicos-, así como un potencial componente de acompañamiento y cuidados -de interés para unas unidades habitualmente unipersonales y de edad avanzada-. Algunos programas similares han sido ya explorados en diferentes municipios de Euskadi, pero sin alteraciones espaciales en la vivienda para que esta se adapte a esa nueva ocupación.

En cuanto a aquellos casos en los que sí se da una agrupación de unidades de convivencia, pero no en el sentido que este trabajo plantea -como Eguzkilore y Jóvenes Solidarios-, el desfase patente entre las necesidades habitacionales de esas unidades a las que están destinados ambos programas y las tipologías de vivienda 
convencional que utilizan como soporte podría servir de aliciente para animar a la transformación de las mismas. Para adaptarlas a los requerimientos de dos casos tan específicos como diferentes: estudiantes de posgrado con un perfil solidario, y grupos de personas en proceso de salida de situaciones de exclusión acompañados por agentes sociales. Por último, están aquellos casos analizados que muestran una mayor cercanía y correspondencia con la estrategia aquí identificada. Dentro de estos predomina la autogestión, pero también ejercen un papel muy importante los agentes que sin gestionar directamente el proyecto de vivienda participan de manera indirecta en el proceso de acceso, como es el caso de Urbania ZH Gestión. Ayudan a fomentar la agrupación de unidades de convivencia como herramienta de empoderamiento. En concreto, al impulsar y apoyar la creación y puesta en marcha de proyectos de viviendas cooperativas. Ya que son estas, de entre todos los agentes y casos analizados, aquellas que han mostrado fórmulas de funcionamiento, escalas de intervención, y tipologías de vivienda propuestas que con mayor facilidad encajan con los espacios de oportunidad. Están ya, en cierta medida, aprovechándolos. Sin embargo, se ha visto que la escala habitual de estos proyectos, que engloba un edificio o parcela completos, resulta difícil de ser reproducida extensamente en el AMB, por la escasa oferta de este tipo de inmuebles en la región.

En conclusión, las iniciativas que mejor encajan y que ya están incorporando este tipo de estrategias -agrupación de unidades de convivencia para la transformación de edificios de cara a acceder a un precio asequible a unas viviendas adecuadas a sus necesidades espaciales- son todavía muy minoritarias y con dificultades de extenderse. Mientras que las dinámicas con un planteamiento opuesto -reproduciendo sin alterar sustancialmente un sistema atomizado de viviendas obsoletas y limitadas a una única unidad de convivencia muy concreta- son precisamente las que mayor volumen de vivienda acumulan y las que comparten muchos de los agentes estudiados. El interesante potencial de aprovechamiento de los espacios de oportunidad que se ha identificado lleva a plantear que sería deseable la extensión de su aplicación a otros ámbitos más allá de las cooperativas privadas.

\section{- 5.1.7 - \\ Sintesis de las variables}

En la Tabla 5.2 se resumen los resultados de las seis variables analizadas hasta aquí y que permiten una primera evaluación del potencial de encaje de los diversos agentes locales de gestión con los espacios de oportunidad detectados para desarrollar la estrategia desarrollada. Estas variables han sido planteadas, entre otras posibles, como herramientas para el análisis por lo que no se busca la 
Tabla 5.2. Síntesis del análisis de las variables de encaje de los agentes locales estudiados con los espacios de oportunidad.

Elaboración propia. categorización precisa de cada caso, si no facilitar la lectura y la síntesis del ejercicio de interpretación desarrollado. Así, en más de una ocasión algunas experiencias comparten más de una categoría dentro de cada variable.

\begin{tabular}{|c|c|c|}
\hline categorías & casos & conclusiones y estrategias \\
\hline \multicolumn{3}{|c|}{ Variable: ESTRUCTURA Y ESCALA DE LA PROPIEDAD GESTIONADA } \\
\hline 1 única vivienda & $\begin{array}{l}\text { Barriztu, Etikalia (venta), } \\
\text { Renta Vitalicia }\end{array}$ & \multirow{3}{*}{$\begin{array}{l}\text { La acumulación de inmuebles } \\
\text { bajo un órgano gestor es } \\
\text { deseable. Cobra importancia } \\
\text { el papel de aquellos agentes } \\
\text { que gestionan viviendas } \\
\text { existentes dispersas por el } \\
\text { parque. }\end{array}$} \\
\hline $\begin{array}{l}\text { Varias viviendas distribuidas por } \\
\text { el parque libre o protegido }\end{array}$ & $\begin{array}{l}\text { Visesa, Alokabide, Bizigune, } \\
\text { ASAP, Eguzkilore, Etikalia } \\
\text { (alquiler), Jóvenes Solidarios }\end{array}$ & \\
\hline $\begin{array}{l}\text { Parcelas y/o edificios completos } \\
\text { (o parte sustancial de ellos) }\end{array}$ & $\begin{array}{l}\text { Visesa, Alokabide, Urbania } \\
\text { ZH Gestión, Marco Coops., } \\
\text { Etxekoop, Egunsentia } \\
\text { Aurora }\end{array}$ & \\
\hline \multicolumn{3}{|c|}{ Variable: SOPORTE ESPACIAL ELEMENTAL QUE CONFORMA LA PROPIEDAD } \\
\hline $\begin{array}{l}1 \text { vivienda }=1 \text { unidad de } \\
\text { convivencia }\end{array}$ & $\begin{array}{l}\text { Visesa, Alokabide, Bizigune, } \\
\text { ASAP, Barriztu, Etikalia, } \\
\text { Renta Vitalicia }\end{array}$ & \multirow{3}{*}{$\begin{array}{l}\text { Carencia de una lectura } \\
\text { crítica de las características } \\
\text { del parque existente y un } \\
\text { análisis profundo de la } \\
\text { necesidad de vivienda. }\end{array}$} \\
\hline $\begin{array}{l}1 \text { vivienda compartida por varias } \\
\text { unidades de convivencia }\end{array}$ & $\begin{array}{l}\text { (AES), (PCV), Eguzkilore, } \\
\text { Jóvenes Solidarios }\end{array}$ & \\
\hline $\begin{array}{l}\text { Edificio entero como soporte } \\
\text { vital de una comunidad real }\end{array}$ & $\begin{array}{l}\text { Urbania ZH Gestión, Marco } \\
\text { Coops., Etxekoop, } \\
\text { Egunsentia Aurora }\end{array}$ & \\
\hline
\end{tabular}

\section{Variable: TIPOLOGÍA DE VIVIENDA GENERADA EN EL SOPORTE}

Reproducción de una tipología conservadora y jerarquizada

Mantenimiento y baja alteración de las tipologías existentes

Diseño adaptado y adecuado a las necesidades
Visesa, Alokabide

Bizigune, ASAP, AES, PCV, Eguzkilore, Barriztu, Jóvenes Solidarios, Etikalia, Renta Vitalicia

Urbania ZH Gestión, Marco Coops., Etxekoop, Egunsentia Aurora, Etikalia + of. téc.
La estrategia de agrupación desarrollada lleva implícita la adaptación de las viviendas.

Hay importantes condicionantes para su aplicación, que requieren cambios normativos y un esfuerzo por difundir y divulgar otras posibilidades tipológicas.

\section{Variable: MODO DE PARTICIPACIÓN EN EL PROCESO DE ACCESO}

Promoción propia

Adquisición de viviendas o edificios a terceros agentes
Visesa, Etxekoop,

Egunsentia Aurora

Visesa, Alokabide, Marco

Coops., Etxekoop,

Egunsentia Aurora,

Eguzkilore, Renta Vitalicia
Los servicios y herramientas ofertadas posibilitan un aprovechamiento de los espacios de oportunidad, aunque es todavía bajo. La divulgación de las bondades de la estrategia es deseable. 
Gestión de viviendas o edificios de terceros agentes

\section{Asesoramiento y}

acompañamiento en la

planificación e intervención

Capacitación para la

rehabilitación de inmuebles
Alokabide, Bizigune, ASAP,

Eguzkilore, Etikalia

Sumae Coop., Urbania ZH

Gestión, Etikalia

Visesa, Alokabide, Bizigune,

ASAP, Marco Coops.,

Etxekoop, Egusentia Aurora,

Eguzkilore, Barriztu, Renta

Vitalicia

\section{Variable: UTILIZACIÓN DE ESTRATEGIAS COLABORATIVAS}

Canales de comunicación entre

promoción y habitantes

Espacios y procesos de participación internos

Convenios y alianzas externas
Visesa, Alokabide

Urbania ZH Gestión, Marco

Coops., Etxekoop,

Egunsentia Aurora

Visesa, Alokabide, Bizigune, ASAP, Sumae Coop.,

Urbania ZH Gestión,

Egunsentia Aurora,

Eguzkilore, Barriztu, Jóvenes

Solidarios, Etiklalia
Las prácticas colaborativas están poco extendidas, fortaleciendo un proceso de acceso a la vivienda aislado, complejo, difícil y traumático. La creación de redes de agentes y unidades de convivencia puede colectivizar la gestión de ese acceso y lograr mejores resultados.

\section{Variable: AGRUPACIÓN DE PERSONAS COMO ESTRATEGIA}

No: destinadas a una sola unidad de convivencia

No: intervienen en viviendas ya ocupadas por una unidad de convivencia

No: hay agrupación, pero por otras razones

Sí: indirectamente

Sí: es el fundamento del proyecto
Visesa, Alokabide, Bizigune, ASAP, AES, PCV, Etikalia, Sumae Coop.

Barriztu, Renta Vitalicia

Eguzkilore, Jóvenes Solidarios

Urbania ZH Gestión

Marco de Coop., Etxekoop, Egunsentia Aurora
Los casos que mejor encajan y están ya aprovechando en cierto modo esas oportunidades son minoritarios y difíciles de generalizar. Los que reproducen el modelo actual conflictivo son mayoritarios en un parque dispuesto para tal fin. El reto está en saber aplicar lecciones de los primeros en los segundos. 
Tabla 5.3. Síntesis de algunas de las principales características, de los agentes analizados, que pueden favorecer u obstaculizar una puesta en práctica de la estrategia de agrupación de unidades de convivencia y transformación de viviendas planteada para lograr un acceso espacial y económicamente digno. Elaboración propia. \\ Capacidades y limitaciones}

Para complementar y enriquecer las variables recién desarrolladas, se propone una síntesis de algunas de las cuestiones que se han ido comentando a lo largo de los capítulos cuarto y quinto en relación a los agentes analizados. En concreto, aquellas características que pueden ejercer una considerable influencia, tanto positiva como negativa, para un encaje y aprovechamiento por parte de estos de los espacios de oportunidad identificados en el capítulo tercero (Tabla 5.3). A pesar de que muchas de ellas hacen referencia a aspectos ya citados, se ha creído conveniente recordar y re-ordenar las mismas para repasar algunas de las principales fortalezas y retos existentes. Pero ahora, con una nueva perspectiva, una mirada ampliada una vez analizadas las seis variables. Se ha considerado oportuno presentar este apartado en un formato resumido para facilitar así la comprensión y no redundar en ideas ya desarrolladas.

\footnotetext{
Visesa y Alokabide

- Una estructura fuerte y en una posición jerárquica poderosa (dependiente del Gobierno Vasco), con importantes recursos económicos y humanos, y con competencia en toda la comunidad autónoma.

- Acceso directo a la base de datos de personas y unidades de convivencia con necesidad de vivienda, y al Observatorio Vasco de la Vivienda.

- Postura cada vez más abierta hacia el colectivo demandante y habitante de las viviendas, buscando responder a sus necesidades.

- Búsqueda activa de sinergias con otras instituciones, públicas y privadas.

- Escala de actuación que habitualmente engloba todo un edificio o parcela, y con competencia para intervenir y transformar su tipología y espacios.
}

- Reproducción de un esquema de unidades de convivencia y viviendas rígido y desfasado, poco abierto a otras posibilidades.

- Una reacción tardía y lenta a las evoluciones demográficas de las unidades de convivencia, sin un análisis profundo de estas, como por ejemplo Alokabide al no permitir el desarrollo de actividad económica en las viviendas.

- A pesar del supuesto giro de Visesa hacia la rehabilitación, el grueso de las promociones realizadas, en marcha, o proyectadas son de obra nueva, sin intervenir en el parque existente a través de operaciones de reforma integral. Algunos de los grandes esfuerzos en esta línea, como el plan Renove 2013-2016 estaba enfocado a ayudas a particulares y comunidades de propietarios. 
- Competencia para desarrollar y/o controlar obras de intervención en las viviendas gestionadas de otras propiedades que están dispersas por el parque (Alokabide).

\section{Bizigune y ASAP}

- Ofrecer cierta flexibilidad en la forma de cesión de las viviendas privadas, lo cual puede resultar atractivo para la incorporación de más inmuebles (Bizigune).

- Acceso directo a la base de datos de personas y unidades de convivencia con necesidad de vivienda, y al Observatorio Vasco de la Vivienda.
- Falta de visión del potencial para fomentar desde lo público la transformación y adaptación del parque privado vacío, al no incidir desde Bizigune en la posibilidad de financiar y realizar reformas en las viviendas movilizadas.

- Mantenimiento de una visión simplista del espacio doméstico en la clasificación de las viviendas movilizadas y en la manera de publicitarlas.

\section{Sumae Coop. y Urbania ZH Gestión}

- Posibilidad de ejercer un papel de agente tractor para difundir e implantar la estrategia de agrupación de personas, ya sea en edificios enteros, promoviendo la creación de pequeñas cooperativas que adquieran o unifiquen la propiedad de viviendas sueltas para su transformación, u ofreciendo ellos mismos la gestión de esto último como línea de negocio.
- Limitada capacidad de actuación por su reducido tamaño.

- Dependencia de la rentabilidad económica de la actividad para su supervivencia, que puede chocar con agrupaciones de unidades de convivencia con limitados recursos económicos.

\section{Marco para Coop. de viviendas en Euskadi / Etxekoop y Egunsentia Aurora}

- Capacidad jurídica e intención de adquirir inmuebles enteros y transformarlos.

- Fuerte demanda e interés por diseñar y/o adaptar los espacios a sus habitantes.

- Habitualmente acompañadas de otros principios y valores sociales con influencia en su entorno social y ambiental inmediato.

- Posicionamiento político y presión a las instituciones públicas para una regulación de este tipo de figuras (Etxekoop).
- Generalización de 'falsas cooperativas' que pervierten el fondo del concepto, enmascaran un modelo inmobiliario hegemónico y desechan el potencial de las 'verdaderas' para desarrollar soluciones más adecuadas a la necesidad de vivienda.

- Limitación de sus proyectos a edificios enteros en un contexto de poca oferta a esa escala, y no identificando la posibilidad de desarrollar cooperativas de viviendas dispersas, transformables e intercambiables según varían los componentes y/o las situaciones vitales de estos.

\footnotetext{
AES y PCV

- En alojamientos colectivos, el número máximo de ayudas será igual al número máximo de plazas; la definición de este tipo de inmuebles residenciales es abierta y flexible, ofreciendo potencial para la estrategia de agrupación de personas si hay un agente gestor detrás (Art. 6.2 Decreto 147/2010).
}

- En viviendas, el número máximo de ayudas es de dos, independientemente de las unidades de convivencia, y de la superficie y capacidad de alojamiento de la vivienda. 


\section{Fundación Eguzkilore}

- Postura abierta a colaboraciones y formación de vínculos entre diversos agentes, tanto públicos como privados.

- Capacidad y herramientas para intervenir en las viviendas; potencial para adaptarlas a nuevas tipologías y necesidades habitacionales.

- En muchos casos mantiene la idea de corresponder a cada vivienda gestionada una unidad de convivencia, sin plantear la posibilidad de adaptar estas para acoger a más unidades.

\section{Barriztu}

- Cuenta con una metodología y un proceso de intervención con gran potencial para ser aplicado a los espacios de oportunidad detectados mediante la estrategia de agrupación. Incluso podría incorporar en algunos casos dicha estrategia manteniendo siempre el fondo de su actividad.

- Participación de diversos agentes enriqueciendo la iniciativa con sus conocimientos y aptitudes específicas.

\section{Jóvenes Solidarios}

- Agrupación de unidades de convivencia de pequeño tamaño con necesidades espaciales diferentes a las recogidas por las tipologías convencionales.

- Perfil de unidades de convivencia con necesidad de vivienda temporal, adecuados a situaciones de viviendas rotacionales.

- Se limita a intervenciones pequeñas no sustanciales de la vivienda.

- Actúa en unidades de convivencia que ya disponen de vivienda.

\section{Etikalia}

- Papel de intermediador entre propiedad y unidades de convivencia con necesidad de vivienda, trabajando en colaboración con un estudio de arquitectura que analiza posibilidades tipológicas.

- Empresa con una visión transversal y abierta del negocio inmobiliario, definiendo objetivos sociales y ambientales en equilibrio con los económicos.

- Capacidad de autocrítica, reflexión y reorientación del negocio.

- Importante potencial como agente tractor para desarrollar la estrategia de agrupación de personas y transformación de viviendas.

- No se aprovecha la posibilidad de transformar y adaptar un parque propio.

- Programa excesivamente basado en la subvención, sin aprovechar la agrupación de rentas.

\section{Renta Vitalicia y Alquiler Garantizado}

- Podía plantear una transformación mayor de la vivienda para acoger a más unidades de convivencia, debido a la habitual ocupación de grandes viviendas por personas mayores solas.
- Continúa con lógicas tipológicas y domésticas rígidas y convencionales, sin analizar ni abordar suficientemente los cambios demográficos en las unidades de convivencia.

- Limitada capacidad de intervenir en los precios de alquiler o venta. 


\section{De la contradicción a la alternativa: un cambio en marcha}

«En el marco de estas contradicciones dinámicas e interactivas es dónde podemos encontrar múltiples proyectos políticos alternativos. Muchos de ellos se forman como respuestas específicas del capital a sus propias contradicciones y por ello están principalmente dirigidos a facilitar su reproducción en condiciones de perpetuo riesgo e incertidumbre, si es que no de crisis en toda regla. Pero incluso en estos casos existen innumerables posibilidades para la inserción de iniciativas que tanto modifiquen el funcionamiento del capital como abran perspectivas respecto a lo que podría ser una alternativa anticapitalista.

[...] Los desarrollos geográficos desiguales no pueden hacer otra cosa que generar "espacios de esperanza" y situaciones heterotópicas en las que pueden florecer nuevos modos de cooperación, al menos durante un tiempo, antes de que sean reabsorbidos por las prácticas dominantes del capital». 



\section{$-6.1-$ \\ Confirmación de la hipótesis}

La hipótesis general de la investigación, formulada primeramente en el apartado 1.3.3 y concretada posteriormente en el 2.7.4, se apoya en una afirmación teórica y se estructura en tres puntos. La cuestión teórica se ha discutido y confirmado localmente en el capítulo segundo; los dos primeros puntos han sido confirmados a partir de los resultados obtenidos en los capítulos tercero y cuarto respectivamente. A partir de lo desarrollado en el capítulo quinto, es posible confirmar el tercer punto de la hipótesis e iniciar así el cierre de la investigación. Con esta tarea se inicia este último capítulo, que queda completado con algunas conclusiones de interés obtenidas a lo largo del trabajo. Una vez planteada la confirmación global de la hipótesis, se destina el resto de este primer apartado a retomar el marco teórico que sustenta su formulación, para reflexionar una vez más sobre su validez. Se trata de plasmar que a partir del estudio de las contradicciones existentes, ha sido posible sugerir la existencia de ciertas alternativas para salvar en cierta medida los condicionantes y obstáculos identificados, y abordar la situación problemática enfocada. El objetivo es cerrar el círculo iniciado, y plasmar que, efectivamente, existen puentes -con sus debilidades y sus limitaciones- sobre los que evitar dichas amenazas para alcanzar las metas.

$$
-6.1 .1-
$$

\section{Un potencial de aprovechamiento sin explotar}

El tercer punto de la hipótesis se construía a partir del cruce de las alternativas planteadas en los otros dos. Si el primero proponía un espacio de oportunidad previsto en el desfase entre tipología residencial y tipos de unidades de convivencia, y el segundo la existencia de agentes de gestión alternativos con una serie de características concretas y actuando frente al modelo inmobiliario residencial predominante, el tercero planteaba que la naturaleza de dichos agentes podía favorecer la incorporación a su actividad de estrategias enfocadas al aprovechamiento de los espacios de oportunidad. Lo que llevaba al doble objetivo de dotar a los mismos de un mayor conocimiento sobre dichos espacios de oportunidad algo ya avanzado en el capítulo tercero-, y analizar el nivel de encaje 
posible entre los espacios de oportunidad y los agentes de gestión. Esto último se ha desarrollado en el capítulo quinto, y permite confirmar que esa tercera parte de la hipótesis puede ser dada por válida. Aunque los retos y las dificultades no son pocas, ni fáciles de superar, el potencial existente en los agentes analizados para asimilar, incorporar y poner en práctica la estrategia de agrupación de unidades de convivencia señalada, y aprovechar así los espacios de oportunidad detectados - a través de la transformación y adaptación del parque existente- para alcanzar un acceso a la vivienda económica y espacialmente digno se cree que es considerable. Esta argumentación puede desarrollarse a partir de la interpretación de tres partes concretas del trabajo desarrollado.

Primero, si bien no es extensible a todos los casos, como se ha visto de una manera generalizada en el apartado 4.7 a las múltiples debilidades internas -una gestión ineficaz limitada por falta de recursos, competencias y/o comprensión de la problemática; la inviabilidad y los obstáculos de carácter económico; el mantenimiento, consciente o no, de la vulnerabilidad residencial a través de algunas de sus acciones; la débil respuesta generalizada que plantea su oferta residencial a necesidades espaciales diversas; o el bajo nivel de participación de las unidades de convivencia que finalmente van a ocupar las viviendas- se han de sumar importantes amenazas externas. Como el contexto político y cultural de un modelo de gobierno muy jerárquico y una sociedad considerablemente pasiva e individualista, la rigidez y obsolescencia del sistema normativo relativo al diseño, o la ausencia de información detallada y actualizada - sin previsión de que vaya a ser generada-. Pero frente a ello $-\mathrm{y}$ reflejo de esa transversalidad de las contradicciones ya señalada- también se han detectado fortalezas propias de los agentes, como una apuesta clara y decidida por la función social de la vivienda, un giro más o menos firme hacia la intervención en el parque existente como estrategia prioritaria, una (lenta) interiorización de la necesidad de desarrollar políticas para la adaptación tipológica, la búsqueda del control del coste final de acceso a la vivienda para mantenerlo bajo límites dignos, o la incorporación de variables complementarias como la convivencia y la cohesión social. A las que se han de sumar las oportunidades identificadas en la generación de posibles $-\mathrm{o}$ fortalecimiento de existentes- sinergias y alianzas entre los diferentes agentes, o el encaje y la influencia que sus actividades pueden ejercer en las grandes políticas públicas de vivienda. En suma, como fenómeno social que es, la gestión de la vivienda presenta una naturaleza compleja llena de múltiples matices, intereses y contradicciones que se han de desgranar para abordar con un mínimo de garantía cualquier planificación hacia las metas planteadas.

Segundo, y de manera complementaria, el estudio de las variables a tener en cuenta para el encaje entre los agentes de gestión y los espacios de oportunidad desarrollado en el apartado 5.1.1 y 
sintetizado en la Tabla 5.2, permite señalar tres lecturas de interés, entre otras posibles:

- Se ha señalado la necesidad de que estos espacios de oportunidad sean planificados y puestos en carga a un ritmo y una escala de intervención determinado para que su influencia en las metas propuestas sea relevante. Ante la dificultad que a dicha labor añade el hecho de que el objeto físico con el que se ha de contar se encuentre disperso -geográficamente a lo largo del parque residencial existente, y administrativamente en múltiples propiedades de diverso tamaño-, la centralización de la gestión de múltiples inmuebles, propios o no, que muchos de estos agentes ofrecen es un poderoso instrumento que puede facilitar dicha planificación e intervención a escalas intermedias.

- Se ha insistido recurrentemente en la necesidad, implícita en la estrategia de agrupación de unidades de convivencia apuntada, de realizar transformaciones físicas en las viviendas y/o edificios para adaptar estos inmuebles a esas unidades que no encuentran en la oferta actual ni precios, ni tipos, de vivienda adecuados a sus situaciones vitales. Pero se ha observado una carencia generalizada, salvo excepciones, de una lectura crítica de este desfase en los agentes analizados. Este es quizás uno de los principales obstáculos para que tomen los espacios de oportunidad identificados como un posible soporte para el desarrollo de su actividad en el proceso de acceso a la vivienda. Sin embargo, los servicios y las herramientas que estos agentes están en la actualidad ofreciendo y aplicando conforman un marco con un alto potencial para intervenir en el parque y aprovechar dicha alternativa. Lo cual tiene el interés añadido de no necesitar grandes cambios en la gestión, ni depender de profundos cambios normativos.

- Los agentes con mayor volumen de gestión mantienen en general una estructura heredada de viviendas atomizada. A esta se hace corresponder de manera individual a las unidades convivenciales que acceden a dichas viviendas, con la obligación de adaptarse forzosamente a sus tipologías, realizando en ocasiones actuaciones superficiales que no alteran las mismas o, en el mejor de los casos, intervenciones parciales de ajuste espacial. Pero se han podido detectar otro tipo de agentes, con una presencia mucho menor en el AMB, que se puede considerar que están aprovechando, o intentando hacerlo, algunos de estos espacios de oportunidad con estrategias de agrupación de unidades de convivencia. Pero lo hacen desde una posición de debilidad y marginación. Lo cual llevaba a plantear que las oportunidades detectadas de alianzas y colaboraciones entre agentes podrían favorecer el intercambio de planteamientos, métodos y valores de los segundos a los primeros y de medios, recursos y estructuras de gestión en el sentido contrario. Lo cual 
facilitaría, en definitiva, un mayor aprovechamiento de los espacios de oportunidad por parte de todos los agentes.

Tercero, las limitaciones resumidas en la Tabla 5.3 indican la extendida presencia y el consecuente efecto negativo que los condicionantes y obstáculos apuntados al inicio del trabajo (Esquema 2.1) ejercen sobre y desde la propia actividad desarrollada por los agentes. Las debilidades y amenazas identificadas están originadas y/o influenciadas de manera transversal por los tres grandes condicionantes y obstáculos señalados en el capítulo segundo: un poder económico que predomina sobre la justicia social y limita la capacidad de actuación, una visión conservadora del espacio doméstico que oculta otras posibles soluciones espaciales, y una fuerte inercia urbanizadora heredada que todavía influye en la manera en que se aborda la intervención sobre la ciudad residencial existente. La contraposición de muchas de estas debilidades con las también existentes fortalezas, del potencial con los condicionantes, de las capacidades con las limitaciones, muestran cómo las contradicciones apuntadas en el marco teórico propias del modelo urbanístico y residencial actual, se ven reflejadas en la práctica de estos agentes. Lo cual se puede mostrar con tres ejemplos, relacionados con las tres metas:

- La lucha por un control del coste final de las viviendas ofertadas, y la clara apuesta por la función social de la vivienda comunes a la práctica totalidad de casos, se ve contradicha por el desarrollo de una gestión que no es del todo eficaz, altamente condicionada por un mercado agresivo, lo cual favorece en ciertas cuestiones un mantenimiento de la vulnerabilidad residencial de la población con necesidad de acceso a una vivienda.

- A pesar de observarse cierta inquietud por ajustar y adaptar las características espaciales -tipológicas- de la oferta generada a las necesidades y deseos delas unidades de convivencia demandantes, estas no acaban de ser estudiadas en profundidad ni asumida su complejidad y riqueza, por lo que la respuesta a dichas necesidades espaciales es todavía muy pobre con un bajo nivel real de participación por parte del público final.

- El giro firme dado en los últimos años por parte de las políticas públicas hacia la intervención en la ciudad existente para abordar tanto las carencias constructivas, como diversos retos sociales y ambientales, incluye la búsqueda de la puesta en carga del parque residencial infrautilizado -especialmente mediante la movilización de viviendas libres vacías hacia el alquiler social-. Pero ha resultado de momento incapaz de desarrollar modelos que sean viables económicamente y lo suficientemente atractivos para una estructura de pequeñas y grandes propiedades con una baja sensibilidad social.

No obstante, también se apuntan en dicha Tabla 5.3 algunas de las interesantes capacidades que estos agentes ofrecen y defienden, y que 
pueden ser contextualizadas en las fases de Contenido e Instrumentos propias de la respuesta que la sociedad da en el proceso de gobernanza urbana planteado en el Esquema 2.1. Capacidades que les permitiría poner en práctica la estrategia de agrupación de unidades de convivencia para aprovechar los espacios de oportunidad detectados en el parque residencial existente. Es decir, a pesar de las debilidades, amenazas, limitaciones y condicionantes mostrados, las fortalezas, oportunidades, capacidades y el potencial detectados llevan en general a valorar el panorama de este particular grupo de agentes como abierto a la incorporación en su actividad de los espacios de oportunidad identificados.

$-6.1 .2-$

\section{La contradicción como generadora de alternativas}

Más allá de identificar y profundizar en las alternativas formuladas como parte de la hipótesis para avanzar hacia las tres metas definidas, el cuerpo de la investigación permite confirmar el marco teórico sobre el que se ha apoyado el planteamiento y diseño de la misma. Así, se apuntan a continuación de manera breve algunas cuestiones que permiten afirmar y reforzar la idea del estudio de las contradicciones propias del sistema capitalista actual como un camino para la búsqueda, comprensión y puesta en valor de las soluciones y vías alternativas que el mismo sistema genera fruto de sus conflictos internos.

\section{Del desajuste de la oferta a la adaptación espacial}

En este punto interesa aclarar una cuestión crucial para uno de los principales aportes planteados de este trabajo, como es la estrategia de agrupación de unidades de convivencia como herramienta de empoderamiento para el acceso a la vivienda. Se viene a lo largo del mismo poniendo un especial énfasis, e insistiendo, en la importancia que se cree que tiene el reorientar tanto las políticas públicas como los esfuerzos privados hacia la cuestión tipológica. Esto se debe, no solo al repetido desfase entre una homogénea y cada vez más obsoleta oferta de tipologías y la diversidad de unidades de convivencia demandantes. La relevancia de esta cuestión se ve fortalecida debido a que la oportunidad detectada en el capítulo tercero en lo relativo a esta dimensión espacial no es tanto una consecuencia o una posibilidad generada a partir de la agrupación de unidades de convivencia y por lo tanto, de rentas. El razonamiento se construye, de hecho, en sentido contrario: es precisamente la existencia de esta característica tipológica generalizada en el parque de viviendas, en un contexto socio-económico y demográfico concreto, la variable que hace posible el acceso digno y adecuado a partir de la acumulación de 
rentas y personas. Es decir, si la tipología predominante en el parque residencial fuese la más adecuada para satisfacer las necesidades habitacionales de la gran mayoría de unidades de convivencia con necesidad de vivienda, manteniéndose la incapacidad de pago actual, no habría margen para la adaptación espacial de las viviendas, ni por lo tanto, para una estrategia de agrupación de personas que permitiese un reparto de los costes. Se plantea, por lo tanto, que el desfase identificado entre tipologías de vivienda y perfiles de unidades convivenciales es lo que realmente posibilita alcanzar -mediante esta estrategia colectiva de transformación espacial- el acceso económico. En definitiva, es la contradicción existente entre oferta y demanda del mercado inmobiliario residencial la que posibilita en última instancia la alternativa de acceso digno y adecuado señalada en la hipótesis y confirmada en el capítulo tercero.

\section{De la hegemonía del dinero al empoderamiento de la defensa del derecho}

A través de diferentes esferas y planteamientos, se desarrolla en este grupo de agentes analizados un importante trabajo desde un posicionamiento por la defensa del interés público en general, y en favor de un acceso digno a la vivienda en particular. Se trata así de un objetivo altamente compartido por todos ellos, y que pone en cuestión el desequilibrio existente entre un valor de cambio de la vivienda que predomina sobre el de uso. Ante esta afirmación, podría considerarse que es la existencia de este tipo de agentes y modelos alternativos de gestión residencial la que hace posible, entre otras razones, el enfrentamiento a la contradicción apuntada entre la hegemonía del valor de cambio de la vivienda y la defensa de esta como un derecho humano fundamental desarrollado en un diverso marco regulador. Sin embargo, al igual que en el caso anterior, es posible dar la vuelta al razonamiento: la superioridad que el contexto social y cultural atribuye al valor de cambio de la vivienda frente al de uso, y las graves consecuencias que supone generando carencias en el acceso a la misma, fortalecen una situación problemática de urgente solución, que es precisamente la que motiva la aparición de este tipo de agentes privados, programas mixtos y políticas públicas.

Aunque en este caso se está haciendo referencia a una acción práctica, pero de manera similar a como señala Brenner para la teoría -enmarcando estas contradicciones dentro de la totalidad social que es «el carácter fragmentado, fracturado o contradictorio del capitalismo»-, si «la totalidad estuviese cerrada, o no fuese contradictoria o completa, no podría haber una conciencia crítica sobre ella. No habría necesidad de crítica -de hecho, la crítica sería estructuralmente imposible-. La crítica emerge precisamente debido a que la sociedad está en conflicto consigo misma, es decir, porque el modelo de desarrollo es autocontradictorio» (Brenner, 2017b: 242). Sin situación problemática, no habría necesidad de agentes luchando 
por un acceso digno al derecho a la vivienda. Es por tanto la contradicción entre el valor de uso y de cambio de la vivienda la que genera prácticas alternativas, más o menos exitosas, de gestión de la vivienda centradas en su dimensión social, tal y como se ha planteado en la hipótesis y confirmado en el capítulo cuarto. En ambos casos, la argumentación se apoya en el marco teórico inicialmente presentado, y es posible enfrentarlos a una argumentación simplificadora de la realidad (Tabla 6.1).

\begin{tabular}{|c|c|}
\hline $\begin{array}{l}\text { argumentación } \\
\text { simplificada }\end{array}$ & $\begin{array}{l}\text { argumentación en el marco } \\
\text { de la identificación de } \\
\text { alternativas debidas a las } \\
\text { contradicciones internas }\end{array}$ \\
\hline $\begin{array}{l}\text { La oportunidad de acceder } \\
\text { bajo condiciones } \\
\text { económicas y espaciales } \\
\text { dignas transformando las } \\
\text { viviendas se debe a la } \\
\text { agrupación de unidades de } \\
\text { convivencia y rentas. }\end{array}$ & $\begin{array}{l}\text { El desfase de precios y } \\
\text { tipologías existente entre la } \\
\text { oferta y la demanda de vivienda } \\
\text { posibilita que mediante la } \\
\text { agrupación de unidades de } \\
\text { convivencia y rentas se puedan } \\
\text { adaptar y transformar las } \\
\text { viviendas repartiendo los costes } \\
\text { entre un mayor número de } \\
\text { unidades de menor tamaño que } \\
\text { aquellas para los que fueron } \\
\text { diseñadas dichas viviendas. }\end{array}$ \\
\hline $\begin{array}{l}\text { La existencia de agentes } \\
\text { alternativos que participan } \\
\text { en la gestión de la vivienda } \\
\text { hacen posible el abordar y } \\
\text { luchar contra los } \\
\text { condicionantes y } \\
\text { obstáculos identificados } \\
\text { para acceder a la misma. }\end{array}$ & $\begin{array}{l}\text { La presión y la urgencia de la } \\
\text { situación social debidas a la } \\
\text { asfixia que el predominio del } \\
\text { valor de cambio de la vivienda } \\
\text { genera sobre el valor de uso de } \\
\text { la misma motiva la aparición de } \\
\text { agentes alternativos en lucha } \\
\text { por reducir la situación } \\
\text { problemática del acceso a un } \\
\text { alojamiento digno. }\end{array}$ \\
\hline
\end{tabular}

Tabla 6.1. Comparativa de las posibles lecturas de las alternativas detectadas en la investigación según la manera de aproximarse a las mismas. Elaboración propia. 


\section{$-6.2-$ \\ Oportunidades complementarias: diversificación y cohesión}

Se ha visto que la convergencia de las alternativas espaciales y de gestión identificadas y analizadas presenta un interesante potencial de cambio transformador del modelo residencial actual, no falto de dificultades. Se apuntan a continuación algunas reflexiones y conclusiones sobre ciertos aspectos complementarios de las oportunidades que ese encaje de alternativas podrían llegar a posibilitar. Todo ello, a través de la estrategia de agrupación de unidades de convivencia para la transformación y adaptación del parque residencial existente.

\section{Diversificar la vivienda en respuesta a necesidades y usos cambiantes}

\section{Diversificar la gestión y el espacio}

Como se ha defendido a lo largo del trabajo, tanto las oportunidades detectadas en el parque actual, como el mapa de agentes de gestión alternativos y activos en el AMB, permiten aventurar la existencia de posibilidades para diversificar la vivienda. Una diversificación que tiene dos caras. Por un lado, se ha demostrado que otra manera de abordar el acceso a la vivienda fuera del mercado y de las grandes políticas públicas es posible $-\mathrm{y}$ de hecho se viene haciendo minoritariamente en el AMB-, aún jugando bajo las reglas de ambas esferas. Hay por lo tanto un importante potencial para fortalecer, extender y fomentar estos modelos de gestión diferentes; desarrollar otras maneras, otros posicionamientos desde los que incorporar parte de este parque a la oferta de vivienda asequible -ya sea a través de los programas y experiencias existentes, o de otros nuevos-. 
Por otro lado, está la cuestión de diversificar la tipología de vivienda; la de romper una oferta mayoritariamente uniforme. Sobre esto se ha tratado en diferentes puntos a lo largo del trabajo. Como estrategia general y salvando casos específicos, parece que la respuesta a la tendencia de reducción del tamaño de las unidades de convivencia -sean estas unidades nuevas, o existentes que se ven alteradas por diversos fenómenos socio-demográficos- ha de tener en cuenta dos cuestiones. Primero, ha de ir más allá de la reproducción de la vivienda habitual del mercado escalada a una menor superficie. Segundo, se insiste en que es necesario alterar la máxima de hacer corresponder a cada vivienda existente, sin alteración alguna, una unidad de convivencia demandante. Este dogma que reina en el subconsciente social, empresarial, político y técnico ha de ser superado para construir un marco que permita abordar la transformación del parque existente de una manera exitosa. Y más en una región en la que hay un crecimiento urbano limitado (Ayuntamiento de Bilbao, 2013: 41).

Pero se trata de ir más allá de intervenciones ya habituales como la segregación de una vivienda en dos, o las pequeñas reformas convencionales para eliminar algún tabique, unir cocina y salón, o renovar las zonas húmedas. Se trata de responder mediante el diseño y el conocimiento local e internacional existente, mediante soluciones imaginativas que sepan leer la complejidad de la problemática, a esos grandes retos sociales para los que la práctica totalidad de las viviendas existentes, y lamentablemente también las nuevas promociones, no están preparadas. Retos como la emancipación de un colectivo joven muy diferente de aquellas parejas que construían una familia en la segunda mitad del siglo pasado, la eliminación del estigma de los pisos compartidos -para jóvenes, adultos o mayores-, los pisos tutelados, pisos adaptados a personas dependientes y a las responsables de su cuidado, las personas que se ven obligadas al hacinamiento por falta de recursos, y muchos otros casos entre los que están, por supuesto, aquellas unidades de convivencia con mayor vulnerabilidad por carecer de alojamiento. Todas ellas, reflejo doméstico de la creciente diversidad socio-cultural y desigualdad socio-económica. Las limitaciones de pago de muchas de esas personas se ha visto que podrían ser atendidas en gran medida.

\section{De la solución formal y fija a la facilitación del proceso}

Se ha venido haciendo mención a la necesidad de ofrecer otro tipo de respuestas habitacionales debido a la obsolescencia de las tipologías más frecuentes para satisfacer las necesidades de muchas unidades de convivencia. Y se ha visto, por las referencias apuntadas a lo largo del trabajo, que no es este un posicionamiento aislado ni nuevo (Alguacil, 1995: 74). No obstante, la necesidad no se limita -O no solo- a ofrecer nuevos tipos de viviendas. Como ya se ha apuntado, el contexto socio-económico y un deseable ajuste del desequilibrio entre la oferta en propiedad y en alquiler -hoy en día 
este muy minoritario- hacen que el desarrollo de espacios domésticos versátiles y en cierta manera indefinidos tipológicamente pueda suponer una acertada estrategia. El motivo es que la homogénea oferta actual no responde a las diferentes formas de habitar, y no solo por el hecho de contar con muy diversos tipos de unidades y formas de convivencia, si no porque la vida doméstica y las necesidades de una misma unidad convivencial puede también variar enormemente en el tiempo.

La diversidad de las necesidades y la naturaleza cambiante de las mismas exige que todos los agentes participantes en la gestión de la vivienda asuman e interioricen un cambio en la manera de abordar las intervenciones y el diseño de los espacios domésticos. Se necesitan soluciones que permitan una diferente apropiación y adaptación a lo largo del tiempo. Por ello, la pauta habitual de generar soluciones considerablemente homogéneas, fijas y definitivas como respuesta a una unidad de convivencia tipo que no representa al abanico completo de perfiles existentes ha de dejar paso, no tanto a un múltiple catálogo de soluciones fijas y definitivas -algo difícil en la arquitectura residencial colectiva, en la que no se suele conocer a sus habitantes finales-, si no a una arquitectura cuya versatilidad y neutralidad espacial y funcional sea una de sus principales virtudes. Esto es aplicable a intervenciones de diferente escala en la ciudad residencial heredada. La asimilación de la complejidad propia de la producción del hábitat conlleva la aproximación a la vivienda como proceso que ha de ser abordado con respuestas integradas y dinámicas, no como objeto al que implantar soluciones parciales y estáticas (Romero y Mesías, 2004: 18). Es decir, el contexto pide incorporar una variable más o menos constante de cambio, y asimilar los procesos como elementos centrales para que estos espacios domésticos pueden ser adecuados a diversas unidades de convivencia y/o diversas necesidades en el tiempo:

«Hasta ahora hemos ido avanzando en modelos con soluciones formales (no quiero decir formalistas) que iban dando opciones de solución a modos de vida diferentes. El objeto de estudio y experimentación no es el resultado final construido, sino los procesos, tanto de modificación de modos de vida, como de elaboración de proyecto y composición. Esto es determinante. Ya no debemos proyectar para el resultado final, sino generar las condiciones para que los procesos de vida den un resultado final. Algo así como fabricar piezas, para que luego los usuarios determinen definitivamente sus espacios en función de lo que necesitan (y esto es cambiante). Somos gestores, no "fabricantes finales".

La industria, que nos contrata, quiere modelos acabados, y a ser posible los de siempre [...] Mientras que cuando se busca un modelo concreto una vez que se consigue se reproduce con la certeza de que está bien, cuando se busca un proceso los 
resultados son enormemente diversos, ya no tan fácilmente identificables formalmente, menos ejemplarizantes $[\ldots]$ Desaparecida la forma como factor de decisión y convertida en consecuencia la investigación parece decidirse en primer lugar por la perversión y transformación de los modelos conocidos» (Ballesteros, 2009).

\section{Apropiación y personalización del espacio doméstico}

Uno de los aspectos de interés en relación a esta diversificación de la vivienda está en la pluralidad inherente al propio acto de habitar un espacio doméstico; es la base para defender la existencia de diversas necesidades tipológicas. Estas no se dan solo entre tipos o perfiles de unidades de convivencia diferentes, si no también entre unidades con estructuras y tamaños similares. Se trata de una cuestión altamente dependiente e influida por la propia personalidad y situación de cada unidad de convivencia. La apropiación y colonización del espacio residencial no será entonces la misma para cada vivienda, si no que dependerá de las personas que la habitan. Esto sucede igualmente cuando se trata de viviendas idénticas, ocupadas por diferentes personas. Así, un mismo tipo de unidad convivencial no funcionará igual en dos culturas diferentes, ya que «cada sociedad desarrolla sus propios modelos de habitar» (Alguacil, 1995: 129). Podría decirse que dentro de una misma cultura, ciudad, incluso un mismo bloque de viviendas, dos unidades con mismo tamaño y estructura ocuparán, adaptarán y definirán su espacio doméstico de diferente manera. Un nivel de versatilidad y flexibilidad considerable de dicho soporte hará que esa apropiación sea de cierta calidad y permita, con mayor o menor facilidad y más o menos obstáculos, el desarrollo adecuado de la vida doméstica. Si por lo contrario, se trata de viviendas muy específicas, pensadas para acoger a unidades de convivencia con estructuras y formas de vida muy concretos, formalizadas en lo que Patricio y Sust denominaban vivienda-estuche (2000), las limitaciones serán importantes.

Esto se ha podido comprobar en diferentes estudios y trabajos, movidos todos por la inquietud de demostrar que la vivienda debe ser el «potenciador de la apropiación diferenciada e individualizada de los espacios [domésticos] por parte de sus habitantes» (Montaner et al., 2011: 125). Algunos casos de interés son los realizados en el edificio de vivienda social Nemausus en Nimes (Copans y Neumann, 1995) mostrados en las Imágenes 6.1 a 6.4; en el edificio de apartamentos Mitre en Barcelona (Monteys y Fuertes, 1998) de la Imagen 6.5; en las torres de Holly Street de Londres fotografiadas por Tom Hunter en los años 1997-1998 (Imágenes 6.6 a 6.9), en las viviendas de Lafayette Park, Detroit (Aubert et al., 2012), o los apartamentos del 860-880 de Lake Shore Drive, en Chicago (Imagen 6.10). En todos ellos, se puede observar cómo un mismo soporte arquitectónico es ocupado, apropiado y organizado de manera diversa, exclusiva y personal.
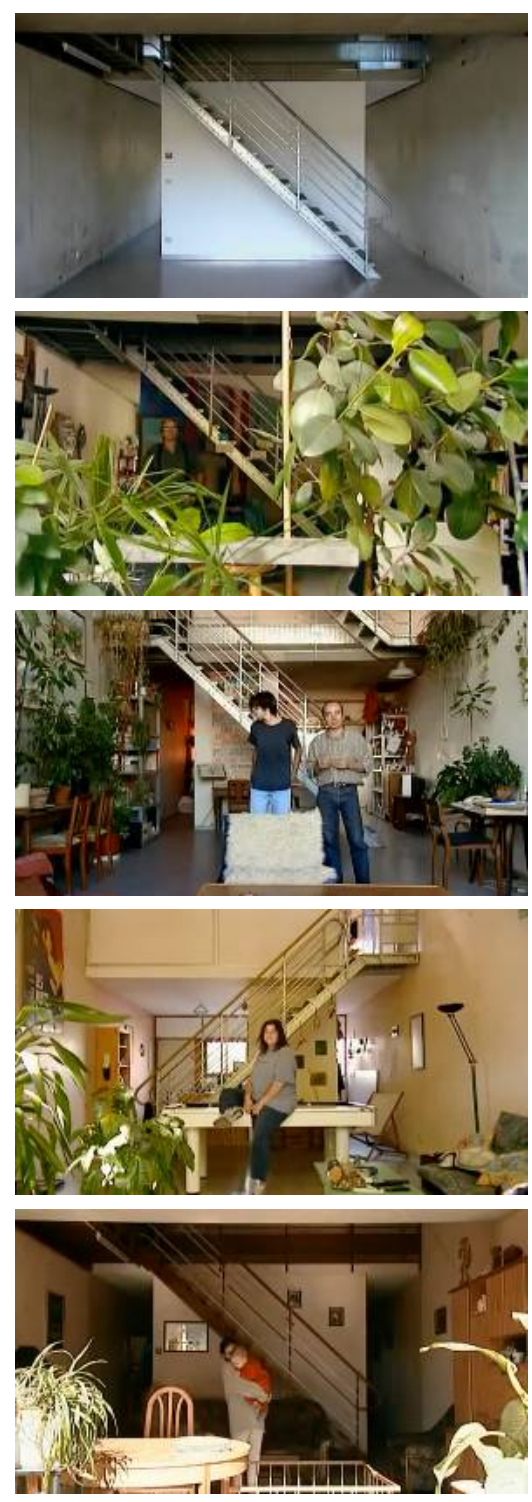

Imágenes 6.1 a 6.4. Soporte espacial y cuatro ejemplos de apropiación diferentes en las viviendas sociales Nemausus de en Nimes, Francia. Copans y Neumann, 1995. 

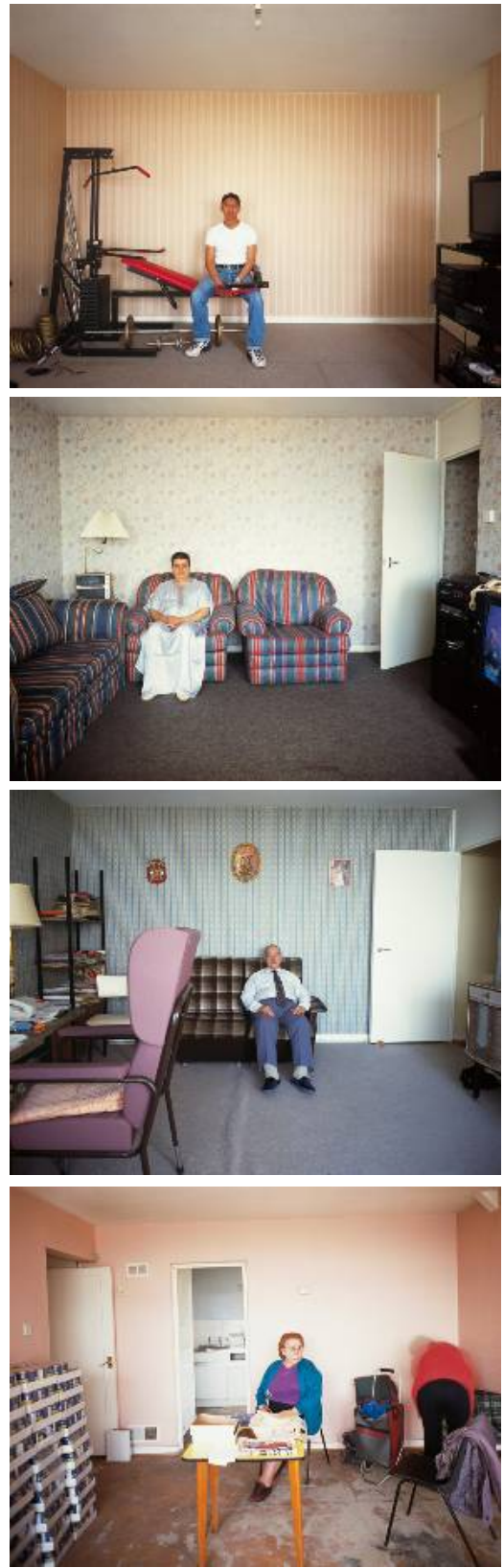

Imágenes 6.6 a 6.9. Extracto de la serie fotográfica de Tom Hunter en las torres de Holly Street, Londres. Tom Hunter.

Imágenes 6.5 y 6.10. Vistas interiores de algunos apartamentos en el edificio Mitre, Barcelona (arriba), y vista exterior parcial del edificio de apartamentos en el 860-880 de Lake Shore Drive, Chicago. Gili, 1995, y Time Inc, 1957.
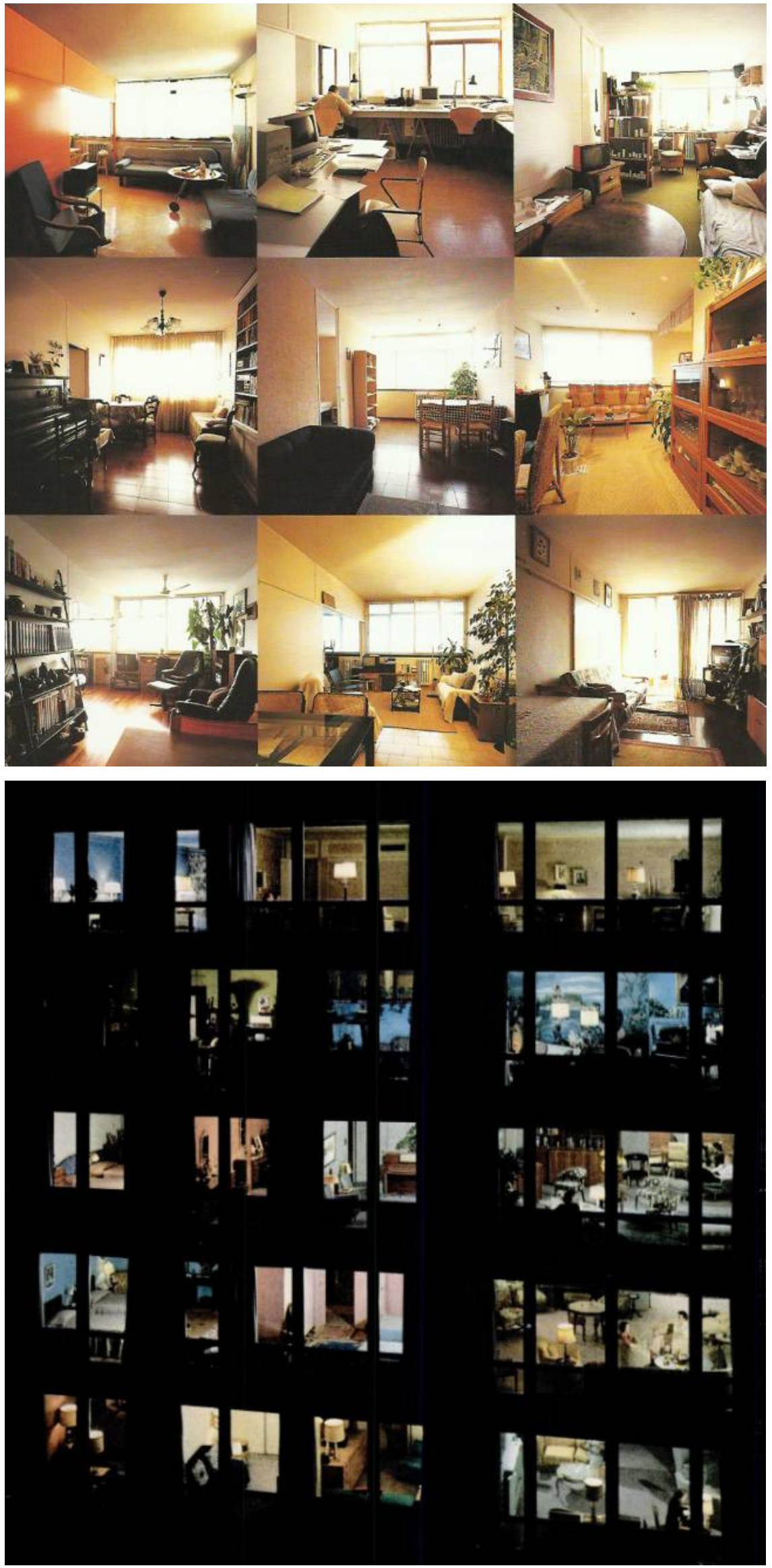
Estos ejemplos son una muestra parcial, pero refuerzan la idea de que existen múltiples necesidades, y lleva a plantear la urgencia de una arquitectura versátil que facilite su desarrollo. Así, esta diversificación de la tipología trata también sobre el hecho de aceptar la diversidad inherente a cada unidad de convivencia, incluso dentro de cada tipo y/o estructura similar. Los resultados de la investigación llevan a afirmar que se puede aprovechar la oportunidad que presenta el desfase entre la oferta y la necesidad de vivienda -la alternativa fruto de esa contradicción- para difundir y asimilar esa diversa manera de apropiación y personalización del espacio doméstico, reflejo de la rica combinación de necesidades que hay en cada unidad de convivencia. Recíprocamente, el fomentar esa toma de conciencia, el trabajar para quitar las ataduras propias de esa idea única de vivienda ligada a la tipología de vivienda convencional -que consecuentemente fuerzan a buscar una idea única de habitar, aún en contra de las propias necesidades-, podría reforzar la implantación de la estrategia de agrupación de unidades de convivencia para poner en carga los espacios de oportunidad detectados. Todo ello, favorecido por la gestión de agentes como los analizados.

$$
-6.2 .2-
$$

\section{Cohesionar la sociedad ocupando los espacios de acumulación}

\section{Desigual reparto geográfico de las oportunidades}

Otra de las interesantes oportunidades detectadas hace referencia a la posibilidad de dar pequeños pasos hacia la mezcla social a partir de una redistribución parcial de la población utilizando como herramienta la localización de la residencia habitual. Tal y como se ha visto en el apartado 3.3.2, la polarización social de la población se ve reflejada geográficamente a través del mercado inmobiliario. Existen diferencias muy marcadas en algunas áreas del AMB, donde se observan límites espaciales claramente perceptibles que dividen tanto poblaciones de diferente perfil socio-económico y cultural, como parques residenciales con características diversas. Convergiendo así morfología social y morfología urbana residencial en un paisaje de precios (Roch, 2009). Una realidad que arraiga en la percepción colectiva el «aceptar como normal una ciudad en que la población está segmentada y distribuida en términos de renta, donde parece inevitable que coexistan en paralelo mundos urbanos totalmente distintos sin apenas comunicarse, a pesar de su colindancias (Sevilla, 2015). Al igual que en el caso anterior para la diversificación de la vivienda, aquí la oportunidad de cohesionar la sociedad se genera también gracias a la suma de dos fenómenos complementarios 
pertenecientes a dos ámbitos diferentes: las características de los espacios de oportunidad, y el papel de los agentes para aprovecharlos.

El primero ha sido identificado en el apartado 3.3.3 y versa sobre la dimensión geográfica de los espacios de oportunidad; en él se ha visto que el potencial existente en el parque actual para implantar la estrategia de agrupación de unidades de convivencia y transformación de dicho parque como herramienta de acceso digno a la vivienda está desigualmente repartido a lo largo de la geografía del AMB. Una territorialización que al depender de dos variables -precio y tamaño de la vivienda en el ejercicio realizado, a falta de datos extendidos sobre la tipología- aparece en ocasiones con fuerza en determinadas zonas con precios altos e incluso muy altos, mientras que en otras con precios bajos resulta más difícil que se den las condiciones para la aparición de estos espacios de oportunidad (Mapas 3.21 y 3.22). Este fenómeno sienta las bases para una hipotética mezcla social en el caso de que esos espacios de oportunidad se activen a través de la mencionada agrupación de unidades de convivencia con rentas bajas.

El segundo fenómeno se debe a la naturaleza de algunos de los métodos llevados a cabo por los agentes estudiados. Estos, de manera intencionada o no, despliegan una serie de herramientas en favor de la mezcla social. Es el caso de los programas públicos Bizigune y ASAP de movilización de vivienda privada a la oferta de vivienda social en alquiler. Al alimentarse de viviendas dispersas a lo largo del parque, los programas llevan implícita la incorporación de unidades de convivencia de rentas medias y bajas -cumplen los requisitos necesarios para ser adjudicados con una vivienda protegida- en un bloque de vivienda colectiva de promoción privada. Aunque este hecho no baste para garantizar la mezcla social, pues fácilmente puede tratarse de un entorno socio-económico similar, sí abre la puerta a que viviendas de entornos diferentes sean incorporadas al programa. Es decir, la metodología de estos programas podría llegar a aprovechar esa territorialización dispersa de los espacios de oportunidad para impulsar cierta cohesión social a través de la residencia habitual. Una cohesión que está también detrás de otros de los casos analizados, con estrategias diferentes. El programa Barriztu es en sí mismo un instrumento que permite a unidades de convivencia formadas por personas mayores, mayoritariamente unipersonales e integradas por mujeres, seguir en su vivienda a través de mejoras en su habitabilidad. Se evitan así posibles desplazamientos a viviendas de familiares o a residencias colectivas, y la posible sustitución de esa unidad convivencial por uno más socio-económicamente más homogéneo respecto a su entorno. A otra escala, los proyectos cooperativos de Etxekoop y Egunsentia Aurora, así como el de Jóvenes Solidarios, incluyen también entre sus objetivos dar pasos hacia una cohesión social de sus integrantes en el barrio en el que se han de ubicar, buscando una integración del proyecto en la comunidad local. 


\section{Hacia el (des)equilibrio del espacio social residencial}

Se trata de oportunidades puntuales y dispersas a lo largo del parque para que, población con rentas por debajo de la media de esas áreas, o con perfiles socio-demográficos diversos, establezca en dichos barrios su residencia habitual, introduciendo pequeños desequilibrios -O equilibrios, más bien- en la geografía social del AMB en general, y en la baja diversidad socio-residencial de algunas de áreas de la región en particular. Efectivamente, estas inserciones de unidades de convivencia podrían interpretarse como posibles equilibrios en un espacio social polarizado tendente a la homogeneización de áreas urbanas concretas, propio de un modelo de alojamiento basado en la acumulación patrimonial a través de la extensión de la vivienda habitual en régimen de propiedad (Roch, 2009):

«...un modelo que podemos calificar de propiedad extendida o generalizada, que impone cualidades bien diferentes al espacio que despliega, que rechaza firmemente la promiscuidad de la morfología precedente y que recorta, no ya el viejo espacio doméstico de las clases superiores, sino todo el Plano de la ciudad, según un mosaico tan depurado como sea posible de piezas de contenido social homogéneo» (Roch, 2009: 176).

Una acumulación que, según el autor, es alimentada por la depuración de los contenidos sociales diversificados de modelos de ciudad residencial precedentes, así como por la degradación de lo urbano en un proceso de homogeneización en camino hacia la segregación. Es por ello que más allá de diversificar la vivienda, los espacios de oportunidad aquí detectados podrían ayudar a desestabilizar en cierta medida el proceso de homogeneización en marcha del espacio social y residencial. Tomando prestada la referencia que Roch (2009) utiliza de Balzac y siguiendo el argumento del autor, podría establecerse un paralelismo etiquetando a estas oportunidades aquí señaladas como pequeños actos revolucionarios que adoptan formas inmobiliarias y que permitirían a ciertas unidades de convivencia «ocupar un espacio [de acumulación] que no les pertenecía, al que acceden como nuevos propietarios o nuevos arrendatarios [para lo cual] se necesita de alguna crisis propiciada por las idas y venidas del poder político y del propio espacio social» (Roch, 2009: 175). Una vez más, son las contradicciones internas del espacio social las que están detrás de esa crisis, y las que generan a su vez estas alternativas de acceso a la vivienda y de cohesión social.

Una ocupación de espacios de acumulación a través de la mezcla social que vendría a suponer una especie de fenómeno opuesto a habituales procesos de gentrificación. Disfrazados de políticas de equilibrio social, estos ocultan el traslado de clases medias a zonas de clases bajas y el consiguiente desplazamiento de las segundas (Slater, 2015; Smith, 2015). Este fenómeno, ya existente en ciertos barrios del $\mathrm{AMB}$, ha de servir como alerta a la hora de evaluar la heterogénea 
distribución de los espacios de oportunidad identificados, para anticiparse a que esta estrategia planteada pueda suponer la generación o refuerzo de posibles procesos similares. Se ha de resaltar que con lo argumentado en este apartado, no se está haciendo referencia a grandes operaciones de realojamiento de colectivos sociales con características alejadas de las de aquellos que residen en el barrio de destino. Esto facilitaría un probable rechazo de la población anfitriona, y una posible alteración de la convivencia por el choque de sentimientos, prejuicios, culturas, niveles y ritmos de consumo, pautas vitales, usos del espacio público, de los espacios de transición o de los propios espacios domésticos. La oportunidad detectada trata más sobre un goteo de nueva población, con mayor o menor constancia, que podría ayudar a la integración y el enriquecimiento mutuo de nuevos y viejos habitantes, normalizando los procesos. Como Blomley apunta, citado por el propio Slater (2015), habitualmente la mezcla social se construye y defiende sobre la promesa de la igualdad ante la jerarquía, pero es «socialmente unilateral»; en este sentido, si los beneficios de dicha mezcla son deseables, «ipor qué no es posible hacer que los pobres vivan en barrios ricos?» (Blomley, 2004: 89). 


\section{$-6.3-$ \\ La acción colectiva como herramienta}

«Nos hallamos en una encrucijada histórica, que no admite medias tintas: defender la vivienda de quienes solo quieren lucrarse de ella se ha convertido en un deber colectivo. Dependen de ello nuestro futuro y el de las generaciones venideras» (Palomera, 2018: 20).

Una revisión de todo lo analizado y planteado hasta aquí pondría en evidencia las tremendas dificultades a las que se habría de enfrentar cualquier estrategia -como la esbozada en el trabajo- para alterar tanto las características del parque residencial existente, como las inercias y puntos de vista economicistas y poco transformadores comunes en muchos de los agentes con algún papel en el proceso de acceso a la vivienda. El modelo hegemónico señalado presenta una rigidez compleja que hace difícil el avance y el desarrollo de estas estrategias y estas experiencias. La alienación residencial, potenciada por un extendido régimen de tenencia en propiedad, lleva a la individualización de todo lo relacionado con la vivienda, y a la internalización de los conflictos existentes en lugar de entenderlos como parte de estructuras sociales y políticas (Madden y Marcuse, 2018: 115). Pero como los mismos autores señalan, ese nuevo sujeto político urbano al que apuntaba Lefebvre en El derecho a la ciudad capaz de constituirse como fuerza transformadora de la sociedad- es la base para una colectivización del acceso a la vivienda, el empoderamiento ciudadano en torno a las políticas de vivienda, y la lucha contra la alienación residencial (Madden y Marcuse, 2018: 33, $77,80)$.

En este sentido, se ha podido observar que en el AMB se están dando pequeños pasos, y que se puede trabajar para que sea más fácil seguir dándolos. Los resultados del trabajo llevan a afirmar que existen pequeñas experiencias profundizando en un proceso de empoderamiento ciudadano y en el desarrollo de una gobernanza de mayor calidad. Lo cual supondría una mayor capacidad de aprovechar las oportunidades aquí detectadas. Aplicando al objeto de estudio de este trabajo las palabras que Roch destinaba a la escala urbana y territorial, podría decirse que «una nueva cultura de la planificación [...] podría reconocer esas realidades fundamentales excluidas, y eso significa volver a empezar desde un proyecto emancipador con una base social amplia y con enfoques integradores: lo contrario del actual divorcio» (Roch, 2016). Es decir, entran en juego aquí aspectos identificados como necesarios para el desarrollo de un urbanismo -en 
este caso en lo que a la vivienda respecta- alternativo: «una ciudadanía que lo demande y una voluntad política que lo implemente» que favorezca «la intersección de esos tres momentos hasta ahora desacoplados: el técnico [...], el social y el político» (Sevilla, 2015).

Ya se han desarrollado en diversos puntos del trabajo -junto a sus retos y limitaciones- las ventajas y el potencial propio de la estrategia de agrupación de unidades de convivencia como herramienta para lograr el acceso económica y espacialmente digno a la vivienda a través de una transformación y una de-construcción de la estructura de la propiedad del parque actual, incorporando, entre otras medidas, una apertura hacia nuevos regímenes de tenencia y formas de organización comunitaria. En la base de todo ello está una necesaria acción colectiva, y una apertura a la conformación -o recuperaciónde una escala de convivencia comunitaria. Esta naturaleza colectiva ha de entenderse en un doble sentido. Las alternativas de gestión han de serlo para tener posibilidades de éxito en el aprovechamiento de los espacios de oportunidad; la respuesta habrá de ser colectiva como sociedad, y darse desde el ámbito privado empresarial, las instituciones, la sociedad civil, o fórmulas mixtas. Ese carácter necesariamente colectivo de la propuesta de agrupación de unidades de convivencia ha sido ya desarrollado. A continuación se apuntan, brevemente, algunas otras dimensiones y escalas de actuación colectiva imprescindibles para generar un contexto adecuado de cara al desarrollo de esta estrategia.

\section{De los retos individuales a la red de agentes}

La baja generalización observada de prácticas colaborativas entre los agentes analizados en el capítulo cuarto se enmarca en lo que se ha señalado como un proceso -el actual- de acceso a la vivienda habitualmente aislado, complejo, difícil y traumático. Las colaboraciones existentes entre algunos de estos agentes son en general débiles; pero el cruce de información que puede llegar a darse entre ellos a través de prácticas basadas en la retroalimentación y la puesta en común de las lecciones aprendidas, así como del desarrollo de proyectos conjuntos, puede llegar a dar resultados de gran interés. Las debilidades de unos y fortalezas de otros pueden subsanarse en cierto modo a través de la oportunidad de reforzar relaciones existentes y crear nuevas alianzas. Se ha visto que avanzar hacia una colectivización del acceso a la vivienda podría permitir alcanzar mejores resultados; también, que se cuenta con un parque residencial que hace deseable la concentración de la gestión en diversos agentes para el desarrollo de la estrategia de agrupación planteada. Ambas cuestiones llevan a la conclusión de que se trata de un camino que ha de pasar por fortalecer y expandir una red que cuente, entre otras, con experiencias ciudadanas, programas públicos, o empresas del tercer sector trabajando de manera colaborativa hacia el objetivo común. Es decir, la generación de redes eficaces de colaboración y comunicación, no ya solo entre agentes de gestión, si no entre estos, propiedad de las 
viviendas y unidades de convivencia con necesidad de las mismas, podría dar forma a una suerte de ecosistema en torno a la vivienda digna. El potencial de desarrollo de una red así por parte de las iniciativas analizadas se cree que es considerable. Lo cual ayudaría a avanzar hacia las tres metas tratadas en la investigación.

\section{Un cambio de mentalidad hacia la responsabilidad social compartida}

Si bien más arriba se ha hecho referencia a los tres momentos que Sevilla (2015) identificaba en el urbanismo actual como desacoplados -el técnico, el social y el político-, esta terna puede en el ámbito de la gestión de la vivienda ser sustituida y/o ampliada por cuatro protagonistas deseables para alterar el estado actual de la cuestión: una sociedad civil activa, una administración pública comprometida y eficaz, un tercer sector viable y desarrollado, y un sector técnico socialmente responsable. Sobre el sector técnico, se han apuntado algunas cuestiones al inicio del trabajo: se ha hecho referencia a la crítica de la razón instrumental como corriente que incorpora cuestiones éticas a la labor técnica (Brenner, 2017b) y que se aleja de posicionamientos que refuerzan, sin su cuestionamiento, las desigualdades actualmente reproducidas por las técnicas y los instrumentos vigentes. En cuanto a la ciudadanía, para lograr poner en marcha los planteamientos de agrupación de unidades de convivencia propuestos y alcanzar un éxito relevante en las diferentes actividades que desarrollan los agentes analizados, el papel a jugar por una sociedad activa y comprometida que ayude a generar valor público es determinante, como viene siendo apuntado desde academia e instituciones públicas (Gobierno Vasco, 2014a; Zubero, 2016). Se ha podido comprobar que, tal y como se planteaba en la herramienta teórica de análisis, las contradicciones del modelo hegemónico no se reducen a una realidad simple de bandos enfrentados -lo que facilitaría en gran medida la dirección hacia la que dirigir las políticas e intervenciones para paliar la situación problemática-, si no que están desigualmente repartidas y son internas a muchos de los agentes y esferas participantes o afectadas. Entre ellas, la sociedad civil:

«ंno ha sido la fiebre inmobiliaria un proyecto de acumulación que, aun urdido por instituciones y élites nacionales y europeas, ha terminado galvanizando la imaginación de una amplia mayoría de ciudadanos comunes? Cuenten, por ejemplo, el número de personas conocidas que decidieron adquirir una segunda vivienda como inversión; que dejaron sus zapaterías, fruterías y negocios tradicionales para convertirse en "operadores" urbanísticos; que decidieron pasarse del alquiler a la propiedad alentados por las expectativas de crecimiento infinito de los precios. En efecto, la ciudad y el urbanismo han servido de vehículos para asegurar una 
hegemonía que ofrecía un horizonte de prosperidad nacional inagotable» (Sevilla, 2015).

Así, la extensión de iniciativas ciudadanas como Etxekoop o Egunsentia Aurora es de gran valor para avanzar hacia la transformación del sistema inmobiliario residencial actual, pues «la acción pública por sí sola no parece suficiente para plantear alternativas a este modelo» (González y Gayoso, 2018). En este sentido, «la experiencia acumulada durante años por los diversos colectivos sociales supone un importante bagaje de conocimiento de incalculable valor que es necesario poner en valor, dar a conocer y utilizar para la construcción colectiva de una alternativa posible más inclusiva y socialmente más justa» (González y Gayoso, 2018). No obstante, y aunque existen tanto en Euskadi como en el AMB interesantes casos acumulando experiencia y conocimiento ${ }^{100}$, la posición general de la sociedad civil evidencia una todavía baja organización al respecto (Burón, 2015c).

La participación de «nuevos actores en el monocorde panorama inmobiliario» será una de las condiciones del necesario y «verdadero rearme democrático, unido a un rearme moral, para que la ciudadanía perciba a los especuladores como una vergonzosa plaga social y no como personas a imitar» (Naredo, 2015: 82). En este sentido, esta puede definir una demanda muy concreta de vivienda e influir y exigir una oferta acorde a la misma -por ejemplo, a través de los cauces de participación y talleres de diseño paulatinamente abiertos desde Alokabide y Visesa-; puede empoderarse, asociarse y actuar como promotora de sus propias viviendas -como en los casos de Etxekoop y Egunsentia Aurora-; y puede desarrollar junto a los agentes públicoprivados que gestionan vivienda proyectos y políticas de diversa escala -como en los casos de Bizigune, ASAP, Eguzkilore, Sumae Coop. o Urbania ZH Gestión-. En muchos de estos casos, la colaboración por parte de una administración pública comprometida y eficaz facilitará en gran medida el proceso. Como señala Naredo (2015), la observación de otros modelos inmobiliarios del extranjero, o la consideración de algunos valiosos trabajos desarrollados y promovidos por las propias instituciones locales sobre la materia permiten identificar la visión integrada y el cambio de lógica como ejes sobre los que construir un compromiso público institucional apoyado en, entre otros, «un núcleo administrativo responsable capaz de gestionar con esa visión integrada» (Naredo, 2015: 82).

\footnotetext{
${ }^{100}$ Se ha podido ver en algunos de los casos de gestión analizados, pero también en la aplicación de la herramienta teórica al contexto social local. Y existen otros muchos casos de interés, como diversos movimientos ciudadanos que realizan labores de acogida a personas refugiadas -entre ellas alojarlas en viviendas de personas voluntarias-, o la aprobación por diversos colectivos sociales y sindicatos en 2014 de la Carta de Derechos Sociales de Euskal Herria -entre los que se incluían cuestiones relacionadas con la ordenación del territorio, el urbanismo y la vivienda-, entre otros ejemplos.
} 
Pero en lo que a este trabajo respecta, buena parte del interés radica en el tercer pilar señalado: el de un tercer sector que juegue un papel importante en la gestión y generación de oferta de vivienda accesible y de calidad, con apoyo institucional y participación ciudadana. Algo que ni en España en general, ni en Euskadi en particular, puede decirse que presente un nivel de desarrollo alto (Burón, 2015b, 2015c), o al menos no como el de otros países europeos con una mayor tradición de esa auto-organización -lo cual no impide la existencia de casos concretos que no han de ser minusvalorados, algunos con largas trayectorias- (Moya, 2008; Trilla, 2002; Whitehead y Scanlon, 2007, 2008).

«Conviene recordar que ningún estado europeo ha conseguido buenos resultados en materia de vivienda sin la utilización de varios de estos sistemas: los parques públicos de alquiler; las empresas privadas sin ánimo de lucro o con ánimo de lucro que proveen alquiler asequible a clases populares y medias (housing associations); las ayudas públicas al pago del alquiler por parte de personas y familias (sea este público, privado non profit o privado mercantil); o la limitación legal de los alquileres privados. Algunos de estos elementos ya existen en Euskadi, aunque en una dimensión cuantitativa y cualitativa aún insuficiente» (Burón, 2015c).

Algunos de los agentes de gestión aquí analizados tienen un perfil similar a las citadas empresas privadas de provisión de alquiler, con unos objetivos compartidos y similares, aunque ninguno pueda definirse como tal. La relativa urgencia de que este tipo de agentes nazcan y se extiendan por el AMB es una percepción compartida por diversos profesionales; una llamada a un tercer sector que ejerza un papel clave en la generación de oferta residencial asequible, en gran medida motivada por la insostenibilidad económica de la subvención pública generalizada a todo la población con problemas de acceso a la vivienda (Cerezo, 2016). El reto viene así definido por aunar un servicio público de vivienda de calidad, un tercer sector fuerte, y unas entidades profesionales y mercantiles capaces de ofrecer dicho servicio (Burón, 2016); la responsabilidad social deberá estar presente en todas ellas, una vez vistas las causas contradictorias que están detrás de la compleja problemática. Con todo, la mera incorporación -y puesta en relación- al proceso de acceso a la vivienda de estos cuatro protagonistas -sociedad civil, administración, tercer sector y equipos técnicos- no puede tomarse como suficiente para el éxito. Pues aunque podría enmarcarse en ese proceso de innovación social definido como de 'gobernanza más allá del estado', este puede ser profundamente afectado o subordinado a una naturaleza frecuentemente engañosa del concepto, bajo el cual el carácter democrático de la esfera política es erosionado por las fuerzas del mercado (Swyngedouw, 2005). 
Esquema 6.1. Esquema conceptual de las estrategias del megáfono y el embudo en procesos de gobernanza. Elaboración propia.

\section{A través de una toma de decisiones informada, abierta y participada}

«La arquitectura, el medio ambiente físico construido y, dentro de éste, la vivienda, son sólo algunos de los campos en los que la actuación aislada e independiente de los especialistas ha generado resultados polémicos» (Romero y Mesías, 2004: 57).

Uno de los obstáculos para lograr incorporar otras visiones a los momentos de toma de decisiones es el desequilibrado peso en la participación, por parte de los diferentes agentes involucrados y/o afectados, en los procesos de planificación urbana y territorial actuales. $\mathrm{Y}$ en este caso, en las políticas de vivienda. Se trata en general de una toma de decisiones totalmente parcelada y monopolizada, realizada de arriba a abajo. Las aproximaciones han sido y son excesivamente funcionalistas y cuantitativas, actuando de manera parcial y aislada, desarrollando objetos acabados bajo procesos desvinculados «de los deseos, necesidades y posibilidades cambiantes de sus habitantes» (Romero y Mesías, 2004: 15). Muchos agentes tiene gran dificultad de participación, quedando fuera, de esta manera, esas muchas otras visiones y perspectivas de gran importancia; y reflejándose en un desequilibrio físico $\mathrm{y}$ socioeconómico en el territorio.
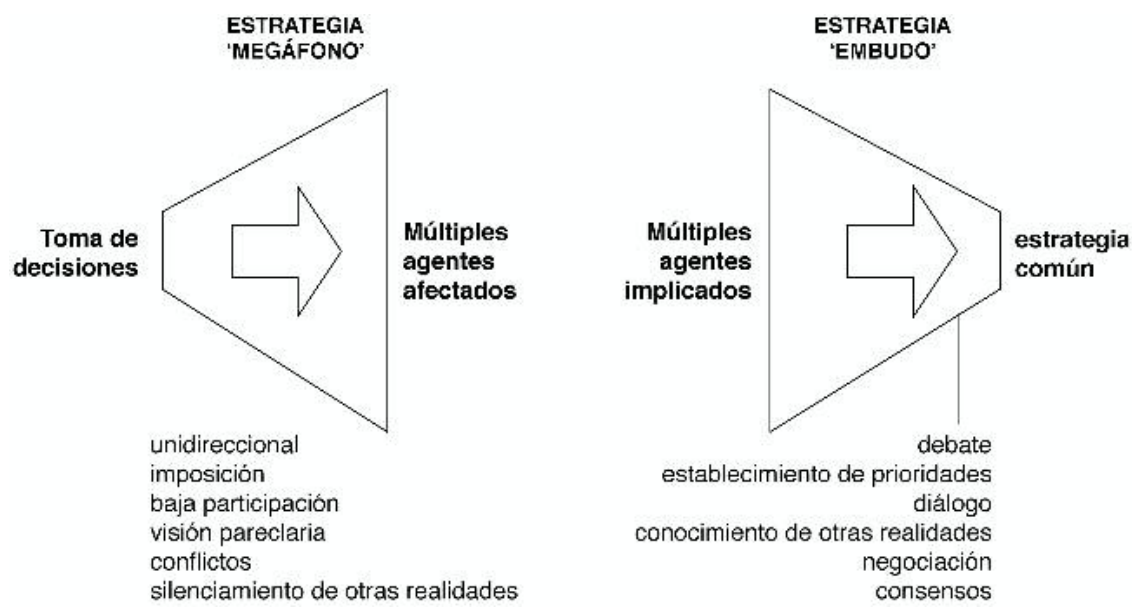

El modelo anterior puede definirse de una manera sintetizada como la estrategia del megáfono (Esquema 6.1), en la que unas pocas entidades o un sector concreto -en este caso, el formado por los agentes cuyas contradicciones internas se decantan hacia una visión mercantilista de la vivienda- habla, dicta y difunde una serie de normas, imposiciones o lógicas, y el resto de actores trata de aplicarlas o adaptarlas a su realidad. Son tomas de decisiones alejadas de la población finalmente afectada, unidireccionales, con visiones parciales de la problemática a tratar, y con facilidad para generar conflictos y 
silenciar posturas divergentes. Hay «pocas oportunidades para debatir cuestiones fundamentales relacionadas con la naturaleza del sistema habitacional. El debate político urbano está circunscrito a un consenso muy estrecho. Los movimientos sociales tienen poco espacio para reivindicar alternativas dentro de los límites del debate contemporáneo» (Madden y Marcuse, 2018: 202). Pero desde otras posiciones, se vienen exigiendo y planteando estrategias tipo embudo, en el que se introducen muchas visiones e intereses y sale una propuesta o planteamiento unitario. Esta segunda opción conlleva la implicación de mayor número y diversidad de agentes, la incorporación de más y más diversa necesidades e intereses, la necesidad de dialogar y debatir, establecer prioridades, llegar a consensos, o dar espacio a realidades generalmente excluidas, logrando una estrategia común en mayor o menor nivel compartida. En definitiva, una toma de decisiones abierta a otras posturas, opiniones, necesidades y realidades.

Se trata, por tanto, de abrir los procesos de toma de decisiones a todos esos agentes involucrados y/o interesados para combatir una 'gobernanza más allá del estado' excesivamente dirigida desde ámbitos de mercado. El Libro Blanco de Democracia y Participación Ciudadana para Euskadi (Gobierno Vasco, 2014a) incluía, entre una serie de propuestas de cambio, la construcción de lo público desde lo colectivo a través de dos líneas de actuación en sintonía con lo apuntado previamente: una administración cercana y permeable que promueva el diálogo constante y la cooperación con la ciudadanía, y una ciudadanía comprometida que asuma un papel más activo en la generación de valor público. Uno de los grandes retos para ello es que los agentes participantes, y especialmente la ciudadanía, esté suficientemente informada para que su aporte sea de calidad y relevante. Es esta otra de las patas necesarias para cimentar el compromiso público institucional con «un proceso que incentive y facilite la participación informada de los ciudadanos en la toma de decisiones» reforzando específicamente «la democracia participativa en el escalón local» (Naredo, 2015: 81):

«Por eso es tan importante un análisis de las contradicciones capaces de generar tales crisis generales. Si los movimientos de oposición y en particular los anticapitalistas saben qué pueden esperar en general al ampliarse e intensificarse las contradicciones, estarán mejor preparados para aprovecharlas, en lugar de verse sorprendidos y frustrados por su desarrollo (tanto geográfico como sectorial) en el curso de la formación y resolución de las crisis. Si éstas son fases de transición y turbulencia en las que el capital se reconstituye con una nueva forma, son también fases en las que se pueden plantear cuestiones profundas y los movimientos sociales que tratan de rehacer el mundo transformándolo pueden actuar sobre ellas» (Harvey, 2014: 29). 
En lo que a los resultados de este trabajo se refiere, aquí entra en juego la educación y la divulgación de otras opciones tipológicas, de regímenes de tenencia, de los espacios de oportunidad aprovechables mediante la agrupación a diferentes escalas,... En definitiva, la necesidad de divulgar y difundir las oportunidades espaciales y de gestión aquí presentadas. No solo en la esfera de la política y la gestión inmobiliaria, si no también entre las personas potencialmente habitantes de estas viviendas. Para que sean conscientes de las posibilidades que se les ofrecen y puedan así demandarlas y exigirlas tanto a las instituciones y al mercado, o autoabastecerse. Otro de los grandes retos será la definición, establecimiento y fomento de nuevos o diferentes entornos de relación que engloben a ciudadanía, las instituciones y la empresa privada para la adecuada implantación y desarrollo de este tipo de estrategias con el fin de responder al problema de acceso a la vivienda. En este sentido, se ha podido ver que algunos de los modelos alternativos que se han analizado permiten o introducen una mayor participación por parte de la ciudadanía y otros agentes -lo que conlleva a mejores respuestas-. En cualquier caso, esta apertura de los procesos de gobernanza para dar cabida y soporte a un ecosistema de agentes más diverso y complejo, supone la necesidad de que estos sean desarrollados con el apoyo de otro tipo de herramientas de participación diferentes a las hasta ahora utilizadas (Enet, 2008; Romero y Mesías, 2004):

«Para desalienar y humanizar el sistema habitacional, los residentes deberían ser los principales responsables de la toma de decisiones, tanto en las viviendas privadas como en las públicas, y su voz debería tenerse más en cuenta en el proceso de planeamiento de ordenación urbana» (Madden y Marcuse, 2018: 224)

\section{Agentes complementarios y otras herramientas}

Cabe apuntar que la diversidad de agentes participantes $-\mathrm{y}$ afectados- en la gestión de la vivienda es mucho más rica que la muestra parcial analizada en el trabajo, habiéndose centrado esta en aquellos que juegan algún papel en el proceso de acceso. Fuera de este, son muchos los que desarrollan una actividad fundamental para lograr entornos domésticos y comunitarios de calidad; entidades públicas y privadas dedicadas a la prevención y mediación de conflictos y el fomento de la convivencia, o empresas administradoras de fincas con un enfoque muy centrado en la convivencia y en lograr comunidades informadas y responsables con su entorno socioambiental, entre otras. La idea de abordar desde lo colectivo las estrategias de transformación y gestión de la vivienda puede extenderse y alcanzar múltiples esferas y dimensiones. La complejidad y multidimensionalidad de la vivienda, ya comentada en el capítulo primero, hace que muchos sean los ámbitos influidos y/o interesados. 
Uno de ellos es la posibilidad de generar empleo, bajo una serie de criterios específicos, al proceso de transformación de las viviendas incorporado en la propia estrategia de agrupación de unidades de convivencia. Más allá del interés compartido por parte de muchos agentes públicos y privados por alimentar el sector de la construcción -el fomento de estas actuaciones llevaría implícito un fomento del empleo en dicho sector, algo que se está buscando con bastante ímpetu desde que se comenzó a frenar el ritmo de edificación de nuevas viviendas-, el interés de colectivizar esta dimensión constructiva radica en apostar por que se haga de una manera socialmente responsable, facilitando a empresas constructoras con políticas de reinserción social o de contratación de personas en desempleo propias de los barrios en los que se actúe -las experiencias de Eguzkilore y Barriztu así lo hacen-. 


\section{- 6.4 - \\ Necesidad y contradicciones vigentes y en evolución}

«Una suave manera de calificar la situación del mercado de la vivienda es la grave crisis entre oferta y demanda de alojamiento. En efecto, la oferta inmobiliaria se ha dirigido a demandas solventes y rentables, lo que en el período del "boom inmobiliario" ha producido entre otras cuestiones, un importante conjunto de viviendas secundarias y de altos precios, muy alejadas de las capacidades económicas de la población con necesidades de alojamiento, agravando no sólo un problema social importante sino mostrando además que las inversiones realizadas con fuertes recursos crediticios, han sido social y económicamente ruinosas» (León Paniagua, 1995:45).

Estas palabras, que podrían perfectamente ser un análisis del mercado residencial de la última década en España, resultan ser una lectura del mercado de la primera mitad de la década de 1990. La vigencia y la repetición de ciertos ciclos de los problemas relacionados con el acceso a la vivienda a lo largo del tiempo reafirman el carácter estructural de los mismos, tal y como se ha defendido en este trabajo. Un panorama que se mantiene en líneas generales, pero que va sufriendo cambios y evoluciones. En el capítulo segundo se ha visto que existe, hoy en día en el AMB, una necesidad de vivienda no cubierta, plasmada en la situación problemática. A lo largo del trabajo se ha ido apuntado a cómo esta puede ir variando según cambien factores como los perfiles de las unidades de convivencia necesitadas y demandantes, las características del parque residencial para satisfacer dicha necesidad, o el posicionamiento desde el que actúen los agentes implicados en el proceso. Cambios que se producirán de manera inevitable en la medida en que son variables que pertenecen a un contexto más amplio con sus correspondientes cambios sociales, económicos, ambientales o culturales.

Como problemática generada dentro de y debido a un sistema de organización social concreto, mientras se mantengan las principales características de este se podrá afirmar tanto la vigencia de la problemática, como su permanente evolución. Es un fenómeno inmerso en un espacio geográfico y social concreto, y por lo tanto influido por interacciones contextuales de manera fundamental (Brenner et al., 2015). Los datos presentados a lo largo del trabajo, 
desde la aplicación local del marco teórico y su herramienta de análisis, al breve repaso a la historia reciente de algunas respuestas públicas, civiles y privadas desarrolladas para atajar el problema de acceso a la vivienda en el AMB son una prueba de ello. La intención del presente apartado es, transcurrido un tiempo desde el desarrollo de los primeros capítulos de la tesis, poner el énfasis en la -todavíaurgente necesidad de abordar dicha problemática; se hace a través de una serie de muestras parciales que evidencian la rabiosa actualidad de los condicionantes y obstáculos que generan las contradicciones señaladas. Lo cual lleva a reafirmar lo planteado sobre la necesidad de tomar caminos con cierto componente imaginativo y experimental como los aquí analizados para afrontar todo ello. Estrategias que desarrollen mecanismos de análisis y elaboración continua para pasar del plan a la planificación continua y poder así responder con mayor éxito a fenómenos aún ni imaginados (Tejerina, 2015).

\section{Evolución de precios y rentas}

Durante el desarrollo del capítulo tercero, se observaba en los años previos al momento de la toma de datos para la investigación una brecha que se iba estrechando, si bien lo hacía a un ritmo lento, entre renta personal -mantenida o ligeramente en aumento- y precios de mercado -en descenso-. De manera que la tendencia auguraba una mayor accesibilidad económica, puesto que parecía que iba a darse una capacidad de pago similar ante una oferta algo más asequible. Es decir, dado que el parque seguiría siendo el mismo en cuanto a sus características de tamaño y tipológicas, cada vez sería posible el acceso a viviendas con un tamaño mayor, para una misma agrupación de unidades de convivencia. Sin embargo, desde el momento de la toma de datos, en la primavera de 2015, hasta la redacción final de este trabajo, en el otoño de 2018, la pauta ha cambiado. Si bien la renta media sigue una tendencia ligera hacia el alza, se puede decir que se mantiene en valores muy estables y cercanos a los $1.400 €$ de referencia tomados para el cálculo de la accesibilidad económica (J. López, 2014). Los datos del INE hasta 2017 para toda la comunidad autónoma de Euskadi sitúan la renta personal media en torno a los $1.200 €$ mensuales, mientras que los del Eustat, hasta 2016, son algo más positivos. La renta total en Euskadi para ese año era de 1.703€; 1.651€ en Bizkaia y 1.642€ en el Gran Bilbao. La renta disponible, más baja, se situaba en $1.429 €, 1.380 €$ y $1.371 €$ respectivamente (Gráfica 6.1). En cualquier caso, todo ello, al igual que la referencia utilizada del trabajo de López (2014), se ha de tomar con la cautela a la hora de interpretar con detalle los resultados obtenidos. Ya que el mantenimiento o leve repunte de la renta media puede ocultar una polarización del espectro total y una baja capacidad económica de demanda de vivienda en los colectivos que a este trabajo interesan (Gráfica 6.2).

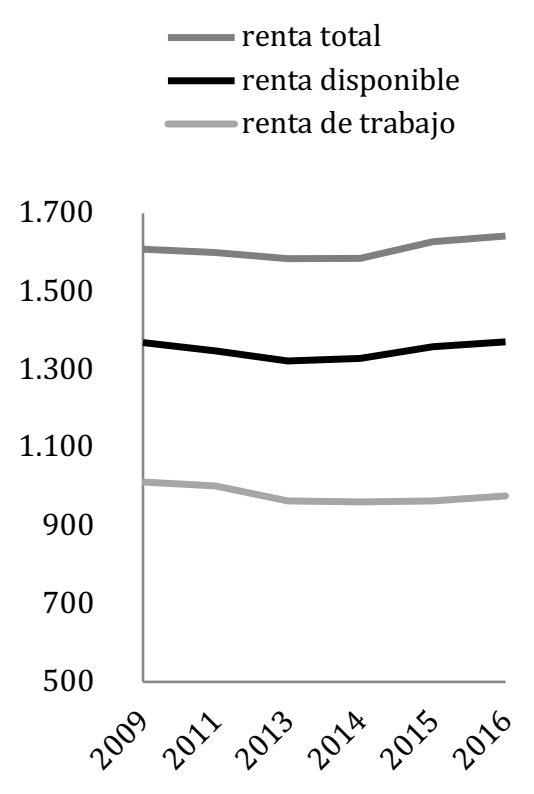

Gráfica 6.1. Evolución de la renta media en Euskadi en el periodo 2009-2016. Eustat, 2018. 
Gráfica 6.2. Evolución de los ingresos mensuales netos per cápita en Euskadi en el periodo 2008-2016, por decilas de ingresos. Eustat, Encuesta de Pobreza y Desigualdades Sociales.

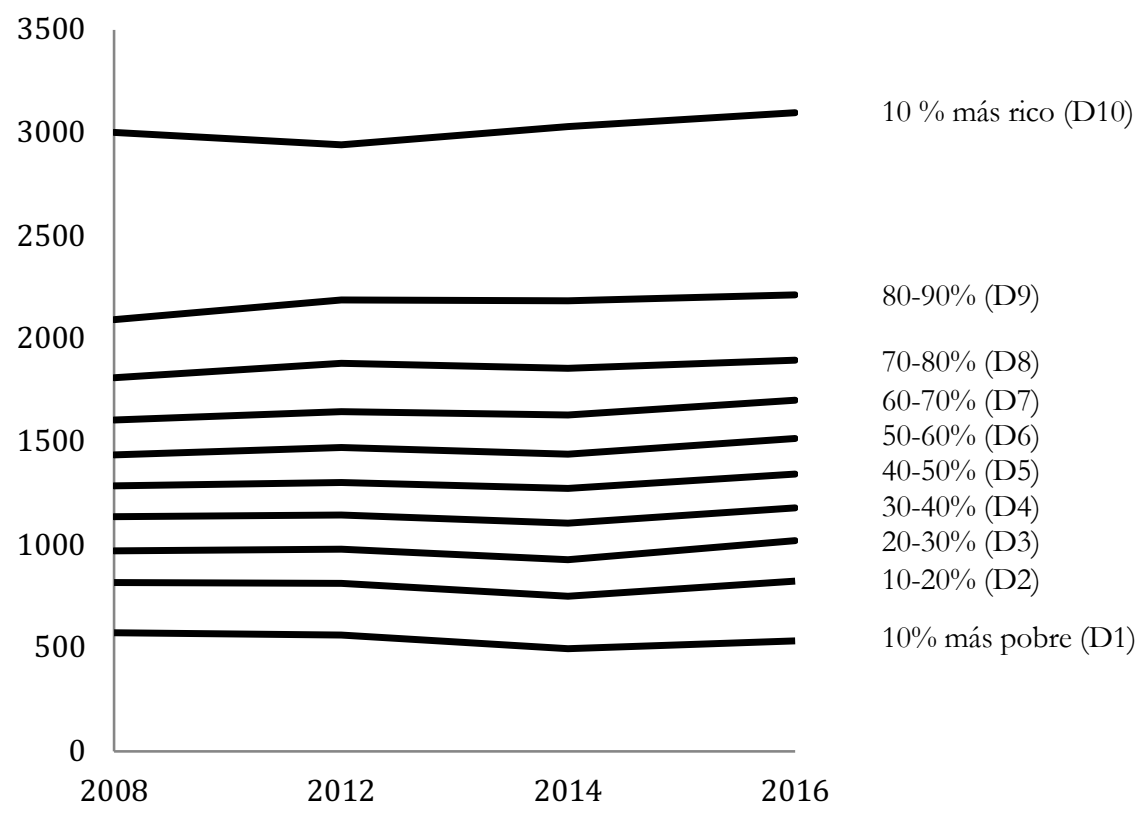

Todo ello deberá ser evaluado de manera pormenorizada en fases en las que se aplique el conocimiento y los planteamientos aquí propuestos, a través de estudios cuantitativa y cualitativamente más profundos. De esta manera, los datos disponibles de rentas personales indican que, a priori, las referencias tomadas en el trabajo siguen siendo válidas ${ }^{101}$. Lo cual no debe tomarse como algo positivo pues, como se ha visto, el porcentaje de la renta disponible destinada a los gastos propios de la vivienda para una parte importante de la población está muy por encima del $30 \%$ deseado y planteado tanto por entidades públicas, sociales, y financieras. Algo que parece ir de hecho en aumento según datos nacionales; las personas jóvenes destinan alrededor de un $60 \%$ de sus ingresos al pago de la hipoteca en el caso de la compra, y en torno al $90 \%$ en el caso del alquiler ${ }^{102}$. Un fenómeno que además tiene otras dimensiones añadidas de exclusión, en este caso por género: las mujeres destinan un 17\% más

101 Una referencia lejana y fuera del alcance de muchas personas, ya sea por no contar con rentas de trabajo, por que estas sean intermitentes, o sencillamente por ser inferiores a la misma. Sin embargo, la necesidad - para el desarrollo de la investigación- de tomar una base establecida externamente con criterios compartidos, así como de contar con una cifra como objetivo mínimamente digno a alcanzar en el contexto actual, ha llevado a tomar dichos 1.400€. Por otro lado, el margen que la estrategia de agrupación presenta para personas sin capacidad de pago ofrece cierta flexibilidad a unidades de convivencia que no llegan a dicha cifra.

102 Pisos.com (2018): «Los jóvenes menores de 25 años destinan a la vivienda un $8 \%$ más que el año pasado», disponible en https://www.pisos.com/salaprensa/los_jovenes_ destinan_a_la_vivienda_un_12_mas_que_el_ano_pasado.pdf.

El País (2018): «Los jóvenes españoles ya no pueden ni comprar ni alquilar vivienda», disponible en https://elpais.com/economia/2018/11/22/actualidad/1542902550_758805. html. 
la hipoteca y un 25\% más al alquiler que los hombres según el informe citado de la agencia inmobiliaria Pisos.com.

Por lo tanto, el cambio observado no está en la capacidad de renta -que sigue en valores similares, y la cual ya se había visto como deseable que se incrementase para equilibrar el gasto excesivo destinado por cada unidad de convivencia a la vivienda, con los precios de 2015-, si no en los precios. Tomando como fuente de información la misma que la usada para el análisis del parque en 2015 -el portal inmobiliario Idealista-, puede observarse un cambio en la pauta de descenso de precios detectada entonces, produciéndose el inicio de una nueva subida en la oferta de viviendas de segunda mano en el AMB (Gráfica 6.3).

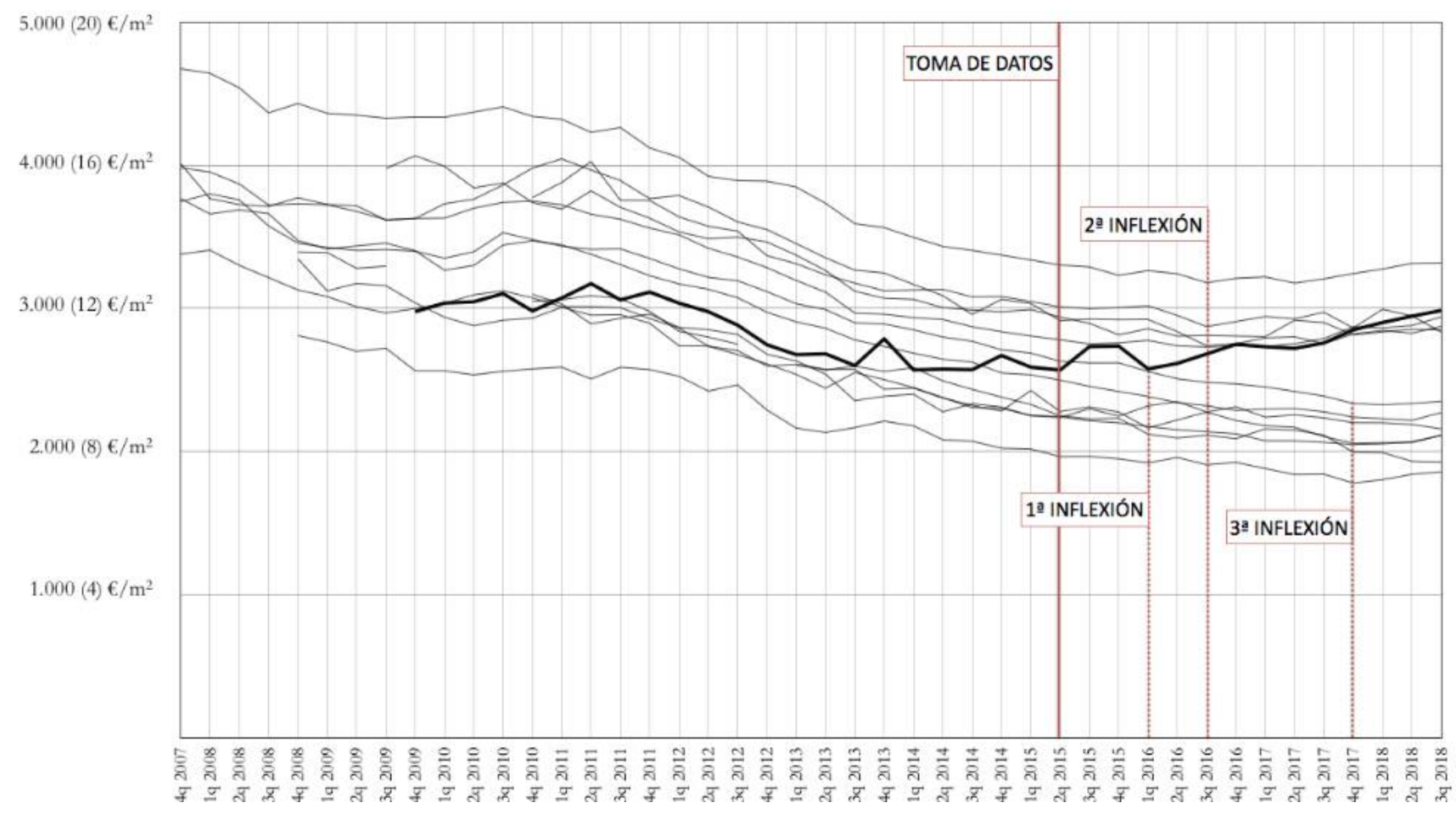

Un cambio que no se produce al unísono en todas las áreas geográficas en las que la fuente disgrega el $\mathrm{AMB}$, si no que parece tener tiempos diferentes según la zona. Como se indica en la gráfica, y en el caso de la venta, aproximadamente un año después de la recogida de datos para el análisis del parque residencial local se observa un punto de inflexión (tercer trimestre de $2016,2^{\circ}$ en la Gráfica 6.3) a partir del cual los datos relativos a varios municipios comienzan una fase de ascenso. Los datos disponibles no incluyen a la totalidad de los municipios del AMB, pero sí pueden considerarse como una muestra parcial representativa. Así, este grupo en el que la subida se produce primero lo forman principalmente municipios de la Margen Derecha -Berango, Getxo, Leioa y Sopela- así como el propio Bilbao. Es decir, municipios con rentas y precios de mercado
Gráfica 6.3. Evolución de los precios de la oferta de vivienda usada en venta en el AMB en el periodo 2007-2018 (municipios de Barakaldo, Basauri, Berango, Bilbao, Galdakao, Getxo, Leioa, Ortuella, Portugalete, Santurtzi, Sestao y Sopela). Resaltado, los valores para el alquiler en Bilbao. Elaboración propia a partir de Idealista, 2018. 
Mapa 6.1. Clasificación de los municipios en función de la fecha en que se produce el punto de inflexión y comienza una nueva fase de subida de precios de venta en el AMB; en oscuro, tercer trimestre de 2016, en claro cuarto de 207. Elaboración propia a partir de Idealista, 2018. más altos. Aproximadamente un año después (cuarto trimestre de $2017,3^{\circ}$ en la Gráfica 6.3) se observa como en el resto de los municipios de los que se disponen datos se comienza a dar un reflejo de los anteriores, comenzando una fase de subida de precios de la vivienda usada, que es, como se ha de recordar, el objeto de estudio de este trabajo. En este caso, son municipios pertenecientes a la Margen Izquierda y al Bajo Nervión -Barakaldo, Basauri, Galdakao, Ortuella, Portugalete, Santurtzi, y Sestao-, es decir, de rentas y precios medios más bajos. Este desfase temporal, claramente diferenciado y geográficamente localizado (Mapa 6.1), podría interpretarse como un ejemplo del efecto muelle anteriormente mencionado, generando una tensión de la capacidad de pago que no encuentra grandes impedimentos para alcanzar incluso aquellas zonas con problemas de exclusión y vulnerabilidad residencial (Roch, 2009), y confirmando así uno de los fenómenos internos del propio modelo residencial que hacen que pueda interpretarse este como estructuralmente contradictorio.

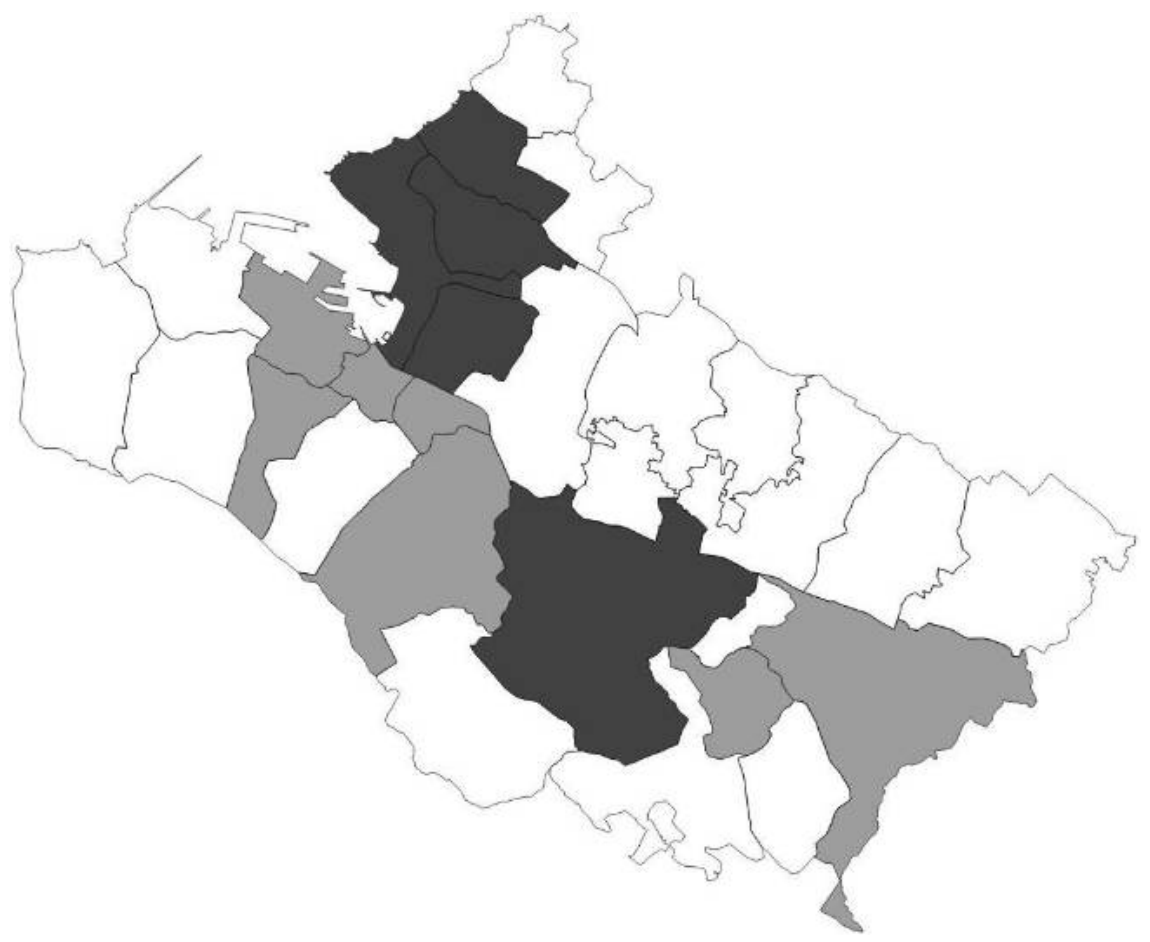

Para el caso del alquiler, en el portal de Idealista solo se cuenta con datos históricos de la evolución del mercado de la oferta para el caso de Bilbao, y no del resto de municipios. En cualquier caso, el momento de inflexión de este parece que se haya dado incluso algo antes que el de la venta, en torno al primer trimestre de $2016\left(1^{\circ}\right.$ en la Gráfica 6.3), y con una clara tendencia hacia la subida. No obstante, la falta de datos a través de esta fuente puede, en un momento aproximativo, suplirse con otras. Más allá de la disparidad entre fuentes y datos, sí parece haber un diagnóstico compartido: la subida 
de los precios del alquiler es un fenómeno evidente. En agosto de 2018 se calculaba que la media de Bizkaia había subido un 5\% en el último año ${ }^{103}$; algo similar se estimaba del mercado bilbaíno en marzo de ese mismo año ${ }^{104}$. Un fenómeno que comienza a alcanzar tintes de ir configurando una nueva burbuja inmobiliaria, como se apuntará más adelante.

Todo esta evolución tiene al menos dos importantes lecturas. En primer lugar, a la ya conflictiva y urgente situación inicial desarrollada en el capítulo segundo, se suma una deriva preocupante. Junto a una continua precarización de las clases con menos recursos del espectro social -los bajos salarios, la precariedad e inestabilidad laboral, y la nula capacidad de ahorro están llevando a una verdadera exclusión residencia ${ }^{105}$-, comienza una nueva etapa de subida generalizada de precios, posiblemente arrastrada por diversos fenómenos. Como el de ciertos colectivos que sí están alcanzando una capacidad adquisitiva mayor y de esta manera están estirando el rango superior de la oferta -a pesar del incremento generalizado de los ingresos mensuales netos, las cifras son bajas en los primeros rangos, estando cerca del $60 \%$ de la población con rentas por debajo de los $1.400 €$ tomados como referencia (Gráfica 6.2), con lo cual todavía lejos de poder demandar vivienda en el mercado bajo condiciones dignas ${ }^{106}$ - O la irrupción de grupos y fondos de inversión de escala global en el mercado inmobiliario local -aunque en menor medida que en otras ciudades y regiones, también se está dando en Bilbao, con grupos internacionales buscando operaciones de al menos 15 millones de euros en 'productos' como viviendas, o residencias de estudiantes y mayores ${ }^{107}$, facilitado a través de empresas consultoras locales orientadas a este tipo de actividades-, y el crecimiento y asentamiento, también pausado pero evidente en el AMB, de un sector de las viviendas en alquiler orientadas al turismo ${ }^{108}$. Fenómenos que pueden ser parte de

103 El Correo(2018): «El precio medio del alquiler en Euskadi alcanza ya los 983 euros y supera su récord histórico», disponible en https://www.elcorreo.com/economia/preciomedio-alquiler-20180830224359-nt.html.

104 Europapress (2018): «El precio del alquiler en País Vasco sube un 1,90\% en el primer trimestre, hasta una renta media de 1.096 euros», disponible en https://www.europapress. es/euskadi/noticia-precio-alquiler-pais-vasco-sube-190-primer-tri mestre-renta-media-1096euros-20180409111449.html.

105 El País (2018): «Los jóvenes españoles ya no pueden ni comprar ni alquilar vivienda», disponible en https://elpais.com/economia/2018/11/22/actualidad/1542902550_758805. html.

106 Noticias de Álava (2017): «La desigualdad persiste pese a la menor tasa de pobreza de Euskadi», disponible en https://www.noticiasdealava.eus/2017/10/17/sociedad/la-desigual dad-persiste-pese-a-la-menor-tasa-de-pobreza-de-euskadi.

107 Idealista News (2018): «El fondo alemán Patrizia quiere invertir más en España: busca activos en Valencia, Sevilla y Bilbao», disponible en https://www.idealista.com /news/inmobiliario/empresas/2018/12/11/770356-el-fondo-aleman-patrizia-quiereinvertir-mas-en-espana-busca-activos-mas-alla-de?sf_ua=1.

108 Deia (2017): «Pablo Rey: "Internet permite que se anuncien con licencia pisos turísticos que no la tienen"», disponible en https://www.deia. eus/2017/09/18/bizkaia /internet-permite-utilizar-con-licencia-pisos-turisticos-que-no-la-tienen. 
una tendencia más amplia de recuperación de valor desigualmente repartido tras la crisis del sector:

«En cualquier caso, la recuperación del valor de la propiedad inmobiliaria, especialmente en Estados Unidos y Gran Bretaña, donde había sido severamente golpeada durante la crisis, implicó el restablecimiento del valor de una enorme cantidad de activos, aunque, como siempre sucede, ahora se encontraban en manos de los ricos, contribuyendo así a la enorme redistribución regresiva de la riqueza que, en ausencia de intervenciones revolucionarias, se produce habitualmente en el transcurso de una crisis. Las devaluaciones tendrían que haber sido mucho mayores y duraderas que las experimentadas en 2008, quizá cercanas a las de las décadas de 1930 y 1940, para tener realmente cierto efecto corrector» (Harvey, 2014: 230).

En segundo lugar, los cálculos desarrollados para el indicador de la Accesibilidad Económica, y por consiguiente los de la Accesibilidad Total, pueden verse obsoletos en la medida en que los precios de la vivienda libre sigan una evolución al alza relevante, como la que parece que puede estar iniciándose, mientras los ingresos se mantengan o apenas suban. Los altos porcentajes de vivienda económica y espacialmente asequibles, y por lo tanto potencialmente transformables, detectados en este trabajo ofrecen todavía quizás un margen de maniobra considerable para poder poner en práctica la estrategia de agrupación, acceso y transformación planteada. Pero la tendencia que parece ha comenzado, señalada en la Gráfica 6.3, supone el refuerzo de la ya existente presión sobre las unidades de convivencia con necesidad de vivienda en el AMB, y posiblemente haya puesto en marcha la cuenta atrás para poder desarrollar y aplicar las oportunidades detectadas y las propuestas aquí lanzadas.

El margen es todavía amplio, teniendo en cuenta que los precios con los que se ha trabajado son de oferta y no de cierre de contratos de compra-venta o alquiler, probablemente más bajos en general. Pero la tendencia identificada ha cambiado y, una vez más, las evoluciones del mercado inmobiliario siguen su curso sin llegar a alcanzar un ajuste satisfactorio entre la oferta y la demanda (y necesidad) de vivienda de una importante parte de la población. La oferta vuelve a la senda del estrangulamiento de la capacidad de pago, normalizando el esfuerzo económico de muchas unidades de convivencia. Esto verifica el anómalo comportamiento del mercado inmobiliario (Naredo y Montiel, 2011; Roch, 2009), y de unas teóricas leyes de equilibrio entre la oferta y la demanda que no son aplicables a la vivienda. Esta investigación muestra algo ya conocido como es la existencia de una creciente polarización y desigualdad social en el acceso a la vivienda. Pero sus resultados, además de ofrecer matices, aportar nuevo conocimiento al tema, y señalar posibles estrategias de transformación, pueden servir de base para estudios de la evolución del parque a lo largo de los años. 


\section{Diversificación constante de unidades de convivencia}

Más allá de las estadísticas y categorías oficiales en las que se encaja el amplio abanico de unidades de convivencia (Tabla 2.6), una mirada más cualitativa al contexto social permite poner en evidencia que hay una constante evolución socio-demográfica. Una diversificación que toma forma en muy diversas situaciones vitales, y que conforma en última instancia las diferentes unidades de convivencia. Algunas de estas diversas situaciones han sido señaladas a lo largo del trabajo, y se cree que una adecuada respuesta a estas debe superar las estadísticas de unidades de convivencia convencionales, observando de manera transversal otros fenómenos más amplios, y cómo estos pueden afectar a la estructura del colectivo con necesidad de vivienda asequible. Se quiere apoyar este argumento con dos pequeños ejemplos locales y actuales.

El primero, es la diversa variedad de situaciones de necesaria acogida de personas vulnerables en viviendas, fuera de dispositivos de otro tipo como albergues u otros centros de atención. El AMB, como otras muchas regiones del mundo $-\mathrm{y}$ no solo recientemente, aunque la crisis global de personas refugiadas ha aumentado la demanda y el sistema público de acogida se ha visto superado ${ }^{109}$ - es punto de llegada y/o de paso de personas vulnerables con necesidad de, entre otras cosas, un alojamiento digno para poder construir y desarrollar una vida en condiciones. Son en general personas solas o familias en busca de asilo político que huyen de diferentes situaciones conflictivas en sus países de origen, y para las que contar con una red de apoyo formada por instituciones y/o entidades del tercer sector resulta indispensable para lograr la autonomía personal. Redes que además de otras cuestiones como el asesoramiento jurídico, aprendizaje del idioma local, o facilitar la inserción sociolaboral, ofrecen en muchos casos pisos de acogida temporales. Y son precisamente estos últimos los que posibilitan que a través del resto de herramientas desplegadas se normalice su situación. Es decir, la vivienda como soporte elemental de la vida sobre la que apoyar otras dimensiones fundamentales.

${ }^{109}$ Los medios vienen reflejando esta situación, especialmente en los últimos tiempos:

El Mundo (2015): «Bizkaia revé la llegada de un centenar de refugiados por trimestre en 2 años», disponible en https://www.elmundo.es/pais-vasco/2015/10/05/561299fc46163fa5 798b4583.html.

Deia (2018): «Euskadi Prevé alcanzar este año los 2.000 refugiados», disponible en https://www.deia.eus/2018/02/06/sociedad/euskadi/euskadi-preve-alcanzar-este-ano-los2000-refugiados? random $=334507$.

Deia (2018): «Unos 80 migrantes y refugiados han llegado a Bilbao en las últimas semanas», disponible en https://www.deia.eus/2018/07/05/bizkaia/bilbao/unos-80-mi grantes-y-refugiados-han-llegado-a-bilbao-en-las-ultimas-semanas-.

Deia (2018): «Crean un alojamiento de urgencia de 48 plazas para migrantes que llegan a Bilbao», disponible en https://www.deia.eus/2018/07/04/bizkaia/crean-un-alojamiento-deurgencia-de-48-plazas-para-migrantes-que-llegan-a-bilbao-. 
Algunas de estas iniciativas son desarrolladas por organizaciones como la Comisión de Ayuda al Refugiado (CEAR) en Euskadi, o Cruz Roja, entre otras. En ambos casos, los pisos de acogida que ofrecen forman parte de un sistema de respuesta con un límite temporal. CEAR Euskadi cuenta en Bizkaia con 17 dispositivos de este tipo; los utilizan en la primera fase del itinerario de asilo, que dura entre 6 y 9 meses. En el caso de la Cruz Roja, la intervención total consta también de varias fases con una duración total de entre 18 a 24 meses. Según datos de 2005, esta entidad tenía en Bilbao dos pisos de acogida de ocho plazas cada uno; uno de ellos se destinaba a familias y el otro a personas no acompañadas. En ambos casos se alertaba de que, a pesar de existir viviendas vacías en el parque privado, existe una dificultad importante para lograr que se alquilen estas para este tipo de fines ${ }^{110}$. Según organizaciones como SOS Racismo y Eraberean, las situaciones de discriminación a la hora de acceder al mercado de la vivienda se dan con facilidad. La primera detectó en una encuesta realizada en 2015 altos porcentajes de la misma hacia personas de otras nacionalidades -un $70-80 \%$ frente a un $30 \%$ de personas autóctonas-, mientras que la segunda detectó 28 casos documentados en 2017. Son algunos ejemplos de las numerosas demandas que diversos colectivos y asociaciones civiles han realizado al Ararteko, Defensor del Pueblo vasco, en relación a los obstáculos encontrados por, especialmente, colectivos de personas migrantes en busca de protección internacional -algunas con estatuto reconocido de refugiadas-, o pertenecientes a minorías étnicas y culturales ${ }^{111}$. Todo ello, a pesar de contar en ocasiones con ingresos laborales o contar con prestaciones económicas públicas, lo cual ha hecho que esta figura haya solicitado al Gobierno Vasco el desarrollo de medidas para evitar este tipo de discriminación.

La lectura de todo ello es que, lejos de ser una realidad coyuntural, se trata de una demanda real y constante -CEAR Euskadi lleva activa desde 1989, y Cruz Roja Bizkaia cuenta con pisos de acogida en Bilbao desde 1999- que se ve forzada a habitar viviendas con tipologías convencionales, pensadas como residencia habitual para familias nucleares con hijos o hijas - provienen del parque residencial libre, y en muchas ocasiones son en régimen de alquiler, por lo que es muy probable que se mantengan esas disposiciones espaciales-. Y sin embargo, la temporalidad del destino de estos inmuebles como dispositivos de transición hacia la independencia y la autonomía personal y familiar, la diversidad de las unidades de convivencia que

110 Deia (2016): «CEAR alerta de la dificultad para hallar pisos para refugiados», disponible en https://www.deia.eus/2016/01/23/sociedad/euskadi/cear-alerta-de-la-dificul tad-para-hallar-pisos-para-refugiados.

Cruz Roja (2018): «Cruz Roja atendió en Euskadi a 518 personas solicitantes de asilo y refugio en 2017», disponible en http://www.cruzrojabizkaia.org/es/cruz-roja-atendio-eneuskadi-a-518-personas-solicitantes-de-asilo-y-refugio-en-2017/.

${ }^{111}$ El Diario.es (2018): «Se busca piso para refugiado», disponible en https://www. eldiario .es/norte/euskadi/busca-piso-refugiado_0_775172994.html. 
los habitan o incluso los comparten, sumada a que son personas con diferentes orígenes, idiomas, culturas, o costumbres, llevan a identificar un completo desfase entre tipología y necesidades espaciales. Una problemática similar a esta es la de aquellas personas menores de edad no acompañadas que no cuentan con un entorno familiar propio. Diversos programas de acogida familiar promovidos desde la Diputación Foral de Bizkaia -activos desde 1997- evidencian otra realidad estructural de entornos domésticos cambiantes y diferentes a la familia 'tipo' para la cual se diseñan y reproducen la gran parte de viviendas del parque actual.

El segundo fenómeno a señalar, desde un ámbito muy diferente, ofrece también oportunidades de converger con las políticas públicas de vivienda y con una potencial adaptación a la diversidad de unidades de convivencia. Consecuentemente, podrían converger con los espacios de oportunidad detectados, con la estrategia de agrupación desarrollada, y con la actividad de algunos de los agentes de gestión de la vivienda estudiados. Como ya se ha señalado, la región del $\mathrm{AMB}$ lleva desde hace varias décadas adaptándose a un proceso de desindustrialización, buscando otros sectores de desarrollo económico, y apostando por situarse como una metrópoli de servicios global. Una de las estrategias recientes ha sido la de intentar posicionar a Bilbao y Bizkaia en un supuesto panorama internacional de red de ciudades creativas, que puede quizás leerse como un eco retardado de un movimiento iniciado con las propuestas de Richard Florida para centrar los esfuerzos de las políticas urbanas en atraer y conservar a una clase creativa como forma de desarrollo económico (Florida, 2003). Unos planteamientos que han sido analizados y cuestionados desde posiciones críticas, evidenciando la relación entre los mismos y la continuidad de políticas socialmente excluyentes. Así, lo que Florida presentaba como una nueva revolución social, algunos autores han tachado de maniobra de corte neoliberal que ocultaba la competitividad y rivalidad entre ciudades, el fomento del consumo de las clases medias, o el impulso de la marca ciudad. Esto ha incorporado procesos de gentrificación, subordinado el bienestar social al desarrollo económico -esperando que el primero permita el desarrollo del segundo-, y generado una receta para la distribución creativa del mercado, en vez de para la redistribución social (Peck, 2015). Aunque en el AMB ya se venían desde hace años dando algunos de estos síntomas y políticas, es en el año 2009 cuando se desarrolla desde el gobierno local de Bilbao un informe para «obtener la información necesaria para liderar, junto a otros agentes institucionales y económicos, un proyecto integral de promoción del sector de las industrias creativas en Bilbao» (Ayuntamiento de Bilbao, 2009). En el año 2013 pone en marcha, junto al gobierno provincial, la plataforma Bilbao Bizkaia Design Council «con el fin de promover las industrias creativas como factor de desarrollo económico y de proyección internacional»(BEAZ, 2018). En el año 2014 pasa esta ciudad a formar parte de la red Creative Cities de la UNESCO, y en el 2017 es incluida en el informe Cultural and Creative Cities C3 
Monitor de la Comisión Europea. En este contexto, pueden localizarse iniciativas como la sociedad pública BEAZ, perteneciente a la Diputación Foral de Bizkaia y creada para apoyar a empresas y personas emprendedoras a contribuir al crecimiento de la actividad económica y la creación de empleo, que tiene entre sus líneas de trabajo el impulso a las industrias creativas. O el proyecto Auzo Factory puesto en marcha por el consistorio en 2014, «un proyecto de nuevos espacios urbanos atractivos para la creatividad y convivencia entre la ciudadanía, asociaciones, agentes, personas emprendedoras y empresas, creados a partir de la regeneración de espacios antiguos en desuso y que focalizan su actuación en los sectores estratégicos para el municipio de Bilbao» (Bilbaogazte, 2018).

Es decir, ante un panorama de difícil acceso al mercado laboral, especialmente para parte de la población joven, se están poniendo en marcha estrategias para el fomento del emprendizaje y la nueva creación de empresas, con un especial énfasis en el sector creativo y digital. Una apuesta que requiere a su vez de una red de espacios de trabajo asequibles para el desarrollo de esas empresas; para lo cual se ofrecen espacios a modo de incubadoras, como es el caso de los Auzo Factory. Sin embargo, fuera de esa oferta pública es difícil encontrar espacios adecuados a las capacidades económicas de este colectivo. Se trata de una actividad económica con unos requerimientos relativamente sencillos de infraestructuras de producción -son usos de oficina, con material informático y zonas de reunión principalmente-, y altamente compatible con el uso residencial. Por otro lado, dada la dificultad que generalmente este colectivo joven tiene para acceder a una vivienda en condiciones adecuadas, podrían estas políticas de desarrollo económico converger con las políticas de vivienda municipales y ofrecer alojamientos planteados para acoger ambos usos, vivienda y trabajo, en unas condiciones dignas y adecuadamente separados ${ }^{112}$. Espacios que podrían ser planteados $-\mathrm{a}$ través de la estrategia de agrupación de unidades de convivenciatanto en viviendas actuales transformadas, como en edificios completos no residenciales existentes en zonas destinadas a uso residencial. La adaptación de los mismos se podría realizar manteniendo la estrategia de búsqueda de sinergias y colaboración que ofrecen espacios como los Auzo Factory, y conservando además un patrimonio cultural arquitectónico de gran interés en zonas centrales de la ciudad, que viene siendo habitualmente derribado en procesos de sustitución urbana para la construcción de nuevas viviendas. Con todo, la intención de este segundo ejemplo es, no solo abrir la mirada a otras posibles - de entre tantas- conformaciones de unidades de convivencia y la consecuente necesidad de adaptar el parque a las mismas, si no poner sobre la mesa la posibilidad de combinar políticas que pueden verse mutuamente favorecidas. Los

112 Un ejemplo más, como el ya señalado de las Madres de Día (ver nota al margen número 29), de que hay unidades de convivencia para las que el espacio destinado a la vivienda puede requerir dedicar una superficie de la misma a la actividad productiva. 
conflictos sectoriales complejos, en este caso de la vivienda, pueden ser reducidos mediante colaboraciones más transversales, como señalaba Alguacil (1995: 78) en la introducción del capítulo primero de este trabajo.

\section{El 'ideal' de la propiedad}

A pesar de la decidida apuesta por el alquiler como fórmula para el desarrollo de las políticas públicas de vivienda en Euskadi, todavía el parque residencial en régimen de alquiler es minoritario; un 13\% aproximadamente en esta comunidad autónoma. Aunque sí ha subido varios puntos desde los datos de 1991, y ha recuperado el peso perdido a lo largo de los últimos años de la burbuja inmobiliaria -se observa en los bajos datos del censo de 2001- el reparto total de grandes tipos de regímenes es muy estable desde hace al menos 27 años (Tabla 6.2), con la propiedad siempre por encima del $80 \%$ de las viviendas principales -en torno al 55\% totalmente pagada y cerca del $30 \%$ con pagos pendientes, esta última en ligero descenso-. La amplitud del periodo, albergando etapas de emancipación de varias generaciones, permite afirmar que dichos datos reflejan una muy fuerte tendencia hacia la propiedad firmemente asentada en la sociedad y el sistema inmobiliario residencial local, algunas de cuyas razones han sido apuntadas en el apartado en su momento. Es, por lo tanto, en parte debido a una cuestión política y mercantil (Burón, 2012), que sigue esta primacía por la propiedad arraigada en la sociedad vasca.

\begin{tabular}{llll}
\hline año & propiedad & \multicolumn{1}{c}{ alquiler } & \multicolumn{1}{c}{ cedida } \\
\hline 1991 & $83,47 \%$ & $10,61 \%$ & $3,76 \%$ \\
2001 & $89,00 \%$ & $7,27 \%$ & $1,63 \%$ \\
2011 & $84,24 \%$ & $9,81 \%$ & $1,72 \%$ \\
2013 & $86,61 \%$ & $10,25 \%$ & $3,15 \%$ \\
2014 & $84,38 \%$ & $11,73 \%$ & $3,90 \%$ \\
2015 & $84,20 \%$ & $12,39 \%$ & $3,42 \%$ \\
2016 & $85,14 \%$ & $11,55 \%$ & $3,32 \%$ \\
2017 & $82,19 \%$ & $13,07 \%$ & $4,73 \%$ \\
\hline
\end{tabular}

Pero no parecen las únicas razones. En los últimos años, la demanda de vivienda en alquiler en Euskadi se ha visto incrementada tanto en la vivienda protegida -de manera muy importante, también señalado en el capítulo segundo- como en el mercado libre ${ }^{113}$. Un
11320 Minutos (2009): «Ahora nadie quiere comprar, y se dispara la demanda de alquiler», disponible en https://www.20minutos.es/noticia/454582/0/alquiler/vivienda/pisos.
Tabla 6.2. Reparto del régimen de tenencia de la vivienda principal en Euskadi por grandes tipos en el periodo 1991-2017. INE, Encuesta Continua de Hogares 2013-2017 y Censos de Población y viviendas 1991, 2001 y 2011. 
cambio producido no tanto por un cambio cultural, si no principalmente por la resaca de la subida de precios de las viviendas en régimen de propiedad hasta más o menos el año 2008. La dificultad de acceder a la oferta en venta llevó a muchas unidades de convivencia a tomar el alquiler como alternativa temporal a la espera de que bajasen los precios. Las esperanzas generadas en ciertos sectores porque este fenómeno ayudase a dar un vuelco paulatino al mapa de regímenes de tenencia y equilibrar el ratio propiedad/alquiler se dieron de bruces contra una realidad bien diferente. El aumento de la demanda del alquiler tuvo como respuesta una escalada de los precios de este en el mercado libre ${ }^{114}$ (ver Gráfica 6.3, notas al margen 103 y 104), confirmando una vez más el generalizado tratamiento y gestión de la vivienda como objeto de acumulación de capital con una predominante dimensión económica; la sociedad volvía a mostrar eficazmente como el valor de cambio de la vivienda se priorizaba ante el de uso. Así, este mantenimiento de la propiedad como régimen predominante viene también en parte reforzado por la subida de los alquileres de los últimos años, y vuelve a tomar fuerza esa idea de que "alquilar es tirar el dinero".

En cierta medida, esta 'vuelta a la vivienda en propiedad' parece que está siendo facilitada por ciertos fenómenos de gran relevancia. Dada la precarización de una gran parte de la sociedad, y especialmente de los colectivos en edad de emancipación, muchos de estos están, ante la subida del alquiler, recibiendo un apoyo familiar de generaciones mayores para poder acceder a una vivienda en propiedad (ver nota al margen 105). Una apuesta que puede presentar dos variables. En algunos casos el apoyo es directamente económico, con el préstamo o directamente donación de capital económico para la compra. Pero en otros, se da una situación que comprende un proceso que ha de ser valorado en profundidad, dadas sus consecuencias. Se trata de «las cesiones o donaciones de viviendas por parte de abuelos o padres, que son los que, llegado el momento, plantean su propia emancipación para dejar la casa familiar a los hijos» (S. López, 2018). Esto puede ser rastreado a través de la Encuesta Continua de Hogares del INE. Según esta, en Euskadi las viviendas principales cedidas gratis o a bajo precio pasaron de ser 28.100 en 2013 a 42.700 en 2017. Un fenómeno que supone, no solo el compartir y responder a la vulnerabilidad residencial entre diferentes miembros familiares, si no un traslado de esta a una generación en las puertas de, o en plena, edad de jubilación. Algunas de estas personas puedan afrontar este peso gracias a que han tenido una vida laboral más o menos constante y en muchos casos con unas condiciones mejores que las de su generación posterior $-\mathrm{y}$ con todo, la situación generalizada de los pensionistas es preocupante y viene siendo

114 Idealista News (2017): «España, uno de los países europeos donde el alquiler 'se come' más ingresos familiares», disponible en https://www.idealista.com/news/inmobiliario/vivien da/2017/10/05/748304-espana-uno-de-los-paises-de-la-eurozona-con-mas-poblaciondejandose-gran-parte-del?sf_ua $=1$. 
denunciada con fuerza durante los últimos meses. Sin embargo, que el acceso a una vivienda venga siendo posibilitado por un fenómeno así ha de ser tenido muy en cuenta, dado que en el panorama actual es muy poco probable que las generaciones futuras cuenten con un sistema de pensiones como el de ahora, o mejor -se ha de tener en cuenta que las viviendas heredadas no se incluyen en dicha categoría de la encuesta-. La cara más débil de todo este apoyo familiar es la que conforman aquellos casos en los que ninguna de ambas opciones es posible, de manera que los hijos o hijas, o bien no pueden emanciparse y se mantienen en la vivienda de sus progenitores, o bien se ven forzados a retornar al mismo tras renunciar a su vivienda de alquiler o propiedad por no poder pagar las rentas o los pagos de la hipoteca.

Pero por otro lado, la paradoja de este corto viaje de ida y vuelta al alquiler es que el retorno a un ideal de la propiedad es, como se ha querido mostrar en el capítulo segundo, cada vez más inalcanzable para muchas unidades de convivencia. Lo que lleva a situaciones de secuestro económico por las hipotecas, con graves consecuencias como la extensión de los impagos y desahucios. Como señalan Madden y Marcuse (2018), el apostar por un sistema basado en la propiedad sin acabar primero con los problemas de desigualdad social existentes no hará si no generar más deuda y más inseguridad. Una mayor proporción del parque residencial destinado al alquiler es una posición defendida desde diversos sectores, y por diferentes razones (Burón, 2008, 2012; Gobierno Vasco, 2013a, 2017; Observatorio Vasco de la Vivienda, 2009). Es un régimen que retoma «la cultura de lo apropiado frente a lo privado, del bien de uso frente al bien de cambio» (Alguacil, 1995: 75). Su justificación se ha defendido por motivos de igualdad de oportunidades, por razones macroeconómicas - permitiendo destinar ahorros e inversiones privadas a otros fines productivos y sociales-, como respuesta a fenómenos de mayor movilidad laboral y formativa, o por disponer de una oferta de modalidades de acceso más variada que responda a demandas de alojamiento cada vez más diversas y cambiantes (León, 1995: 61). Ante ciertos discursos defensores de la propiedad como herramienta para el bienestar social, Madden y Marcuse recuerdan que:

«Como bien saben los millones de personas que recientemente han perdido sus hogares por la ejecución de sus hipotecas, una vivienda en propiedad no es garantía de estabilidad. [...] Es verdad que ciertas investigaciones confirman que la titularidad de la vivienda coincide con una serie de mediciones de salud física y psicológica. Sin embargo, otros estudios han demostrado que no se derivan una mayor seguridad emocional ni más beneficios para la salud específicamente del hecho de tener un título de propiedad. Parece más bien que las personas más ricas suelen sentirse más seguras y que estas, además, suelen tener su vivienda en propiedad. La titularidad de la vivienda como forma de tenencia 
del hogar no tiene nada de mágico» (Madden y Marcuse, 2018: 96).

En este sentido, mediante las estrategias y las oportunidades presentadas a lo largo de este trabajo se podría aprovechar para incorporar parte del parque en venta al alquiler. Lo cual va en la línea de las políticas de vivienda actuales, y de las necesidades y demandas de la vivienda protegida. La estrategia de agrupación de unidades de convivencia desarrollada para aprovechar los espacios de oportunidad detectados en el parque existente puede ser una interesante herramienta para ello. Ante la fase de subida de precios que parece se está iniciando, el acceso económico digno que puede llegar a facilitar esta estrategia serviría para dar cierto empuje al alquiler o a otro tipo de regímenes de tenencia compartida como las cooperativas en régimen de cesión de uso. La mayor adaptación a las necesidades y el consecuente mayor encaje entre oferta y demanda que la transformación física implícita en dicha estrategia supone, puede ser un aliciente para que cierta propiedad con viviendas -actualmente a la venta o no, pero sin poner en carga en definitiva- se decidan a apostar por este camino a través del alquiler. Por otro lado, todo ello se vería además favorecido por el papel que juegan algunos de los agentes de gestión analizados en el trabajo. Como se ha visto, muchos de ellos trabajan por impulsar y extender no solo una mayor oferta y cultura del alquiler bajo unas condiciones adecuadas para la parte arrendadora y arrendataria, sino que además buscan otras fórmulas diferentes de acceso a la vivienda. La concentración de la gestión de varias viviendas por parte de algunos de estos agentes es también una variable a favor para el fomento del alquiler en sus diversas vertientes.

\section{Mantenimiento del discurso}

Esta rápida reacción que el mercado ha tenido ante el incremento de la demanda de vivienda en alquiler en el AMB en forma de una subida generalizada de precios ha logrado expulsar paulatinamente de esta oferta a buena parte de las unidades de convivencia que lo habían ya sido de la oferta de vivienda en venta. Se hace así patente la vigencia de una serie de condicionantes y obstáculos fundamentales como los identificados en el capítulo segundo para que se mantenga la situación problemática abordada. Es posible identificar y observar continuamente discursos contradictorios que pueden ser enmarcados en las dos grandes contradicciones estructurales señaladas en el marco teórico del trabajo. También, intereses enfrentados y visiones sesgadas de la vivienda tendentes a leerla como un bien económico y apuntando como privilegio aquellas actuaciones de marcado carácter social. En definitiva, algunas de las actuaciones o posicionamientos de los agentes alternativos mostrados en el capítulo cuarto son una realidad minoritaria en un sistema hegemónico que sigue las contradicciones señaladas. Se muestran a continuación algunos ejemplos de entre muchos otros posibles. 
En ocasiones, las señales son meramente cuestiones de lenguaje que apuntan un marcado sesgo ideológico ${ }^{115}$-consciente o no-, pero que permiten enmarcar a algunos agentes con cierta facilidad en el esquema propuesto para la conceptualización de la generación de contradicciones (Esquema 2.1). En octubre de 2017, se anunciaba por parte de la sociedad Viviendas Municipales de Bilbao la asignación de 59 pisos en el municipio a unidades de convivencia formadas por personas de hasta 35 años con dificultades de acceso al mercado libre ${ }^{116}$, y por una renta de $175 €$ mensuales. El objetivo era doble: facilitar su emancipación, y lograr que se mantuviesen en sus barrios de origen -Otxarkoaga, Bilbao La Vieja y San Francisco-. Un portal inmobiliario cuya actividad se centra en la gestión de pisos de alquiler destacaba en su apartado de noticias este hecho como un «reparto» de pisos para que los jóvenes «echen raíces» ${ }^{117}$. Más allá de la acepción de la propia palabra repartir -distribuir algo dividiéndolo en partes; distribuir por lugares distintos o entre personas diferentes,...-, se puede apreciar cierto posicionamiento. El lenguaje utilizado no parece indicar que se esté tratando la noticia siendo consciente del problema social que hay detrás, si no valorando el hecho de que se hayan repartido esas viviendas a esas personas concretas, casi como si fueran un regalo, y señalando que «incluso tienen algunos electrodomésticos gracias a la colaboración de Surbisa, la sociedad municipal que se ocupa de obras de reforma» (Simón, 2017).

Otro ejemplo de cómo el lenguaje utilizado en los medios de comunicación puede evidenciar la manera sesgada y excluyente con que se aborda la problemática de la vivienda se pudo ver en un pequeño artículo de prensa publicado en agosto de $2018^{118}$. Bajo un estilo aparentemente neutral limitado a ofrecer datos estadísticos sobre la evolución de los precios de la vivienda en Euskadi, se comenzaba apuntando que el «precio de la vivienda sigue repuntando en Euskadi aunque a un ritmo inferior al del conjunto del país, según un informe del INE del tercer trimestre» (Gude, 2018). Tanto el título del artículo señalado como este inicio, de por sí podrían llevar a interpretar la noticia, si no como positiva -por el encarecimiento de

115 No se cuestiona que sea visible la ideología, se señala esta como causa de fondo del posicionamiento de esos agentes. La presencia de una ideología es inevitable, incluso en los debates más técnicos, e igualmente lo es en una cuestión como la aquí abordada, ya que se trata de una dimensión social y política de un derecho humano fundamental. Dentro del rigor académico, esta investigación se enmarca en una corriente ideológica concreta, y señala las consecuencias de un contexto ideológico igualmente específico.

116 AVS Euskadi (2017): «Viviendas Municipales de Bilbao adjudica 59 apartamentos para jóvenes por 175 euros al mes», disponible en http://avseuskadi.com/viviendas-municipalesde-bilbao-adjudica-59-apartamentos-para-jovenes-por-175-euros-al-mes/.

117 Enalquiler (2017): «Bilbao reparte pisos en alquiler a 175 euros al mes para que los jóvenes echen raíces en sus barrios de origen», disponible en https://blog.enal quiler.com/2017/ayudas-alquiler/bilbao-reparte-pisos-en-alquiler-a-175-euros-al-mes-paraque-los-jovenes-echen-raices-en-sus-barrios-de-origen/.

118 El Correo (2018): «La vivienda se encarece menos en Euskadi que la media nacional», disponible en https://www.elcorreo.com/economia/tu-economia/vivienda-encarece-euskadi-20181207170847-nt. html. 
los precios en lo que al acceso a la vivienda respecta-, sí de manera que llevase a una menor preocupación que en otras zonas. Sin embargo, seguidamente se especificaba que la diferencia de casi 2,5 puntos de diferencia entre el crecimiento nacional y el vasco «no se trata, con todo, de un dato alarmante ya que siete regiones arrojan un aumento inferior» (Gude, 2018). Es decir, la alarma parece estar justificada en la medida en que los precios no suban todo lo deseado, aunque parece que para al autor del artículo el incremento de los mismos en Euskadi es de alguna manera suficiente. A pesar de lo cual el incremento del 4,8\%, «eso sí, se sitúa lejos del 10,9\% de Madrid y el 9,1\% de Cataluña» (Gude, 2018). Los graves problemas que las dos comunidades citadas tienen para garantizar el acceso a la vivienda, incluso con episodios que sí se podrían calificar de verdaderamente alarmantes -pérdida de patrimonio público en Madrid tras la venta a fondos de inversión globales ${ }^{119}$, o una asumida crisis habitacional en Barcelona cuya respuesta ciudadana a través de la Plataforma de Afectados por la Hipoteca fue el germen del cambio en el gobierno local y sigue todavía sin resolverse ${ }^{120}-$, no parecen ser alicientes suficientes para reflexionar sobre los efectos dañinos que la subida de los precios pueden tener en muchas unidades de convivencia vascas que se ven excluidas del mercado residencial.

Aunque las evidencias de la vigencia de la legitimidad social e institucional de este enfoque parcial sobre la vivienda pueden localizarse con facilidad en otros ámbitos. Desde una empresa privada orientada a la gestión de inversiones inmobiliarias en Bizkaia, en agosto de 2017 se apuntaba que la «desconfianza en los productos ofrecidos por la banca tradicional y la inestabilidad de la bolsa, hacen que la inversión en activos residenciales en zonas prime sea una de las opciones más interesantes en la actualidad. Esto se debe, entre otras cosas, a que todo indica que la corrección de precios a la baja que comenzó en 2007 ha cambiado su rumbo con un crecimiento sostenido de precios desde 2015, a que las hipotecas siguen en unos precios muy atractivos (tipos fijos desde el $1,8 \%$ a 20 años o variables desde Euribor $+0,75 \%$ ), a los diferentes vehículos que existen para invertir y a que, de nuevo, hay un crecimiento general de la economía

119 A finales de 2013 y principios de 2014 el Ayuntamiento de Madrid vendía al fondo de inversiones Blackstone 5.315 inmuebles entre los que había 1.860 viviendas públicas. La operación tuvo entre sus consecuencias la subida de las rentas de las unidades de convivencia que habitaban muchas de ellas. Recientemente, el Tribunal de Cuentas, tras la demanda interpuesta por el equipo de gobierno que relevó al que cerró dicha operación, ha condenado a las personas responsables de dicha venta al pago de más de 25 millones de euros por la infracción de diversas normas en el proceso y haberse hecho por un precio sustancialmente inferior al debido, con una pérdida patrimonial pública importante:

El Diario.es (2018): «Ana Botella y siete cargos de su Gobierno, condenados a pagar 25 millones por vender pisos públicos con rebajas a fondos buitre», disponible en https://www.eldiario.es/madrid/Ana-Botella-Gobierno-condenados-millones-ventavivienda-fondos-buitre_0_851114898.html.

${ }^{120}$ El Periódico (2018): «La vivienda, un problema grave (y recurrente)», disponible en https://www.elperiodico.com/es/barcelona/20180702/problema-acceso-viviendabarcelona-alquileres-caros-6921095. 
de la clase media» (Kategora Real State, 2017). Posteriormente, la citada fuente se centraba en algunos de los aspectos clave para elegir el lugar donde invertir en vivienda. Entre los que estaba las expectativas de subida de precio de la zona, lo que aseguraría la alta rentabilidad de la operación. Esta llamada a utilizar la vivienda como producto de inversión económica se observa también en torno a eventos concretos como el sorteo de la Lotería de Navidad. Un fenómeno que no debe subestimarse desde el ámbito inmobiliario, pues según Loterías y Apuestas del Estado, un 41\% de las personas con boletos premiados destinarán el dinero recibido a la compra de viviendas. Desde algunas plataformas se insta a que así se haga, dado que «la vivienda se afianza como una alternativa de inversión sólida y a largo plazo para los perfiles más conservadores. Su rentabilidad está por muy encima de los depósitos y presenta menos riesgos que la bolsa» (Aragón, 2018). Y se señala incluso a Bilbao como la tercera ciudad más rentable para ello en España, en el caso del alquiler, por detrás de Soria y Huesca ${ }^{121}$. La mención de la utilización de la vivienda como inversión económica a la cual destinar dicho premio, con especial énfasis en el alquiler, se observa en diversos medios de comunicación, incluida la Corporación de Radio y Televisión Española, un ente público ${ }^{122}$.

Pero el papel de alimentar esta concepción exclusivamente economicista de la vivienda no se limita a ciertos agentes privados y particulares como los señalados; limitar la visión de esta manera sería cerrar los ojos al planteamiento que se ha desarrollado en el capítulo segundo en torno a las contradicciones internas, no solo del sistema en sí, si no de cada agente participante. En el caso de algunas instituciones públicas, esta propiedad internamente contradictoria se puede rastrear fácilmente. Así, mientras se desarrollan programas y políticas y se destinan no pocos recursos a actuaciones públicas para extender el acceso a la vivienda, en paralelo se despliegan ciertos instrumentos que favorecen la incorporación de algunos agentes al ecosistema residencial con una clara intención inversora. Y cuyas actividades favorecen la subida de los precios de la vivienda, actuando directamente en contra de esos otros esfuerzos institucionales. Un ejemplo de ello es la política fiscal que afecta tanto al momento de la compra de inmuebles residenciales como al de la venta. Para el

${ }^{121}$ Finanzas.com (2018): «Si gana el Gordo la mejor inversión es...la vivienda», disponible en http://www.finanzas.com/noticias/economia/20181220/gana-gordo-mejor-inversion-39 65305.html.

122 ABC (2018): «¿En qué invertir si te toca el «Gordo» de la Lotería de Navidad?», disponible en https://www.abc.es/loteria-de-navidad/abci-invertir-si-toca-gordo-loterianavidad-201812031628_noticia.html.

El Mundo (2018): «Si te toca El Gordo de la Lotería de Navidad puedes llegar a vivir 12 años sin trabajar», disponible en https://www.elmundo.es/economia/2018/12/05/5c07be 8521 efa0d2028b45cf.html.

Rtve.es (2018): «Lotería de Navidad 2018. Recomendaciones para invertir si te toca la Lotería», disponible en http://www.rtve.es/rtve/20181203/recomendaciones-para-invertirsi-toca-loteria/1847620.shtml. 
primero, el Impuesto de Transmisiones Patrimoniales de Bizkaia para viviendas tiene un tipo general del 4\% -el reducido de 2,5\% corresponde a casos en los que se trate de vivienda habitual, pero también a viviendas con una superficie inferior a $120 \mathrm{~m}^{2}-\mathrm{La}$ diferencia de este tipo, que sería de aplicación en Bilbao, con los aplicables en otras ciudades $-6,75 \%$ en Madrid, $8 \%$ en Valencia, o $9,2 \%$ en Barcelona, Málaga o Sevilla (Kategora Real State, 2017)- es de señalar. Para el momento de la venta, esta empresa consultora de inversiones inmobiliarias evidencia a través de un ejemplo cómo «Bizkaia [es] una de las mejores plazas para invertir en residencial» (Kategora Real State, 2017). La consultora tomaba el hipotético caso de una vivienda comprada hace 7 años por $500.000 €$-cerca de un 5\% de la muestra analizada en Bilbao en el capítulo tercero de este trabajo ronda ese precio-, y estimaba en $1.500 €$ la cantidad a abonar por el impuesto de plusvalía municipal en Bilbao, mientras que esta cantidad sería de 37.000€ en Barcelona, 25.000€ en Madrid, 36.000€ en Málaga, $32.000 €$ en Sevilla o $31.000 €$ en Valencia (Kategora Real State, 2017). Así, «la gran diferencia a la hora de realizar operaciones similares en diferentes ciudades es que en Bilbao los gastos que suponen el ITP, a la hora de adquirir el activo, y la plusvalía, en el momento de la desinversión, son mucho menores que en el resto de las ciudades comparadas. Y esto supone una gran ventaja para los inversores que desean realizar este tipo de operaciones» (Kategora Real State, 2017).

La presión que este tipo de operaciones puede llegar a ejercer sobre los precios de venta y de alquiler fomentando su subida, y el efecto tractor de esta sobre las franjas de precios inferiores ya señalado más arriba (Roch, 2009), choca frontalmente con las políticas públicas de vivienda de los dos últimos Planes Directores de Vivienda de Euskadi, que pretenden extender el alquiler -público y privado- como el régimen de tenencia que permita alcanzar el derecho a la vivienda a aquellas unidades de convivencia que quedan fuera del mercado de venta. El hecho de que muchas de estas inversiones estén destinadas a la obtención de rentabilidad a través del alquiler del inmueble durante unos años para su posterior venta, alimenta la aparición de lo que desde ciertas posiciones se está alertando como una nueva burbuja inmobiliaria centrada en el alquiler. La vigencia y la extendida realidad de estos y otros discursos dominantes en capas y esferas muy diversas ${ }^{123}$ es una prueba del mantenimiento de los condicionantes y obstáculos señalados al inicio, y del papel de estos en la generación de las contradicciones que afectan a la consecución de un acceso económica y espacialmente digno a la vivienda. Por ello resulta crucial, ante el panorama

123 En una entrevista realizada en diciembre de 2018, un consejero delegado de Jaureguizar, empresa promotora y constructora bilbaína, señalaba que «la crisis ha sido muy dura. El precio de la vivienda, de media, en Euskadi ha caído un 30\% y no se ha recuperado todavía» (Salaberri, 2018: 13). Una vez más, la bajada de precios de venta se toma como una mala noticia, al contrario que la subida. Una bajada que parece leerse como un episodio temporal, pues se ha de recuperar. 
presentado, el desarrollo de herramientas, la generación de conocimiento, y la identificación de vías y estrategias alternativas que permitan el empoderamiento de agentes como los analizados -con discursos en mayor o menor medida enfrentados a los anteriores-, para que puedan ampliar su rango de acción en torno a las tres metas apuntadas. En ese contexto, esta investigación ha pretendido hacer un -limitado- aporte desde la teoría y su aplicación al análisis empírico.

\section{Hacia una burbuja del alquiler}

Ya se ha ido adelantando en estos últimos apartados un fenómeno que se viene extendiendo en grandes capitales de provincia de España, y así se está dando en el AMB. Una nueva burbuja inmobiliaria construida sobre la oferta residencial en alquiler que viene siendo señalada ${ }^{124}$ y que empieza a mostrar pautas similares a experiencias recientes para la compra: escalada de precios inflados, atracción de agentes con interés exclusivamente inversor a participar en la gestión de un derecho humano fundamental, y expulsión de unidades de convivencia de un proceso de mercantilización agresivo. La subida de precios se ha apuntado ya en apartados previos. Una subida que ha sido además, como se ha visto, relativamente rápida debido a las oportunidades de acumulación de capital que suponía el incremento de la demanda de alquiler por parte de una población que había sido excluida del mercado de. Y sin embargo, la todavía inaccesibilidad económica de muchas unidades de convivencia a una propiedad deseada hace que, a pesar de dicha subida del alquiler, se vean obligadas - en el mejor de los casos- a destinar un alto porcentaje de sus rentas al mismo.

Esta subida de precios, más allá de un tejido previamente existente de pequeñas y medianas propiedades con viviendas en alquiler que estén actuando así, se ve reforzada por la incorporación de nuevos

124 Todavía sin demasiada producción académica al respecto, pues los trabajos más recientes se limitan a estudiar la burbuja de las décadas pasadas o a señalar tímidamente la posible burbuja del alquiler (Blas, 2017; Górgolas, 2017; Leal y Martínez del Olmo, 2017; Naredo, 2015; Naredo y Montiel, 2011; Rodríguez, 2017), sí viene siendo analizada y denunciada desde otras plataformas:

El País (2018): «La burbuja del alquiler», disponible en https://elpais.com/elpais/20 18/11/21/opinion/1542824483_084051.html.

El País (2018): «España vuelve a especular con la vivienda», disponible en https://elpais. com/economia/2018/08/30/actualidad/1535643025_269129.html.

El Mundo (2018): «Se alquila burbuja: cómo vivir en España tras el 'crack' inmobiliario», disponible en https://www.elmundo.es/espana/2018/08/06/5b673451ca47411d148b4580. html.

Alnavío (2018): «Estos datos confirman la burbuja del alquiler en España», disponible en https://alnavio.com/noticia/14881/bitacora/estos-datos-confirman-la-burbuja-del-alquileren-espana.html.

Infolibre (2018): «Jóvenes y burbuja de alquiler en España», disponible en https:// www.infolibre.es/noticias/opinion/plaza_publica/2018/10/14/jovenes_burbuja_alquiler_es pana_87574_2003.html. 
agentes. Por un lado, también se ha señalado con anterioridad, el fenómeno de la alta rentabilidad económica del alquiler como fuente de inversión de los últimos años está atrayendo a $-\mathrm{y}$ siendo a su vez alimentado por- diversos fondos de inversión inmobiliaria de ámbito internacional, de países como Estados Unidos (Blackstone, KKR), Holanda (APG), Alemania (DWS), o de carácter transnacional como CBRE, pero uniendo esfuerzos con empresas españolas (Renta Corporación, Azora, Altamar Capital Partners,...) que no descartan invertir en Bilbao ${ }^{125}$, y que no dudan en sumarse al «negocio del alquiler» tal y como se categorizaba el fenómeno desde el portal inmobiliario de Idealista (ver nota la margen 107). En general, son operaciones destinadas a la búsqueda de rentabilidad en dos tiempos: la de las rentas del alquiler, y la de la posterior venta del inmueble en un contexto de subida de precios (Kategora Real State, 2017).

Por otro lado, aunque con menos fuerza que en otras ciudades del estado, en el AMB se observa un fenómeno creciente de la utilización de parte del parque de viviendas como soporte para el alquiler vacacional. Este muestra dos caras diferentes: la de agentes promotores y/o inversores de cierto tamaño y capacidad económica para desarrollar actuaciones de cierta escala (ver Imágenes 2.3 y 2.4), o la de particulares y familias que tienen cierta holgura económica y pueden solicitar un crédito hipotecario para adquirir una vivienda y destinarla a este uso (ver nota al margen 108). Esta segunda opción tiene una variante más precaria: aquellas unidades de convivencia que habiendo adquirido su vivienda habitual -estando completamente pagada, o en muchos casos con pagos pendientes y en situaciones cercanas a la exclusión o vulnerabilidad social- utilizan la misma también para un fin de alquiler vacacional, incluso si para ello se han de alojar puntualmente en casas de familiares. Con la recompensa de acelerar el pago de la hipoteca, o simplemente de lograr lo que pueden ser sus únicos ingresos, e incumpliendo en algunos casos normativas municipales y autonómicas ${ }^{126}$. El fenómeno es internacional, e incluso en Estados Unidos algunas entidades financieras y organismos gubernamentales aceptan los ingresos generados por el arrendamiento de la vivienda habitual para refinanciar una hipoteca ${ }^{127}$.

${ }^{125}$ Expansión (2018): «Deutsche Bank, APG y CBRE GI se lanzan a por la vivienda en alquiler en España», disponible en http://www.expansion.com/empresas/inmobiliario/20 18/12/07/5c097dbf22601d4c218b45b1.html.

${ }^{126}$ El Mundo (2017): «"Si no fuera por Airbnb, habría perdido mi casa"», disponible en https://www.elmundo.es/madrid/2017/10/09/59da04c5e5fdea03608b45b9.html.

El Confidencial (2018): «Los anfitriones se rebelan: "Pago mi hipoteca gracias a Airbnb y ahora Madrid lo prohibirá"», disponible en https://www.elconfidencial. com/tecnologia/2018-08-06/airbnb-madrid-prohibicion_1600606/.

El Correo (2018): «"Puse mi VPO en alquiler para pagar mi hipoteca. No sabía que era ilegal"», disponible en https://www.elcorreo.com/bizkaia/puse-alquiler-pagar-201801302249 14-nt.html.

127 Airbnb.es (2018): «Refinanciación de hipoteca», disponible en https://www.airbnb.es /help/article/2193/mortgage-refinancing. 
Como ya se ha señalado, desde diversas posiciones -entre ellas las políticas de vivienda del Gobierno Vasco- se viene asumiendo y fomentando el alquiler como el régimen de tenencia más adecuado para responder a las características actuales de la población con necesidad de vivienda y dificultades de acceso a la misma. A la falta de acceso a la financiación necesaria para la compra, se ha de sumar otra cuestión: muchas de esas unidades de convivencia buscan una vivienda de transición, ya sea por estar en proceso de conformación de una unidad convivencial de mayor tamaño, por cuestiones de movilidad laboral, o de incertidumbre general. La incipiente burbuja supone por tanto una cuestión a tener en cuenta en este sentido, ya que las consecuencias de la misma empiezan a ser evidentes, con una evolución -pero en el fondo mantenimiento de sus pilares fundamentales- de algunos de los síntomas presentados en la situación problemática inicial. Es el caso de los desahucios por impago en España; mientras el número de los debidos a ejecuciones hipotecarias llevaba en diciembre de 2018 trece trimestres consecutivos en descenso, los propios de los impagos del alquiler y consecuencia de procedimientos enmarcados en la Ley de Arrendamientos Urbanos aumentaban por quinto trimestre consecutivo $^{128}$. En este contexto, es de destacar que los espacios de oportunidad detectados en el capítulo tercero para implantar una estrategia de agrupación de unidades de convivencia parecen darse con mayor frecuencia en la muestra de oferta en alquiler, que en la de venta (Tabla 3.21). En definitiva, la permanencia de las contradicciones y la problemática enfrentada lleva a plantear la necesidad vigente de una crítica teórica alternativa que sea reflexiva, se enfrente a la razón instrumental y busque caminos alternativos al presente (Brenner, 2017b), sean estos a largo, medio o corto plazo, y que permita la acción a través de su aplicación. La hipótesis planteada y confirmada se cree que puede ser una herramienta útil para ello.

${ }^{128}$ El Diario.es (2018): «Los desahucios por impago de alquiler siguen al alza y superan los 7.500 entre julio y septiembre», disponible en https://www.eldiario.es/economia/desahu cios-impago-alquiler-superan-septiembre_0_844815616.html. 


\section{Abrir y flexibilizar los instrumentos de planificación}

Como última interpretación y conclusión, se quiere hacer una pequeña reflexión sobre algunas derivas deseables en la planificación de esta problemática del acceso a la vivienda en general, y de las estrategias y agentes estudiados en particular, en función de los resultados obtenidos en el trabajo. Como se ha planteado en el apartado 1.3.1, los caminos a tomar para abordar esta problemática urbana $-\mathrm{y}$ aplicables a otros retos posibles- pueden ser definidos desde posiciones, con plazos y a ritmos diversos, siendo una situación ideal que se vayan recorriendo de manera paralela y poder así enriquecerse mutuamente. En cualquier caso, dado que el marco tomado para este trabajo es el de un plazo de actuación intermedio, y asumiendo con sus ventajas e inconvenientes el contexto instrumental existente, esta reflexión no trata sobre una llamada a la construcción de nuevos instrumentos para la gestión de la ciudad residencial -lo cual no quiere decir que no se estimen como necesarios-, si no sobre la conveniencia de adaptar y enriquecer los existentes con agentes, miradas, datos y herramientas actualmente fuera de los procesos más habituales de decisión. Concretamente, dos son los aspectos en los que se centra este apartado: las carencias de la planificación para responder a la problemática aquí abordada, y la calidad y vigencia de la información a partir de la cual se toman las decisiones.

\section{Enriquecer la planificación a diferentes escalas}

Debido a la convergencia de varios factores ya desarrollados, como son la colmatación de los suelos adecuados para la urbanización y expansión de la ciudad residencial en el AMB, el estancamiento del crecimiento demográfico -no suficientemente contrarrestado por el descenso del tamaño medio de la unidad de convivencia, ni por los flujos migratorios-, y el envejecimiento de una ciudad que ha de ser mantenida, intervenida, adaptada y renovada, las herramientas propias de la planificación urbana tradicional destinadas a grandes suelos a intervenir empiezan a detectarse como obsoletas. Muestra de ello son los pasos que se vienen dando en el ámbito legislativo a nivel estatal, muy especialmente con la Ley 8/2013 de rehabilitación, regeneración y renovación urbanas, y el posterior Texto Refundido de la Ley de suelo y rehabilitación urbana aprobado por el Real Decreto 
Legislativo 7/2015. La evolución de las necesidades de la gestión espacial de la ciudad se ha ido enfrentando a realidades complejas como las mostradas en este trabajo, que exigen maneras diferentes de abordar las situaciones. Muchas de ellas piden intervenir de manera desagregada en el espacio y en el tiempo, a pequeña escala, y bajo promociones tanto privadas, mixtas, o públicas. Como se ha visto, la estrategia de acceso a la vivienda aquí desarrollada puede ser implantada por agentes como los analizados, propios de esas tres esferas. En cualquier caso, la administración sí cuenta con la responsabilidad de favorecer un marco adecuado para que esas intervenciones se lleven a cabo -instrumentos, normativas, ayudas, información, divulgación, educación,...-. Es decir, si bien no ha de cargar con toda la responsabilidad del proceso, sí ha de propiciar el marco.

Esta dispersión de las actuaciones en múltiples intervenciones de escala intermedia o pequeña que supone la estrategia de agrupación de unidades de convivencia, es también una razón para identificar como necesaria una planificación pública a mayor escala que coja perspectiva y sepa priorizar espacios geográficos y sociales en los que intervenir. Tanto porque sus características las identifiquen como espacios de oportunidad, como por la urgencia que su población con necesidad de vivienda pueda llegar a presentar. Algunos instrumentos existentes pueden en este sentido ejercer, al menos de manera parcial, esta función; como el Plan Director de Vivienda -actualmente vigente el del periodo 2018-2020-, las Directrices de Ordenación del Territorio, o el Plan Territorial Parcial del Bilbao Metropolitano. Instrumentos con los que muchas de las consideraciones de este trabajo convergen y encajan. La conjunción de esferas y escalas tan diversas como son la geográfica con la doméstica lleva a plantear una flexibilidad y una apertura $-\mathrm{O}$ interrelación- de los instrumentos existentes hacia estrategias multi-escalares que puedan ir de lo territorial a lo edificatorio, y viceversa. Y pasando por la comunidad, el barrio y la ciudad. La creciente nitidez con que es posible analizar la realidad según se va reduciendo la escala lleva a plantear que, tal y como se ha hecho en el trabajo, parece adecuado plantear la prioridad de un análisis de arriba a abajo (y retroalimentado de abajo a arriba) a través de una planificación multi-escalar que vaya de la región, al barrio -normalmente los barrios cuentan con tipologías edificatorias y sectores de población similares- y de este a la vivienda -cada vivienda tendrá sus posibilidades, su propiedad y, en su caso, sus personas arrendatarias-. Este papel planificador y regulador puede ser incorporado de manera transversal a instrumentos de gestión de diversa escala, como los territoriales arriba mencionados, o los urbanos: planes generales de ordenación urbana u ordenanzas, entre otros. Un ejercicio que puede ser trasladado a agentes de gestión de la vivienda como los analizados según se va reduciendo la escala, dado que su conocimiento, sus capacidades y su potencial para conocer, intervenir y facilitar el acceso digno a la misma pueden ser importantes. Esto va además en la línea de una de las conclusiones 
obtenidas en el apartado 5.1.1, respecto a la conveniencia de que la gestión de los inmuebles que encajan en este concepto de espacios de oportunidad sean agrupados en torno a diferentes agentes para una planificación e intervención más eficaz.

La comprensión del AMB como un espacio geográfico, económico y social único, con sus muy diversas realidades, es un paso previo fundamental para una adecuada planificación del mismo. Esto es algo asumido por las instituciones públicas desde hace décadas, como se ha podido comprobar con los diferentes intentos de desarrollar instrumentos de planificación de escala regional realizados desde mediados del siglo pasado. Y que fue finalmente consolidado en 1990 con la aprobación de la Ley de ordenación del territorio de Euskadi, momento a partir de cual fueron redactándose los diferentes instrumentos que en ella se preveían -lo que ha llevado varios años, pues en el caso del PTP del Bilbao Metropolitano su aprobación definitiva no llegó hasta 2006; actualmente en revisión-. Dada la relevancia social de la vivienda como derecho, la movilidad que se da por motivos de cambio de residencia dentro de la propia área metropolitana, y la cada vez más integrada red de transporte público a lo largo de la misma -entre otras razones-, se podría plantear incluir en un instrumento como el PTP una rama que analice, en la línea de esta investigación, las posibilidades y retos que presenta el parque residencial del AMB de cara a orientar la política de vivienda en la región. Dejando para los instrumentos de planificación urbana las escalas más detalladas, este trabajo ha demostrado que se puede identificar, a través de un análisis global de las características y la distribución de su parque y su población, aquellas zonas que ofrecen un mayor índice de oportunidades para implantar la estrategia de agrupación de unidades de convivencia y transformación de viviendas con el objeto de facilitar el acceso a la vivienda y aprovechar con mayor eficacia el parque residencial. Información que a su vez sería de enorme relevancia para el surgimiento, el desarrollo y la actividad de agentes privados, públicos o mixtos que se dedicasen a gestionar dichas oportunidades.

Pero, lo que señalaba Burón (2016) sobre el Área Metropolitana de Barcelona, es aplicable a la de Bilbao, ya que «lo que todavía no hay es una política pública metropolitana de vivienda». Una política que entre otras muchas cuestiones, podría incorporar lo desarrollado a lo largo de este trabajo. Aunque en el AMB existe cierta planificación residencial a dicha escala establecida por las DOT o el PTP, se trata de una aproximación principalmente cuantitativa, sin entrar en cuestiones cualitativas que, como se apuntaba más arriba, la política de vivienda urge incorporar. La dispersión y multiplicación de muchas pequeñas intervenciones fuera de una planificación más amplia, sustituyendo a las pocas grandes del pasado, supone reflexionar sobre los conceptos de tamaño y escala, y de las fronteras entre la planificación urbana y la territorial. Así, el hecho de que se trate de operaciones de pequeño tamaño no implica que no puedan formar 
parte de una ordenación o planificación a gran escala. De tal modo que se puede hacer planificación territorial mediante pequeñas intervenciones, al igual que se puede hacer planificación urbana mediante intervenciones territoriales (Jornet i Fornet, 2015). Algo que la conocida como Declaración de Toledo incorporaba en cierta manera:

«Desde un punto de vista espacial, una visión integrada o plan de ciudad debe ir más allá de la suma de acciones puntuales aisladas, y considerar al mismo tiempo su puesta en práctica en la escala funcional o administrativa correspondiente.

En la escala local, esta visión espacial integrada debe reflejarse en la coordinación de las acciones, con la meta de asegurar un desarrollo equilibrado de la ciudad como totalidad y de sus partes, y más aún, considerando su papel dentro del territorio;

En la escala regional, en la coordinación de las políticas locales y sectoriales bajo una perspectiva regional más amplia, y en la articulación de las relaciones urbano-rurales, promoviendo los clusters regionales de cooperación e innovación, reforzando la contribución del desarrollo económico territorial como una fuerza motriz capaz de fortalecer una estructura policéntrica bien equilibrada y un modelo integrado basado en las diversas identidades territoriales» (VV.AA., 2010).

Por debajo de la escala territorial o regional, y bajo la ordenación de los instrumentos de escala municipal, se sitúa la escala de barrio. Como se ha planteado en el capítulo tercero, la importancia de una adecuada integración de este tipo de estrategias y agentes con el entorno local, en muy diferentes dimensiones, puede facilitar en gran medida el éxito de ciertas políticas urbanas. Por ello, estudios similares al aquí desarrollado pueden ser incorporados tanto a instrumentos tradicionales de planeamiento, como a trabajos de gran interés que abordan esta escala de trabajo, como los diferentes análisis urbanísticos de barrios vulnerables de España llevados a cabo a partir de datos estadísticos y censales (Hernández Aja et al., 2015), el Observatorio Urbano de Barrios de Bilbao ${ }^{129}$, o herramientas de evaluación de planes y programas de regeneración urbana que buscan una mejor implantación de dichas políticas (Hernández Aja et al., 2016). Todas ellas, herramientas existentes que pueden hacer de conexión entre la escala regional, de ciudad, y de barrio con unas inferiores de edificio y vivienda. Serían en estas últimas donde intervendrían mayoritariamente los agentes de gestión de la vivienda

129 Una herramienta puesta en marcha por el ayuntamiento en 2008 para el análisis y diagnóstico de la situación urbanística y social de los diferentes barrios de la ciudad con el objeto de favorecer la transparencia y la mejora en la gestión municipal. Así mismo, publica estudios sociológicos periódicos a través de un convenio suscrito con la Universidad de Deusto. 
analizados en el capítulo cuarto, implantando entre otras actuaciones la estrategia de agrupación de unidades de convivencia y transformación de viviendas propuesta en el capítulo tercero, para aprovechar los espacios de oportunidad detectados en el mismo.

\section{A través de un análisis detallado y multi-variable}

Finalmente, tanto las propuestas anteriores en torno a lograr una gobernanza abierta y de una calidad democrática alta, como las recién planteadas sobre la planificación multi-escalar, dependen de manera necesaria -aunque no suficiente- de un factor fundamental: se trata de lo que Naredo define como la tercera pata -ya se han mencionado las otras dos: una administración responsable y eficaz, y una participación informada de la ciudadanía- necesaria para que el compromiso público institucional se formalice adecuadamente: «un sistema de información capaz de describir el comportamiento y la evolución del sistema urbano-territorial (con especial referencias a los dos stocks fundamentales a gestionar en régimen de escasez: el territorio y el patrimonio construido)» (Naredo, 2015: 81). Esta es una cuestión altamente compartida por el planteamiento general de esta investigación, que se ha buscado integrar desde el inicio del mismo.

Así, el desarrollo del capítulo tercero es una demostración -y una de las conclusiones clave del trabajo- de cómo al profundizar en la realidad del parque y en la población que lo ha de habitar se logran datos sobre más variables que las tratadas normalmente. Lo cual permite una mayor comprensión del objeto socio-espacial que es la vivienda, así como visualizar un mayor abanico de opciones. Se logra así material para una toma de decisiones más informada. Actualmente, el desarrollo y la paulatina extensión de diferentes herramientas de monitorización y de gestión de múltiple información con un componente espacial está facilitando la gestión de procesos complejos; desde herramientas de modelado y gestión de proyectos edificatorios al análisis geográfico de ciudades y territorios. Estos instrumentos permitirían una ampliación, un ajuste y una optimización de los resultados obtenidos en el capítulo tercero. Por otro lado, algunas de las carencias detectadas en los agentes analizados y que dificultan el aprovechamiento de los espacios de oportunidad identificados podrían ser subsanadas al incorporar análisis más ricos y profundos del objeto de su actividad: la vivienda y sus ocupantes. 


\section{$-6.6-$ \\ Perspectivas de trabajo}

Con la limitación propia de los medios disponibles, la presente tesis doctoral ha buscado en lo posible enfocar la cuestión con una mirada post-disciplinaria. Se ha tratado así de ampliar miradas habituales excesivamente sectoriales; la de una arquitectura centrada en la vivienda como soporte -aún pretendiendo abarcar la sociedad que la habita-, o la de unas ciencias sociales centradas en las relaciones -sin incorporar una variable geográfica o espacial-. Esto hace que, aún dentro de un objeto de estudio limitado a la dimensión social de la vivienda, y un ámbito geográfico limitado al Área Metropolitana de Bilbao, la diversidad de esferas, escalas y temáticas abordadas hacen que los caminos abiertos de cara a continuar y ramificar la línea de investigación iniciada sean múltiples. Entre todos ellos, se destacan cuatro principales:

- Respecto al marco teórico en el que se ha contextualizado y apoyado el trabajo, y la herramienta de análisis propuesta que ha permitido la formulación y posterior demostración de una hipótesis de investigación, hay un interés por evaluar la capacidad de dicho instrumento teórico de ser aplicada en otros contextos geográficos y/o sobre otros retos urbanos.

- Las otras tres vías se centran en el tema y ámbito geográfico del trabajo. Sobre las alternativas espaciales, a partir de los resultados del capítulo tercero es posible profundizar en los espacios de oportunidad detectados. Para ello, sería de interés replicar lo desarrollado con información más completa y actualizada. El carácter experimental de la metodología aquí empleada puede ser optimizado con una muestra mayor, con datos más detallados y precisos, con técnicas y métodos de recogida y tratamiento de datos más potentes y, sobre todo, con el trabajo conjunto de diferentes entidades, instituciones y fuentes de información. En esta línea, sería deseable obtener resultados disgregados de las diferentes accesibilidades posiblemente existentes a estos espacios de oportunidad en función de variables de género, clase, educación u origen, entre otras.

- En cuanto a la gestión, a partir de los resultados del capítulo quinto se podría profundizar en el encaje de estos y otros agentes con los espacios de oportunidad. Esto supondría, en primer lugar, la transmisión del conocimiento y los resultados aquí obtenidos para su evaluación por dichos agentes. Se pasaría así de un primer análisis externo a un análisis interno conjunto más preciso. A ello podrían dedicarse entrevistas personales, talleres y reuniones grupales para evaluar de manera colectiva las posibilidades y los 
retos de aplicar e incorporar en su actividad la estrategia desarrollada. Esto conllevaría una revisión paralela de la metodología DAFO utilizada en el análisis de los casos seleccionados, dentro del capítulo cuarto.

- Finalmente, una interesante vía de trabajo consistiría en dirigir una mirada al exterior para localizar y estudiar modelos de gestión similares o diferentes en otras áreas urbanas. Conocidas las necesidades y los retos del contexto local, se trataría de evaluar el potencial encaje de otras fórmulas de gestión con la estrategia desarrollada y con los espacios de oportunidad del AMB, para analizar una posible transferencia de esos modelos a la región de cara a una implantación y aprovechamiento de estos. 
Bibliografía 
AinZ, M. J., GONZÁLEZ, M. J., y MORO, I. (2008). Sostenibilidad de las propuestas de suelo para nuevos desarrollos residenciales en la planificación territorial de Bizkaia. Forum de Sostenibilidad, 2, 111-125.

ALGUACIL, J. (1995). Veinticinco tesis sobre la complejidad del concepto de lo social en las intervenciones de vivienda pública. En L. Cortés (Ed.), Pensar la vivienda (pp. 70-90). Madrid: Talasa.

AlguACIL, J. (1998). Calidad de vida y praxis urbana. Nuevas iniciativas de gestión ciudadana en la periferia social de Madrid [Tesis Doctoral]. Universidad Complutense de Madrid, Madrid.

AlOKABIDE. (2012). Marco estratégico 20132016.

AlOKABIDE. (2013). Memoria 2013.

ALOKABIDE. (2014). Memoria 2014.

ALOKABIDE. (2016). ALOKABIDE | Sociedad Pública de Alquiler de vivienda protegida en Euskadi. Disponible en: http://www.alokabide.euskadi. eus/home-alokabide/

AltunA, M. (2018). El Ayuntamiento tapia una vivienda municipal que había estado 'ocupada' durante dos años. Gara. Disponible en: https://bilbotarra.naiz.eus/eu/info_bilbo tarra/20180626/el-ayuntamiento-tapia-unavivienda-municipal-que-habia-sido-ocupada

AMANN, A. (2005). El espacio doméstico: La mujer y la casa [Tesis Doctoral]. Universidad

Politécnica de Madrid, Madrid.

ANTOLÍN, J. E., FERNÁNDEZ, J. M., y LORENTE, E. (2010). Estrategias de regeneración urbana y segregación residencial en Bilbao: Apariencias y realidades. Ciudady territorio: Estudios territoriales, 163, 67-82.

ANTÓN, F., BARROSO, A., LIDÓN, E., RODRIGUEZ, E., y SOTO, Ó. (2007). Vivienda y opinión pública en España. Madrid: Centro de Investigaciones Sociológicas.

ARAGÓN, A. (2018). La vivienda es la mejor inversión si te toca el Gordo de la lotería de Navidad [Blog]. Al día. Disponible en: https: //www.pisos.com/aldia/la-vivienda-es-lamejor-inversion-si-te-toca-el-gordo-de-laloteria-de-navidad/1632010/

Arroyo, C. (2002). Carlos Arroyo. Arquitecto. Disponible en: https://www.carlosarroyo.net ASOCIACIÓN DE VECINOS DE ANDRA MARI. (2014). Más de la mitad del lantalde de Getxo abandona [Blog]. Asociación de Vecinos de Andra Mari. Disponible en: http://getxovecinos.com AUbert, D., CAVAR, L., y CHANDANI, N. (2012). Thanks for the view, Mr Mies: Lafayette Park Detroit. New York: Metropolis Books.

Auster, P. (2010). Sunset Park. Barcelona: Anagrama.

ÁvILA, J. L. (1998). El suelo como elemento ambiental: Perspectiva territorial y urbanistica. Bilbao: Universidad de Deusto.

AVS. (2018). Carta de la Asociación Española de Gestores Públicos de Vivienda y Suelo al Ministerio de Hacienda de España.

AyUnTAMiento de BAKIO. (2017). Plan General de Ordenación Urbana (Avance).

AYUNTAMIENTO DE BARAKALDO. (2004). Ordenanza reguladora de viviendas de protección local.

AYUNTAMIENTO DE BARAKALDO. (2009). Bases reguladoras de la conseción de ayudas económicas municipales destinadas a prevenir, evitar o paliar situaciones de marginacion social.

AyUnTAMIENTO DE BILBAO. (1995). La problemática de la vivienda en Bilbao.

AyUnTAMIENTO DE BILBAO. (2009). Estudio sobre el potencial de las Industrias creativas en Bilbao.

Ayuntamiento DE BILBAO. (2012). Resumen ejecutivo del prediagnóstico de la revisión del PGOU de Bilbao. Ayuntamiento de Bilbao. Área de Planificación Urbana.

Ayuntamiento DE BILBAO. (2013). Diagnóstico participado de la revisión del PGOU de Bilbao. Ayuntamiento de Bilbao. Área de Planificación Urbana.

Ayuntamiento De BilbaO. (2015). Revisión del Plan General de Ordenación Urbana. Resumen global de conclusiones del diagnóstico participado desde la óptica urbanistica. Ayuntamiento de Bilbao. Área de Planificación Urbana.

Ayuntamiento de BilbaO. (2016a). Plan General de Ordenación Urbana (Avance). Ayuntamiento de Bilbao. Área de Planificación Urbana.

Ayuntamiento de BilbaO. (2016b). Programa de Viviendas Municpales de Bilbao Jóvenes Solidarios.

AYUNTAMIENTO DE ETXEBARRI. (2018). Conocer Etxebarri. Demografía. Disponible en: http://www.etxebarri.eus/es-ES/Conocer/ Demografia/Paginas/default.aspx 
AZPIRI, A. (1997). El aumento de la superficie urbanizable ¿conduce a un descenso de los precios del suelo? Una reflexión histórica sobre Bilbao en el entorno del año 1900. Ciudad y territorio: Estudios territoriales, 111, 127142.

BALLesteros, J. (2009). Nuevo espacio doméstico. Pasajes de arquitectura y crítica, 109, 6.

BARANDiARAN, X. (2015). Asamblea de Etxekoop [Blog]. Wikitoki. Disponible en: http://wikitoki.org/actividad/asamblea-deetxekoop/

BÁrCena, M. J., Menendez, P., PALacious, M. B., y TUSELL, F. J. (2011). Measuring the real estate bubble: A house price index for Bilbao. Documentos de Trabajo Biltoki.

BARGOS, C. (2017). Claves de la vivienda desde el punto de vista de la inserción social. Presentación en «Nuevo Plan Director de Vivienda 2018-2020: un paso más hacia el acceso efectivo y sostenible a la vivienda», Bilbao.

BASTIDA, R. (1924). El problema de la vivienda en Vizcaya. Arquitectura: órgano de la Sociedad Central de Arquitectos, 64, 221-222.

BeAscoecheA, J. M. (2007). Propiedad, burguesia y territorio: La conformación urbana de Getxo en la ría de Bilbao (1850-1900). Leioa: Universidad del País Vasco/Euskal Herriko Unibertsitatea, Servicio Editorial.

BEAZ. (2018). Beaz Birkaia. Disponible en: https://beaz.bizkaia.eus

BELAUSTEGUi, J. (2016). Gipuzkoa ante los residuos, ¿sumar o dividir? Gara. Disponible en: http://www.naiz.eus/eu/hemeroteca/gara /editions/2016-11-24/hemeroteca_articles/gi puzkoa-ante-los-residuos-sumar-o-dividir

BELTRÁN, M. (2009). Las legislaciones de vivienda social. Ciudad y territorio: Estudios territoriales, 161, 453-472.

BILBAO, A. (2014). El límite competencial del Consejo Rector frente a la Asamblea General de Socios en las Cooperativas de Vivienda. Gizarte Ekonomiaren Euskal Aldizkaria - Revista $V$ asca de Economía Social, O(11), 7-23.

Bilbao, C. B., y PRIETO, J. (2007). Efectos del tratamiento fiscal de las segundas viviendas en la oferta en alquiler. XIV Encuentro de Economía Pública: políticas públicas y reformas fiscales, Santander.
BilbaO, L. (2016). Debates y controversias en torno a la vivienda en Bilbao (1965-1975). Bidebarrieta, 0(26), 98-119.

Bilbao Metrópoli 30. (1992). Plan Estratégico para la Revitalización del Bilbao Metropolitano (FASE I).

BILBAO Ría 2000. (2017). Bilbao Ría 2000. Disponible en: http://www.bilbaoria2000.org Bilbaogazte. (2018). Bilbao Auro Factory. Disponible en: http://bilbaogazte.bilbao.eus /es/programa/auzo-factory-bilbao/

BLAS, I. (2017). Análisis de los factores determinantes de la burbuja inmobiliaria en España [Trabajo de Fin de Grado]. Universidad de León, León.

BLOMLEY, N. (2004). Unsettling the city: Urban land and the politics of property. New York: Routledge.

BORJA, J. (2011). ¿Un cambio de ciclo o un cambio de época? Siete líneas para la reflexión y la acción. Urban, 01, 83-90.

BRENNER, N. (2004). New State Spaces: Urban governance and the rescaling of statehood. New York: Oxford University Press.

BRENNER, N. (2017a). La era de la urbanización. En Á. Sevilla (Ed.), Neil Brenner: Teoría urbana crítica y politicas de escala (pp. 255268). Barcelona: Icaria.

BRENNER, N. (2017b). ¿Qué es la teoría urbana crítica? En Á. Sevilla (Ed.), Neil Brenner: Teoria urbana crítica y politicas de escala (pp. 234254). Barcelona: Icaria.

BRENNER, N., PeCK, J., y THEOdORE, N. (2015). Urbanismo neoliberal: La ciudad y el imperio de los mercados. En Observatorio Metropolitano de Madrid (Ed.), El mercado contra la ciudad. Globalización, gentrificación y políticas urbanas (pp. 211-244). Madrid: Traficantes de Sueños.

BRENNER, N., y THEODORE, N. (2017). Las ciudades y las geografías del «neoliberalismo realmente existente». En Á. Sevilla (Ed.), Neil Brenner: Teoría urbana crítica y politicas de escala (pp. 113-159). Barcelona: Icaria.

BURÓN, J. (2005). La política de vivienda del Gobierno Vasco. Documentación social, 138, 119156.

BURÓN, J. (2008). Una política de vivienda alternativa. Ciudad y territorio: Estudios territoriales, 155, 9-40. 
Burón, J. (2010). Pacto por la vivienda en Euskadi: Rescate del mercado, el PIB y el empleo [Blog]. Leolo. Disponible en: http://leo lo.blogspirit.com/archive/2010/06/16/pactopor-la-vivienda-en-euskadi-mas-bien-pactopor-el-emple.html

BuRÓN, J. (2011). Rehabilitando la rehabilitación. El Correo. 14 de abril.

Burón, J. (2012). El tratamiento de la vivienda vacía en España [Blog]. Paisaje Transversal. Disponible en: http://www.paisaje transversal.org/2012/01/el-tratamiento-de-lavivienda-vacia-en_16.html

Burón, J. (2014). Taxonomía de las cooperativas de vivienda españolas y la necesaria convergencia con occidente [Blog]. Leolo. Disponible en: http://leolo.blogspirit. com/archive/2014/07/30/autenticas-falsascooperativas-de-vivienda-y-falsas-falsas-c3012346.html

Burón, J. (2015a). El Tribunal Constitucional falla inconstitucionalmente en materia de vivienda. eldiario.es. Disponible en: http://www.eldiario.es/agendapublica/blog/ Tribunal-Constitucionalinconstitucionalmente-materiavivienda_6_392720770.html

BURÓN, J. (2015b). Javier Burón: "El problema es que no hay politicas de vivienda" [La Marea]. Disponible en: https://www.lamarea.com/201 5/05/20/javier-buron-el-problema-es-que-nohay-politicas-de-vivienda/

BURÓN, J. (2015c). Una política de vivienda no homologable en Europa. El Correo. Disponible en: http://leolo.blogspirit.com/ar chive/2015/05/20/¿debemos-converger-conlos-lideres-europeos-en-vivienda-aseq3047668.html

BuRÓn, J. (2016). Hay que limitar el precio de la vivienda para proteger a los consumidores y al mismo mercado. eldiario.es. Disponible en: https://www.eldiario.es/catalunya/barcelona/ limitar-vivienda-proteger-consumidoresmercado_0_562394079.html

Bustillo, V. E. (2004). Vivir de habitación en Bilbao (Un estudio de la disponibilidad de la vivienda durante los años del desarrollo). Bidebarrieta: Revista de humanidades y ciencias sociales de Bilbao, 15, 283-310.

CACHO, R. (2016a). Construyendo el concepto de inmobiliaria ética [Blog]. Etikalia.
Disponible en: https://www.etikalia.es/blog $/ 8$

CACHO, R. (2016b). El programa ASAP de alquiler del Gobierno Vasco languidece [Blog]. Etikalia. Disponible en: http://etikalia.com/ blog/item/19-el-programa-asap-de-alquilerasequible-del-gobierno-vasco-languidece

CACHO, R. (2016c). Estrenamos servicio para facilitar la venta de viviendas [Blog]. Etikalia. Disponible en: https:/ /www.etikalia.es/es/ blog/12-estrenamos-servicio-para-facilitar-laventa-de-viviendas $/$ ?pagina $=3$

CACHO, R. (2016d). Una posible estrategia para movilizar viviendas vacías [Blog]. Etikalia. Disponible en: https:/ /www.etikalia.es/es/ blog/25-una-posible-estrategia-para-movilizarviviendas-vacias $/$ ?pagina $=4$

CAMinO, F. (2016). Usemos las viviendas vacías [Blog]. Arqtículos. Disponible en: http:// www.arquitasa.com/usemos-las-viviendasvacias/

CAPEL, H. (1997). La rehabilitación y el uso del patrimonio histórico industrial. Documents d'anàlisi geogràfica, 29, 19-50.

CÁRITAS BIZKAIA. (2010). Informe Anual.

CÁRITAS BIZKAIA. (2011). Informe Anual.

CÁRITAS BIZKAIA. (2012). Informe Anual.

CÁRITAS BIZKAIA. (2013). Informe Anual.

CÁRITAS BIZKAIA. (2014). Informe Anual.

CÁRITAS BIZKAIA. (2015a). "Barriztu”: Eliminar barreras para envejecer con dignidad en el propio hogar. Bihotzez, 62, 15-17.

CÁRITAS BIZKAIA. (2015b). Informe Anual.

CÁRITAS BIZKAIA. (2016). Informe Anual.

CEREZO, Á. (2016). Las actuaciones 3R:

delimitación y equidistribución. Presentación en «XLI Curso de Urbanismo del Instituto Vasco de Administración Pública», Bilbao.

Collantes, E., Arreche, I., GOÑI, N., ALMANDOZ, A., GOÑI, I., LAMEDICA, M., Salbide, J., AlmandoZ, A., Grisaleña, D., ElorriagA, M., y BAÑOS, L. (2013). Proyecto Berreibar: Reconversión proactiva de edificios industriales en desuso. AUS ART Journal for Research in Art, 1(1), 123-132.

COMISIÓN EUROPEA. (1999). Estrategia Territorial Europea. Hacia un desarrollo equilibrado y sostenible del territorio de la Unión Europea. 
Oficina de Publicaciones Oficiales de las Comunidades Europeas.

COMISIÓN EUROPEA. (2006). Comunicación de la Comisión al Consejo y al Parlamento Europeo sobre una Estrategia temática para el medio ambiente urbano.

COMITÉ DE DERECHOS ECONÓMICOS, SOCIALES Y CULTURALES DE NACIONES UNIDAS. (1991). Observación General no 4: El derecho a una vivienda adecuada.

CONSEJO DE EUROPA. (1996). Carta Social Europea (revisada).

CONSEJO DE LA JUVENTUd DE ESPAÑA. (2013). Observatorio de emancipación. Primer trimestre 2013.

CONSEJO DE LA JUVENTUd DE ESPAÑA. (2016). Observatorio de emancipación. País Vasco.1er semestre de 2015.

CONSTITUCIÓN ESPAÑOLA. (1978).

COPANS, R., y NeUmanN, S. (1995). Nemausus 1, une HLM des années 80 [Película].

DAILY, G. C. (1997). Nature's Services: Societal dependence on natural ecosystem. Washington D.C.: Island Press.

DAVIES, J. S. (2011). Challenging governance theory: From networks to hegemony. Bristol: Policy Press.

DECRETO 2/2010, DE 12 DE ENERO. (2010). Prestación Complementaria de Vivienda.

DECRETO 4/2011, DE 18 DE ENERO. (2011). Ayudas de Emergencia Social.

DECRETO 4/2016, DE 19 DE ENERO. (2016). Modificación del Decreto por el que se aprueban definitivamente las Directrices de Ordenación Territorial de la Comunidad Autónoma del País $V$ asco, en lo relativo a la cuantificación residencial. Anexo.

DECRETO 28/1997, DE 12 DE FEBRERO, SuPLEMENTO. (1997). Directrices de Ordenación del Territorio de la Comunidad Autónoma del País Vasco.

DeCRETO 43/2012, DE 27 DE MARZO. (2012). Programa de Intermediación en el Mercado de Alquiler de Vivienda Libre AS AP (Alokairu Segurua, Arrazoizko Prezioa).

DECRETO 61/2009, DE 10 DE MARZO. (2009). Tercera modificación del Decreto 316/2002, de 30 de diciembre, por el que se promueve e impulsa el

Programa de Vivienda V acía, se establece su régimen jurídico y se encomienda su gestión a la sociedad pública de Gestión de Viviendas en Alquiler / Etxebizitza Alokairuetarako Sozietate Publikoa, S.A.

DECRETO 96/2011. (2011). Modificación de los estatutos sociales de la sociedad pública "Vivienda y Suelo de Euskadi, S.A. - Euskadiko Etxebiritra eta Lurra, E. A.» (Visesa).

DECRETO 100/2004, DE 1 DE JUNIO. (2004). Modificación del Decreto por el que se promueve e impulsa el «Programa de Vivienda Vacía».

DECRETO 141/2012, DE 30 DE OCTUBRE. (2012). Condiciones mínimas de habitabilidad de las viviendas y la cédula de habitabilidad de Cataluna.

DECRETO 147/2010, DE 25 DE MAYO. (2010). Renta de Garantía de Ingresos.

DECRETO 179/2006, DE 26 DE SEPTIEMBRE, ANEXo I-MEMORIA. (2006). Plan Territorial Parcial del Bilbao Metropolitano. Memoria.

DECRETO 179/2006, DE 26 DE SEPTIEMBRE, ANEXO I-NORMATIVA. (2006). Plan Territorial Parcial del Bilbao Metropolitano. Normas de Ordenación.

DECRETO 180/2014, DE 23 DE SEPTIEMBRE. (2014). Modificación del Decreto por el que se crea el Programa de Intermediación en el Mercado de Alquiler de Vivienda Libre AS AP (Alokairu Segurua, Arrazoizko Prezioa).

DECRETO 193/2012, DE 2 DE OCTUBRE. (2012). Conservación y fomento del uso del suelo agrario en la Comunidad Autónoma de Euskadi.

DECRETO 316/2002, DE 30 DE DICIEMBRE. (2002). Promoción e impulso del «Programa de Vivienda Vacia», se establece su régimen jurídico y se encomienda su gestión a la Sociedad Pública "Vivienda y Suelo de Euskadi S.A./Euskadiko Etxebizitza eta Lurra, E.A» (VISESA).

DECRETO 466/2013, DE 23 DE DICIEMBRE. (2013). Programa de Vivienda Vacía «Bizigune».

DESAZKunDEA. (2016). Etxekoop [Blog]. Desazkundea. Disponible en: http://desazkun dea.org/language/es/grupos-detrabajo/etxekoop/

DOMINGO, M. DEL M. (2005). Vivienda obrera en Bilbao y el Bajo Nervión: Las casas baratas, una nueva forma de alojamiento (1911-1936) [Tesis Doctoral]. Universitat de Girona, Girona.

DRUOT, F., LACATON, A., y VASSAL, J.-P. (2007). PLUS. La vivienda colectiva, territorio de excepción. Barcelona: GG. 
DuQue, J. M. (2014). Políticas de servicios sociales para la atención a personas en situación de exclusión residencial grave. Elementos para un diagnóstico y propuestas estratégicas. Zerbitzuan: Gizarte zerbitzuetarako aldizkaria $=$ Revista de servicios sociales, 55, 35-46.

EAGLETON, T. (2011). Why Marx was right. London: Yale University Press.

EGIDO, J. A. (2000). Los cambios en el tamaño de las empresas del área metropolitana de Bilbao: Uno de los ejes del paso de la sociedad industrial a la post-industrial. Vasconia, 30, 515-526.

EgUNSENTIA AuRORA. (2016). EgunsentiaAurora. Disponible en: http://egunsentiaurora. wixsite.com/egunsentia

ElORDUY, P., y GARCÍA, T. (2014). El desierto de las casas sin gente. Diagonal. Disponible en: https://www.diagonalperiodi co.net/panorama/24761-la-bulimia-casas-singente.html

ELORZA, A. (1985). Introducción. En H. Marcuse, El hombre unidimensional: Ensayo sobre la ideología de la sociedad industrial avanzada. Barcelona: Planeta-De Agostini.

ENET, M. (2008). Herramientas para pensar y crear en colectivo: En programas intersectoriales de hábitat. Buenos Aires: CYTED.

ENGELS, F. (1974). El problema de la vivienda y las grandes ciudades. Barcelona: Gustavo Gili.

ENGELS, F. (2006). Contribución al problema de la vivienda. Madrid: Fundación Federico Engels.

ESPAÑA, MINISTERIO DE VIVIENDA. (2010). Libro Blanco de la Sostenibilidad en el Planeamiento Urbanístico Español. Madrid: Centro de Publicaciones, Ministerio de Fomento.

ESPuelas, F. (2007). Presentación. En J. M. García-Pablos (Ed.), Perspectivas urbanas: Residencia, ciudad, territorio. Madrid: Editorial Fundación COAM.

ETIKALIA. (2016). Etikalia Inmobiliaria Ética. Disponible en: https://www.etikalia.es/es/pre sentacion

ETXABE, IGOR. (2016). Igor Etxabe Saenz De Zaitegi. Director de Atención y Comunicación Externa de ALOKABIDE [Etxebizitza]. Disponible en: https://etxebizitza.blog.euska di.eus/es/elkarrizketa/igor-etxabe-saenz-dezaitegi-director-de-atencion-y-comunicacionexterna-de-alokabide/
ETXABE, ION. (2010). Familia berriak, BOE zaharrak. Aldiri: arkitektura eta abar, 1, 16-18.

ETXABE, ION. (2012). La necesidad de un cambio de modelo de desarrollo y su reflejo en la Ordenación Territorial (El caso de las Directrices de Ordenación del Territorio del País Vasco). Territorios en formación, O(2), 21-36.

ETXEZARRETA, A. (2010). Vivienda vacía e intervención pública en la Comunidad Autónoma del País Vasco en el contexto europeo. Revista de economía crítica, 10(Semi monográfico: Crisis del modelo agroalimentario y alternativas), 4-26.

EtXeZarreta, A., Cano, G., Hoekstra, J., y DoL, K. (2013). Analisis multiescalar de la burbuja inmobiliaria y los desahucios: La comunidad autonoma de Euskadi en el contexto estatal y europeo. Revista de Estudios Regionales, 98, 51-76.

ETXEZARRETA, A., y ETXEZARRETA, E. (2007). EAEko etxebizitza-kooperatibak: Argi eta ilunak. Revista vasca de economía social $=$ Gizarte ekonomiaren euskal aldizkaria, 3, 145-162.

EUROPEAN ENVIRONMENT AGENCY. (2006). Urban sprawl in Europe-The ignored challenge. Copenhagen: Office for Official Publications of the European Communities.

EUROPEAN UNION AGENCY FOR FUNDAMENTAL RIGHTS. (2018). Being black in the EU.

EUSKADI LAGUNKOIA. (2017). Guía práctica para la implantación y uso en municipios. Gobierno Vasco. Departamento de Empleo y Políticas Sociales.

EUSKADI LAGUNKOIA. (2018). Euskadi Lagunkoia. Disponible en: http://euskadilagun koia.net

EUSKO LANGILEEN ALKARTASUNA. (2010). Pacto Social por la Vivienda en Euskadi. Valoración de ELA.

Eustat. (2010). Análisis de tipos de las secciones censales de la C.A. de Euskadi.

FARIÑA, J. (2004). Sostenibilidad y racionalización de los procesos de urbanización. En Cuadernos de Investigación Urbanística 42 (pp. 7-12). Madrid: Instituto Juan de Herrera.

FARIÑA, J. (2007). La ciudad y el medio natural. Madrid: Akal. 
FERNÁNDEZ, C., y ROCH, F. (2012). La quiebra de la ciudad global y sus efectos en la morfología urbana. Madrid, bajo la lógica inmobiliaria de la acumulación-desposesión. Urban, 3, 45-63.

FERNÁNDEZ DE BETOÑO, U. (2014). Egoitza kuantifikazio urgenteaz. Gaur 8. Disponible en: https://www.naiz.eus/en/hemeroteca/gaur8/ editions/gaur8_2014-08-09-07-

00/hemeroteca_articles/egoitza-kuantifikaziourgenteaz

FERNÁNDEZ, J. M. (2006). Planificación estratégica de ciudades: Nuevos instrumentos y procesos. Barcelona: Reverte.

FERNÁNDEZ, L. (2015). Viviendas solidarias para facilitar la integración social. Disponible en: http:/ / www.vidasolidaria.com/noticias/201501-30/hemos-visto-que-recurso-inabarcable1448.html

FERNÁNDEZ, R. (2009). El tsunami urbanizador español y mundial: Sobre sus causas y repercusiones devastadoras, y la necesidad de prepararse para el previsible estallido de la burbuja inmobiliaria. Barcelona: Virus.

FLORES, R., y UBRICH, T. (2014). Informe sobre exclusión y desarrollo social en el País V asco. Resultados de la Encuesta sobre Integración y Necesidades Sociales, 2013. Fundación FOESSA.

FLORIDA, R. (2003). The rise of the creative class: And how it's transforming work, leisure, community and everyday life. New York: Basic Books.

FONSECA, M. (2014). Casa sin género. Presentación en «I Congreso Internacional de Vivienda Colectiva Sostenible», Barcelona.

FOTOCASA. (2016). Casi la mitad de los españoles que comparte vivienda tiene entre 30 y 50 años [Blog]. Fotocasa. Disponible en: http://www.fotocasa.es/blog/alquiler/casi-lamitad-de-los-espanoles-que-compartevivienda-tiene-entre-30-y-50-anos

FUMADÓ, J. L., y PARICIO, I. (1999). El tendido de las instalaciones. Barcelona: Bisagra.

FUNDACIÓN EGUZKILORE. (2015). Etikalia: Una inmobiliaria diferente [Blog]. Fundación Eguqkilore. Disponible en: http://www.funda cioneguzkilore.org/720/etikalia-unainmobiliaria-diferente/

FUNDACIÓN EGUZKILORE. (2016). Fundación Eguqkilore.
GAJA, F. (2003). El suelo como excusa: El desarrollismo rampante. Papeles de la Fundación de Investigaciones Marxistas, 20 2a época, 55-65.

GARCÍA, L. V. (1987). La formación de una ciudad industrial. El despegue urbano de Bilbao. Oñati: Instituto Vasco de Administración Pública.

GARCÍA, P. (2018). Debemos de inculcar una cultura del mantenimiento de lo cotidiano [Bilbao no 338].

GARCÍA-VÁZQUEZ, C. (2015). La

obsolescencia de las tipologías de vivienda de los polígonos residenciales construidos entre 1950 y 1976. Desajustes con la realidad sociocultural contemporánea. Informes de la construcción, 67(1).

GILI, G. (1999). Mi casa, mi paraíso: La construcción del universo doméstico ideal. Barcelona: Gustavo Gili.

Gobierno Vasco (Ed.). (2010a). Estrategias de adaptación y mitigación del Cambio Climático en planificación espacial.

GOBIERNO VASCO. (2010b). Pacto social por la vivienda. Un acuerdo para construir futuro. VitoriaGasteiz: Servicio Central de Publicaciones del Gobierno Vasco.

GOBIERNO VASCO. (2011a). Adaptación y mitigación del Cambio Climático.

GOBIERNO VASCO. (2011b). Ecoeuskadi. Estrategia de desarrollo sostenible de Euskadi 2020.

GOBIERNO VASCO. (2012). Modificación de las DOT como consecuencia de su Reestudio. Documento para la aprobación inicial.

GobIERnO VAsCO. (2013a). Plan Director de Vivienda 2013-2016. Fase I: información y diagnóstico.

Gobierno VAsco. (2013b). Plan Director de Vivienda 2013-2016. Fase II: estrategia y plan de acción.

Gobierno VASCO. (2013c). Programa de Gobierno 2012-2016. Programa 1000 dias para afrontar tres compromisos de país. X legislatura.

GOBIERNO VASCO. (2014a). Libro blanco de democracia y participación ciudadana para Euskadi.

GOBIERNO VASCO. (2014b). Modificación de las DOT, en lo relativo a la Cuantificación Residencial. Aprobación Inicial.

GOBIERNO VASCO. (2015a). El Gobierno Vasco pide responsabilidad politica para alcanzar un mayor consenso en el Proyecto de Ley de Vivienda tras los 
comicios. Disponible en: https://www.irekia.eus kadi.eus/es/news/26013

GOBIERNO VASCO. (2015b). Encuesta de Necesidades y Demanda de Vivienda.

GOBIERNO VASCO. (2015c). Sistema de alertas $A S A P$. Disponible en: https://www.euskadi. eus/informacion/sistema-de-alertas-asap/x39contgasa/es/\#propietarios

GOBIERNO VASCO. (2016a). Euskadi 2020.

Programa de Gobierno. XI Legislatura (2016-2020).

GOBIERNO VASCO. (2016b). Ordenanzas municipales de edificación.

GOBIERNO VASCO. (2016c). Programa de Intermediación en el mercado de alquiler de vivienda libre AS AP (Alokairu Segurua, Arrazoizko Prezio. Guia rápida.

GOBIERNO VASCO. (2016d). Udalplan.

Información del suelo Residencial, Actividades Económicas, Sistemas Generales y categorización del Suelo no urbanizable. Disponible en: http:/ / www.ingurumena.ejgv.euskadi.eus/r49udalplan/es/aa33aWAR/interfacesJSP/index.j sp

GobIERnO VAsco. (2017). Plan de Vivienda 2018-2020. Informe diagnóstico. Informe final.

GOBIERNO VASCO. (2018a). Consulta pública previa sobre proyecto de Decreto que regula las condiciones minimas de habitabilidad y las normas de diseño de las viviendas y de los alojamientos dotacionales en la Comunidad Autónoma del País Vasco.

GOBIERNO VASCO. (2018b). El Departamento de Vivienda convertirá locales vacios en viviendas de alquiler social. Nota de prensa.

GÓMEZ, A. J. (2004). La imagen de la vivienda obrera, la tipología de las casas baratas en Bilbao. Bidebarrieta: Revista de humanidades y ciencias sociales de Bilbao, 15, 173-201.

GÓmEZ, A. J. (2009). De la estampa de la residencia real a la fotografía de la vivienda obrera de Bilbao 1911-1936. Zainak. Cuadernos de Antropología-Etnografía, 32, 755-771.

GONDRA, G. (2004). Euskadiko EtxebizitzenKooperatibak (iruzkinak). Revista V asca de Economia Social - Gizarte Ekonomia Euskal Aldizkaria, O(0), 107-138.

GONZÁLEZ, I., y GAYOSO, M. (2018). Identidad colectiva e identidades compartidas (Dossier). Universidad Social de Vallecas.
GONZÁLEZ, J., KUNZ, I., y MARÍA, D. (2003). Uso residencial. En Usos de suelo y territorio: Tipos y lógicas de localización en la ciudad de México (pp. 173-201). México, D.F.: Plaza y Valdés.

GONZÁLEZ, M. (2001). Los origenes de una metropoli industrial: La ria de Bilbao. Bilbao: Fundación BBVA.

GONZÁLEZ, M. J. (2013). El derecho a la vivienda. Reflexiones en un contexto socioeconómico complejo. Madrid: Dykinson.

GÓRGOLAS, P. (2017). Burbujas inmobiliarias y planeamiento urbano en España: "Una amistad peligrosa". Cuadernos de investigación urbanistica, 111, 5-64.

Greene, S., Chambers, L., MASINDE, K., y O'BRIEN-TEENGS, D. (2013). A house is not a home: The housing experiences of african and caribbean mothers living with HIV. Housing Studies, 28(1), 116-134.

GRUPO RETIRO. (2016). Inversiones de Rentas Inmobiliarias. Disponible en: https://www.in versionrentavitalicia.com/

GUDE, E. (2018). La vivienda se encarece menos en Euskadi que la media nacional. El Correo. Disponible en: https://www.elcorreo. com/economia/tu-economia/viviendaencarece-euskadi-20181207170847-nt.html

GuIDOTTI, E., y ARROYO, C. (2004). Formas de vida: Ideas sobre vivienda social y vivienda de protección oficial. El Croquis, 119, 176-181.

GuTiÉrREZ, A., y ViveS-Miró, S. (2018). Acumulación de viviendas por parte de los bancos a través de los desahucios. Geografía de la desposesión de vivienda en Cataluña. EURE: revista latinoamericana de estudios urbano regionales, 44(132), 5-26.

HABRAKEN, N. J. (1972). Supports: An alternative to mass housing. London: The Architectural Press.

HARVEY, D. (1977). Urbanismo y desigualdad social. Madrid: Siglo XXI.

HARVEY, D. (1996). Cities or urbanization? City, 1(1-2), 38-61.

HARVEY, D. (2003). Espacios de esperanza. Madrid: Akal.

HARVEY, D. (2004). Las grietas de la ciudad capitalista: Entrevista a David Harvey [Archipiélago: Cuadernos de crítica de la cultura no 62]. 
HARVEY, D. (2014). Diecisiete contradicciones y el fin del capitalismo. Madrid: Traficantes de Sueños.

HERnÁndEZ AJA, A. (2008). Sostenibilidad, medio ambiente y derecho a la ciudad. (Documento inédito dentro del Grupo de Investigación en Arquitectura y Urbanismo más Sostenibles).

Hernández Aja, A., Alguacil, J., MedinA, M., y MorenO, C. (1997). La ciudad de los ciudadanos. Madrid: Ministerio de Fomento.

HERnÁNDEZ AJA, A., GARCÍA, C., MATESANZ, Á., RODRÍGUEZ, I., AlguACIL, J., CAmACHO, J., CASTRILlo, M. Á., APARICIO, A., FARIÑA, J., GONZÁLEZ, I., RuIZ, L. G., ROMÁN, M. E., SÁNCHEZ, D., VEgA, P., TAMayo, A., FERnANDEZ, V., LORITE, I., y GALVEZ, M. A. (2016). Recuperando la ciudad. Estrategia para el diseño y la evaluación de planes programas de regeneración urbana integrada. Madrid: Instituto Juan de Herrera.

HeRnÁndeZ AjA, A., y LEIVA, A. (2006). Parámetros dotacionales para la ciudad de los ciudadanos. Madrid: Instituto Juan de Herrera.

HERnÁNDEZ AjA, A., MATESANZ, Á., García, C., Alguacil, J., CAMACHO, J., y FERNÁNDEZ, C. (2015). Atlas de Barrios Vulnerables de España: 12 Ciudades 1991/2001/ 2006. Madrid: Instituto Juan de Herrera.

HOUSEKIDE. (2016). Housekide. Disponible en: https://sites.google.com/site/housekide/

IHOBE. (2017). Udalsarea 21. Disponible en: http://www.udalsarea21.net/Default.aspx?Id Menu=7ADD69FD-7B71-4861-AD3CF526ACBDE138\&Idioma=es-ES

INSTITUTO NACIONAL DE ESTADÍSTICA. (2012). Condiciones de vida. Cifras INE. Boletin informativo del Instituto Nacional de Estadística, 10(4).

INSTITUTO NACIONAL DE ESTADÍSTICA. (2014). Las formas de convivencia. Cifras INE. Boletín informativo del Instituto Nacional de Estadística, 7.

INSTITUTO NACIONAL DE ESTADÍSTICA. (2015). Encuesta continua de hogares. Año 2014. Nota de prensa.

INSTITUTO NACIONAL DE ESTADÍsTICA. (2017). Encuesta continua de hogares. Año 2016. Nota de prensa.
InURrietA, A., Irigoien, E., MurGui, N., y NAREDO, J. M. (2013). Qué hacemos por la vivienda. Madrid: Akal.

JEssop, B. (1997). Capitalism and its future: Remarks on regulation, government and governance. Review of International Political Economy, 4(3), 561-581.

JESSOP, B. (2002a). Governance and metagovernance in the face of complexity: On the roles of requisite variety, reflexive observation, and romantic Irony in participatory governance. En H. Heinelt, P. Getimis, G. Kafkalas, R. Smith, \& E. Swyngedouw (Eds.), Participatory governance in multi-level context: Concepts and experience (pp. 33-58). Wiesbaden: VS Verlag für Sozialwissenschaften.

JESSOP, B. (2002b). The future of the capitalist state. Cambridge: Polity Press.

JEssop, B. (2007). State Power: A strategicrelational approach. Cambridge: Polity.

Jessop, B. (2017). El Estado. Pasado, presente y futuro. Madrid: Catarata.

JORNET I FORNET, S. (2015). La ciudad consolidada. Presentación en «Euskal Hiria Kongresua 2015», Bilbao.

KATEGORA REAL STATE. (2017). Los atractivos de invertir en el sector inmobiliario en Bizkaia con Kategora Senior Finance [Blog]. Kategora. Disponible en: http://katego ra.com/es_es/noticias/los-atractivos-invertirsector-inmobiliario-bilbao-kategora-seniorfinance/

KNIGHT FRANK. (2016). Tendencias del mercado Residencial en España. Disponible en: http:/ / www.knightfrank.es/noticias/madrid-málagabarcelona-pa $\% \mathrm{C} 3 \%$ ADs-vasco-y-balearesserán-las-provincias-con-mayor-proyecciónresidencial-en-2017-010159.aspx

KONFEKOOP. (2016). Konfekoop, Confederación de Cooperativas de Euskadi. Disponible en: https: //www.konfekoop.coop/lang/es/

KOOIMAN, J. (2002). Societal governance: Levels, models and orders of socio-political interaction. En J. Pierre (Ed.), Debating Governance: Authority, Steering, and Democracy (pp. 138-166). Oxford: Oxford University Press.

LABAYRU, E. J. DE. (1970). Historia general del señorio de Bizcaya. Bilbao: La Gran Enciclopedia Vasca. 
LARREA, A., y GAMARRA, G. (2007). Bilbao y su doble: ¿regeneración urbana o destrucción de la vida pública? Bilbao: Gatazka.

LARSSON, O. L. (2013). Sovereign power beyond the state: A critical reappraisal of governance by networks. Critical Policy Studies, 7(2), 99-114.

LEAL, J. (1992). Informe para una nueva política de vivienda. Ministerio de Obras Publicas y Urbanismo.

LEAL, J. (1995). La cuestión de la vivienda o la vivienda como problema social. En L. Cortés (Ed.), Pensar la vivienda (pp. 17-30). Madrid: Talasa.

LEAL, J. (2018). Jesús Leal: «Si no se promueve más vivienda social en alquiler veremos hacinamiento en los pisos» [Idealista.com]. Disponible en: https:/ / www.idealista.com/news/especiales/reportaje s/2018/10/17/768727-jesus-leal-si-no-sepromueve-mas-vivienda-social-veremoshacinamiento?sf_ua $=1$

LEAL, J., y MARTÍNEZ DEL OLMO, A. (2017). Tendencias recientes de la política de vivienda en España. Cuadernos de relaciones laborales, 35(1), 15-41.

LEFEBVRE, H. (1976). La revolución urbana.

Madrid: Alianza Editorial.

LEFEBVRE, H. (2013). La producción del espacio. Madrid: Capitán Swing.

LEMKE, T. (2002). Foucault, governmentality, and critique. Rethinking Marxsim, 14(3), 49-64.

LEÓN, J. (1995). Balance y perspectivas de la política de vivienda en españa. En L. Cortés (Ed.), Pensar la vivienda (pp. 45-69). Madrid: Talasa.

LEY 2/2006, DE 30 DE JUNIO. (2006). Ley de Suelo y Urbanismo de Euskadi.

LEY 3/2015, DE 18 DE JUNIO. (2015). Ley de Vivienda de Euskadi.

LEY 18/2008, DE 23 DE DICIEMBRE. (2008). Ley para la garantía de ingresos y de inclusión social.

LEY 27/1999, DE 16 DE JULIO. (1999). Ley de Cooperativas.

LEY 38/1999, DE 5 DE NOVIEMBRE. (1999). Ley de Ordenación de la Edificación.

LEY 49/1960, DE 21 DE JULIO. (1960). Ley de Propiedad Horizontal.
LEY ORGÁNICA 3/1979, DE 18 DE

DICIEMBRE. (1979). Estatuto de Autonomía para el País V asco.

LIESE, J. (2009). Cooperativas: Un modelo de vivienda con futuro. Detail: revista de arquitectura $y$ detalles constructivos, 3, 277-280.

Lleó, B. (Ed.). (2006). Informe habitar. Madrid: EMVS.

LOGAN, J. R., y MOLOTCH, H. (2015). La ciudad como máquina de crecimiento. En Observatorio Metropolitano de Madrid, El mercado contra la ciudad. Globalización, gentrificación y políticas urbanas (pp. 157-210). Madrid: Traficantes de Sueños.

Loos, A. (2016). Das Andere (B. Colomina, Ed.). Zurich: Lars Muller Publishers.

López, Í. (2016). Otxarkoaga, un caso de Poblado Dirigido en Bilbao. De la chabola a la marginación urbana en el desarrollismo franquista. Historia contemporánea, 52, 309-345.

LÓPEZ, J. (2014). El coste de la emancipación residencial en Euskadi 2007-2013. Observatorio Vasco de la Juventud.

LÓPEZ, S. (2018). Los jóvenes españoles ya no pueden ni comprar ni alquilar vivienda. El País. Disponible en: https://elpais.com/econo mia/2018/11/22/actualidad/1542902550_758 805.html

LUjAMBIO, A. (2009). Estudio del número de vivienda vacia en Andoain. Andoaingo Udala.

MADDEN, D. (2019). David Madden: "La desigualdad es lo que define el modelo urbano actual” [El Salto]. Disponible en: https://www.elsalto diario.com/vivienda/david-madden-librodefensa-vivienda

Madden, D., y MARcuse, P. (2018). En defensa de la vivienda. Madrid: Capitán Swing.

MAguregui, I. (2007). Planteamientos básicos y ejes estratégicos de la Ley Vasca 2/2006, de 30 de Junio, de Suelo y Urbanismo. ACE: architecture, city and environment, 1(3), 304364.

MALDONADO, J. (2008). La vocación de los espacios periurbanos: Puente entre lo urbano y lo rural. Congreso Nacional de Medio Ambiente 9, Madrid.

MARCUSE, H. (1985). El hombre unidimensional: Ensayo sobre la ideología de la sociedad industrial avanzada. Barcelona: Planeta-De Agostini. 
MÁRQUEZ, J. (2012). MD \#51 «La nula planificación urbana de Santiago». Disponible en: https://www.youtube.com/watch?time_conti nue $=380 \& v=M Z 4 \_X e J 3 X \_k$

Más Que unA CASA. (2017). Más que una Casa. Procesos colectivos de vivienda. Disponible en: http: //masqueunacasa.org/es

MAS SERRA, E. (2010). ¿Plan estratégico o estrategia para un discurso? El caso de Bilbao. Scripta Nova: revista electrónica de geografía y ciencias sociales, 14(328).

MASSEY, D. B. (1995). Spatial divisions of labor: Social structures and the geography of production. New York: Routledge.

MATESANZ, Á. (2012). El suelo en la legislación urbanística española. Boletín $C F+S$, 51, 7-60.

MEADOws, D. H. (1972). Los límites del crecimiento: Informe al Club De Roma sobre el predicamento de la humanidad. México: Fondo de Cultura Económica.

MÉNDEZ, R., ABAD, L. D., y ECHAVES, C. (2015). Atlas de la crisis. Impactos socioeconómicos y territorios vulnerables en España. Valencia: Tirant.

Merodio, L. A. (1996). «Cada día es más pequeño el espacio que nos queda a los promotores privados»: Luis Andrés Merodio, presidente de ASCOVI- BIEBA [Bilbao no 92].

M-ETXEA. (2017). Qué es M-etxea [M-etxea]. Disponible en: https://m-etxea.com/zer-dam-etxea/

MONDRAGON, J., IZAOLA, A., y SANTAMARíA, E. (2011). Condiciones de vida y ausencia de bienestar de las personas mayores. Análisis del caso de Bizkaia (Comunidad Autónoma del País Vasco). Oñati Socio-Legal Series, 1(8), 1-23.

MONTANER, JOSEP MARIA. (2015). La arquitectura de la vivienda colectiva. Barcelona: Reverté.

MONTANER, JOSEP MARÍA, y MUXí, Z. (2009). Seriación y singularidad. Ciudady territorio: Estudios territoriales, 161-162, 571-580.

MONTANER, JOSEP MARIA, MuXí, Z., y FALAGÁN, D. H. (2011). Herramientas para babitar el presente. Barcelona: Máster Laboratorio de la Vivienda del Siglo XXI.

MONTEYS, X., y Fuertes, P. (1998). Mitre, F. J. Barba Corsini. Barcelona: Actar, COAC.
MONTEYS, X., y FUERTES, P. (2002). Casa collage: Un ensayo sobre la arquitectura de la casa. Barcelona: Gustavo Gili.

Moreno, G. (2009). Características y tipologías de las personas sin hogar en Bizkaia. Hacia un enfoque complejo de la realidad del sinhogarismo. Zerbitzuan: Gizarte žerbitzuetarako aldizkaria $=$ Revista de servicios sociales, 46, 35-44.

MorenO, G. (2013). El impacto de la crisis sobre las personas sin hogar, rupturas y continuidades en un contexto de cambio. El caso de Bizkaia. Cuadernos de trabajo social, 26(2), 479-488.

Moya, L. (Ed.). (2007). VR, vivienda reducida. Mairea.

MOYA, L. (2008). La vivienda social en Europa: Alemania, Francia y Países Bajos desde 1945. Mairea Libros.

MOYA, L. (2009). Espacios de transición. Ciudad y territorio: Estudios territoriales, 161, 559570.

MuMFORD, L. (1956). Historia natural de la urbanización. Boletín $C F+S$, 21. Disponible en: http://habitat.aq.upm.es/boletin/n21/almum. html

MUMFORD, L. (1970). The culture of cities. Orlando: Harcourt Brace Jovanivich, Publishers.

MUÑOZ, F. J. (2009). Habitar periferias urbanas: La gestión de la vivienda en los márgenes de la ciudad en Bilbao. Zainak. Cuadernos de Antropología-Etnografía, 32, 773803.

MuÑOZ, J. (2010). «Queremos que los pisos protegidos sean más caros si el adjudicatario gana más». El Correo. Disponible en: http:// www.elcorreo.com/vizcaya/20100102/pvasco -espana/queremos-pisos-protegidos-sean20100102.html

MuÑOZ, J. (2014). Caseros comienzan a retirar sus pisos del alquiler social al rebajarse la renta a 450 euros. El Diario V asco. Disponible en: http://www.diariovasco.com/v/20140128/aldia-sociedad/caseros-comienzan-retirar-pisos20140128.html

MuXÍ, Z. (2009). Recomanacions per a un habitatge no jeràrquic ni androcentric. Barcelona: Institut Català de les Dones.

NACIONES UNIDAS. (1966). Pacto Internacional de Derechos Económicos, Sociales y Culturales. 
NACIONES UniDAS. (1972). Declaración de la Conferencia de Naciones Unidas sobre el Medio Humano.

NACIONES UnidAs. (1992). Agenda 21: Programa de acción de las Naciones Unidas de Río. New York: Departamento de Información Pública de las Naciones Unidas.

NACIONES UNIDAS. (2008). Informe del Relator Especial sobre una vivienda adecuada como elemento integrante del derecho a un nivel de vida adecuado, $S r$. Miloon Kothari. Misión a España.

NACIONES UNIDAS. (2015). Declaración Universal de Derechos Humanos.

NAREDO, J. M. (1994). El funcionamiento de las ciudades y su incidencia en el territorio. Ciudad y territorio: Estudios territoriales, 100, 233249.

NAREDO, J. M. (1997). Sobre la insostenibilidad de las actuales conurbaciones y el modo de paliarla. En Primer catálogo español de buenas prácticas. Madrid: Ministerio de Obras Publicas, Transportes y Medio Ambiente. Disponible en: http://habitat.aq.upm.es/cs/p 2/a007.html

NAREDO, J. M. (2003). Instrumentos para paliar la insostenibilidad de los sistemas urbanos. Boletin $C F+S$, 24. Disponible en: http://habitat.aq.upm.es/boletin/n24/ajnar.ht $\mathrm{ml}$

NAREDO, J. M. (2004a). Diagnóstico sobre la sostenibilidad: La especie humana como patología terrestre. Archipiélago. Cuadernos de crítica de la cultura, 62, 13-23.

NAREDO, J. M. (2004b). Sobre el origen, el uso y el contenido del término sostenible. En Cuadernos de Investigación Urbanística 41 (pp. 7 18). Madrid: Instituto Juan de Herrera.

NAREDO, J. M. (2015). Un episodio relevante: La burbuja especulativa y la crisis inmobiliaria en perspectiva. Cuadernos de Investigación Urbanística, 0(100), 77-82.

NAREDO, J. M., y MONTIEL, A. (2011). El modelo inmobiliario español y su culminación en el caso valenciano. Barcelona: Icaria.

NAREDO, J. M., REDONDO, Ó. C., y MARCOS, C. (2008). Patrimonio inmobiliario y balance nacional de la economía española (1995-2007). Madrid: Fundación de las Cajas de Ahorros.

NOLLA, M. (2003). La crisis de la vivienda: Un «llamamiento» a la sociedad civil. Papeles de la
Fundación de Investigaciones Marxistas, $202^{a}$ época, 9-18.

NYU FuRMAN CENTER. (2015). The Challenge of Rising Rents: Exploring Whether a New Tax Benefit Could Help Keep Unsubsidized Rental Units Affordable.

OBSERVATORIO VASCO DE LA VIVIENDA. (2009). Políticas de fomento de la vivienda de alquiler en Europa.

OBSERVATORIO VASCO DE LA VIVIENDA. (2012a). Demanda de vivienda en la CAE-

Solicitudes de Etxebdide.

OBSERVATORIO VASCO DE LA VIVIENDA. (2012b). Informe de Evaluación de la Politica de Vivienda 2012.

OBSERVATORIO VASCO DE LA VIVIENDA. (2013). Encuesta de necesidades y demanda de vivienda en la CAPV 2011.

OBSERVATORIO VASCO DE LA VIVIENDA. (2014a). Encuesta de necesidades y demanda de vivienda en la CAPV 2013.

OBSERVATORIO VASCO DE LA VIVIENDA. (2014b). Informe sobre renuncias: Principales mafgnitudes 2005-2013.

OBSERVATORIO VASCO DE LA VIVIENDA. (2014c). La Masovería Urbana: La experiencia del modelo catalán.

OBSERVATORIO VASCO DE LA VIVIENDA. (2015a). Estadística sobre vivienda vacia.

OBSERVATORIO VASCO DE LA VIVIENDA. (2015b). Indicadores del mercado de la vivienda en la C.A. de Euskadi (4o trimestre 2015).

OBSERVATORIO VASCO DE LA VIVIENDA. (2015c). Informe comparado de las políticas de alquiler en las CCAA.

OBSERVATORIO VASCO DE LA VIVIENDA. (2015d). Informe sobre la Política de Vivienda en Europa.

OBSERVATORIO VASCO DE LA VIVIENDA. (2015e). Informe sobre las cooperativas y la promoción de VPP.

OBSERVATORIO VASCO DE LA VIVIENDA. (2017a). Indicadores del mercado de la vivienda en la C.A. de Euskadi (3er trimestre 2017).

OBSERVATORIO VASCO DE LA VIVIENDA. (2017b). Los efectos de la crisis: La respuesta de la politica de vivienda a los desahucios y el sobreendeudamiento. 
OCIO, M. (2018). Ponencia. Presentación en «Promoción inmobiliaria en Euskadi: Nuevos retos, oportunidades y obstáculos. Asociación de Constructores y Promotores de Bizkaia ASCOBI-BIEBA», Bilbao.

ODuM, E. P. (1969). La estrategia de desarrollo de los ecosistemas. Boletín $C F+S$, 26. Disponible en: http://habitat.aq.upm.es/ boletin/n26/aeodu.html

ONU-HABITAT. (2016). Reporte ciudades del mundo 2016: Urbanización y desarrollo. Futuros emergentes. Nairobi: ONU-Habitat.

OPEN DATA EUSKADI. (2017a). Indicadores municipales de sostenibilidad: Solicitudes de vivienda que constan en Etxebide (\%o babitantes).

OPEN DATA EUSKADI. (2017b). Indicadores municipales de sostenibilidad: Unidades convivenciales perceptoras de Ayudas de Emergencia Social (\%o habitantes).

ORDEN DE 22 ABRIL DE 2003, DEL CONSEJERO DE VIVIENDA Y ASUNTOS SOCIALES. (2003). Condiciones de cesión y procedimiento de adjudicación del «Programa de Vivienda Vacía».

OrIVE, L. A. (2006). Relaciones ciudadnaturaleza en Vitoria-Gasteiz. Boletín $C F+S$, 38/39. Disponible en: http://habitat.aq.upm. es/boletin/n38/aland.html

OruetA, F. D., y SEOANE, M. L. L. (2005). Desigualdad socialy vivienda. Madrid: Editorial Club Universitario.

OZCÁRIZ, J., y PRATS, F. (2009). Cambio Global España 2020/50. Programa Ciudades. Resumen Ejecutivo. Centro Complutense de Estudios e Información Ambiental y Fundación CONAMA.

PACHO, M. J. (2010). Higienismo y arquitectura en Bilbao entre 1850 y 1900: La tipología de vivienda obrera. Kobie. Antropología cultural, 14, 77-96.

PAlOMERA, J. (2018). Prólogo. En D. Madden \& P. Marcuse, En defensa de la vivienda (pp. 1124). Madrid: Capitán Swing.

PARICIO, I., y SUST, X. (2000). La Vivienda contemporánea: Programa y tecnología. Barcelona: Institut de Tecnologia de la Construcció de Catalunya - ITeC.

PARLAMENTO EUROPEO. (2013). La vivienda social en la Unión Europea.
PECK, J. (2015). A vueltas con la clase creativa. En El mercado contra la ciudad. Globalización, gentrificación y políticas urbanas (pp. 53-106). Madrid: Traficantes de Sueños.

PECK, J., y TICKELL, A. (2002). Neoliberalizing Space. Antipode, 34(3), 380404.

Pereda, C., Actis, W., y PradA, M. Á. DE. (2005). Inmigración y vivienda en España.

Ministerio de Trabajo y Asuntos Sociales.

PEREMiQuel, F., FONT, A., y SALVÀ, I. (2000). Vivienda: Innovación y proyecto. Necesidades, nuevas tecnologías y estrategias proyectuales.

Barcelona: Col.legi d'Arquitectes de Catalunya.

PÉREZ DE LA PEÑA, G. (2004). El problema de la vivienda pública en Bilbao en la posguerra: La propuesta de Germán Aguirre. Bidebarrieta: Revista de humanidades y ciencias sociales de Bilbao, 15, 267-282.

PÉREZ, J. A. (2002). La transformación del mundo laboral en el área industrial del Gran Bilbao 1958-1977: Una visión histórica. Scripta Nova: Revista electrónica de geografía y ciencias sociales, 6(119).

PÉREZ, P. M. (1997). Vivienda obrera y primeros negocios inmobiliarios en la zona industrial de Vizcaya. Historia Social, 27, 107126.

PISARELLO, G. (2003). Vivienda para todos: Un derecho en (de)construcción, el derecho a una vivienda digna y adecuada como derecho exigible. Barcelona: Icaria Editorial.

PLATAFORMA POR UNA VIVIENDA DIGNA. (2017). Por una vivienda digna. Juntos podemos. Disponible en: http://www.viviendadigna.org

POSTONE, M. (1993). Time, labor, and social domination: A reinterpretation of Marx's critical theory. Cambridge: Cambridge University Press.

Poulantzas, N. (2000). State, Power, Socialism. London: Verso.

PRATS, F. (2007). Intervención. En J. M.

García-Pablos (Ed.), Perspectivas urbanas:

Residencia, ciudad, territorio (pp. 89-100). Madrid: Editorial Fundación COAM.

PRICEWATERHOUSECOOPERS

INTERNACIONAL LIMITED. (2015). Dinámicas residenciales en España. El mercado de vivienda sale a flote.

Puerta, I. DE LA. (2018). Ponencia.

Presentación en «Promoción inmobiliaria en 
Euskadi: Nuevos retos, oportunidades y obstáculos. Asociación de Constructores y Promotores de Bizkaia ASCOBI-BIEBA», Bilbao.

PUIGJANER, A. (2018). La ciudad sin cocina [Arquetipos]. Disponible en: http://arquetipos.arquia.es/anna-puigjaner/

REAL DECRETO 233/2013, DE 5 DE ABRIL. (2013). Plan Estatal de fomento del alquiler de viviendas, la rehabilitación edificatoria, y la regeneración y renovación urbanas para los años 20132016.

REAL DECRETO LEGISLATIVO 2/2008, DE 28 DE MAYO. (2008). Texto refundido de la Ley del Suelo.

REAL DECRETO LEGISLATIVO 7/2015, DE 30 DE OCTUBRE. (2015). Texto refundido de la Ley de Suelo y Rebabilitación Urbana.

REAL DECRETO-LEY 6/2012, DE 9 DE MARZO. (2012). Medidas urgentes de protección de deudores hipotecarios sin recursos.

REAL DECRETO-LEY 27/2012, DE 15 DE NOVIEMBRE. (2012). Medidas urgentes para reforzar la protección a los deudores hipotecarios.

REVIRIEGO, J. M. (2016). El Ayuntamiento subirá un $50 \%$ el IBI a los 5.453 pisos vacíos detectados en Bilbao. El Correo, 18 de noviembre.

ROCH, F. (2000). Algunas notas sobre el funcionamiento del mercado de la vivienda. En P. Taltavull (Ed.), Vivienda y familia (pp. 417-442). Madrid: Fundación Argentaria.

ROCH, F. (2003). La ciudad inmobiliaria y el precio de la vivienda. Papeles de la Fundación de Investigaciones Marxistas, 20 2a época, 115-129.

RoCH, F. (2007). Coloquio. En J. M. GarcíaPablos (Ed.), Perspectivas urbanas: Residencia, ciudad, territorio (pp. 117-128). Madrid: Editorial Fundación COAM.

RoCH, F. (2009). Morfología, deterioro urbano y precio de la vivienda en Madrid. Ciudades: Revista del Instituto Universitario de Urbanistica de la Universidad de Valladolid, 12, 171-196.

ROCH, F. (2016). Entrevista a Fernando Roch [El blog de José Fariña]. Disponible en: https:/ / el blogdefarina.blogspot.com/2016/06/entrevist a-fernando-roch.html

ROCH, F., FERNÁNDEZ, J. M., y SEVILLA, Á. (2011). Nueva época, viejos conflictos:
Ciudades y teorías urbanas en la encrucijada. Urban, 01, 3-12.

RODRÍGUEZ, A. (2002). Reinventar la ciudad: Milagros y espejismos de la revitalización urbana en Bilbao. Lan Harremanak, 6, 69-108.

RoDríguEZ, A. (2018). Bilbao, la fábula posmoderna (I): Las claves de la regeneración urbana. El Salto. Disponible en: https://www. elsaltodiario.com/urbanismo/bilbao-fabulaposmoderna-claves-regeneracion-urbana

RodrígueZ, A., MARTíneZ, E., y GUENAGA, G. (2001). Uneven Redevelopment. New urban policies and socio-spatial fragmentation in Metropolitan Bilbao. European Urban and Regional Studies, 8(2), 161-178.

RODRÍGUEZ ALONSO, R. (2009). La política de vivienda en España en el contexto europeo. Deudas y Retos. CF+S. Disponible en: http://habitat.aq. upm.es/boletin/n47/n47-arrod.pdf

RODRÍGUEZ ALONSO, R. (2018). Del derecho a la vivienda al derecho a la ciudad (Dossier). Universidad Social de Vallecas.

RODRÍGuEZ ALONSO, R., y FERnÁnDEZ, A. (2016). Cesión de uso: Gotas en el desierto inmobiliario. Diagonal. Disponible en: https:// www.diagonalperiodico.net/global/32162cesion-uso-gotas-desierto-inmobiliario.html

RODRÍGUEZ, JESÚS. (2001). Estructura y cambios del parque residencial de la C.A. de Euskadi.

Eustat. Instituto Vasco de Estadística.

RODRÍGUEZ, JULIO. (2017). Las viviendas que pudieron hundir la economía española. La caída del mercado de vivienda y sus consecuencias. Cuadernos de relaciones laborales, 35(1), 71-99.

ROEDIG SCHOP ARCHITEKTEN. (2009). Cooperativa de viviendas en Berlín. Detail: revista de arquitectura y detalles constructivos, 3, 342352.

Romero, G., \& Mesías, R. (Eds.). (2004). La participacion en el diseño urbano y arquitectónico en la producción social del hábitat. México, D.F.: CYTED.

RuIZ DE AZÚA, E. (1978). Casas y viviendas en Bilbao en la segunda mitad del siglo XIX. Revista de la Universidad Complutense, 113, 45-78.

RUZAFA, R. (1993). Los patronos levantaron su Baracaldo: El sentido de un crecimiento urbano antes, durante y después de la 
Restauración. V asconia: Cuadernos de historia geografía, 21, 287-300.

SALABERRI, M. (2018). Zorrotzaurre encaja en nuestro ideario de hacer social [Bilbao no 342].

SANTAS, A. (2007). Urbanismo y vivienda en Bilbao: Veinte años de posguerra. Bilbao: Colegio Oficial de Arquitectos Vasco-Navarro.

SARRIA, A. (2015). Necesidad de vivienda y cuantificación residencial [Blog]. Estudio K. Disponible en: http:/ / estudiok.es/necesidadde-vivienda/

SASIGAIN, P., OZERIN, L., y UnZurRunZAGA, A. (2004). Diagnóstico sobre los problemas de acceso a la vivienda en la CAPV. Consejo Económico y Social Vasco.

SCHARPF, F. W. (1993). Games in hierarchies and networks: Analytical and empirical approaches to the study of governance institutions. Frankfurt: Campus Verlag.

SERVIHÁBITAT. (2017). Mercado residencial en España. Primer semestre 2017.

SEVILLA, Á. (2015). Contrahegemonías urbanas para transformar Madrid [Blog]. Multilpliciudades. Disponible en: https://multi pliciudades.org/2015/03/08/contrahegemoni as-urbanas-para-transformar-madrid/

SIMÓN, A. (2017). Bilbao reparte pisos en alquiler a 175 euros al mes para que los jóvenes echen raíces en sus barrios de origen [Blog]. El Blog de EnAlquiler.com. Disponible en: https://blog.enalquiler.com/2017/ayudasalquiler/bilbao-reparte-pisos-en-alquiler-a-175euros-al-mes-para-que-los-jovenes-echenraices-en-sus-barrios-de-origen/

SLATER, T. (2015). La expulsión de las perspectivas críticas en la investigación sobre gentrificación. En El mercado contra la ciudad. Globalización, gentrificación y políticas urbanas (pp. 107-144). Madrid: Traficantes de Sueños.

SMITH, N. (2015). Nuevo globalismo y nuevo urbanismo. La gentrificación como estrategia urbana global. En El mercado contra la ciudad. Globalización, gentrificación y politicas urbanas (pp. 245-270). Madrid: Traficantes de Sueños.

SmITH, N. (2010). Uneven Development: Nature, Capital, and the Production of Space. London: Verso.

SPECTOR, J. (2016). Detroit's ambitious plan to jump-start its housing market. Disponible en: https://www.citylab.com/equity/2016/02/de troit-home-mortgage-housing-marketappraisals-lending-clinton-globalinitiative/463395/

STANDING, G. (2013). El precariado: Una nueva clase social. Barcelona: Pasado y Presente.

SUMAE. (2016). Sumae Coop. Experiencia compartida. Disponible en: http://sumae.coop/

SWYNGEDOUW, E. (2005). Governance innovation and the citizen: The janus face of governance-beyond-the-State. Urban Studies, 42(11), 1991-2006.

SWYNGEDOUW, E., MOUlAERT, F., y RODRÍGUEZ, A. (2002). Neoliberal urbanization in Europe: Large-scale urban development projects and the New Urban Policy. Antipode. A Radical Journal of Geography, 34(3), 542-577.

TALLER DE IDEAS. (2011). Euskal Hiria NET, Nueva Estrategia Territorial. Modificación de las DOT como consecuencia de su Reestudio. Departamento de Medio Ambiente, Planificación Territorial, Agricultura y Pesca del Gobierno Vasco.

TEJEDOR, J. (2015). Nuevo paradigma normativo sobre la ciudad: Retornando a la ciudad tradicional. Informes de la construcción, 67 Extra 1.

TEJERINA, I. (2015). Mesa redonda: La ordenación del territorio surgida de la Ley 4/1990.

Presentación en Congreso Euskal Hiria 2015, Bilbao.

TEjERINA, I. (2016). Modelos urbanísticos. En Manual de ejecución urbanística del País Vasco (pp. 25-37). Bilbao: Instituto Vasco de

Administración Pública.

TEJERINA, I., y CEREZO, A. (2015a). Ley vasca de Vivienda (3): Problemas que no creeríais... [Blog]. Orbenismo. Disponible en: http://orbe nismo.es/ley-vasca-de-vivienda-3-problemasque-no-creeriais/

TEJERINA, I., y CEREZO, A. (2015b). Ley vasca de Vivienda (y 4): Joder que tropa!!! [Blog]. Orbenismo. Disponible en: http://orbe nismo.es/ley-vasca-de-vivienda-y-4-joder-quetropa/

TEJERINA, I., y CEREZO, A. (2017). La viabilidad económica del planeamiento y el tiro en el pie [Blog]. Orbenismo. Disponible en: http:/ / orbenismo.es/la-viabilidad-economicadel-planeamiento-y-el-tiro-en-el-pie/ 
TORRES, J. (2018). Jurjo Torres: "El debate sobre educación no sale en los grandes medios o salen anécdotas y chorradas" [El Salto]. Disponible en: https://www.elsaltodiario.com/educacion/ent revista-jurjo-torres-pedagogia-liberalizacionensenanza

TRIBUNAL SUPERIOR DE JUSTICIA DEL PAÍS VASCO. (2017). Sentencia 1542/ 2017.

TriLla, C. (2002). La política de vivienda en una perspectiva europea comparada (Vol. 9). Barcelona: Fundación La Caixa.

Trovato, G. (2009). Definición de ámbitos de flexibilidad para una vivienda versátil, perfectible, móvil y ampliable. Ciudady territorio: Estudios territoriales, 161-162, 599-614.

TURNER, J. F. C. (1977). Vivienda, todo el poder para los usuarios: Hacia la economía en la construcción del entorno. Madrid: Blume.

TURNER, J. F. C., y FiCHTER, R. (1976). Libertad para construir: El proceso babitacional controlado por el usuario. México: Siglo XXI.

UgarTe, P. (1999). Historia de Bilbao: De los origenes a nuestros dias. San Sebastián: Txertoa.

URBANIA. (2016). Urbania ZH Gestión.

Disponible en: http://www.urbaniazhgestion .com/

URKIDI, P. (2009). El planeamiento territorial de la Comunidad Autónoma del País Vasco: Visión general y tratamiento del medio físico (1940-2006).

Leioa: Universidad del País Vasco/Euskal Herriko Unibertsitatea, Servicio Editorial.

URKIDI, P. (2010). Las políticas de ordenación del territorio en la Comunidad Autónoma Vasca, 1990-2006. Boletin de la Asociación de Geógrafos Españoles, 52, 189-212.

URRUTIA, V. (1993). La ideología higienista y la vivienda en Bilbao a comienzos del siglo XX. Vasconia: Cuadernos de bistoria - geografia, 21, 329-344.

URTEAGA, E. (2011). Modelos de Ordenación del territorio en Europa: Francia, Alemania y Reino Unido. Estudios geográficos, 72(270), 263289.

VALENZUELA, L. M., y SORIA, J. A. (2012). La incidencia de la planificación: Propuesta de evaluación aplicada al desarrollo metropolitano. Urban, 03, 81-104.

VÁZQUEZ, M. (2010). El territorio desde la perspectiva ecológica. Boletín $C F+S, 42 / 43$.
Disponible en: http://habitat.aq.upm.es/bo letin/n42/ac3.html

VEGARA, A. (1999). Los SmartLands. El milagro de Bilbao. Ciudades: Revista del Instituto Universitario de Urbanistica de la Universidad de Valladolid, 5, 21-42.

VeILler, L. (1905). The Housing Problem in American Cities. The Annals of the American Academy of Political and Social Science, 25, 46-70.

VICARIO, L., y MARTíNEZ, P. M. (2003). Another 'Guggenheim effect'? The generation of a potentially gentrifiable neighbourhood in Bilbao. Urban Studies, 40(12), 2383-2400.

VICARIO, L., y RODRÍGUEZ, A. (2005). Innovación, competitividad y regeneración urbana: Los espacios retóricos de la «ciudad creativa» en el nuevo Bilbao. Ekonomiaz: Revista vasca de economía, 58, 262-295.

VIDARTE, J. I. (2007). Nuevas infraestructuras culturales como factor de renovación urbanística, revitalización social y regeneración económica. El Museo Guggenheim Bilbao. Museo: Revista de la Asociación Profesional de Museólogos de España, 12, 99-108.

VInUESA, J. (2013). El festín de la vivienda. Ange y caída del negocio inmobiliario en España. Madrid: Diaz \& Pons.

VISESA. (2005). Informe anual 2005.

VISESA. (2006). Informe anual 2006.

VISESA. (2007). Informe anual 2007.

VISESA. (2008). Informe anual 2008.

VISESA. (2009). Informe anual 2009.

VISESA. (2010). Memoria de gestión 2010.

VISESA. (2011). Memoria 2011. Calidad a tu alcance.

VISESA. (2012). Presentación y memoria 2012.

VISESA. (2013a). Memoria de sostenibilidad 2011 2013.

VISESA. (2013b). Presentación y memoria 2013.

VISESA. (2014). Presentación y memoria 2014.

VISESA. (2016). Carta de servicios.

VV.AA. (1994). Carta de las Ciudades Europeas hacia la Sostenibilidad (Carta de Aalbory).

VV.AA. (2003). Suelo y Vivienda. Papeles de la Fundación de Investigaciones Marxistas, 20 2a época.

VV.AA. (2010). Declaración de Toledo. 
Whitehead, C., \& Scanlon, K. (Eds.). (2007).

Social Housing in Europe. London: London

School of Economics and Political Science.

Whitehead, C., \& Scanlon, K. (Eds.). (2008).

Social Housing in Europe II. A review of policies and outcomes. London: London School of

Economics and Political Science.

YBARRA, J. DE. (2002). Nosotros, los Ybarra:

Vida, economia y sociedad (1744-1902). Barcelona:

Tusquets.

ZAZO, A. (2011). El Parque Agrario:

Preservación de la actividad agraria en espacios periurbanos (El caso del Bajo Llobregat). Territorios en formación, 1(01).

Zubero, I. (2012). «Primero tomaremos

Manhattan»: Regeneración urbana, insurgencias ciudadanas y emergencias culturales en Zorrotzaurre (Bilbao). Urban, 03, 65-80.

ZuBERO, I. (2016). Ciudades jóvenes del futuro: Construyendo desde los valores. Presentación en «Gaztetalk Bilbao 2016», Bilbao.

Zurro, G. (2018). "Viviendas Municipales es un elemento de cohesión" [Bilbao n³33]. 
Bilbao, 19 de octubre de 2020 